ESCOLA POLITÉCNICA DA UNIVERSIDADE DE SÃO PAULO DEPARTAMENTO DE ENGENHARIA DE CONSTRUÇÃO CIVIL

RAFAEL BARRETO CASTELO DA CRUZ

PROPOSTA METODOLÓGICA PARA PARTICIPAÇÃO POPULAR NA DEFINIÇÃO DE ESTRATÉGIAS EM PLANEJAMENTO URBANO 
RAFAEL BARRETO CASTELO DA CRUZ

\title{
PROPOSTA METODOLÓGICA PARA PARTICIPAÇÃO POPULAR NA DEFINIÇÃO DE ESTRATÉGIAS EM PLANEJAMENTO URBANO
}

\author{
Tese apresentada à Escola Politécnica da \\ Universidade de São Paulo, como requisito \\ para obtenção do título de Doutor em \\ Ciências.
}

São Paulo 
CRUZ, R.B.C. Proposta Metodológica para participação popular na definição de estratégias em planejamento urbano. Tese apresentada à Escola Politécnica da Universidade De São Paulo para obtenção do título de Doutor em Ciências.

Aprovado em: 25 de Setembro de 2019

\section{Banca Examinadora}

Prof. Dr ${ }^{\mathrm{a}}$. Karin Regina de Castro Marins

Instituição: EPUSP

Julgamento: Aprovado

Prof. Drº Francisco de Assis Comarú

Instituição: UFABC

Julgamento: Aprovado

Prof. Dr ${ }^{\mathrm{a}}$. Silvia Aparecida Mikami Gonçalves Pina

Instituição: UNICAMP

Julgamento: Aprovado

Prof. Drº. Adrian Gurza Lavalle

Instituição: FFLCH -USP

Julgamento: Aprovado

Prof. Dra ${ }^{\mathrm{a}}$. Fernando Akira Kurokawa

Instituição: EPUSP

Julgamento: Aprovado 
RAFAEL BARRETO CASTELO DA CRUZ

\section{PROPOSTA METODOLÓGICA PARA PARTICIPAÇÃO POPULAR NA DEFINIÇÃO DE ESTRATÉGIAS EM PLANEJAMENTO URBANO}

Tese apresentada à Escola Politécnica da Universidade de São Paulo, como requisito para obtenção do título de Doutor em Ciências.

Área de Concentração: Engenharia de Construção Civil e Urbana.

Orientadora: Professora Doutora Karin Regina de Castro Marins 
Autorizo a reprodução e divulgação total ou parcial deste trabalho, por qualquer meio convencional ou eletrônico, para fins de estudo e pesquisa, desde que citada a fonte.

A elaboração da Tese contou com apoio da Reitoria da PUC/SP por meio do edital PIPEQ 5201/2019 para Auxílio à Capacitação Docente.

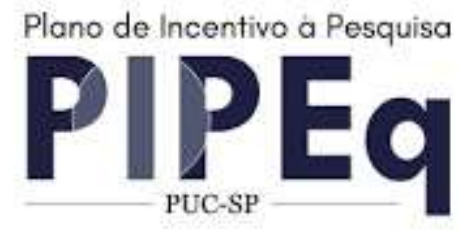

Este exemplar foi revisado e corrigido em relação à versão original, sob responsabilidade única do autor e com a anuência de seu orientador.

São Paulo, 20 de Novembro de 2019

Assinatura do autor:

Assinatura do orientador:

Catalogação-na-publicação

Cruz, Rafael Barreto Castelo da

Proposta Metodológica para participação popular na definição de estratégias em planejamento urbano / R. B. C. Cruz -- versão corr. -- São Paulo, 2019.

$552 \mathrm{p}$.

Tese (Doutorado) - Escola Politécnica da Universidade de São Paulo. Departamento de Engenharia de Construção Civil.

1.Engenharia e Planejamento Urbano I.Universidade de São Paulo. Escola Politécnica. Departamento de Engenharia de Construção Civil II.t. 


\section{AGRADECIMENTOS}

Ao Grande Arquiteto do Universo, por me dar força e energia para que essa desafiadora pesquisa saísse de um sonho e se tornasse realidade.

A minha Orientadora, Prof. ${ }^{a}$. Dr ${ }^{a}$. Karin Regina de Castro Marins - cuja enorme inteligência, sabedoria, paciência, orientação, e humildade são ímpares -, pela oportunidade e acolhida. Manifesto minha mais profunda gratidão e eterna admiração.

À Universidade de São Paulo e ao Programa de Pós-Graduação em Engenharia Civil, por criar os caminhos e os meios para que esta pesquisa se realizasse.

Às secretárias do Programa, em especial Wandréa, que com prontidão e paciência nos ajuda em diversos momentos complexos.

Aos colegas do grupo de pesquisa, Marcelo, Ricardo, Thiago, Martina, Quentin, Renato e Carolina, cujas reflexões amadureceram inúmeras percepções minhas. Em especial à Silvia e Larissa, cuja iniciativa e ajuda muito contribuíram para a obtenção dos resultados e condução das dinâmicas de grupo neste trabalho - sem elas isso não seria possível.

Aos Professores do programa, cada um deles contribui significativamente para a expansão de horizontes de conhecimento, em especial ao Professor Dr ${ }^{\circ}$. Fernando Akira Kurokawa, cuja paciência, dedicação e apoio no equacionamento do trabalho foram fundamentais para a conclusão- sempre de forma profícua e proativa dispôs do seu tempo para contribuir com esta pesquisa.

Às Professoras Dr${ }^{a}$. Úrsula Peres e Dra. Paula Santoro, que mesmo não podendo participar da banca, fizeram contribuições únicas ao trabalho e me auxiliaram muito na compreensão dos processos participativos, com acolhimento, de braços abertos, na EACH e na FAU.

Agradeço à Pontifícia Universidade Católica de São Paulo pelo apoio institucional, a concessão do espaço físico e do apoio financeiro recebido pelo Plano de Incentivo à Pesquisa - PIPEQ, ressaltando-se que o conteúdo deste trabalho e sua respectiva divulgação/publicação é de minha exclusiva responsabilidade, e que as opiniões, declarações, conclusões e as recomendações manifestadas no presente trabalho não refletem obrigatoriamente a posição da PUC-SP.

Agradeço aos parceiros, amigos e alunos da PUC/SP, da FEI e da USJT, que ajudaram na divulgação do projeto, nas opiniões para criação das peças gráficas e na organização das atividades. Também ao Departamento de Engenharia de Construção Civil da POLI/USP pela divulgação institucional do projeto, manifesto meu agradecimento.

Especialmente, agradeço aos moradores da Móoca, do Belém e do Belenzinho que me acolheram de braços abertos no bairro, se engajaram e participaram das dinâmicas, cada um deles tem um pedaço deste resultado, sem eles nada seria possível, e expresso a eles minha eterna gratidão.

Aos meus familiares, em especial meus pais, Antônio e Elza, que em sua simplicidade sempre me apoiaram e entenderam os inúmeros dias de ausência e os finais de semana dedicados ao trabalho, além de sempre me ajudarem incondicionalmente, tanto quanto meus queridos irmãos Vivian e Ricardo. Meus cunhados Denis e Sheila, que sempre me incentivaram e apostaram no sucesso desta pesquisa.

E a tantos outros que também contribuíram para que este trabalho fosse realizado, alguns ajudando diretamente nas discussões, opiniões e revisões sobre os vários temas tratados, outros de forma indireta, nos seminários, congressos, simpósios e palestras que sempre enriqueceram o meu repertório e, consequentemente, o do trabalho. A todos que participam de cada detalhe da minha vida, meu profundo agradecimento. E, por fim, a minha companheira, amada e paciente, Aline, por entender os momentos de ausência e, apesar de tudo, contribuir para que este sonho se tornasse realidade. A todos, meu muito obrigado. 


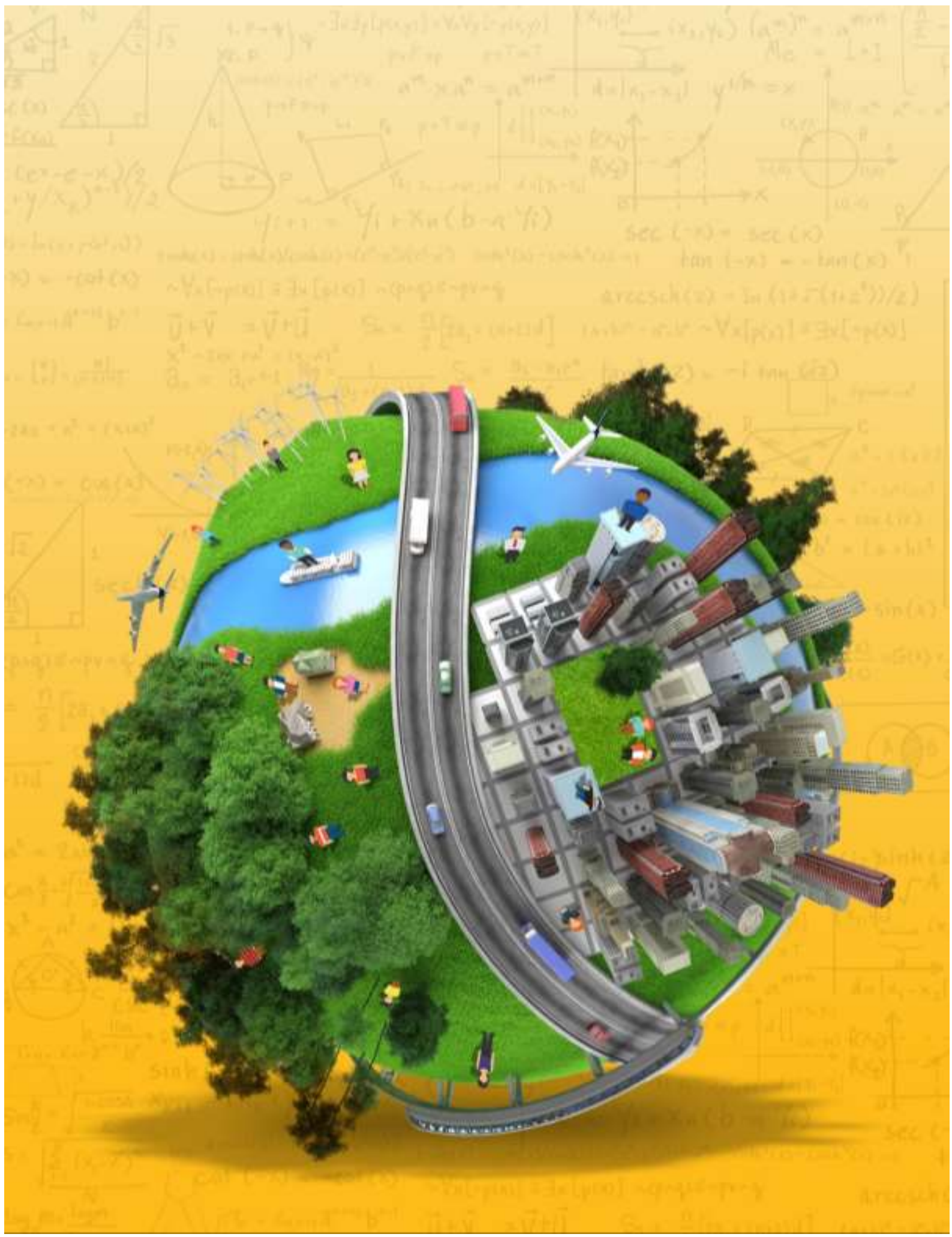

Não sabendo que era impossível, ele foi lá e fez.

(Jean Cocteau) 


\section{RESUMO}

As políticas públicas urbanas promovem o bem-estar humano nas cidades e sua relação com a dinâmica territorial. Uma das formas que as instituições governamentais têm para promover essa relação são elementos que abrangem um conjunto de intervenções e medidas que podem ou, ainda, devem - congregar a participação democrática da sociedade. A pesquisa consiste, em primeiro plano, no questionamento sobre a possibilidade de proposição de um procedimento metodológico de apoio a decisões, que integre de forma mais efetiva as contribuições sociais. Considera-se que estas possam indicar insumos técnicos, critérios, objetivos e alternativas que possibilitem a hierarquização e a melhoria das soluções em planejamento e engenharia urbanos, no desenvolvimento de áreas urbanas definidas, tais como bairros e distritos urbanos, assim como áreas de intervenção urbana, como as operações urbanas consorciadas. O objetivo da pesquisa foi desenvolver e aplicar uma proposta metodológica para inclusão da participação popular nos processos de tomada de decisão a fim de definir e hierarquizar estratégias em planejamento urbano, de forma construtivista, com apoio de revisão bibliográfica, entrevistas e aplicação da proposta metodológica em um estudo de caso na região do Belém, subprefeitura da Mooca, no município de São Paulo. A pesquisa partiu de aprofundamento teórico sobre os processos de desenvolvimento de áreas urbanas e sobre os processos decisórios participativos. Em seguida, foram realizadas a identificação e a análise de métodos e ferramentas que captassem a percepção dos agentes - em particular da participação popular - que pudessem auxiliar na construção de uma proposta metodológica para avaliação e captação da participação popular aplicável a processos de tomada de decisão, de forma estruturada e multicriterial. Os resultados apontaram que, quando há integração de abordagens à luz da ciência pós-normal, instrumentos e técnicas de consulta popular e a ciência de decisões, em processos de planejamento urbano, é possível um delineamento de diretrizes e procedimentos para tornar a participação popular mais efetiva do que a prática corrente. Interessante observar que uma abordagem transversal, e multidisciplinar, quando aplicada ao planejamento urbano favorece a resolução de questões que envolvem incertezas gerando valiosas contribuições ancoradas nos anseios da população. Complementarmente, a pesquisa desenvolveu um novo modelo racional de aplicação de modelos multicriteriais que reduz a subjetividade de comparações paritárias.

Palavras-chave: Planejamento Urbano, Projetos de Transformação Urbanística, Metodologia, Tomada de Decisão Multicriterial, Participação Popular. 


\begin{abstract}
Urban public policies seek to promote human well-being in cities and their relationship with territorial dynamics. One of the ways that government institutions have to promote this relationship is that it encompasses a set of interventions and measures that can - or must - bring together the democratic participation of society. The research consists, first of all, in the questioning of the possibility of proposing a methodological procedure to support decisions that could more effectively integrate social contributions. This method application could deliver technical inputs, criteria, objectives and alternatives that allow the hierarchy and improvement of solutions in urban planning and engineering, in the development of defined urban areas, such as neighborhoods and urban districts, as well as urban intervention areas, such as consortium urban operations. The objective of the research was to develop and apply a methodological proposal to include popular participation in decision making processes for the definition and hierarchization of strategies in urban planning, in a constructivist way, with support of bibliographic review, interviews and application of the methodological proposal in one. The research started from a theoretical background on the development processes of urban areas and on participatory decision-making processes. Next, the identification and analysis of methods and tools that capture the agents' perception - in particular of popular participation were carried out, which may help in the construction of a methodological proposal for the evaluation and capture of popular participation applicable to decision-making processes, in a structured and multicriterial procedure The results showed that when there is an integration of approaches in the light of post-normal science, instruments and techniques of popular consultation and the science of decisions, in urban planning processes, it is possible to outline guidelines and procedures to make popular participation more effective than current practice. It is interesting to note that a cross-sectional and multidisciplinary approach, when applied to urban planning, favors the resolution of issues involving uncertainties generating valuable contributions anchored in the wishes of the population. In addition, the research has developed a rational process of applying multicriteria models that reduces the subjectivity of parity comparisons.
\end{abstract}

Keywords: Urban Planning, Urban Transformation Projects, Methodology, Multicriteria Decision Making, Popular Participation. 


\section{LISTA DE ILUSTRAÇÕES}

Figura 1 - Status e Projeções das Dez Maiores Populações Urbanas ..................................... 26

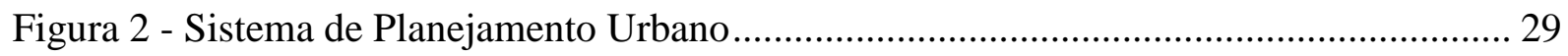

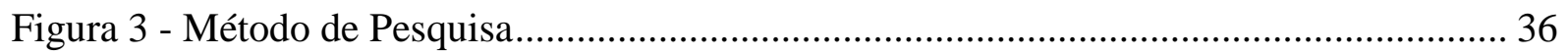

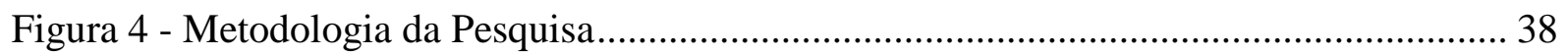

Figura 5 - Três Fases do Processo de Urbanização............................................................... 44

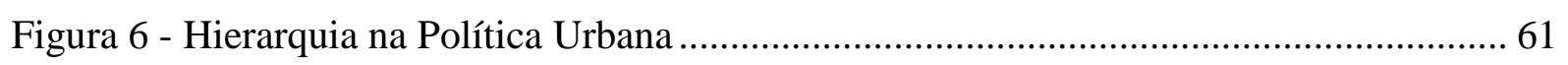

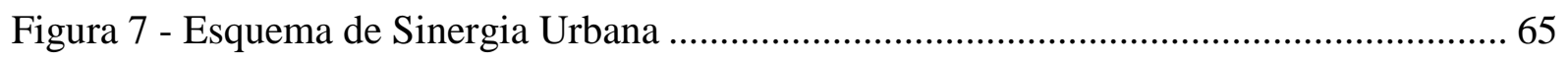

Figura 8 - Sujeitos Sociais Envolvidos no Processo de Tomada de Decisão .......................... 77

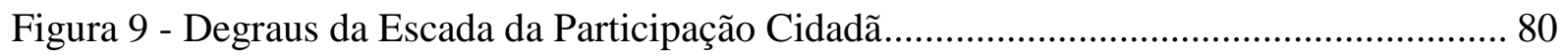

Figura 10 - Escada de Participação: Nível "Não Participação" ................................................ 80

Figura 11 - Escada de Participação: Nível "Pseudoparticipação" .......................................... 81

Figura 12 - Escada de Participação: Nível "Participação" ....................................................... 81

Figura 13 - Níveis de participação conforme Arnstein e Choguill........................................ 82

Figura 14 - Mecanismos de Participação Institucionalizados no Brasil .................................. 83

Figura 15 - Mecanismos de Participação Direta e Indireta ...................................................... 93

Figura 16 - Relação entre Visões, Ações e Planejamento em âmbito local .......................... 101

Figura 17 - Capacidade deliberativa e a diversidade dos atores.......................................... 105

Figura 18 - Participação em Processos de Planejamento e Abordagens Participativas ......... 113

Figura 19 - Abordagem Educacional na Fundamentação de Abordagens Participativas ...... 115

Figura 20 - Espaços inclusivos e exclusivos de participação popular .................................. 117

Figura 21 - Distribuição das contribuições em cada oficina ............................................... 128

Figura 22 - Distribuição das contribuições por tema .......................................................... 130

Figura 23 - Seleção de pontos para aplicação das entrevistas ............................................... 137

Figura 24 - Condicionantes para a falta de engajamento em processos participativos .......... 138

Figura 25 - Contexto multicritério para tomada de decisão ............................................... 196

Figura 26 - Estrutura genérica hierárquica de redes multicriteriais ................................... 209

Figura 27 - Estrutura de construção da proposta metodológica .......................................... 210

Figura 28 - Proposta de Abordagem Metodológica Participativa Com Apoio Multicriterial 212

Figura 29 - Estruturação Hierárquica de Análise Multicriterial (MCDA) ............................. 215

Figura 30 - Fluxo estruturado da proposta metodológica ..................................................... 222

Figura 31 - Distritos da Subprefeitura da Mooca e a Localização na Região Metropolitana 309

Figura 32 - Distribuição da Densidade Demográfica em 2010 ............................................. 311 
Figura 33 - Taxa de Crescimento da População entre 2000 e 2010

Figura 34 - Sumarização de Desenvolvimento Social 2010 ….............................................313

Figura 35 - Mapa do Zoneamento Vigente em São Paulo (2016) .......................................... 314

Figura 36 - Mapa do Zoneamento Anterior de São Paulo (2004) ......................................... 316

Figura 37 - Taxas de Ocupação segundo o Zoneamento de 2004 e 2016 para a Subprefeitura da Mooca

Figura 38 - Variação do Coeficiente de Aproveitamento Mínimo (CAmín) e Máximo (CAmáx) entre 2004 e 2016

Figura 39 - Distribuição Espacial das Associações na Área Objeto de Estudo.......................323

Figura 40 - Recorte de aplicação da proposta metodológica ..............................................325

Figura 41 - Peças gráfica do padrão de identidade visual....................................................337

Figura 42 - Capa da página de envolvimento do projeto ....................................................338

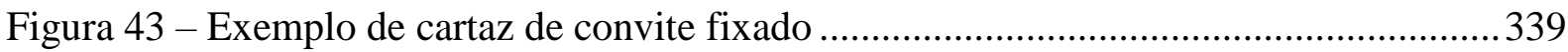

Figura 44 - Detalhe das informações apresentadas nos cartazes .........................................340

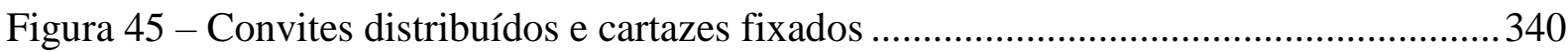

Figura 46 - Estratégia de envolvimento com redes sociais ................................................ 341

Figura 47 - Organização da etapa de mobilização ............................................................. 342

Figura 48 - Preparação dos locais e recepção para as dinâmicas ..........................................343

Figura 49 - Organização das salas para aplicação das dinâmicas ...........................................344

Figura 50 - Preparação da sala com fotografias e mapas da aera objeto de estudo ................345

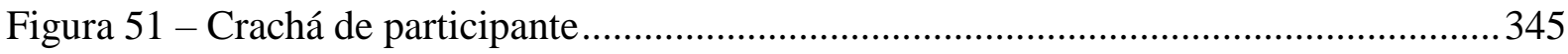

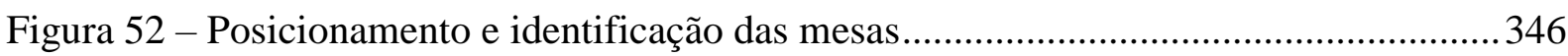

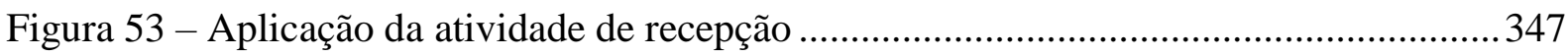

Figura 54 - Representação da dinâmica de apresentação.................................................... 348

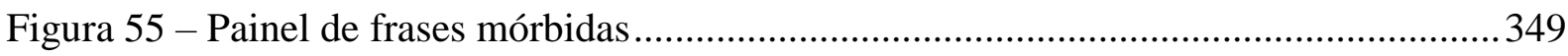

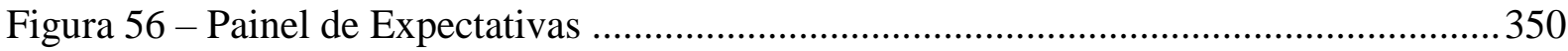

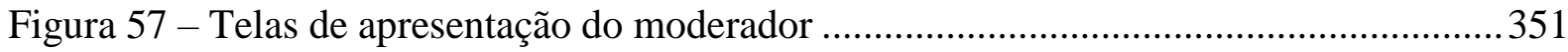

Figura 58 - Aplicação do Painel de Seleção de Problemas.......................................................352

Figura 59 - Painel de Seleção de Problemas preenchido ..........................................................353

Figura 60 - Aplicação das fichas para tempestade cerebral de soluções ...............................354

Figura 61 - Painel Gráfico colaborativo da Visão .............................................................. 355

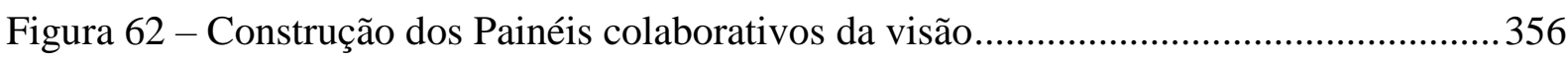

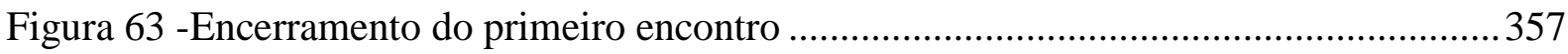


Figura 64 - Interpretação dos Painéis de Seleção de Problemas e Gráfico Colaborativo da Visão 359

Figura 65 - Construção do Painel de Impacto dos Problemas 360

Figura 66 - Interpretação da Tempestade cerebral de soluções e do painel colaborativo da visão 360

Figura 67 - Construção do Painel de Avaliação das Alternativas (Dificuldade de Implantação 361

Figura 68 - Elaboração do Painel de Abrangência 362

Figura 69 - Elaboração do Painel de Crítica Postergada (Seleção de nós críticos). 363

Figura 70 - Elaboração do Painel de ligação Peer-to-Peer (Correlação e Ligação) . 364

Figura 71 - Elaboração do Painel de Análise e Correlação de Alternativas. .365

Figura 72 - Disposição da sala para aplicação das dinâmicas 367

Figura 73 - Exemplo de tela de exposição do moderador 368

Figura 74 - Disposição dos painéis de valoração dos problemas 369

Figura 75 - Valoração do Painel de Efeitos e Impactos dos Problemas 370

Figura 76 - Estabelecimento das Redes Peer-to-Peer..... 371

Figura 77 - Verificação da intensidade das correlações 372

Figura 78 - Verificação da intensidade das correlações 373

Figura 79 - Preenchimento do painel de abrangência ( Inserção territorial e escala) 374

Figura 80 - Avaliação de fraquezas e ameaças (Seleção de nós críticos e critica postergada) 375

Figura 81 - Elaboração do Mosaico de Fotos de Problemas e Alternativas..... 376

Figura 82 - Retomada ao painel de expectativas 377

Figura 83 - Pesquisa de satisfação e emissão de certificados. 378

Figura 84 - Distribuição dos participantes por canal de envolvimento .385

Figura 85 - Distribuição de frases mórbidas 388

Figura 86 - Distribuição de expectativas 388

Figura 87 - Interpretação dos painéis para seleção dos problemas 389

Figura 88 - Sistematização de problemas para o grupo 1. 390

Figura 89 - Sistematização de problemas para o grupo 2 391

Figura 90 - Sistematização de problemas para o grupo 3 392

Figura 91 - Sistematização de problemas para o grupo 4 . 393

Figura 92 - Interpretação das alternativas 394

Figura 93 - Sistematização de alternativas para o grupo 1 395 


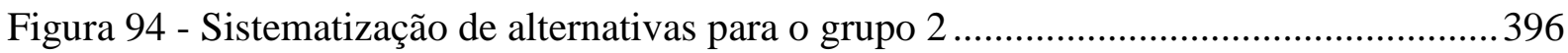

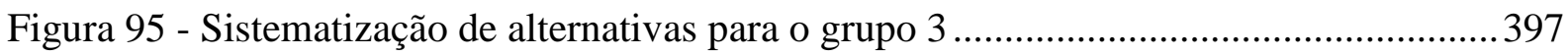

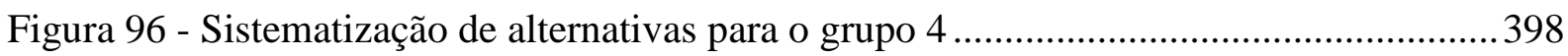

Figura 97 - Obtenção dos índices a partir dos painéis valorados ..........................................399

Figura 98 - Processo de hierarquização das alternativas a partir da valoração dos painéis ...456

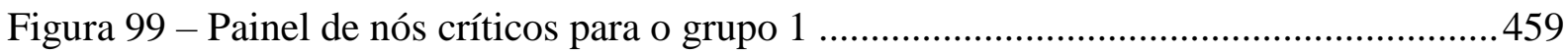

Figura 100 - Avaliação da Segurança na Área de Estudo ....................................................486

Figura 101 - Avaliação dos Serviços na Área de Estudo ....................................................487

Figura 102 - Avaliação do Transporte na Área de Estudo ...................................................487

Figura 103 - Avaliação do Lazer na Área de Estudo............................................................48

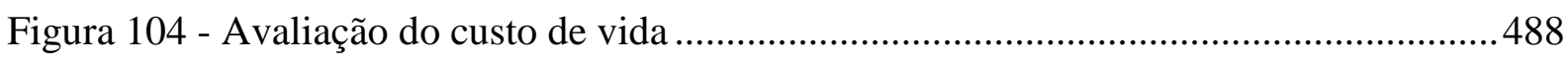

Figura 105 - Considerações sobre o Bairro ou a Cidade Ideal - Antes da Aplicação das

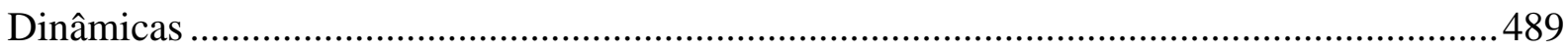

Figura 106 - Considerações sobre o Bairro ou a Cidade Ideal - Após a Aplicação das Dinâmicas

Figura 107 - Avaliação quanto a redução do número de vagas de estacionamento ..............491

Figura 108 - Avaliação quanto à ampliação das calçadas...................................................491

Figura 109 - Avaliação sobre a construção de edifícios de uso misto..................................492

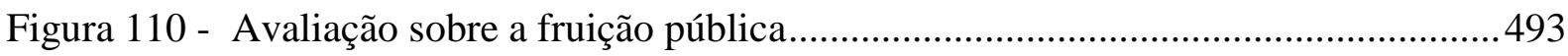

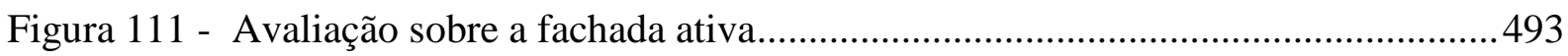

Figura 112 - Tempo médio de deslocamento na cidade para os participantes ......................494

Figura 113 - Frequência de utilização do transporte públicos pelos participantes................495

Figura 114 - Frequência de locomoção a pé pelos participantes ...........................................495

Figura 115 - Frequência de utilização dos espaços públicos pelos participantes ..................496

Figura 116 - Satisfação dos participantes quanto as etapas da proposta metodológica.........498

Figura 117 - Avaliação dos participantes quanto ao instrumentos ......................................498

Figura 118 - Avaliação dos participantes quanto ao instrumentos e sua dificuldade ............499

Figura 119 - Avaliação dos participantes quanto as expectativas........................................499 


\section{LISTA DE TABELAS}

Tabela 1 - Exemplo de matriz de comparação pareada de problemas 252

Tabela 2 - Resultado do exemplo de matriz de comparação pareada de problemas 252

Tabela 3 -Dados do exemplo da matriz de comparação pareada dos problemas para obtenção da constate $\mathrm{K}$ e determinação da função valor 254

Tabela 4 - Valores de y após aplicação da função valor no exemplo de comparação pareada dos problemas . 255

Tabela 5 - Resultados simplificado de aplicação da função valor no exemplo de comparação pareada dos problemas. 256

Tabela 6 - Intervalos da distância relativa (x) associados a escala de Saaty (y) ...... 256

Tabela 7 - Intervalos da distância relativa (x) associados a escala de Saaty (y) para os recíprocos 257

Tabela 8 - Dados do exemplo da matriz de comparação antes da transformação para escalda de Saaty 258

Tabela 9 - Dados do exemplo da matriz de comparação após a transformação para escala de Saaty 258

Tabela 10 - Comparação pareada dos problemas com a escala de Saaty antes da normalização 259

Tabela 11 - Comparação pareada dos problemas com a escala de Saaty após a normalização 259

Tabela 12 - Exemplo de dominância de cada problema a partir da norma da matriz de comparação pareada. 260

Tabela 13 - Determinação do IHP para o exemplo proposto .............................................. 260

Tabela 14 - Exemplo de cálculo dos índices de flexibilidade de problemas......................... 263

Tabela 15 - Exemplo de cálculo dos índices de flexibilidade de alternativas ....................... 265

Tabela 16 - Exemplo de composição de marcações diretas, indiretas, completas e incompletas

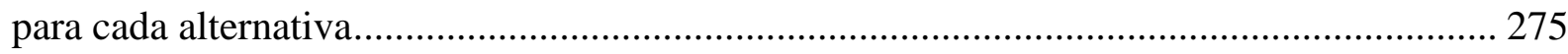

Tabela 17 - Exemplo dos índices de avaliação das alternativas .......................................... 275

Tabela 18 - Exemplo dos índices de avaliação das alternativas normalizados ..................... 276

Tabela 19 - Exemplo de cálculo do Índice Geral de Assertividade das Alternativas Ponderado

Tabela 20 - Exemplo de Cálculo das distâncias relativas do Índice Geral de Assertividade das Alternativas Ponderado 
Tabela 21 - Exemplo da dominância de uma alternativa a outra após aplicação da função valor

Tabela 22 - Exemplo de cálculo do índice geral de abrangência das alternativas hierarquizado

Tabela 23 - Exemplo de composição de marcações diretas, indiretas, completas e incompletas para cada problema. 288

Tabela 24 - Exemplo dos índices de avaliação dos problemas. 289

Tabela 25 - - Exemplo dos índices de avaliação dos problemas normalizados 289

Tabela 26 - Exemplo de cálculo do Índice Geral de Assertividade dos Problemas Ponderado

Tabela 27 - Exemplo de Cálculo das distâncias relativas do Índice Geral de Assertividade dos Problemas Ponderado 290

Tabela 28 - Exemplo da dominância de um problema a outro após aplicação da função valor 290

Tabela 29 - Exemplo de cálculo do Índice Geral de Assertividade dos Problemas hierarquizado 290

Tabela 30 - Exemplo de comparação dos índices gerais de dificuldade das alternativas ......298 Tabela 31 - Exemplo das distancias relativas dos índices gerais de dificuldade das alternativas 299

Tabela 32 - Exemplo de comparação paritária das alternativas na escala semântica de Saaty após a aplicação da função valor

Tabela 33 - Exemplo de preparação das comparações paritária para o cálculo do índice hierárquico das alternativas 301

Tabela 34 - Exemplo de normalização das comparações paritárias para cálculo do índice hierárquico das alternativas 302

Tabela 35 - Exemplo da norma 1 aplicada a comparação paritária das alternativas para cálculo do índice hierárquico das alternativas 302

Tabela 36 -Exemplo de cálculo do Índice hierárquico das alternativas 302

Tabela 37 - Exemplo de cálculos dos índices priorizadores de problemas e de alternativas.304

Tabela 38 - Áreas das Zonas do Zoneamento Vigente - 2016 315

Tabela 39 - Áreas das Zonas do Zoneamento de 2004 317

Tabela 40- Áreas de Taxa de Ocupação Máxima do Zoneamento Vigente e do Zoneamento de 2004 318 
Tabela 41 - Áreas Coeficiente de Aproveitamento Mínimo do Zoneamento Vigente e do Zoneamento de 2004

Tabela 42 - Áreas de Coeficiente de Aproveitamento Máximo do Zoneamento Vigente e do Zoneamento de 2004 320

Tabela 43 - Detalhamento dos encontros e da presença nas dinâmicas ................................ 383

Tabela 44 - Distribuição Etária e por Gênero das dinâmicas ............................................... 386

Tabela 45 - Distribuição de renda e escolaridade dos participantes..................................... 386

Tabela 46 - Preenchimento dos Painel de Impacto dos Problemas para o grupo 1.............. 400

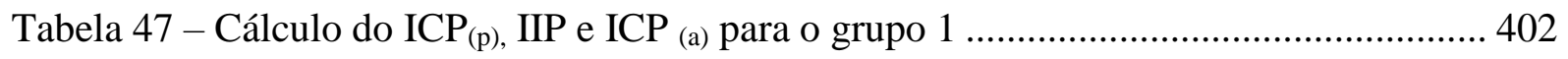

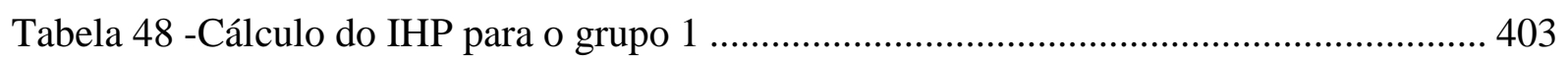

Tabela 49 - Preenchimento dos Painel de Impacto dos Problemas para o grupo 2 2............. 404

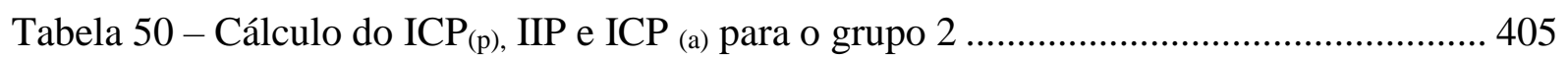

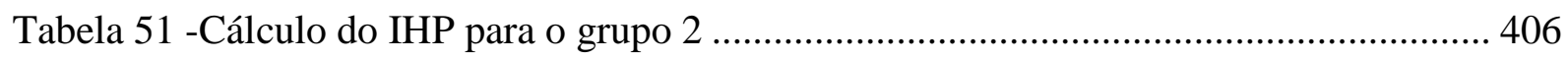

Tabela 52 - Preenchimento dos Painel de Impacto dos Problemas para o grupo 3.............. 407

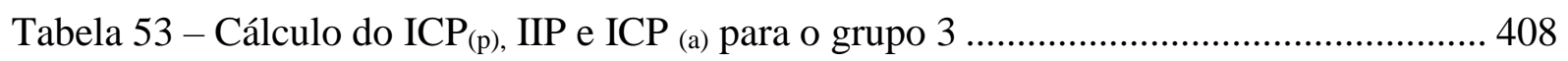

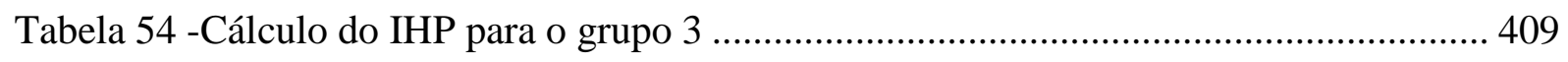

Tabela 55 - Preenchimento dos Painel de Impacto dos Problemas para o grupo 4.............. 409

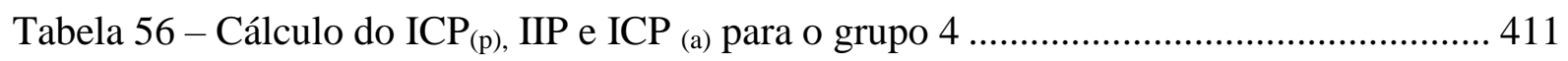

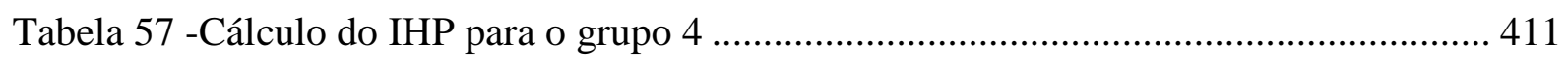

Tabela 58 - Analisa do painel de correção de alternativas e problemas para o grupo 1 ....... 413

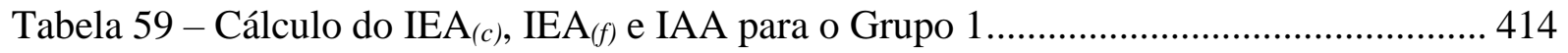

Tabela 60 - Cálculo do IEA $(\mathrm{e})$, ISA, ICA e IIA para o grupo 1 ........................................... 415

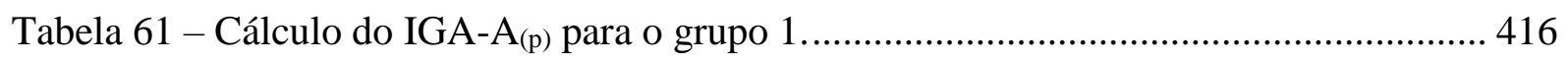

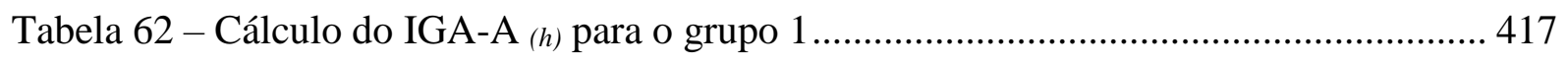

Tabela 63 - Marcações para atendimento dos problemas no grupo 1 ................................... 418

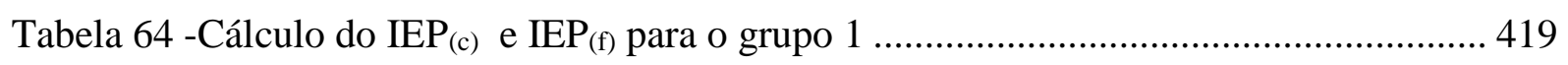

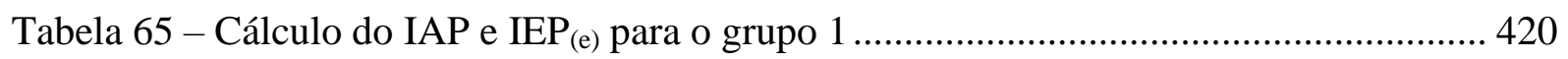

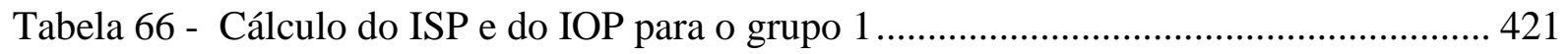

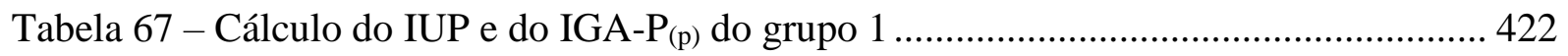

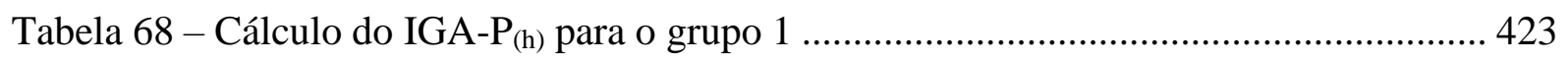

Tabela 69 - Cálculo dos avaliadores do processo para o grupo 1 ........................................ 424

Tabela 70 - Marcações no painel de correlação para o grupo 1 ............................................ 424

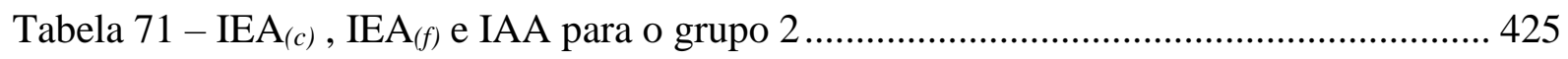

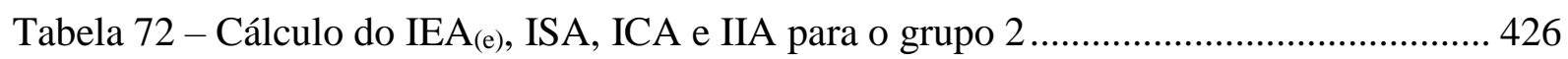




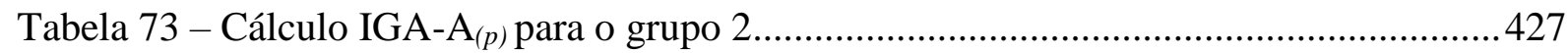

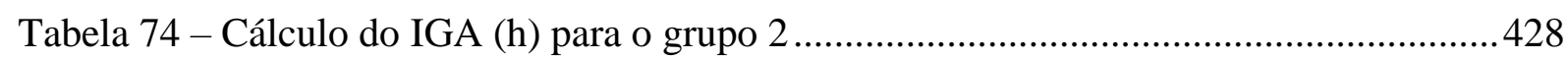

Tabela 75 - Marcações no painel de correlações para os problemas no grupo 2 …............... 429

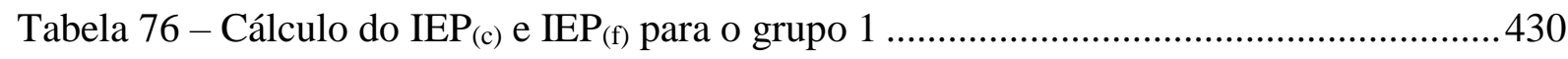

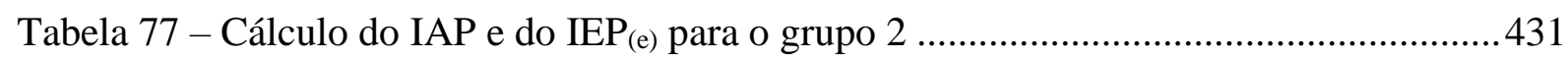

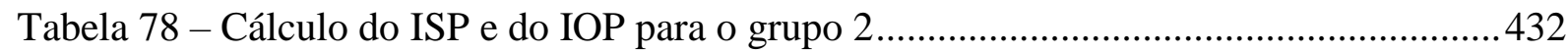

Tabela 79 - Cálculo do IUP e do IGA-P(p) para o grupo 2 ................................................433

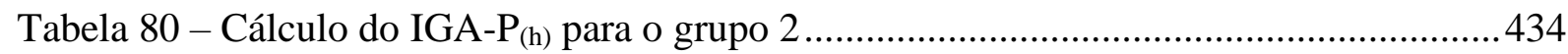

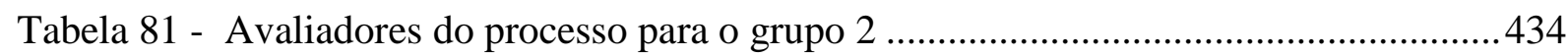

Tabela 82 - Marcações das alternativas no painel de correlação para o grupo 3...................435

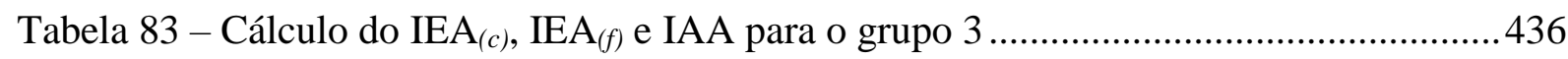

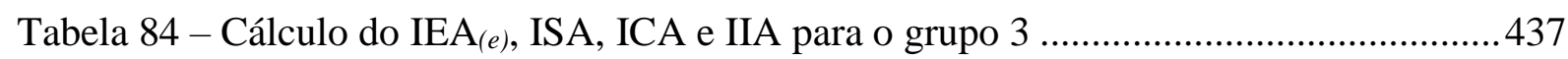

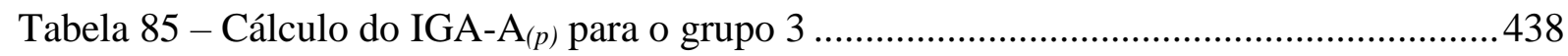

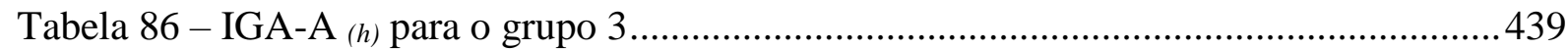

Tabela 87 - Marcações nos problemas no painel de correlação para o grupo 3 .....................440

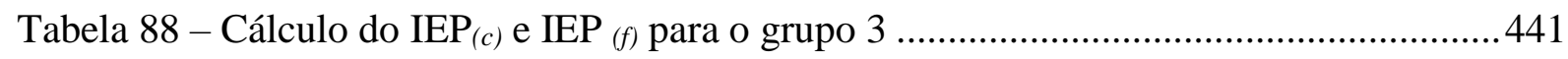

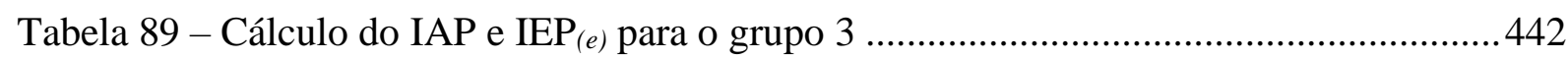

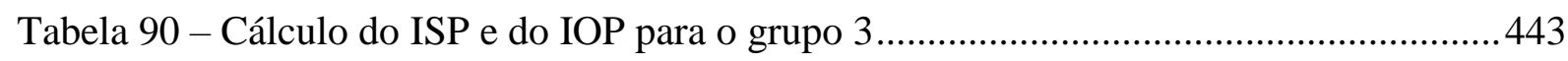

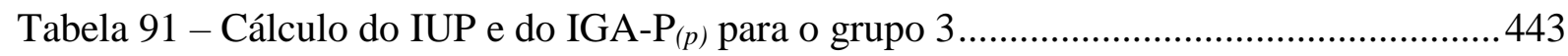

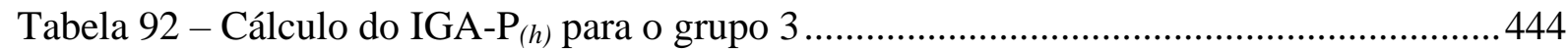

Tabela 93 - Avaliadores do processo para o grupo 3 ............................................................444

Tabela 94 - Marcações nas alternativas no painel de correlação para o grupo 4...................445

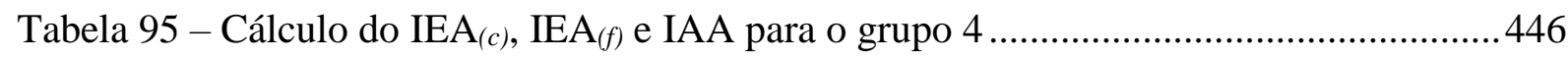

Tabela 96 - Cálculo do IEA $_{(e)}$, ISA, ICA e IIA para o grupo 4 ..........................................446

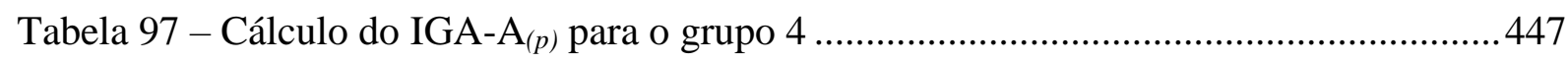

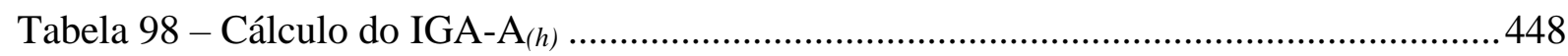

Tabela 99 - Marcações para os problemas no painel de correlação para o grupo 4 ..............449

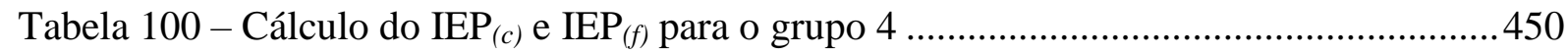

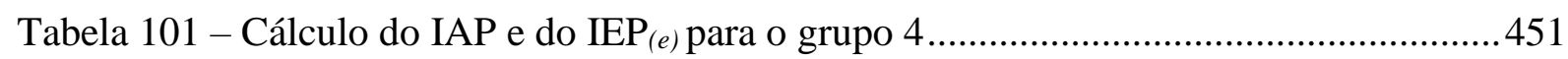

Tabela 102 - Cálculo do ISP e do IOP para o grupo 4 ........................................................452

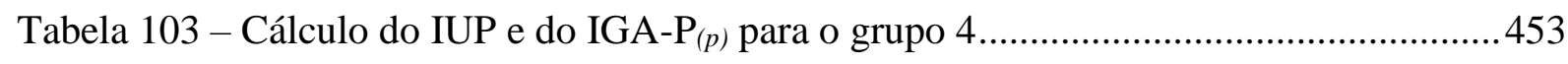

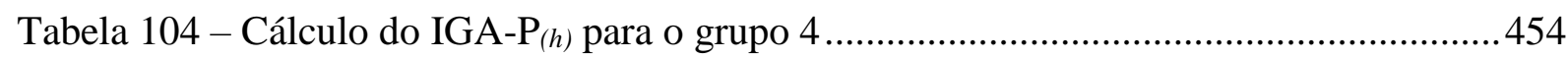

Tabela 105 - Avaliador do processo para o grupo 4 ..........................................................454

Tabela 106 - Comparativo entre os avaliadores do processo para os diferentes grupos........455 
Tabela 107 - Preenchimento do painel de dificuldades para o grupo 1 456

Tabela 108 - Cálculo no IDI-A, IDA-A e IGD-A para o grupo 1 457

Tabela 109 - Cálculo do IDI-A, IDA-A e IGD-A para o grupo 1 apenas para alternativas favoráveis 458

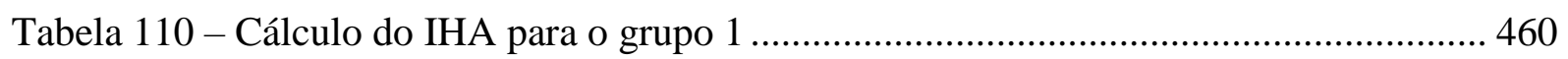

Tabela 111 - Valoração para dificuldade nas alternativas para o grupo 2 …....................... 461

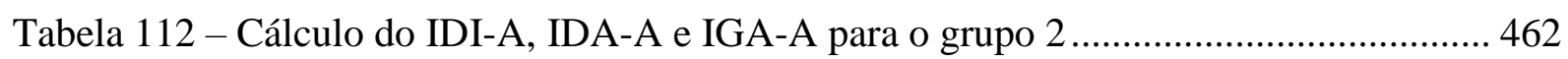

Tabela 113 - IDI, IDA-A e IGD-A para o grupo 2 apenas para alternativas favoráveis....... 462

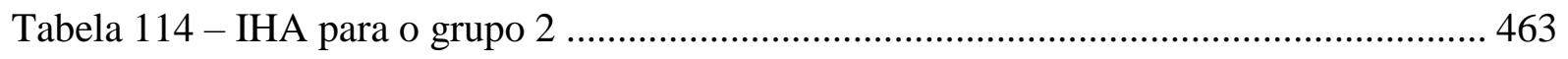

Tabela 115 - Valoração das dificuldades das alternativas para o grupo 3 ........................... 464

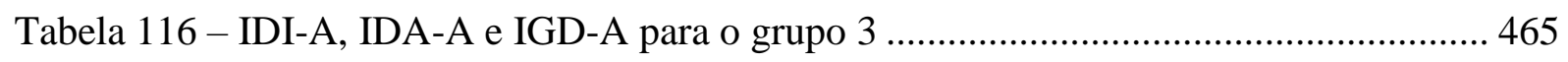

Tabela 117 - IDI-A, IDA-A e IGD-A somente para as alternativas favoráveis do grupo 3.. 466

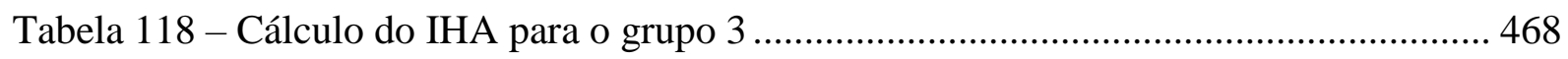

Tabela 119 - Valoração das dificuldades das alternativas para o grupo 4 ........................... 469

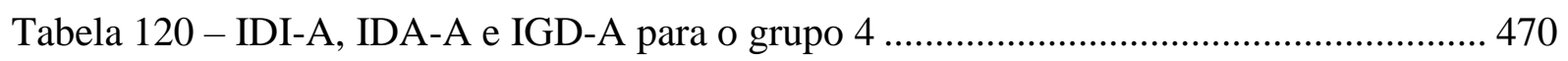

Tabela 121 - IDI-A, IDA-A e IGD-A para o grupo 4 considerando apenas as alternativas

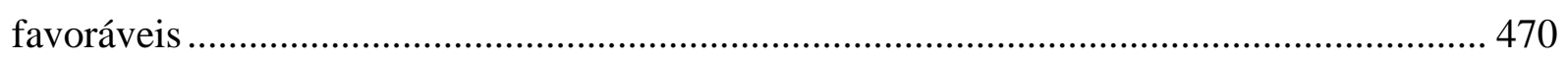

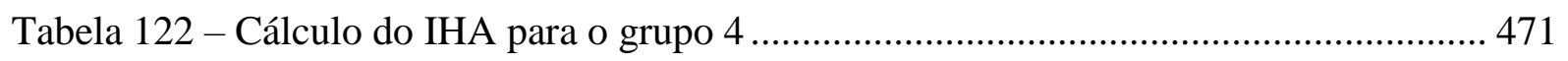

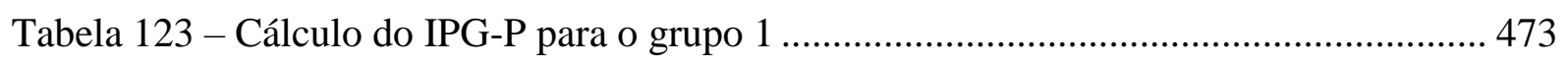

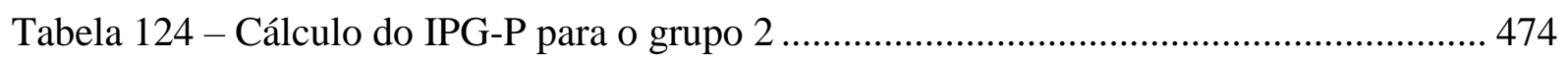

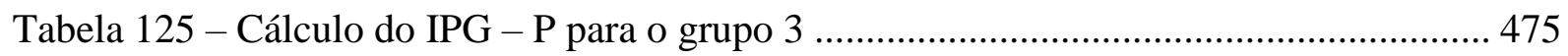

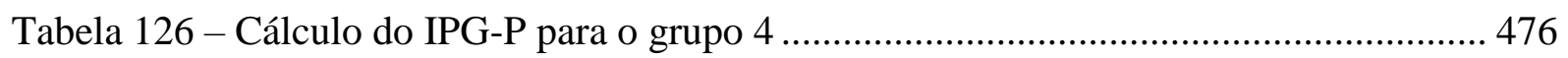

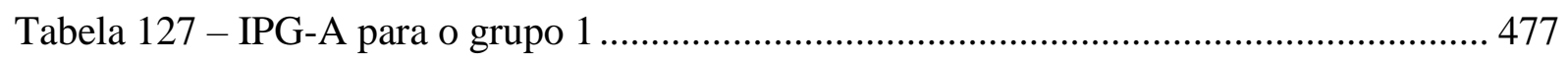

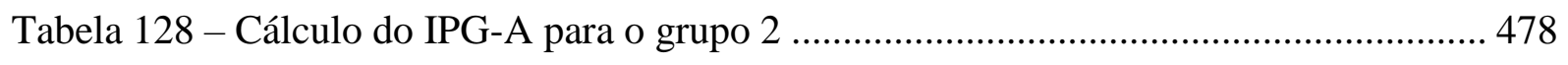

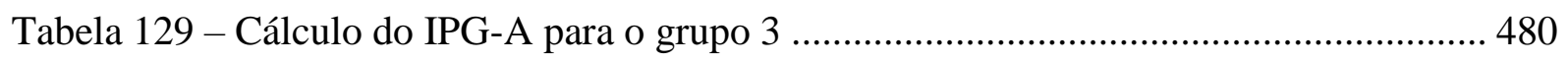

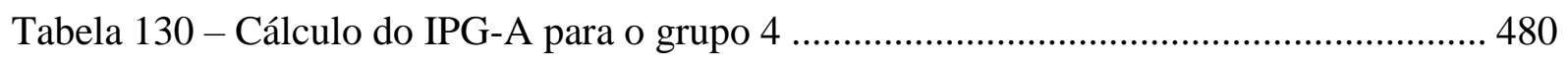

Tabela 131 - Cálculo do IEG-P para definição de estratégias.............................................. 481

Tabela 132 - Cálculo do IEG -A para definição de estratégias ........................................... 483 


\section{LISTA DE QUADROS}

Quadro 1 - Fatores Incidentes na Definição da Forma Urbana ............................................. 70

Quadro 2 - Sumarização dos Instrumentos Legais Participativos no Brasil ........................... 89

Quadro 3 - Formas e Características das Formas Usuais de Representação ............................ 96

Quadro 4 - Metodologia para a Construção de Consenso ...................................................... 109

Quadro 5 - Sumarização dos Grupos Focais .................................................................... 165

Quadro 6 - Sumarização da Cartografia Participativa e de Mapas Falantes ......................... 171

Quadro 7 - Momentos de MAPP - Passos ................................................................... 178

Quadro 8 - Distribuição de Participantes em Passos e Momentos ........................................ 179

Quadro 9 - Matriz de Comparação Pareada dos Critérios ...................................................... 194

Quadro 10 - Escala Semântica de Preferência..................................................................... 197

Quadro 11 - Índices de consistência aleatório de Saaty..................................................... 198

Quadro 12 - Função de transformação das distancias relativas para escala Semântica de

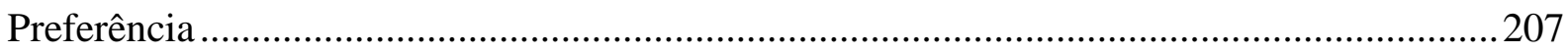

Quadro 13 - Determinação da função valor para escala Semântica de Preferência...............255

Quadro 14 - Exemplo de preenchimento do painel de correlação entre alternativas e problemas

Quadro 15 - Exemplo de preenchimento do painel de correlação entre alternativas e problemas .288

Quadro 16 - Exemplo de preenchimento do painel de correlação entre alternativas e problemas

Quadro 17 - Exemplo de cálculo dos avaliadores do processo

Quadro 18 - Propostas para a Subprefeitura da Mooca Resultantes da Audiência Pública ... 329

Quadro 19 - Propostas para a Subprefeitura da Mooca Resultantes da Audiência Pública ...330

Quadro 20 - Propostas para a Subprefeitura da Mooca Resultantes da Audiência Pública ...331

Quadro 21 - Propostas para a Subprefeitura da Mooca Resultantes da Audiência Pública ...332

Quadro 22 - Propostas para a Subprefeitura da Mooca Resultantes da Audiência Pública ...333

Quadro 23 - Distribuição das atividades, materiais, objetivos e duração no primeiro encontro

Quadro 24 - Distribuição das atividades, materiais, objetivos e duração no segundo encontro 


\section{LISTA DE ABREVIATURAS E SIGLAS}

A

AAP

AEP

AFP

AHP

AIA

AQC

BID

CA

$\mathrm{CA}$

$\mathrm{CA}_{i}$

$\mathrm{CCP}$

$\mathrm{CP}$

$\mathrm{CP}_{\mathrm{i}}$

$\mathrm{D}_{(\mathrm{a})}$

$\mathrm{D}_{(\mathrm{c})}$

$\mathrm{D}_{(\mathrm{d})}$

$\mathrm{D}_{(\mathrm{e})}$

$\mathrm{D}_{(\mathrm{f})}$

$\mathrm{D}_{(\mathrm{p})}$

$\mathrm{D}_{(\mathrm{r})}$

$\mathrm{D}_{(\mathrm{t})}$

$\mathrm{DC}_{(i)}$

$\mathrm{DC}_{(i)}$

$\mathrm{DC}_{(i)}$

$\mathrm{DI}_{(i)}$

$\mathrm{DI}_{(j)}$

$\mathrm{DI}_{(j)}$

EIA

EIV

ELECTRE

EPA

Número total de alternativas

Avaliador de Atendimento dos Problemas

Avaliador de Efetividade no Processo

Avaliador de Eficiência do Processo

Analytic Hierarch Process

Avaliação de Impacto Ambiental

Avaliador de Qualidade de Completude do Processo

Banco Interamericano de Desenvolvimento

Conexões da Alternativa

Coeficiente de Aproveitamento

Conexões da i-ésima Alternativa;

Compromise Programming

Conexões do Problema

Conexões do i-ésimo Problema

Pontuação total da dimensão dificuldade de aceitação popular

Pontuação total da dimensão dificuldade de correção dos problemas

Pontuação total da dimensão dificuldade de detecção dos problemas

Pontuação total da dimensão dificuldade econômica

Pontuação total da dimensão frequência do problema

Pontuação total da dimensão dificuldade política

Pontuação total da dimensão relevância do problema

Pontuação total da dimensão dificuldade técnica

i-ésima marcação direta e completa

i-ésima marcação direta e completa na alternativa

i-ésima marcação direta e completa no problema

$i$-ésima marcação direta e incompleta

j-ésima marcação direta e incompleta na alternativa

j-ésima marcação direta e incompleta no problema

Estudo de Impacto Ambiental

Estudo de Impacto de Vizinhança

Elimination et Choix Traduisant la Realité

Elementos Primários de Avaliação 
$f_{p}$

$\mathrm{f}_{\mathrm{t}}$

HIS

HMP

IAA

IAP

IBGE

$\mathrm{IC}_{(i)}$

$\mathrm{IC}_{(j)}$

IC

$\mathrm{IC}_{(k)}$

$\mathrm{IC}_{(k)}$

ICA

$\mathrm{ICP}_{(\mathrm{p})}$

$\mathrm{ICP}_{(\mathrm{a})}$

IDA-A

IDI-A

$\operatorname{IEA}_{(\mathrm{c})}$

$\operatorname{IEA}_{(\mathrm{e})}$

$\operatorname{IEA}_{(\mathrm{f})}$

IEG- $\mathrm{A}_{j}$

IEG- $\mathrm{P}_{i}$

$\operatorname{IEP}_{(\mathrm{c})}$

$\operatorname{IEP}_{(e)}$

$\operatorname{IEP}_{(\mathrm{f})}$

$\operatorname{IFA}_{(\mathrm{p})}$

$\mathrm{IFA}_{(\mathrm{r})}$

$\operatorname{IFP}_{(\mathrm{p})}$

$\operatorname{IFP}_{(\mathrm{r})}$

IGA-P $_{(\mathrm{p})}$

IGA-P $_{(\mathrm{h})}$

IGA-P $_{(h) i}$
Fator de majoração ou minoração da dificuldade econômica Fator de majoração ou minoração da dificuldade econômica Fator de majoração ou minoração da dificuldade política Fator de majoração ou minoração da dificuldade técnica Habitação de Interesse Social Habitação de Mercado Popular Índice de Abrangência das Alternativas Índice de Abrangências dos Problemas Instituto Brasileiro de Geografia e Estatística i-ésima marcação indireta e completa j-ésima marcação indireta e completa na alternativa j-ésima marcação indireta e completa no problema k-ésima marcação indireta e completa na alternativa k-ésima marcação indireta e completa no problema; Índice de Colateralidade das Alternativas Índice de Caracterização de Problemas Preliminar Índice de Caracterização de Problemas Ampliado Índice de Dificuldade de Ação nas Alternativas Índice de Dificuldade de Implantação de Alternativas Índice de Eficácia das Alternativas Índice de Eficiência das Alternativas Índice de Efetividade das Alternativas Índice de Estratégico Geral da Alternativa da j-ésima alternativa Índice Estratégico Geral do Problema do i-ésimo problema Índice de Eficácia dos Problemas Índice de Eficiência dos Problemas Índice de Efetividade dos Problemas Índice de Flexibilidade de Alternativas Preliminar Índice de Flexibilidade de Alternativas Relativo Índice de Flexibilidade de Problemas Preliminar Índice de Flexibilidade de Problemas Relativo Índice de Geral de Abrangência dos Problemas Ponderado Índice de Geral de Abrangência dos Problemas Hierarquizado Índice Geral de Abrangência dos Problema do i-ésimo problema. 


\begin{tabular}{|c|c|}
\hline IGA-A(p) & Índice Geral de Abrangência das Alternativas Ponderado \\
\hline IGA-A(h) & Índice Geral de Abrangência das Alternativas Hierarquizado \\
\hline IGA-A $(h) i$ & Índice Geral de Abrangência das Alternativas da $i$-ésima alternativa. \\
\hline IGD-A & Índice de Geral de Dificuldade da Alternativa \\
\hline $\mathrm{IGD}_{\mathrm{A}} \mathrm{A}_{(\mathrm{p})}$ & Índice de Geral de Dificuldade da Alternativa Ponderado \\
\hline IHA & Índice Hierárquico de Alternativas \\
\hline $\mathrm{IHA}_{\mathrm{i}}$ & Índice Hierárquico de Alternativas da $i$-ésima alternativa \\
\hline IPG-P normalizado $(i)$ & Índice priorizador geral de problemas do i-ésimo problema \\
\hline IHP & Índice Hierárquico do Problema \\
\hline $\mathrm{IHP}_{\mathrm{i}}$ & Índice Hierárquico de Problema do $i$-ésimo problema \\
\hline $\mathrm{II}_{(i)}$ & i-ésima marcação indireta e incompleta \\
\hline $\mathrm{II}_{(w)}$ & w-ésima marcação indireta e incompleta na alternativa \\
\hline $\mathrm{II}_{(w)}$ & w-ésima marcação indireta e incompleta no problema \\
\hline IIA & Índice de Incompletude das Alternativas \\
\hline IIP & Índice de Intervenção de Problemas \\
\hline IOP & Índice de Colateralidade nos Problemas \\
\hline IPG-P $P_{i}$ & Índice Priorizador Geral de Problemas do i-ésimo problema \\
\hline IPG-A $A_{i}$ & Índice Priorizador Geral de Alternativas da $i$-ésima alternativa \\
\hline IPG-A normalizado ( $j)$ & Índice priorizador geral de alternativas da j-ésima alternativa; \\
\hline ISA & Índice de Assertividade das Alternativas \\
\hline ISP & Índice de Assertividade nos Problemas \\
\hline IUP & Índice de Incompletude nos Problema \\
\hline 1 & Número total de marcações indiretas e incompletas na alternativa \\
\hline 1 & Número total de marcações indiretas e incompletas no problema \\
\hline LPUOS & Lei de Parcelamento, Uso e Ocupação de Solo \\
\hline $\mathrm{m}$ & Número total de marcações indiretas e completa na alternativa \\
\hline $\mathrm{m}$ & Número total de marcações diretas e incompletas na alternativa \\
\hline $\mathrm{m}$ & Número total de marcações indiretas e completas no problema \\
\hline MAPP & Método Altadir de Planejamento Popular \\
\hline MACBETH & Measuring Attractiviness by a Categorical Evaluation Technique \\
\hline MCDA & Multiple Criteria Decision Aid \\
\hline MCDM & Multiple Criteria Decision Making \\
\hline $\mathrm{N}$ & Número total de problemas \\
\hline $\mathrm{n}$ & Número total de problemas \\
\hline
\end{tabular}


n

ONG

ONU

OUC

$\mathrm{P}$

$\mathrm{pc}$

pi

PMCM

PDE

PMSP

PNPS

PROMETHEE

PUC

RMSP

SIG

SNPS

$\mathrm{t}$

t

USP

Z

Z

ZEIS
Número total de marcações diretas e completa na alternativa

Número total de marcações diretas e completas no problema

Organização Não Governamental

Organização das Nações Unidas

Operação Urbana Consorciada

Número total de problemas

Peso atribuído as soluções completas

Peso atribuído as soluções incompletas

Proposta metodológica Cruz \& Marins

Plano Diretor Estratégico

Prefeitura do Município de São Paulo

Política Nacional de Participação Social

Preference Ranking Organization Methods for Enrichment Evaluations

Pontifícia Universidade Católica de São Paulo

Região Metropolitana de São Paulo

Sistema de Informações Geográficas

Sistema Nacional de Participação Social

Número total de Grupos que contém o t-ésimo problema

Número total de Grupos que contém a t-ésima alternativa

Universidade de São Paulo

Número total de marcações indiretas e completas na alternativa

Número total de marcações indiretas e completas no problema

Zona Especial de Interesse Social 


\section{SUMÁRIO}

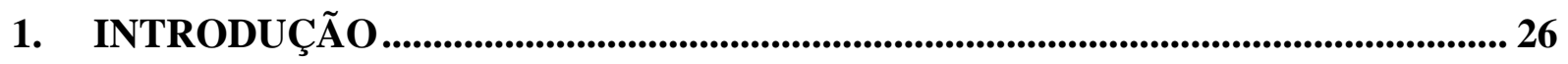

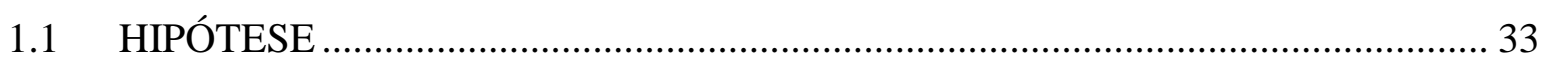

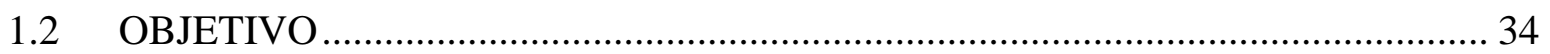

1.3 JUSTIFICATIVA E INEDITISMO DO TRABALHO............................................. 34

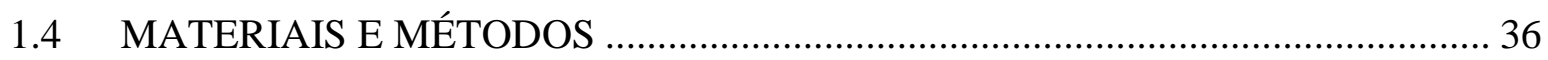

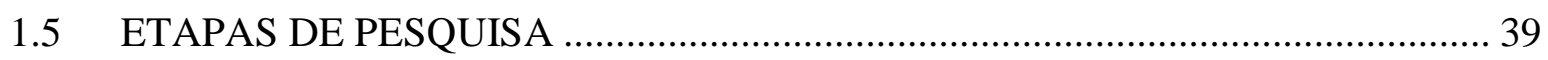

2. INSTRUMENTAÇÃO, ESTRUTURA E ESCALAS DE GOVERNANÇA URBANA NO BRASIL ............................................................................................................................... 42

2.3 MÉTRICAS EM INSTRUMENTOS URBANÍSTICOS E GESTÃO URBANA.... 62

2.4 ESCALAS URBANAS E AS INTERVENÇÕES URBANAS ………………….... 72

3. PARTICIPAÇÃO POPULAR EM PROCESSOS DECISÓRIOS RELATIVOS A

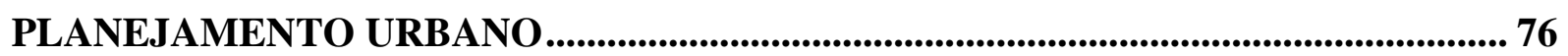

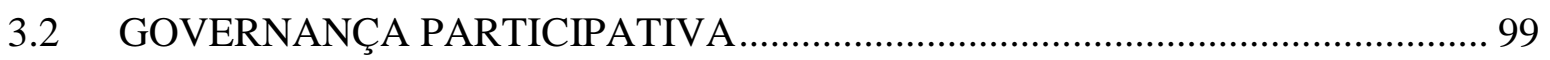

3.3 A PARTICIPAÇÃO POPULAR EM ÂMBITO LOCAL ....................................... 102

3.4 O PROCESSO DELIBERATIVO E A PARTICIPAÇÃO POPULAR …………..... 116

3.5 AVALIAÇÃO DO PROCESSO PARTICIPATIVO DE REVISÃO DO PDE DE SÃO PAULO DE 2014

3.6 APLICAÇÃO DE QUESTIONÁRIOS EM AREA URBANA SELECIONADA. 133

4. METODOLOGIAS DE PLANEJAMENTO E TOMADA DE DECISÃO APLICÁ VEIS A PROCESSOS PARTICIPATIVOS EM PLANEJAMENTO URBANO 142

4.1 ABORDAGENS À LUZ DA CIENCIA PÓS-NORMAL ……………………........ 142

4.2 GRUPO FOCAL COMO METODOLOGIA QUALITATIVA …………….......... 152

4.3 A CARTOGRAFIA PARTICIPATIVA E FALANTE........................................... 165

4.4 ABORDAGEM ESTRATÉGICA DE PLANEJAMENTO ……………………....... 171

4.5 MÉTODOS MULTICRITÉRIO DE AUXÍLIO À DECISÃO …………………...... 181

5. DESENVOLVIMENTO DE UMA PROPOSTA METODOLÓGICA PARA PARTICIPAÇÃO POPULAR NA DEFINIÇÃO DE ESTRATÉGIAS EM PLANEJAMENTO URBANO....................................................................................... 210

5.1 PROPOSTA METODOLÓGICA CRUZ \& MARINS - (PMCM) ......................... 218

6. APLICAÇÃO DA PROPOSTA METODOLÓGICA NA ÁREA SELECIONADA 308 
6.1 CARACTERIZAÇÃO DA ÁREA DE ESTUDO

6.2 ANÁLISE DA PARTICIPAÇÃO DA POPULAÇÃO DA SUBPREFEITURA DA MOOCA NA REVISÃO DO PDE DE 2014 E LPUOS DE 2016

6.3 APLICAÇÃO DA PROPOSTA METODÓLOGICA NA ÁREA SELECIONADA NO DISTRITO DO BELÉM, SUBPREFEITURA DA MOOCA, NO MUNICÍPIO DE SÃO PAULO. 336

7. ANÁLISE DO PROCESSO DE APLICAÇÃO DA PROPOSTA METODOLÓGICA 381

7.1 ANÁLISE DOS RESULTADOS DA APLICAÇÃO DA PROPOSTA METODOLÓGICA 382

8. CONCLUSÕES E CONSIDERAÇÕES FINAIS ....................................................501

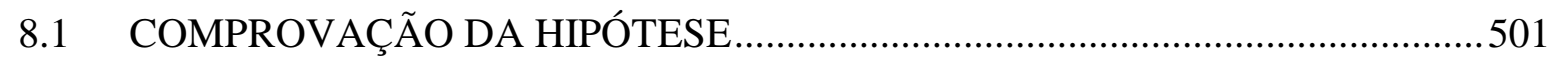

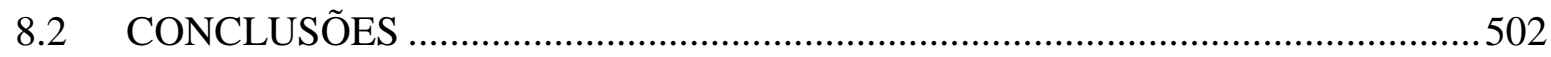

8.3 RECOMENDAÇÕES PARA CONTINUIDADE DA PESQUISA E OPORTUNIDADE DE TRABALHOS FUTUROS …………....................................506

REFERÊNCIAS ........................................................................................................508

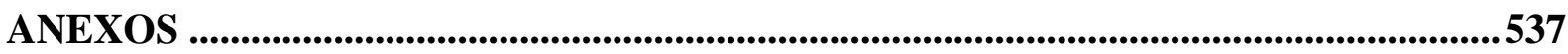

ANEXO A - APROVAÇÃO DO COMITÊ DE ÉTICA EM PESQUISA .........................538

ANEXO B - FLUXO GERAL DO PLANEJAMENTO ESTRATÉGICO SITUACIONAL - MÉTODO ALTADIR DE PLANEJAMENTO POPULAR - MAPP .............................540

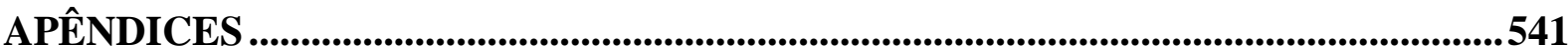

APÊNDICE A - TERMO DE CONSENTIMENTO E LIVRE ESCLARECIMENTO.542 APÊNDICE B - LISTA DAS ASSOCIAÇÕES E ORGANIZAÇÕES ATUANTES NA SUBPREFEITURA DA MOOCA .......................................................................544

APÊNDICE C - QUESTIONÁRIO APLICADO ÀS ENTREVISTAS............................549 APÊNDICE D- FLUXO GERAL DA PROPOSTA METODOLÓGICA CRUZ \& MARINS. 552 


\section{INTRODUCÃ̃O}

A Organização das Nações Unidas (ONU) constatou, em 2016, as informações sobre a população mundial, que, no século XXI a popualação mundial se tornou predominantemente urbana. A população urbana mundial em 2016 era do mesmo tamanho que a população total do mundo em 2004. O relatório mais recente da ONU, mostra que a população urbana quintuplicou nos últimos 60 anos, saltando de 746 milhões, em 1950, para 3,9 bilhões de habitantes, em 2014 (UNITED NATIONS, 2006 e 2016), conforme figura 1. Nas três décadas seguintes, esse número tende a aumentar, ultrapassando o total de 6 bilhões de habitantes em áreas urbanas em 2045, conforme previsões.

Figura 1 - Status e Projeções das Dez Maiores Populações Urbanas

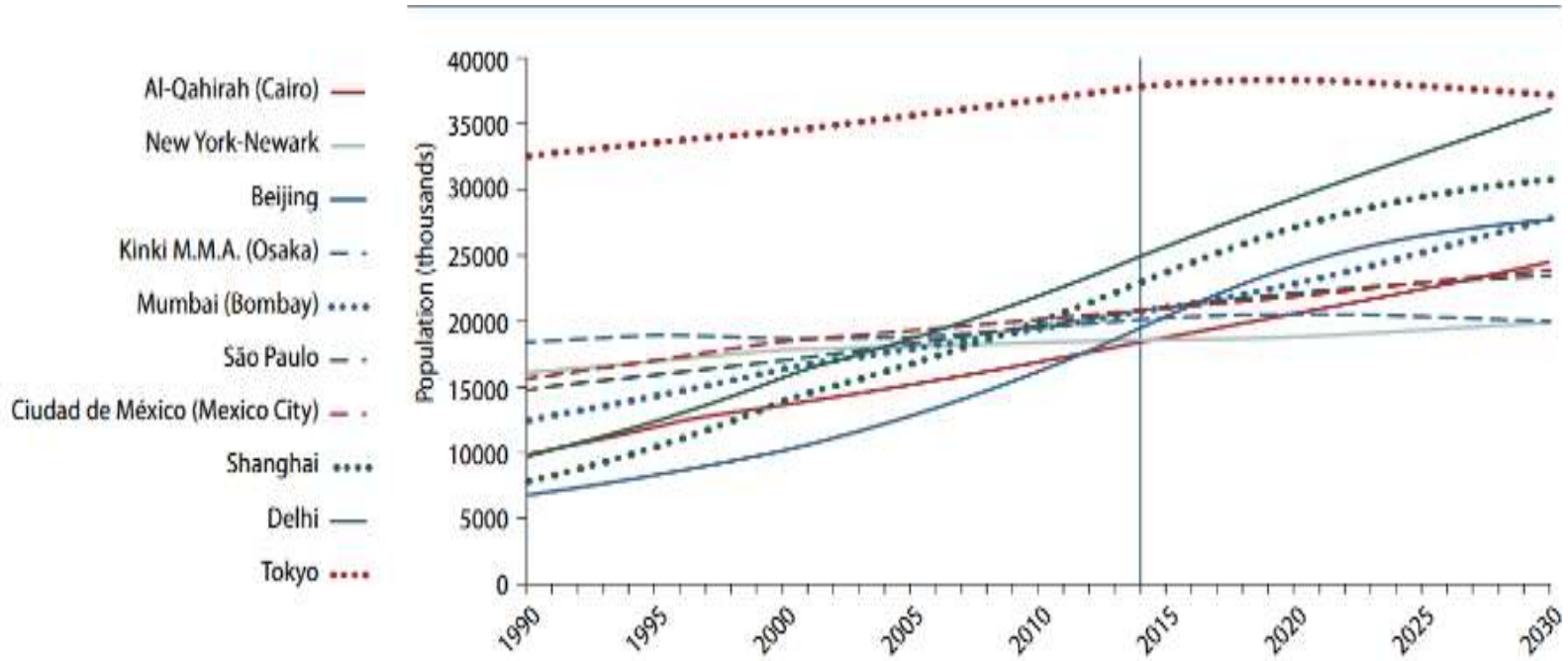

Fonte: Nações Unidas (2014) ${ }^{1}$.

Corroborando esse fato, praticamente todo o crescimento da população mundial é absorvido pelas áreas urbanas das regiões menos desenvolvidas e das em desenvolvimento. Boa parte desse crescimento está acontecendo nas cidades ${ }^{2}$ localizadas em países em desenvolvimento, tais como Índia, Brasil e África do Sul. Logo, esses serão os ambientes urbanos que mais se desenvolverão, em população e extensão territorial. Entre as regiões menos desenvolvidas, a América Latina tem um nível excepcionalmente alto de urbanização, de modo que cerca de $78 \%$ da população vive em áreas urbanas (Ibidem). Em 1990, havia 10

\footnotetext{
${ }^{1}$ Projeção Populacional - Relatório das Nações Unidas - Disponível em:

<https://esa.un.org/unpd/wup/publications/files/wup2014-highlights.Pdf>. Acesso em: 31 mai. 2017.

${ }^{2}$ Cidade é o espaço de um município delimitado por um perímetro urbano.
} 
megacidades $^{3}$ no mundo, habitadas por 153 milhões de pessoas, cerca de $7 \%$ da população urbana, sendo apenas duas no hemisfério sul, e três em países em desenvolvimento. Em 2014, chegou-se a 28 megacidades, onde vivem 453 milhões de pessoas, aproximadamente $12 \%$ dos habitantes do planeta, sendo 7 dessas megacidades localizadas no hemisfério sul, e mais de uma dezena, em países em desenvolvimento (Ibidem).

Também houve a explosão do número de cidades com população entre 5 e 10 milhões de habitantes, as quais eram quase inexistentes (ou pouquíssimas) na década de 1990 e se tornaram dezenas em 2014, demonstrando significativo crescimento em curto espaço de tempo. Isso nos leva a crer que o crescimento das cidades é inevitável e irreversível.

Segundo Gaspar (2007), o resultado dessa explosão urbana é uma transformação radical na estrutura das cidades, acompanhada de complexas mudanças sociais, econômicas e ambientais. Assim, cidades com estas características enfrentarão desafios para atender às necessidades do crescimento e do adensamento populacional. Nesse cenário, coloca-se a importância da promoção e do controle qualitativo da transformação desses espaços urbanos frente às necessidades sociais, o que depende das soluções que serão adotadas para a ocupação e o uso dos espaços.

No contexto urbano brasileiro, o município de São Paulo apresentou reduzidas taxas de crescimento da população total (entre 1950 e 2000, teve crescimento médio de 3,98\% ao ano; entre 2000 e 2010, de 1,36\% ao ano; e estima-se que, de 2010 a 2025, o crescimento médio será de $0,60 \%$ ao ano, conforme o mesmo relatório). Mesmo assim, a metrópole corresponde à região mais populosa do país, tendo se destacado por ser a $5^{\text {a }}$ maior aglomeração urbana no mundo, com aproximadamente 21 milhões de habitantes, conforme o Relatório de Urbanização da ONU de 2014 (UNITED NATIONS, 2016).

Entretanto, São Paulo passa por um processo de dispersão, com adensamento periférico e crescimento muito baixo ou mesmo negativo em zonas mais centralizadas. Conforme dados da Prefeitura do Município de São Paulo (SÃO PAULO, 2015), os distritos centrais (tais como Lapa, Pinheiros, Sé e Vila Mariana) apresentaram, nas últimas três décadas, crescimento médio de $-0,46 \%$ ao ano, enquanto distritos periféricos (tais como Guaianases, Itaim Paulista, Itaquera e São Matheus) apresentaram crescimento médio de 2,31\% ao ano. Além disso, o Município de São Paulo, em particular, tem nas zonas centrais muitas áreas que demandam projetos de

\footnotetext{
${ }^{3}$ Megacidade é o termo para definir uma cidade que sedia uma aglomeração urbana com mais de dez milhões de habitantes com rápido processo de urbanização (UNITED NATIONS, 2016).
} 
transformação urbana, a fim de adequar seu uso, sua ocupação e sua infraestrutura às necessidades mais atuais da população.

As políticas públicas urbanas visam, ultimamente, fixar e estabelecer prioridades com o objetivo de promover o bem-estar humano nas cidades. suportando o desenvolvimento e a implantação planos e programas urbanos, assim como de projetos de intervenção urbana ${ }^{4}$. Estes, em particular, são definidos visando a atender demandas urbanas mais específicas, sendo previstos na legislação urbanística, quer seja no Plano Diretor e na Lei de Zoneamento, quer seja por meio de políticas urbanas complementares.

Por conseguinte, a definição de projetos de intervenção urbana permeará a consideração de aspectos sociais, econômicos, técnicos e ambientais. Em contrapartida à ação da administração municipal, observa-se a sociedade organizando maneiras de sobrevivência que escapam ao domínio do planejamento realizado pelo poder público, conforme aponta Gaspar (2007).

Saboya (2007) aponta que o planejamento urbano consiste em estabelecer objetivos de uma determina área e selecionar as diretrizes mais adequadas para orientar ações futuras. Argumenta ainda que um olhar exclusivamente normativo pode não orientar adequadamente ações, ou seja, há dificuldade de determinar com qual prioridade as ações devem ser implantadas. Portanto, o texto normativo orienta ações, prevê diretrizes, apresenta normas e sugere incentivos, processos que intrinsecamente balizam o uso e a ocupação de solos, além de viabilizarem as ações do poder público e dos indivíduos.

Este complexo arranjo, ilustrado na figura 2, evidencia a característica do arcabouço legal que ampara um modelo de gestão dos instrumentos da política urbana, associado aos seus mecanismos e instrumentos.

Como exemplos dos projetos de intervenção e transformação urbana, as Operações Urbanas Consorciadas (OUC), estabelecidas conforme os artigos 32 e 33 do Estatuto da Cidade, prescindem da definição e da delimitação de territórios estratégicos para a aplicação deste instrumento. Ademais, essas operações devem ser exigidas dos proprietários, dos usuários e dos investidores privados, como contrapartida.

São ponderados os benefícios previstos e deve ser definida a forma de controle da operação, obrigatoriamente compartilhada e com representação da sociedade civil. Com isso,

\footnotetext{
${ }^{4}$ Conjunto de ações de natureza urbanística praticadas pelo município por meio de obras públicas e desapropriações, sendo que o custo delas inclui todas as despesas necessárias à sua realização, inclusive os gastos incorridos com projetos.
} 
as operações urbanas consorciadas representam, por exemplo, um campo fértil para a discussão acerca da parceria do poder público com o setor privado, associada à participação popular, nos processos de construção e reconstrução da cidade.

Figura 2 - Sistema de Planejamento Urbano

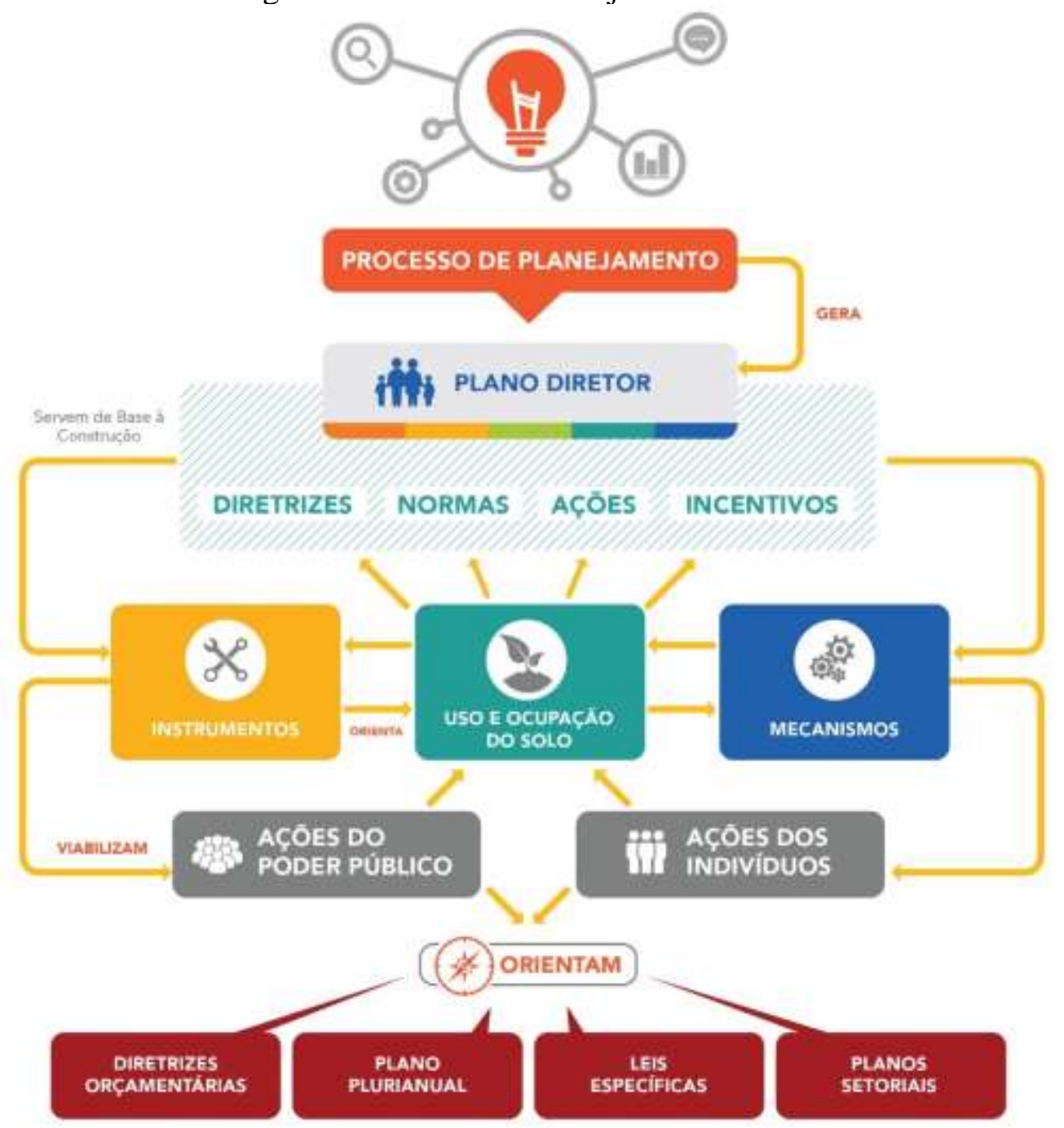

Fonte: Adaptado de Saboya (2006, 2007).

Outro exemplo relativo aos projetos de intervenção urbana abrangem os planos de bairros. Estes planos foram instrumentos estabelecidos pelo Plano Diretor Estratégico do Município de São Paulo (Lei n. 16.050/2014) para orientar o desenvolvimento dos bairros na cidade. Os planos de bairro visam fortalecer o planejamento e o controle social local para promover melhorias urbanísticas, ambientais, paisagísticas e habitacionais na escala local, por meio de ações, investimentos e intervenções previamente programadas. Ainda, os planos de bairro buscam estabelecer uma gestão democrática da participação popular. É indicado, já na forma de lei aprovada no artigo 313, em seu inciso IV, do novo PDE (inclusive, é estabelecida uma seção especifica no texto da lei, a Seção III), que esses planos deverão utilizar metodologias 
participativas que garantam a colaboração da sociedade em todas as etapas de sua elaboração, para identificação de diferentes demandas urbanas, sociais e ambientais. Estas demandas deverão se pautar por:

a) pesquisas de campo realizadas junto aos moradores dos bairros;

b) análises de dados secundários produzidos por diferentes órgãos de pesquisa;

c) análises de estudos existentes;

d) utilização de metodologias participativas nas diferentes etapas de elaboração;

e) utilização de abordagens interdisciplinares.

As propostas de intervenção e transformação urbanística se caracterizam, em geral, por preconizarem a modificação de índices e características de parcelamento, uso e ocupação do solo e do subsolo, o que pode alterar a estruturação da forma urbana, no que tange seu uso e ocupação. Porém, é difícil mensurar se as alterações na forma e no uso do espaço urbano estão alinhadas com o atendimento às reais expectativas de uma população, uma vez que as cidades, em suas diversões regiões, áreas ou territórios possuem condições, demandas e ofertas com diversos níveis de atendimento e de carências, assim como há diferenças em termos sociais e comunitários de cada região, o que assevera as reflexões sobre os produtos resultantes das intervenções e transformações urbanísticas.

Uma outra discussão emergente é que, consequentemente, em alguns casos, a definição da forma urbana, orientada por parâmetros previstos na Lei de Uso e Ocupação de Solo (do Plano Diretor), não garante que haja equidade e desenvolvimento urbano em todo o território, podendo existir áreas que necessitam de um "vetor de transformação" ou desenvolvimento, estimulado por projetos específicos para cada região. Somando-se a esses fatores, a deficiência no controle do uso e da ocupação do solo e a atuação do mercado imobiliário podem desencadear a expulsão de populações de menor renda das áreas com melhores condições de vida, favorecendo a segregação socioespacial, de modo que fica evidente o privilégio do interesse privado em questões imobiliárias, em detrimento do interesse público.

Neste cenário, coloca-se a necessidade de os instrumentos urbanísticos atuarem de maneira progressiva para recuperação e promoção de setores do território com provisão de habitação e equipamentos públicos. Os instrumentos podem ainda atuar na distribuição das atividades na cidade, recuperando o déficit social e, assim, evitando a revalorização de áreas já valorizadas nas cidades. Neste ponto, a identificação de áreas apropriadas à implantação projetos de intervenção urbanística, direcionados para a transformação do solo, visa, em certa 
medida, promover uma distribuição mais equilibrada dos ônus e benefícios decorrentes dos investimentos públicos e privados, por meio da adequação de uso e ocupação do solo e de sua interface com a infraestrutura existente e a implantar.

Villaça (2001) ressalta que "a estrutura territorial” também está articulada a outras não territoriais, como a econômica, a política e a ideológica. Insiste, ainda, na importância de se identificar e relacionar os movimentos dos diversos elementos das estruturas territoriais urbanas - os vários bairros, o centro urbano, a estrutura de transportes etc. - com os de outras estruturas a eles articuladas.

Além disso, segundo Gaspar (2007), há de se mensurar as variáveis que os próprios moradores julgam pertinentes para o bairro em que moram, sendo necessária, portanto, a percepção das questões a cada variável que traz satisfação ou insatisfação para os moradores. O planejamento de áreas urbanas se baseia, dessa forma, em princípios de interdisciplinaridade e intersetorialidade, bem como na participação dos principais atores ou agentes sociais que vivenciam e interferem na dinâmica territorial de produção do espaço. No cenário, as relações entre esses múltiplos princípios e agentes variados podem estabelecer decisões com abordagens diversas e resultados que podem não ser suficientemente abrangentes.

Coloca-se, assim, o desafio de estabelecer um processo claro e transparente, compatibilizando não só os objetivos, mas também os critérios que os caracterizam e suas respectivas ações, mediante envolvimento dos agentes, além de ferramentas ou métodos ${ }^{5}$ adequados que permitam orientar adequadamente os processos de tomada de decisão. Isso culmina em áreas urbanas planejadas considerando as múltiplas demandas (saneamento, energia, mobilidade urbana, drenagem, produção de habitação, distribuição de atividades, mercado imobiliário, energia, entre outros), segundo diversos pontos de vista (comunidades, poder público, organizações privadas etc.).

\footnotetext{
${ }^{5}$ Entende-se que um "método" seja um conjunto de princípios, diretrizes e rotinas operacionais que orientam uma sequência de operações empíricas e racionais nitidamente distintas e rigidamente concatenadas; por sua vez, uma "ferramenta" é um utensílio, ou dispositivo, ou mecanismo (físico ou intelectual) utilizado para facilitar a realização de uma tarefa (FEYERABAND, 1977). Porém, em determinados contextos, um "método" pode ser entendido como uma "ferramenta", uma vez que tem a função de facilitar a conquista de determinadas metas (ou objetivos), como se verá neste trabalho.

Resumidamente um método é uma maneira de ordenar a ação de acordo com certos princípios. Um procedimento é um método a ser cumprido, é uma forma específica de executar uma atividade ou um processo. Um processo de acordo com a ISO 9000:2015, é um conjunto de atividades inter-relacionadas ou interativas que transformam entradas em saídas, ou seja, processo é uma sequência de atividades que transformam entradas (informações, materiais, instruções ou matérias-primas) em saídas (produtos, serviços ou decisões). O que se observa é uma discussão semântica importante, que, contudo, não será avaliada neste trabalho, e por tal razão, a sequência de etapas, com entradas e saídas, com um roteiro de aplicação, será considerada como uma proposta metodológica, pois absorve um método, uma série de procedimentos e um processor inter-relacionando de etapas.
} 
Verifica-se, dessa forma, que a utilização de um procedimento metodológico mais completo para apoio à decisão - que considere os múltiplos aspectos e agentes envolvidos no desenvolvimento de áreas urbanas -, pode ter grande utilidade nos processos decisórios em projetos e políticas públicas urbanas. Nessas situações, as decisões precisam se pautar em critérios (qualitativos e quantitativos) técnicos, objetivos e transparentes, que sejam capazes de incorporar os juízos de natureza política e subjetiva dos gestores públicos e, sobretudo, da sociedade civil.

Por meio da participação, a população traz conhecimentos e experiências que lhe são inerentes e que muitas vezes são imperceptíveis ao poder público local e aos demais agentes da gestão urbana. Dowbor (1993) sugere que um dos caminhos a serem galgados para a solução dos impasses da gestão das cidades esteja realmente em inserir a população que efetivamente sente os impactos, nas tomadas de decisões do governo local e na formulação de políticas públicas. Santos, Thomaziello e Weill (2007) apontam que, para haver participação, deve haver uma preparação, a qual requer educação, comunicação e, acima de tudo, respeito entre os diversos atores. Segundo Giaretta (2011), o surgimento da participação social e do envolvimento da sociedade, enquanto parte da gestão municipal, tem contribuído de forma significativa para avanços na formulação, na execução e no acompanhamento de políticas, estratégias e instrumentos de desenvolvimento urbano.

Nesse contexto, Saboya (2007) sugere que a atividade de planejamento requer uma reflexão mais elaborada acerca do futuro, e esta reflexões só podem ser estudadas se considerarem as relações intrínsecas aos elementos constantes no sistema urbano.

Conforme Azevedo e Anastásia (2002), no âmbito do planejamento urbano, em particular, uma reflexão relevante diz respeito à possibilidade de a morfologia urbana, orientada por parâmetros incorporados em normativas, códigos e leis, propiciar equidade, desenvolvimento urbano e aproximação de abordagens técnicas com o saber popular. Entendese, dessa forma, que, na implantação de instrumentos e políticas de intervenção urbana, a determinação - ou a adequada hierarquização de iniciativas de impacto coletivo e público pode determinar o sucesso dessas decisões, criando ações reais mais próximas às realidades locais, pois as assimetrias podem ser melhor trabalhadas. Nessa direção, a contribuição da participação popular pode trazer um saber coletivo vivencial relevante no processo de decisão.

Diante disso, uma proposta metodológica que torne mais clara e objetiva a captação das percepções populares sobre problemas e soluções (ou alternativas) poderia contribuir para a 
melhoria dos processos de planejamento do desenvolvimento urbano, facilitando a definição de estratégias e sua possível hierarquização.

A questão que se coloca, mais uma vez, no escopo desta pesquisa é como integrar os insumos decorrentes do processo participativo no planejamento e na tomada de decisão para o planejamento urbano, agregando efetividade, eficiência e eficácia às soluções?. Partindo destes pontos, há de se aferir a importância da participação dos agentes da sociedade para o planejamento urbano ou, em outras palavras, quais as contribuições que a participação social poderia trazer para o planejamento urbano e quais as coincidências e divergências existentes entre teoria e prática participativas em relação ao planejamento urbano. Uma das dimensões debatidas sobre a participação refere-se ao seu papel nas tomadas de decisão, embora a participação popular seja uma premissa em qualquer processo decisório democrático.

\subsection{HIPÓTESE}

A hipótese da pesquisa é de que a participação popular pode fornecer contribuições mais efetivas para diagnóstico de demandas e a proposição de estratégias em desenvolvimento urbano aplicando-se metodologias que integrem a participação popular em processos decisórios relativos aos processos de desenvolvimento e planejamento urbanos.

Acredita-se que as contribuições sociais possam fornecer insumos que possibilitem o diagnóstico de problemas e prioridades em áreas urbanas definidas, assim como a hierarquização de soluções e respectivas alternativas, definindo estratégias de intervenção urbana.

Nessa discussão, colocam-se algumas questões que têm orientado o desenvolvimento da pesquisa:

a) Os resultados dos processos participativos corroboram a priorização de projetos de intervenção e transformação urbanística, para benefícios sociais coletivos, que atendem a maior parte da população, contribuindo para a redução das desigualdades socioterritoriais e para melhor qualidade e desempenho das ocupações urbanas?

b) Ferramentas e modelos técnicos ou científicos podem ser capazes de coletar dados e estabelecer estratégias que traduzam as percepções da participação popular?

c) Pode-se extrair da participação popular critérios sinérgicos que contribuam para o avanço do processo de decisão e hierarquização em projetos de intervenção ou transformação urbanística? 
d) Uma abordagem estabelecida nas ciências das decisões, possivelmente com análise multicriterial, pode estabelecer um processo claro e transparente de tomada decisão, com participação popular?

\subsection{OBJETIVO}

O objetivo desta pesquisa de doutorado foi desenvolver uma proposta metodológica para inclusão da participação popular nos processos de tomada de decisão para definição e hierarquização de estratégias em planejamento urbano, , e aplicar uma prova de conceito da proposta em area urbana selecionada. O trabalho buscou, dessa forma, propor diretrizes e procedimentos que possam tornar a participação popular mais efetiva do que a prática corrente, integrando abordagens da ciência pós normal, instrumentos e técnicas de consulta popular, ciência de decisões, processos de planejamento urbano e condicionantes da participação popular.

Para que esse objetivo seja exequível, os objetivos específicos foram:

a) diagnosticar o processo decisório que envolve criação, hierarquização, priorização e seleção de projetos de intervenção ou transformação urbanística, verificando como foi (e se houve) a condução da participação popular nessas decisões;

b) investigar as lições aprendidas nos projetos que já foram concluídos por meio da participação popular;

c) propor uma metodologia que estabeleça procedimentos para otimização da participação popular, captando-se as percepções e as hierarquizando.

Ainda como objetivo específico, neste cenário, coloca-se a necessidade de analisar, sob o ponto de vista metodológico, os aspectos da legislação urbana e a identificação de processos inovadores de construção de instrumentos urbanísticos com envolvimento direto das comunidades. Busca identificar um ambiente em que as decisões incorporem os anseios de especialistas e também de agentes sociais, contribuindo para o desenvolvimento planejado das cidades.

\subsection{JUSTIFICATIVA E INEDITISMO DO TRABALHO}

Conforme contextualizado, a transformação e a construção dos espaços urbanos são tendências crescentes no processo de urbanização corrente e futuro, em muitas cidades no mundo e no Brasil, e também em São Paulo. Indaga-se sobre a efetividade da participação social 
no processo decisório, bem como da captação dos anseios dos agentes variados nesses processos.

Diante da situação, há necessidade - e se acredita que há condições para tal - de se estruturar mais adequadamente os métodos até então em uso ou agregar novos métodos aos processos decisórios participativos, a fim de promover participação popular de forma mais efetiva no planejamento de áreas urbanas selecionadas. No cenário de planejamento urbano, especificamente, verifica-se uma lacuna na forma de integração das percepções da sociedade frente aos problemas urbanos quando da definição de ações e soluções urbanísticas. devido à falta de aporte metodológico mais efetivo.

Esta pesquisa reconhece o cenário dinâmico em que as decisões hoje estão inseridas, no qual diversas soluções são apresentadas para o mesmo sistema e/ou problema, visando atender a vários objetivos. Acredita-se que a proposição e a aplicação de uma metodologia que busque ampliar os efeitos positivos da participação popular sobre o planejamento urbano pode trazer novos elementos para compreensão do desenvolvimento urbano, dentre eles as perspectivas de diversos agentes que interagem com as transformações.

O caráter inédito da pesquisa é justificado pela proposta de integração de ferramentas diversificadas, aplicadas em ciências sociais, às ferramentas de tomada de decisão, baseadas em análises multicriteriais, para compor uma metodologia nova de apoio à decisão em planejamento urbano, visando operacionalizar, de forma mais efetiva, o planejamento estratégico participativo quando da elaboração de estratégias, hierarquização de alternativas, partindo-se do delineamento e compreensão dos problemas que permeiam o planejamento e o desenvolvimento de áreas urbanas.

Mellinger e Floriani (2015) apontam que, embora haja inúmeros arranjos institucionais (e formais) de participação que se delimitam por leis, normas e procedimentos e permeiam os processos de negociação e decisão - tais como associações, assembleias, audiências e conselhos -, todos eles ainda são pouco integrados. Portanto, existe dificuldade de incorporar variáveis e percepções que reproduzam expectativas, experiências e contribuições da população na estruturação e no planejamento de áreas urbanas.

Ainda há desafios nas formas de construir processos participativos que sejam capazes de vencer essa dificuldade, uma vez que as cidades, em suas diversas regiões, áreas, distritos e demais frações de território urbano, possuem elementos distintos e complexos. E estes, em 
muitos casos, são diagnosticados pela percepção que os indivíduos têm da experiência em uma determinada realidade.

\subsection{MATERIAIS E MÉTODOS}

Neste trabalho, como estratégia de pesquisa, foi assumido um método hipotéticodedutivo, segundo o qual, a partir de uma determinada observação, foram formuladas hipóteses explicativas de determinadas questões e estudadas suas causas. Então, com um processo de indução, foram formuladas conclusões prováveis a partir da aplicação da proposta metodológica desta pesquisa. Essa rotina, percolada por formulação do problema, desenvolvimento de hipóteses, dedução de consequências, teste da hipótese e sua confirmação, é exemplificada na figura 3 .

Figura 3 - Método de Pesquisa

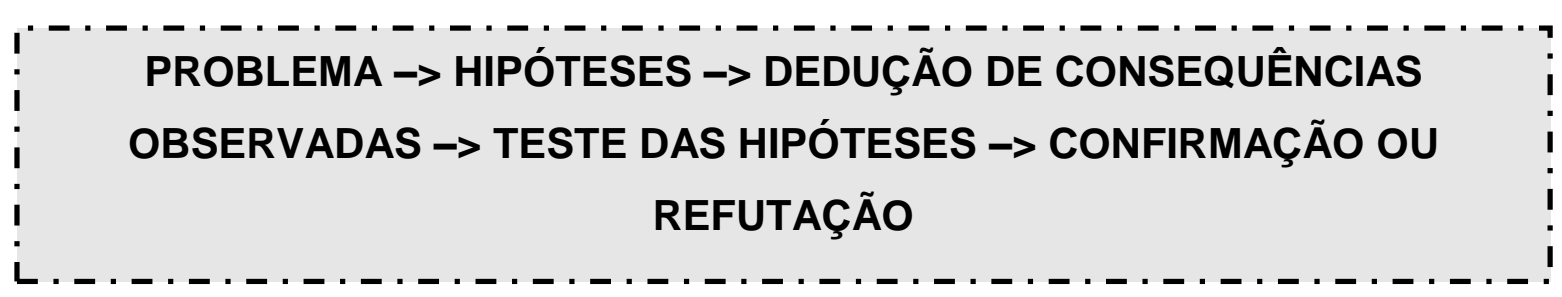

Fonte: Do autor (2019).

A natureza da metodologia assumida neste trabalho é qualitativa, pois não há o compromisso com a representatividade numérica dos resultados, nem com sua distribuição estatística. O cerne do trabalho é o aprofundamento da compreensão social de uma questão e suas relações de causa e consequência. A natureza qualitativa, hipotético-dedutiva, inserida nesta pesquisa, associou pesquisa exploratória (com a exploração de levantamento bibliográfico e entrevistas), pesquisa descritiva (com a exploração de estudo de caso) e abordagem participante em um determinado grupo.

Portanto, de forma abrangente, trata-se de uma pesquisa construtivista que estabelece uma série de procedimentos de pesquisa para produzir artefatos, com o intuito de resolver problemas encontrados no mundo real e, desta forma, contribuir com "constructos" aplicáveis. Inclui uma tentativa de implementar a proposta envolvendo o teste para a sua aplicabilidade prática. A abordagem construtivista, como método emergente de pesquisa, considera o ser humano como o centro do seu percurso em direção à construção do conhecimento.

Siqueira, Portela e Areiano (2000) e Gil (2002) apontam que a pesquisa construtivista se consolida em sete etapas estruturadas, conforme figura 4, apoiada com múltiplos métodos de 
pesquisa tais como, entrevistas e análise da literatura, que permitam a conceituação do problema. A revisão da literatura também permiti identificar e analisar a contribuição teórica do "constructo" desenvolvido. Por fim, o desenvolvimento e teste prático da solução permite avaliar seu funcionamento e colocá-lo em uso. Não se menospreza a explicação da contribuição teórica do estudo, i.e, refletir sobre os achados, referindo-se à teoria prévia.

As partes A, B e C deste trabalho foram desenvolvidas de forma exploratória, com síntese da literatura sobre (i) instrumentação, estrutura e escalas de governança urbana no Brasil, (ii) participação popular em processos decisórios relativos ao planejamento urbano (iii) metodologias de planejamento e tomada de decisão aplicáveis a processos participativos em planejamento urbano. A parte D foi desenvolvida de forma hipotético-dedutiva, em função dos resultados obtidos nas partes A, B e C. Por sua vez, a comprovação de sua aplicação foi feita com estudo de caso, envolto em uma abordagem participativa.

Na parte D, foi proposta a determinação do processo participativo realizado na área objeto de estudo. Tanto na Parte E como na parte F, buscou-se a aproximação com a opinião popular e, para tal, foram conduzidos encontros com associações de bairro. Assim, foi possível correlacionar as bases desenvolvidas nas partes A, B e C com a formulação da proposta da parte D, aplicação da proposta metodológica na parte E e sua consolidação na Parte F.

As partes E e F consistem na aplicação, confirmação da aplicabilidade e consolidação da proposta metodológica criada nesta pesquisa. Nessas etapas, a pesquisa contou com apoio de projetos de Iniciação Científica para aplicar a metodologia no escopo do objeto de estudo, configurando um estudo de caso selecionado. Este, por sua vez, foi realizado na comunidade atuante, ou com potencial de atuação, em um recorte urbano no município de São Paulo conformado na área de abrangência da Subprefeitura da Mooca. Também, na área de estudo, foram executadas as entrevistas diretas com a população para apoiar o processo hipotéticodedutivo de criação da proposta metodológica, constantes nas parte B.

De acordo com Gil (2002), a classificação das pesquisas pode ser baseada em dois grandes critérios: (i) com base nos seus objetivos gerais, o que permite estabelecer um marco teórico com aproximação conceitual; e (ii) com base nos procedimentos metodológicos técnicos utilizados, o que permite estabelecer um delineamento da pesquisa considerando o ambiente e as formas de controle das variáveis envolvidas. Assim, quanto ao objetivo, esta pesquisa é construtivista, quanto ao processo é qualitativa. Já quanto à lógica é dedutiva, e quanto ao resultado, é aplicada. 
Figura 4 - Metodologia da Pesquisa

\begin{tabular}{|c|c|c|c|}
\hline Etapa & Parte & Capítulo & Método \\
\hline $\begin{array}{c}\text { Encontrar um problema } \\
\text { prático relevante, que tem } \\
\text { potencial de contribuição } \\
\text { acadêmica }\end{array}$ & A & $\begin{array}{c}\text { Instrumentação, estrutura e } \\
\text { escalas de governança urbana } \\
\text { no Brasil }\end{array}$ & \multirow{3}{*}{$\begin{array}{l}\text { Exploratório } \\
\text { com revisão } \\
\text { bibliográfica }\end{array}$} \\
\hline $\begin{array}{l}\text { Examinar o potencial de } \\
\text { cooperação de pesquisa de } \\
\text { longo prazo com uma } \\
\text { temática alvo }\end{array}$ & B & $\begin{array}{c}\text { Participação popular em } \\
\text { processos decisórios relativos } \\
\text { ao planejamento urbano }\end{array}$ & \\
\hline $\begin{array}{l}\text { Obter compreensão } \\
\text { profunda do tópico na área } \\
\text { tanto na prática como na } \\
\text { teoria. }\end{array}$ & $\mathrm{C}$ & $\begin{array}{c}\text { Metodologias de } \\
\text { planejamento e tomada de } \\
\text { decisão aplicáveis a processos } \\
\text { participativos em } \\
\text { planejamento urbano }\end{array}$ & \\
\hline $\begin{array}{c}\text { Formular uma ideia } \\
\text { inovadora e desenvolver } \\
\text { um artefato que soluciona } \\
\text { o problema, que tenha } \\
\text { potencial de contribuição } \\
\text { teórica }\end{array}$ & $\mathrm{D}$ & $\begin{array}{l}\text { Desenvolvimento de uma } \\
\text { proposta metodológica para } \\
\text { participação popular na } \\
\text { definição de estratégias em } \\
\text { planejamento urbano }\end{array}$ & \multirow{4}{*}{$\begin{array}{l}\text { Construtivista } \\
\text { com estudo de } \\
\text { caso }\end{array}$} \\
\hline $\begin{array}{l}\text { Implementar e testar a } \\
\text { solução comprovando } \\
\text { como funciona }\end{array}$ & $\mathrm{E}$ & $\begin{array}{c}\text { Aplicação da proposta } \\
\text { metodológica no Belenzinho }\end{array}$ & \\
\hline $\begin{array}{l}\text { Ponderar sobre o escopo } \\
\text { da aplicabilidade da } \\
\text { solução }\end{array}$ & $\mathrm{F}$ & Conclusões & \\
\hline $\begin{array}{l}\text { Identificar e analisar a } \\
\text { contribuição teórica }\end{array}$ & $\mathrm{F}$ & $\begin{array}{l}\text { Comprovação da hipótese, } \\
\text { conclusões e continuidade da } \\
\text { pesquisa }\end{array}$ & \\
\hline
\end{tabular}

Fonte: Do autor (2019).

Um método é um conjunto de princípios, diretrizes e rotinas operacionais que orientam uma sequência de operações empíricas e racionais nitidamente distintas e rigidamente 
concatenadas. É uma maneira de ordenar a ação de acordo com certos princípios. Um procedimento é um método a ser cumprido, é uma forma específica de executar uma atividade ou um processo. Um processo de acordo com a ISO 9000:2015, é um conjunto de atividades inter-relacionadas ou interativas que transformam entradas em saídas, ou seja, processo é uma sequência de atividades que transformam entradas (informações, materiais, instruções ou matérias-primas) em saídas (produtos, serviços ou decisões). O que se observa é uma discussão semântica importante, que, contudo, não será avaliada neste trabalho, e por tal razão, a sequência de etapas, com entradas e saídas, com um roteiro de aplicação, será considerada como uma proposta metodológica, pois absorve um método, uma série de procedimentos e um processor inter-relacionando de etapas

\subsection{ETAPAS DE PESQUISA}

A pesquisa, em função do seu delineamento metodológico, foi desenvolvida em seis partes principais, conforme descrito a seguir.

a) Parte A - Instrumentação, estrutura e escalas de governança urbana no Brasil: foi desenvolvida síntese bibliográfica com aprofundamento teórico sobre os processos de desenvolvimento de áreas urbanas. Foram incluídos aspectos de planejamento, projetos de intervenção e transformação urbanísticas e suas possíveis modificações, contribuições para uso e ocupação do solo e suas implicações na oferta de infraestrutura e serviços públicos urbanos. O processo foi fundamentado com os seguintes elementos: (i) facilidades e barreiras definidas nas legislações federal, estadual e municipal; (ii) parâmetros de planejamento e prática de uso e ocupação do solo e sistemas de infraestrutura urbana; (iii) externalidades negativas e positivas dos processos de planejamento urbano;

b) Parte B - Participação popular em processos decisórios relativos ao planejamento urbano: consolida informações sobre a participação dos agentes, destacando-se a participação popular, em processos decisórios relativos a desenvolvimento urbano: foi desenvolvida síntese bibliográfica para aprofundar conhecimentos sobre o processo decisório participativo aplicado ao desenvolvimento de projetos urbanos, com o objetivo de identificar, sistematizar e analisar abordagens e experiências sobre este processo. Em seguida, buscou-se entender como o processo participativo interfere na tomada de decisão sobre criação, hierarquização e seleção de projetos de intervenção e transformação urbanística. Também, com a cooperação de uma pesquisadora de iniciação cientifica, foi 
realizada uma investigação em campo de forma a avaliar as percepções constatadas na análise bibliográfica. Os resultados foram consolidados analisando o processo participativo aplicado na revisão do Plano Diretor Estratégico do município de São Paulo, com pesquisa exploratória de abordagem qualitativa e quantitativa, com a utilização de dados secundários coletados em bases disponibilizadas pela prefeitura de São Paulo disponíveis seu sitio na internet, especificamente aos dados inerentes à gestão urbana. Os dados analisados contêm informações sobre o processo participativo conduzido pela prefeitura, tais como a natureza das contribuições recebidas e os grupos que manifestaram as contribuições. Também foram conduzidas entrevistas diretas à população, e seus resultados foram sintetizados graficamente nesta etapa, que conforme apontado por Gil (2002) nas pesquisas documentais de cunho quantitativo;

c) Parte C - Metodologias de planejamento e tomada de decisão aplicáveis a processos participativos em planejamento urbano: identifica e analisa metodologias aplicáveis a processos participativos de planejamento. Foram identificados e analisados métodos e ferramentas que captassem a percepção dos agentes, em particular da participação popular, incluindo procedimentos metodológicos e ferramentas adotados e/ou disponíveis para a pesquisa e o envolvimento de grupos e indivíduos. Além disso, foram estudados métodos de apoio à decisão, analisando sua abordagem e seu tratamento, possivelmente multicriterial, que pudessem permitir a hierarquização de projetos de intervenção e transformação urbanística com os insumos resultantes do procedimento metodológico de participação popular. Os resultados desta revisão bibliográfica permitiu a partir da literatura já publicada desenvolver o ferramental metodológico para construção da proposta, detectando os principais entraves teóricos ou metodológicos;

d) Parte D - Desenvolvimento de uma proposta metodológica para participação popular na definição de estratégias em planejamento urbano: com base nos estudos anteriores foi elaborada uma proposta metodológica para avaliação e captação da participação popular em processos de tomada de decisão, cujas aplicações, ao menos parcialmente, pudessem se dar na definição e hierarquização de estratégias em planejamento urbano a partir de uma série de índices que foram elaborados neste trabalho. Esta etapa permitiu aplicar os achados relevantes, e originais, constantes na revisão bibliográfica e nas entrevistas, desenvolvidos nas Partes A, B e C. São apresentados os procedimentos para aplicação da proposta reforçando o que ela traz de novo ou de relevante para a área de estudo; 
e) Parte E - Aplicação do método proposto no estudo de caso selecionado: foi definida, de forma preliminar, como objeto para aplicação do procedimento metodológico estabelecido, a abrangência de uma divisão administrativa do Município de São Paulo e, de forma específica, a abrangência de atuação de um recorte na divisão administrativa da Mooca, denominada Belenzinho. Objetivou-se, deste modo, testar o processo metodológico proposto para a situação urbana selecionada, permitindo entender a aplicabilidade da proposta e sua revisão em função dos resultados obtidos;

f) Parte F - Consolidação da proposta metodológica e conclusões: com apoio de dois projetos de Iniciação Científica, esta parte consistiu em testar a metodologia proposta identificando um possível grupo de interesse com a comprovação da possibilidade de aplicação da metodologia aqui estabelecida. A partir disso, foram feitas a análise dos resultados e a demonstração do método proposto ser reproduzível em outros contextos urbanos. Os resultados a partir da aplicação em estudo de caso proporcionou uma aplicação empírica de proposições teóricas para conduzir a coleta e a análise de dados. Os achados desta aplicação reforçam os achados na literatura detectando as limitações e os aspectos positivos. Por fim a pesquisa é finalizada com a indicação de possíveis desdobramentos para a continuidade da pesquisa. 


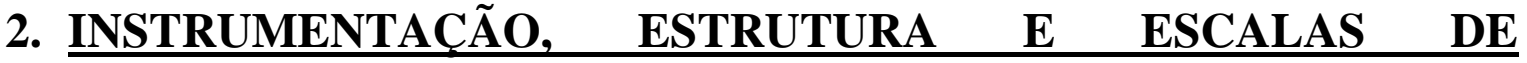 GOVERNANCA URBANA NO BRASIL}

No Brasil, bem como em outros países, há uma tendência crescente de urbanização ${ }^{6}$. Tal processo pode ser analisado, no Brasil, verificando que a população urbana, em relação à população total, saltou de 31,3\% em 1940 para 84,3\% em 2010. De 1960 a 1970, a população urbana passou de $44,7 \%$ para $55,9 \%$ da população total, tornando-se crescentemente majoritária, conforme figura 4. Em termos absolutos, a população urbana brasileira passou de 12,8 milhões para 160,9 milhões de habitantes entre 1940 e 2010, aportando mais de 148 milhões de novos moradores nas cidades - estas despreparadas para abrigar tal contingente ${ }^{7}$.Vale salientar que sob a mesma estatística de população urbana, os padrões de urbanização não são uniformes e variam de país a país, no que tange a formas de ocupação, adensamento populacional e construído, influenciados inclusive pelos instrumentos urbanísticos vigentes. As regiões metropolitanas brasileiras têm, em geral, sua urbanização marcada por forte dispersão e adensamento populacional periférico, o que gera inúmeros impactos negativos para a qualidade de vida da população, para a economia urbana como um todo e para o meio ambiente, enquanto dificulta a gestão municipal e metropolitana.

Gaspar (2007) reforça que mais que simplesmente um fenômeno demográfico, a rápida urbanização é um dos processos que mais afetam as metrópoles de países em desenvolvimento. O resultado disso é uma transformação radical na estrutura das cidades, acompanhada de complexas mudanças sociais, econômicas e ambientais.

Sobre o aspecto da urbanidade $^{8}$, verifica-se que a densidade populacional, principalmente nos países em desenvolvimento, propiciou o acúmulo de uma superpopulação marginal, cujos integrantes, mesmo deixados à revelia, “[...] se viram muito ocupados com os problemas prementes que diziam respeito à sua sobrevivência [...]” (SANTOS, 1988, p. 16) e, de certa forma, aqueles que preferiram migrar para cidades grandes " [...] tiveram de enfrentar como puderam a necessidade de inventar empregos, lugares de moradia, transporte, saneamento, opções de lazer." (Ibidem).

Assim, o processo de urbanização, por um lado, trouxe avanços relevantes em questões ligadas a saúde pública e educação, por exemplo, mas, por outro, certamente acentua problemas

\footnotetext{
${ }^{6}$ Urbanização é o processo no qual a população ocupa predominante cidades.

${ }^{7}$ IBGE, censos de 1940, 1960, 1970 e 2000.

${ }^{8}$ Segundo o dicionário Aurélio, é a qualidade daquele que vive no ambiente urbano - cidade.
} 
latentes, como o habitacional. Diante desse contexto, a gestão das aglomerações urbanas enfrenta desafios para atender às necessidades do crescimento da população urbana (UGEDA JUNIOR e AMORIM, 2009).

O início da experiência brasileira na elaboração de planos $^{9}$ urbanos pode ser referenciado ao final do século XIX, com algumas cidades sendo planejadas, como Belo Horizonte. Villaça (2010, p. 193) afirma que "foi sob a égide dos planos de embelezamento que nasceu o planejamento urbano (lato sensu) no Brasil". Referia-se a melhoramentos das cidades, incluindo infraestrutura, principalmente de circulação e saneamento, e até as décadas de 1930 e 1940, muitos deles foram implantados.

O Plano Pereira Passos, de 1930, para o Rio de Janeiro (único implantado em sua integralidade), bem como o Plano Agache, também para o Rio de Janeiro, e o Plano Prestes Maia, para São Paulo, elaborados na década de 1930 (implantados parcialmente), são exemplos dessa fase, como apontam Caldas (2015, p.33), Misoczky e Guedes (2012) e Simon (1970). Contudo, esses planos urbanos ganham, de fato, impulso apenas a partir do processo de industrialização iniciado em 1930. Voltados para a cidade industrial, são influenciados, principalmente, pelos conceitos modernos progressista/racionalista, cujos princípios foram publicados na Carta de $\operatorname{Atenas}^{10}$.

As preocupações do urbanismo seguiam em sintonia com o estabelecimento de padrões estéticos e de racionalidade no desenho da forma urbana, de modo que se descolavam das problemáticas sociais do espaço, da mobilidade e da acessibilidade, entre outros (GENTIL, 2015; PLÁ, 2013; SILVA, 2013, 2008; e MONTE-MÓR, 2008). Algumas fases, sinteticamente, podem ser destacadas na figura 5 .

Até 1930, a Fase I diversos planos foram baseados em uma tradição europeia, que na prática favorece ruas mais largas e a população e as habitações de baixa renda deslocadas para áreas distantes da região central, em geral mais densas.

Após a década de 30 até meados da década de 70, a Fase II estabelece planos que passam a olhar para a cidade de forma mais ampla, preocupando-se com diretrizes válidas para todo o território e não apenas determinadas regiões. A expansão periférica das cidades se delineia em função dos eixos ferroviários favorecendo o surgimento de centralidades lindeira às estações

\footnotetext{
${ }^{9}$ Plano é a expressão de um processo de tomada antecipada de decisões (SIMON, 1970; MISOCZKY e GUEDES, 2011).

${ }^{10}$ A Carta de Atenas foi elaborada em 1933 e publicada em 1942, mas antes mesmo da sua publicação já influenciava urbanistas brasileiros (MONTE-MÓR, 2008).
} 
ferroviárias. Neste instante as cidades passam a refletir a divisão do território lastreada em zoneamentos, na legislação sobre uso e ocupação do solo e na articulação dos bairros com o centro a partir de sistemas de transporte.

A partir da década de 70, na Fase III, com apoio da expansão da indústria automobilística no Brasil, a cidades, e suas inúmeras oportunidades se tornam pólos de atração e concentram os fluxos migratórios. O crescimento desordenado e a necessidade de planejar as cidades de forma mais consistente são emergentes e surgem iniciativas como o Plano de Avenidas, de São Paulo, e o Plano Agache, no Rio de Janeiro, que abordam diversos aspectos do ambiente urbano, como legislação urbanística, habitação, ordenamento territorial consolidado em eixos viários.

Figura 5 - Três Fases do Processo de Urbanização

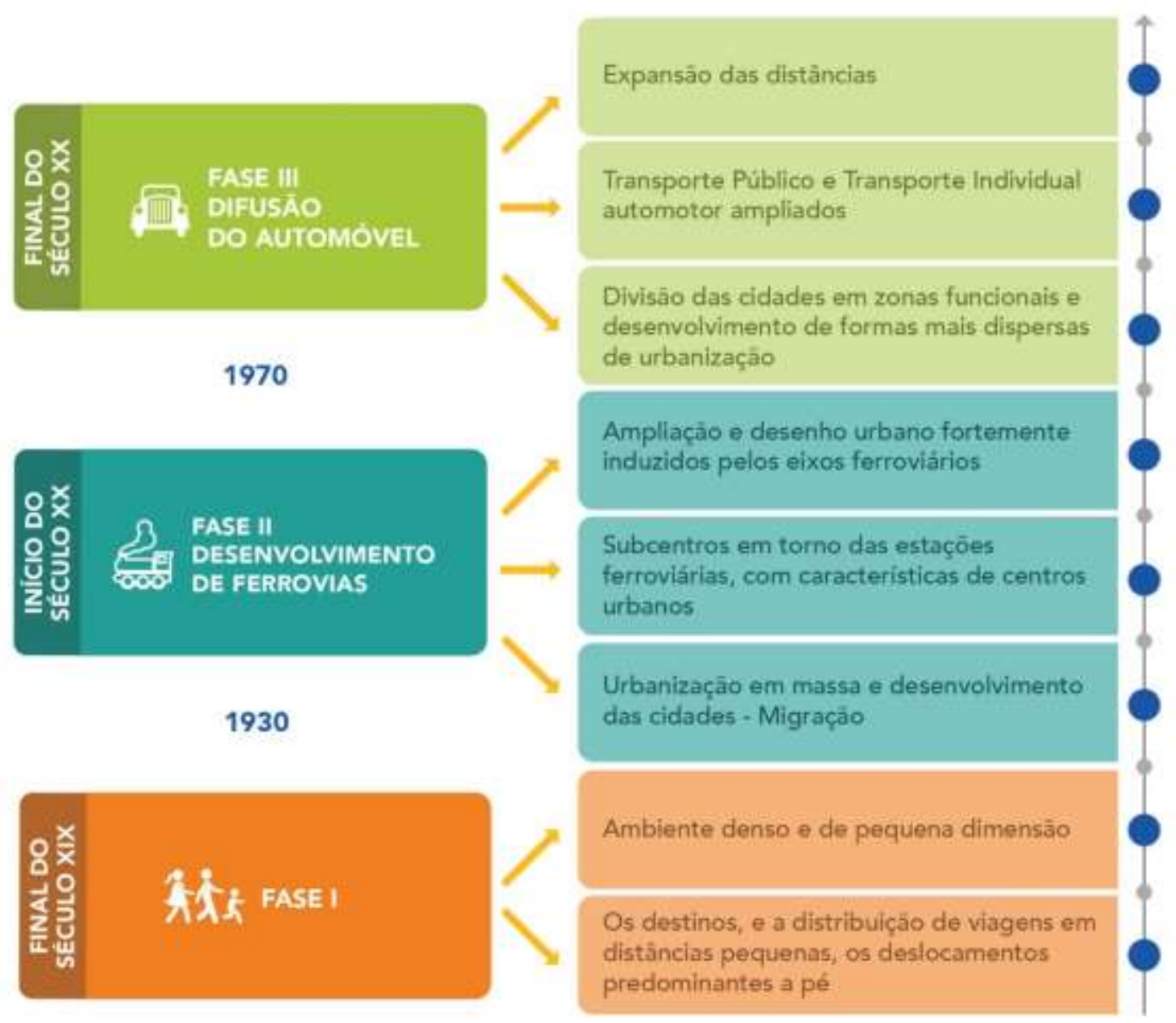

Fonte: Adaptado de Silva (2008, 2013) e Gentil (2015).

Monte-Mór (2008) registra que o modelo racionalista se enquadrava perfeitamente no momento histórico que o Brasil atravessava, resultante do processo de industrialização, influenciado pelas missões americanas e dos organismos internacionais que atingiam o governo, com foco no automóvel e destaque às vias de circulação. Por um lado, denota uma eficiência no transporte individual motorizado, e, por outro, uma organização simplificada do 
território pode por vezes alienar o cidadão com o lugar, afastando-o de um senso de pertencimento.

O zoneamento ${ }^{11}$, por sua vez, mesmo que de forma indireta, molda cidades com traços de segregação das classes sociais e funções urbanas, visando atender demandas específicas e aumentar a eficiência da cidade. A ênfase que se dá ao processo de elaboração do zoneamento marca intervenções, como é o caso de Brasília, conforme apontam Barbosa e Carvalho (2010), exercendo um modelo funcional e racional.

$\mathrm{Na}$ atualidade os planos começam a incorporar outros aspectos além dos relacionados ao território, como os econômicos e sociais, não são raros os exemplos de planos de desenvolvimento, e planejamento urbano, tornaram-se documentos cada vez mais densos e complexos. Não se pode abster as questões metropolitanas e o planejamento não restrito somente aos limites de um município.

Neste momento temporal, final da década de 1980, o Estado exerceu um papel mediador entre o sistema político e a mobilização direta das massas, principalmente no nível urbano. Por sua vez, agentes privados, movimentos sociais e sociedade civil pouco exerciam influência nas decisões, inclusive em planejamento urbano. Tal momento reverberou nas ações de planejamento racionalista, que no momento se demonstraram eficazes aos interesses propostos.

Na década de 1980, como parte do processo de redemocratização do país e de elaboração da Constituição Federal de 1988, ocorreu o movimento pela Reforma Urbana, o qual culminou na inclusão de dois artigos, nessa Constituição, relativos à Política Urbana (artigos 182 e 183). Pela primeira vez no país, a questão urbana integrou o conteúdo de uma Constituição Federal, estabelecendo um instrumento básico fundamental: o Plano Diretor de Desenvolvimento Urbano. Este “... deve estabelecer os objetivos e estratégias para implementação de uma política urbana", sendo parte integrante do processo de planejamento dos municípios ${ }^{12}$. Por sua vez, o Plano Diretor, detalhado no Estatuto da Cidade, tornou-se obrigatório para todas as cidades brasileiras com mais de vinte mil habitantes. Esse instrumento técnico e legal tem o objetivo de orientar, ou reorientar, a estruturação do território municipal a partir da releitura de sua atual

\footnotetext{
${ }^{11} \mathrm{O}$ zoneamento é um instrumento, utilizado em planos diretores, através do qual a cidade é dividida em áreas sobre as quais incidem diretrizes específicas para o parcelamento, o uso e a ocupação do solo, especialmente regulando os índices urbanísticos. Obedece às características e às necessidades das regiões específicas delimitando áreas com características correlatas.

12 BRASIL. Constituição (1988). Constituição da República Federativa do Brasil. Brasília, DF: Senado Federal: Centro Gráfico, 1988. 292 p.
} 
capacidade, assegurando o atendimento das necessidades dos cidadãos quanto à qualidade de vida, à justiça social e ao desenvolvimento das atividades econômicas.

Tal percepção alia-se à contribuição de Maricato (2009, p. 139) sobre o planejamento urbano até 1980, segundo a qual "álibi ou convicção positivista, o planejamento foi tomado como solução para o ‘caos urbano’ e o crescimento descontrolado”. Essas ideias dissimulavam os conflitos e os reais motores desse 'caos'. No entanto, afirma ainda a autora:

[...] foi exatamente durante a implantação do primeiro e único sistema nacional de planejamento urbano e municipal e do crescimento da produção acadêmica sobre o assunto que as cidades brasileiras mais cresceram... fora da lei”. (Ibidem, p. 140).

[...] a história do planejamento urbano no Brasil mostra uma demanda complexa e profunda entre a retórica e a sua prática, marcada por contradições, que envolvem direitos universais, normatividade cidadã - no texto e no discurso - versus cooptação, favor, discriminação e desigualdade - na prática da gestão urbana. (Ibidem, p. 135).

No entanto, os crescentes problemas urbanos decorrentes da acelerada urbanização tornaram cada vez mais presente a necessidade de intervenções governamentais (CALDAS, 2015). Assim, com a urbanização crescente no país nas décadas de 1980, 1990 e 2000, uma ótica mais abrangente e compreensiva da cidade é desenvolvida no Brasil através dos Planos Diretores $^{13}$, que nesta abordagem valorizam principalmente o caráter funcional das cidades e as técnicas urbanísticas.

Segundo a Constituição Federal de 1988, a Política Urbana objetiva a garantia do bemestar dos moradores da cidade. Este, portanto, deve ser entendido como o ponto de partida e a base para o estabelecimento de princípios e diretrizes visando ao pleno desenvolvimento ordenado das funções sociais da cidade com base na justiça social, - uma nova ordem jurídica que tem como princípio o direito à cidade - e que conferem a todos os cidadãos o direito ao seu usufruto pleno, equilibrado, sustentável, democrático e socialmente igualitário.

A Constituição de 1988 também introduziu a gestão descentralizada e participativa e a autonomia dos entes federados. No âmbito do planejamento urbano, o arcabouço legal construído ao longo de décadas de reflexões e transformações, da Carta da República ao Estatuto da Cidade objetiva uma melhor distribuição das funções sociais da cidade e dos aspectos inerentes a funcionalidade, conforto, sossego, segurança e qualidade de vida (BRASIL, CONSTITUIÇÃO FEDERAL, 1988, artigo 182).

\footnotetext{
13 “Os Planos Diretores surgiram nos EUA no início do século XX, diante dos problemas que a urbanização acelerada impunha, mormente no tocante à oferta de serviços de consumo coletivo e à expansão física das cidades" (MONTE-MÓR, 2008, p. 43).
} 
O Estatuto da Cidade ${ }^{14}$. também assegura o processo de participação popular na escolha das prioridades, conforme aponta Silva (2001). A política urbana prevê que sejam utilizados os seguintes instrumentos: (a) criação de órgãos colegiados de política urbana nos níveis nacional, estadual e municipal; (b) debates, audiências e consultas públicas; (c) conferências sobre assuntos de interesse urbano, nos níveis nacional, estadual e municipal; e (d) iniciativa popular de projeto de lei e de planos, programas e projetos de desenvolvimento urbano (artigo 43, I, II, III e IV do Estatuto da Cidade).

O Estatuto reforça a competência municipal no planejamento e na gestão de questões urbanas no Brasil, onde o município é responsável, gestor, decisor, planejador e condutor da política urbana, seguindo uma tendência descentralizadora e com foco em ações locais. As diretrizes serão construídas e aplicadas nas localidades onde "as disputas sociais e as correlações de força nos processos participativos deverão ocorrer", nas quais as parcerias público-privadas, inserindo o cidadão como ator neste contexto, poderão ser desenhadas e implementadas, segundo Caldas (2015).

Ainda, por meio do Estatuto da Cidade, outras inovações foram estabelecidas no novo marco regulatório brasileiro, como o parcelamento, a edificação ou a utilização compulsórios, o IPTU progressivo, a desapropriação para fins da reforma urbana, o direito de preempção, a transferência do direito de construir e a regularização fundiária. Estes instrumentos demonstram a capacidade de intervenção no mercado e legalmente foram disponibilizados aos municípios brasileiros pelo Estatuto da Cidade.

A partir de 2003, tem início um novo período no qual a questão urbana volta a ocupar a agenda governamental, sob a forte pressão dos movimentos sociais para a retomada da intervenção do Estado no planejamento e na gestão das cidades. Foi criado o Ministério das Cidades, cuja estrutura organizou-se em secretarias que dialogam com alguns dos principais problemas que afetam a vida urbana, como aponta VIEIRA et al.( 2013).

Com a participação de acadêmicos, militantes e organizações não governamentais, foram formuladas importantes políticas setoriais para o enfrentamento dos problemas urbanos. Construiu-se um novo arcabouço jurídico para orientar a formulação dessas políticas, como é o caso das políticas de saneamento, de mobilidade urbana e de resíduos sólidos, e para fomentar

\footnotetext{
${ }^{14}$ Pode-se afirmar que a Lei 10.257/2001 teve origem no Projeto de Lei n. 775 de 1983, originário do próprio Poder Executivo, e que inspirou a edição do Projeto de Lei n. 181/89, de autoria do Senador Pompeu de Souza, recebendo, na Câmara de Deputados a classificação de Projeto de Lei n. 5.788/90. (ARAÚJO, 2008, p. 174)
} 
a cooperação intergovernamental, como a legislação que regulamentou a formação de consórcios públicos (TONELLA, 2013).

Dessa forma, surgiram novos instrumentos balizadores do planejamento urbano no Brasil. Fernandes (2008) afirma que seu conteúdo se baseia em paradigmas fundamentalmente distintos da concepção que embasou a primeira geração de planejamento urbano no Brasil. Esse estatuto pautou-se por uma série de novos instrumentos urbanísticos que foram sendo desenvolvidos ao longo do tempo em várias cidades brasileiras (ARAÚJO, 2008). Neste diapasão, o Plano Diretor, concebido como instrumento de orientação para a aplicação dos preceitos constitucionais, assume papel importante. Afirmam Ribeiro e Cardoso (2003, p. 108): “a elaboração de planos diretores deve ser encarada como uma forma de defesa do compromisso do poder público em assegurar um determinado nível de bem-estar coletivo”.

“O Plano Diretor, instituído pelo Estatuto da Cidade, deixaria de ser, apenas, instrumento técnico de ordenamento territorial, pois a ele caberia a definição do direito de propriedade imobiliária na nova ordem jurídica brasileira" aponta Caldas (2015, p. 42). A implementação de mudanças institucionais e normativas está aliada a uma nova concepção, "o Plano Diretor abandona a separação entre o planejamento operado pela esfera técnica e a gestão pela esfera política", segundo Fernandes (2008, p.128), aonde até então ambos muitas vezes foram conduzidos de forma conflituosa. Então passa a assumir a proposta participativa de construção de um plano que atendesse ao interesse público.

Os Planos Diretores elaborados tentavam induzir com vieses de ordenamento territorial o crescimento das cidades, e incorporaram ao desenho urbano as preocupações com os serviços e a infraestrutura, consolidando uma visão tecnicista da cidade. Esta, então, passou a ser vista sob um prisma técnico e institucional, resultante dos sistemas de serviços e infraestrutura requeridos, sob responsabilidade e oferta direta do poder público.

Segundo Villaça (2010), uma quantidade inédita de Planos Diretores foi elaborada no Brasil na década de 1970, por consultores pouco engajados com a realidade sociocultural local e sem a participação nem mesmo de técnicos municipais. Muitos autores analisam e questionam a eficácia dos Planos Diretores na solução de problemas urbanos. Entre eles, Villaça afirma que:

a sociedade está encharcada da ideia generalizada de que o Plano Diretor é um poderoso instrumento para a solução de nossos problemas urbanos [...] se tais problemas persistem é porque nossas cidades não têm conseguido ter e aplicar esse miraculoso Plano Diretor (Idem, 2005, p.10). 
Uma questão tão preocupante, ainda conforme Villaça (Ibidem), acontece no cenário que é um instrumento existente há tantas décadas, e são escassos os exemplos que tenham diretrizes e soluções pautadas, minimamente, por um Plano Diretor com escopo que ultrapasse as questões do zoneamento. Por fim, o autor afirma que os Planos Diretores são, na verdade, cortinas de fumaça para tentar ocultar o fracasso da classe dominante em resolver os problemas urbanos, e que nada sobra que seja do interesse público ou da maioria da população.

De fato, segundo Caldas (2015), a concepção tradicional dos Planos Diretores baseavase em um ideal de cidade a ser alcançado paulatinamente, por meio da definição de parâmetros adequados de organização do espaço físico da cidade formal, os quais seriam atingidos por meio de investimentos públicos e de legislação de uso e ocupação do solo condizente.

O planejamento deve passar a ser entendido não só como atividade de elaboração de planos de ordenamento espacial para a "cidade ideal", preocupados com fatores como o traçado urbanístico, mas também como análise das densidades de ocupação, da racionalização dos fluxos e do uso do solo, entre outras características de aspectos da dinâmica social (HARVEY, 1993; SOUZA, 2002; e MACHADO, 2008), decorrentes da urbanização, e outras externalidades. Da mesma forma, foram instituídos instrumentos para permitir a recuperação de mais valia. Com isso, é possível que os municípios que detêm funções regulatórias, ou seja, devem controlar a expansão urbana, a ocupação e o uso da terra, com instrumentos específicos.

Há, ainda, medidas que proporcionaram avanços para a gestão democrática das cidades e para participação e controle social do processo de expansão urbana. A implicação mais imediata desses instrumentos, nas palavras de Galvão (2005, p. 31) seria a de "aumentar a capacidade de regulação urbanística ao permitir maior poder ao Estado em interferir nos mercados imobiliários". Assim, é possível uma maior influência do Estado em benefício da coletividade, na própria regulação do mercado imobiliário e, indiretamente, em sua formação de preços dos terrenos e dos imóveis nesses mercados.

O Plano Diretor, diante desta conjuntura, é um instrumento para (re)orientar a estruturação do território municipal a partir da releitura de sua atual capacidade, sob o aspecto não só das diretrizes técnicas e urbanísticas, mas também de sua capacidade de refletir as demandas sociais da vida citadina. O Estatuto da Cidade traz ainda a prerrogativa de que o Plano Diretor deve ser elaborado com a participação de diferentes setores da sociedade, empoderando-o como o principal instrumento de política e planejamento de longo prazo da esfera urbana. Segundo a Constituição Federal de 1988, o Plano Diretor deve ser elaborado, ainda, pelas cidades com mais de 20 mil habitantes ou aquelas localizadas em regiões 
metropolitanas e/ou aglomerados urbanos ${ }^{15}$. Segundo o Estatuto da Cidade, estes Planos, enquanto políticas urbanas obrigatórias, deveriam estar elaborados, obrigatoriamente, até o ano de 2006.

No entanto, a ideia do Plano Diretor como instituto jurídico que viabiliza as políticas públicas de inclusão socioespacial precisa ser examinada e instrumentalizada. A primeira geração de planejamento urbano no Brasil tentou fazer planejamento urbano sem enfrentar a questão do direito de propriedade imobiliária, com base na noção de que a função social da propriedade se reduz às "limitações" e/ou "restrições" administrativas impostas ao uso da propriedade e no exercício do poder de polícia da administração pública, segundo Caldas (2015, p. 42).

Alguns autores (SERRA, 1991; COSTA, 2008; ADEODATO, 2010; RODRIGUES e BARBOSA, 2010) pontuam que essa iniciativa representa uma ruptura com o modelo anterior. Afinal, ela incorpora, dessa forma, a ideia de processo contínuo de planejamento, inserido no contexto político-administrativo como atividade, colocando maior destaque na escala local. Maricato (2009) afirma que os planos e demais instrumentos de regulação sempre foram concebidos para uma parte da cidade, a chamada cidade formal, e atenderam a interesses de regulação manipulados pelas elites - em especial, pelo mercado imobiliário. Enquanto isso, grande parte da população ocupou territórios de forma predatória, desconhecendo os planos urbanísticos. No entanto, segundo afirma a autora, a ineficácia dessa legislação é apenas aparente:

a ocupação ilegal da terra urbana é não só permitida como parte do modelo de desenvolvimento urbano no Brasil [...] é funcional para a manutenção do baixo custo da reprodução da força de trabalho, como também de um mercado imobiliário especulativo. (Ibidem, p. 147).

Assim, a aplicação de um Plano Diretor passa por duas principais dificuldades: a necessidade de compreensão, por parte dos gestores públicos, para com o objetivo do

\footnotetext{
${ }^{15}$ Conforme Art. 41. da Lei Federal LEI No 10.257, DE 10 DE JULHO DE 2001. O plano diretor é obrigatório para cidades com mais de vinte mil habitantes, integrantes de regiões metropolitanas e aglomerações urbanas, onde o Poder Público municipal pretenda utilizar os instrumentos previstos no § 4o do art. 182 da Constituição Federal, integrantes de áreas de especial interesse turístico, inseridas na área de influência de empreendimentos ou atividades com significativo impacto ambiental de âmbito regional ou nacional, incluídas no cadastro nacional de Municípios com áreas suscetíveis à ocorrência de deslizamentos de grande impacto, inundações bruscas ou processos geológicos ou hidrológicos correlatos.
} 
planejamento, e o papel da legislação no planejamento (STEPHAN, 2006). A elaboração do plano, além de cumprir o que exige a lei, atende eventualmente à pressão exercida por um grupo reduzido de pessoas interessadas em sua existência. Desse modo, é um desafio tanto elaborar, quanto aplicar os planos diretores.

Segundo Almeida (2012), os elementos dos planos diretores que se relacionam de forma direta com a organização e o ordenamento do território são (i) macrozoneamento; (ii) zoneamento; e (iii) instrumentos urbanísticos. Contudo, a prática recente demonstra que somente estes elementos não são suficientes. Os planos diretores passam a definir estratégias e diretrizes, ancoradas em uma visão de futuro. Já segundo o "Guia para Implementação do Estatuto pelos Municípios e Cidadãos" (BRASIL, 2005, p. 41), o Macrozoneamento é “a divisão do território em unidades territoriais que expressem o destino que o município pretende dar às diferentes áreas da cidade", estabelecendo um "referencial espacial para o uso e a ocupação do solo”. Assim é que devem ser demarcadas grandes áreas nas quais, em função do interesse de uso, se buscará incentivar, coibir ou qualificar a ocupação.

Nessa lógica, deverão ser definidas, ao menos, as macrozonas urbana e rural, abrangendo a totalidade do perímetro urbano. Apesar de o conceito de Macrozoneamento não ter sido introduzido pelo Estatuto, segundo Almeida (2012), foi este que o fez ganhar especial importância, por impor que o plano diretor abrangesse toda a área do Município. Dessa forma, aumentando a abrangência do zoneamento tradicional, passou-se a estabelecer o macrozoneamento como um primeiro nível de definição das diretrizes espaciais do Plano Diretor, de acordo com Saboya (2007). Entretanto, o Observatório das Metrópoles (2010) ${ }^{16}$, na análise dos planos pós-Estatuto, mostrou que, no âmbito nacional, a maioria dos Planos Diretores não explicita se os municípios possuíam, pelo menos, leis de perímetro urbano em vigor. Também são imprecisas as referências sobre as alterações realizadas na sua delimitação.

Assim, o tema do planejamento urbano ocupou, e ainda ocupa, a agenda de municípios com os mais diversos portes e perfis, em todo o país. O Governo Federal, por meio do Ministério das Cidades e do Conselho Nacional das Cidades, apoiou a elaboração dos planos diretores

\footnotetext{
16 OBSERVATÓRIO DAS METRÓPOLES, 2010 . Relatório Nacional. Rede de Avaliação e Capacitação para a implementação dos Planos Diretores Participativos. <http://web.observatoriodasmetropoles.net/images/abook_file/plano_diretor.pdf/>. Acesso em 13 mar. 2016.
} 
através de uma Campanha Nacional ${ }^{17}$ realizada em 2005. Em 2015, 2.786 municípios $^{18}$ - ou seja, metade dos 5.572 municípios brasileiros - tinha plano diretor de desenvolvimento urbano, segundo o IBGE (2016). Segundo Gaspar (2007, p. 4), “a análise da qualidade do espaço urbano ocupado passa a ser a questão primordial de análise em diversas esferas e sob as mais variadas óticas", em um contexto em que a condição de bem-estar para a população passa a ser a chave para o sucesso de planos administrativos locais.

Neste prisma, é o Estatuto da Cidade que assevera o processo de participação popular na escolha das prioridades. Nessa direção, a política urbana prevê que sejam utilizados os seguintes instrumentos:

a) criação de órgãos colegiados de política urbana nos níveis nacional, estadual e municipal;

b) debates, audiências e consultas públicas;

c) conferências sobre assuntos de interesse urbano, nos níveis nacional, estadual e municipal;

d) iniciativa popular de projeto de lei e de planos, programas e projetos de desenvolvimento urbano (artigo 43, I, II, III e IV do Estatuto das Cidades).

O protagonismo do município no campo da política urbana e o papel da União constituem pontos centrais para avaliação dos eventuais avanços ou retrocessos da Política Urbana vigente. Maricato (2010, p. 6) lembra que as cidades brasileiras têm "características muito diferenciadas, e a aplicação de uma regra geral definida pelo nível federal, apresentará resultados variáveis dependentes da correlação de forças locais”.

Analisando, brevemente, a evolução dos elementos de transformação urbana no Município de São Paulo, vale ressaltar que, na década de 1920, com a implantação de "melhoramentos" - serviços de água encanada, iluminação pública, pavimentação, entre outros -, foi possível viabilizar o surgimento da "urbanidade" da cidade. Mas, isso aconteceu em pontos distintos e não simultâneos da cidade. Historicamente, as áreas com melhores qualidades urbanísticas foram destinadas à elite. Por exemplo, um agente privado que mantinha o monopólio do fornecimento de energia, telefonia e transporte urbano sobre trilhos, a Companhia

\footnotetext{
${ }^{17} \mathrm{O}$ Governo Federal investiu cerca de R $\$ 54$ milhões no apoio aos municípios para elaboração de planos diretores, além de desenvolver atividades de capacitação e mobilização, segundo Santos Junior e Montadon (2011), Oliveira e Biaotto (2011).

${ }^{18}$ Município é o espaço territorial político dentro de um estado ou unidade federativa; é o espaço administrado por uma prefeitura. O município possui sua zona rural e sua zona urbanizada.
} 
Light, direcionou, no início, a infraestrutura para esses sistemas, acarretando valorização imobiliária de terrenos, segundo Rolnik (2001).

No Município de São Paulo, foi elaborado o primeiro Projeto de Lei Urbana em 1963 (Goulard), que culminou na Lei de Uso e Ocupação do Solo (1970). A partir desse ponto, uma série de temas avançaram em sua discussão, sua técnica e sua política, cujas aspirações tiveram como objetivo definir instrumentos urbanísticos que atendessem questões relevantes a um melhor planejamento das cidades brasileiras.

O Estatuto da Cidade, estabelecido em julho de 2001 pela Lei Federal n. 10.257/ 2001, definiu normas de ordem pública e interesse social que regulam o uso da propriedade urbana em prol dos interesses coletivos, da segurança e do bem-estar dos cidadãos, além do equilíbrio ambiental. Esta política urbana tem por objetivo orientar o ordenamento urbano, o pleno desenvolvimento das funções sociais da cidade e da propriedade urbana, estabelecendo, para isso, diretrizes e instrumentos.

Inicialmente, observa-se que o Estatuto da Cidade regulamenta o artigo 182, da Constituição Federal de 1988, dispondo acerca das diretrizes gerais e dos instrumentos da política urbana, tais como a efetiva aplicação do plano diretor, do direito de preempção, da operação urbana consorciada e da outorga onerosa do direito de construir (solo criado). Conforme Pagani (2009, p.185), o objetivo para a consecução dessa lei foi "combater a especulação imobiliária" e fomentar um vetor orientado de adensamento e diversificação de usos em determinados eixos, ou ainda, ocupar áreas subutilizadas - seja pela degradação urbana, seja pelo esvaziamento populacional - que possuem boa infraestrutura, visando a sua requalificação urbana. Assim, projetos de intervenção urbana são propostos como vetores de transformação induzida que não só corroborem para resultados favoráveis ao mercado imobiliário, mas também contribuam para a melhoria do espaço urbano, conforme apontam Maricato e Ferreira (2002), por meio dos instrumentos. A partir do marco de regulamentação, alguns instrumentos tiveram sua habilitação legal e puderam permitir os estudos, por exemplo, das operações urbanas ${ }^{19}$, e a elaboração dos Planos Diretores no município de São Paulo.

Após quase 20 anos da promulgação da Constituição Federal e da necessidade de atendimento ao Estatuto da Cidade, houve a criação da Lei Municipal n. 13.430, datada de 13 de setembro de 2002 - Plano Diretor Estratégico da Cidade de São Paulo, PDE. Como

\footnotetext{
${ }^{19}$ Operação Urbana ou Operação Urbana Consorciada é um instrumento urbanístico que excepciona a Lei de Uso e Ocupação do Solo e é utilizada para requalificar uma área da cidade ou para implantar e/ou ampliar infraestruturas urbanas.
} 
elementos contidos no Plano Diretor de Desenvolvimento Urbano, destacam-se, a partir deste ponto, elementos de Intervenção e Transformação Urbanísticas, tais como Planos Urbanísticos, Operações Urbanas, Planos de Bairro e Zonas Especiais de Interesse Social (ZEIS).

O processo de revisão do Plano Diretor Estratégico (PDE) do Município de São Paulo se iniciou em janeiro de 2013 e se estendeu até o final de 2014, culminando na lei n. 16.050/2014 - Política de Desenvolvimento Urbano e Plano Diretor Estratégico do Município de São Paulo. O Plano Diretor Estratégico de São Paulo (Lei n. 16.050/2014) está em sua segunda versão e deve começar a ser revisto em 2021, já que tal lei tem um tempo de duração de 10 anos. O principal objetivo do PDE 2014 foi "humanizar e reequilibrar São Paulo, aproximando moradia e emprego e enfrentando as desigualdades socioterritoriais" (SÃO PAULO, 2014)

O plano é apresentado segundo conceitos, princípios, diretrizes e objetivos que regem as estratégias e os mecanismos da política formulada, a qual se deseja implementar. As "estratégias" do PDE 2014 assemelham-se às metas, os resultados esperados, da execução do Plano Diretor. Essas metas podem ser sumarizadas conforme segue:

a) Estratégia 1: socializar os ganhos da produção da cidade;

b) Estratégia 2: assegurar direito à moradia digna para quem precisa;

c) Estratégia 3: melhorar a mobilidade urbana;

d) Estratégia 4: qualificar a vida urbana dos bairros;

e) Estratégia 5: orientar o crescimento da cidade nas proximidades do transporte público;

f) Estratégia 6: reorganizar as dinâmicas metropolitanas;

g) Estratégia 7: promover o desenvolvimento econômico da cidade;

h) Estratégia 8: incorporar a agenda ambiental ao desenvolvimento da cidade;

i) Estratégia 9: preservar o patrimônio e valorizar as iniciativas culturais;

j) Estratégia 10: fortalecer a participação popular nas decisões dos rumos da cidade.

Estes instrumentos de desenvolvimento urbano abrangem um conjunto de intervenções e medidas coordenadas pelo Poder Público municipal. Conforme o Estatuto da Cidade (2001), elas devem congregar a participação de proprietários, moradores, usuários permanentes e investidores privados, com o objetivo de alcançar, em uma área urbana definida, transformações urbanísticas estruturais, melhorias sociais e valorização ambiental. 


\subsubsection{Política Nacional de Desenvolvimento Urbano}

A Política Nacional de Desenvolvimento Urbano (PNDU) tem por objeto o espaço socialmente construído, por meio do qual são apresentados os princípios e diretrizes das políticas setoriais que a compõem, as quais são detalhadas nos Cadernos específicos, quais sejam: Participação e Controle Social (Caderno 2); Planejamento Territorial Urbano e Política Fundiária (Caderno 3); Política Nacional de Habitação (Caderno 4); Saneamento Ambiental (Caderno 5); Política Nacional de Mobilidade Urbana Sustentável (Caderno 6); Trânsito, Questão de Cidadania (Caderno 7); e Capacitação e Informação (Caderno 8).

Segundo a PNDU, o desenvolvimento urbano é definido como "a melhoria das condições materiais e subjetivas de vida na cidade, com a diminuição da desigualdade social e garantia de sustentabilidade social e econômica” (BRASIL, 2004, p. 8). Caldas (2015) afirma ser inegável que os elementos preconizados nessa política, da qual se ressaltam habitação, saneamento ambiental, mobilidade urbana e política fundiária/ imobiliária, sejam estruturantes do ambiente urbano, e estão intimamente ligados às condições de vida dos cidadãos.

Para além da dimensão quantitativa da infraestrutura, dos serviços e equipamentos urbanos, o documento refere-se à "ampliação da expressão social, cultural e política do indivíduo e da coletividade, em contraponto aos preconceitos, à segregação, à discriminação, ao clientelismo e à cooptação" (Ibidem, p. 8). Sendo o governo local a principal instância de reivindicação popular, uma vez que tal instância está territorialmente ligada aos problemas que surgem na vida cotidiana, conforme aponta Pizzirani (2006), a cidade passa a ganhar destaque. Quando o município passa do papel de coadjuvante para o de ator principal, o crescimento das cidades traz para as prefeituras municipais a necessidade de maiores investimentos em infraestrutura, tais como saneamento, iluminação, moradia, segurança, saúde, educação, mobilidade, comunicação e lazer, indispensáveis ao modo de vida moderno.

Ocorre que, como afirma Fernandes (2008, p.132), ainda que possa haver um consenso a respeito da centralidade que deve ser dada ao município na formulação de suas políticas urbanas, "é preciso encarar o fato de que situações institucionais, financeiras e técnicas profundamente heterogêneas dentre os municípios brasileiros não deveriam ser tratadas com o mesmo aparato jurídico". Ou seja, o tratamento jurídico igual de situações desiguais continuará a gerar distorções profundas e a limitar o alcance das políticas urbanas.

O Brasil, por sua dimensão e por suas particularidades históricas, culturais, sociais, políticas e econômicas, é um país muito heterogêneo e marcado muito mais pelas diferenças do 
que pelas semelhanças. De forma preliminar, o desenvolvimento urbano não pode prescindir de estratégias que busquem diminuir as desigualdades estruturais, sociais e econômicas, segundo Araújo (1993). Assim, a formulação das políticas urbanas e sua territorialização não podem ser tratadas de forma incipiente. Há inúmeras diferenças históricas entre as regiões, diferenças expressivas entre Estados de uma mesma região, diferenças entre municípios do mesmo Estado, ou entre bairros do mesmo município. Como já afirmava Araújo:

Do ponto de vista espacial o Brasil não é sequer observado pela política governamental. O viés abrangente dos macroeconomistas, não permite trabalhar com um dado essencial da nossa realidade: somos um país desigual. Não apenas socialmente, mas também regionalmente. E a heterogeneidade não é um mal em si, nem uma fatalidade. Pode até ser trabalhada como uma potencialidade (Ibidem, p. 94).

Finalmente, as discussões sobre desenvolvimento regional, no âmbito do Governo Federal, foram constantes e resultaram em um documento produzido pelo Ministério da Integração Nacional que, em $2007^{20}$, propôs um conjunto de instrumentos corroborados por estudos $^{21}$ promovidos pelo Ministério das Cidades, os quais sugerem propostas para reconfiguração da rede urbana brasileira. Nesse documento, conforme Caldas (2015), destacaram-se as seguintes diretrizes principais: criação de novas centralidades urbanas, definição de políticas públicas específicas segundo a diversidade da rede urbana e prioridade para as regiões metropolitanas.

Esta rede urbana, focalizada na dispersão e na definição de novas centralidades, com foco nas abordagens locais e particulares, associada ao desenvolvimento metropolitano, aprofunda também a reflexão sobre o agravamento das condições sociais nas cidades. As consequências desse cenário favoreceram a fragmentação urbana, tendendo a agravar a desigualdade já existente na sociedade brasileira, e, por tal razão, a política urbana prevê instrumentos que possam equalizar a dinâmica dos municípios e a vida nas cidades.

\footnotetext{
${ }^{20}$ Foram oficializadas pelo Decreto n. 6.047 que "Institui a Política Nacional de Desenvolvimento Regional" (PNDR) ALVES, A. M.; ROCHA NETO, J. M. da. A nova Política Nacional de Desenvolvimento Regional - PNDR II: entre a perspectiva de inovação e a persistência de desafios. Revista Política e Planejamento Regional, v. 1, n. 2, Rio de Janeiro, jul./ dez. 2014, p. 311-338. ROCHA NETO, J. M. da. Cooperação e Competição entre políticas públicas no Brasil: os custos da governabilidade no presidencialismo de coalizão. Tese (Doutorado em Administração) - Universidade Federal do Rio Grande do Norte, como pré-requisito à obtenção do grau de Doutor, Natal, 2013. Para aprofundar o debate neste tema consultar: Federal do Rio Grande do Norte, Natal, 2013.

${ }^{21}$ O documento refere-se a um estudo elaborado em 2003, com objetivo de priorizar a questão metropolitana no contexto das políticas públicas nacionais, denominado Plano de Ação para Metrópoles em Risco, que definia prioridades para investimento nas regiões metropolitanas.
} 


\subsubsection{Instrumentos de combate à retenção especulativa}

A política urbana possui elementos no Plano Diretor que atuam como instrumentos urbanísticos vinculados a estratégias de desenvolvimento urbano relacionados com o cumprimento da função social da cidade e da propriedade, conforme aponta Motta (2009). São preconizados no Estatuto da Cidade:

a) parcelamento, edificação ou utilização compulsórios (artigos $5^{\circ}$ e $6^{\circ}$ ): tratam-se de ferramentas que permitem ao Poder Público, mediante notificação e fixação de prazo, compelir o proprietário de terreno localizado em área previamente estipulada no Plano Diretor municipal a dar destinação ao solo urbano não edificado, subutilizado ou não utilizado. Os critérios para configuração de subutilização serão fornecidos pelo PD ou por lei específica dele decorrente;

b) IPTU progressivo no tempo $\left(\operatorname{artigo} 7^{\circ}\right.$ ): para reprimir a ociosidade, os imóveis que não cumprirem a obrigação de parcelar, edificar ou utilizar, receberão aumento crescente de tributo. A aplicação do Imposto Predial e Territorial Urbano (IPTU) progressivo no tempo implica a majoração da alíquota pelo prazo de cinco anos consecutivos. O valor da alíquota modificada será fixado em lei específica;

c) desapropriação com pagamento em título (artigo $8^{\circ}$ ): o município poderá desapropriar o imóvel que, mesmo depois de decorridos cinco anos de cobrança do IPTU progressivo, não tenha cumprido a obrigação previamente estabelecida de parcelamento, edificação ou utilização compulsórios. O pagamento se dará através de títulos da dívida pública, resgatados no prazo de até dez anos;

d) direito de superfície (artigos 21 a 24): trata da possibilidade de o proprietário urbano conceder a outrem o direito de utilização do solo, subsolo ou espaço aéreo de seu imóvel, sem perda da propriedade. A concessão pode ser gratuita ou onerosa e deve ser feita mediante escritura pública registrada no cartório de registro de imóveis;

e) direito de preempção (artigos 25 a 27): instrumento que confere ao Município a preferência na aquisição de imóvel urbano objeto de alienação onerosa entre particulares. A delimitação das áreas sobre as quais deverá incidir o direito será definida em lei municipal baseada no Plano Diretor. Após a notificação da intenção de venda, o Município disporá de trinta dias para manifestar por escrito sua intenção de exercer o direito de preferência.

Conforme Pagani (2009), o objetivo para a consecução destes elementos no Estatuto da Cidade, foi combater a retenção de terrenos e imóveis ociosos e fomentar um vetor orientado 
de adensamento e diversificação de usos em determinados eixos, ou, ainda, ocupar áreas subutilizadas, seja pela degradação urbana, ou ainda pelo esvaziamento populacional, mas que possuem boa infraestrutura, visando a sua requalificação urbana.

\subsubsection{Instrumentos de Distribuição dos Benefícios e dos Ônus do Processo de Urbanização}

Projetos de intervenção urbana são propostos como vetores de transformação induzida que não só corroborem para resultados favoráveis ao mercado imobiliário, mas também contribuam para a melhoria do espaço urbano e das diretrizes de planejamento urbano a fim de que sejam efetivamente indutores da distribuição de ônus e benefícios nas cidades, conforme apontam Maricato e Ferreira (2002), por meio dos instrumentos:

a) outorga onerosa do direito de construir (artigos 28 a 31): o Plano Diretor poderá fixar áreas onde seja exigida contrapartida para o exercício do direito de construir que extrapole o coeficiente de aproveitamento básico estabelecido. Neste caso, utiliza-se o termo "solo criado”. A fórmula de cálculo para cobrança e os possíveis casos de isenção do pagamento pela outorga serão estabelecidos em lei específica;

b) operações urbanas consorciadas (artigos 32 a 34): caracterizam-se por um conjunto de intervenções e medidas coordenadas pelo Poder Público municipal, com a participação dos proprietários, moradores, e investidores privados, com o objetivo de alcançar em uma área transformações urbanísticas estruturais, melhorias sociais e valorização ambiental. A lei municipal de aprovação da operação deverá conter o plano de operação consorciada com definição da área atingida, programa de atendimento econômico e social para a população diretamente afetada, finalidades da operação, estudo prévio de impacto de vizinhança. Além disso, o Plano define a contrapartida a ser exigida pelo investidor privado em função de benefícios que podem ser concedidos na área da operação, tais como modificação de índices e características de parcelamento, uso e ocupação do solo;

c) transferência do direito de construir (artigo 35): autoriza proprietário de imóvel urbano, particular ou público, a exercer o direito de construir em outro local - ou alienar o direito de construir, mediante escritura pública -, quando o referido imóvel for considerado necessário para fins de 1- implantação de equipamentos urbanos e comunitários; 2- preservação (imóveis de interesse histórico, ambiental, paisagístico, social ou cultural); ou 3- programas de regularização fundiária, urbanização de áreas ocupadas por população de baixa renda e habitação de interesse social. A aplicação da 
transferência do direito de construir é estabelecida segundo lei municipal baseada no Plano Diretor;

d) Estudo de Impacto de Vizinhança (artigos 36 a 38): o Estudo prévio de Impacto de Vizinhança (EIV) será obrigatório para que determinados empreendimentos e atividades em área urbana, definidos por lei municipal, possam obter licenças ou autorizações de construção. Tem por objetivo analisar o impacto, positivo ou negativo, do empreendimento ou da atividade em questão na área e em suas proximidades. Essa análise inclui avaliações sobre adensamento populacional; equipamentos urbanos e comunitários; uso e ocupação do solo; valorização imobiliária; geração de tráfego e demanda por transporte público; ventilação e iluminação; e paisagem urbana e patrimônio natural e cultural. A lei ressalta ainda que o EIV não substitui o EIA - Estudo prévio de Impacto Ambiental -, requerido pela legislação ambiental;

e) usucapião especial de imóvel urbano (artigos $9^{\circ}$ a 14 ): representa a concessão ao homem ou à mulher, ou a ambos, para sua moradia, do título de domínio do imóvel de até duzentos e cinquenta metros quadrados, ocupado, sem oposição do proprietário, há mais de cinco anos. $\mathrm{O}$ instrumento se aplica desde que o beneficiário não seja proprietário de outro imóvel.

Inicialmente, observa-se que o Estatuto da Cidade regulamenta o artigo 182, da Constituição Federal de 1988, dispondo acerca das diretrizes gerais e dos instrumentos da política urbana, tais como a efetiva aplicação do plano diretor, do direito de preempção, da operação urbana consorciada e da outorga onerosa do direito de construir (solo criado).

\subsection{GOVERNANÇA URBANA}

Como contextualizado, o marco legal para a formulação da Política Urbana brasileira vigente tem origem na Constituição Federal (CF) de 1988, em especial, em seus artigos 182 e 183, posteriormente regulamentados pelo Estatuto da Cidade (EC), com a Lei 10.257, de 2001, bem como pelo Estatuto da Metrópole, com a Lei 13.089, de 2015, e tem uma relação hierárquica, conforme a figura 6. Esses instrumentos foram ampliados com o Ministério das Cidades e a instituição da Conferência Nacional das Cidades, da Política Nacional de Desenvolvimento Urbano (PNDU) e das Políticas Setoriais que a compõem, preconizadas pelo Ministério das Cidades"22, em 2004, e publicadas em oito volumes denominados "Cadernos

${ }^{22}$ O Ministério das Cidades foi instituído pela Lei n. 10.683, de 28 de maio de 2003. 
Cidades", por meio dos quais foram apresentados seus princípios, diretrizes e propostas estruturantes.

\begin{abstract}
o Ministério das Cidades [...] teve sua estrutura baseada nos três principais problemas sociais que afetam as populações urbanas e que estão relacionados ao território, são eles: a moradia, saneamento básico (que agrega água, esgoto, drenagem e coleta e destinação de resíduos sólidos) e as questões reunidas sob o tema do transporte da população urbana - mobilidade e trânsito. Considerando a centralidade da questão fundiária e imobiliária para o desenvolvimento urbano, foi criada uma quarta secretaria, que se ocupa especialmente do planejamento territorial e da regularização fundiária. Como estas competências são essencialmente das prefeituras municipais, o governo federal pode ter um importante papel coordenador, fomentador e financiador de estudos e ações. (MARICATO, 2006, p. 214).
\end{abstract}

Embora a presença de vários setores de desenvolvimento urbano em um mesmo ministério tenha propiciado espaço de diálogo e troca intensa, a forte cultura setorial e corporativa existente nos meios técnicos e uma interlocução na gestão em todos os níveis e nos setores empresariais ligados aos vários temas, "ainda não permitiu a construção de políticas realmente integradas, por meio de ações e programas multissetoriais” (ROLNIK, 2006, p. 208).

O ministério, criado para proporcionar condições para a formulação e a articulação da Política Urbana, deu início ao processo que denominou de "Pacto para Construção da Política Nacional de Desenvolvimento Urbano" (PNDU). Este se consolidou em uma articulação de base política com participação popular, admitindo que a construção da política urbana está no reconhecimento de que a participação nas políticas públicas é um direito do cidadão e que o “[...] caminho para o enfrentamento da crise urbana está diretamente vinculado à articulação e a integração de esforços e recursos nos três níveis de governo - federal, estadual e municipal [...]" com a participação dos diferentes segmentos da sociedade (BRASIL, 2004, p.75).

Do ponto de vista normativo, as questões levantadas são viabilizadas com apoio de instrumentos aplicados ao planejamento urbano, os quais se destacam na figura 6 e podem ser apresentados hierarquicamente a seguir:

a) Constituição Federal de 1988, com a Política Urbana (artigo 182/183);

b) Lei n. 10.257/2001 (Estatuto da Cidade);

c) Lei n. 13.089/2015 (Estatuto da Metrópole);

d) Planos Diretores, com o Participativo de Desenvolvimento Urbano;

e) Leis Federais e Municipais de Parcelamento, Uso e Ocupação do Solo; 
f) Leis Municipais para Projetos de Intervenções Urbanas e Operações Urbanas Consorciadas;

g) Políticas Setoriais;

h) Códigos de Posturas.

Figura 6 - Hierarquia na Política Urbana

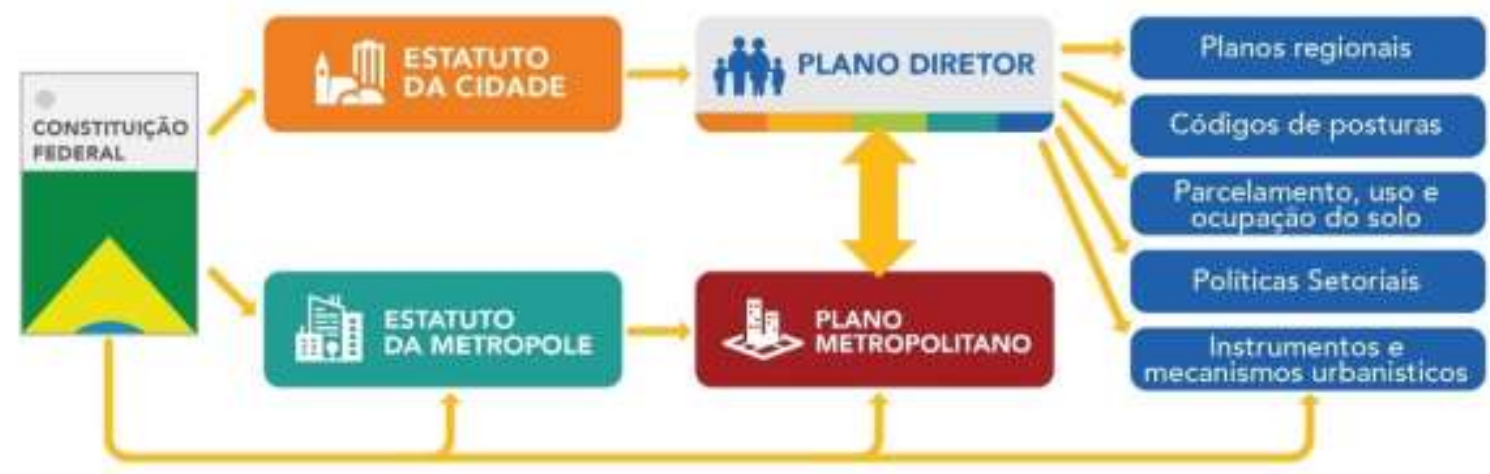

Fonte: Do autor (2016) - Adaptado de Marins (2016) ${ }^{23}$.

Este movimento culminou, em 2003, em consonância com os princípios democráticos do Estatuto da Cidade, em um ciclo de conferências realizadas em 3.547 municípios (62\% dos municípios brasileiros), que mobilizaram 320 mil pessoas dos mais diversos segmentos e elegeram 2.510 delegados, com representação de todos os 26 Estados e o Distrito Federal, para participarem da Conferência Nacional das Cidades. Esta promoveu a eleição do Conselho das Cidades.

De acordo com o Decreto n. 5.031, de abril de $2004^{24}$, o Conselho das Cidades integra a estrutura do Ministério das Cidades, possui natureza deliberativa e consultiva e tem por finalidade estudar e propor diretrizes para a formulação e a implementação da política nacional de desenvolvimento urbano. Além disso, deve acompanhar e avaliar a sua execução, conforme disposto no Estatuto da Cidade.

\footnotetext{
${ }^{23}$ Fluxograma com a legislação vigente para o desenvolvimento dos Planos Diretores apresenta também os principais artigos que influenciam nos aspectos de planejamento urbano nas cidades e áreas metropolitanas. Fonte: $\mathrm{O}$ autor (2016), adaptado de MARINS, K. R. C. C. Governança em áreas urbanas. Apresentação. PPGEC, 2016.

${ }^{24}$ Decreto n. 5.031, de abril de 2004, posteriormente substituído pelo Decreto n. 5.790, de 25 de maio de 2006. O Conselho Nacional das Cidades (ConCidades) é constituído por 86 titulares, e a mesma quantidade de suplentes, dos quais 49 representam segmentos da sociedade civil (movimentos populares, entidades empresariais, trabalhadores, entidades profissionais, acadêmicas ou de pesquisa e organizações não governamentais); 37 representam os poderes públicos federal, estadual e municipal. Em sua estrutura existem quatro Comitês Técnicos que espelham as funções do Ministério das Cidades e podem constituir Grupos de Trabalho para realização de atividades especificas: Comitê Técnico de Planejamento e Gestão do Uso do Solo; Comitê Técnico de Habitação; Comitê Técnico de Saneamento Ambiental e Comitê Técnico de Transporte e Mobilidade Urbana (SANTOS JÚNIOR, O. A.; RIBEIRO, L. C. Q.; AZEVEDO, S. (Orgs.). Governança democrática e poder local: a experiência dos Conselhos municipais no Brasil. Rio de Janeiro: Revan, FASE, 2004).
} 


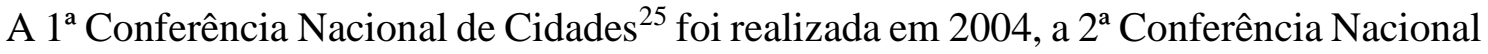
das Cidades ocorreu em 2005, a $3^{\text {a }}$ Conferência Nacional das Cidades ocorreu em 2007, a $4^{\text {a }}$ Conferência Nacional das Cidades ocorreu em 2010 , a 5 a Conferência Nacional das Cidades

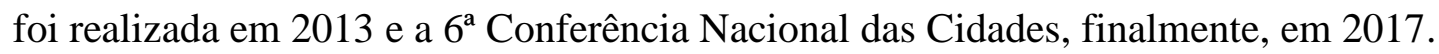

As conferências referendaram o Estatuto da Cidade e formularam um conjunto de princípios e diretrizes, em consonância com seus objetivos e se discutiu as formulações da Política Nacional de Desenvolvimento Urbano. Pode-se afirmar que esse conjunto de conferências têm ênfase nos princípios de Justiça Social, Planejamento Urbano e Ambiental e Gestão Democrática, e que, apesar de defender explicitamente a descentralização da Política Nacional de Desenvolvimento Urbano, reconhece a relevância do papel da União na regulação nacional para orientação da ação dos demais entes federativos.

Os temas levados a debate foram a participação e o controle social, a questão federativa, a política urbana regional e metropolitana e o financiamento do desenvolvimento urbano, e reforçando o desenvolvimento urbano com participação popular e justiça social, com foco na discussão sobre o avanço na gestão democrática das cidades. Refletiu-se sobre o descontentamento social com o andamento do processo de implantação da Política Nacional de Desenvolvimento Urbano, doze anos após a homologação do Estatuto da Cidade.

As conferências foram delineadas em temas, tais como "Cidade para Todos Construindo uma política democrática e integrada para as cidades", "Cidade para todos e todas com gestão democrática, participativa e controle social", "Quem muda a cidade somos nós: Reforma Urbana já" e "Cidades inclusivas, participativas e socialmente justas"(MINISTÉRIO DAS CIDADES, 2013a, grifo do autor).

O que se nota é que a adoção de temas parece indicar que o percurso da implantação da reforma urbana no Brasil andou em círculos, no sentido de que a abordagem dos processos participativos ainda é um campo fértil, e ainda há dificuldade na construção de uma gestão participativa, que não se restringe a, apenas, transparência e consulta.

\subsection{MÉTRICAS EM INSTRUMENTOS URBANÍSTICOS E GESTÃO URBANA}

O zoneamento, por sua vez, é um instrumento de controle de uso e ocupação do solo. Por meio da divisão espacial da cidade, diretrizes, parâmetros e índices urbanísticos específicos são

25 Conteúdo e resoluções das Conferências Nacionais da Cidade: <http://www.cidades.gov.br/conselho-dascidades/secretaria-executiva $>$. 
atribuídos a cada uma das subdivisões. Para Cardoso e Ribeiro (2003), o zoneamento deve ultrapassar os limites de uma "visão puramente urbanística/funcionalista" para, incorporando princípios de um planejamento politizado, "servir, então, para o controle do uso do solo, tendo em vista a preocupação de proteger certos padrões de qualidade de vida e, ao mesmo tempo, de gestão democrática da cidade".

Considera-se, então, o zoneamento como responsável por definir e separar usos e densidades de ocupação, conforme sinaliza Saboya (2007), aliados a parâmetros urbanísticos para controle da ocupação do solo, por meio da restrição quanto ao porte da edificação ou dos lotes. Assim, o zoneamento influencia, de forma direta, no controle da verticalização, da densidade populacional e, consequentemente, da expansão urbana.

No caso brasileiro, segundo Villaça (1999, p. 238), “zoneamento e Plano Diretor desenvolveram-se de forma paralela e independente". O autor destaca que, em cidades como Rio de Janeiro e São Paulo, o zoneamento já vinha sendo utilizado antes mesmo da definição do conceito de Plano Diretor. Almeida (2012), Saboya (2007, 2009) e Netto e Saboya (2010), lastreados por dados do Observatório das Metrópoles (2010), apontam que, em geral, os Planos Diretores oferecem informações suficientes para determinação do potencial construtivo atribuído às diferentes parcelas do território, definidas no zoneamento. A regulação do solo urbano costuma ser remetida para legislação específica, como a Lei de Uso e Ocupação do Solo ou a Lei de Parcelamento, a serem elaboradas posteriormente ao plano.

A referência ao termo "parâmetros" remete quase intrinsecamente ao termo "diretrizes". São coisas distintas, uma vez que, segundo Almeida (2012, p. 25), diretrizes sugerem a inserção de linhas reguladoras, instruções ou indicações, que, para a prática de uso e ocupação de solos regulada e instrumentalizada, são "as normas balizadoras e indutoras da aplicação dos instrumentos de política urbana regulamentados na lei” (BRASIL, 2005, p. 31). Já um parâmetro, um dado necessário para analisar ou valorizar uma situação, pertence a uma equação e pode ser usado como sinônimo de regra, padrão ou norma.

No momento em que as diretrizes regulamentadoras de política urbana instrumentalizam as práticas de uso e ocupação de solo como normas obrigatórias, e as chamam de diretrizes, fazem com que instruções, ou indicações, tornem-se linhas reguladoras, e consequentemente regras, transformando-as em parâmetros. Assim, a atuação do Estado, em vistas aos instrumentos que lhe cabem, segue diretrizes gerais, dentre as quais há a inserção do direito a cidades sustentáveis e da gestão democrática (artigo $2^{\circ}$, I e II da Constituição Federal). A primeira diretriz abriga uma expressão nova no panorama legislativo do país, "cidades 
sustentáveis", que, segundo o próprio inciso, deve ser entendida como o "direito à terra urbana, à moradia, ao saneamento ambiental, à infraestrutura urbana, ao transporte e aos serviços públicos, ao trabalho e ao lazer, para as presentes e futuras gerações”.

Em tese, percebe-se que a utilização dos instrumentos depende da prévia identificação das áreas passíveis de sua aplicação, e, portanto, é “durante seu processo de elaboração que devem se aprofundar as discussões sobre a cidade atual e a cidade desejada, estabelecendo-se os pactos urbanos possíveis" (CALDAS, 2015). Por conseguinte, são pressupostos a disponibilidade de informações que subsidiem a discussão sobre o território, um adequado nível de conhecimento do problema urbano e das dinâmicas do mercado imobiliário, além dos aspectos que assegurem as condições adequadas para a efetiva participação social no processo deliberativo das diretrizes dos Planos, entre outras abordagens técnicas.

Nesse momento, talvez seja necessário revisar o tema do processo decisório, especialmente no que se refere à abordagem da racionalidade limitada decorrente das formulações de Simon (1970). Este autor alerta ser um problema complexo avaliar as alternativas de que dispõem e todas as consequências de suas escolhas. Outra limitação reside na impossibilidade do acesso, por problemas de custo e tempo, a todas as informações necessárias para avaliar de forma completa as possibilidades de ação. Por isso, o administrador deve decidir considerando um número limitado de informações que possibilite a identificação dos problemas e algumas soluções alternativas.

Entretanto, a razão de ser de um plano ${ }^{26}$ inclui a possibilidade de reduzir as incertezas; guiar a ação até chegar à situação desejada; e organizar os meios para atingir tal situação. A noção de plano pressupõe um conjunto de ideias, tais como previsão, organização, coordenação de esforços, acompanhamento e controle de ações, além de avaliação de resultados, conforme Misoczky e Guedes (2012).

Estes pressupostos se configuram em diagnósticos necessários à compreensão do padrão de expansão urbana, da identificação de processos de ocupação e retenção de terrenos ociosos em área urbanizada, dos vazios urbanos, das áreas irregulares, dos assentamentos precários, da forma urbana e sua morfologia, da infraestrutura de transporte, da densidade, da diversidade, enfim, do conhecimento necessário sobre o território que garanta a pertinência para utilização dos instrumentos urbanísticos.

\footnotetext{
${ }^{26}$ Neste trabalho se considera que o planejamento define o caminho a ser percorrido para se alcançar um objetivo almejado e envolve um conjunto de iniciativas e ações, entre as quais as elaborações de plano e projetos. O plano é materialização escrita e formal das estratégias aplicadas para um determinado objetivo.
} 
Nesse cenário, áreas especificas de intervenção urbana que eventualmente possam estar subutilizadas - seja pela degradação urbana ou ainda pelo esvaziamento populacional -, mas que possuem boa infraestrutura, tornam-se objeto de estudo por parte do Poder Público, visando a sua requalificação urbana. Nestas áreas, consolidam-se projetos de intervenção urbanística que, associados a diretrizes de uso e ocupação de solo, podem fornecer insumos para analisar a eficiência de instrumentos de regulação urbanística no que tange ao adensamento urbano (populacional e construído).

A associação do adensamento com a parametrização da forma urbana pode refletir em projetos com maiores densidades, com diversificação de atividades, e mais $\operatorname{compactos}^{27}$. Por sua vez, é possível que os resultados apresentem características interessantes que contribuam para um espaço urbano menos segregado e mais igualitário, estabelecendo a distribuição dos serviços e equipamentos urbanos, integrando centro e periferia, definindo parâmetros urbanísticos - como taxas de ocupação, coeficientes de aproveitamento, recuos, gabaritos, permeabilidade e uso do solo -, os quais balizarão os padrões de uso e ocupação do solo urbano, de forma mais sinérgica, conforme mostra a figura 7.

Figura 7 - Esquema de Sinergia Urbana
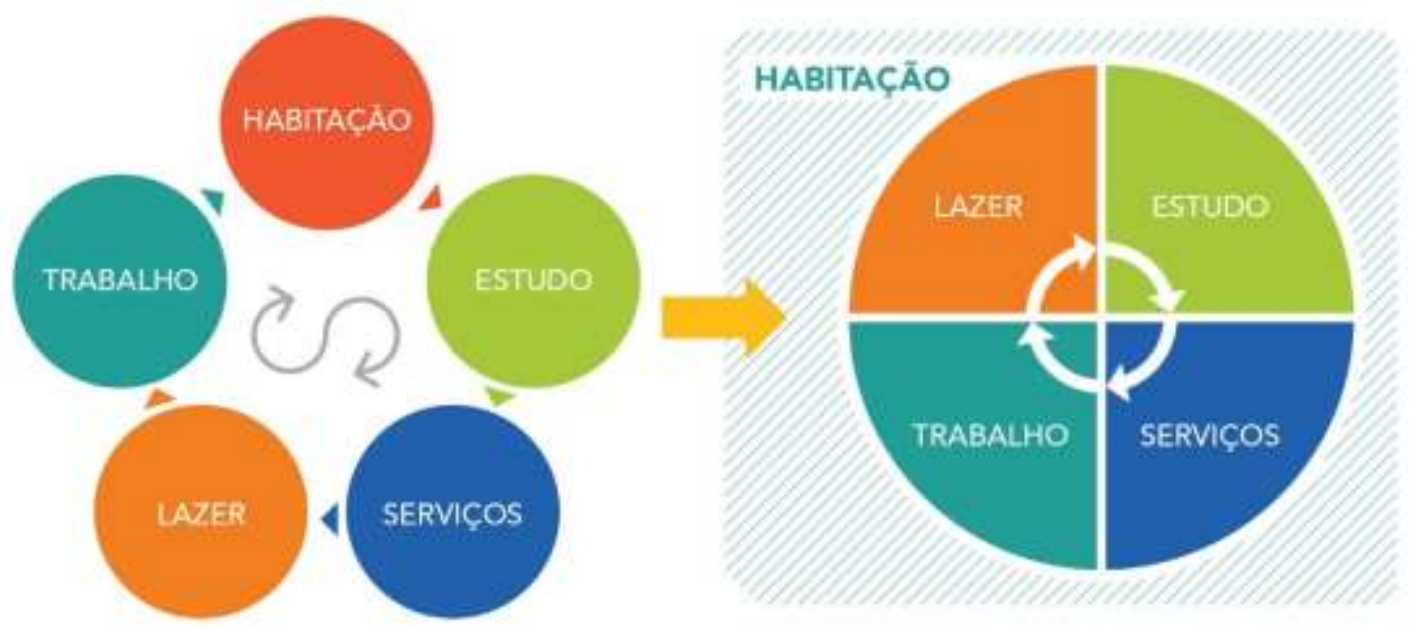

Fonte: Do autor (2019) - Baseado em Rogers e Gumuchdjian (2001).

Dessa forma Rogers e Gumuchdjian (2001) apontam que a tarefa de planejar as cidades só será melhorada se os projetistas forem capazes de compreender algumas das relações entre

\footnotetext{
${ }^{27}$ A cidade compacta se desenvolve em torno de centros de atividades sociais e comerciais localizados estrategicamente junto a pontos nodais de transporte público de massa, e em volta dos mesmos, nesse entendimento, se constitui em uma rede dessas vizinhanças, cada uma delas abrigando uma gama de atividades públicas e privadas sobrepostas, em uma estrutura urbana policêntrica. Essa estrutura, por sua vez, diminuiria a necessidade de deslocamentos por automóvel e poderia ser atendida por um sistema de transporte coletivo que interligasse os diferentes centros de vizinhança, deixando a distribuição local para sistemas locais. A cidade compacta é uma proposta que preconiza a proximidade, os espaços públicos, o contato entre indivíduos e potencializa a atividade humana, conforme Rogers e Gumuchdjian (2001).
} 
os componentes das cidades durante o processo de planejamento, e este entendimento pode ser aprimorado com a aplicação de métricas socioespaciais adicionando uma percepção qualitativa e quantitativa a processo de planejar.

Essa preocupação com intervenções urbanas não é intrínseca à realidade brasileira, e cidades ao redor do mundo compartilham princípios norteadores capitaneados pelo relatório "Cidades do Mundo", publicado pela ONU-Habitat (UNITED NATIONS, 2016). Esses princípios dependem da boa governança, de modo que se aliam os seguintes princípios:

a) promover o desenvolvimento sustentável;

b) atingir o planejamento integrado;

c) integrar planos com orçamentos;

d) planejar com parceiros e operadores;

e) aplicar o princípio da subsidiariedade;

f) promover a receptividade do mercado;

g) garantir o acesso à terra;

h) desenvolver ferramentas de planejamento apropriadas à realidade local;

i) favorecer populações de menor renda de forma inclusiva;

j) reconhecer a diversidade cultural.

Por sua vez, conforme Wheeler (2000), o desenvolvimento urbano prescinde do atendimento de alguns princípios, tais como forma urbana compacta, preservação de espaços abertos, criação de espaços comunitários ambientalmente saudáveis, habitação decente (acessível e adequadamente localizada), promoção da equidade social e criação de oportunidades para os menos favorecidos e desenvolvimento de uma economia local restauradora. Esta lista não é exaustiva, e nem consensual, mas busca transmitir a ideia geral de que a contínua promoção do bem-estar humano, em longo prazo, deve ser incluída como premissa em todos os âmbitos do planejamento (NAHAS, 2015).

Assim, a parametrização e a prática de planejamento urbano estão sujeitas a princípios, a exemplo de compacidade, diversificação, equidade social, fortalecimento da economia local e valorização de espaços públicos, como apontam Wheeler, (2000), Weiland (2006), Baxamusa (2008), Nahas (2015) e United Nations (2016). Ademais, Marins (2010) destaca que o planejamento de distritos, bairros e unidade de vizinhança, configurando-se também como 
subcentros, ou poli centralidades ${ }^{28}$, pode atenuar a dependência cotidiana com relação a outras áreas da cidade ou da metrópole, iniciativa que busca um desenvolvimento urbano integrado. Tal colocação reforça a proximidade às demandas locais.

Santoro (2012) aponta que os termos "uso e ocupação do solo" são associados às normas que configuram o regime urbanístico, relativas à densificação, ao regime de atividades, aos dispositivos de controle das edificações e ao parcelamento do solo. Esse instrumento tradicionalmente, segundo a autora, é uma forma ativa de o Estado atuar na realidade construída. Em termos práticos, o uso e a ocupação do solo delimitam o que pode ou não ser construído e as restrições geométricas das construções nos terrenos. Além disso, genericamente apresentam variáveis intrínsecas à finalidade das edificações, à quantidade de pessoas e à distribuição das atividades.

Existem diversos mecanismos que atuam nesse instrumento da política urbana, tais como:

a) Coeficiente de Aproveitamento: a razão entre a área construída e a área do lote, onde a área construída geralmente é a soma das áreas dos pisos cobertos do edifício. Para cálculo de Coeficiente de Aproveitamento, a equação proposta é apresentada na eq.(1).

$$
C A=A C / A T
$$

Em que:

$\mathrm{CA}=$ Coeficiente de aproveitamento;

$\mathrm{AC}=$ Área útil total construída;

$\mathrm{AT}=$ Área total do lote.

b) Taxa de Ocupação: a razão entre a área ocupada e a área do lote, onde a área ocupada é a área da projeção horizontal do edifício no lote. Para cálculo de Taxa de Ocupação, a equação é proposta na eq.(2).

$$
T O=A P / A T
$$

Em que:

TO = Taxa de ocupação;

$\mathrm{AP}=$ Área de projeção da construção no lote;

$\mathrm{AT}=$ Área total do lote.

\footnotetext{
${ }^{28}$ Decorrente da dispersão, quando uma área tem densidade demográfica e econômica importante, criam-se centros secundários para a distribuição de mercadorias ou de serviços. A cidade, durante seu crescimento, engloba pequenos centros semiurbanos ou antigos subúrbios, que se transformaram em centros secundários (SANTOS, 1989).
} 
Existe uma relação intrínseca entre o Coeficiente de Aproveitamento e a Taxa de Ocupação, a qual resulta na quantidade de andares de uma edificação. Afinal, enquanto o Coeficiente de Aproveitamento determina o limite de área construída, a Taxa de Ocupação limita como será a implantação desta área construída no lote.

Marins et al. (2018) apontam que essa relação tem implicações inclusive no aproveitamento fotovoltaico na cobertura das edificações, conforto ambiental e condições de acesso ao sol pelos pedestres. Se, por um lado, maiores Coeficientes de Aproveitamento podem induzir uma maior densidade construída e, consequentemente, uma maior oferta de atividades e habitações em uma região, por outro lado, quando associadas a menores Taxas de Ocupação, podem induzir uma maior verticalidade e, consequentemente, influenciar na ventilação e insolação de uma região.

Contudo, outros parâmetros são comumente encontrados nos instrumentos urbanísticos. Alguns exemplos são: (i) o recuo, que determina a distância que separa as divisas do lote da projeção horizontal do edifício, podendo ser frontal, lateral ou de fundos; (ii) a área mínima do lote, que determina a menor fração de área que um lote pode possuir; (iii) a frente mínima do lote, que determina a menor largura inicial que um lote pode possuir; e (iv) o gabarito, que indica geralmente a altura máxima permitida dos edifícios. Em síntese, os municípios aplicam uma divisão de sua área em zonas homogêneas, para as quais são designados usos e especificadas as densidades de ocupação, por meio de índices urbanísticos como o Coeficiente Máximo de Aproveitamento, a Taxa de Ocupação máxima, os recuos mínimos, a área mínima dos lotes, a frente mínima dos lotes e o gabarito máximo das edificações.

\subsubsection{Indicadores da morfologia e da dinâmica urbanas}

Para inserir o parâmetro de forma urbana, é importante refletir sobre como esse tema que vai além do estudo da forma ou da morfologia urbana -, compreendido como uma abordagem do detalhamento formal por meio do conjunto de edificações, malha viária e densidades que compõem o espaço urbano, é uma área de conhecimento complexo, conforme apontam Holanda (2001, 2002, 2003), Ribeiro et al. (2012) e Cantalice (2012). Por sua vez, Lamas (2007) fornece definição considerando forma urbana como o "modo como se organizam os elementos morfológicos que constituem e definem o espaço urbano, relativamente à materialização dos aspectos de organização funcional e quantitativa e dos aspectos qualitativos e figurativos", que compreendem: 
I.) Aspectos quantitativos: tudo que pode ser quantificável - densidades, superfícies, fluxos, coeficientes volumétricos, dimensões, perfis, etc. Todos os dados que podem ser utilizados para controlar o aspecto físico da cidade;

II.) Aspectos de organização funcional: relacionam-se com as atividades humanas, uso da área em questão, ou seja, tipo do uso do solo (residencial, escolar, comercial...);

III.) Aspectos qualitativos: referem-se ao tratamento dado aos espaços urbanos para imprimir maior conforto ou comodidade. O meio urbano pode ser caracterizado pelo tipo de pavimento, adaptação ao clima (abrigo dos ventos e chuvas), acessibilidade, etc;

IV.) Aspectos figurativos: relacionam-se com a comunicação estética. Entende-se que, apesar de haver uma área de sobreposição entre os aspectos qualitativos e estéticos, convém distinguir que os aspectos qualitativos não são necessariamente estéticos - um ambiente com alto grau estético não implica necessariamente em boa comodidade ou conforto e vice-versa (Ibidem).

A forma urbana, segundo Gentil (2015, p. 40), também pode ser compreendida como "a distribuição, planejamento e projeto de elementos fixos que se distribuem em uma determinada área urbana”. Assim, são refletidas em padrões de uso do solo as densidades, a configuração das redes de transporte, os serviços e a infraestrutura. Duarte et al. (2008) complementam essa análise afirmando que a forma urbana também é resultado de diversos agentes e fatores combinados no espaço e no tempo, como o Estado, o setor privado, a dinâmica social e econômica.

Braga (2006) e Braga et al. (2004) justificam que, em princípio, as cidades canalizam suas preocupações no que tange à infraestrutura, às vias de circulação, às canaletas e aos canais de drenagem, também utilizados para a dispersão das águas servidas, e aos poços de água e cisternas de acúmulo de água de chuva destinados ao abastecimento de água potável. Herce Vallejo (1998) e Herce Vallejo e Farrerons (2002, p. 8) apontam que essas redes de serviços primordiais quase sempre foram constituídas pelo aproveitamento de antigos sistemas de circulação, drenagem e irrigação de áreas rurais.

As vias de circulação, normalmente berço dos dispositivos de drenagem, pouco a pouco se constituíram também no lugar das novas redes de serviços urbanos disponibilizados pelo desenvolvimento tecnológico, como a distribuição de água potável e a dispersão de água pluvial e servida em sistemas canalizados, a distribuição de gás, a iluminação pública, a rede elétrica, os transportes mecanizados públicos e privados, bem como os sistemas de telecomunicação por rádio, fio e fibra ótica, conforme Braga (2006). A forma que tomará a cidade é resultado dessas interconexões.

Litman (2012) estabelece uma série de fatores relacionados a padrões de uso e ocupação do solo que podem afetar o comportamento da circulação em áreas urbanas. Contudo, o autor 
enfatiza que esses atributos são pouco considerados em estudos de mobilidade urbana. Tais variáveis são destacadas no quadro 1 .

Quadro 1 - Fatores Incidentes na Definição da Forma Urbana

\begin{tabular}{|c|c|}
\hline Fator & Definição \\
\hline $\begin{array}{l}\text { Densidade } \\
\text { (Populacional e de } \\
\text { Empregos) }\end{array}$ & As pessoas ou empregos por unidade de área de terra. \\
\hline Densidade Construída & Área Construída por unidade de área de terra. \\
\hline Diversidade de Uso & $\begin{array}{l}\text { Graus que relacionam os usos do solo (residenciais e não } \\
\text { residenciais), seja em números absolutos (quantidade) ou por } \\
\text { área destinada por área de terra. }\end{array}$ \\
\hline Acessibilidade & $\begin{array}{c}\text { Local de desenvolvimento relativo ao centro urbano, medido } \\
\text { como o número de trabalhos (ou usos específicos) dentro de um } \\
\text { tempo de viagem controlado. }\end{array}$ \\
\hline Centralidade & $\begin{array}{c}\text { Porção comercial (ou não residencial) em centros de } \\
\text { convergência ou de atividades principais. }\end{array}$ \\
\hline Conectividade & $\begin{array}{l}\text { Grau de vias e caminhos conectados que permitem a viagem } \\
\text { direta entre destinos. }\end{array}$ \\
\hline Gestão da Mobilidade & $\begin{array}{c}\text { Programas e estratégias de estímulo (ou desestímulo) a } \\
\text { determinados padrões de viagem; controle de velocidades, } \\
\text { tráfego e uso, a favor de modos eficientes, além de intervenções } \\
\text { nas atividades com foco no transporte. }\end{array}$ \\
\hline $\begin{array}{l}\text { Estacionamento } \\
\text { (Provisão e Gestão) }\end{array}$ & $\begin{array}{c}\text { Número de espaços para estacionar por unidade de área terra ou } \\
\text { por unidade de área construída, e o grau com o qual eles são } \\
\text { estimulados (ou desestimulados) e regulados. }\end{array}$ \\
\hline $\begin{array}{c}\text { Caminhadas e } \\
\text { Condições de Ciclismo }\end{array}$ & $\begin{array}{l}\text { Qualidade de caminhar e condições de transporte cicloviário, } \\
\text { incluindo a quantidade e qualidade de calçadas, faixas para } \\
\text { pedestres, caminhos e pistas de bicicleta e o nível de segurança } \\
\text { dos pedestres. }\end{array}$ \\
\hline $\begin{array}{l}\text { Qualidade de } \\
\text { Transporte público e } \\
\text { acessibilidade }\end{array}$ & $\begin{array}{l}\text { A qualidade de serviço de trânsito e o grau para os quais destinos } \\
\text { são acessíveis por qualidade no transporte em uma área. }\end{array}$ \\
\hline Desenho Urbano & $\begin{array}{l}\text { O plano e o desenho dos edifícios e espaços públicos, desenho de } \\
\text { ruas e quadras, infraestrutura e condicionantes de serviços. }\end{array}$ \\
\hline
\end{tabular}

Fonte: Adaptado de Litman (2012), Fernandes et al. (2011) e Fernandes (2008).

Cabe aos envolvidos no planejamento identificar os agentes envolvidos, decidir critérios e ponderar sobre as alternativas possíveis a cada estudo feito que considere a existência de novas abordagens que venham a possibilitar uma visão global dos processos que compõem a cidade e suas interrelações com diversos fatores incidentes influentes na forma urbana. 
A forma reticular em quadrícula normalmente adotada para estas redes, mais que uma opção estética abstrata, foi a melhor maneira encontrada para permitir a necessária e contínua expansão multidirecional das infraestruturas urbanas, conforme Fernandes (2008).

Medeiros (2006, 2013) e Gentil et al. (2014) destacam que a cidade não é apenas um sistema viário de vias e avenidas articuladas ou a disposição de espaços abertos e fechados, mas também um complexo conjunto de relações - é um lugar para onde convergem, concentram-se e interagem grupos de relações sociais econômicas, culturais e políticas. Essas variáveis podem ser tomadas como elementos que constroem o planejamento urbano e, assim, devem refletir as percepções cotidianas das pessoas, que neste contexto, devem ser modeladas a partir dos processos participativos, que fornecerão elementos que os transformem em objetivos e critérios.

Ademais, essas variáveis criam conexões que, conforme Lentino (2005, p. 25), apontam interfaces com a "dinâmica urbana", na qual há contínua transformação do espaço urbano como um todo, isto é, dos espaços públicos e privados da cidade, em função das forças ou mecanismos que o produzem. Outra variável relevante nessa dinâmica urbana é a forma com que a densidade urbana pode ser dimensionada, à luz de indicadores e elementos que traduzem uma determinada realidade local.

Essa abordagem, à luz da literarura e da análise de casos como paradigma, consolida cenários, indicadores de qualidade de vida e demais elementos que, inclusive, podem lastrear os planos de bairro e ações locais especificas. Por exemplo, os níveis de desenvolvimento econômico e de desenvolvimento social de uma região podem ser medidos pela taxa de urbanização, pelo crescimento da população urbana, pela densidade populacional e pela densidade de empregos em uma área urbana, segundo aponta Zhen (2018). Portanto, identificar um método que analise quantitativamente o efeito de cada indicador na cidade e determine seu peso, é relevante para avaliar a dinâmica urbana.

Os indicadores espaciais permitem examinar questões de diversidade, como uma composição setorial (distribuição e concentração de diferentes atividades e uso da terra), e avaliar a diversidade de uso do solo com moradia, escritórios, edifícios comerciais, áreas verdes, dentre outras áreas residencias e não redisenciais. Essas questões podem ser examinadas dentro dos limites de um único distrito ou entre vários distritos (BOURDIC; SALAT; NOWACKI, 2012).

Para avaliar a diversidade, é possivel aplicar o índice de Simpson, ou índice de diversidade (I), dado pela eq. (3), onde $n_{i}$ é a quantidade de ocupações de um tipo de uso da 
categoria $i$; e $N$ é a quantidade total de unidades de todos os tipos de uso, conforme Bourdic, Salat e Nowacki (2012).

$$
I=1-\sum_{i=1}^{\infty}\left(\frac{n_{i}}{N}\right)^{2}
$$

A densidade, por sua vez, é um indicador de intensidade cada vez mais utilizado. Ela pode medir a concentração de um objeto, de pessoas ou empregos, em uma determinada escala. Pode, então, descrever uma relação de concentração de pessoas e oportunidades de emprego com uso eficiente do solo em um distrito. É possível destacar a densidade humana, a densidade de construções, a densidade habitacional e a densidade de trabalho, conforme Bourdic, Salat e Nowacki (Ibidem), dadas, por exemplo, pelas equações eq.(4) e eq.(5).

$$
\begin{gathered}
\text { Densidade Populacional }=\frac{\text { população }}{\text { área de estudo }} \\
\text { Densidade de empregos }=\frac{\text { total de emprego }}{\text { área de estudo }}
\end{gathered}
$$

Indicadores da forma urbana descrevem o tecido urbano. Esses indicadores dão detalhes sobre a morfologia urbana. Cruz e Marins (2017) e Willians et al. (2000) apontam que as formas urbanas mais densas, mais diversificadas e mais compactas proporcionam um uso eficiente da terra e da infraestrutura, contrbuindo para a sustentabilidade urbana. A compactação é calculada de acordo com a comparação média entre o perímetro de cada distrito e o perímetro de um círculo que tem a mesma área, conforme apontam Li e Yeh (2004), onde IC é o valor do Índice de Compacidade, $S_{j}$ e $P_{j}$ são respectivamente a área e o perímetro do distrito analisado, dados pela eq. (6).

$$
\text { Índice de Compacidade }=I C=2 \times \frac{\sqrt{\pi \times S_{j}}}{P_{j}}
$$

O IC é o índice frequentemente aplicado para representar a compactação e a organização espacial. O Índice de Compacidade de uma cidade circular tem um valor de 1, e valores de IC mais baixos indicam um espaço mais amplo, segundo Cruz e Marins (2017), Lu e Liu (2016) e Bourdic, Salat e Nowacki (2012).

\subsection{ESCALAS URBANAS E AS INTERVENÇÕES URBANAS}

Segundo Silva e Romero (2011), o estudo urbano prescinde da consideração das diversas escalas de abordagem, pois dá uma visão ampla das condicionantes e determinantes que agem 
sobre a cidade e, ao mesmo tempo, permite uma percepção local mais coerente com as dinâmicas regionais que atuam na produção e reprodução do urbano. Nesse raciocínio, deve-se pensar não apenas na oferta de serviços inerentes à infraestrutura, nem tão somente no atendimento das necessidades da vida urbana, mas também em um modelo de ocupação do solo que trate o espaço urbano e a localização das atividades de forma competente, a fim de garantir o equilíbrio entre a demanda e a oferta das necessidades urbanas e dos serviços - e o uso do solo é uma condicionante estrutural desse raciocínio.

Villaça (2001) reforça que a escala intraurbana é essencial na compreensão da cidade. Nesse âmbito, o autor estabelece duas abordagens escalares: (i) a Escala Urbano-Regional - na qual há o espaço urbano-regional e seus deslocamentos de mercadorias, energia e comunicação -, em que os modelos de desenvolvimento são determinantes para a articulação da organização espacial, os elementos dessa escala focam a reestruturação produtiva, o trabalho e a descentralização industrial; e (ii) a Escala Intraurbana, que impacta na estrutura do espaço intraurbano, e sua reestruturação é ocasionada pelos transportes e pela mobilidade de pessoas enquanto portadores de mercadoria, informação, força de trabalho ou de consumo espacial aqui, os modelos de desenvolvimento e intervenção regional não influem diretamente na sua estrutura.

$\mathrm{Na}$ escala intraurbana, os temas se dedicam a esclarecer a descentralização, a polinucleação, os subcentros, a reestruturação intraurbana etc. Dessa forma, a junção dos conceitos acerca do urbano pôde ser demonstrada também por Rueda (1998, 1999, 2001a, 2001b, 2005), Romero (2003, 2009), Guimarães (2004), Silva, G. J. A. (2011a, 2010a) e Villaça (2010), com a seguinte subdivisão:

a) Macrossistemas urbanos, que equacionam os fluxos e as interações que ocorrem nas escalas internacional e nacional;

b) Mesossistemas urbanos, que determinam os fluxos e as interações que ocorrem nas escalas estadual e regional;

c) Microssistemas Urbanos, que se referem aos fluxos e às interações que ocorrem nas escalas urbana e local.

Nesse contexto, Silva e Romero (2010) propõem um organograma representativo dos sistemas urbanos a partir das escalas de análise, os contextos e subcontextos interligados, de uma escala a outra, que permitem uma abordagem sistêmica de formas de apropriação do espaço, condizente com as necessidades emergenciais apresentadas, em âmbitos global e local. 
A análise em escalas de Romero (2003, 2009) estabeleceu um entendimento das escalas do urbano de forma completa, subdivididas em macro, meso e microescalas. São elas:

a) Escala das grandes estruturas ou da cidade - permite analisar as grandes estruturas urbanas, entendidas como os espaços da organização, dos recursos e da produção, bem como sistema de informação e de comunicação (ARGAN e BOTTMANN, 1992), a exemplo da massa edificada, dos espaços que permeiam, da diversidade de alturas, do grau de fragmentação, da qualidade perceptiva da grande forma física e organizacional, da variedade ambiental, do macrossistema de transporte, da permanência e da continuidade do construído;

b) Escala intermediária do setor - esta corresponde à escala do bairro/ da área/ do setor, determinada com base nos critérios de organização produtiva do espaço em análise, a exemplo das relações morfológicas e sua respectiva resposta ambiental, da acessibilidade ambiental/ funcional, da centralidade, dos marcos urbanos, do conhecimento pessoal e da funcionalidade;

c) Escala específica do lugar - corresponde ao espaço coletivo e de valor das ações cotidianas, que não deve ser confundido com o espaço físico de implementação das construções, a exemplo de identidade, otimização das relações pessoais, especificidade das funções, caracterização estética, apelo às emoções e segurança;

d) Escala específica do edifício - corresponde à dimensão específica da unidade do abrigo e do espaço social e individual, o edifício, a exemplo de proteção, otimização microclimática, controle (grau de privacidade) e afeto (sentido de abrigo ao grupo social familiar).

Tais localidades apresentam algo em comum, o aumento da interatividade entre lugares, dando base ao surgimento de um novo tipo de espaço, que Castells $(2009,1999)$ denomina “espaço de fluxos". Segundo o autor "espaço de fluxos" é "a organização material das práticas sociais de tempo compartilhado que funcionam por meio de fluxos", pois "nenhum lugar existe por si mesmo, já que as posições são definidas por fluxos".

Relacionando a questão da escala com a questão dos espaços e sua localização, é possível externalizar os processos de planejamento e implantação de projetos de intervenção urbana como um sistema urbano. A partir destes, alguns autores propõem a sistematização em quatro temas principais, recorrentes em teorias:

a) Conexões Urbanas - Mobilidade, Acessibilidade, Sistema Viário e Segregação Espacial; 
b) Identidade e Percepção Urbana e Ambiental - Social, Econômica e Cultural, Perceptiva e Visual;

c) Morfologia - Aspectos Morfológicos e Ambiente Edificado;

d) Meio Ambiente - Vegetação e Microclima, Recursos Hídricos, Poluição e Energia.

A análise do espaço urbano por meio de escalas visa à percepção do todo, mas também das particularidades. Assim, segundo Romero (2009), torna-se possível parametrizar o espaço urbano por meio do entendimento das escalas do urbano, da área e do lugar. A autora estabelece ainda o entendimento de espaço a partir de três grandes frentes do urbano: a edificação (superfície de fronteira - planos verticais); as redes (elementos de base, os fluxos - planos horizontais); e a massa (entorno, conjunto urbano - vegetação, água, construção, solo). 


\title{
3. PARTICIPACÃO POPULAR EM PROCESSOS DECISÓRIOS RELATIVOS A PLANEJAMENTO URBANO
}

Participar é meramente intervir em um processo decisório qualquer, conforme resume Modesto (1999). Já participação cidadã é um processo complexo e contraditório envolvendo sociedade civil, Estado e o setor privado, em que os papéis se redefinem pelo fortalecimento da sociedade civil, mediante a atuação organizada dos indivíduos, grupos e associações, segundo Teixeira (2001) e Misoczky (2002). Para Kliksberg (1999), a participação é uma estratégia para a melhoria dos resultados da ação governamental.

Inserem-se, nesse ponto, os pressupostos da cooperação para o desenvolvimento, cuja boa governança é caracterizada por um processo aberto e esclarecido de formulação de políticas. Por sua vez, não se pode descartar o papel de uma sociedade civil forte, participando dos negócios públicos, conforme salienta o Banco Mundial em seu relatório sobre práticas de participação (WORLD BANK, 1996).

Os estudos em Políticas Públicas são bastante amplos, abrangendo desde os processos de elaboração até a avaliação de conteúdo e de impactos das políticas, considerando:

\begin{abstract}
Como surgem os problemas de decisão política, e como chegam às agendas as autoridades governamentais; em seguida, como as pessoas formulam os temas de ação governamental, como se processa a subsequente ação legislativa, ou de outra natureza, como os administradores aplicam a política escolhida e, finalmente, no término do processo, como essa política pode ser avaliada (LINDBLOM, 1981, p. 10-11).
\end{abstract}

De acordo com as etapas propostas por diversos autores, como Dror (1983), Hogwood e Gunn (1984) e Bardach (1998), o processo de elaboração de políticas públicas envolve uma fase na qual é preciso compreender a realidade em que se pretende atuar e definir o problema a ser enfrentado, a partir da formulação de um modelo causal que considera hipóteses e pressupostos sobre determinados fenômenos sociais.

Essas políticas constituem, muitas vezes, as bases para a definição de planos de ação que estabelecem as diretrizes para programas, os quais, por sua vez, são implementados na forma de projetos. Assim, o entendimento do problema, o modelo causal, que influencia na elaboração de políticas públicas, acaba se tornando também um modelo para o planejamento de projetos.

Ainda, há de se acrescentar que o reconhecimento dos inúmeros atores sociais e o condicionamento da elaboração e da execução dos planos pelo forte jogo de interesses, presentes na vida política local, são fatores que conferem maior complexidade e mais dificuldades às administrações públicas municipais. Tal complexidade de objetivo, atores e 
elementos, que se constituem de forma direta, indireta, ou semi-indireta, em níveis de representação e decisão, cuja estrutura hierárquica compilada por Lentino (2005), pode ser visualizada na figura 8 .

Figura 8 - Sujeitos Sociais Envolvidos no Processo de Tomada de Decisão

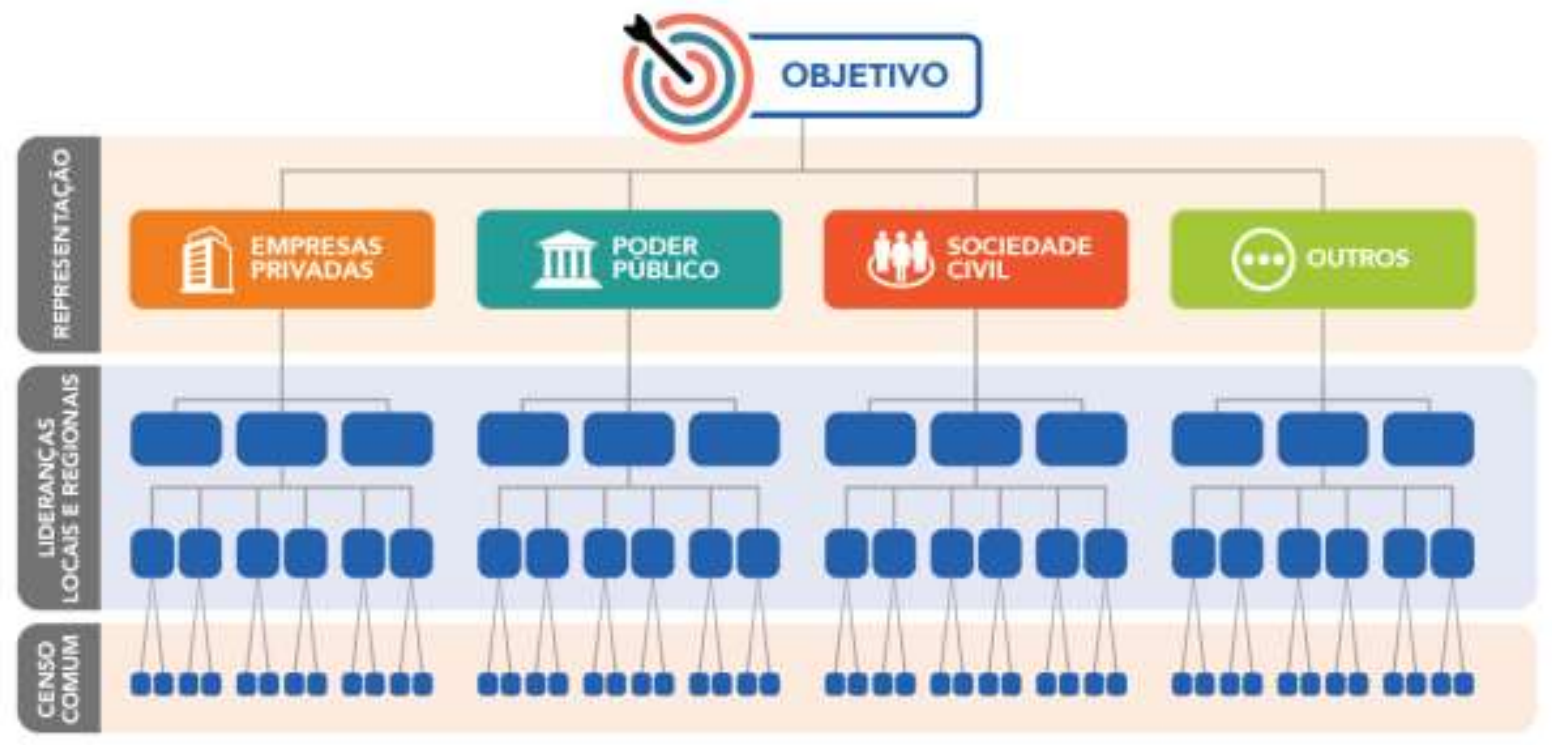

Fonte: Adaptado de Lentino (2005).

De Rousseau (1978) ${ }^{29}$ até Dahl $(2001)^{30}$, passando por Schumpeter $(1961)^{31}$, Kelsen $(1978)^{32}$, Macpherson $(1978)^{33}$, Habermas $(1984)^{34}$, Pateman $(1992)^{35}$, Demo $(1996)^{36}$ e Sousa Santos $(2002)^{37}$, entre outros, pode-se entender que "os conceitos de democracia e de participação se entrelaçam" (UGARTE, 2004, p. 94-95). São muitas as teorias que tratam desses tópicos, dentre as quais uma se destaca: a de que esses conceitos, quando combinados, permanecem como processos inacabados e em eterna evolução construtiva, como expõem Demo (1996) e Schier (2002):

[...] participação é conquista para significar que é processo, no sentido legítimo do termo: infindável, em constante vir a ser, sempre se fazendo. Assim, participação é em essência autopromoção e existe enquanto conquista processual. Não existe participação suficiente, nem acabada. Participação que se imagina completa, nisto mesmo começa a regredir (DEMO, 1996, p. 18).

\footnotetext{
${ }^{29}$ Cf. ROUSSEAU, Jean-Jacques. Do contrato social. São Paulo: Abril Cultural, 1978.

${ }^{30}$ Cf. DAHL, Robert A. In. Sobre a Democracia. Brasília: UNB, 2001.

${ }^{31}$ Cf. SCHUMPETER, Joseph Alois. Capitalismo, socialismo e democracia. Fundo de Cultura, 1961.

${ }^{32}$ Cf. KELSEN, HANS. Pure Theory of Law. London: Berkeley, 1978.

${ }^{33}$ Cf. MACPHERSON, C. B. A democracia liberal: origens e evolução. Rio de Janeiro: Zahar. 1978.

${ }^{34}$ Cf. HABERMAS, Jürgen. Mudança estrutural da esfera pública: investigações quanto a uma categoria da sociedade burguesa. Rio de Janeiro: Tempo Brasileiro, 1984.

${ }^{35}$ Cf. PATEMAN, C. Participação e teoria democrática. Rio de Janeiro: Paz e Terra, 1992.

${ }^{36}$ Cf. DEMO, Pedro. Participação é conquista: noções da política social participativa. São Paulo: Cortez, 1996.

${ }^{37}$ Cf. SOUSA SANTOS, Boaventura de. Democracia e participação: o caso do orçamento participativo de Porto Alegre.

Porto: Afrontamento, 2002.
} 
O direito de participação concretiza [...] o princípio democrático, manifestando-se através de regras que asseguram aos cidadãos a possibilidade de interferir e auxiliar na tomada das decisões quanto às atividades do poder público, vinculando tais decisões ao bem comum historicamente definido, contribuindo, nesta medida, com a realização do Estado Social (SCHIER, 2002, p. 75).

Por sua vez, Dasso Junior (2010) sugere três principais vantagens do exercício da participação democrática: mediar conflitos, ouvir diferentes pontos de vista e propor algo de interesse comum. A visão é reforçada por Araújo (2014), cuja análise sobre a democracia está amplamente ligada a participação, equidade, eficiência, cidadania, autonomia e descentralização.

Estes elementos, em uma visão sistêmica, são balizadores e norteadores para o enfrentamento dos problemas urbanos nas cidades. Muito mais do que um posicionamento político, estes elementos impulsionam a quebra de paradigma - pois a participação e a cidadania fomentam o senso de pertencimento, que são intimamente ligados à introdução do cidadão no processo democrático e, consequentemente, em um ciclo virtuoso participativo. $\mathrm{O}$ cidadão participa, colabora, manifesta-se, posiciona-se, orienta, fiscaliza e decide, em uma lógica de empoderamento individual e, até coletivo. Esse cenário induz (em sentido virtuoso) o cidadão a um papel de cogestor na construção do desenvolvimento sustentável da sociedade e de áreas urbanas.

Em sua análise sobre participação na esfera pública, Habermas (1997) sugere que um processo democrático deveria proporcionar para seus cidadãos, no mínimo, a inclusão de todas as pessoas envolvidas, com chances reais de participação no processo político, repartidas equitativamente. É importante que nesses processos, todos tenham o direito à escolha dos temas da agenda e igual direito a participação nas decisões. Criam-se, assim, condições para que todos os participantes, tendo à mão informações suficientes e bons argumentos, possam formar uma compreensão articulada acerca das matérias a serem regulamentadas e dos interesses controversos.

No Brasil, a participação popular é entendida como processo de “(...) esforços organizados para aumentar o controle sobre os recursos e as instituições que controlavam a vida em sociedade" (GOHN, 2001). Neste prisma, é possível verificar que a nossa cidadania se exerce em diversos níveis, mas é no plano local que a participação pode se expressar de forma mais concreta, antecipando as diretrizes expressas pela ONU-Habitat (2010), por Salles (2000) e Castells (1980). Estes defendem que o nível local é o espaço mais favorável à prática participativa. 
Na maior parte dos municípios brasileiros, a democracia representativa é a única prática democrática reconhecida pela população como forma de exercer seus direitos civis, tendo como principal momento as eleições, segundo Pizzirani (2006). No entanto, a participação popular permite o controle social, por exemplo, sobre políticas setoriais, sendo, portanto, uma forma de permitir a democratização do espaço de discussão em áreas tidas como complexas ou de atuação restrita a técnicos, conforme salienta Feenberg (1991, 2002, 2003).

Dessa forma, o exercício da democracia não se restringe ao simples ato e à liberdade de votar e ser votado (concepção de democracia liberal), pois pressupõe a liberdade de organização e expressão e, frequentemente, a contraposição a posições do Estado (HERNÁNDEZ e BERMANN, 2006). Apesar disso, não existe, para a maior parte da população brasileira, uma prática democrática cotidiana.

Por outro lado, os processos participativos vêm ganhando forma e mais adeptos. No entanto, nas experiências brasileiras, estes processos em sua maioria são comandados pelo poder público, instância que exerce, formalmente, o poder. Assim, a gestão democrática é apresentada como uma ferramenta que serve para articular a participação popular e os demais segmentos da sociedade civil na formulação, na implementação e na avaliação de planos, programas e políticas públicas.

\subsection{PARTICIPAÇÃO POPULAR NO BRASIL E A "ESCADA DE PARTICIPAÇÃO POPULAR"}

Uma das formas de atuação de gestão democrática é o planejamento participativo. Todo e qualquer processo de participação onde não haja redistribuição de poder permite àqueles que têm poder de decisão escolher os futuros beneficiários e, depois, argumentar que todos os lados foram ouvidos e contemplados sem alterar o status quo recorrente. Para impedir isso, segundo Arnstein (2002) - em revisão ao artigo publicado em 1969 -, conhecer e analisar os níveis de participação existentes pode ajudar.

Sobre esse assunto, Arnstein (Ibidem) deixou uma contribuição valiosa a respeito de podermos analisar e autoanalisar até que ponto os esforços de uma abordagem participativa estão caminhando com qualidade e dando seus frutos conforme o esperado. A tipologia proposta pelo autor, representada na figura 9, segue uma metáfora de "escada", na qual "cada degrau corresponde à amplitude do poder da população em decidir as ações e/ou programas" que a afetam. 
Figura 9 - Degraus da Escada da Participação Cidadã

\section{Maior poder Cidadão e Maior participação Popular nas Decisôes}

NIVEIS DE

CONCESSĀO MINNIMA

DE PODER

\section{(1) Pacificaçāo}

Consulta

(1) Informaçāo
NÃO PARTICIPAÇÃO

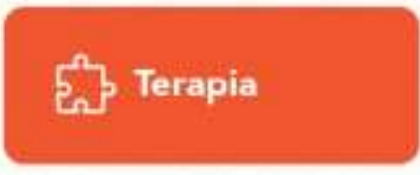

$\%$ Manipulação
NÍVEIS DE PODER CIDADẢO
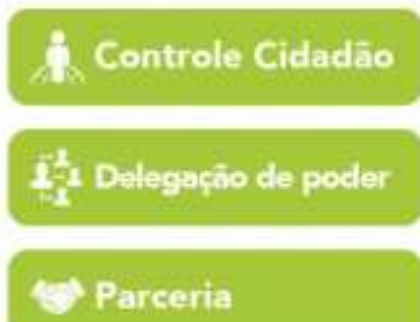

\section{Menor poder Cidadão e Menor participação Popuçar nas Decisões}

Fonte: Adaptado de Arnstein (2002).

A "Escada de Participação Popular" pressupõe um processo de delegação de poder e de accountability entre poder público e cidadão, que, em conjunto, devem determinar metas e políticas, o que serve de elemento de categorização dos níveis de governança participativa. De acordo com Arnstein (1969) e Souza (2001), nas categorias "Manipulação", "Coerção (ou Decoração)" e "Informação", não há participação nenhuma da sociedade civil nas atividades públicas. Nessas categorias, esquematizadas na figura 10, a opinião da sociedade é manipulada pelo poder público, e os participantes não exercem, de fato, influência na tomada de decisão.

Figura 10 - Escada de Participação: Nível "Não Participação"

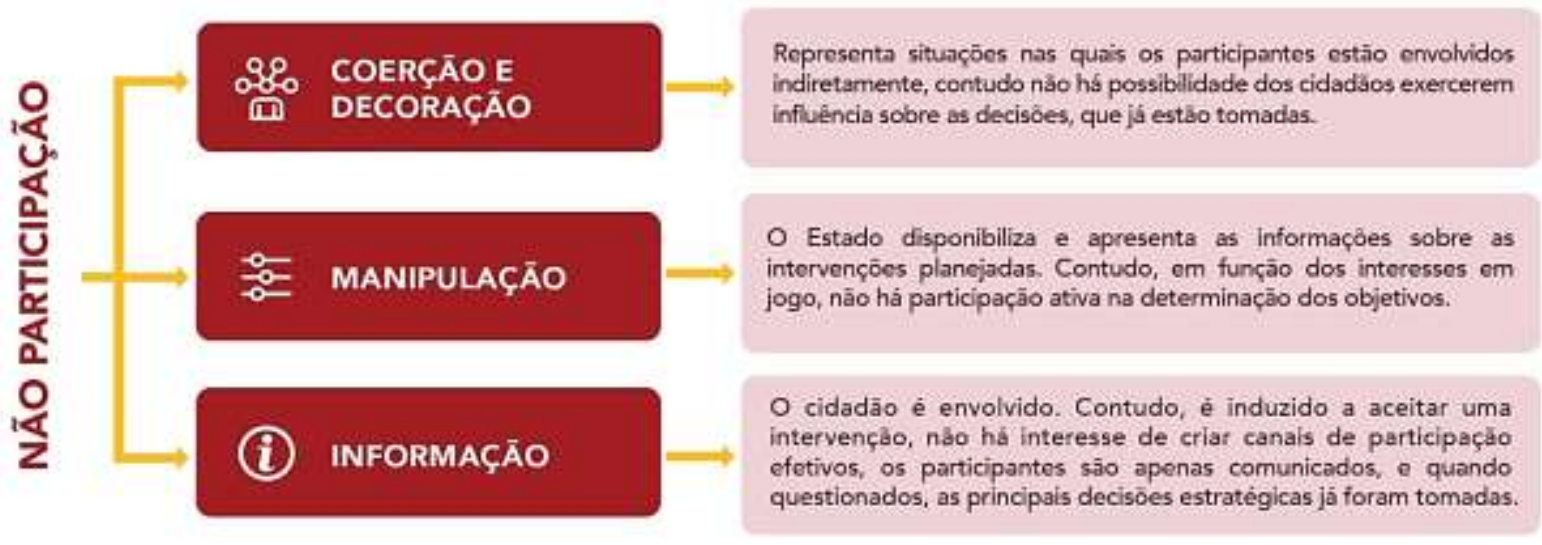

Fonte: Adaptado de Arnstein (1969), Rudd et al. (2006), Souza (2000) e Cruz, Collaço e Marins (2016).

No segundo nível de participação popular, encontram-se as categorias que proporcionam uma "Pseudoparticipação", indicadas na figura 11. Elas recebem tal 
classificação, pois, apesar de o poder público disponibilizar informação e abrir o espaço para o diálogo, não existem ferramentas que garantam a adoção das contribuições dos participantes na tomada de decisão.

Figura 11 - Escada de Participação: Nível "Pseudoparticipação"

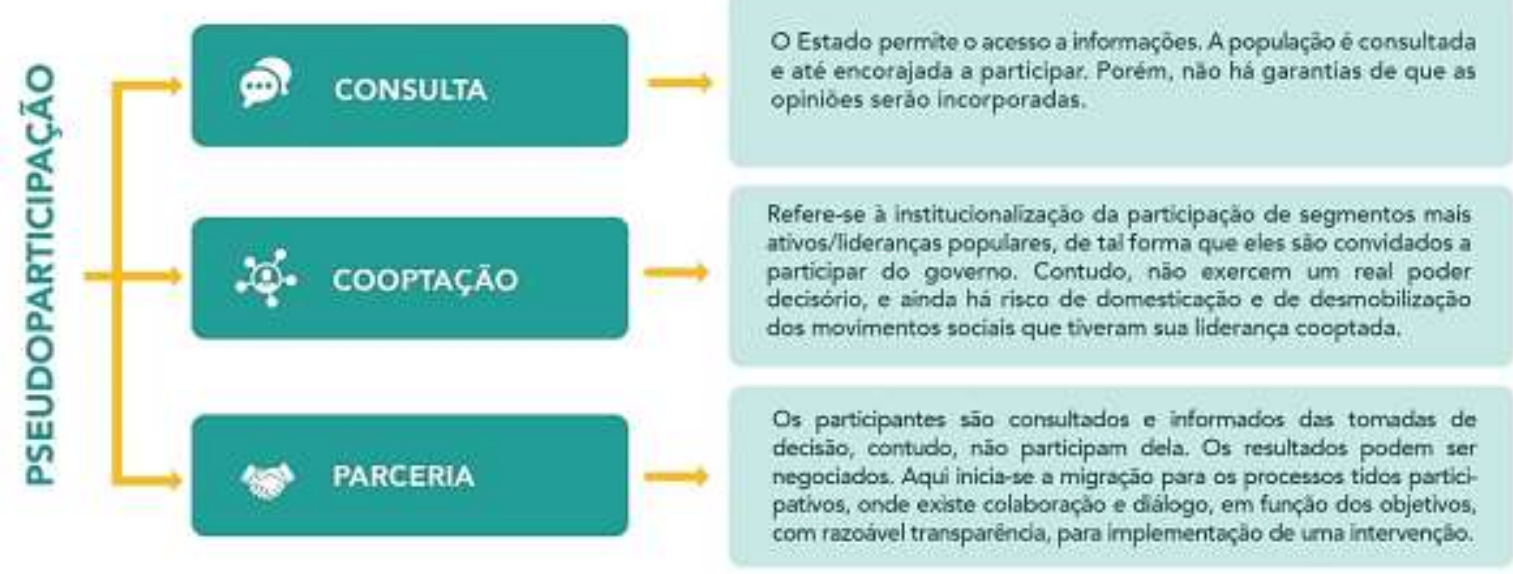

Fonte: Adaptado de Arnstein (1969), Rudd et al. (2006), Souza (2000) e Cruz, Collaço e Marins (2016).

Ao contrário das outras categorias já mencionadas, na "Autogestão" e na "Delegação de Poder", integrantes do terceiro nível da Escada de Participação, conforme figura 12, o poder público compartilha os espaços decisórios com a sociedade civil, permitindo, dessa forma, uma participação efetiva no processo decisório.

Figura 12 - Escada de Participação: Nível "Participação"

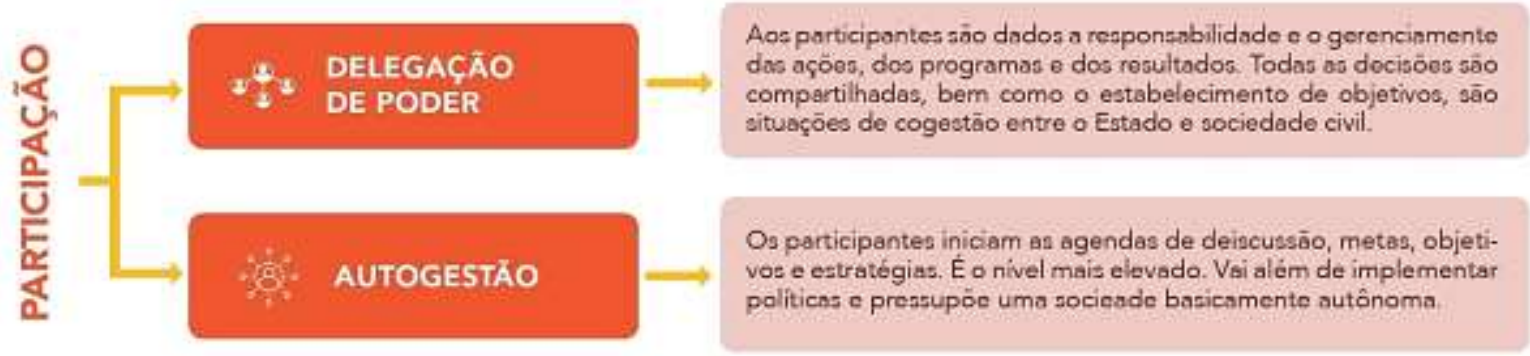

Fonte: Adaptado de Arnstein (1969), Rudd et al. (2006), Souza (2000) e Cruz, Collaço e Marins (2016).

Primeiramente, a análise do comportamento dos possíveis níveis de uma participação cidadã recai na compreensão do processo de tomada de decisão intrínseco e de todas as demais etapas próprias do mesmo, desde a formulação, passando pela implementação e indo até a sua avaliação, perfazendo o ciclo que se realimenta. 
No contexto dos países em desenvolvimento, mais do que controle, ainda se busca empoderamento. Os níveis em que o Estado considera a participação vão da negligência ao suporte, pois os agentes sociais querem serviços urbanos básicos e habitação de um governo que não possui recurso para fornecê-los (CHOGUILL, 1996). A inserção de Arnstein (1969) e Choguill (1996), pode ser analisada de forma comparativa na figura 13 a seguir.

Figura 13 - Níveis de participação conforme Arnstein e Choguill

\begin{tabular}{|c|c|}
\hline $\begin{array}{c}\text { Consideração do } \\
\text { Estado }\end{array}$ & $\begin{array}{c}\text { Nível de } \\
\text { Participação } \\
\text { Arnstein (1969) }\end{array}$ \\
\hline $\begin{array}{c}\text { Empontrole } \\
\text { Cidadão }\end{array}$ & $\begin{array}{c}\text { Cidadão } \\
\text { Delegação de } \\
\text { Poder }\end{array}$ \\
\hline \multirow{2}{*}{ Pseudoparticipação } & \begin{tabular}{c} 
Parceria \\
Cooptação \\
\hline Consulta
\end{tabular} \\
\hline Não participação & $\begin{array}{c}\text { Informação } \\
\text { Terapia }\end{array}$ \\
\hline & Manipulação \\
\hline
\end{tabular}

\begin{tabular}{|c|}
\hline $\begin{array}{c}\text { Nível de } \\
\text { Participação } \\
\text { Choguill (1996) }\end{array}$ \\
\hline Empoderamento \\
\hline Parceria \\
\hline Conciliação \\
\hline Dissimulação \\
\hline Diplomacia \\
\hline Informação \\
\hline Conspiração \\
\hline Autogerenciamento \\
\hline
\end{tabular}

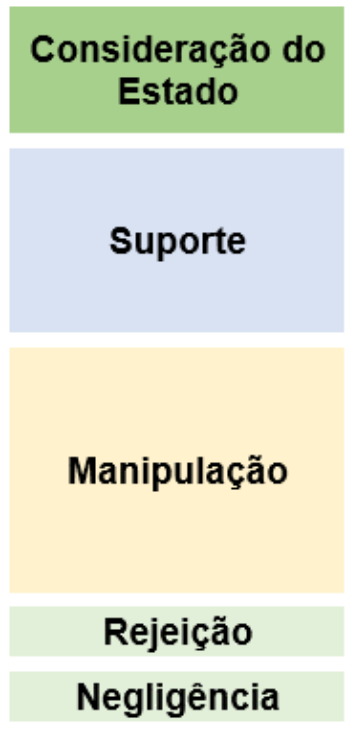

Fonte: Adaptado de Arnstein (1969) e Choguill (1996).

Conforme Choguill (1996), os vínculos e as alianças devem ser estabelecidos para a provisão de apoio duradouro às comunidades, e somente dessa maneira pode-se alcançar um desenvolvimento comunitário genuíno. Entretanto, ainda permanece sem resposta o questionamento sobre como poderá ser conduzido de envolvimento dos cidadãos para o avanço de um nível a outro, de forma evolutiva.

Assim, embora do ponto de vista teórico esses modelos sejam úteis para ilustrar os conceitos fundamentais dos processos participativos, ainda são limitados quanto à proposição de ferramentas e métodos participativos adequados para o contexto de planejamento urbano. Isso reforça a dificuldade do governo em gerir as expectativas das comunidades de forma efetiva, pois ainda são incipientes as formas de avaliar os arranjos participativos adequados. Contudo, entende-se o princípio para a participação que os atores envolvidos atuem na elaboração, idealização, implementação e avaliação de ações do Estado.

Sobre a dimensão da participação para Arnstein (2002, p. 04), a participação constitui um sinônimo para poder cidadão. A participação constitui o meio pelo qual os sem-nada podem 
promover reformas sociais significativas que lhes permitam compartilhar dos benefícios da sociedade envolvente.

\subsubsection{Instâncias participativas no Brasil}

A participação necessita ser viabilizada em todos os canais decisórios do Estado, para que o processo participativo seja perene e institucionalizado. Assim, os procedimentos, mecanismos e instrumentos participativos podem ser continuamente adequados e ajustados ao contexto decisório e seguir uma rotina de ampliação a parcelas da população que tradicionalmente são excluídas dos processos de tomada de decisão. Atualmente, em âmbito nacional, já existem mecanismos institucionalizados de participação, sumarizados na figura 14, destacados numa organização segundo a teoria de Montesquieu. Assim, os poderes da União são divididos em três: Legislativo, Executivo e Judiciário, independentes e harmônicos entre si, conforme explica Araújo (2014).

Figura 14 - Mecanismos de Participação Institucionalizados no Brasil

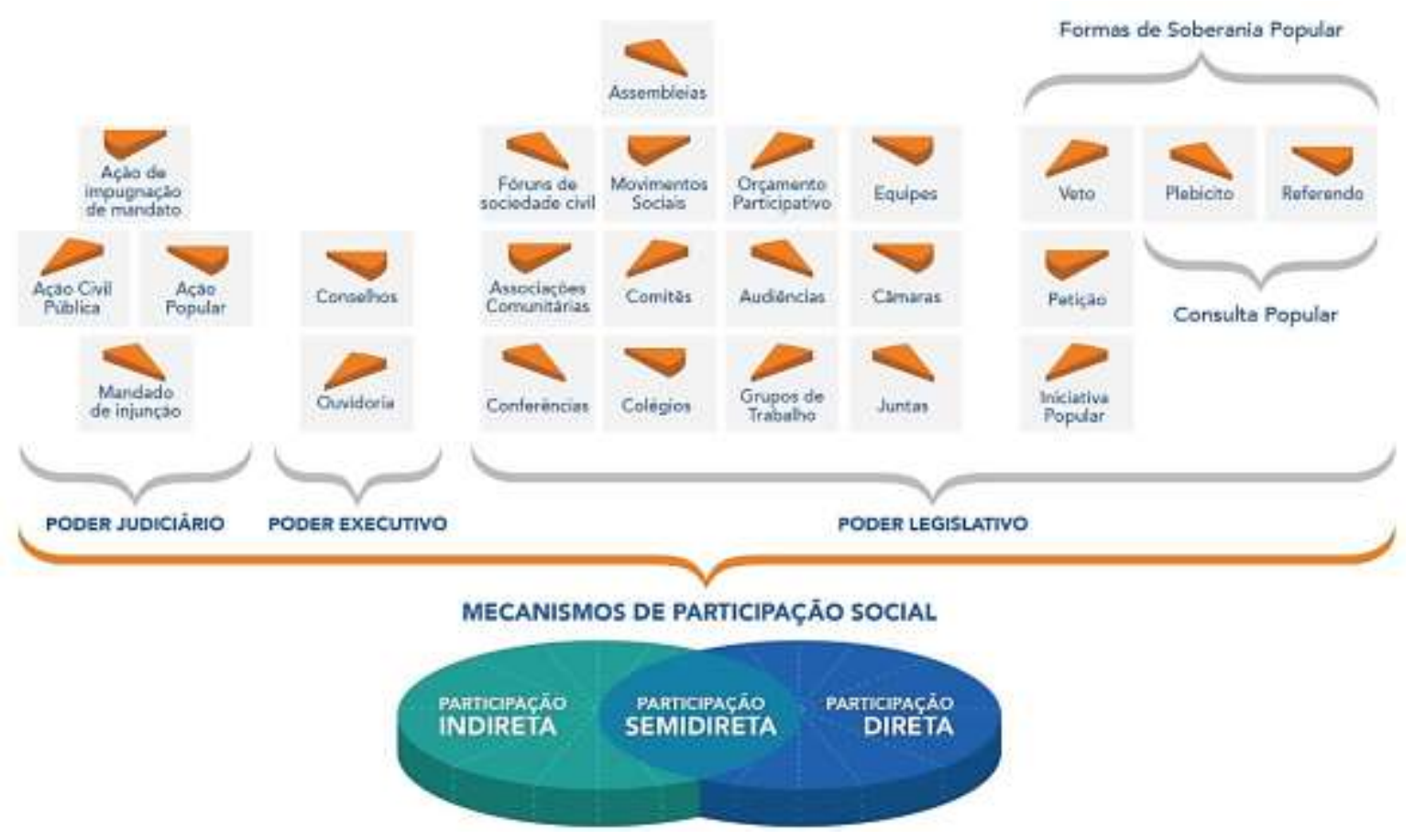

Fonte: Do autor (2019), adaptado de Araújo (2014).

No contexto brasileiro, os principais espaços de participação social que possuem marco legal, do ponto de vista institucional e jurídico, podem ser sintetizados abaixo, com base na revisão de Mancini (2015), Costa e Peres (2014) e Araújo (2014):

a) Ação Civil Pública: é um instrumento processual, de ordem constitucional (BRASIL, artigo 129, Inciso III da CRFB/1988), destinado à defesa de interesses difusos e coletivos 
- sua propositura pode ser feita pelo Ministério Público, pela União, pelos Estados e Municípios, disciplinada pela Lei Federal n. 7.347, de 24 de julho de 1985;

b) Ação de Impugnação de Mandato Parlamentar: prevista pela Lei Maior brasileira (BRASIL, artigo $14, \S 10^{\circ}$ e $\S 11^{\circ}$ ), ela permite a impugnação de mandato eletivo se instruída por partido, coligações, candidatos ou Ministério Público, no prazo de 15 dias após diplomação ${ }^{38}$, com provas de abuso do poder econômico, corrupção ou fraude, perante a justiça federal;

c) Ação Popular: prevista no artigo $5^{\circ}$, inciso LXXIII da CRFB/1988, assevera que qualquer cidadão (eleitor) é parte legítima na sua proposição contra o poder público ou entidade de que participe em defesa e proteção de interesse ou direito da coletividade esse mecanismo é regulado pela Lei de Ação Popular, isto é, pela Lei Federal n. 4.717, de 29 de junho de 1965;

d) Audiência Pública: é uma sessão pública aberta a todos os possíveis interessados, destinada a instruir matéria em trâmite ou apenas debate de assunto de interesse público - nela a sociedade civil interessada no tema é convidada a expor suas ideias. As audiências são, na maioria das vezes, inseridas na fase pré-instauração do processo decisório, podendo prever instâncias de deliberação. Sua função é a de esclarecer a discussão de todos os aspectos envolvidos na questão. Quanto a isso, Moreira Neto $(2006)^{39}$ declara que as audiências públicas estão submetidas a maior formalidade processual quando comparadas aos debates públicos, podendo ser determinantes ou não para a tomada de decisão. Esta modalidade de participação popular, que possibilita que a cidadania seja consultada sobre a pertinência de determinado projeto ou política pública, encontra-se prevista em cinco artigos da CRFB/1988 (BRASIL, artigo 58, § 2º Inciso II; artigo 84, Inciso XII; artigo 107, Inciso II, $\S 2^{\circ}$; artigo 115, Inciso II, $\S 2^{\circ}$; e artigo $125, \S$ $7^{\circ}$ ), no Estatuto da Cidade, na Lei de Responsabilidade Fiscal (Lei Federal Complementar n. 101, de 4 de maio de 2000, que estabelece normas de finanças públicas voltadas para a responsabilidade na gestão fiscal e dá outras providências) e na Lei Federal n. 9.764, de 29 de janeiro de 1999, que regula o processo administrativo no âmbito da Administração

\footnotetext{
${ }^{38}$ Diplomação é o ato pelo qual a Justiça Eleitoral habilita os eleitos a exercer mandato. O diploma devidamente assinado e fornecido aos eleitos atesta quem são os mandatários. A competência para expedir diploma de presidente e vice-presidente da República é do Tribunal Superior Eleitoral (TSE). No caso de diplomas de governadores e vices, deputados federais e estaduais, senadores e suplentes, a competência é do Tribunal Regional Eleitoral (TRE). E os diplomas de prefeitos, vice-prefeitos e vereadores são expedidos por Junta Eleitoral. (BARRETTO, L. Investigação Judicial Eleitoral e Ação de Impugnação de Mandato Eletivo. Bauru, SP: Edipro, 1999. p.70-76)
}

${ }^{39}$ MOREIRA NETO, D. de F. Mutações do Direito Público. Rio de Janeiro: Renovar, 2006. p. 85-86. 
Pública Federal (artigos 32, 34 e 35). As audiências públicas são estruturadas em modelo de troca de informações entre sociedade e administração pública, no qual não há uma regra específica de obrigação entre as partes. De forma trivial, o gestor público se comunica com os interessados e afetados por suas decisões e também para ouvi-los. Esse canal é motivado em função da vontade da administração pública, mas existem casos em que se fazem obrigatórias por lei;

e) Câmaras Setoriais: são órgãos de caráter técnico que visam reunir determinados setores estratégicos de gestão em torno de cadeias produtivas e outras redes, como fóruns de apoio, de proposição e de acompanhamento de ações, para o desenvolvimento de atividades setoriais. O Conselho das Cidades (ConCidades), do até então Ministério das Cidades, por exemplo, foi composto por quatro câmaras setoriais - habitação, planejamento territorial urbano, saneamento ambiental e transporte e mobilidade urbana;

f) Conferências: são eventos nos quais as principais questões e os direcionamentos normativos de áreas temáticas em políticas públicas são determinados - as conferências ocorrem geralmente nos três níveis de governo (municipal, estadual e nacional), sendo que, a cada nível, problemáticas correlatas são discutidas e, conforme o avançar das negociações, levadas ao próximo nível -, e neles a participação é aberta ao público, ainda que, nos níveis estadual e nacional, apenas delegados escolhidos no âmbito das conferências do nível anterior tenham poder de voto. As conferências são instâncias participativas criadas pelo poder público para que a sociedade participe em atividades de planejamento, controle e gestão de um conjunto de políticas públicas ou mesmo de uma determinada política específica. Elas acontecem nos níveis municipal, estadual e federal, e entre as conferências de maior destaque realizadas no Brasil estão as de saúde, educação, juventude, assistência social, cultura e comunicação;

g) Conselhos de Políticas Públicas: são entidades consultivas ou deliberativas, de acordo com a norma de criação ou autorização, que partilham poder. Se deliberativos, repartem o poder decisório do chefe do Poder Executivo com outros membros da estrutura orgânica administrativa, o texto constitucional brasileiro (BRASIL, artigo 203 e artigo 204 da CRFB/1988) assegura as suas várias formas de implementação. Criados por lei ou mediante autorização legal, os conselhos brasileiros atuam nas três esferas do Governo, possuem representação mista de atores da sociedade civil e atores estatais, além de competência para formular, coordenar e fiscalizar políticas. Eles não possuem personalidade jurídica, ou seja, eles não gozam de autonomia gerencial, administrativa ou 
financeira - estes institutos são obrigatórios nas áreas de saúde, assistência social, meio ambiente, criança e adolescente e educação, por vincularem o seu funcionamento à liberação de recursos financeiros a estados e municípios. Os conselhos expandiram-se para diversas áreas e temáticas, são espaços consultivos e muitas vezes até deliberativos para discussão em determinadas áreas de políticas públicas, congregando representantes tanto do Estado quanto da sociedade civil. Hoje, é possível observar inúmeros conselhos nacionais, estaduais, distritais e municipais que tratam de diversos temas como educação, saúde, segurança, assistência social, criança e adolescente, transporte e meio ambiente, entre outros;

h) Consultas públicas: as consultas públicas são instrumentos bastante semelhantes às audiências públicas, principalmente no que tange à compreensão dos principais reclames e demandas da sociedade em questões bastante específicas. A principal diferença da consulta pública é que sua estruturação não se dá somente presencialmente, mas também através de ferramentas de votação e colaboração a distância, como internet e telefone;

i) Direito de Petição: é o direito que permite a toda pessoa, perante a autoridade administrativa competente de quaisquer dos Poderes, defender seus direitos ou interesses coletivos, sendo exercitável por meio de petição escrita e assinada, por pessoa física ou jurídica - no Brasil, o direito de petição está previsto no artigo $5^{\circ}$, Inciso XXXIV da CRFB/1988. Mas, a Constituição Federal brasileira não definiu nenhuma forma para o exercício do direito de petição; logo, a petição poderá assumir várias formas (requerimento, ofício, carta etc.), a critério do órgão que a regulamentar, mas nunca com o intuito de restringi-lo;

j) Fóruns de Sociedade Civil: são instâncias de interesse público que reúnem representantes da sociedade civil com a finalidade de garantir direitos humanos e sociais fundamentais. No Brasil, os fóruns possuem formato e nível de institucionalização diversificados, podendo ou não ter uma estrutura jurídica - na prática, os fóruns se constituem em espaços de articulação, informação, discussão, formação e mobilização, que exercem pressão e controle social sobre as ações de governo, ou mesmo de instituições não governamentais;

k) Grupos de Trabalho: espaço de debate e proposição sobre um tema específico ou de acompanhamento de um processo político, os grupos de trabalho podem ser estritamente governamentais (com a presença de representantes da sociedade civil como convidados), paritários e com integrantes que representam majoritariamente a sociedade. Em geral, são 
criados por algum instrumento normativo (decreto, portaria etc.) que define seus objetivos, prazo de funcionamento e composição;

1) Iniciativa Popular Legislativa: trata-se do instrumento que permite ao povo brasileiro apresentar ao Poder Legislativo um projeto normativo de interesse coletivo, o qual, após análise parlamentar e cumprimento dos requisitos processuais, pode vir a se transformar em lei - ou seja, "é um instituto que, quando bem estruturado, dá força de voz à soberania popular" (AUAD et al., 2004). A Constituição brasileira (BRASIL, artigo 14 da CRFB/1988) prevê esse instituto pelo qual o povo participa da primeira etapa do processo legislativo, na iniciativa da lei, dando "o primeiro pontapé" - artigo 61, § $2^{\circ}$ (União), artigo 29, XIII (Municípios), artigo 27, § $4^{\circ}$ (Estados), todos da CRFB/1988. Urge destacar que o artigo $61, \S 1^{\circ}$, II, “b” da CRFB/1988 é uma restrição à iniciativa popular, pois a delimita (BRASIL, 1988) - em âmbito nacional, para exercer esse direito, os interessados devem coletar assinaturas de $1 \%$ do total do eleitorado brasileiro (hoje por volta de 1,6 milhão) residente em pelo menos cinco estados, com porcentuais de $0,3 \%$ dos eleitores de cada região. Os projetos de lei de iniciativa popular, em grande parte das vezes, esbarram em requisitos extremamente formais, que dificultam e até mesmo impedem a efetiva prática desse direito, haja vista a grande quantidade necessária de assinaturas de eleitores, as formalidades para a obtenção destas assinaturas e a falta de previsão de tempo mínimo para a aprovação ou rejeição da Lei. Levando em consideração as dificuldades, o Projeto de Lei de Iniciativa Popular depende em grande parte de articulação política e de pressão popular. Das três ferramentas de demonstração direta da vontade da população - isto é, referendo, plebiscito e iniciativa popular - utilizadas pelo Brasil, apenas a iniciativa popular de apresentação de Projeto de Lei configura realmente o exercício da vontade popular. Vê-se que, em relação ao plebiscito e ao referendo, o povo é convocado a se manifestar sobre determinada decisão já tomada pelo Estado, e, nesses casos, portanto, o exercício democrático fica restrito a decidir entre as opções políticas preestabelecidas pelo governante. Assim, o poder popular não se mostra efetivamente soberano, uma vez que adstrito ou limitado pelos poderes constituídos;

m) Mandado de Injunção: previsto no artigo $5^{\circ}$, Inciso LXXI, e no artigo 102, Inciso I, alínea "q" da CRFB/1988, este instrumento possibilita que a sociedade, legalmente representada (Ministério Público, associações, organização sindical etc.), possa pedir a regulamentação de norma da Constituição não regulamentada. O pedido é feito para garantir o direito de cidadão prejudicado pela omissão do Estado (BRASIL, 1988); 
n) Orçamento Participativo: é uma forma aberta de livre entrada e participação de atores sociais, capaz de gerar participação de baixo para cima - na Administração Pública brasileira, atua como mecanismo de caráter consultivo ou opinativo desenvolvido com o desígnio de democratizar o processo de definição orçamentária municipal por meio de audiências públicas. Segundo Boaventura de Souza Santos $(2009 \text {, p. 467 })^{40}$, os três pilares que regem o orçamento participativo são (1) abertura de possibilidade de participação para todos os cidadãos, (2) desenvolvimento integrando regras de democracia direta e representativa e (3) combinação de critérios técnicos do Executivo e gerais de órgãos participativos, de modo a possibilitar que os recursos sejam distribuídos direcionados pelo objetivo. O orçamento participativo é uma experiência brasileira inovadora, que se dá normalmente com a organização de plenárias, regionais, especificas e temáticas, em diversos eixos, para debater e decidir a destinação de recursos e investimentos em bens e serviços a partir de parte dos recursos do orçamento público;

o) Ouvidoria Pública: é um canal institucional no qual é disponibilizado aos cidadãos um serviço que tem por fim precípuo recepcionar sugestões, reclamações e denúncias, além de afiançar a prevalência dos princípios fundamentais da Administração Pública brasileira - quais sejam legalidade, impessoalidade, moralidade, economia e publicidade -, os quais, consequentemente, assegurarão a transparência administrativa;

p) Plebiscito: é um instrumento no qual a sociedade é ouvida, em consulta pública, sobre determinada decisão a ser tomada - no Brasil, está previsto no artigo 14 da CRFB/1988 e significa consulta prévia, antes de o fato (Lei) acontecer, autorizada pelo Poder Legislativo (artigo 18, § $3^{\circ}$ e $4^{\circ}$ da CRFB/1988) (BRASIL, 1998);

q) Referendo: é uma consulta pós-fato, convocada por decreto legislativo, pela qual o povo ratifica ou não determinada decisão. É o instrumento pelo qual o povo adquire o poder de sancionar leis. Previsto no artigo 14 da CRFB/1988 e regulamentado pela Lei Federal n. 9.709, de 18 de novembro de 1998 - artigo 49, XV da CRFB/1988 (BRASIL, 1998).

Uma das formas de atuação de gestão democrática é o planejamento participativo. Também é possível destacar a Política Nacional de Participação Social (PNPS), que juntamente com o Sistema Nacional de Participação Social(SNPS), criados pelo Decreto $n^{\circ} 8.243$ de 23 de maio de 2014 da Presidência da República, representam uma tentativa de instituição, de

\footnotetext{
${ }^{40}$ SOUSA SANTOS, B. de. Democracia participativa em ação. In: (Org.). Democratizar a democracia: os caminhos da democracia participativa. Rio de Janeiro: Civilização Brasileira: 2009. p. 467.
} 
fortalecer e articular os mecanismos e as instâncias democráticas de diálogo e a atuação conjunta entre a administração pública federal e a sociedade civil. Contudo esta política foi revogada, recentemente, pelo Decreto ${ }^{\circ} 9.759$ de 11 de abril de $2019^{41}$.

Principalmente a PNPS, cujos artigo $2^{\circ}$ apresentavam os mecanismos de participação e artigo $3^{\circ}$ as diretrizes gerais para participação social, abre caminho para as novas formas de participação social, por meio das redes sociais e dos mecanismos digitais de participação via internet. Esse caminho pavimentado pode conferir protagonismo aos novos movimentos sociais em rede, ao mesmo tempo em que reconhece e valoriza as formas tradicionais de participação e os movimentos sociais históricos. Contudo o atual decreto não prevê a inserção da internet, por exemplo, como ferramenta institucionalizada de participação. De forma sintética, a articulação legal e normativa pode ser sumarizada no quadro 2

Quadro 2 - Sumarização dos Instrumentos Legais Participativos no Brasil

\begin{tabular}{|c|c|c|c|}
\hline Instrumento & Quem participa & O que é decidido & Quem decide \\
\hline $\begin{array}{l}\text { Ação Civil } \\
\text { Pública }\end{array}$ & $\begin{array}{l}\text { Destinada à defesa } \\
\text { de interesses } \\
\text { difusos e coletivos }\end{array}$ & $\begin{array}{c}\text { Proteção do patrimônio público, } \\
\text { conferindo-lhe âmbito análogo ao } \\
\text { da ação popular. }\end{array}$ & $\begin{array}{l}\text { Ministério } \\
\text { Público, União, } \\
\text { Estados e } \\
\text { Municípios }\end{array}$ \\
\hline $\begin{array}{c}\text { Ação de } \\
\text { Impugnação de } \\
\text { Mandato } \\
\text { Parlamentar }\end{array}$ & $\begin{array}{c}\text { Partidos, } \\
\text { coligações, } \\
\text { candidatos e } \\
\text { Ministério público }\end{array}$ & $\begin{array}{l}\text { Impugnar o mandato obtido com } \\
\text { abuso de poder econômico, } \\
\text { corrupção ou fraude. }\end{array}$ & $\begin{array}{c}\text { TSE, TER e Junta } \\
\text { Eleitoral }\end{array}$ \\
\hline Ação Popular & $\begin{array}{l}\text { Qualquer cidadão } \\
\text { (eleitor) }\end{array}$ & $\begin{array}{l}\text { É parte legítima na sua proposição } \\
\text { contra o poder público ou entidade } \\
\text { de que participe em defesa e } \\
\text { proteção de interesse ou direito da } \\
\text { coletividade }\end{array}$ & Poder Judiciário \\
\hline $\begin{array}{l}\text { Audiências } \\
\text { Pública }\end{array}$ & $\begin{array}{l}\text { Sessão Pública } \\
\text { aberta a todos os } \\
\text { possíveis } \\
\text { interessados }\end{array}$ & $\begin{array}{l}\text { Destinadas a instruir matéria em } \\
\text { trâmite ou apenas debate de assunto } \\
\text { de interesse público }\end{array}$ & $\begin{array}{c}\text { Poder Executivo } \\
\text { ou Legislativo ou } \\
\text { do Ministério } \\
\text { Público } \\
\end{array}$ \\
\hline Câmaras Setoriais & $\begin{array}{l}\text { Pessoas } \\
\text { envolvidas no } \\
\text { setor }\end{array}$ & $\begin{array}{c}\text { São fóruns de discussão que reúnem } \\
\text { representantes de entidades públicas } \\
\text { e privadas de determinada cadeia } \\
\text { produtiva }\end{array}$ & $\begin{array}{l}\text { Poder Executivo } \\
\text { ou Legislativo }\end{array}$ \\
\hline Conferências & $\begin{array}{c}\text { Abertas ao público } \\
\text { em níveis estadual } \\
\text { e nacional }\end{array}$ & $\begin{array}{l}\text { São instâncias participativas criadas } \\
\text { para que a sociedade participe em } \\
\text { atividades de planejamento, controle } \\
\text { e gestão de um conjunto de políticas } \\
\text { públicas }\end{array}$ & $\begin{array}{l}\text { Governo federal, } \\
\text { estadual ou } \\
\text { municipal }\end{array}$ \\
\hline
\end{tabular}

continua

\footnotetext{
${ }^{41}$ Durante a elaboração do presente artigo foi editado o Decreto Federal 9.759, em 11 de abril de 2019, que extingue instâncias participativas e estabelece diretrizes, regras e limitações para colegiados da administração federal direta, autárquica e fundacional. Tal decreto em sua exposição de motivos se justifica pela desburocratização, simplificação administrativa e contenção de gastos e despesas. Porém, na prática, pode significar a contenção de grupos de pressão e por fim, a redução da participação social. Isso, porém, dependerá de análises futuras, razão pela qual deixa-se de analisar a questão.
} 
continuação

\begin{tabular}{|c|c|c|c|}
\hline $\begin{array}{l}\text { Conselhos de } \\
\text { Políticas } \\
\text { Públicas }\end{array}$ & $\begin{array}{l}\text { Abertos ao } \\
\text { público }\end{array}$ & $\begin{array}{l}\text { Criados por lei ou mediante autorização } \\
\text { legal, os conselhos brasileiros atuam } \\
\text { nas três esferas do Governo; possuem } \\
\text { representação mista de atores da } \\
\text { sociedade civil e atores estatais; e } \\
\text { competência para formular, coordenar e } \\
\text { fiscalizar políticas }\end{array}$ & Poder Executivo \\
\hline $\begin{array}{l}\text { Consultas } \\
\text { Públicas }\end{array}$ & $\begin{array}{l}\text { Sessões Pública } \\
\text { aberta a todos } \\
\text { os possíveis } \\
\text { interessados } \\
\end{array}$ & $\begin{array}{l}\text { São processos democráticos para } \\
\text { construção conjunta de políticas } \\
\text { públicas entre governo e sociedade }\end{array}$ & Câmaras municipais \\
\hline $\begin{array}{l}\text { Direito de } \\
\text { Petição }\end{array}$ & $\begin{array}{l}\text { Todas as } \\
\text { pessoas }\end{array}$ & $\begin{array}{l}\text { Em defesa de direitos ou contra } \\
\text { ilegalidade ou abuso de poder (de } \\
\text { interesse individual ou coletivo) }\end{array}$ & Poder Judiciário \\
\hline $\begin{array}{l}\text { Fórum de } \\
\text { Sociedade } \\
\text { Civil }\end{array}$ & $\begin{array}{l}\text { Todas as } \\
\text { pessoas }\end{array}$ & $\begin{array}{c}\text { Garantir Direitos Humanos e Sociais } \\
\text { Fundamentais }\end{array}$ & $\begin{array}{l}\text { Ações de governo ou } \\
\text { instituições não } \\
\text { governamentais. }\end{array}$ \\
\hline $\begin{array}{l}\text { Grupo de } \\
\text { Trabalho }\end{array}$ & $\begin{array}{l}\text { Todas as } \\
\text { pessoas }\end{array}$ & $\begin{array}{c}\text { Espaço de debate e proposição sobre } \\
\text { um tema específico ou de } \\
\text { acompanhamento de um processo } \\
\text { político }\end{array}$ & $\begin{array}{c}\text { São criados por } \\
\text { alguns instrumentos } \\
\text { normativos (decreto, } \\
\text { portaria etc.) }\end{array}$ \\
\hline $\begin{array}{l}\text { Iniciativa } \\
\text { Popular } \\
\text { Legislativa }\end{array}$ & $\begin{array}{l}\text { Todas as } \\
\text { pessoas }\end{array}$ & $\begin{array}{c}\text { Permite que as pessoas apresentem ao } \\
\text { Poder Legislativo um projeto } \\
\text { normativo de interesse coletivo }\end{array}$ & Poder Legislativo \\
\hline $\begin{array}{l}\text { Mandado de } \\
\text { injunção }\end{array}$ & $\begin{array}{l}\text { Sociedade civil } \\
\text { organizada }\end{array}$ & $\begin{array}{l}\text { Possibilita que a sociedade, legalmente } \\
\text { representada, possa pedir a } \\
\text { regulamentação de norma da } \\
\text { Constituição não regulamentada }\end{array}$ & Poder Judiciário \\
\hline $\begin{array}{l}\text { Orçamento } \\
\text { Participativo }\end{array}$ & $\begin{array}{l}\text { Todas as } \\
\text { pessoas }\end{array}$ & $\begin{array}{c}\text { Instrumento de complementação da } \\
\text { democracia representativa, permite que } \\
\text { o cidadão debata e defina os destinos } \\
\text { de uma cidade }\end{array}$ & Poder Executivo \\
\hline $\begin{array}{l}\text { Ouvidoria } \\
\text { Pública }\end{array}$ & $\begin{array}{l}\text { Todas as } \\
\text { pessoas }\end{array}$ & $\begin{array}{l}\text { Serviço que recepciona sugestões, } \\
\text { reclamações e denúncias }\end{array}$ & $\begin{array}{c}\text { Governo do } \\
\text { Município, Estado ou } \\
\text { União }\end{array}$ \\
\hline Plebiscito & $\begin{array}{l}\text { Todas as } \\
\text { pessoas }\end{array}$ & $\begin{array}{l}\text { A sociedade é ouvida, em consulta } \\
\text { pública, sobre determinada decisão a } \\
\text { ser tomada }\end{array}$ & $\begin{array}{l}\text { Tribunal Superior } \\
\text { Eleitoral. } \\
\text { Poder Executivo } \\
\text { Poder Legislativo }\end{array}$ \\
\hline Referendo & $\begin{array}{l}\text { Todas as } \\
\text { pessoas }\end{array}$ & $\begin{array}{l}\text { O congresso apresenta à população } \\
\text { uma matéria pronta; o povo tem as } \\
\text { opções de acatar ou rejeitar a proposta }\end{array}$ & $\begin{array}{c}\text { TSE, } \\
\text { Poder Executivo ou } \\
\text { Legislativo }\end{array}$ \\
\hline
\end{tabular}

Fonte: Do autor (2019).

A dinâmica de articulação nos processos participativos pode destacar a visibilidade social. A esfera pública, mesmo ao tratar sobre questões individuais e particulares, deve expressar-se com transparência, para todos que participam (ou não) das decisões. 
Essa visibilidade ancora-se nos princípios da impessoalidade e da publicidade, cujas informações que orientam as deliberações, inclusive nos espaços de representação ou de participação, supõem acesso à informação e transparência para todos. Pontua-se, assim, uma questão: o simples acesso à informação configura-se como participação? Na realidade, o acesso às decisões, por meio da participação da sociedade, inclusive na formulação de regras, deve conduzir à negociação de diferentes interesses, segundo Mancini (2014).

Segundo Costa e Peres (2014), os arranjos participativos têm características, formas de composição e níveis de institucionalização variados. Nesse contexto, são marcados e determinados pela maior ou menor composição participativa do Estado e dos representantes da sociedade. Os autores ainda pontuam, por exemplo, que as Audiências Públicas "são um meio de troca de informação entre sociedade e administração pública”, e, nessa relação de troca, o governo pode estabelecer um canal de apresentação de informações e também de consulta, em que ainda, segundo os autores citados, "não se cria como regra uma obrigação entre as partes. Serve como uma forma de o gestor público se comunicar com os interessados e afetados por suas decisões e também os ouvir" (Ibidem).

Por outro lado, canais com entrega, recebimento, devolução e, ainda, construção de políticas de forma coletiva, ancorados a modelos de gestão participativa que se aproximam da autogestão, são processos que podem trazer uma nova abordagem à participação popular. Os autores Costa e Peres (Ibidem) ainda pontuam que "autogestão se remete na gestão de meios de produção ou de organizações sociais desde que indivíduos ou mesmo grupos tenham direito a participação".

A dificuldade da aplicação desse processo na sua totalidade esbarra na complexidade social, que impõe suas diferenciações e determina restrições para sua consecução. É preciso garantir aos cidadãos direitos de comunicação e direitos de participação política para se legitimar o processo democrático. Neste, habita a necessidade de os cidadãos deliberarem sobre suas demandas sociais, as quais, por sua vez, direcionam o poder administrativo ao atendimento das demandas em questão. No que tange à deliberação e ao direito de participação, a esfera pública é o espaço de todos os cidadãos que, por meio dos direitos de comunicação e participação política, tornaram-se politicamente autônomos. Podem, então, discutir na esfera pública através dos movimentos sociais, que funcionam como um canal para suas reivindicações, conforme aponta Habermas (1997, 2003a, 2003b).

A democracia participativa é uma forma de exercício do poder baseada na participação dos cidadãos nas tomadas de decisão política. Teóricos da democracia representativa 
(SCHUMPETRE, 1961; SARTORI, 1994; BOBBIO, 2004; ARAÚJO, 2014) descrevem a participação direta como um procedimento de seleção de representantes legitimados pelas eleições. Esta abordagem defende que a principal salvaguarda contra a instabilidade política é a participação de um grupo minoritário, ao invés da "participação do homem comum, apático, com pouco senso de eficácia política" (PATEMAN, 1992, p. 138-139). O povo elege representantes que possam defender, gerir, estabelecer e executar todos os interesses da população.

De forma sintética, a democracia participativa sumariza um conjunto de experiências e mecanismos que têm como finalidade estimular a participação direta dos cidadãos na vida política, em de canais de discussão e decisão. Entretanto, a requerida representatividade talvez não seja capaz de equilibrar o jogo de forças da esfera pública. Hoje, em meio às crises que assolam o mundo, há necessidade de se politizar a sociedade, de modo que os cidadãos possam interferir em algumas questões políticas de forma mais ativa.

Vale ainda acrescentar que o conceito de participação democrática transmite uma ideia elementar de interação direta entre governantes e governados - os governos democráticos. A ideia, construída tendo em vista o termo "democracia" em sua qualidade de indicativo legitimador de regime governamental, assevera que todo o poder emana do povo, o qual o exerce de forma direta, indireta ou semidiretamente, conforme apontam Freide (1998) e Araújo (2014) e é esquematizado na figura 15.

Participação direta é aquela em que o povo, em sua totalidade, toma as decisões, executaas e, a um só tempo, controla e fiscaliza as deliberações pactuadas (LOEWENSTEIN, 1983; ARAÚJO, 2014). Outra questão relevante é a capacidade de organização e participação, pois estas não se atêm apenas à questão quantitativa, mas também a sua qualidade de organização e contribuição. Não é suficiente existirem diversos contra-argumentos ou um número relevante de mobilizados, pois estes precisam também ser eficientes e eficazes.

Ou seja, esse tipo de participação abarca a ação direta dos cidadãos, sem intermediação, nas várias instâncias de decisão. Atualmente, com o desenvolvimento das sociedades complexas e heterogêneas, os movimentos sociais e as associações participativas são também heterogêneos, e esses espaços participativos não coincidem mais com as formas tradicionais, e 
até legais, de organização. Logo, em grupos tão heterogêneos, a formação de facções ${ }^{42}$ é uma questão relevante.

Figura 15 - Mecanismos de Participação Direta e Indireta

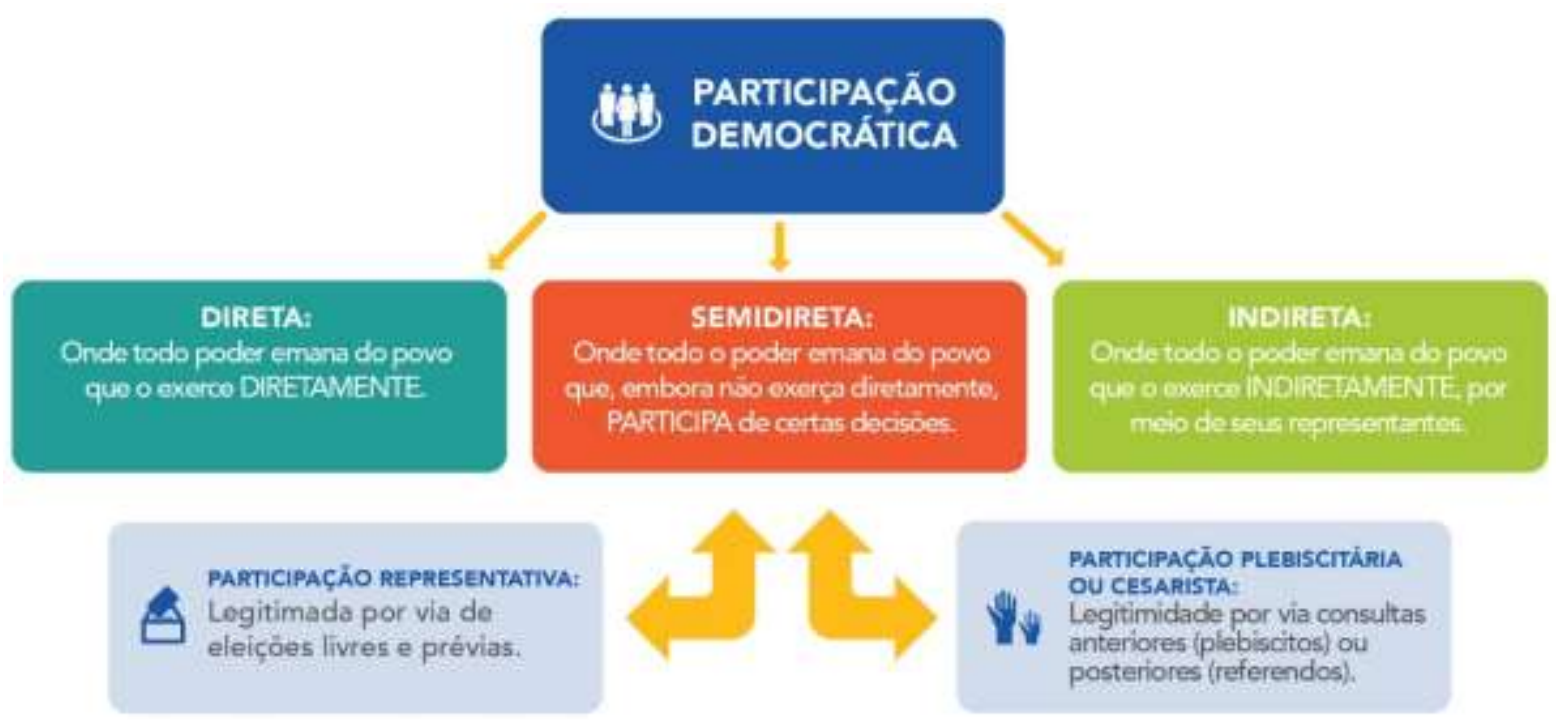

Fonte: Adaptado de Araújo (2014).

Tais formas não são aderentes aos canais estáveis de representação, e, assim, surge um novo modelo emancipatório na concepção da sociedade democrática e em seus canais de participação, mediação e solução de conflitos. A participação semidireta é aquela que "agrega representantes e representados em um único sistema que intermedeia mecanismos de participação direta e indireta", de modo a permitir que a sociedade civil influencie e ratifique as decisões tomadas em seu nome, segundo Araújo (2014). Ademais, admite deliberações de interesse coletivo pelos representantes.

A participação indireta ou representativa, por outro lado, compreende todas as manifestações do cidadão junto ao sistema de governo, desde os atos eleitorais até as ações que visam definir orientações políticas dos órgãos de poder ou de controlá-los por meio de mecanismos de intermediação, como aponta Araújo (Ibidem). Ou seja, na participação indireta, o povo governa por intermédio de representantes eleitos previamente, que tomam em seu nome e interesse as decisões (participação representativa), e decidem com ou sem consulta dos representados, antes (por meio de plebiscito) ou depois (por meio de referendo) da tomada de decisão (dita como participação plebiscitária ou cesarista).

A existência dos movimentos sociais é de fundamental importância para a sociedade civil enquanto meio de manifestação e reivindicação. Cada um dos espaços ou mecanismos de

42 Uniões de grupos populacionais, dentro de determinados grupos, com base em objetivos comuns a fim de fazer prevalecer as ideias e os interesses de seus membros. 
participação existentes pode se configurar de maneiras muito heterogêneas e variar de forma significativa de acordo com diferentes contextos. Ainda, a busca por novos espaços de participação da sociedade civil permite a construção de mecanismos com a fim de transferir parcelas de poder do Estado para a sociedade civil organizada.

A existência de diversos canais e mecanismos que permitem a participação da sociedade nos processos decisórios, embora seja um requisito fundamental para uma governança democrática, não necessariamente induz a uma maior qualidade na participação, conforme Araújo (Ibidem). A prática destes mecanismos depende da ativação da esfera pública orientada como uma dimensão social, onde os indivíduos possam agir de forma coletiva, através de deliberações comuns, sobre os assuntos que afetam a comunidade. Um processo democrático deve propiciar um terreno fértil para a inclusão de todas as pessoas envolvidas, com chances no direito de escolha dos temas da agenda e igual direito a voto nas decisões. Criam-se, assim, condições para que todos os participantes, tendo à mão informações suficientes e bons argumentos, possam formar uma compreensão articulada acerca dos interesses e das matérias a serem regulamentadas.

Além disso, a representação refere-se ao posicionamento e à localização, com o sentido de constituir percepções por parte dos indivíduos, materializados em representantes. Esse processo é desencadeado por fenômenos interativos oriundos nas relações sociais cotidianas. Conforme o entendimento clássico de Weber (1964) e reforçado por Ferreira (2007), também é importante observar que o processo coloca as questões de como selecionar os representantes adequados e de como controlá-los de modo que respondam satisfatoriamente aos interesses dos representados. O conceito inclui não apenas autorização do mandato e prestação de contas (accountability), mas também reforça a associação entre representação e inclusão.

Esse processo de representação pode ser organizado, conforme sugere Araújo (2014), quanto ao grau de separação entre representantes e representados:

a) Representação apropriada: é a forma com que os representantes e os representados têm a ligação com o maior fator de separação, porque os seus representantes não são escolhidos, designados ou controlados diretamente pelos representados, mas apenas interpretam o interesse e a vontade dos representados - nela, os representantes usufruem de todos os poderes decisórios;

b) Representação livre ou vinculada: é característica dos sistemas parlamentares, onde os representados têm tênue ligação direta com os representantes, mas seu controle é 
sujeitado ou limitado - nela, a liberdade dos representantes é inversamente proporcional ao grau de escolha ou controle dos representados, ou seja, refere-se à representação limitada por um mandato imperativo com direito à revogação e relacionado ao assentimento dos representados;

c) Representação instruída: é aquela em que os representados têm as rédeas do comando - nela, os representados usufruem de diferentes mecanismos de representação direta, como eleições frequentes, a revogabilidade de mandatos etc., de forma a exercer o poder de decisão.

Algumas reflexões avaliam que as transformações contemporâneas estariam tencionando o formato atual da representação. Para Aires (2009, p. 20), essa "crise do conceito convencional" vincula-se a fatores como: a emergência de novas demandas e funções representativas; a diversificação dos espaços de tomada de decisões coletivas, com uma pluralização dos atores que exercem funções representativas; e uma diversificação dos espaços nos quais ela é exercida.

Além disso, Young (2006) indica três elementos que caracterizariam o "sentir-se representado". São eles:

\begin{abstract}
i.) quando alguém está cuidando de interesses que reconheço como meus e que compartilho com algumas outras pessoas"; ii.) "os princípios, valores e prioridades que penso deveriam nortear as decisões políticas sejam verbalizados nas discussões que as deliberam"; e iii.) "quando pelo menos algumas dessas discussões e deliberações sobre políticas captam e expressam o tipo de experiência social que me diz respeito, em razão da minha posição num grupo social e da história das relações desse grupo social (YOUNG, 2006, p. 158).
\end{abstract}

Nessa perspectiva, ao mesmo tempo, "as experiências participativas inauguram novos mecanismos e relações de representação política que apresentam especificidades e diferenças substantivas com o modelo da representação eleitoral" (LÜCHMANN, 2007, p. 145), inclusive “(...) por combinarem, em seu interior, mecanismos de representação com participação direta”, ou "por articularem, de forma imediata, participação com representação da sociedade civil" (Ibidem).

Para Avritzer (2007, p. 458), há diferentes tipos de relação com o(s) representado(s) e de legitimação da representação, como indicado no quadro 3. Dessa forma, Dagnino (2006, p. 716) aponta que a participação da sociedade civil é ativa e propositiva e que, portanto, as estratégias inovadoras incorporam um “discurso participacionista e de revalorização simbólica 
da sociedade civil", com diferentes nuances, deslizando entre a governabilidade e a despolitização associada a viés técnico-gerencial (Ibidem, p. 14).

Quadro 3 - Formas e Características das Formas Usuais de Representação

\begin{tabular}{|c|c|c|c|}
\hline \multicolumn{3}{|c|}{ Formas de Representação na Política Contemporânea } \\
\hline $\begin{array}{c}\text { Tipo de } \\
\text { representação }\end{array}$ & $\begin{array}{c}\text { Relação com o } \\
\text { representado }\end{array}$ & $\begin{array}{c}\text { Forma de } \\
\text { legitimidade da } \\
\text { representação }\end{array}$ & $\begin{array}{c}\text { Sentido da } \\
\text { representação }\end{array}$ \\
\hline Eleitoral & Autorização pelo voto & Pelo processo & $\begin{array}{c}\text { Representação de } \\
\text { pessoas }\end{array}$ \\
\hline Advocatícia & $\begin{array}{c}\text { Identificação com a } \\
\text { condição }\end{array}$ & Pela finalidade & $\begin{array}{c}\text { Representação de } \\
\text { discursos e ideias }\end{array}$ \\
\hline $\begin{array}{c}\text { Representação da } \\
\text { Sociedade Civil }\end{array}$ & $\begin{array}{c}\text { Autorização dos atores } \\
\text { com experiência ou } \\
\text { relevância no tema }\end{array}$ & $\begin{array}{c}\text { Pela finalidade e } \\
\text { pelo processo }\end{array}$ & $\begin{array}{c}\text { Representação de } \\
\text { temas e experiências }\end{array}$ \\
\hline
\end{tabular}

Fonte: Adaptado de Avritzer (2007).

Caracteriza-se como parte do cenário contemporâneo uma "hegemonia do ideário participacionista", evidenciando a participação como princípio hegemônico que se afirma em diferentes filiações político-ideológicas, segundo Tatagiba (2006, 2007). A participação, desse modo, passa a ser vinculada à reorganização da gestão pública, visando a sua eficiência e a sua eficácia e se despolitizando ao ser pensada como ferramenta de gestão que detém vantagens competitivas e gera resultados superiores. É por isso que Tatagiba (2006) afirma que a própria abertura de canais institucionalizados de participação pode assumir o significado de mecanismos através dos quais se realiza a despolitização do debate e das decisões públicas, e, muitas vezes, o que se efetiva "não é a partilha do poder de governar, mas a dissolução desse poder na gerência eficiente.

Machado (2010), por sua vez, destaca consequências sociais diversificadas relacionadas às diferentes propostas democráticas e participativas, envolvendo metodologias, formatos institucionais, sistemas e procedimentos de formação das decisões e das lideranças. Não obstante, as representações e as esferas participativas parecem prescindir de qualquer necessidade de autorização formal, uma vez que sua legitimação se dá, na realidade, pela identificação com a causa. A representação, aqui, não é de pessoas, mas de ideias e discursos.

Dessa forma, as experiências democráticas e/ou participativas podem assumir sentidos de cooptação, integração, despolitização, tutela, cogestão, legitimação, partilha do poder, autogestão, transformação institucional e/ou social, reprodução da ordem ou do status quo 
estabelecido, educação, entre outros. Estas experiências demonstram que representação é um veículo da participação.

Assim, a representação e a participação abrem inúmeras possibilidades empíricas de expansão, sobretudo de grupos específicos ou sub-representações, via arranjos representativos, ampliando os espaços e as modalidades de representação. É justamente nesse contexto que se situam os novos arranjos participativos. No cenário, faz-se necessário aporte metodológico para problematizar as condições de participação, acesso e igualdade política nas associações civis e nas arenas deliberativas, frequentemente apontadas como forma de ampliação da participação e, assim, da representação de grupos marginalizados.

Os principais alicerces da democracia, conforme Bobbio (2000), são soberania, liberdade e participação popular. Isso descende do princípio democrático que impõe o respeito à soberania popular na medida em que garante a participação de todos e de cada um dos cidadãos, particularmente, na vida política do país. Tudo sem se esquecer de que o "poder em público", definido por Bobbio (2000, p. 386) como “[...] expedientes institucionais que obrigam os governantes a tomarem as suas decisões às claras $[\ldots . .$. ”, por si só não basta para dar ao povo o direito de escolher. É imperativo que lhe sejam dados o direito e as condições para exercê-lo.

O município configura-se como a forma de organização política mais próxima da população, constituindo um papel indispensável na viabilização do processo de participação permanente na regulação, na fiscalização e no controle sobre os serviços e bens públicos. Para tanto, é necessário que existam transparência e acesso às informações públicas, de forma a viabilizar a prática participativa (HABERMAS, 1997; AVRITZER, 2007).

A participação popular é condição para a prestação de contas do Estado, para com a sociedade, e a responsabilização política dos gestores, por meio do controle social, como forma de garantir a eficiência das políticas públicas, que se dá, sobretudo, na esfera municipal. A multiplicação de experiências participativas, visando ampliar o controle social sobre políticas públicas e políticos - ou seja, orientadas, implícita ou explicitamente, pelas noções de accountability $^{43}$-, tornou-se fenômeno relevante no Brasil e no mundo (VERA e LAVALLE, 2011; LAVALLE et al., 2006).

Waltner-Towes (2001) e Kay et al. (1999) também destacam a importância dos feedbacks no processo participativo, já que determinados estímulos (atratores) exercem papel decisivo nos processos de auto-organização de sistemas. Os atratores, por sua interferência, retroalimentam

\footnotetext{
${ }^{43}$ Responsabilização política, prestação de contas.
} 
o processo de organização. Este, com vistas a retroalimentação, é uma estratégia de intervenção participativa com feedback que contribui para maior ou menor participação. Esse feedback, de acordo com Waltner-Towes (2001) e Kay et al. (1999), pode ser classificado em:

a) Feedback direto/ imediato: estimula a participação dos sujeitos em tempo real, pois oferece evidências como resultados da pesquisa, ao mesmo tempo em que contribui para adequações metodológicas - é o caso de instrumentos aplicados com envolvimento direto dos sujeitos, enquanto construções coletivas "pesquisadores-sujeitos" -, e são considerados dialéticos os instrumentos produtores desse tipo de feedback;

b) Feedback indireto/ não imediato: estimula a participação dos sujeitos em um segundo momento, pois constituem instrumentos que não são executados em interações diretas "pesquisadores-sujeitos", mas promovem retroalimentação por sua capacidade de preencher importantes lacunas que vão sendo identificadas no decorrer do processo de pesquisa e intervenção.

Dessa forma, entre os fatores que parecem contribuir para uma participação mais envolvente, é possível destacar (i) maior conhecimento da população acerca de seu papel e de sua competência, (ii) maior envolvimento no controle das deliberações, (iii) maior interesse e disponibilidade dos envolvidos e (iv) maior igualdade entre o saber técnico e a contribuição das vivências. Ainda, segundo Ferreira e Fonseca (2014), esse processo passa por uma maior integração com a população local, com estratégias que permeiam um processo de educação e aprendizado, qualificando e estimulando a participação ativa na formulação de políticas e estratégias.

Compreende-se, então, que a participação popular é condição para a ocorrência da prestação de contas do Estado e a responsabilização política dos gestores, por meio do controle social, como forma de garantir a eficiência das políticas públicas, em outras palavras para a prestação de contas do estado ter efetividade no sentido de alcançar seus interessados de forma mais ampla, a participação social deve ser promovida de forma eficaz.

Tal controle ocorre eminentemente no âmbito do município, uma vez que a concretização dos serviços públicos se dá fisicamente no local onde se desenvolve a vida dos cidadãos, ou seja, na cidade. Nessa perspectiva, portanto, o município se configura como a forma de organização política mais próxima da população, constituindo um papel indispensável na viabilização do processo de participação permanente na regulação, na fiscalização e no controle sobre os serviços e bens públicos. Para tanto, é necessário que existam transparência e acesso às informações públicas, como premissa para a prática participativa. 


\subsection{GOVERNANÇA PARTICIPATIVA}

O termo "governança" não é estritamente contemporâneo - já existia desde a Idade Média, sendo empregado nas ideias de leading, steering e directing (LE GALÈS, 1995, 2003, 2006). No fim do século XIX, o termo passou a ser utilizado para representar oposição às limitações do conceito de governo, com a clássica separação entre Estado, Sociedade e Mercado.

Segundo a Comissão sobre Governança Global, “(...) governança diz respeito não só a instituições e regimes formais autorizados, mas também a acordos informais que atendam aos interesses das pessoas e instituições” (BANCO MUNDIAL ${ }^{44}, 1992$ apud DINIZ, 1995, p. 56). Dessa forma, absorve instituições governamentais, bem como outras instituições informais. $\mathrm{O}$ elemento comum, nessa forma de organização, é que uma determinada conduta tenha sua atuação atendendo necessidades das demandas comuns das instituições.

Mancini (2014) aponta que a gestão pública, se baseada em modelos de governança que incluam a participação da sociedade civil organizada, promove uma maior democratização por meio da descentralização, pois o Estado segue uma gestão mais horizontal, opondo-se ao modelo vertical hierárquico. O modelo horizontal de gestão é identificado, inclusive, pelos instrumentos participativos aplicados no Brasil, dado que as decisões são concentradas majoritariamente nas esferas estatais, sejam elas do executivo, do legislativo ou do judiciário.

Nos anos 1980, o termo "governança" tomou maior amplitude entre os economistas, que estavam interessados na melhoria da eficiência das empresas, além de se tornar uma referência para outras áreas de estudo (MCCARTNEY, 1997, 1997a, 2011). Essa abordagem aponta para a perspectiva de que o processo de governança se dê por meio do diálogo entre o poder público e as organizações da sociedade civil, principalmente em espaços institucionais de descentralização política. A utilização desse termo passou, então, a ser amplamente incorporada em diferentes áreas e sob formas diversas, sempre na busca de descrições sobre tipos de relações e coordenações entre atores em diversas escalas e âmbitos.

A participação social é um dos elementos fundamentais que consolidam a governança participativa, e está ligada à capacidade de gestores públicos promoverem a abertura necessária para que a participação se concretize. Com isso, a governança participativa surge reunindo condições que garantem um Estado eficiente e que transferem o foco da atenção das implicações da ação estatal para uma visão mais abrangente, envolvendo as dimensões sociais e políticas da gestão pública - consultando e compartilhando as tomadas de decisão, segundo Diniz (1995).

\footnotetext{
${ }^{44}$ Banco Mundial, em seu documento Governance and Development, de 1992.
} 
Nesse caso, a capacidade do Estado de governar passa a ser avaliada não apenas pelos resultados das políticas governamentais, mas também pela forma mediante a qual o governo exerce o seu poder. Mecanismos e de princípios voltados à promoção e à aplicação de estratégias para a emancipação social, ampliação dos direitos de cidadania e o acesso individual e coletivo aos espaços públicos tornam-se fundamentais. As principais características da boa governança são: "transparência, Estado de direito, responsabilidade, orientação por consenso, igualdade e inclusividade, efetividade e eficiência e prestação de contas” (Ibidem, p. 43).

Smith (2009) aponta que a governança participativa é um arranjo institucional que têm como finalidade possibilitar a integração dos cidadãos nos processos decisórios sobre as políticas públicas, permitindo a democratização do sistema político, o qual é conduzido dentro de um espírito de deliberação e contestação de ideias que favorecem os resultados e a qualidade das políticas públicas. De forma intrínseca, refere-se a um conjunto de arranjos institucionais que têm por objetivo facilitar a participação de cidadãos comuns no processo de desenho de políticas públicas, bem como na avaliação e no monitoramento das mesmas.

Assim, as práticas governamentais, em função de sua articulação público-privada, exercem predominante relevância nas avaliações dos projetos e moldam o formato institucional do processo decisório. Nas políticas públicas, não é diferente: a abertura maior, ou menor, para a participação dos setores interessados, ou das esferas de poder, articula os modelos de governança, como aponta o Banco Mundial (1992, apud DINIZ, 1995, p. 400).

Assim, a governança participativa pode pavimentar um caminho para inclusão da população nas estruturas de tomada de decisão sobre as políticas públicas, permitindo incrementar e fortalecer as capacidades de intervenção das camadas sociais mais desfavorecidas e superar as estruturas políticas e de poder tradicionais. Embora a governança participativa normalmente abranja as instituições governamentais, ela também implica mecanismos informais de caráter não governamental que fazem a sociedade civil e as organizações envolvidas terem uma conduta participativa e parceira.

Essa governança como estratégia de "governar" potencializa as ações políticoadministrativas e diminui resistências e oposição aos seus projetos públicos. A inclusão de todos os atores representativos envolvidos, com a mobilização de todo conhecimento disponível na sociedade, conforme Bourdin (2007) melhora o desempenho administrativo e a democratização dos processos decisórios. 
Simione e Ckagnazaroff (2017) apontam que, com o apoio do engajamento direto no nível local, tende-se a ampliar a presença de atores sociais de diversos tipos. No âmbito da tomada de decisão das políticas públicas, a governança participativa possibilita o aumento da cidadania por meio da inclusão de movimentos sociais e atores, reduzindo, dessa forma, a tensão gerada pelo problema da representação e da legitimidade política.

Essa preocupação é percebida inclusive no relatório "Cidades do Mundo", publicado pela ONU-Habitat (UNITED NATIONS, 2016), apontando que as cidades sustentáveis, resilientes e inclusivas dependem da boa governança, com planejamento integrado, planos aderentes aos respectivos orçamentos e planejamento com parceiros e operadores. Ademais, estes elementos devem ser instrumentalizados com ferramentas aderentes às realidades locais, considerando suas respectivas diversidades. Nesse diapasão, ferramentas integradas aos diversos objetivos coletivos poderão envolver parceiros e operadores, por meio de visões, percepções e ações locais, também planejadas e controladas localmente, conforme esquematizado na figura 16.

Figura 16 - Relação entre Visões, Ações e Planejamento em âmbito local

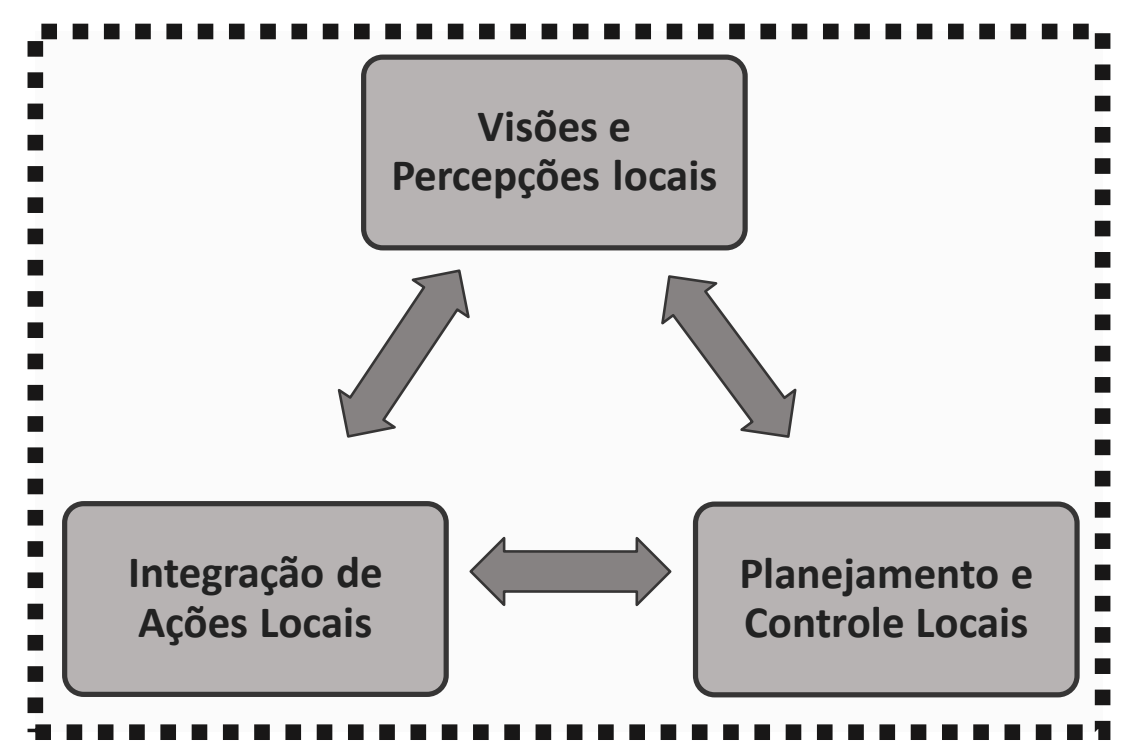

Fonte: Do autor (2019).

Assim, originalmente vista como um conjunto de relações intergovernamentais, a governança hoje é entendida de forma mais ampla e envolve organizações não governamentais (ONGs), movimentos civis e empresas privadas. Sua dimensão essencial diz respeito à participação de todos estes atores envolvidos. Além disso, as transformações efetivas e duradouras no campo do planejamento urbano necessitam, obrigatoriamente, articular-se a transformações estruturais nos processos de produção social do espaço urbano e nos sistemas, nas normas e nas instituições políticas, como afirma Machado (2010, p. 88). 
Há uma relação entre a importância da participação pública e a governança com as decisões em ambientes de incerteza e controvérsias. Contudo, na abordagem participativa, a interação entre cidadãos e governo deveria gerar envolvimento efetivo nas etapas cruciais de tomada de decisão, elevando a confiança e a legitimidade. A literatura aponta a importância política da deliberação pública como um elemento necessário, colaborando para a articulação de preocupações públicas, em um cenário no qual as questões seguem trajetórias de baixo para cima (em um cenário upstream ou bottom-up) e para o direcionamento futuro de trajetórias socialmente vigorosas, conforme Guivant e Macnaghten (2011).

\subsection{A PARTICIPAÇÃO POPULAR EM ÂMBITO LOCAL}

Segundo Martins (2002), atualmente, há uma tendência em pensar e projetar o desenvolvimento de modo a dotá-lo de um caráter mais humano, ao considerar o homem simultaneamente como sujeito e beneficiário. A disposição advém do desígnio de que as pessoas devem participar ativamente e não apenas serem beneficiárias do desenvolvimento. A esse respeito, Buarque (2006) chama a atenção para o fato de que:

O desenvolvimento local pode ser conceituado como um processo endógeno de mudança, que leva ao dinamismo econômico e à melhoria da qualidade de vida da população em pequenas unidades territoriais e agrupamentos humanos. Para ser consistente e sustentável, o desenvolvimento local deve mobilizar e explorar as potencialidades locais e contribuir para elevar as oportunidades sociais e a viabilidade e competitividade da economia local; ao mesmo tempo, deve assegurar a conservação dos recursos naturais locais, que não são a base mesma das suas potencialidades e condição para a qualidade de vida da população local (Ibidem, p. 25).

Na busca por resultados efetivos para o desenvolvimento local, Gohn (2003) coloca que participar significa dividir as responsabilidades na construção coletiva de um processo, que objetiva fortalecer a sociedade civil para a construção de caminhos que apontem para uma nova realidade social, sem injustiças, exclusões, desigualdades ou discriminações. Por sua vez, para o estudioso Araújo (2015, p. 52), a “construção compartilhada de um projeto de sociedade local pode levar a novas formas de desenvolvimento, baseadas na corresponsabilidade entre os atores e nas parceiras entre governo e sociedade". Assim, esta relação de poder com envolvimento por parte da sociedade local pode promover mudanças nas próprias relações de poder. E tais mudanças de enfoque trazem importantes implicações para a formulação de leis, normas, diretrizes e propostas de intervenção urbana local.

O local mais propício para o exercício da democracia é o município, conforme já explorado na revisão da literatura. É nele que, devido à maior proximidade espacial entre os 
indivíduos e com suas respectivas comunidades, existe maior interação entre as partes, possibilitando maior poder de influência nas decisões que interferem no seu dia a dia. Ao se estabelecer interações entre os diversos atores sociais envolvidos e se suscitar a existência de lacunas entre as demandas locais das populações e as ações do governo, é necessário que se tenha conhecimento do todo e que se compreenda, por exemplo, o rito dos projetos urbanos, ou seja, quem são os atores envolvidos, quando ocorre o quê, e por quê, quais as fases intrínsecas, quais recursos estão disponíveis, quais são as influências externas e a quem se dirigir para esclarecer dúvidas, pleitear direitos, sugerir soluções.

A participação popular é considerada um modelo que viabiliza a interação da população local com seus representantes nos processos de tomada de decisão, envolvendo a organização e o manejo de recursos financeiros, humanos e técnicos, sendo materializada em um conjunto de processos sociais e canais institucionalizados de participação, conselhos, comissões, conferências, comitês, consórcios municipais, entre outros. É reforçada por instrumentos políticos sociais de participação cidadã: fóruns, plenárias, grupos de pressão e conselhos populares não legalizados. Isso pode significar exprimir prioridades futuras acerca de bens públicos, expansões, alterações e construções urbanas. Ademais, pode ser sinônimo de politizar as relações sociais e culturais no processo de constituição de espaços públicos para formulação ou reformulação de políticas públicas locais.

É importante lembrar que o Estatuto da Cidade reserva um capítulo inteiro (Capítulo IV) para tratar da "Gestão Democrática da Cidade". O artigo 43, por exemplo, estabelece que para garantir a gestão democrática devem ser utilizados, entre outros, os seguintes instrumentos: órgãos colegiados de política urbana; debates, audiências e consultas públicas; conferências sobre assuntos de interesse urbano; iniciativa popular de projetos de lei e de planos, programas e projetos de desenvolvimento urbano.

$\mathrm{O}$ artigo 44, por sua vez, que trata da gestão orçamentária participativa, estabelece a necessária inclusão da realização de debates, audiências e consultas públicas sobre as propostas do plano plurianual, da lei de diretrizes orçamentárias e do orçamento anual, sendo tais mecanismos uma condição obrigatória para sua aprovação pela Câmara Municipal. E o artigo 45 prevê que os organismos gestores das regiões metropolitanas e aglomerações urbanas deverão incluir obrigatória e significativa participação popular e de associações para garantir o controle direto de suas atividades e pleno exercício da cidadania. No entanto, não há menção de formas de participação direta efetiva na legislação e, muito menos, de quaisquer tipos de participação direta individual. 
A implementação de tais instrumentos é capaz de proporcionar, sob determinadas condições, acesso direto da população à administração municipal, a fim de que não somente participe da tomada das decisões, mas também lhe seja possível interferir e ajudar nos processos de desenvolvimento da cidade. Habermas (1992a) reforça a hipótese de que a força "sociointegrativa" emana das interações comunicativas contextualizadas nas ações reais da vida, e que não migram imediatamente ao plano político, daí o resultado da formação de opinião e a vontade coletiva culminam na legitimidade política. Esse processo operado na gestão pública estabelece condições de mediação entre as percepções e as estratégias políticas, permitindo a tomada de decisões:

[...] apresentar novas contribuições para a solução de problemas, de oferecer novas informações e de corroborar os bons motivos, denunciando os maus, de forma a introduzir um impulso nos ânimos capaz de alterar os parâmetros constitucionais da formação da vontade política e de pressionar os parlamentos, os judiciários e os governos em favor de determinadas políticas (HABERMAS, 1992a, p. 448).

Segundo Milani (2008), a ação pública local se refere a uma ação coletiva em que atores governamentais e não governamentais tomam parte de um processo político sobre um assunto de natureza pública. A intensidade dessa ação depende do grau com que esses atores atuam em torno da política. Quanto maiores a densidade democrática da deliberação e a capacidade do processo em incluir um leque diversificado de atores locais, maior será a intensidade da ação pública local.

Dessa forma, conclui-se que as ações públicas locais com alta efetividade contribuem significativamente para o engajamento nos processos políticos, e resultarão em políticas melhor formuladas, mais robustas e articuladas. Burton e Mustelin (2013) apontam que, nesse estágio, os cidadãos demonstram maior disposição; eles poderão apreciar o processo em si e não tão somente o resultado. Dessa forma, aumenta-se a probabilidade de aprovação e adaptação das divergências; a própria diversidade pode, inclusive, representar um ponto de apreciação. Logo, é possível afirmar que há uma relação entre as ações públicas de caráter local, no âmbito do planejamento urbano, com desenhos participativos com características deliberativas, conforme apontam Avritzer (2008) e Swapan (2016).

Contudo, é importante considerar a diversidade dos atores que participam do processo. Afinal, quanto maior for a capacidade deliberativa, maior será sua eficácia - e quanto maior a diversidade dos atores, maior será a efetividade das ações em âmbito local. Essa relação entre a capacidade deliberativa e a diversidade dos atores é construída com base no interesse coletivo em âmbito local, ou seja, quanto maior a capacidade deliberativa e maior a diversidade dos 
atores sociais, maiores serão a eficácia e a efetividade das ações públicas locais, e este raciocínio pode ser diagramado na figura 17.

Figura 17 - Capacidade deliberativa e a diversidade dos atores

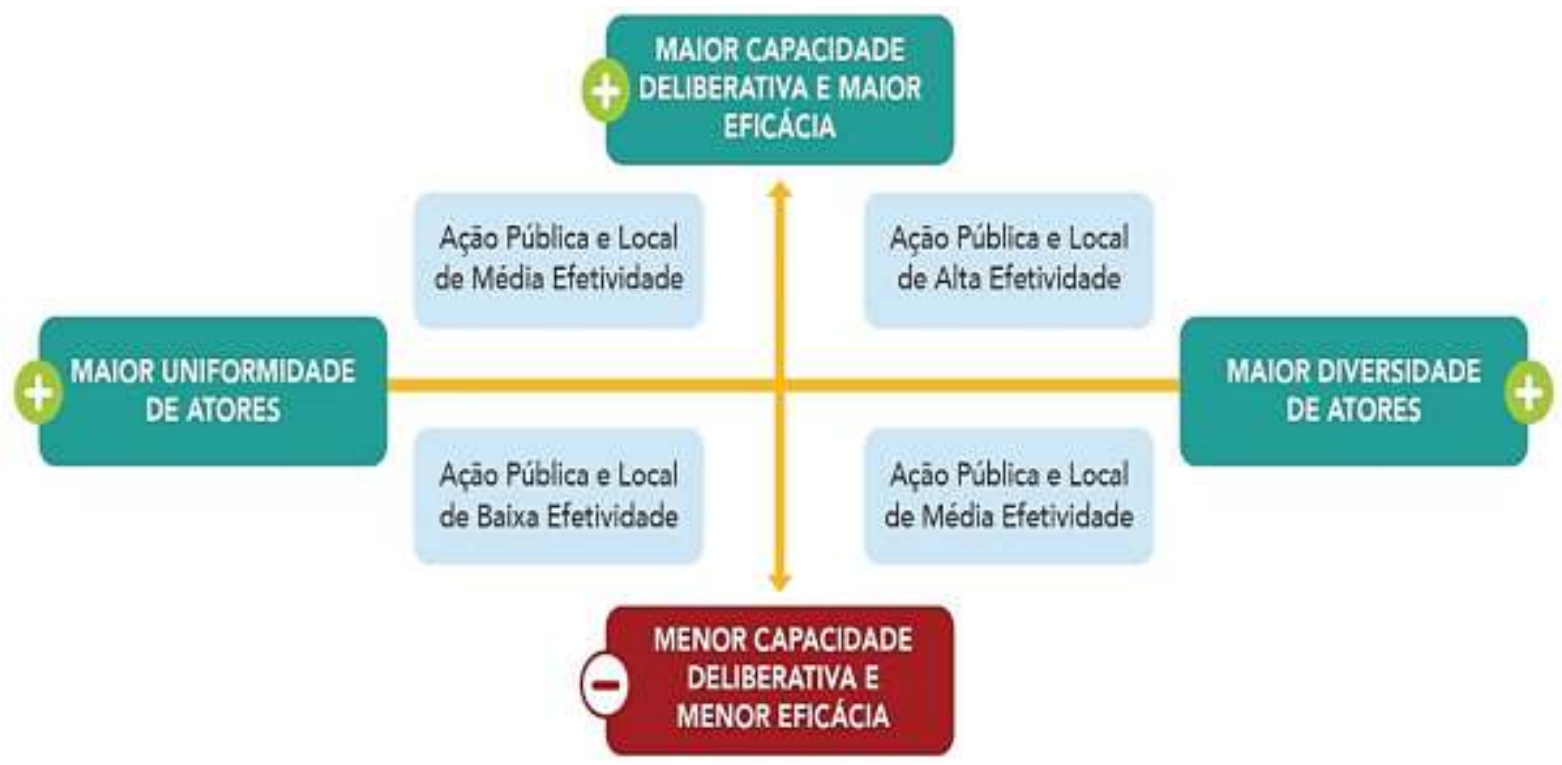

Fonte: Do autor (2019), baseado em Milani (2008), Avritzer (2008) e Swapan (2016).

Resumidamente, quanto maior a diversidade dos atores, maior será a efetividade das ações em âmbito local; quanto maior a diversidade dos atores sociais, maior serão a eficácia e a efetividade das ações públicas locais; quanto maior a capacidade deliberativa, maior será a intensidade da ação pública local; e quanto maior a capacidade deliberativa, maior será sua eficácia. As discussões de Arnstein (2002) sobre os vários tipos de participação na arena pública estão relacionados aos níveis de participação e aos canais ou instrumentos, oferecidos pelo poder público aos cidadãos, numa escala de importância de decisão e intervenções cidadãs nas políticas pública.

\subsubsection{Aprendizagem Social}

A contribuição de diferentes conhecimentos está correlacionada com a interdisciplinaridade e a transversalidade. O processo de aprendizagem social, intrínseco aos processos participativos, implica o reconhecimento e a explicitação dos conflitos em determinadas questões, ou seja, seu entendimento coletivo (JACOBI et al., 2006). Pontual (2000) e Costa e Peres (2014) reforçam o papel das contribuições do processo educativo e da aprendizagem social dos diversos atores e da sociedade civil, mas não só. O Estado também é um agente que passa pelo processo de aprendizagem, uma vez que as experiências participativas 
realizam um processo de mediação e construção de consensos educativos. Tal elemento é necessário para gerar aprendizado dos atores.

Os autores enfatizam que os processos de educação e aprendizagem social são fatores fundamentais para a construção da cidadania, e, nesse contexto, a construção de um modelo participativo complexo, com recepção, consulta, devolução e retroalimentação de contribuições e ações, é um modelo de educação popular. A noção básica de aprendizagem social é definida como "aprender junto para compartilhar", conforme Harmonicop (2003a). Seria a oportunidade que os atores atuantes têm para desenvolver seu próprio plano de ação de gestão, o que promoveria uma construção coletiva e facilitaria uma aprendizagem coletiva.

Essa perspectiva cooperativa sustenta o trabalho de um grupo que tem um objetivo comum, que, se estruturado de forma metodológica, traz à tona interesses individuais. Como esses interesses individuais são contextualizados em demandas coletivas, a transformação é fundamental para criar relações perenes e motivadoras em processos de gestão participativa. $\mathrm{O}$ desafio de como o particular se configura no coletivo é, na atualidade, uma questão relevante em planejamento urbano.

O trabalho colaborativo promove um diálogo reflexivo no qual contexto, processo e resultados são elementos essenciais para compreensão da criticidade, do arcabouço jurídicoinstitucional, dos obstáculos, das possibilidades de intervenção, assim como do plano e dos atores envolvidos. O tipo de contribuição que pode ser dada por cada um depende de seus recursos controlados e cooperados, seu nível de participação e o modo para negociar com os mesmos, conforme Jacobi et al. (2006). As concepções de aprendizagem social e trabalhos colaborativos seguem pressupostos de que a transmissão do saber (popular e técnico) é elemento do desenvolvimento da cidadania e que dependem do ato de participar em organizações da sociedade civil, além de exercer o controle sobre as prioridades das políticas e de como equacionar os conflitos e consensos.

A gestão participativa, ancorada nesse processo educativo como elemento central para a aprendizagem social, liga-se efetivamente ao trabalho cooperativo, promovendo a participação coletiva e o diálogo entre os atores envolvidos na gestão. O processo educativo, nessa proposição, envolveria políticos, burocratas, população e movimentos sociais, configurando um caldeirão heterogêneo e diverso de saberes, e a aprendizagem social compreenderia valores coletivos, civismo, organização social, percepções e demandas particulares e coletivas, estratégias e ações técnicas, construindo a cidadania, conforme destaca Souza (2001). 
Isso envolve não somente o aprendizado dos atores, mas também a maneira como eles lidam uns com os outros e suas interdependências, reconhecendo as estratégias uns dos outros e buscando um campo sinérgico de negociação, segundo Jacobi et al. (2006). Uma nova cultura política surgiria a partir da conscientização e proporcionaria uma melhoria na qualidade de vida das pessoas envolvidas, sendo a educação popular o maior ganho da democracia participativa. Dessa forma, os arranjos devem buscar o fortalecimento dos movimentos sociais, de atores sociais e atores políticos por meio da educação social extracurricular.

De acordo com Costa e Peres (2014), as instituições participativas seriam capazes de gerar um processo educativo a todos os atores envolvidos. A aprendizagem compreenderia valores cívicos, coletivos e de cidadania. O caráter pedagógico das instituições participativas criaria certo empoderamento de grupos marginalizados.

A inserção do indivíduo em redes de relações sociais, segundo Costa e Peres (Ibidem), "através de laços de confiança interpessoal e redes de cooperação inerentes a estrutura dessas relações gerariam benefícios e externalidades positivas”. A aprendizagem social, uma construção coletiva, permite que as posições coletivas e individuais sejam colocadas em mesas de negociação, de preferência num modelo de ganhos mútuos e em processos de aprendizagem colaborativa, como salientam Jacobi et al. (2006).

A criação de práticas de participação que privilegiem a organização da população atua como mecanismo para influenciar o processo de tomada de decisão. O estabelecimento de mecanismos de interação social que envolvam a realização de encontros periódicos cria a ambiência para discutir sobre os resultados das ações e as recepções de devolutivas. Por fim, a utilização de reuniões públicas como mecanismo voltado para resolução de problemas locais, identificados junto à população e os decorrentes da implementação dos programas e planos de ação, representa uma forma de acompanhamento das ações governamentais e intervenção. Ainda, enquadram-se na perspectiva do processo de envolvimento dos cidadãos nas decisões, aberto à ampla participação das pessoas nas decisões do governo.

\subsubsection{Negociação e interação em ambientes participativos}

No referencial da aprendizagem social, a negociação é uma importante estratégia para construção de decisões conjuntas pois as decisões são construídas conjuntamente, e assim o aprendizado vai sendo consolidado. Experiências ligadas às questões ambientais e comitês de bacia, por exemplo, têm sido estudados por Jacobi et al. (Ibidem), que têm aplicado modelos 
com ênfase na cooperação em processos de consensos gradativos, como facilitadores na resolução de conflitos.

Portanto, confiança é uma noção essencial para as atitudes de negociação, como destaca Giddens (1990, 1992, 1994, 1998), e um indivíduo que não considera alternativas está numa situação de crença, enquanto alguém que reconhece essas alternativas e tenta calcular os riscos assim reconhecidos, engaja-se em confiança. Nem sempre é possível construir o consenso, mas sempre se pode optar pela negociação. Algumas ferramentas de negociação pressupõem que o conflito expresso por seus atores tem a mesma relação de força e de poder, e que argumentos explicitados podem ajudar na negociação e na capacitação. Essa percepção é reforçada por Jacobi et al. (2006), bem como a relevância de propiciar um comportamento mais adequado nas questões de negociação.

A confiança em pessoas não é enfocada por conexões personalizadas no interior da comunidade local e das redes de parentesco. Isso requer a abertura do indivíduo para o outro; consiste em abertura e cordialidade demonstráveis. Bredariol (2001), por sua vez, reforça que o conhecimento, a mediação e a aplicação de técnicas para a resolução de conflitos, com vistas à elaboração de instrumentos de intervenção, têm ação sobre a relação de atores sociais entre si e com o ambiente urbano e busca alcançar uma inserção dinâmica na construção da realidade social.

Práticas de negociação dos conflitos, seja através de métodos comportamentais, seja através de técnicas de planejamento e avaliação de políticas e projetos, ou através de metodologias de resolução, dissolução, mediação ou negociação de conflitos, poderão ajudar os diferentes grupos sociais a se representarem. Sem negar o conflito existente, as relações e os vetores de forças nele contidos, a aposta é a existência de possibilidade de enfrentamento dos conflitos com metodologias que, ao mesmo tempo, negociam os futuros cenários e podem oferecer estratégias de institucionalização do conhecimento e intervenção conjunta, conforme Jacobi et al. (2006).

Nesse contexto, a divulgação de métodos e técnicas de análise e o apoio à resolução de conflitos pode representar iniciativas que auxiliem a construção de políticas locais, a democratização do Estado e a representação dos diferentes interesses da sociedade. Assim, os espaços participativos podem representar e ampliar as possibilidades de escuta da sociedade, acolhendo suas demandas e percepções e facilitando a caracterização de problemas. 
Técnicas e abordagens participativas que permitem o mapeamento dos atores envolvidos, seus interesses, suas preferências, suas estratégias e seus dilemas, associadas à melhoria da comunicação entre atores, podem motivar processos contínuos de interação fruto da sucessão de negociações. Tais processos contribuem para melhoria da gestão com racionalidade na tomada de decisão, na definição de estratégias e na hierarquização de alternativas (RESOLVE, 1998), conforme sintetizado no quadro 4.

A estruturação de um processo dinâmico que passa pela análise da situação-problema, escolhas estratégicas e acordos com visões compartilhadas do futuro dos atores intervenientes - pressupondo envolvimento, corresponsabilidade e emancipação - são processos criativos de ação interativa com riqueza de negociação. Afinal, os atores, além de terem interesses em função da posição que ocupam na realidade (conceito "situacional"), detêm recursos que são valiosos para suas realizações e agem em função de seus interesses e suas visões parciais sobre a realidade, conforme pontuado por Jacobi, et al. (2006).

Quadro 4 - Metodologia para a Construção de Consenso

\begin{tabular}{c|c|c}
\hline \multicolumn{2}{c}{ Hierarquização do Consenso e Mediação do Conflito } \\
\hline Princípios & Etapas & Objetivo \\
\hline $\begin{array}{c}\text { Discutir em direção a } \\
\text { interesses coletivos }\end{array}$ & Pré-Negociação & $\begin{array}{c}\text { Organizar as questões e } \\
\text { construir relações de } \\
\text { confiança }\end{array}$ \\
\hline $\begin{array}{c}\text { Enfatizar o papel das } \\
\text { percepções individuais e } \\
\text { associar a dinâmica } \\
\text { interpessoal }\end{array}$ & Negociação & $\begin{array}{c}\text { Extrair percepções e } \\
\text { identificar o senso comum, } \\
\text { combinando regras básicas } \\
\text { e premissas }\end{array}$ \\
\hline $\begin{array}{c}\text { Gerar opções, } \\
\text { minimizando julgamentos }\end{array}$ & $\begin{array}{c}\text { Definir regras comuns e os } \\
\text { passos necessários para um } \\
\text { consenso }\end{array}$ \\
\hline $\begin{array}{c}\text { Promover acordos e os } \\
\text { critérios para julgar opções }\end{array}$ & Implementação e & $\begin{array}{c}\text { Promover acordos } \\
\text { participativos e concessões, } \\
\text { pactuadas de forma } \\
\text { participativa }\end{array}$ \\
\hline $\begin{array}{c}\text { Promover soluções } \\
\text { mutuamente aceitáveis } \\
\text { mediante as opções }\end{array}$ & acompanhamento & $\begin{array}{c}\text { Emitir relatório, monitorar } \\
\text { e implementar soluções }\end{array}$ \\
\hline
\end{tabular}

Fonte: Adaptado de Resolve (1998).

Bernard Marchand (1997), do Instituto Francês de Urbanismo, desenvolveu um software para a simulação de negociações de decisões do desenvolvimento urbano. Ele tem como ponto de partida a definição dos conceitos básicos de negociação e protagonistas para a escolha otimizada de projetos urbanos. A negociação implica projetos e balizamentos, sendo que projeto designa uma proposta específica a ser submetida a aceitação, financiamento e implementação, 
e o balizamento se refere ao valor que cada protagonista atribui a um projeto particular, medido, numa escala de -10 a +10 . A solução ótima é avaliada segundo os princípios de maximização da satisfação, maximização da justiça e maximização da equidade.

Marsick e Watkins (2003) ressaltam que as estratégias de ação requerem o alinhamento de percepções para compartilhar intenções de desenvolvimento de ações que exigem a capacidade de colaborar em ações coletivas dentro de diferentes espaços e limites. Toda negociação gera algum aprendizado, pois as interações de uns com os outros estabelecem relações sociais, dentro de um determinado contexto. A presença simultânea desse conjunto de atores converge a uma série de ações e reações concomitantes, em sentidos comumente opostos, configurando situação conflituosa, segundo Jacobi et al. (2006).

Mesmo sendo a negociação entendida como sendo a busca de um acordo por meio da convergência de interesses e ideias, de modo que se tornem comuns ou complementares, Matos (1989) defende a ideia de que um acordo é oriundo de alvos comuns, com a administração das concessões, pois no centro do processo há a renúncias em favor da aceitação do bem comum. De forma inequívoca, nas concessões e renúncias, os embates existem porque os recursos (financeiros, políticos, humanos, materiais, naturais, tecnológicos, de conhecimento e de influência) são escassos e limitados, e as opções deveras conflitantes, segundo Jacobi et al. (2006).

Nierenberg (1981) e Jacobi et al. (2006) sugerem que negociação é um processo que pode afetar profundamente qualquer tipo de relacionamento humano e produzir benefícios duradouros para todos os participantes. Assim, as abordagens participativas que analisam e incorporam as relações de negociação podem: permitir a representação de todos os interesses dos atores; obter entendimento compartilhado sobre os interesses de cada um, com questões técnicas, políticas, sociais, econômicas e ambientais envolvidas; construir alternativas em conjunto que se configurem como mais factíveis, criativas e com maior aceitabilidade que as inicialmente propostas por qualquer um dos envolvidos; e, neste cenário, buscar acordos que satisfaçam os interesses prioritários de cada um.

A satisfação dos diferentes atores e passa por um processo de formação de opiniões cuja intervenção conjunta, e proposição de cenários consensuais, só é possível se remetida a um contexto que apresente uma situação-problema que possa ser percebida pelos atores. mediante as ferramentas que dominam (linguagem, visão de mundo, experiência, recursos que dispõem etc.) reforçam Scare e Martinelli (2001) e Jacobi et al. (2006). 
Teixeira (2011) também sugere que um clima favorável para negociação é construído quando há possibilidade de identificar as necessidades e as expectativas do outro, sendo seguida do esclarecimento de dúvidas, dos questionamentos e da posterior retomada sintética dos objetivos. Nesse cenário, Jacobi et al. (2006) reforçam a percepção de que podem ser formadas arenas de negociação nas quais os participantes ofereçam suas contribuições ao processo de gestão.

Para Thomas (1992), a participação de muitos atores, com interesses diferentes e opostos, em um contexto de incertezas e riscos, torna a gestão pública um local de constantes conflitos. Assim, dificulta a formação do consenso tão imprescindível para a eficaz e eficiente gestão.

Para Schermerhorn, Hunt e Osborn (1999) toda situação de conflito é finalizada com resultados imprevisíveis e variados. Os resultados dessa mediação, em políticas públicas e em planejamento urbano, podem atingir aos atores de forma geral, tanto os que participam quanto os que não participam do processo. Segundo os autores, os conflitos podem ser divididos pelos possíveis resultados gerados e comportamentos dos indivíduos em três relações: (a) conflito perde-perde, (b) conflito ganha-perde e (c) conflito ganha-ganha, sendo que:

a) Conflito perde-perde: ocorre quando as partes envolvidas não conseguem alcançar seus objetivos. Ambas as partes não conseguem realizar seus verdadeiros objetivos e intenções, e as razões que são subjacentes ao conflito continuam não sendo solucionadas;

b) Conflito ganha-perde: pode resultar de uma competição direta, ou seja, quando uma das partes envolvidas consegue os seus objetivos à custa e exclusão dos objetivos que a outra parte almejava. O conflito ganha-perde não considera os interesses das partes e as causas básicas do conflito, suprimindo os objetivos de pelo menos uma das partes envolvidas;

c) Conflito ganha-ganha: é aquela na qual os participantes examinam as verdadeiras questões e colaboram para encontrar uma solução que reconcilie diferenças. Resulta da administração do conflito por colaboração ou negociação, de modo que as pessoas cedem em relação a algum interesse particular para conseguir um objetivo maior.

A negociação pretendida em planejamento urbano se insere na aprendizagem social, pois ambiciona que a gestão esteja completamente enraizada numa sociedade democrática ou na busca de mecanismos para fortalecimento e empoderamento desses atores. Jacobi et al. (2006) salientam que esse processo não é simples, pois se trata de uma espiral de comprometimento e aprendizagem conjunta, que leva seu próprio tempo de maturação. 


\subsubsection{Estratégia nas Relações de Participação}

A participação é um dos elementos fundamentais para a sequência de negociações entre os múltiplos atores. Muitas questões técnicas permeiam a tomada de decisão, e nem sempre os conflitos cognitivos e o conhecimento técnico-científico são conhecidos por todos os atores, conforme aponta Guiddens (1990, 1992, 1994, 1998, 1999). A própria linguagem e a designação de termos podem, por vezes, criar um ambiente de segregação e exclusão. Nem sempre a forma de comunicação continua e diária da realidade das pessoas é a mesma daquela aplicada na elaboração de instrumentos técnicos e legais.

O entendimento do problema implica diferentes leituras, criando intersecções, as quais serão a base para os espaços de negociação. Ao invés de estratégias de controle, o que se espera é uma estratégia flexível e adaptativa cujos gerenciamento e eficácia serão determinados com o real encaminhamento das propostas dos atores. Todos os interessados influenciam, controlam e desenvolvem iniciativas e tomam decisões, reverberando possíveis consequências que os afetam.

O arcabouço teórico da aprendizagem social demonstra que o aprendizado conjunto é fundamental para realização de tarefas e construção de acordos comuns. Sua consolidação requisita a aplicação de instrumentos participativos, metodologicamente elaborados, com sequenciamento, divulgação de informações, colaboração, coordenação, consulta e representação. A aprendizagem social não pode ser ensinada por alguém de fora do contexto, mas é na co-reflexão prática de todos os atores envolvidos que o aprendizado e a intervenção conjunta, por meio de um processo negociado, construirão um ciclo de diálogo, análise, ações e reações participativas, a fim de incorporar as opiniões de todos os níveis da sociedade civil, desde as comunidades até os setores públicos e privados, na formulação de políticas e na implementação de programas, como aponta Harmonicop (2003a).

Portanto, o crescente envolvimento e o aprendizado conjunto dos atores partícipes na gestão, reforçam a estratégia do aprender junto para intervir junto. Isso também reverbera nas dimensões de participação, compartilhamento (intercâmbio de informação) e corresponsabilização para decidir (consulta, colaboração e delegação de poder). Essa rotina de participação-compartilhamento e decisão-responsabilização, cria cenários cujo conjunto do processo decisório determina posições, prioridades e funções, como aponta Meximiano (1995).

As propostas de agregação entre aprendizagem social e arenas de negociação não estão desconexas, como propostas normativas, ou seja, um alia-se ao outro. O processo de negociação 
é um processo de aprendizagem e vice-versa. Essa experiência tem respaldo prático em diversos países da Europa com arcabouço teórico consistente, estudados por Harmonicop (2003b), com abordagens voltadas a comissões conjuntas, grupos de trabalho e de atividades conjuntas com representantes dos interessados, trabalho conjunto com grupos de usuários e grupos afins, atribuição da responsabilidade de implementação aos interessados, reuniões para solucionar divergências, para obter acordos e gerar propriedade e análises públicas de projetos, além de sua revisão.

Nas negociações com abordagens participativas, podem ser criados processos cognitivos, visando tanto à educação como ao preparo para a negociação. As questões objeto de negociação servem, inclusive, como modelagem para o entendimento da realidade, e permitem aos atores explorar e discutir os cenários para construção dos respectivos acordos.

Estas ferramentas visam facilitar, por meio da formalização participativa (com vistas a aprendizagem), seguidas de exploração de cenários negociados, a construção de uma representação compartilhada do funcionamento das variáveis e do contexto que se analisa. Elas envolvem não somente as relações entre atores, recurso e processos governamentais, mas também as interações entre atores, conforme figura 18.

Figura 18 - Participação em Processos de Planejamento e Abordagens Participativas

\begin{tabular}{|c|c|c|}
\hline Grupos de interesse & $\begin{array}{c}\text { Abordagens participativas } \\
\text { e negociações }\end{array}$ & $\begin{array}{c}\text { Processos } \\
\text { Governamentais }\end{array}$ \\
\hline Público em Geral & & Revisões setoriais \\
\hline Governo & & Planejamento local \\
\hline Assembleias representativas & & Alocações de recursos \\
\hline Sociedade civil organizada & & $\begin{array}{l}\text { Implementação de } \\
\text { programas }\end{array}$ \\
\hline Setor privado & & Monitoramento \\
\hline $\begin{array}{r}\text { Divulgação de inform } \\
\text { comissões e grup }\end{array}$ & $\begin{array}{l}\text { - Pesquisa participativa - C } \\
\text { trabalho - Integracão com }\end{array}$ & $\begin{array}{l}\text { ltas - Formação de } \\
\text { essos políticos. }\end{array}$ \\
\hline
\end{tabular}

Fonte: Do autor (2019).

Para isso, devem ser estruturadas abordagens nas quais participam grupos de interesse, que trabalham de forma coletiva para entender a natureza de um problema comum, cooperando 
entre si para resolver os problemas e/ou conflitos relacionados e, por fim, montando ações conjuntas para intervir na gestão.

Motta (1981) aponta que o modelo participativo busca uma integração, no intuito de se criar cenário favorável para que as pessoas aprendam a conviver de forma mais colaborativa e aceitando as opiniões divergentes, respeitando os pontos de vista alheios, confrontando opiniões, sem agressões pessoais.

A construção de plataformas que proporcionem a participação de múltiplos grupos de interesses, por exemplo, pode potencializar a intervenção, sem perder de vista os processos de democratização (participação para todos), de emancipação e empoderamento dos atores que apoiam a resolução de conflitos e da gestão. Esse diapasão permite explorar os diferentes tipos de participação e de envolvimento, circunscritos em uma ferramenta de planejamento e gestão.

A revisão da literatura aponta que existem ainda complexidades que se referem ao trato dos interesses de diferentes grupos que participam dos processos de gestão, ao conflito nos processos decisórios e nas escolhas de prioridades, às condições estruturais e políticas da organização dos grupos e à legitimidade dos interesses políticos da sociedade civil. Estas impactam os resultados da democracia.

\subsubsection{A Abordagem Educativa como Estratégia de Implementação}

Jacobi et al. (2006) salientam que a aprendizagem deve orientar a implementação de processos participativos. Neles, são relevantes a informação e a comunicação, pontos com os quais se pretende alavancar mudanças que culminem em ambientes participativos abertos a indeterminações, mudanças, diversidade e complexidade. Esse processo não é estanque e deve passar pela construção e pela reconstrução, em um processo contínuo de novas leituras e interpretações, de questões inclusive superadas, a fim de configurar possibilidades de ação naquilo que ainda há de se analisar.

Numa leitura mais crítica, essas práticas se baseiam em: promoção de uma atitude problematizadora; compreensão da complexidade e politização da problemática; e participação dos sujeitos, o que explicita uma ênfase em práticas sociais menos rígidas, centradas na cooperação entre os atores. Verifica-se que, ao passo que o envolvimento avança, as pessoas participam mais da própria decisão, em vez de simplesmente fornecerem insumos para que outros decidam. Assim, o envolvimento começa na informação e chega até a transferência dos poderes de decisão para o indivíduo, ou o grupo, resolver problemas. 
As análises seguem as sugestões de Jacobi et al. (Ibidem) e Jacobi (2005), cuja sequência para implantar as abordagens participativas eficientes é aprimorar a comunicação e a formação. Deve-se, entretanto, ressaltar que as práticas educativas devem ser compreendidas como parte do macrossistema social, subordinando-se ao contexto de desenvolvimento existente que condiciona sua direção pedagógica e política.

As práticas educativas, articuladas à problemática urbana contextualizada em espaços participativos, consultivos ou deliberativos, é uma parte componente de um processo metodológico, mas também devem procurar comunicar-se, transmitindo informações para baixo e para os lados, sobre fatos e decisões importantes. As abordagens participativas com enlace educativo e entrelaçamentos entre diversos saberes fortalece as relações de confiança entre os técnicos e os atores, de tal forma que as informações que recebem podem ser melhor codificadas e transmitidas. Tal análise contributiva pode ser sumarizada na figura 19.

Figura 19 - Abordagem Educacional na Fundamentação de Abordagens Participativas

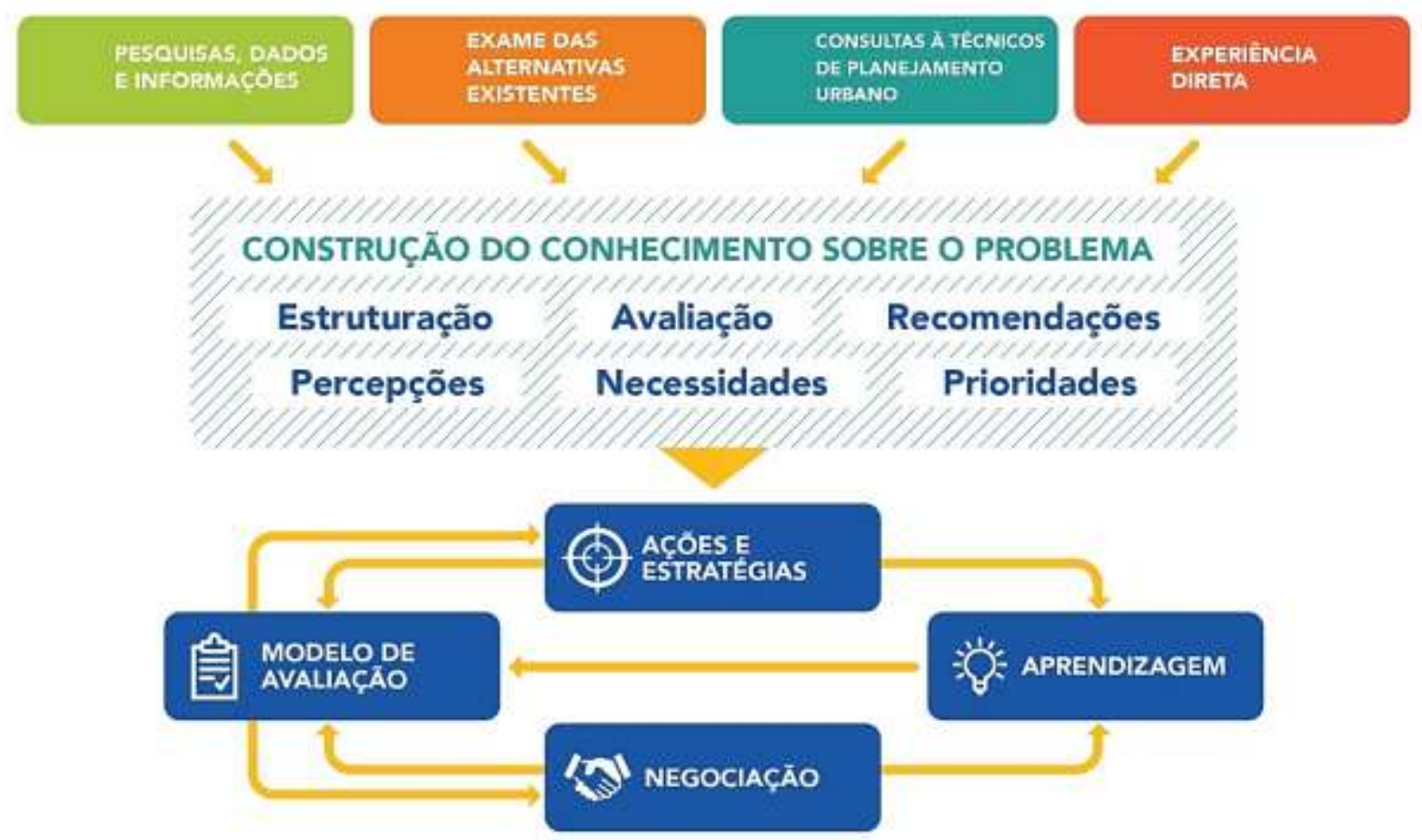

Fonte: Do autor (2019).

O aprendizado social é baseado no diálogo e na interação em constante processo de recriação e reinterpretação de informações, conceitos e significados, originados do aprendizado, para aprimorar práticas da sociedade civil e do poder público na gestão compartilhada (JACOBI et al., 2006). De forma analítica, o aprendizado é crescente com constante capacitação para perceber as relações entre as áreas e como um todo, enfatizando uma formação local/ global, 
seguindo com a consolidação institucional de canais abertos para a participação, numa perspectiva pluralista.

Conhecimento é gerado na estruturação de ideias, na avaliação de necessidades e na definição de prioridades, com uma estrutura correlacionada de elementos, exemplificados na figura 19.

A expressão dos significados em torno do contexto urbano e de suas intersecções, com uma abordagem participativa metodológica, pode estabelecer os níveis de compartilhamento das decisões e os tipos específicos de decisão que os atores podem tomar, conforme é apontado por Robbins (2001).Essa articulação de conhecimentos, ao interferir no processo de aprendizagem, contribui para o refinamento das percepções e promoção de uma ótica diferente sobre as representações. Também se alteram as visões sobre a relação dos indivíduos com suas condutas cotidianas, a promoção de instrumentos e estratégias, e como esses elementos afetam a qualidade de vida, conforme colocado por Jacobi et al. (2006), em relação a questões de saúde ambiental.

\subsection{O PROCESSO DELIBERATIVO E A PARTICIPAÇÃO POPULAR}

Fung e Cohen (2007) definem que na democracia deliberativa, as leis e as políticas resultam de processos nos quais os cidadãos defendem soluções para problemas de sua realidade em função de sua relevância. Por sua vez, a relevância de um problema é avaliada de acordo com razões às quais os cidadãos atribuem uma importância, e, portanto, eles discordarão a respeito da magnitude de cada problema. Nesse contexto, deliberação e participação não são necessariamente correlacionadas, segundo Ackerman e Fishkin (2002).

Já a participação e o poder de tomar decisão, ou seja, deliberar, podem se combinar. As deliberações participativas na atualidade configuram o processo em que as deliberações em questão procuram enfocar problemas mais específicos, em algum bairro, na alocação de recursos e em projetos e bairros de uma cidade. Convocar grupos de cidadãos para diagnosticar problemas, desenvolver soluções e deliberar sobre questões de interesse público local contribuem para a igualdade política, ao aumentar o papel da mobilização popular e da deliberação nas tomadas de decisão políticas, conforme Fung e Cohen (2007). Os autores ainda reforçam que um dos desafios para um equilíbrio do processo participativo e deliberativo é a construção de arranjos participativo-deliberativos que abordem problemas práticos. 
Nessa direção, Fung (2006) sugere um mecanismo para identificar ou selecionar os atores que participam diretamente em discussões ou decisões sobre assuntos: podem ser ordenados esquematicamente do mais exclusivo para o mais inclusivo. Este mecanismo de arranjo, proposto pelo autor, estabelece um desenho institucional de como os participantes podem efetivamente interagir em um local de discussão pública, ou de decisão, como é apresentado na figura 20.

Figura 20 - Espaços inclusivos e exclusivos de participação popular

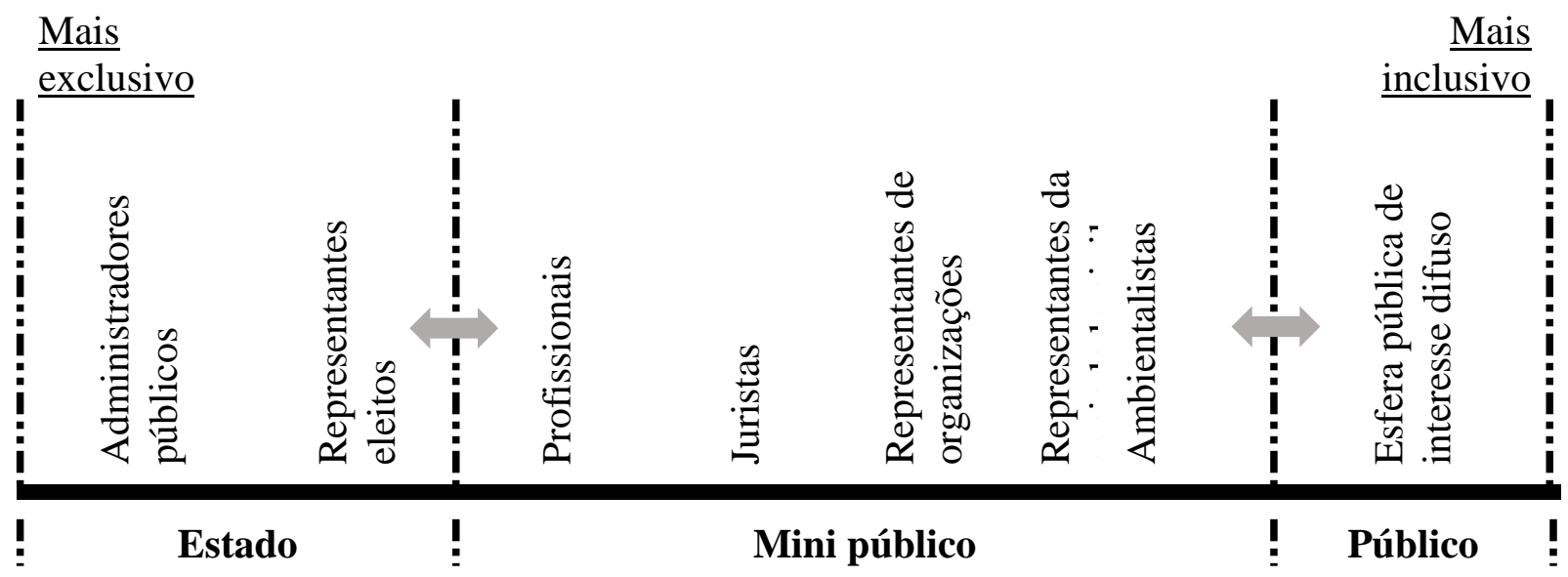

Fonte: Adaptado de Fung (2006).

Conforme mostrado na Figura 20, o grupo denominado pelo autor como "publico" abrange os espaços em que a sociedade civil, em geral estabelece cotidianamente suas discussões, já o "mini públicos” agrupa intencionalmente um grupo específico de pessoas para discutir ou decidir questões. Elas representam, na realidade, profissionais e minorias recrutadas por interesses particulares. Esses atores situam-se em uma posição de medição entre os representantes do Estado e os interesses públicos difusos. Em uma extremidade está o "Estado", que supostamente representa os interesses da população, a partir dos representantes eleitos, mas considera aspectos políticos da administração pública, que nem sempre representam a vontade dos cidadãos - é um espaço exclusivo para participação política, ou seja, nem todos são representados, e a abertura para as discussões depende da abertura de canais pelos administradores públicos.

A transição de um estágio a outro pode ser realizada pelos conselhos, pois são espaços públicos que possibilitam a representação de interesses públicos difusos em âmbito político são simultaneamente parte do Estado e do Público. Ao mesmo tempo, são distintos dos representantes da sociedade civil, pois sua estrutura é legalmente definida e institucionalizada, 
e atua de forma conjunta com o Estado para elaboração de políticas, como destaca Carneiro (2006). Nessa linha de raciocínio, a efetividade da participação dos atores da sociedade civil é associada ao poder de influência no aparato estatal e aos impactos das decisões.

Nesse contexto, Lavalle (2011, p.84) reforça a importância de novas instâncias de mediação entre representantes e representados, e, portanto, existem desafios metodológicos neste cenário, inclusive com a multiplicação de espaços que favoreçam a participação cidadã que auxiliem na definição de prioridades públicas.

\subsubsection{Consenso e engajamento}

Após as repetidas análises tecnocráticas de expertise e o crescimento concomitante de desconfiança pública, as abordagens deliberativas vêm ganhando espaço, no qual o público (e outros atores sociais) recebe um papel mais relevante na governança com a articulação do papel do engajamento público e a formação do consenso entre os agentes, conforme aponta Bucchi e Neresini (2008) e Guivant e Macnaghten (2011).

A participação pública pode ser definida como um conjunto diverso de situações, atividade e processo, sejam eles espontâneos ou não, estruturados e organizados, pelos quais os agentes se envolvem em processos decisórios e expõem suas percepções para a construção de uma agenda coletiva para formulação de políticas. Apesar de existir consenso acerca da importância de o engajamento público ser difundido para a participação popular, o fenômeno social da participação, em si, não é novo nem em teoria, nem na prática gerencial. Ademais, tanto o engajamento quanto a participação não são conceitos monolíticos, segundo Guivant e Macnaghten (Ibidem).

Joly e Kaufmann (2008) defendem a necessidade de um "engajamento de baixo para cima" e, ainda, identificam que as relações de consenso e engajamento, associadas a processos participativos, produzem uma variedade de formas concretas de ação, conforme os motivos inspiradores e as circunstâncias socioeconômicas dos agentes participantes. Os autores Joly e Kaufmann (2008) e Guivant e Macnaghten (2011) observam que, no mundo contemporâneo, as condições sociais têm aguçado identidades e contradições especialmente verdadeiras quando redes sociotécnicas já estão alinhadas por atores. Para o engajamento público ter um impacto maior na tomada de decisão, acentua-se a preocupação com as dimensões participativas, e os autores sugerem uma abordagem que alinhe modelos e ferramentas analíticas, com a reflexiva e corrente implementação da participação pública. 
Joly e Kaufmann (2008) e Motta (1981) mencionam que o engajamento público é uma questão crítica nos processos de participação e sugerem que estudiosos reflitam sobre a articulação entre o conhecimento que eles produzem e as políticas públicas em curso. Segundo os atores, a sociedade contemporânea tem experimentado, em diversas instituições sociais, uma democratização cada vez mais acentuada. Este é um bom ponto, mas ainda é uma resposta parcial na construção de um quadro de análise mais complexo da virada participativa.

Ottinger (2010) indica os fatores que moldam a capacidade da ciência cidadã de verdadeiramente influenciar os responsáveis pela tomada de decisão. Ele argumenta que a efetividade da ciência cidadã ${ }^{45}$ é significativamente influenciada por padrões e práticas padronizadas. Assumir a responsabilidade no processo de tomada de decisão associada às relações sociais, diárias e cotidianas, por sua vez, reverbera formas de organização de instituições sociais que, por sua vez, geram pressões. Esses elementos, quando organizados, solidificam as relações.

Nesse diapasão, as relações constituídas para apoiar processos decisórios seguem com foco no cidadão partem de premissas como: (i) os cidadãos podem atuar como contribuintes, colaboradores ou líderes de projetos e assumir papéis significativos no projeto; (ii) tanto os decisores quanto os cidadãos se beneficiam de sua participação nos projetos; (iii) os cidadãos devem receber feedback dos projetos; (iv) dados e metadados resultantes de projetos devem ser tornados públicos e, sempre que possível, publicados num formato de acesso livre. Esse modelo pode gerar benefícios que incluem a publicação de resultados da investigação, oportunidades de aprendizagem, prazer pessoal, benefícios sociais e satisfação. Além disso, seus resultados podem fomentar respostas para questões com relevância local, nacional ou internacional e, assim, influenciar políticas.

Bickerstaff et al. (2010), por sua vez, identificaram diferentes modelos de engajar o público em questões científicas, não apenas em termos de processos aplicados, mas também em tomadas de decisão em diversos contextos de problemas e enquadramentos de experiências. As decisões são realizadas em situações de conflito que resultam da interação entre possibilidades e aspirações. As frustrações das relações de aspiração e identificação de possibilidades podem gerar necessidades de adaptação dos modelos ou dos processos participativos.

\footnotetext{
${ }^{45}$ A ciência cidadã é um conceito flexível que pode ser adaptado e aplicado a diversas situações e disciplinas. Foi desenvolvida pelo grupo de trabalho 'Sharing best practice and building capacity' da Associação Europeia de Ciência Cidadã. <https://ecsa.citizen-science.net/sites/default/files/ecsa_ten_principles_of_cs_portuguese.pdf> Acesso em: 12 fev. 2017.
} 
A institucionalização do diálogo, em outras palavras, como o diálogo é (ou não) praticado, depende dos modos, de acordo com padrões sociais existentes, que reproduzem a cultura de organização dos espaços participativos. Para as teorias que admitem que o conflito tem origem organizacional e individual, a participação é normalmente considerada uma forma eficaz de solução, acomodação ou equilíbrio entre grupos divergentes. Nas configurações organizacionais e institucionais que permitem a expressão de tipos particulares de percepções, e o impacto correspondente nas práticas, políticas e procedimentos de tomada de decisão, verifica-se uma contextualização mais ampla das questões.

Motta (1981) aponta que, com relação à corrente de pensamento que presume a existência de conflito de interesses reais, a participação é vista de duas maneiras. Primeiro, é entendida como uma simples acomodação provisória de um conflito permanente entre interesses inconciliáveis, em que a participação não muda as relações de poder. Em segundo lugar, vê-se como uma alternativa única ao unilateralismo do processo decisório, onde há interesses permanentemente divergentes.

Assim, a participação constitui uma forma dinâmica de restaurar o equilíbrio de poder e atenuar as assimetrias dos agentes de tal forma a culminar na solução de conflitos reais. Nesse sentido, a participação, aos poucos, altera relações de poder, pois seus espaços heterogêneos, e sua própria aplicação, mudam as dimensões e a capacidade de escolha coletiva. Macnaghten e Chilvers $(2012,2010)$ fornecem uma crítica similar. Baseados na análise da relação entre preocupações do público - ou seja a população em geral -, articuladas com iniciativas de engajamento público, e questões de governança, eles enfatizam a importância de mapear diálogos individuais para examinar preocupações de governança implícitas que orientam respostas do público.

Decisores, técnicos e cidadãos precisam, de forma colaborativa, criar condições que lhes deem resultados satisfatórios. Dessa forma, as chamadas questões "de baixo para cima", ou antecipatórias, a respeito das propostas, também são importantes em situações de engajamento mais imediatamente associadas com domínios "de cima para baixo" ou "de governança de riscos", conforme Felt e Wynne (2007) e Wildson e Willi (2004).

Além disso, os autores argumentam que responder a questões de confiança e preocupações de governança levantadas pelo público não é simplesmente uma questão de comunicar melhor ou de proporcionar maior envolvimento. Isso requer uma apreciação mais ampla do sistema de governança, do qual o diálogo público constitui apenas uma parte, incluindo a diversidade de quais valores públicos podem moldar a técnica, assim como modos 
de análise detalhada, transparência e accountability pública. É de interesse, portanto, de todas as partes, não se oporem e colaborarem para atingir os objetivos. Assim, a autoridade, a coordenação e a direção são exercidas em nome do interesse geral.

Nesse sentido, as respostas da governança devem estar em sintonia com as preocupações do público, e modo que, um melhor entendimento dos processos que mediam relações institucionais de participação pode reforçar formas mais reflexivas, relacionais e transformadoras de aprendizado institucional colaborativo e participativo. $\mathrm{O}$ argumento sobre cooperação tende a ser enfatizado em várias instâncias, e há de se valorizar o aspecto de interdependência dos interesses coletivos e da cooperação no relacionamento do grupo com o individual, e do individual com o grupo.

Nesse cenário, segundo Simione e Ckagnazaroff (2017), o processo de participação, insere o cidadão como um ator indispensável na tomada de decisões acerca dos assuntos que são considerados de seu interesse, e permite uma maior interdependência e articulação entre os diferentes atores sociais. No engajamento público, há a pressuposição da importância de aderir ao conhecimento e à percepção de questões inerentes aos atores.

Autores como Braun e Kropp (2010) apontam na direção de respostas institucionais, ou seja, das instituições, à pluralidade existente de pontos de vista e ajustes mais sofisticados de incerteza em diversas áreas. Os autores explicam que o objetivo é explorar diferentes formas de governança que estão emergindo em áreas como a saúde pública. Responsáveis políticos pela tomada de decisões, consequentemente, sentem que não podem seguramente confiar na autoridade da ciência como um meio efetivo de encerramento de questões e debates políticos.

As formas de participação e agregação de interesses são desenvolvidas não só porque os objetivos acima mencionados necessitam de definições mais aprimoradas e estruturas de poder para influenciar as decisões, mas também porque essas decisões são tomadas fora do contexto individual ou particular, escapando-lhes a possibilidade de contato pessoal. Conforme Simione e Ckagnazaroff (2017), instâncias de intervenção que vinculam a ação governamental aos cidadãos, por meio de relacionamentos nos espaços deliberativos, servem para envolver cidadãos, movimentos sociais e outros grupos de interesse com o setor público.

A ênfase na abordagem participativa poderia ser entendida em um nível mais geral como formadora de uma resposta institucional para problematizações das formas de interação entre políticos e sociedade. O fato de que governos e instituições experimentaram formas de 
engajamento, envolvimento e participação pública, pode ser entendido como uma resposta à percepção de que as relações existentes entre sociedade e políticas se tornaram problemáticas.

Essas intervenções se estruturam em um meio ou instrumento de adaptação existente, de forma natural, em um ambiente conflituoso. Assim, o elemento que pode garantir maior legitimidade, na origem dos processos participativos e, principalmente, reivindicatórios, é a percepção que cada indivíduo tem do seu grau de contribuição - isto é, sua percepção de suas contribuições e de seu grau de retribuição.

Outra questão envolve a concepção de que os grupos são representados por uma pluralidade de interesses de indivíduos, e até de outros grupos articulados e agregados interna e externamente. Esses interesses prevalecem com maior ou menor intensidade conforme a distribuição de recursos, as relações individuais e coletivas de problemas e as consequentes relações de poder atribuídas ou adquiridas pelos diversos grupos e indivíduos.

Ainda, a consciência individual de cada ator desempenha um fator importante em sua relação com grupos, embora não haja, necessariamente, uma relação entre tal característica e a propensão a participar. As condições sociais externas, a estrutura participativa aplicada e os papéis desempenhados pelos diversos atores sociais determinam a natureza da cooperação, do conflito e do consenso.

As percepções ideológicas de cada ator, tanto quanto suas demandas particulares e coletivas, no cumprimento de seu papel social, refletem as convergências possíveis e as divergências inevitáveis. Portanto, as formas de participação constituem uma resposta organizacional para administrar essas convergências e divergências e garantir a sobrevivência, o progresso e a adaptação da construção coletiva de estratégias e ações. Essa resposta, por sua vez, determina o nível (qualitativo e quantitativo) do engajamento.

\subsection{AVALIAÇÃO dO PROCESSO PARTICIPATIVO DE REVISÃO DO PDE DE SÃO PAULO DE 2014}

Para avaliar a eficácia das abordagens participativas no contexto de planejamento urbano, foi selecionado o caso do Plano Diretor Estratégico do Município de São Paulo. O processo de revisão dos instrumentos de planejamento e gestão urbanos do município de São Paulo se iniciou em janeiro de 2013 e se estendeu até o final de 2016. Pode ser organizado em três grandes etapas: a primeira, com foco na Lei Municipal $n^{\circ} 13.430$, que estabelece o Plano Diretor Estratégico, ocorrida de fevereiro a setembro de 2014; a segunda, que revisou a Lei de 
Parcelamento, Uso e Ocupação do Solo e Planos Regionais Estratégicos, de agosto de 2014 até março de 2016, e os Planos de Bairro, em fase de elaboração; e a terceira etapa, que corresponde à revisão do Código de Obras, também em fase de elaboração, e leis complementares.

A revisão ocorreu após onze anos de vigência do anterior Plano Diretor Estratégico (instituído pela Lei Municipal n. 13.430, de 13 de setembro de 2002). Nessa revisão, é relevante o interesse de diversos setores da sociedade: salienta-se que a realização desse processo com base na participação social e popular não é uma opção, que pode ou não ser adotada como diretriz dos trabalhos, pois trata-se de uma obrigação determinada pelo Estatuto da Cidade,

O processo de revisão do Plano Diretor Estratégico - PDE (Etapa 1) foi realizado segundo quatro fases de desenvolvimento: 1a. Fase de Avaliação Participativa do PDE de 2002 e de sua aplicação; 2a. Fase de Recepção de Propostas; 3a. Fase Interna de Sistematização das contribuições, e; 4a. Fase de Devolutivas à sociedade e composição da Minuta do Projeto de Lei do novo Plano Diretor. Este trabalho analisará atividades participativas inerentes à primeira etapa, no que tange à fase 1 de elaboração do referido Plano cujo foco foi o compartilhamento das avaliações da sociedade e de avaliações técnicas realizadas pela prefeitura.

A revisão do Plano Diretor Estratégico do Município de São Paulo foi realizada em quatro fases:

a) Avaliação do plano diretor até então vigente no município;

b) Recepção de propostas dos cidadãos;

c) Sistematização das propostas e elaboração do Projeto de Lei;

d) Devolução das propostas recebidas e composição final do Projeto de Lei, consolidando o Plano Diretor Estratégico.

A etapa 1, objeto de estudo, contou com atividades informativas e de reflexão, realizadas coletivamente (de forma comunitária, por temática ou envolvendo um determinado segmento social), sobre aspectos da política urbana regulados pelo PDE. Significou uma fase de "alinhamento" de informações, com a identificação e discussão dos principais problemas diagnosticados tanto nos estudos técnicos, quanto pela experiência dos participantes.

Vale salientar que dentro do parâmetro legal construído, não há obrigação do município para incorporar as propostas do cidadão, e, ademais, dentro do processo político, o Plano Diretor passa pela revisão e pela aprovação do legislativo e, por último, a revisão e aprovação do chefe do executivo. 
Como recorte experimental de análise, foram consideradas as atividades participativas inerentes à fase de avaliação do Plano Diretor de 2002 e de recepção de proposta para o PDE 2014. O foco dessas atividades foi o compartilhamento das avaliações da sociedade e de avaliações técnicas realizadas pela Prefeitura, o que foi realizado simultaneamente com a recepção de propostas enviadas pela população.

Resumidamente, o processo de recepção das propostas e da análise do Plano Diretor de 2002 contou com atividades de compartilhamento de informações, experiências, resultados e, por fim, reflexões. Ele seguiu um arranjo inerente às audiências públicas, realizadas de forma comunitária em determinadas regiões administrativas da cidade, ou em torno de alguma temática, algum aspecto urbano ou social que pudesse ser regulado pelo Plano Diretor Estratégico. Por exemplo, objetivos da revisão e a cidade que queremos, uso e ocupação do solo, instrumentos de política urbana, habitação, meio ambiente, mobilidade urbana e, por último, investimentos prioritários, planos regionais e planos de bairro.

As análises das estratégias de participação mostraram, superficialmente, uma preocupação do governo municipal em disponibilizar diferentes formatos de consulta pública que permitissem, ao mesmo tempo, a participação mais ampla da sociedade e a criação de espaços para debate, nos quais os cidadãos pudessem conhecer e reconhecer posicionamentos, interesses e propostas defendidos pelos diversos segmentos e/ou grupos sociais interessados em influenciar na composição da nova lei.

Na elaboração do PDE de São Paulo, no escopo de análise do presente trabalho, foram identificadas duas grandes estratégias, articuladas e complementares, de envolvimento dos cidadãos: i) o desenvolvimento de atividades participativas presenciais, e; ii) a construção da Plataforma Participativa Digital. Assim os técnicos da prefeitura do município de São, a partir da secretaria de desenvolvimento urbano deliberou pela realização da primeira sessão aberta à comunidade em janeiro de 2013. A dinâmica das atividades propostas se iniciou com a apresentação de estudos realizados pela Secretaria Municipal de Desenvolvimento Urbano (SMDU), as dinâmicas ocorreram em todas as cidade, em locais públicos definidos e agendados pela municipalidade, complementada por dinâmicas que buscavam estimular os as pessoas que participaram da audiência a formular perguntas, esclarecer dúvidas e expressar sua forma de ver o assunto.

O primeiro instrumento adotado foram as Fichas, as fichas consistiram em papeletas que permitiam que qualquer um escrevesse a sua demanda sobre a cidade, que possibilitavam aos participantes a elaboração de sua contribuição individual. Para organizar as pessoas, os técnicos 
agruparam pessoas que representassem um movimento organizado em grupos. Nas atividades em Grupos as questões temáticas eram conduzidas por um técnico da Prefeitura e os participantes apresentavam suas contribuições aos participantes do grupo que, em conjunto, decidiam e votavam nas melhores contribuições.

Os resultados desse processo foram apresentados nas Plenárias, que na realidade foram um espaço para discussão pública e apresentação das demandas pelas pessoas em um palco, nas quais alguns participantes, previamente inscritos, também tinham direito à fala, conforme os relatórios publicados pelo município de São Paulo.

Nessa fase, participaram cerca de $1.804^{46}$ pessoas (dentre as quais, havia lideranças comunitárias, lideranças de movimentos sociais, representantes dos segmentos de universidades, categorias profissionais, trabalhadores representados por suas entidades sindicais, ONGs empresários e cidadãos em geral). Foram recebidas 1.846 contribuições, em seis audiências públicas realizadas em diferentes regiões da cidade.

Essa experiência gerou um alinhamento de informações sobre os problemas diagnosticados pelos planejadores do Estado, os quais foram correlacionados às experiências dos participantes, conforme relatório da Prefeitura do Município de São Paulo, realizado em parceria com o Centro de Estudos da Metrópole (CEM, 2014a, 2014b). Pela primeira vez em São Paulo, foi disponibilizada uma plataforma participativa digital, via internet, onde, nessa fase, as contribuições da população poderiam ser recebidas pelo governo municipal. Nas atividades presenciais, os participantes recebiam um volume impresso da Revisão Participativa e de "Informações Básicas para os Participantes", com um descritivo das atividades que ocorreriam naquele dia. O que se notou, nas atividades presencias, foi, de partida, a mobilização de movimentos organizados da sociedade civil, principalmente dos movimentos ligados à moradia popular.

Em linhas gerais, as atividades presenciais se iniciaram com uma primeira etapa de apresentação dos estudos técnicos realizado pela Prefeitura, constituindo uma etapa informativa. Esse formato era análogo às audiências públicas, e nele as discussões eram estimuladas, para que fossem esclarecidas dúvidas e para que os participantes pudessem expressar sua interpretação e sua percepção sobre o assunto. Uma segunda etapa, ou seja, a recepção de propostas dos cidadãos, seguiu um formato em que, por um lado, as discussões eram estimuladas, e determinadas opiniões das pessoas eram aceitas. Por outro lado, como o

\footnotetext{
${ }^{46}$ Dados obtidos pelo relatório fornecido pela Prefeitura do Município de São Paulo em parceria com o Centro de Estudos da Metrópole (CEM, 2014a, 2014b).
} 
processo foi conduzido por técnicos da Prefeitura, certas opiniões eram aceitas, mas se rejeitavam determinadas colocações.

A implantação das estratégias de participação descritas mostrou uma preocupação do governo municipal em disponibilizar diferentes formatos de consulta pública, que permitissem, ao mesmo tempo, a participação mais ampla da sociedade, assim como a criação de espaços para debate, nos quais os cidadãos pudessem conhecer e reconhecer os posicionamentos, interesses e propostas defendidas pelos diversos segmentos e/ou grupos sociais interessados em influenciar na composição da nova lei.

Assim, a sistematização das propostas efetuadas pelo cidadão e a devolução dos resultados das análises consolidaram um nível de informação em que o governo apenas transmitiu resultados à população. Desse modo, essa etapa não pode ser considerada participativa, seja pela avaliação teórica de Arnstein (1969) ou pela de Choguill (1996).

Nas audiências presenciais, um instrumento interessante adotado foram fichas escritas, as quais possibilitaram aos participantes a elaboração de sua contribuição individual. Naquela oportunidade, o governo propôs uma divisão dos participantes em grupos de aproximadamente 50 pessoas, apoiados por um moderador e um relator, representantes do governo. Nessa atividade, as discussões eram conduzidas pelo representante do governo.

Este formato é descrito teoricamente por Choguill (1996) como uma etapa de diplomacia, em que há uma condução para a conciliação de questões simples e, que para outras questões, desvia-se de respostas para problemas urbanos complexos inerentes a cada indivíduo, sendo chamada, pelo autor, de dissimulação. Os participantes apresentavam suas contribuições uns aos outros, e, por fim, em conjunto, votavam nas melhores contribuições, possivelmente em função das características de cada grupo.

Os resultados variaram, e algumas questões foram desprezadas grupo a grupo. Por exemplo, em grupos com forte participação de movimentos de moradia social, demandas inerentes a espaços públicos e meio ambiente foram negligenciadas em favor de demandas habitacionais. Outrora, em grupos com uma participação mais heterogênea, inúmeras demandas difusas foram pautadas, onde talvez a contagem dos votos não representasse de fato a relevância de determinada demanda ou a magnitude do problema. Assim como as prioridades, as demandas escolhidas com o voto simplesmente favoreciam as contribuições daqueles que possuíam melhor poder de articulação. Cabe a observação de que não foram anotadas 
informações sobre os participantes, o que dificulta diagnosticar cada grupo e analisar se há, ou não, correlações das contribuições dos grupos com a diversidade ou coesão deles.

Em um terceiro momento, os resultados desse processo (separação em grupos) foram apresentados em audiência, para todos os participantes. Eventualmente, alguns participantes, previamente inscritos, também tinham direito à fala. Cabe observar que em boa parte dos grupos investigados, as pessoas naturalmente se organizavam e elegiam, informalmente, um porta-voz. Outro fato relevante é que a forma de condução dos grupos pelos representantes do governo variava: alguns permitiam a livre discussão, outros conduziam as questões discutidas em torno de duas ou três temáticas norteadoras.

Em todos os grupos foram fornecidas fichas coloridas inerentes a determinadas temáticas, tais como habitação, equipamentos sociais, meio ambiente, mobilidade e transporte, a fim de facilitar o agrupamento das contribuições. Estas foram sistematizadas pelo governo em arquivo eletrônico disponível na internet, intitulado "Balanço Quantitativo das Contribuições"47. Um terço dos participantes respondeu à ficha de avaliação das atividades participativas classificando-a, majoritariamente, como "bom" e "ótimo", com relação tanto à dinâmica realizada, quanto à estrutura disponibilizada para as atividades, conforme CEM (2014a, 2014b).

Os materiais consultados abrangem documentos públicos disponibilizados pela Prefeitura do Município de São Paulo, em seu site institucional ${ }^{48}$, e consistiram, basicamente, em uma planilha elaborada em Microsoft Excel, intitulada "Banco de Contribuições da $1^{\text {a }}$ fase do PDE", e no "Caderno Versão 1", publicação na qual é descrito todo o processo participativo de desenvolvimento do PDE da cidade de São Paulo. Foram quantificados e caracterizados os seguintes dados referentes à primeira fase do processo do PDE de São Paulo: número de participantes do processo (enquanto forma de participação e representação por grupos de interesse), tipos de dinâmicas de participação, número de contribuições total e por dinâmica, por tema e por participante, e os resultados apresentados de forma gráfica e subsequentemente analisados.

As oficinas realizadas na revisão do Plano Diretor Estratégico de São Paulo, em formato de audiência pública, dividiram-se em seis eixos temáticos:

\footnotetext{
${ }^{47}$ Arquivos de Sistematização das Contribuições disponíveis no site: <http://gestaourbana.prefeitura.sp.gov.br/arquivos-pdebiblio/>. Acesso em 03 jul. 2017.

${ }^{48}$ Informações disponibilizadas, desde abril de 2013, pela Secretaria Municipal de Desenvolvimento Urbano (SMDU), pelo portal Gestão Urbana SP, no site: <http://gestaourbana.prefeitura.sp.gov.br/arquivos-pde-biblio/>. Acesso em 03 jul. 2017.
} 

a) Habitação;
b) Instrumentos Urbanísticos;
c) Investimentos Prioritários;
d) Meio Ambiente;
e) Mobilidade;
f) Uso e Ocupação do Solo.

A análise do processo aplicado em São Paulo indicou o forte poder mobilizador da temática habitação, cuja oficina temática recebeu 608 contribuições, cerca de $33 \%$ do total, e também concentrou boa parte dos participantes, aproximadamente $30 \%$ do total. Ou seja, apenas 01 (uma) das 06 (seis) oficinas realizadas mobilizou cerca de 1/3 (um terço) das pessoas e 1/3 (um terço) das contribuições, conforme indicado na figura 21.

Figura 21 - Distribuição das contribuições em cada oficina

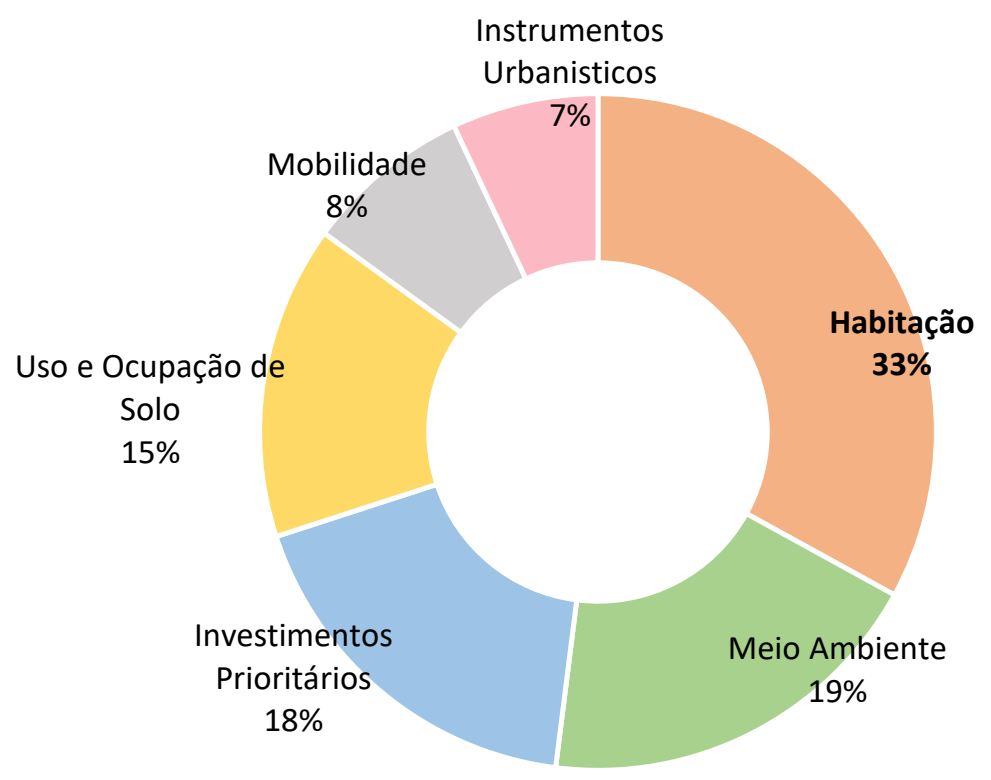

Fonte: Do autor (2019), baseado em São Paulo $(2014)^{49}$.

\footnotetext{
${ }^{49}$ BALANCO QUANTITATIVO DAS CONTRIBUIÇÕES. SÃO PAULO. Secretaria Municipal de Desenvolvimento Urbano. Gestão Urbana - Relatório do Plano diretor Estratégico. São Paulo (2014). Disponível em: <http://gestaourbana.prefeitura.sp.gov.br/arquivos/PDE_lei_final_aprovada/APRESENTACAO/SMDU_PDE_140731_san cao_FINAL.pdf). Acesso em: 09 dez. 2017.
} 
Cabe ressaltar que, embora as audiências tenham sido focadas em eixos temáticos norteadores, eram permitidas a discussão e as contribuições acerca de outros temas.

É latente que este resultado decorre da massiva participação de diversos movimentos organizados da sociedade civil, formais ou informais, ligados à moradia popular. Tal fato aponta sua predominância sobre os demais temas. Em segundo lugar, ficaram as contribuições da oficina "Meio Ambiente", que contou com 345 contribuições, à frente, portanto, de oficinas como "Investimentos Prioritários", "Uso e Ocupação de Solo" e "Mobilidade". Isso apontou, naquele momento, para a priorização de questões relacionadas a habitação e meio ambiente, em relação aos demais temas.

Observa-se, também, que a audiência que versou sobre as diretrizes de uso e ocupação de solo contou com $15 \%$ dos participantes e gerou $15 \%$ das contribuições. Este dado chama à atenção, pois as diretrizes de uso e ocupação de solo são as que de fato consolidam mecanismos para operacionalizar o atendimento a diversas demandas sociais. Contudo, as pessoas, in lato sensu, não geram contribuições dessa natureza, talvez por sua insegurança em contribuir com diretrizes consideradas mais técnicas.

Cabe salientar que os temas discutidos podem ser difusos, ou seja, a participação na audiência de habitação não significa que todas as contribuições foram sobre habitação. No entanto, é possível afirmar que este foi o que mobilizou maior número de frequentadores.

Agruparam-se as contribuições recebidas em todas as audiências em categorias, tais como: (i) equipamentos sociais; (ii) financiamento e investimentos; (iii) gestão democrática; (iv) habitação; (v) instrumentos urbanísticos; (vi) meio ambiente; (vii) metodologia; (viii) transporte e mobilidade; e (ix) uso e ocupação de solo. Nota-se que, embora a prefeitura tenha organizado seis oficinas temáticas, as contribuições foram sintetizadas em nove temas. Percebese, assim, que existiram mais grupos de contribuições do que temas organizados em oficinas, sugerindo-se a necessidade de se ampliar os grupos e temas dentro de futuros arranjos participativos propostos em planejamento urbano.

Ao analisar as contribuições por tema, conforme o gráfico da figura 22 a seguir, ratificase o tema "Habitação" como um catalisador de envolvimento, pois quando analisadas as 1.846 contribuições, em todas as audiências, independentemente do tema, considerações sobre habitação dominaram pouco mais de $31 \%$ do total das colocações realizadas pelos participantes.

Contudo, embora a oficina temática de "Meio Ambiente" tenha sido a segunda que mais recebeu contribuições, a mesma ficou em terceiro plano quanto ao total de contribuições 
especificas ao tema de meio ambiente, com $14 \%$ do total, sendo superada pelas contribuições ligadas a "Investimentos Prioritários", com 16\% do total. Ademais, chama à atenção que o tema ligado a "Equipamentos Sociais" seja o que menos reuniu contribuições, com apenas cerca de $1 \%$, conforme figura 22 .

Figura 22 - Distribuição das contribuições por tema

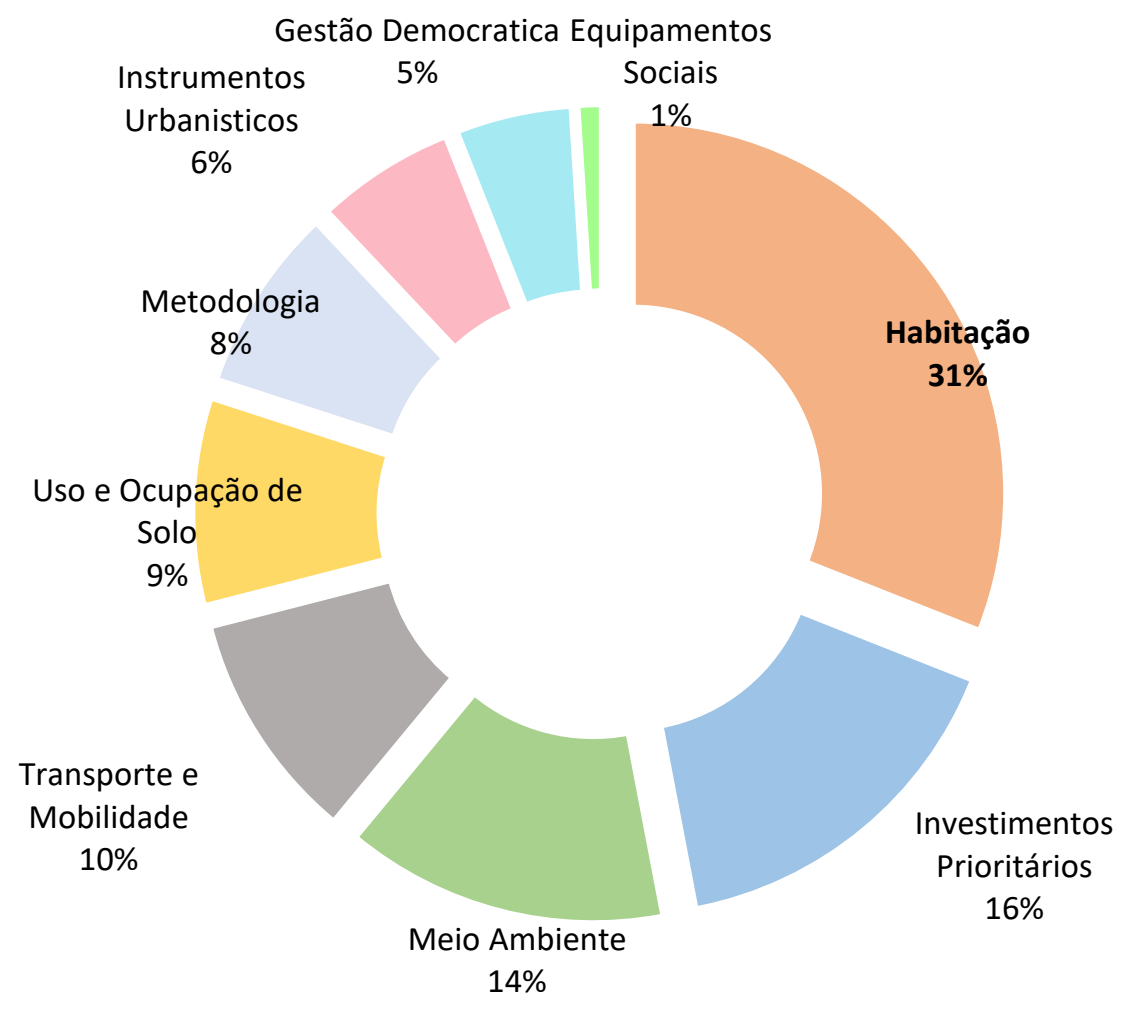

Fonte: Do autor (2019), baseado em São Paulo $(2014)^{50}$.

Choguill (1996) apontou que, em países em desenvolvimento, a alocação de recursos para demandas básicas é um fator relevante para a população. Isso foi ratificado ao se verificar que, após o tema de habitação, a principal preocupação refletida nas contribuições foi acerca de financiamentos e investimentos, demonstrada no item "Investimentos Prioritários".

No entanto, no caso avaliado em São Paulo, as estratégias adotadas com a finalidade de mobilização das pessoas para participar da revisão do Plano Diretor foram ineficazes, pois em uma cidade com 12 milhões de habitantes, participou não mais do que $0,1 \%$ da população. $\mathrm{Na}$ realidade brasileira, a imposição constitucional e normativa para concepção de Planos Diretores Participativos, em tese, articularia a influência da população ao desenvolvimento das cidades. Contudo, o que se percebe na prática é que, embora se tenha avançado, ainda existem inúmeras

\footnotetext{
${ }^{50}$ BALANCO QUANTITATIVO DAS CONTRIBUIÇÕES. SÃO PAULO. Secretaria Municipal de Desenvolvimento Urbano. Gestão Urbana - Relatório do Plano Estratégico. São Paulo (2014). Disponível em: <http://gestaourbana.prefeitura.sp.gov.br/arquivos/PDE_lei_final_aprovada/APRESENTACAO/SMDU_PDE_140731_san cao_FINAL.pdf)>. Acesso em: 9 dez. 2017.
} 
lacunas no processo participativo que precisam sem preenchidas, inclusive a magnitude e a abrangência do que se chama de participação em planejamento urbano.

Portanto, o direito, as ciências sociais, as ciências políticas e o planejamento urbano, são em si, complementares e elementos de um único objeto de expectativa resultante de um processo participativo. São indissociáveis e conforme Bucci (2008), o desafio é como sistematizar as análises extraindo conclusões efetivas do processo decisório e suas componentes jurídicas.

O processo participativo ideal e almejado deve ocorrer com parceria ou controle cidadão, de forma plural, para que a tomada de decisão seja fortemente influenciada pela percepção e pela opinião das comunidades e, assim, os planos delineados possam, em princípio, responder às demandas da população com eficiência, efetividade e eficácia

Arnstein (1969) salienta que em processos participativos há uma tendência de entrada assimétrica de certos grupos minoritários fortemente organizados nos processos de planejamento urbano conduzidos pelo governo. E isso é percebido no caso paulistano, quando há dominância das contribuições geradas por grupos, principalmente perceber que as demandas quanto à habitação foram aquelas que, representativamente, foram as dominantes.

As contribuições, embora ainda tímidas por gestão democrática com $5 \%$ das contribuições, e pelos achados na literatura apontam que a avaliação positiva de um processo participativo requer um avanço nos níveis de participação. Tão somente fornecer informações já não é o bastante. A necessidade de receber respostas do que efetivamente foi realizado com as contribuições fornecidas emerge, demonstrando que há um desejo de avanço dos níveis de participação.

\subsubsection{Análise de Resultados do Processo de Revisão do PDE de São Paulo}

A revisão bibliográfica permitiu analisar os meandros associados ao processo decisório participativo e algumas características relevantes de sua aplicação no desenvolvimento de projetos urbanos. Desse modo, a participação popular é uma ferramenta que possibilita aproximação entre a sociedade civil e a esfera pública. A criação de novos canais e mecanismos capazes de desenvolver esse diálogo e cooperação fará com que a própria comunidade se torne agente ativo e corresponsável pelas decisões e ações realizadas. Assim, para um desenvolvimento sustentável das cidades, torna-se imprescindível a participação popular. A 
participação é multilateral e versátil, permite a identificação das necessidades locais, envolve organizações públicas e privadas e concilia os interesses da comunidade.

Não se abstém a dificuldade de formação de consenso, contudo o engajamento da sociedade fortalece a identidade comunitária. Quando as decisões são partilhadas entre a sociedade e o poder público, estreitam-se as relações de confiança em um processo contínuo vinculado a aprendizagem, escuta, troca de informações e experiências e estímulo às inovações coletivas. Entretanto, ainda é relevante avaliar a percepção das pessoas acerca desses processos participativos e a identificação de requisitos que favoreçam o engajamento delas nesses processos. Tal trabalho se faz necessário para que seja possível construir uma situação inicial de diagnóstico, com o objetivo de identificar, quantificar e analisar os principais perfis de participação popular em processos decisórios, envolvendo o desenvolvimento e a implantação de projetos urbanos.

A imposição constitucional e normativa para concepção de Planos Diretores Participativos, em tese, articula a influência da população na construção das cidades. Com isso, a classificação sobre o processo de construção do PDE como sendo de "Informação ou Consulta", mostra que, embora tenhamos avançado, estamos aquém do almejado para o processo, que deve ocorrer segundo uma participação plural e determinante para a tomada de decisão em comunidades.

As ferramentas virtuais podem contribuir para este avanço, mas, com elas, a discussão e o debate são pormenorizados, valorando as percepções individuais. Isto, por sua vez, gera um risco potencial para o envolvimento coletivo e a aprendizagem comunitária, por meio dos quais se discutem as diversidades e se valida o consenso.

Embora haja esforços para promover a transparência, os processos participativos são geralmente vistos como sucessivas esferas de consulta, enquanto na prática, verificou-se que a voz dos interessados pode não ser ouvida e incorporada de fato nas decisões. Neste caso, é difícil considerar que o processo promoveu o empoderamento, o que se nota no caso paulistano é que apenas um pequeno grupo que tem coesão, e organização consolidada, será representado.

Neste contexto, o gestor público ao estabelecer canais de participação popular precisa implantar estratégias que permitam que a participação popular evolua na escada de participação, de forma que o processo estabelecido, possa de fato, ser qualificado como participativo com mecanismos que favoreçam as deliberações nas decisões com apoio popular. 
A pesquisa se restringe às análises do município de São Saulo, objetivamente a política urbana. Considerando que o município de São Paulo é o maior do Brasil, por um lado mais heterogêneo e por outro com inúmeras questões sociais que são motivadas pela política urbana, os esforços governamentais ainda não são capazes de criar um espaço participativo que de fato considere importante a participação social. Outros contextos participativos, em outras cidades, devem ser investigados para que se possa verificar se os achados neste trabalho são específicos da realidade paulistana, ou se é algo sistêmico da realidade política brasileira.

Ainda assim, a reflexão que se propõem é que uma redução na amplitude da política nacional de participação social pode asseverar negativamente a participação popular, uma vez que reduz os mecanismos legalmente institucionalizados de participação popular, excluindo, por exemplo, a participação pela internet que é uma realidade na vida das pessoas na atualidade.

\subsection{APLICAÇÃO DE QUESTIONÁRIOS EM AREA URBANA SELECIONADA}

Também foram aplicados questionários e entrevistas diretas para consulta à população em uma área objeto de estudo - tanto a população residente, quanto a empregada e a de passagem, cujos resultados foram sistematizados. As entrevistas foram realizadas entre os dias seis de abril e quatro de maio de 2017, com o propósito de diagnosticar os condicionantes para que a participação ocorra efetivamente de modo a contribuir para o planejamento urbano.

Foi selecionada a abrangência de uma divisão administrativa do município de São Paulo, a região delimitada pela Subprefeitura da Mooca, como estudo de caso, para aplicação das entrevistas, justifica-se pela sua localização lindeira ao centro do município e por reunir características simultâneas de uma região com infraestrutura já consolidada, porém em processo de transformação do uso e ocupação do solo. Nos últimos anos, a região recebeu inúmeros investimentos em empreendimentos verticalizados, sobretudo para uso residencial, mas ainda possui diversos terrenos e áreas industriais ociosos, com potencial de ocupação. Há uma miscelânea de ocupações horizontais atendidas por comércio e serviços de abrangência e âmbito local. Além disso, há sobreposição censitária dos dados secundários oficiais, permitindo uma análise dos dados sem extrapolação ou correção específica, e possui, nesse setor, pouco mais do que 340 mil habitantes.

Os resultados apresentados caracterizando a participação popular no processo de revisão do PDE do município de São Paulo, não permitiu avaliar se houve, ou há, o engajamento da sociedade. Quando as decisões são partilhadas entre a sociedade e o poder público, as relações 
de confiança se estreitam em um processo continuo vinculado à aprendizagem, escuta, troca de informações e experiências, bem como estímulo às inovações coletivas.

Portanto é relevante avaliar a percepção das pessoas acerca destes processos participativos e a identificação de requisitos que favoreçam o engajamento das pessoas nestes processos. Tal trabalho se faz necessário para que seja possível construir uma situação inicial de diagnóstico para identificar, quantificar e analisar os principais perfis de participação popular em processos decisórios envolvendo o desenvolvimento e implantação de projetos urbanos.

De forma exploratória a partir da aplicação de questionários para uma parcela da população da Móoca com o diagnóstico da percepção popular sobre os processos participativos aplicados em planejamento urbano, particularmente ao processo de revisão do plano diretor estratégico do município de São Paulo. Os questionários foram aplicados diretamente a população e realizados presencialmente entre os dias 06/04/2017 e 04/05/2017.

O questionário foi elaborado conforme o Apêndice C, com onze questões binárias de resposta negativa ou positiva ( $\operatorname{sim}$ ou não) para avaliar o conhecimento de legislação urbanística, participação e accountability. Havia, também, seis questões de resposta aberta para avaliar processos envolvidos, associações envolvidas, razões e critérios motivadores para participação popular. Por fim, havia quatro questões de caracterização em faixas (sexo ou gênero), faixas etárias, escolaridade, relação de atividades e relações de interesse da amostra no bairro.

As entrevistas realizadas, conforme descrito e conforme questionários do Apêndice C, permitiram explorar a natureza da dinâmica social. As perguntas abertas permitiram uma liberdade ilimitada de respostas ao informante e trouxeram a vantagem de não haver influência de respostas pré-estabelecidas pelo pesquisador. Contudo, dificultaram a codificação e compilação das respostas por serem menos objetivas, de modo que são mais onerosas e demoradas para analisar.

Já as perguntas fechadas trouxeram alternativas específicas para que o informante escolhesse uma, mas, como aspecto negativo, houve limitação das possibilidades de respostas, restringindo, pois, as possibilidades de manifestação do interrogado, podendo influenciá-lo. Por sua vez, é positivo que a facilidade de aplicação e a rapidez de resposta apresentem pouca possibilidade de erros.

Esse método de coleta de dados buscou fornecer um diagnóstico da comunidade local e suas representações organizadas, além do perfil de participação da sua população. Contribuiu, 
dessa forma, para o debate público acerca dos instrumentos em uso e do grau de adesão dos cidadãos, tendo ancorado:

a) a caracterização simplificada do perfil da amostra participativa da região;

b) a avaliação do conhecimento da amostra selecionada (comerciantes, moradores, participantes de associação de bairro, trabalhadores e estudantes) sobre as políticas de uso, ocupação e parcelamento de solo urbano, plano diretores, planos de bairro e projetos de intervenção urbanística;

c) a avaliação do conhecimento dos participantes da amostra selecionada (comerciantes, moradores, participantes de associação de bairro, trabalhadores e estudantes) sobre o processo de elaboração das políticas de uso, ocupação e parcelamento de solo urbano, plano diretores, planos de bairro e projetos de intervenção urbanística;

d) a avaliação sobre conhecimento e participação (presente ou passada) da amostra selecionada em processos participativos de qualquer natureza, e também aplicados a planejamento urbano;

e) a avaliação de razões, critérios, variáveis, requisitos e demais elementos qualitativos que motivam as pessoas a atuarem (ou não) em espaços participativos, aplicados ou não em planejamento urbano;

f) a avaliação da percepção da amostra sobre as respostas ou devolutivas esperadas e recebidas em processos participativos, de forma qualitativa e quantitativa;

g) a avaliação da percepção das abordagens participativas da amostra selecionada.

De forma preliminar, esse processo permitiu identificar as condições em que se dão a participação da população, individualmente ou organizada em grupos ou associações, e os instrumentos utilizados, como atividade relevante na análise dos métodos de participação hoje empregados no desenvolvimento de políticas e projetos urbanos. Os pontos destacados representam os locais onde as entrevistas foram realizadas:

a) Ponto 1 (06/04/2017): Avenida Paes de Barros, entre a Rua Bixira e a Rua da Mooca, a principal avenida da área de estudo - essa avenida se consolida no PDE como um dos eixos de estruturação urbana; faz ligação entre a Avenida Salim Farah Maluf e a Avenida Radial Leste; e é caracterizada por adensamento construtivo, relevante uso comercial e residencial (vertical e horizontal) e relevante adensamento populacional; 
b) Ponto 2 (14/04/2017 e 17/04/2017): Rua Padre Adelino, entre as ruas Siqueira Bueno e Salim Farah Maluf, é uma rua paralela à Avenida Alcântara Machado, limítrofe do eixo - essa rua é caracterizada por uso comercial e uso de serviços, com adensamento construído predominantemente horizontal, equipamento de lazer significativo (SESC) e adensamento populacional bastante relevante;

c) Ponto 3 (21/04/2017): Avenida Celso Garcia, entre a Rua Tuiuti e a Avenida Salim Farah Maluf - essa avenida está em uma Zona de Eixo Projetado, tem relevante fator histórico e cruza zonas de ZEIS;

d) Ponto 4 (24/04/2017 e 04/05/2017): Avenida Celso Garcia, entre a Rua Bresser e a Rua Miller, configurada por adensamento comercial relevante, eixo de estruturação e zona de desenvolvimento econômico induzida pelo PDE;

e) Pontos 5, 6 e 7 (11/04/2017, 12/04/2017 e 13/04/2017): foram aplicados a pedestres na saída do metro Belém, em frente à Universidade São Judas Tadeus e em frente à Subprefeitura da Mooca.

Os questionários foram aplicados em entrevistas diretas a comerciantes, pedestres e moradores, nas datas e locais selecionados, conforme indica a figura 23. Foram realizadas114 entrevistas $0,33 \%$ da população total residente), nos períodos e nos locais designados, mediante trabalho de dois pesquisadores. É importante salientar que esse não é um resultado paramétrico, ou seja, a quantificação das opiniões e comportamentos não foi gerada para generalizar os resultados de uma população de amostra maior. Com abordagem qualitativa, os resultados buscam a compreensão do fenômeno observado e o diagnóstico à luz da literatura, a fim de descobrir tendências de pensamento e de opiniões.

Nessa primeira abordagem, não foi verificada (perguntada) a renda, pois no caso de uma abordagem inicial em entrevistas aplicadas na rua, isso pode criar uma dificuldade de aproximação. Na caracterização dos entrevistados, $60 \%$ deles são do sexo masculino. As faixas etárias predominantes são entre 21 e 25 anos, 26 a 35 anos e 46 a 60 anos, com respectivamente $54 \%, 19 \%$ e $9 \%$ da amostra selecionada.

A maioria dos entrevistados tem ensino superior incompleto, cerca de $60 \%$, seguido pelo ensino médio completo, com $17 \%$, e superior completo $11 \%$ - os outros $9 \%$ estão distribuídos em pessoas com ensino fundamental completo ou incompleto. Das atividades que as pessoas realizam na área objeto de estudo, 29\% da amostra mora na região, 25\% trabalha na região, $15 \%$ estuda na região, $8 \%$ está na região para usufruir de opções de lazer, $6 \%$ mora e trabalha na região, $4 \%$ trabalha e estuda na região e $13 \%$ estava somente de passagem pela região. 
Figura 23 - Seleção de pontos para aplicação das entrevistas

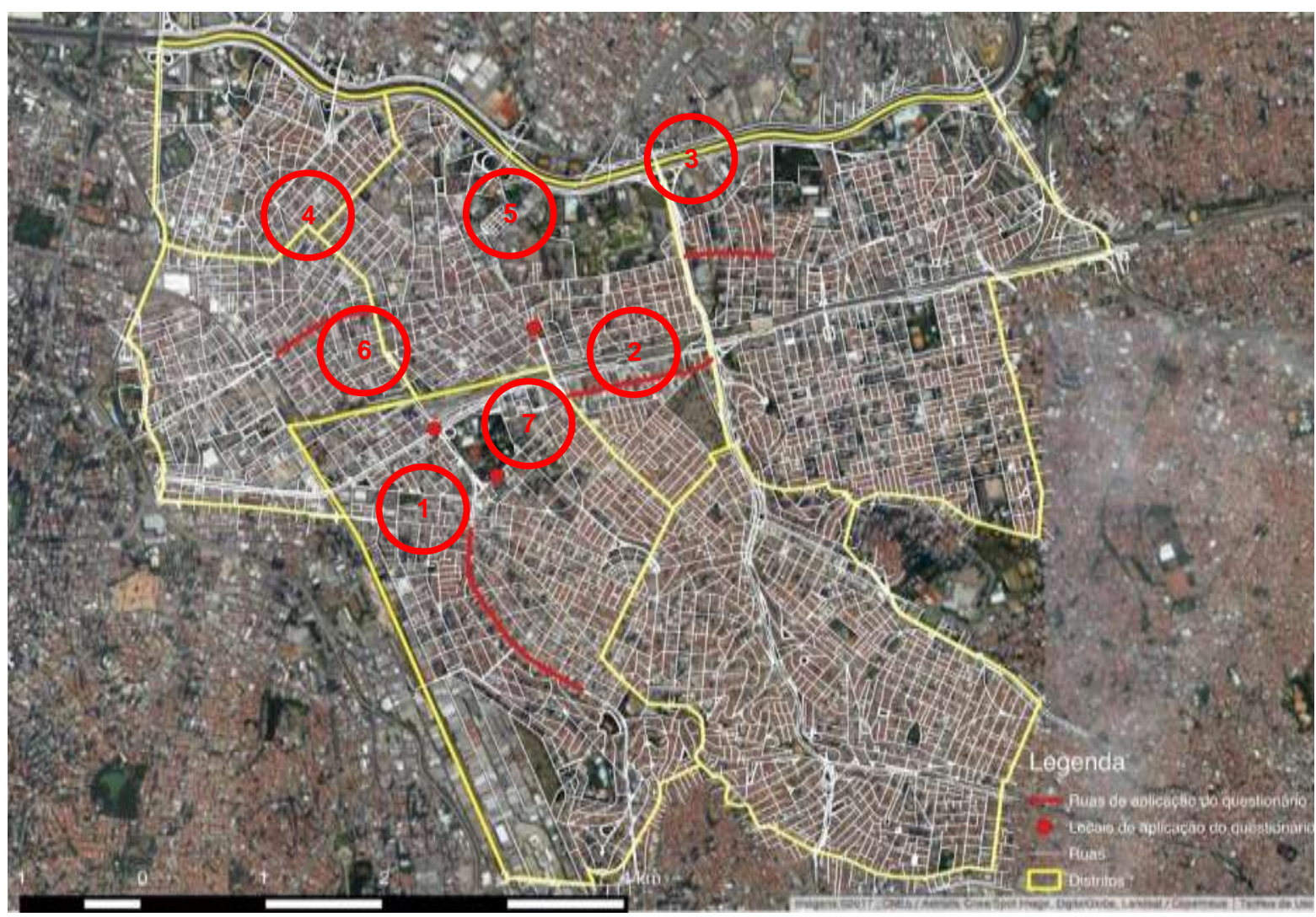

Fonte: Mauad e Cruz (2017) ${ }^{51}$ - adaptado de Google Earth (2017).

Nesse contexto, foi perguntado se o entrevistado "sabe o que é Plano Diretor e Zoneamento", e, para esta pergunta, 63\% da amostra respondeu positivamente. Entretanto, quando a pergunta questiona se o entrevistado "sabe o que é um Plano Regional de Subprefeitura", "sabe o que é um Plano de Bairro" ou "sabe o que é um Plano de Intervenção Urbanística", mais do que $78 \%$ do perfil entrevistado não tem conhecimento acerca dos respectivos temas. Portanto, enquanto aproximadamente seis em cada dez pessoas sabem o que é um Plano Diretor e Zoneamento, quase oito em cada dez pessoas da amostra não têm conhecimento de como funciona o processo de elaboração de nenhum plano intrínseco ao Plano Diretor.

Também, $72 \%$ dos entrevistados, quando questionados, não ficaram sabendo do processo participativo ou da revisão do novo PDE e da LPUOS em São Paulo. Nesse caso, é importante reforçar que mais de $90 \%$ da amostra não participou do processo de revisão ou nunca participou de qualquer processo de consulta induzido pelo governo. Mas, esse cenário não é exclusivo do

\footnotetext{
${ }^{51}$ Mapa elaborado pelo o Autor com apoio de Silvia Vitali dos Santos Mauad, como resultado de seu trabalho de iniciação cientifica, com o título "Diagnóstico da participação popular em projetos urbanos, no município de São Paulo", orientado pela Professora Doutora Karin Regina de Casas Castro Marins.
} 
governo, pois ao perguntar "se participam de alguma ONG, associação de bairro, conselho ou qualquer outro espaço participativo", $92 \%$ do perfil da amostra não participa desses espaços, e os poucos que participam são idosos que, por interesses pessoais, participam de Conselhos de Segurança (CONSEG).

Para os indivíduos que participam, dois aspectos negativos sobre os espaços chamaram à atenção. Um deles é o pouco tempo dado aos debates, e o outro, mais interessante ainda, é que as questões discutidas pouco se tornaram medidas de fato, já que existe muita burocracia. Em resumo das respostas obtidas sobre os motivos de não atuar em espaços participativos e deliberativos, destacam-se (i) desconhecimento ou falta de informação sobre estes processos, (ii) não saber como participar ou não ter a oportunidade de participar, (iii) jornada de trabalho excessiva, de modo que não há tempo livre para participar, (iv) falta de conhecimento necessário para fazer contribuições que agreguem valor e (v) falta de interesse.

Com relação a não participar dos processos, $49 \%$ das pessoas afirmam não participar por falta de conhecimento da existência dos processos, $27 \%$, por falta de tempo, 19\%, por falta de interesse e $5 \%$ por falta de oportunidade, conforme gráfico da figura 24 a seguir.

Figura 24 - Condicionantes para a falta de engajamento em processos participativos

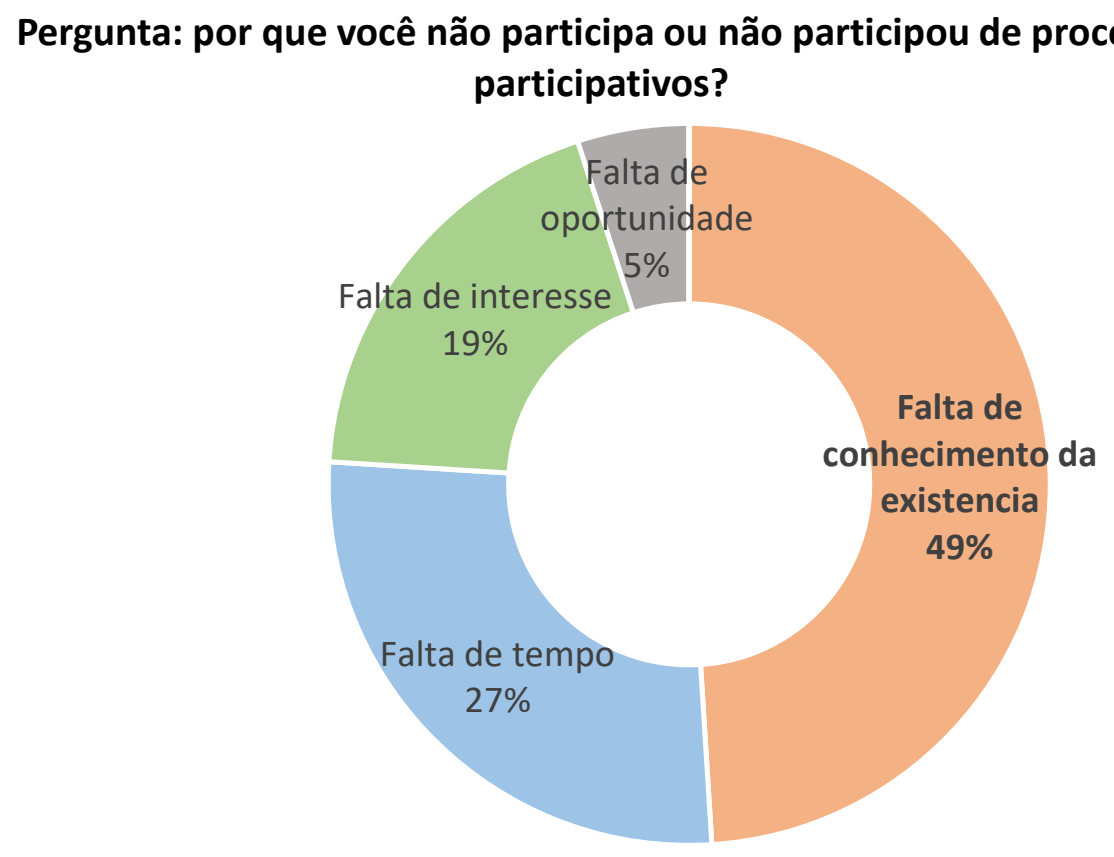

Fonte: Do autor (2019).

No entanto, o prognóstico, na amostra, é animador, pois $85 \%$ do perfil considera participar em processos de revisão de instrumentos de planejamento urbano no futuro caso 
tenha oportunidade, e $95 \%$ reconhece que é importante que a população participe desses processos de planejamento de cidade. As razões são, por exemplo: (i) acreditar que pessoas que residem na região podem contribuir com sugestões de melhoria, pois elas vivenciam a realidade cotidiana; (ii) entender que a população não deve somente reclamar direitos, mas também abraçar oportunidades de ajudar a promover melhorias para a cidade; (iii) entender que a participação ativa faz diferença; (iv) entender que o cidadão deve se colocar como membro ativo e protagonista do processo; (v) entender que deve fazer parte das mudanças que vão ocorrer no bairro ou na cidade; (vi) entender que as opiniões podem restringir, limitar ou ampliar futuras construções; (vii) entender que, além de dar sugestões, é importante fiscalizar o que acontece na cidade; (viii) entender que quando opinião os projetos são realizados atendendo a necessidade real da população; e (ix) se envolver aprimora a compreensão e facilita sugestão de melhorias.

Dos que participaram, mesmo sendo poucos, $77 \%$ acreditam que sua participação ou contribuição não foi atendida ou ouvida de forma efetiva. Ainda, $80 \%$ da amostra total acredita que nunca será informada se suas contribuições ao governo serão transformadas em ações concretas ou propostas. Dos 92 \% que não participam, 27\% são aqueles de menor escolaridade - na realidade, $99 \%$ das pessoas de menor escolaridade não participam de nenhum processo participativo -, e dos $15 \%$ que não pretendem participar no futuro, $99 \%$ também são aqueles de menor escolaridade. Embora não se possa generalizar as conclusões, a tendência aponta que os processos participativos não estimulam as pessoas de menor escolaridade a se engajarem.

Outra percepção é que dos 92\% que não participam $15 \%$ representam aqueles com 46 anos ou mais, na realidade $84 \%$ das pessoas de maior idade não participaram do processo, e dos $15 \%$ que não pretendem participar $88 \%$ também são aqueles de maior idade. O que se pode notar, é que há uma tendência que os processos participativos têm maior engajamento dos mais jovens, e há o desafio de como engajar as pessoas de maior idade em participar.

Tanto a análise do processo de revisão do PDE estabelecido em São Paulo, quanto a aplicação das entrevistas permitiram um diagnóstico do processo decisório que hierarquiza a transformação urbana na realidade paulistana e a verificação de como a condução dos processos influencia a participação popular. Não se nega a importância da participação dos agentes da sociedade para o planejamento urbano; contudo, as audiências públicas, ou esforços realizados, até então, pelo poder público, não permitem avaliar efetivamente o papel dos processos participativos nas tomadas de decisão, embora a participação popular seja uma premissa em qualquer processo decisório democrático. 
Portanto, verificar abordagens metodológicas cujas contribuições sociais possam fornecer insumos que possibilitem o diagnóstico de problemas, a definição de prioridades e a hierarquização de projetos e soluções de intervenção urbana, de uma forma mais efetiva, auxiliaria a prática corrente no modus operandi ${ }^{52}$ das audiências públicas ou de outros debates públicos em planejamento urbano.

O processo participativo, do ponto de vista institucional, vem sendo utilizado pelo poder público para ratificar as estratégias já desenvolvidas por técnicos e planejadores governamentais. Pouco se percebe uma efetiva partilha de poder, ou mesmo que o processo é algo que emerge da sociedade em um formato de baixo para cima. Ainda existem desafios para avançar no empoderamento, com parceria, delegação de poder, e maior envolvimento popular nas tomadas de decisão. Embora o governo conduza processos, e aparentemente compartilhe os espaços de tomada de decisão com a sociedade civil, não há um compromisso total, uma vez que as propostas são votadas pelo legislativo, com revisões e ajustes sem mais explicações compartilhadas e, finalmente, a decisão é ratificada pelo chefe de o executivo.

Apesar da evolução da participação nos processos observados em São Paulo, o governo recebe informações da população, consulta a opinião da sociedade e, de alguma forma, atua com diplomacia na solução de conflitos, fatos que apontam a existência de uma certa medida de participação. No entanto, o que realmente não ocorre é a inserção de opiniões como insumo relevante na tomada de decisão. Assim, apesar de o poder público fornecer informações e abrir espaço para o diálogo, não existem instrumentos que garantam a consideração das contribuições dos participantes na tomada de decisões.

A imposição constitucional e normativa para a concepção de Planos Diretores Participativos, em teoria, articula a influência da população na construção das cidades. No entanto, em termos práticos, esse processo participativo ainda está em construção. No caso de São Paulo, boa parte do processo foi informativo ou consultivo, mostrando que apesar de notados avanços, ainda não é o bastante para este processo, que deve ocorrer de acordo com uma participação pluralista decisiva para a tomada de decisão nas comunidades.

De acordo com os resultados, o ambiente participativo pode catalisar a identificação de soluções para os problemas, mas é muito difícil encontrar o fator de motivação para essa participação. Talvez os resultados no planejamento urbano demorem a aparecer, gerando uma

\footnotetext{
${ }^{52}$ Modo pelo qual um indivíduo ou uma organização desenvolve ou opera suas atividades.
} 
pseudo-percepção de inércia das ações, e essa inércia afasta a população para participar do processo participativo.

No caso de São Paulo, o desenho institucional favoreceu a aproximação de grupos influentes e de interesse com finalidades específicas. Por exemplo, na realidade brasileira, especificamente no município de São Paulo, a demanda por habitação social é latente, o que é fortemente identificado nas ações previstas nos instrumentos legais de planejamento urbano analisados.

No entanto, ainda é necessário medir a eficácia dessas ações para grupos e indivíduos interessados. Um processo de gestão é necessário na tomada de decisão participativa para que a política urbana possa propor instrumentos que possam alcançar oportunidades iguais para a participação da sociedade civil e para as ações planejadas pelo Estado.

A pesquisa mostrou que as pessoas estão cientes de que elas são essenciais no processo de elaboração de políticas públicas urbanas, especialmente em escala de vizinhança. No entanto, a motivação para ainda é um ponto a ser melhor abordado, principalmente em relação à participação de idosos e de pessoas menos escolarizadas.

Entende-se que os espaços deliberativos são mais eficazes que os espaços não deliberativos. E que a maior diversidade pode aumentar o número de ações e, portanto, são mais eficazes do que as diversidades menores, que geram decisões setoriais que atendem a grupos específicos.

Então, quando combinamos, por exemplo, um amplo espaço deliberativo (que aumenta a efetividade) com um grupo pouco diversificado (que reduz a efetividade), teremos uma efetividade média das ações. E ao contrário o mesmo.

Como apontado por Arnstein (1969) e Choguill (1996), há uma entrada assimétrica de certos grupos minoritários fortemente organizados nos processos de planejamento urbano conduzidos pelo governo. Embora haja esforços para promover a transparência, os processos participativos são geralmente vistos como sucessivas esferas de consulta, enquanto, na verdade, a voz de partes interessadas relevantes e representativas pode não ser ouvida e tomada relevante pelo tomador de decisões. Neste caso, há empoderamento, mas apenas um pequeno grupo que tenha coesão e organização consolidada será representado. 


\section{METODOLOGIAS DE PLANEJAMENTO E TOMADA DE DECISÃO APLICÁVEIS A PROCESSOS PARTICIPATIVOS EM PLANEJAMENTO URBANO}

A ampliação do debate sobre participação pública no processo decisório aponta a questão de como considerar as percepções individuais e coletivas em um cenário cujos indivíduos passam a integrar os conhecimentos locais aos conhecimentos técnico-científicos, de forma a estender o diálogo sobre a definição de estratégias e a formulação de políticas públicas.

Nesta direção uma abordagem que considere os problemas urbanos, discutidos de forma participante - favorecendo o engajamento, que aplique instrumentos de coleta de dados em dinâmicas de grupos colaborativas poderá contribuir para uma abordagem estratégica de planejamento. Ademais a abordagem estratégica de planejamento poderá ser operacionalizada a partir de uma hierarquização que consolida as questões.de forma multicriterial.

\subsection{ABORDAGENS À LUZ DA CIENCIA PÓS-NORMAL}

Nenhuma política, ato legal, plano, programa ou medida efetivamente se estabelece se não houver consenso e aceitação pela maior parte da população, conforme pontuam Funtowicz e Ravetz (1997), Freitas (2000), Santos, Thomaziello e Weill (2007), Renn (2008), Di Giulio (2012) e Di Giulio et al. (2012). Os problemas urbanos atuais, seja em nível individual ou em nível comunitário, têm características comuns que os distinguem dos problemas científicos tradicionais. Além disso, seguem uma escala e uma dinâmica com foco nas pessoas e em sua percepção da realidade, associando suas relações necessárias ao ambiente urbano. Sua escala é planetária, e seu impacto, de longa duração.

$\mathrm{Na}$ atualidade existem problemas urbanos que são novos, complexos, variáveis e, com frequência, mal compreendidos. Diante disso, dados sobre seus efeitos podem ser insuficientes ou inadequados. Em alguns casos, modelos tradicionais de pesquisa e diagnóstico podem não fornecer respostas teóricas para explicar e prever esses problemas, conforme apontam Funtowicz e Ravetz (1997), e, na realidade urbana, vivemos novos paradigmas decorrentes do processo de urbanização.

Os modelos matemáticos e as simulações computadorizadas consolidados em métodos científicos tradicionais encontram dificuldades em abordagens mais globais, cujas percepções de pessoas instrumentalizam decisões políticas, as quais nem sempre podem ser testadas por 
métodos triviais. Com base nesse paradigma incerto, decisões políticas devem ser tomadas, e com certa urgência, como apontam Funtowicz e Ravetz (Ibidem).

Assim, as políticas destinadas a solucionar os problemas urbanos não podem ser determinadas, somente, à luz de predições científicas apoiadas apenas em cálculos, e também não devem ser encaradas apenas sob o prisma das ciências sociais. Com isso, o termo "pósnormal" é aplicado para caracterizar a ultrapassagem de uma era em que a norma para a prática científica eficaz poderia ser a rotineira resolução de quebra-cabeças (KUHN, 1962), ignorandose as questões mais amplas de naturezas metodológica, social e ética, suscitadas pela atividade e por seus produtos.

As limitações, segundo Funtowicz e Ravetz (1997), inerentes às estratégias tradicionais de resolução de problemas são reveladas por uma característica estrutural dos novos tipos de problemas: as decisões dependem de avaliações de estados futuros, dos recursos e da sociedade humana, mas não se conhecem, nem se podem conhecer, em detalhes nenhum desses estados. Além disso, as irremediáveis incertezas embutidas nos conhecimentos relevantes para a formulação de políticas somam-se às complexidades situacionais e realidades locais.

Nesse contexto, há de se relacionar o entendimento de um saber metodológico científico não só pela experimentação tradicional, mas também através da formação de comunidades participantes, com pares que admitam todos os setores relevantes (populares, públicos e privados) que têm influência sobre uma determinada questão. Tais elementos e abordagens propiciam o fortalecimento das discussões e dos diálogos, tornando o próprio processo metodológico um processo de transformação. Os argumentos envolvem-se no âmbito de um diálogo contínuo que não se consegue reduzir à lógica trivial matemática; contudo, estes argumentos têm um valor relevante na direção de aclarar as formas como são construídas as soluções.

Em debates sobre questões particulares, quando qualquer agente vê seus interesses ameaçados, pode sempre identificar alguma falha metodológica e a usar para contestar a qualidade do processo e das contribuições apresentadas pelo outro lado, segundo Funtowicz e Ravetz (1997). Isso acontece facilmente, sobretudo, no caso de decisões regulamentadoras de riscos ou do meio ambiente, em que evidências e argumentos são de uma incerteza aguda.

De maneira similar, o conhecimento local não se restringe aos aspectos do meio ambiente, pois no espaço urbano se referem a componentes da vida cotidiana e da construção de relações da dinâmica social. Assim, na formulação de políticas, o foro para os debates se alarga, de 
maneira a incluir, além dos aspectos técnicos, todos aqueles interesses comerciais ou corporativos, bem como motivações individuais e coletivas, com demandas públicas e políticas, as quais acreditam no resultado das decisões, como salientam Funtowicz e Ravetz (Ibidem).

Há uma grande crença no poder de solução dos problemas cotidianos pela delegação de poder e a dependência dos resultados das políticas públicas. Mesmo boas decisões podem gerar resultados que demoram a se realizar e que, nem sempre, podem ser medidos de forma direta, fazendo com que uma abordagem contínua, participativa e pós-normal favoreça a interpretação dos contextos particulares e individuais.

As tendências que levam a um foro de debate ampliado manifestam-se com mais força ainda no caso da ciência pós-normal. Analisar as condições sociais da produção de resultados, em um contexto no qual os atores são susceptíveis a interferir no processo, cria um exercício de habilidades que desempenham papel essencial, mas que devem transcorrer num arcabouço técnico que integre os problemas de maneira mais ampla. Dessa forma, Funtowicz e Ravetz (Ibidem) reforçam que a direção e a garantia de qualidade, bem como os meios para obter uma solução negociada de problemas relacionados às políticas em questão, a despeito das complexidades e incertezas inerentes a eles, emergem do diálogo.

Enquanto, na ciência normal, os leigos eram efetivamente excluídos do diálogo, a abordagem pós-normal lida com incertezas e defronta decisões em escalas local e global. Nelas, por sua vez, os resultados não podem mais ser delegados a especialistas isolados da comunidade. Embora existam outros autores tais como Thiollent (1997), Pelicioni (2000) e Toledo (2005), que apresentem a ciência pós normal, o delineamento proposto por Funtowicz e Ravetz, são aqueles que estabelecem uma relação mais aproximada com temática da pesquisa.

\subsubsection{Estratégia de pesquisa-ação}

A definição de pesquisa-ação é, conforme Thiollent:

(...) um tipo de pesquisa social com base empírica que é concebida e realizada em estreita associação com uma ação ou com a resolução de um problema coletivo e no qual os pesquisadores e os participantes representativos da situação ou do problema estão envolvidos de modo cooperativo ou participativo (THIOLLENT, 1997, p.16).

Essa estratégia busca contribuir para o desenvolvimento de critérios - ao mesmo tempo, abertos e consistentes - que, aderentes a uma relevância social, possuam descrição e 
interpretação relevantes aos sujeitos e com a exercício do conhecimento individual, de forma reflexiva e prática.

Fellows e Liu (2005) e Thiollent (1997) afirmam que se existe a participação dos pesquisadores no estudo, então se trata de pesquisa-ação, uma vez que dá atenção à potencialidade do conhecimento produzido. Dick (1994), Costa (2003) e Collis e Hussey (2005) evidenciam que os objetivos da pesquisa-ação são de proporcionar mudanças a alguma comunidade ou organização, além de aumentar o entendimento sobre o objeto de pesquisa, e o estudo se desenvolve em meio às contradições da sociedade. Ademais, a pesquisa-ação é uma estratégia que visa, ativa e intencionalmente, desencadear uma mudança em um sistema social, e se mostra na ação do pesquisador e na ação dos sujeitos envolvidos na pesquisa.

Collis e Hussey (2005) apontam a pesquisa-ação em cenários cujo foco seja a resolução de problemas do mundo real, sendo essa estratégia um tipo de pesquisa aplicada, em que pesquisador e pesquisa fazem parte da mudança contínua em que o mundo social está inserido. Para Yin (2010), a confiança no outro é um elemento imprescindível quando se trata de pesquisa participante e, de certa forma, tangencia a análise de estudos de caso. As condições básicas para adoção de estudo de caso, apontadas por Yin (2005), também poderiam ser factíveis para a adoção da estratégia de pesquisa-ação. Estas condições básicas são:
a) tipo de questão de pesquisa - visam, geralmente, responder questões do tipo "como" (estudos descritivos) e "por quê" (estudos exploratórios);
b) o controle pouco ou nenhum do pesquisador sobre os eventos comportamentais efetivos;
c) o grau de conhecimento que se tem sobre o assunto - isto é, se o foco da pesquisa é direcionado a fenômenos históricos ou contemporâneos.

Essa estratégia de pesquisa pode nos ajudar a encontrar mecanismos para superar algumas questões, e, de acordo com Thiollent (1997), a pesquisa-ação pode ser aplicada basicamente em três contextos:

a) um ator social homogêneo realiza seus objetivos práticos, tendo suficiente autonomia e controle da pesquisa;

b) a pesquisa é realizada dentro de uma organização;

c) a pesquisa é organizada em um meio aberto - por exemplo, uma comunidade ou um bairro. 
Uma crítica frequente a essas estratégias de pesquisa é que as conclusões não podem ser generalizadas. Contudo, Laville e Dionne (1999) e Yin (2010) destacam que a pesquisa-ação se trata de pesquisa aplicada. Booth, Colomb e Williams (2000) afirmam que esse tipo de pesquisa se propõe a resolver o problema de certa área de ignorância, o que tem consequências tangíveis em diversas escalas.

O pesquisador, portanto, deve sempre ter um cuidado minucioso para escolher casos típicos, representativos, a partir dos quais possa extrapolar do particular para o geral. Afinal, não há ganho inútil sobre as relações humanas cujos destaques, mesmo que particulares, aumentam a compreensão do todo, como reforçam Laville e Dionne (1999). Para eles, o processo deve permear questões que fomentem as reflexões que alimentarão o processo de tomada de decisão.

A formulação, a implantação e a execução de ações tornam-se conhecimento social e requisitam um canal de comunicação entre o ente público e a sociedade. Contudo, para preservar o caráter científico de uma pesquisa-ação, deve existir a colaboração entre o pesquisador e os participantes representativos da situação ou do problema. Nessa esfera, devem ser evitadas interpretações errôneas quanto ao caráter científico da pesquisa. Collis e Hussey (2005) e Granja (2009) salientam que a crítica mais comum à estratégia de pesquisa-ação é que ela é, muitas vezes, é considerada prestação de serviços.

Nesse cenário, é relevante a criação de um contexto capacitante para construção, registro, organização e disseminação do conhecimento construído no processo. Os objetivos da pesquisa devem estar bem definidos desde o começo, mesmo que possam ser alterados no decorrer da pesquisa, assim como a forma da pesquisa conduzida, principalmente, em relação aos dados a serem coletados, ao controle desses dados, à análise dos resultados e às suas contribuições para o desenvolvimento social, segundo Thiollent (1997).

Deve-se dar especial atenção à metodologia de pesquisa, a qual deve ser cuidadosamente explicada e justificada, pois tem maior importância do que a ação que se quer implementar, conforme salienta Granja (2009). Tanto a informação, quanto o conhecimento, são produtos de uma construção social, e a pesquisa-ação costuma ser desenvolvida por si só; portanto, a literatura relevante poderá ser redirecionada conforme a pesquisa evolui.

Ainda, segundo Granja (Ibidem), uma pesquisa-ação pode ser caracterizada como: cíclica, pois tem a tendência de recorrência de passos similares; participativa, pois prescinde do envolvimento dos participantes no processo de pesquisa; qualitativa, pois muitas vezes lida 
mais com a "linguagem" do que com números; e, reflexiva, pois exige reflexão crítica ao longo do processo. Os resultados são componentes de cada ciclo, viabilizando sua externalização entre os colaboradores e contribuindo para a inovação e para o aumento da capacidade de resposta às mudanças.

Por sua vez, existe um ciclo essencial em toda pesquisa-ação: Planejamento - Ação Avaliação - Reflexão. Planejamento refere-se à análise inicial, assim como ao plano de ações para resolver o problema. Ação refere-se às ações a serem praticadas. Avaliação é feita com base nos resultados da ação. Por fim, é feita uma Reflexão sobre ações e da avaliação, conforme aponta Samaniego (2007). Este ciclo é consolidado no âmbito participativo construtivista e ancora processos de diagnósticos e planejamentos participativos, bem como pressupõe divisão de poder no processo decisório, passando pelo controle das partes sobre a execução e a avaliação dos resultados pretendidos.

De acordo com Granja (2009), os ciclos de reflexão são fundamentais, visto que a contribuição original da pesquisa surge dessas reflexões, devendo fomentar a experiência de autoavaliação e avaliação da cultura do grupo. Ele sugere os seguintes passos no desenvolvimento de uma pesquisa-ação:

a) programar uma mudança - o pesquisador deve planejar as ações com o grupo, distanciarse para refletir sobre o que foi planejado e fazer nova reunião, após a ação, para comparar o que foi alcançado e com quais resultados;

b) na reflexão após a ação, o grupo deve avaliar os métodos utilizados e tudo que é relevante;

c) ao final de cada ciclo, o pesquisador deve refletir sobre o estudo - como o grupo planejou, agiu, observou e refletiu.

Nota-se, por fim, que este ciclo sugerido por Granja (Ibidem) é bastante semelhante ao ciclo de ação da metodologia multicriterial a que pertence. Ele demanda capacidade reflexiva sobre os efeitos de vida cotidianos, capacidade de criar e recriar objetivos materiais e, fundamentalmente, criar e recriar formas de vida e de convivência social, conforme aponta Thomaz (2002).

\subsubsection{Instrumentos de Pesquisa, Intervenção e Engajamento}

No contexto de pesquisas que pretendem estabelecer engajamento, pois necessitam de participação popular, as ações decorrentes de percepções relativas às realidades são desenvolvidas, em parte, pela interação entre pessoas e grupos, e os resultados são influenciados 
pelo meio em que as questões estão inseridas. Nessa situação, as formas de engajamento e intervenção podem ser ancoradas em abordagens de grupos focais. Estes, afinal, permitem a inserção de elementos de planejamento, com cenários que podem ser adotados visando à proposição de pesquisas participativas, a partir de uma adaptação dos princípios da pesquisaação e da pesquisa de intervenção.

Em discussões em grupos, um censo coletivo é estabelecido, os significados são negociados e as identidades são elaboradas pelos processos de interação social entre as pessoas. A pesquisa-ação passa pela geração de conhecimento prático que seja útil às pessoas em suas vidas cotidianas. Ademais, passa pelo entendimento de que, com base nesse conhecimento, os indivíduos e as próprias comunidades podem melhorar seu bem-estar e estabelecer um relacionamento mais sustentável com o ambiente em que vivem, como apontam Reason e Bradbury (2006).

A pesquisa de intervenção, que é uma variante da pesquisa-ação, parte de uma perspectiva integrada de produção de conhecimento. Ela leva em conta tanto as implicações para a condução da pesquisa como para a prática, no sentido de promover transformações na realidade estudada, segundo Rothman e Thomas (1994) e Avenier e Nourry (1999). Os autores sustentam que a pesquisa de intervenção envolve um processo de interação contínuo. Este, por sua vez, tem início ainda na fase de negociação e cria incentivos para iniciar processos de aprendizagem, uma vez que as experiências dos participantes e seus desafios cognitivos desenvolvem argumentos e, algumas vezes, até mesmo modificam suas opiniões durante o debate, como aponta Billig (1996).

Cruzamentos entre os projetos e as demandas identificadas resultam na (re)elaboração de um projeto final que deve ser mutuamente benéfico tanto para a equipe de especialistas quanto para as partes interessadas. Cabe, ainda, ressaltar que o modo de interação entre pesquisadores e interessados, durante a pesquisa, deve visar à aprendizagem coletiva e à produção de conhecimentos a partir da troca de informações.

Esses conhecimentos gerados incluem: conhecimento local que deve oferecer resultados para as demandas; conhecimento obtido com a condução da pesquisa sobre os grupos que representam, incluindo conhecimento sobre as dinâmicas e práticas sociais locais; experiências vividas; percepções sobre as questões e os problemas debatidos; elementos que interferem nas percepções; possibilidades de diálogo entre os grupos sociais etc.; além de conhecimento traduzido de forma normativa, a partir de seus objetivos. 
Nessa abordagem, argumentos podem ser úteis, uma vez que identificam as demandas e as opções das comunidades locais, para se adaptarem, bem como a possibilidade de essas escolhas reduzirem a vulnerabilidade local. Além disso, a perspectiva de uma pesquisa participante, visando a aprendizagem coletiva e a produção de conhecimentos, pode potencializar o uso do conhecimento gerado pelas partes interessadas, uma vez que trabalham juntos desde a identificação do problema até a análise das recomendações e das estratégias propostas, com base nas informações levantadas.

Krueger (1994) considera que as percepções, opiniões e atitudes são socialmente construídas. Logo, o método de grupo focal possibilita extrair mais facilmente a expressão dos indivíduos participantes. No processo de interação, os comentários colocados pelos envolvidos no processo participativo, são fatores indutores que podem estimular e gerar mais opiniões de outros participantes sobre o assunto debatido, um processo social dinâmico em que os participantes estão engajados na construção coletiva de avaliação, ou complementação, sobre uma determinada questão, como aponta Di Giulio (2012). Morgan $(1988,1998)$ sugere que essa abordagem pode explorar a promoção dos confrontos individuais - como ajuda na formação de uma rede de conhecimento socialmente compartilhado -, emergentes através da discussão em grupo com os participantes.

No processo de pesquisa-ação, é possível obter interpretações dos participantes sobre o assunto debatido, estabelecer conexões com o tema em um âmbito mais amplo, gerar hipóteses com base nas informações providas pelos participantes e desenvolver posteriormente questionários, além de captar as percepções dos indivíduos participantes sobre as questões em análise e apreender suas experiências e perspectivas.

Uma das técnicas que pode ser aplicada em pesquisa ação é grupo focal, em que um grupo de discussão, moderado, tem o número de participantes variável - sendo a média entre seis e dez, oito e dez, quatro e quinze, seis e quinze -, como apontam diversos autores Morgan (1988 e 1998), Krueger (1994) e Billig (1996). Grupos menores são interessantes quando o pesquisador deseja um envolvimento forte e um claro sentido de reação de cada participante sobre o tema debatido. Esses participantes, em geral, têm um alto nível de envolvimento com a questão. Já grupos maiores são realizados quando os indivíduos têm um nível baixo de envolvimento sobre o tópico discutido, e o objetivo é apenas ouvir inúmeras sugestões sobre um assunto (como em um brainstorming). Independentemente do tamanho do grupo, faz-se necessário um planejamento das atividades desenvolvidas em cada encontro, propondo linhas centrais de discussão e objetivos, elencando perguntas que orientem a discussão. 
Em todos os grupos focais, os participantes devem ter algo a dizer sobre o tópico em questão e devem sentir-se confortáveis nos seus comentários com os outros. Como sustenta Morgan (1998), o objetivo é a homogeneidade entre os participantes, e não homogeneidade de atitude. Krueger (1994), ao discorrer sobre esse método, oferece dicas importantes para que a realização de grupos focais alcance os resultados esperados. É preciso que o local onde será realizado o encontro seja de fácil acesso e o ambiente seja neutro, além de propiciar contato visual entre os participantes, que deverão estar sentados em círculo.

Os grupos focais propiciam um debate aberto e acessível em torno de um tema de interesse comum aos participantes. Um debate se fundamenta numa discussão racional; contudo, para facilitar a realização de um grupo focal, é válido contar com uma equipe de pelo menos duas pessoas: o moderador, que conduz o debate entre os participantes, explora e media questões de interesse da pesquisa desenvolvida, esclarece a finalidade e o formato da discussão e incentiva a participação de todos; e o relator, que deve tomar notas dos pontos principais do debate, incluindo observações sobre atitudes não verbais dos participantes (expressões faciais e gestos, por exemplo) e destacar, em um quadro visível, as palavras-chave da discussão, com a finalidade de auxiliar o fechamento do debate.

É válido lembrar que, em um grupo focal, o moderador não busca convencer, ou censurar os participantes, de modo que seu objetivo é criar uma oportunidade para que os outros falem e ele escute, como reforça Morgan (1998). Assim, cabe a ele prover diferentes tipos de questões para fomentar e aquecer a discussão e deixar os participantes confortáveis para que desenvolvam seus comentários e sustentem seus argumentos. Alguns autores apontam que espaços privados e comunitários são comumente acionados para realização do grupo focal, tais como escritórios, salões de igreja, sedes de associações de bairro e escolas. Nesse sentido, conforme Krueger (1994), o moderador pode lançar mão de:

a) questões iniciais para identificar características comuns entre os participantes;

b) questões introdutórias, para introduzir o tópico geral do debate e prover aos participantes oportunidade para refletirem sobre experiências passadas e conexões com o assunto debatido;

c) questões de transição, para ajudar os participantes a vislumbrarem o tema em um âmbito mais amplo;

d) questões-chave, que direcionam o debate de fato para os objetivos do estudo; 
e) questões de finalização, que devem fechar a discussão, ajudando os participantes a fazerem uma análise crítica do que foi debatido.

Há, todavia, como nos demais métodos adotados em pesquisas qualitativas, algumas limitações. Gondim (2003) e Veiga e Gondim (2001), ao fazerem análises sobre elas, enfocam, por exemplo: o tamanho da amostra, ressaltando que a representatividade de um grupo focal pode tornar inviável a generalização para a população investigada; a falta de controle do desempenho do moderador; o nível de resposta a ser considerado para efeito de análise nos grupos focais, já que a formação de opinião é resultado das interações sociais; e há limitações de comparação de resultados obtidos nos grupos focais com outras técnicas de investigação.

O tipo de instrumento em questão, ou seja, o grupo focal, propicia a geração de um enfoque sistêmico para o desenvolvimento e a avaliação de planos, estratégias e políticas públicas para enfrentar situações e circunstâncias incertas, por meio da criação de futuros plausíveis nos quais eles possam ser testados, como pontua O’Brien (2000). Esse enfoque sistêmico pode subsidiar o planejamento com cenários, enquanto essa abordagem possibilita a criação de futuros plausíveis, criando insumos para informar o processo de decisão. Assim, a abordagem leva a uma participação efetiva, uma vez que aflora a compressão de diferenças e divergências, contraposições e contradições, em função das reais possibilidades.

O planejamento com cenários necessita de uma estrutura sistêmica através da qual uma série de ações e cenários plausíveis pode ser explorada, segundo Cork et al. (2005). Nesse contexto, as etapas envolvidas no planejamento com cenários incluem:

a) identificação de um problema ou assunto focal;

b) avaliação de fatores certos e incertos que influenciam esse problema ou assunto durante um período determinado;

c) desenvolvimento de opções baseadas nesses fatores, a criação de cenários plausíveis e coerentes com as ideias de futuros plausíveis;

d) desenvolvimento de narrativas para descrever a transição do presente para os futuros plausíveis (incluindo uma trajetória para cada cenário, assim como sinais que poderiam indicar que um futuro estaria se tornando mais real do que outro);

e) avaliação de planos, estratégias e políticas públicas de acordo com as características desses futuros plausíveis. 
O potencial do planejamento com cenários está relacionado à possibilidade da geração de um contexto para que uma decisão sobre determinado assunto ou problema possa ser feita no presente, mesmo que suas consequências só possam ser sentidas no futuro. O’Brien (2000) justifica que isso é possibilitado através de descrição e exploração sistêmica das formas em que as incertezas poderiam se manifestar no futuro, além dos impactos que elas poderiam causar na decisão em questão, advindos de informações sobre o que as pessoas pensam, sentem ou, ainda, como agem frente a determinadas questões inerentes a sua realidade e à realidade alheia.

O planejamento com cenários pode apresentar variações no seu enfoque qualitativo ou quantitativo. No entanto, é importante ressaltar que esse método, baseado na geração de descrições de futuros plausíveis, envolve um alto grau de incerteza e não resulta em previsões de nenhum futuro específico, conforme aponta O’Brien (Ibidem). Também convém ressaltar que os participantes devem ter vivência com o tema a ser discutido, o que propiciaria riqueza na troca de informações e coleta de percepções.

\subsection{GRUPO FOCAL COMO METODOLOGIA QUALITATIVA}

Segundo Gilbert (1990), para modificar comportamentos é necessário primeiro que se entenda o contexto no qual ocorrem os significados e a importância a eles atribuída pelos seus agentes. Enquanto pequena parcela do significado do contexto comportamental é de cunho pessoal e particular, grande parte dele é culturalmente moldada e socialmente construída. Quando o foco principal é um tema de conhecimento e interesse de todos, as relações e interações são facilitadas.

Como técnica de pesquisa qualitativa, os grupos focais obtêm dados a partir de reuniões em grupo com pessoas que representam o objeto de estudo. Iervolino e Pelicioni (2001) sugerem que um dos instrumentos científicos utilizados para a resolução desse problema é o emprego de metodologia de pesquisa que permita, ao mesmo tempo, aproximação da população e compreensão dos símbolos, significados e significantes que esta utiliza na contextualização diagnóstica da realidade. Os grupos focais têm sido utilizados internacionalmente para a estruturação de ações para definição e diagnóstico de problemas, para o planejamento de atividades e para a formação educativa e colaborativa acerca de um tema.

Relativamente simples e rápido, o grupo focal parece responder a contento em cenários que têm a perspectiva do indivíduo que integra um grupo social. Ademais, estrutura-se em 
conteúdos e abordagens, locais e sistêmicas, centradas na perspectiva da percepção de seus possíveis beneficiários, como apontam Mckinlay (1992) e Yach (1992).

Basch (1987), Glik e Gordon (1988) e Ramirez (1988) afirmam que o grupo focal enfatiza a compreensão dos problemas do ponto de vista dos grupos populacionais, assim como o conhecimento das aspirações da comunidade expressos por ela própria. Apontam também que, em sua utilização, é consistente a aprendizagem social, por se apoiar no princípio da participação integral do agente no processo de construção de informações. Segundo Basch (1987), o uso do grupo focal pode minimizar o número de programas que resultam em baixa efetividade, e, ainda, pode reduzir o número de iniciativas distorcidas e embasadas na percepção e nos interesses dos dirigentes (e não da população). O uso do grupo focal pode, por fim, servir como forma de aproximação, integração e envolvimento com os participantes.

Por sua vez, Morgan (1997) define grupos focais como uma técnica de pesquisa que coleta dados por meio das interações grupais, ao se discutir um tópico especial sugerido pelo pesquisador. Além disso, tem um caráter diagnóstico que permite o entendimento e o redirecionamento de problemas e questões com a incorporação da perspectiva das pessoas. Em síntese, desenvolver abordagens participativas utilizando o grupo focal implica desenvolver um processo que contém procedimentos que visam à compreensão das experiências do grupo participante, do seu próprio ponto de vista, e de suas percepções. Como técnica, ocupa uma posição intermediária entre a observação participante e as entrevistas, em profundidade. Pode ser caracterizada também como um recurso para compreender o processo de construção das percepções, atitudes e representações sociais de grupos humanos, como apontam Veiga e Gondim (2001).

Fern (2001) pontua que há duas orientações: a primeira visa a confirmação de hipóteses e a avaliação da teoria, mais comumente adotada por acadêmicos; já a segunda dirige-se às aplicações práticas, ou seja, o uso dos achados em contextos particulares. Estas duas orientações podem estar combinadas em três modalidades de grupos focais: exploratórios, clínicos e vivenciais.

Os grupos exploratórios estão centrados na produção de conteúdo, e é preciso prepararse para a possível necessidade de ter de aplicar ferramentas de dinâmicas em grupo para garantir uma participação mais efetiva. Sua orientação teórica está voltada para a geração de hipóteses, assim como para o desenvolvimento de modelos e teorias. 
As modalidades clínica e vivencial têm como alvo a produção de novas ideias, a identificação das necessidades e expectativas e a descoberta de outros usos para um produto específico, ressaltando a maior facilidade em conseguir captar mais indivíduos com disponibilidade de participação. Sua ênfase reside no plano intersubjetivo, ou melhor, naquilo que permite identificar aspectos comuns de um grupo alvo. A construção de modelos teóricos já dispõe de metodologia apropriada: a teoria fundamentada desenvolvida por Strauss e Corbin (1994), definida pelo apoio na captura e análise sistemática de dados. Esta é uma teoria construída indutivamente, a partir da relação contínua entre coleta e interpretação dos dados, conforme aponta Charmaz (2000).

Os grupos focais também podem ser utilizados com a finalidade de gerar o conhecimento necessário para a construção de instrumentos, assim como de futuros programas a serem implantados - não só como meio para se obter a interpretação de um grupo sobre resultados quantitativos, mas também para fornecer um quadro inicial. Neste caso, objetiva-se utilizar os grupos apenas para fazer uma análise prévia, pois a meta final é a construção de instrumento ou a implantação de ações, conforme Gondim (2003) e Veiga e Gondim (2001). Esta técnica permite identificar, no caso de construção de instrumentos, o que é relevante sobre o tópico e com isto apontar os domínios que devem ser cobertos. Além disso, avalia o conjunto de dimensões que irá cobrir cada domínio (quantidade de itens), promove insights de como os itens devem ser apresentados (evitando distorções de entendimento) e serve de substrato para formulação de questionários e escalas de avaliação, como sugerem os autores Gondim (2003) e Veiga e Gondim (2001).

Dois outros fatores são considerados: o papel do moderador e a análise dos resultados. Conforme Morgan (1997), um moderador deve procurar cobrir a máxima variedade de tópicos relevantes sobre o assunto e promover uma discussão produtiva. Para conseguir tal objetivo ele precisa limitar suas intervenções e permitir que a discussão flua, só intervindo para introduzir novas questões e para facilitar o processo em curso. Gondim (2003) e Veiga e Gondim (2001) reforçam que é necessário estar atento para não deixar que o grupo comece a falar sobre um assunto importante apenas quando for tarde demais para ser explorado, e evitar que as interpelações e discussões sejam interrompidas antes da hora. Algumas diretrizes são importantes, tais como (i) uma pessoa fala de cada vez, (ii) evitar discussões paralelas para que todos participem, (iii) evitar que alguém domine a discussão e (iv) garantir o direito de todos de dizer o que pensam. A análise dos resultados é o último fator a ser considerado. 
O grupo focal depende, segundo Bardin (1977) e Smith (2000), do tipo de ação ou elemento que se pretende construir, seja um projeto, uma tomada de decisão, uma produção teórica, uma carta de intenções, uma lista de estratégias, objetivos ou critérios que serão estabelecidos com base nos conteúdos que emergem na conversação empreendida no grupo. $\mathrm{O}$ moderador deve, em sua abordagem e condução, colocar algumas perguntas ou tópicos para debate. Alerta-se que um roteiro é importante - sem ser confundido com um questionário. Um bom roteiro é aquele que permite um aprofundamento progressivo e a condução contínua e progressiva da discussão. Então, os próprios agentes e sua percepções devem criar visões críticas e convergentes em relação ao consenso sobre determinadas questões, sem que o moderador precise intervir muitas vezes. A explicitação das regras do grupo focal nos momentos iniciais pode ajudar na sua autonomia, segundo Gondim (2003) e Veiga e Gondim (2001).

Ademais, alguns cuidados na interpretação dos resultados precisam ser tomados. Conforme Morgan (1997), é necessário distinguir entre o importante e o interessante. O grupo que discute muito um assunto, acha-o, com certeza, interessante, mas isto não quer dizer nada quanto à sua importância. Por outro lado, falar pouco de um tema indica ser ele desinteressante, mas não se pode afirmar sua baixa importância. A única forma de evitar uma interpretação equivocada é perguntar diretamente ao grupo, razão pela qual o papel do moderador é importante - afinal, ao acompanhar o aprofundamento da discussão, ele formula interpretações e averigua se elas fazem sentido para o grupo -, como reforçam Gondim (2003) e Veiga e Gondim (2001).

Thiollent (1997) menciona que a análise, no entanto, é realizada concomitantemente à produção de conhecimento pelo grupo, com vistas à ação, sendo diferenciada a forma de divulgação. Isso o levará a reorientar ou confirmar sua interpretação, e a consolidar uma abordagem congruente em uma perspectiva qualitativa. Enquanto a pesquisa de mercado presta contas ao contratante, que geralmente não tem interesse em difundir as bases que sustentaram suas decisões, a abordagem participativa em políticas públicas, ainda mais em planejamento urbano, é partidária da publicação dos resultados, difundindo o conhecimento produzido e a metodologia, submetidos à avaliação de pares e da comunidade.

Com base nisso, Gondim (2003) e Veiga e Gondim (2001) afirmam que há uma construção progressiva no processo, tanto dos agentes, como dos condutores, pois tem-se a chance de avaliar a pertinência das explicações e concepções técnicas, previamente determinadas, junto ao próprio grupo. Desse modo, as abordagens participativas ativas, com 
foco nos agentes e em suas percepções, distintamente, assumem um compromisso maior com a comunidade e com o que decorre do processo realizado, sendo o êxito de seu produto avaliado pelo impacto na comunidade local.

Faz-se importante acrescentar que o desenvolvimento da pesquisa por meio de grupos focais em ambientes de pesquisa-ação, à luz de uma abordagem pós- normal, está intimamente relacionado à maneira de lidar com o processo de discussão no próprio grupo, e à configuração deste em um processo metodológico de abrangência local, com resultados sistêmicos. Ademais, em ações comunitárias, como o caso de Gondim (2003) e Veiga e Gondim (2001), o foco maior é a conscientização para a ação prática que faça sentido para o próprio grupo. Desse modo, prefere-se as locações em ambientes da comunidade. A mesma argumentação serve para justificar a escolha de profissionais treinados, que recorrem a pessoas da comunidade para coordenar o processo com seu condutor.

\subsubsection{Características e Aplicabilidade do Grupo Focal}

O grupo focal pode ser utilizado no entendimento das diferentes percepções e atitudes acerca de um fato, uma prática, um produto ou um serviço. Pode ser considerado uma espécie de entrevista de grupo, embora não no sentido de ser um processo onde se alternam perguntas do pesquisador e respostas dos participantes. Nesse contexto, há estímulo à participação comunitária em ações que incluam a troca de saberes, em um contexto onde a população compreenda a importância do local em que vive, com diversas relações com a dinâmica social.

A essência do grupo focal consiste justamente na interação entre os participantes, que objetiva colher dados a partir da discussão focada em tópicos específicos e diretivos (por isso é chamado grupo focal). Este é composto por participantes que não são familiares uns aos outros, mas com quem pode haver um senso de pertencimento por parte da população. Esses participantes são selecionados por apresentarem certas características em comum, que estão associadas ao tópico pesquisado. Sua duração típica é de uma hora e meia, segundo Krueger (1998, 1994) e Morgan (1988).

Essa abordagem participativa é um instrumento de inserção da percepção crítica, que torna latente a visualização das interações entre a comunidade, seu meio e as formas específicas pelas quais essas interações ocorrem. Iervolino e Pelicione (2001) sugerem que a coleta de dados através do grupo focal tem como uma de suas maiores riquezas basear-se na tendência humana de formar opiniões e atitudes na interação com outros indivíduos. Isso fica ainda mais 
explícito em relação a sua função de orientar interações sobre o desenvolvimento de temas locais, com abrangências sistêmicas.

O método contrasta, nesse sentido, com dados colhidos em questionários fechados ou entrevistas individuais, nos quais o indivíduo é convocado a emitir opiniões sobre assuntos que talvez nunca tenha pensado anteriormente, e ainda sem avaliação crítica de um consenso de sua relação, e suas questões, com o meio. As pessoas, em geral, precisam ouvir as opiniões dos outros antes de formar as suas próprias, e constantemente mudam de posição (ou fundamentam melhor sua posição inicial) quando expostas à discussão em grupo. É exatamente este processo que o grupo focal tenta captar, segundo Duarte (2007), Krueger (1998, 1994) e Morgan (1988).

A atividade de planejamento necessita de reflexões mais elaboradas sobre o futuro e sobre as consequências das possíveis alternativas. Aliada à análise dos agentes de planejamento, pois os atores sociais serão influenciados pelas ações efetivas, e, portanto, as ações só podem ser estudadas se forem levadas em consideração as relações entre os elementos urbanos e sua relação (ou correlação) com as necessidades hierárquicas locais e sistêmicas. Nesse cenário, na condução de abordagens participativas em grupos, de forma específica aos grupos focais, cabe ao moderador do grupo (geralmente o pesquisador) criar um ambiente propício para que diferentes percepções e pontos de vista venham à tona, sem que haja nenhuma pressão para que seus participantes votem, cheguem a um consenso ou estabeleçam algum plano conclusivo.

Morgan (1988) aponta que esse ambiente relaxado e condutor de troca de experiências e perspectivas, deve também ser garantido por meio de alguns outros cuidados: (i) seus participantes podem, ou não, pertencer ao mesmo círculo de amizade ou trabalho, mas se já há relações intrínsecas entre os sujeitos, a livre expressão de ideias no grupo, de forma espontânea, é prejudicada pelo temor do impacto (real ou imaginário) que essas opiniões terão posteriormente, de modo que cabe ao moderador estabelecer os objetos de análise e descolar as relações de afeto ou dependência para que não ocorram cooptações; e (ii) seus participantes devem ser homogêneos em termos de características que interfiram radicalmente na percepção do assunto em foco, visando garantir o clima confortável para a troca de experiências e impressões de caráter muitas vezes pessoal.

É importante enfatizar, no entanto, que a busca de homogeneidade em algumas características pessoais não deve implicar na busca de homogeneidade da percepção do problema. Se assim fosse, o grupo focal perderia a sua riqueza fundamental, que é o contraste de diferentes perspectivas entre pessoas semelhantes, como salienta Carlini-Cotrim (1996). Com as características definidas, tanto das pessoas como dos grupos, há de se pensar em uma 
variabilidade etária, de gênero, de classe social e de escolaridade, tendo por lastro a troca de saberes e convivências contrastantes.

Portanto, a seleção dos participantes deve ser homóloga e não restritiva. Em estudos que utilizam o grupo focal, as discussões são conduzidas várias vezes com diferentes grupos, visando identificar tendências e padrões na percepção do que se definiu como foco de estudo. A análise sistemática e cuidadosa das discussões vai fornecer pistas e insights sobre a forma como é percebida uma determinada ação ou estratégia, e os critérios que podem ser relevantes. Ademais, há a importância de utilizar o grupo focal no entendimento de como se formam e se diferem as percepções, opiniões e atitudes, como reforçam Iervolino e Pelicione (2001).

\subsubsection{Elaboração e Condução dos Grupos}

O planejamento e a montagem do grupo focal são talvez a parte mais trabalhosa de um estudo que utilize esse método de pesquisa. Deve-se organizar um número de grupos suficientes para que haja saturação do tema. Contudo, a quantidade de grupos focais é muito menos importante do que a qualidade ou riqueza das discussões, geralmente proporcionada pelo estilo de condução adotado pelo moderador e por um bom guia de temas. É claro que, como qualquer outro estudo, as possibilidades a serem consideradas vão depender de fatores básicos, tais como o tempo e os recursos financeiros disponíveis.

De qualquer maneira, há demandas que precisam ser respondidas e que se referem, basicamente: ao recrutamento de participantes; à escolha de um moderador e seus assistentes; à organização de recursos técnicos para a gravação das sessões; à seleção de um local adequado para a realização dos grupos e da contratação de profissionais para transcreverem e analisarem os dados - conforme sugerem Gondim (2003) e Veiga e Gondim (2001). Entretanto, a discussão deve transcorrer de forma espontânea e ainda assegurar que novas questões possam ser introduzidas.

O recrutamento dos participantes vai ocorrer depois de clara determinação do grupo social que se quer estudar. É importante ter em mente que a pesquisa qualitativa, como é o caso do grupo focal, não trabalha com amostras probabilísticas e nem visa estudar a frequência com que determinado comportamento ou opinião ocorre. Observadas estas regras básicas, o recrutamento de voluntários pode se dar:

a) de modo aleatório, pelo telefone;

b) por meio de um breve questionário para selecionar os participantes adequados; 
c) por anúncio em canais de comunicação;

d) pelo contato com associações comunitárias;

e) por meio de indicações sucessivas de pessoas pertencentes à população alvo do estudo;

f) por meio de informantes-chave da comunidade em questão.

O moderador tem o papel fundamental de garantir, por meio de uma intervenção ao mesmo tempo discreta e firme, que o grupo aborde os tópicos de interesse do estudo da maneira menos diretiva possível. Ele deve contar com a presença, no grupo, de dois colaboradores - um para anotar os acontecimentos de maior interesse para a pesquisa (relator) e outro para auxiliar na observação da comunicação não verbal (observador), como forma de compreender os sentimentos dos participantes sobre os tópicos discutidos e, eventualmente, intervir na condução do grupo -, segundo Krueger (1988).

Dentre as características do moderador, ressalta-se a abertura para a discussão e a postura de acolhimento diante dos participantes, o distanciamento com relação a percepções particulares, de forma a acolher posições contrárias de maneira respeitosa e hábil para escutar os integrantes, e a consciência das suas intervenções verbais e não verbais. O local onde o grupo focal vai se realizar deve ser idealmente neutro, acessível, silencioso, não movimentado e composto de uma sala com cadeiras dispostas em círculo ou com uma mesa retangular ou oval com cadeiras. É comum a utilização de salões de igrejas, escritórios, salões comunitários, prédios públicos e escolas.

\subsubsection{A Condução do Grupo}

O sucesso para a boa condução de um grupo focal começa no momento inicial de acolhida já dos primeiros participantes e, ainda, sem seu convite, auxilia ao estreitar relações de confiança. Além de receber cada participante de maneira cordial, cabe ao moderador criar um ambiente agradável de espera e evitar ao máximo que o tema do grupo focal seja abordado precocemente em conversas informais, o que eventualmente pode "esfriar" a discussão no momento formal de coleta de dados. Quanto à experiência e aos antecedentes do moderador, observa-se que o conhecimento especializado no tema de estudo possibilita uma mediação mais fluida. É muito comum também a distribuição de uma folha de autopreenchimento visando obter informações básicas sobre os participantes (idade, sexo, profissão), para posterior controle da equipe de pesquisa, como pontua Morgan (1988), com a finalidade de obter dados acerca do tema da pesquisa. 
Uma vez iniciados os trabalhos, a palavra cabe primeiramente ao moderador, que vai apresentar-se e também aos outros membros (observador e relator) da equipe. Ele deverá expor os objetivos da pesquisa e do grupo de forma honesta, rápida e genérica, apresentar e explicar os objetivos do grupo e, em seguida, assegurar os participantes de que não existem opiniões corretas, que opiniões contrárias serão bem-vindas e que não há interesse em nenhuma opinião em particular.

O moderador pedirá aos participantes que falem um de cada vez e explicará que é permitido intervir na fala do outro, mas que devem ser evitadas interrupções desnecessárias. Segundo Morgan (Ibidem), a melhor maneira de introduzir o que se espera daquele grupo é francamente admitir que o moderador está lá para aprender. Só que este aprender deve ser colocado em termos de "entendimento incompleto" e não de total ignorância, o que obviamente pode soar falso. Também é importante explicar a forma de funcionamento do grupo e suas regras gerais. Deverá ser explicitamente enfatizado que não se busca consenso na discussão a ser empreendida e que a divergência de perspectiva e experiências é muito importante, além de salientar que a heterogeneidade das percepções ajudará em uma composição crítica da abordagem.

Em alguns casos, é importante solicitar consentimento ao grupo para efetuar a gravação e filmagem (em alguns casos pode-se utilizar esse recurso como mais um apoio para análise dos dados obtidos durante a aplicação do método) e dar garantia do total sigilo do material obtido. A condução do grupo focal se dará a partir de um roteiro de tópicos, relacionados primeiramente, às questões inerentes à realidade que se busca diagnosticar e conhecer ou da qual se busca extrair insumos. Como a proposta do método é desenvolver uma discussão focada em um tema específico, recomenda-se que esse roteiro contenha tópicos planejados com antecedência. Não é incomum a utilização de cartazes, figuras, filmes ou estórias como fontes de estímulo ao grupo.

Durante a condução do grupo, cabe ao moderador exercer os mais variados papéis, conforme Westphal (1996):
a) solicitar esclarecimento ou aprofundamento em pontos específicos;
b) conduzir o grupo para o próximo tópico quando um ponto já foi suficientemente explorado;
c) estimular os tímidos;
d) desestimular os tipos dominadores (que não param de falar);
e) finalizar o grupo. 
Ademais, o roteiro deve pautar a exploração inicial, destacando motivações, desejos e estilos de vida dos grupos, objetivando uma compreensão da linguagem e das perspectivas do grupo. Se possível, também deve incluir teste de conceitos e questões para futuras investigações quantitativas e a forma com a qual as questões balizarão a obtenção de informações sobre um contexto específico.

\subsubsection{Coleta, Análise e Avaliação dos Dados}

Os dados colhidos com a utilização da metodologia de grupo focal são de natureza qualitativa. Isso implica a necessidade de analisar os dados também de forma qualitativa, ou seja, não há tratamento estatístico sobre os dados e suas distribuições e análises estocásticas não são o foco do processo. Mas, há de se verificar um conjunto de procedimentos que visam organizar as informações e sua relevância, de modo que eles revelem, com as máximas objetividade e isenção possíveis, como os grupos em questão percebem e se relacionam com a questão (ou as questões) em pauta desenvolvida no grupo.

Morgan (1988) sugere duas formas de se proceder à análise, que são o sumário, acompanhado da codificação dos dados via análise de conteúdo, e a aglutinação de similaridades. Neste procedimento, há uma descrição das citações textuais dos participantes do grupo, que vão assim ilustrar os achados principais da análise e, por fim, enfatizar a descrição numérica de como determinadas categorias explicativas aparecem ou estão ausentes nas discussões e em quais contextos ocorrem. Cabe comentar que eles não são excludentes entre si, sendo possível combiná-los em um só relatório de análise, conforme aponta Carlini-Cotrim (1966). Por ocasião, o processo de análise acontece de modo simultâneo à coleta de dados.

Iervolino e Pelicione (2001) e Carlini-Cotrim (1996) concordam ao assumir que, por adotar um processo indutivo, em que as categorias e as hipóteses explicativas se formam a partir dos dados, é procedimento habitual de pesquisa qualitativa refletir sobre e analisar resultados parciais, visando adequar os procedimentos de coleta de dados aos objetivos da pesquisa. Iervolino (2001) reforça a ideia de que o método do grupo focal, conforme demonstrado nos relatos das experiências, pode, portanto, ser utilizado em estudos com diferentes propósitos:

a) criação de hipóteses sobre um assunto a partir da perspectiva dos informantes selecionados;

b) avaliação de um serviço ou intervenção de material instrucional; 
c) fornecimento de um quadro inicial para estudo de um campo até então não explorado cientificamente;

d) pesquisa exploratória ou diagnóstico preliminar;

e) obtenção da interpretação de um grupo sobre resultados quantitativos obtidos em estudo prévio;

f) contribuição para montagem e teste de questionários e escalas para projetos de pesquisas quantitativas.

A interação ocorrida pode fomentar respostas mais interessantes ou novas, assim como ideias originais. Da mesma forma, a pressão de participantes homogêneos facilita suas reflexões, ao mesmo tempo em que incita opiniões contrárias acerca de temas que têm a possibilidade de serem discutidos por todos os participantes.

\subsubsection{Abordagem Metodológica na Pesquisa de Grupos Focais}

Embora para alguns possa ser injusto julgar os estudos qualitativos sob a perspectiva quantitativa, e vice-versa, conforme salienta Smith (2000) - visto que se parte da premissa de que são distintos em seus pressupostos -, é importante fazer referência a algumas dessas críticas, tal como descritas por Fern (2001). Afinal, deve-se considerar sua utilidade para a reflexão daqueles que se aproximam não só das técnicas como também da abordagem qualitativa de pesquisa.

Além disso, cabe acrescentar que a técnica dos grupos focais é classificada como de natureza qualitativa, e seu uso não é privilégio dos teóricos construtivistas, de modo que há inúmeros esforços para ajustar a técnica às exigências de um modelo mais determinístico. Isso ocorre, pois, através dela, pode-se explorar desde a natureza da vida social, até questões técnicas e científicas observadas em experimentação. Ao contrário de temas sobre os quais ainda não se tem desenvolvido conhecimento adequado, os métodos qualitativos auxiliam na construção do objeto estudado. Contudo, algumas críticas dirigidas aos grupos focais se referem ao tamanho da amostra.

Uma das críticas se pauta na não representatividade, o que tornaria inviável a generalização para a população investigada. A rigor, os grupos focais são compostos a partir do que se convenciona chamar de amostras por conveniência, segundo Gondim (2003). Sua escala deve ser feita de acordo com o tipo de aplicação e a finalidade, e os resultados obtidos são de 
natureza de diagnóstico de percepções imediatas e locais. Ademais, as características gerais nem sempre são regras, e a consolidação de regras uniformes e parametrizadas não é o objetivo.

Outra justificativa encontra aporte no fato de a abordagem qualitativa estar comprometida com a compreensão e o entendimento do fenômeno, inseridos em um contexto específico e local, e, sendo assim, a representatividade estatística não é o mais importante. Novamente, Gondim (Ibidem) destaca que essa abordagem deve ter uma leitura de adaptação às necessidades de cada situação. Familiarizar-se com a questão investigada e o contexto de inserção dos participantes pode dar ênfase à determinação de quais conceitos devem ser medidos, e como devem ser medidos, com a abordagem quantitativa. Por sua vez, ela busca a explicação e os nexos causais necessários para se proceder a generalizações e descobrir novas possibilidades e dimensões da população de interesse. Nada impede, entretanto, que os grupos focais possam ser estratificados, quando se deseja minimizar as diferenças dentro dos grupos (homogeneidade) e maximizar as diferenças intergrupais (heterogeneidade). Isso depende dos objetivos do processo, segundo Gondim (Ibidem).

Outra crítica se dirige à falta de controle do desempenho do moderador. Admite-se a impossibilidade de controle, na medida em que cada grupo possui uma dinâmica particular que exige flexibilidade do moderador. A maior ou menor diretividade na condução dos grupos oscilará conforme os objetivos. A realidade que se objetiva é aquela em que não se desconsiderem, no grupo, potenciais alternativas de discussão, as quais demandariam alguma reflexão, conforme Gondim (Ibidem). As perguntas devem ser formuladas de maneira clara, concreta e precisa.

No processo, é fundamental contar com o sistema de preferência dos participantes, bem como o seu nível de informação sobre a questão e a escala progressiva, a qual se inicia com elementos simples e, ao fim, apresenta elementos mais complexos. Ela parte do pressuposto de que há uma construção educacional dentro do próprio processo e as questões mais delicadas no meio do instrumento, diluídas durante a realização do grupo, atenuando seu possível impacto de constrangimento e cooptação.

De forma crítica, há de se avaliar e analisar também um conjunto de elementos que, interrelacionados, permitam a construção de escalas de avaliação, que de alguma forma possam configurar uma métrica de acompanhamento, gestão e controle. Assim, a consolidação, no que se refere ao nível de resposta a ser considerado para efeito de análise nos grupos focais, é complexa, pois ele traduz um objeto local e unitário. Essa é a posição da maioria dos que atuam com grupos focais e decorre do fato de se presumir que a formação de opinião é fruto das 
interações sociais, e, portanto, há interdependência nas respostas, que não são, então, exclusivas de uma pessoa - pois emergem em um contexto particular de discussão grupal, sendo difícil diferenciar o que pertence a uma, em particular, por não se saber o efeito de um respondente na declaração feita por outro, como aponta Gondim (Ibidem).

No entanto, no cenário desta pesquisa e da proposta metodológica, busca-se atribuir uma quantificação a "constructos" ou fatores que não podem ser diretamente observáveis, além de permitir a simplificação das percepções locais. Desse modo, estas serão transformadas em dados, uma vez que tais elementos podem descrever as variáveis necessárias para descrever as necessidades locais. Outra questão crítica é dirigida às limitações de se comparar resultados dos grupos focais com os gerados por outras técnicas de investigação. No entanto, a abordagem comparativa não é o foco da análise: o estudo enfoca a indicação de uma efetividade da participação dos atores e seus impactos nos debates políticos e nas tomadas de decisão em planejamento urbano, em um espaço participativo de construção democrática, mais próximo de sua realidade e de seu contexto.

Não há controvérsia sobre a potencialidade dos grupos focais em gerar um volume de informações expressivo em curto espaço de tempo, quando comparados a outras técnicas. Fern (2001) adverte, contudo, que não há evidência empírica satisfatória em relação a isso, nem estudos suficientes que permitam comparar os resultados dos grupos focais com os de pesquisas que recorrem a outras técnicas. Todavia, é uma ferramenta poderosa para reduzir o constrangimento e focalizar um consenso em questões controversas, reduzindo os particularismos cuja sumarização da aplicação é descrita no quadro 5.

Defende-se, no entanto, que os esforços deveriam ser dirigidos inicialmente para o aperfeiçoamento do uso da técnica, visando demarcar seus limites e possibilidades, para depois centralizar as comparações de seus resultados com os produzidos por outras técnicas e abordagens de pesquisa, conforme aponta Gondim (2003).

Já existem desafios presentes que envolvem as temáticas da participação social e da construção de políticas públicas, cuja proposição de novas abordagens e instrumentos auxiliares, que atuem em consonância com os instrumentos legais, possibilite a compreensão e a explicação de padrões e perspectivas no processo de construção de políticas públicas de planejamento urbano. 
Quadro 5 - Sumarização dos Grupos Focais

\begin{tabular}{|c|c|c|c|}
\hline Quem participa & O que é decidido & Quem decide & Como decide \\
\hline \multicolumn{4}{|c|}{ Condução - Equipe de moderador e relator } \\
\hline Todas as pessoas & $\begin{array}{l}\text { Estruturação de } \\
\text { ações diagnósticas; } \\
\text { levantamento de } \\
\text { problemas para o } \\
\text { planejamento de } \\
\text { atividades; } \\
\text { formação educativa } \\
\text { e colaborativa acerca } \\
\text { de um tema }\end{array}$ & $\begin{array}{l}\text { Deve-se considerar } \\
\text { um conjunto de } \\
\text { elementos que } \\
\text { garantam seu pleno } \\
\text { desenvolvimento; } \\
\text { as pessoas que } \\
\text { fornecem focalizam } \\
\text { os temas e } \\
\text { consensualmente } \\
\text { determinam as } \\
\text { alternativas }\end{array}$ & $\begin{array}{c}\text { O planejamento com } \\
\text { cenários pode } \\
\text { apresentar variações } \\
\text { no enfoque } \\
\text { qualitativo ou } \\
\text { quantitativo, } \\
\text { ressaltando que os } \\
\text { participantes devem } \\
\text { ter vivência com o } \\
\text { tema a ser discutido, } \\
\text { propiciando riqueza } \\
\text { na troca de } \\
\text { informações e coleta } \\
\text { de percepções }\end{array}$ \\
\hline \multicolumn{4}{|c|}{$\begin{array}{l}\text { Deve-se considerar seu pleno desenvolvimento como: recursos necessários, número de } \\
\text { participantes e grupos, perfil dos participantes, processo de seleção dos participantes e } \\
\text { tempo de duração. }\end{array}$} \\
\hline
\end{tabular}

Fonte: Do autor (2019).

Há de se pensar em metodologias - e o grupo focal é uma alternativa neste sentido - que envolvam, simultaneamente, sociedade civil e instituições políticas, em espaços que vão da homogeneidade à heterogeneidade e não são analisados única e exclusivamente a partir dos espaços institucionais de participação. Na atuação junto a comunidades, os grupos focais podem auxiliar na compreensão dos grupos sociais desfavorecidos e nas ações comunitárias. Ou seja, os pesquisadores encontram nos grupos focais uma técnica que os ajuda na investigação de crenças, valores, atitudes, opiniões e processos de influência, bem como se obtém suporte para a geração de hipóteses, a construção teórica e a elaboração de instrumentos.

\subsection{A CARTOGRAFIA PARTICIPATIVA E FALANTE}

Conforme Neto, Silva e Costa (2016), a complexidade inerente aos cenários de intervenção social em áreas urbanas se apresenta como dimensão de análise que requer leituras que ultrapassem as meras descrições quantitativas, segundo Carballeda (2012) e Neto, Silva e Costa (2016). Dirigir a ótica para a realidade local, dentro de uma cidade, tem sua relevância, uma vez que sua delimitação se desconecta dos limites legais ou administrativos, configurando- 
se uma formação de situações históricas, ambientais, sociais, econômicas, territoriais, físicas e culturais que promovem condições particulares para a produção de demandas inerentes a cada região. Este espaço é o espaço da produção das rotinas da vida, e onde são latentes as questões urbanas mais próximas à realidade das pessoas, o espaço que deve ser coletivamente formado.

Nesse contexto, a construção de mapas colaborativos, participativos em abordagens inerentes a uma cartografia social, configura-se como um procedimento metodológico que visa à construção de mapas, levando-se em consideração múltiplas dimensões. Os saberes e a relação coletiva e participativa, necessários para a produção do conhecimento presente no território, quando aplicados em grupos focais, podem ser uma estratégia de multiplicação e territorialização de percepções, saberes, demandas e insumos que balizam estratégias locais de planejamento urbano.

Tetamanti (2012) acentua que os mapas elaborados sob estas características seguem um conjunto de representações do cotidiano dos grupos sociais com a incorporação dos aspectos naturais, culturais e ideológicos, bem como a demonstração de conflitos existentes no território. Eles são importantes para o trabalho de planejamento urbano e já têm sua aplicação consolidada, em pesquisas ligadas a geografia, saúde pública e questões ambientais, como apontam Pussinini, Pidorodeski e Toledo (2012).

As iniciativas de mapeamentos participativos difundiram-se mundialmente no início da década de 1990 com a participação de organizações não governamentais (ONGs), associações indígenas, organismos multilaterais e de cooperação internacional, fundações privadas, universidades, entre outras - apontam Acselrad e Coli (2008) e Acselrad (2015). Esse mapeamento participativo deve estar fundamentado na transposição didática dos conceitos, fundamentos e técnicas aliados à população que vai realizar o processo de mapeamento. Os grupos sociais são protagonistas do mapeamento e contribuem para as características territoriais.

Para a realização do mapeamento participativo, é necessário escolher o público-alvo buscar, recrutar e conversar com pessoas que são ligadas à localidade desejada, e que tenham a vivência do cotidiano. Após essa seleção, deve-se ter uma primeira conversa com todos que participarão do mapeamento, explicando, passo a passo, como será a confecção dos mapas e quais serão os objetos que eles utilizarão para a plotagem de informações. Logo, deve ficar bem claro que os mapas serão demarcados por eles, que devem demarcar seus locais de convívio, de lazer, trabalho e até de conflitos/ problemas (ambientais, sociais etc.). 
Para Gorayeb (2014) e Gorayeb, Meireles e Silva (2015), a participação na construção do mapa é uma forma de fortalecer a mobilização de grupos que se apropriam de uma ferramenta, a cartografia, para uso de seus interesses. Além disso, a participação dos grupos mobilizados não se restringe à confecção dos mapas, pois, a partir do processo de construção desses mapas, as demandas são fortalecidas e há o reconhecimento de direitos, o que pode direcionar a estratégias de atuação coletiva.

Cada situação de mapeamento tem seus próprios objetivos. Uma classificação possível, entre tantas outras, dos objetivos presentes nos processos de mapeamento participativo realizados no Brasil, pode ser a seguinte:

a) busca por legitimidade;

b) busca por informações mais precisas;

c) busca pelo fortalecimento da mobilização dos grupos.

O mapeamento participativo é a criação de mapas pela comunidade local, em muitos casos envolvendo organizações de suporte, como o governo (em diversos níveis), organizações não governamentais (ONGs), universidades e outros agentes envolvidos no desenvolvimento e no planejamento as áreas urbanas. Trata-se de um processo de produção de mapas que objetiva tornar visível a associação entre o espaço urbano, o $\operatorname{lugar}^{53} \mathrm{e}$ as comunidades locais, ao usar a linguagem comumente entendida e reconhecida da cartografia, partindo do local e expandindose ao global.

Existem vários procedimentos para executar a envolver a população de forma ativa ao território, tais como o mapa mental, o mapa falante, fotografias aéreas e imagens de sensoriamento remoto, sistema de informação geográfica (SIG) e outras tecnologias, até mesmo desenhos sobrepostos a mapas e delimitações oficiais. Esse tipo de mapeamento pode ajudar a comunidade a identificar suas principais formas de representação da realidade, utilizando apenas folhas grandes de papel e canetas coloridas. Nesse procedimento, os participantes do mapeamento têm a chance de escolher quais materiais utilizarão e quais itens acham relevantes para representar nos mapas, avaliando suas formas e como elas serão desenhadas - e sua variação pode estar diretamente ligada ao grau de importância dessas questões e demandas para a comunidade.

\footnotetext{
${ }^{53}$ No contexto desta pesquisa lugar é o espaço dotado de valor pelo homem, e este está contemplado naquele, em presença física e/ou simbólica. O lugar é o espaço ocupado, ou seja, ,habitado. Lugar (do latim localis, de lócus), este é o "espaço ocupado, localidade". CABRAL, L.O. Revisitando as noções de espaço, lugar, paisagem e território, sob uma perspectiva geográfica. Revista de Ciências Humanas, Florianópolis, EDUFSC, v. 41, n. 1 e 2, p. 141-155,2007.
} 
O mapa não se preocupa em representar medidas exatas, escalas consistentes e georreferenciadas, já que está aberto para interpretação do sujeito sobre sua realidade e dá chance para esse sujeito representá-la. A ideia do mapa falante vem do entendimento de território e de lugar como espaço do cotidiano, e pode ser um instrumento para fazer a leitura da realidade em suas múltiplas dimensões, a partir do território, e contribuir com um material gráfico para compreensão da mesma.

Segundo Chambers (2006), independentemente da forma e dos meios para executar o mapeamento participativo (no chão, no papel ou em SIG), a natureza dos resultados dependerá das atitudes e do comportamento dos facilitadores e de quem controla o processo, influenciando na tomada de decisão dos resultados. O mapeamento participativo, como metodologia de análise do território, pode auxiliar no processo de aplicação da metodologia em campo e na elaboração do mapa síntese com as informações representadas. Silva e Verbicaro (2016) ressaltam que para uma boa aplicação da metodologia, um bom relacionamento do pesquisador com a comunidade é a chave para o sucesso.

Esse relacionamento deve conter três ingredientes importantíssimos: transparência, tempo e confiança. Caso contrário, o processo de mapeamento participativo poderá se tornar improdutivo ou até mesmo inviável. Portanto, é necessário manter-se transparente na abordagem, sendo aconselhável promover reuniões para definir e expor a metodologia. Devese também utilizar uma linguagem simples, clara e criativa que envolva todos os participantes.

Outro ponto que vale ressaltar é a importância do planejamento das atividades. O pesquisador deverá verificar e selecionar os conteúdos a serem representados (áreas de lazer, conflitos, comunitárias/coletivas, festas, religião etc.), bem como objetivos, metodologias de coleta de informações, materiais e equipamentos necessários, textos de apoio e a definição do público-alvo que participará da elaboração dos mapas. A realização de reuniões coletivas com os indivíduos pode ser eficaz se tiver, além da elaboração dos mapas, outro objetivo, como as reuniões de organizações sociais, religiosas ou escolares, que agregam os participantes para a resolução de conflitos ou a discussão de assuntos de interesse coletivo.

Silva e Verbicaro (Ibidem) ainda salientam que o pesquisador deve possuir o conhecimento prévio sobre o assunto que será coletado e sobre as características gerais da região pesquisada, pois é necessário o conhecimento antecipado dos costumes, principais ocupações dos moradores, meios de transporte, alimentação etc., para serem debatidos e inquiridos antes do início da coleta de informações. Envolver-se na comunidade e construir relações de confiança é uma das etapas do processo participativo, no qual, de antemão, é 
importante verificar se os conceitos e categorias discutidos e apresentados para a elaboração dos mapas participativos são aceitos pela comunidade, como forma de evitar a indução ao erro e/ou a representação incorreta no mapa gerado.

Antes de iniciar a aplicação da metodologia, os facilitadores precisam verificar a infraestrutura onde serão realizadas as reuniões, pois é importante possibilitar a participação de todos os moradores que desejam representar cartograficamente suas atividades ou seu modo de vida. É necessária uma apresentação das noções básicas de localização, escala e outros conceitos - uma das tarefas inseridas no momento explicativo do Método Altadir de Planejamento Popular (MAPP) -, de forma clara e didática, para enfatizar a importância dessa metodologia como forma de fortalecer a necessidade do mapeamento do território. Segundo Silva e Verbicaro (Ibidem), durante o procedimento de plotagem das informações, a equipe de facilitadores tem como finalidade escutar os participantes, encorajá-los, realizar perguntas, sondar e, principalmente, não interferir com preconceito de origem, etnia, gênero, religião, idade ou condição socioeconômica. Afinal, a ênfase nesses temas pode gerar novos conflitos, inexistentes antes da aplicação da metodologia participativa. O foco, nessa abordagem, são questões ligadas ao planejamento urbano.

A equipe deve promover, durante a elaboração dos mapas participativos, atividades de inclusão e discussão em grupo, que permitirão aos indivíduos analisar de forma crítica os seus modos de vida e sua participação na comunidade. No decorrer da aplicação do procedimento, os mediadores devem atentar para falta de precisão e diferentes escalas, além de ter cuidado com as generalizações acentuadas. É necessário ter cautela também com a influência da visão parcial do moderador, pois a visão do entrevistado/ mapeador deve ser valorizada, e, ao transformar os dados em informação, os símbolos utilizados devem ser reconhecidos por todos os participantes. Outro ponto importante que precisa ser executado em campo é a verificação das informações coletadas, entre elas a identificação pessoal e a de feições conhecidas aos moradores, como sugerem Silva e Verbicaro (Ibidem). Assim, é recomendada uma acareação das informações coletadas com mais de um morador para evitar informações incorretas ou inverídicas.

No procedimento de mapeamento com base cartográfica, é necessário ter vários mapas base da área estudada, em branco e impressos, para a coleta de diversas informações e sobreposição posterior, com a digitalização e vetorização em software de geoprocessamento. Se a técnica utilizada for o mapeamento com a carta-imagem, deve-se procurar imagens de 
sensores óticos (coloridas), que apresentem cores e tonalidades percebidas próximas do real, ao contrário de imagens de sensores de micro-ondas (radar), que informam tons de cinza.

O moderador deve definir critérios e parâmetros próprios adequados para a comunidade pesquisada, pois o uso de símbolos, ferramentas e outras técnicas é diferenciado de acordo com a comunidade estudada. Silva e Verbicaro (Ibidem) recomendam construir uma simbologia na própria comunidade, no momento do mapeamento, referindo-se sempre à representação cartográfica da realidade mapeada. Por último, o moderador deverá apresentar o mapa final para as comunidades participantes para confirmação da veracidade das informações. A disponibilização de diversas cópias do mapa final elaborado para a comunidade deve servir como ferramenta de reconhecimento e reafirmação do uso do território em documentos oficiais.

\subsubsection{Mapas Falantes}

O mapa falante, segundo Pelicioni (2000) e Toledo (2005), é uma técnica de representação gráfica de uma situação problematizada da realidade comunitária, a qual deve ser elaborada coletivamente por pessoas interessadas em conhecer e resolver problemas identificados. A finalidade dessa técnica é a valorização das palavras, ou seja, a comunicação das pessoas dentro do campo de experiências, o que permite um esclarecimento e uma compreensão do particular e do social coletivo, além de contribuir como exercício de percepção do espaço e da interpretação da realidade social dos agentes envolvidos com a pesquisa.

Essas recomendações podem servir como suporte ao moderador durante a aplicação de técnicas de mapeamento participativo do território. Sabemos que existirão sugestões próprias e outras que o pesquisador encontrará somente em campo. Assim, a aplicação do mapeamento participativo não é uma receita terminada, a ser seguida cegamente. Antes de tudo, é uma metodologia de análise territorial que precisa ser entendida e adequada à realidade em foco, como salientam Silva e Verbicaro (2016).

Essa representação gráfica, de uma situação problematizada da realidade comunitária, deve ser elaborada coletivamente por pessoas interessadas em conhecer e resolver problemas identificados, segundo Pelicioni (2000). É recomendável a sua aplicação quando se deseja a participação da população na realização do diagnóstico da situação da comunidade e na formulação de planos e programas de ações, visando mudar a situação diagnosticada, conforme quadro 6. 
Quadro 6 - Sumarização da Cartografia Participativa e de Mapas Falantes

\begin{tabular}{|c|c|c|c|}
\hline Instrumento & $\begin{array}{c}\text { Quem } \\
\text { participa }\end{array}$ & O que é decidido & Como decide \\
\hline $\begin{array}{c}\text { Cartografia } \\
\text { Participativa ou } \\
\text { Mapa Falante }\end{array}$ & $\begin{array}{l}\text { Todas as } \\
\text { pessoas }\end{array}$ & $\begin{array}{c}\text { São mapas } \\
\text { colaborativos e } \\
\text { desenhos; o } \\
\text { mapeamento } \\
\text { participativo busca um } \\
\text { público que tenha } \\
\text { contato com a } \\
\text { realidade local, e o } \\
\text { mapa falante a } \\
\text { apresentação gráfica } \\
\text { de uma percepção }\end{array}$ & $\begin{array}{l}\text { Após a coleta de dados de } \\
\text { determinada região, é } \\
\text { recomendada a participação da } \\
\text { população na realização do } \\
\text { diagnóstico da situação da } \\
\text { comunidade e na formulação de } \\
\text { planos e programas de ações, com } \\
\text { desenhos, colagens, mapas e } \\
\text { demais artifícios gráficos }\end{array}$ \\
\hline
\end{tabular}

Fonte: Do autor (2019).

Cada participante deve desenhar o lugar onde vive, sua casa e/ou o entorno, incluindo elementos importantes de sua vida familiar, vizinhos e amigos. Esses desenhos serão fixados em uma parede. Podem também ser anotadas informações que os participantes julgarem necessárias nos desenhos. Utilizar gravuras de revistas e jornais pode ser uma alternativa, caso os participantes demonstrem alguma resistência em desenhar. Quando todos terminarem, os participantes poderão explicar seus desenhos ou fazer comentários sobre os outros.

A discussão sobre o tema objeto do Mapa Falante será, então, estimulada pelo coordenador, de modo a aprofundar a reflexão sobre as causas e consequências do problema, anotando-se ou gravando as conclusões, como sugere Pelicioni (2000).

\subsection{ABORDAGEM ESTRATÉGICA DE PLANEJAMENTO}

Segundo De Toni, Salermo e Bertini (2008), é comum observar, em diversos grupos organizados da sociedade civil, como sindicatos, partidos, associações e grupos técnicos, mas também em âmbito estatal, a quase permanente frustração em relação ao cumprimento de objetivos. Afinal, as metas traçadas pelo próprio grupo eventualmente não são atingidas na sua integralidade ou não refletem as necessidades dos indivíduos.

Mesmo em atividades mais simples, até nas mais complexas, percebe-se improvisação nas práticas de planejamento e gestão, principalmente nas organizações sociais. A rotina diária e os acontecimentos cotidianos determinam as condutas, e os resultados nem sempre são previstos de forma analítica, resultando em ineficiência das atividades e ineficácia das ações. 
De Toni, Salermo e Bertini (Ibidem) ainda sugerem que isto acontece principalmente porque os métodos de planejamento possuem baixa eficiência (desperdício de recursos) e baixa eficácia (não atingem os resultados).

Nesta conjuntura complexa, a forma de planejar e conduzir as ações é dirigida unicamente pela visão normativa, linear e mecânica, enquanto as consequentes análises da realidade e de seu contexto são triviais e imediatistas, conforme a direção momentânea dos próprios grupos. Para tentar corrigir essas deficiências e construir um modelo estratégico aderente a um contexto construtivista, o economista chileno Carlos Matus $(1987,1991)$ propôs um método alternativo de planejamento estratégico conhecido como "Método Altadir de Planejamento Popular" (MAPP). Este enfoque metodológico foi constituído a partir das reflexões originais enquanto foi ministro do Governo Allende, no Chile, no decorrer dos anos 1970 e $1980^{54}$, publicando a obra "Planificación de Situaciones “, em 1980.

O MAPP tem sido utilizado no contexto brasileiro principalmente nos sindicatos de trabalhadores e nas entidades dos movimentos sociais populares. Ele vem se constituindo como uma ferramenta de organização de grupos e estratégias, apoiando a melhoria dos níveis de gestão interna com uma abordagem mais clara e construindo um projeto planejado de longo prazo.

Segundo De Toni, Salermo e Bertini (2008), a crítica ao planejamento normativo e sua tradição normativa, isto é, determinística, deve-se a sua atuação linear sobre a realidade, sem conceber a existência de outros atores sociais ou da multiplicidade de recursos disponíveis e necessários para execução das ações planejadas. O enfoque normativo de planejamento, fortemente enraizado na cultura estatal, pode ser caracterizado pelos seguintes pressupostos (RIVERA, 1992):

a) o planejamento supõe um objeto e um sujeito independentes, e o sujeito está colocado fora da realidade, que é um sistema incontrolável;

b) o planejamento procura conhecer a realidade através do "diagnóstico" e se orienta pela busca da "verdade objetiva", "científica", considerando que só há uma "verdadeira explicação" para fatos e acontecimentos, um único diagnóstico;

\footnotetext{
${ }^{54}$ Carlos Matus dirigiu uma fundação na Venezuela denominada Fundação Altadir (de Alta Direção), de onde deriva o nome do método. O MAPP é uma "versão simplificada" do método PES (Planejamento Estratégico e Situacional), como é conhecido no Brasil, destinado originalmente ao trabalho com grupos populares. Carlos Matus faleceu em 1998, após diversas cooperações com FIOCRUZ, CUT, DIEESE e INAP. As pesquisas que abordam seu método são conhecidas no meio acadêmico como pesquisas de enfoque matusiano.
} 
c) a realidade apresenta comportamentos sociais estáveis e previsíveis, passíveis de serem estudados através de modelos analíticos ou de causalidade das ciências naturais (existe uma "realidade objetiva");

d) como a realidade é "objetiva", a única normatividade possível é a econômica, enquanto o elemento político é um dado exógeno ou, no máximo, uma mera restrição;

e) o planejamento normativo trabalha com a noção de sistema com final fechado, em que só há uma chegada e uma única possível trajetória.

A simplificação do planejamento estratégico, estruturado pelo MAPP, faz uma crítica radical a esses pressupostos, afirmando exatamente o oposto:

a) o sujeito está dentro do objeto, e existe "o outro" que participa (grifo do autor) com ele no sistema, de modo que há uma relação entre atores sociais;

b) toda explicação é dita por alguém a partir de uma situação específica, e há mais de uma explicação verdadeira sobre a mesma realidade (grifo do autor), não há uma "verdade objetiva”, ou seja, uma explicação situacional é a apreciação de uma situação estando-se consciente da explicação dos outros atores;

c) explicar (ao invés do diagnóstico normativo) implica compreender como os outros atores sociais criam suas possibilidades num sistema criativo (grifo do autor) de vida social - nem sempre há leis para descobrir, a capacidade de prever é limitada pelo universo de variáveis conhecidas, e há a necessidade de trabalhar com cenários, não só variáveis e diagnósticos;

d) o poder é sempre um recurso escasso, porque os outros atores sociais também o possuem e o utilizam, de modo que esta utilização pelos outros estabelece limites à viabilidade do “dever ser" de um ator, e que a negociação e o consenso são intrínsecos ao processo de decidir;

e) o plano é fundamentalmente um "sistema de apostas" bem fundamentadas, combinando apostas difusas com grande incerteza, enquanto o final é sempre aberto, um sistema probabilístico e não determinista;

f) a normatividade econômica não é a única, e a viabilidade política passa a ser um elemento endógeno ao plano e à sua execução.

Para utilizar o enfoque estratégico de planejamento é necessário, portanto, reconhecer a existência de outros atores sociais, de modo que a eficácia do projeto planejado depende da eficácia da tradução em planos dos objetivos dos demais atores. O planejamento de 
organizações sociais sempre é um planejamento de Sistemas Complexos ${ }^{55}$, ou seja, é preciso lidar com a forte incerteza, com a diversidade de recursos, com as surpresas e o desconhecido. O MAPP pressupõe a análise da realidade social como um jogo criativo, dinâmico e de final aberto.

\subsubsection{Os Momentos de Elaboração do Planejamento}

De Toni, Salermo e Bertini (2008) apontam que, antes de ser um método pronto e acabado, o planejamento participativo, estratégico e com enfoque sistêmico, deve ser visto muito mais como um enfoque metodológico dinâmico e fluido, a ser adaptado em cada cenário e assim ajustado a cada contexto específico. Os "momentos" - ou seja, as etapas estruturadas para aplicação do MAPP não são enfoques baseados em etapas independentes, mas fazem parte de um processo constante de permanente aprendizagem, cálculo e recálculo. Admite-se que diante das incertezas eles podem se repetir incessantemente, em um processo contínuo de planejamento, sempre se ajustando ao contexto, ao lugar e ao tempo.

De Toni, Salermo e Bertini (2008) e Matus $(1987,1991)$ sugerem quatro momentos do MAPP: (a) Momento Explicativo ("a hora da verdade"); (b) Momento Normativo ("a hora do desejo"); (c) Momento Estratégico (“a hora do poder”); e (d) Momento Tático-Operacional (“a hora de fazer"). Tais momentos são explicados a seguir:

a) Momento Explicativo: equivale a um diagnóstico do enfoque normativo-tradicional. Parte da compreensão de que um ator social possui problemas que demandam análises e soluções, e é a partir deles que se deve explicar situacionalmente a realidade. Deve-se montar um fluxograma, onde o problema selecionado seja decomposto em causas, descritores e consequências. Esta tarefa pode favorecer a criação de relação de dependência entre descritores de critérios e de objetivos, que podem possuir uma natureza multicriterial. Para os atores, neste momento, essas questões são explicadas segundo seus valores, objetivos e conduta.

As causas dos problemas podem ser decompostas em toda sua complexidade, constituindo, elas mesmas, subproblemas. Explicar significa, neste caso, manifestar uma intencionalidade real e factível de ação, é possível entender este momento a partir da frase

\footnotetext{
${ }^{55}$ Os sistemas complexos são compostos de muitos elementos e agentes que interagem entre si, tendo as mesmas ou diferentes estratégias, e com o ambiente. As interações entre esses muitos agentes resultam em um comportamento de alta ordem, ou seja, um comportamento mais inteligente. Embora esses sistemas não tenham um controle central, auto organizam-se de forma coerente, segundo Kauffman (1992, 1995) e Mitchell (2011).
} 
“explico o problema para mudar as suas causas". A identificação das causas é essencial, pois não se atua sobre as consequências ou descritores (sintomas) de um problema, contudo estes descritores contribuem para a desparticularização das questões, construindo relações de confiança e consenso. Essas causas fundamentais do problema são denominadas de "Nós Críticos". O principal produto deste momento é o que se denomina “Árvore do Problema”, onde todos podem visualizar (em tarjetas ou cartelas), com abordagens ligadas a mapas cognitivos, desenhos, redes de grafos, entre outros, toda a rede causal que envolve determinado problema e quais são aquelas causas fundamentais, sobre as quais será fundamentada a vontade de mudança, além das operações e ações do Plano.

Há duas diferenças com relação ao enfoque normativo do "diagnóstico" tradicional: em primeiro lugar, evita-se o costume de simplesmente descrever e listar problemas confundindo causas, consequências e sintomas; a outra é a continuidade do momento explicativo que não cessa nunca (é situacional), já que a realidade, os atores e os próprios planos estão sempre em mutação, principalmente em relações participativas de construção perene e coletiva. Nesse momento, o ator, que já é decisor também, define uma situação objetivo, ou seja, o diagnóstico neutro e o bom, escala que é concretizada nas abordagens multicriteriais, onde quer se chegar situacionalmente, lembrando que na vida concreta não "resolvemos" problemas, apenas os intercambiamos por problemas menores e menos complexos.

A situação "objetivo" é o inverso da situação "inicial”, isto é, ao invés da Árvore do Problema, construímos uma Árvore de Resultados, na qual, a partir dos objetivos centrais (problema visto como solução), define-se a rede de objetivos complementares necessários para atingi-las (as causas vistas como objetivos/soluções parciais em relação ao problema);

b) Momento Normativo: é o desenho do "dever ser" do plano. Este é o aspecto principal do planejamento tradicional, e agora ele passa a ser apenas mais um momento no enfoque estratégico, enquanto o Momento Explicativo é o momento do "foi", do "é" e do "tende a ser". Nota-se que a abordagem colaborativa é construtivista e atua de forma pedagógica. Cada momento reúne insumos e os distribui em um espaço participativo, uniformizando os saberes.

Agora, elevado o nível de conhecimento acerca do problema e de suas características, tem-se um novo momento, o do "deve ser", isto é, da manifestação da intencionalidade do ator, de sua vontade de mudar as coisas, atuando sobre a raiz dos seus problemas (os 
“Nós Críticos"). Afere-se, dentre outras percepções, as próprias dificuldades inerentes à execução dos planos e ações, mede-se o nível de engajamento dos atores e decisores e a verificação de objetivos atingíveis.

Quando se desenha as operações para enfrentar e "desatar" os Nós Críticos, deve-se interrogar sobre a eficácia direcional do que está se fazendo. Isto implica em desenhar operações com poucos recursos (políticos, econômicos, cognitivos, humanos etc.), considerar o produto e o resultado de cada operação, detalhá-la em ações coerentes e compatíveis, analisar a eficiência (relação entre recursos e produto) e a eficácia (relação entre produto e resultado) de cada operação. Quanto mais simples forem os recursos alocados em cada operação, mais tangíveis serão as ações operacionais.

Planejar estrategicamente requer um "cálculo interativo" que concebe o resultado dos processos sociais como produto do conflito entre os diversos planos, requer uma apreciação situacional, de repetições de cenários. Esta apreciação pode ser entendida como um "texto" explicativo situado num "contexto" explícito que completa seu significado. Os diversos atores sociais escolhem seus planos, mas não as condições nas quais são feitos e executados, daí a importância de trabalhar com diversos cenários e submeter o conjunto das operações a cada um deles, readequando sua eficiência e eficácia, analisando o comportamento e enumerando possíveis surpresas (nem todas podem ser imaginadas).

O planejamento, agora transformado em um conjunto de operações, deve conduzir (não deterministicamente) à situação objetivo definida pelo grupo para isso. Deve-se, ainda, hierarquizar as operações, abordagem na qual são aplicáveis modelos multicriteriais, incorporando a subjetividade e a escala semântica de preferência de um elemento a outro, de forma a analisar seus múltiplos impactos no problema (a realidade sempre é multidimensional), verificar sua vulnerabilidade (os pressupostos de cada uma) e considerar as limitações de tempo, recursos etc.;

c) Momento Estratégico: é o momento do "pode ser" (do que é possível ser realizado) e do "dever ser" (do que de fato se almeja). É o momento em que se deve construir a viabilidade estratégica para a execução do programa direcional verificado no momento normativo, resultado do diagnóstico do momento explicativo. Esse é o momento de poder analisar a possível reação de cada ator social diante do plano, prever estratégias de cooperação, cooptação, conflito, negociação ou confronto. Neste momento, o plano é avaliado e discutido, e as relações de controle social são implementadas. Para isso, é necessário identificar quais são os reais interesses dos demais atores sociais (grupos, 
organizações etc.) envolvidos no problema, para identificar possíveis aliados, oponentes e aqueles que são indiferentes.

As relações de confiança são solidificadas. Para cada uma serão necessária estratégias diferenciadas. Neste momento, deve-se responder a quatro questões básicas: "com quem?” (política de alianças); “para quê?” (operações e resultados que devem ser obtidos com a estratégia); "como?” (combinações de estratégias a serem adotadas: autoridade, negociação, confrontação); e "com que possibilidade de êxito?" (análise dos riscos envolvidos em cada opção e balanceamento das trajetórias de menor perda);

d) Momento Tático-Operacional: é o momento do "fazer", no qual tudo se decide, pois, o plano só se completa na ação concreta. É o momento em que duas poderosas forças se encontram: de um lado, a força "dos fatos", a "correnteza" do dia a dia, as urgências, o reino da improvisação; do outro lado, o cálculo interativo que precede e preside a ação, o planejamento consciente, a apreciação situacional. Nesse embate criativo e dinâmico são gerados os fatos sociais (intrinsecamente políticos). Enquanto os momentos anteriores constituem análises, desenhos e simulações que não perturbam a realidade, este momento incide diretamente sobre ela como parte dela mesma.

Distinguem-se agora várias tarefas: apreciação da situação conjuntural (avaliar a realidade, a direção do planejamento, fatos e processos novos); pré-avaliação das decisões possíveis (confrontar o desenho das operações e ações e verificar quais são, naquele momento, mais eficazes); tomada de decisões e execução (através de meios de gestão e direção organizacional apropriadas, de critérios econômicos e políticos, executar o planejado de acordo com cada cenário analisado); e pós-avaliação das decisões tomadas (é a comparação entre os efeitos esperados e os realizados sobre o problema e em relação à situação objetivo). Estas tarefas estão permanentemente se retroalimentando, isto é, juntas constituem uma dinâmica (como numa espiral) incessante em direção aos objetivos traçados.

Admite-se que planejar não é só calcular sobre o futuro, mas também dominar a arte e a ciência de conduzir e governar, aumentando progressivamente a governabilidade sobre os fatos sociais nos quais o ator social que planeja está completamente imerso; por fim, é reforçada a governança participativa. Os esforços concentram-se no presente, para ter racionalidade no "hoje". Deve-se, contudo, imaginar objetivos considerando um determinado horizonte temporal, como por exemplo de um a cinco anos no futuro. A construção de cenários colaborativos de curto, longo e médio prazo é uma estratégia para o accountability do plano. Entretanto "olhar para frente" não é suficiente, pois deve-se 
aprender com o passado, "olhar para trás" com frequência, para melhorar o cálculo sobre o presente em direção aos objetivos futuros.

Neste momento, são analisados, junto ao grupo, quais são os sistemas de gestão e responsabilização existentes (são de baixa ou alta responsabilidade?). O MAPP requer alta responsabilidade no gerir. Isto significa organizações que têm sistema de prestação de contas de alto a baixo (ninguém fica sem pedir ou prestar contas nos diversos níveis), sem dúvida, com enfoque Bottom-up e Top-Down, simultaneamente, controle da agenda da direção onde as "urgências" deem lugar às "importâncias" e onde o planejamento seja feito através do processamento técnico-político de problemas (gerência por operações).

O MAPP pode ser sumarizado em 15 passos elaborados em cada um dos momentos específicos de análise, que podem ser sumarizados no quadro 7.

Quadro 7 - Momentos de MAPP - Passos

\begin{tabular}{|c|c|c|c|}
\hline Explicativo & Normativo & Estratégico & Tático operacional \\
\hline $\begin{array}{l}\text { 1- Seleção dos } \\
\text { problemas do } \\
\text { plano }\end{array}$ & \multirow{2}{*}{$\begin{array}{c}\text { 6- Desenho das } \\
\text { operações e demanda } \\
\text { das operações }\end{array}$} & $\begin{array}{l}\text { 9- Avaliação e } \\
\text { cálculo dos recursos } \\
\text { necessários para } \\
\text { desenvolver as } \\
\text { operações }\end{array}$ & \multirow{6}{*}{$\begin{array}{l}\text { 15- Desenho do } \\
\text { sistema de prestação de } \\
\text { contas }\end{array}$} \\
\hline $\begin{array}{c}\text { 2- Descrição do } \\
\text { problema }\end{array}$ & & $\begin{array}{l}\text { 10- Identificação de } \\
\text { atores sociais } \\
\text { relevantes e sua } \\
\text { motivação frente ao } \\
\text { plano }\end{array}$ & \\
\hline $\begin{array}{l}\text { 3- Explicação } \\
\text { do problema: } \\
\text { Árvore de } \\
\text { problemas }\end{array}$ & \multirow{2}{*}{$\begin{array}{l}\text { 7- Definição das } \\
\text { responsabilidades } \\
\text { pelas operações }\end{array}$} & $\begin{array}{l}\text { 11- Identificação de } \\
\text { recursos críticos para } \\
\text { desenvolver as } \\
\text { operações }\end{array}$ & \\
\hline $\begin{array}{l}\text { 4- Desenho da } \\
\text { situação } \\
\text { objetivo }\end{array}$ & & $\begin{array}{l}\text { 12- Identificação dos } \\
\text { atores que controlam } \\
\text { recursos }\end{array}$ & \\
\hline \multirow{2}{*}{$\begin{array}{l}\text { 5- Seleção dos } \\
\text { nós críticos }\end{array}$} & \multirow{2}{*}{$\begin{array}{c}\text { 8- Definição dos } \\
\text { responsáveis pelas } \\
\text { demandas de operação }\end{array}$} & $\begin{array}{l}\text { 13- Seleção de } \\
\text { trajetórias }\end{array}$ & \\
\hline & & $\begin{array}{c}\text { 14- Análise de } \\
\text { vulnerabilidade do } \\
\text { plano }\end{array}$ & \\
\hline
\end{tabular}

Fonte: Do autor (2019).

O MAPP constitui-se, portanto, num instrumento metodológico no qual os resultados efetivos de sua aplicação aparecem quando ele deixa de ser um método simplesmente (com suas regras e nomenclatura) para ser enraizado nos processos dinâmicos e participativos, 
incorporado às particularidades e ao cotidiano da vida dos grupos que o utilizam. Outras características são sua capacidade de flexibilização e adaptação e a aplicação universal de seus princípios, integral ou parcialmente.

Também, nesse enfoque, é possível associar a participação da sociedade civil com especialistas em cada momento, conforme distribuído no quadro 8.

Quadro 8 - Distribuição de Participantes em Passos e Momentos

PARTICIPANTES EM CADA MOMENTO

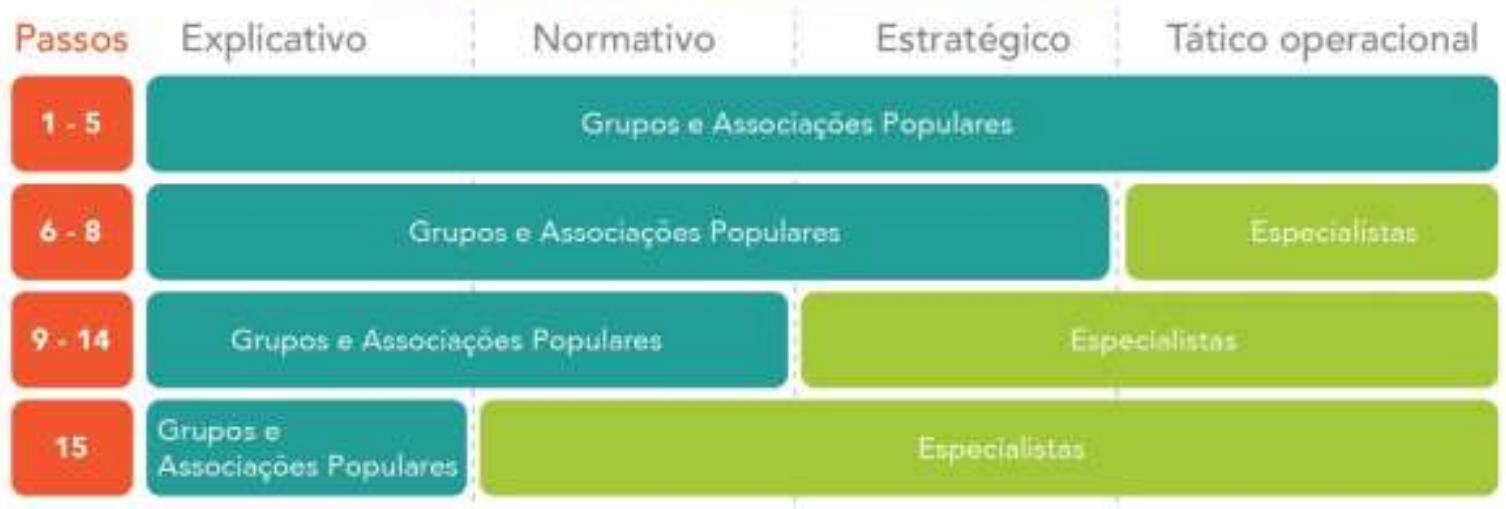

Fonte: Do autor (2019).

O MAPP, segundo De Toni, Salermo e Bertini (2008), pode ser utilizado por uma Secretaria do Governo de um Município (onde os problemas gerenciais são evidentemente mais complexos), ou até por um Sindicado de trabalhadores rurais, por uma associação de moradores (grifo do autor) ou mesmo para organização do orçamento doméstico. É um instrumento útil para enfrentar e diluir problemas, reduzindo sua complexidade e facilitando seu enfrentamento.

Sendo assim, a análise combinada da formulação estruturada em momentos definidos, com aporte metodológico no planejamento urbano e em sua operacionalidade na experiência local, deve fornecer um panorama de princípios, estratégias, mecanismos, diretrizes e objetivos da recepção prática, ancorados em um diagnóstico do alcance e da efetividade da própria participação popular. Os passos aplicados ao processo de planejamento urbanos, para a construção das estratégias e ações, foram designados para cada momento com relação ao que cada um representa segundo os quatro momentos apresentados por MAPP.

O momento de explicação representa a fase de diagnóstico, na qual existe a compreensão sobre os problemas do ator social e ocorre a busca da identificação dos problemas. As decisões tomadas durante essa etapa são obtidas por meio do ator social, que analisa e prevê onde gostaria 
de chegar. No momento normativo será trabalhado e considerado um desenho de operações. As questões são resolvidas, e é possível aferir se o projeto é viável, dando início às funções do momento estratégico que visa ao planejamento, prevendo a política de alianças com quem será realizado o projeto. O planejamento passa da análise para ação.

Uma consolidação do planejamento urbano e do plano diretor sobre bases participativas, metodologicamente estruturadas, que forneçam insumos relevantes à tradução técnica, pode constituir uma possibilidade de práticas de planejamento urbano locais, estabelecidas em passos e momentos. Essa direção aponta caminhos em que o aprimoramento e a efetividade da normatividade urbanística passam pela qualificação do planejamento como uma questão decisória, com o propósito de retirar sua alcunha de peça restrita à técnica.

\subsubsection{O MAPP e Sua Aplicação}

Normalmente, a construção do planejamento com bases no MAPP requer por volta de 40 horas para sua execução, considerando os quatro momentos, segundo Matus (1988, 1991), a depender da complexidade do grupo e dos problemas selecionados para serem trabalhados. É importante ressaltar que nessa metodologia "planeja quem governa e governa quem planeja". Isto é, os componentes devem estar presentes e assumir responsabilidade pelo planejamento (pelas operações), bem como pelas mudanças organizacionais necessárias ao gerenciamento do plano, fazendo com que sua atuação se aproxime de abordagens de pesquisa, cujo método é a pesquisa-ação. Segundo De Toni, Salermo e Bertini (2008), não deve existir uma divisão entre os que pensam, os que planejam e os que obedecem e executam. Outra dimensão é a participação e integração de técnicos, agentes sociais e políticos em igual nível no processo (grifo do autor).

Com base em Matus (1987, 1991), a execução do planejamento pode ser feita por um ou dois mediadores, dependendo dos fatores já mencionados em relação à duração da atividade. $\mathrm{O}$ papel do monitor é ser um "facilitador" de situações e do desenvolvimento do grupo, utilizando, se for necessário, diversas técnicas de animação e dinâmicas compatíveis com cada momento do método. Um momento essencial diz respeito ao que acontece antes de sua utilização pelo grupo assessorado, ou seja, a sensibilização ou a preparação do ator social. Ele consiste no primeiro contato do grupo (ou de uma comissão representativa) com o método, suas características, os materiais necessários à sua execução e o tempo requerido, o que mais uma vez reverbera no enfoque educacional das ações. 
Todos os momentos e debates são visualizados permanentemente por todo o grupo através do uso de tarjetas (cartelas de papel) feitas pelos próprios participantes segundo as indicações do moderador, seguindo um roteiro metodológico, ancorados pela Cartografia Participativa e por Mapas Falantes, cujas alternativas e critérios são definidos, além de grupos focais. A retroalimentação participativa permanente desse processo, avançando e analisando o que já foi definido em passos anteriores, facilita o debate, permite recuperar argumentos ou conceitos já discutidos, ajuda no processo de compreensão e objetiva significativamente as "longas" discussões comuns nos movimentos sociais. Além disso, facilita e agiliza a confecção do relatório, que é um instrumento indispensável para todos os participantes no gerenciamento e no acompanhamento do plano elaborado.

\subsection{MÉTODOS MULTICRITÉRIO DE AUXÍLIO À DECISÃO}

De acordo com Schön ${ }^{56}$ (1982 apud ENSSLIN; MONTIBELLER NETO; NORONHA, 2001), as tomadas de decisões, estruturadas em processos decisórios, em problemas e sistemas complexos, nunca serão iguais; consequentemente, as decisões complexas serão únicas. Em sistemas complexos, é fundamental a incorporação dos aspectos subjetivos, e que estes fatores atuem explicitados e quantificados, contudo não se abstém a possibilidade de que certos aspectos qualitativos, em função de suas características, possam permanecer sob a forma qualitativa. Os aspectos qualitativos (influenciados pela percepção dos atores) são tão relevantes quanto os fatores quantitativos (custos, características físicas etc.) inerentes a cada processo decisório e problema, conforme apontam Kauffman (1992, 1995) e Mitchell (2011).

Cada uma das possíveis alternativas deve ser analisada em função de suas repercussões e influências nos objetivos estabelecidos. A decisão tomada, de forma estruturada, deve considerar os aspectos qualitativos e quantitativos pontuados por todos os decisores, como salienta Kenney (1992). Ademais, segundo Bana e Costa, De Corte e Vansnick (2005), Ensslin, Montibeller Neto e Noronha (2001) e Kenney (1992), a análise multicriterial de apoio à decisão propõe um paradigma construtivista que incorpora todos esses aspectos.

As mudanças de paradigmas, com novos modelos de planejamento, gerenciamento, governança e gestão urbana alcançam outros horizontes com o avanço tecnológico, a heterogeneidade urbana e os desafios enfrentados com o crescimento das cidades. Ribeiro e Vargas (2001a, 2001b) e Vargas (2001) apontam que as estruturas tradicionais de tomadas de

${ }^{56}$ SCHON, D. A. The reflective Practitioner. New York: Basic Books, 1982. 
decisão não são adequadas para atender a essa mudança. Para Romero (2003, 2007), é essencial compreender a relação entre quatro elementos principais que determinem projetos urbanos mais inclusivos e com abordagens sistêmicas e multicriteriais, sendo eles:

a) Enlace - integração das esferas do econômico, social e cultural - é relativo a desenvolvimento econômico, habitação acessível, segurança, proteção do meio ambiente e mobilidade, de modo que todos se inter-relacionam, devendo ser abordados de maneira integrada;

b) Inclusão - dos segmentos e interesses coletivos - é o elemento por meio do qual se deve considerar uma variedade de interessados para identificar e alcançar valores e objetivos comuns;

c) Previsão - otimização de investimentos - é fundamento para a elaboração de objetivos em longo prazo;

d) Qualidade - promoção da diversidade urbana - garante que sejam buscados e privilegiados elementos que contribuam para manter a diversidade e, por meio desta, é assegurada a qualidade e não apenas a quantidade dos espaços, proporcionando a qualidade global da vida urbana.

Nessa direção, novas ferramentas de planejamento e gestão com abordagem sistêmica, integrada e participativa, são elementos que podem estruturar metodologias de apoio à decisão que, segundo Santos, Thomaziello e Weill (2007), podem, de forma construtivista, reconhecer esse desafio.

Parte-se do pressuposto de que não há uma decisão única e verdadeira para um determinado problema quando se trata de questões que envolvam múltiplos critérios, tais como as questões ligadas ao ambiente urbano, à dinâmica social e até, analogamente, a planejamento urbano e gestão urbana. Além disso, pressupõe-se que uma solução, para um determinado contexto, em um determinado caso, pode não ser o caminho para outro. Então, para se desenvolver um processo de tomada de decisão em situações complexas e típicas, quando há múltiplos critérios, deve-se compor um quadro de avaliação considerando instrumentos técnicos, sociais, legais e de políticas públicas, como aponta Thomaziello (2007). Santos, Thomaziello e Weill (2007) destacam, também, que para haver participação, deve deve-se ter uma preparação prévia, a qual prescinde de educação e comunicação e, acima de tudo, respeito entre os diversos atores.

Segundo Ribeiro e Vargas (2001a), uma das barreiras comumente encontradas nos instrumentos tradicionais de gestão urbana é o desconhecimento generalizado sobre o 
problema, fato que contribui como elemento de barreira para as ações necessárias. Este desconhecimento pode ser em relação aos objetivos desejados, às formas de ação para se atingir os objetivos ou à relação entre os meios e os fins pretendidos. O mesmo problema é recorrente nas mais diversas situações de tomada de decisão. Segundo Kenney (1992), nos contextos de gerenciamento, a realidade não é diferente.

Aliado a essas colocações, Santos, Thomaziello e Weill (2007), Weill e Pires Neto (2007) e Weill (1990) afirmam que as decisões baseadas em apenas parte do problema, geralmente, resultam em ações pouco efetivas ou, pior ainda, ilegítimas, visão replicada por Ribeiro e Vargas (2001a) e Fantinatti (2008). Por fim, Pelizzoli (2002), Rattner (2000) e Ribeiro e Vargas (2001a) defendem a urgência de a sociedade contemporânea adotar um novo paradigma nos processos decisórios. Afinal, persiste o desafio de instaurar processos participativos consistentes e contínuos com os quais a sociedade tenha representatividade e eficácia no processo de desenvolvimento - além de encontrar formas para tal.

\subsubsection{Métodos Multicritério de Auxílio à Decisão}

Métodos tradicionais, geralmente determinísticos de resolução de problemas, que enquadram os problemas em categorias isoladas e independentes, têm seu foco na avaliação de alternativas e, em função dessa avaliação de alternativas, na consolidação de uma solução ótima. Os métodos tradicionais são construídos, ainda, com base em regras racionais, ou seja, um único critério que possui medida objetiva, que permita uma comparação direta.

Esses modelos, muitas vezes não consideram uma correlação mais profunda entre as variáveis que consolidam os problemas, tal como a subjetividade dos decisores, ou atores, na avaliação das alternativas e consequentemente no processo decisório, segundo Keeney (1992), Montibeller Neto (2000), Ensslin, Montibeller Neto e Noronha (2001), Fabretti et al. (2011) e Fantinatti et al. (2015). Tomar decisões complexas não é trivial, é um cenário complexo: mesmo de forma individual, ou em grupos, é uma tarefa difícil, pois envolve inúmeras atividades, percepções conflitantes e, na maioria dos casos, é uma dinâmica que agrega diversos pontos de vista, opções, informações e objetivos.

Fantinatti et al. (2015) também fazem uma importante contribuição, no sentido de apontar que estes métodos tradicionais não são capazes de lidar com situações complexas, as quais requerem decisão importante. Complementarmente, apontam a dificuldade dos modelos determinísticos quando existem questões que são ligadas à incerteza, ao conflito de valores e 
objetivos, às diferenças nas relações de poder, aos múltiplos critérios de avaliação, à infinita (ou escassa) quantidade de informações (qualitativas e quantitativas), geralmente incompletas, ou ainda quando os problemas exigem soluções criativas e, até mesmo, inéditas.

Ainda é possível pontuar que no caso de problemas de decisão, ou escolhas, que envolvam diversos atores, cada um deles terá seu sistema de valor e seus objetivos, os quais inegavelmente traduzem e representam seus interesses individuais.

Portanto, apresenta-se a exigência de que os decisores - ou, ainda, os responsáveis pela execução de ações - encontrem alternativas adequadas a cada contexto, assumindo-se a existência de conflitos e que é muito difícil a solução ótima, sendo assim assumida a solução de melhor compromisso coletivo. Thomaz (2002) afirma que o processo de estruturação, no paradigma construtivista, ajuda a modelar melhor o problema, desde que conte com a participação dos diversos atores envolvidos no processo decisório.

Após analisar a participação popular, outra questão relevante é a observação da assimetria de informações que, normalmente, interfere e potencializa as relações de conflito em processos de tomada de decisão, ainda mais quando os atores, decisores e envolvidos possuem diferentes posicionamentos, independentemente de suas motivações, por falta de conhecimento ou por conflito de interesses. Desse modo, não se atinge um entendimento compartilhado comum.

\subsubsection{Estruturação dos Critérios}

Nos processos multicriteriais de apoio à decisão, as variáveis que determinam a avaliação de alternativas e dos objetivos fundamentais são denominadas critérios, segundo Bana e Costa e Sanchez-Lopez (2009). Cada critério é um elemento que pode definir uma alternativa e deve ser analisado individualmente a partir de percepções e valoração dos atores do processo decisório. Os autores também definem os critérios como objetivos fundamentais, ou seja, são as os primeiros elementos a serem definidos, pois categorizarão as alternativas.

Segundo Bana e Costa e Sanchez-Lopez (2009), os critérios devem ser definidos por atores que possuem bom conhecimento sobre o problema, de tal forma que nas realidades locais em que convivem, então conhecem as problemáticas que fornecem insumos valiosos nesses processos. Os estudiosos ainda afirmam que, geralmente, esses atores podem ser os decisores apoiados por grupos de especialistas e que os critérios devem refletir os objetivos estratégicos e direcionar as ações para atendê-los. Os objetivos fundamentais podem ser encontrados com 
outras nomenclaturas, tais como: "pontos de vista fundamentais", conforme Bana e Costa, De Corte e Vansnick (2005) ou “elementos primários de avaliação”, conforme Ensslin, Montibeller Neto e Noronha (2001).

Na etapa de elaboração da lista de critérios, Keeney (1992) aponta que devem ser identificados os candidatos a objetivos fundamentais, os quais devem ser, necessariamente, oriundos de um mapeamento cognitivo (grifo do autor) a partir dos valores dos decisores, e então, deve-se proceder a uma verificação em relação ao cumprimento de nove requisitos Essenciais, Controláveis, Completos, Mensuráveis, Operacionais, Isoláveis, Não Redundantes, Concisos e Compreensivos -, para que os candidatos a objetivos fundamentais possam ser, de fato, aceitos como critérios de avaliação.

Os critérios devem atender nove requisitos apontados por Keeney (1992) e Fantinatti (2011):

a) Essenciais: devem levar em conta os aspectos de fundamental importância segundo o sistema de valores dos decisores;

b) Controláveis: devem representar um aspecto que seja influenciado apenas pelas ações potenciais;

c) Completos: o conjunto de objetivos fundamentais deve incluir todos os aspectos considerados com fundamentais pelos decisores;

d) Mensuráveis: permitem especificar, com a menor dúvida possível, o desempenho das ações potenciais, segundo os aspectos considerados fundamentais pelos decisores;

e) Operacionais: possibilitam coletar as informações requeridas sobre o desempenho das ações potenciais, dentro do tempo disponível e com esforço viável;

f) Isoláveis: permitem a análise de um aspecto fundamental de forma independente com relação aos demais aspectos do conjunto;

g) Não redundantes: o conjunto de objetivos fundamentais não deve levar em conta o mesmo aspecto mais de uma vez;

h) Concisos: o número de aspectos considerados pelo conjunto de objetivos fundamentais deve ser o mínimo necessário para modelar, de forma adequada, o problema segundo a visão dos decisores;

i) Compreensíveis: devem ter o seu significado claro para os decisores, permitindo a geração e comunicação de ideias.

Como já pontuado, para proceder com a análise dos critérios, devem ser identificados os elementos primários de avaliação, os quais são constituídos de objetivos, metas, valores, ações, 
opções e alternativas. Segundo Keeney (1992), deve-se estimular a criatividade, pois quanto maior o número elementos primários de avaliação, mais bem-sucedida será a tarefa de seleção de critérios e, consequentemente, dos indicadores adequados. Esses critérios, eventualmente, podem ser construídos com o diagnóstico de indicadores. Estes, quando refletidos em uma situação-objetivo - ou seja, um cenário-meta que responderá às percepções de prospecções -, podem ser úteis na compreensão dos problemas e na determinação de ações mais pontuais. Afinal, fornecem uma imagem representativa do objeto, reduzem a complexidade da análise e ainda podem ser moldados de maneira que se possa acompanhar as mudanças ou tendências do fenômeno estudado, adquirindo capacidade de resposta às mudanças.

Essa análise, aplicada às práticas recentes das intervenções urbanas, executadas por meio de parcerias entre o Poder Público e a iniciativa privada, poderia orientar a análise dos resultados destas intervenções. Assim, após identificados os critérios, cada um define um conceito e, portanto, deve-se inserir verbos que remetam a ações. Uma forma de auxiliar nesse processo é, segundo Ensslin, Montibeller Neto e Noronha (2001), utilizar duas perguntas: (i) “por que esse conceito (objetivo) é importante, ou seja, quais são os fins desejados?”; e (ii) como ele (objetivo) pode ser alcançado, isto é, quais são os meios disponíveis?

O raciocínio focado na valoração dos critérios, os quais podem ser construídos com mapas cognitivos (mapas falantes e grupos focais), são elementos também defendidos por Keeney (1992) e Franco (2006), como instrumentos que auxiliam na identificação dos critérios mais adequados e aderentes a realidades locais. A estrutura básica do mapeamento cognitivo, construtivista, contribui para definir os objetivos fundamentais, os objetivos-fins (essenciais) e os objetivos-meios (formas de atingir os objetivos-fins), segundo Ensslin, Montibeller Neto e Noronha (2001), Montibeller (2000) e Franco (2001).

Tais questões, ancoradas em processos participativos e reflexivos, na construção de um saber comum, podem subsidiar uma análise focada do problema e sua estruturação. Dessa forma, as questões, mesmo que particularizadas em um processo contributivo de análise, podem ser transformadas em questões coletivas. Ensslin, Montibeller Neto e Noronha (2001) apontam que, no processo de mapeamento cognitivo, devem ser identificados e determinados pontos de intersecção, os quais definem objetivos e critérios relacionados a um mesmo objetivo fundamental, e, ainda, em cada intersecção, devem ser identificadas ligações relacionadas com um mesmo objetivo-fim. Os objetivos-meio dos níveis mais elementares em cada ramo serão os critérios em que as alternativas serão, de fato, avaliadas, criando uma análise de redes e 
dependências correlatas. Essa abordagem segue os pressupostos nodais (nós críticos) propostos pelo planejamento estratégico inerente ao MAPP.

Estando os critérios estabelecidos, cada um deve ter uma descrição, de tal modo que ocorra uniformização dos elementos já construídos por Keeney (1992), ou seja, uma análise reflexiva de essencialidade, controle, abrangência, mensuração, operação, isolação, redundância, concisão e compreensão. A proposta está na sistematização descritiva dos critérios. Os critérios auxiliam na compreensão acerca do que os decisores estão considerando, tornam os objetivos inteligíveis, permitem a geração de ações de aperfeiçoamento, possibilitam a mensuração do desempenho de ações de um critério e auxiliam na construção de um modelo global de avaliação, segundo Fantinatti (2011).

\subsubsection{Avaliação dos Níveis de Desempenho e Ponderação de Cada Critério}

Definidos e sistematizados os critérios de avaliação com seus respectivos descritores, é importante estabelecer a função de valores, e seus intervalos, para cada um dos critérios de forma independente, funções as quais permitirão a avaliação e a mensuração de seu comportamento, além da consequente avaliação do desempenho de cada alternativa frente a cada função de valor dos critérios. Bana e Costa, De Corte e Vansnick (2005) e Bana e Costa e Vansnick (2008) defendem a adoção de escalas semânticas para o estabelecimento das funções de valor, independentemente de os critérios serem de natureza qualitativa ou quantitativa.

Essa determinação, mais uma vez, consolida a abordagem participativa. Afinal, a partir de uma escala semântica, o processo de captura dos valores cognitivos dos decisores e/ou especialistas é melhor conduzido e, portanto, melhor traduzido para uma escala cardinal, relacionando os consensos e debates de cada critério durante o processo.

Bana e Costa, De Corte e Vansnick (2005) e Bana e Costa e Vansnick (2008) propõem, então, da mesma forma que Keeney (1992), o estabelecimento de dois níveis de desempenho para cada critério: um nível "Neutro", o qual corresponde ao desempenho mínimo aceitável para qualquer alternativa, dentro do contexto decisório em análise; e um nível "Bom”, o qual corresponde ao desempenho desejável para qualquer alternativa dentro do contexto decisório em análise. Tais níveis, inseridos em uma escala cartesiana, na qual é possível avaliar a distância entre cada um dos desempenhos, ajudam os decisores na percepção e na resposta da pergunta 
“como alcançar?”, já consolidando as relações de dificuldades para atingir determinados níveis de desempenhos em alguns objetivos.

Tal observação é importante, pois, nesse momento, as particularizações sob a ótica de cada participante, inerentes a cada questão, podem ganhar visão sistêmica e coletiva, ou a exclusão de questões e objetivos particulares individuais do problema de decisão, avançando mais uma vez no saber comum e distribuído entre todos os agentes. Keeney (Ibidem) afirma que a ponderação entre os critérios de avaliação (definição dos pesos) deve ser estabelecida a partir da comparação dos critérios, pareada, dois a dois, dentro do contexto decisório. Tal comparação justifica-se pela análise, inclusive sensorial, dos indivíduos, os quais podem incorporar as questões subjetivas na valoração dos critérios.

Bana e Costa e Sanchez-Lopez (2009), Bana e Costa, De Corte e Vansnick (2005) apresentam um exemplo prático para a definição de pesos entre os critérios, proposta por Keeney (1992), pelo qual devem ser montados cenários de avaliação, partindo-se de um cenário-base, no qual todos os critérios sejam considerados com desempenho no nível "Neutro". Tal exemplo indica que, a partir do cenário-base, devem ser criados cenários nos quais cada critério varie, um a um, para o nível "Bom" de desempenho. A partir disso, os decisores deverão explicitar, na mesma escala semântica descrita pelo método que estiver sendo usado, os graus de preferência entre os diversos cenários (dois a dois). Cada cenário representa a preferência do decisor, ou ainda o conjunto de decisores em relação aos respectivos critérios.

\subsubsection{Avaliação das Alternativas}

Keeney (1992), Zuffo (1998) e Fantinatti et al. (2015) afirmam que há vários modelos matemáticos para avaliação de alternativas, sendo que os mais usados são os modelos aditivos e os multiplicativos. A partir da definição dos critérios, bem como suas respectivas funções de valor e os pesos relativos, é possível proceder à avaliação das possíveis alternativas. Nesse tocante, a avaliação das alternativas por modelos matemáticos tem empregado o modelo aditivo do método CP (Compromisse Programming) ou o modelo multiplicativo do método CGT (Cooperative Games Theory).

Keeney (1992) ressalta que deve ser tomado o cuidado de usar o modelo matemático adequado para o contexto decisório. $\mathrm{O}$ autor afirma que o modelo aditivo tem, por exemplo, certas restrições de aplicação em relação ao modelo multiplicativo. Essa opinião é 
compartilhada, por exemplo, por Zuffo e Genovez (2006) e reforçada por Fantinatti (2011), segundo os quais modelos são uma representação de um fenômeno real.

Keeney (1992) e Ensslin, Montibeller Neto e Noronha (2001) afirmam que, mais do que escolher entre alternativas pré-selecionadas, as abordagens multicriteriais, são flexíveis e construtivistas de tal forma que permitem aos decisores criar alternativas mais adequadas à solução do problema em análise. Esse enfoque construtivista favorece o aprendizado e a negociação em ambientes de incerteza, de modo que se torna possível emergirem soluções a partir dos valores dos decisores.

Essas avaliações demandam, ainda, uma análise de sensibilidade para verificar a robustez da estruturação dos critérios e do modelo matemático aplicado. Assim, a simulação de alteração dos pesos para mais ou para menos é relevante para verificar se ocorre alguma inversão na ordem das alternativas, o que poderia indicar fragilidade, quer seja na estruturação dos critérios, quer seja no modelo matemático escolhido.

\subsubsection{Métodos Usuais de Análise Multicriterial de Apoio à Decisão}

De acordo com Fantinatti et al. (2015), Fantinatti (2011), Figueira, Greco e Ehrgott (2005) e Zuffo (1998), os métodos multicritério de auxílio à decisão são divididos, basicamente, em quatro grandes grupos:

a) Métodos baseados na programação matemática (MOLP, sigla em inglês para Multiobjective Linear Programming), dos quais se destacam: a Programação por Compromisso (CP - Compromisse Programming) (COCHRANE e ZELENY, 1973); e a Teoria dos Jogos Cooperativos (CGT- Cooperative Games Theory) (NASH, $1951^{57}$ apud JUNQUEIRA, 2005). Eles são desenvolvidos principalmente no âmbito de uma caracterização de passos computacionais, tratados de formas repetidas e interativas de convergência, permitindo trade-offs (LÉGER e MARTEL, 2002). Esses métodos buscam uma alternativa que seja dominante em objetivos estabelecidos; são modelados com a agregação das preferências dos decisores e cálculos matemáticos, interativos e sucessivos, com a avaliação das alternativas considerando uma possível alteração da estrutura de preferências, em face de novas informações, disponíveis objetivando à convergência para uma solução final que estabeleça um compromisso aceitável entre as funções;

\footnotetext{
${ }^{57} \mathrm{NASH}$, J. F. Non-cooperative games. Annals of Mathematics, n. 54, p. 286-295, 1951.
} 
b) Métodos baseados nas Teorias do Valor e da Utilidade Multiatributo (MAUT, Multiattribute Utility Theory), dos quais se destacam: o AHP (Analytic Hierarch Process) (SAATY, 1977, 1980); e o MACBETH (Measuring Attractiviness by a Categorical Evaluation Technique) (BANA E COSTA; DE CORTE; VANSNICK, 2004, 2005). Eles são derivados da corrente americana, embora o MACBETH tenha origem em Portugal, na qual as preferências do decisor por determinada alternativa são avaliadas mediante um conjunto de critérios ou indicadores e, de forma subsequente, são agregadas em um valor de utilidade único mensurado de forma aditiva (com trade-offs). Ou seja, é gerada uma escala de pontuação de cada alternativa com base no desempenho que apresentou em cada critério, de modo que as alternativas mais bem avaliadas são as que obtiverem a melhor pontuação acumulada aditiva;

c) Métodos baseados nas Relações de Preferências, dos quais se destacam: o ELECTRE (Elimination et Choix Traduisant la Realité) (BENAYOUN; ROY; SUSSMAN ${ }^{58}, 1966$ apud ZUFFO et al., 2002; FIGUEIRA; MOUSSEAU; ROY, 2005); e o PROMETHEE (Preference Ranking Organization Methods for Enrichment Evaluations) (BRANS; MARESCHAL, 2005). Eles são derivados da corrente francesa, na qual são construídas relações binárias que representam as preferências do decisor com base nas informações das alternativas, sem comparações (sem trade-offs). O principal objetivo é a construção de relações binárias que representem as preferências do decisor com base na informação disponível (sem trade-offs) em cada critério. Neste método são geradas escalas de alternativas em função de seu desempenho em cada critério. Com uma seguinte comparação par a par, verifica-se qual alternativa é melhor avaliada em cada um dos critérios, estabelecendo-se uma relação de superação no confronto entre duas alternativas. Assim, as alternativas são classificadas de forma decrescente - da alternativa que apresenta superioridade em mais critérios para a que a apresenta superioridade em menos critérios;

d) Abordagens não clássicas em MCDA, das quais se destacam os métodos que incorporam a teoria da lógica Fuzzy (GRABISCH; LABREUCHE, 2005; MEYER;

\footnotetext{
${ }^{58}$ Benayoun R., Roy B. and Sussman B. ELECTRE: Une méthode pour guider le choix en presence de points de vue multiples. Note de travail 49, SEMA-METRA International, Direction Scientifique, 1966.
} 
ROUBENS, 2005; ZADEH ${ }^{59}$, 1965 apud BARROS, 1997; ZIMMERMANN ${ }^{60}, 1985$ apud CARLSSON; FULLÉR, 1996).

De acordo com Zuffo et al. (2002), percebe-se uma diferença nas escolas americanas e europeias, pois os métodos europeus enfocam e priorizam o apoio a decisão, enquanto processo. A escola europeia preocupa-se no auxilio, admitindo que não há uma solução ótima que responda a todos os objetivos, elenca uma série de alternativas e determina as soluções em escalas de compromisso com os objetivos. Já os métodos americanos se propõem a definir a tomada de decisão e seu consequente resultado.

\subsubsection{O Método da Programação por Compromisso (CP)}

O método CP, segundo Cochrane e Zeleny (1973) e Fantinatti (2011), é um método que busca identificar soluções não dominantes, que estão mais próximas a uma solução ideal, por meio de um procedimento de medida de distância entre os patamares neutros e bons. O método também é categorizado dentro das características de métodos que buscam a otimização da função “distância da solução ideal” (SOUZA et al., 2001; CORDEIRO NETTO et al., 2000).

Zuffo et al. (2002) resumem o método CP, o qual está baseado no Teorema de Pitágoras - mais precisamente, no conceito da distância métrica entre dois pontos de coordenadas cartesianas conhecidas. A partir desse princípio, procura-se minimizar a distância de todos os possíveis pontos próximos a um ponto ideal definido pelo decisor. Por fim, a solução ideal é definida como o vetor dos melhores valores alcançados em cada critério $\left(\mathrm{f}_{\mathrm{i}}{ }^{*}\right)$, ou seja, aquele possuirá menores distâncias do ponto ideal, em uma matriz de avaliação. Essa maximização da função objetivo é representada abaixo pela eq.(7).

$$
\mathrm{f}_{\mathrm{i}}^{*}=\operatorname{Max} \mathrm{f}_{\mathrm{i}}(\mathrm{x}) .
$$

O vetor $\mathrm{f}^{*}$, cujos elementos são todos máximos, é chamado de vetor ideal e é dado pela eq.(8).

$$
\mathrm{f}^{*}=\left(\mathrm{f} 1^{*}, \mathrm{f} 2^{*}, \ldots, \mathrm{fn} *\right)
$$

\footnotetext{
${ }^{59}$ ZADEH, L. A. Fuzzy Sets. Information and Control, 8 - Department of Electrical Engineering and Electronics Research Laboratory, University of California, Berkeley, California, p. 338-355, 1965.

${ }^{60}$ ZIMMERMANN, H. J., Fuzzy Set Theory and Its Applications, U.S.A, Kluwer Nijhoff Publishing, 1985.
} 
Ademais, é determinado um vetor com os piores valores, que é utilizado para indicar a distância relativa da alternativa à solução mais desfavorável $\left(\mathrm{f}_{\mathrm{i}, \mathrm{w}}\right)$. Uma vez que a solução ideal é, praticamente, impossível de ser conquistada, mede-se a distância das soluções possíveis a partir da solução ideal. Esta distância é obtida pela família métrica " $l_{\mathrm{s}}$ ”, definida pela eq.(9).

$$
l_{s}=\sqrt[s]{\left(\sum_{i=1}^{n} \propto_{i}^{S}\left|\frac{f_{i}^{*}-f_{i}(x)}{f_{i}^{*}-f_{i, w}}\right|^{S}\right)},
$$

Em que:

- $\propto_{i}^{S}$ : é o peso atribuído a cada critério pelo decisor, subjetivamente, ou derivado de alguma estrutura de preferência;

- $\mathrm{f}_{\mathrm{i}, \mathrm{w}}$ : é o pior valor (desempenho) obtido por cada critério;

- $\mathrm{f}_{\mathrm{i}}(\mathrm{x})$ : é o desempenho da alternativa " $\mathrm{x}$ " em relação ao i-ésimo critério;

- S: reflete a importância que o decisor atribui aos desvios máximos, podendo variar de um (1) a infinito $(\infty)$.

Percebe-se que, na verdade, há dois esquemas de pesos; sendo que o parâmetro " $\alpha_{i}$ " reflete a importância do critério "i"; e o parâmetro "S" reflete a importância que o decisor atribui aos desvios máximos. No caso de $\mathrm{S}=1$, todos os desvios são considerados proporcionalmente às suas magnitudes. Quanto maior for o valor de "S", maior influência sobre o resultado terão os desvios de maior magnitude. No caso de $\mathrm{S}=\infty$, o maior desvio será o único considerado, conforme Gershon e Duckstein (1983).

Segundo Zuffo et al. (2002) e Fantinatti (2011), quando as alternativas de solução estão discretizadas, já valoradas por cada medida de desempenho de cada um dos critérios - e estes representados em uma matriz de avaliação -, esse método é eficaz em sua aplicação, e se calculam as distâncias das alternativas para a solução ideal. Assim, é apontada a solução de melhor compromisso como aquela que apresentar a menor distância.

\subsubsection{O Método da Teoria dos Jogos Cooperativos (CGT)}

Segundo Gershon e Duckstein (1983), o método CGT se contrapõe ao método CP, pois, ao invés de procurar a menor distância do "Ponto Ideal", busca a maior distância geométrica de um nível mínimo estabelecido como "status quo" ou ponto neutro. Ainda segundo os autores, 
o método CGT, desenvolvido por Szidarovsky, Duckstein e Bogardi (1979), foi uma generalização para " $n$ " jogadores, a partir da teoria dos jogos cooperativos para duas pessoas, desenvolvido por Nash ${ }^{61}$ (1951) apud Junqueira (2005).

Segundo Zuffo et al. (2002), o processo desenvolvido em teoria dos jogos é um estudo matemático para resolução de conflitos, e, de forma particular, a teoria dos jogos cooperativos permite aos participantes se comunicarem e formarem relações de concordâncias (acordos). Estes acordos resultam em uma matriz de avaliação, cuja função de distância é dada pela eq.(10).

$$
l_{s}(x)=\prod_{i=1}^{n}\left|f_{i}(x)-f_{i}\right|^{\alpha_{i}}
$$

Em que:

- $\propto_{i}$ : é o peso do i-ésimo critério;

- $\mathrm{f}_{\mathrm{i}}$ : é desempenho do i-ésimo critério do ponto "status quo";

- $\mathrm{f}_{\mathrm{i}}(\mathrm{x})$ : é o desempenho da alternativa " $\mathrm{x}$ ” em relação ao i-ésimo critério.

De acordo com Zuffo et al. (2002) e Fantinatti (2011), o método CGT conta com axiomas que definem uma solução cooperativa. Os autores afirmam que o método evidencia que há uma única solução "ótima”, a qual é obtida por meio de um caminho único, usando a programação não linear, típica da escola americana. Contudo, Gershon e Duckstein (1983) apontam que o método CGT tem a vantagem de indicar outras soluções viáveis, além da solução "ótima", devido à composição de algoritmos de programação não linear. Zuffo et al. (2002) apontam que o método CGT considera que os objetivos trabalham em cooperação em vez de competirem entre si, o que possibilita indicar, também, uma ou mais soluções satisfatórias.

\subsubsection{O Método Analítico Hierárquico (AHP)}

O método AHP é um dos métodos multicritério mais difundidos e utilizados, atualmente, em todo o mundo, segundo Cruz (2013) e Silva e Feitosa (2007). Por meio desse método, é possível selecionar, ordenar e avaliar, subjetivamente, alternativas com um ou mais objetivos, conforme salienta Zuffo et al. (2002). Por sua vez, o método AHP, criado por Saaty (1977, 1980), estabelece a comparação par a par das alternativas, ao invés de avaliar todas ao mesmo

${ }^{61}$ NASH, J. F. Non-cooperative games. Annals of Mathematics, n. 54, p. 286-295, 1951. 
tempo. Os critérios (objetivos) são determinados e comparados entre si, preferencialmente, por uma equipe multidisciplinar.

Definidos os critérios de avaliação, deve ser montada uma matriz de comparação A (n x n), em que cada elemento " $a_{i j}$ ", na diagonal superior, indica o grau de superioridade do critério i sobre o critério j, conforme indicado na eq.(10). E na diagonal inferior, cada elemento "aji" indica o inverso da preferência do critério i sobre o critério j, conforme indicado na eq.(11).

$$
\begin{aligned}
& a_{i j}=\frac{\alpha_{i}}{\alpha_{j}} \\
& a_{j i}=\frac{1}{a_{i j}},
\end{aligned}
$$

Em que:

- $\propto_{i}$ : é o peso do i-ésimo critério;

- $\propto_{j}$ : é o peso do j-ésimo critério.

Saaty (1977, 1980) e Fantinatti (2011) afirmam que a mente humana é, em geral, capaz de distinguir sete níveis diferentes, variando dois níveis - para mais ou para menos -, conforme sua capacidade cognitiva. Nessa premissa, é proposto que as matrizes de avaliação sejam de 5 x 5 a 9 x 9. O desafio que se coloca é como aplicar esta ferramenta para matrizes com mais do que nove critérios, ou ainda, com mais do que nove alternativas. No quadro 9 está representada uma matriz teórica de comparação do método AHP.

Quadro 9 - Matriz de Comparação Pareada dos Critérios

\begin{tabular}{|c|cccc|}
\hline Matriz A & Critério 1 & Critério 2 & $(\ldots)$ & Critério n \\
\hline Critério 1 & 1 & $\mathrm{a}_{12}$ & $(\ldots)$ & $\mathrm{a}_{1 n}$ \\
\hline Critério 2 & $\mathrm{a}_{21}$ & 1 & $(\ldots)$ & $\mathrm{a}_{2 n}$ \\
\hline$(\ldots)$ & $(\ldots)$ & $(\ldots)$ & 1 & $(\ldots)$ \\
\hline Critério n & $\mathrm{a}_{n 1}$ & $\mathrm{a}_{n 2}$ & $(\ldots)$ & 1 \\
\hline
\end{tabular}

Fonte: Adaptado de Saaty (1980).

De acordo com Saaty (1977, 1980), os pesos dos critérios são estabelecidos por uma escala semântica, por refletir a maneira pela qual a mente humana estabelece as relações (conceitos e estrutura) em um problema complexo. De acordo com o autor, a mente humana, quando se depara com um problema complexo, com um grande número de variáveis - 
controláveis ou não -, naturalmente, organiza-as em grupos, segundo propriedades comuns. Isto é, quando o ser humano identifica alguma coisa complexa, decompõe sua complexidade e, quando descobre relações, sintetiza-as. Este é o processo fundamental da percepção: decomposição e síntese, segundo Orofino (1996).

Uma das características do método AHP está na sua capacidade de analisar um problema de tomada de decisão que contemple muitas variáveis, por meio da construção de níveis hierárquicos. Assim, o problema é decomposto em fatores, e estes são decompostos em níveis mais detalhados de fatores - e assim por diante até um determinado nível. Também são organizados hierarquicamente em inúmeros níveis, em que os objetivos finais devem estar no topo, seguidos de seus objetivos em níveis inferiores, das forças limitadoras dos decisores, dos objetivos dos decisores e dos vários resultados possíveis: os cenários (Ibidem).

Dessa forma, o método AHP permite estruturar hierarquicamente problemas complexos, com múltiplos critérios, com múltiplos decisores e em múltiplos períodos, etapa a etapa, de forma subsequente até a solução. É um processo flexível, baseado na lógica, e que usa, ao mesmo tempo, a intuição e a subjetividade dos atores, de acordo com Schmidt (1995). As etapas do método AHP são sistematizadas em (i) estruturação (hierarquização), (ii) definição dos pesos (preferências) e (iii) elaboração da matriz de avaliação, conforme Fantinatti(2011).

De acordo com Schmidt (Ibidem), na etapa de hierarquização, devem ser considerados os detalhes relevantes para representar o problema, de modo que se incluam todos os elementos importantes para a avaliação e, ainda, a viabilização da alteração deles, se necessário. Deve-se considerar o contexto do problema, identificar as ações e particularidades (grifo do autor) que contribuam para a solução - e identificar os atores e decisores relativos ao problema em análise (grifo do autor).

Haller et al. (1996) e Saaty e Shih (2009) apontam que uma estrutura hierárquica baseada em redes é uma forma que ajuda a pensar sobre qual é o problema. Esta estrutura pode contextualizar os elementos que compõe o problema, suas conexões e s influências. Esta etapa ajuda a desenvolver uma estrutura hierárquica que melhor se adapte à decisão.

Essa estrutura é construída de cima para baixo, com o objetivo da decisão, passando pelos níveis intermediários (critérios) até o nível mais baixo - o que geralmente é um conjunto de alternativas avaliados a partir de cada critério-. Uma vez que o objetivo é definido, as possíveis soluções são delineadas, e as oportunidades verificadas, é necessário construir um modelo de tal forma que os critérios, e as alternativas realmente relevantes, possam ser identificados (RUSSO e CAMACHO, 2015). 
A figura 25 aponta que, em um contexto complexo, muitos problemas que exigem soluções e aponta, algumas oportunidades que requerem alternativas viáveis. A decisão, quando estruturada, pode listar critérios e compor um regime de avaliação alternativa. Este cenário estruturado favorece a decisão.

Figura 25 - Contexto multicritério para tomada de decisão

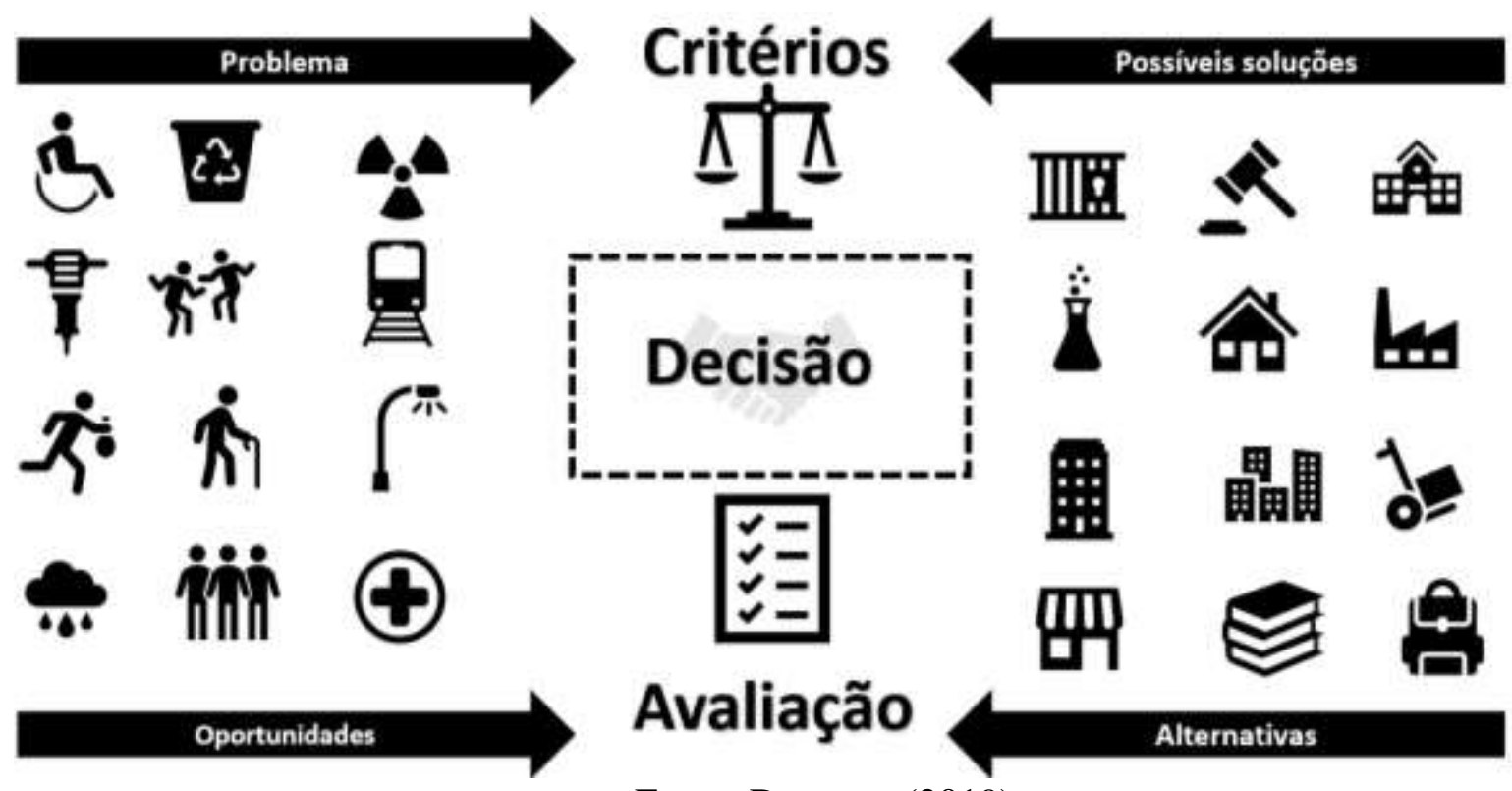

Fonte: Do autor (2019).

Os julgamentos ou a definição dos pesos, dados na forma de comparação par a par, são feitos a partir da escala semântica determinada por Saaty (1977, 1980), a qual é traduzida para uma escala numérica, tal como apresentado no quadro 10. Corresponde, assim, aos valores 2 , 4,6 e 8 , respectivamente, que mediam relações de consenso - quando se procura uma condição de compromisso entre duas preferências, segundo Saaty (Ibidem).

Os resultados numéricos obtidos a partir dos julgamentos semânticos (pesos) são colocados na matriz quadrada A (n $x$ n). Ainda pode haver julgamentos semânticos intermediários, isto é, classificados entre os níveis de preferência descritos. A partir dos resultados inseridos na matriz de avaliação, são calculados os auto-vetores, (eigen vector), e os auto-valores. O auto-vetor dá a ordem de prioridade, e o auto-valor é a medida de consistência do julgamento, para que eventuais relações semânticas de importância de critérios indiretamente relacionados se consolidem. Para " $n$ " critérios, haverá " $n$ " autovalores e respectivos auto-vetores, de acordo com Saaty (Ibidem) e Malinowski (2006). 
Quadro 10 - Escala Semântica de Preferência

\begin{tabular}{|ccl|}
\hline $\begin{array}{c}\text { Escala Semântica de } \\
\text { Preferência }\end{array}$ & $\begin{array}{c}\text { Peso ou Escala } \\
\text { Numérica }\end{array}$ & \multicolumn{1}{c|}{ Explicação } \\
\hline $\begin{array}{c}\text { De igual importância ou } \\
\text { recíproca }\end{array}$ & 1 & $\begin{array}{l}\text { Duas atividades contribuem } \\
\text { igualmente para o objetivo }\end{array}$ \\
\hline $\begin{array}{c}\text { De pequena ou moderada } \\
\text { importância sobre o segundo }\end{array}$ & 3 & $\begin{array}{l}\text { A experiência, ou o julgamento, é } \\
\text { moderadamente a favor de uma } \\
\text { atividade sobre a outra }\end{array}$ \\
\hline $\begin{array}{c}\text { De grande (ou forte) } \\
\text { importância sobre o segundo }\end{array}$ & 5 & $\begin{array}{l}\text { A experiência, ou o julgamento, é } \\
\text { fortemente a favor de uma atividade } \\
\text { sobre a outra }\end{array}$ \\
\hline $\begin{array}{l}\text { De importância muito grande } \\
\text { (ou fortemente) demonstrada } \\
\text { importância sobre o segundo }\end{array}$ & 7 & $\begin{array}{l}\text { Uma atividade é muito fortemente } \\
\text { preferida sobre a outra; as } \\
\text { dominâncias são visíveis e possíveis } \\
\text { na prática }\end{array}$ \\
\hline $\begin{array}{c}\text { De importância absoluta (ou } \\
\text { extrema) sobre o segundo }\end{array}$ & 9 & $\begin{array}{l}\text { As dominâncias são latentes de uma } \\
\text { atividade sobre a outra, e sua } \\
\text { preferência é plenamente afirmada }\end{array}$ \\
\hline
\end{tabular}

Fonte: Adaptado de Saaty (1980).

Para matrizes de elementos positivos (matriz definida positiva) haverá maior auto-valor positivo e seu respectivo auto-vetor. De acordo com Saaty $(1977,1980)$, será o vetor dos pesos dos critérios (W). Esse vetor será obtido por meio das equações eq.(12) e eq.(13):

$$
\begin{aligned}
& A . W=\lambda . W \\
& |A-\lambda . I|=0
\end{aligned}
$$

Sendo " $\lambda$ " o autovalor da matriz " $A$ ", uma vez que " $W$ " é o auto-vetor da matriz " $A$ ", Saaty (Ibidem) afirma que a consistência cardinal só será alcançada se " $\mathrm{n}-1$ " dos autovalores forem iguais a zero e se o maior autovalor for igual a $\mathrm{n}$. Se os julgamentos forem inconsistentes, o maior autovalor irá se tornar maior que "n", aumentando as inconsistências (em número e dimensão).

De acordo com Schmidt (1995) e Zuffo (1998), para se determinar o grau de consistência da matriz de avaliação, deve-se determinar a Razão de Consistência (RC), a qual é determinada pela relação entre o Índice de Consistência (IC) e um Índice Randômico (IR), estabelecido por Saaty (1980), conforme a eq.(14):

$$
R C=\frac{I C}{I R} .
$$


A Razão de Consistência (RC) - ou Consistence Rate (CR) - deve ser menor que 0,10 (10\%). Esta razão permite avaliar o grau de violação da proporcionalidade e transitividade dos julgamentos dos atores.

Quando o grau de consistência é pobre, é necessário obter mais informação nas comparações dos critérios, e tal ação envolve coletar informações a partir de uma nova rodada de julgamentos, conforme pontua Saaty $(1977,1980)$. Afinal, há a percepção de que espaços participativos heterogêneos, com maior riqueza de insumos particulares, podem contribuir para esse refinamento dos julgamentos.

O Índice de Consistência (IC) - ou Consistence Index (CI) - é calculado segundo a eq.(15). Ele também é designado na bibliografia como Aleatory Consistence Index (ACI).

$$
I C=\frac{\left(\lambda_{\operatorname{máx}}-n\right)}{(n-1)} .
$$

Na eq.(15), " $\lambda_{\text {máx }}$ é o maior autovalor encontrado, e "n" é o número de critérios. Segundo Zuffo et al. (2002), quanto mais próximo de zero for o valor de IC, maior será a consistência da matriz de avaliação (“A”). Para um IC pequeno, o respectivo autovetor será a solução procurada. Por fim, o Índice Randômico (IR) é tabelado em função do número de critérios (" $n$ "), conforme apontado no Quadro 11, sugerido por Saaty (1980), a partir de diversas comparações paritárias realizadas por Saaty.

Quando é inconsistente, o autovalor principal excede uma medida de inconsistência, formando uma razão, chamada razão de consistência - RC. Esta RC é medida em razão da consistência usando o próprio índice aleatório de cálculos (IR) proposto por Saaty (1977). Saaty (1977) calculou os índices aleatórios como dados no quadro 11.

Quadro 11 - Índices de consistência aleatório de Saaty

\begin{tabular}{|c|ccccccccccc|}
\hline $\mathbf{n}$ & $\mathbf{1}$ & $\mathbf{2}$ & $\mathbf{3}$ & $\mathbf{4}$ & $\mathbf{5}$ & $\mathbf{6}$ & $\mathbf{7}$ & $\mathbf{8}$ & $\mathbf{9}$ & $\mathbf{1 0}$ & $\mathbf{1 1}$ \\
\hline $\mathbf{I R}$ & 0,00 & 0,00 & 0,58 & 0,90 & 1,12 & 1,24 & 1,32 & 1,41 & 1,45 & 1,49 & 1,51 \\
\hline \multicolumn{7}{c|}{$\begin{array}{c}\text { Para comparações de 1 ou 2 alternativas , ou critérios, a comparação sempre será } \\
\text { consistente e por tal razão tem índices de consistências aleatórios iguais a 0 }\end{array}$} \\
\hline
\end{tabular}

Fonte: Adaptado de Saaty (1980).

As prioridades calculadas são plausíveis apenas para matrizes ligeiramente inconsistentes: se a razão de consistência (RC), a razão de $\mathrm{IC}^{62}$ e IR for menor que $10 \%$.

\footnotetext{
${ }^{62} \mathrm{O}$ IC médio de 500 matrizes preenchidas aleatoriamente.
} 
Apesar de o método AHP ser bastante difundido, Silva e Feitosa (2007) e Zuffo et al. (2002) reforçam a ideia de que ele não é uma unanimidade. Belton (1986) critica, por exemplo, sua ambiguidade em relação aos critérios de formação dos pesos e a subjetividade das escalas para medidas dos valores. Contudo, a crítica de Belton (1986) não leva em consideração que os métodos multicriteriais admitem em si a subjetividade, e que problemas complexos têm diferentes soluções em diferentes contextos. Assumir esta subjetividade a partir do julgamento dos atores, em abordagens locais de tomada de decisão, é uma característica intrínseca ao método.

Fabretti et al. (2011) criticam o uso equivocado do método AHP por um grande número de usuários (pesquisadores e consultores) que, ao invés de fazerem uso da escala semântica proposta por Saaty, utilizam-se, diretamente, de sua correspondência numérica, potencializando o erro apontado por Belton (1986). Por fim, Bana e Costa e Vansnick (2008) criticam o método AHP por não respeitar, sequer, as condições matemáticas dos axiomas ou a condição de cardinalidade explicitadas pelo próprio método.

Russo e Camacho (2015), em uma revisão bibliográfica sistemática de 52 artigos publicados nos últimos 13 anos, revelam que a aplicação do AHP é predominante nos estudos de casos relacionados principalmente às indústrias, e três artigos buscam como classificar indicadores. Para facilitar a análise da consistência, as pesquisas mantêm o número de critérios e alternativas em sete ou menos. Os autores apontam que o julgamento, para a análise de comparação pareada, em alguns casos não é claro como foi realizado. Os autores relataram a importância da ocorrência de um processo de validação de resultados.

Esses achados apontam recomendações para futuros estudos sobre as dificuldades na aplicação do AHP, como escolher os melhores critérios, como obter consenso e como fazer um melhor julgamento na comparação pareada. Existe um número infinito de maneiras de obter o vetor de prioridades a partir da matriz de comparação das alternativas. O problema de aceitar ou rejeitar matrizes tem sido muito discutido, especialmente a relação entre a consistência e a escala usada para representar os julgamentos do decisor.

O que se observa na literatura é que as relações de importância associadas à comparação paritária de critérios, e alternativas, podem resultar em conclusões, que não representam corretamente a importância de critérios ou alternativas.

Nesse contexto, a escala verbal proposta por Saaty possui uma escala linear de variação. Trabalhos com o de Franek e Kresta (2014), apontam a necessidade de uma abordagem com 
programação matemática, aplicando diferentes escalas de julgamento, pode ser um destaque em pesquisas posteriores, e assim representar uma comparação melhor delineada.

\subsubsection{O Método de Organização do Ranking de Preferências - PROMETHEE I e II}

Os métodos da série PROMETHEE pertencem à família de métodos hierárquicos que consistem em melhorar a ordem de dominância, por meio de comparações par a par, segundo Zuffo (1998). São compostos por três fases: (i) construção de critérios generalizados; (ii) determinação de uma relação de hierarquização entre os critérios; e (iii) avaliação dessa relação para propiciar uma resposta ao problema, analisando o conjunto de alternativas.

Os métodos PROMETHEE estabelecem uma estrutura de preferência entre alternativas discretas, conforme apontam Zuffo (1998), Zuffo et al. (2002), Fantinatti (2011) e Fantinatti et al. (2015). Ademais, prescindem de informações adicionais, conforme apontam Zuffo (1998), Zuffo et al. (2002), Fantinatti (2011) e Fantinatti et al. (2015), tais como:

a) Entre critérios - representada por pesos (" $a_{i}$ "), os quais indicam a importância relativa entre os critérios. Os pesos são assumidos positivos, e o maior peso de um critério, entre os demais, indica a maior importância deste em relação aos outros critérios. A soma dos pesos deve ser, sempre, igual a 1;

b) Internamente aos critérios - nas comparações par a par das alternativas, devem-se observar as diferenças entre os valores de um mesmo critério para as diferentes alternativas. Esses desvios indicam, por menor que possam ser, uma preferência do decisor para a melhor alternativa. Um maior desvio indicará uma maior preferência. As preferências devem assumir números reais compreendidos entre 0 e 1 . Onde $P$ representa o conjunto de alternativas analisadas.

Para cada critério "I", o decisor tem em mente a função " $\mathrm{f}_{\mathrm{i}}(\mathrm{k})$ ", representada na eq,(16).:

$$
P_{i}(a, b)=P_{i}\left[d_{i}(a, b)\right], \forall a, b \in P,
$$

Em que: $d_{i}(a, b)=f_{i}(a)-f_{i}(b) e 0<P_{i}(a, b)<1$.

No caso de o critério ser maximizado, dada a preferência de "a" sobre "b", observa-se a diferença entre "a" e "b" segundo o critério "I". Essa diferença pode ser expressa por uma função de preferência, conforme indicado na eq.(17):

$$
P_{i}(a, b)=f_{i}\left[d_{i}(a, b)\right], \forall a, b \in P .
$$


No caso de o critério ser minimizado, a diferença observada entre "a" e "b" pode ser representada pela função de preferência, dada pela eq.(18).

$$
\boldsymbol{P}_{j}(\boldsymbol{a}, \boldsymbol{b})=\boldsymbol{P}_{j}\left[-d_{i}(a, b)\right], \forall a, b \in P .
$$

Na aplicação do método PROMETHEE, devem ser definidos os índices agregados de preferência e os fluxos de hierarquização. Os índices agregados de preferência são dados, abaixo, pela eq.(19).

$$
\pi(a, b)=\sum_{j=1}^{m} P_{j}(a, b) \propto_{j}, \forall a, b \in P,
$$

Em que:

$\pi(a, b)$ : expressa como, e com que grau, "a" é preferível a "b" sobre todos os critérios; $\pi(b, a)$ : expressa como "b" é preferível a "a".

De acordo com Zuffo (1998), tem-se " $\pi(a, b)$ " e " $\pi$ (b, a)" usualmente positivos, e com as seguintes propriedades: $\boldsymbol{\pi}(\boldsymbol{b}, \boldsymbol{a})=\mathbf{0} ; \mathrm{e}, \mathbf{0} \leq \boldsymbol{\pi}(\boldsymbol{a}, \boldsymbol{b}) \leq \mathbf{1} ; \forall \boldsymbol{a}, \boldsymbol{b} \in \boldsymbol{P}$.

A partir das avaliações " $\pi(a, b)$ " e " $\pi(b, a)$ ", para todos os pares de alternativas "a, b $\epsilon$ $P$ ", é possível elaborar um gráfico de ordenação dos valores das preferências sobre " $P$ ".

Por meio do método PROMETHEE, deve-se estabelecer os fluxos de importância entre as alternativas. Estes refletem o modo como uma alternativa supera (fluxo positivo) as demais alternativas ou é superada (fluxo negativo) por elas. Os fluxos em questão são definidos, respectivamente, pelas eq. (20) e eq.(21).

$$
\begin{aligned}
& \emptyset^{+}=\frac{1}{n-1} \sum_{x \in P} \pi(a, x), \\
& \emptyset^{-}=\frac{1}{n-1} \sum_{x \in P} \pi(a, x) .
\end{aligned}
$$

Os fluxos de importância refletem com uma alternativa supera outra alternativa (fluxo positivo), ou é superada por outra alternativa (fluxo negativo), definidos pelas equações 20 (positivos) e 21 (negativos).

Dessa forma, tanto o maior fluxo positivo, quanto o menor fluxo negativo definem a melhor alternativa (“a”) em relação às “( $(n-1)$ ” alternativas restantes. O método PROMETHEE promove, em sua concepção original, uma ordenação parcial entre as alternativas (ZUFFO, 1998 E FANTINATTI, 2011). Resumidamente, as alternativas com maiores fluxos positivos são aquelas que mais superam outras alternativas, e as alternativas com maiores fluxos negativos são aquelas que são mais superadas por outras alternativas. Portanto, as alternativas 
que simultaneamente possuem maiores fluxos positivos e menores fluxos negativos, são aquelas que predominam na decisão.

Por sua vez, o método PROMETHEE II, de acordo com Zuffo et al. (2002), promove uma ordenação completa a partir do balanço entre os fluxos de importância, para cada alternativa ("a $\in P$ ”). O fluxo de importância líquido de cada alternativa é dado pela eq.(22).

$$
\emptyset(\boldsymbol{a})=\emptyset^{+}(\boldsymbol{a})-\emptyset^{-}(\boldsymbol{a})
$$

Na ordenação completa do método PROMETHEE II, de acordo com Zuffo et al. (Ibidem), todas as alternativas devem ser comparáveis. Assim, as alternativas que não podem ser comparadas não devem permanecer na avaliação. A ordenação completa do método PROMETHEE II é definida pelos seguintes axiomas: a $\mathrm{P}^{\mathrm{II}} \mathrm{b}$, se $\phi(\mathrm{a})>\phi(\mathrm{b})$ e; $a \mathrm{I}^{\mathrm{II}} \mathrm{b}$, se $\phi(\mathrm{a})=$ $\phi(b)$.

Ainda, segundo Zuffo et al. (Ibidem), “a informação resultante é mais contestável, visto que uma parte considerável das informações se perdem, pois, consideram-se as diferenças" (Ibidem, p. 90).

\subsubsection{O Método de Medida de Atratividade por Avaliação Categórica (MACBETH)}

O método MACBETH difere dos demais por considerar, na fase de estruturação do problema, os conceitos do pensamento focado nos valores (KEENEY, 1992). Dessa maneira, por meio do método MACBETH (BANA E COSTA, DE CORTE e VANSNICK, 2005), devese, primeiro, estabelecer os valores do decisor, ou grupo de decisores, a partir dos quais será feita a análise do problema a ser resolvido.

Para todos os critérios, após terem sido definidos por meio de mapeamentos cognitivos do(s) decisor(es) e ou especialista(s), devem-se estabelecer os descritores, os quais indicarão as funções de valor de cada critério. Assim como definido por Keeney (1992), devem ser estabelecidos os níveis de desempenho "neutro" e "bom" para cada critério e, a partir deles, definir outros níveis de desempenho para que se possa prosseguir com as avaliações semânticas que indicarão as funções de valor de cada critério.

Para a conversão da escala semântica em uma escala numérica, Bana e Costa, De Corte e Vansnick (2005) propõem que se estabeleça o valor zero (0) para o nível "neutro" e o valor cem (100) para o nível "bom", para todos os critérios. Os autores (Ibidem) propõem, ainda, que 
devem ser estabelecidos não valores diretos para os demais níveis de desempenho em cada critério, mas preferências semânticas entre os diversos níveis de desempenho por parte dos decisores e ou especialistas.

Bana e Costa, De Corte e Vansnick $(2004,2005)$ defendem que, de acordo com as "teorias das preferências", o processo cognitivo não contempla escalas numéricas. Ao contrário, segundo os autores, o cérebro humano trabalha com escalas semânticas, tais como "ótimo", "bom”, "igual”, "ruim”, "péssimo” etc. Assim, propõem uma escala semântica de sete níveis de preferência: (i) extrema; (ii) muito forte; (iii) forte; (iv) moderada; (v) fraca; (vi) muito fraca; e (vii) nula.

Por fim, a partir da análise das preferências estabelecidas, respeitando-se as seguintes condições matemáticas, é que se estabelecem os valores (v(i)) para os demais níveis de desempenho em cada critério:

a) $\quad \mathrm{v}(\mathrm{a})>\mathrm{v}(\mathrm{b})$, se, e somente se, "a" é mais atrativa que "b" (a P b);

b) $\quad \mathrm{v}(\mathrm{a})=\mathrm{v}(\mathrm{e})$, se, e somente se, "a" é indiferente a "e" (a I e);

c) $\quad \mathrm{v}(\mathrm{a})-\mathrm{v}(\mathrm{b})>\mathrm{v}(\mathrm{c})-\mathrm{v}(\mathrm{d})$, se, e somente se, a diferença de atratividade entre "a" e "b" é maior que a diferença de atratividade entre "c" e " $d$ ".

Bana e Costa, De Corte e Vansnick (2005) propõem que, baseado no pensamento focado nos valores (KEENEY, 1992), depois de estabelecida a ordinalidade entre os critérios de avaliação, deve ser estabelecida a cardinalidade entre eles. No caso, a cardinalidade deverá ser definida a partir da comparação dos critérios - dois a dois - dentro do contexto decisório.

O método MACBETH usa a mesma escala semântica para a ponderação dos pesos entre os critérios, estabelecendo cenários fictícios, nos quais se estabelecem alternativas com níveis de desempenho "neutro" e "bom" em critérios conjuntos (dois a dois). E se verifica o grau de preferência do decisor, ou grupo de decisores, em relação ao cenário de desempenho "neutro", a partir de outros dois cenários, cada um com desempenho "bom" em apenas um dos critérios, permanecendo o outro critério no nível "neutro".

Os graus de preferência de um ou outro cenário indicarão qual é o critério mais importante segundo os valores dos decisores e, ainda, qual é o valor dessas preferências, de acordo com as condições matemáticas acima descritas. A avaliação e a hierarquização das alternativas pelo método MACBETH seguem o princípio de partir, primeiramente, da definição dos critérios e seus respectivos níveis de desempenho e, em segundo momento, da definição dos pesos de todos os critérios. 
O método MACBETH pressupõe o uso de uma função aditiva, conforme indicado na eq.(23).

$$
V(a)=\sum_{i=1}^{n} v(a)_{i} * \alpha_{i}
$$

Em que:

- $\mathrm{V}(\boldsymbol{a})$ é o valor de desempenho total, ponderado da alternativa “ $\boldsymbol{a}$ ”;

- $\mathrm{v}(\boldsymbol{a})$ é o valor desempenho da alternativa " $\boldsymbol{a}$ ”, no critério "i";

- $\quad \alpha_{\mathrm{i}}$ é o peso do critério “ $i$ ".

\subsubsection{Adaptação das metodologias MCDA para construção da proposta metodológica}

Keeney (1992), corroborado por Ensslin, Montibeller Neto e Noronha (2001) e Bana e Costa, De Corte e Vansnick (2004), afirma que, para a aplicação eficiente das metodologias multicritério de apoio à decisão, deve-se garantir a atuação dos decisores durante toda a estruturação dos problemas. Em abordagens participativas, a avaliação pareada de objetivos, com apoio da percepção dos atingidos pelo problema em questão, fornecerá insumos relevantes à análise. Deve-se definir, claramente, a escala de preferência desse grupo, o que é um dos principais pilares na resolução dos problemas pelo paradigma construtivista, inerente à metodologia.

Keeney (1992), Ensslin, Montibeller Neto e Noronha (2001) e Bana e Costa, De Corte e Vansnick (2004), entre outros, afirmam que a fase de estruturação dos critérios de avaliação das alternativas é a fase mais importante e decisiva para o sucesso da metodologia multicriterial.

Segundo Keeney (1992), o uso de um modelo aditivo pressupõe que os critérios sejam independentes não apenas em relação à análise de desempenho - isto é, o desempenho de qualquer alternativa em um determinado critério não pode ser influenciado pelo seu desempenho em qualquer outro critério -, mas também em relação às consequências do desempenho; ou seja, um desempenho positivo em um determinado critério deveria poder ser aproveitável (como consequência) no contexto decisório, independentemente do desempenho em qualquer outro critério.

Por isso, conforme apontado por Zuffo e Genovez (2006) e com base nos princípios do pensamento focado nos valores para análise multicriterial, desenvolvidos por Keeney (1992), 
os modelos multiplicativos podem ser mais recomendados para problemas relativos a questões urbanas, dependendo do contexto de análise.

Bana e Costa e Vansnick (2008) apontam e criticam as inconsistências do método AHP (SAATY, 1977, 1980). Belton (1986) critica a escala adotada por Saaty (1977), afirmando que sua pequena margem de variação implica valores subjetivos, isto é, não traduz com clareza os valores cognitivos dos decisores. Por sua vez, Fabretti et al. (2011) criticam o uso (equivocado) de escalas cardinais em vez de escalas semânticas, inclusive em métodos que prescindem de uma escala semântica, como o AHP.

Bana e Costa e Sanchez-Lopez (2009) afirmam que a abordagem construtivista é a única capaz de agregar, adequadamente, os aspectos subjetivos de temas transversais, tais como ambientais, urbanos e sociais, aos contextos de decisão. No mesmo sentido, Keeney (1992) afirma que as metodologias tradicionais erram ao focar a solução dos problemas na escolha de alternativas pré-definidas e defende que para uma solução mais legítima, eficiente e duradoura, o foco deve estar nos valores dos decisores. Depois de estabelecer os critérios de avaliação, a partir dos valores dos decisores, deve-se escolher a melhor alternativa ou, até mesmo, criar uma alternativa que se adeque melhor ao contexto decisório.

Keeney (1992) e Bana e Costa, De Corte e Vansnick (2005) criticam, também, o uso equivocado de escalas cardinais em vez de escalas semânticas, uma vez que as primeiras não são capazes de traduzir corretamente o processo cognitivo do pensamento humano. Por fim, Keeney (1992) afirma que o erro crítico mais comum é o de estabelecer pesos para os critérios sem considerar a independência entre eles e suas variações devidas às possíveis alterações no contexto decisório. Esse "erro crítico mais comum" (Ibidem, p. 147), presente constantemente nas metodologias tradicionais, apresenta-se na forma da pergunta "quanto um critério vale mais do que outro?".

Conforme Fantinatti (2011), a análise pode ser feita por meio de métodos quantitativos ou qualitativos. Vale ressaltar que o método científico e seus produtos não se dão à margem das questões políticas e econômicas e, portanto, não podem ser considerados objetos totalmente neutros. Para Buchanan e O’Connel (2006), o estudo da tomada de decisão é uma composição de várias áreas do conhecimento, como matemática, sociologia, psicologia, economia e ciência política. Já o estudo do risco e do comportamento organizacional nasce de um desejo mais prático: ajudar o decisor a obter melhores resultados. 
A crescente sofisticação da gestão de risco, a compreensão das variações do comportamento humano e o avanço tecnológico - que respalda e simula processos cognitivos - ajudam a melhorar, em muitas situações, a tomada de decisão. Assim, Santos, Thomaziello e Weill (2007) defendem que não há uma decisão única e verdadeira para um determinado problema quando se trata de questões que envolvam múltiplos critérios, tais como as questões ambientais e, analogamente, aquelas relativas ao gerenciamento dos recursos hídricos. Além disso, a "verdade" para um determinado caso pode não o ser para outro. Os autores ainda afirmam que, para se desenvolver um bom processo de tomada de decisão em situações complexas, típicas quando são envolvidos múltiplos critérios, deve-se compor um quadro de avaliação considerando instrumentos técnicos, sociais, legais e de políticas públicas.

Fica evidente, portanto, que as abordagens tradicionais não conseguem expressar as questões subjetivas inerentes a um problema complexo de múltiplos critérios, como é apontado por Ensslin, Montibeller Neto e Noronha (2001). Para Santos, Thomaziello e Weill (2007), as decisões baseadas em apenas parte do problema geralmente resultam em ações pouco efetivas ou - pior ainda - ilegítimas. Métodos tradicionais de resolução de problemas, que procuram enquadrar os problemas em categorias, focalizam a escolha de alternativas e a busca de uma solução ótima, baseando-se, exclusivamente, nas regras da racionalidade e desconsiderando a subjetividade dos atores envolvidos no processo decisório.

Por outro lado, ancorado pelo método AHP, o que se propõe nesta pesquisa, é que a avaliação das alternativas, por cada um dos critérios, pode ser feita com comparações das alternativas em função das características de sua função, em comparações relativas gradativas em função do comportamento de cada alternativa.

Em outras palavras, é possível adaptar a escala usada para comparar elementos no AHP, que é restrito aos números absolutos entre 1 e 9, por uma função matemática. Esta função pode ser aplicada por escalas numéricas, por exemplo, linear, exponencial, raiz quadrada, logarítmica, função recíproca e outras. Autores, como Ishizaka e Labib (2011), Saaty e Shang (2011) e Franek e Kresta (2014) e, já sugeriram em pesquisas anteriores que uma maneira de reduzir a inconsistência são a escala verbal de Saaty dos julgamentos, porém não ajustar as próprias comparações em intervalos de domínio representativos de cada importância.

Os valores de comparação pareadas são ajustados à escala qualitativa de importância relativa proposta por Saaty. Para isso, a função matemática que melhor se ajusta aos dados deve ser determinada (linear, exponencial, raiz quadrada, logarítmica, função recíproca e outras), associando a distância relativa entre as alternativas e os valores da escala de Saaty. Cada uma 
dessas funções possui características específicas, associando uma variável x., que é a distância matemática entre as alternativas, de acordo com cada critério, e uma constante K.

O valor de y será o respectivo valor na escala de Saaty. A função pode resultar em números inteiros, para que os intervalos possam ser fixados na escala semântica de Saaty os resultados podem ser aproximados em intervalos, dependendo dos limites inferior e superior de cada domínio. Embora x e k sejam reais y deve assumir valores racionais positivos ajustados em intervalos ajustados a escalas semânticas de Saaty. Cada intervalo deve ser calculado para cada caso, conforme exemplificado no quadro 12.

Neste contexto, para determinar a constante K, como as funções são conhecidas, os valores possíveis de y podem inicialmente assumir valores conhecidos $(1,2, \ldots, 9$ e seus valores recíprocos de $1 / 2,1 / 3, \ldots 1 / 9)$. Supõe-se que a maior distância positiva determina a dominância de uma alternativa contra outra, em um determinado critério. Esta distância será o valor de x, a maior dominância, ou seja, y, receberá o valor de 9.

Determinada a constante $\mathrm{K}$, é possível determinar os valores x para cada transição na escala de Saaty, e portanto todas as distancias associadas, ou seja o x para cada alternativa, estará em um intervalo inferior e superior, associado também a um intervalo inferior e superior de $\mathrm{y}$, em outras palavras os intervalos dos valores de x estarão associados a intervalos de y inteiro, ou racional, na escala de Saaty. Portando cada comparação pareadas pode ser descrita, a partir da função de transformação conhecida - associada a intervalos e limite inferiores e superiores da distância relativa à escala de Saaty.

Quadro 12 - Função de transformação das distancias relativas para escala Semântica de Preferência

\begin{tabular}{|c|l|c|}
\hline Função & \multicolumn{1}{|c|}{ Equação } & Parâmetros \\
\hline Linear & $\mathrm{y}=\mathrm{k} \cdot \mathrm{x}$ & \\
\hline Exponencial & $\mathrm{y}=\mathrm{k}^{\mathrm{x}}$ & \\
\cline { 1 - 1 } Raiz quadrada & $\mathrm{y}=\mathrm{k} \cdot \sqrt{\mathrm{x}}$ & \multirow{2}{*}{$\mathrm{x} ; \mathrm{y} ; \mathrm{k} \in \mathbb{R} \mid\left(\mathrm{y} \in \mathbb{Q}_{+}\right)$} \\
\hline Logarítmica & $\mathrm{y}=\mathrm{k} \cdot \log (\mathrm{x})$ & \\
\hline Reciproca & $\mathrm{y}=\mathrm{k} \cdot \mathrm{x}^{-1}$ & \\
\hline Geométrica & $\mathrm{y}=\mathrm{k}^{\mathrm{x}-1}$ & \\
\hline
\end{tabular}

Fonte: Do autor (2019). 
Ao aplicar a função de transformação diretamente às distâncias relativas, quando são pequenas, menores que 1 e maiores que 0 , há uma tendência de distorção do resultado. No entanto, ao aplicar a função de transformação e associá-la à recíproca, há uma inversão de dominância, dividindo-se 1 por um valor menor que 1 .

Essa razão, por si só, fortalece a necessidade de análise por intervalos de domínio. Em teoria, o ajuste é simples, ou seja, para cada intervalo da escala semântica de Saaty, está associado a um valor de distância limite relativo associado. Desta forma, as distâncias relativas positivas podem ser associadas à escala de preferência com um número inteiro na escala proposta por Saaty. Os recíprocos, ou seja, as distâncias relativas negativas, também podem ser ajustados a partir de intervalos, da mesma forma que as distâncias relativas positivas, desde que estejam associadas às razões positivas recíprocas de Saaty.

$\mathrm{Na}$ comparação pareada dos critérios cada critério recebe um valor relativo à sua importância, ou dominância, em relação a outro. Existem várias maneiras de compará-los, por exemplo, assumir que todos têm a mesma importância, ou realizar entrevistas e questionários com especialistas para avaliar o comportamento comparativo entre os critérios.

Independentemente do método estabelecido para comparação, entre si, dos critérios, a verdade é que esse processo absorve a subjetividade de cada caso em análise e, portanto, é uma forma versátil de análise, pois há combinações infinitas de pesos relativos para cada critério. Estes postulados estão ancorados nos axiomas de Euclides ${ }^{63}$, pois as coisas que são iguais à mesmas coisas são iguais entre si. Portanto, as coisas que coincidem umas com as outras são iguais entre si.

Os tomadores de decisão podem eliminar as alternativas consideradas impraticáveis ou que não correspondem aos critérios considerados relevantes. Outra maneira é pensar uma decomposição hierárquica em termos de causas e efeitos, essas relações podem formar uma hierarquia, como um diagrama de redes.

A estrutura de uma hierarquia, ou de rede é uma maneira de representar um problema do mundo real pelos olhos do observador, conforme a Figura 26. Na pesquisa operacional, uma decisão pode ser abordada pela maneira como realizar avaliações contínuas e propõe regras para testar a validade de um resultado.

\footnotetext{
${ }^{63}$ Euclides de Alexandria foi um professor, matemático platónico e escritor grego, muitas vezes referido como o "Pai da Geometria". Além de sua principal obra, Os Elementos, Euclides também escreveu sobre perspectivas, seções cônicas, geometria esférica, teoria dos números e rigor.
} 
Figura 26 - Estrutura genérica hierárquica de redes multicriteriais

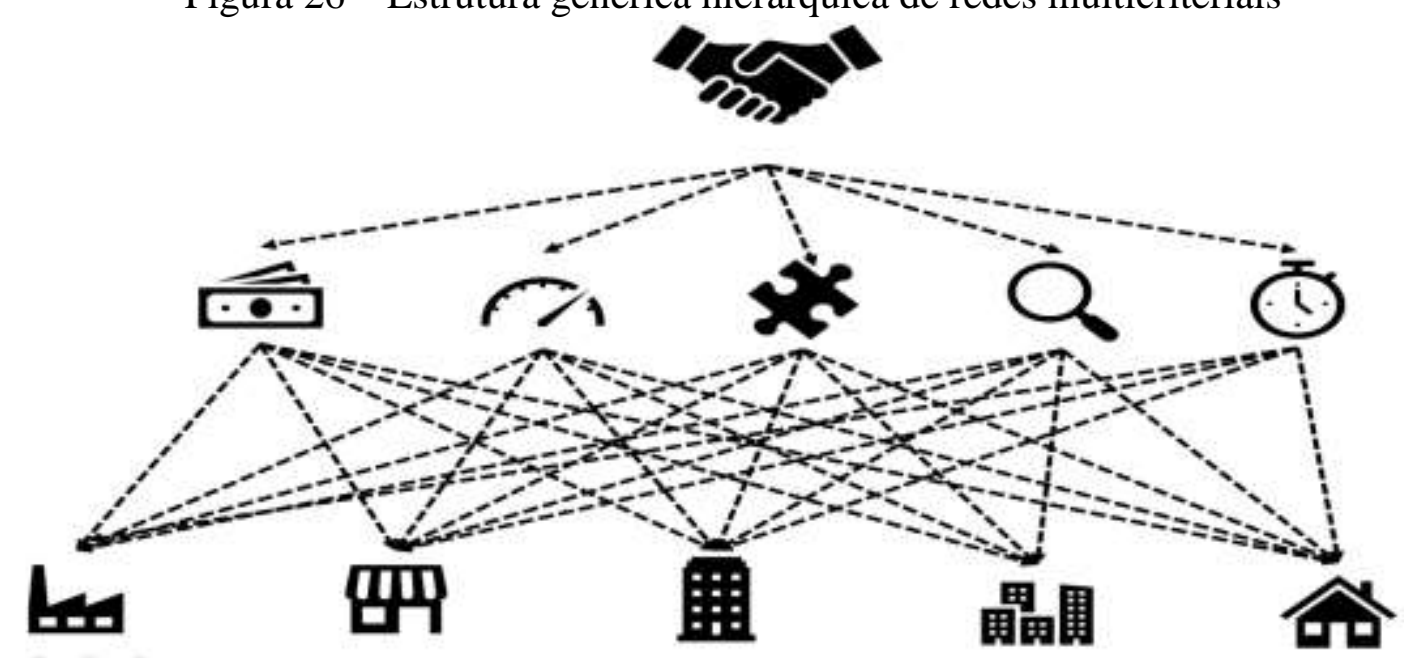

Fonte: Do autor (2019).

Uma estrutura hierárquica, testa em cada critério, o comportamento das alternativas, ou soluções, por exemplo, como na figura 26. No primeiro grau (topo) a "decisão", no segundo (intermediário) a lista de critérios selecionados, e no terceiro nível (abaixo) as alternativas que serão avaliadas.

Alguns autores (por exemplo, Jahangeer, Showkat e Sultan Bhat, 2018) já têm aplicado o método AHP no contexto de planejamento urbano. Em muitos casos, o AHP é uma ferramenta aplicada para a identificação, comparação e análise de decisão multicritério do planejamento e gerenciamento de demandas para o desenvolvimento urbano. Geralmente aplicam o método para se determinar a preferência das soluções a partir de parâmetros valorados a partir de opiniões.

Método da Programação por Compromisso (CP), ao apontar um modelo baseado no conceito da distância métrica entre dois pontos, O Método da Teoria dos Jogos Cooperativos (CGT) ao buscar a maior distância geométrica de um nível mínimo - que permite aos participantes se comunicarem e formarem relações de concordâncias, O Método Analítico Hierárquico (AHP) permitindo comparações paritárias a partir de uma escala semântica de julgamento, O Método de Organização do Ranking de Preferências (PROMETHEE I e II) que permite uma hierarquia partir da busca pela melhor ordem de dominância e o Método de Medida de Atratividade por Avaliação Categórica (MACBETH) ao estabelecer os valores do decisor, ou grupo de decisores, a partir dos quais será feita a análise do problema a ser resolvido, permitiriam estabelecer um modelo matemático multicriterial que permite hierarquizar elementos a partir da distância relativa para cada característica do elemento avaliado, e assim consolidando a proposta metodológica proposta nesta pesquisa. 


\section{DESENVOLVIMENTO DE UMA PROPOSTA METODOLÓGICA PARA PARTICIPACÃO POPULAR NA DEFINIĈ̃̃ DE ESTRATÉGIAS EM PLANEJAMENTO URBANO}

A revisão bibliográfica desenvolvida em planejamento urbano permitiu detectar as possibilidades de aplicação da proposta metodológica. A revisão bibliográfica , a análise do processo participativo do processo aplicado ao município de São Paulo e as entrevistas aplicadas à população, permitiram detectar as condicionantes necessárias aos processos participativos, e por fim, a revisão bibliográfica investigando instrumentos participativos, e metodologias de pesquisas participantes - associadas a uma abordagem matemática multicriterial, permitiram detectar as características necessárias para implementação de instrumentos de pesquisa participativa e como elaborar um modelo matemático que permita a hierarquização de estratégias. Essa abordagem sinérgica da pesquisa é apresentada na figura 27.

Figura 27 - Estrutura de construção da proposta metodológica

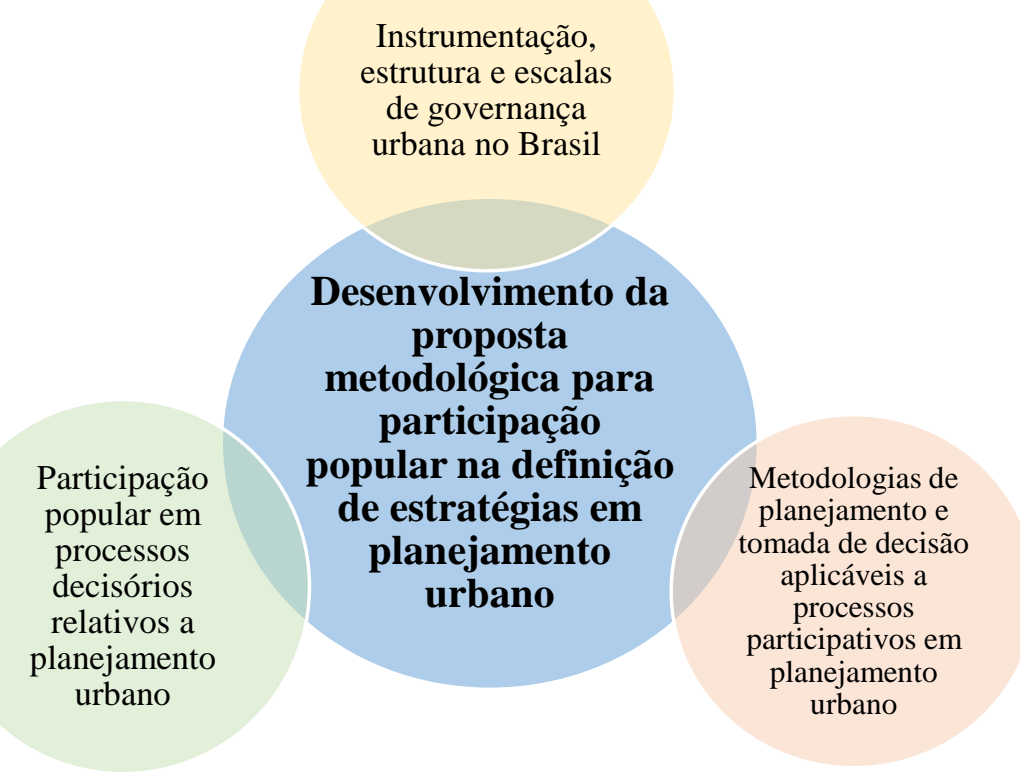

Fonte: Do autor (2019).

O aporte metodológico proposto nesta pesquisa consolida a ideia de que abordagens multicriteriais, construídas coletivamente e com participação popular, devem ser aplicadas em diversas etapas do planejamento urbano, como ferramenta de análise de alternativas, definição e seleção de objetivos, bem como de hierarquização de critérios. O procedimento em questão também poderia ser sistematizado em uma ferramenta de gerenciamento dos processos de governança urbana participativa. 
Propõe-se que essa abordagem possa ser uma ferramenta consistente e aderente para se conquistar, na prática, uma inovação na forma com a qual os processos participativos são construídos e na forma com que as demandas explicitadas nos processos podem construir, de forma estratégica, planos de ação. O desenvolvimento da proposta parte do princípio de que os decisores devem construir coletivamente sistemas de avaliação de alternativas, refletindo e definindo qual problema será resolvido e quais critérios serão usados na avaliação das alternativas. Ademais, a proposta proporciona a definição dos problemas, a identificação de alternativas e o delineamento das estratégias.

Diante disso, a metodologia proposta correlaciona a construção de critérios, seus níveis de desempenho, com a identificação e a avaliação de alternativas, em uma abordagem construtivista com que se aproprie simultaneamente de características dos grupos focais, e apoiada com a construção mapas falantes. A proposta metodológica permite a operacionalização dos momentos de planejamento estratégico sugeridos pelo MAPP - que é uma metodologia de planejamento participativo-, em que a governança participativa, usando modelagens multicriteriais, pode formar um processo de aprendizagem social com negociação e consenso. Essa visão é sumarizada no esquema de abordagem metodológica proposta, conforme figura 28.

Este modelo pode auxiliar na definição de estratégias em planejamento urbano, e possivelmente resultar em desdobramentos que permitam a elaboração de planos de bairro e projetos de intervenção em uma gestão participativa mediada. Essa rotina, na qual os resultados de pesquisa são construídos com ações sociais, é ancorada em uma perspectiva metodológica de Pesquisa-Ação.

Apesar de todo o aporte teórico e bibliográfico apresentado neste trabalho, nota-se que a atividade de planejamento, embora já robustamente instrumentalizada, necessita de reflexões e inserções multidisciplinares e do envolvimento efetivo de diversos atores. Dessa forma, insumos obtidos nos grupos focais e nos mapas falantes fornecerão, a partir do roteiro metodológico proposto, elementos que permitirão a aplicação dos Modelos Multicriteriais de Apoio à Decisão - os quais, por sua vez, subsidiarão a construção de elementos estratégicos de planejamento participativo. Esses procedimentos têm caráter educacional, com construção de consensos e negociações por meio de aprendizagem. Nesse esquema, os participantes são responsáveis pela decisão, exercendo a governança participativa. 
Figura 28 - Proposta de Abordagem Metodológica Participativa Com Apoio Multicriterial

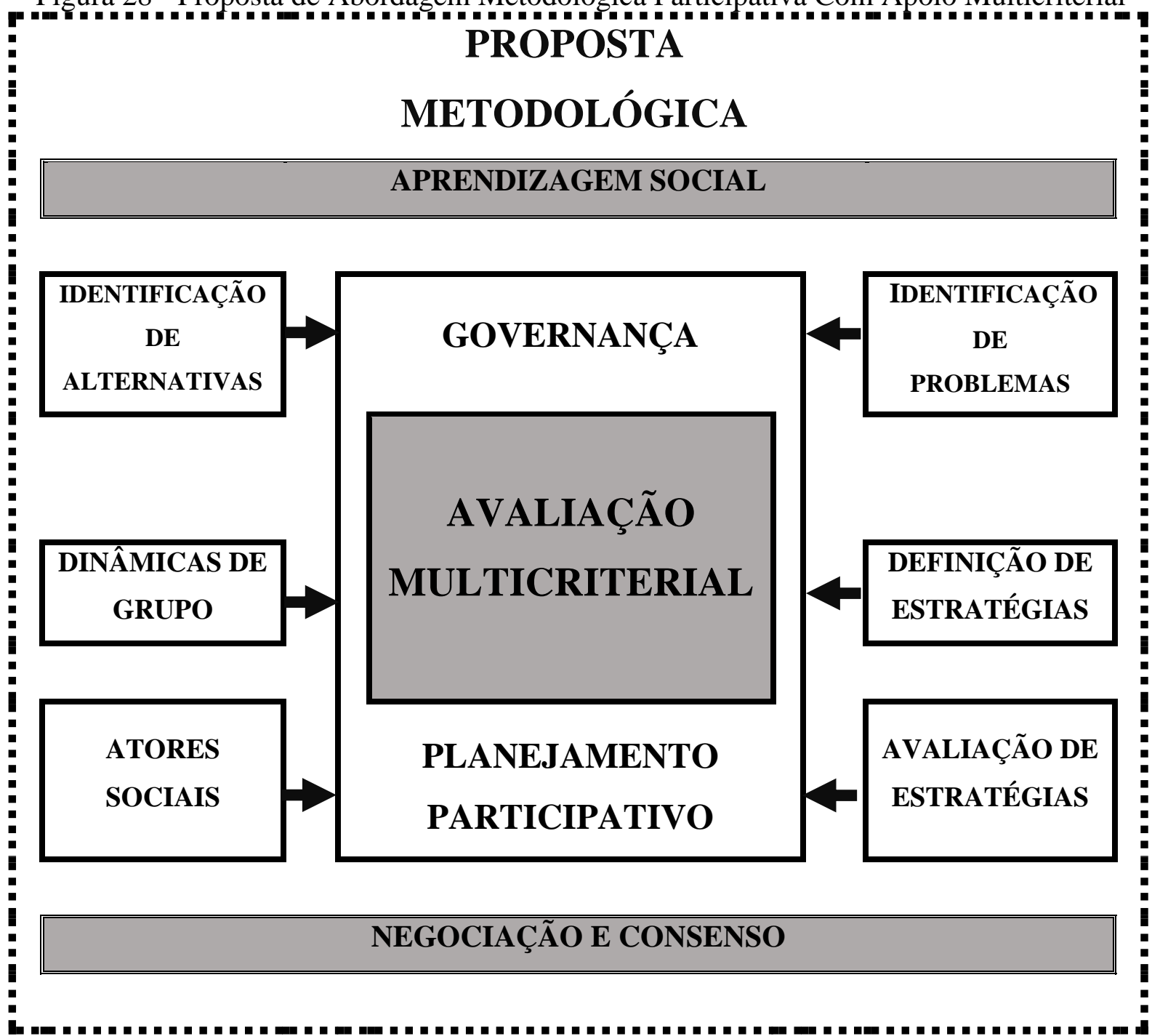

Fonte: Do autor (2019).

As reflexões técnicas de engenharia, de arquitetura e urbanismo, de ciências políticas, ciências sociais, matemática, psicologia e economia podem, mutuamente, construir ferramentas eficientes de planejamento urbano. Contudo, nota-se que nem sempre há sinergia entre essas áreas de conhecimento e atuação profissional e que a combinação de métodos propostos em cada uma dessas cadeiras podem compor um cenário mais elaborado sobre o futuro das cidades e as consequências das possíveis ações.

Métodos e abordagens que considerem os agentes de participação como decisores e sorvedouro de saber, podem considerar de forma valiosa as relações, por exemplo, entre os elementos do sistema urbano, o projeto de redes de transporte e serviço, a locação de equipamentos públicos e equipamentos urbanos, e até as diretrizes de uso e ocupação do solo. 
Ancorada nos processos de elaboração de políticas públicas urbanas, demonstra-se a estruturação utilizada para formulação das diretrizes construídas com saber individual e consolidação de técnicas e de metodologias estruturadas para cada etapa e para cada objetivo.

Sem dúvida, etapas como uma leitura técnica comunitária do município fornecerão insumos iniciais. Entretanto, neste momento, é relevante que se iniciem identificação e mobilização de grupos de interesse, ações comunitárias e detecção dos atores envolvidos, com intuito, ainda, de sistematizar essas informações, de forma a organizar os eventos participativos, bem como instrumentalizar o processo decisório e a hierarquização de critérios, objetivos e alternativas.

Partindo já para o extremo do processo (após a aplicação das metodologias participativas), o que se espera de uma etapa final é a formulação de propostas, a definição de estratégias, a priorização de ações e intervenções, a identificação dos processos de gestão e controle, bem como dos responsáveis e de sua prestação de contas, alinhadas a cenários alvos de abrangência local e suas tangências com os instrumentos municipais necessários.

Nesse contexto, em decisões urbanas, é importante reforçar que a cidade é o cenário em que as relações pessoais acontecem e que as alternativas são substrato para contextualizar a dinâmica dessas relações pessoais. Assim, é importante considerar:

a) interpenetralidade entre sujeito e objeto, ou seja, é muito difícil, ou improvável, a separação em sujeito e objeto que está em avaliação (seja ela alternativa, objetivo ou critério), pois a avaliação associa-se a valores e percepções do sujeito, e percepções colaborativas em processos participativos inclusivos podem retroalimentar as percepções individuais em torno de um objeto;

b) participação, delegação de poder e controle cidadão, já que os atores devem participar ativamente de todo o processo de estruturação, desde o diagnóstico dos problemas (do particular ao local e do local ao particular), construindo um saber comum pulverizado, em um processo inclusive educativo, de formação do agente social urbano;

c) construtivismo colaborativo, partindo dos princípios de que o decisor não conhece profundamente o problema e que seu conhecimento é evolutivo e contínuo, de modo que a interação dos envolvidos constrói a problemática e as ações necessárias para atingir um estado-meta de satisfação.

As abordagens multicriteriais serão a espinha dorsal de consolidação da proposta metodológica, de sua valiosa relação entre o construtivismo, a participação e a 
interpenetralidade, de sua disciplina hierárquica, que associa estruturação, avaliação e proposição. Sua análise evolutiva pode fornecer um entendimento do problema e a construção de uma rede de insumos necessários para seu avanço, criando um pano de fundo para a metodologia de suporte à decisão, ou hierarquização, em planejamento urbano.

Um critério permite a comparação de alternativas segundo um eixo particularmente significativo ou ponto de vista. Além disso, permite a avaliação das alternativas de forma a verificar que, para uma alteração na classificação de uma alternativa (segundo um dado critério), será observada uma redução ou um aumento da satisfação das alternativas. Os critérios aceitam que a subjetividade esteja sempre presente nos processos de decisão. Uma estrutura de valores dos decisores, associada aos critérios existentes, permite que as alternativas sejam examinadas, avaliadas e, caso possível, priorizadas.

Com atributos de sistemas complexos inseridos em metodologia multicritério de apoio à decisão (MCDA), instrumentalizados com a participação de representantes dos diversos atores nos processos de planejamento e gestão de áreas urbanas, será possível identificar e adotar, consensualmente, soluções de melhor compromisso e, portanto, mais inclusivas a serem implementadas de forma efetiva (legítima) e sistemática (constante). Tal consolidação pode ser exemplificada no mapa hierárquico da figura 29.

Do modelo proposto emerge, contudo, a questão de como operacionalizá-lo, e, ademais, na fase de estruturação, questiona-se quem fará a articulação e quem serão os atores - ou ainda, como, em um processo de escolha, agregar julgamentos múltiplos, conflitantes e de saberes heterogêneos? E de forma mais direta, como as percepções, informações e problemas serão recolhidos? Na fase de avaliação, outras questões, também de ordem operacional, ainda não estão equacionadas: como agregar as avaliações de alternativas sobre diversas ações e critérios? Quem define e como são definidos o desempenho e a ponderação dos critérios? Como as correlações são construídas? Como equacionar os trade-off? Como estabelecer consenso em grupos heterogêneos? E, por fim, como medir a eficiência e a eficácia das recomendações?

A proposta é que os objetivos, e as consequentes alternativas, a partir do diagnóstico de cenários atual e planejado, sejam explorados mediante Mapas Falantes e Cartografia Participativa, cujo processo metodológico está sumarizado na revisão bibliográfica. Esse processo contribuirá com a construção cooperativa de saber, por meio da reflexão entre moderador e sujeitos. Essa reflexão, imbuída em nexos causais de possíveis soluções, e sua difusão fornecerão os elementos para construção dos modelos multicriteriais, propostos no MCDA, e sua fase de estruturação. 
Figura 29 - Estruturação Hierárquica de Análise Multicriterial (MCDA)

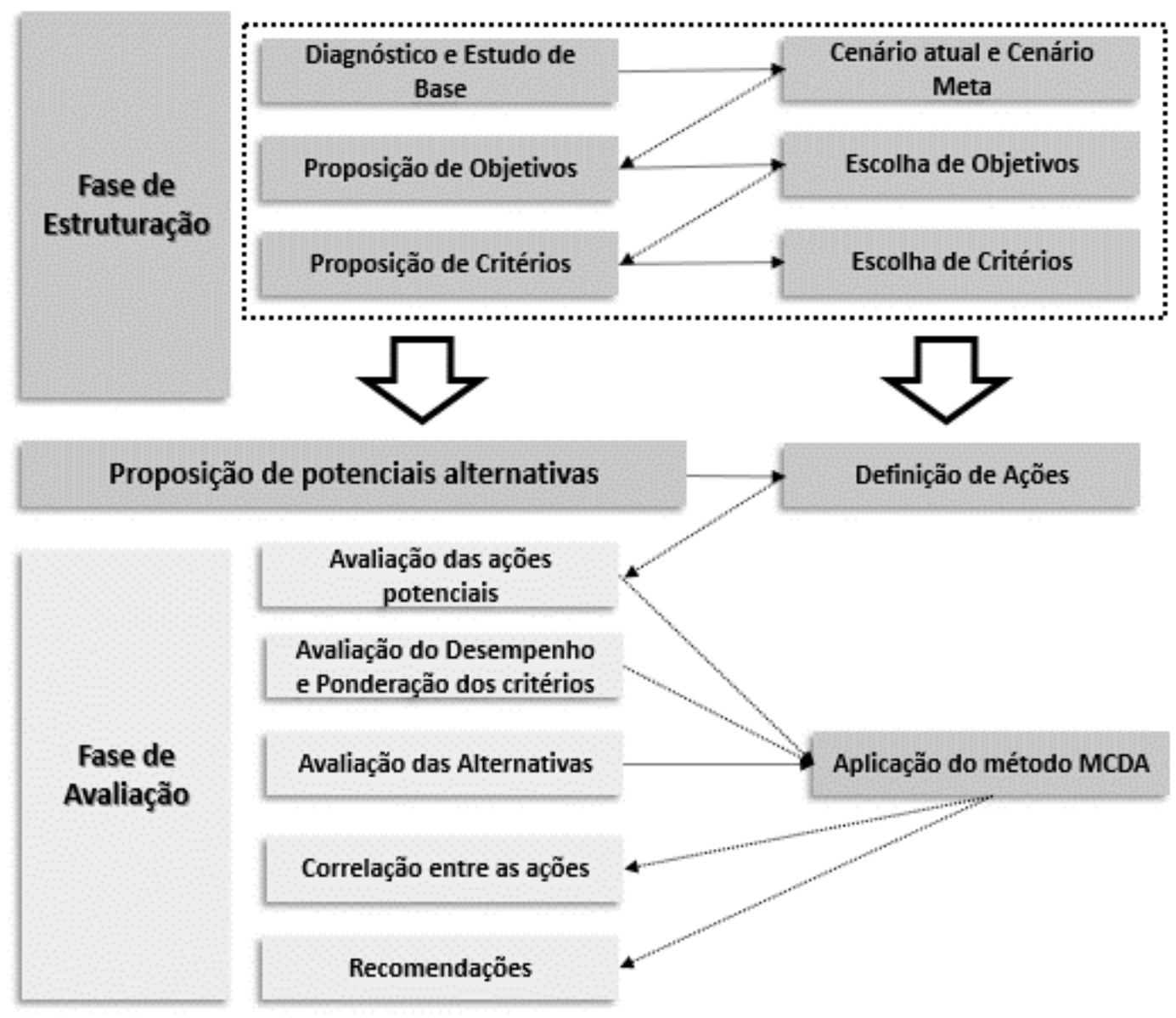

\section{Construção e Hierarquização de Propostas}

Fonte: Do autor (2019), adaptado de Fantinatti (2011).

Já a abordagem com grupos focais fornecerá os critérios e sua valoração, que orbitam cada uma das alternativas, apoiando, dessa forma, a fase de avaliação dos modelos multicriteriais MCDA. Nos grupos focais, serão estruturadas ações diagnósticas e a forma como elas serão encaradas em função do levantamento de problemas, para o planejamento de atividades e a formação educativa e colaborativa acerca de um tema, devendo ser considerados os recursos necessários.

O planejamento com cenários pode apresentar variações no seu enfoque qualitativo ou quantitativo. Ressalta-se que os participantes devem ter vivência com o tema a ser discutido, propiciando riqueza na troca de informações e coleta de percepções. Após a coleta de dados de determinada região, é recomendada a participação da população na realização do diagnóstico 
da situação da comunidade e na formulação de planos e programas de ações, com Mapas Falantes, cuja aplicação metodológica proposta é:

a) discussão e definições iniciais: debate para caracterização preliminar e acordo sobre quais as demandas específicas serão objetos de mapeamento no encontro. Define-se preliminarmente os objetivos do mapa que será produzido, a problemática e os conceitos a serem utilizados;

b) roteirização do mapeamento: serão apresentados os conceitos inerentes a planejamento urbano e suas variáveis de ação na realidade local, definindo-se, ao grupo, as escalas. Esta etapa pode auxiliar na construção do saber uniformizando e, assim, no levantamento de informações iniciais e expectativas sobre o que será encontrado no território;

c) mapeamento e qualificação das demandas: levantamento adicional de informações através do uso desenhos, figuras e fotografias - associados a mapas em escala -, sobrepondo as informações desenvolvidas no grupo à aplicação real e distribuída no território e verificando as possíveis tangências entre as ações;

d) análise crítica da produção posterior à análise de campo: recomenda-se que, após a construção do mapeamento, os participantes vão a campo e verifiquem a aplicação de suas propostas no local, despertando o "eu imaginário" e retomando, em uma segunda rodada do processo, no encontro seguinte. Assim, afina-se a construção do mapa e, por fim, obtêm-se as alternativas possíveis e os objetivos intrínsecos em cada alternativa.

Essa dinâmica circular retroalimentando o processo é o que permitirá uma ação efetiva da proposta metodológica. Na condução dos grupos, o roteiro metodológico proposto é:

a) acolhida: os participantes são apresentados, e os moderadores e observadores apresentam o foco da avaliação;

b) definições preliminares: são realizadas pelo moderador e pelo grupo, por quem a problemática específica será discutida, e o público participante será identificado (já serão acordadas as rotinas do grupo, o número de sessões e o tempo de cada intervenção);

definições das questões: para cada problemática desenrolada, devem ser identificadas questões centrais que a caracterizam, e, a partir destas questões, deve-se criar uma relação de dependência entre elas, além de, neste momento, haver perspectiva de que surjam alternativas e critérios, que definem estas alternativas, os quais deverão ser retroalimentados pelas contribuições oriundas dos Mapas Falantes e da Cartografia Participativa; 
c) análise das alternativas: neste momento, recomenda-se a valoração de cada critério e de cada alternativa frente a cada critério, verificando sua aderência ao escopo do problema, da situação atual e da situação-objetivo.

Este roteiro metodológico pressupõe que o avanço retroalimentado - questão a questão, critério a critério, alternativa a alternativa -poderá, à medida que os grupos focais e os Mapas Falantes ocorram com grupos diferentes, evitar o constrangimento de um frente a outro e, assim, auxiliar a lidar com situações complexas.

Dado que certas variáveis são elencadas por grupos distintos, talvez para o mesmo problema, a análise das questões em que conflito podem culminar em um consenso dado que as assimetrias e diferenças nas relações de poder serão reduzidas. Múltiplos critérios de avaliação, quando analisados em instantes diferentes, de forma mais profunda, não considerarão, em uma única rodada, que o problema esteja totalmente delineado.

No modelo em questão, os atores construirão o modelo de avaliação de alternativas, refletindo e definindo o problema a ser resolvido e os critérios que serão usados na avaliação das alternativas. Além disso, os técnicos apenas aplicarão o MCDA para obter uma resposta numérica hierarquizada de ações, que novamente serão colocadas em discussão, para aumentar a compreensão dos decisores sobre o problema, viabilizando sua melhor e constante atualização.

Nesse processo de estruturação, com a participação dos diversos atores, pode-se reduzir a assimetria de informações, uma vez que haverá uma construção inclusive educacional das possibilidades e limitações das intervenções. O fluxo metodológico, detalhado no Apêndice E, estrutura-se no modelo em que os Mapas Falantes fornecerão alternativas e objetivos, necessários para realização do MAPP. A partir dessa análise, o MAPP orientará a execução de um planejamento estratégico, explicativo e normativo, estruturado nos 15 passos.

De forma paralela, os grupos serão realizados para o desenvolvimento de objetivos e critérios. Neste momento, os objetivos que forem identificados nesta etapa, os quais possuem tangência com os objetivos apresentados nos Mapas Falantes, serão correlacionados. Com essa correlação construída, será possível a aplicação da abordagem multicriterial destacada no fluxo, com seus consequentes elementos, correlacionados com as etapas propostas. Assim, será permitida, após sua aplicação - também participativa -, a determinação de sistema de priorização, bem como as escalas de avaliação, com seu respectivo sistema de prestação de contas. 


\subsection{PROPOSTA METODOLÓGICA CRUZ \& MARINS - (PMCM)}

A problemática urbana pode ser encarada como uma questão mal estruturada, ou seja, aquela que não tem uma solução simplesmente equacionável, mas possui múltiplas possibilidades de soluções. Os problemas mal estruturados são aqueles em que a imaginação criativa terá a sua maior aplicabilidade, e a originalidade de suas soluções depende da qualidade das ideias que surgirão em um processo metodológico estruturado para tal.

A presente proposta metodológica, nesse contexto de problemas, busca desenvolver soluções e propor melhorias, estimulando e aplicando pensamento criativo e crítico para compreender, visualizar e descrever os problemas complexos ou mal estruturados. Assim, deve ser estruturada com a combinação de diversos métodos e dinâmicas de grupo.

Com base no contexto apresentado e nos achados na literatura, a proposta metodológica desenvolvida apresenta uma ferramenta de apoio aplicada a participação popular, de tal forma que possa: capacitar e difundir conhecimento e aprendizado aos participantes; contribuir coletivamente com a participação popular, para elaboração de um diagnóstico hierarquizado de problemas e alternativas para o contexto analisado; fortalecer o diálogo e o consenso por meio da troca de experiências e vivências, com inserção social; e finalmente a elaboração de uma hierarquia de problemas e soluções (ou potencial alternativas e estratégias).

As pessoas, em geral, precisam ouvir as opiniões dos outros antes de formar as suas próprias e, constantemente, mudam de posição (ou fundamentam melhor sua posição inicial) quando expostas à discussão em grupo. O processo de escuta da população é uma tarefa inesgotável, pois deve se repetir por inúmeras vezes, analisando as contribuições e verticalizando-as a cada novo debate proposto. Ou seja, as metodologias participativas devem ser aplicadas, reaplicadas e analisadas, criando um ciclo de retroalimentação.

Para que a participação popular atue de forma profícua, algumas premissas e diretrizes são importantes: (i) reconhecer lideranças locais e construir relações de confiança; (ii) os atores sociais que participam têm capacidade de analisar questões urbanas intrínsecas a sua realidade local; (iii) as questões individuais e particulares, quando discutidas com agentes sociais de mesma realidade, tornar-se-ão questões coletivas ou serão absorvidas em um contexto local; e (iv) abordagens de natureza construtivista serão realizadas na área de influência de atores sociais e, portanto, em sua organização local

Em resumo, a proposta combina elementos de pesquisas de opinião estruturadas em questionários, grupos focais, painéis integrados, Mapas Falantes e Cartografia Participativa. 
Essa combinação estruturada pretende contribuir para preencher a lacuna metodológica existente no processo de formulação de estratégias de planejamento urbano, a hierarquização de instrumentos urbanísticos e o delineamento de políticas públicas urbanas, que carece de efetiva influência participativa da população, mostrando, por muitas vezes, que não há relação entre os objetivos desejados e as formas de ação para que estes objetivos sejam alcançados.

A proposta metodológica incorpora índices de avaliação, que atuam no suporte ao diagnóstico de determinada situação, tornando-se instrumentos de análise do atendimento, ou não, dos requisitos ${ }^{64}$ de uma determinada população, comunidade ou região. Podem ser úteis na compreensão dos problemas e na determinação de ações, pois fornecem uma imagem representativa do objeto, reduzem a complexidade da análise e ainda podem ser moldados de maneira que se possa acompanhar as mudanças ou tendências do fenômeno estudado, agregando capacidade de resposta às mudanças.

Deve-se montar um fluxograma onde as questões relacionadas são decompostas em relações de causa e consequência, tarefa por meio da qual podem ser criadas relações de dependência entre os problemas e soluções. As causas dos problemas podem ser decompostas em toda a sua complexidade, constituindo inclusive subproblemas. A identificação das causas é essencial, pois não se atua sobre as consequências (sintomas) de um problema. Tal estreitamento colaborativo contribui para a "desparticularização" das questões, construindo relações de confiança e consenso.

Ademais, as dinâmicas de participação trazem aprendizado para a comunidade participante, dependendo dos métodos participativos empregados. Em grupos locais, por exemplo, que reúnem insumos gráficos e os distribuem em um espaço participativo, enfoca-se a uniformização dos saberes, desenvolvendo uma abordagem cognitiva colaborativa, que atua de forma pedagógica. Elevado o nível de conhecimento do problema e de suas características, verifica-se a manifestação da intencionalidade dos indivíduos e seu envolvimento na transformação local, atuando sobre a raiz dos seus problemas, de forma colaborativa e, com o aporte multicriterial, hierarquizando ações prioritárias. Nesse processo, afere-se, dentre outras percepções, as próprias dificuldades inerentes à execução dos planos e ações, e o próprio nível de engajamento dos atores e decisores e a verificação de objetivos atingíveis.

Diante disso, o envolvimento de grupos é um fato relevante a ser considerado, de modo que devem ser constituídos métodos de sensibilização ou de preparação. Outro ponto

\footnotetext{
${ }^{64}$ Requisitos são necessidades, desejos e expectativas que são quantificados por critérios, que por sua vez, são elementos de juízo, discernimento ou avaliação.
} 
importante é o pleno acesso de todos os participantes à informação. Assim, as redes multicriteriais devem ser visualizadas permanentemente por todo o grupo - por exemplo, com uso tarjetas (cartelas de papel), feitas pelos próprios participantes.

A proposta metodológica, se consolida em 6 etapas , e uma avaliação final do processo. As etapas são (i) etapa de mobilização - responsável pelo engajamento e envolvimento dos atores; (ii) etapa de preparação - responsável pela preparação dos materiais e insumos aplicados nas etapas presenciais; (iii) etapa de aplicação inclusiva-propositiva - responsável pela acolhida e aplicação dos instrumentos de identificação e definição de problemas, alternativas e estratégias; (iv) etapa de interpretação e sistematização - responsável pela sistematização dos insumos obtidos na etapa inclusiva-propositiva; (v) etapa de valoraçãoavaliação - responsável pela avaliação qualitativa e quantitativa dos problemas, alternativas e estratégias; e finalmente (vi) etapa de consolidação de resultados - responsável pela sistematização da valoração estabelecida, cálculo dos índices e hierarquização dos problema e alternativas.

A avaliação final permite uma associação multicriterial entre os problemas e as alternativas, permitindo ao gestor uma hierarquização das estratégias prioritárias, que pode considerar uma miscelânea de índices. A etapa de mobilização deve criar canais de convite e envolvimento da população, a etapa de preparação deve estabelecer rotinas de diagnóstico e reconhecimento do problema, do contexto ou da área objeto de estudo.

A etapa de aplicação inclusiva-propositiva, é dividida em três blocos de atividade. $\mathrm{O}$ primeiro bloco consiste em seis atividades: (i) recepção; (ii) dinâmica inicial de estreitamento de relacionamento; (iii) dinâmica de apresentação; (iv) dinâmica de estimulo positivista; (v) registro de expectativas; e por fim (v) exposição do moderador. O segundo bloco consiste em duas atividades: (i) tempestade cerebral de soluções; e o (ii) painel gráfico colaborativo da visão. Entre o primeiro e o segundo bloco, á uma etapa intermediária de aplicação do painel de seleção de problemas. O terceiro bloco consiste em duas atividades: (i) sensibilização do olhar; e (ii) retomada ao registro de expectativas.

A etapa de sistematização deve consolidar os resultados inerentes aos instrumentos aplicados na etapa inclusiva-propositiva, fornecendo insumos para as etapas subsequentes. Também deve contar a preparação das próximas etapas, inclusive a organização do espaço físico. 
A etapa de sistematização propõe organização do material registrado, a interpretação sobre a característica do grupo, a busca de representações, organização do material produzido, sistematização dos problemas, a elaboração do Painel de Impacto dos Problemas, a sistematização de soluções a elaboração de Painel de Ligação Peer-to-Peer, a elaboração de Painel de Análise e Correlação de Alternativas, a elaboração de Painel de Avaliação das Alternativas a elaboração de Painel de Críticas Postergadas, a elaboração de Painel de Abrangência e a elaboração de Painéis Iconográficos.

A etapa de valoração-avaliação é organizada em 5 blocos. Nas atividades desta etapa, os atores envolvidos no processo atribuem valores as estratégias delineadas e sintetizadas nos painéis preparados. Os blocos são organizados de tal forma que o primeiro bloco conte com as seguintes atividades: (i) recepção; (ii) exposição de reforço do compromisso; (iii) dinâmica laboral de estreitamento; e por fim (iv) dinâmica de fortalecimento de vínculos. O segundo bloco conta com as atividades: (i) valoração do Painel de Efeitos e Impactos dos Problemas; e (ii) estabelecimento das redes peer-to-peer; verificação da intensidade das correlações. $\mathrm{O}$ terceiro bloco conta com as atividades: (i) análise e valoração de oportunidades e ameaças nas alternativas; e (ii) inserção territorial e escalas.

No quarto bloco ocorrem as atividades : (i) avaliação de fraquezas e ameaças; e o (ii) mosaico de fotos. Finalizando, o quinto bloco conta com as atividades: (i) fechamento das expectativas; e (ii) revalidação de opiniões. Resumidamente, todos os painéis elaborados na etapa de sistematização são preenchidos pela população.

A etapa de consolidação de resultados permite o cálculo dos índices de apoio para hierarquização dos problemas e das alternativas valoradas na etapa anterior. E por fim a associação multicriterial de problemas e alternativas, permite uma visão integrada do processo apoiando os decisores na hierarquização, e definição, de estratégias.

Genericamente, as diversas etapas, blocos e atividades consolidadas na proposta metodológica podem ser visualizadas em um fluxo de aplicação apresentado na figura 30. 
Figura 30 - Fluxo estruturado da proposta metodológica

\begin{tabular}{|c|c|c|c|c|}
\hline \multirow{2}{*}{\multicolumn{2}{|c|}{$\begin{array}{c}\text { Etapa de aplicação inclusiva- } \\
\text { propositiva }\end{array}$}} & & \\
\hline & & $\begin{array}{c}\text { Etapa de interpretação e } \\
\text { sistematização }\end{array}$ & \multicolumn{2}{|c|}{ Etapa de valoração - avaliação } \\
\hline Recep̧̧̃̃o & \multirow{6}{*}{$\begin{array}{c}\text { Bloco } \\
1\end{array}$} & Organização do material registrado & Recepção & \multirow{4}{*}{$\begin{array}{c}\text { Bloco } \\
1\end{array}$} \\
\hline $\begin{array}{l}\text { Dinâmica inicial de estreitamento } \\
\text { de relacionamento }\end{array}$ & & $\begin{array}{c}\text { Interpretação sobre a característica do } \\
\text { grupo }\end{array}$ & Exposição de reforço do compromisso & \\
\hline Dinâmica de apresentação & & Busca de representações & Dinâmica laboral de estreitamento & \\
\hline Dinâmica de estimulo positivista & & Organização do material produzido & $\begin{array}{c}\text { Dinâmica de fortalecimento de } \\
\text { vínculos }\end{array}$ & \\
\hline Registro de expectativas & & Sistematização dos problemas & $\begin{array}{c}\text { Valoração do Painel de Impacto dos } \\
\text { Problemas }\end{array}$ & \multirow{3}{*}{$\begin{array}{c}\text { Bloco } \\
2\end{array}$} \\
\hline Exposição do moderador & & Sistematização de soluções & $\begin{array}{c}\text { Estabelecimento das redes Peer-to- } \\
\text { Peer }\end{array}$ & \\
\hline Painel de seleção de probl & & $\begin{array}{c}\text { Elaboração do Painel de Impacto dos } \\
\text { Problemas }\end{array}$ & $\begin{array}{l}\text { Verificação da intensidade das } \\
\text { correlações }\end{array}$ & \\
\hline Tempestade cerebral de soluções & \multirow{2}{*}{$\begin{array}{c}\text { Bloco } \\
2\end{array}$} & $\begin{array}{c}\text { Elaboração de Painel de Ligação Peer- } \\
\qquad \text { to-Peer }\end{array}$ & $\begin{array}{c}\text { Análise e valoração de oportunidades e } \\
\text { ameaça nas alternativas }\end{array}$ & \multirow{2}{*}{$\begin{array}{c}\text { Bloco } \\
3\end{array}$} \\
\hline $\begin{array}{l}\text { Painel gráfico colaborativo da } \\
\text { visão }\end{array}$ & & $\begin{array}{l}\text { Elaboração de Painel de Análise e } \\
\text { Correlação de Alternativas }\end{array}$ & Inserção territorial e escalas & \\
\hline Sensibilização do olhar & \multirow{4}{*}{$\begin{array}{c}\text { Bloco } \\
3\end{array}$} & $\begin{array}{c}\text { Elaboração de Painel de Avaliação das } \\
\text { Alternativas }\end{array}$ & Avaliação de fraquezas e ameaças & \multirow{2}{*}{$\begin{array}{c}\text { Bloco } \\
4\end{array}$} \\
\hline $\begin{array}{c}\text { Retomada ao registro de } \\
\text { expectativas }\end{array}$ & & $\begin{array}{c}\text { Elaboração de Painel de Críticas } \\
\text { Postergadas }\end{array}$ & Mosaico de fotos & \\
\hline & & Elaboração de Painel de Abrangência & Fechamento de expectativas & Bloco \\
\hline & & Elaboração de Painéis Iconográficos & Revalidação de Opiniões & 5 \\
\hline
\end{tabular}

\begin{tabular}{|c|c|}
\hline $\begin{array}{c}\text { Etapa de consolidação de } \\
\text { resultados }\end{array}$ & $\rightarrow$ Índices correlatos \\
\hline Hierarquização multicriterial de problemas & $I C P_{(p) ;} I I P ; I C P_{(a) ;} I H P$ \\
\hline $\begin{array}{l}\text { Hierarquização Multicriterial de Ligação } \\
\text { entre Problemas e Alternativas }\end{array}$ & $\begin{array}{c}I F P_{(p) ;} I F P_{(r)} ; I F A_{(p)} \\
\quad I F A_{(r)}\end{array}$ \\
\hline $\begin{array}{l}\text { Hierarquização Multicriterial de } \\
\text { Abrangência das Alternativas }\end{array}$ & $\begin{array}{c}I E A_{(c)} I E A_{(f) ;} I E A_{(e) ;} \\
I A A_{;} I S A ; I C A ; I I A_{i} I G A- \\
A_{(p) ;}: I G A-A_{(h)}\end{array}$ \\
\hline $\begin{array}{l}\text { Hierarquização Multicriterial de } \\
\text { Abrangência dos Problemas }\end{array}$ & $\begin{array}{c}I E P_{(c)} I E P_{(f) ;} I E P_{(e)} \\
I A P_{I} I S P_{I} I O P_{;} I U P_{I} I G A- \\
P_{(p)} ; I G A-P_{(h)}\end{array}$ \\
\hline $\begin{array}{l}\text { Avaliação do Processo de Correlação de } \\
\text { Alternativas e Problemas }\end{array}$ & $A Q C ; A A P ; A E P ; A F P$ \\
\hline Avaliação Hierárquica de Alternativas & $\begin{array}{c}I D I-A_{;} I D A-A_{;} I G D- \\
A_{;} I G D-A_{(p)} \\
I H A\end{array}$ \\
\hline
\end{tabular}

Fonte: Do autor (2019). 


\subsubsection{Etapa de mobilização}

No âmbito deste trabalho, a mobilização é considerada como o processo motivador para a reunião de atores que pretendem se envolver na discussão e no diagnóstico de problemas, na proposição e na avaliação de soluções, em uma dada realidade. Tanto o problema, quanto a solução, são considerados de interesse público coletivo. Nesse sentido, a mobilização é essencialmente uma tarefa de comunicação e engajamento. A arena de consulta social requer um planejamento estruturado de ações comunicativas, propiciando condições para participação e manutenção dos atores sociais engajados. Em uma sociedade complexa, os processos pelos quais os atores se mobilizam requerem novas estratégias. Na atualidade, não se pode ignorar o acoplamento das várias tecnologias, especialmente dos meios eletrônicos. Afinal, estes estabelecem um contato cada vez mais intenso e rápido entre os indivíduos e destes com as informações. Exemplos coordenados da construção da comunicação para a mobilização são as logomarcas associadas ao projeto, à produção e à disseminação de informações e convites, tais como folhetos, panfletos e cartazes, e mesmo a promoção de mídias, como vídeos institucionais, páginas em redes sociais e, por fim, a promoção de eventos - estas estratégias podem garantir e ampliar a visibilidade da proposta.

As ações de envolvimento devem se dar em âmbito local, de forma multidirecional e aberta, a fim de combater com a estagnação e a acomodação dos indivíduos, despertando sua curiosidade. É importante salientar que uma abrangência ampla de instrumentos e meios de comunicação é indispensável. O uso programado e articulado desses meios poderá criar um espaço participativo mais diverso e eficaz. Os instrumentos e veículos se complementam e se reforçam mutuamente. As chamadas e as ações de convite para atuar na arena de participação devem apresentar problemas reais em movimento e circulação na sociedade, e para as pessoas se engajarem em uma determinada ação, precisam de informação para se mobilizarem.

Um desafio é criar uma estratégia gráfica, textual, e visual que compartilhe do imaginário, das emoções e dos conhecimentos sobre a realidade à volta de cada um, gerando reflexão. Fundamentalmente, é importante tocar a emoção das pessoas, sem, contudo, manipulá-las. A troca de informações constitui uma rede de colaboração, que por sua vez, depende da geração de vínculos com a situação-objeto de análise. Nesse caso, a mobilização é, em essência, uma etapa para que os vínculos sejam fortalecidos e a confiança seja plantada, além de ser uma iniciativa para que as pessoas se percebam como protagonistas e sejam capazes de tomar iniciativas espontâneas, a fim de contribuir à causa dentro de suas especialidades e possibilidades. 
Contudo, a etapa de mobilização é um conjunto de ações coordenadas, cujo propósito é gerar e conduzir canais abertos e multilaterais de comunicação. Essa etapa deve motivar, associar e integrar os diversos públicos através da criação, da manutenção e do fortalecimento dos vínculos com o projeto proposto. Por sua vez, projetos mobilizadores são associados à troca de informações, com uma produção sistêmica de conhecimentos que permitam diagnosticar causas e consequências. A esfera participativa deve estruturar um processo dialógico de troca de experiências com o objetivo de solucionar problemas. Então, a proposta metodológica, em sua etapa de mobilização, deve se manifestar com uma unidade visual e gráfica característica, isto é, com imagens, cores, textos e informações que dialoguem com a realidade local. Ademais, a linguagem deve ser coesa em relação ao discurso do público alvo.

Evidentemente, não se minimiza o papel dos especialistas. Contudo, para que o projeto não se enverede por um viés tecnocrático, deve ser estabelecida uma estratégia de aprendizagem coletiva, ou seja, as informações são elaboradas e reelaboradas a partir do conhecimento adquirido na realidade local, produzindo informações úteis a quem as recebe e não a quem a transmite. As informações de parte a parte se consolidam em um encadeamento de intervenções comunicativas, que visam, entre outros objetivos, envolver a população de uma dada região, ou as pessoas envolvidas em uma determinada situação, a atuar em eventos participativos, sejam eles presenciais ou não.

\subsubsection{Etapa de preparação}

Após a realização da etapa de mobilização, é importante criar a arena em que a discussão e o diagnóstico de problemas, a proposição e a avaliação de soluções ocorrerão. A preparação desse espaço segue modelos de pesquisa-ação, na qual a importância do papel ativo do indivíduo na descoberta do conhecimento é fundamental. Aspectos como a construção e/ou a transformação da percepção social são processos de construção de conhecimento. Deve ser criado um ambiente que acolha uma abordagem compreensiva na intervenção, que inclui aspectos cognitivos e afetivos.

Nesse contexto, o domínio da problemática e a caracterização territorial do objeto de análise são importantes. Ambientam-se o moderador e sua equipe na condução das dinâmicas em grupo que serão aplicadas. Em outros termos, é fundamental uma pré-análise, que inclui um levantamento de dados e aspectos importantes de uma demanda, os quais poderão ser relevantes para a oficina, a dinâmica ou a arena de participação proposta. Na pré-análise, deve inteirar-se 
e ambientar-se na problemática a ser discutida, ou seja, a equipe condutora deve coletar dados, estudar, refletir e obter informações relevantes. É importante salientar que esse processo não cria, necessariamente, um programa rígido a ser seguido, mas, na realidade, qualifica a equipe para o encontro com os atores sociais. Assim, a equipe se prepara para a ação, antecipa temas e estratégias, como uma forma de qualificar-se para a condução.

O tema da dinâmica é o foco em torno do qual o trabalho será desenvolvido. Logo, ele precisa ser conciso, pois o foco determina a qualidade das percepções, e abrangente, no sentido de que a diversidade de atores favorece a riqueza dos insumos produzidos. O controle de tempo dedicado a cada tarefa na dinâmica, bem como a duração total da dinâmica, com a clara definição do foco, evitam uma excessiva mobilização afetiva e o personalismo nas questões.

A equipe responsável deve ser sensível para não levantar conflitos de forma indiscriminada no grupo e deve sempre recusar a postura de quem detém o saber, assumindo o lugar de dinamizador e facilitador do processo. A equipe tem papel ativo, mas não intrusivo, e é responsável pelo acolhimento, pelo incentivo e pela motivação do grupo. Em dinâmicas, realizadas presencialmente, devem ser planejados detalhes como local e horário de realização das dinâmicas, preparação física do espaço, identificação dos participantes e determinação dos locais onde cada participante terá assento.

Os atores participantes precisam ser lembrados da realização dos encontros, saber quantos encontros serão realizados e a duração de cada um deles. As aplicações preliminares dessa proposta metodológica apontam que o número de participantes deve ser dimensionado em função do tamanho da equipe de moderação dos encontros, em uma relação de 4/1 (quatro participantes para um moderador) a 10/1 (dez participantes para um moderador). Os participantes devem apresentar pelo menos um traço comum, que os unifica, determinado pelo objetivo do estudo, a exemplo da relação com a área objeto de estudo, conforme sugestões aplicadas aos grupos focais.

Os sujeitos, com idades, níveis de escolaridade e ocupações variadas, mobilizados na etapa de mobilização, a partir de características em comum associadas ao tema, inscrevem-se para participação nas dinâmicas, cada um com motivações específicas, que, em oportuno momento, deverão ser diagnosticadas. Evidentemente, algumas limitações devem ser analisadas - particularmente, a disponibilidade de horários -, e, portanto, devem ser oferecidas opções para os participantes. A experiência, neste trabalho, apontou que a convocação com uma semana de antecedência e um dia antes da realização das dinâmicas é interessante para que os 
convocados possam se organizar. O envio, de modo muito claro, da localização, com apresentação das formas de acesso, pode facilitar o cumprimento dos horários.

Na inscrição, disponibilizada em formulário impresso distribuído na área objeto de estudo e por mídias digitais, permite-se caracterizar o perfil dos mobilizados inscritos para participar das dinâmicas. As informações recolhidas são: endereço de e-mail, nome, dia e horário em que pretende participar, cidade em que reside, bairro em que reside, cidade em que estuda, trabalha ou exerce atividade, bairro em que exerce atividade, ocupação, idade, escolaridade e como tomou conhecimento ou se mobilizou para participar. Essa etapa permite o esclarecimento e a sistematização do perfil dos participantes e de suas experiências.

O ambiente facilita a aplicação da dinâmica, de modo que é recomendável um ambiente agradável, iluminado, sem objetos que possam desviar a atenção do grupo ou interromper as discussões. A localização dos sujeitos no espaço inclui cada um com uma mesa e uma cadeira, dispostos em semicírculo ou em formato de "U"; assim, todos podem se ver, e a interação entre os participantes é facilitada. A disposição de elementos gráficos com fotografias e vistas aéreas da região a ser tratada na dinâmica, destacando referências espaciais ((tais como avenidas, clubes, parques, edifícios públicos e terminais de transporte) auxilia os participantes a se localizar no território e construir uma visão global e de escala de toda a região, em âmbito coletivo.

O local de assento de cada participante deve ser planejado de forma que evite a proximidade de participantes que já se conheçam ou com quem possuam alguma familiaridade. Para tal, sugere-se colocar lado a lado: (i) pessoas que não se conhecem; (ii) pessoas com maior diferença de idade; (iii) pessoas com maior diferença de escolaridade; e (iv) pessoas com maior diferença de renda. Preliminarmente, a entrega de crachás nominais impressos para cada participante, com o primeiro nome e uma fotografia, e documento orientativo para identificação do local onde cada pessoa deverá ter assento, favorece a organização do espaço, bem como um relacionamento inicial de personificação do indivíduo no grupo.

\subsubsection{Etapa de aplicação inclusiva-propositiva}

Para que a dinâmica potencialize a motivação tanto dos participantes quanto da equipe de moderação, o tempo de duração ideal pressupõe dois encontros com duração entre 3 a 4 horas cada. A equipe deve deixar a sala preparada, desde de o layout até a identificação dos locais, posicionamento das fotografias inerentes ao tema, os painéis em branco que serão 
oportunamente preenchidos e os materiais utilizados (canetas, folhas sulfite, lápis coloridos, tesouras, réguas, colas, papéis coloridos, jornais e revistas) para as atividade laborais. A preparação de um lanche rápido, para acolhida dos participantes, favorece a criação de um ambiente mais agradável. As pessoas permeadas pela comensalidade se permitem uma troca de ideias mais descontraída. Contudo, a narrativa que fazemos de nós é uma forma de contar para nós mesmos e para os outros quem somos, contribuindo para construir uma identidade de grupo que facilite as identificações interpessoais.

A dinâmica segue um roteiro de atividades sequenciais, cujo delineamento cria a interação do grupo e torna-se parte integrante da técnica. Isso ocorre de forma a ultrapassar o nível superficial e defensivo dos sujeitos, normal em qualquer interação entre pessoas desconhecidas, com intuito de alcançar o lado autêntico e reflexivo de cada participante, no primeiro encontro, em um primeiro bloco de fortalecimento de relações, cujas etapas estão destacadas em seis atividades:

a) recepção: as pessoas são recebidas, assinam uma lista de presença, recebem o crachá nominal e são apresentadas ao local, além de indicadas a se sentar junto às mesas, nas posições indicadas pelo nome. Lá estarão uma caneta, um bloco com folhas em branco, e um crachá nominal. Pode ser interessante a equipe preparar um formulário para os participantes, com algumas questões acerca do tema proposto, para que os participantes atribuam notas ("péssimo", "ruim”, "regular”, "bom” e “ótimo”), para algumas situações acerca da área objeto de estudo, cada participante preencherá individualmente esse formulário;

b) dinâmica inicial de estreitamento de relacionamento: neste momento, ocorre a formação de sentimento e identidade de grupo. O moderador se apresenta e apresenta a equipe de apoio. É fundamental que o moderador crie o ambiente de igualdade, e é importante a equipe salientar que nesse espaço não existem títulos ou hierarquias, que as pessoas são indivíduos e que os pronomes de tratamento (senhor, senhora, professor, professora) devem ser evitados, de forma que cada um deve referir-se ao outro apenas pelo nome. Este procedimento estabelece uma rede de identificações e de coesão entre os membros;

c) dinâmica de apresentação: nesta etapa deve ser criado o ambiente de envolvimento e sensibilização, inclusive de forma laboral. As pessoas devem se sentir confortáveis no processo. A proposta apresenta um roteiro para que as pessoas se conheçam, e a atividade consiste em separar as pessoas em duplas, geralmente as duas sentadas ao lado uma da 
outra. Então, a pessoa "A" se apresenta individualmente para a pessoa "B"; em seguida, a pessoa "'B" se apresenta individualmente para a pessoa "A" (sugere-se um tempo de 5 a 10 minutos para esta etapa). Depois disso, as pessoas são convidadas a se apresentarem em voz alta para todo o grupo, contudo a pessoa " $A$ " se apresenta ao grupo como se fosse a pessoa "B", e a pessoa "B" se apresenta ao grupo como se fosse a pessoa "A". Após todos realizarem essa tarefa, são colocadas algumas questões para reflexão do grupo, tais como "como nos sentimos quando fomos apresentando por outros em nosso lugar?" e “como nos sentimos quando apresentamos o outro?". Neste momento reflexivo, o moderador deve provocar o grupo instigando para que as pessoas apontem o que faltou e por que faltou. Esta etapa permite que as pessoas possam se colocar no lugar das outras, e assim o ambiente positivo para troca de percepções é cultivado. Aqui são percebidos o surgimento das diferenças e a construção de condições de produtividade do grupo. $\mathrm{O}$ moderador deve apontar os laços que se formam dentro do grupo. Ao desempenhar papéis, o indivíduo participa de um mundo que não é o seu, e ao interiorizar esses papéis, o mesmo mundo torna-se subjetivamente real para ele. Esta dinâmica, embora simples, possibilita que as pessoas se coloquem no lugar do outro, com a intenção de que se possa entender mais facilmente as opiniões, ideias e visões de uma outra pessoa, antes mesmo de possíveis julgamentos;

d) dinâmica de estímulo positivista: por vezes, as pessoas ficam inseguras ao apresentarem suas opiniões, com receio de julgamentos. Criticar é algo intrínseco à natureza humana, contudo, nesta proposta, o momento da crítica deve ser apropriado. Para que a ideia flua livremente, é estabelecido um pacto no grupo, um "contrato" positivista. Para isso, a proposta metodológica sugere que seja reservado no fundo da sala um painel em branco, chamado de Painel de Killer Phrases ou Painel de Frases Mórbidas. Este painel é reservado para que os participantes preencham com frases ou críticas destrutivas. Seu funcionamento consiste na rotina de que quando algum participante, intencionalmente ou não, proferir alguma frase crítica destrutiva (por exemplo, “isso é inviável”, “isso é impossível" ou "você é maluco"), enquanto outras pessoas fazem sugestões, ele deverá ir até o painel e escrever a frase. Ao moderador cabe reforçar que o momento da crítica chegará, que, por hora, o espaço abriga ideias e sugestões, sem julgamentos. Esta dinâmica, além de criar um ambiente descontraído, propicia que as próprias pessoas, de forma autônoma, quando alguém falar algo destrutivo, já indiquem que o autor da frase destrutiva vá ao painel. $\mathrm{O}$ tom de brincadeira não constrange as pessoas, e, assim, todos 
ficam confortáveis para fazer contribuições. O importante é fazer com que cada indivíduo criativo e o grupo se sensibilizem com as frases mórbidas;

e) registro de expectativa: Neste momento, também em um painel em branco, agora na frente da sala, o moderador sugere aos participantes que apontem as suas expectativas individuais para o encontro. O moderador solicita que as pessoas verbalizem suas intenções. Desta maneira, tanto o grupo quanto o moderador podem reconhecer as singularidades de cada indivíduo. O moderador, por sua vez deve sublinhar as diferenças enfatizando o que cada participante traz de produtivo para o grupo. É possível que nesta dinâmica os participantes podem atuar como "interpretadores" uns para os outros fortalecendo a rede e incrementando o estabelecimento de transferências;

f) exposição do moderador: chegado a este ponto, o moderador e sua equipe devem apresentar aos participantes as expectativas da equipe e o propósito da realização dos trabalhos. Complementarmente, é importante que o moderador e sua equipe realizem a apresentação de conteúdo relevante ao tema. O aprendizado é importante e é um fator agregador, portanto, como retribuição à participação dos sujeitos, especialmente quando isso ocorre de forma voluntária, a equipe deve preparar a explanação de conceitos, definições e envolvimento ao tema proposto. Essa tarefa ajuda a nivelar o conteúdo entre os participantes e a capacitá-los. Também, de forma subsequente, o moderador, de forma isenta, deve apresentar dados sobre a temática de estudo, a caracterização do objeto de estudo, do tema e da área, e pode usar as figuras que decoram a sala como exemplos (são detalhes importantes a serem levados em conta na etapa de preparação e mobilização). Ao fim desta exposição, o moderador pode recolher os formulários preenchidos, se foram preparados pela equipe, entregues na atividade "a" deste bloco.

A exposição do moderador no fim deste primeiro bloco atua como uma etapa intermediária de preparação para o processo de pensamento criativo que virá a seguir, é a fase onde existe uma sensibilização acerca do problema. Uma condição para o descobrimento de um problema é a intensa preocupação com os aspectos e elementos deste problema, assim como a motivação da pessoa para reconhecer e dissecar o problema. A adequada fundamentação detalhada do objeto de estudo deve apresentar um contexto no qual os problemas, quando discutidos pelos participantes, possam ser analisados com flexibilidade para possibilitar posteriores mudanças.

Finalizado esse primeiro bloco de atividades com duração aproximada de uma hora a uma hora e meia, o moderador propõe uma pausa para um lanche. Neste momento, há um 
espaço da interação informal e paralela do grupo e, portanto, o aprofundamento de relações pessoais entre os participantes. Após a pausa, o moderador convida os participantes a retornarem aos seu lugares, para iniciar o segundo bloco de atividades, que será o momento de elaboração, ou seja, os sujeitos trabalharão a experiência através da comunicação, envolvidos de maneira integral, para sentir, pensar e agir, sobre as problemáticas do tema de estudo, com a aplicação de uma atividade colaborativa, com o Painel de Seleção de Problemas.

Esta etapa (Painel de Seleção de Problemas) é estruturada com base no método do painel integrado, ou seja, os participantes são separados em subgrupos, com entre duas e quatro pessoas. O moderador, conhecedor prévio do perfil dos participantes, deve compor grupos baseados na diversidade e na heterogeneidade dos participantes. A equipe deve selecionar o critério de divergência, por exemplo: grupos compostos por indivíduos mais jovens e mais velhos, ou ainda indivíduos de maior escolaridade e de menor escolaridade juntos. Deve ser colocado um tema para discussão dos grupos. Nesta etapa, o moderador sugere que os grupos apontem os principais problemas acerca do tema objeto de análise. Cada subgrupo é identificado com uma cor e escreverá em seu painel os problemas, durante cinco a dez minutos. Ao fim do tempo, o moderador sugere que parem sua atividade e que cada subgrupo vá ao painel de outro subgrupo. Por exemplo, se são gerados quatro subgrupos de participantes (grupo A, grupo B, grupo C e grupo D), na primeira rodada, cada grupo escreve os problemas acerca do tema em seu próprio painel, e na segunda rodada, o grupo A irá para o painel do grupo B, o grupo B irá para o painel do grupo C, o grupo C irá para o painel do grupo D, e o grupo D irá para o painel do grupo A. A mesma questão é colocada, ou seja, "quais são os problemas objetivos acerca do tema proposto?”, e os painéis são complementados. A rotina se repete até que cada grupo tenha elaborado contribuições em todos os painéis e tenha retornado ao seu inicial.

Esta etapa, particularmente, provoca uma troca metódica de elementos e percepções, e, ademais, permite a piramidação do conhecimento do problema. O moderador, no início da atividade, deve reforçar a regra básica da "não critica" e relembrar o painel de frases mórbidas. Este bloco, de formulação de problemas, auxilia o moderador e o grupo a enunciar problemas ou questões. A fase de enunciação do problema é fundamental para não só criar uma compreensão completa e aprofundada da questão, mas também construir uma "tensão criativa" em torno da sensibilização consciente e inconsciente para a busca de soluções adequadas.

O painel integrado é uma ferramenta interessante nesse modelo, uma vez que, ao chegar a um novo painel, a equipe precisa exaurir os desdobramentos dos problemas, pois a folha em 
branco não existe mais, e podem existir questões que já tenham sido apontadas por grupos anteriores. Os comportamentos de contribuição, e não os de censura, devem ser estimulados pelo moderador e pela equipe. A ideia é que os problemas sejam apresentados de maneira espontânea, no painel em branco, e de maneira reflexiva nos painéis já preenchidos, e assim a leitura dos problemas já preenchidos pode inspirar o aparecimento de problemas não triviais. Este é o princípio aqui designado da piramidação, ou seja, em que cada contribuição eleva o nível de aprofundamento até o topo.

Nesse sentido, busca-se motivar o grupo a construir sobre todas as sugestões dadas e não as criticar de antemão. Ao fim da dinâmica, para cada subgrupo, deve ser escolhido um relator para fazer a apresentação das conclusões finais do painel de seu subgrupo. Discutir os problemas, dessa maneira, sem efetivamente territorializá-los, localizá-los ou particularizá-los, é interessante, pois permite às pessoas reconhecer outras visões acerca de seu envolvimento com a área de estudo. A discussão de grupo sobre os problemas não requisita um consenso, e, portanto, nesta etapa, a sua relevância não é mensurada.

O moderador sublinha os problemas que se repetem e retira os painéis de problema. Estes painéis serão analisados pela equipe em etapa posterior. Ao fim da aplicação do painel de seleção de problemas, deve-se seguir para atividades laborais que fomentem a imaginação, que é força propulsora para as soluções de problemas. O processo criativo é um fenômeno interativo entre um ou mais indivíduos no ambiente social ou físico. Esta interação é um processo biunívoco em que o meio ambiente estimula o indivíduo, e, por outro lado, o indivíduo transforma o seu meio ambiente.

A metodologia participativa supõe que existe um aumento significativo de criatividade por meio de processos de dinâmica de grupo. Por outro lado, o grupo também pode tolher a criatividade individual, uma vez que, através de suas tensões interpessoais, poderá inibir o indivíduo de desenvolver o seu fluxo de ideias. O jogo interpessoal de forças é, portanto, muito importante num grupo que aplica os métodos de criatividade. Ele poderá inibir a tal ponto que a aplicação do método não chegará a resultado nenhum ou, ao contrário, fará com que a potencialidade metodológica proporcione resultados estupendos.

As pessoas podem ser estimuladas a propor soluções aos problemas, considerando-se a capacidade inovadora do ser humano. Dessa forma, sua potencialidade contributiva pode ser estimulada, educada e treinada para se tornar vigorosa. Nesse âmbito, a proposta metodológica, então, visa proporcionar a experiência e a vivência adequadas para que o participante se desenvolva a partir dos conceitos e das experiências. 
Para isso, uma forma, em grupo, que não tolha o indivíduo pode ser consolidada de forma discursiva, é a exposição individual de ideias de forma escrita, particular e colaborativa, de modo para serem compartilhadas anonimamente. De forma reflexiva, o indivíduo compreende o pensamento do outro e, a partir daí, sugere novas ideias complementares, de forma visual, em que o indivíduo ilustra suas opiniões com imagens, desenhos, figuras e mapas de forma colaborativa.

Nesse segundo bloco de atividades, o mais importante é a geração de muitas ideias, e não necessariamente a qualidade de ideias. A quantidade a ser produzida deve ter por princípio que as ideias se complementem, estimulem e gerem outras ideias mais audazes e mais criativas, que busquem alternativas. Não se pode ignorar que ideias podem ser formuladas de maneira verbal, escrita e imagética. $\mathrm{O}$ gesto de uma pessoa pode estimular a outra a desenvolver um segundo pensamento. Logo, este terceiro bloco é delineado em duas atividades:

a) Tempestade Cerebral de Soluções: segue um delineamento estruturado no Brain Writing, ou seja, os participantes trabalham individualmente, em fichas previamente estruturadas, gerando ideias por escrito. Nesta técnica, não há comunicação verbal, para que não se iniba a geração de ideias. Objetivamente, o moderador propõe que os participantes escrevam alternativas, propostas e soluções, para um cenário cujo tema ou cuja área de estudo se adeque a suas expectativas e seu imaginário. A proposta é que cada participante, sem identificar sua ficha, escreva três propostas em cinco minutos. Ao final dos cinco minutos, as fichas são recolhidas pela equipe, e o moderador as redistribui de forma aleatória entre os participantes, então estes são convidados a escrever mais três propostas em dez minutos. Essa rotina se repete, por mais vezes, a critério da equipe, e se recomenda um mínimo de três rodadas. O moderador deve, a todo momento, relembrar que não há limitações, ou seja, as propostas não devem limitar-se por custos, técnica ou quaisquer outras restrições. A fase de geração de ideias é sensível a barreiras sociais e psicológicas. Deve-se ressaltar a impessoalidade das fichas, pois as pessoas temem ser ridicularizadas ou criticadas. Também deve-se reforçar que este é um ambiente sem críticas e que todos os pensamentos e atitudes destrutivos já estão fora do contexto, pois estão no fundo da sala, registrados no painel de frases mórbidas. Esta ferramenta permite que a equipe documente todas as propostas, sem conhecer de fato quem as gerou;

b) Painel Gráfico Colaborativo da Visão: nesta atividade, adota-se a combinação de Mapas Falantes e painel de fotos. O Mapa Falante é um procedimento que envolve o diagnóstico situacional de um tema por uma comunidade. Ele permite a caracterização de 
problemas e o compartilhamento de soluções. Representa graficamente o contexto da realidade e a resolução de problemas identificados. Sua aplicação permite a inclusão de pessoas com os mais diversos níveis de escolaridade, de grande amplitude etária. O método sugere que cada participante possa fazer desenhos, anotar informações, elaborar mapeamentos interligando situações e desenhos, da forma que julgar necessário. Por ser algo lúdico, a introspecção pode ser atenuada. Por outro lado, o painel de fotos utiliza gravuras de jornais e revistas, e é complementar ao Mapa Falante, para os casos em que os participantes demonstrem resistência em desenhar. Ambos podem ser elaborados de forma complementar, ou seja, é possível montar um painel único com ilustrações, figuras, fotografias, recortes, frases, mapas e interligações. Em termos práticos, o moderador apresenta a mesma questão que foi discutida na tempestade cerebral de soluções, isto é, propõe que os participantes colaborativamente apresentem um desenho, uma somatória de recortes de revistas, figuras e fotografias com alternativas, propostas e soluções, para um cenário cujo tema ou cuja área de estudo se adeque às expectativas e ao imaginário do grupo. O painel deve apresentar, de forma gráfica, essas propostas em um cenário temporal de curto prazo (5 a 10 anos), médio prazo (10 a 20 anos) e longo prazo (20 a 30 anos). Essa atividade coletiva permite que os participantes avaliem as soluções para os problemas, sob o aspecto da possibilidade de elas ocorrerem, e intuitivamente o subconsciente é estimulado, e a provocação visual pode evocar a potencialidade de algum participante cuja manifestação verbal ou escrita é prejudicada. Para essa tarefa, o mediador pode separar os participantes em dois ou mais subgrupos, gerando mais de um painel para ser discutido. A divisão dos grupos deve seguir uma organização em que não se repitam os integrantes já subgrupados no painel de seleção de problemas. Para essa atividade, sugere-se um tempo de 30 a 45 minutos. Ao término da construção das peças gráficas, as mesmas são fixadas em uma parede, e os participantes convidados a explicálas e fazer comentários sobre os painéis dos outros. A discussão sobre o tema objeto do painel gráfico deverá, então, ser estimulada pelo moderador, de modo a aprofundar a reflexão sobre as causas e consequências dos problemas apontados. As reflexões deverão ser anotadas pela equipe, ou gravadas para posterior análise. Esta atividade é um instrumento participativo de captação das respostas dos sujeitos, identificação de conhecimentos prévios e construção de novos conhecimentos.

Saboya (2007) aponta que após um evento de leitura, os participantes podem ter uma boa ideia do que os outros participantes entendem como soluções, o que aumenta a qualidade das 
proposições. O grupo se constitui em um circuito de trocas sociais, simbólicas e afetivas que envolve relação e comunicação. Assim, é preciso abordar e analisar os elementos que dificultam essas trocas, os filtros ideológicos, os tabus e as zonas de silêncio. A comunicação só se realiza através da interação entre indivíduos. As modalidades multivariadas aplicadas buscam adentrar a subjetividade dos participantes e suas relações, para que possam refletir sobre as censuras impostas à sua própria comunicação.

A complexidade das questões, nas várias esferas da vida social, coloca, para o indivíduo, um problema de integração, então ele necessita reunir várias representações para apresentar sua perspectiva. Essa proposta favorece um espaço em que a criatividade e a formação de ideias sejam delineadas em um ambiente sem crítica. Em outras palavras, para compreender os problemas e apresentar soluções, o ambiente deve ser favorecido pela reserva da crítica no momento adequado; portanto, o julgamento deve ser postergado. Numa sociedade aberta, democrática e participativa, o julgamento postergado, ou a reserva da crítica, podem parecer algo fora de propósito. Contudo, é justamente essa atitude que favorece o consenso e a dinâmica colaborativa. Se não houver compromisso do grupo com a atitude, o processo de ebulição do conhecimento poderá ser prejudicado.

Dessa forma, esta fase da proposta metodológica é, mais do que tudo, comportamental. Difere-se extremamente da vida cotidiana, que se caracteriza por constantes críticas a tudo o que se realiza e se propõe. Assim, com o intuito de fortalecer a relação dos participantes com o tema objeto de estudo, a dinâmica precisa inserir o participante na realidade objeto de estudo. O grupo favorece a possibilidade narrativa de inserção, contudo a sensibilização e a vivência são individuais. Nota-se, então, a necessidade de acrescentar uma atividade laboral que permita desenvolver a capacidade de observar e perceber o meio, ou seja, um processo iconográfico que retrate o cotidiano das pessoas.

Também é relevante fortalecer o compromisso, isto é, o grupo depende de cada um, e as atividades do encontro seguinte dependem também de cada indivíduo presente. Dessa forma, o terceiro bloco de atividades reúne as tarefas:

a) sensibilização do olhar: cada participante é incumbido de produzir uma fotografia de um aspecto negativo associado ao tema objeto de estudo e uma fotografia de um aspecto positivo associado ao tema objeto de estudo, em sua rotina cotidiana. Essa interação por meio de vivência do participante com o tema provoca uma atitude observadora, pois ao escolher apenas uma fotografia de cada aspecto, ele deverá observar o meio e tomar decisões. Os participantes finalizam o primeiro encontro com o compromisso de trazer as 
fotografias no encontro seguinte, então os aspectos inerentes à discussão das dinâmicas, em suas práticas cotidianas, influenciarão a forma com que julga negativamente ou positivamente a questão discutida;

b) retomada ao registro de expectativas: neste momento final, os participantes são convidados a olharem ao painel das expectativas, construído no primeiro bloco. Todos expressaram seus sentimentos em relação às atividades propostas, se atenderam às expectativas geradas. $\mathrm{O}$ moderador e sua equipe devem estimular os participantes a refletirem sobre o sentimento acerca do processo realizado. As pessoas precisam perceber a realização de suas expectativas, riscando as que foram atendidas e justificando as que não foram atendidas.

O moderador, então, deve explicar rapidamente o propósito de cada técnica aplicada e, finalizado os três blocos e suas respectivas atividades, deve agradecer aos participantes e reforçar a necessidade da presença no encontro seguinte.

É possível observar que inúmeras informações podem ser recolhidas nesse processo. As informações geradas são, principalmente, de natureza qualitativa. Por um lado, há um conjunto de problemas, elencados no painel de seleção de problemas, que precisam ser sistematizados e associados à explicação conclusiva verbal de cada subgrupo; por outro lado, existe um conjunto de soluções ou alternativas, elencado na tempestade cerebral de soluções, que pode ser aprimorado com a interpretação gráfica do painel gráfico colaborativo e da explicação e crítica verbal manifestada pelo grupo.

\subsubsection{Etapa de interpretação e sistematização}

Esta etapa é realizada pela equipe de organização e moderação. A natureza dos dados é intrinsecamente qualitativa, embora algumas análises possam ser realizadas de forma quantitativa. Por exemplo, é possível contar o número de ocorrências, ou seja, quantas vezes cada problema é escrito nos diferentes painéis de seleção de problemas, ou ainda contar quantas vezes uma determinada solução é descrita na tempestade cerebral de soluções. Contudo, a percepção desses elementos e do nível de ocorrência de determinado problema ou solução, não é o que determina sua relevância, nesta etapa de interpretação. Portanto, uma análise conjunta dos materiais produzidos fornecerá uma melhor compreensão do conteúdo escrito, das imagens e dos relatos. 
Uma estratégia adotada é a triangulação, isto é, na interpretação de insumos qualitativos de pesquisa, a compreensão da realidade é ampliada quando observada por diversos ângulos. Logo, não há uma única interpretação objetiva dos dados gerados. Dessa maneira, preliminarmente, a equipe deve analisar as percepções dos participantes, processo em que as seguintes etapas podem ser destacadas:

a) organização do material registrado: agrupamento de fotografias, anotações, vídeos e impressões pessoais da equipe, resultado de questionários e entrevistas. Sugere-se que estas informações sejam agrupadas em categorias, tais como: (i) registro das falas e percepções dos problemas acerca do tema proposto; (ii) registro das falas e percepções das soluções para o tema proposto; (iii) registro das impressões sobre as frases mórbidas, expectativas e apresentações;

b) interpretação sobre a característica do grupo: a equipe deve transcrever os registros, anotando como cada participante reage às situações. Esses dados apoiam a equipe no planejamento da dinâmica. Os resultados podem apontar a eficácia ou a ineficácia das estratégias para criar o ambiente colaborativo. Especialmente, deve ser registrado algum atributo ou característica que os participantes manifestam a respeito de um problema ou uma solução, ou seja, eles podem ser melhor descritos do que de fato estão registrados no material;

c) busca de representações: embora a abordagem quantitativa não seja relevante, a equipe deve registrar as representações coincidentes e divergentes notadas em cada instrumento aplicado.

A interpretação dos dados deve procurar ultrapassar as falas dos participantes, pois as informações devem ser analisadas mediante conhecimentos prévios obtidos, por exemplo, na revisão bibliográfica e no conhecimento desenvolvido na caracterização da área, realizados na etapa de preparação.

Quanto à sistematização dos dados escritos e gráficos produzidos, uma abordagem qualitativa também é aplicada, o que gera insumos que serão objeto de avaliação no encontro subsequente do grupo. Diante disso, a equipe, além de sistematizar os dados, precisa produzir peças para serem analisadas pelos participantes no encontro seguinte. Essas peças são elaboradas pelas etapas destacadas: 
a) organização do material produzido: os painéis produzidos por cada subgrupo, no painel de seleção de problemas, e todas as fichas produzidas na tempestade cerebral de soluções, bem como os painéis gráficos colaborativos da visão, são agrupados;

b) sistematização dos problemas: a equipe deve transcrever, em registro próprio, todos os problemas escritos em todos os painéis de seleção de problemas. A interpretação busca, se necessário, reescrever os problemas de forma objetiva, sempre descrevendo as situações apontadas na forma de problemas (por exemplo, se no painel de problemas algum grupo escreveu "Segurança", este problema é transcrito na forma depreciativa, tal como "Insegurança" ou "Falta de Segurança"). O intuito é de que os problemas sejam descritos de forma objetiva, pois a transcrição deve ser clara para que a situação proposta se configure, de fato, como um problema tangível. A interpretação das representações verbais já registradas pode apoiar a equipe nesta tarefa;

c) elaboração do Painel de Impacto dos Problemas: a partir da transcrição sistematizada dos problemas, a equipe deve estruturar um painel cujo título é "Problemas", com o subtítulo "Impacto". Os problemas, já sistematizados, são escritos sequencialmente, um abaixo do outro (um problema em cada linha da primeira coluna). O painel é complementado com quatro colunas, e o título desse grupo de quatro colunas é " Dimensão". Cada uma das quatro recebe um subtítulo, respectivamente "Frequência", "Relevância", "Dificuldade de Correção" e "Dificuldade de Detecção";

d) sistematização de soluções: a equipe deve transcrever em registro próprio todas as soluções, ideias e propostas obtidas nas fichas aplicadas na tempestade cerebral de soluções. A interpretação poderá ajustar a redação das propostas de forma objetiva, ou seja, a proposta deve ser escrita como uma ação concreta, geralmente associada a um adjetivo ou um verbo. Por exemplo, é possível que um participante escreva nas soluções a palavra "Muros", o que, nesse contexto, é difícil entender sem a explicação do sujeito sobre sua intenção. Portanto, a equipe deve ser imparcial na transcrição, interpretando essa sugestão de duas formas, tais como "Incentivo à Construção de Muros" ou “Desincentivo à Construção de Muros". Desse modo, uma solução escrita pode se desdobrar em duas alternativas igualmente possíveis, então a associação de adjetivos e verbos às propostas pode facilitar o futuro julgamento delas. Os painéis gráficos da visão têm as alternativas descritas na explicação do grupo, e, assim, estas são sistematizadas a partir das anotações da equipe e do registro em vídeos; 
e) elaboração de Painel de Ligação Peer-to-Peer: a partir da transcrição e da sistematização dos problemas e das soluções, que agora se configuram em ações ou alternativas, a equipe deve estruturar um painel com o título "Correlação e Ligação". Todos os problemas anotados são transcritos sequencialmente, um abaixo do outro, em cada linha de uma coluna com o título "Problemas", alinhados à coluna mais à esquerda. No mesmo painel, todas as alternativas são transcritas sequencialmente, uma abaixo da outra, em cada linha de uma coluna com o título "Alternativas", alinhadas à coluna mais à direita. Assim, haverá um espaço em branco entre as colunas;

f) elaboração de Painel de Análise e Correlação de Alternativas: a partir da transcrição e da sistematização dos problemas e das alternativas, a equipe deve estruturar um painel com o título "Análise e Correlação". A primeira coluna terá o título "Alternativas", e nela serão transcritas sequencialmente, uma abaixo da outra, as alternativas, de modo que cada linha representará uma delas. Os problemas deverão ser transcritos sequencialmente, um após o outro, em colunas, de forma que cada coluna representará um problema.;

g) elaboração de Painel de Avaliação das Alternativas: a partir da transcrição e da sistematização das alternativas, a equipe deve estruturar um painel com o título “Dificuldade e Implantação". Neste painel, a primeira coluna, com o título “Alternativas", deverá agrupar a transcrição das alternativas, de forma sequencial, uma abaixo da outra, de modo que cada linha representará uma alternativa. Devem ser inseridas mais quatro colunas subsequentes, com os títulos "Técnica", "Econômica", "Política" e "Aceitação Popular", respectivamente;

h) elaboração de Painel de Críticas Postergadas: a partir da transcrição e da sistematização das alternativas, a equipe deve estruturar um painel com o título "Críticas Postergadas". Neste painel, a primeira coluna, com o título “Alternativas", deverá agrupar a transcrição das alternativas, de forma sequencial, uma abaixo da outra, de modo que cada linha representará uma alternativa. Subsequentemente, ao lado de cada alternativa, deverá existir um espaço significativo em branco;

i) elaboração de Painel de Abrangência: a partir da transcrição e da sistematização das alternativas, a equipe deve estruturar um painel com o título "Abrangência". Neste painel, a primeira coluna, com o título "Alternativas", deverá agrupar a transcrição das alternativas, de forma sequencial, uma abaixo da outra, de modo que cada linha representará uma alternativa. Devem ser inseridas mais quatro colunas subsequentes, com os títulos "Quadra", "Bairro", “Zona" e "Cidade", respectivamente; 
j) elaboração de Painéis Iconográficos: serão elaborados dois painéis, em branco, um com

o título "Problemas - Painel de Fotos" e outro com o título "Alternativas - Painel de Fotos.

Esta etapa requer uma ação coordenada da equipe, de tal forma que tudo seja preparado para a configuração e informação adequadas do espaço que receberá os participantes. Os painéis devem ser impressos em um tamanho que permita aos participantes interagir com eles, bem como em número adequado aos subgrupos que serão formados durante os trabalhos.

O espaço tem os assentos posicionados da mesma forma que no encontro anterior, o painel de frases mórbidas fica na mesma posição e, também, o painel de expectativas. Contudo, deve ser preparado um novo espaço de apoio. No espaço inicial, permanecem os assentos, o painel de frases mórbidas e o painel de expectativas; no fundo da sala, são fixados os painéis de ligação peer-to-peer; na frente da sala, são fixados os painéis iconográficos; de um lado da sala, são fixados os painéis de impacto dos problemas, e neste caso, sugere-se a parede oposta à porta ou a mais distante dela possível; em um espaço de transição, como um corredor, a parede associada à porta ou a mais perto dela na sala original, são fixados os painéis de análise e correlação de alternativas. Em uma nova sala, ou novo espaço, são fixados ao fundo os painéis de avaliação das alternativas; na lateral, está o painel de avaliação das alternativas; em outra lateral, está o painel de abrangência; e à frente da sala ficam os painéis de crítica postergada.

Com o espaço montado, os participantes são novamente contatados para garantir a presença no encontro seguinte, e a equipe preparará os materiais para as avaliações das percepções, agora sistematizadas e organizadas.

\subsubsection{Etapa de valoração - avaliação}

Neste segundo encontro, novamente com o layout dos assentos posicionados em semicírculo ou em forma de "U", este formato é estruturado de tal modo que os participantes tenham a possibilidade de olhar e interagir uns com os outros, além de todos poderem ver os mediadores e a projeção de informações. Todos os participantes devem possuir identificações individuais com crachás, e seus lugares, previamente determinados, também devem ser identificados, de modo que pessoas de perfis diferentes e desconhecidas se localizem próximas umas das outras. Mesmo sendo um novo encontro é importante a organização do espaço que fortaleça o convívio com a diversidade. 
Nesta etapa, o primeiro bloco é destinado à recepção das pessoas e ao estreitamento das relações, com as seguintes atividades:

a) recepção: a equipe recebe os participantes na entrada, os participantes assinam a lista de presença, e são encaminhados aos seus lugares, preferencialmente em lugares distintos do primeiro encontro, de modo que novas relações sejam estabelecidas. As pessoas recebem uma caneta e um bloco de folhas sulfites;

b) exposição de reforço do compromisso: o moderador inicia a apresentação, reiterando que os títulos não existem e que o tratamento entre as pessoas deve ser feito pelo nome. Essa atitude reforça a quebra de hierarquias entre os indivíduos, garantindo que todos ali tenham a mesma importância para a realização do evento. $\mathrm{O}$ moderador também deve reforçar que o painel de frases mórbidas ainda existe, e as críticas devem ser registradas no mesmo para que fiquem fora desse semicírculo. O painel denominado "Killer Phrases", ou "Frases mórbidas", registra qualquer crítica ou comentário negativo, seja dos moderadores ou dos participantes. A frase mórbida, de desestímulo, deve ser escrita no painel pela pessoa que a disse. Nesse momento, ainda, é importante que as pessoas não se sintam inibidas e que possam opinar e dar ideias sem restrições, críticas ou julgamentos. Os participantes também são estimulados a completar o painel de expectativas, ou seja, se novas expectativas, diferentes daquelas expressas no primeiro encontro, foram geradas, serão incluídas no painel;

c) dinâmica laboral de estreitamento: as pausas em dinâmicas podem desempenhar uma atividade compensatória, ou seja, mantêm a atenção dos participantes. Trabalhar com a mente e com o corpo pode estimular o autoconhecimento e estreitar relacionamentos, de modo que atividades laborais podem melhorar o relacionamento entre os participantes. Nesta proposta metodológica, o moderador deve aplicar alguma atividade que promova o exercício do corpo e da mente dos participantes, além de fortalecer o relacionamento. Uma das possibilidades é a "dinâmica do pistoleiro", na qual todos ficam de pé em um círculo, para que comece a rodada 1 - um dos participantes, com a mão, simula empunhar uma pistola, rapidamente mira um dos participantes do grupo e pronuncia o som "Pif", o que faz com que essa pessoa se abaixe, abrindo espaço entre duas outras pessoas, e a primeira que apontar a mão à outra simulando uma pistola e pronunciar a palavra "Paf" permanece na brincadeira (enquanto a pessoa que foi "atingida" sai da brincadeira), e a pessoa que abaixou, levanta-se. $\mathrm{O}$ vencedor desta rodada agora detém a posse da pistola, e a atividade retorna à rodada 1 , e o último que permanecer de pé é o vencedor. Esta 
atividade lúdica, em tom de brincadeira, favorece que os participantes olhem para todos que estão a sua volta, e esgota a necessidade de um apontar ao outro, assim reforçando que, já que todos se apontam, não é mais o momento de julgamentos ou críticas. A atividade de mobilização, envolvimento e sensibilização, inclusive de forma laboral, deixa as pessoas mais confortáveis no ambiente;

d) dinâmica de fortalecimento de vínculos: esta atividade tem o objetivo de exercitar a observação do participante, ou seja, como as pessoas interpretam, o que veem e escutam dos outros. O moderador sugere uma situação, no tema proposto, para que a pessoa imagine a situação na qual ela gostaria que tudo se resolvesse, como seria o imaginário ideal acerca da problemática estudada. O moderador propõe, em seguida, que as pessoas sejam organizadas em trios. Primeira rodada: a pessoa "A" relata à pessoa "B" como seria sua visão, entre três e cinco minutos, e a pessoa " $\mathrm{C}$ " apenas observar o relato; ao fím do tempo, a pessoa "C" apresenta ao grupo o resumo do relato da pessoa "A". Segunda rodada: a pessoa "C" relata sua visão para a pessoa " $A$ ", enquanto a pessoa " $B$ " apenas observa o relato; ao fim do tempo, a pessoa "B" apresenta o resumo do relato da pessoa “C” ao grupo. Terceira rodada: a pessoa "B" relata à pessoa "C" sua visão, enquanto a pessoa " $\mathrm{A}$ " apenas observa o relato; ao fim do tempo, a pessoa " $\mathrm{A}$ " apresenta ao grupo o resumo do relado da pessoa "B". Esta atividade tem uma duração variável, pois depende do número de participantes no grupo.

A última atividade deste primeiro bloco, embora pareça muito simples, é fundamental, pois estimula inúmeras habilidades dos indivíduos, tais como: (i) o poder de desfrutar individualmente de uma visão positiva acerca do tema; (ii) a oportunidade de dividir sem inibições sua visão e seu ponto de vista com alguém, livre de críticas; (iii) o exercício do poder de escuta, para apreender a visão de outros e perceber como um mesmo problema, sobre um tema, pode gerar inúmeros desdobramentos de futuros possíveis; (iv) o poder de observação, de ver e ouvir outros discutindo sobre um tema e, em silêncio, interpretar o que nota da visão de outros; e (v) o poder de síntese e responsabilidade com outros, uma vez que o sujeito precisa sintetizar o que absorveu de situações as quais não participa e, oportunamente, precisa compartilhar isso com outros.

Em outras palavras, imaginar, transmitir, ouvir, observar e sintetizar informações, cria um cenário participante inclusivo e reflexivo ao indivíduo. Possivelmente, as concessões, o consenso e a medição, neste cenário lúdico, propiciarão uma arena salutar à discussão de temas 
complexos e controversos. O primeiro bloco permite que esse espaço seja criado, ou seja, para a participação ser efetiva, o cenário deve ser propiciado para tal.

A comensalidade é o ápice da hospitalidade. As pessoas requerem retribuição, portanto, neste momento, é salutar que a equipe ofereça uma pausa para um lanche. No espaço participativo, há um contrato imaginário de troca, baseado em dar, receber e retribuir. As interações sociais e comunicativas se observam nas refeições, e vínculos de solidariedade e cooperação podem ser estabelecidos nesta pausa. Os ganhos são difíceis de se mensurar, contudo, é uma demonstração de preocupação e cuidado com os que voluntariamente participam da arena. As pausas geralmente ocorrem com um intervalo de 10 a 15 minutos.

Feita a pausa e estabelecido o ambiente favorável, é chegada a hora de valorar e avaliar as alternativas e os problemas, com vistas à opinião das pessoas. A rotina de sistematizar a forma como os participantes transformam suas experiências em atributos é objeto de estudo no segundo bloco, com apoios das atividades destacadas:

a) valoração do Painel de Efeitos e Impactos dos Problemas: o moderador separa o grupo em subgrupos, e cada grupo recebe um conjunto de marcadores de 4 cores diferentes. Nesse momento, os participantes são apresentados ao painel de impacto dos problemas, o qual apresenta a lista de todos os problemas do encontro anterior sintetizados, e os participantes devem usar os marcadores coloridos para avaliar cada dimensão do problema (cada cor deve representar uma dimensão específica). Para cada dimensão, em cada um dos problemas, os participantes podem atribuir uma valoração à intensidade que varia de 1 a 3. Por exemplo, se o problema é o déficit habitacional, caso ele seja pouco frequente, recebe uma marcação na célula que pertencia à coluna de frequência; se é frequente recebe duas marcações, e se é muito frequente, três marcações. Essa rotina é aplicada a todas as dimensões, considerando que a frequência representa a recorrência dos problemas, a relevância representa a consequência dos problemas e como eles atingem as pessoas, a dificuldade de correção representa o esforço necessário para se solucionar os problemas, e a detecção representa a facilidade de se observar os problemas. O painel gera dados importantes aos pesquisadores, pois fornece resultados numéricos que valoram os problemas sob a ótica da população e, portanto, podem fornecer subsídios para hierarquizar a prioridade dos problemas, cuja sistematização será analisada oportunamente pela equipe de apoio;

b) estabelecimento das redes peer-to-peer: superada a etapa de pontuar os problemas, uma questão que se coloca é se as alternativas que foram elaboradas pelo grupo, no encontro 
anterior, podem responder ou solucionar os problemas apontados. Na proposta metodológica, tanto os problemas quanto as soluções emergem da população (não são sugeridas por outros para a população). Trata-se de uma inversão da ordem política e pode ser complementar ao processo de gestão pública e formulação de políticas. A dinâmica proposta para verificar essas ligações é reflexiva e visual, ou seja, aqui será utilizado o painel de ligação peer-to-peer. Em uma coluna, é apresentada a lista sistematizada dos problemas, e em outra coluna oposta, a lista de alternativas. Nesta dinâmica, os participantes são estimulados a ligar os problemas às alternativas, isto é, verificar quais problemas podem ser solucionados por quais alternativas. Um problema pode ser ligado a uma alternativa por uma linha, um problema pode ser ligado a duas alternativas por duas linhas, e dois, ou mais problemas, podem ser ligados a uma alternativa, cada um com uma linha. Essa atividade, com ambientação lúdica, permite que os participantes desenvolvam cognitivamente a habilidade relacional, ou seja, identificar como um elemento se relaciona a outro é, em essência, construção de conhecimento e aprendizado. Isso fortalece no indivíduo habilidades sociais e cognitivas, considerando que a comunicação e o relacionamento entre objetos têm a função organizadora do pensamento. Essa dinâmica simula um jogo, e, portanto, é um processo para compreender ideias, desenvolver habilidades e, em um contexto de aprendizagem, aumentar o envolvimento e a motivação. Por outro lado, são gerados dados valiosos aos pesquisadores, uma vez que a atividade correlaciona as alternativas aos problemas. Além disso, permite observar, preliminarmente, alternativas mais eficazes - ou seja, aquelas que simultaneamente solucionam mais problemas - e a flexibilidade dos problemas - isto é, os problemas que simultaneamente são solucionados por mais alternativas diferentes. Os insumos gerados na atividade devem ser sistematizados oportunamente pela equipe;

c) verificação da intensidade das correlações: embora as ligações construídas na rede peer-to-peer apontem uma ligação preliminar entre os problemas e as alternativas, eventualmente, se alguma alternativa gera ganhos colaterais - isto é, contribui para solução de um problema, mas não diretamente -, as ligações podem não refletir esta percepção, e, portanto, os participantes não realizam esta ligação. Nessa etapa, o moderador apresentará o painel de análise e correlação das alternativas. Cada linha do painel corresponde a uma alternativa, e cada coluna corresponde a um problema. Os participantes são separados em subgrupos e recebem 5 marcadores coloridos, por exemplo, a cor branca representa que a alternativa não responde ao problema, a cor azul 
representa que a alternativa responde ao problema indiretamente, mas não o soluciona completamente, a cor verde representa que a alternativa responde ao problema indiretamente, mas o soluciona completamente, a cor vermelha representa que a alternativa responde ao problema diretamente, mas não o soluciona completamente, e, por fim, a cor rosa representa que a alternativa responde ao problema diretamente e soluciona completamente o problema. Portanto, cada alternativa terá uma associação a cada problema. Essa rotina produz discussões bastante ricas entre os sujeitos, e, como anteriormente eles já criaram as ligações na rede peer-to-peer, poderão debater em profundidade cada alternativa, o que fortalece e aumenta o nível de abrangência das alternativas para os indivíduos. Por outro lado, os dados gerados nesse processo apoiam a equipe na avaliação das consequências diretas e indiretas de cada alternativa e, consequentemente, os aspectos sociais de cada alternativa - ou seja, as alternativas que solucionam completamente os problemas, sejam elas direta ou indiretamente envolvidas. Complementarmente, o processo destaca as alternativas menos eficazes sob a perspectiva das pessoas. Os dados gerados nesta etapa devem ser sintetizados pela equipe.

Neste segundo bloco de atividades conforme o fluxo estruturado da proposta metodológica na figura 30, há uma imersão dos participantes no comportamento dos problemas e sua relação com as alternativas. Salienta-se a importância da utilização de sinais coloridos na proposta, o que facilita a interação e inclui aqueles que têm maior dificuldade com símbolos, letras e números. O moderador deve assegurar que todos os procedimentos adotados na proposta metodológica devem obedecer às normas éticas vigentes, e ainda ressaltar o anonimato dos participantes, de tal forma que não haja divulgação de quaisquer aspectos individuais nos resultados obtidos. Nessa direção, ao fim deste bloco, é interessante abrir um espaço para perguntas, sugestões e comentários dos participantes e, em seguida, sugerir uma pausa para um lanche.

Para o próximo bloco de atividades, sugere-se que os participantes sejam convidados a ir a outro espaço, outra sala. A razão para tal é informar que o bloco anterior foi uma imersão nos problemas e que agora eles devem ser deixados para trás. Subjetivamente, transmite-se a mensagem de que após a reflexão sobre os problemas e sua correlação com algumas alternativas, isso deve ser guardado, e que um novo espaço deve ser criado. Portanto, no novo espaço, agora livre de problemas, a proposta deve se concentrar na reflexão das soluções e consequentemente ordená-las hierarquicamente. A valoração das alternativas deve ser 
estimulada nos participantes para pensar na viabilidade de sua execução neste terceiro bloco, com as atividades destacadas:

a) análise e valoração de oportunidades e ameaças nas alternativas: o moderador, neste novo espaço, deve reforçar que é a hora da ação, ou seja, identificar como colocar em prática as ações propostas. Os participantes são apresentados ao painel de avaliação das alternativas, em que cada linha representa uma alternativa, e cada coluna representa uma dimensão associada à dificuldade de implantação das alternativas. As dimensões que podem ser avaliadas são a dificuldade técnica - ou seja, quais os esforços técnicos e tecnológicos para concretizar a alternativa -, a dificuldade econômica - a disponibilidade de recursos e quantidade de recursos necessários para concretizar a alternativa -, a dificuldade política - a dificuldade aprovação formal do Estado e seus desdobramentos, em um processo político para efetivar a alternativa - e, por fim, a dificuldade de aceitação popular - possíveis reações das pessoas à alternativa proposta, no que tange sua aceitação. Cada dimensão está associada a um marcador ou a uma cor, e os participantes podem inserir de 1 a 3 marcadores em cada dimensão para cada alternativa. Por exemplo, se para implantar uma alternativa como a "Ampliação de Áreas Verdes" os participantes consideram que há baixa dificuldade técnica, será inserido um marcador, se consideram que há média dificuldade econômica serão inseridos dois marcadores, se consideram que há dificuldade de aprovar isso politicamente, serão inseridos 3 marcadores, e se consideram que há baixa dificuldade na aceitação popular será inserido um marcador nessa coluna. Para os participantes, esse momento é interessante, pois os coloca como sujeitos ativos no processo, e é possível vivenciar a dificuldade de se tomar decisões, então relações negociais são construídas com o grupo. Por outro lado, os insumos produzidos na atividade permitem uma hierarquização das alternativas, inversamente à sua dificuldade de aplicação, e, assim, de forma integrada, definem as alternativas que possuem menor dificuldade de implantação, ao mesmo tempo em que resolvem de forma mais abrangente os problemas. Os dados produzidos nessa atividade devem ser sistematizados pela equipe;

b) inserção territorial e escalas: nesta nova atividade, a experiência vivencial é relevante, pois os participantes necessitam inserir as alternativas no território, em locais ou em escalas nos quais os resultados podem ser potencializados. Portanto, será preenchido o painel de abrangências. $\mathrm{O}$ método de preenchimento não requer uma classificação de intensidade. Assim, cada linha representa uma alternativa, e cada coluna representa uma 
escala de aplicação, tal como na abrangência da quadra, na abrangência do bairro, na abrangência da zona e na abrangência da cidade (outras escalas podem ser elaboradas, em função do tema e da área objeto de estudo). Cada cor representa uma escala (azul a quadra, verde o bairro, vermelho a zona e rosa a cidade), então se a alternativa pode ser aplicada na escala da quadra, recebe uma marca azul na coluna da quadra, por exemplo. Cabe reforçar que uma mesma alternativa pode possuir duas ou mais marcações, ou seja, pode simultaneamente ser aplicada nas escalas da quadra, do bairro e da cidade. A inserção das pessoas em uma escala contribui para o fortalecimento do senso de lugar, a percepção das possíveis interferências de uma alternativa e a dimensão preliminar da população atingida pelas decisões. As pessoas podem pensar localmente, mas suas proposições terem impactos em outras escalas.

Avaliar soluções não é uma tarefa trivial, pois cada alternativa possui fraquezas e forças específicas, então fortalecer os atributos e reduzir as ameaças de cada alternativa é imperativo. As atividades realizadas no terceiro bloco desapegam as pessoas dos problemas, e os esforços são direcionados às alternativas. Por ora, esquecer os problemas e se dedicar ao ambiente de ideias é convidativo, afinal permite ao sujeito reconstruir conceitos, transitando do básico ao elaborado.

Muito mais do que comunicar às pessoas sobre a inviabilidade de suas sugestões, é preciso motivá-las a refletir sobre as ações até produzirem sua própria noção de dificuldade. É possível que se note, ao longo do processo, que o problema real não está em sua caracterização, mas sim em outro contexto e que, portanto, merece ser reanalisado. Além das dificuldades, os pontos fracos devem ser percebidos, e, portanto, uma sequência progressiva de críticas eleva o nível de conhecimento, buscando uma outra esfera de entendimento. Neste cenário, é proposto o quarto bloco de atividades, destacadas:

a) avaliação de fraquezas e ameaças: este é o momento para identificar as questões associadas às alternativas que podem dar errado e contrapor as oportunidades. Portanto, é o momento da crítica, então o moderador sugere que os participantes retornem à sala inicial e os apresenta ao painel de crítica postergada. Neste painel, cada linha representa uma alternativa, e assim os participantes são estimulados a escrever, sem consultar ninguém e sem debates, as críticas, os comentários e as opiniões negativas que cada um associa a alguma alternativa específica. O anonimato é respeitado, e o painel fica disponível para que os participantes a qualquer momento insiram suas críticas. Para os sujeitos, identificar todas as questões que podem dar errado e contrapor as oportunidades 
cria uma consciência que dá credibilidade ao processo de valoração. O painel é único e colaborativo, para todo o grupo. A desconstrução das ideias é um processo que ajuda a encontrar nós críticos e pontos de atenção, os quais a avaliação das dificuldades pode não diagnosticar;

b) mosaico de fotos: a representação de problemas e de soluções pode ser relativa, ou seja, o que um sujeito percebe como problema, para outro sujeito pode ser uma alternativa. A construção de painéis com fotos registradas pelos próprios sujeitos fortalece a percepção de lugar. Após montar os painéis, o moderador, para ampliar o entendimento, pode perguntar "por que isso acontece?". Nesse momento, os participantes são apresentados aos painéis iconográficos, um dedicado às alternativas e outro, aos problemas. As fotografias produzidas por cada participante são então misturadas, tanto as fotografias dos aspectos negativos, quanto as dos aspectos positivos, e o moderador informa que cada participante deve escolher uma que represente o que ele considera negativo, a qual deve ser colada no painel iconográfico de problemas, e outra do que ele considera que represente algo positivo, a qual deve ser colada no painel iconográfico de alternativas. Deve ser salientada a regra de que o participante não pode escolher fotografias que ele tenha produzido.

Na atividade "c" do quarto bloco - a produção do mosaico de fotos -, após sua produção, cada participante deve explicar ao grupo por que escolheu a fotografia do aspecto negativo e a inseriu no painel. Logo após, quem produziu a fotografia deve justificar a escolha da fotografia. A mesma dinâmica é aplicada ao painel iconográfico de alternativas. Essa experiência permite que a forma de observação e a forma de interpretação de aspectos negativos e positivos, podem ser diferentes, e cada indivíduo tem uma percepção da realidade. Ademais, a experiência tem um viés pedagógico de mudança social, com incorporação de uma linguagem não verbal, inclusive metafórica.

Por fim, o encerramento dessa etapa também é metodologicamente organizado, de tal forma que os participantes notem os ganhos do processo e se tornem multiplicadores das ações. A responsabilização é um dos caminhos para o engajamento e a multiplicação; portanto, este quinto, e último, bloco de atividades é organizado em:

a) fechamento das expectativas: o moderador deve retomar os painéis de expectativas. Os participantes precisam olhar para as expectativas que foram geradas e registradas e verificar se elas foram atendidas. Neste momento, não se espera um dado resultado, mas a constatação de um processo compartilhado de informações, vivências e percepções. 
Após isso, todas as ferramentas aplicadas servem para expandir o conhecimento do grupo e abrir possibilidades de interações;

b) revalidação de opiniões: neste momento, caso na recepção do primeiro encontro tenham sido preparados formulários com questões acerca do tema proposto, a fim de que os participantes atribuíssem notas ("péssimo", "ruim", "regular", "bom” e "ótimo"), para algumas situações a respeito da área objeto de estudo, o moderador devolve os formulários aos participantes com uma nova cor de caneta, para que eles possam reavaliar, se assim quiserem, suas considerações e acrescentar novas ideias (o preenchimento é individual). Também é relevante aplicar uma pesquisa de satisfação aos participantes. Eles podem atribuir notas a todo o processo, a cada um dos encontros e a cada uma das atividades propostas, além de avaliar se a duração dos encontros foi adequada, se as expectativas foram atendidas, se voltariam a participar, se sentem-se capazes de reproduzir os trabalhos, bem como escrever em um espaço para livre redação (o preenchimento deve ser anônimo). Os dados produzidos por esta atividade devem ser analisados pela equipe;

c) encerramento: o moderador agradece a presença de todos e reforça que os participantes são multiplicadores. Além disso, a equipe deve preparar certificados nominais de participação, os quais têm valor intangível aos participantes, pois reforçam que há uma preocupação da equipe em formalizar o processo e registrar que os participantes levam algo para si.

Portanto, esta etapa consiste em uma interação entre participantes que permite reunir informações para hierarquização de problemas e alternativas Ela é "disruptiva", no sentido de que todas as ações surgem da contribuição popular, e é acima de tudo um processo dinâmico de aprendizagem dos sujeitos, lado a lado, entre si e entre os sujeitos e a equipe. A motivação dos sujeitos é associada à sua aprendizagem, e essa dinâmica de trocas é fundamental na ação de sujeitos sociais. A equipe precisa transformar os insumos produzidos em resultados analíticos.

\subsubsection{Etapa de consolidação de resultados}

O desafio que se coloca a partir dos dados reunidos diz respeito ao processo de transformar a interação entre os sujeitos em uma estrutura de ação para atingir objetivos partilhados. A avaliação e a comparação entre as alternativas são inerentes ao processo 
decisório, e, em um cenário com diversos problemas, inúmeras alternativas asseveram o cenário de incertezas, riscos, múltiplos objetivos e negociação.

\subsubsection{Hierarquização Multicriterial de Problemas}

Os problemas já estão definidos a partir da aplicação das atividades participativas, então a próxima etapa é especificar valores que os representem. Uma estratégia consiste em associar cada problema a um indicador que o represente, o qual simboliza uma simplificação do problema, associando-o a um valor numérico.

As informações valoradas nos painéis, conforme figura 30, serão contabilizadas, associadas e sintetizadas permitindo a elaboração dos índices que permitirão a hierarquização dos problemas, das alternativas, e por fim delineando as estratégias prioritárias.

Inicialmente, o problema pode ser encarado como um objetivo a ser superado, e, portanto, a ordenação de sua prioridade pode ser definida por um índice ${ }^{65}$ de caracterização dos problemas, que podem ser elaborados a partir da sequência metodológica a seguir:

\section{a) Sistematização dos dados para o Índice de Caracterização de Problemas Preliminar:}

a partir da valoração do painel de efeitos e impactos dos problemas, é possível propor uma ordenação de prioridade parcial por meio de um Índice de Caracterização de Problemas Preliminar $\left(\mathrm{ICP}_{(\mathrm{p})}\right)$, ou seja, para cada problema, multiplica-se o total de marcadores (ou pontuação) atribuídos à dimensão da frequência, ao total de marcadores da dimensão da relevância, conforme equação abaixo. Este indicador determina a predominância de cada problema. $\mathrm{O} \mathrm{ICP}_{(\mathrm{p})}$ é um número inteiro positivo assumindo valores entre 1 e 9 , conforme eq.(24).

$$
\operatorname{ICP}_{(p)}=D_{(f)} \times D_{(r)}
$$

\footnotetext{
${ }^{65}$ Um dado, para a construção de indicadores, pode ter como base "um valor quantitativo referente a um fato ou circunstância", um "número bruto que ainda não sofreu qualquer espécie de tratamento estatístico", ou ainda o registro de avaliações ou percepções de atores sociais sobre determinadas questões. As definições mais comuns para "indicador" e a terminologia a ele associada são particularmente diversas, o que potencialmente acarreta problemas de ordem metodológica quando se pretende construir ou utilizar um conjunto de indicadores para qualquer tipo de avaliação ou monitoramento. O termo "indicador" é originário do latim indicare, que significa descobrir, apontar, anunciar, estimar. O indicador comunica ou informa sobre o progresso em direção a uma determinada meta, e é utilizado como um recurso para deixar mais perceptível uma tendência ou fenômeno não imediatamente detectável por meio dos dados isolados. Uma das maneiras de agregar um conjunto de indicadores e facilitar sua comunicabilidade em virtude do grande número de dados e informações disponíveis é a construção de outras formas de obter medidas-síntese, como os indicadores compostos ou os índices. Os índices são elaborados mediante a agregação de dois ou mais indicadores simples, referidos a uma mesma dimensão, ou a diferentes dimensões, da realidade (SOBRAL et. al. 2011) . O objetivo do trabalho não é discutir as diferenças entre dados, indicadores e índices, e como os parâmetros calculados nesta pesquisa dependem de uma associação de informações de valoração, todos os parâmetros desta pesquisa foram definidos como índices.
} 


$$
\begin{gathered}
\left\{I C P_{(p)} \in \mathbb{Z}_{+} \mid 1 \leq I C P_{(p)} \leq 9\right\} \\
\left\{D_{(f)} ; D_{(r)} \in \mathbb{Z}_{+} \mid 1 \leq D_{(f)} \leq 3 ; 1 \leq D_{(r)} \leq 3\right\}
\end{gathered}
$$

Em que:

$\mathrm{ICP}_{(\mathrm{p})}$ : Índice de Caracterização de Problemas Preliminar;

$\mathrm{D}_{(\mathrm{f})}$ : Pontuação total da dimensão frequência do problema;

$\mathrm{D}_{(\mathrm{r})}$ : Pontuação total da dimensão relevância do problema.

Esse índice pode preliminarmente apontar quais problemas possuem uma magnitude maior, porém limita-se a uma amplitude de 9 valores. Essa abordagem resulta em uma ordem parcial de hierarquia dos problemas. Quanto maior esse índice, maior a prioridade de ação sobre o problema.

b) Sistematização dos dados para o Índice de Intervenção de Problemas: a partir da valoração do painel de efeitos e impactos dos problemas, é possível propor uma ordenação dos problemas a partir de um Índice de Intervenção de Problemas (IIP), ou seja, para cada problema, multiplica-se o total de marcadores (ou pontuação) atribuídos à dimensão de dificuldade de correção, ao total de marcadores da dimensão de dificuldade de detecção, conforme equação abaixo. Este índice aponta a predominância do esforço necessário para se atuar em cada problema. O IIP, é um número inteiro, positivo, assumindo valores entre 1 e 9 , conforme eq.(25).

$$
\begin{gathered}
I I P=D_{(c)} \times D_{(d)} \\
\left\{I I P \in \mathbb{Z}_{+} \mid 1 \leq I I P \leq 9\right\} ; \\
\left\{D_{(c)} ; D_{(d)} \in \mathbb{Z}_{+} \mid 1 \leq D_{(d)} \leq 3 ; 1 \leq D_{(c)} \leq 3\right\} ;
\end{gathered}
$$

Em que:

IIP: Índice de Intervenção de Problemas;

$\mathrm{D}_{(\mathrm{c}):}$ Pontuação total da dimensão dificuldade de correção dos problemas;

$\mathrm{D}_{(\mathrm{d}):}$ Pontuação total da dimensão dificuldade de detecção dos problemas.

Este índice pode preliminarmente apontar quais problemas possuem maior esforço para correção, porém limita-se a uma amplitude de 9 valores. Essa abordagem resulta em uma ordem parcial de hierarquia dos problemas. Quanto maior este índice, maior a dificuldade das ações para atuar sobre o problema. 
A partir dessa abordagem, que por ora é analisada separadamente ( $\operatorname{ICP}_{(\mathrm{p})}$ e IIP), é possível criar um indicador mais abrangente e completo, associando as fraquezas e oportunidades de cada problema, ampliando e incluindo a amplitude destes indicadores. Em outras palavras, a razão entre a prioridade de ação em um problema e sua dificuldade de ação, resulta em um Índice de Caracterização de Problema Ampliado ( $\left.\operatorname{ICP}_{(a)}\right)$, que pode ser descrito pela eq.(26).

$$
\begin{gathered}
I C P_{(a)}=\frac{I C P_{(p)}}{I I P} \\
\left\{I C P_{(a)} \in \mathbb{Q}_{+} \mid \frac{1}{9} \leq I C P_{(p)} \leq \frac{9}{9}\right\} \\
\left\{I C P_{(p)} \in \mathbb{Z}_{+} \mid 1 \leq I C P_{(p)} \leq 9\right\} \\
\left\{I I P \in \mathbb{Z}_{+} \mid 1 \leq I I P \leq 9\right\}
\end{gathered}
$$

Em que:

$\mathrm{ICP}_{(\mathrm{a})}$ : Índice de Caracterização de Problemas Ampliado;

$\mathrm{ICP}_{(\mathrm{p})}$ : Índice de Caracterização de Problemas Preliminar;

IIP: Índice de Intervenção de Problemas.

O $\operatorname{ICP}_{(\text {a) }}$ tem uma amplitude de 1/9 até 9/9, ou seja, 81 valores diferentes podem ser associados a cada problema. A interpretação do índice pode compreender os aspectos que o compõem, ou seja, quanto maior o $\mathrm{ICP}_{(\mathrm{p})}$, maiores serão a relevância e o impacto do problema; contudo, quanto maior o IIP, maiores serão os esforços para solução do problema. Por outro lado, quanto menor o $\mathrm{ICP}_{(\mathrm{p})}$, menores serão a relevância e o impacto gerados pelo problema; e quanto menor o IIP, mais simples é a ação de resolução do problema.

Um caso em que o problema tenha um alto valor de $\operatorname{ICP}_{(\mathrm{p})}$ e um baixo valor de IIP, por exemplo, implica que esse problema seja relevante e de alto impacto, mas de fácil percepção e de fácil correção; portanto, deve-se exigir ações prioritárias, e o $\mathrm{ICP}_{(\mathrm{a})}$ será alto. Por outro lado, um problema com baixo valor de $\operatorname{ICP}_{(\mathrm{p})}$, associado a um baixo valor de IIP, implica que o problema não seja tão relevante, e seu impacto é pequeno para as pessoas, ainda que demande grandes esforços para sua correção; dessa forma, deve ser tratado com menor nível de importância e baixa prioridade e, portanto, seu $\mathrm{ICP}_{(\text {a) }}$ será baixo.

Esses índices estabelecem uma ordem hierárquica absoluta dos problemas, contudo é possível relativizá-los - isto é, compará-los entre si - e estabelecer uma escala própria do problema, a qual pode ser associada à função de valor. Esta função é uma representação 
matemática dos julgamentos atribuídos por meio de uma escala numérica. A proposta para construção da função de valor é destacada:

a) construção da matriz de comparação pareada de problemas: a relativização dos índices é verificada a partir da distância dos $\mathrm{ICP}_{(\mathrm{a})}$. Ou seja, faz-se a diferenciação paritária entre os índices calculados dos problemas comparados, por exemplo, com quatro problemas diferentes (o problema "A", o problema "B", o problema "C" e o problema “D”). O problema “A” possui um $\operatorname{ICP}_{(\text {a) }}$ de 9; o "B", um $\operatorname{ICP}_{(\text {a) }}$ de 4; o "C", um $\operatorname{ICP}_{(\text {a) }}$ de 2/6; e o "D" um $\mathrm{ICP}_{(\mathrm{a})}$ de 1/9. As comparações paritárias serão os valores que compõem uma matriz 4x4 (é importante observar que na proposta metodológica podem ser comparados infinitos problemas de for paritária), como no exemplo na Tabela 1 considerando a existência apenas de 4 problemas da seguinte forma:

Tabela 1 - Exemplo de matriz de comparação pareada de problemas

\begin{tabular}{|c|c|c|c|c|c|}
\hline & Problema "A" & Problema "B" & Problema "C" & Problema "D" \\
\hline & & 9 & 4 & $2 / 6$ & $1 / 9$ \\
\hline Problema "A" & 9 & $9-9=0$ & $9-4=5$ & $9-2 / 6=8,66$ & $9-1 / 9=8,88$ \\
\hline Problema "B" & 4 & $4-9=-5$ & $4-4=0$ & $4-2 / 6=3,66$ & $4-1 / 9=3,88$ \\
\hline Problema "C" & $2 / 6$ & $2 / 6-9=-8,66$ & $2 / 6-4=-3,66$ & $2 / 6-2 / 6=0$ & $2 / 6-1 / 9=0,22$ \\
\hline Problema "D" & $1 / 9$ & $1 / 9-9=-8,88$ & $1 / 9-4=-3,88$ & $1 / 9-2 / 6=-0,22$ & $1 / 9-2 / 6=0$ \\
\hline
\end{tabular}

Fonte: Do autor (2019).

Na matriz resultante, todos os problemas são comparados par a par, recebendo a distância $\left(\Delta_{i j}\right)$ entre eles. Cada um desses valores compõe a matriz de comparação pareada de problemas, a qual é uma matriz quadrada, considerando que " $i$ " $e$ " $j$ ” correspondem aos problemas. Portanto, a matriz de comparação pareada, na Tabela 2, do exemplo proposto será :

Tabela 2 - Resultado do exemplo de matriz de comparação pareada de problemas

\begin{tabular}{l|cccc} 
& Problema “A" & Problema "B" & Problema “C" & Problema "D" \\
\hline Problema "A" & $\mathbf{0}$ & 5 & 8,66 & 8,88 \\
Problema "B" & -5 & $\mathbf{0}$ & 3,66 & 3,88 \\
Problema "C" & $-8,66$ & $-3,66$ & $\mathbf{0}$ & 0,22 \\
Problema "D" & $-8,88$ & $-3,88$ & $-0,22$ & $\mathbf{0}$ \\
\hline
\end{tabular}

Fonte: Do autor (2019). 
Nota-se que a diagonal principal desta matriz receberá valores zerados, pois a distância entre o índice associado a um critério dele mesmo é nula, ou seja, “ $\mathrm{a}_{i j}=0$ ”, quando " $i=$ j”. Observa-se também que os valores abaixo da diagonal principal são recíprocos aos valores acima da diagonal principal, contudo com sinais trocados, ou seja, "a $a_{i j}$ " é recíproco a " $\mathrm{a}_{j i}$ ” (ou " $\mathrm{a}_{i j}=-\mathrm{a}_{j i}$ ”);

b) preparação para a construção da função valor: a representação matemática dos índices indicará, através de uma escala, quantas vezes um problema é dominante ao outro. Para tal, será adotada a escala semântica de preferência de Saaty, com valores inteiros entre 1 e 9 e seus correspondentes recíprocos racionais. Esta escala associa um comportamento comparativo entre os problemas. Na proposta metodológica em questão, por sua vez, diferentemente do trabalho de Saaty, cuja escala é construída com base nos julgamentos subjetivos dos decisores, ela será construída a partir da matriz de comparação pareada de problemas, de modo que se houver uma distância relativa entre os problemas, a consistência da comparação sempre será válida. A matriz de comparação pareada dos problemas recebe valores negativos e positivos, enquanto a escala qualitativa de importância relativa proposta por Saaty recebe somente valores positivos. Portanto, é possível associar os valores obtidos na matriz de comparação pareada de problemas aos valores da escala de Saaty por uma função matemática. Esta função de transformação das distâncias relativas à escala de Saaty é obtida associando os valores da escala de Saaty a uma variável "y", à distância relativa calculada a uma variável "x". Portanto, genericamente, expressa " $\mathrm{y}=\mathrm{f}(\mathrm{x})$ ". A função " $\mathrm{f}(\mathrm{x})$ " é uma função matemática determinada (linear, exponencial, raiz quadrada, logarítmica ou função recíproca), associando " $x$ " (que é a distância relativa entre os $\mathrm{ICP}_{(\mathrm{a})}$ ) a uma constante "K", que ajusta a função a cada situação analisada;

c) determinação da constante " $K$ ": a determinação da constante " $K$ " é atrelada à função matemática que será aplicada para representar os problemas. Escolhida a função, os valores em que a função resulta, ou seja, os valores de "y" são conhecidos $(1,2,3,4,5$, $6,7,8,9$ e seus recíprocos, 1/2,1/3,1/4, 1/5, 1/6, 1/7, 1/8 e 1/9). Os valores de "x" também são conhecidos, pois representam as distâncias relativas já preenchidas na matriz de comparação pareada de problemas. Escolhida a função (linear, exponencial, raiz quadrada, logarítmica ou função recíproca), assume-se que a maior distância relativa positiva determina o maior nível de dominância e, portanto, corresponde ao valor de 9 na escala de Saaty. Com os dois valores conhecidos, sua associação permite determinar a 
constante "K" para a situação de análise. Para o exemplo já proposto, a matriz de comparação pareada é apresentada na Tabela 3:

Tabela 3 -Dados do exemplo da matriz de comparação pareada dos problemas para obtenção da constate $\mathrm{K}$ e determinação da função valor

\begin{tabular}{|c|c|c|c|c|}
\hline & Problema "A" & Problema "B" & Problema "C" & Problema "D" \\
\hline Problema "A" & $\mathbf{0}$ & 5 & 8,66 & 8,88 \\
\hline Problema "B" & -5 & $\mathbf{0}$ & 3,66 & 3,88 \\
\hline Problema "C" & $-8,66$ & $-3,66$ & $\mathbf{0}$ & 0,22 \\
\hline Problema "D" & $-8,88$ & $-3,88$ & $-0,22$ & 0 \\
\hline
\end{tabular}

Fonte: Do autor (2019).

Assumindo que nesta situação será adotada uma função linear “ $\mathrm{y}=\mathrm{f}(\mathrm{x})$ ”, quando ajustada pela constante “K”, ela será “ $y=K . x$ ”. Com “y” igual a 9 e "x" igual a 8,88, a constante “K” será 1,01. Dessa forma, a função que associa as distâncias relativas à escala de Saaty será “y =1,01.x”. Uma observação importante é que a função não é aplicada aos valores negativos, pois seu resultado seria também negativo. Portanto, os valores negativos, na realidade, são os recíprocos dos positivos, portanto " $\mathrm{a}_{i j}=\mathrm{y}$ ”, tal como " $\mathrm{a}_{i j}=1 / \mathrm{y}$ ", de modo que uma sugestão interessante é montar a matriz de comparação pareada de problemas com os valores dos $\operatorname{ICP}_{(a)}$ em ordem decrescente, assim os valores acima da diagonal principal serão positivos, e os valores abaixo da diagonal principal serão os recíprocos, na escala de Saaty. Dessa forma, " $\mathbf{a}_{i j}=\mathbf{1} / \mathbf{a}_{i j}$ ". Ademais, quando a distância relativa for nula (“a $i j=0 ")$, a dominância é de igual preferência proposta por Saaty, ou seja, 1.

Para o exemplo apresentado anteriormente, foi aplicada uma função linear, e, como já exposto, outras podem ser aplicadas e genericamente podem ser exemplificadas no Quadro 13. Os valores associados a "y" serão números racionais ${ }^{66}$ e podem ser trabalhados dessa maneira. Contudo, os valores principais de dominância propostos por Saaty são inteiros de 1 a 9 e apenas os recíprocos racionais associados aos dominantes inteiros. Desse modo, é possível fixar intervalos no domínio da função, ou seja, intervalos dos valores de "x", associando cada intervalo a um número inteiro da escala de Saaty. Em outras palavras, é possível, a partir da função de transformação conhecida, associar intervalos (limite superior e limite inferior) da distância relativa dos $\mathrm{ICP}_{(\mathrm{a})}$ a valores na escala de preferência de Saaty.

\footnotetext{
${ }^{66} \mathrm{O}$ fato de y pertencer ao números racionais já foi explicado no item 4.5.6 da pesquisa.
} 
Quadro 13 - Determinação da função valor para escala Semântica de Preferência

\begin{tabular}{|c|l|c|}
\hline Função & \multicolumn{1}{|c|}{ Equação } & Parâmetros \\
\hline Linear & $\mathrm{y}=\mathrm{k} \cdot \mathrm{x}$ & \\
\hline Exponencial & $\mathrm{y}=\mathrm{k}^{\mathrm{x}}$ & \\
\hline Raiz quadrada & $\mathrm{y}=\mathrm{k} \cdot \sqrt{\mathrm{x}}$ & \multirow{2}{*}{$\mathrm{x} ; \mathrm{y} ; \mathrm{k} \in \mathbb{R} \mid\left(\mathrm{y} \in \mathbb{Q}_{+}\right)$} \\
\hline Logarítmica & $\mathrm{y}=\mathrm{k} \cdot \log (\mathrm{x})$ & \\
\hline Reciproca & $\mathrm{y}=\mathrm{k} \cdot \mathrm{x}^{-1}$ & \\
\hline Geométrica & $\mathrm{y}=\mathrm{k}^{\mathrm{x}-1}$ & \\
\hline
\end{tabular}

Fonte: Do autor (2019).

As distâncias relativas referentes à aplicação em exemplo genérico são apresentadas na Tabela 3, apresentada. Aplicando a função de transformação “y = 1,01.x”, já calculada, nos valores positivos do exemplo proposto, teremos a condição da Tabela 4.

Tabela 4 - Valores de y após aplicação da função valor no exemplo de comparação pareada dos problemas

\begin{tabular}{l|cccc} 
& Problema "A" & Problema "B" & Problema “C” & Problema "D" \\
\hline Problema "A" & $\mathbf{0}$ & 5,05 & 8,74 & 9 \\
Problema "B" & $1 / 5,05$ & $\mathbf{0}$ & 3,69 & 3,91 \\
Problema "C" & $1 / 8,74$ & $1 / 3,69$ & $\mathbf{0}$ & 0,22 \\
Problema "D" & $1 / 9$ & $1 / 3,91$ & $1 / 0,22$ & $\mathbf{0}$ \\
\hline
\end{tabular}

Fonte: Do autor (2019).

Associando a distância nula à igual preferência, e simplificando as frações, teremos a tabela 5. O que se nota no exemplo proposto é que, ao aplicar a função de transformação diretamente, quando as distâncias relativas forem pequenas - ou seja menores do que 1 e maiores do que 0 -, há uma tendência de distorção do resultado, pois a matriz de comparação pareada dos problemas aponta que o problema "C" é dominante em relação ao problema "D". Contudo, ao aplicar a função de transformação e a associar ao recíproco, há uma inversão de dominância, em razão da divisão de 1 por um valor menor do que 1 . 
Tabela 5 - Resultados simplificado de aplicação da função valor no exemplo de comparação pareada dos problemas

\begin{tabular}{l|cccc} 
& \multicolumn{4}{|c}{ pareada dos problemas } \\
& Problema "A" & Problema "B" & Problema "C" & Problema "D" \\
\hline Problema "A" & $\mathbf{1}$ & 5,05 & 8,74 & 9 \\
Problema "B" & 0,19 & $\mathbf{1}$ & 3,69 & 3,91 \\
Problema "C" & 0,11 & 0,27 & $\mathbf{1}$ & 0,22 \\
\hline Problema "D" & 0,11 & 0,25 & 4,54 & $\mathbf{1}$ \\
\hline
\end{tabular}

Fonte: Do autor (2019).

Esta razão, por si só, fortalece a necessidade da análise por intervalos do domínio. Em teoria, o ajuste é simples: para cada intervalo da escala semântica de Saaty, associa-se ao seu valor de distância relativa ao seu respectivo limite, ou seja, a escala de preferência de Saaty assume valores inteiros entre 1 e 9, portanto, determina-se com a função valor, quais os intervalos de x (domínios da função) estarão dentro das variações da escala de Saaty em y (imagem da função) . Ainda no exemplo proposto, com " $y=1,01 . x "$, tem-se a Tabela 6.

Tabela 6 - Intervalos da distância relativa (x) associados a escala de Saaty (y)

\begin{tabular}{cc}
$\begin{array}{c}\text { Imagem da função } \\
(\mathbf{y})\end{array}$ & Limites inferior e superior do domínio (x) \\
\hline 1 & $0 \leq x<1,98$ \\
2 & $1,98 \leq x<2,97$ \\
3 & $2,97 \leq x<3,96$ \\
4 & $3,96 \leq x<4,95$ \\
5 & $4,95 \leq x<5,94$ \\
6 & $5,94 \leq x<6,93$ \\
7 & $6,93 \leq x<7,92$ \\
8 & $7,92 \leq x<8,88$ \\
9 & $x \geq 8,88$ \\
\hline
\end{tabular}

Fonte: Do autor (2019).

Dessa maneira, as distâncias relativas positivas racionais podem ser associadas à escala de preferência semântica de números inteiros positivos, proposta por Saaty. Os recíprocos, ou seja, as distâncias relativas negativas racionais, também podem ser ajustados a partir de 
intervalos, da mesma maneira que as distâncias relativas positivas racionais, desde que associadas aos recíprocos racionais positivos de Saaty.

No exemplo proposto, resultando a Tabela 7 com os recíprocos que associam os valores opostos obtidos na aplicação da função valor (domínios de x negativos) a escala semântica inversa de preferência proposta por Saaty (imagem com valores inversos de y) ${ }^{67}$.

Tabela 7 - Intervalos da distância relativa (x) associados a escala de Saaty (y) para os recíprocos

\begin{tabular}{cc}
\hline Imagem da função recíproca (1/y) & Limites inferior e superior do domínio (x) \\
\hline 1 & $0 \geq x>-1,98$ \\
$1 / 2$ & $-1,98 \geq x>-2,97$ \\
$1 / 3$ & $-2,97 \geq x>-3,96$ \\
$1 / 4$ & $-3,96 \geq x>-4,95$ \\
$1 / 5$ & $-4,95 \geq x>-5,94$ \\
$1 / 6$ & $-5,94 \geq x>-6,93$ \\
$1 / 7$ & $-6,93 \geq x>-7,92$ \\
$1 / 8$ & $-7,92 \geq x>-8,88$ \\
$1 / 9$ & $x \leq-8,88$ \\
\hline
\end{tabular}

Fonte: Do autor (2019).

Desse modo, a matriz de comparação pareada dos problemas pode ser reescrita com os valores da escala semântica de Saaty. Com isso, todos os valores associados às distâncias serão positivos e não nulos, permitindo determinar o vetor de prioridade dos problemas relativos e, assim, hierarquizá-los sob um prisma multicriterial de avaliação, conforme roteiro metodológico a seguir:

a) construção da matriz de julgamento relativo de problemas: a partir da escolha pela função que representará a função de transformação da distância relativa entre os índices de caracterização de problemas ampliado, em valores de dominância e preferência propostos por Saaty, da determinação da constante "K" que ajusta a função e da fixação dos intervalos, é possível transformar a matriz de comparação pareada de problemas em uma matriz de julgamentos relativos de problemas, isto é, transformar os valores racionais

\footnotetext{
${ }^{67}$ Um valor para ser o inverso de outro, tem que ser maior quando a outra for menor. Fisicamente, a grandeza 1/G é inversa da grandeza G. Já o oposto é você mudar o sinal de um número. Por exemplo: número G. seu oposto é -G.
} 
positivos, negativos e nulos de uma matriz em valores racionais positivos e não nulos.

Seguindo ainda com o exemplo proposto, apresenta-se a matriz de comparação pareada de problemas, conforme Tabela 8:

Tabela 8 - Dados do exemplo da matriz de comparação antes da transformação para escalda de Saaty

\begin{tabular}{|c|c|c|c|c|}
\hline & Problema "A" & Problema "B" & Problema "C" & Problema "D" \\
\hline Problema "A" & $\mathbf{0}$ & 5 & 8,66 & 8,88 \\
\hline Problema "B" & -5 & $\mathbf{0}$ & 3,66 & 3,88 \\
\hline Problema "C" & $-8,66$ & $-3,66$ & $\mathbf{0}$ & 0,22 \\
\hline Problema "D" & $-8,88$ & $-3,88$ & $-0,22$ & $\mathbf{0}$ \\
\hline
\end{tabular}

Fonte: Do autor (2019).

Quando ajustada aos intervalos superiores e inferiores do domínio calculado, será transformada na matriz de julgamento relativo de problemas, conforme Tabela 9.

Tabela 9 - Dados do exemplo da matriz de comparação após a transformação para escala de Saaty

\begin{tabular}{l|cccc} 
& \multicolumn{4}{|c}{ Saaty } \\
& Problema "A" & Problema "B" & Problema "C" & Problema "D" \\
\hline Problema "A" & $\mathbf{1}$ & 5 & 8 & 9 \\
Problema "B" & $1 / 5$ & $\mathbf{1}$ & 3 & 3 \\
Problema "C" & $1 / 8$ & $1 / 3$ & $\mathbf{1}$ & 1 \\
Problema "D" & $1 / 9$ & $1 / 3$ & 1 & $\mathbf{1}$ \\
\hline
\end{tabular}

Fonte: Do autor (2019).

Com essa matriz de comparação, será possível determinar um Índice Hierárquico do Problema (IHP), que representa o nível hierárquico de um determinado problema quando associado relativamente à temática em avaliação. Ele é estabelecido pelo auto vetor da matriz de julgamento relativo de problemas;

b) determinação do Índice Hierárquico de problema (IHP): o IHP é um valor que cada problema recebe a partir de sua representatividade na matriz de julgamentos relativos de problemas. Resumidamente, se a matriz pode ser representada por um vetor, o índice 
representa a influência de cada problema neste vetor. Sua determinação segue uma sequência de passos, a saber: (i) normalização das colunas da matriz de julgamentos relativos de problemas; (ii) somatória da dominância normalizada da comparação paritária dos problemas, isto é, a soma de todos os elementos da linha de cada problema; e (iii) normalização da somatória normalizada da comparação dos problemas, isto é, a divisão de cada um dos resultados das somas das linhas dividido pela soma de todas as linhas. No exemplo proposto, teremos a Tabela 10.

Tabela 10 - Comparação pareada dos problemas com a escala de Saaty antes da normalização

\begin{tabular}{c|cccc} 
& Problema "A" & Problema "B" & Problema “C" & Problema "D" \\
\hline Problema "A" & $\mathbf{1}$ & 5 & 8 & 9 \\
Problema "B" & $1 / 5$ & $\mathbf{1}$ & 3 & 3 \\
Problema "C" & $1 / 8$ & $1 / 3$ & $\mathbf{1}$ & 1 \\
Problema "D" & $1 / 9$ & $1 / 3$ & 1 & $\mathbf{1}$ \\
\hline$\Sigma$ & $\mathbf{1 , 4 4}$ & $\mathbf{6 , 6 7}$ & $\mathbf{1 3}$ & $\mathbf{1 4}$ \\
\hline
\end{tabular}
Fonte: Do autor (2019).

A matriz normalizada do julgamento relativo de problemas quando normalizada resultará a Tabela 11.

Tabela 11 - Comparação pareada dos problemas com a escala de Saaty após a normalização

\begin{tabular}{c|cccc} 
& Problema “A" & Problema “B” & Problema “C” & Problema “D” \\
\hline Problema "A" & 0,70 & 0,75 & 0,62 & 0,64 \\
Problema "B" & 0,14 & 0,15 & 0,23 & 0,21 \\
Problema “C" & 0,09 & 0,05 & 0,08 & 0,07 \\
Problema "D" & 0,08 & 0,05 & 0,08 & 0,07 \\
\hline $\boldsymbol{\Sigma}$ & $\mathbf{1}$ & $\mathbf{1}$ & $\mathbf{1}$ & $\mathbf{1}$ \\
\hline
\end{tabular}

Fonte: Do autor (2019).

Cabe reforçar que, feita a normalização, a soma dos elementos de uma mesma coluna sempre é igual a 1 . Após a normalização ${ }^{68}$, esta deverá ser somada à linha correspondente

\footnotetext{
${ }^{68}$ Um exemplo de norma matricial é a norma 1 definida como o máximo da soma em módulo das entradas de cada linha. Outras normas podem ainda ser definidas, no entanto para os resultados deste trabalho a norma representa a somatória das dominância de cada elemento frente aos demais.
} 
a cada problema, ou seja, a somatória da dominância total de cada problema, conforme a Tabela 12, neste momento já é possível detectar a dominância de um problema frente aos outros, mas ainda é importante relativiza-los conjuntamente.

Tabela 12 - Exemplo de dominância de cada problema a partir da norma da matriz de comparação pareada

\begin{tabular}{c|cccc|c} 
& $\begin{array}{c}\text { Problema } \\
\text { "A" }\end{array}$ & $\begin{array}{c}\text { Problema } \\
\text { "B" }\end{array}$ & $\begin{array}{c}\text { Problema } \\
\text { "C" }\end{array}$ & $\begin{array}{c}\text { Problema } \\
\text { "D" }\end{array}$ & $\boldsymbol{\Sigma}$ \\
\hline Problema "A" & 0,70 & 0,75 & 0,62 & 0,64 & $\mathbf{2 , 7 0}$ \\
Problema "B" & 0,14 & 0,15 & 0,23 & 0,21 & $\mathbf{0 , 7 3}$ \\
Problema "C" & 0,09 & 0,05 & 0,08 & 0,07 & $\mathbf{0 , 2 9}$ \\
Problema "D" & 0,08 & 0,05 & 0,08 & 0,07 & $\mathbf{0 , 2 8}$ \\
\hline $\boldsymbol{\Sigma}$ & $\mathbf{1}$ & $\mathbf{1}$ & $\mathbf{1}$ & $\mathbf{1}$ & $\mathbf{4}$ \\
\hline
\end{tabular}

Fonte: Do autor (2019).

Por fim, de forma subsequente, a somatória das linhas de dominância é normalizada revelando o IHP de cada um dos problemas analisados, conforme resultados da Tabela 13.

Tabela 13 - Determinação do IHP para o exemplo proposto

\begin{tabular}{c|cccc|c|c} 
& $\begin{array}{c}\text { Problema } \\
\text { "A" }\end{array}$ & $\begin{array}{c}\text { Problema } \\
\text { "B" }\end{array}$ & $\begin{array}{c}\text { Problema } \\
\text { "C" }\end{array}$ & $\begin{array}{c}\text { Problema } \\
\text { "D" }\end{array}$ & $\Sigma$ & $\mathbf{I H P}$ \\
\hline $\begin{array}{c}\text { Problema } \\
\text { "A" }\end{array}$ & 0,70 & 0,75 & 0,62 & 0,64 & 2,70 & $\mathbf{0 , 6 8}$ \\
$\begin{array}{c}\text { Problema } \\
\text { "B" }\end{array}$ & 0,14 & 0,15 & 0,23 & 0,21 & 0,73 & $\mathbf{0 , 1 8}$ \\
$\begin{array}{c}\text { Problema } \\
\text { "C" }\end{array}$ & 0,09 & 0,05 & 0,08 & 0,07 & 0,29 & $\mathbf{0 , 0 7}$ \\
$\begin{array}{c}\text { Problema } \\
\text { "D" }\end{array}$ & 0,08 & 0,05 & 0,08 & 0,07 & 0,28 & $\mathbf{0 , 0 7}$ \\
\hline $\boldsymbol{\Sigma}$ & $\mathbf{1}$ & $\mathbf{1}$ & $\mathbf{1}$ & $\mathbf{1}$ & $\mathbf{4}$ & $\mathbf{1}$ \\
\hline
\end{tabular}

Fonte: Do autor (2019).

Neste exemplo, o problema "A" tem um IHP de 0,68 , o problema "B" tem um IHP de 0,18, o problema “C” tem um IHP de 0,07, e o problema “ $D$ ” tem um IHP de 0,07. Quanto maior o IHP, maior será a prioridade para as medidas de ação para sua solução e mais efetivas elas serão sob a ótica da população. $\mathrm{O}$ índice também aponta aqueles problemas que mais atingem a população. 
Nesta etapa da proposta metodológica, foi apresentada a sistemática para avaliação e hierarquização dos problemas. Lembrando que os problemas foram gerados pela percepção da população a partir da aplicação do painel de seleção de problemas, foram valorados a partir da avaliação do painel de efeitos e impactos dos problemas e permitiram sua sistematização em quatro índices, $\operatorname{ICP}_{(\mathrm{p})}, \mathrm{ICP}_{(\mathrm{a})}, \mathrm{IIP}$ e IHP.

Os índices, em lato sensu, são balizadores para análises, e em políticas urbanas, não é diferente. Eles podem ser construídos a partir de dados de origem diversa e expressam o comportamento de um sistema complexo de forma simplificada. Contudo, são indicação do comportamento de uma determinada questão, aqui considerada como problema. É difícil afirmar que um único índice possa representar todos os desdobramentos de um determinado fenômeno, mas um olhar multifacetado fornece, cada vez mais, melhores caraterizações. Portanto, ao associar o mesmo problema a diferentes índices, estes podem revelar mais amplamente seu comportamento.

$\mathrm{O} \operatorname{ICP}_{(\mathrm{p})}$ expressa uma avaliação preliminar do impacto do problema, refletindo a sua probabilidade de ocorrência (a magnitude de sua frequência), associado aos impactos gerados pela sua ocorrência (a magnitude de sua relevância). Assim, indica, sob a ótica da população, quais são os problemas críticos. Por outro lado, o IIP expressa uma avaliação da dificuldade de ação sobre o problema, refletindo a dificuldade para corrigir o problema, associado à dificuldade de se detectar antecipadamente a ocorrência do problema. Assim, indica, sob a ótica da população, quais problemas requisitam uma ação complexa para sua correção.

Por sua vez, o $\operatorname{ICP}_{(a)}$ expressa uma combinação de avaliações, pois reflete simultaneamente a criticidade de um problema, associado à dificuldade de ação sobre ele. Assim, indica quais dos problemas são prioritários, já que permite a ação sobre os problemas críticos que possuírem menor complexidade na ação corretiva. Por fim, o IHP é um índice relativo. Se, por um lado o $\mathrm{ICP}_{(\mathrm{a})}$ apresenta valores absolutos para cada problema, o IHP, por outro, apresenta uma relativização dos problemas quando comparados entre si. Isto é, o $\mathrm{ICP}_{(\mathrm{a})}$ é um diagnóstico unilateral de um problema, enquanto o IHP é um diagnóstico comparativo entre os problemas em sua própria escala de comparação.

\subsubsection{Hierarquização Multicriterial de Ligação entre Problemas e Alternativas}

A metodologia proposta, com o estabelecimento das redes peer-to-peer e verificação da intensidade das correlações, gera dados que permitem uma estruturação das conexões existentes 
entre problemas e alternativas. Ela permite analisar a articulação entre objetivos e alternativas e, por meio de tal constatação, avaliar o grau de abrangência das alternativas e os desdobramentos de cada problema. Uma forma preliminar de avaliação consiste em quantificar o número de desdobramentos associado a cada problema, isto é, o quão flexível um problema é, permitindo que diversas alternativas o atendam, mesmo que incompletamente ou indiretamente. Por outro lado, também permite avaliar o quão rígido um problema é (quando apenas alternativas focalizadas solucionam um problema em específico).

Complementarmente, também é possível avaliar o quão versátil é uma alternativa, ou seja, o número de problemas em que ela simultaneamente atua, mesmo que de forma colateral (alternativas que possuem um fim, mas também solucionam outros problemas que não aquele para os quais foram propostas). Ademais, permite avaliar quais são as alternativas específicas e localizadas, isto é, alternativas que se destinam a um fim determinado.

Para avaliar o nível de versatilidade dos problemas, é possível determinar um Índice de Flexibilidade de Problemas Preliminar $\left(\operatorname{IFP}_{(\mathrm{p})}\right)$ e um Índice de Flexibilidade de Problemas Relativo $\left(\operatorname{IFP}_{(\mathrm{r})}\right)$, a partir da sistematização:

a) determinação do Índice de Flexibilidade de Problemas Preliminar (IFP(p)): as redes peer-to-peer permitem que os sujeitos conectem, por um emaranhado de linhas, os problemas e as alternativas. Dessa forma, o $\operatorname{IFP}_{(\mathrm{p})}$ é dado pela somatória de conexões geradas a partir de um problema. Resumidamente, é o total de linhas de conexão que um problema gera na qual, quanto maior o $\operatorname{IFP}_{(\mathrm{p})}$, maior o número de desdobramentos possíveis para cada problema. Cada problema possuirá um índice associado a si, o qual é dado pela eq.(27).

$$
\operatorname{IFP}(p)=\sum C P
$$

Em que:

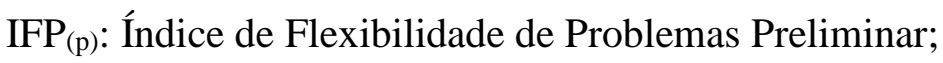

CP: Conexões do Problema.

b) determinação do Índice de Flexibilidade de Problemas Relativo $\left(\operatorname{IFP}_{(\mathrm{r})}\right)$ : no $\operatorname{IFP}_{(\mathrm{p})}$, cada problema possuirá associado a si um número inteiro, positivo, maior ou igual a 0 . Situações diferentes de análise não podem ser comparadas entre si, e a utilização do $\operatorname{IFP}_{(\mathrm{r})}$ pode fazer com que os decisores comparem situações distintas. Afinal, a relativização da situação, em específico, fortalece a hierarquização dos problemas em sua situação de 
análise. Em resumo, $\operatorname{IFP}_{(\mathrm{r})}$ é a normalização do $\operatorname{IFP}_{(\mathrm{p})}$, isto é, o número de conexões geradas por um problema dividido pelo total de conexões geradas por todos os problemas, dado pela eq.(28).

$$
\operatorname{IFP}_{(r)}=\frac{\sum C P}{\sum_{i=1}^{n} C P_{i}}
$$

Em que:

IFP $_{(\mathrm{r})}$ : Índice de Flexibilidade de Problemas Relativo;

CP: Conexões do Problema;

$\mathrm{CP}_{\mathrm{i}}$ Conexões do i-ésimo Problema;

n: Número total de problemas.

Por exemplo, em uma dada situação, o problema “A” possui 5 conexões, o problema "B", 3 conexões, e o problema "C", 1 conexão. Neste caso, teremos os respectivos $\operatorname{IFP}_{(\mathrm{p})}$ e $\operatorname{IFP}_{(\mathrm{r})}$ ,conforme tabela 14 .

Tabela 14 - Exemplo de cálculo dos índices de flexibilidade de problemas

\begin{tabular}{cccc}
\hline Problema & Conexões Geradas & IFP(p) $_{(\mathbf{p})}$ & $\operatorname{IFP}_{(\mathbf{r})}$ \\
\hline Problema "A" & 5 & 5 & $5 / 9=0,56$ \\
Problema "B" & 3 & 3 & $3 / 9=0,33$ \\
Problema "C" & 1 & 1 & $1 / 9=0,11$ \\
\hline $\boldsymbol{\Sigma}$ & $\mathbf{9}$ & & $\mathbf{1}$ \\
\hline
\end{tabular}

Fonte: Do autor (2019).

Quanto maiores forem o $\operatorname{IFP}_{(\mathrm{p})}$ e o $\operatorname{IFP}_{(\mathrm{r})}$, maior será a flexibilidade de um problema. Isso representará, segundo a percepção popular, uma maior abrangência de alternativas que podem solucionar o problema.

Para avaliar o nível de versatilidade das alternativas, é possível determinar um Índice de Flexibilidade de Alternativas Preliminar $\left(\operatorname{IFA}_{(\mathrm{p})}\right)$ e um Índice de Flexibilidade de Alternativas Relativo $\left(\operatorname{IFA}_{(\mathrm{r})}\right)$, a partir da sistematização:

a) determinação do Índice de Flexibilidade de Alternativas Preliminar (IFA(p)): as redes peer-to-peer permitem que os sujeitos conectem por um emaranhado de linhas os problemas e as alternativas. Dessa forma, o $\operatorname{IFA}_{(\mathrm{p})}$ é dado pela somatória de conexões recebidas por uma alternativa. Resumidamente, é o total de linhas de conexão que uma 
alternativa recebe. Quanto maior o $\operatorname{IFA}_{(\mathrm{p})}$, maior a abrangência de cada alternativa (que possuirá um índice associado a si). Ele é dado pela eq.(29).

$$
I F A_{(p)}=\sum C A,
$$

Em que:

IFA $_{(\mathrm{p})}$ : Índice de Flexibilidade de Alternativas Preliminar;

CA: Conexões da Alternativa.

b) determinação do Índice de Flexibilidade de Alternativas Relativo (IFA(r)): no $\operatorname{IFA}_{(\mathrm{p})}$, cada alternativa possuirá associado a si um número inteiro, positivo, maior ou igual a 0 . Situações diferentes de análise não podem ser comparadas entre si, e a utilização do $\operatorname{IFA}_{(\mathrm{r})}$ pode fazer com que os decisores comparem situações distintas. Afinal, a relativização, para a situação em específico, fortalece a hierarquização das alternativas em sua situação de análise. Em resumo, o $\operatorname{IFA}_{(\mathrm{r})}$ é a normalização do $\operatorname{IFA}_{(\mathrm{p})}$, isto é, o número de conexões recebidas por uma alternativa dividido pelo total de conexões recebidas por todas as alternativas, dado pela eq.(30).

$$
I F A_{(r)}=\frac{\sum C A}{\sum_{i=1}^{n} C A_{i}},
$$

Em que:

IFA $_{(\mathrm{r})}$ : Índice de Flexibilidade de Alternativas Relativo;

CA: Conexões da Alternativa;

$\mathrm{CA}_{i:}$ Conexões da $i$-ésima Alternativa;

n: Número total de alternativas.

Por exemplo, em uma dada situação, a alternativa "A" possui 10 conexões; a alternativa "B", 8 conexões; e a alternativa "C", 5 conexões. Neste caso, teremos os respectivos IFA(p) e IFA $_{(\mathrm{r})}$ conforme Tabela 15.

Quanto maiores forem o $\operatorname{IFA}_{(\mathrm{p})}$ e o IFA(r), maior será a abrangência de uma alternativa. Isso representará, segundo a percepção popular, uma maior abrangência de problemas que podem ser solucionados a partir de determinadas alternativas. 
Tabela 15 - Exemplo de cálculo dos índices de flexibilidade de alternativas

\begin{tabular}{cccc}
\hline Alternativa & Conexões Recebidas & IFA(p) & IFA(r) \\
\hline Alternativa "A" & 10 & 10 & $=10 / 23=0,43$ \\
Alternativa "B" & 8 & 8 & $=8 / 23=0,35$ \\
Alternativa "C" & 5 & 5 & $=5 / 23=0,22$ \\
\hline$\Sigma$ & $\mathbf{2 3}$ & & $\mathbf{1}$ \\
\hline
\end{tabular}

Fonte: Do autor (2019).

É importante observar que o $\operatorname{IFP}_{(\mathrm{p})}$, o $\operatorname{IFP}_{(\mathrm{r})}$, o $\operatorname{IFA}_{(\mathrm{p})}$ e o $\operatorname{IFA}_{(\mathrm{r})}$ podem assumir valores nulos, ou seja, 0. Quando o $\operatorname{IFP}_{(\mathrm{p})}$ e o $\operatorname{IFP}_{(\mathrm{r})}$ resultarem em valores nulos, possivelmente o problema é particular a um indivíduo participante do processo, ou ainda, um problema para o qual as pessoas que participam do processo não tem a capacidade de sugerir soluções. Todavia, se o $\operatorname{IFA}_{(\mathrm{p})}$ e o $\operatorname{IFA}_{(\mathrm{r})}$ resultarem em valores nulos, possivelmente a alternativa que recebe o índice nulo é uma alternativa inócua, isto é, não soluciona na prática os problemas apontados pelos sujeitos participantes.

Um axioma é importante nesse processo. O número de conexões totais geradas pelos problemas sempre será igual ao número de conexões totais recebidas pelas alternativas, conforme eq.(31). Assim,

$$
\sum_{i=1}^{n} C P_{i}=\sum_{i=1}^{n} C A_{i} \therefore \sum_{i=1}^{n} C P_{i}-\sum_{i=1}^{n} C A_{i}=0
$$

Matematicamente, os índices são calculados de forma simplificada, contudo já foi pontuado por Leonardo da Vinci que "a simplicidade é o último grau de sofisticação". Muito além do cálculo do índice, a proposta metodológica fornece um instrumento para a coleta de dados intrínseco à participação popular. Por outro lado, índices podem ser aplicados para qualificar o processo de identificação de problemas e propositura de alternativas, e suas correlações. Diante disso, ainda é necessário que se avalie a efetividade e a eficácia das alternativas frente aos problemas. 


\subsubsection{Hierarquização Multicriterial de Abrangência das Alternativas e dos Problemas}

A efetividade é avaliada mediante a análise da transformação dos problemas a partir da ação da alternativa, já a eficácia é dada a partir dos resultados alcançados comparativamente aos resultados esperados. A eficácia se relaciona com o cumprimento de metas, enquanto a efetividade se refere à resolução do que é relevante.

Dessa forma, existem alternativas que atuam sobre problemas, diretamente, mas não têm a capacidade de solucioná-los em sua plenitude. Por outro lado, existem alternativas que não atuam diretamente sobre um problema, mas têm a capacidade de resolvê-lo. No primeiro caso, a alternativa foi efetiva, e não eficaz; no segundo ela não foi efetiva, porém foi eficaz. A alternativa eficaz e efetiva é aquela com capacidade de agir diretamente sobre um problema e o resolver - neste caso, ela é eficiente. Ou seja, a eficiência está ligada a uma ação eficaz e efetiva. Logo, a partir dos dados obtidos na verificação da intensidade das correlações, constante no painel de análise e correlação das alternativas, pode-se sintetizar os seguintes índices:

a) Índice de Eficácia das Alternativas $\left(\operatorname{IEA}_{(c)}\right)$ : este índice avalia as alternativas e sua eficácia, ou seja, aquelas alternativas que solucionam completamente os problemas, direta ou indiretamente. No painel de correlação das alternativas, é somada a pontuação total correspondente (atuação direta completa e atuação indireta completa), dividida pelo total de problemas propostos, conforme a eq.(32).

$$
I E A_{(c)}=\frac{\sum_{i=0}^{n} D C_{i}+\sum_{j=0}^{m} I C_{j}}{\sum P},
$$

Em que:

$\mathrm{IEA}_{(\mathrm{c})}$ : Índice de Eficácia das Alternativas;

$\mathrm{DC}_{(i)}$ : i-ésima marcação direta e completa na alternativa;

$\mathrm{IC}_{(j)}$ : j-ésima marcação indireta e completa na alternativa;

n: Número total de marcações diretas e completa na alternativa;

m: Número total de marcações indiretas e completa na alternativa;

P: Número total de problemas. 
b) Índice de Efetividade das Alternativas (IEA(f)): este índice avalia as alternativas e sua efetividade, ou seja, ou seja aquelas alternativas que solucionam completamente ou incompletamente os problemas, apenas com atuação direta. No painel de correlação das alternativas, é somada a pontuação total correspondente (atuação direta completa e atuação direta incompleta), dividida pelo total de problemas propostos, conforme a eq.(33).

$$
I E A_{(f)}=\frac{\sum_{i=0}^{n} D C_{i}+\sum_{j=0}^{m} D I_{j}}{\sum P}
$$

Em que:

IEA $_{(\mathrm{f})}$ : Índice de Efetividade das Alternativas;

$\mathrm{DC}_{(i)}$ : i-ésima marcação direta e completa na alternativa;

$\mathrm{DI}_{(j)}: j$-ésima marcação direta e incompleta na alternativa;

n: Número total de marcações diretas e completas na alternativa;

m: Número total de marcações direta se incompletas na alternativa;

P: Número total de problemas.

c) Índice de Abrangência das Alternativas (IAA): este índice avalia, dentre as alternativas analisadas, aquelas que contribuem mais para intervenção em problemas. Atua somando todas as atuações, sejam elas diretas ou indiretas, e a sua abrangência, sejam elas completas ou incompletas. É complementar ao $\operatorname{IFA}_{(\mathrm{r})}$, pois enquanto este avalia o nível de conectividade das alternativas, o IAA avalia o nível de atendimento das expectativas frente aos problemas apresentados. Seu cálculo é dado pela razão entre somatória total de atuações da alternativa e a somatória total de problemas, conforme a eq.(34).

$$
I A A=\frac{\sum_{i=0}^{n} D C_{i}+\sum_{j=0}^{m} D I_{j}+\sum_{k=0}^{z} I C_{k}+\sum_{w=0}^{l} I I_{w}}{\sum P}
$$

Em que:

IAA: Índice de Abrangência das Alternativas;

$\mathrm{DC}_{(i)}$ : i-ésima marcação direta e completa na alternativa;

$\mathrm{DI}_{(j)}$ : j-ésima marcação direta e incompleta na alternativa;

n: Número total de marcações diretas e completas na alternativa; 
m: Número total de marcações diretas e incompletas na alternativa;

$\mathrm{IC}_{(k)}$ : $k$-ésima marcação indireta e completa na alternativa;

z: Número total de marcações indiretas e completas na alternativa;

II $_{(w)}:$ w-ésima marcação indireta e incompleta na alternativa;

1: Número total de marcações indiretas e incompletas na alternativa;

P: Número total de problemas.

d) Índice de Eficiência das Alternativas $\left(\operatorname{IEA}_{(\mathrm{e})}\right)$ : este índice avalia as alternativas que são efetivas e eficazes. que corresponde à razão entre o total de problemas em que cada alternativa atua diretamente e soluciona completamente, e a somatória dos problemas em que a alternativa atua diretamente e soluciona completamente, que atua indiretamente e soluciona completamente e que atua diretamente e soluciona incompletamente e completamente. Partindo do pressuposto de que a implantação de todas ações demanda recursos, implantar uma ação que não solucione um problema completamente ou uma solução cujos recursos são pensados para uma outra questão (ainda que influam no problema de análise) pode representar uma falha. Portanto, este índice avalia o quão assertivas são as alternativas propostas, o que pode ser dado pela eq.(35).

$$
I E A_{(e)}=\frac{\sum_{i=0}^{n} D C_{i}}{\sum_{i=0}^{n} D C_{i}+\sum_{j=0}^{m} D I_{j}+\sum_{k=0}^{z} I C_{k}+\sum_{w=0}^{l} I I_{w}}
$$

Em que:

IEA(e): Índice de Eficiência das Alternativas;

$\mathrm{DC}_{(i)}$ : i-ésima marcação direta e completa na alternativa;

$\mathrm{DI}_{(j)}$ : j-ésima marcação direta e incompleta na alternativa;

n: Número total de marcações diretas e completas na alternativa;

m: Número total de marcações diretas e incompletas na alternativa;

$\mathrm{IC}_{(k)}$ : $k$-ésima marcação indireta e completa na alternativa;

z: Número total de marcações indiretas e completas na alternativa;

$\mathrm{II}_{(w)}:$ w-ésima marcação indireta e incompleta na alternativa;

1: Número total de marcações indiretas e incompletas na alternativa. 
e) Índice de Assertividade das Alternativas (ISA): este índice aponta, dentre as soluções, aquelas que são propostas e atendem diretamente aos problemas, comparativamente a todos os atendimentos da alternativa. Este indicador aponta o foco das soluções propostas e é dado pela razão entre os atendimentos diretos, completos e incompletos e o total de atendimentos diretos, indiretos, completos e incompletos da alternativa em análise, conforme a eq.(36).

$$
I S A=\frac{\sum_{i=0}^{n} D C_{i}+\sum_{j=0}^{m} D I_{j}}{\sum_{i=0}^{n} D C_{i}+\sum_{j=0}^{m} D I_{j}+\sum_{k=0}^{z} I C_{k}+\sum_{w=0}^{l} I I_{w}},
$$

Em que:

ISA: Índice de Assertividade das Alternativas;

$\mathrm{DC}_{(i)}$ : i-ésima marcação direta e completa na alternativa;

$\mathrm{DI}_{(j)}$ : j-ésima marcação direta e incompleta na alternativa;

n: Número total de marcações diretas e completas na alternativa;

m: Número total de marcações diretas e incompletas na alternativa;

$\mathrm{IC}_{(k)}$ : k-ésima marcação indireta e completa na alternativa;

z: Número total de marcações indiretas e completas na alternativa;

$\mathrm{II}_{(w)}:$ w-ésima marcação indireta e incompleta na alternativa;

1: Número total de marcações indiretas e incompletas na alternativa.

f) Índice de Colateralidade das Alternativas (ICA): este índice avalia o nível de imprecisão das alternativas, isto é, os atendimentos indiretos completos e incompletos que a alternativa proporciona, comparativamente ao número de atuações. É dado pela razão entre o número total de atendimentos indiretos, completos e incompletos, e o número total de atendimentos diretos, indiretos, completos e incompletos, conforme se observa na eq.(37).

$$
I C A=\frac{\sum_{k=0}^{Z} I C_{z}+\sum_{w=0}^{l} I I_{w}}{\sum_{i=0}^{n} D C_{i}+\sum_{j=0}^{m} D I_{j}+\sum_{k=0}^{Z} I C_{k}+\sum_{w=0}^{l} I I_{w}},
$$

Em que:

ICA: Índice de Colateralidade das Alternativas;

$\mathrm{DC}_{(i)}$ : i-ésima marcação direta e completa na alternativa; 
$\mathrm{DI}_{(j)}$ : j-ésima marcação direta e incompleta na alternativa;

n: Número total de marcações diretas e completas na alternativa;

m: Número total de marcações diretas e incompletas na alternativa;

$\mathrm{IC}_{(k)}$ : $k$-ésima marcação indireta e completa na alternativa;

z: Número total de marcações indiretas e completas na alternativa;

$\mathrm{II}_{(w)}:$ w-ésima marcação indireta e incompleta na alternativa;

1: Número total de marcações indiretas e incompletas na alternativa;

P: Número total de problemas.

g) Índice de Incompletude das Alternativas (IIA): este índice avalia, dentre as alternativas propostas, aquelas que não têm potencial para solucionar completamente os problemas. Representa intrinsecamente as alternativas que consomem recursos (podem ser efetivas, mas não são eficazes). É determinado pela razão entre o total de marcações incompletas, diretas e indiretas, associadas a uma alternativa, e o total de atuações diretas, indiretas, completas e incompletas de uma alternativa. O cálculo se dá pela eq.(38).

$$
I I A=\frac{\sum_{j=0}^{m} D I_{j}++\sum_{w=0}^{l} I I_{w}}{\sum_{i=0}^{n} D C_{i}+\sum_{j=0}^{m} D I_{j}+\sum_{k=0}^{z} I C_{k}+\sum_{w=0}^{l} I I_{w}},
$$

Em que:

IIA: Índice de Incompletude das Alternativas;

$\mathrm{DC}_{(i)}$ : $i$-ésima marcação direta e completa na alternativa;

$\mathrm{DI}_{(j)}$ : j-ésima marcação direta e incompleta na alternativa;

n: Número total de marcações diretas e completas na alternativa;

m: Número total de marcações diretas e incompletas na alternativa;

$\mathrm{IC}_{(k)}$ : $k$-ésima marcação indireta e completa na alternativa;

z: Número total de marcações indiretas e completas na alternativa;

II $_{(w)}:$ w-ésima marcação indireta e incompleta na alternativa;

1: Número total de marcações indiretas e incompletas na alternativa.

Os sete índices associados à qualificação das alternativas, quanto a sua abrangência e seu atendimento, desdobraram-se em uma avaliação multifacetada das alternativas. Os índices 
propostos avaliam, complementarmente entre si, os níveis de eficiência, eficácia e efetividade das alternativas frente aos problemas apresentados, com apoio do IAA, do $\operatorname{IEA}_{(\mathrm{f})}$, do $\operatorname{IEA}_{(\mathrm{c})}$ e do $\operatorname{IEA}_{(\mathrm{e})}$. Ademais, eles permitem avaliar a qualidade das alternativas propostas, como apoio do IIA, do ICA e do ISA.

Entretanto, é importante avaliar o impacto das ações, em função de atuação na solução de problemas, considerando que a população busca ter seus anseios atendidos completamente, pouco importando se as ações são diretas ou indiretas. Também não se pode negligenciar que as ações, mesmo quando incompletas, contribuem positivamente na solução dos problemas, não importando se são diretas ou indiretas. Dessa forma, é possível hierarquizar as alternativas, a partir de uma análise mais generalista, tal como:

a) Determinação do Índice Geral de Abrangência das Alternativas Ponderado IGA$\mathbf{A}_{(\mathbf{p})}$ : este índice pondera o nível de atendimento dos problemas com a atuação das alternativas. Ele avalia o nível de atendimento das expectativas frente aos problemas considerando sua completude e sua assertividade. É dado pela razão entre a somatória ponderada total de atuações e a somatória total de problemas, como se vê na eq.(39).

$$
\mathrm{IGA}-\mathrm{A}_{(p)}=\frac{p c \times\left(\sum_{i=0}^{n} D C_{i}+\sum_{k=0}^{Z} I C_{k}\right)+p i \times\left(\sum_{w=0}^{l} I I_{w}+\sum_{j=0}^{m} D I_{j}\right)}{\sum P}
$$

IGA-A $(p)$ : Índice Geral de Abrangência das Alternativas Ponderado;

$\mathrm{DC}_{(\mathrm{i})}$ : i-ésima marcação direta e completa na alternativa;

$\mathrm{DI}_{(\mathrm{j})}$ : j-ésima marcação direta e incompleta na alternativa;

n: Número total de marcações diretas e completas na alternativa;

m: Número total de marcações diretas e incompletas na alternativa;

$\mathrm{IC}_{(k)}$ : $k$-ésima marcação indireta e completa na alternativa;

z: Número total de marcações indiretas e completas na alternativa;

$\mathrm{II}_{(w)}$ : w-ésima marcação indiretas e incompletas na alternativa;

1: Número total de marcações indiretas e incompletas na alternativa;

pc: Peso atribuído as soluções completas;

pi: Peso atribuído as soluções incompletas;

P: Número total de problemas. 
Os pesos "pc" e "pi” são números inteiros positivos, não nulos, que são de livre provimento do decisor. Genericamente, podem ser assumidos como 2 para o peso associado aos atendimentos completos e 1 para o peso associado aos atendimentos incompletos.

O IGA-A $(\mathrm{p})$ estabelece uma ordem hierárquica absoluta das alternativas, sob a ótica dos sujeitos, considerando o nível de atendimento das alternativas. Contudo, é possível relativizálos, ou seja, compará-los entre si, e estabelecer uma escala de avaliação de comparação pareada:

a) construção da matriz de comparação pareada da abrangência das alternativas: a relativização do $\operatorname{IGA}_{-A_{(p)}}$ se dá por uma comparação par a par deste índice entre alternativas. Esse procedimento é dado pela distância entre os índices quando comparados par a par, assim, em uma matriz quadrada, cada elemento será a distância " $\Delta_{i j}$ " entre o $\operatorname{IGA}_{(\mathrm{A})}$ e as alternativas comparadas. Essa matriz, quando construída com os IGA-A(p) em ordem decrescente, formará uma matriz cuja diagonal principal receberá valores zerados, pois a distância entre o índice associado a uma alternativa dela mesma é nula, ou seja, " $a_{i j}=0$ ", quando " $i=j$ ”. Observa-se também que os valores abaixo da diagonal principal são recíprocos aos valores acima da diagonal principal, contudo com sinais trocados. Ou seja, "a $\mathrm{a}_{i j}$ ” é recíproco a " $\mathrm{a}_{j i}$ ”, ou ainda " $\mathrm{a}_{i j}=-\mathrm{a}_{i j}$ ”;

b) preparação para a construção da função valor: a representação matemática dos índices representará, através de uma escala, quantas vezes uma alternativa tem abrangência dominante em relação a outra.; Para tal, será adotada a escala semântica de preferência de Saaty, com valores inteiros entre 1 a 9 e seus correspondentes recíprocos racionais. Essa escala associa um comportamento comparativo entre as alternativas. Nesta proposta metodológica, diferente do trabalho de Saaty, cuja escala é construída com base nos julgamentos subjetivos dos decisores, a escala será construída a partir da matriz de comparação pareada das alternativas. A matriz de comparação pareada da abrangência das alternativas recebe valores negativos e positivos, enquanto a escala qualitativa de importância relativa proposta por Saaty recebe somente valores positivos. Portanto, é possível associar os valores obtidos na matriz de comparação pareada das alternativas aos valores da escala de Saaty por uma função matemática. Esta função de transformação das distâncias relativas à escala de Saaty é obtida associando os valores da escala de Saaty a uma variável “y”, e a distância relativa calculada a uma variável “x”, e, portanto, genericamente expressa " $\mathrm{y}=\mathrm{f}(\mathrm{x})$ ". A função matemática " $\mathrm{f}(\mathrm{x})$ " é determinada (linear, exponencial, raiz quadrada, logarítmica ou função recíproca) associando "x" (que é a 
distância relativa entre os IGA-A(p) a uma constante "K" que ajusta a função a cada situação analisada;

c) determinação da constante " $K$ ": a determinação da constante " $K$ " é atrelada à função matemática que será aplicada para representar as alternativas. Escolhida a função, os valores em que ela resulta, ou seja, os valores de "y", são conhecidos $(1,2,3,4,5,6,7$, 8,9 e seus recíprocos, 1/2, 1/3, 1/4, 1/5, 1/6, 1/7, 1/8 e 1/9). Os valores de "x" também são conhecidos, pois representam as distâncias relativas já preenchidas na matriz de

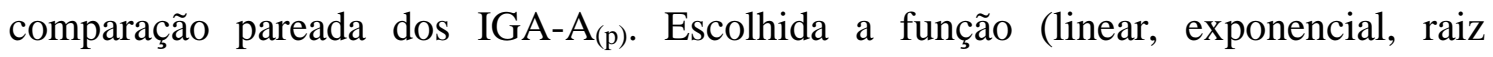
quadrada, logarítmica ou função recíproca), assume-se que a maior distância relativa positiva determina o maior nível de dominância e, portanto, corresponde ao valor de 9 na escala de Saaty. Com os dois valores conhecidos, sua associação permite determinar a constante " $K$ " para a situação de análise. Uma observação importante é que a função não é aplicada aos valores negativos, pois seu resultado também poderia ser negativo, então os valores negativos, na realidade, são os recíprocos dos positivos, de modo que " $\mathrm{a}_{i j}=\mathrm{y}$ ", tal como " $\mathrm{a}_{j i}=1 / \mathrm{y}$ ". Diante disso, uma sugestão interessante é montar a matriz de comparação pareada em ordem decrescente, assim os valores acima da diagonal principal serão positivos, e os valores abaixo da diagonal principal serão os recíprocos na escala de Saaty, então " $\mathrm{a}_{j i}=1 / \mathrm{a}_{i j}$ ". Ademais, quando a distância relativa for nula $\left(\mathrm{a}_{i j}=0\right)$, a dominância é a de igual preferência proposta por Saaty, ou seja, 1. Os valores associados a "y" serão números racionais e podem ser trabalhados dessa maneira. Contudo, os valores principais de dominância propostos por Saaty são inteiros, de 1 a 9, e apenas os recíprocos racionais são associados aos dominantes inteiros. Dessa maneira, é possível fixar intervalos ao domínio da função, ou seja, intervalos dos valores de “x”, associando cada intervalo a um número inteiro na escala de Saaty. Em outras palavras, é possível, a partir da função de transformação conhecida, associar intervalos (limite superior e limite inferior) da distância relativa entre os índices a valores na escala de preferência de Saaty;

d) construção da matriz de julgamento relativo da abrangência das alternativas: a partir da escolha pela função que representará a função de transformação da distância relativa entre os IGA-A $(\mathrm{p})$, em valores de dominância e preferência propostos por Saaty, da determinação da constante "K" que ajusta a função e da fixação dos intervalos, é possível transformar a matriz de comparação pareada da abrangência das alternativas em uma matriz de julgamentos relativos. Isto é, transformar os valores racionais positivos, negativos e nulos em uma matriz em valores racionais positivos e não nulos. Com essa 
matriz de comparação, será possível determinar um Índice Geral de Abrangência das Alternativas Hierárquico $\left(\mathrm{IGA}_{\mathrm{A}}\right)$, que representa o nível hierárquico de uma determinada alternativa quando associado relativamente ao nível de completude dos problemas propostos. Ele é estabelecido pelo auto vetor da matriz de julgamento relativo da abrangência das alternativas;

e) determinação do Índice de Abrangência Geral das Alternativas Hierárquico (IGA$\mathbf{A}_{(h))}$ o IGA-A (h) é um valor que cada alternativa recebe a partir de sua abrangência e de sua atuação nos problemas. Sua determinação segue uma sequência de passos, a saber: (i) normalização das colunas da matriz de julgamentos relativos da abrangência das alternativas; (ii) somatória da dominância normalizada da comparação paritária entre as alternativas, isto é, a soma de todos os elementos da linha de cada alternativa; e (iii) normalização da somatória normalizada da comparação das alternativas, isto é, a divisão de cada um dos resultados das somas das linhas pela soma de todas as linhas. Cabe reforçar que, feita a normalização, a soma dos elementos de uma mesma coluna sempre é igual a 1. Após essa normalização, deverá ser somada a linha correspondente a cada alternativa, ou seja, a somatória da dominância total de cada alternativa. Por fim, de forma subsequente, a somatória das linhas de dominância é normalizada, revelando o IGA-A $(\mathrm{h})$ de cada uma das alternativas. Quanto maior for o índice, maior serão a abrangência e a completude das consequências de uma alternativa, e, portanto, esta pode ser priorizada gerando ações mais efetivas, eficazes e eficientes simultaneamente sob a ótica da população.

O procedimento parece complexo, mas não é, e pode ser delineado a partir de um exemplo. Consideremos que a aplicação do painel de análise e correlação das alternativas em uma dinâmica tenha produzido o Quadro 14.

Quadro 14 - Exemplo de preenchimento do painel de correlação entre alternativas e problemas

\begin{tabular}{|c|ccc|}
\hline & Problema "A" & Problema "B" & Problema "C" \\
\hline Alternativa "A" & $D C$ & & $I I$ \\
Alternativa "B" & & $I C$ & $D I$ \\
Alternativa "C" & $D C$ & & $D C$ \\
Alternativa "D" & $I C$ & $I I$ & $D I$ \\
\hline
\end{tabular}

Fonte: Do autor (2019). 
A interpretação do quadro permite perceber que (i) a alternativa " $A$ " atuou diretamente e solucionou completamente o problema “A” (portanto, “DC"), contudo atuou indiretamente e solucionou incompletamente o problema "C" (portanto, “II"); (ii) a alternativa "B" atuou indiretamente e solucionou completamente o problema "B", (portanto, “IC"), contudo atuou diretamente e solucionou incompletamente o problema "C" (portanto, "DI"); (iii) a alternativa "C" atuou diretamente e solucionou completamente o problema "A" (portanto, " $D C$ ") e também atuou diretamente e solucionou completamente o problema "C" (portanto, " $D C$ "); e (iv) a alternativa " $\mathrm{D}$ ", atuou indiretamente e solucionou completamente o problema "A" (portanto, “ $I C$ "), contudo atuou indiretamente e solucionou incompletamente o problema " $\mathrm{B}$ " (portanto, “II") e atuou diretamente, mas solucionou incompletamente o problema "CC" (portanto, "DI'). No exemplo, são quatro alternativas e três problemas, e as somatórias de "DC", "DI", "IC", e "II" são apresentadas na Tabela 16.

Tabela 16 - Exemplo de composição de marcações diretas, indiretas, completas e incompletas para cada alternativa

\begin{tabular}{c|cccc|c}
\hline & $\boldsymbol{\Sigma}$ DC & $\boldsymbol{\Sigma}$ DI & $\boldsymbol{\Sigma}$ IC & $\boldsymbol{\Sigma}$ II & $\boldsymbol{\Sigma}$ DC $+\boldsymbol{\Sigma}$ DI $+\Sigma$ IC $+\Sigma$ II \\
\hline Alternativa "A" & 1 & 0 & 0 & 1 & 2 \\
Alternativa "B" & 0 & 1 & 1 & 0 & 2 \\
Alternativa "C" & 2 & 0 & 0 & 0 & 2 \\
Alternativa "D" & 0 & 1 & 1 & 1 & 3 \\
\hline $\boldsymbol{\Sigma}$ & $\mathbf{3}$ & $\mathbf{2}$ & $\mathbf{2}$ & $\mathbf{2}$ & $\mathbf{9}$ \\
\hline
\end{tabular}

Fonte: Do autor (2019).

Com esses dados, é possível calcular o IAA, o $\operatorname{IEA}_{(\mathrm{f})}$, o $\operatorname{IEA}_{(\mathrm{c})}$, o IEA(e), o IIA, o ICA e o ISA, conforme Tabela 17.

Tabela 17 - Exemplo dos índices de avaliação das alternativas

\begin{tabular}{c|ccccccc}
\hline & IAA & IEA(f) $_{(\mathbf{f}}$ & IEA(c) $_{(\mathbf{c}}$ & IEA $_{(\mathbf{e})}$ & IIA & ICA & ISA \\
\hline Alternativa "A" & 0,66 & 0,33 & 0,33 & 0,11 & 0,11 & 0,11 & 0,11 \\
Alternativa "B" & 0,66 & 0,33 & 0,33 & 0 & 0,11 & 0,11 & 0,11 \\
Alternativa "C" & 0,66 & 0,66 & 0,66 & 0,22 & 0 & 0 & 0,22 \\
Alternativa "D" & 1 & 0,33 & 0,33 & 0 & 0,22 & 0,22 & 0,11 \\
\hline $\boldsymbol{\Sigma}$ & $\mathbf{2 , 9 8}$ & $\mathbf{1 , 6 5}$ & $\mathbf{1 , 6 5}$ & $\mathbf{0 , 3 3}$ & $\mathbf{0 , 4 4}$ & $\mathbf{0 , 4 4}$ & $\mathbf{0 , 5 5}$ \\
\hline
\end{tabular}

Fonte: Do autor (2019). 
A avaliação multifacetada desses índices pode proporcionar insumos aos tomadores de decisão, de tal maneira que a complexidade da relação entre problemas e alternativas, asseverada pelas expectativas da população, possa ser melhor entendida, fortalecendo as ações tomadas com apoio popular.

Esses índices, para uma melhor visualização, podem ser normalizados, gerando então o IAA-N (Índice de Abrangências das Alternativas Normalizado), o IEA(f)-N (Índice de Efetividade das Alternativas Normalizado), o $\operatorname{IEA}_{(\mathrm{c})}-\mathrm{N}$ (Índice de Eficácia das Alternativas Normalizado), o IEA $(\mathrm{e})-\mathrm{N}$ (Índice de Eficiência das Alternativas Normalizado), o IIA-N (Índice de Incompletude das Alternativas Normalizado), o ICA-N (Índice de Colateralidade das Alternativas Normalizado) e o ISA-N (Índice de Assertividade das Alternativas Normalizado), conforme Tabela 18 .

A interpretação que se dá é que a alternativa " $D$ " é a mais atuante sobre os problemas. Por ser a mais abrangente (maior IAA), é a que mais atua indiretamente em problemas (maior ICA), contudo é a que deixa as soluções mais incompletas (maior IIA) e é uma das menos eficientes, junto à alternativa "B". Por outro lado, a alternativa "C" é a que mais atua diretamente sobre problemas (maior $\operatorname{IEA}_{(\mathrm{f})}$ e maior ISA) e é, ainda, a que mais atua solucionado completamente problemas (maior IEA(c) $)$, razão pela qual é a mais eficiente (maior $\operatorname{IEA}_{(\mathrm{e})}$ ). Vale salientar que a abrangência, a eficácia e a efetividade são verificadas em função dos problemas tratados, enquanto a assertividade, a incompletude, a colateralidade e a eficiência são verificadas em função da atuação das alternativas.

Tabela 18 - Exemplo dos índices de avaliação das alternativas normalizados

\begin{tabular}{c|ccccccc}
\hline & IAA-N & IEA(f)-N & IEA(c)-N $_{(\mathbf{s}}$ & IEA $_{(\mathbf{e})-\mathbf{N}}$ & IIA-N & ICA-N & ISA-N \\
\hline Alternativa "A" & 0,22 & 0,20 & 0,20 & 0,33 & 0,25 & 0,25 & 0,20 \\
Alternativa "B" & 0,22 & 0,20 & 0,20 & 0 & 0,25 & 0,25 & 0,20 \\
Alternativa "C" & 0,22 & 0,40 & 0,40 & 0,67 & 0 & 0 & 0,40 \\
Alternativa "D" & 0,34 & 0,20 & 0,20 & 0 & 0,50 & 0,50 & 0,20 \\
\hline $\boldsymbol{\Sigma}$ & $\mathbf{1}$ & $\mathbf{1}$ & $\mathbf{1}$ & $\mathbf{1}$ & $\mathbf{1}$ & $\mathbf{1}$ & $\mathbf{1}$ \\
\hline
\end{tabular}

Fonte: Do autor (2019).

Também é possível incorporar a majoração da assertividade em função dos atendimentos completos, em face dos problemas avaliados com o cálculo do Índice Geral de Abrangência das Alternativas Ponderado (IGA-A $(\mathrm{p})$ ). Considerando os pesos "pc" e "pi", como sugerido nas 
propostas metodológicas 2 e 1, respectivamente. Diferente do ISA, que avalia os atendimentos diretos sobre os problemas a partir de todos os atendimentos propostos, o Índice Geral de Assertividade avalia as atuações completas majoradas frente às incompletas em função total de problemas demandados. Seu cálculo é exemplificado na Tabela 19.

Tabela 19 - Exemplo de cálculo do Índice Geral de Assertividade das Alternativas Ponderado

\begin{tabular}{c|cccc|c}
\hline & $\Sigma$ DC & $\Sigma$ DI & $\Sigma$ IC & $\Sigma$ II & IGA-A(p) \\
\hline Alternativa "A" & 1 & 0 & 0 & 1 & 1 \\
Alternativa "B" & 0 & 1 & 1 & 0 & 1 \\
Alternativa "C" & 2 & 0 & 0 & 0 & 1,33 \\
Alternativa "D" & 0 & 1 & 1 & 1 & 1,33 \\
\hline $\boldsymbol{\Sigma}$ & $\mathbf{3}$ & $\mathbf{2}$ & $\mathbf{2}$ & $\mathbf{2}$ & $\mathbf{4 , 6 6}$ \\
\hline
\end{tabular}

Fonte: Do autor (2019).

Em seguida, é possível comparar paritariamente as alternativas a partir da diferença entre os respectivos do IGA-A $\left(\mathrm{A}^{6}{ }^{69}\right.$, conforme exemplo na Tabela 20.

A diferença entre os índices, poderá ser negativa, uma vez que o índice de alternativa referência na linha, é menor do que o índice da alternativa a que se compara, na coluna. Esta análise permite, indiretamente, perceber a distância parcial entre alternativas que já foram comparadas entre si.

Tabela 20 - Exemplo de Cálculo das distâncias relativas do Índice Geral de Assertividade das Alternativas Ponderado

\begin{tabular}{l|c|cccc}
\hline \multicolumn{2}{l|}{} & $\begin{array}{c}\text { Alternativa } \\
\text { "D" }\end{array}$ & $\begin{array}{c}\text { Alternativa } \\
\text { "C"C }\end{array}$ & $\begin{array}{c}\text { Alternativa } \\
\text { "B" }\end{array}$ & $\begin{array}{c}\text { Alternativa } \\
\text { "A"A }\end{array}$ \\
\cline { 3 - 6 } & & $\mathbf{1 , 3 3}$ & $\mathbf{1 , 3 3}$ & $\mathbf{1}$ & $\mathbf{1}$ \\
\hline Alternativa "D" & $\mathbf{1 , 3 3}$ & 0 & 0 & 0,33 & 0,33 \\
Alternativa "C" & $\mathbf{1 , 3 3}$ & 0 & 0 & 0,33 & 0,33 \\
Alternativa "B" & $\mathbf{1}$ & $-0,33$ & $-0,33$ & 0 & 0 \\
Alternativa "A" & $\mathbf{1}$ & $-0,33$ & $-0,33$ & 0 & 0 \\
\hline
\end{tabular}

Fonte: Do autor (2019).

\footnotetext{
${ }^{69}$ A diferença entre os respectivos índices é análoga a expressão distância relativa designa a distância medida em função de uma determinada variável. Quando se diz que determinada distância relativa entre alternativas alternativa relativa de outra, por exemplo, quer dizer existe uma diferença entre elas, contudo quando duas alternativas são valoradas igualmente, a distância relativa entre elas é 0 .
} 
Após a comparação par a par, a construção da função de transformação e sua constante “K”, para associação dos valores das diferenças à escala semântica de Saaty, é possível a construção da matriz de julgamento relativo da abrangência das alternativas no exemplo proposto, consolidado na Tabela 21.

Tabela 21 - Exemplo da dominância de uma alternativa a outra após aplicação da função valor

\begin{tabular}{c|cccc}
\hline & $\begin{array}{c}\text { Alternativa } \\
\text { "D" }\end{array}$ & $\begin{array}{c}\text { Alternativa } \\
\text { "CC" }\end{array}$ & $\begin{array}{c}\text { Alternativa } \\
\text { "B" }\end{array}$ & $\begin{array}{c}\text { Alternativa } \\
\text { "A" }\end{array}$ \\
\hline Alternativa "D" & 1 & 1 & 9 & 9 \\
Alternativa "C" & 1 & 1 & 9 & 9 \\
Alternativa "B" & $1 / 9$ & $1 / 9$ & 1 & 1 \\
Alternativa "A" & $1 / 9$ & $1 / 9$ & 1 & 1 \\
\hline
\end{tabular}

Fonte: Do autor (2019).

Normalizando a matriz de julgamento relativo da tabela 20, é possível calcular seu auto vetor e, consequentemente, o IGA-A $(\mathrm{h})$, conforme Tabela 22.

Para este exemplo proposto nota-se que as alternativas D e C, possuem uma dominância maior, quando comparadas as alternativas B e A, no que se refere a abrangência de atendimento aos problemas propostos. O exemplo, com propósito didático, avaliou apenas quatro alternativas, contudo a proposta metodológica permite a comparação de infinitas alternativas, que quando analisadas com apoio da função valor, geram comparações consistentes ${ }^{70}$.

Tabela 22 - Exemplo de cálculo do índice geral de abrangência das alternativas hierarquizado

\begin{tabular}{c|cccc|c|c}
\hline & $\begin{array}{c}\text { Alternativa } \\
\text { "D" }\end{array}$ & $\begin{array}{c}\text { Alternativa } \\
\text { "C" }\end{array}$ & $\begin{array}{c}\text { Alternativa } \\
\text { "B" }\end{array}$ & $\begin{array}{c}\text { Alternativa } \\
\text { "A" }\end{array}$ & $\Sigma$ & IGA-A $(h)$ \\
\hline $\begin{array}{c}\text { Alternativa } \\
\text { "D" }\end{array}$ & 0,45 & 0,45 & 0,45 & 0,45 & 1,8 & $\mathbf{0 , 4 5}$ \\
$\begin{array}{c}\text { Alternativa } \\
\text { "C" }\end{array}$ & 0,45 & 0,45 & 0,45 & 0,45 & 1,8 & $\mathbf{0 , 4 5}$ \\
$\begin{array}{c}\text { Alternativa } \\
\text { "B" }\end{array}$ & 0,05 & 0,05 & 0,05 & 0,05 & 0,2 & $\mathbf{0 , 0 5}$ \\
$\begin{array}{c}\text { Alternativa } \\
\text { "A" }\end{array}$ & 0,05 & 0,05 & 0,05 & 0,05 & 0,2 & $\mathbf{0 , 0 5}$ \\
\hline $\boldsymbol{\Sigma}$ & $\mathbf{1}$ & $\mathbf{1}$ & $\mathbf{1}$ & $\mathbf{1}$ & $\mathbf{4}$ & $\mathbf{1}$ \\
\hline
\end{tabular}

Fonte: Do autor (2019).

\footnotetext{
${ }^{70}$ As comparações paritárias, mesmo com um número grande de comparações, quando constituídas a partir da distância relativa passam a validar os julgamentos e assegurar que eles são consistentes, de modo que um conjunto de comparações paritárias seja consistente com um outro conjunto de comparações. Portanto a metodologia permite verificar a coerência dos julgamentos.
} 
A metodologia de hierarquização de comparação pareada para construção do IGA-A $($ h) pode ser aplicada aos demais índices de caracterização das alternativas. Não há um índice que seja melhor do que outro, pois cada um deles tem facetas específicas. O que se reforça é que a obtenção de uma série de índices que caracterizam um processo pode instrumentalizar melhor os tomadores de decisão.

\subsubsection{Hierarquização Multicriterial de Abrangência dos Problemas e Alternativas}

A partir do painel de análise e correlação das alternativas, também é possível avaliar o nível de atendimento dos problemas, em função das alternativas propostas. Em outras palavras, pode-se verificar se, além das dificuldades já pontuadas para tratamento dos problemas, as soluções geradas em um processo participativo têm a real capacidade de atuar no problema. Essa avaliação pode ser feita a partir dos indicadores destacados:

a) Índice de Eficácia dos Problemas $\left(\operatorname{IEP}_{(\mathfrak{c})}\right)$ : este índice avalia os problemas e a eficácia das alternativas propostas para sua solução, ou seja, se os problemas possuem alternativas que solucionam completamente, direta ou indiretamente. No painel de correlação das alternativas, é somada a pontuação total correspondente (atuação direta completa e atuação indireta completa) nos problemas, dividida pelo total de alternativas propostas, conforme a eq.(40).

$$
I E P_{(c)}=\frac{\sum_{i=0}^{n} D C_{i}+\sum_{j=0}^{m} I C_{j}}{\sum A}
$$

Em que:

IEP $_{(\mathrm{c})}$ : Índice de Eficácia dos Problemas;

$\mathrm{DC}_{(\mathrm{i})}$ : i-ésima marcação direta e completa no problema;

$\mathrm{IC}_{(\mathrm{j})}$ : j-ésima marcação indireta e completa no problema;

n: Número total de marcações diretas e completas no problema;

m: Número total de marcações indiretas e completas no problema;

A: Número total de alternativas.

b) Índice de Efetividade dos Problemas (IEP(f) $)$ : este índice avalia os problemas e a efetividade das tratativas propostas, ou seja, aquele problema cujas alternativas o solucionam completamente ou incompletamente, apenas com atuação direta. No painel de correlação das alternativas, é somada a pontuação total correspondente (atuação direta 
completa e atuação direta incompleta) no problema, dividida pelo total de alternativas propostas, conforme é mostrado na eq.(41).

$$
\operatorname{IEP}_{(f)}=\frac{\sum_{i=0}^{n} D C_{i}+\sum_{j=0}^{m} D I_{j}}{\sum A}
$$

Em que:

$\operatorname{IEP}_{(\mathrm{f})}$ : Índice de Efetividade dos Problemas;

$\mathrm{DC}_{(\mathrm{i})}:$ i-ésima marcação direta e completa no problema;

$\mathrm{DI}_{(\mathrm{j})}: j$-ésima marcação direta e incompleta no problema;

n: Número total de marcações diretas e completas no problema;

m: Número total de marcações diretas e incompletas no problema;

A: Número total de alternativas.

c) Índice de Abrangência dos Problemas (IAP): este índice avalia, dentre os problemas analisados, aqueles que possuem maior número de intervenções propostas. Ele atua somando todas as atuações, sejam elas diretas ou indiretas, e a sua abrangência, seja ela completa ou incompleta nos problemas, relacionada com o total de atuações existentes no processo. É complementar ao $\operatorname{IFA}_{(\mathrm{r})}$, pois, enquanto o $\operatorname{IFP}_{(\mathrm{r})}$ avalia o nível de conectividade dos problemas, o IAP avalia o nível de atendimento das expectativas frente às alternativas apresentadas em cada problema. Seu cálculo é dado pela razão entre a somatória total de atuações da alternativa no problema e a somatória total de alternativas, como se vê na eq.(42). a seguir.

$$
I A P=\frac{\sum_{i=0}^{n} D C_{i}+\sum_{j=0}^{m} D I_{j}+\sum_{k=0}^{Z} I C_{k}+\sum_{w=0}^{l} I I_{w}}{\sum A}
$$

Em que:

IAP: Índice de Abrangências dos Problemas;

$\mathrm{DC}_{(i)}$ : i-ésima marcação direta e completa no problema;

$\mathrm{DI}_{(j)}$ : j-ésima marcação direta e incompleta no problema;

n: Número total de marcações diretas e completas no problema;

m: Número total de marcações diretas e incompletas no problema;

$\mathrm{IC}_{(k)}$ : k-ésima marcação indireta e completa no problema; 
z: Número total de marcações indiretas e completas no problema;

$\mathrm{II}_{(w)}$ : w-ésima marcação indireta e incompleta no problema;

1: Número total de marcações indiretas e incompletas no problema;

A: Número total de alternativas.

d) Índice de Eficiência dos Problemas $\left(\operatorname{IEP}_{(\mathrm{e})}\right)$ : este índice avalia os problemas que são resolvidos com efetividade e eficácia. Assim, corresponde à razão entre o total de problemas cujas alternativas atuam diretamente e os solucionam completamente, sobre a somatória das atuações no problema, seja a alternativa que atua diretamente e soluciona completamente, a que atua indiretamente e soluciona completamente ou a que atua diretamente e soluciona incompletamente e completamente. Partindo do pressuposto de que a implantação de todas as ações demanda recursos, implantar uma ação que não solucione um problema completamente ou ainda uma solução cujos recursos são pensados para uma outra questão, mas influem no problema de análise, pode representar uma falha. Portanto, esse índice avalia o quão assertivas são as alternativas propostas no problema especificamente, conforme eq.(43).

$$
\operatorname{IEP}_{(e)}=\frac{\sum_{i=0}^{n} D C_{i}}{\sum_{i=0}^{n} D C_{i}+\sum_{j=0}^{m} D I_{j}+\sum_{k=0}^{z} I C_{k}+\sum_{w=0}^{l} I I_{w}},
$$

Em que:

$\operatorname{IEP}_{(e)}$ : Índice de Eficiência dos Problemas;

$\mathrm{DC}_{(i)}$ : i-ésima marcação direta e completa no problema;

$\mathrm{DI}_{(j)}:$ j-ésima marcação direta e incompleta no problema;

n: Número total de marcações diretas e completas no problema;

m: Número total de marcações diretas e incompletas no problema;

$\mathrm{IC}_{(k)}$ : $k$-ésima marcação indireta e completa no problema;

z: Número total de marcações indiretas e completas no problema;

$\mathrm{II}_{(w)}:$ w-ésima marcação indireta e incompleta no problema;

1: Número total de marcações indiretas e incompletas no problema.

e) Índice de Assertividade nos Problemas (ISP): este índice aponta, em cada problema, as soluções propostas que o atendam diretamente, comparativamente a todos os 
atendimentos prestados a esse problema. Esse indicador aponta o foco das soluções propostas para os problemas; ele é dado pela razão entre os atendimentos diretos, completos e incompletos e o total de atendimentos diretos, indiretos, completos e incompletos no problema em análise, conforme eq.(44).

$$
I S P=\frac{\sum_{i=0}^{n} D C_{i}+\sum_{j=0}^{m} D I_{j}}{\sum_{i=0}^{n} D C_{i}+\sum_{j=0}^{m} D I_{j}+\sum_{k=0}^{Z} I C_{k}+\sum_{w=0}^{l} I I_{w}},
$$

Em que:

ISP: Índice de Assertividade nos Problemas;

$\mathrm{DC}_{(i)}$ : i-ésima marcação direta e completa no problema;

$\mathrm{DI}_{(j)}$ : j-ésima marcação direta e incompleta no problema;

n: Número total de marcações diretas e completas no problema;

m: Número total de marcações diretas e incompletas no problema;

$\mathrm{IC}_{(k)}$ : $k$-ésima marcação indireta e completa no problema;

z: Número total de marcações indiretas e completas no problema;

$\mathrm{II}_{(w)}:$ w-ésima marcação indireta e incompleta no problema;

1: Número total de marcações indiretas e incompletas no problema.

f) Índice de Colateralidade nos Problemas (IOP): este índice avalia o nível de imprecisão das alternativas que atuam nos problemas, isto é, os atendimentos indiretos completos e incompletos que alternativas proporcionam em cada problema, comparativamente ao número de atuações no problema. É dado pela razão entre o número total de atendimentos indiretos, completo e incompletos, e o número total de atendimentos diretos, indiretos, completos e incompletos no problema, conforme eq.(45).

$$
I O P=\frac{\sum_{k=0}^{z} I C_{z}+\sum_{w=0}^{l} I I_{w}}{\sum_{i=0}^{n} D C_{i}+\sum_{j=0}^{m} D I_{j}+\sum_{k=0}^{z} I C_{k}+\sum_{w=0}^{l} I I_{w}},
$$

Em que:

IOP: Índice de Colateralidade nos Problemas;

$\mathrm{DC}_{(i)}$ : i-ésima marcação direta e completa no problema;

$\mathrm{DI}_{(j)}$ : j-ésima marcação direta e incompleta no problema; 
n: Número total de marcações diretas e completas no problema;

m: Número total de marcações diretas e incompletas na no problema;

$\mathrm{IC}_{(k)}$ : k-ésima marcação indireta e completa no problema;

z: Número total de marcações indiretas e completas no problema;

$\mathrm{II}_{(w)}:$ w-ésima marcação indireta e incompleta no problema;

1: Número total de marcações indiretas e incompletas no problema.

g) Índice de Incompletude nos Problemas (IUP): este índice avalia, em cada problema, as alternativas propostas para ele, aquelas que não têm potencial para os solucionar completamente. Ele representa intrinsecamente aquelas alternativas que consomem recursos e podem ser efetivas, mas não são eficazes. É determinado pela razão entre o total de marcações incompletas, diretas e indiretas, associadas a cada problema, e o total de atuações diretas, indiretas, completas e incompletas no problema, como pode ser observado na eq.(46).

$$
I U P=\frac{\sum_{j=0}^{m} D I_{j}++\sum_{w=0}^{l} I I_{w}}{\sum_{i=0}^{n} D C_{i}+\sum_{j=0}^{m} D I_{j}+\sum_{k=0}^{z} I C_{k}+\sum_{w=0}^{l} I I_{w}},
$$

Em que:

IUP: Índice de Incompletude nos Problema;

$\mathrm{DC}_{(i)}:$ i-ésima marcação direta e completa no problema;

$\mathrm{DI}_{(j)}$ : j-ésima marcação direta e incompleta no problema;

n: Número total de marcações diretas e completas no problema;

m: Número total de marcações diretas e incompletas no problema;

$\mathrm{IC}_{(k)}$ : k-ésima marcação indireta e completa no problema;

z: Número total de marcações indiretas e completas no problema;

$\mathrm{II}_{(w)}$ : w-ésima marcação indireta e incompleta no problema;

1: Número total de marcações indiretas e incompletas no problema.

Os sete índices associados à qualificação dos problemas, consoante aos atendimentos propostos pelas alternativas, desdobraram-se em uma avaliação multifacetada sob a ótica da possibilidade de atendimento, e cabe salientar que tanto os problemas quanto as alternativas são 
gerados, na dinâmica participativa, pelos sujeitos. Os achados nesta proposta metodológica permitem que os técnicos e decisores possam utilizar contribuições das diferentes narrativas, que ampliam o leque de situações de enfrentamento e soluções, com uma negociação intrínseca ao processo dos sujeitos. A metodologia, associada aos índices extraídos, permite a elaboração de propostas com desfechos que diminuem as chances de lacunas nas intervenções.

Por sua vez, os índices propostos avaliam, complementarmente entre si, o nível de eficiência, eficácia e efetividade da ação nos problemas frente às alternativas propostas, com apoio do IAP, do $\operatorname{IEP}_{(\mathrm{f})}$, do $\operatorname{IEP}_{(\mathrm{c})}$ e do $\operatorname{IEP}_{(\mathrm{e})}$. Ademais, permitem avaliar o quanto os problemas são solucionados, qualitativamente, pelas alternativas propostas, com apoio do IUP, do IOP e do ISP. Entretanto, é importante avaliar o impacto das ações nos problemas, considerando que, para a população, o que se busca é ter seus anseios atendidos completamente, pouco importando se as ações são diretas ou indiretas. Também não se pode negligenciar que as ações, mesmo quando incompletas, contribuem positivamente na solução dos problemas, não importando se isso ocorre direta ou indiretamente.

Dessa forma, é possível hierarquizar as alternativas a partir de uma análise mais generalista, tal como:

a) determinação do IGA-P(p) (Índice Geral de Abrangência dos Problemas

Ponderado): este índice pondera o nível de atendimento dos problemas com a atuação das alternativas. Ele avalia o nível de atendimento das expectativas frente às soluções apresentadas considerando sua completude e sua assertividade. É dado pela razão entre a somatória ponderada total de atuações no problema e a somatória total de alternativas, como mostra a eq.(47).

$$
I G A-P_{(p)}=\frac{p c \times\left(\sum_{i=0}^{n} D C_{i}+\sum_{k=0}^{Z} I C_{k}\right)+p i \times\left(\sum_{w=0}^{l} I I_{w}+\sum_{j=0}^{m} D I_{j}\right)}{\sum A}
$$

Em que:

IGA-P $(\mathrm{p})$ : Índice de Geral de Abrangência dos Problemas Ponderado;

$\mathrm{DC}_{(i)}$ : i-ésima marcação direta e completa no problema;

$\mathrm{DI}_{(j)}$ : j-ésima marcação direta e incompleta no problema;

n: Número total de marcações diretas e completas no problema;

m: Número total de marcações diretas e incompletas no problema;

$\mathrm{IC}_{(k)}$ : $k$-ésima marcação indireta e completa no problema; 
z: Número total de marcações indiretas e completas no problema;

$\mathrm{II}_{(w)}$ : w-ésima marcação indireta e incompleta no problema;

1: Número total de marcações indiretas e incompletas no problema;

pc: peso atribuído às soluções completas;

pi: peso atribuído às soluções incompletas;

A: Número total de alternativas.

Os pesos "pc" e "pi" são números inteiros positivos, não nulos, que são de livre provimento do decisor. Genericamente, podem ser assumidos como 2 para o peso associado aos atendimentos completos e 1 para o peso associado aos atendimentos incompletos.

O IGA-P $\mathrm{P}_{(\mathrm{p})}$ estabelece uma ordem hierárquica absoluta dos problemas, sob a ótica dos sujeitos, considerando o nível de atendimento por parte das alternativas propostas. Contudo, é possível relativizá-los, ou seja, compará-los entre si, e estabelecer uma escala de avaliação de comparação pareada:

a) construção da matriz de comparação pareada da abrangência dos problemas: a relativização do $\operatorname{IGA}_{(\mathrm{p})}$ se dá por uma comparação par a par deste índice entre problemas. O procedimento é dado pela distância entre os índices quando comparados par a par, assim, em uma matriz quadrada, cada elemento será a distância " $\Delta_{i j}$ ” entre o IGA-P $_{(\mathrm{p})}$ e os problemas comparados. Essa matriz, quando construída com os IGA-P(p) em ordem decrescente, formará uma matriz cuja diagonal principal receberá valores zerados, pois a distância entre o índice associado a um problema dele mesmo é nula (" $\mathrm{a}_{i j}$ $=0$ ”, quando “ $i=j$ ”). Além disso, pode-se observar que os valores abaixo da diagonal principal são recíprocos aos valores acima da diagonal principal, mas com sinais trocados, de modo que " $\mathrm{a}_{i j}$ ” é recíproco a " $\mathrm{a}_{j i}$ ” (ou " $\mathrm{a}_{i j}=-\mathrm{a}_{j i}$ ”);

b) preparação para a construção da função valor: A representação matemática dos índices apontará, através de uma escala, quantas vezes um problema tem abrangência dominante ao outro, e para tal será adotada a escala semântica de preferência de Saaty, com valores inteiros entre 1 a 9 e seus correspondentes recíprocos racionais. Essa escala associa um comportamento comparativo entre os problemas. Na proposta metodológica, diferentemente do trabalho de Saaty cuja escala é construída com base nos julgamentos subjetivos dos decisores, a escala será construída a partir da matriz de comparação pareada da abrangência dos problemas. Esta recebe valores negativos e positivos, 
enquanto a escala qualitativa de importância relativa proposta por Saaty recebe somente valores positivos. Portanto, é possível associar os valores obtidos na matriz de comparação pareada dos problemas aos valores da escala de Saaty por uma função matemática de transformação das distâncias relativas à escala de Saaty, a qual é obtida associando os valores desta a uma variável " $y$ ", a distância relativa calculada a uma variável " $\mathrm{x}$ ", assim genericamente expressa " $y=f(x)$ ". A função $f(x)$ é uma função matemática determinada (linear, exponencial, raiz quadrada, logarítmica ou função recíproca), associando " $\mathrm{x}$ " (que é a distância relativa entre os IGA-P(p)) a uma constante "K” que ajusta a função a cada situação analisada;

c) determinação da constante "K": é atrelada à função matemática que será aplicada para representar os problemas. Escolhida a função, os valores em que ela resulta (os valores de "y") são conhecidos $(1,2,3,4,5,6,7,8,9$ e seus recíprocos, $1 / 2,1 / 3,1 / 4,1 / 5,1 / 6,1 / 7,1 / 8$ e $1 / 9$ ). Os valores de " $x$ " também são conhecidos, pois representam as distâncias relativas já preenchidas na matriz de comparação pareada dos $\operatorname{IGA}_{\mathrm{a}} \mathrm{P}_{(\mathrm{p})}$. Escolhida a função (linear, exponencial, raiz quadrada, logarítmica ou função recíproca), assume-se que a maior distância relativa positiva determina o maior nível de dominância e, portanto, corresponde ao valor de 9 na escala de Saaty. Com os dois valores conhecidos, sua associação permite determinar a constante "K" para a situação de análise. É importante observar que a função não é aplicada aos valores negativos, pois seu resultado também poderia ser negativo, de modo que os valores negativos, na realidade, são os recíprocos dos positivos, então " $\mathrm{a}_{i j}=$ y", tal como " $\mathrm{a}_{j i}=1 / \mathrm{y}$ ". Diante disso, uma sugestão interessante é montar a matriz de comparação pareada em ordem decrescente, assim os valores acima da diagonal principal serão positivos, e os valores abaixo da diagonal principal serão os recíprocos na escala de Saaty, de forma que " $\mathrm{a}_{j i}=1 / \mathrm{a}_{i j}$ ". Além disso, quando a distância relativa for nula (" $\mathrm{a}_{i j}=$ 0”), a dominância é a de igual preferência proposta por Saaty, ou seja, 1. Os valores associados a “y” serão números racionais e podem ser trabalhados desta maneira. Contudo, os valores principais de dominância propostos por Saaty são inteiros de 1 a 9, e apenas os recíprocos racionais são associados aos dominantes inteiros. Dessa maneira, é possível fixar intervalos ao domínio da função, ou seja, intervalos dos valores de "x", associando cada intervalo a um número inteiro da escala de Saaty. Em outras palavras, é possível, a partir da função de transformação conhecida, associar intervalos (limite superior e limite inferior) da distância relativa entre os índices a valores na escala de preferência de Saaty; 
d) construção da matriz de julgamento relativo da abrangência dos problemas: a partir da escolha pela função que representará a função de transformação da distância relativa entre os IGA-P $(\mathrm{p})$, em valores de dominância e preferência propostos por Saaty, da determinação da constante "K" que ajusta a função e da fixação dos intervalos, é possível transformar a matriz de comparação pareada da abrangência dos problemas em uma matriz de julgamentos relativos, isto é, transformar os valores racionais positivos, negativos e nulos de uma matriz em valores racionais positivos e não nulos. Com essa matriz de comparação, será possível determinar um IGA- $\mathrm{P}_{(\mathrm{h})}$, que representa o nível hierárquico de um determinado problema associado relativamente ao seu nível de completude e ao total de alternativas propostas. Ele é estabelecido pelo auto vetor da matriz de julgamento relativo da abrangência dos problemas;

c) determinação do Índice Geral de Abrangência dos Problemas Hierárquico (IGA$\left.\mathbf{P}_{(\mathbf{h})}\right)$ : o Índice Geral de Abrangência dos Problemas Hierárquico é um valor que cada problema recebe, a partir de sua abrangência e atuação nos problemas e de sua comparação paritária com os demais problemas. Sua determinação segue uma sequência de passos, a saber (i) normalização das colunas da matriz de julgamentos relativos da abrangência dos problemas, (ii) somatória da dominância normalizada da comparação paritária entre os problemas, isto é, a soma de todos os elementos da linha de cada problema e (iii) normalização da somatória normalizada da comparação dos problemas, isto é, a divisão de cada um dos resultados das somas das linhas dividido pela soma de todas as linhas. Cabe reforçar que, quando normalizadas, a soma dos elementos de uma mesma coluna sempre é igual a 1. Após essa normalização, deverá ser somada a linha correspondente a cada problema, ou seja, a somatória da dominância total de cada problema. Por fim, de forma subsequente, a somatória das linhas de dominância é normalizada, revelando o IGA-P $(\mathrm{h})$ de cada um dos problemas. Quanto maior o índice, maior serão a abrangência e a completude do atendimento de um problema, e, assim, as ações que atuam sobre ele podem ser priorizadas, gerando resultados mais efetivos, eficazes e eficientes simultaneamente sob a ótica da população.

A avaliação multifacetada desses índices pode proporcionar insumos aos tomadores de decisão, de tal maneira que a complexidade da relação entre problemas e alternativas, asseverada pelas expectativas população, possa ser melhor entendida, fortalecendo as ações tomadas com apoio popular, em problemas que têm maior potencial de atendimento. $\mathrm{O}$ procedimento parece complexo, mas não é, e pode ser delineado a partir de um exemplo. 
Consideremos que a aplicação do painel de análise e correlação das alternativas em uma dinâmica tenha produzido o Quadro 15.

Quadro 15 - Exemplo de preenchimento do painel de correlação entre alternativas e problemas

\begin{tabular}{|c|ccc|}
\hline & Problema "A" & Problema "B" & Problema "C" \\
\hline Alternativa "A" & $D C$ & & $I I$ \\
Alternativa "B" & & $I C$ & $D I$ \\
Alternativa "C" & $D C$ & & $D C$ \\
Alternativa "D" & $I C$ & $I I$ & $D I$ \\
\hline
\end{tabular}

Fonte: Do autor (2019).

A interpretação da tabela permite perceber que (i) a alternativa " $A$ " atuou diretamente e solucionou completamente o problema "A" (portanto, "DC"), contudo atuou indiretamente e solucionou incompletamente o problema "C" (portanto, "II"); (ii) a alternativa "B" atuou indiretamente e solucionou completamente o problema "B" (portanto, "IC"), contudo atuou diretamente e solucionou incompletamente o problema "C" (portanto, "DI"); (iii) a alternativa "C" atuou diretamente e solucionou completamente o problema "A" (portanto, "DC") e também atuou diretamente e solucionou completamente o problema "C" (portanto, "DC"); e (iv) a alternativa " $D$ " atuou indiretamente e solucionou completamente o problema "A" (portanto, "IC"), contudo atuou indiretamente e solucionou incompletamente o problema "B" (portanto, "II") e atuou diretamente, mas solucionou incompletamente o problema "C" (portanto, "DI"). No exemplo, são quatro alternativas e três problemas, e as somatórias de "DC", "DI", "IC", e "II" são apresentados na Tabela 23.

Tabela 23 - Exemplo de composição de marcações diretas, indiretas, completas e incompletas para cada problema

\begin{tabular}{c|ccc|c}
\hline & Problema "A" & Problema "B" & Problema "C" & $\boldsymbol{\Sigma}$ \\
\hline$\Sigma$ DC & 2 & 0 & 1 & $\mathbf{3}$ \\
$\Sigma$ DI & 0 & 0 & 2 & $\mathbf{2}$ \\
$\Sigma$ IC & 1 & 1 & 0 & $\mathbf{2}$ \\
$\Sigma$ II & 0 & 1 & 1 & $\mathbf{2}$ \\
\hline$\Sigma$ DC $+\Sigma$ DI+ $\Sigma$ IC+ $\Sigma$ II & $\mathbf{3}$ & $\mathbf{2}$ & $\mathbf{4}$ & $\mathbf{9}$ \\
\hline
\end{tabular}

Fonte: Do autor (2019).

Este processo, sinteticamente, representa o cálculo da norma 1 da matriz que aponta o total de marcações em cada categoria (direta completa, direta incompleta, indireta completa e indireta incompleta) em cada problema analisado 
Com esses dados, é possível calcular o IAP, o $\operatorname{IEP}_{(\mathrm{f})}$, o $\operatorname{IEP}_{(\mathrm{c})}$, o IEP(e) , o IUP, o IOP e o ISP, conforme tabela 24.

Tabela 24 - Exemplo dos índices de avaliação dos problemas

\begin{tabular}{c|ccccccc}
\hline & IAP & IEP $_{(\mathbf{f})}$ & IEP $_{(\mathbf{c})}$ & IEP $_{(\mathbf{e})}$ & IUP & IOP & ISP \\
\hline Problema "A" & 0,75 & 0,5 & 0,75 & 0,67 & 0 & 0,33 & 0,67 \\
Problema "B" & 0,5 & 0 & 0,25 & 0 & 0,5 & 1 & 0 \\
Problema "C" & 1 & 0,75 & 0,25 & 0,33 & 0,75 & 0,25 & 0,75 \\
\hline $\boldsymbol{\Sigma}$ & $\mathbf{2 , 2 5}$ & $\mathbf{1 , 2 5}$ & $\mathbf{1 , 2 5}$ & $\mathbf{1}$ & $\mathbf{1 , 2 5}$ & $\mathbf{1 , 5 8}$ & $\mathbf{1 , 4 2}$ \\
\hline
\end{tabular}

Fonte: Do autor (2019).

Esses índices, para uma melhor visualização, podem ser normalizados, gerando, então, o

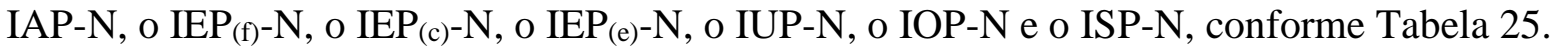

Tabela 25 - - Exemplo dos índices de avaliação dos problemas normalizados

\begin{tabular}{c|ccccccc}
\hline & IAP-N & IEP $_{(\mathbf{f})-\mathbf{N}}$ & IEP $_{(\mathbf{c})-\mathbf{N}}$ & IEP $_{(\mathbf{e})-\mathbf{N}}$ & IUP-N & IOP-N & ISP-N \\
\hline Problema "A" & 0,33 & 0,4 & 0,60 & 0,67 & 0 & 0,21 & 0,47 \\
Problema "B" & 0,22 & 0 & 0,20 & 0 & 0,4 & 0,63 & 0 \\
Problema "C" & 0,45 & 0,6 & 0,20 & 0,33 & 0,6 & 0,16 & 0,53 \\
\hline $\boldsymbol{\Sigma}$ & $\mathbf{1}$ & $\mathbf{1}$ & $\mathbf{1}$ & $\mathbf{1}$ & $\mathbf{1}$ & $\mathbf{1}$ & \\
\hline
\end{tabular}

Fonte: Do autor (2019).

Interpreta-se, em relação ao problema "A", que existem mais soluções que o atendem completamente (maiores $\operatorname{IEA}_{(c)}$ e IEA(e) e menos soluções que o solucionam incompletamente (menor IUP). Por outro lado, o problema "B" é aquele que tem mais alternativas que atuam indiretamente sobre ele, de forma colateral (maior IOP), e nenhuma ação que atua sobre ele diretamente (menores $\operatorname{IEA}_{(\mathrm{e})}$ e IEA(f), e ISP nulo). Já o problema "C", é aquele que possui mais ações que atuam sobre ele diretamente (maiores ISP e IAP), mais soluções que o atendem incompletamente (maior IUP) e com ações mais efetivas (maior $\operatorname{EAP}_{(\mathrm{f})}$ ), ainda que pouco eficazes (menor $\left.\operatorname{IEA}_{(\mathrm{c})}\right)$.

Também é possível incorporar a majoração da assertividade nos problemas, em função dos atendimentos completos em face das alternativas propostas, com o cálculo do IGA-P(p), considerando os pesos "pc" e "pi", como sugerido nas propostas metodológicas 2 e 1, respectivamente. Esse índice, diferentemente do ISP, que avalia os atendimentos diretos aos problemas, a partir de todos os atendimentos propostos, o Índice Geral de Assertividade avalia as atuações completas majoradas frente às incompletas, em função total de problemas demandados, seu cálculo é exemplificado na Tabela 26. 
Tabela 26 - Exemplo de cálculo do Índice Geral de Assertividade dos Problemas Ponderado

\begin{tabular}{c|cccc|c}
\hline & $\Sigma$ DC & $\Sigma$ DI & $\Sigma$ IC & $\Sigma$ II & IGA-P(p) \\
\hline Problema "A" & 2 & 0 & 1 & 0 & 1,50 \\
Problema "B" & 0 & 0 & 1 & 1 & 0,75 \\
Problema "C" & 1 & 2 & 0 & 1 & 1,25 \\
\hline$\Sigma$ & $\mathbf{3}$ & $\mathbf{2}$ & $\mathbf{2}$ & $\mathbf{2}$ & $\mathbf{3 , 5}$ \\
\hline
\end{tabular}

Fonte: Do autor (2019).

Em seguida, é possível comparar paritariamente os problemas a partir da diferença entre os respectivos do IGA-P(p), conforme exemplo na tabela 27.

Tabela 27 - Exemplo de Cálculo das distâncias relativas do Índice Geral de Assertividade dos Problemas Ponderado

\begin{tabular}{l|c|ccc}
\hline \multicolumn{2}{l|}{} & Problema "A" & Problema "C" & Problema "B" \\
\cline { 2 - 5 } \multicolumn{2}{l|}{} & $\mathbf{1 , 5 0}$ & $\mathbf{1 , 2 5}$ & $\mathbf{0 , 7 5}$ \\
\hline Problema "A" & $\mathbf{1 , 5 0}$ & 0 & 0,25 & 0,75 \\
Problema "C" & $\mathbf{1 , 2 5}$ & $-0,25$ & 0 & 0,5 \\
Problema "B" & $\mathbf{0 , 7 5}$ & $-0,75$ & $-0,5$ & 0 \\
\hline
\end{tabular}

Fonte: Do autor (2019).

Após a comparação par a par, a construção da função de transformação e sua constante "K” para associação dos valores das diferenças à escala semântica de Saaty, considerando uma função linear, é possível a construção da matriz de julgamento relativo da abrangência dos problemas no exemplo proposto, consolidando a Tabela 28.

A dominância já consolidada com apoio da função valor, e seu intervalos definidos, com a escala semântica de Saaty.

Tabela 28 - Exemplo da dominância de um problema a outro após aplicação da função valor

\begin{tabular}{l|ccc}
\hline & Problema "A" & Problema "C" & Problema "B" \\
\hline Problema "A" & 1 & 3 & 9 \\
Problema "C" & $1 / 3$ & 1 & 6 \\
Problema "B" & $1 / 9$ & $1 / 6$ & 1 \\
\hline
\end{tabular}

Fonte: Do autor (2019).

Normalizando a matriz de julgamento relativo da tabela anterior, é possível calcular seu auto vetor e, consequentemente, o IGA-P $(\mathrm{h})$, conforme a Tabela a 29.

Tabela 29 - Exemplo de cálculo do Índice Geral de Assertividade dos Problemas hierarquizado

\begin{tabular}{c|ccc|c|c}
\hline & Problema "A" & Problema "C" & Problema "B" & $\Sigma$ & IGA-P(h) \\
\hline Problema "A" & 1 & 3 & 9 & 13 & $\mathbf{0 , 6 0}$ \\
Problema "C" & $1 / 3$ & 1 & 6 & $\mathbf{7 , 3 3}$ & $\mathbf{0 , 3 4}$ \\
Problema "B" & $1 / 9$ & $1 / 6$ & 1 & $\mathbf{1 , 2 7}$ & $\mathbf{0 , 0 6}$ \\
\hline$\Sigma$ & $\mathbf{1 , 4 4}$ & $\mathbf{4 , 1 6}$ & $\mathbf{1 6}$ & $\mathbf{2 1 , 6}$ & $\mathbf{1}$ \\
\hline
\end{tabular}

Fonte: Do autor (2019). 
A metodologia de hierarquização de comparação pareada para construção IGA-P $\mathrm{P}_{(\mathrm{h})}$ pode ser aplicada aos demais índices de caracterização dos problemas. Não há um índice que seja melhor do que o outro, pois cada um deles tem facetas específicas. O que se reforça é que a obtenção de uma série de índices que caracterizam um processo pode instrumentalizar melhor os tomadores de decisão, ao hierarquizar problemas cujas alternativas propostas coloquem-nos em maior destaque, sob a perspectiva de soluções ao olhar da população.

\subsubsection{Avaliação do Processo de Correlação de Alternativas e Problemas}

Inúmeras podem ser as estratégias definidas no processo, e a identificação dos problemas pode ser ainda mais abrangente. Este procedimento metodológico é favorecido quando há diversos pontos de vistas acerca do tema, e o diagnóstico participativo integrado à criação conjunta de soluções amplia o comprometimento dos atores implicados na situação.

A interação formativa reconhece os sujeitos como protagonistas da ação e depende do envolvimento deles e da contribuição técnica para fomentar o processo criativo. Contudo, é possível avaliar com indicadores a riqueza e a qualidade do procedimento participativo aplicado a partir de índices, também denominados avaliadores, os quais qualificam o procedimento. Para tal, quatro avaliadores são propostos:

a) Avaliador de Qualidade de Completude do Processo (AQC): este índice, ou indicador, aponta o quão completas podem ser as soluções que surgiram no processo criativo. Ele ajuda a perceber se os sujeitos têm a capacidade de gerar soluções que podem, de fato, atuar para resolver completamente problemas. É dado pela razão entre o total de atendimentos completos existentes no processo e o total de problemas analisados. Por outro lado, mede a eficácia do processo criativo. Este índice é um número real positivo, e quanto maior, melhor delineado é o processo criativo para proposta de soluções eficazes, dado pela eq.(48):

$$
A Q C=\frac{\left(\sum_{i=0}^{N} D C_{i}+\sum_{i=0}^{N} I C_{i}\right)}{N}
$$

Em que:

AQC: Avaliador de Qualidade de Completude do Processo;

$\mathrm{DC}_{(i)}:$ i-ésima marcação direta e completa; 
$\mathrm{IC}_{(i)}$ : $i$-ésima marcação indireta e completa;

$\mathrm{N}$ : Número total de problemas.

b) Avaliador de Atendimento dos Problemas (AAP): este índice mede a relação entre os problemas propostos e as soluções propostas. Se o índice apresenta um resultado menor do que 1, representa que os sujeitos têm maior capacidade de enumerar problemas; por outro lado, se o resultado é maior do que 1, os sujeitos têm maior capacidade de propor soluções, eficazes ou efetivas. Pode ser aplicado como seletor de grupos que tenham mais facilidade na identificação de problemas e grupos que tenham maior facilidade na proposição de ações. É dado pela razão entre o total de atendimentos de problemas, completos e incompletos, diretos e indiretos, sobre o total de problemas. O processo não é medido pelo número de alternativas propostas, mas sim pelo número de alternativas que atuam nos problemas elencados, o que se pode observar na eq.(49).

$$
A A P=\frac{\sum_{i=0}^{N} D C_{i}+\sum_{i=0}^{N} I C_{i}+\sum_{i=0}^{N} I I_{i}+\sum_{i=0}^{N} D I_{i}}{N},
$$

Em que:

AAP: Avaliador de Atendimento dos Problemas;

$\mathrm{DC}_{(\mathrm{i})}$ : i-ésima marcação direta e completa;

$\mathrm{DI}_{(\mathrm{i})}$ : i-ésima marcação direta e incompleta;

$\mathrm{IC}_{(\mathrm{i})}$ : $i$-ésima marcação indireta e completa;

$\mathrm{II}_{(\mathrm{i})}$ : i-ésima marcação indireta e incompleta;

$\mathrm{N}$ : Número total de problemas.

c) Avaliador de Efetividade do Processo (AEP): este índice avalia o quanto as soluções propostas são elaboradas concretamente para problemas ou, em outras palavras, o quanto a ação direta se manifesta no processo. É dado pela razão entre os atendimentos diretos, completos e incompletos e o total de problemas analisados, conforme a eq.(50).

$$
A E P=\frac{\left(\sum_{i=0}^{N} D C_{i}+\sum_{i=0}^{N} D I_{i}\right)}{N}
$$

Em que:

AEP: Avaliador de Efetividade no Processo; 
$\mathrm{DC}_{(\mathrm{i})}:$ i-ésima marcação direta e completa;

$\mathrm{DI}_{(\mathrm{i})}$ : i-ésima marcação indireta e completa;

$\mathrm{N}$ : Número total de problemas.

d) Avaliador de Eficiência do Processo (AFP): este índice avalia quão efetivas são as soluções propostas para problemas diretamente, e eficazes, ou seja, soluções que resolvam completamente problemas, são as alternativas apresentadas no processo. É dado pela razão entre o total de atendimentos diretos e completos e o número de problemas, conforme a eq.(51).

$$
A F P=\frac{\sum_{i=0}^{N} D C_{i}}{N}
$$

Em que:

AFP: Avaliador de Eficiência do Processo;

$\mathrm{DC}_{(\mathrm{i})}:$ i-ésima marcação direta e completa;

$\mathrm{N}$ : Número total de problemas.

Aplicando estes avaliadores a um exemplo, considera-se que a aplicação do painel de análise e correlação das alternativas em uma dinâmica tenha produzido o quadro 16. A interpretação da tabela permite perceber que (i) a alternativa " $A$ " atuou diretamente e solucionou completamente o problema "A" (portanto, " $D C$ "), contudo atuou indiretamente e solucionou incompletamente o problema "C" (portanto, “II"); (ii) a alternativa "B" atuou indiretamente e solucionou completamente o problema "B" (portanto, “IC"), contudo atuou diretamente e solucionou incompletamente o problema "C" (portanto, "DI”); (iii) a alternativa "C" atuou diretamente e solucionou completamente o problema "A" (portanto, "DC") e também atuou diretamente e solucionou completamente o problema " $\mathrm{C}$ " (portanto, " $D C$ "); e (iv) a alternativa " $\mathrm{D}$ " atuou indiretamente e solucionou completamente o problema "A" (portanto, “IC"), contudo atuou indiretamente e solucionou incompletamente o problema "B" (portanto, "II"), e também atuou diretamente e solucionou incompletamente o problema "C" (portanto, “DI”). 
Quadro 16 - Exemplo de preenchimento do painel de correlação entre alternativas e problemas

\begin{tabular}{|c|ccc|}
\hline & Problema "A" & Problema "B" & Problema "C" \\
\hline Alternativa "A" & $D C$ & & $I I$ \\
Alternativa "B" & & $I C$ & $D I$ \\
Alternativa "C" & $D C$ & & $D C$ \\
Alternativa "D" & $I C$ & $I I$ & $D I$ \\
\hline
\end{tabular}

Fonte: Do autor (2019).

A partir dessa interpretação, no exemplo, é possível resumir que (i) o total de atendimentos diretos e completos é 3; (ii) o total de atendimentos diretos e incompletos é 2; (iii) o total de atendimentos indiretos e completos é 2; e, por fim (iv) o total de atendimentos indiretos e incompletos é 2. Portanto, é possível calcular o AQC, o AAP, o AEP e o AFP, conforme no Quadro 17.

Quadro 17 - Exemplo de cálculo dos avaliadores do processo

\begin{tabular}{|cll|}
\hline Avaliador & Valor & \\
\hline AQC & $\Rightarrow(3+2) / 3$ & $=1,66$ \\
AAP & $\Rightarrow(3+2+2+2) / 3=3$ \\
AEP & $\Rightarrow(3+2) / 3$ & $=1,66$ \\
AFP & $\Rightarrow 3 / 3$ & $=1$ \\
\hline
\end{tabular}

Fonte: Do autor (2019).

Esses avaliadores não são comparáveis entre si, mas comparáveis com diferentes dinâmicas participativas aplicadas. O que se pode dizer a partir deles é que ele tem um nível de atendimento favorável, pois existem mais atendimentos do que problemas de fato.

\subsubsection{Avaliação Hierárquica de Alternativas}

Nessa etapa, as alternativas identificadas no processo criativo parte desta proposta metodológica já foram correlacionadas aos problemas. Contudo, além de sua interligação, é importante avaliar a dificuldade de concretização dos problemas, isto é, os esforços necessários para que alternativas se tornem efetivamente ações reais e solucionem problemas. Uma estratégia é associar cada alternativa a um indicador, ou índice, que a represente. A realização 
das alternativas pode ser encarada como um objetivo a ser alcançado, e, portanto, uma ordenação de prioridades pode ser definida a partir de um índice hierárquico associado a cada alternativa, o que pode ser elaborado a partir da sequência metodológica:

a) Sistematização dos dados para o Índice de Dificuldade de Implantação das Alternativas (IDI-A): a partir da valoração do painel de avaliação das alternativas, é possível propor uma ordenação de prioridades parcial através de um IDI-A. É uma oportunidade para associar as alternativas aos empecilhos de sua implantação, traduzidos pela dificuldade técnica ${ }^{71}$ de sua realização e a dificuldade econômica de sua implantação. Sua obtenção se dá pelo inverso da multiplicação do total de marcadores, ou a pontuação, atribuídos à dimensão de dificuldade técnica e à dimensão de dificuldade econômica, conforme a eq.(52).

$$
\begin{gathered}
I D I-A=\frac{1}{D_{(t)} \times D_{(e)}} \\
\left\{I D I-A \in \mathbb{Q}_{+} \mid 0<I D I-A \leq 1 / 9\right\} \\
\left\{D_{(t)} ; D_{(e)} \in \mathbb{Z}_{+} \mid 1 \leq D_{(t)} \leq 3 ; 1 \leq D_{(e)} \leq 3\right\}
\end{gathered}
$$

Em que:

IDI-A: Índice de Dificuldade de Implantação de Alternativas;

$\mathrm{D}_{(\mathrm{t}):}$ Pontuação total da dimensão dificuldade técnica;

$\mathrm{D}_{(\mathrm{e}):}$ Pontuação total da dimensão dificuldade econômica;

Para escolher entre as alternativas propostas, os sujeitos, ou tomadores de decisão, podem identificar os pontos de dificuldade e intrinsecamente a capacidade real das alternativas para atuarem em soluções, bem como a partir de uma ordem hierárquica das alternativas que possuem as maiores ameaças a serem enfrentadas. Quanto maior o IDI-A, menor o grau de dificuldade de implantação preliminar das alternativas;

b) Sistematização dos dados para o Índice de Dificuldade de Ação nas Alternativas (IDA-A): a partir da valoração do painel de avaliação das alternativas, não se pode negligenciar que a maneira com que uma alternativa pode ser aplicada é determinada por ações políticas e aceitação da população. Este índice é dado pelo inverso da multiplicação

\footnotetext{
71 A dificuldade técnica pode representar, por exemplo, aspectos tecnológicos, construtivos, geotécnicos, hidrológicos, topográficos e ambientais.
} 
dos marcadores, ou da pontuação, associado à dimensão de dificuldade política e à dimensão de dificuldade para aceitação popular, conforme a eq.(53).

$$
\begin{gathered}
I D A-A=\frac{1}{D_{(p)} \times D_{(a)}} \\
\left\{I D A-A \in \mathbb{Q}_{+} \mid 0<I D A-A \leq 1 / 9\right\} ; \\
\left\{D_{(p)} ; D_{(a)} \in \mid 1 \leq D_{(p)} \leq 3 ; 1 \leq D_{(a)} \leq 3\right\}
\end{gathered}
$$

Em que:

IDA-A: Índice de Dificuldade de Ação nas Alternativas;

$\mathrm{D}_{(\mathrm{p}):}$ Pontuação total da dimensão dificuldade política;

$\mathrm{D}_{(\mathrm{a}):}$ Pontuação total da dimensão dificuldade de aceitação popular.

Esse índice avalia aspectos intangíveis na dificuldade para viabilizar determinadas ações. Quanto maior o IDA-A, maior será a facilidade de implantação das ações de uma alternativa sob os aspectos políticos e de aceitação popular;

c) Índice Geral de Dificuldade da Alternativa (IGD-A): a partir do painel de avaliação das alternativas, espera-se, com apoio das valorações dadas às ameaças que dificultam as alternativas (técnica, econômica, política e aceitação popular), avaliar sistemicamente as alternativas que possuam maior facilidade de ação. Portanto, o IGD-A permite uma hierarquização das alternativas, inversamente a sua dificuldade de aplicação e, assim, de forma integrada, define quais alternativas possuem menor dificuldade de implantação. É dado pelo inverso da multiplicação das pontuações associadas a cada dimensão de dificuldade, na eq.(54).

$$
\begin{gathered}
I G D-A=\frac{1}{D_{(e)} \times D_{(t)} \times D_{(p)} \times D_{(a)}} \\
\left\{I G D-A \in \mathbb{Q}_{+} \mid 0<I G D-A \leq 1 / 81\right\} ; \\
\left\{D_{(p)} ; D_{(a)} \in \mathbb{Z}_{+} \mid 1 \leq D_{(p)} \leq 3 ; 1 \leq D_{(a)} \leq 3\right\} ; \\
\left\{D_{(t)} ; D_{(e)} \in \mathbb{Z}_{+} \mid 1 \leq D_{(t)} \leq 3 ; 1 \leq D_{(e)} \leq 3\right\} ;
\end{gathered}
$$

Em que:

IGD-A: Índice de Geral Dificuldade da Alternativa;

$\mathrm{D}_{(\mathrm{t}):}$ Pontuação total da dimensão dificuldade técnica; 
$\mathrm{D}_{(\mathrm{e}):}$ Pontuação total da dimensão dificuldade econômica;

$\mathrm{D}_{(\mathrm{p}):}$ Pontuação total da dimensão dificuldade política;

$\mathrm{D}_{(\mathrm{a}):}$ Pontuação total da dimensão dificuldade de aceitação popular.

Esta aplicação do IGD-A pressupõe que cada uma das dimensões de dificuldade age de maneira homogênea nas alternativas. Por outro lado, é possível que o impacto dessas ameaças, ou dificuldades, possa ser tratado separadamente, ou seja, as diferentes dimensões têm impactos distintos, ou importância sobre as alternativas;

d) Índice Geral de Dificuldade da Alternativa Ponderado (IGD-A(p)): este índice é análogo ao IGD-A, contudo permite majorar ou minorar cada dimensão de dificuldade por um fator de relevância, que pode ser atribuído, ou não, pelos sujeitos ou decisores. Assim, incorpora de forma heterogênea a ação de cada dimensão nas alternativas, como é dado pela eq.(55).

$$
\begin{gathered}
I G D-A_{(p)}=\frac{1}{\left(f_{e} \times D_{(e)}\right) \times\left(f_{t} \times D_{(t)}\right) \times\left(f_{p} \times D_{(p)}\right) \times\left(f_{a} \times D_{(a)}\right)} \\
\left\{I G D-A \in \mathbb{Q}_{+} \mid 0<I G D-A \leq \infty\right\} ; \\
\left\{D_{(p)} ; D_{(a)} \in \mathbb{Z}_{+} \mid 1 \leq D_{(p)} \leq 3 ; 1 \leq D_{(a)} \leq 3\right\} ; \\
\left\{D_{(t)} ; D_{(e)} \in \mathbb{Z}_{+} \mid 1 \leq D_{(t)} \leq 3 ; 1 \leq D_{(e)} \leq 3\right\} ; \\
\left\{f_{e} ; f_{t} ; f_{p} ; f_{a} \in \mathbb{R}_{+} \mid 0<f_{e} ; f_{t} ; f_{p} ; f_{a} \leq \infty\right\} ;
\end{gathered}
$$

Em que:

IGD-A(p): Índice de Geral Dificuldade da Alternativa Ponderado;

$\mathrm{D}_{(\mathrm{t})}$ :Pontuação total da dimensão dificuldade técnica;

$\mathrm{D}_{(\mathrm{e})}$ : Pontuação total da dimensão dificuldade econômica;

$\mathrm{D}_{(\mathrm{p})}$ : Pontuação total da dimensão dificuldade política;

$\mathrm{D}_{(\mathrm{a})}$ : Pontuação total da dimensão dificuldade de aceitação popular;

$\mathrm{f}_{\mathrm{e}}$ : fator de majoração ou minoração da dificuldade econômica;

$\mathrm{f}_{\mathrm{t}}$ : fator de majoração ou minoração da dificuldade técnica;

$\mathrm{f}_{\mathrm{p}}$ : fator de majoração ou minoração da dificuldade política; 
$\mathrm{f}_{\mathrm{a}}$ : fator de majoração ou minoração da dificuldade econômica.

A partir dessa abordagem, é possível hierarquizar de forma absoluta as alternativas em função da dificuldade de sua implantação. Quanto maiores o IGD-A e o IGD-A(p), menor será a dificuldade para instalação de uma alternativa.

Por outro lado, é possível relativizar o IGD-A ou o IGD-A(p), ao compará-los entre si, e estabelecer uma escala própria das alternativas, na temática estudada. Assim, será possível associá-la à função de valor. Esta, por sua vez, é uma representação matemática dos julgamentos atribuídos por meio de uma escala numérica. A proposta para construção da função de valor é destacada no seguinte delineamento metodológico:

a) construção da matriz de comparação pareada de dificuldade de alternativas: a relativização dos índices é verificada a partir da distância dos índices gerais de dificuldade da alternativa, ponderado ou não. Isto é, faz-se a diferença paritária entre os índices calculados de cada alternativa comparados entre si. Por exemplo, com quatro alternativas diferentes, a alternativa “A” com IGD-A igual a 1/3, a alternativa "B" com IGD-A de 1/9, a alternativa "C" com IGD-A de 1/36 e a alternativa "D" com IGD-A de 1/54. As comparações paritárias serão os valores que compões uma matriz "4x4"72 (contudo a proposta metodológica pode ser aplicada para um número infinito de alternativas, o que segue abaixo é apenas um exemplo didático de aplicação), da seguinte forma na Tabela 30:

Tabela 30 - Exemplo de comparação dos índices gerais de dificuldade das alternativas

\begin{tabular}{|c|c|c|c|c|c|}
\hline & & $\begin{array}{c}\text { Alternativa" A" } \\
1 / 3\end{array}$ & $\begin{array}{c}\text { Alternativa "B" } \\
1 / 9\end{array}$ & $\begin{array}{c}\text { Alternativa "C" } \\
1 / 36\end{array}$ & $\begin{array}{c}\text { Alternativa "D" } \\
1 / 54\end{array}$ \\
\hline $\begin{array}{l}\text { Alternativa } \\
\text { "A" }\end{array}$ & $1 / 3$ & $1 / 3-1 / 3=0$ & $1 / 3-1 / 9=0,22$ & $1 / 3-1 / 36=0,30$ & $1 / 3-1 / 54=0,31$ \\
\hline $\begin{array}{l}\text { Alternativa } \\
\text { "B" }\end{array}$ & $1 / 9$ & $1 / 9-1 / 3=-0,22$ & $1 / 9-1 / 9=0$ & $1 / 9-1 / 36=0,08$ & $1 / 9-1 / 54=0,09$ \\
\hline $\begin{array}{l}\text { Alternativa } \\
\text { "C" }\end{array}$ & $1 / 36$ & $1 / 36-1 / 3=-0,30$ & $1 / 36-1 / 9=-0,08$ & $1 / 36-1 / 36=0$ & $1 / 36-1 / 54=0,01$ \\
\hline $\begin{array}{c}\text { Alternativa } \\
\text { "D" }\end{array}$ & $1 / 54$ & $1 / 54-1 / 3=-0,31$ & $1 / 54-1 / 9=-0,09$ & $1 / 54-1 / 36=-0,01$ & $1 / 54-1 / 54=0$ \\
\hline
\end{tabular}

Fonte: Do autor (2019).

Na matriz resultante, todas as alternativas são comparadas par a par, recebendo a distância " $\Delta_{i j}$ " entre eles. Cada um destes valores compõe a matriz de comparação pareada de

\footnotetext{
${ }^{72}$ As comparações par a par são realizadas a partir da distância relativa entre o IGD-A da alternativa na linha, com a alternativa na coluna. Estas comparações admitem valores negativos, positivos e zero.
} 
dificuldade de alternativas, a qual é quadrada, considerando que " $i$ ” $e$ " $j$ ” correspondem às alternativas. Logo, a matriz de comparação pareada do exemplo, na tabela 31, proposta será :

Tabela 31 - Exemplo das distancias relativas dos índices gerais de dificuldade das alternativas

\begin{tabular}{l|cccc} 
& $\begin{array}{c}\text { Alternativa" } \\
\text { A" }\end{array}$ & $\begin{array}{c}\text { Alternativa } \\
\text { "B" }\end{array}$ & $\begin{array}{c}\text { Alternativa } \\
\text { "C" }\end{array}$ & $\begin{array}{c}\text { Alternativa } \\
\text { "D" }\end{array}$ \\
\hline Alternativa "A" & 0 & 0,22 & 0,30 & 0,31 \\
Alternativa "B" & $-0,22$ & 0 & 0,08 & 0,09 \\
Alternativa "C" & $-0,30$ & $-0,08$ & 0 & 0,01 \\
Alternativa "D" & $-0,31$ & $-0,09$ & $-0,01$ & 0 \\
\hline
\end{tabular}

Fonte: Do autor (2019).

Nota-se que a diagonal principal desta matriz receberá valores zerados, pois a distância entre o índice associado a uma alternativa dela mesma, é nula (" $\mathrm{a}_{i j}=0$ ”, quando " $i=j$ "). Os valores abaixo da diagonal principal são opostos aos da diagonal principal, e, portanto, recíprocos (" $\mathrm{a}_{i j}$ ” é recíproco a " $\mathrm{a}_{j i}$ ”, ou ainda " $\mathrm{a}_{i j}=-\mathrm{a}_{j i}$ ”);

b) preparação para a construção da função valor: a comparação entre os valores dos índices associados a cada alternativa com apoio de suas distâncias, como já apresentado, pode apresentar valores nulos e negativos. Então, associa-se esses valores a uma representação matemática dos índices através de uma escala que aponte quantas vezes um é dominante ao outro. Para tal, será adotada a escala semântica de preferência de Saaty, com valores inteiros entre 1 a 9 e seus correspondentes recíprocos racionais, enquanto na escala das diferenças, tem-se valores opostos aos recíprocos (na escala de Saaty, tem-se valores inversos). Esta proposta metodológica, diferentemente do trabalho de Saaty, cuja escala é construída com base nos julgamentos subjetivos dos decisores, será construída a partir da matriz de comparação pareada de alternativas. Este procedimento faz com que a consistência da matriz de comparação seja válida. Portanto, é possível associar os valores obtidos na matriz de comparação pareada de alternativas aos valores da escala de Saaty por uma função matemática. Esta função de transformação das distâncias relativas à escala de Saaty é obtida associando os valores da escala de Saaty a uma variável "y”, a distância relativa calculada a uma variável " $x$ ”, genericamente expressa " $y=f(x)$ ". A função "f(x)" é uma função matemática determinada (linear, exponencial, raiz quadrada, logarítmica ou função recíproca), associando " $\mathrm{x}$ " (IGD-A ou IGD-A(p) a uma constante “K”, que ajusta a função a cada situação analisada;

c) determinação da constante "K": é atrelada à função matemática que será aplicada para transformar os valores das distâncias pareadas entre os índices na escala semântica de 
Saaty. Escolhida a função, os valores em que ela resulta, ou seja, os valores de “y”, são conhecidos $(1,2,3,4,5,6,7,8,9$ e seus recíprocos, $1 / 2,1 / 3,1 / 4,1 / 5,1 / 6,1 / 7,1 / 8$ e $1 / 9)$. Os valores de " $\mathrm{x}$ " também são conhecidos, pois representam as distâncias relativas já preenchidas na matriz de comparação pareada de alternativas. Escolhida a função (linear, exponencial, raiz quadrada, logarítmica ou função recíproca), assume-se que a maior distância relativa positiva determina o maior nível de dominância e, portanto, corresponde ao valor de 9 na escala de Saaty. Com os dois valores conhecidos, sua associação permite determinar a constante "K” para a situação de análise. No exemplo proposto, assume-se que nesta situação será adotada uma função linear (" $\mathrm{y}=\mathrm{f}(\mathrm{x})$ ”), que quando ajustada pela constante "K”, será “y = K. x". Com “y” igual a 9 e " $x$ ” igual a 0,31 , a constante "K” será 29,03. Dessa forma, a função que associa as distâncias relativas à escala de Saaty será “ $y=29,03$. x". Uma observação importante é que a função não é aplicada aos valores negativos, pois seu resultado seria também negativo, então os valores negativos na realidade são os recíprocos dos positivos, portanto " $\mathrm{a}_{i j}=\mathrm{y}$ ”, tal como " $\mathrm{a}_{j i}=1 / \mathrm{y}$ ". Também, quando a distância relativa for nula, ou seja, " $\mathrm{a}_{i j}=0$ ", a dominância é a de igual preferência proposta por Saaty, ou seja, 1. Os valores associados a "y" serão números racionais e podem ser analisados dessa forma. Contudo, os valores principais de dominância propostos por Saaty são inteiros de 1 a 9 , e apenas os recíprocos racionais são associados aos dominantes inteiros. Desse modo, é possível fixar intervalos ao domínio da função, ou seja, intervalos dos valores de “x”, associando cada intervalo a um número inteiro da escala de Saaty. No exemplo proposto, aplicando a função de transformação “y =29,03. x", já calculada, aos valores positivos, associando a distância nula à igual preferência, simplificando as frações e associando as distâncias aos intervalos do domínio para a imagem na escala semântica de Saaty, na Tabela 32, tem-se que:

Tabela 32 - Exemplo de comparação paritária das alternativas na escala semântica de Saaty após a aplicação da função valor

\begin{tabular}{l|cccc} 
& $\begin{array}{c}\text { Alternativa } \\
\text { "A"A" }\end{array}$ & $\begin{array}{c}\text { Alternativa } \\
\text { "B" }\end{array}$ & $\begin{array}{c}\text { Alternativa } \\
\text { "C" }\end{array}$ & $\begin{array}{c}\text { Alternativa } \\
\text { "D" }\end{array}$ \\
\hline Alternativa "A" & 1 & 6 & 8 & 9 \\
Alternativa "B" & $1 / 6$ & 1 & 2 & 2 \\
Alternativa "C" & $1 / 8$ & $1 / 2$ & 1 & 1 \\
Alternativa "D" & $1 / 9$ & $1 / 2$ & 1 & 1 \\
\hline
\end{tabular}

Fonte: Do autor (2019). 
Com essa matriz de comparação, será possível determinar um Índice Hierárquico de Alternativas (IHA), que representa o nível hierárquico de uma determinada alternativa, levando em conta a dificuldade de sua implantação associada relativamente à temática em avaliação. Ele é estabelecido pelo auto vetor da matriz de julgamento relativo das alternativas;

d) determinação do Índice Hierárquico de Alternativas (IHA): o IHA é um valor que cada alternativa recebe a partir de sua representatividade na matriz de julgamentos relativos de alternativas. Resumidamente, se a matriz pode ser representada por um vetor, o índice representa a influência de cada alternativa nele. Sua determinação segue uma sequência de passos, a saber: (i) normalização das colunas da matriz de julgamentos relativos das alternativas, (ii) somatória da dominância normalizada da comparação paritária das alternativas, isto é, a soma de todos os elementos da linha de cada alternativa, e (iii) normalização da somatória normalizada da comparação das alternativas, isto é, a divisão de cada um dos resultados das somas das linhas dividido pela soma de todas as linhas. No exemplo proposto, teremos a matriz na Tabela 33, com a soma das colunas respectivas a cada alternativa.

Tabela 33 - Exemplo de preparação das comparações paritária para o cálculo do índice hierárquico das alternativas

\begin{tabular}{c|cccc} 
& $\begin{array}{c}\text { Alternativa } \\
\text { "A" }\end{array}$ & $\begin{array}{c}\text { Alternativa } \\
\text { "B" }\end{array}$ & $\begin{array}{c}\text { Alternativa } \\
\text { "C" }\end{array}$ & $\begin{array}{c}\text { Alternativa } \\
\text { "D" }\end{array}$ \\
\hline $\begin{array}{c}\text { Alternativa } \\
\text { "A" }\end{array}$ & 1 & 6 & 8 & 9 \\
$\begin{array}{c}\text { Alternativa } \\
\text { "B" } \\
\begin{array}{c}\text { Alternativa } \\
\text { "C" } \\
\text { Alternativa } \\
\text { "D" }\end{array}\end{array}$ & $1 / 6$ & 1 & 2 & 2 \\
\hline$\Sigma$ & $1 / 8$ & $1 / 2$ & 1 & 1 \\
\hline$\Sigma$ & $\mathbf{1 , 4 0}$ & $1 / 2$ & 1 & 1 \\
\hline
\end{tabular}

Fonte: Do autor (2019).

A matriz normalizada do julgamento relativo alternativas, quando normalizada, resultará na matriz da Tabela 34. 
Tabela 34 - Exemplo de normalização das comparações paritárias para cálculo do índice hierárquico das alternativas

\begin{tabular}{c|cccc} 
& $\begin{array}{c}\text { Alternativa } \\
\text { "A" }\end{array}$ & $\begin{array}{c}\text { Alternativa } \\
\text { "B" }\end{array}$ & $\begin{array}{c}\text { Alternativa } \\
\text { "C" }\end{array}$ & $\begin{array}{c}\text { Alternativa } \\
\text { "D" }\end{array}$ \\
\hline Alternativa "A" & 0,71 & 0,75 & 0,67 & 0,69 \\
Alternativa "B" & 0,12 & 0,13 & 0,17 & 0,15 \\
Alternativa "C" & 0,09 & 0,06 & 0,08 & 0,08 \\
Alternativa "D" & 0,08 & 0,06 & 0,08 & 0,08 \\
\hline $\boldsymbol{\Sigma}$ & $\mathbf{1}$ & $\mathbf{1}$ & $\mathbf{1}$ & $\mathbf{1}$ \\
\hline
\end{tabular}

Fonte: Do autor (2019).

Cabe reforçar que, quando normalizadas, a soma dos elementos de uma mesma coluna sempre é igual a 1. Após esta normalização, deverá ser somada a linha correspondente a cada problema, ou seja, a somatória da dominância total de cada problema, conforme a matriz na Tabela 35.

Tabela 35 - Exemplo da norma 1 aplicada a comparação paritária das alternativas para cálculo do índice hierárquico das alternativas

\begin{tabular}{c|cccc|c} 
& $\begin{array}{c}\text { Alternativa } \\
\text { "A" }\end{array}$ & $\begin{array}{c}\text { Alternativa } \\
\text { "B" }\end{array}$ & $\begin{array}{c}\text { Alternativa } \\
\text { "C" }\end{array}$ & $\begin{array}{c}\text { Alternativa } \\
\text { "D" }\end{array}$ & $\boldsymbol{\Sigma}$ \\
\hline Alternativa "A" & 0,71 & 0,75 & 0,67 & 0,69 & 2,82 \\
Alternativa "B" & 0,12 & 0,13 & 0,17 & 0,15 & 0,56 \\
Alternativa "C" & 0,09 & 0,06 & 0,08 & 0,08 & 0,31 \\
Alternativa "D" & 0,08 & 0,06 & 0,08 & 0,08 & 0,30 \\
\hline $\boldsymbol{\Sigma}$ & $\mathbf{1}$ & $\mathbf{1}$ & $\mathbf{1}$ & $\mathbf{1}$ & $\mathbf{4}$ \\
\hline
\end{tabular}

Fonte: Do autor (2019).

Por fim, de forma subsequente, a somatória das linhas de dominância é normalizada revelando o IHA de cada um dos problemas analisados, conforme matriz da Tabela 36.

Tabela 36 -Exemplo de cálculo do Índice hierárquico das alternativas

\begin{tabular}{c|cccc|c|c} 
& $\begin{array}{c}\text { Alternativa } \\
\text { "A" }\end{array}$ & $\begin{array}{c}\text { Alternativa } \\
\text { "B"B" }\end{array}$ & $\begin{array}{c}\text { Alternativa } \\
\text { "C"C }\end{array}$ & $\begin{array}{c}\text { Alternativa } \\
\text { "D" }\end{array}$ & $\boldsymbol{\Sigma}$ & $\mathbf{I H A}$ \\
\hline Alternativa "A" & 0,71 & 0,75 & 0,67 & 0,69 & 2,82 & 0,71 \\
Alternativa "B" & 0,12 & 0,13 & 0,17 & 0,15 & 0,56 & 0,14 \\
Alternativa "C" & 0,09 & 0,06 & 0,08 & 0,08 & 0,31 & 0,08 \\
Alternativa "D" & 0,08 & 0,06 & 0,08 & 0,08 & 0,30 & 0,07 \\
\hline $\boldsymbol{\Sigma}$ & $\mathbf{1}$ & $\mathbf{1}$ & $\mathbf{1}$ & $\mathbf{1}$ & $\mathbf{4}$ & $\mathbf{1}$ \\
\hline
\end{tabular}

Fonte: Do autor (2019). 
Neste exemplo, a alternativa "A" tem um IHA de 0,71 , a alternativa "B" tem um IHA de 0,14, a alternativa "C" tem um IHA de 0,08, e a alternativa "D" tem um IHA de 0,07. Quanto maior for o índice, menores serão as dificuldades para implantação das alternativas, e, portanto, podem ser priorizadas sob a ótica da população.

\subsubsection{Associação multicriterial de problemas e alternativas}

Se, por um lado, o IHP permite a hierarquização dos problemas a partir de seu impacto, ou seja, a partir de sua frequência, sua relevância, sua dificuldade de correção e sua dificuldade de detecção, por outro lado, o IGA-P $($ h) permite a hierarquização dos problemas a partir das alternativas que atuam sobre ele e o poder das alternativas de solucionarem os problemas. Nessa direção, é possível incorporar o comportamento das alternativas na hierarquização dos problemas, considerando o impacto destes. Essa hierarquização se dá pela multiplicação do IHP pelo IGA-P $(\mathrm{h})$ associado a cada problema. Este hierarquizador é um índice, sugerido nesta proposta metodológica, chamado de Índice Priorizador Geral de Problemas (IPG-P), o qual associa as características do problema às características das alternativas propostas, como é dado pela eq.(56).

$$
I P G-P_{i}=\left(I H P_{i}\right) \times\left(I G A-P_{(h)_{i}}\right)
$$

Em que:

IPG-Pi: Índice Priorizador Geral de Problemas do i-ésimo problema;

IHP $\mathrm{i}$ : Índice Hierárquico de Problema do i-ésimo problema;

IGA-P $(\mathrm{h})$ : Índice Geral de Abrangência dos Problema Hierárquico do i-ésimo problema.

Nesse mesmo sentido, IHA permite a hierarquização das alternativas a partir da dificuldade de sua implantação, seja técnica, econômica, política ou de aceitação popular. Enquanto isso, o IGA-A $($ h) permite a hierarquização das alternativas a partir do atendimento aos problemas.

Com isso, é possível correlacionar a dificuldade de implantação das alternativas ao nível de atendimento dos problemas, associando o IHA com o IGA-A $\mathrm{A}_{(\mathrm{h})}$ de cada alternativa. Esta associação permite a proposta de um hierarquizador chamado Índice Priorizador Geral de Alternativas, a partir da eq.(57). 


$$
I P G-A_{i}=\left(I H A_{i}\right) \times\left(I G A-A_{(h)_{i}}\right)
$$

Em que:

IPG-A $\mathrm{A}_{\mathrm{i}}$ : Índice Priorizador Geral de Alternativas da i-ésima alternativa;

IHA $\mathrm{A}_{\mathrm{i}}$ Índice Hierárquico de Alternativas da i-ésima alternativa;

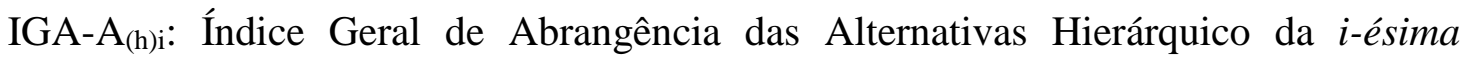
alternativa.

Esses dois indicadores permitem a hierarquização dos problemas, considerando o comportamento do problema e a influência das alternativas nele, e a hierarquização das alternativas, considerando o comportamento das alternativas e a influência dos problemas nelas. Eles devem ser normalizados para que se tenha uma escala relativa adequada a cada situação de análise.

Para ilustrar o cálculo desses índices, seguindo com os resultados dos IHP e dos IGA-P(h) associados a cada problema, além dos IHA e dos IGA- $\mathrm{A}_{(\mathrm{h})}$ associados a cada alternativa, já apontando para o exemplo desenvolvido os IPG-P e IPG-A, normalizados, para este exemplo o problema A é dominante frente aos outros, e a alternativa $\mathrm{C}$ é dominante frente as outras, portanto a atuação hierárquica neste problema e nesta alternativa define as estratégias prioritária de ação, conforme tabela 37.

Tabela 37 - Exemplo de cálculos dos índices priorizadores de problemas e de alternativas

\begin{tabular}{c|ccc|c} 
Problemas & IHP & IGA-P(h) $_{(\mathbf{h}}$ & IPG-P & IPG-P (Normalizado) \\
\hline Problema "A" & 0,68 & 0,60 & 0,408 & $\mathbf{0 , 8 6}$ \\
Problema "B" & 0,18 & 0,34 & 0,061 & $\mathbf{0 , 1 2}$ \\
Problema "C" & 0,14 & 0,06 & 0,008 & $\mathbf{0 , 0 2}$ \\
\hline $\boldsymbol{\Sigma}$ & $\mathbf{1}$ & $\mathbf{1}$ & $\mathbf{0 , 4 7 7}$ & $\mathbf{1}$ \\
\hline Alternativas & $\mathbf{I H A}$ & $\mathbf{I G A - A}_{(\mathbf{h})}$ & $\mathbf{I P G - A}$ & IPG-A (Normalizado) \\
\hline Alternativa "C" & 0,20 & 0,50 & 0,10 & $\mathbf{0 , 4 8}$ \\
Alternativa "A" & 0,70 & 0,10 & 0,07 & $\mathbf{0 , 3 3}$ \\
Alternativa "B" & 0,10 & 0,40 & 0,04 & $\mathbf{0 , 1 9}$ \\
\hline $\boldsymbol{\Sigma}$ & $\mathbf{1}$ & $\mathbf{1}$ & $\mathbf{0 , 2 1}$ & $\mathbf{1}$ \\
\hline
\end{tabular}

Fonte: Do autor (2019). 
Com apoio desses índices de hierarquização, as decisões podem ser tomadas, apontando para os interessados o processo de seleção de problemas e alternativas, considerando a percepção da população. Dessa maneira, uma abordagem estabelecida nas ciências das decisões, com análise multicriterial, pode suportar um processo claro e transparente de tomada decisão. Ademais, o resultado do processo participativo corrobora para a priorização de projetos com benefícios coletivos.

Conforme detalhado, a proposta participativa incorpora instrumentos científicos para coletar dados e estabelecer estratégias que traduzem as percepções da participação popular e assim permite criar, hierarquizar e selecionar propostas e problemas. A proposta metodológica apresentada é uma ferramenta que apoia a condução de processos participativos, incorporando (i) pesquisas de campo realizadas junto aos moradores dos bairros; (ii) análise de dados secundários produzidos por diferentes órgãos de pesquisa; (iii) utilização de metodologias participativas nas diferentes etapas de elaboração; e (iv) utilização de abordagens interdisciplinares.

Em uma mesma temática, a proposta pode ser aplicada em 01 (um) ou mais grupos, desde que todas as etapas metodológicas sigam da mesma maneira. Quando da aplicação em mais de um grupo, é possível analisar sinergicamente os resultados obtidos nos diferentes grupos.

É possível, finalmente, calcular um índice que agrega a somatória hierárquica dos problemas que se observaram nos grupos, o Índice Estratégico Geral de Problemas (IEG-P), dado pela eq.(58).

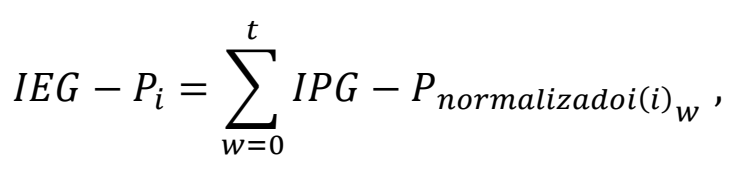

Em que:

IEG- $\mathrm{P}_{i}$ : Índice Estratégico Geral do Problema do i-ésimo problema;

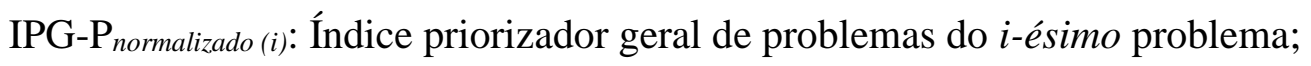

t: Número total de Grupos que contém o i-ésimo problema.

Portanto, quanto maior o número de ocorrências de um determinado problema, nos diferentes grupos, , e quanto maior for seu índice priorizador geral, maior sua relevância na determinação das estratégias. 
É possível calcular um índice que agrega a somatória hierárquica das alternativas que se observaram nos grupos, o Índice Estratégico Geral de Alternativas (IEG-A), dado pela eq.(59).

$$
I E G-A_{j}=\sum_{w=0}^{t} I P G-A_{\text {normalizadoi }(j)_{w}}
$$

Em que:

IEG- $\mathrm{A}_{j}$ : Índice de Estratégico Geral da Alternativa da j-ésima alternativa;

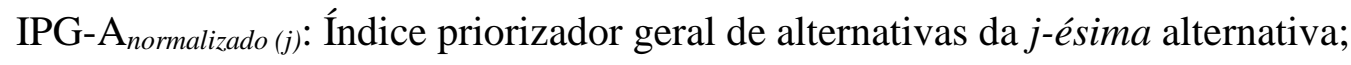

t: Número total de Grupos que contém o j-ésima alternativa.

Portanto quanto maior o número de ocorrências, nos diferentes grupos, de uma determinada alternativa, e quanto maior seu índice priorizador geral, maior sua relevância na determinação de estratégias.

\subsection{DIAGNÓSTICO DOS INSTRUMENTOS QUALITATIVOS DA PROPOSTA}

O mosaico de fotos e a avaliação de fraquezas e ameaças não produzem dados que possam ser transformados em índices, e esses instrumentos não têm isso como objetivo. Eles possuem um caráter de aprendizagem que permite o estreitamento entre as ações propostas e a efetiva intervenção, além de aproximar os pesquisadores e decisores da população, pois se proporciona a compreensão dos símbolos e significados de uma dada realidade. Estes elementos subsidiam, então, uma melhor interpretação do painel integrado de problemas.

No procedimento, há uma descrição das citações textuais dos participantes do grupo, o que ilustra os achados principais da análise e explica elementos que não aparecem ou estão ausentes das discussões. Objetiva-se tornar visível a associação entre o espaço urbano, o lugar e as comunidades locais, e se aplica como exercício de percepção do espaço e da interpretação da realidade social dos agentes envolvidos com a pesquisa. Esses elementos gráficos são associados aos índices hierarquizadores e, portanto, podem explicá-los e qualificá-los, ou seja, entender as razões pelas quais determinadas alternativas e determinados problemas possuem maiores ou menores índices associados a si.

Por outro lado, a aplicação do painel de abrangências permite apontar em que escala os sujeitos entendem a melhor aplicação de determinadas alternativas, posto que ajuda a compreender como as pessoas inserem as alternativas propostas. Os índices gerados na proposta 
metodológica criam um paradigma de avaliação e hierarquização com uma abordagem bottomup, a partir de resultados gerados pelos cidadãos, baseados em sua experiência, seu envolvimento, sua percepção, seu diálogo e seu consenso, obtidos em uma rotina participativa de negociação. O envolvimento público proporciona a identificação não só das deficiências e dos problemas locais, mas também das ações que são aderentes ao contexto estudado sob a ótica popular. 


\section{APLICACÃO DA PROPOSTA METODOLÓGICA NA ÁREA SELECIONADA}

A aplicação da proposta metodológica será realizada em uma área selecionada no distrito do Belém, subprefeitura da Moóca, no município de São Paulo. Este trabalho definiu a hipótese de que a participação popular pode fornecer contribuições mais efetivas para a definição das soluções adotadas em projetos de intervenção urbana, se desenvolvidos e aplicados procedimentos metodológicos nos processos de tomada de decisão que suportem e orientem a participação da população. Assim, aplicando-se metodologias mais efetivas, que integrem a participação popular em processos decisórios relativos aos projetos urbanos, acredita-se que as contribuições sociais possam fornecer insumos que possibilitem o diagnóstico de problemas e prioridades em áreas urbanas definidas, assim como a hierarquização de projetos e soluções de intervenção urbana, de uma forma mais efetiva que a prática corrente.

Para verificação da hipótese, foi definida, de forma preliminar, a abrangência de uma divisão administrativa do Município de São Paulo como objeto para aplicação do procedimento metodológico estabelecido: a Subprefeitura da Moóca. De forma específica, é analisada a abrangência de atuação de uma associação de bairro, e, desse modo, testa-se o processo metodológico proposto na situação urbana selecionada, permitindo entender a aplicabilidade da proposta e sua revisão em função dos resultados obtidos. A escolha de uma Subprefeitura remete ao fato de ela significar, do ponto de vista administrativo, uma célula do município. Ainda, ela constitui uma escala da comunidade em que se acredita ser possível obter apreciação tanto de questões locais, do cotidiano do cidadão, até questões em macro escala urbana, de interesse da subprefeitura ou do município como um todo.

A escolha da Subprefeitura da Mooca como estudo de caso justifica-se por sua localização lindeira ao centro do município de São Paulo, reunindo características simultâneas de uma região com infraestrutura já consolidada, porém em processo de transformação do uso e da ocupação do solo. Nos últimos anos, recebeu inúmeros investimentos em empreendimentos verticalizados, sobretudo para uso residencial, mas ainda possui diversos terrenos e áreas industriais ociosos, com potencial de ocupação, uma miscelânea de ocupações horizontais atendidas por comércio e serviços de abrangência e âmbito local. Além disso, há sobreposição censitária dos dados secundários oficiais, permitindo uma análise dos dados sem extrapolação ou correção específica. Ademais, salienta-se que a densidade demográfica, o rendimento familiar e os níveis de instrução e alfabetização heterogêneos - fatos que podem representar de 
forma latente uma série de problemáticas ligadas à dinâmica urbana e social - impactam em decisões urbanas, bem como na priorização de projetos e intervenções.

A Subprefeitura da Mooca é uma das 32 Subprefeituras de São Paulo, localizada na zona leste do município, conforme a figura 31. A área possui seis distritos, Água Rasa, Belém, Brás, Pari, Mooca e Tatuapé, com as respectivas populações de 84.963 hab., 45.057 hab., 29.265 hab., 17.299 hab., 75.724 hab. e 91.672 hab., totalizando 343.980 habitantes na Subprefeitura. Esta, por sua vez, representa 3\% da população do Município de São Paulo. Além disso, possui densidade demográfica de 97,72 hab./ha, acima da média da RMSP (74,58 hab./ha). (IBGE, $2010)^{73}$.

Figura 31 - Distritos da Subprefeitura da Mooca e a Localização na Região Metropolitana Municipio de São Paulo

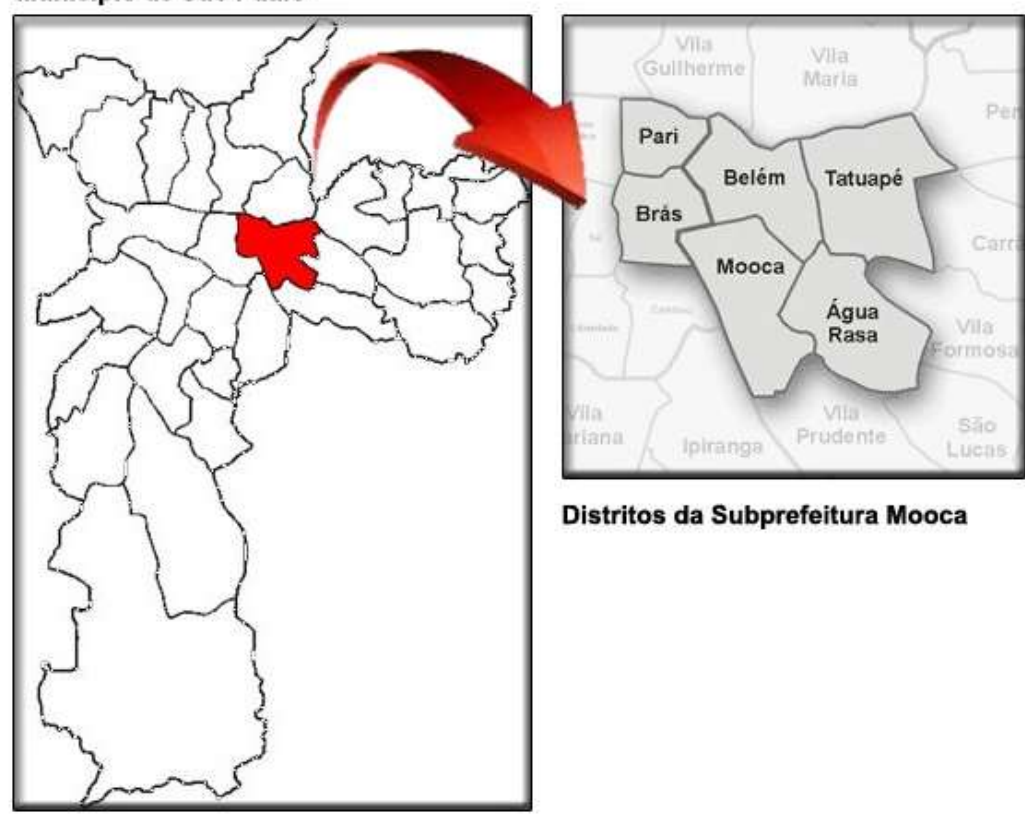

Fonte: Plataforma da Prefeitura de São Paulo (2017).

A Subprefeitura da Mooca também integra a futura Operação Urbana Consorciada Mooca-Vila Carioca, prevista no Plano Diretor Estratégico de 2002. Os estudos preliminares começaram em outubro de 2011 e têm como objetivo promover o desenvolvimento do perímetro que abrange os bairros Mooca, Cambuci, Ipiranga, Vila Zelina, Vila Prudente e Vila Carioca. A Operação Urbana visa aproximar o trabalho da moradia, aumentar o número de áreas verdes, promover maior acesso a serviços, cultura, lazer e equipamentos sociais, bem como melhorar a mobilidade urbana e minimizar as inundações na região. A prefeitura promoveu

\footnotetext{
${ }^{73}$ IBGE (Instituto de Geografia e Estatística). Censo Demográfico 2010 - Características Gerais da População. Resultados da Amostra. IBGE, 2010. Disponível em:

<http://www.ibge.gov.br/home/estatistica/populacao/cnso2000/default_populacao.shtm>.
} 
diálogos com a população para receber contribuições ao projeto, e o projeto está em fase de licenciamento ambiental ${ }^{74}$.

A proposta tem origem nos primeiros estudos da Operação Urbana Diagonal Sul, prevista pelo Plano Diretor Estratégico de 2002 com desenvolvimento realizado pela antiga Secretaria Municipal de Planejamento. A partir de 2012 novos estudos urbanísticos, já sob as premissas da Operação Urbana Mooca-Vila Carioca foram elaborados e a proposta foi rebatizada para Operação Urbana Consorciada Bairros do Tamanduateí, o projeto apresentado trata-se de um conjunto de ações e estratégias urbanísticas, sociais, ambientais e econômicas formatadas sob as orientações do PDE.

Estas diretrizes seguirão às ações determinadas por um Projeto de Intervenção Urbana (PIU) para os bairros do Tamanduateí. Neste momento, se reinicia o processo participativo, agora no âmbito do poder Legislativo. A Câmara Municipal coordenará o debate público e novo ciclo de audiências se inicia para a continuidade do aprimoramento da proposta desenvolvida, mas sem agenda disponível ${ }^{75}$, até julho de 2019.

\subsection{CARACTERIZAÇÃO DA ÁREA DE ESTUDO}

A caracterização da área, tanto quanto à investigação de informações preliminares referente ao perfil de participação popular, foi realizada a partir de levantamento documental e pesquisa de dados secundários, obtidos no Censo de 2010 do IBGE, com o qual foi realizada a caracterização socioeconômica da população, por meio de mapas temáticos.

Foram construídos mapas temáticos para a Subprefeitura em estudo a fim de caracterizar a população residente. Além disso, para a execução dos mapas demográficos e socioeconômicos, foram utilizados diversos dados coletados, tais como: "População Recenseada, Taxas de Crescimento Populacional e Densidade Demográfica” (1991, 2000, 2010); "Domicílios por Faixa de Rendimento, em Salários Mínimos” (2000, 2010); "População de 10 Anos ou Mais de Idade, por Nível de Instrução" (2010); "População Total e Alfabetizada de 10 Anos e Mais e Taxa de Alfabetização" (2000, 2010). Todos estes dados foram

\footnotetext{
${ }^{74}$ O estudo de EIA-RIMA da OPERAÇÃO CONSORCIADA MOOCA-VILA CARIOCA, publicado em 2013 pela prefeitura do município de São Paulo, encontra-se disponível em :

https://www.prefeitura.sp.gov.br/cidade/secretarias/upload/desenvolvimento_urbano/arquivos/eia/rima_rev100813_1.pdf

75 Informações disponível no site da prefeitura (https://www.prefeitura.sp.gov.br/cidade/secretarias/urbanismo/sp_urbanismo/operacoes_urbanas/index.php?p=202120), e até o dia 14 de julho de 2019 não existia agenda para o processo participativo (http://www.saopaulo.sp.leg.br/tamanduatei/agenda/)
} 
disponibilizados pelo domínio virtual da Prefeitura do Município de São Paulo, nas plataformas Infocidade $^{76}$ e Gestão Urbana ${ }^{77}$, com dados sumarizados do Censo do IBGE de 2010.

No mapa apresentado na figura 32 a seguir, é possível verificar que os distritos de Tatuapé e Água Rasa são os mais densos, pois essas áreas são predominantemente residenciais. Em contraste, Belém e Pari são os menos densos, pois são dissidentes da desmobilização de áreas industriais características dessas regiões. É importante salientar que a densidade é resultado da população residente e não da população flutuante.

Figura 32 - Distribuição da Densidade Demográfica em 2010

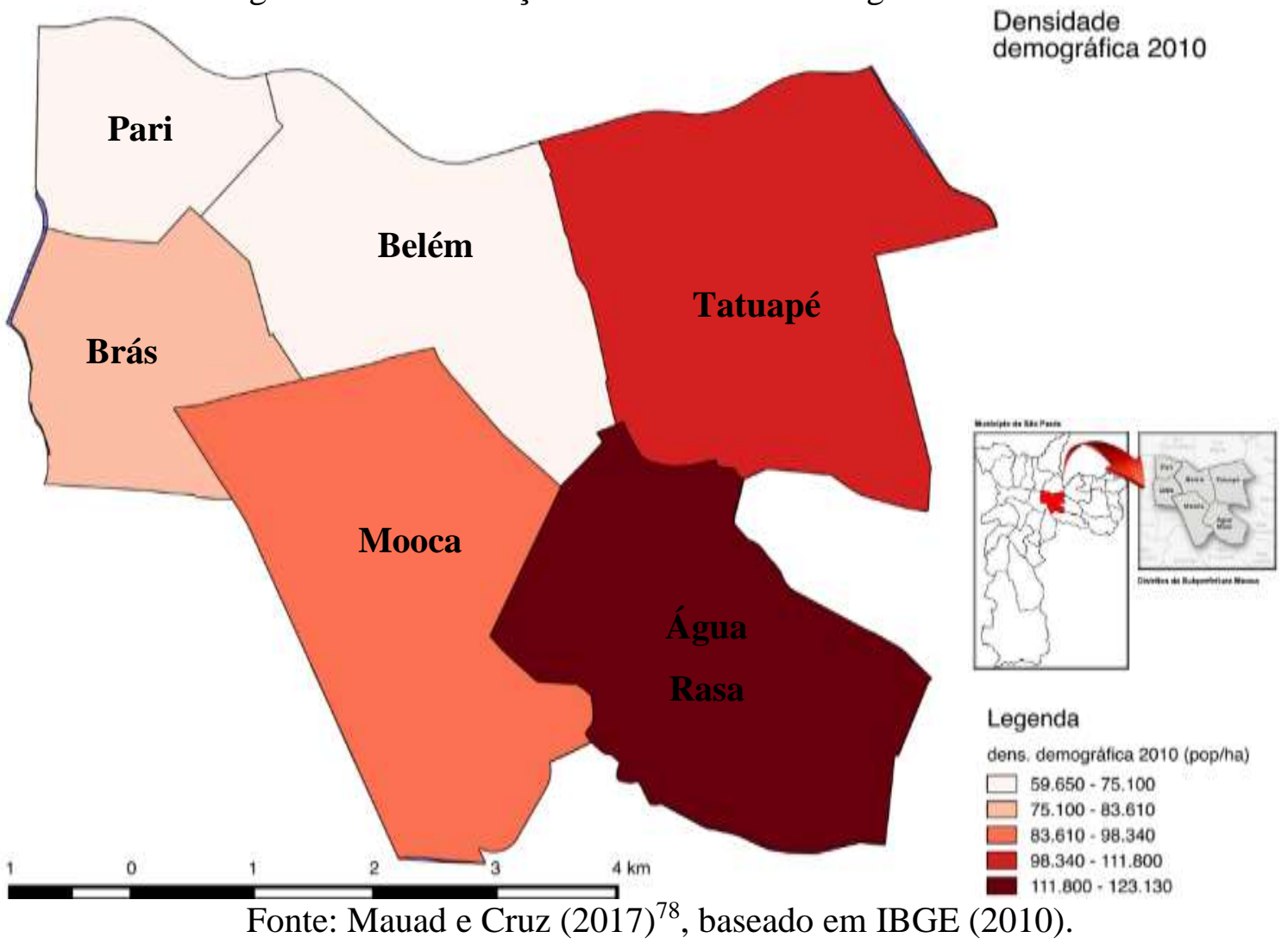

Além disso, como no mapa da Figura 33, a população da Mooca apresentou uma taxa de crescimento positiva - entre 2000 e 2010, tendo o distrito da Mooca a maior taxa de crescimento, possivelmente decorrente de uma maior atividade imobiliária. O Pari, por sua vez, vem ganhando destaque pela incorporação de áreas ociosas e industriais pelo mercado

\footnotetext{
76 Infocidade (Plataforma de dados da Secretaria Municipal de Urbanismo e Licenciamento (SMUL). Disponível em: <infocidade.prefeitura.sp.gov.br>. Acesso em: 04 fev. 2017.

77 PMSP (Prefeitura do Município de São Paulo). Plataforma Gestão Urbana. Disponível em: <http://gestaourbana.prefeitura.sp.gov.br>. Acesso em: 04 fev. 2017.

${ }^{78}$ Mapa elaborado pelo o Autor com apoio de Silvia Vitali dos Santo Mauad, como resultado de seu trabalho de iniciação cientifica, com o título“ Diagnóstico da participação popular em projetos urbanos, no município de São Paulo” orientado pelo Professora Doutora Karin Regina de Casas Castro Marins.
} 
imobiliário, concentrando lançamentos que potencializam as taxas de crescimento populacional. Apenas os distritos de Água Rasa (o mais denso) e Belém apresentaram crescimento populacional negativo no período. De forma específica, Belém chama atenção por possuir, dentro da região estudada, uma baixa densidade, ligada ainda a um crescimento populacional negativo.

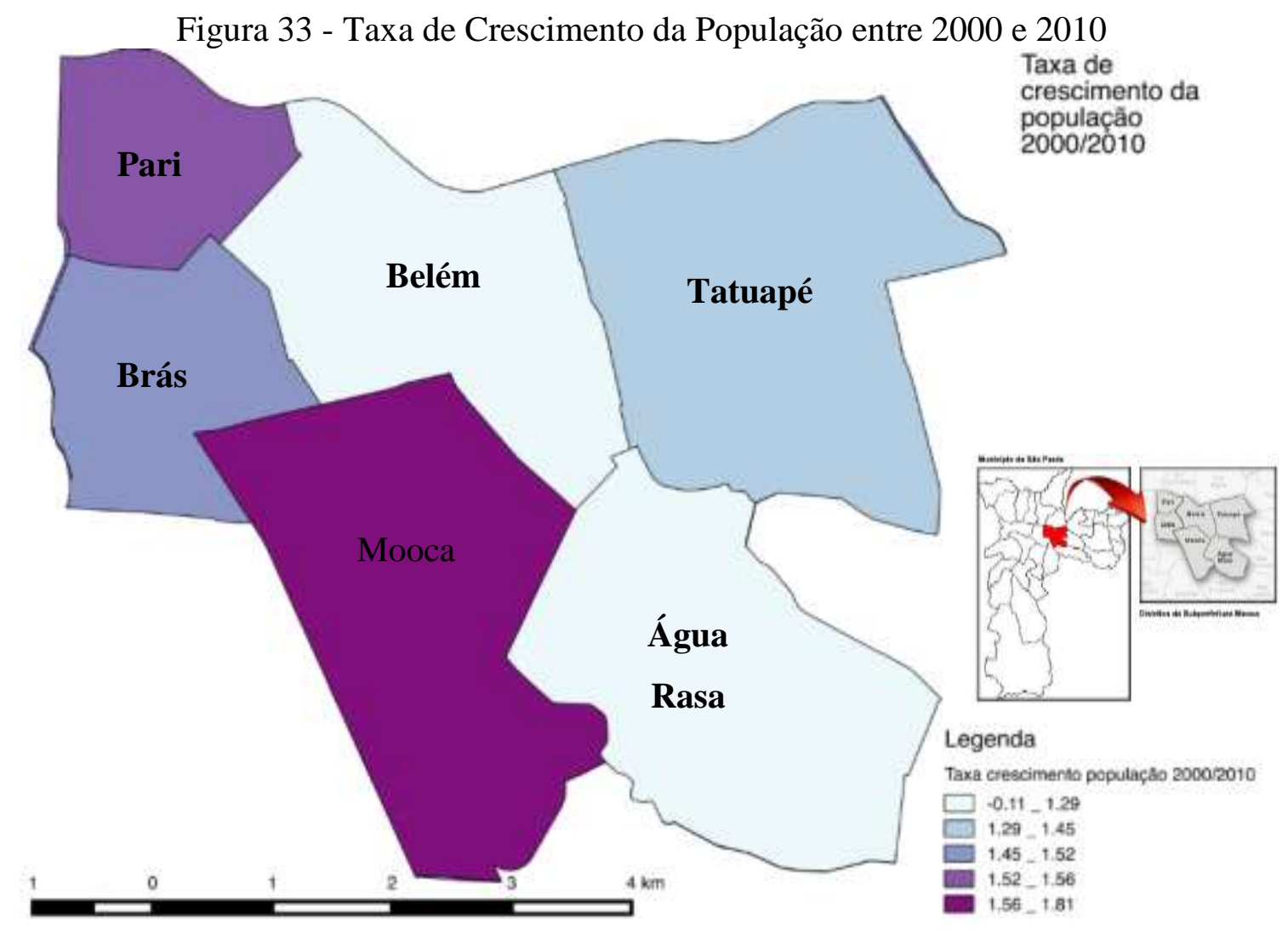

Fonte: Mauad e Cruz (2017) ${ }^{79}$, baseado em IBGE (2010).

Algumas das ocupações nesta região ainda são horizontais, de pequenas densidades, porém nota-se a incorporação de grandes empreendimentos residenciais. Segundo Marins et al. (2017), em um estudo realizado a partir de um recorte de 16 quadras do distrito de Belém (representando quase 25\% do distrito) foi identificado que, na região, 59\% das ocupações são residenciais, e 57\% destas (mais de 1/3 do total) são residenciais horizontais de baixo padrão.

Ainda, pela análise da sumarização dos mapas da figura 34, é possível perceber que Mooca, Água Rasa e Tatuapé, os distritos com maiores densidades populacionais, são aqueles que têm maiores índices de envelhecimento da população.

79 Mapa elaborado pelo o Autor com apoio de Silvia Vitali dos Santo Mauad, como resultado de seu trabalho de iniciação cientifica, com o título“ Diagnóstico da participação popular em projetos urbanos, no município de São Paulo", orientado pelo Professora Doutora Karin Regina de Casas Castro Marins. 
Também se nota que os distritos Mooca e Tatuapé são os que possuem níveis mais altos de desenvolvimento socioeconômico (se associados renda, instrução e índice de envelhecimento), enquanto possuem as maiores taxas de rendimento mensal, nível de instrução e taxa de alfabetização. Em contraposição, estão Brás e Pari, com menores taxas.

Figura 34 - Sumarização de Desenvolvimento Social 2010

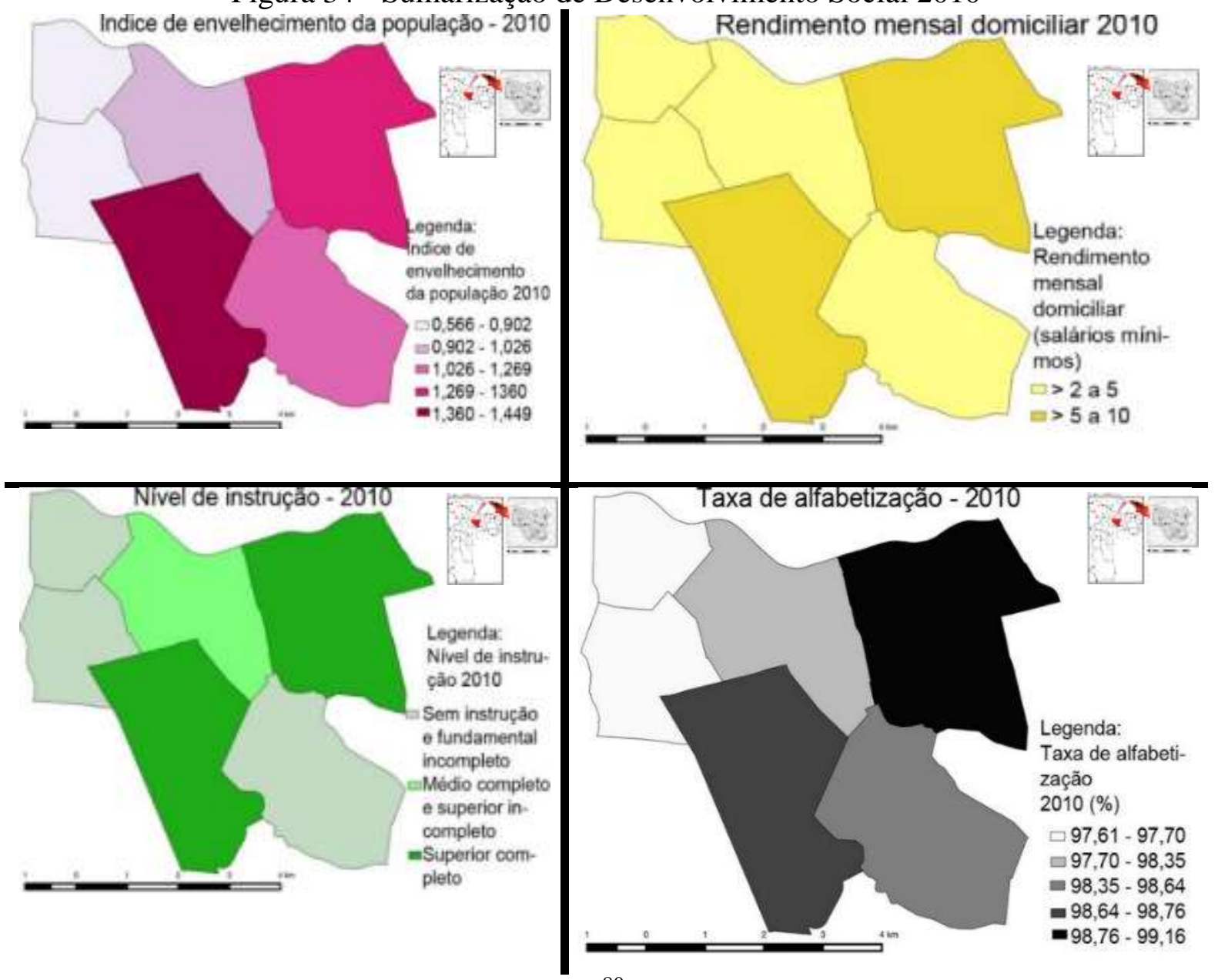

Fonte: Mauad e Cruz (2017) ${ }^{80}$, baseado em IBGE (2010).

Como forma de comparação das Leis de Zoneamento de 2004 e 2016, foram elaborados mapas temáticos para o recorte urbano do zoneamento, aprovado em 2004, e o seu substitutivo, aprovado em 2016. Também foram elaborados mapas temáticos de coeficiente de aproveitamento máximo, coeficiente de aproveitamento mínimo e taxa de ocupação máxima, relativos às Leis de Zoneamento de 2004 e 2016.

\footnotetext{
${ }^{80}$ Mapa elaborado pelo o Autor com apoio de Silvia Vitali dos Santo Mauad, como resultado de seu trabalho de iniciação cientifica, com o título "Diagnóstico da participação popular em projetos urbanos, no município de São Paulo" orientado pelo Professora Doutora Karin Regina de Casas Castro Marins.
} 


\subsubsection{Caracterização Urbanística do Recorte de Estudo}

É relevante avaliar a distribuição de uso e ocupação da área objeto de estudo, então foram construídos mapas em função do zoneamento atual (BRASIL, Lei n. 16.402, de 22 de março de 2016), do zoneamento anterior (BRASIL, Lei n. 13.885, de 25 de agosto de 2004), e dos coeficientes urbanísticos de ambos (coeficiente de aproveitamento mínimo, coeficiente de aproveitamento máximo e taxa de ocupação máxima). O mapa com o zoneamento atual, após a revisão do PDE, é apresentado na figura 35.

Figura 35 - Mapa do Zoneamento Vigente em São Paulo (2016)

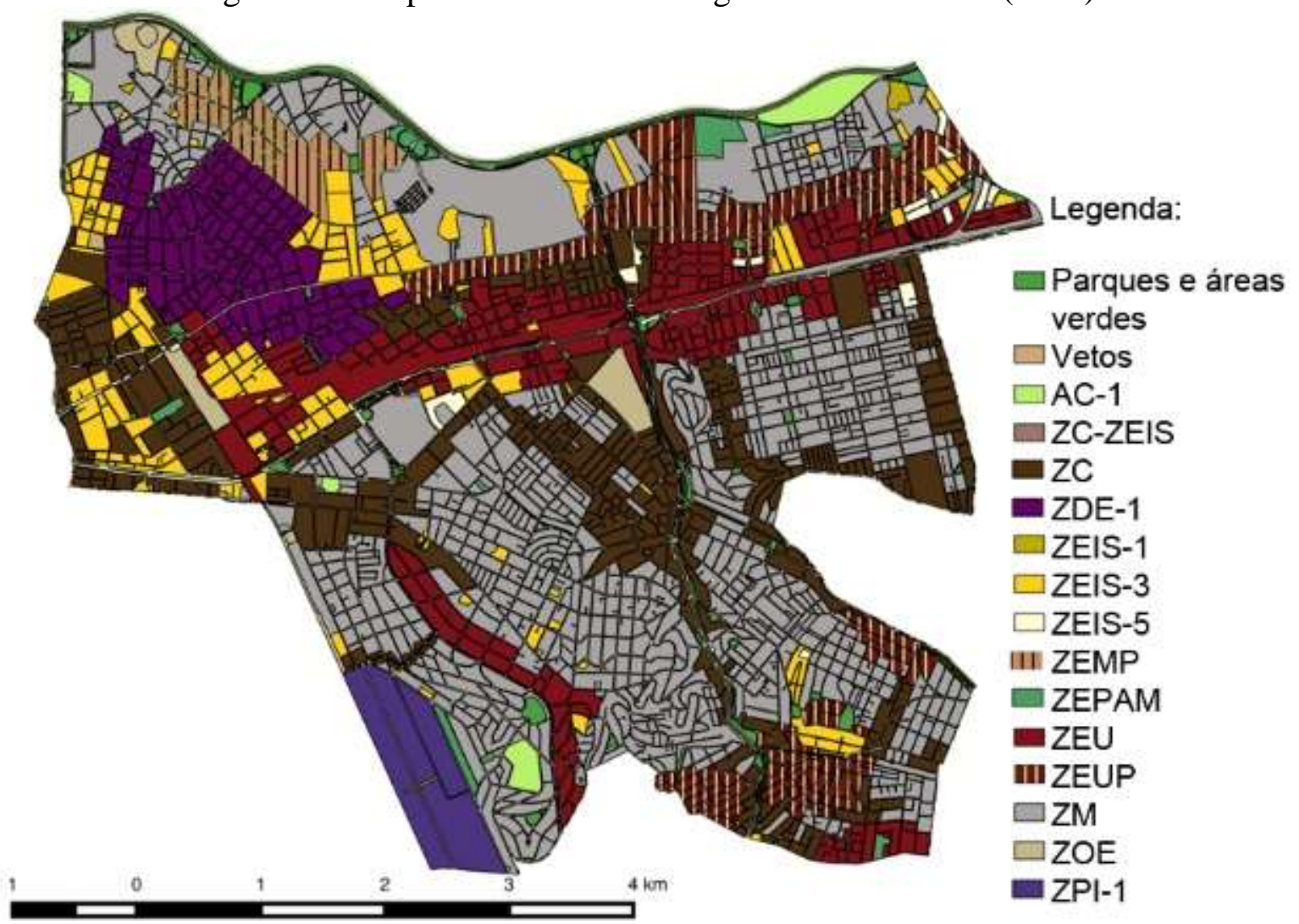

Fonte: São Paulo (2016) ${ }^{81}$

No zoneamento atual, foram criadas zonas que anteriormente não existiam. Dentre as zonas criadas, estão a ZEU (Zona de Estruturação Urbana), a ZDE (Zona de Desenvolvimento Econômico) e as ZEIS-5 (Zonas Especiais de Interesse Social - 5). As zonas foram, no atual e revisado PDE, consolidadas na Lei de Parcelamento, Uso e Ocupação de Solo (LPUOS) e foram organizadas em 3 diferentes agrupamentos: territórios de transformação, qualificação e preservação.

\footnotetext{
${ }^{81}$ LEI No 16.402, de 22 de março de 2016
} 
A organização, resumidamente, determina que os territórios de transformação objetivam adensamento construtivo e populacional das atividades econômicas e dos serviços públicos, diversificação de atividades e qualificação urbana com sinergia aos espaços públicos, de forma a adequar o uso do solo à oferta de transporte público coletivo e absorver as zonas ZEU, ZEU, ZEM e ZEMP. Já os territórios de qualificação objetivam a manutenção de usos não residenciais existentes, o fomento às atividades produtivas, a diversificação de usos e o adensamento populacional moderado, além de absorver as zonas ZOE, ZPI, DEZ, ZEIS (de 1 a 5), ZM, ZCOR e ZC. Por último, os territórios de preservação objetivam a preservação de bairros consolidados de baixa e média densidades, de conjuntos urbanos específicos e territórios destinados à promoção de atividades econômicas sustentáveis conjugada à preservação ambiental, além da preservação cultural, e absorve as zonas ZEPEC, ZEP, ZEPAM, ZPDS, ZER e ZPR. A tabela 38 resume a quantificação referente ao zoneamento de 2016, das áreas específicas a cada zona.

Tabela 38 - Áreas das Zonas do Zoneamento Vigente - 2016

\begin{tabular}{c|c}
\hline & \\
Zoneamento Vigente & Área $\left(\mathbf{m}^{\mathbf{2}}\right)$ \\
\hline ZEU & 3.652 .630 \\
ZEUP & 2.195 .890 \\
ZEMP & 667.687 \\
ZC & 4.993 .800 \\
ZC-ZEIS & 5.080 \\
ZM & 12.225 .800 \\
ZEIS-1 & 41.881 \\
ZEIS-3 & 2.311 .870 \\
ZEIS-5 & 204.883 \\
ZDE-1 & 2.019 .800 \\
ZPI-1 & 1.047 .180 \\
ZEPAM & 281.377 \\
AC-1 & 342.917 \\
ZOE & 497.499 \\
Parques e áreas verdes & 1.043 .030 \\
\hline
\end{tabular}

Fonte: Mauad e Cruz (2017) $)^{82}$ - Adaptado de LPUOS (2016).

Quando comparado com o zoneamento anterior, em que foi revisada a ZM (Zona Mista), predominante no zoneamento de 2004 e ainda a maior parte da área, vê-se um aumento no

\footnotetext{
${ }^{82}$ Mapa elaborado pelo o Autor com apoio de Silvia Vitali dos Santo Mauad, como resultado de seu trabalho de iniciação cientifica, com o título“ Diagnóstico da participação popular em projetos urbanos, no município de São Paulo” orientado pelo Professora Doutora Karin Regina de Casas Castro Marins.
} 
número de zonas, passando de 9, previstas no zoneamento estabelecido no PDE anterior, de 2004, conforme mapa da figura 36, para 15 diferentes grupos de zonas.

Figura 36 - Mapa do Zoneamento Anterior de São Paulo (2004)

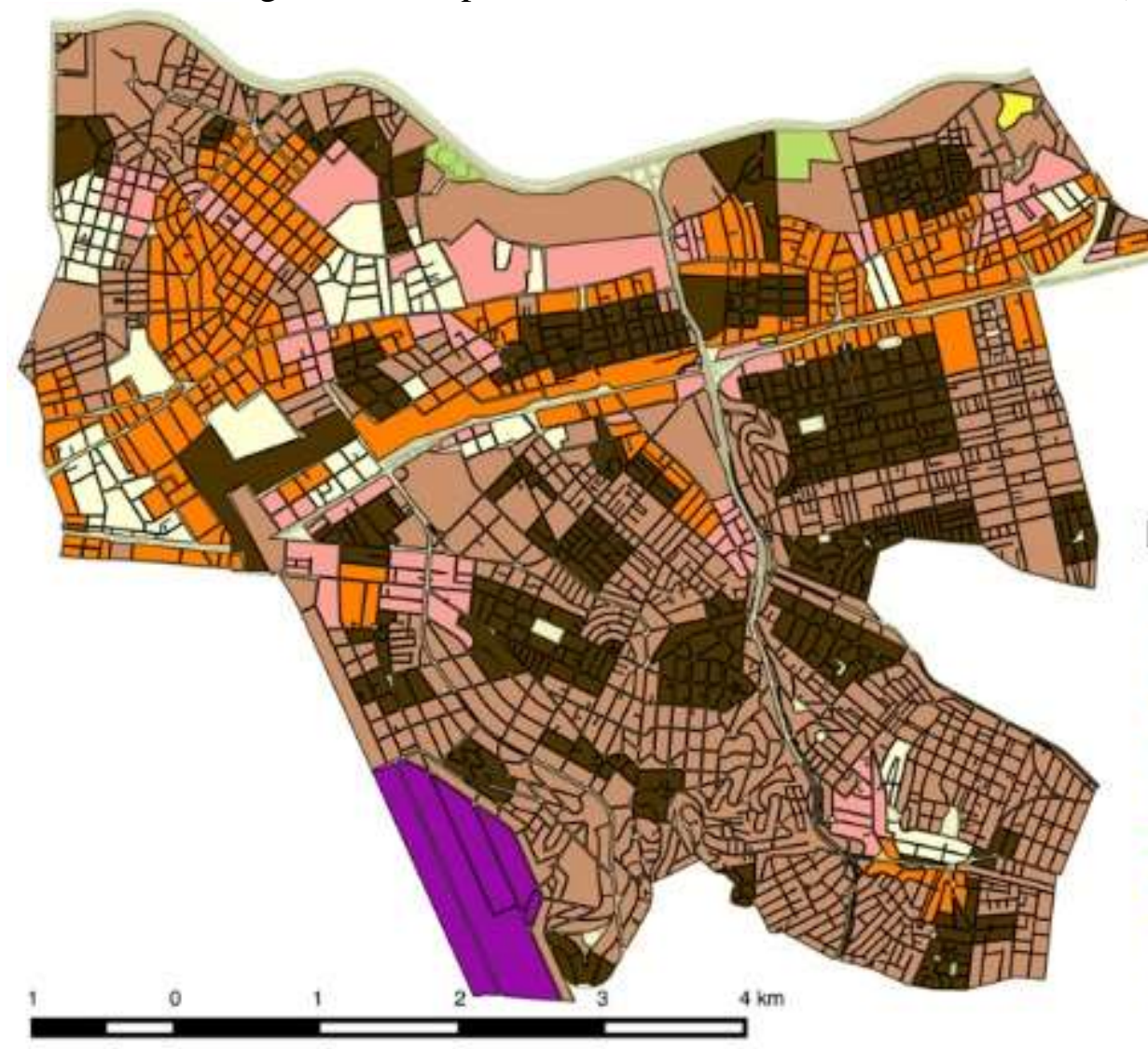

Legenda:

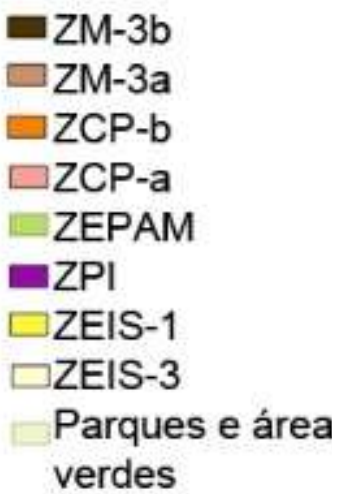

Fonte: São Paulo (2004) ${ }^{83}$.

A tabela 39 retrata, para o zoneamento de 2004 e as áreas específicas a cada zona, sumarizando quantitativamente, a análise visual de predominância das áreas, exposta no mapa analisado anteriormente.

Verifica-se ainda a latente concentração de Zonas Mistas, porém há uma evolução no sentido de incentivar as Zonas de Estruturação Urbana. Essa leitura denota uma oportunidade para implantação de empreendimentos com base nas novas diretrizes propostas no PDE, que podem requerer uma atenção da população do bairro, para que o desenvolvimento dos espaços públicos e privados siga uma diretriz de estruturação efetiva da região. Também cabe uma leitura da ampliação das Zonas Especiais de Interesse Social inseridas na área.

\footnotetext{
${ }^{83}$ Lei n. 13.885 , de 25 de agosto de 2004.
} 
Tabela 39 - Áreas das Zonas do Zoneamento de 2004

\begin{tabular}{c|c}
\hline Zoneamento de $\mathbf{2 0 0 4}$ & Área $\left(\mathbf{m}^{2}\right)$ \\
\hline ZM-3a & 13.831 .000 \\
ZM-3b & 5.848 .940 \\
ZCP-a & 2.459 .220 \\
ZCP-b & 4.898 .320 \\
ZPI & 1.016 .770 \\
ZEPAM & 161.211 \\
ZEIS-1 & 47.011 \\
ZEIS-3 & 1.912 .180 \\
\hline
\end{tabular}

Fonte: Mauad e Cruz (2017) ${ }^{84}-$ Adaptado de LPUOS (2004).

Como, para as ZEIS, os coeficientes urbanísticos podem depender do tamanho do lote, foi sobreposto o mapa de zoneamento da Mooca às quadras oficiais da prefeitura, e foram considerados lotes com suas áreas determinadas pelas quadras fiscais do mapa oficial da cidade. Os mapas da taxa de ocupação máxima para o zoneamento atual e o zoneamento anterior estão classificados em valores que vão de 0 a 0,85 . Nota-se que, para a o zoneamento vigente, esses valores estão predominantemente entre 0,65 e 0,85. Já para o zoneamento de 2004, esses valores estão predominantemente entre 0 e 0,65 , conforme os mapas da figura 37 .

Figura 37 - Taxas de Ocupação segundo o Zoneamento de 2004 e 2016 para a Subprefeitura da Mooca
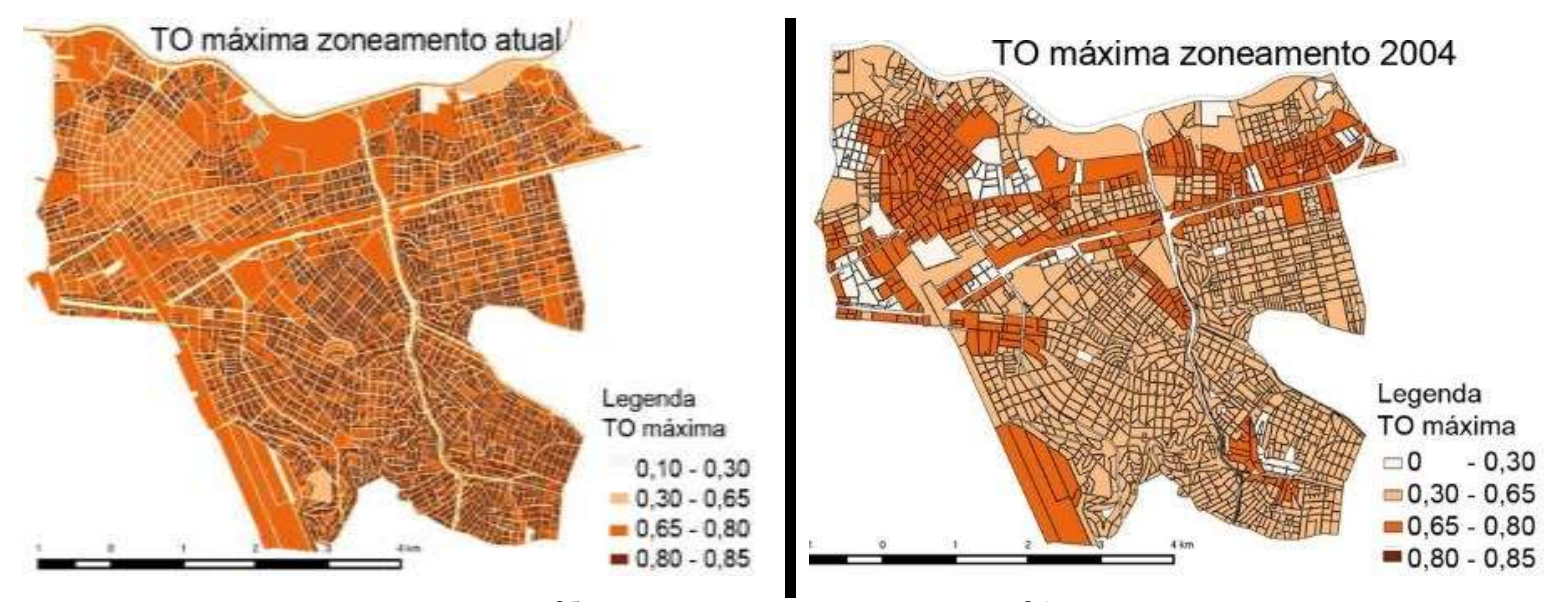

Fonte: Mauad e Cruz (2017) ${ }^{85}$ - Adaptado de Geosampa ${ }^{86}$ e da LPUOS $(2016,2004)$.

\footnotetext{
${ }^{84}$ Tabela elaborada pelo o Autor com apoio de Silvia Vitali dos Santo Mauad, como resultado de seu trabalho de iniciação cientifica, com o título“ Diagnóstico da participação popular em projetos urbanos, no município de São Paulo” orientado pelo Professora Doutora Karin Regina de Casas Castro Marins.

${ }^{85}$ Mapa elaborado pelo o Autor com apoio de Silvia Vitali dos Santos Mauad, como resultado de seu trabalho de iniciação cientifica, com o título“ Diagnóstico da participação popular em projetos urbanos, no município de São Paulo” orientado pelo Professora Doutora Karin Regina de Casas Castro Marins.
}

${ }^{86}$ GEOSAMPA. Plataforma Digital de Dados Georreferenciados da Prefeitura do Município de São Paulo - Disponível em: <http://geosampa.prefeitura.sp.gov.br/PaginasPublicas/_SBC.aspx>. Acesso em: 20 mai. 2017. 
Para realização dos mapas com coeficientes urbanísticos, por sua vez, foram utilizados dados do Quadro 3, "Parâmetros de ocupação, Exceto de Quota Ambiental", anexo da Lei Municipal n. 16.402/2016. Para os casos dos valores de coeficiente de aproveitamento máximo ( $\mathrm{CA}_{\text {máx }}$ para cada zona, nos casos específicos de Zeis 1, Zeis 3 e Zeis 5, há observações referentes ao tamanho do lote no Quadro 3 da lei. Para Zeis 1 e Zeis 5, o CAmáx é igual a 2 quando o lote é menor que $1000 \mathrm{~m}^{2}$. Quando o lote é maior ou igual a $1000 \mathrm{~m}^{2}$, o CAmáx é respectivamente igual a 2,5 e 4. Já para a Zeis 3, quando o lote é maior ou igual a $500 \mathrm{~m}^{2}$, o $\mathrm{CA}_{\text {máx }}$ é igual a 4 , e quando é menor que $500 \mathrm{~m}^{2}$, o $\mathrm{CA}_{\text {máx }}$ é igual a 2.

A tabela 40 retrata quantitativamente, para o zoneamento vigente e o anterior, as áreas sujeitas às diferentes taxas de ocupação.

Tabela 40- Áreas de Taxa de Ocupação Máxima do Zoneamento Vigente e do Zoneamento de

\begin{tabular}{c|c|c}
\multicolumn{3}{c}{2004} \\
\hline \multirow{2}{*}{ TO máx. } & \multicolumn{2}{c}{ Área $\left(\mathbf{m}^{2}\right)$} \\
& Z. vigente & Z. 2004 \\
\hline NA & 1.540 .529 & - \\
$\mathbf{0 , 1}$ & 281.377 & 161.211 \\
$\mathbf{0 , 5}$ & - & 19.679 .900 \\
$\mathbf{0 , 6}$ & 342.917 & - \\
$\mathbf{0 , 7}$ & 15.868 .300 & 8.374 .300 \\
$\mathbf{0 , 8 5}$ & 11.591 .700 & - \\
\hline Fonte: Mauad e Cruz $(2017)^{87}-$ Adaptado de LPUOS (2004, 2016).
\end{tabular}

Para a área da subprefeitura, buscou-se analisar a modificação dos coeficientes de aproveitamento para entender se o potencial construtivo aumentou ou diminuiu, gerando, consequentemente, um possível adensamento construtivo ou verticalização na região. Vale salientar que essa análise é construída com base nos parâmetros normativos, explícitos no texto da lei, e não nas ocupações efetivamente aplicadas nos lotes da área de estudo, conforme figura 38. Para os mapas de coeficiente mínimo, os valores estão compreendidos entre 0 e 0,5 . Para o zoneamento atual, os valores estão predominantemente entre 0,2 e 0,5 , sendo que para as Zonas de Estruturação Urbana, estes são os maiores valores. Para o zoneamento de 2004, os valores estão predominantemente entre 0 e 0,2 .

\footnotetext{
${ }^{87}$ Tabela elaborado pelo o Autor com apoio de Silvia Vitali dos Santos Mauad, como resultado de seu trabalho de iniciação cientifica, com o título“ Diagnóstico da participação popular em projetos urbanos, no município de São Paulo” orientado pelo Professora Doutora Karin Regina de Casas Castro Marins.
} 
Figura 38 - Variação do Coeficiente de Aproveitamento Mínimo (CAmín) e Máximo

(CA máx) entre 2004 e 2016

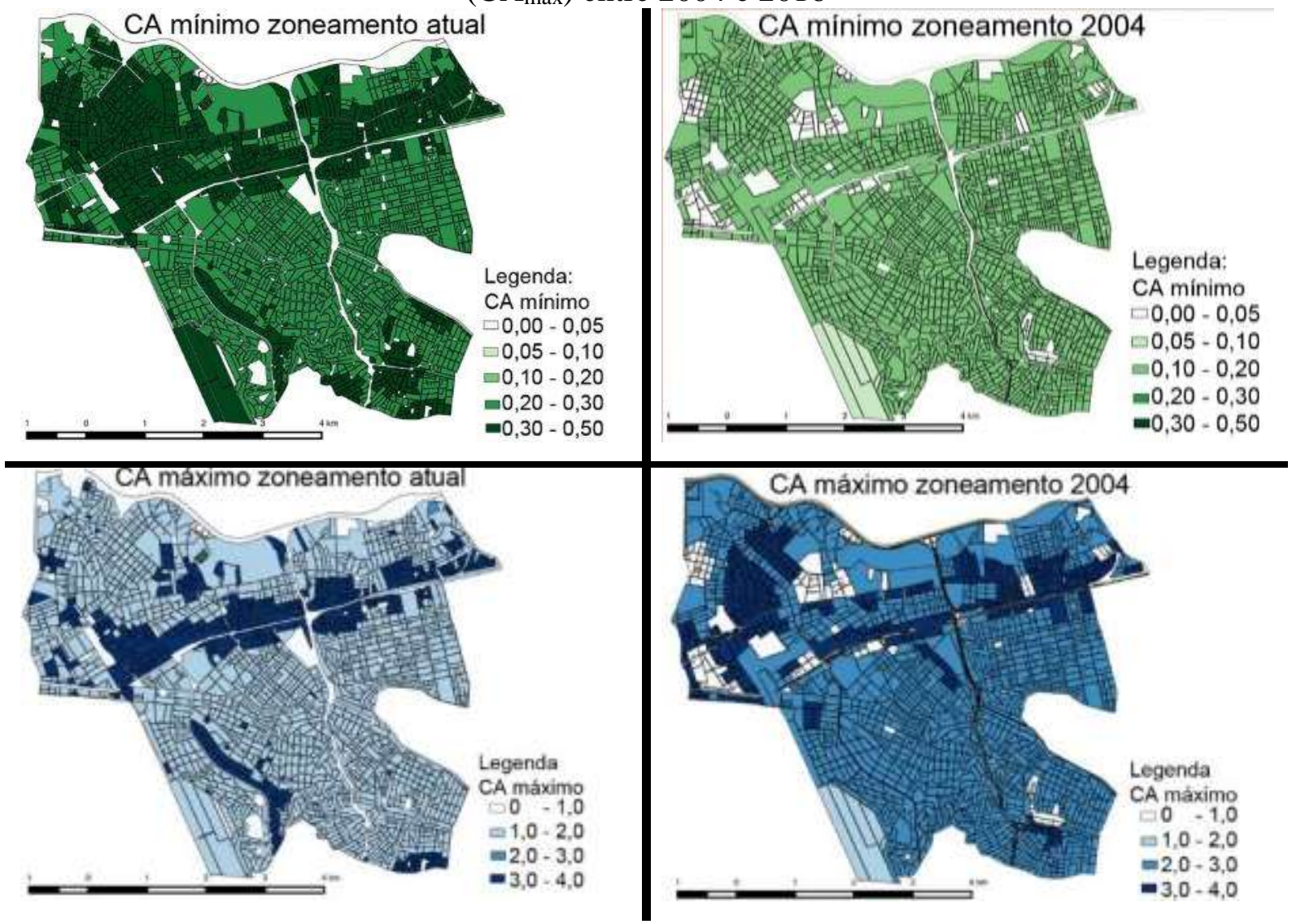

Fonte: Mauad e Cruz (2017) ${ }^{88}$ - Adaptado de Geosampa e da LPUOS (2004, 2016).

Conforme a tabela 41, é possível verificar a alocação de área para o zoneamento vigente e o de 2004

Tabela 41 - Áreas Coeficiente de Aproveitamento Mínimo do Zoneamento Vigente e do Zoneamento de 2004

\begin{tabular}{c|c|c}
\hline \multirow{2}{*}{ CA mín } & \multicolumn{2}{|c}{ Área $\left(\mathbf{m}^{2}\right)$} \\
\hline NA & 2.164 .823 & Z. 2004 \\
$\mathbf{0 , 1}$ & - & 161.211 \\
$\mathbf{0 , 2}$ & - & 1.016 .770 \\
$\mathbf{0 , 3}$ & 17.219 .600 & 27.037 .400 \\
$\mathbf{0 , 5}$ & 12.146 .900 & 1.912 .180 \\
\hline
\end{tabular}

\footnotetext{
${ }^{88}$ Mapa elaborado pelo o Autor com apoio de Silvia Vitali dos Santos Mauad, como resultado de seu trabalho de iniciação cientifica, com o título“ Diagnóstico da participação popular em projetos urbanos, no município de São Paulo” orientado pelo Professora Doutora Karin Regina de Casas Castro Marins.

${ }^{89}$ Tabela elaborada pelo o Autor com apoio de Silvia Vitali dos Santos Mauad, como resultado de seu trabalho de iniciação cientifica, com o título“ Diagnóstico da participação popular em projetos urbanos, no município de São Paulo” orientado pelo Professora Doutora Karin Regina de Casas Castro Marins.
} 
Para os mapas de coeficiente máximo, a variação está entre 0 e 4, sendo que, para o zoneamento vigente, há um predomínio de 0 a 2, exceto nos eixos onde estes valores são os mais altos ("CA $A_{\text {máx }}=4$ "). Para o zoneamento anterior, o $\mathrm{CA}_{\text {máx }}$ estava predominantemente entre 2 e 4. Conforme tabela 42, é possível analisar quantitativamente a distribuição de áreas segundo o CA, referente ao zoneamento vigente e o de 2004.

Tabela 42 - Áreas de Coeficiente de Aproveitamento Máximo do Zoneamento Vigente e do

\begin{tabular}{c|c|c}
\multicolumn{3}{c}{ Zoneamento de 2004 } \\
\hline \multirow{2}{*}{ CA máx. } & \multicolumn{2}{|c}{ Área $\left(\mathbf{m}^{2}\right)$} \\
\hline NA & 1.540 .529 & Z. 2004 \\
$\mathbf{0 , 1}$ & 281.377 & - \\
$\mathbf{0 , 6}$ & 342.917 & 161.211 \\
$\mathbf{1 , 5}$ & 1.047 .180 & - \\
$\mathbf{2}$ & 22.785 .100 & 1.016 .770 \\
$\mathbf{2 , 5}$ & 40.282 & - \\
$\mathbf{3}$ & - & 16.290 .200 \\
$\mathbf{4}$ & 5.493 .870 & 5.848 .940 \\
\end{tabular}

Fonte: Mauad e Cruz (2017) $)^{90}$ - Adaptado de LPUOS (2004, 2016).

Sinteticamente, notou-se por meio dos mapas e tabelas apresentados, que as taxas de ocupação aumentaram, passando de 0 a 0,65, no zoneamento de 2004, para 0,65 a 0,85, na LPUOS de 2016. Com relação aos coeficientes de aproveitamento, no zoneamento vigente, há um predomínio de 0 a 2, exceto na Zona dos Eixos de Estruturação da Transformação Urbana (EETU), onde estes valores são mais altos (“CA = 4"), e no zoneamento de 2004, quando o predomínio do CA era entre 2 e 4.

\subsubsection{Representações Participativas na Região de Estudo}

Foram identificados dois conselhos participativos atuantes na região, provocados formalmente pelo governo municipal, são o Conselho Participativo Municipal e o Conselho Regional de Meio Ambiente, Desenvolvimento Sustentável e Cultura de Paz (CADES). Os Membros do Conselho Participativo Municipal são divididos por distrito. Em Água Rasa são

\footnotetext{
${ }^{90}$ Tabela elaborada pelo o Autor com apoio de Silvia Vitali dos Santos Mauad, como resultado de seu trabalho de iniciação cientifica, com o título“ Diagnóstico da participação popular em projetos urbanos, no município de São Paulo” orientado pelo Professora Doutora Karin Regina de Casas Castro Marins.
} 
oito, no Belém são cinco, no Brás são cinco, na Mooca são oito, no Pari são cinco e no Tatuapé são nove, totalizando 40 membros na subprefeitura. A duração do mandato dos conselheiros é de dois anos, e o conselho é aberto à participação do público que quiser comparecer às reuniões, incluindo associações e movimentos sociais.

Os Conselhos possuem caráter eminentemente público e é organismo autônomo da sociedade civil, reconhecido pelo:

Poder Público Municipal como instância de representação da população de cada região da cidade para exercer o direito dos cidadãos ao controle social, por meio da fiscalização de ações e gastos públicos, bem como da apresentação de demandas, necessidades e prioridades na área de sua abrangência. ${ }^{91}$

Dentre as principais funções executadas pelos Conselhos, estão: o monitoramento da execução orçamentária; a evolução dos indicadores de desempenho dos serviços públicos; a execução do Programa de Metas; o zelo para que os direitos da população e os interesses públicos sejam atendidos nos serviços, programas e projetos públicos da região; o desenvolvimento de ação integrada com conselhos, fóruns e outras formas de organização da sociedade civil; o acompanhamento de audiências públicas e outras iniciativas de participação popular. As reuniões desse Conselho ocorrem em todas as segundas e terças-feiras de cada mês, às 19 horas e 30 minutos, na Rua Taquari, número 549 - Mooca -, dentro do Clube Escola Mooca. Esta informação está divulgada no site da Subprefeitura da Mooca ${ }^{92}$. Semestralmente, o Conselho deve ouvir em plenárias associações, movimentos sociais, outros conselhos e organizações não governamentais. Nas reuniões, são discutidos os problemas observados na região e outras questões referentes às funções executadas citadas. O processo de decisão nestas reuniões, que deveria estar divulgado em regime interno disponível no site, não está divulgado em nenhum local. As atas das reuniões, que também deveriam estar divulgadas, não estão.

Por outro lado, o Conselho Regional de Meio Ambiente, Desenvolvimento Sustentável e Cultura de Paz (CADES) conta com oito representantes da Sociedade Civil (com oito suplentes) e seis conselheiros do Poder Público, sendo eles quatro secretários, um subprefeito e um indicado por este para coordenador, totalizando 14 membros. A duração do mandato dos conselheiros é de dois anos. O CADES tem como objetivo: colaborar com a formulação de políticas municipais de meio ambiente, cultura e paz; apoiar a implementação de Agenda 21

\footnotetext{
${ }^{91}$ Decreto Municipal n 54.156, de $1^{\circ}$ de Agosto de 2013 - Prefeitura do Município de São Paulo.

92 Agenda Disponível em:

https://www.prefeitura.sp.gov.br/cidade/secretarias/subprefeituras/mooca/participacao social/conselhos e orgaos colegiado s/index.php?p=51667 . Acessado em 01 de março de 2019.
} 
local e Agenda Ambiental na Administração Pública; apoiar a implementação do Plano Diretor Estratégico e Planos Diretores Regionais em questões relativas à proteção ao meio ambiente; apoiar ações públicas ou privadas de conservação de meio ambiente, desenvolvimento sustentável e cultura de paz; e promover ações conjuntas com outros Conselhos da região da subprefeitura.

As reuniões do CADES ocorrem em todas últimas segundas-feiras do mês, às 18 horas e 30 minutos, na sala de reuniões da Subprefeitura da Mooca, localizada na Rua Taquari, número 549 (informação divulgada no site da Subprefeitura da Mooca $^{93}$ ). Nessas reuniões, são discutidas pautas previamente divulgadas por e-mail, as quais referem-se aos assuntos citados anteriormente. O processo de decisão ocorre por voto de todos os presentes. Essas deliberações são tomadas por maioria simples (mais da metade dos membros empossados do CADES Mooca), desde que esteja presente a maioria dos membros titulares do Conselho. Apesar de, diferentemente do Conselho Municipal, o CADES divulgar as atas de reunião, a última que está divulgada está bem desatualizada - é de março de 2016.

\subsubsection{Associações de Bairro}

A principal associação de classe presente na Subprefeitura da Mooca é a Associação Comercial de São Paulo (ACSP), uma associação que trabalha pelo interesse dos comerciantes dos bairros Mooca, Alto da Mooca, Água Rasa, Vila Oratório, Belém, Brás, Vila Prudente, São Lucas e Sapopemba. A associação atende desde comércios familiares a grandes indústrias e possui como causas promover ambiente favorável para os negócios e facilitar o empreendedorismo.

Foram também identificadas instituições, associações e organizações que atuam na região, conforme mostrado na figura a seguir, e é latente sua concentração na região da Mooca. Contudo, para os outros distritos da área objeto de estudo, essas instituições ainda serão identificadas. Vale salientar que elas são formalmente instituídas e cadastradas na Prefeitura do Município de São Paulo. No mapa, da figura 39, elas foram classificadas em categorias, tais como Conselhos e Associações de Bairro, Filantrópicas, Culturais, Ambientais e Educacionais. Nesse universo, três associações são mais ativas e mais organizadas na área de estudo:

\footnotetext{
${ }^{93}$ Disponível em:

https://www.prefeitura.sp.gov.br/cidade/secretarias/subprefeituras/mooca/participacao social/conselhos e orgaos colegiado s/cades/ Acessado em 01 de março de 2019.
} 
Associação Amo a Mooca, Sociedade Amigos do Belém e $8^{\circ}$ Conselho de Segurança (Conseg) - Brás, Mooca e Belenzinho.

Figura 39 - Distribuição Espacial das Associações na Área Objeto de Estudo

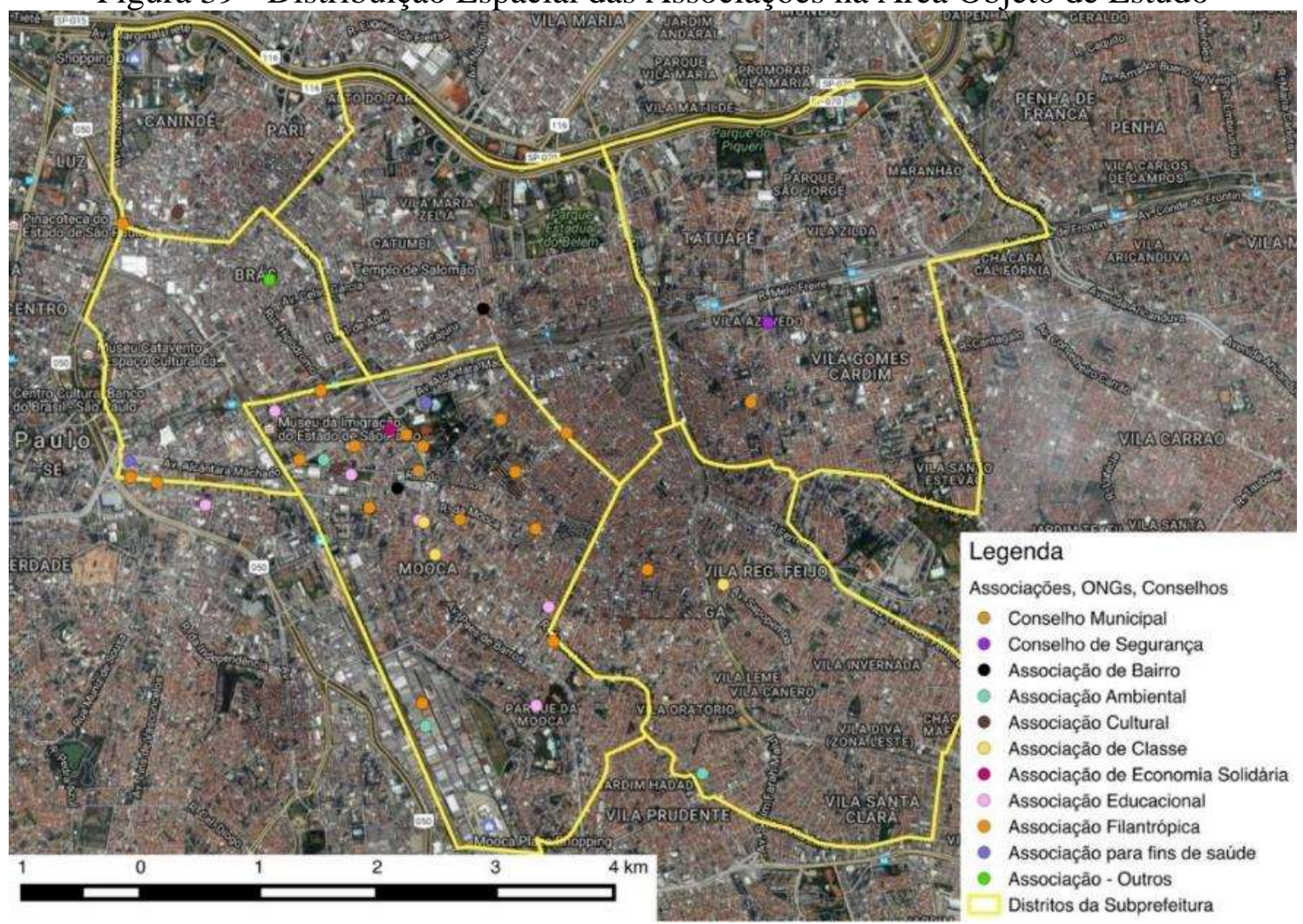

Fonte: Mauad e Cruz (2017) ${ }^{94}$ - Adaptado de GoogleEarth (2017).

A Associação Amo a Mooca (Associação dos Moradores e Amigos da Mooca) foi fundada em 30 de julho de 2001 e atua no bairro Mooca. Realiza reuniões mensais públicas na Rua Javari, número 403, as quais ocorrem nas primeiras quintas-feiras de todo mês. Os objetivos da associação são a preservação, a valorização e a divulgação de história, cultura, arte, esporte e arquitetura do bairro da Mooca, além da valorização da terceira idade. A associação promove várias atividades com esses objetivos, entre elas concursos literários, coral, cursos de línguas estrangeiras, exposição de fotos antigas, festival de inverno, homenagens a exjogadores de futebol amador na Mooca, memórias orais e reuniões mensais. Nas reuniões mensais, são também discutidos os problemas da comunidade, e, inclusive, a associação atribui a ela as seguintes conquistas: Praça Amo a Mooca, Praça Minetti \& Gamba, Praça Pérsio Molina, Praça Vermelha, Crucifixo do Cotonifício Crespi, Espaço Cultural Mooca - Sala Valentim dos Santos, Marco comemorativo "M" dos 450 anos de fundação da Mooca,

\footnotetext{
${ }^{94}$ Mapa elaborado pelo o Autor com apoio de Silvia Vitali dos Santos Mauad, como resultado de seu trabalho de iniciação cientifica, com o título“ Diagnóstico da participação popular em projetos urbanos, no município de São Paulo” orientado pelo Professora Doutora Karin Regina de Casas Castro Marins.
} 
Tombamento do Cotonifício Crespi, Tombamento do Moinho Minetti e Gamba. Ademais, tem como solicitações pendentes: Alargamento da Rua da Mooca (trecho da Rua Borges de Figueiredo/ Rua Piratininga), Estação Mooca/Juventus (CPTM), Parque Municipal da Mooca (Rua Bresser), Plantio de árvores no terreno da feira confinada. ${ }^{95}$

Além das reuniões e dos demais eventos promovidos pela Amo a Mooca, a associação também possui publicações próprias. Dentre elas, a coluna quinzenal no Jornal da Zona Leste, Crônicas da Mooca e Moocalendário.

A Sociedade Amigos do Belém é uma associação atuante no bairro Belenzinho. As reuniões ocorrem no Largo São José do Belém - Belenzinho, São Paulo - SP, 03057-040. Enquanto isso, o $8^{\circ}$ Conseg - Brás, Mooca e Belenzinho - é atuante nos bairros Brás, Mooca e Belenzinho. Ele tem como principal objetivo esclarecer e orientar a comunidade da área quanto às questões de segurança, difundir o conhecimento adequado e prestar atendimento visando a segurança e qualidade de vida, o que é cumprido através de atuação, na comunidade, junto às Polícias Civil e Militar e à Guarda Civil Metropolitana.

\subsubsection{Definição do Recorte Urbano para Aplicação da Proposta Metodológica}

Dada a extensão territorial e populacional da área objeto de estudo, foi selecionado um recorte na área no Distrito do Belém. De acordo com o último censo feito pelo IBGE, no ano de 2010, o bairro do Belém possui uma área de 6 quilômetros quadrados, uma população de 45.057 habitantes e uma densidade demográfica de 7.510 habitantes por quilômetro quadrado. A Figura XX mostra o perímetro da área selecionada e identifica os principais eixos viários e de transporte público coletivo presentes na região conforme destaque da figura 39 .

De acordo com o PDE de 2014 e a LPUOS de 2016, a área reúne pelo menos seis eixos de estruturação urbana, sejam eles existentes ou em projeto. Tratam-se de áreas de adensamento populacional e construído definidos na atualização do PDE em função de eixos específicos ligados ao transporte, aos quais são previstos incentivos construtivos para promover o desenvolvimento de usos residenciais e não residenciais, conforme Lamour (2018).

Essa delimitação do Belém tem um perímetro demarcado em função de eixos de transporte rodoviários e ferroviários. Ao norte delimitado pela eixos rodoviário da marginal do rio Tietê, a leste pelo eixo rodoviário da avenida Salim Farah Maluf, no sul, pela avenida Alcântara

${ }^{95}$ Informações obtidas a partir de visitas e entrevistas realizadas com representantes da associação de bairro em Fevereiro de 2018. 
Machado (radial leste) e o eixo metroferroviário da linha vermelha do metrô paulistano - com uma pequena extensão absorvendo o Sesc Belenzinho, e no oeste pelo viaduto Bresser fazendo a transição para a região do Brás, limitada pela estação Bresser do metrô, conforme figura 40.

Figura 40 - Recorte de aplicação da proposta metodológica
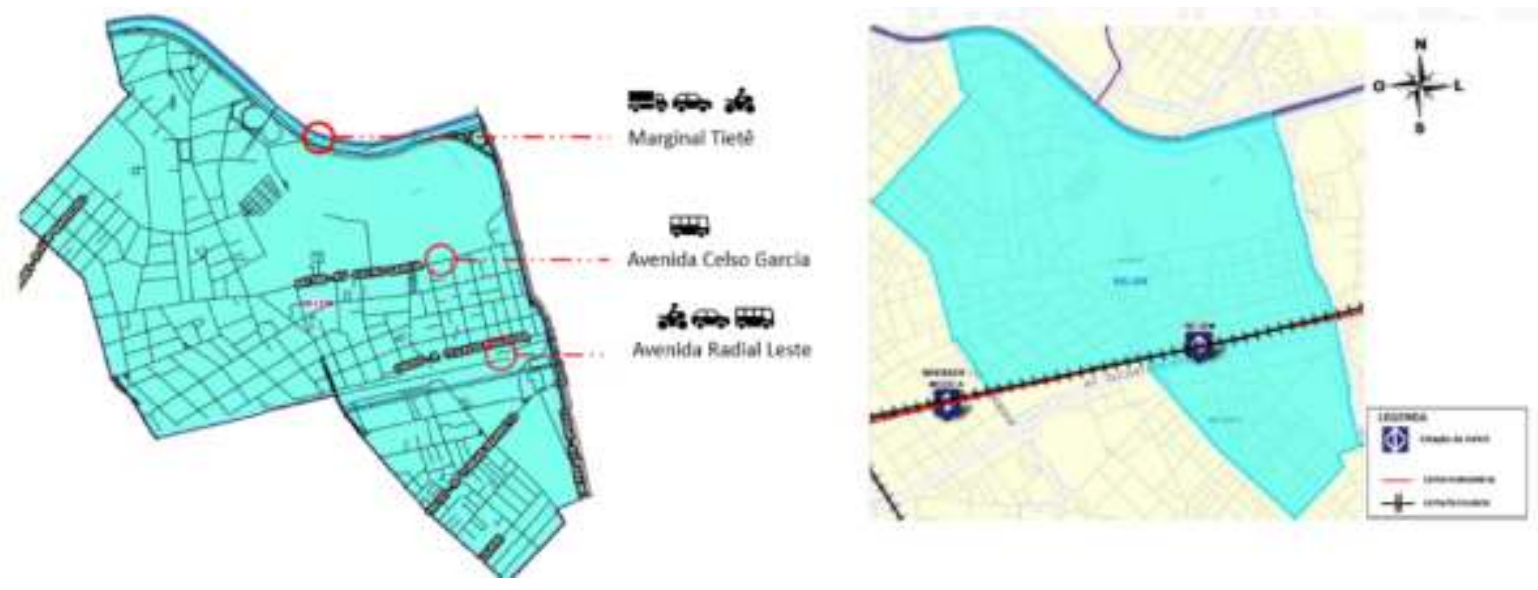

Fonte: Do autor (2019).

\subsection{ANÁLISE DA PARTICIPAÇÃO DA POPULAÇÃO DA SUBPREFEITURA DA MOOCA NA REVISÃO DO PDE DE 2014 E LPUOS DE 2016}

Tendo em vista identificar as características de participação popular na região estudada com relação ao planejamento e gestão urbanas, buscou-se comparar os mapas realizados nas figuras 35, 36, 37,38 e 39, e as áreas calculadas, nas tabelas 38, 39, 40, 41 e 42 com as contribuições dadas pela população da Mooca na audiência pública do dia seis de julho de 2013 (06/07/2013), correspondente à segunda etapa do processo participativo de revisão do Plano Diretor Estratégico do Município de São Paulo - PDE (etapa de levantamento de propostas) ${ }^{96}$. Essa análise teve por base o balanço quantitativo das contribuições ${ }^{97}$, divulgado pela Prefeitura do Município de São Paulo, visando entender o impacto da participação da população na revisão

\footnotetext{
${ }^{96}$ Segundo a Prefeitura do Muncípio de São Paulo, a revisão do PDE foi feita em quatro grupos de atividades simultâneas. O primeiro ocorreu entre 27/04/2013 e 26/06/2013 e foi de avaliação temática do PDE de 2002. Teve 12 atividades, sendo sete temáticas, quatro por segmento e uma conferência. O segundo, que ocorreu entre 08/06/2013 e 27/07/2013, foi de levantamento de propostas. Neste, foram realizadas 31 oficinas presenciais pelo Executivo. O terceiro foi de sistematização das propostas recebidas e ocorreu entre 28/04/2013 e 23/08/2013. Esta etapa foi interna, quando a prefeitura sumarizou as contribuições das etapas anteriores de tal forma que fosse possível realizar devolutivas à população. Por fim, entre 24/08/2013 e 05/09/2013, foi realizado o quarto grupo de atividades, com devolutiva e discussões públicas da minuta do projeto de lei.
}

${ }^{97}$ Arquivos de Sistematização das Contribuições disponíveis no site: <http://gestaourbana.prefeitura.sp.gov.br/arquivos-pdebiblio/>. Acesso em: 1 mai. 2016. 
do PDE de São Paulo, com repercussões na elaboração da Lei de Parcelamento Uso e Ocupação de Solo (LPUOS) de 2016.

O processo de revisão do PDE seguiu a metodologia das audiências públicas. Sua primeira etapa foi realizada segundo quatro fases de desenvolvimento: ( $\left.1^{\mathrm{a}}\right)$ Fase de Avaliação Participativa do PDE de 2002 e de sua aplicação; (2 $2^{\mathrm{a}}$ ) Fase de Recepção de Propostas; ( $3^{\mathrm{a}}$ ) Fase Interna de Sistematização das Contribuições; e $\left(4^{a}\right)$ Fase de Devolutivas à Sociedade e Composição da Minuta do Projeto de Lei do Novo Plano Diretor. Tal abordagem contou com atividades informativas e de reflexão, coletivas (comunitária, por temática ou de um determinado segmento social), sobre aspectos da política urbana regulados pelo PDE. Significou uma fase de "alinhamento" de informações, com identificação e discussão dos principais problemas diagnosticados, tanto nos estudos técnicos, quanto pela experiência dos participantes.

Na elaboração do PDE de São Paulo, foram identificadas duas grandes estratégias, articuladas e complementares, de envolvimento dos cidadãos: (i) o desenvolvimento de atividades participativas presenciais; e (ii) a construção da Plataforma Participativa Digital. A dinâmica das atividades se iniciou com a apresentação de estudos realizados pela Secretaria Municipal de Desenvolvimento Urbano (SMDU), complementada por dinâmicas que buscavam estimular os participantes a formular perguntas, esclarecer dúvidas e expressar sua forma de ver o assunto ou a questão.

O primeiro instrumento adotado foram as fichas, que possibilitavam aos participantes a elaboração de sua contribuição individual. Nas atividades em grupos, as questões temáticas eram conduzidas por um técnico da prefeitura, e os participantes apresentavam suas contribuições ao grupo, que, em conjunto, decidia e votava nas melhores contribuições. Os resultados desse processo foram apresentados nas plenárias, nas quais alguns participantes previamente inscritos também tinham direito a fala.

Foram organizados Seminários, Oficinas de Avaliação Temática, Diálogos Abertos com Segmentos Sociais e a $6^{\text {a }}$ Conferência Municipal da Cidade de São Paulo. Para discussão de questões específicas e retorno da síntese das discussões das plenárias, foram adotados dois instrumentos: (i) seminários para apresentação dos estudos seguidos de debates em plenária; e (ii) oficinas com apresentação dos estudos, seguidas da divisão da plenária em subgrupo. $\mathrm{O}$ formato de oficina, definido pela prefeitura para o debate público e levantamento de propostas, emergiu justificado por se distinguir das tradicionais atividades regidas por listas de inscritos, 
em que poucos participantes conseguem fazer uso da palavra e apresentar suas opiniões e propostas.

Nos seminários, foi definido o tempo de fala de cada participante do debate em aproximadamente três minutos. Durante a exposição dos técnicos, uma equipe de apoio recolhia a inscrição dos interessados em usar a palavra. Além disso, os interessados poderiam apresentar avaliações em formulário específico. A atividade contou com dois técnicos relatores. As colocações foram posteriormente transcritas para os quadros de sistematização, ou seja, as contribuições foram separadas em arquivo eletrônico intitulado Balanço Quantitativo das Contribuições ${ }^{98}$, organizado por atividade participativa.

Nas oficinas, os participantes recebiam o primeiro Volume da Revisão Participativa e informações básicas, com um descritivo das atividades que ocorreriam naquele dia. Depois da apresentação inicial da avaliação técnica realizada sobre o tema do dia, os participantes foram divididos em salas de até 50 pessoas. Um moderador e um apoiador coordenaram a discussão; um relator anotava todas as colocações em formulário padrão. Foram propostas para todas as salas duas ou três questões norteadoras da discussão e, em seguida, as salas foram subdivididas em subgrupos de 8 a 10 pessoas. Cada subgrupo definiu um porta voz. Foram fornecidas fichas coloridas - cada cor correspondendo a uma questão - e os subgrupos puderam compor quantas respostas considerassem adequadas à questão proposta.

Na sequência, os participantes tiveram de agrupar as questões registradas, de modo a facilitar a apresentação, para a sala, das questões consideradas mais relevantes, as quais foram afixadas em um painel. Cada sala contou com um técnico responsável pela relatoria. Parte dos participantes (1/3) respondeu à ficha de avaliação da atividade, classificando-a, na grande maioria, como "bom" e "ótimo", com relação tanto à dinâmica realizada, quanto à estrutura disponibilizada para a atividade.

Os seminários e as oficinas temáticas foram direcionados para lideranças comunitárias, lideranças de movimentos sociais, representantes dos segmentos de universidades, categorias profissionais, trabalhadores representados por suas entidades sindicais, ONGs, empresários e cidadãos em geral. Segundo a prefeitura, versaram (ou versariam) sobre os seguintes temas:

a) Objetivos da Revisão e a Cidade que Queremos;

b) Uso e Ocupação do Solo;

\footnotetext{
${ }^{98}$ Arquivos de Sistematização das Contribuições disponíveis no site: <http://gestaourbana.prefeitura.sp.gov.br/arquivos-pdebiblio/>. Acesso em 01 mai. 2016.
} 
c) Instrumentos de Política Urbana;

d) Habitação;

e) Meio Ambiente;

f) Mobilidade Urbana;

g) Investimentos Prioritários, Planos Regionais e Planos de Bairro.

Segundo a plataforma Gestão Urbana, a revisão do PDE foi feita em quatro grupos de atividades simultâneas. O primeiro ocorreu entre 27 de abril de 2013 (27/04/2013) e 26 de junho do mesmo ano (26/06/2013), e abordou avaliação temática do PDE de 2002. Teve 12 atividades, sendo sete temáticas, quatro por segmento e uma conferência. O segundo, que ocorreu entre 8 de junho de 2013 (08/06/2013) e 27 de julho do mesmo ano (27/07/2013), ocupou-se de levantamento de propostas. Nesta, foram realizadas 31 oficinas presenciais pelo Executivo. $\mathrm{O}$ terceiro tratou de sistematização das propostas recebidas e ocorreu entre 28 de abril de 2013 (28/04/2013) e 23 de agosto do mesmo ano (23/08/2013). Esta etapa foi interna, quando a prefeitura sumarizou as contribuições das etapas anteriores de forma que fosse possível realizar devolutivas à população. Por fim, entre 24 de agosto de 2013 (24/08/2013) e cinco de setembro do mesmo ano (05/09/2013), ocorreu o quarto grupo de atividades, com devolutiva e discussões públicas da minuta do projeto de lei.

Dentre as audiências realizadas na Subprefeitura da Mooca, foi analisada, nesse primeiro levantamento, a audiência realizada em seis de julho de 2013 (06/07/2013). Ela pertenceu ao segundo grupo de atividades. Nessa oficina, foram recebidas propostas referentes às Subprefeituras de Aricanduva, Ipiranga, Mooca, Vila Prudente/ Sapopemba. As pessoas presentes foram divididas em três grupos de discussão, e discutiu-se em grupo e coletivamente as questões que elas julgavam importantes para a região. No total, foram registradas 28 contribuições relativas à Subprefeitura da Mooca, organizadas em 10 objetivos distintos, relativos a moradia, meio ambiente e transporte.

Conforme sumarizado no quadro $18^{99}$ são apresentadas as contribuições da população no sentido de ampliar as oportunidades de trabalho com distribuição na cidade toda, e o que se nota é o desejo da população para incentivos às pequenas e médias empresas, o fomento aos polos comerciais e uma adequação para permanência zonas industriais que podem ser objeto de

\footnotetext{
${ }^{99}$ Quadro 18 elaborado pelo o Autor com apoio de Silvia Vitali dos Santos Mauad, como resultado de seu trabalho de iniciação cientifica, com o título“ Diagnóstico da participação popular em projetos urbanos, no município de São Paulo", orientado pelo Professora Doutora Karin Regina de Casas Castro Marins.
} 
transformação imobiliária. Também no que tange a melhoria da qualidade do transporte público e a melhoria de condições para os ciclistas, de tal forma que ocorra redução nos congestionamentos, apenas uma proposta foi apresentada

Melhorar a qualidade do transporte coletivo público e as condições para ciclistas e pedestres, reduzindo congestionamento que, na realidade, aponta um desejo para que exista uma maior integração entre os modais de transporte, inclusive com funcionamento 24 horas por dia. Contudo, o que chama a atenção, é que em objetivos, tal como o de transporte, a proposta da população solicita que o planejamento de transporte também ocorra com participação social permanente.

Quadro 18 - Propostas para a Subprefeitura da Mooca Resultantes da Audiência Pública

\begin{tabular}{|c|c|}
\hline Objetivo & Proposta \\
\hline \multirow{4}{*}{$\begin{array}{l}\text { Ampliar as } \\
\text { oportunidades de } \\
\text { trabalho com } \\
\text { distribuição na } \\
\text { cidade toda }\end{array}$} & $\begin{array}{l}\text { Respeitar a tendência de desindustrialização da região e a ampla } \\
\text { vocação comercial, com turismo de negócios, melhorando a } \\
\text { regulamentação de ocupação comercial com análise das atuais áreas } \\
\text { de ZEIS, do zoneamento, e a classificação das vias. }\end{array}$ \\
\hline & $\begin{array}{l}\text { Incentivos às micro, pequenas e médias empresas para localização em } \\
\text { zonas mais populosas do município (zonas sul e leste). }\end{array}$ \\
\hline & $\begin{array}{c}\text { Criação de distritos industriais, preservados das pressões do setor } \\
\text { imobiliário, garantindo a permanência da atividade no município e a } \\
\text { segurança de investimentos futuros dos empresários. }\end{array}$ \\
\hline & Criar polos comerciais em operações urbanas, com incentivos fiscais. \\
\hline $\begin{array}{c}\text { Melhorar a } \\
\text { qualidade do } \\
\text { transporte coletivo } \\
\text { público e as } \\
\text { condições para } \\
\text { ciclistas e pedestres, } \\
\text { reduzindo } \\
\text { congestionamento }\end{array}$ & $\begin{array}{l}\text { Integrar de forma eficiente os modais e órgãos públicos, adotando } \\
\text { estratégias de transporte } 24 \text { horas, por meio de planejamento com } \\
\text { participação social permanente. }\end{array}$ \\
\hline
\end{tabular}

Fonte: Do autor (2019) ${ }^{100}$.

Ao analisar o quadro $19^{101}$, com o objetivo de favorecer um maior aproveitamento dos terrenos ao longo dos eixos de transporte nota-se que este aproveitamento deve ser favorecido tanto com residências, como com ofertas de trabalho.

\footnotetext{
${ }^{100}$ Dados consolidados a partir dos Arquivos de Sistematização das Contribuições disponíveis no site: <http://gestaourbana.prefeitura.sp.gov.br/arquivos-pde-biblio/>. Acesso em 01 mai. 2016.

${ }^{101}$ Quadro 19 elaborado pelo o Autor com apoio de Silvia Vitali dos Santos Mauad, como resultado de seu trabalho de iniciação cientifica, com o título“ Diagnóstico da participação popular em projetos urbanos, no município de São Paulo", orientado pelo Professora Doutora Karin Regina de Casas Castro Marins.
} 
Nessa direção existem sugestões para deslocar as zonas especiais de interesse social (ZEIS). Nas questões ambientais o que se percebe é que as propostas, em geral, tratam muito mais de desejos do que efetivamente propostas de soluções e estratégias, salientando que a população deseja um maior aproveitamento do patrimônio público.

Quadro 19 - Propostas para a Subprefeitura da Mooca Resultantes da Audiência Pública

\begin{tabular}{|c|c|}
\hline Objetivo & Proposta \\
\hline \multirow{4}{*}{$\begin{array}{l}\text { Maior } \\
\text { aproveitamento dos } \\
\text { terrenos ao longo } \\
\text { dos principais eixos } \\
\text { de transporte } \\
\text { coletivo com } \\
\text { moradias e trabalho }\end{array}$} & $\begin{array}{l}\text { Deslocar as atuais ZEIS que estão impedindo o desenvolvimento } \\
\text { comercial e de serviços para as áreas laterais às principais vias de } \\
\text { transporte coletivo de alta densidade (trem e metrô). }\end{array}$ \\
\hline & $\begin{array}{c}\text { Descentralizar as funções da cidade, principalmente os polos de } \\
\text { geração de emprego, por meio da criação de instrumentos de incentivo } \\
\text { a empreendedores de todos os portes, estimulando a geração de } \\
\text { oportunidades de trabalho nos bairros mais afastados do centro e, } \\
\text { assim, contribuindo para ampliação do direito à cidade e melhoria da } \\
\text { mobilidade urbana. }\end{array}$ \\
\hline & $\begin{array}{c}\text { Não permitir que se aumente a concentração de polos comerciais, mas } \\
\text { sem mesclar numa mesma região residências e comércios. Isso } \\
\text { diminuiria o trânsito provocado por pessoas fazendo compras e } \\
\text { desafogaria o transporte e vias públicas, na medida em que os } \\
\text { trabalhadores não teriam grandes deslocamentos de casa para o } \\
\text { trabalho e vice-versa. }\end{array}$ \\
\hline & $\begin{array}{l}\text { Ocupação do terreno para fins de moradia popular na região da } \\
\text { Moóca, indicada pelo endereço rua Behring } 251 \text {. }\end{array}$ \\
\hline \multirow{4}{*}{$\begin{array}{l}\text { Proteger e recuperar } \\
\text { o patrimônio } \\
\text { ambiental (rios, } \\
\text { represas, vegetação, } \\
\text { qualidade do ar) }\end{array}$} & Eliminar a poluição dos rios, lagos e riachos. \\
\hline & Combater o uso de fossa crítica, impermeabilizar. \\
\hline & $\begin{array}{c}\text { Meio ambiente: proteção dos mananciais (seguindo os modelos } \\
\text { existentes em outros países), preservação dos parques existentes e } \\
\text { criação de novos parques, recuperação da qualidade do ar, aumento da } \\
\text { vegetação em geral (adote uma árvore). }\end{array}$ \\
\hline & $\begin{array}{c}\text { Partido Patrimônio Cultural: recuperar, preservar e desenvolver o } \\
\text { patrimônio cultural da cidade, arquitetônico e histórico, com a } \\
\text { consideração das várias etnias que constituem a cidade, visando ao uso } \\
\text { social, educativo e turístico. }\end{array}$ \\
\hline
\end{tabular}

Fonte: Do autor (2019). 
Ao analisar o quadro $20^{102}$, com o objetivo de ampliar o acesso às terras urbanas para produção habitacional e promover a regularização fundiária, mais uma vez se nota uma forte demanda associada às ZEIS, por outro lado também surgem demandas especificas , para áreas ocupadas pela população que requerem uma ação efetiva do Estado.

Quadro 20 - Propostas para a Subprefeitura da Mooca Resultantes da Audiência Pública

\begin{tabular}{|c|c|}
\hline Objetivo & Proposta \\
\hline $\begin{array}{l}\text { Proteger e recuperar } \\
\text { os diversos } \\
\text { patrimônios } \\
\text { históricos }\end{array}$ & $\begin{array}{c}\text { Partido Patrimônio Cultural: recuperar, preservar e desenvolver o } \\
\text { patrimônio cultural da cidade, arquitetônico e histórico, com a } \\
\text { consideração das várias etnias que constituem a cidade, visando ao uso } \\
\text { social, educativo e turístico. }\end{array}$ \\
\hline $\begin{array}{c}\text { Ampliar o acesso às } \\
\text { terras urbanas para a } \\
\text { produção } \\
\text { habitacional de } \\
\text { interesse social }\end{array}$ & $\begin{array}{c}\text { Governo deve ampliar a faixa de renda, cujo teto é de } \mathrm{R} \$ 1.600,00 \text {, } \\
\text { para } \mathrm{R} \$ 2.000,00 \text { nos projetos de habitação social, como o Minha Casa } \\
\text { Minha Vida. }\end{array}$ \\
\hline \multirow{4}{*}{$\begin{array}{l}\text { Melhorar as } \\
\text { condições de vida e } \\
\text { de moradia nas } \\
\text { favelas e nos } \\
\text { loteamentos } \\
\text { irregulares com } \\
\text { regularização } \\
\text { fundiária }\end{array}$} & $\begin{array}{l}\text { A prefeitura deve agilizar o processo de doação de áreas, para } \\
\text { habitação social (ZEIS), que foram desapropriadas por decreto. }\end{array}$ \\
\hline & $\begin{array}{l}\text { Regularização e melhoria das áreas e loteamentos de favelas (Vila } \\
\text { Moreira, no Tatuapé). }\end{array}$ \\
\hline & $\begin{array}{l}\text { Mudança de zoneamento de ZEPAM e APP para ZEIS nos } \\
\text { loteamentos com construções já estabelecidas e habitadas. }\end{array}$ \\
\hline & $\begin{array}{l}\text { Regularização e melhoria das áreas de loteamento de favelas em } \\
\text { Tatuapé e Vila Moreira. } \\
\text { Acelerar o processo referente a Vila Moreira e Tatuapé. }\end{array}$ \\
\hline
\end{tabular}

Fonte: Do autor (2019).

\footnotetext{
${ }^{102}$ Quadro 20 elaborado pelo o Autor com apoio de Silvia Vitali dos Santos Mauad, como resultado de seu trabalho de iniciação cientifica, com o título“ Diagnóstico da participação popular em projetos urbanos, no município de São Paulo”, orientado pelo Professora Doutora Karin Regina de Casas Castro Marins.
} 
Ao analisar o quadro $21^{103}$, sobre a melhoria na oferta de serviços, equipamentos e infraestrutura urbana, é possível perceber que as propostas sugerem o incentivo ao uso misto como estratégia de segurança no bairro. Também a elaboração de projetos urbanísticos que incorporem as zonas industriais abandonadas de forma integrada a população residente na região.

Quadro 21 - Propostas para a Subprefeitura da Mooca Resultantes da Audiência Pública

\begin{tabular}{|c|c|}
\hline Objetivo & Proposta \\
\hline \multirow{4}{*}{$\begin{array}{l}\text { Melhorar a oferta de } \\
\text { serviços, } \\
\text { equipamentos e } \\
\text { infraestruturas } \\
\text { urbanas nos bairros }\end{array}$} & $\begin{array}{l}\text { Garantir o uso misto dos novos empreendimentos, gerando oferta de } \\
\text { empregos e segurança para o bairro. }\end{array}$ \\
\hline & $\begin{array}{l}\text { Desenvolvimento urbanístico deveria ser efetuado nas zonas } \\
\text { industriais abandonadas, de maneira a oferecer à população residente } \\
\text { da Moóca iluminação adequada, ruas limpas, locais propícios para a } \\
\text { prática de esportes, lazer e contato com a natureza, a fim de } \\
\text { compensar toda a poluição ambiental e visual gerada pelas indústrias. }\end{array}$ \\
\hline & $\begin{array}{l}\text { Melhorar a oferta de serviços, equipamentos e infraestruturas urbanas } \\
\text { nos bairros, de forma a permitir que a população usufrua de todo o } \\
\text { espaço disponível e não utilizado na Moóca. }\end{array}$ \\
\hline & $\begin{array}{l}\text { Criação de espaços físicos para implantação de serviços interligados - } \\
\text { "Assistência Social e Saúde, para implementar Centros - Dia para } \\
\text { idosos e acolhimento institucional para pessoa com deficiência. }\end{array}$ \\
\hline
\end{tabular}

Fonte: Do autor (2019).

No quadro $22^{104}$ com o objetivo de promover espaços urbanos qualificados para grupos sociais vulneráveis é observada a proposta de um ator especifico para que sua associação utilize um espaço público desocupado, e por outro lado é apresentada a proposta de promover espaços urbanos qualificados para grupos sociais vulneráveis para crianças, idosos, gestantes, pessoas com deficiência, que na realidade é um objetivo e não uma proposta.

Por outro lado, ainda no quadro 22, no âmbito de fortalecer o planejamento e a gestão urbana, descentralizados com participação e controle social, algumas propostas se destacam com sugestão de ações efetivas, como por exemplo a implantação da descentralização regional

\footnotetext{
${ }^{103}$ Quadro 21 elaborado pelo o Autor com apoio de Silvia Vitali dos Santos Mauad, como resultado de seu trabalho de iniciação cientifica, com o título“ Diagnóstico da participação popular em projetos urbanos, no município de São Paulo”, orientado pelo Professora Doutora Karin Regina de Casas Castro Marins.

${ }^{104}$ Quadro 22 elaborado pelo o Autor com apoio de Silvia Vitali dos Santos Mauad, como resultado de seu trabalho de iniciação cientifica, com o título“ Diagnóstico da participação popular em projetos urbanos, no município de São Paulo”, orientado pelo Professora Doutora Karin Regina de Casas Castro Marins.
} 
através de plano de bairro discutido com os moradores do distrito, a implantação do plano de metas na área de habitação, a elaboração de novos critérios no processo de aprovação nos projetos de habitação de interesse social, a criação da ouvidoria por subprefeitura e alteração do zoneamento de uma determinada rua .

Quadro 22 - Propostas para a Subprefeitura da Mooca Resultantes da Audiência Pública

\begin{tabular}{|c|c|}
\hline Objetivo & Proposta \\
\hline \multirow{2}{*}{$\begin{array}{c}\text { Promover espaços } \\
\text { urbanos } \\
\text { qualificados para } \\
\text { grupos sociais } \\
\text { vulneráveis } \\
\text { (crianças, idosos, } \\
\text { gestantes, pessoas } \\
\text { com deficiência) }\end{array}$} & $\begin{array}{c}\text { A Associação Reciclazero tem interesse em uma área situada na Rua } \\
\text { Catumbi, terreno público desocupado, em construir NCI (Núcleo de } \\
\text { Convivência para Idosos), e também uma república de idosos. Dentro } \\
\text { do trabalho, há atuação com o idoso. Construção de um polo } \\
\text { intergeracional com intuito de atender o idoso em situação de } \\
\text { vulnerabilidade social, idoso da comunidade, promovendo ações de } \\
\text { intergeracionalidade. }\end{array}$ \\
\hline & $\begin{array}{c}\text { Promover espaços urbanos qualificados para grupos sociais } \\
\text { vulneráveis para crianças, idosos, gestantes, pessoas com deficiência. }\end{array}$ \\
\hline \multirow{4}{*}{$\begin{array}{c}\text { Melhorar as } \\
\text { condições de vida e } \\
\text { de moradia nas } \\
\text { favelas e nos } \\
\text { loteamentos } \\
\text { irregulares com } \\
\text { regularização } \\
\text { fundiária }\end{array}$} & $\begin{array}{l}\text { Implantar a descentralização regional através do plano de bairro, para } \\
\text { que o planejamento e a gestão urbana, na cidade de São Paulo como } \\
\text { um todo, sejam discutidos com os moradores do distrito. }\end{array}$ \\
\hline & $\begin{array}{l}\text { Implantação do plano de metas e de bairro e cidade na área de } \\
\text { habitação. Elaboração de novos critérios no processo de aprovação } \\
\text { nos projetos de habitação de interesse social. Levantamento de áreas } \\
\text { em desuso, públicas e privadas, para novos projetos habitacionais }\end{array}$ \\
\hline & Criação da ouvidoria por subprefeitura. \\
\hline & $\begin{array}{l}\text { Entendendo que se deve fortalecer o planejamento e a gestão urbana, } \\
\text { como proposta individual, propõe-se alteração do zoneamento na Rua } \\
\text { Serra do Jaire, Moóca, especialmente da Rua Tobias Barreto até a Rua } \\
\text { João Batista de Lacerda, dos dois lados, considerando as edificações } \\
\text { construídas antes do advento da lei de zoneamento }\end{array}$ \\
\hline
\end{tabular}

Fonte: Do autor (2019). 


\subsubsection{Resultados da análise da participação da população do distrito da Mooca na revisão do PDE com relação à aspectos do zoneamento de SP}

Os mapas temáticos e as tabelas do zoneamento foram comparados às contribuições dadas pela população em audiência pública do processo participativo de revisão do PDE. Uma das preocupações da população se refere à poluição presente na região e à falta de áreas verdes. Nesse contexto, tais contribuições poderiam fomentar, nos instrumentos, um aumento de áreas verdes e áreas de preservação permanente. E foi o que se verificou, pois houve um aumento de aproximadamente $70 \%$ nas áreas das zonas especiais de preservação ambiental (ZEPAM) na área objeto de estudo, pelo ponto de vista normativo, apesar de estas ainda serem pouco representativas em relação à área total da subprefeitura $(0,89 \%$ da área da subprefeitura). Somando às demais áreas verdes (parques e outras áreas verdes), o valor aumenta apenas para $4,2 \%$.

Outra demanda frequentemente observada foi referente ao aumento e à melhoria das zonas especiais de interesse social (ZEIS). Cerca de 5 das 28 contribuições permearam essa demanda. Verificou-se um aumento de $30 \%$ nessas áreas, mas esse aumento ocorreu em função do acréscimo de ZEIS-3 ${ }^{105}$ e da criação das ZEIS-5, que se referem a lotes subutilizados localizados em áreas dotadas de boa infraestrutura. As ZEIS-1, áreas ocupadas por favelas e loteamentos irregulares, tiveram decréscimo de 10\%, e as ZEIS-3, referentes a imóveis subutilizados, encortiçados em área com boa infraestrutura, tiveram um aumento de $20 \%$. No entanto, essas áreas ainda representam parte muito pequena frente à demanda da população. No zoneamento anterior, representavam $6 \%$ da área da subprefeitura e, no atual, $8 \%$.

Houve, ainda, uma demanda específica de um grupo para que algumas ZEIS se deslocassem para áreas de transporte coletivo de alta densidade. Realmente, verificou-se que a maioria das áreas de ZEIS-5 foram criadas na região do Eixo de Estruturação. Parte significativa

\footnotetext{
${ }^{105}$ ZEIS -1 são áreas ocupadas por população de baixa renda. Inclui favelas e loteamentos irregulares e alguns conjuntos habitacionais que não estão regulares ainda. ZEIS- 2 são áreas vazias e destinadas à produção de habitação de interesse social para atender. 60\% do que é produzido será para a população com renda de até 3 salários mínimos e $40 \%$ para famílias com até seis salários mínimos. ZEIS 3 são imóveis ociosos, galpões abandonados, deteriorados, cortiços, em locais onde há boa oferta de infraestrutura. ZEIS-4 é uma situação de área vazia, geralmente em áreas de preservação ambiental. ZEIS-5 caracterizada por imóveis subtilizados para construção de Habitação do Mercado Popular (HMP), geralmente essas áreas estão muito próximas de eixos bem estruturados, próximas de outras ZEIS.
} 
das pessoas discutiram sobre a importância da criação e do estímulo de polos de empregos, incentivo a empresas, criação de distritos industriais e manutenção dos existentes. Um possível reflexo disso é a criação, na região, de uma área significativa de ZDE-1 (Zona de Desenvolvimento Econômico), proposta pelo novo Plano Diretor.

A ZDE tem predominância de uso industrial e é destinada para manutenção, incentivo e modernização desse uso, bem como para atividades produtivas de alta intensidade em conhecimento e tecnologia. Ela representa $6 \%$ do território atual. Por sua vez, as áreas de ZPI (Zonas Predominantemente Industriais) já existentes no zoneamento anterior não tiveram mudança significativa em sua área. As zonas mistas, áreas comerciais e residenciais, também inseridas nessa demanda, já eram maioria no zoneamento anterior e continuaram sendo no atual, totalizando 39\% da área. Entretanto, houve redução, pois antes representavam 65\%, maioria absoluta da área da subprefeitura.

Outra interpretação ao incentivo a novos empreendimentos é que estes demandarão maiores permissões construtivas. Entretanto, observou-se que houve diminuição nos coeficientes máximos permitidos. A área de $\mathrm{CA}_{\text {máx }}$ ("CAmáx $=4$ ") teve $19 \%$ de redução. Além disso, este $\mathrm{CA}_{\text {máx }}$ atualmente ocorre principalmente nos eixos de estruturação urbana. No zoneamento vigente, a grande maioria da área (72\%) possui $\mathrm{CA}_{\text {máx }}$ de 2 . No anterior, $96 \%$ da área possuía $\mathrm{CA}_{\text {máx }}$ acima ou igual a 2,5. Apesar dessa diminuição do coeficiente de

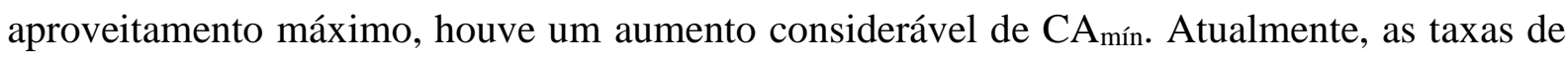
0,3 e 0,5 representam $93 \%$ da área. No anterior, o máximo valor era 0,3 e representava apenas $6 \%$.

Quanto ao parâmetro relativo à ocupação do solo, houve um aumento muito grande. A taxa de ocupação máxima predominante no zoneamento de 2004 era de 0,5, representando 70\% da área da subprefeitura. Atualmente, as taxas de 0,7 e 0,8 representam 93\% da área total da subprefeitura. As demandas da população presente na oficina, a respeito dos objetivos 1 e 3 dos quadros 1 e 2, estiveram, de certa forma, refletidas na mudança do zoneamento, pois houve, na subprefeitura, um aumento da taxa de ocupação máxima nos lotes, um aumento da necessidade de se construir minimamente (aumento do $\mathrm{CA}_{\text {mín }}$ e um aumento de $\mathrm{CA}_{\text {máx }}$ para as áreas dos eixos de estruturação (dotados de transporte público). Houve, ainda, a criação da zona ZDE, que pode propiciar a criação de mais empregos. Com relação à demanda pelas ZEIS, houve um aumento dessas áreas, mas este ainda se mostra pequeno em vista do déficit habitacional presente atualmente. 
Por fim, analisando a participação da população, nota-se ainda problemas para que esta seja considerada representativa. Ela se mostrou reduzida (28 contribuições em uma oficina de PDE de uma subprefeitura com mais de 300 mil habitantes) e falta uma melhor organização do Poder Público para realmente ouvir demandas sociais e se apropriar de possíveis propostas de solução para problemas urbanos.

\subsection{APLICAÇÃO DA PROPOSTA METODÓLOGICA NA ÁREA SELECIONADA NO DISTRITO DO BELÉM, SUBPREFEITURA DA MOOCA, NO MUNICÍPIO DE SÃO PAULO}

A aplicação da proposta metodológica na área objeto de estudo seguirá o roteiro proposto no item 5.1 do trabalho exemplificando, em um estudo de caso, as características dos procedimentos detalhados.

Além disso, para realização da aplicação metodológica, solicitada a aprovação do projeto de pesquisa pela Comissão de Ética em Pesquisa, com apoio da Plataforma Brasil. A pesquisa foi registrada sob o CAEE 65227017.4.0000.5421 e foi aprovada pelo parecer 2.667.959, em 22 de maio de 2018. Assim, todas as atividades práticas realizadas e descritas nessa seção, encontram-se aprovadas pela Comissão de Ética em Pesquisa.

A aplicação da proposta metodológica em um estudo de caso selecionado tem o objetivo de verificar se os procedimentos estabelecidos podem tornar a participação popular mais efetiva e se os insumos produzidos permitem hierarquizar estratégias em planejamento urbano. Por outro lado, a aplicação permitiu a identificação de elementos estratégicos inerentes à infraestrutura pública, aos equipamentos públicos, à ocupação dos lotes, à tipologia dos edifícios e ao planejamento estruturado do uso do solo. Resumidamente, a aplicação da proposta metodológica, neste estudo de caso, tem o objetivo de apontar estratégias de transformação urbana, com vistas ao planejamento urbano, para a melhoria da qualidade de vida, cujo tema da dinâmica desenvolvida foi "Encontro Público para Discutir Questões Fundamentais para a Qualidade de Vida no seu Bairro". Também uma afirmação inportante intriseca à aplicação da dinâmica foi que às soluções poderiam ser estruturadas "Independentemente do custo, da viabilidade, tendo em mente qual seria a cidade ou bairro que gostaria de viver, quais seriam as ações para transformá-lo?”, 


\subsubsection{Aplicação da Etapa de Mobilização}

A mobilização é essencialmente uma tarefa de comunicação e engajamento. Desse modo, foram elaboradas peças gráficas de comunicação visual com intuito de gerar uma identidade e se fazer reconhecer. A identidade visual contou com a chancela da comissão de Pós-Graduação da Escola Politécnica da Universidade de São Paulo, aprovada em Ata do dia 27 de abril de 2018. O projeto foi intitulado "A Cidade é Nossa", e sua imagem segue representada na figura 41. A partir deste padrão de identidade visual, foram elaboradas peças de comunicação, tais como banner, cartazes e convites, informando o local, as datas e os objetivos dos encontros.

O projeto contou com apoio da Pontifícia Universidade Católica de São Paulo, para concessão dos espaços e da infraestrutura física para realização das dinâmicas, localizado à Rua Marquês de Paranaguá, 111 - Consolação, São Paulo.

Em todos os materiais gerados, fez-se constar as informações "Projeto de Pesquisa do Programa de Pós-Graduação em Engenharia Civil", "Pesquisa de Doutorado", "Pesquisador Rafael Barreto Castelo da Cruz", "Orientação de Prof. a. Dra . Karin Regina de Castro Marins", "Projeto não governamental".

Figura 41 - Peças gráfica do padrão de identidade visual
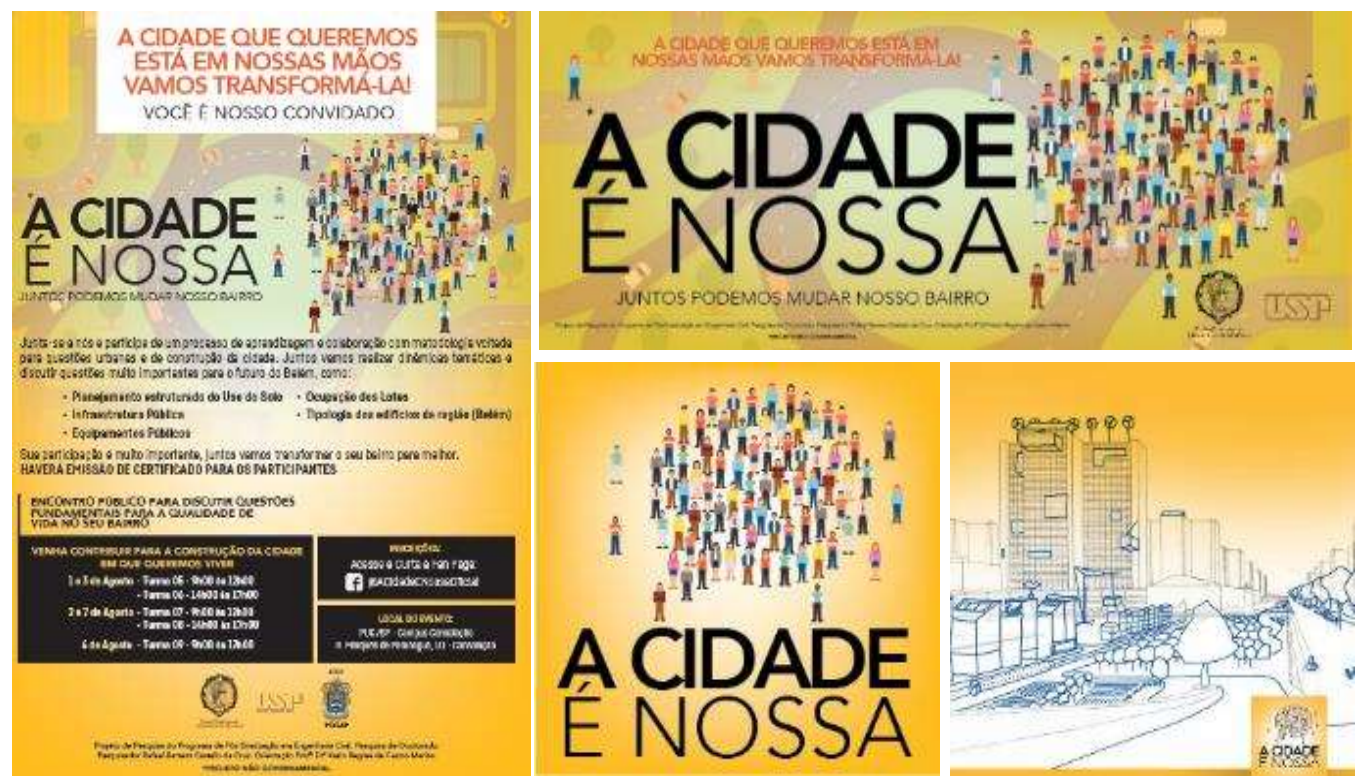

Fonte: Do autor (2019).

$\mathrm{Na}$ atualidade, não se pode ignorar o acoplamento das várias tecnologias, especialmente dos meios eletrônicos. Estes estabelecem um contato cada vez mais intenso e rápido. Então, a primeira ação foi criar uma página institucional nas redes sociais, com o endereço "https://www.facebook.com/acidadeenossaoficial”. A página permitiu gerenciar os encontros, 
criar um canal de comunicação com a população e fornecer conteúdo na temática de planejamento urbano, como mostrado na figura 42.

A partir da página criada, foram propostas quatro agendas de dinâmicas participativas em horários e dias variados. Foram propostas três agendas presencias, durante a semana, sendo duas no período da tarde e uma no período da manhã. A quarta agenda foi proposta para um sábado, nos períodos da manhã e da tarde. As dinâmicas foram distribuídas da seguinte forma:

a) $\mathrm{o} 1^{\circ}$ Grupo de Trabalho, programado com dois encontros presenciais para os dias 17 e 19 de julho de 2018, cada encontro com duração de três horas, no período da manhã;

b) $\mathrm{o} 2^{\circ}$ Grupo de Trabalho, programado com dois encontros presenciais para os dias 17 e 19 de julho de 2018, cada encontro com duração de três horas, no período da tarde;

c) $\mathrm{o} 3^{\circ}$ Grupo de Trabalho, programado com dois encontros presenciais para os dias 2 e 7 de agosto de 2018, cada encontro com duração de 3 horas, no período da tarde;

d) $\mathrm{o} 4^{\circ}$ Grupo de Trabalho, programado com um encontro presencial no dia 4 de agosto de 2018, com duração de 3 horas no período da manhã e 3 horas no período da tarde.

Figura 42 - Capa da página de envolvimento do projeto

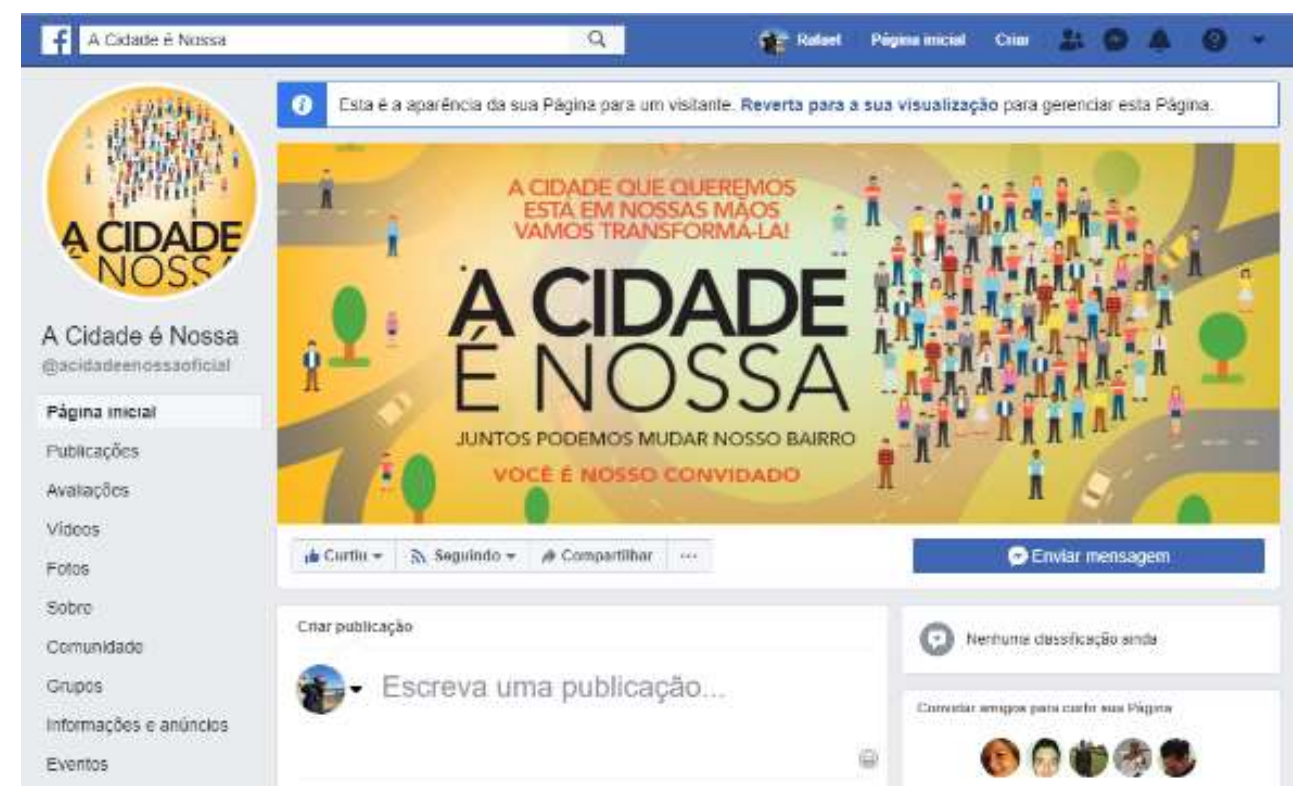

Fonte: Do autor (2019).

As estratégias de convite foram: fixação de cartazes em associações de bairro, escolas públicas e postos de saúde; distribuição de convites impressos no recorte urbano selecionado; compartilhamento do evento no perfil social do Departamento de Engenharia de Construção Civil da Universidade de São Paulo; e envio de e-mail para as associações de bairro atuantes na 
área objeto de estudo. Um exemplo de fixação de cartazes em escola ${ }^{106}$ pode ser destacado na figura 43.

Também foram inseridos cartazes na unidade basica de saúde (UBS) Moóca I, localizada na rua Taquari número 549, na Biblioteca Affonso Taunay, localizada na rua Taquari número 549, na escola técnica estadual Professor Camargo Aranha, localizada na rua Marcial número 25, no centro de educação infantil Indir Maria de Belém, localizado na rua Monteiro do Caminhoá número 83, entre outros edifícos públicos e privados que permitiram a fixação de cartazes.

Figura 43 - Exemplo de cartaz de convite fixado

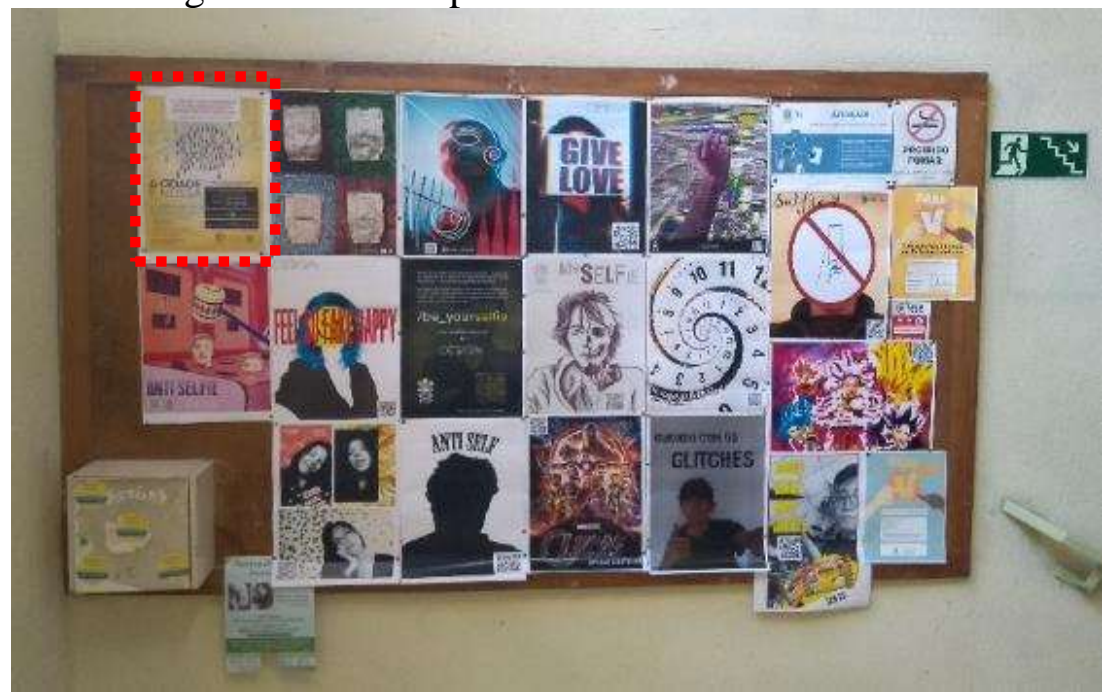

Fonte: Do autor (2019).

Os cartazes, impressos em formato "A3", apresentavam informações sobre as datas do evento, local, acesso para a página virtual do evento e outras informações sobre as dinâmicas, conforme figura 44. A elaboração de certificados é uma estratégia que pode ser adotada de tal forma que os sujeitos percebam que a participação em si é um processo de aprendizado.

Entende-se que a etapa de mobilização deve ser promovida muito além do acesso e divulgação de convites a lideranças locais. Um desafio é criar uma estratégia gráfica, textual e visual que compartilhe do imaginário, das emoções e dos conhecimentos sobre a realidade no entorno da população, gerando reflexão.

Para tanto, decidiu-se empreender a distribuição de convites impressos individuais em cada edificação, trabalho que foi realizado por uma equipe de três pessoas. Foram entregues 2000 endereços na área objeto de estudo, conforme eventos ilustrados na Figura 45. Esta

${ }^{106}$ Cartaz fixado na escola estadual Amadeu Amaral localizada no largo São José do Belém, 66. 
estratégia consolidou a presença territorial. As ações referentes à entrega de convites foram realizadas sistemicamente no período compreendido entre 8 de junho e 3 de agosto de 2018, os convites apresentavam as datas dos encontros e o endereço da página no facebook do projeto.

Figura 44 - Detalhe das informações apresentadas nos cartazes

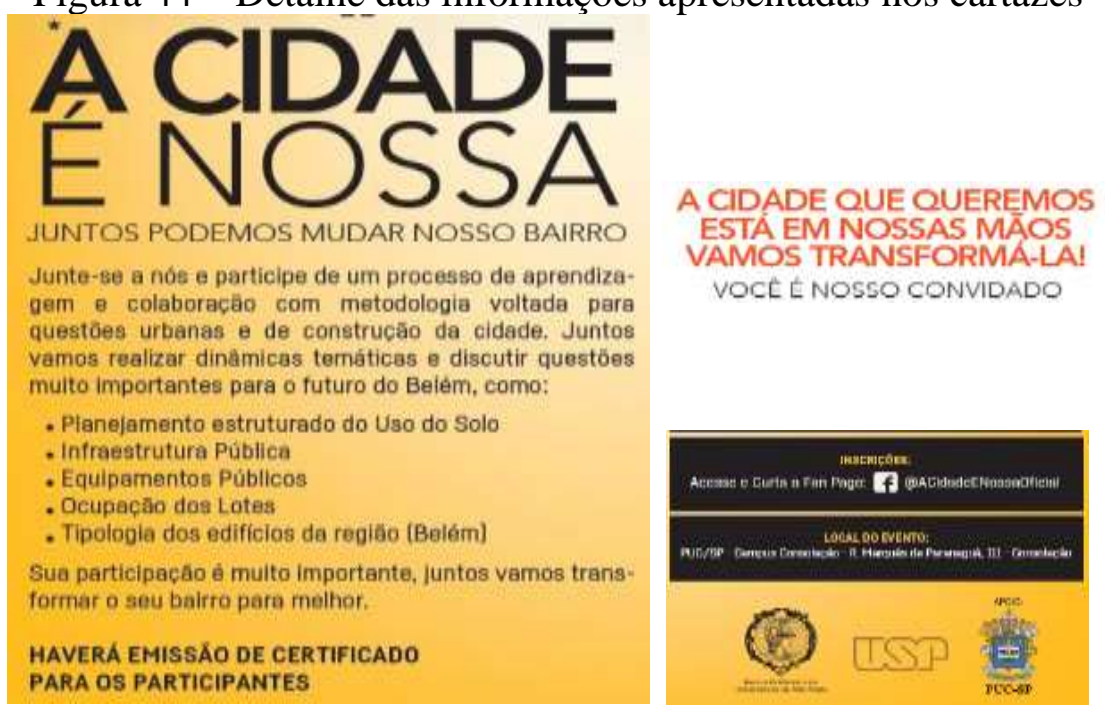

Fonte: Do autor (2019).

Fundamentalmente, é importante tocar a emoção das pessoas, sem, contudo, manipulálas. A troca de informações constitui uma rede de colaboração que, por sua vez, depende da geração de vínculos com a situação objeto de análise. Nesse contexto, foi também preparado um vídeo de mobilização com entrevistas aos moradores, o qual foi vinculado na página ${ }^{107}$ virtual do projeto.

Figura 45 - Convites distribuídos e cartazes fixados
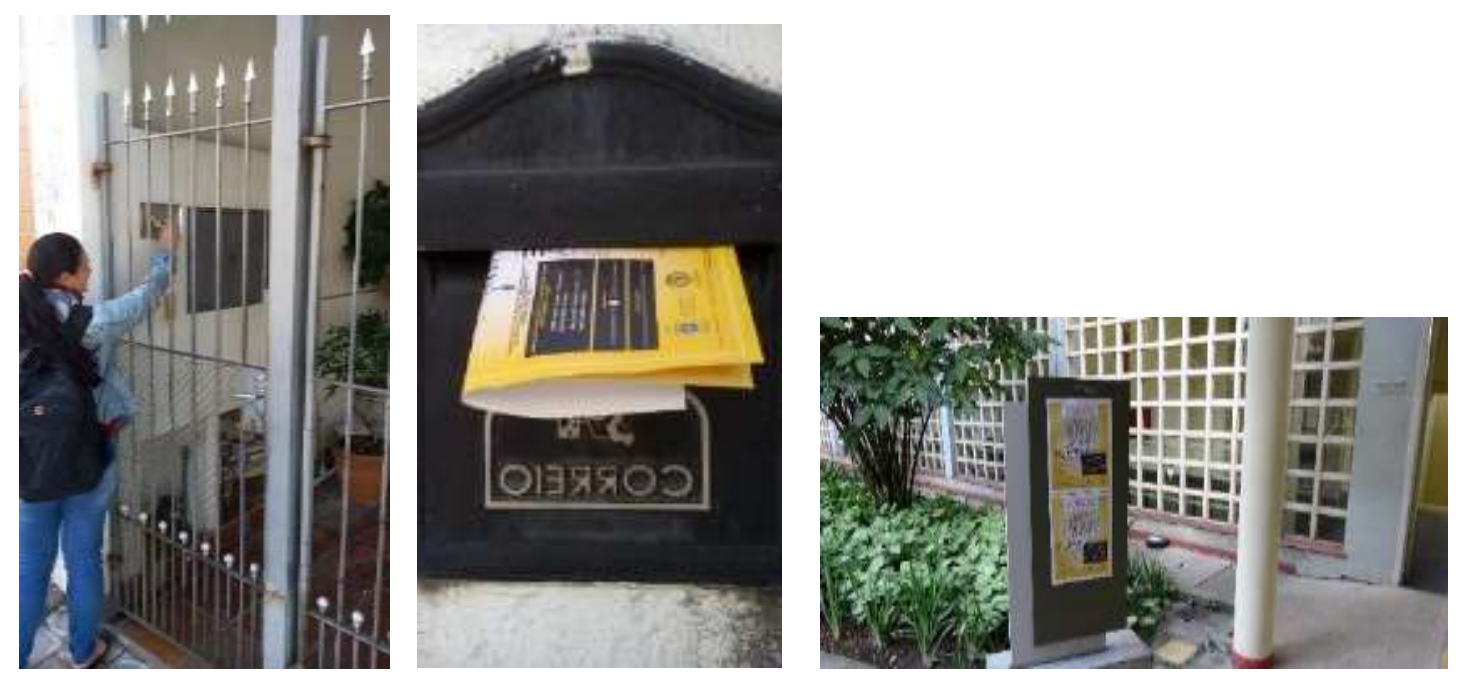

Fonte: Do autor (2019).

\footnotetext{
${ }^{107} \mathrm{O}$ vídeo está disponível no endereço: 〈https://www.facebook.com/watch/?v=411301109369501〉.
} 
As informações circulam nas redes sociais, inclusive sem ação direta dos organizadores das dinâmicas, e, assim, tornam-se persistentes, capazes de ser buscadas e organizadas, direcionadas a audiências invisíveis e facilmente replicáveis. Portanto, as redes sociais são constituídas das representações dos atores sociais e de suas conexões. A gestão desta tarefa foi realizada pela equipe responsável pela aplicação da proposta metodológica. Ainda na etapa de mobilização, para consolidar o processo de aprendizagem e o processo de construção do conhecimento acerca do problema, e para fortalecer o diagnóstico situacional e a criatividade das propostas, a cada dois dias, novos conteúdos foram disponibilizados na página oficial do projeto $^{108}$ ilustrado, conforme figura 46.

Figura 46 - Estratégia de envolvimento com redes sociais

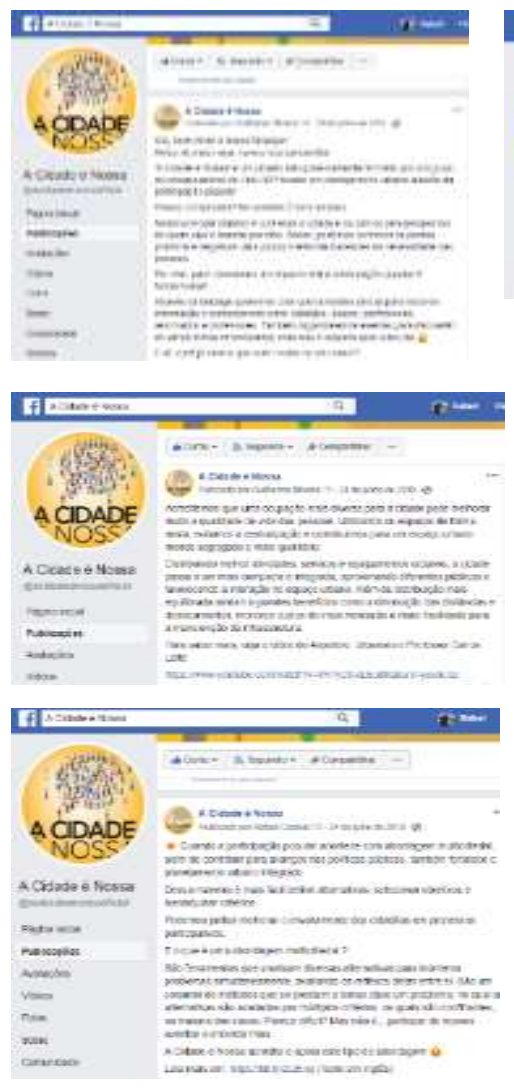

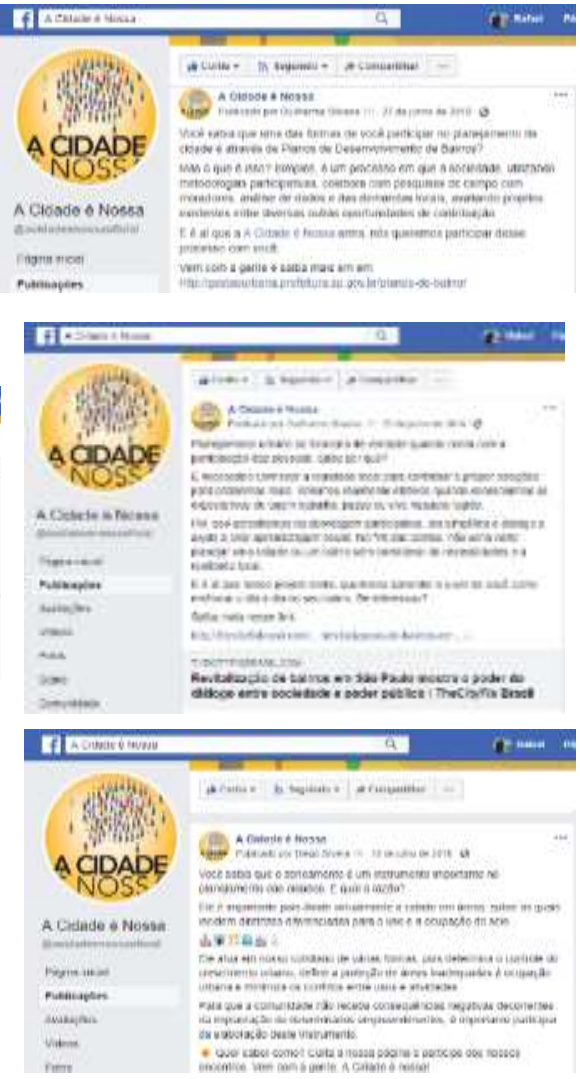

Fonte: Do autor (2019).

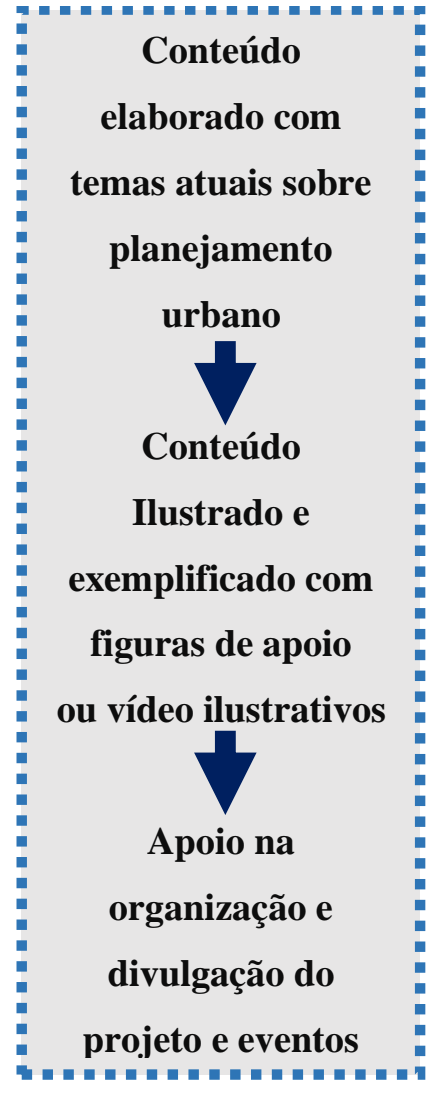

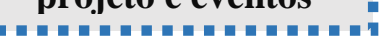

Consoante a essa etapa de mobilização, foi proposto que os interessados realizassem um cadastro simplificado, escolhendo datas e horários de interesse, para que a equipe de organização pudesse planejar o espaço. Objetivamente, foi disponibilizado um link na plataforma Google Forms ${ }^{109}$ com perguntas referentes a: (i) endereço de e-mail; (ii) nome ; (iii)

\footnotetext{
${ }^{108}$ A página está disponível na rede no endereço: < https://www.facebook.com/acidadeenossaoficial/>.

${ }^{109}$ Formulário de inscrição disponível em: <https://goo.gl/forms/P9gqr7RgRpomt3AE2〉.
} 
dias e horários em que participaria das dinâmicas; (iv) cidade em que reside; (v) bairro em que reside; (vi) cidade em que trabalha ou estuda; (vii) bairro em que trabalha ou estuda; (viii) ocupação; (ix) faixa etária; e (x) como ficou sabendo do evento. Esses dados puderam ajudar a equipe a traçar e analisar um perfil dos participantes e as estratégias de convite mais eficientes, bem como a preparar o material das dinâmicas presenciais, em função dos interessados em participar que se cadastraram na plataforma. É importante salientar que o cadastro na plataforma não é um requisito para participar, pois a dinâmica é aberta, inclusive àqueles que receberam convite impresso e não possuem acesso à rede.

A etapa de mobilizaição, deste a criação das peças garficas, desenvolvimento das midias sociais, mobilização e engajamento no bairro foram delienadas em aproximadamente três meses e organizadas, conforme a figura 47.

Figura 47 - Organização da etapa de mobilização

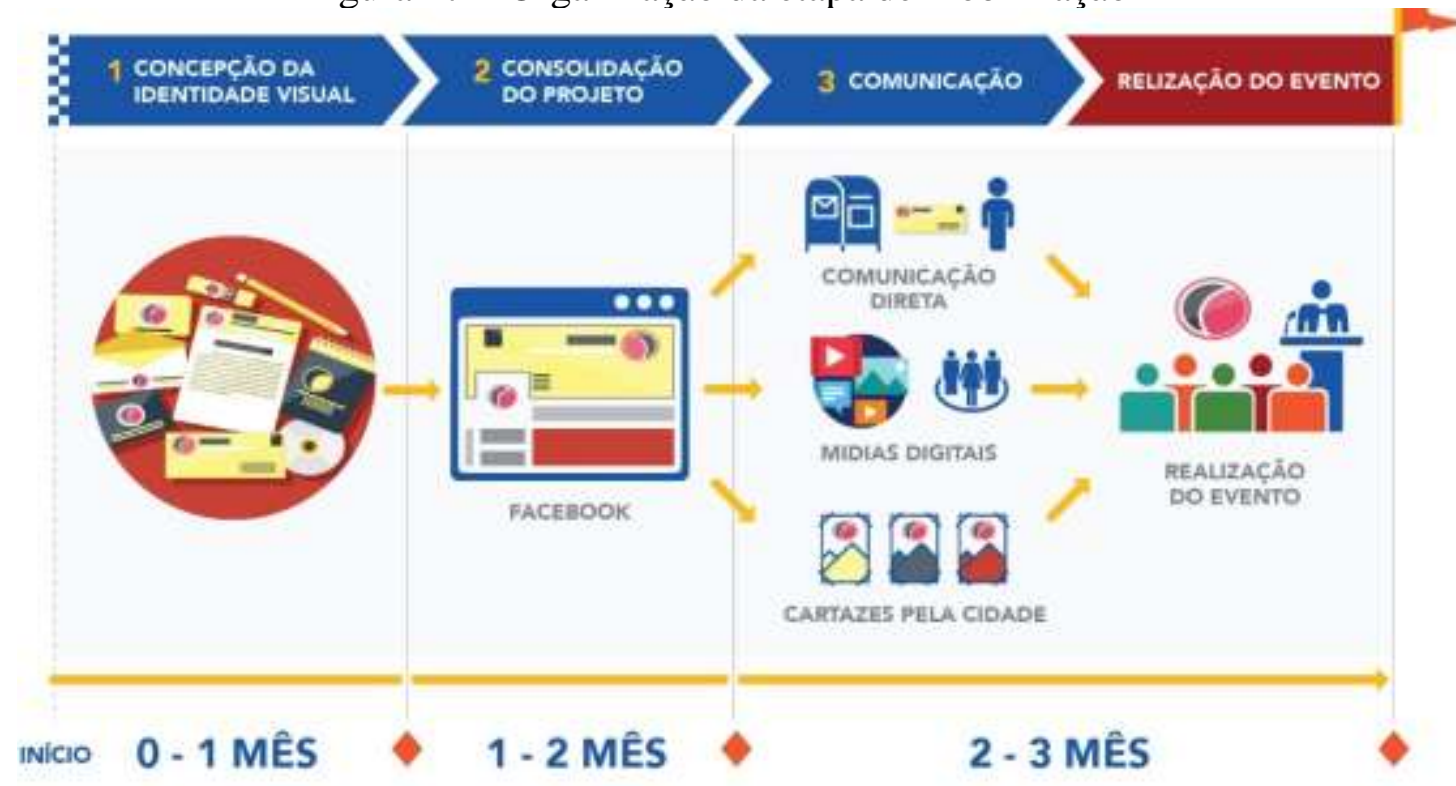

Fonte: Do autor (2019).

\subsubsection{Aplicação da Etapa de Preparação}

Após a realização da etapa de mobilização, é importante criar a arena em que a discussão ocorrerá. O tema da dinâmica desenvolvido foi "Encontro Público para Discutir Questões Fundamentais para a Qualidade de Vida no seu Bairro". Para apoiar a abrangência e a diversidade dos fatores, todo material de comunicação apresentou informações tais como "discutir questões do Belém, como planejamento estruturado do uso do solo; infraestrutura pública; equipamentos públicos; ocupação dos lotes; e tipologia dos edifícios da região". As 
dinâmicas foram realizadas sempre com dois moderadores, um para condução do processo e outro para registro das informações, e foram realizadas no Prédio da Pontifícia Universidade Católica de São Paulo, na Rua Marques de Paranaguá, número 111, no Bairro da Consolação, com os acessos e o local identificados com o padrão de comunicação visual adotado, conforme figura 48 .

Figura 48 - Preparação dos locais e recepção para as dinâmicas
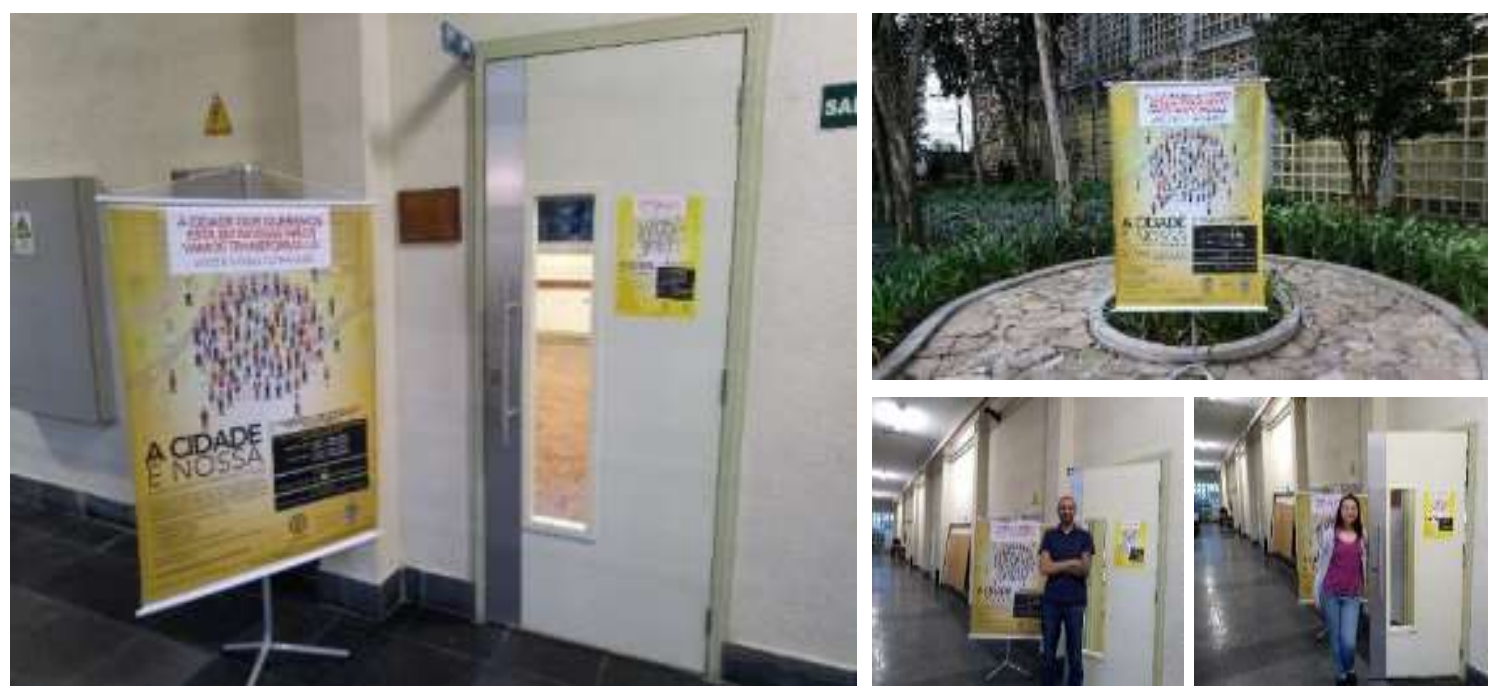

Fonte: Do autor (2019).

O ambiente sem objetos que possam desviar a atenção do grupo ou interromper as discussões facilita a aplicação da dinâmica. A localização dos sujeitos no espaço, cada um com uma mesa e uma cadeira, com disposição em semicírculo ou em formato de "U", de modo que todos possam se ver, facilita a interação entre os participantes, conforme figura 49.

O local de assento de cada participante deve ser planejado de tal forma que evite a proximidade de participantes que já se conhecem (ou possuem alguma familiaridade), então foi adotada a regra de colocar lado a lado (i) pessoas que não se conhecem, (ii) pessoas com maior diferença de idade; e (iii) pessoas com maior diferença de escolaridade.

A sala foi preparada para favorecer a ambientação e concentração do grupo nas atividades com fotografias aéreas da região objeto de estudo, e em cada uma das fotografias, foram destacados pontos de referências (avenidas, clubes, parques, edifícios públicos e terminais de transporte), para que as pessoas pudessem se localizar no território e construir uma visão global de toda a região com os demais participantes, assim como prover informações. 
Figura 49 - Organização das salas para aplicação das dinâmicas
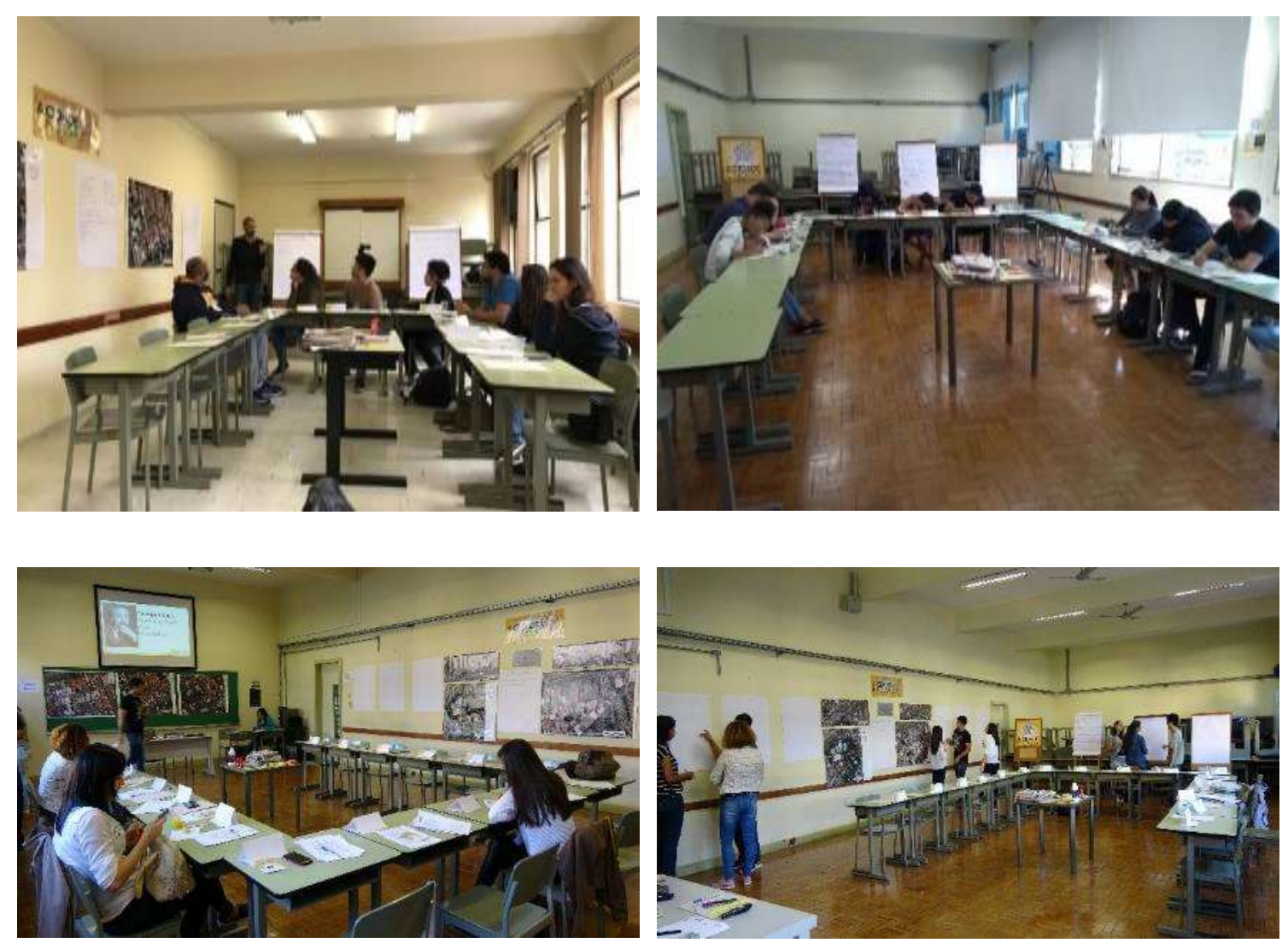

Fonte: Do autor (2019).

A ambientação territorial ajuda na construção da visão de escala. Seguindo o roteiro metodológico, as imagens foram retiradas do Google Earth, em escala 1:500, com a indicação do norte e da marcação dos pontos de referência.

As imagens foram espalhadas nas paredes da sala para que os sujeitos reconhecessem o local de abrangência das atividades, conforme a figura 50. Preliminarmente, houve a impressão de crachás nominais para cada participante - ilustrados na figura 51 -, com o primeiro nome e uma fotografia para facilitar o reconhecimento, o diálogo e um relacionamento inicial de personificação do indivíduo no grupo.

Ademais, a impressão da identificação do local onde cada pessoa deverá ter assento favorece a organização do espaço e a proposta de que as pessoas com maior diversidade se localizem próximas umas das outras, conforme figura 52. 
Figura 50 - Preparação da sala com fotografias e mapas da aera objeto de estudo
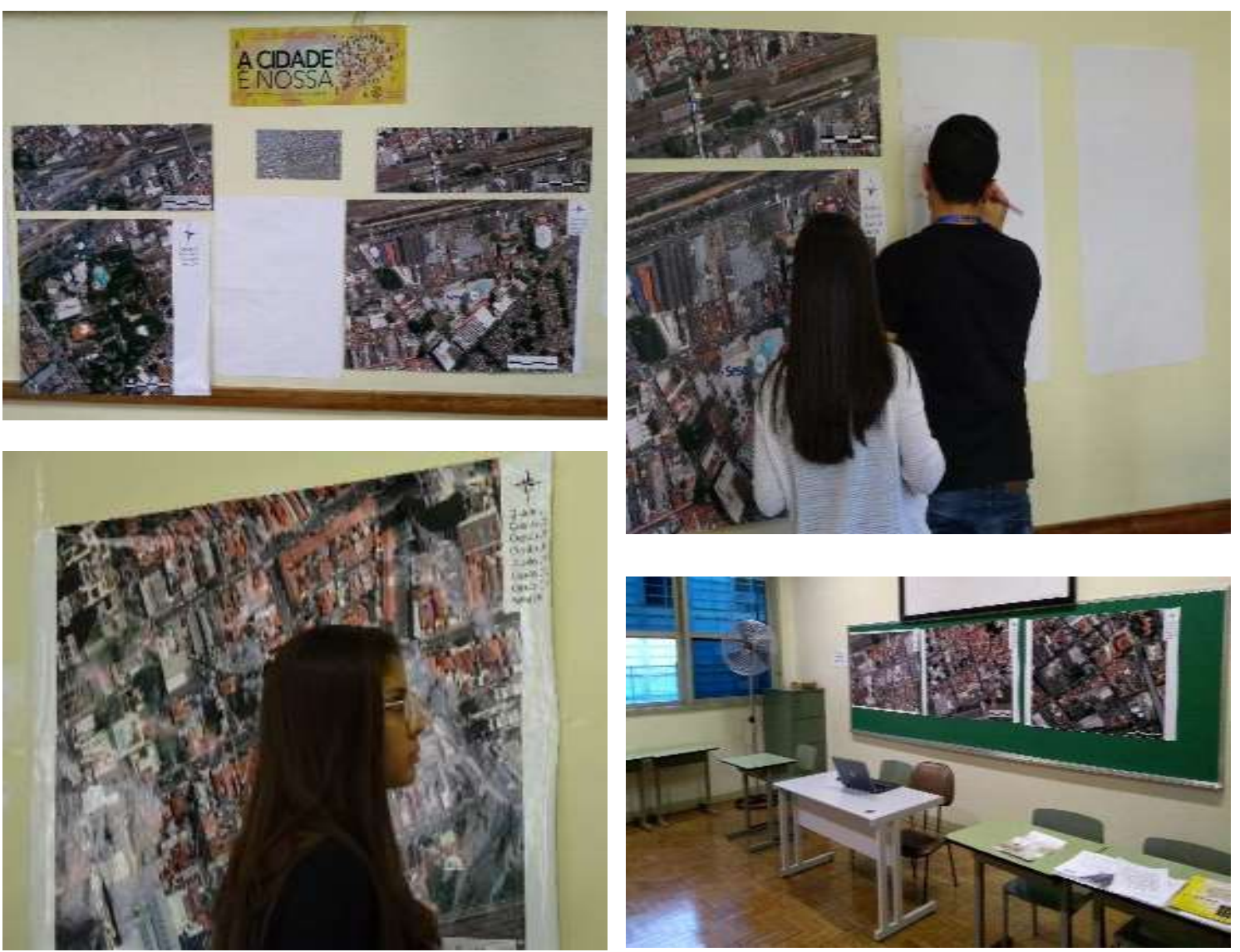

Fonte: Do autor (2019).

Figura 51 - Crachá de participante

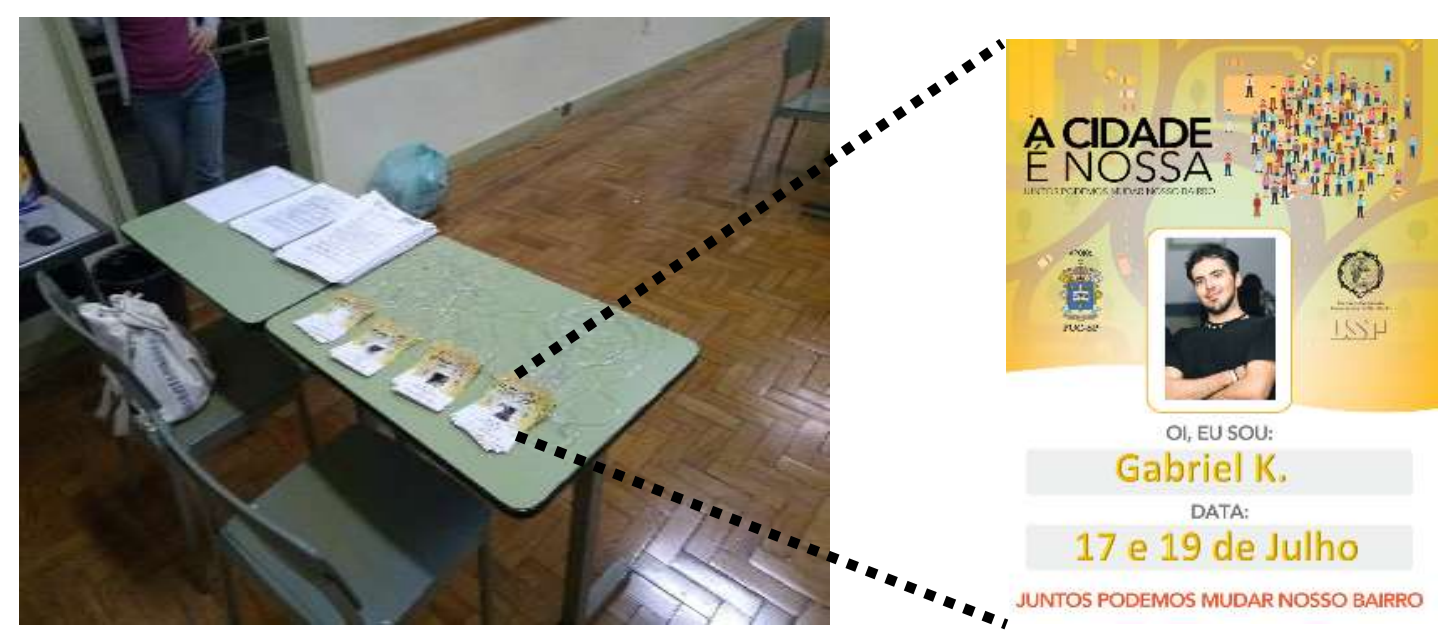

Fonte: Do autor (2019). 
Figura 52 - Posicionamento e identificação das mesas
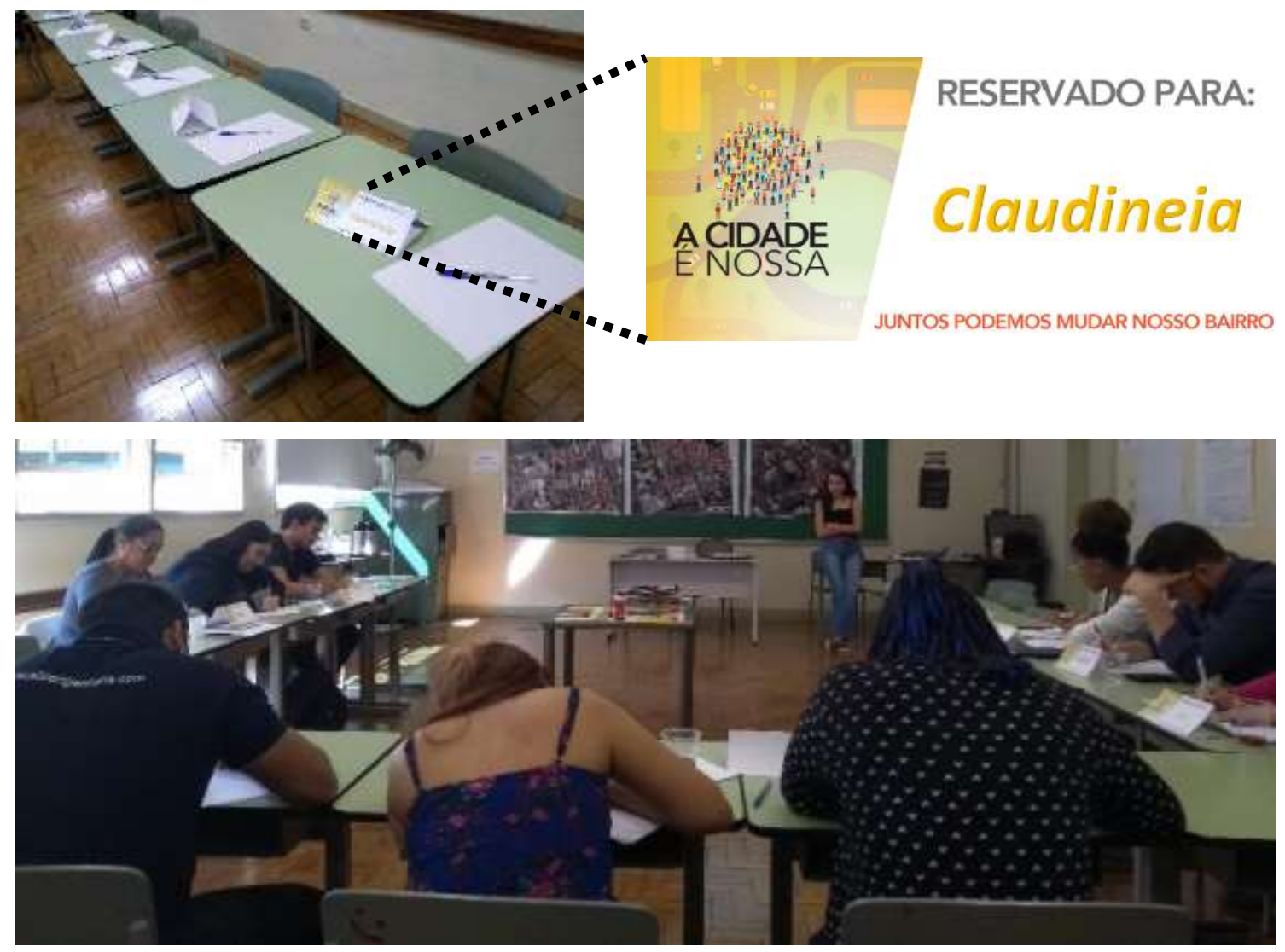

Fonte: Do autor (2019).

Para a construção da percepção social e de conhecimento, deve ser criado um ambiente que acolha a importância de uma abordagem compreensiva na intervenção, o que inclui aspectos cognitivos e afetivos, e este é um ambiente de acolhimento. Portanto, devem ser planejados detalhes da preparação física do espaço, da identificação dos participantes e da determinação dos locais onde cada participante terá assento, para que o ambiente seja favorável ao processo criativo.

\subsubsection{Aplicação da Etapa Inclusiva Propositiva}

As dinâmicas propuseram a identificação dos problemas e objetivos da população para a região do Belém, no primeiro dia de dinâmica, denominado Etapa Inclusiva Propositiva. A etapa teve como objetivo determinar os problemas e as alternativas pertinentes à região. Foram então aplicados cada um dos passos (ou atividades) referentes a essa etapa da proposta metodológica, a saber: (a) Recepção; (b) Dinâmica de Apresentação; (c) Dinâmica de Estímulo Positivista; (d) Registro de Expectativas; (e) Exposição do Moderador; (f) Painel de Seleção de Problemas; (g) Tempestade Cerebral de Soluções; (h) Painel Gráfico Colaborativo da Visão; e 
(i) Proposta de Sensibilização do Olhar e Retomada do Registro de Expectativas e Encerramento. $\mathrm{O}$ detalhamento passo-a-passo constou das seguintes atividades:

a) Recepção: Em todas as dinâmicas, as pessoas foram recebidas da mesma maneira - na entrada, recebiam o crachá, eram encaminhadas ao lugar demarcado, assinavam a lista de presença, o termo de consentimento livre esclarecimento (TCLE), conforme Apêndice, e um formulário inicial de percepção (que deveria ser preenchido em caneta de cor azul), conforme figura 53.

Figura 53 - Aplicação da atividade de recepção
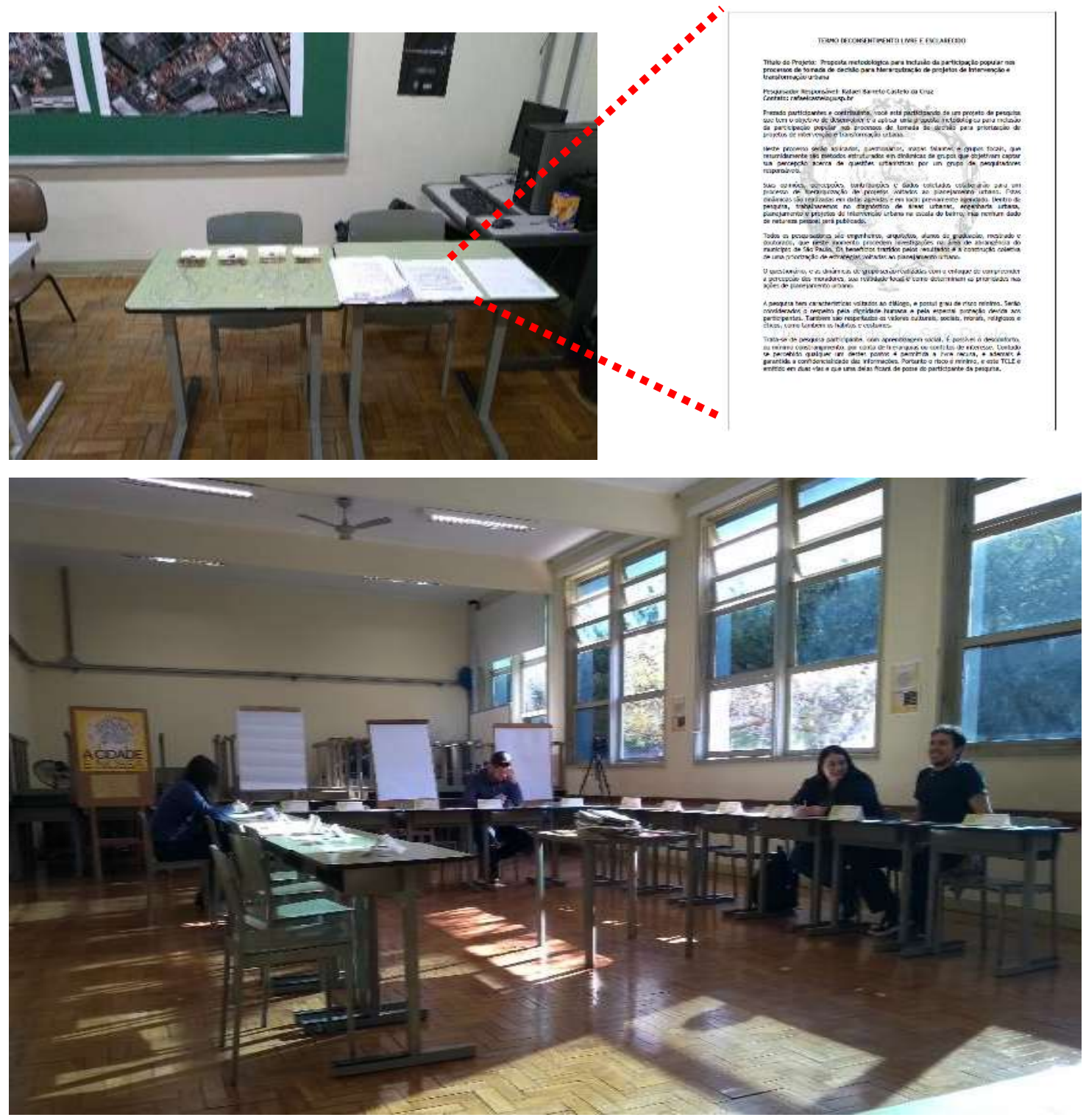

Fonte: Do autor (2019).

O formulário de percepção foi dividido em três blocos. O primeiro bloco, para caracterização do perfil dos participantes, incluía seis perguntas sobre idade, gênero, escolaridade, atividades que realiza na cidade e renda. $\mathrm{O}$ segundo bloco, com perguntas 
para avaliação da cidade e do bairro, incluía atribuição de notas para aspectos como segurança, qualidade dos serviços públicos, mobilidade, custo de vida, tempo de deslocamento na cidade, frequência de utilização do transporte público, utilização de espaços públicos e desejos sobre a cidade. O terceiro e último bloco incluía perguntas sobre política urbana, especificamente sobre o Plano Diretor do Município de São Paulo;

b) Dinâmica de Apresentação: a atividade consistiu em separar as pessoas em duplas, geralmente as sentadas ao lado uma da outra, a fim de que a pessoa " $A$ " se apresentasse individualmente para a pessoa "B", e, em seguida, a pessoa “'B" se apresentasse individualmente para a pessoa "A", usando entre 5 e 10 minutos, tempo sugerido para esta etapa. Depois, as pessoas foram convidadas a se apresentar em voz alta para todo o grupo, mas a pessoa "A" se apresentaria ao grupo como se fosse a pessoa "B" e viceversa, conforme exemplo da figura 54.

Figura 54 - Representação da dinâmica de apresentação

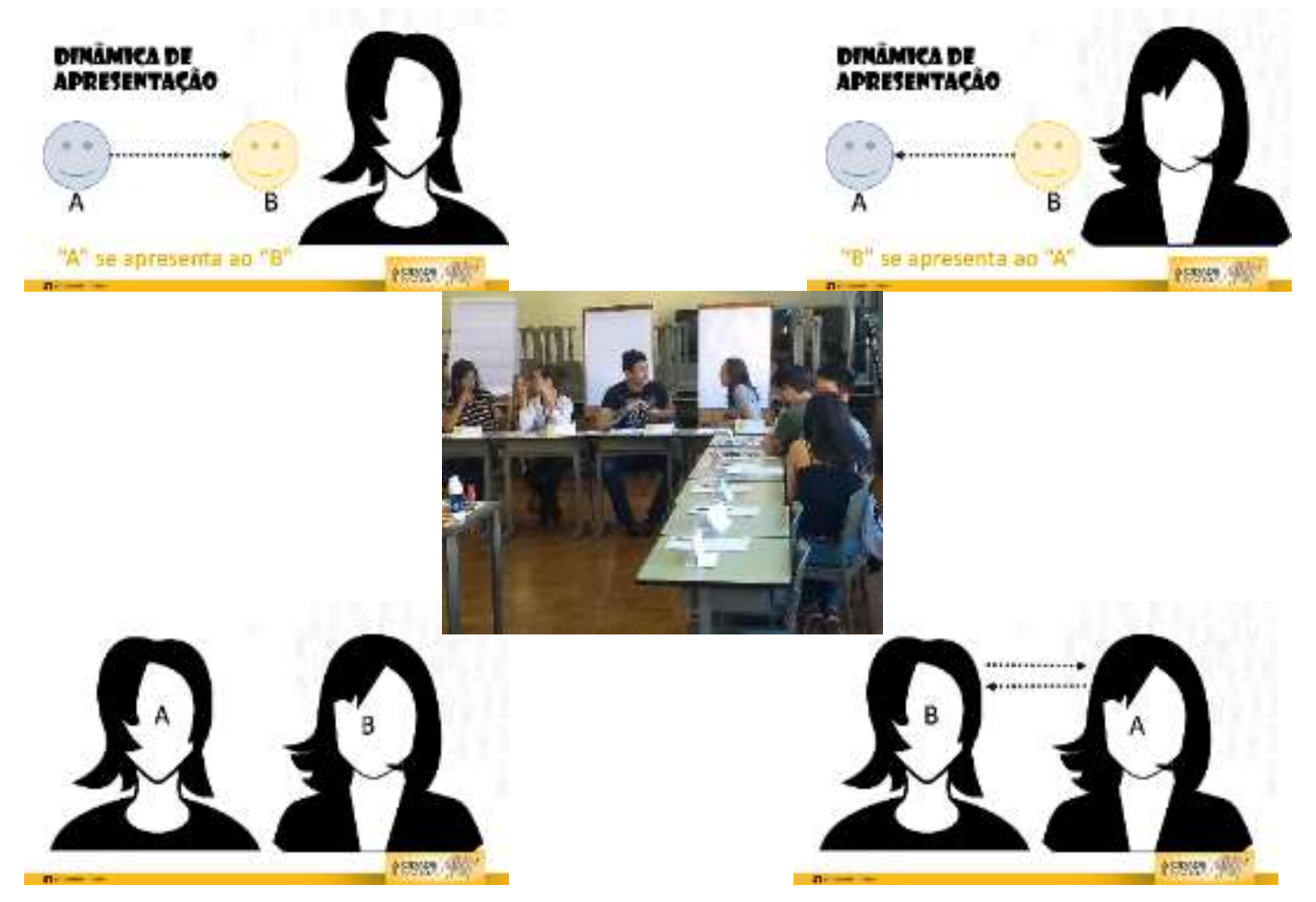

Fonte: Do autor (2019).

Esta etapa, embora não produza resultados mensuráveis, permite que as pessoas possam se colocar no lugar das outras, e, assim, o ambiente positivo para troca de percepções é cultivado. Buscou-se que os sujeitos pudessem entender mais facilmente as opiniões, ideias e visões de uma outra pessoa, antes de possíveis julgamentos. De qualquer forma, 
é importante ter claro que dinâmica teve como objetivo estimular os participantes a refletir sobre como escutar e entender os demais e, assim, auxiliar na construção dos consensos;

c) Dinâmica de Estímulo Positivista: os sujeitos deveriam expressar livremente seus juízos, sem pedir permissão e sem criticar nenhum ponto de vista. Para isso, a proposta metodológica sugeriu que fosse reservado, no fundo da sala, um painel em branco, chamado de Painel de Killer Phrases, ou Painel de Frases Mórbidas, o qual era reservado para que os participantes preenchessem com frases ou críticas destrutivas, conforme figura 55.

Figura 55 - Painel de frases mórbidas

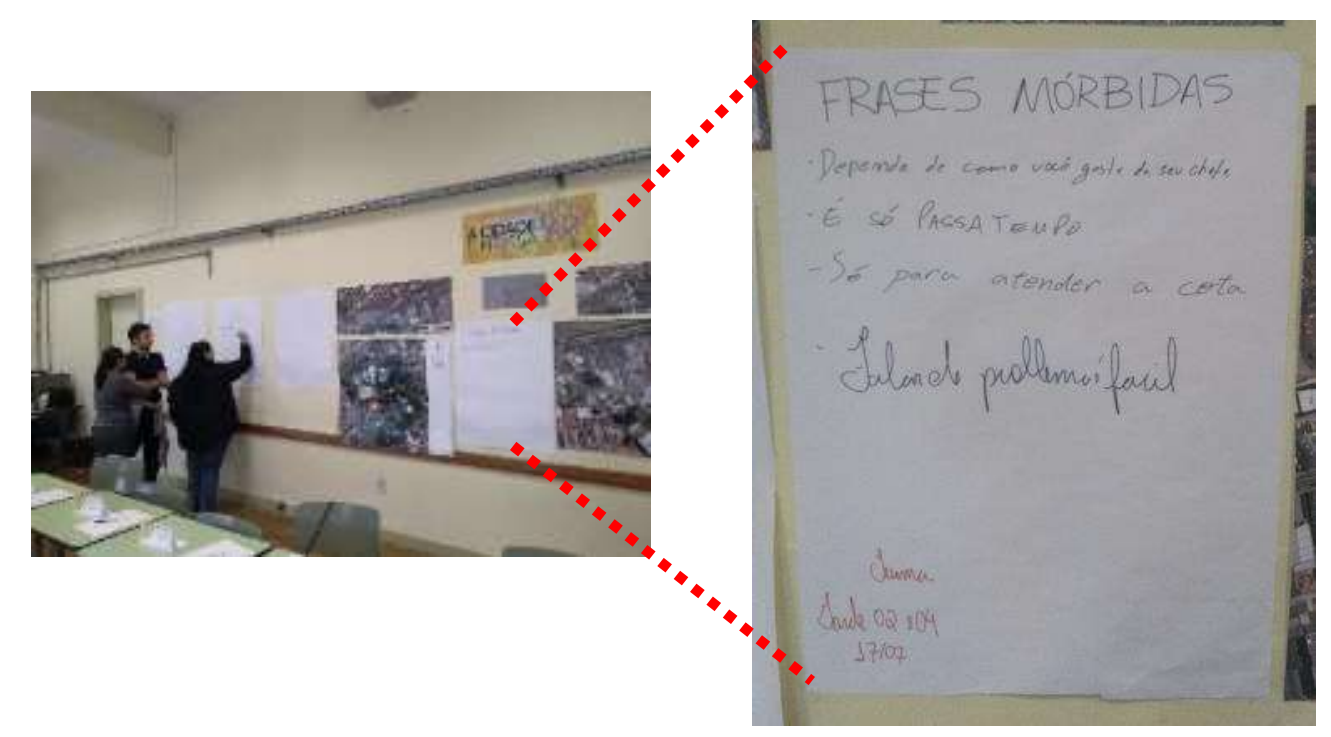

Fonte: Do autor (2019).

Nesta dinâmica, foram utilizados como materiais um flip-chart e canetas coloridas. O moderador deveria esclarecer que a única regra do espaço era não criticar as ideias, de forma que todas as contribuições seriam bem-vindas, afinal, por ora, o importante era a quantidade de percepções e não a qualidade delas. Esta etapa não produz essencialmente resultados, contudo favorece o cenário para que os resultados sejam obtidos nas demais atividades;

d) Registro de Expectativa: neste momento, foi solicitado às pessoas que verbalizassem suas intenções, no evento, principalmente explanando os motivos para sua participação na dinâmica. O moderador deveria começar perguntando sobre as expectativas, um a um, sem julgar o que viria a ser respondido. Assim, as contribuições começariam a aparecer naturalmente e seriam registradas em um painel, conforme figura 56. 
Figura 56 - Painel de Expectativas

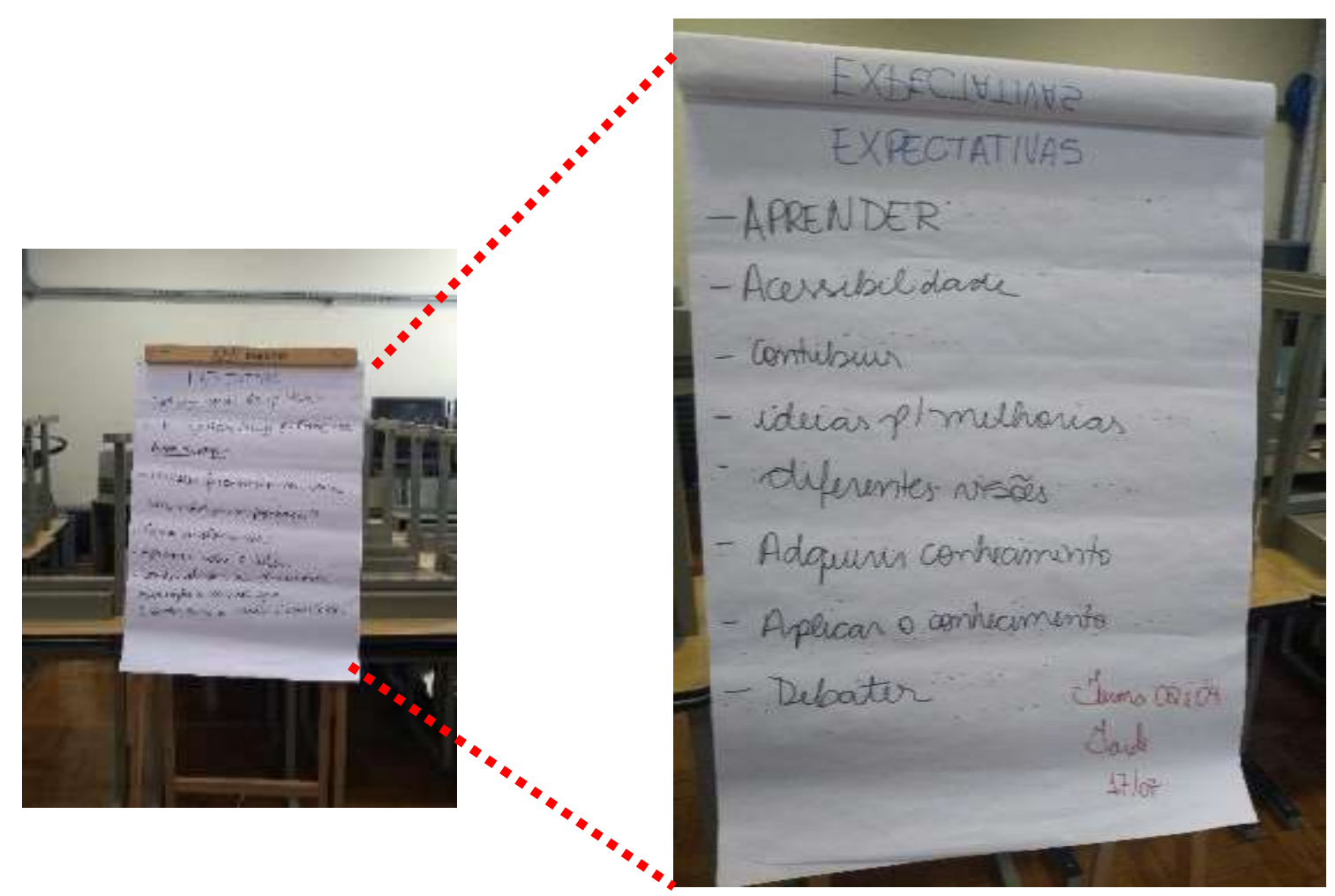

Fonte: Do autor (2019).

Nesta dinâmica, foram utilizados como materiais um flip-chart e canetas coloridas. Os protagonistas da ação foram os sujeitos, e o registro das expectativas no painel resultou em um quadro que permite avaliar as razões da atuação das pessoas em espaços participativos, então deveriam ser registradas e analisadas as expectativas;

e) Exposição do Moderador: foi elaborada uma apresentação com o intuito de fomentar uma problematização, como forma de estimular os participantes a refletir sobre suas condições e sobre seus objetivos para o futuro, bem como sobre as possíveis maneiras de atingi-los, destacando o funcionamento dos instrumentos legais de planejamento urbano no Brasil. Intrinsecamente, também foram apresentados os dados que caracterizam a região. A ação pode ser ilustrada na figura a 57.

$\mathrm{Na}$ apresentação, tomou-se o cuidado de não influenciar os participantes com externalidades positivas ou negativas do processo de urbanização, dos instrumentos legais e da região. A preocupação se deu em torno de permitir a construção de uma base teórica a todos, incluindo as possibilidades legais e dados oficias de caracterização local; 
Figura 57 - Telas de apresentação do moderador
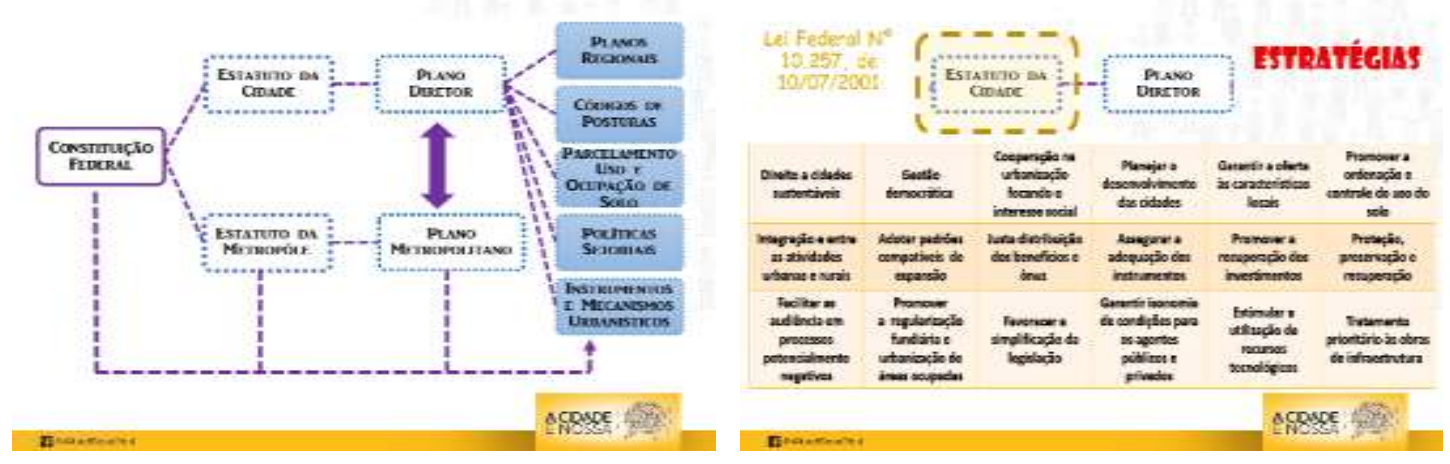

\section{CARCATERILAÇÃO DA AREA}
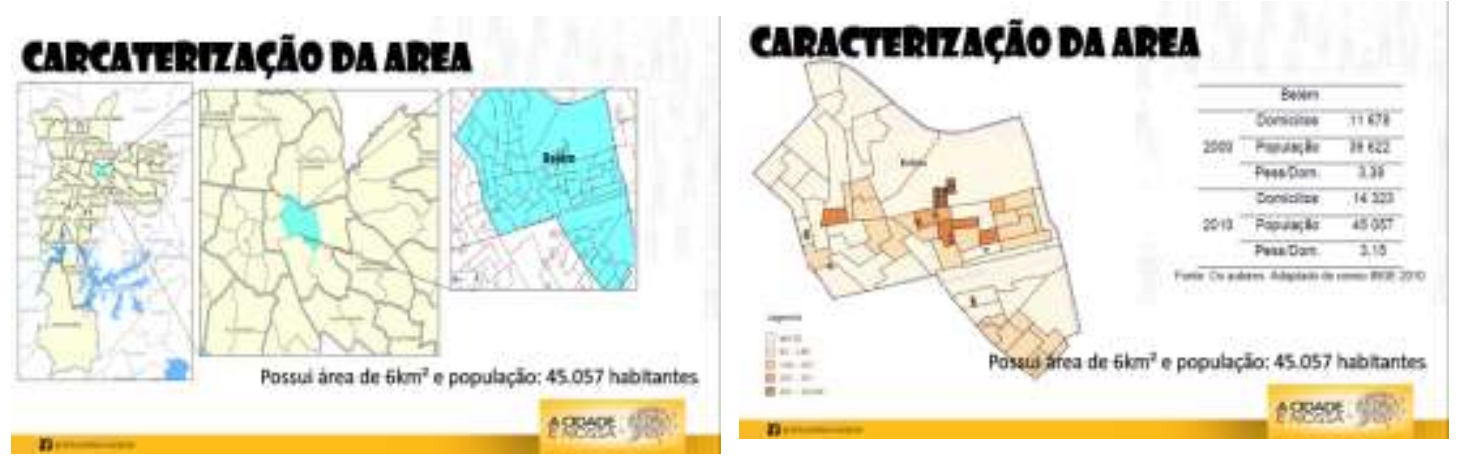

Fonte: Do autor (2019).

f) Painel de Seleção de Problemas: os participantes foram separados em subgrupos (de três a quatro pessoas), seguindo a lógica de agrupar pessoas com maior diversidade (o critério utilizado foi a idade, seguido da escolaridade, da renda e, por fim, de gênero). Para o delineamento e a identificação dos problemas, foram apresentadas as questões de problematização "Quais os problemas do seu bairro ou da cidade?" e "O que menos gosta no bairro ou na cidade?". Cada subgrupo foi identificado com uma cor e escreveu em seu painel os problemas, durante 5 a 10 minutos, e, ao fim do tempo, cada subgrupo foi alocado no painel de outro subgrupo. Nesta dinâmica, é importante ter claro que a problemática visa estimular os participantes a refletir de forma colaborativa e sem receios sobre o problema e sobre os apontamentos dos grupos anteriores a eles. É normal o grupo se sentir intimidado no início dos trabalhos, então sempre foi verificado se todos estavam seguindo as regras estabelecidas de não julgar as ideias apresentadas, para que as contribuições começassem a aparecer naturalmente. Essa dinâmica pode ser ilustrada pela figura 58. Nesta dinâmica, foram utilizados um flip-chart e canetas coloridas. Durante o processo, foi indicado aos participantes que, sempre que possível, escrevessem verbos no infinitivo, de tal forma que os problemas se manifestassem orientados à ação. 
Figura 58 - Aplicação do Painel de Seleção de Problemas
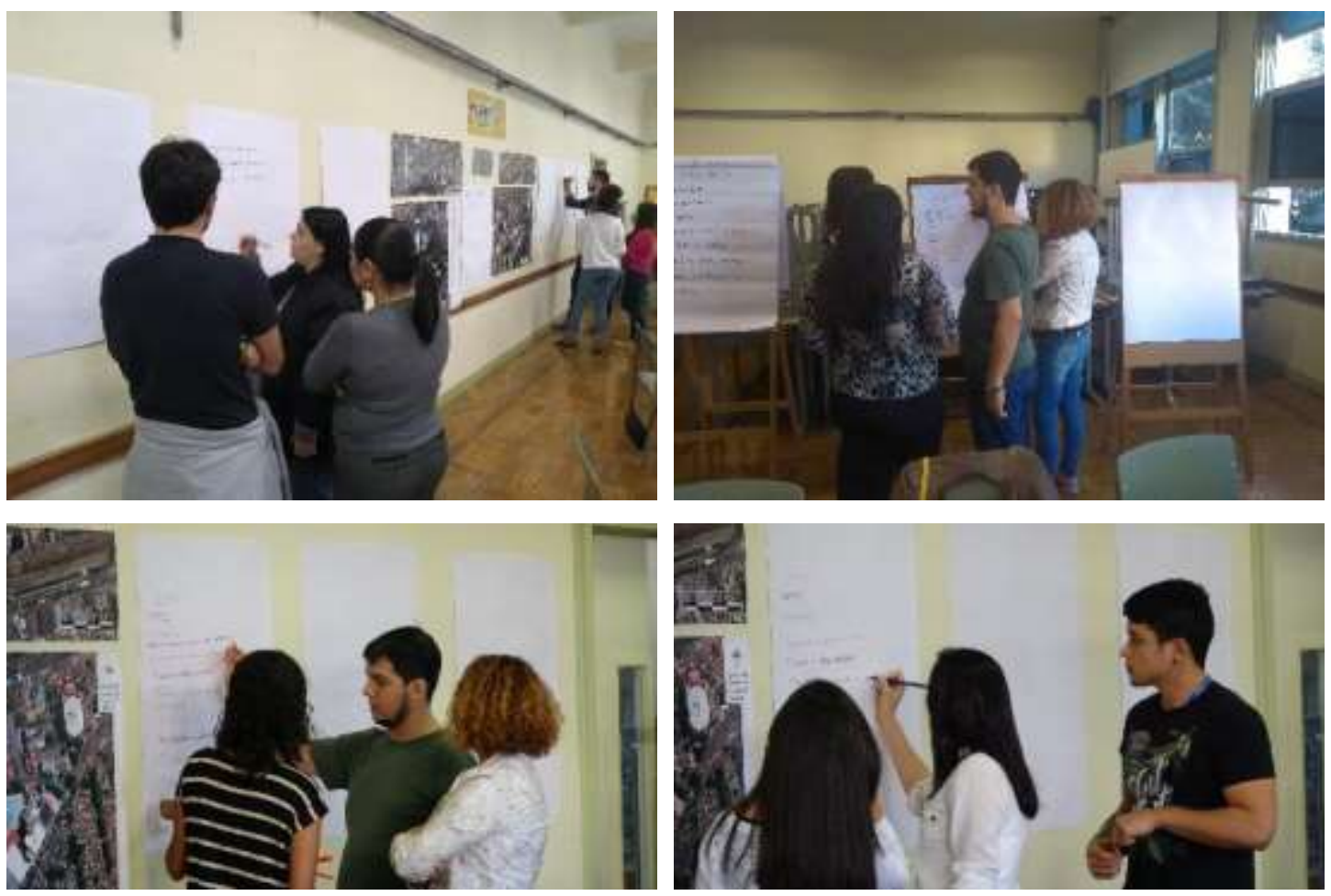

Fonte: Do autor (2019).

Quando se sugere o verbo para caracterizar problemas, há uma maior clareza das ideias. Por exemplo, ao propor que "emprego" se torne "estimular a oferta de empregos". Como os problemas são apontados de forma aberta pelos sujeitos, visto que não existiram problemas pré-definidos, é possível que as categorias representem mais fielmente a visão do problema que os participantes têm. Por outro lado, representa uma dificuldade à equipe de pesquisa no momento de juntar os dados provenientes de áreas e eventos diferentes. A atividade permite manifestar e registrar resultados concretos, ou seja, um conjunto de ações registradas afixadas em local visível, contendo problemas que representam os objetivos, os desejos, os valores, as condicionantes e as percepções dos sujeitos. O processo reflexivo, dado pela leitura de um painel que já contém outros problemas escritos, proporciona aos sujeitos, e ao processo em si, uma melhora do entendimento sob o ponto de vista do participante. Este modelo foi adotado na dinâmica, pois permite que cada grupo construa seu próprio entendimento do problema, contextualizando melhor sua realidade. Dessa forma, o resultado sintetizará uma lista de problemas gerais validados pelos participantes em um painel escrito, conforme exemplo da figura 59. 
Figura 59 - Painel de Seleção de Problemas preenchido

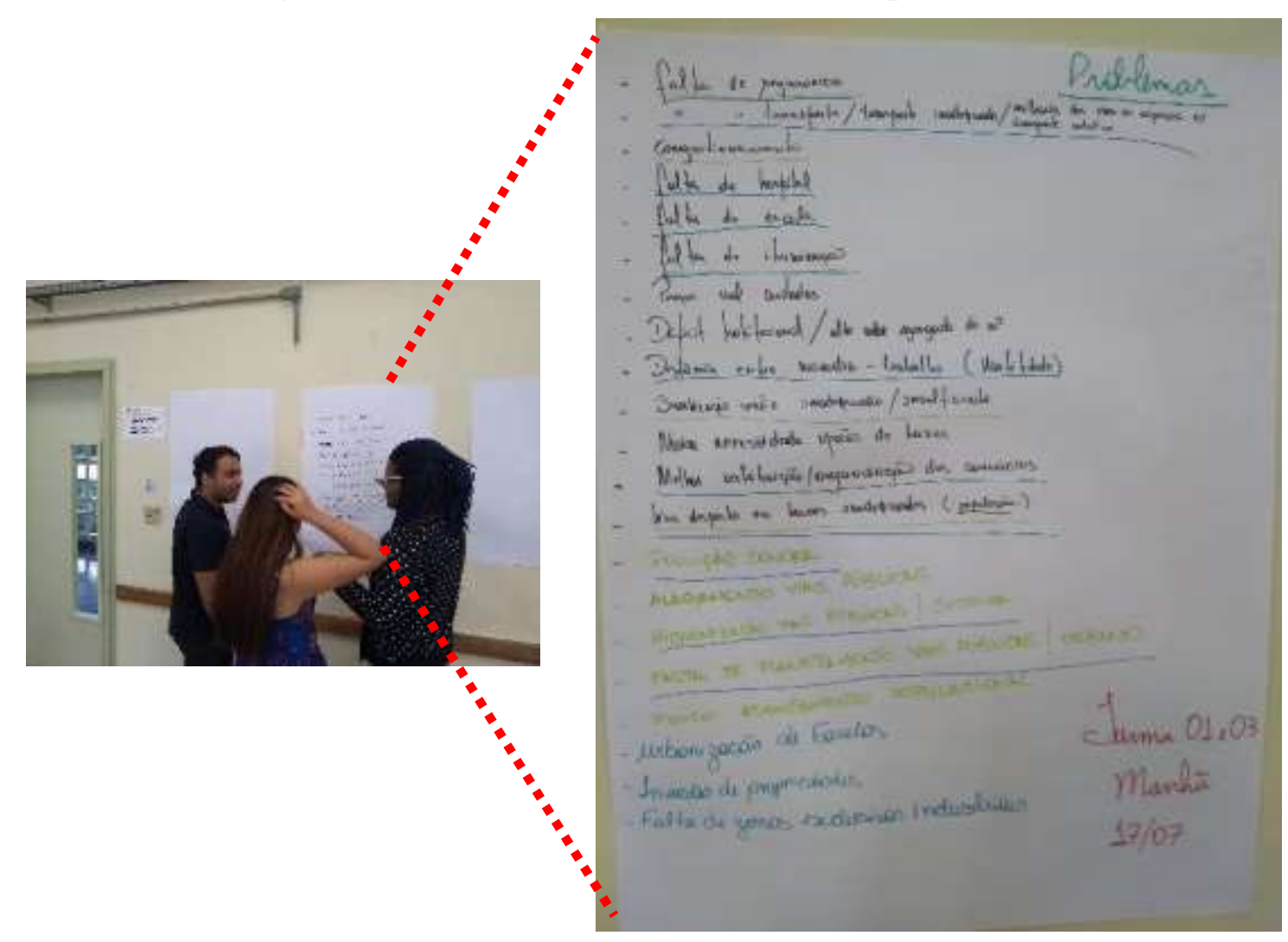

Fonte: Do autor (2019).

Esta etapa é estruturada com base no método do painel integrado. É importante observar que os participantes não deveriam votar nos problemas, ou seja, toda manifestação de problema apontado pelos sujeitos deveria ser escrita, e se não estivesse claro, deveria ser explicado ao grupo. A troca de informações e percepções é um ganho intangível substancial inerente ao processo proposto. $\mathrm{O}$ modelo da atividade permitiu que um grupo, ao ler as respostas de um outro grupo, pudesse refinar suas próprias considerações, e, assim, surgiram problemas mais específicos e não tão fáceis de serem visualizados, consistindo no que se chamou de piramidação;

g) Tempestade Cerebral de Soluções: esta atividade segue um delineamento estruturado no Brain Writing, técnica em que os participantes escrevem as propostas, sem identificação, e repassam a outros, preservando o anonimato e, assim, contribuindo para que os mais inibidos façam sugestões. Foram distribuídas fichas aos participantes e foi colocada a seguinte questão estruturante "Independentemente do custo, da viabilidade, tendo em mente qual seria a cidade ou bairro que gostaria de viver, quais seriam as ações para transformá-lo?". A dinâmica foi explicada em linhas gerais, e a leitura de alternativas 
propostas por outros participantes favoreceu que os sujeitos pudessem aprender enquanto praticavam. As fichas seguiram o modelo da figura 60.

Figura 60 - Aplicação das fichas para tempestade cerebral de soluções

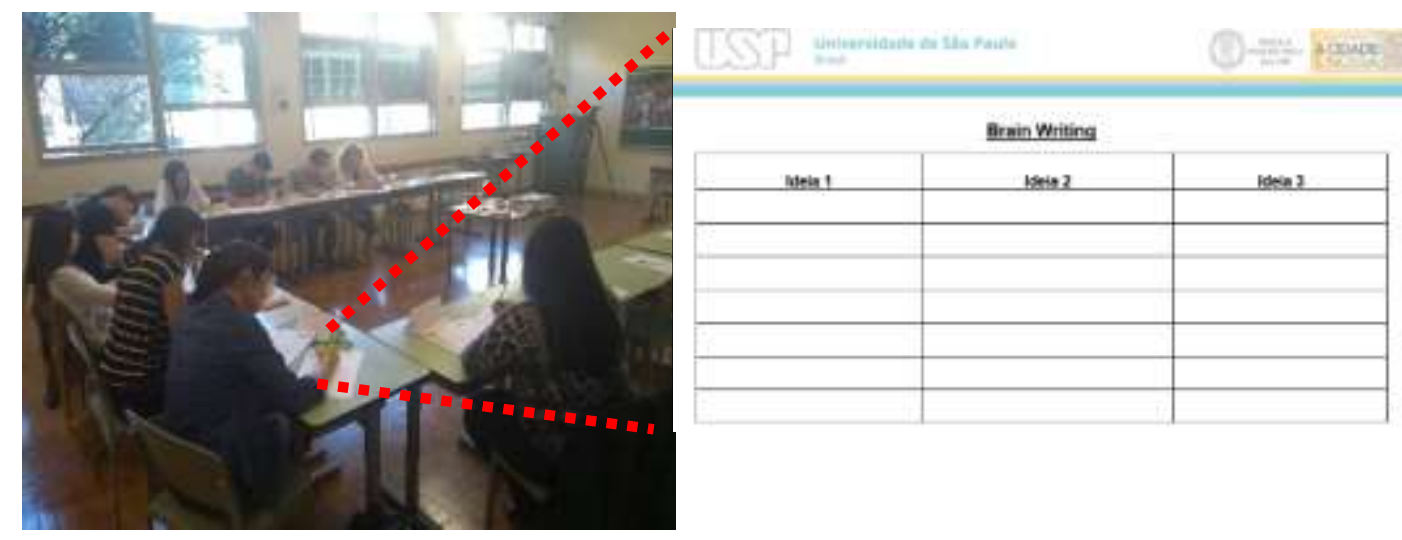

Fonte: Do autor (2019).

A proposta utilizou fichas impressas pré-formatadas e canetas, e cada participante, individualmente e sem identificar sua ficha, escreveu inicialmente três propostas, em cinco minutos. Ao final do tempo, as fichas foram recolhidas pela equipe, e o moderador as redistribuiu de forma aleatória entre os participantes, que foram convidados a escrever mais três propostas em dez minutos. Essa rotina se repetiu mais três vezes, e a ferramenta permitiu que a equipe documentasse e registrasse todas as propostas. Os participantes realizavam essa etapa sentados em seus lugares, cuja disposição de preparação da sala fazia com que estivessem de costas para os problemas que estavam escritos nos painéis, o que representava que aquele era o momento de deixar os problemas de lado e pensar nas soluções que desejavam. Os resultados gerados são objetivos, ações e alternativas de intervenção, ainda de forma aleatória e não organizada. A totalidade de ideias representa um conjunto de ações necessárias para o futuro desenvolvimento do bairro ou do município, sob o ponto de vista da comunidade consultada. Durante o preenchimento, foi incentivado que os participantes não se restringissem ao que já existia, e foi estimulado que adotassem uma visão proativa, mais direcionada às ações a serem executadas e menos limitada a uma simples enumeração de aspectos considerados problemáticos, pois estes já foram listados na etapa anterior. Nesta etapa, ocorre o desenvolvimento dos objetivos e dos programas e ações que virão a compor as alternativas. Também é importante que os sujeitos sejam instruídos a inserir ações com verbos, ou seja, ações apontadas como "Transporte Público" devem ser escritas como "Incentivar Transporte Público", "Moradia" deve ser escrita como "Estimular a Oferta de Moradias"; 
h) Painel Gráfico Colaborativo da Visão: esta atividade permite identificar o estado atual da realidade das pessoas e fornece indicações sobre as tendências para o futuro. Mantida a questão estruturante "Independentemente do custo, da viabilidade, tendo em mente qual seria a cidade ou bairro que gostaria de viver, quais seriam as ações para transformá-lo?”, foi solicitado aos participantes, divididos em dois grupos, que apresentassem um desenho, uma somatória de recortes, um mosaico, um painel de frases ou outra forma gráfica que o grupo julgasse adequada, mesmo que com todos esses elementos juntos, respondendo à questão com referência a um cenário de curto prazo (2020), um de médio prazo (2030) e um de longo prazo (2050), conforme figura 61. Os desenhos, as gravuras e as informações nos painéis induziram os sujeitos a refletir sobre os aspectos considerados mais importantes e urgentes a serem enfrentados, bem como a chegar a uma visão conjunta, ainda que aproximada, sobre quais são as prioridades locais.

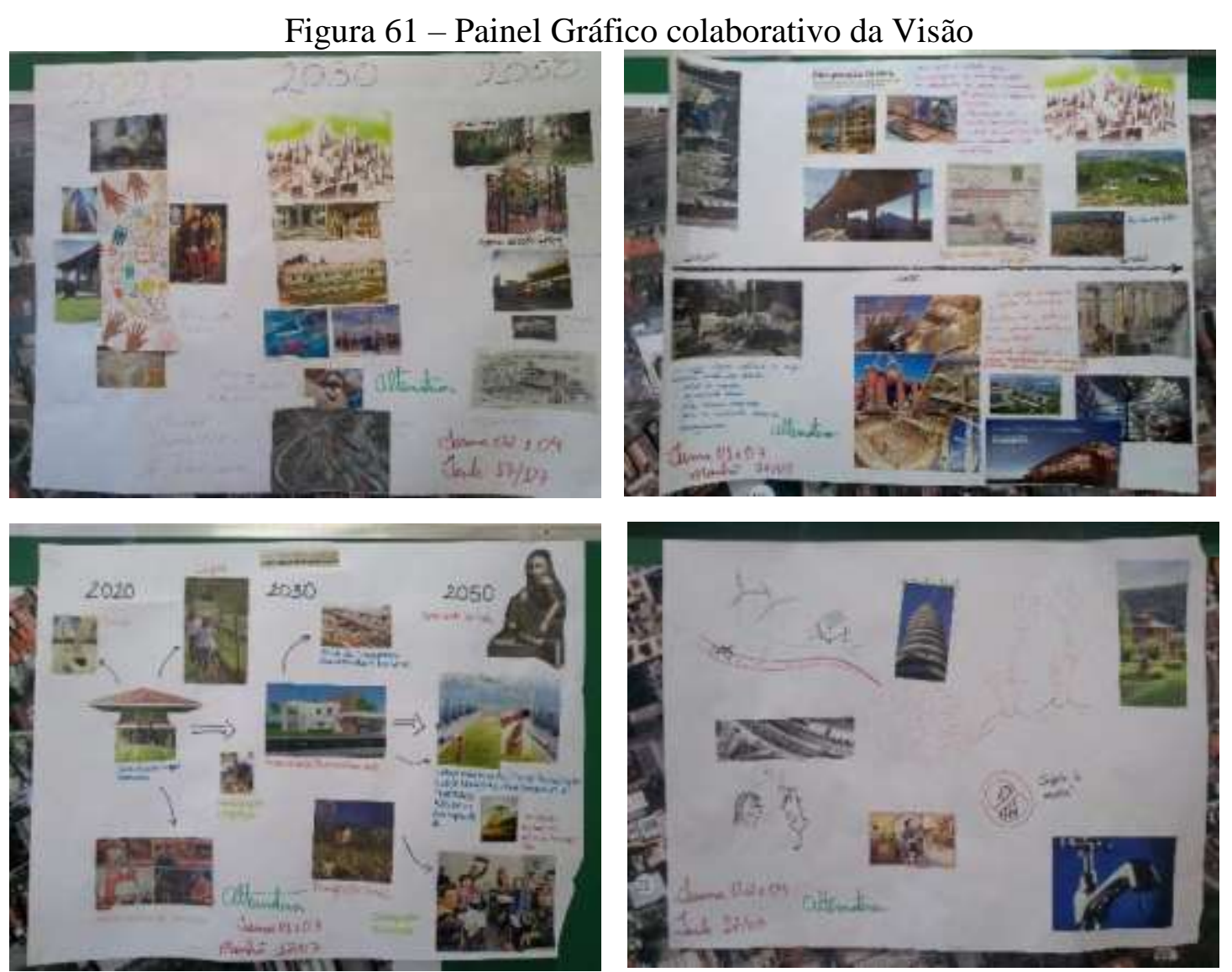

Fonte: Do autor (2019).

Esta técnica pode esclarecer aspectos não triviais apresentados nas outras atividades e, ainda, observando a narrativa dos participantes, estabelecer relações de causa e efeito. Os materiais utilizados foram jornais, revistas, papéis coloridos, adesivos coloridos, canetas coloridas, cola, fita adesiva e tesoura, em ambiente lúdico, conforme a figura 62 , o que atenuou a introspecção dos sujeitos. Os resultados dessa dinâmica forneceram 
novas alternativas que eventualmente não foram listadas nas atividades anteriores, e a evocação do longo prazo pode favorecer o surgimento de uma ação não trivial, o que não pode ser descartado. Ao término da construção das peças gráficas, todas elas foram fixadas em local visível, e os participantes convidados a explicar suas produções e fazer comentários sobre os painéis alheios. As reflexões anotadas pela equipe permitiram a identificação das ações que podem melhorar a qualidade de vida no bairro ou na cidade, do ponto de vista dos participantes.

Figura 62 - Construção dos Painéis colaborativos da visão
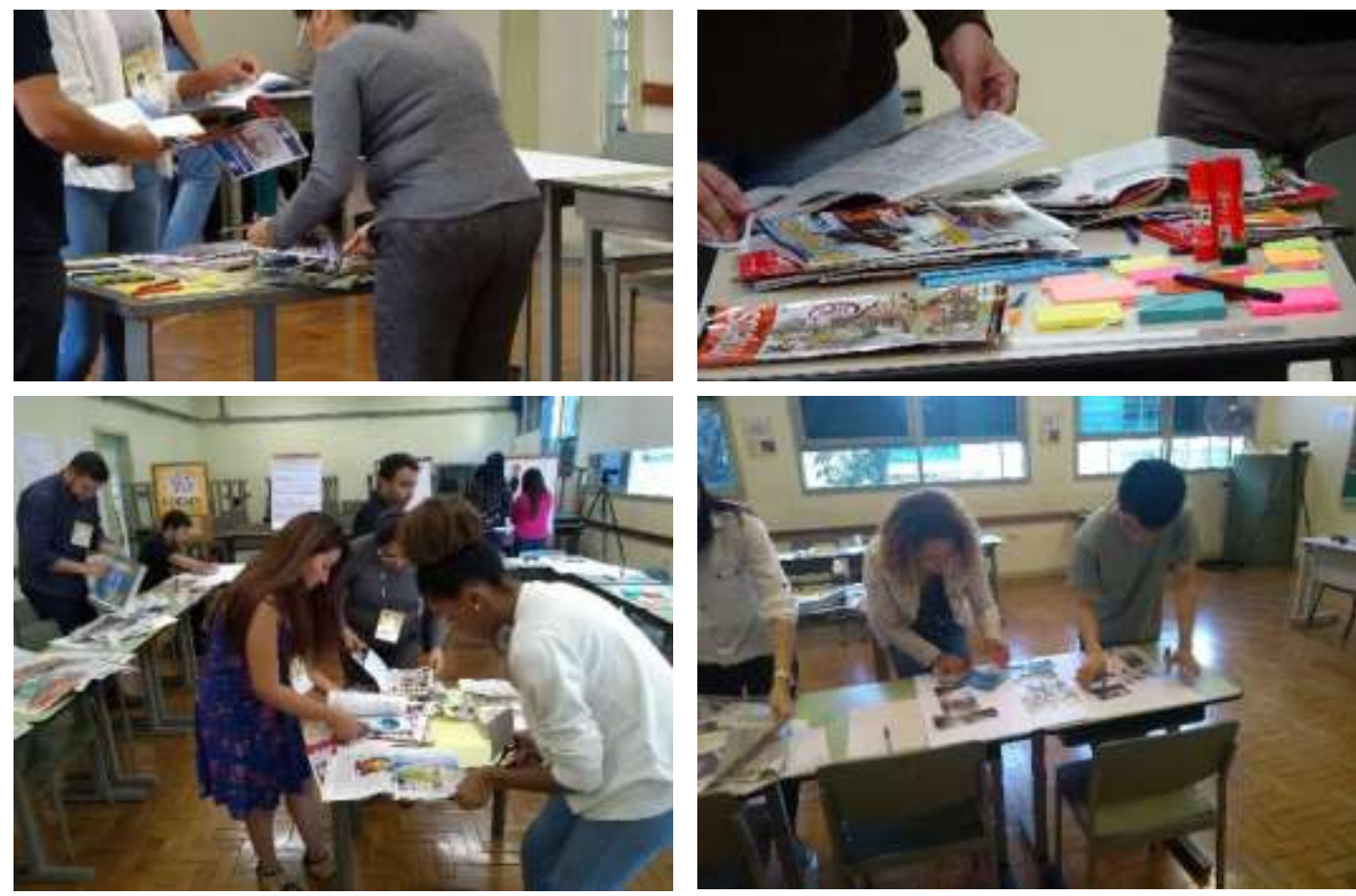

Fonte: Do autor (2019).

No final desta atividade, além dos insumos sintetizados pela equipe de pesquisas, de forma intangível, há a perspectiva de que os participantes tenham construído uma série de conhecimentos e visões que os apresente às relações entre todas as áreas de preocupação levantadas durante o processo;

i) Sensibilização do Olhar, Retomada ao Registro de Expectativas e Encerramento: cada participante foi incumbido de produzir uma fotografia de um aspecto negativo e um aspecto positivo no bairro ou na cidade, para continuidade das atividades no próximo encontro. Foi indicado que ele poderia trazer a fotografia impressa ou poderia enviar à equipe virtualmente. Esperava-se, com a atividade, provocar os participantes a contribuir com uma experiência vivencial. No final da primeira parte da dinâmica, foi verificado com os participantes se algumas das expectativas já registradas foram atendidas e se 
foram criadas novas. Os trabalhos foram encerrados, e foi reiterada a importância da presença no próximo encontro, conforme figura 63.

Figura 63 -Encerramento do primeiro encontro

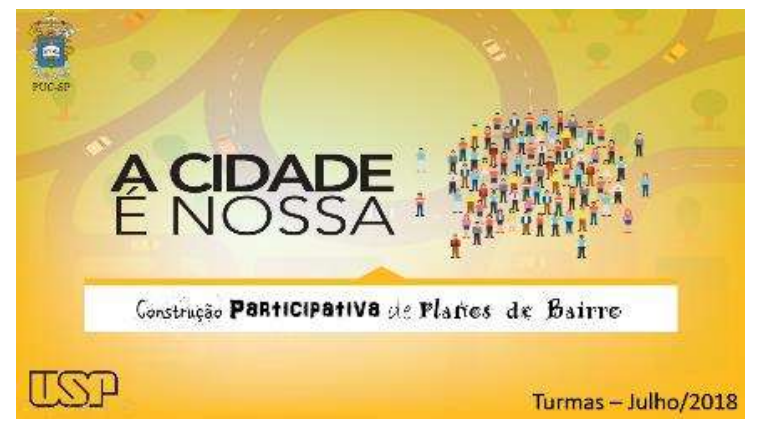

\section{ICC̆̃O dE CASA}

- Liçăo de casa, enviar por e-mail no dia $16 / 07$ ( amanhă) até as $15 \mathrm{hr}$ duas fotografias, uma de exemplo bom e outra de exemplo ruim de questões urbanas, pode ser por WhatsApp também....
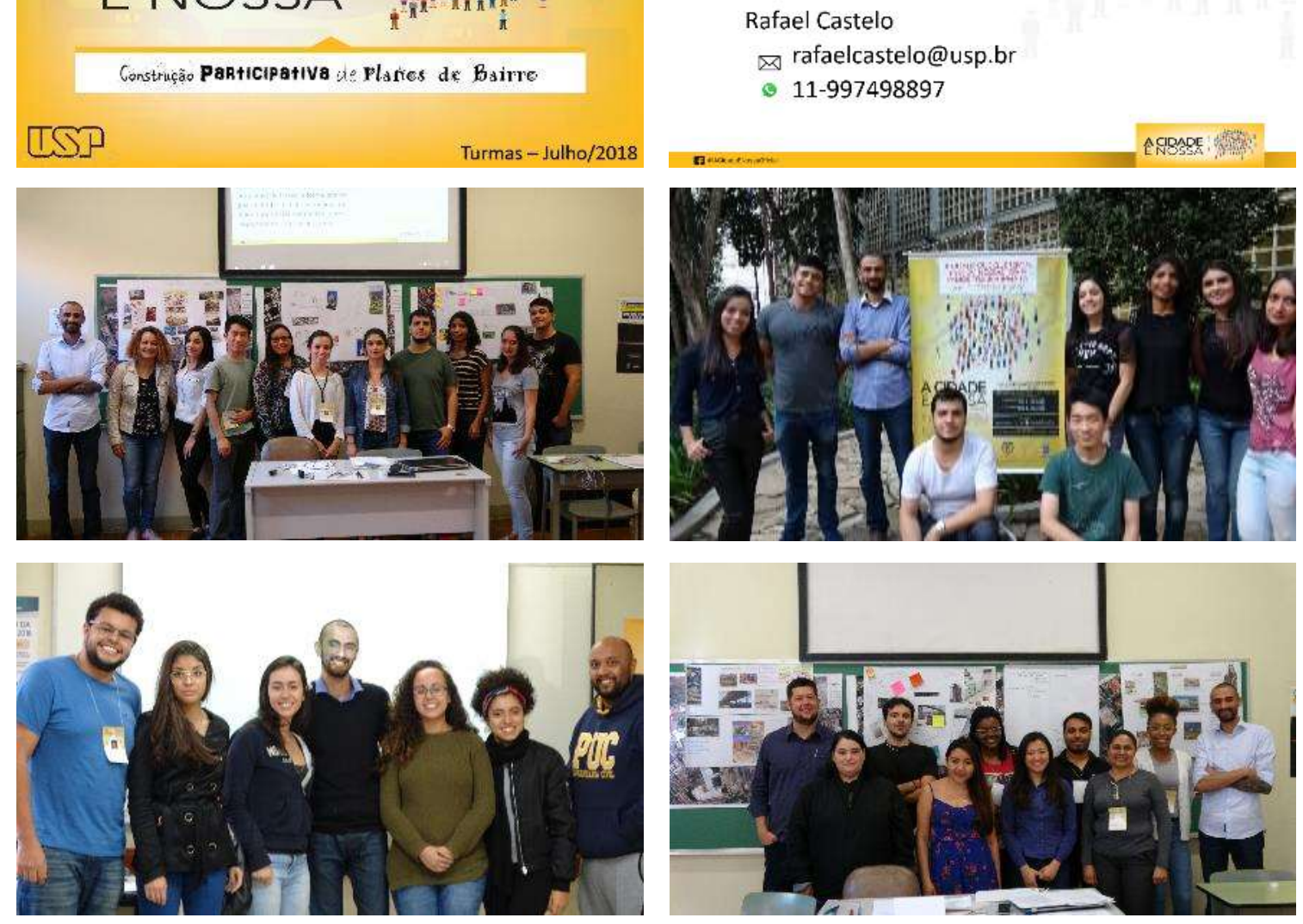

Fonte: Do autor (2019).

As atividades realizadas no primeiro dia do encontro, com duração total de 3 horas e 30 minutos para cada grupo, com a duração de cada atividade e os materiais envolvidos são sumarizadas no quadro 23.

As informações quanto ao número de participantes e os resultados produzidos em cada uma das dinâmicas aplicadas serão apresentadas nos itens 6.4 e 6.5 desta pesquisa e serão analisados a partir dos procedimentos metodológicos propostos. 
Quadro 23 - Distribuição das atividades, materiais, objetivos e duração no primeiro encontro

\begin{tabular}{|c|c|c|c|}
\hline $\begin{array}{l}\text { Duração } \\
\text { (minutos) }\end{array}$ & Atividade & Materiais & Resultados e Objetivos \\
\hline 15 & Recepção dos Participantes & $\begin{array}{l}\text { Formulários impressos, } \\
\text { crachás impressos, } \\
\text { lista de presença, } \\
\text { canetas esferográficas }\end{array}$ & $\begin{array}{l}\text { Receber os sujeitos e } \\
\text { caracterizar o perfil dos } \\
\text { participantes }\end{array}$ \\
\hline 20 & Dinâmica de Apresentação & Apresentação expositiva & Estreitar relacionamentos \\
\hline 10 & Dinâmica de Estímulo Positivista & $\begin{array}{c}\text { Flip-chart, } \\
\text { Canetas coloridas }\end{array}$ & $\begin{array}{c}\text { Preencher o Painel de Frases } \\
\text { Mórbidas }\end{array}$ \\
\hline 10 & Registro de Expectativas & $\begin{array}{c}\text { Flip-chart, } \\
\text { Canetas coloridas }\end{array}$ & $\begin{array}{c}\text { Preencher o Painel de } \\
\text { Expectativas }\end{array}$ \\
\hline 30 & $\begin{array}{l}\text { Apresentação do Evento } \\
\text { Introdução à Política Urbana } \\
\text { Caracterização da Área } \\
\end{array}$ & $\begin{array}{l}\text { Data show, } \\
\text { mapas impressos }\end{array}$ & $\begin{array}{l}\text { Disseminar conhecimento, } \\
\text { introduzir informações }\end{array}$ \\
\hline 15 & Intervalo & Coffee break & Favorecer a interação \\
\hline 35 & Painel de Seleção de Problemas & $\begin{array}{l}\text { Flip-chart, } \\
\text { canetas coloridas }\end{array}$ & $\begin{array}{l}\text { Produzir insumos para } \\
\text { caracterização dos } \\
\text { problemas }\end{array}$ \\
\hline 35 & Tempestade Cerebral de Soluções & $\begin{array}{l}\text { Fichas de Brain Writing, } \\
\text { canetas esferográficas }\end{array}$ & $\begin{array}{l}\text { Produzir insumos para } \\
\text { caracterização das } \\
\text { alternativas }\end{array}$ \\
\hline 30 & $\begin{array}{l}\text { Painel Gráfico Colaborativo da } \\
\text { Visão }\end{array}$ & $\begin{array}{c}\text { Cartolinas, } \\
\text { flip-chart, } \\
\text { cola, } \\
\text { tesoura, } \\
\text { fita adesiva, } \\
\text { adesivos coloridos, } \\
\text { papéis coloridos, } \\
\text { canetas esferográficas, } \\
\text { lápis de cor }\end{array}$ & $\begin{array}{c}\text { Produzir insumos para } \\
\text { caraterização de problemas e } \\
\text { de alternativas }\end{array}$ \\
\hline 10 & $\begin{array}{c}\text { Próximos Passos } \\
\text { Síntese das Atividades } \\
\text { Encerramento }\end{array}$ & Data show & $\begin{array}{l}\text { Fortalecer vínculos e } \\
\text { proporcionar a } \\
\text { sensibilização do olhar }\end{array}$ \\
\hline
\end{tabular}

Fonte: Do autor (2019).

\subsubsection{Aplicação da Etapa de Interpretação e Sistematização e preparação para a Etapa Valoração-Avaliação}

As informações registradas no painel de seleção de problemas e nas fichas da Tempestade Cerebral de Soluções, ilustradas pelo Painel Colaborativo da Visão, precisam ser sistematizados em um conjunto de problemas e de alternativas.

Nesta etapa, os insumos produzidos no primeiro dia de aplicação da proposta metodológica foram organizados pela equipe de moderadores. É uma tarefa interna, sem a participação dos sujeitos e foi realizada no intervalo entre os dias de aplicação das dinâmicas. 
A partir do Painel de Seleção de Problemas, a equipe transcreveu os problemas e, quando necessário, associou-os a um verbo que o caracterizasse, conforme figura 64.

Figura 64 - Interpretação dos Painéis de Seleção de Problemas e Gráfico Colaborativo da

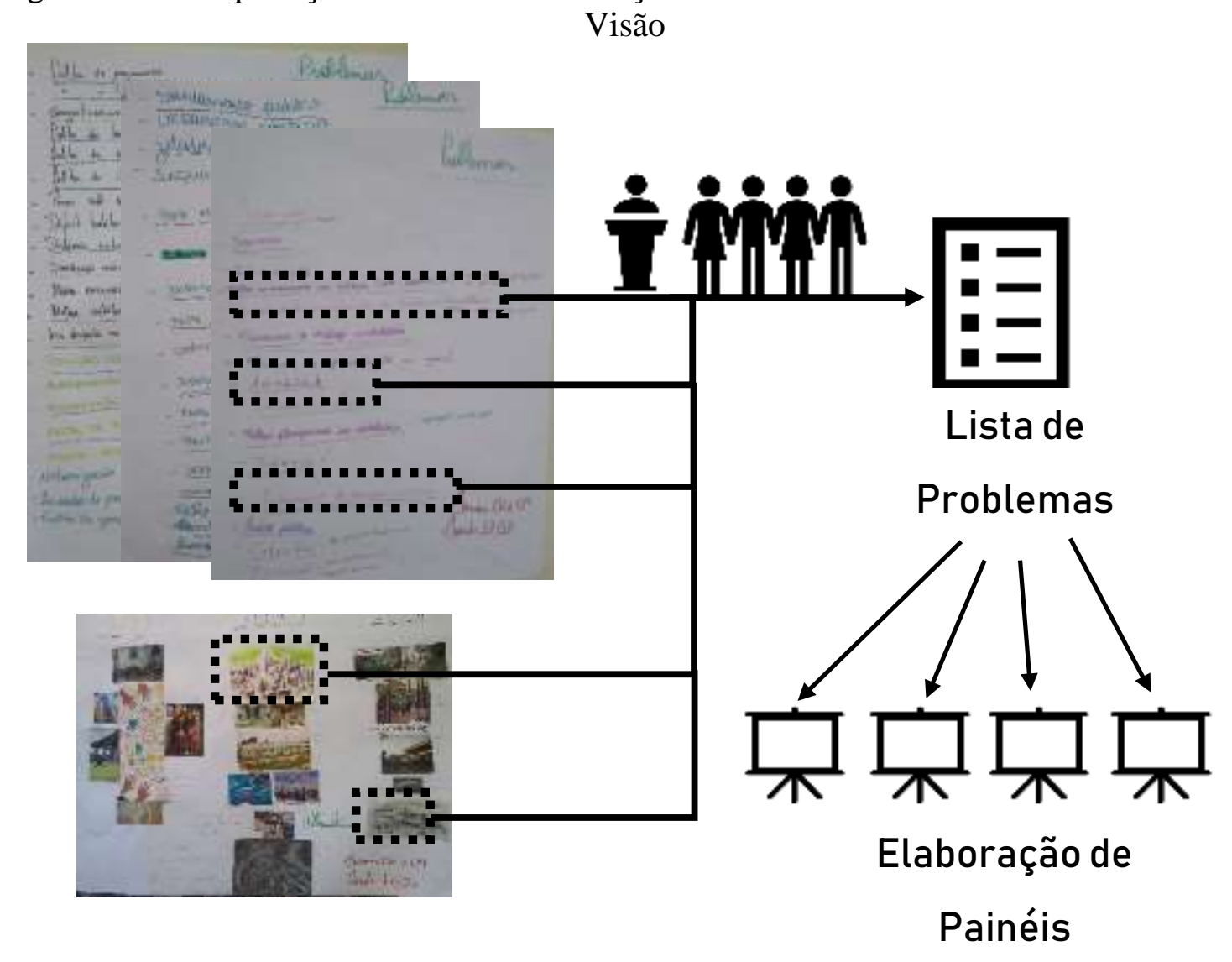

\section{Visão}

Fonte: Do autor (2019).

A leitura dos painéis e das fichas demandou da equipe uma reflexão cuidadosa dos problemas e das alternativas, o que foi organizado em categorias para facilitar a consolidação dos painéis. A interpretação resultou em:

a) Elaboração do Painel de Impacto dos Problemas: a partir da transcrição sistematizada dos problemas, obtidos no Painel de Seleção de Problemas, a equipe estruturou um novo painel cujo o título é "Problemas", com um subtítulo "Impacto". Os problemas, já sistematizados, foram escritos sequencialmente, um abaixo do outro (um problema em cada linha da primeira coluna), e esse painel é complementado com um grupo de quatro colunas, cujo título é " Dimensão". Cada uma das quatro colunas recebe um subtítulo, "frequência" com legenda na cor azul, "relevância" com legenda na cor verde, “dificuldade de correção" com legenda na cor vermelha e "dificuldade de detecção" com legenda na cor magenta, conforme figura 65. 
Figura 65 - Construção do Painel de Impacto dos Problemas

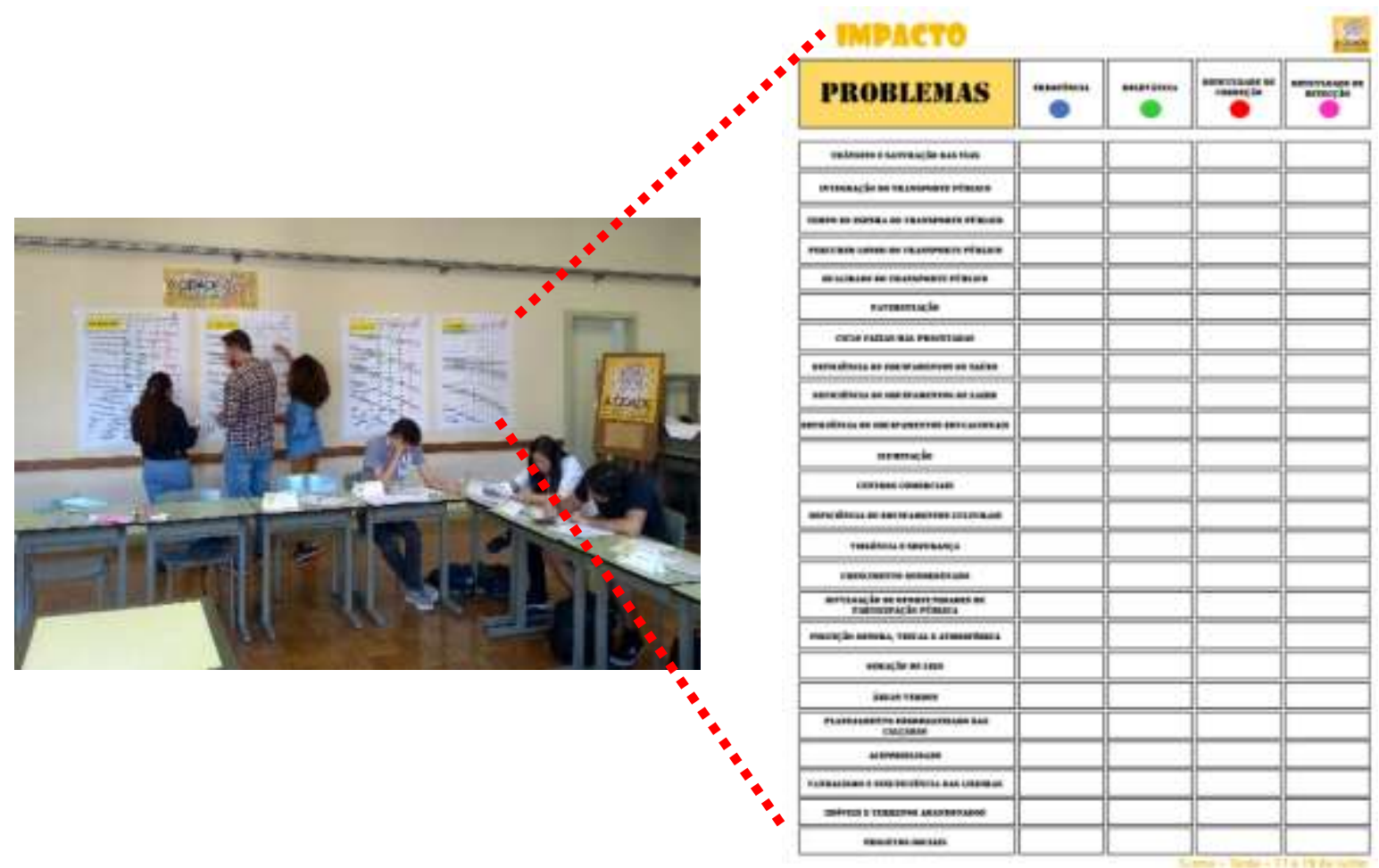

Fonte: Do autor (2019).

A interpretação das alternativas, com apoio das fichas de tempestade cerebral de soluções e dos painéis da visão, conforme figura 66, permitiu a elaboração: (ii) do Painel de Avaliação de Alternativas; (iii) do Painel de Abrangência; e (iv) do Painel de Crítica Postergada.

Figura 66 - Interpretação da Tempestade cerebral de soluções e do painel colaborativo da visão

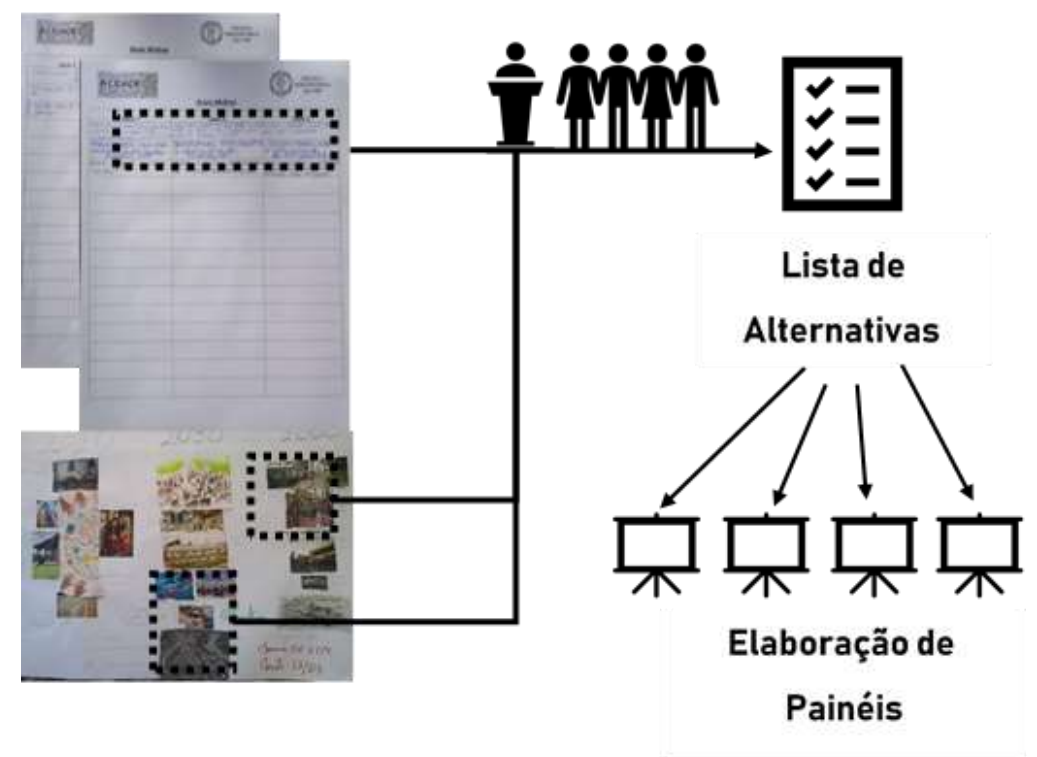

Fonte: Do autor (2019). 
Alternativas que foram escritas de forma muito abrangente, por exemplo, "Novas Construções", para evitar um viés, foram desdobradas em duas alternativas "Incentivar novas construções" e "Desincentivar novas construções".

b) Elaboração de Painel de Avaliação das Alternativas: a partir da transcrição e da sistematização das alternativas, a equipe estruturou um painel com o título "Dificuldade de Implantação". Neste, a primeira coluna, com o título "Alternativas", agrupou a transcrição das alternativas, de forma sequencial, uma abaixo da outra, cada linha para uma alternativa. Foram inseridas mais quatro colunas subsequentes para qualificar as alternativas, com os títulos "Técnica" com legenda na cor azul, "Econômica" com legenda na cor verde, "Política" com legenda na cor vermelha e "Aceitação Popular" com legenda na cor magenta. A cada dimensão de avaliação (dificuldade técnica, dificuldade econômica, dificuldade política e dificuldade de aceitação popular), foi atribuída uma cor que a representasse, culminando no painel da figura 67.

Figura 67 - Construção do Painel de Avaliação das Alternativas (Dificuldade de Implantação

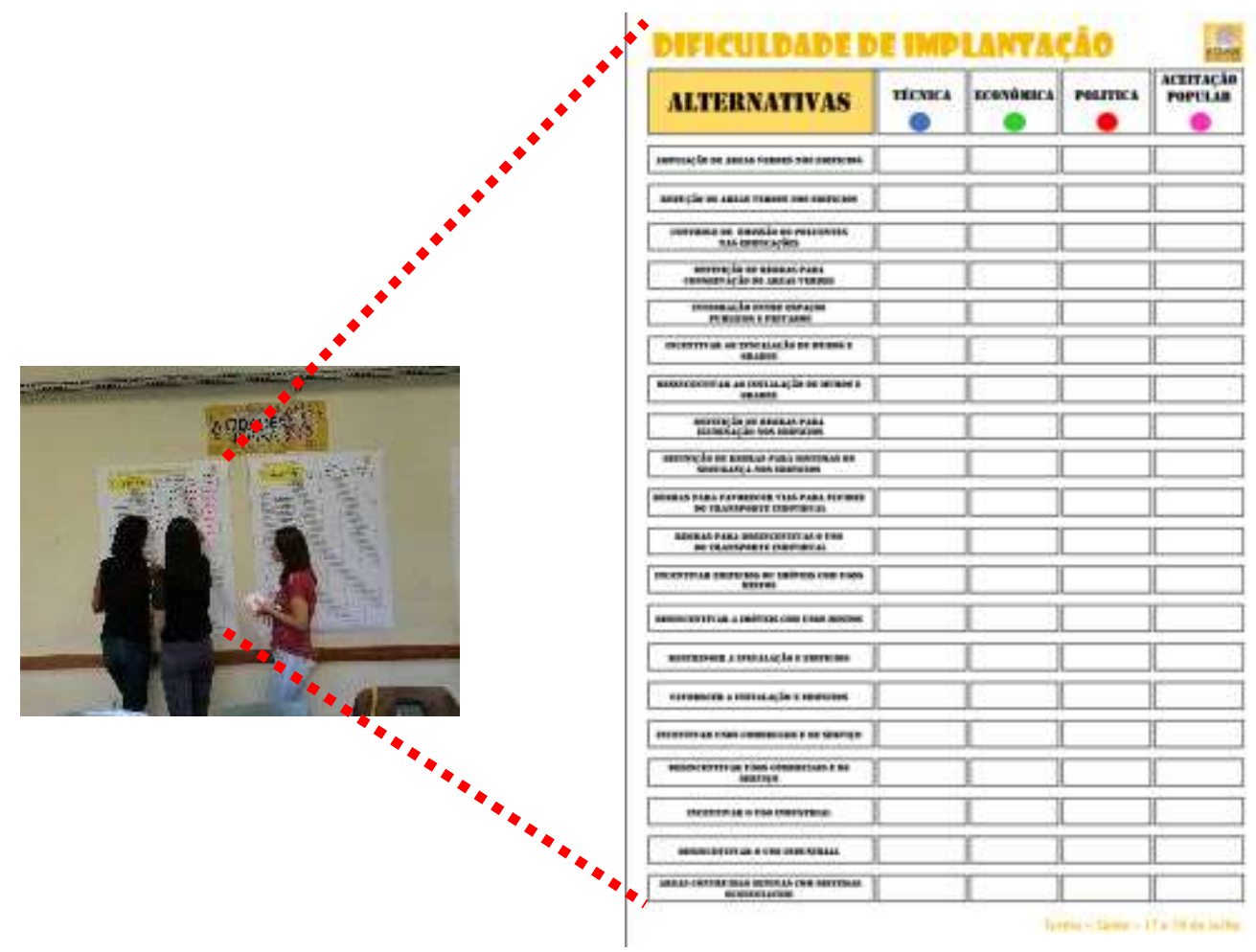

Fonte: Do autor (2019).

O resultado deste painel sintetiza todas as ações delimitadas no processo pelos sujeitos. As soluções devem sempre ser escritas na forma de ação, para facilitar o entendimento de 
suas consequências práticas. Sugestões com o mesmo significado semântico, foram incorporadas em uma única alternativa.

É importante que a sistematização seja fiel às soluções propostas. Contudo, os objetivos de cada alternativa devem ser explícitos na forma com que cada uma delas é transcrita, tornando mais difíceis modificações que venham a distorcer ou prejudicar o entendimento de cada solução;

c) Elaboração de Painel de Abrangência: a partir da transcrição e da sistematização das alternativas, a equipe estruturou um painel com o título "Abrangência". Neste, a primeira coluna, com o título "Alternativas", agrupou as alternativas, de forma sequencial, uma abaixo da outra. Foram inseridas mais quatro colunas subsequentes, com os títulos "Quadra”, "Bairro", "Zona" e "Cidade", cada uma com uma cor que a representasse, indicada na legenda (azul, verde, vermelho e magenta, respectivamente). O painel pode ser ilustrado na figura 68.

Figura 68 - Elaboração do Painel de Abrangência

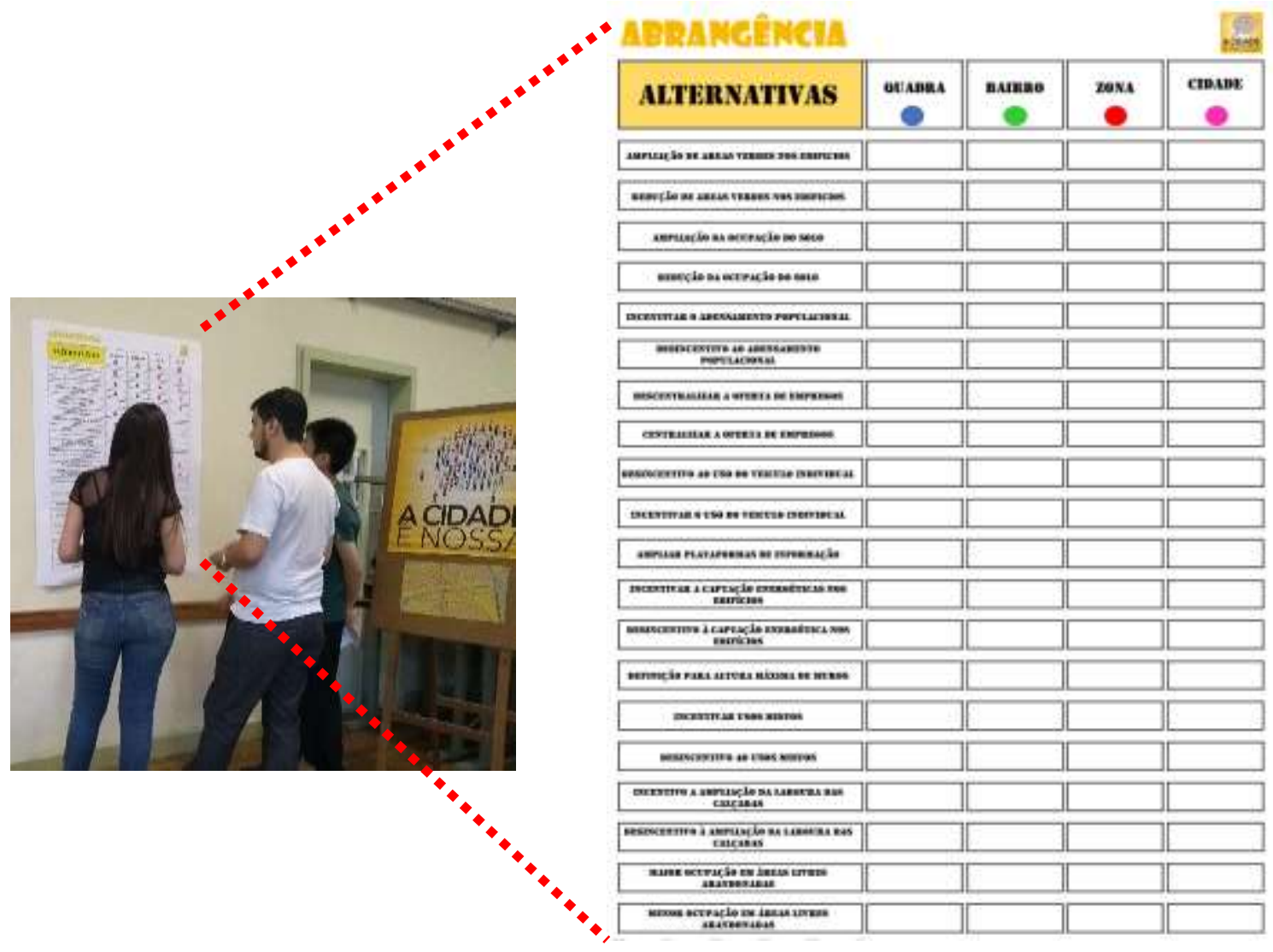

Fonte: Do autor (2019). 
O painel produzirá um resultado, ao final da dinâmica, que permitirá à equipe identificar a escala de inserção de cada alternativa. É uma forma de criar referência espacial das alternativas cujo objetivo é aprimorar nos sujeitos uma coerência global para as alternativas que eles sugerem no processo.

d) Elaboração de Painel de Crítica Postergada: Depois que as ideias se manifestarem e que os elementos forem valorados, é importante abrir um painel para que as pessoas apresentem críticas, as quais podem representar um ponto de atenção aos elementos. Discutir os resultados obtidos ao final da dinâmica em um painel é uma alternativa que a equipe adotou. No final do evento, em um painel específico, chamado de Painel de Crítica Postergada, os participantes eram indicados para registrar e explicarem o porquê de determinadas soluções terem sido consideradas prioritárias., conforme ilustrado na figura 69.

Figura 69 - Elaboração do Painel de Crítica Postergada (Seleção de nós críticos)

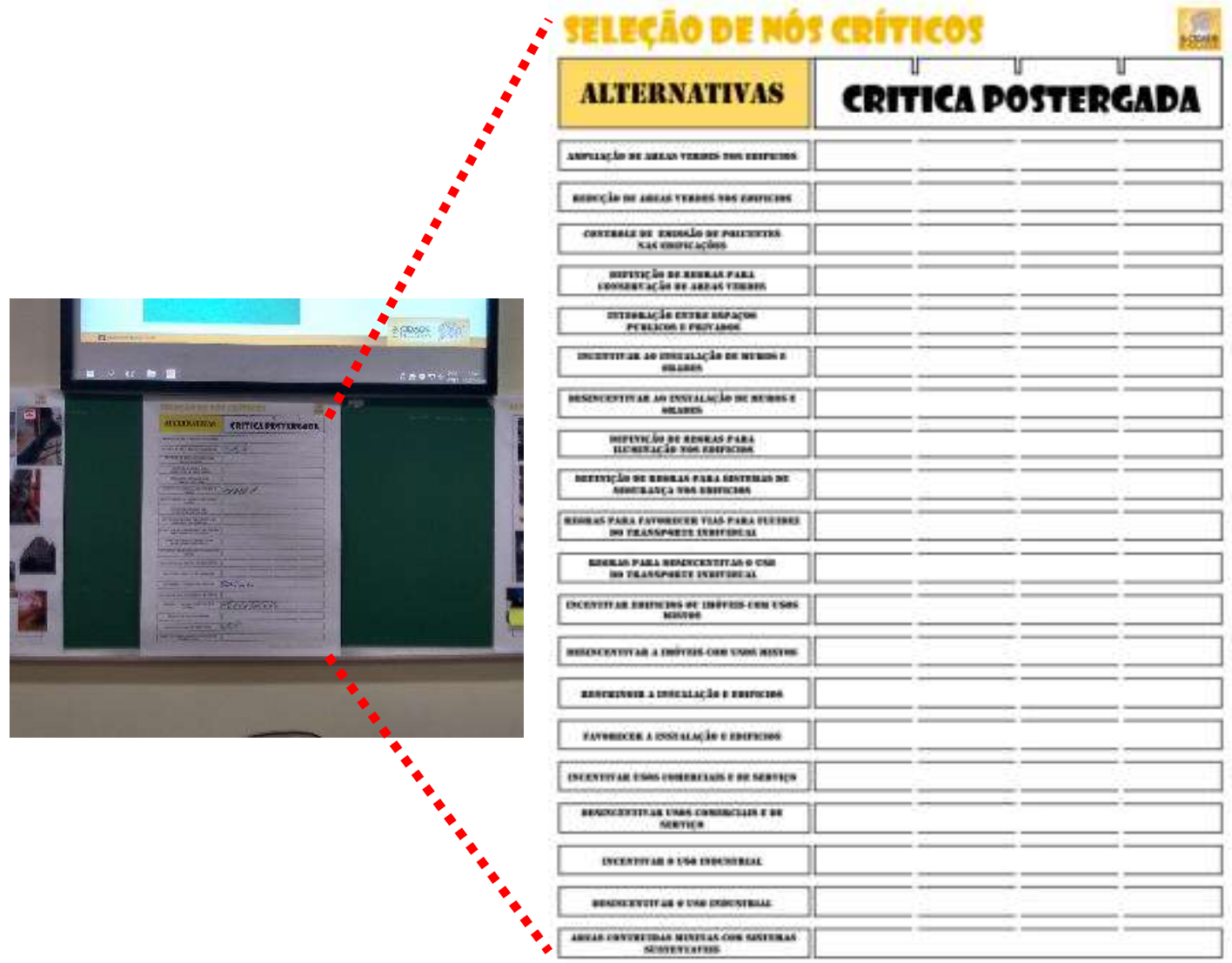

Fonte: Do autor (2019).

Neste, a primeira coluna, com o título "Alternativas", agrupou a transcrição das alternativas, de forma sequencial, uma abaixo da outra, com cada linha representando uma alternativa. De forma subsequente, ao lado de cada alternativa, foi mantido um 
espaço significativo em branco para ser preenchido pelos participantes, com textos, adesivos, recortes e qualquer informação que ele julgar ser relevante para criticar uma solução. Uma vez que os painéis permitirão avaliar problemas e alternativas, é importante criar peças gráficas, ou painéis, em que deverá ser explorado como as alternativas solucionam os problemas, de tal forma que se possa verificar estratégias necessárias para operacionalizá-las. A proposta lança mão de duas ferramentas para desenvolver mapas causais, analisando a influência de cada alternativa em cada problema e visualizando a integração entre elas, conforme o descrito na proposta metodológica. Os painéis são modelos com representações simplificadas em um quadro simplificado de ligações, elaboradas a partir do Painel de Ligação Peer-to-Peer com o objetivo de compreendê-la com apoio do Painel de Análise e Correlação de Alternativas;

e) Elaboração de Painel de ligação Peer-to-Peer: a partir da transcrição e da sistematização dos problemas e das soluções, que agora se configuram em ações ou alternativas, a equipe estruturou um painel com o título "Correlação e Ligação". Todos os problemas foram transcritos sequencialmente, um abaixo do outro, um em cada linha, em uma coluna com o título "Problemas", alinhada mais à esquerda. Enquanto isso, no mesmo painel, todas as alternativas foram transcritas sequencialmente, uma abaixo da outra, uma em cada linha, em uma coluna com o título "Alternativas", alinhada mais à direita. Assim, restou um espaço em branco entre as colunas, o que permitiria aos sujeitos ligarem um lado ao outro, conforme figura 70.

Figura 70 - Elaboração do Painel de ligação Peer-to-Peer (Correlação e Ligação)

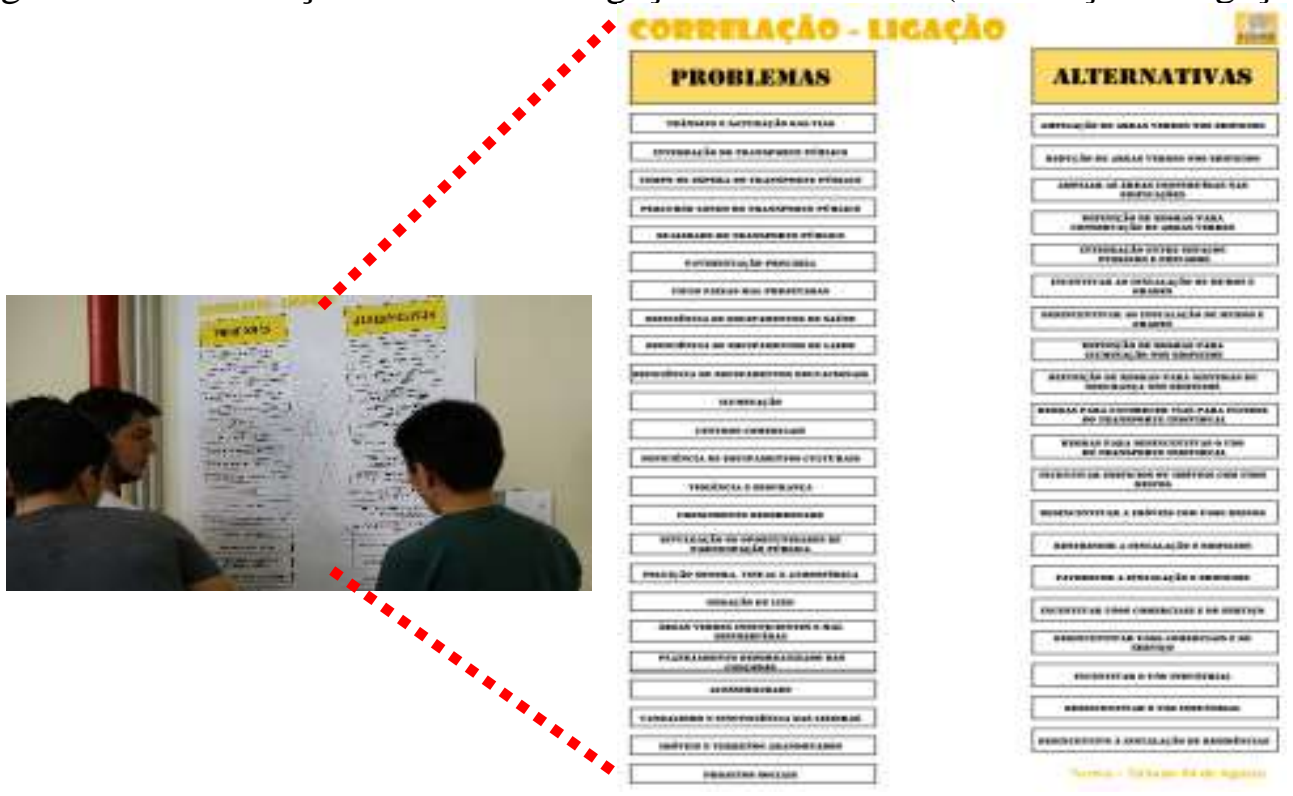

Fonte: Do autor (2019). 
f) Elaboração de Painel de Análise e Correlação de Alternativas: a equipe estruturou um painel com o título "Análise e Correlação", cuja primeira coluna continha o título “Alternativas". Nesta, foram transcritas sequencialmente, uma abaixo da outra, todas as alternativas, e os problemas foram transcritos sequencialmente, um após o outro, em colunas, ou seja, cada coluna representou um problema, e cada linha representou uma alternativa. Uma legenda de cores foi proposta, onde a cor branca (ou sem marcação), representa que alternativa não afetaria ou não atenderia o problema, a cor azul representa que a alternativa atua indiretamente em um problema sem o solucionar completamente, a cor verde representa que a alternativa atua indiretamente sem solucionar completamente o problema, a cor vermelha representa que a alternativa atua diretamente no problema o solucionando incompletamente, e a cor magenta representa que a alternativa atua diretamente no problema e o soluciona completamente, conforme ilustrado na figura 71.

Figura 71 - Elaboração do Painel de Análise e Correlação de Alternativas

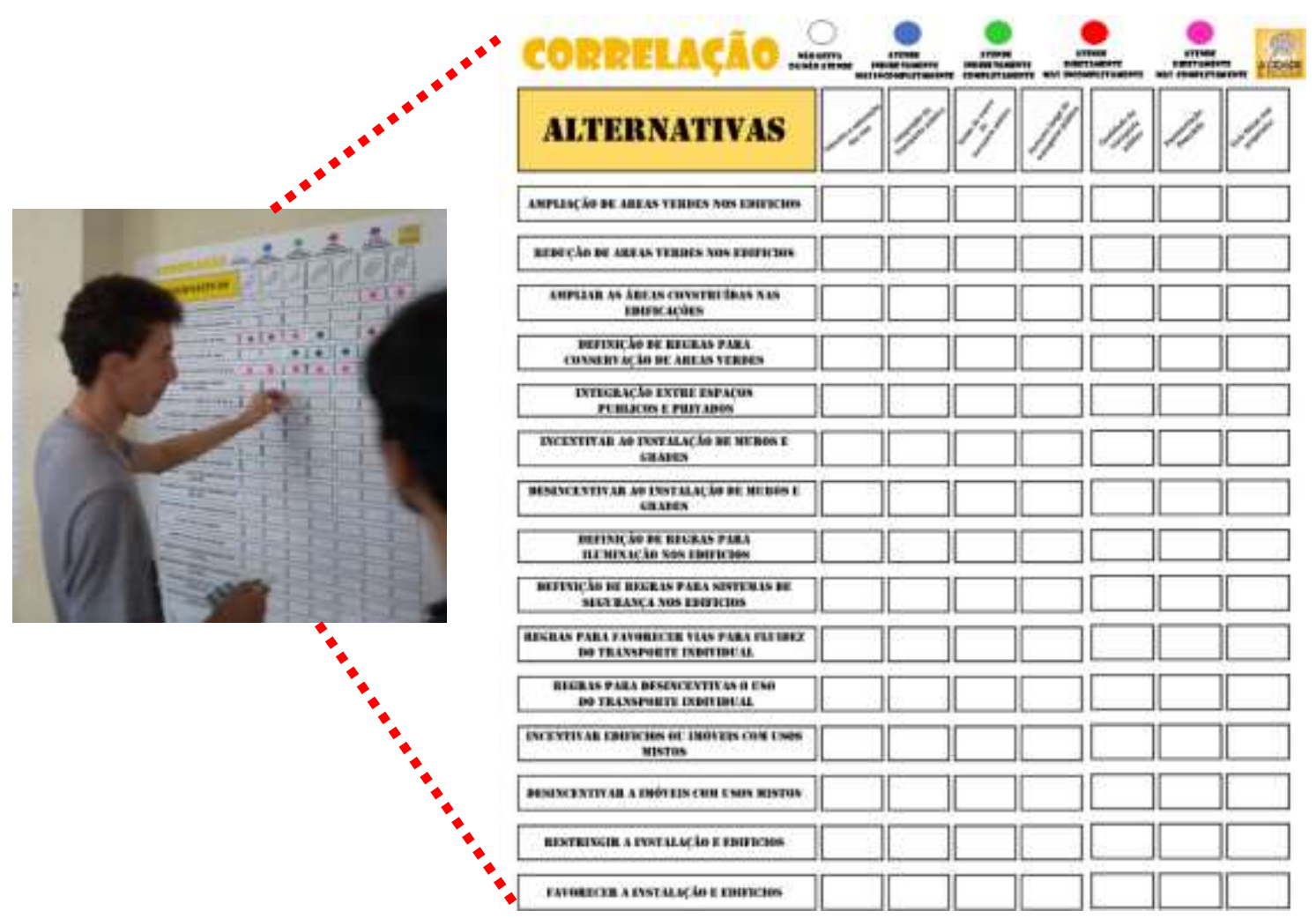

Fonte: Do autor (2019).

Os painéis gerados permitiram, na etapa subsequente, a valoração das alternativas e dos problemas. Na etapa de interpretação e sistematização, a aplicação da metodologia apontou que é importante que a equipe condutora do processo homogeneíze a forma com que interpreta os insumos gerados pela participação popular, e há de se tomar o cuidado de transcrever os 
problemas escritos no painel de problemas, as soluções propostas na fichas, e a interpretação do painel gráfico de figuras e desenhos de forma fidedigna, como foram escritas, incorporando apenas verbos que melhor representem as ações.

Para se evitar vieses, quando as propostas não eram claras, buscou-se transcrevê-las com mais de um aspecto caracterizante, por exemplo, se um sujeito escreveu “Áreas Verdes” como solução, é difícil precisar o que se está valorizando, então o item foi transcrito como "Ampliar Áreas Verdes" e "Reduzir Áreas Verdes", de maneira a garantir um universo semântico mais abrangente. As alternativas com caracterização não enviesada favoreceram a distinção individual e autônoma do comportamento das alternativas.

Todos os painéis foram impressos em formato “A0” (841mm x 1189mm), coloridos. Novamente, a sala foi preparada com os painéis fixados nas paredes. Para o dia seguinte de dinâmicas, todos os painéis que valoravam só problemas foram dispostos fora da sala, os que valoravam só alternativas foram dispostos dentro da sala, e os que correlacionavam problemas com alternativas ficaram em um espaço intermediário. Ou seja, os painéis só de problemas ficaram fora da sala, mais afastados; os que continham a avaliação conjunta de problemas e alternativas ficaram fora da sala, contudo mais próximos ao acesso; e os que continham apenas alternativas ficaram dentro da sala. Assume-se que essa disposição (deixar os problemas de fora, e longe) faz com que os sujeitos avaliem as alternativas de forma isenta, em um momento posterior. Além disso, as fotografias enviadas pelos participantes foram impressas, assim como os certificados de participação preparados.

\subsubsection{Aplicação da Etapa Valoração-Avaliação}

Com o espaço montado, e as pessoas do lado de fora, no segundo dia de encontro, os lugares nos quais teriam assento estavam igualmente pré-demarcados, contudo não ao lado das pessoas que já estavam lado a lado no encontro anterior. Neste segundo encontro, foram realizadas atividades para avaliação dos problemas propostos e das alternativas sugeridas, com apoio dos painéis produzidos e impressos na etapa de interpretação e sistematização, também já fixados nas paredes.

Neste segundo encontro, foram realizadas as seguintes atividades: (a) recepção; (b) reforço do compromisso; (c) dinâmica laboral de estreitamento; (d) dinâmica de fortalecimento de vínculos; (e) valoração do Painel de Efeito e Impacto dos Problemas; (f) estabelecimento das redes peer-to-peer; (g) verificação da intensidade das correlações; (h) análise e valoração 
de oportunidades e ameaças nas alternativas; (i) inserção territorial e escalas; (j) avaliação de fraquezas e ameaças; (k) mosaico de fotos; (l) fechamento de expectativas e revalidação de opiniões; e (m) encerramento.

a) Recepção: a equipe recebeu os participantes na entrada, para que eles assinassem a lista de presença e fossem encaminhados aos seus lugares (preferencialmente lugares distintos do primeiro encontro, a fim de que novas relações fossem estabelecidas). As pessoas receberam uma caneta de cor vermelha e um bloco de folhas sulfites, na sala com assentos dispostos em formato de "U”, conforme figura a 72.

Figura 72 - Disposição da sala para aplicação das dinâmicas

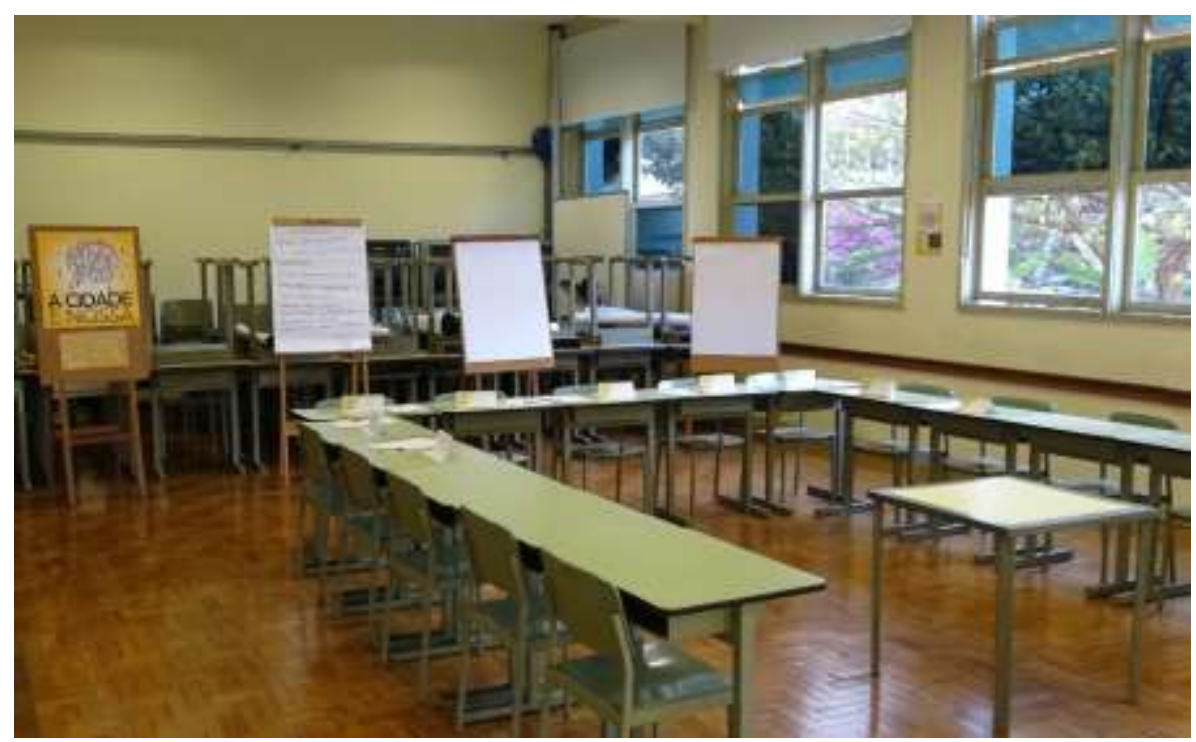

Fonte: Do autor (2019).

b) Exposição de reforço do compromisso: a equipe começou a exposição reforçando que os títulos não existem e que o tratamento entre as pessoas deve ser feito pelo nome. Também foi reiterado que as críticas ainda não são permitidas, apontando ao Painel de Frases Mórbidas. Os participantes também foram estimulados a completar o Painel de Expectativas, ou seja, se surgiram novas expectativas, diferentes daquelas expressas no primeiro encontro, deveriam ser incluídas no painel, conforme figura 73.

A equipe buscou observar atentamente se havia repreensões entre os próprios participantes e as coibir sempre que possível, indicando que o participante, de forma autônoma, a registrasse no painel. A equipe ouviu todos e registrou ideias, mesmo que em contradição com outras já registradas, além de periodicamente relembrá-los sobre a regra de evitar críticas às ideias apresentadas; 
Figura 73 - Exemplo de tela de exposição do moderador
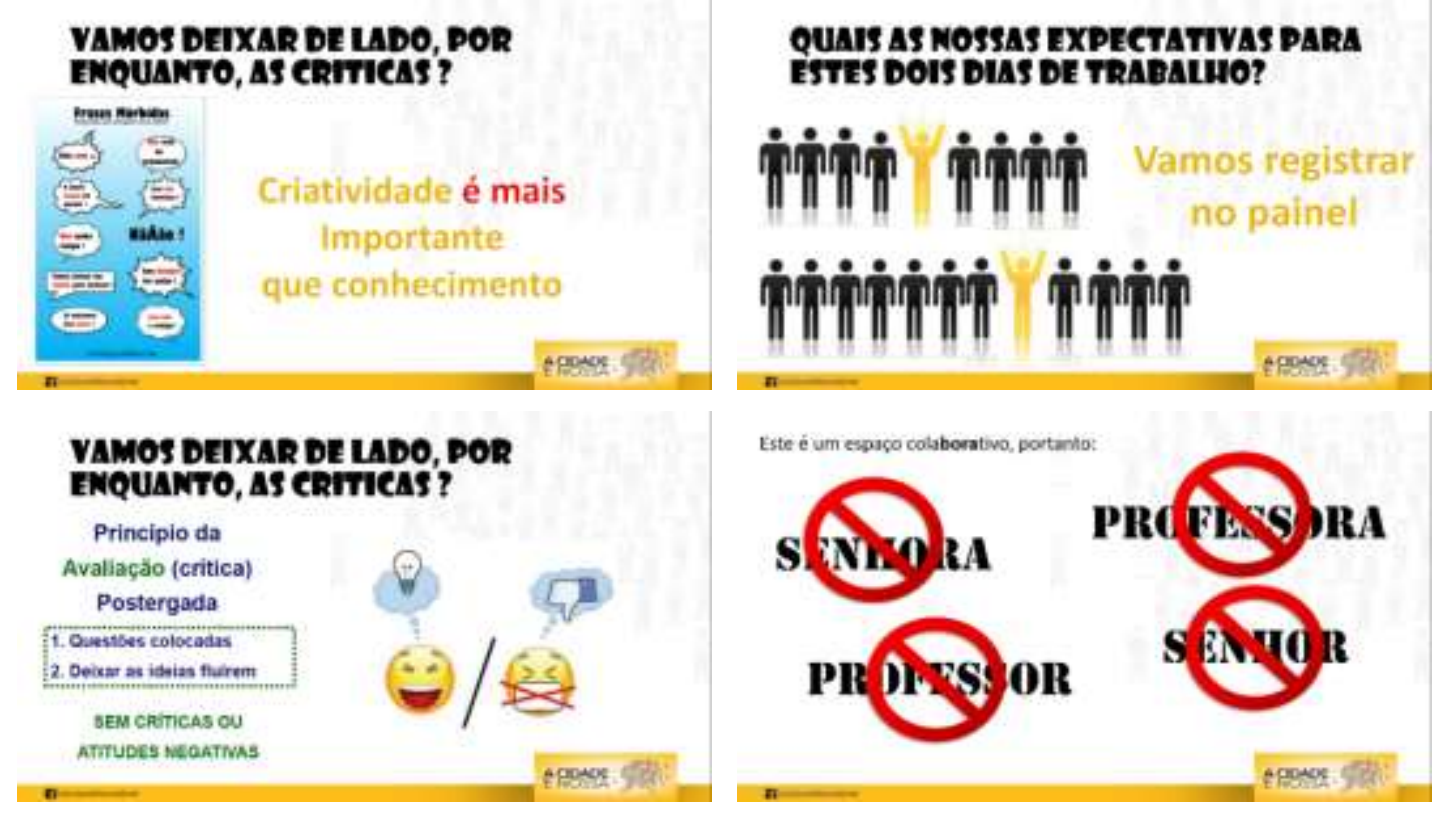

Fonte: Do autor (2019).

c) Dinâmica laboral de estreitamento: conforme a proposta metodológica, o moderador aplicou a "dinâmica do pistoleiro", conforme descrito e aplicado no primeiro encontro, para motivar mobilização, envolvimento e sensibilização, inclusive de forma laboral, deixou as pessoas mais confortáveis no ambiente;

d) Dinâmica de fortalecimento de vínculos: nesta atividade, o moderador sugeriu que as pessoas imaginassem como seria a sua visão de bairro ideal. Em seguida, as pessoas foram organizadas em trios. Na primeira rodada, a pessoa "A" relata à pessoa "B" como seria sua visão, usando entre 3 e 5 minutos, enquanto a pessoa " $C$ " apenas observar o relato. Ao fim do tempo, a pessoa "C" apresenta ao grupo o resumo do relato da pessoa " $\mathrm{A}$ ". $\mathrm{Na}$ segunda rodada, a pessoa "C" relata sua visão à pessoa "A", usando o mesmo período de tempo, enquanto a pessoa "B" apenas observa o relato. Depois, a pessoa "B" apresenta o resumo do relato da pessoa "C" ao grupo. Na terceira rodada, a pessoa "B" relata à pessoa "C" sua visão, usando o mesmo período de tempo, enquanto a pessoa " $A$ " apenas observa o relato. Então, a pessoa "A" apresenta ao grupo o resumo do relado da pessoa "B". Esta última atividade, muito mais laboral do que para produzir resultados, permite à equipe de pesquisa notar como as pessoas filtram o que escutam sobre outras pessoas, posto que de tudo que se escuta, nem todas as informações são efetivamente apreendidas. Ao perguntar o que as pessoas acharam mais difícil, foi relatado que é curioso ver suas opiniões 
transmitidas por outra pessoa e que, às vezes, um detalhe para quem escuta é, para quem fala, o mais importante. Depois disso, os participantes foram levados para fora da sala, até os painéis que sintetizam os problemas gerados, e informados de que os problemas ali dispostos foram determinados a partir das dinâmicas elaboradas no encontro anterior, conforme figura 74 .

Figura 74 - Disposição dos painéis de valoração dos problemas

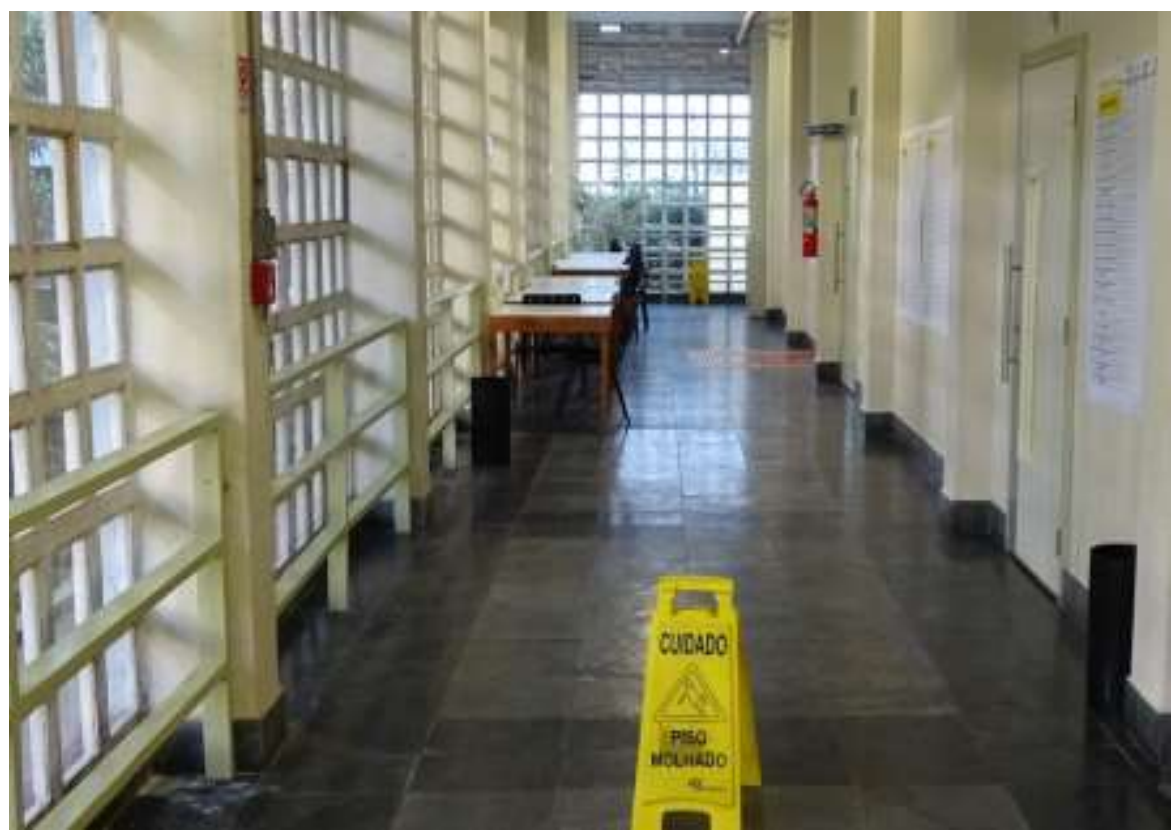

Fonte: Do autor (2019).

e) Valoração do Painel de Efeitos e Impactos dos Problemas: os grupos receberam adesivos coloridos em quatro cores diferentes (azul, verde, vermelho e magenta), e os participantes foram apresentados ao Painel de Efeitos e Impactos dos Problemas, o qual apresenta a lista de todos os problemas do encontro anterior sintetizados. Foi dada a instrução de usar os marcadores coloridos para avaliar cada dimensão do problema, de maneira que cada cor representasse uma dimensão específica. Para cada dimensão, em cada um dos problemas, os participantes poderiam atribuir uma valoração à intensidade, que varia de 1 a 3.

Foram quatro dimensões de valoração, considerando que a frequência (azul) representa a recorrência do problema, a relevância (verde) representa a consequência do problema e sua forma de atingir as pessoas, a dificuldade de correção (vermelho) representa o esforço necessário para solucionar o problema, e a dificuldade de detecção (magenta) representa a facilidade de se identificar o problema. Nesta atividade, são usados o Painel de Efeitos e Impactos dos Problemas, fita adesiva e adesivos coloridos, conforme figura 75. 
Figura 75 - Valoração do Painel de Efeitos e Impactos dos Problemas

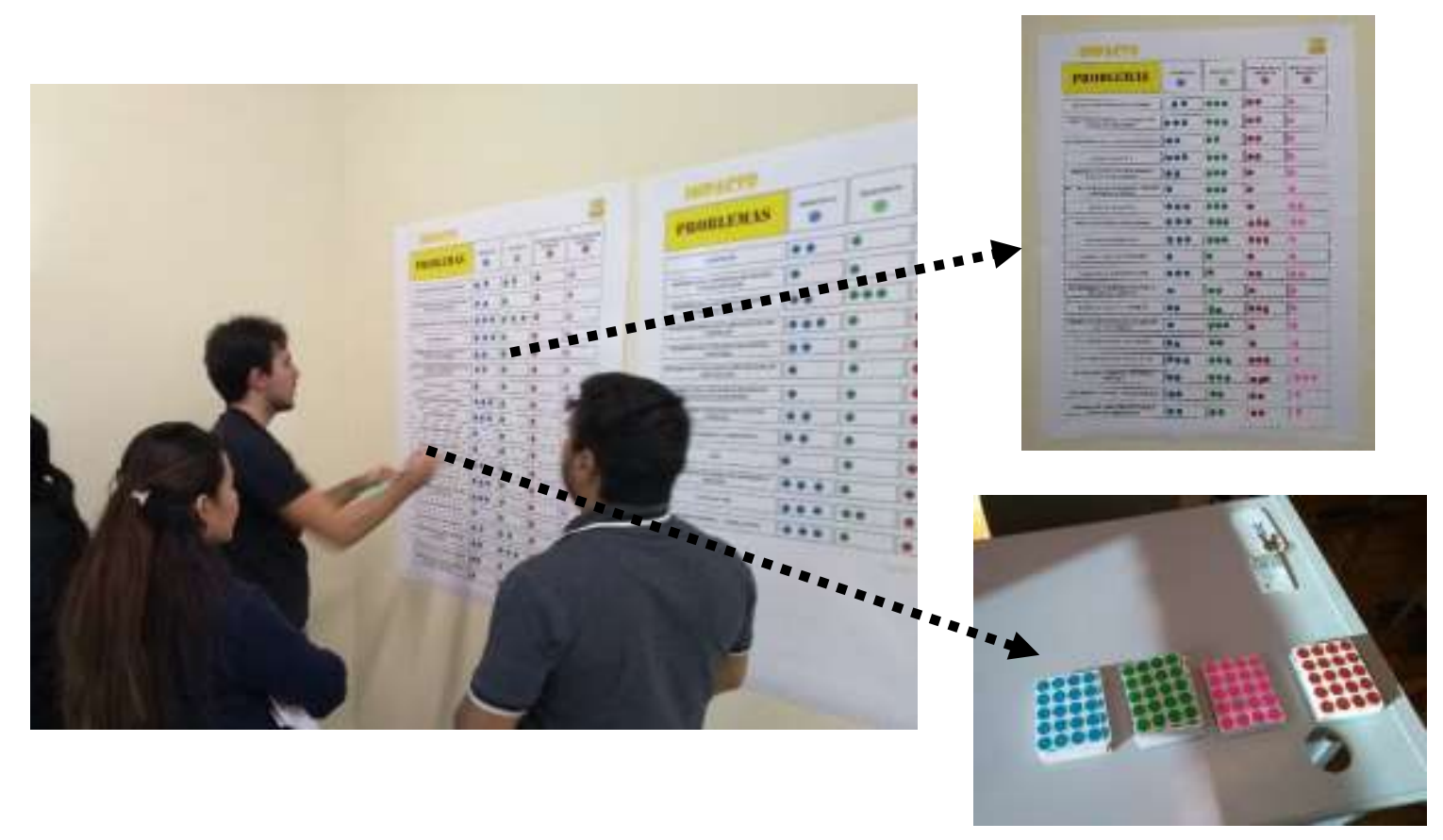

Fonte: Do autor (2019).

Este painel gera dados importantes aos pesquisadores, incluindo resultados numéricos que valoram os problemas sob a ótica da população - e, portanto, podem hierarquizar a prioridade dos problemas, com os índices gerados $\mathrm{ICP}_{(\mathrm{p})}$ (Índice de Caracterização de Problemas Preliminar), IIP (Índice de Intervenção de Problemas), $\operatorname{ICP}_{(a)}$ (Índice de Caracterização de Problemas Ampliado), IHP (Índice Hierárquico de Problemas) e IPGP (Índice Priorizador Geral de Problemas);

f) Estabelecimento das Redes Peer-to-Peer: nesta atividade, os sujeitos foram apresentados ao Painel de Ligação Peer-to-Peer. Os participantes foram estimulados a ligar os problemas às alternativas, ou seja, verificar quais alternativas podem ser solucionados por quais alternativas. As possibilidades sugeridas foram que um problema poderia ser ligado a uma alternativa por uma linha, um problema poderia ser ligado a duas alternativas por duas linhas, e dois ou mais problemas poderiam ser ligados a uma alternativa, conforme figura 76.

Nessa dinâmica, são utilizadas canetas hidrográficas coloridas. Os resultados gerados apontam as conexões de cada um dos problemas e de cada uma das alternativas, e permitem o cálculos dos índices: $\operatorname{IFP}_{(\mathrm{p})}$ (Índice de Flexibilidade de Problemas Preliminar), $\operatorname{IFP}_{(\mathrm{r})}$ (Índice de Flexibilidade de Problemas Relativo), IFA(p) (Índice de Flexibilidade de Alternativas Preliminar), e IFA $_{(\mathrm{r})}$ (Índice de Flexibilidade de Alternativas Relativo); 
Figura 76 - Estabelecimento das Redes Peer-to-Peer

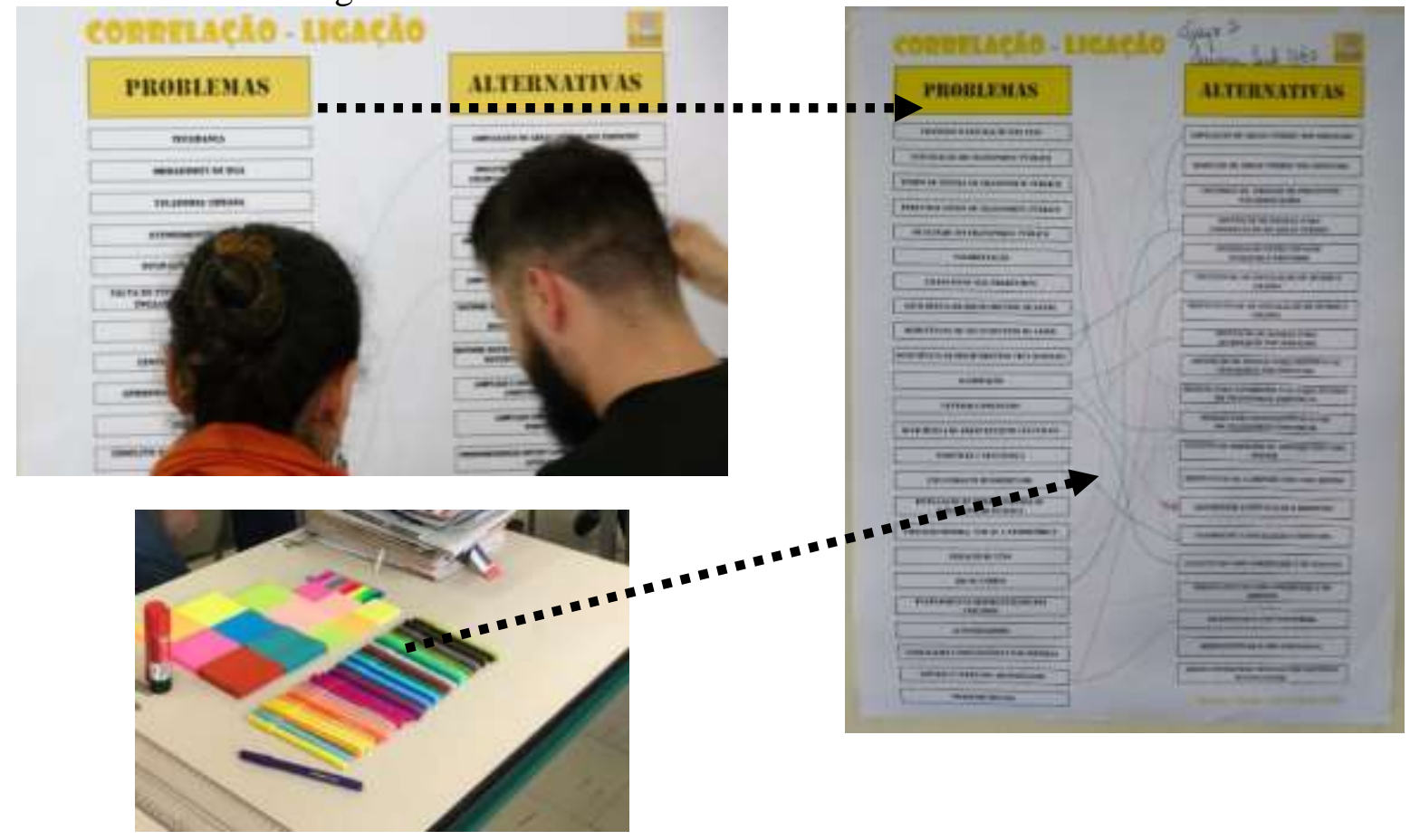

Fonte: Do autor (2019).

g) Verificação da intensidade das correlações: nesta etapa, o moderador apresentou o Painel de Análise e Correlação das Alternativas e explicou o significado de cada uma das cores (cor branca ou ausência de marcação representa que a alternativa não afetaria ou não atenderia o problema, a cor azul representa que a alternativa atua indiretamente em um problema sem o solucionar completamente, a cor verde representa que a alternativa atua indiretamente e soluciona completamente o problema, a cor vermelha representa que a alternativa atua diretamente no problema solucionando-o incompletamente, e a cor magenta representa que a alternativa atua diretamente no problema e o soluciona completamente). Cada linha do painel corresponde a uma alternativa, e cada coluna corresponde a um problema. Portanto, os participantes associaram cada alternativa a um dos problemas, conforme figura 77.

Então, os participantes foram levados novamente para dentro da sala, e agora o moderador informou que os problemas foram deixados para trás (estão do lado de fora do ambiente), pois o momento deveria ser dedicado a falar sobre soluções. Isso, psicologicamente, cria um ambiente favorável aos participantes e remove as barreiras ao avaliar alternativas, o que se mostrou interessante em todas as dinâmicas, pois no novo espaço, agora livre de problemas, a proposta propiciou a concentração na reflexão das soluções e, consequentemente, ordenou-as hierarquicamente, a partir de uma valoração; 
Figura 77 - Verificação da intensidade das correlações

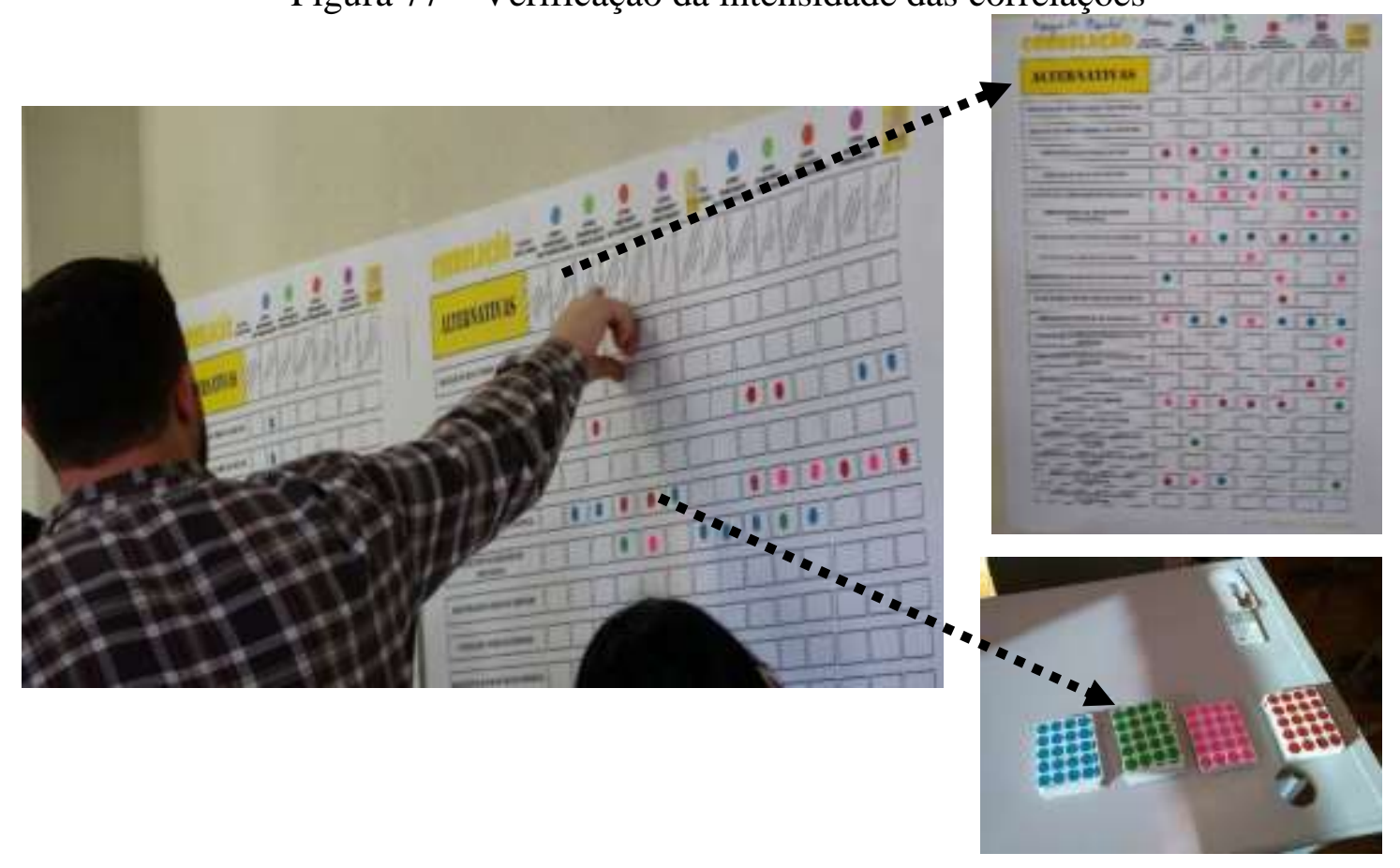

Fonte: Do autor (2019).

h) Análise e valoração de oportunidade e ameaças nas alternativas: o moderador apresentou aos participantes o Painel de Avaliação das Alternativas, em que cada linha representa uma alternativa, e cada coluna representa uma dimensão associada à dificuldade de sua implantação, com os títulos "Técnica" (legenda azul), "Econômica" (legenda verde), "Política" (legenda vermelha) e "Aceitação Popular" (legenda magenta). O moderador explicou que a dificuldade técnica representava os esforços técnicos e tecnológicos para concretizar a alternativa, a dificuldade econômica representava a disponibilidade de recursos e a quantidade de recursos necessários para concretizar a alternativa, a dificuldade política representava a dificuldade de aprovação formal pelo Estado e seus desdobramentos em um processo político para efetivar a alternativa, e a dificuldade de aceitação popular representava a forma de as pessoas poderem reagir à alternativa proposta, no que tange a sua aceitação. Em cada dimensão, os participantes puderam inserir de 1 a 3 marcadores para cada alternativa, conforme figura 78 .

O processo criado desde a sua concepção fez com que o resultado da valoração fosse satisfatório, uma vez que foi possível perceber nos participantes uma capacidade de negociação e consenso mais elaborada, bem como sua consciência a respeito das dificuldades de se enfrentar os problemas urbanos. Na etapa anterior de verificação de correlações e nesta atividade de valoração de dificuldades, percebeu-se maior atenção, reflexão e discussão entre os participantes. 
Figura 78 - Verificação da intensidade das correlações

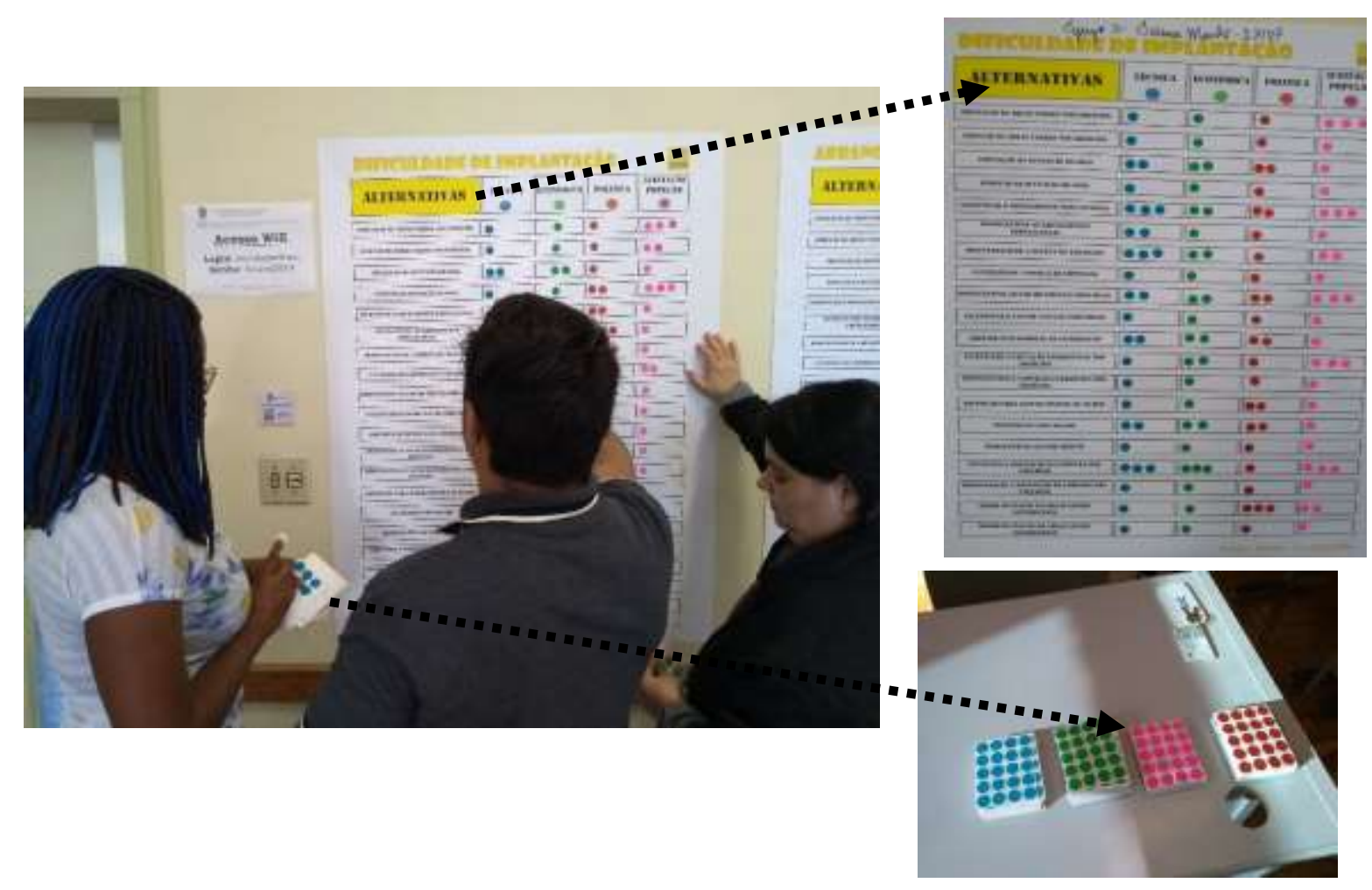

Fonte: Do autor (2019).

Nesta atividade, foram usados adesivos coloridos, e os resultados produzidos permitiram o cálculo dos índices IDI-A (Índice de Dificuldade de Implantação de Alternativas), IDAA (Índice de Dificuldade de Ação nas Alternativas), IGD-A (Índice Geral Dificuldade da Alternativa), IGD-A $(\mathrm{p})$ (Índice Geral de Dificuldade da Alternativa Ponderado), IHA (Índice Hierárquico de Alternativas) e IPG-A (Índice Priorizador Geral de Alternativas);

i) Inserção territorial e escalas: nesta nova atividade, o moderador apresentou aos participantes o Painel de Abrangências e instruiu os sujeitos a respeito de o preenchimento não requerer uma classificação de intensidade. Assim, cada linha representou uma alternativa, e cada coluna representou uma escala de aplicação, tal como na abrangência da quadra, do bairro, da zona e da cidade (outras escalas podem ser elaboras, em função do tema e da área objeto de estudo). Cada cor representou uma escala, quais sejam azul a quadra, verde o bairro, vermelho a zona e magenta a cidade. Uma mesma alternativa poderia possuir duas ou mais marcações, ou seja, pode simultaneamente ser aplicada na escalda da quadra, do bairro e da cidade, conforme se observa na figura 79. 
Figura 79 - Preenchimento do painel de abrangência ( Inserção territorial e escala)

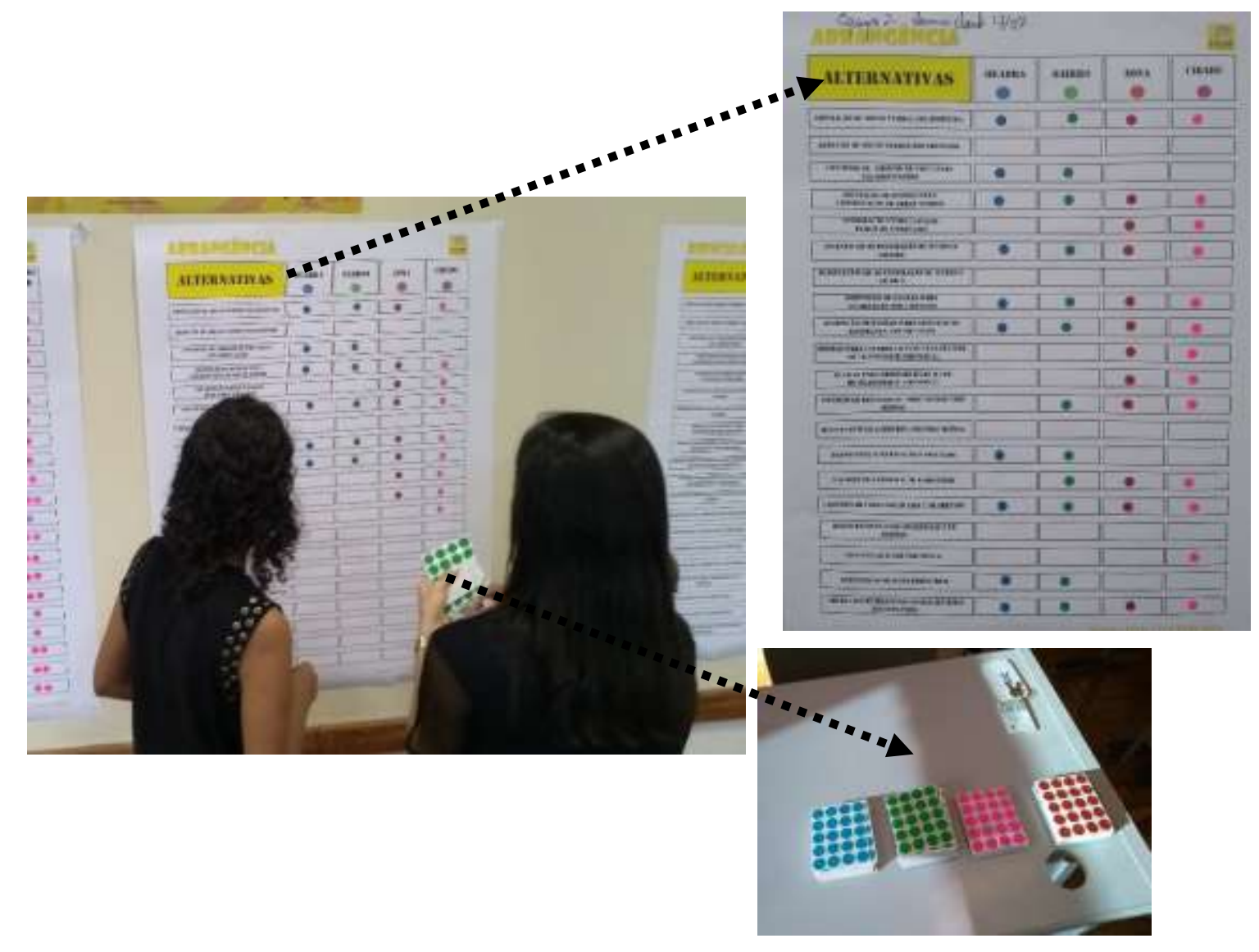

Fonte: Do autor (2019).

Nesta etapa, foram utilizados adesivos coloridos e ajuda da equipe de pesquisa para entender, sob a perspectiva da população, em que escala as alternativas poderiam ser aplicadas. O resultado desta etapa é muito mais qualitativo do que quantitativo;

j) Avaliação de fraquezas e ameaças: neste momento, para se identificar as questões associadas às alternativas que podem atuar com barreiras em sua aplicação, o moderador apresentou o Painel de Crítica Postergada, no qual cada linha representa uma alternativa. Assim, os participantes foram estimulados a escrever (sem consultar ninguém e sem debates) críticas, comentários e opiniões negativas que cada um associa a alguma alternativa específica, conforme figura 80.

Nem sempre é necessário apoio incondicional a uma proposta. Nesta atividade, foram utilizados canetas coloridas, papéis coloridos, cola e fita adesiva. Esperava-se que, ao final da dinâmica, os participantes conseguissem expressar suas opiniões e críticas, envolvendo preocupações para a implantação das alternativas. Notou-se que, na prática, 
exaurida a etapa de valoração os sujeitos, não havia mais elementos de crítica, e raras foram as manifestações nesse painel em todos os grupos;

Figura 80 - Avaliação de fraquezas e ameaças (Seleção de nós críticos e critica postergada)

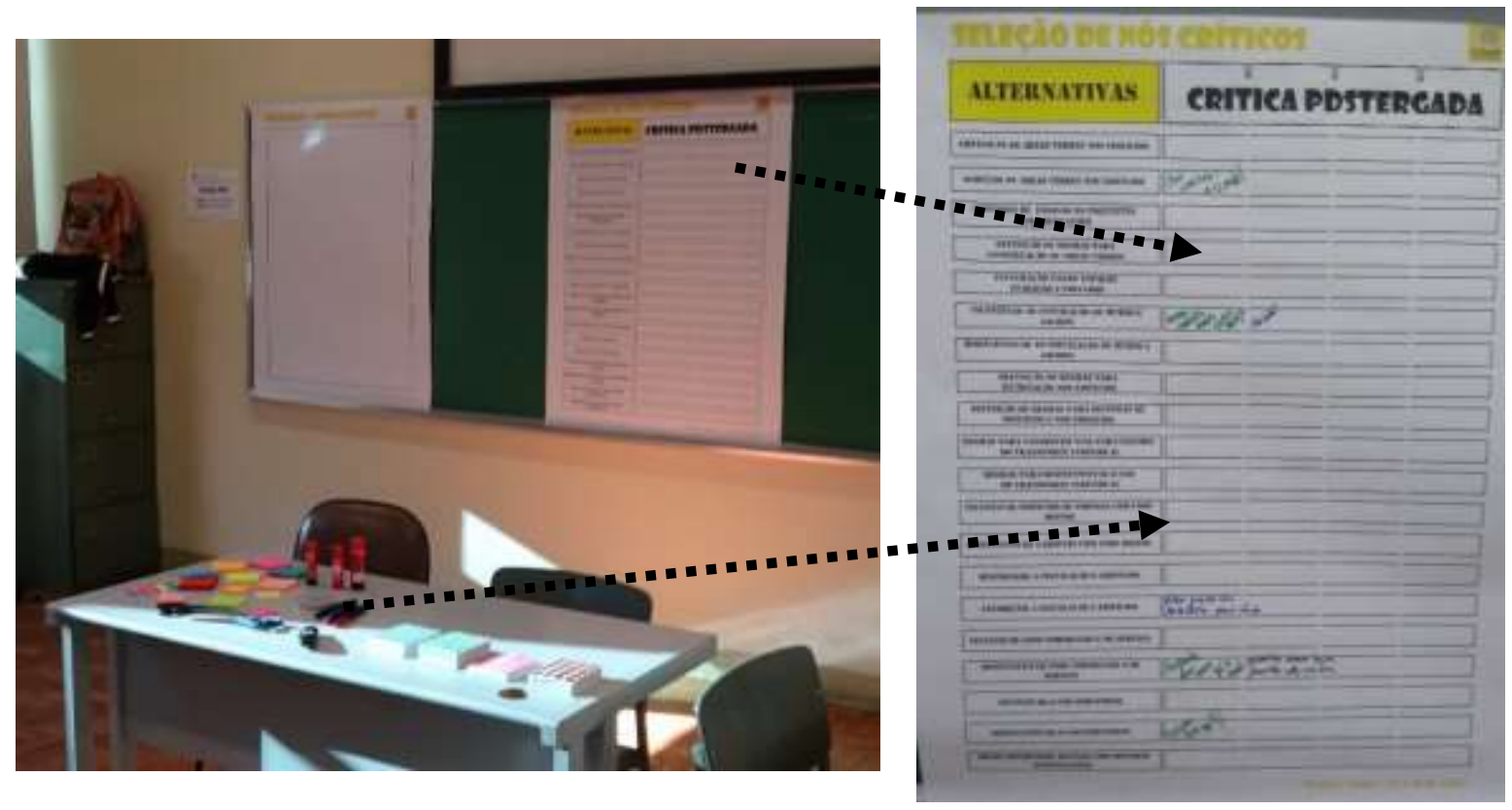

Fonte: Do autor (2019).

k) Mosaico de fotos: as fotos dos aspectos negativos e positivos enviadas pelos participantes foram impressas e misturadas, para que nenhum participante soubesse de fato o que era considerado positivo ou negativo. O moderador sugeriu que cada participante selecionasse duas fotos, e colasse uma delas no painel de alternativas e outra no painel de problemas. A única regra era que os participantes não deveriam usar a foto que trouxeram e nem comunicar ao demais sobre a foto que haviam enviado, conforme figura 81 .

O material usado nesta atividade foi composto por fotos impressas, cola, tesoura, adesivos coloridos, papéis coloridos, canetas coloridas, fita adesiva, tesoura e cola. O resultado esperado já havia sido consolidado, na realidade, pois objetivava-se que as pessoas, no momento em que circulavam pela cidade, escolhessem apenas um aspecto negativo e um aspecto positivo, o que as fez vivenciar na prática inúmeras situações, sensibilizando seu olhar. Os relatos obtidos na pesquisa apontaram que os participantes afirmavam frases como "eu nunca tinha reparado nisso, e isso é mais frequente do que eu imaginava". O ganho proporcionado pela atividade é dos participantes e não da equipe de pesquisa, de forma que é uma etapa de aprendizagem social que contribui para formação de pessoas críticas em relação à cidade, ao bairro e aos serviços urbanos. O conhecimento é emancipatório, e como a atividade foi realizada no intervalo entre os blocos (e antes da 
etapa de valoração), permitiu que a avaliação dos problemas e das alternativas fosse incrementada com a experiência individual;

Figura 81 - Elaboração do Mosaico de Fotos de Problemas e Alternativas

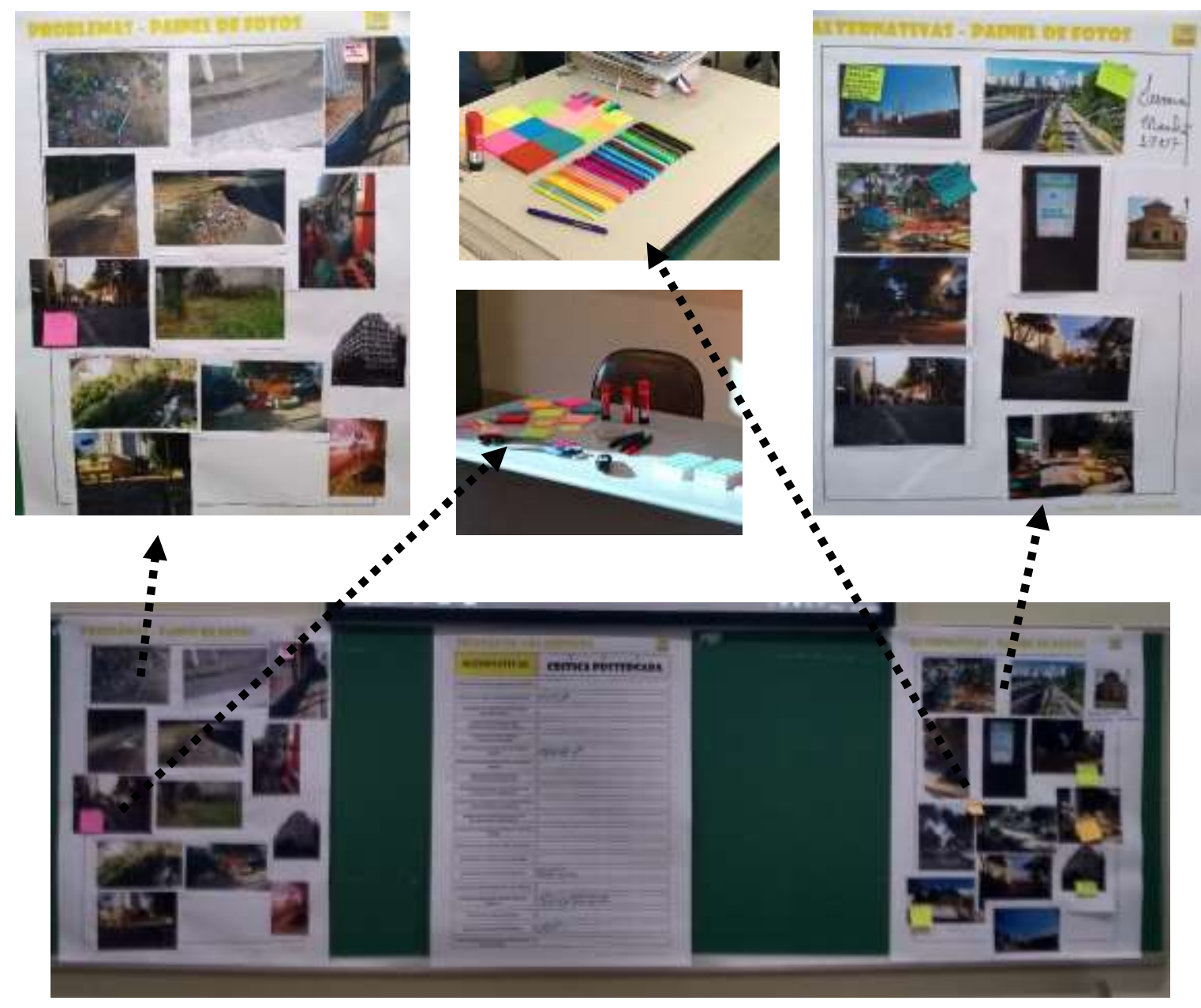

Fonte: Do autor (2019).

I) Fechamento de expectativas e revalidação de opiniões: nesta etapa, os participantes receberam o formulário que já haviam preenchido, com caneta azul, no primeiro dia de atividades, o qual continha três blocos de perguntas. O primeiro bloco incluía seis perguntas para caracterização do perfil dos participantes, questionando idade, gênero, escolaridade, atividades que realiza na cidade e renda. O segundo bloco incluía perguntas para avaliação da cidade e do bairro, com notas a serem atribuídas para aspectos como segurança, qualidade dos serviços públicos, mobilidade, custo de vida, tempo de deslocamento na cidade, frequência de utilização do transporte público, utilização de espaços públicos e desejos sobre a cidade. O terceiro bloco incluía perguntas sobre política urbana, especificamente sobre o Plano Diretor do Município de São Paulo. Neste momento, o moderador instruiu os participantes a preencherem o formulário, caso 
quisessem mudar alguma resposta, contudo com caneta vermelha. Esta atividade busca avaliar se houve disseminação de conteúdo e, ainda, se as pessoas mudaram de opinião com relação ao bairro ou à cidade onde moram. Enquanto o formulário era preenchido, o moderador reforçou que gostaria de aferir se as expectativas registradas no painel de expectativas haviam sido atendidas e, em voz alta, perguntou aos participantes, um a um, se foram atendidas ou não (e, se não foram, pergunta por que não), conforme figura 82.

Figura 82 - Retomada ao painel de expectativas

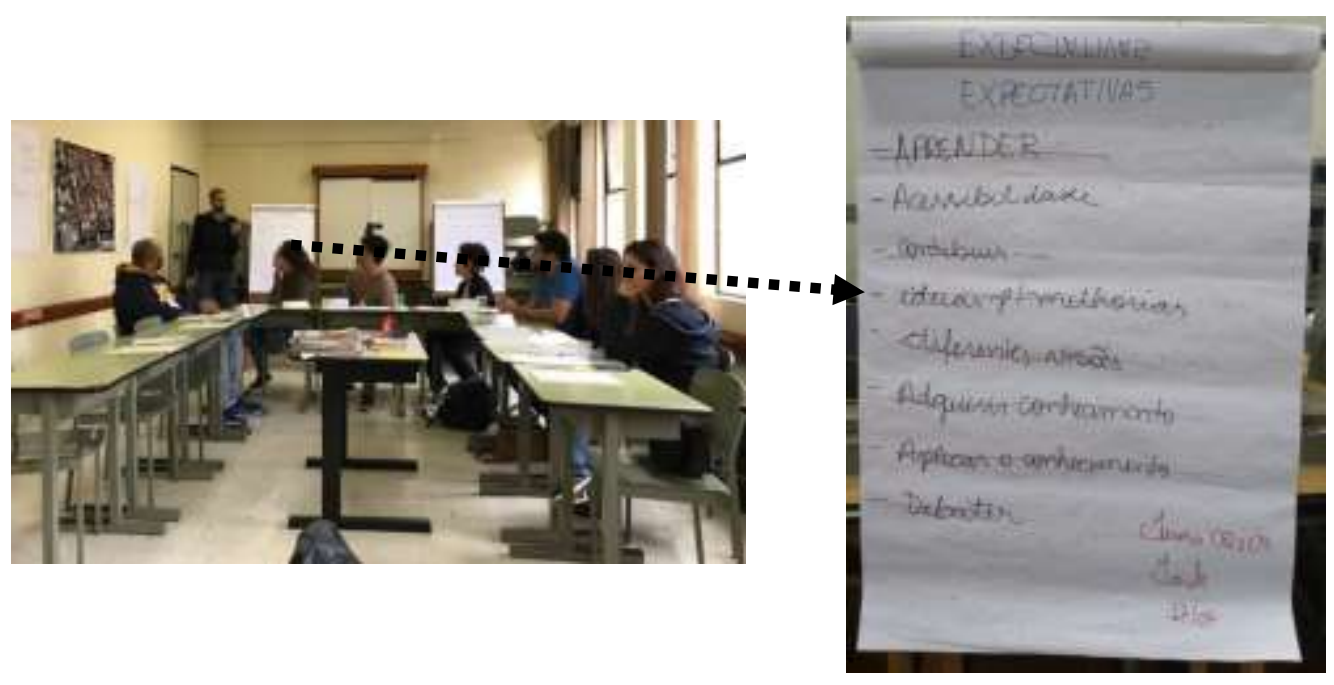

Fonte: Do autor (2019).

Esta etapa contribuiu com a sensação de missão cumprida, garantindo que as pessoas saíssem de um encontro com a percepção de que, além de dar contribuições, levaram algo para si. Esse nível de engajamento, ou seja, de troca, fortalece os indivíduos e promove a atitude de eles se tornarem multiplicadoras de um processo participativo de sucesso;

m) Encerramento: o moderador agradeceu a todos pela presença e reiterou que os participantes são multiplicadores. Além disso, a equipe entregou certificados nominais de participação $^{110}$ a cada um dos presentes. O certificado tem valor intangível aos participantes, pois reforça que há uma preocupação da equipe em formalizar o processo e registrar que os participantes levem algo para si. Ademais, em processos consultivos, é prudente preparar uma pesquisa de satisfação aos participantes. No caso, foram impressos formulários anônimos, solicitando (i) nota de 0 a 10 para o primeiro dia de dinâmicas, (ii)

\footnotetext{
110 O projeto de pesquisa contou com apoio institucional da Faculdade de Ciências Exatas e Tecnologia da Pontifícia Universidade Católica de São Paulo. O apoio incluiu a disponibilização das salas para realização das dinâmicas, com infraestrutura de informática (computadores e Data Show), cadeiras, mesas, limpeza e sanitários. Houve também apoio parcial para obtenção de material impresso e emissão formal de certificados, chancelados pelo Diretor da Faculdade Exmo. Professor Doutor Daniel Couto Gatti. A utilização dos logotipos foi autorizada pela direção e seguiu o manual da marca da Pontifícia Universidade Católica de São Paulo.
} 
nota de 0 a 10 para o segundo dia de dinâmicas, (iii) nota de 0 a 10 para o evento como um todo, (iv) nota de 0 a 10 para cada uma das atividades propostas, (v) avaliação da duração das atividades ("ruim", "regular", "boa" ou "excelente”), (vi) avaliação do atendimento às expectativas (“sim”, "não" ou "parcialmente”), (vii) avaliação sobre a possibilidade de voltar a participar ("sim" ou "não"), (viii) avaliação sobre o sentimento de capacidade de aplicar as ferramentas aprendidas, e (ix) outros comentários (espaço livre), como mostra a figura 83 .

Figura 83 - Pesquisa de satisfação e emissão de certificados
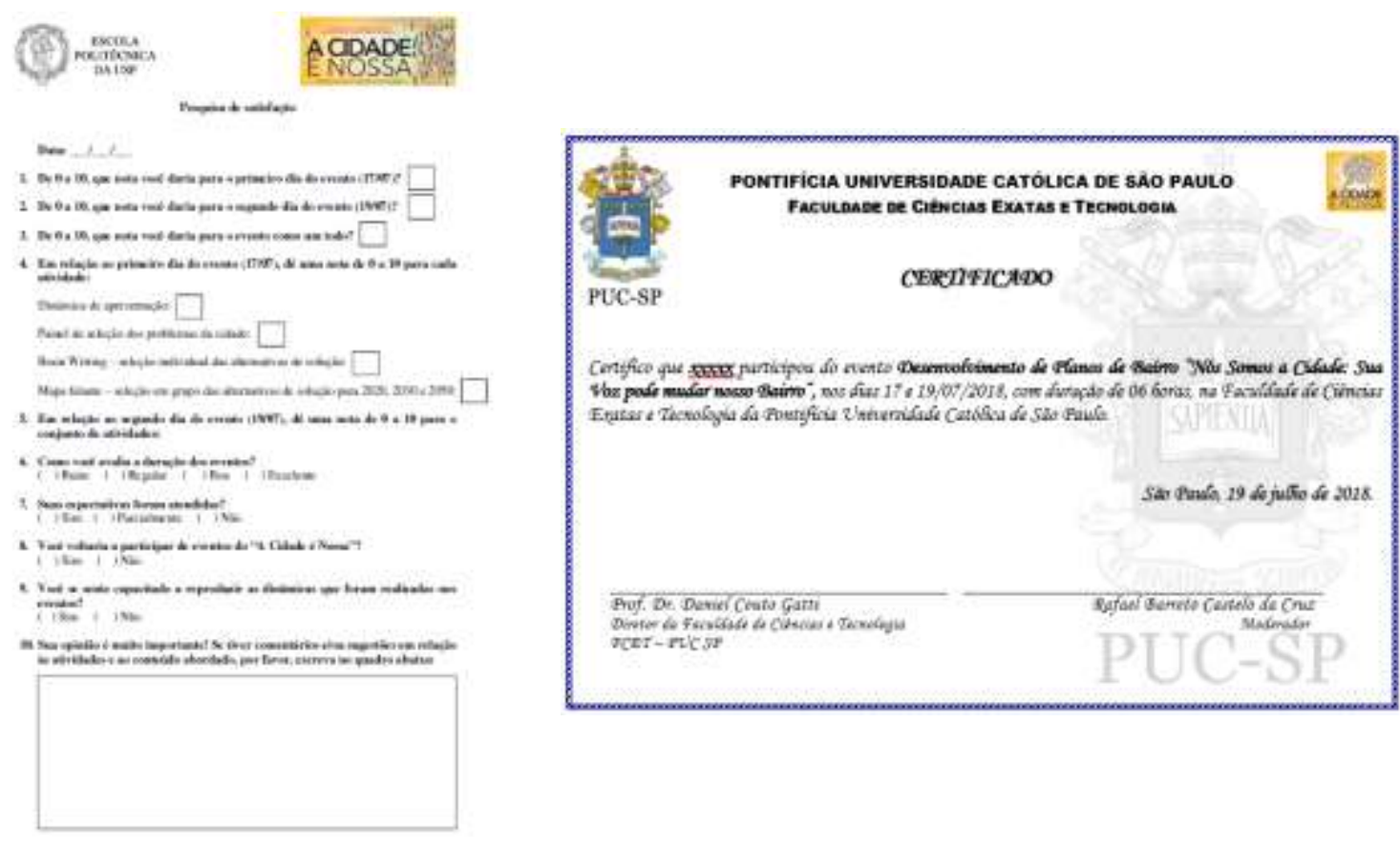

Fonte: Do autor (2019).

O quadro 24 resume a distribuição das atividades ilustradas anteriormente ao longo desta etapa da dinâmica, consolidando a duração, os materiais usados e os resultados obtidos. A aplicação da proposta metodológica até este ponto se mostrou satisfatória para a obtenção de dados que pudessem auxiliar nas decisões de planejamento urbano do ponto de vista qualitativo. O desafio de se agregar, de forma única e concisa, a posição de vários grupos e/ou populações foi superado com a sequência de passos propostos. 
Quadro 24 - Distribuição das atividades, materiais, objetivos e duração no segundo encontro

\begin{tabular}{|c|c|c|c|}
\hline $\begin{array}{l}\text { Duração } \\
\text { (minutos) }\end{array}$ & Atividade & Materiais & $\begin{array}{l}\text { Resultados e } \\
\text { Objetivos }\end{array}$ \\
\hline 10 & $\begin{array}{l}\text { Recepção dos } \\
\text { participantes }\end{array}$ & $\begin{array}{l}\text { Formulários impressos, } \\
\text { lista de presença, } \\
\text { canetas esferográficas }\end{array}$ & $\begin{array}{l}\text { Receber os } \\
\text { participantes }\end{array}$ \\
\hline 10 & $\begin{array}{l}\text { Exposição do reforço do } \\
\text { compromisso }\end{array}$ & $\begin{array}{l}\text { Canetas coloridas, } \\
\text { Painel de Expectativas, } \\
\text { Painel de Frases } \\
\text { Mórbidas }\end{array}$ & $\begin{array}{c}\text { Reforçar as } \\
\text { expectativas, } \\
\text { Reforçar o ambiente } \\
\text { de não crítica }\end{array}$ \\
\hline 10 & $\begin{array}{l}\text { Dinâmica laboral de } \\
\text { estreitamento }\end{array}$ & 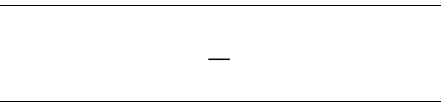 & $\begin{array}{c}\text { Relaxar fisicamente os } \\
\text { participantes }\end{array}$ \\
\hline 10 & $\begin{array}{c}\text { Dinâmica de } \\
\text { fortalecimento de } \\
\text { vínculos }\end{array}$ & - & $\begin{array}{l}\text { Treinar a capacidade } \\
\text { de explicar, ouvir, } \\
\text { observar e comunicar }\end{array}$ \\
\hline 30 & $\begin{array}{l}\text { Valoração do Painel de } \\
\text { Efeitos e Impactos dos } \\
\text { Problema }\end{array}$ & $\begin{array}{l}\text { Painel de Efeitos e } \\
\text { Impactos dos Problemas, } \\
\text { adesivos coloridos }\end{array}$ & $\begin{array}{l}\text { 7. } \mathrm{ICP}_{(\mathrm{p})}, \mathrm{IIP}, \\
\text { 8. } \mathrm{ICP}_{(\mathrm{a})}, \mathrm{IHP}, \\
\text { IPG-P }\end{array}$ \\
\hline 15 & Intervalo & Coffee break & Favorecer a interação \\
\hline 15 & $\begin{array}{l}\text { Estabelecimento das } \\
\text { Redes Peer-to-Peer }\end{array}$ & $\begin{array}{l}\text { Painel de Ligação, } \\
\text { adesivos coloridos }\end{array}$ & $\begin{array}{c}\operatorname{IFP}_{(\mathrm{p})}, \operatorname{IFP}_{(\mathrm{r})}, \operatorname{IFA}_{(\mathrm{p})} \\
\operatorname{IFA}_{(\mathrm{r})}\end{array}$ \\
\hline 30 & $\begin{array}{l}\text { Verificação da } \\
\text { intensidade das } \\
\text { correlações }\end{array}$ & $\begin{array}{l}\text { Painel de Análise e } \\
\text { Correlação das } \\
\text { Alternativas, } \\
\text { adesivos coloridos }\end{array}$ & 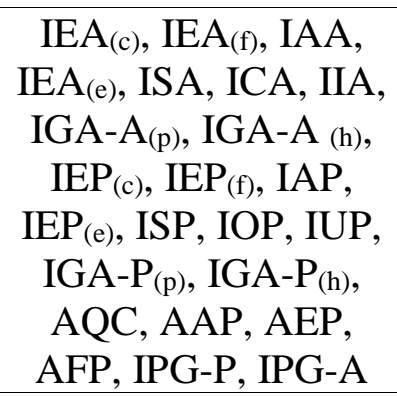 \\
\hline 30 & $\begin{array}{c}\text { Análise e valoração de } \\
\text { oportunidades e ameaças } \\
\text { nas alternativas }\end{array}$ & $\begin{array}{c}\text { Painel de Avaliação das } \\
\text { Alternativas, } \\
\text { adesivos coloridos }\end{array}$ & $\begin{array}{c}\text { IDI-A, IDA-A, IGD- } \\
\text { A, IGD-A(p), IHA, } \\
\text { IPG-A }\end{array}$ \\
\hline 10 & $\begin{array}{l}\text { Inserção territorial e } \\
\text { escalas }\end{array}$ & $\begin{array}{l}\text { Painel de Abrangência, } \\
\text { adesivos coloridos }\end{array}$ & $\begin{array}{l}\text { Avaliar a inserção } \\
\text { territorial das } \\
\text { alternativas }\end{array}$ \\
\hline 10 & $\begin{array}{c}\text { Avaliação de Fraquezas } \\
\text { e Ameaças }\end{array}$ & $\begin{array}{c}\text { Painel de Crítica } \\
\text { Postergada } \\
\text { Adesivos Coloridos } \\
\text { Papéis Coloridos } \\
\text { Canetas Coloridas } \\
\text { Cola }\end{array}$ & $\begin{array}{l}\text { Avaliar os nós críticos } \\
\text { e barreiras para } \\
\text { implantação das } \\
\text { alternativas }\end{array}$ \\
\hline
\end{tabular}




\begin{tabular}{|c|c|c|c|}
\hline 10 & Mosaico de fotos & $\begin{array}{c}\text { Painel de Fotos de } \\
\text { Alternativas, } \\
\text { Painel de Fotos de } \\
\text { Problemas, } \\
\text { adesivos coloridos, } \\
\text { papéis coloridos, } \\
\text { canetas coloridas, } \\
\text { cola, } \\
\text { tesoura, } \\
\text { fotografias impressas }\end{array}$ & $\begin{array}{l}\text { Sensibilização do } \\
\text { olhar, } \\
\text { aprendizagem } \\
\text { vivencial }\end{array}$ \\
\hline 10 & $\begin{array}{l}\text { Fechamento de } \\
\text { expectativas }\end{array}$ & $\begin{array}{l}\text { Painel de Expectativas, } \\
\text { canetas coloridas, } \\
\text { canetas esferográficas, } \\
\text { formulário de } \\
\text { caraterização } \\
\end{array}$ & $\begin{array}{l}\text { Analisar a satisfação } \\
\text { dos participantes, } \\
\text { avaliar o aprendizado } \\
\text { obtido no processo }\end{array}$ \\
\hline 10 & Encerramento & $\begin{array}{l}\text { Pesquisa de satisfação, } \\
\text { canetas esferográficas, } \\
\text { certificados impressos }\end{array}$ & $\begin{array}{c}\text { Fortalecer vínculos, } \\
\text { avaliar os } \\
\text { instrumentos } \\
\text { participativos }\end{array}$ \\
\hline
\end{tabular}

Fonte: Do autor (2019). 


\section{ANÁLISE DO PROCESSO DE APLICACÃO DA PROPOSTA METODOLÓGICA}

Os instrumentos lúdicos, multifacetados e de valoração, quando aplicados isoladamente, podem não representar a opinião efetiva da população. Porém, quando aplicados com o sequenciamento proposto, verificou-se que o consenso foi naturalmente construído. $\mathrm{O}$ consenso, nesse contexto, pode ser mais valioso que o voto, pois este admite que as escolhas são binárias, e, assim, nem sempre as diversas opiniões são consideradas; por outro lado, o consenso tem uma relação de troca e aprendizado em que as vontades são somadas e mediadas pelos próprios agentes.

A abordagem de grupo, a adaptação dos grupos focais, os mapas falantes, o painel integrado e a pesquisa participativa se mostraram instrumentos eficazes para a consulta popular no contexto de planejamento urbano. Mesmo sem perceber, os participantes realizaram uma análise de valoração multicriterial ao atribuir pontuações às diversas dimensões propostas, e ainda ao correlacionar alternativas e problemas. Em relação ao aspecto de planejamento estratégico, a aplicação da proposta metodológica sob um olhar explicativo conseguiu, nas dinâmicas do primeiro encontro, com o Painel de Seleção de Problemas e o Painel da Visão, selecionar e descrever problemas. No mesmo encontro, também foi possível desenhar uma situação objetiva e, com a tempestade cerebral de soluções e o painel da visão, propor alternativas e selecionar trajetórias.

Ainda em relação ao aspecto de planejamento estratégico, no segundo encontro, as dinâmicas de valoração do impacto dos problemas permitiram, sob um olhar explicativo, selecionar nós críticos, e sob um olhar estratégico, identificar recursos críticos a cada problema, bem como sua vulnerabilidade. As dinâmicas de ligação e correlação entre alternativas e problemas permitem, adicionalmente, selecionar trajetórias. Também no segundo encontro, o painel de valoração das alternativas, sob um olhar estratégico, permitiu delimitar os recursos necessário para concretizar as ações, e ainda, identificar os atores sociais relevantes e a vulnerabilidade das ações.

Assim, por meio da aplicação da proposta metodológica, os participantes podem, indiretamente, construir uma avaliação multicriterial, ainda que sem perceber. Pois, a partir de um diagnóstico situacional, puderam propor objetivos, problemas e alternativas, além de avaliar o desempenho das alternativas e dos problemas e a correlação entre os problemas, os objetivos e as alternativas, fechando um ciclo multicriterial de estruturação e avaliação. Ademais, o processo contribui para a formação cidadã, e o próprio processo reflexivo, pois fortalece o 
engajamento dos sujeitos, com interlocução sinérgica, inclusive quando as opiniões podem não ser convergentes.

O que se percebeu foi que as abordagens participativas são ancoradas em relações de confiança e que são imprescindíveis o feedback e a justificativa das decisões e das ações. Abordagens que simplificam o diálogo, baseadas nas ciências sociais, podem instrumentalizar elementos de planejamento urbano. Estas estratégias inclusivas podem demonstrar um vetor convidativo à participação das pessoas, lembrando sempre que a aprendizagem no processo é relevante tanto para as pessoas quanto para os técnicos. Por fim, apresenta-se a necessidade de construir uma escala, ou uma métrica, para avaliar a aderência dos resultados da proposta metodológica na percepção das pessoas, bem como analisa-los, para que os índices propostos possam apontar uma hierarquização mais concreta dos resultados.

\subsection{ANÁlise dOS RESULTAdOS DA APLICAÇÃo DA PROPOSTA METODOLÓGICA}

Ao propor uma metodologia que estabeleça procedimentos para otimização da participação popular, captando-se as percepções e as hierarquizando, os índices propostos estabelecem uma relação multifacetada de hierarquização. No entanto, ainda é necessário avaliar sua operacionalidade no estudo de caso, o qual permitirá testar a hipótese de que a participação popular pode fornecer contribuições mais efetivas para a definição das soluções adotadas em projetos de intervenção urbana, se desenvolvidos e aplicados procedimentos metodológicos, nos processos de tomada de decisão, que suportem e orientem a participação da população.

Por essas razões, os resultados da aplicação da proposta metodológica estão organizados de tal forma que (i) avaliem-se as ferramentas de envolvimento adotadas; (ii) avalie-se a adequação das ferramentas aplicadas à população; (iii) avalie-se a contribuição do procedimento adotado para o aprendizado da população; e (iv) se hierarquizem problemas e alternativas a partir de um enfoque multicriterial.

\subsubsection{Avaliação da Estratégia de Envolvimento}

Objetivamente, as dinâmicas contaram com 42 participantes, distribuídos nas quatro dinâmicas realizadas, nos diferentes dias e horários propostos, conforme tabela 43, para uma população de 45.057 habitantes na área objeto de estudo. 
A partir do formulário de inscrição disponibilizados, foram 59 pessoas inscritas. Apenas 2 participantes - um participante no primeiro grupo e um no grupo 4, participaram das dinâmicas sem prévia inscrição.

Portanto, das 59 pessoas previamente inscritas, 40 pessoas se inscreveram previamente e efetivamente compareceram aos encontros, resultando em aproximadamente $68 \%$ de sucesso no procedimento de inscrição.

Em resumo, foi constatada a participação de pouco mais $0,09 \%$ dos habitantes da área objeto de estudo. Pode parecer pouco, contudo, comparando-se com, por exemplo, as atividades de participação realizadas na primeira etapa de revisão do Plano Diretor Estratégico do Município de São Paulo, com 1.804 pessoas presentes, a participação representou pouco mais do que $0,01 \%$ dos habitantes do município. É importante destacar que esta pesquisa não tem a perspectiva de generalizar os resultados de forma paramétrica, entretanto o resultado do engajamento proposto na proposta metodológica foi 9 vezes maior do que a primeira fase de diagnóstico realizada pela Prefeitura de São Paulo. Se considerarmos todo o processo participativo realizado para a revisão do PDE em São Paulo, o total foi de 25.692 participantes, ou seja, $0,18 \%$ da população total, em 114 audiências realizadas, enquanto aplicação desta proposta metodológica, sem o apoio do aparato estatal, realizou apenas quatro encontros.

Tabela 43 - Detalhamento dos encontros e da presença nas dinâmicas

\begin{tabular}{|c|c|c|c|c|}
\hline Grupo & $1^{\circ}$ Encontro & $2^{\circ}$ Encontro & $\begin{array}{c}\text { Participantes } \\
\text { Inscritos }\end{array}$ & $\begin{array}{c}\text { Participantes } \\
\text { Presentes } \\
\end{array}$ \\
\hline Grupo 1 & $\begin{array}{c}\text { 17/07/2018 } \\
\text { Manhã }\end{array}$ & $\begin{array}{c}\text { 19/07/2018 } \\
\text { Manhã }\end{array}$ & 20 & 12 \\
\hline Grupo 2 & $\begin{array}{l}\text { 17/07/2018 } \\
\text { Tarde }\end{array}$ & $\begin{array}{l}\text { 19/07/2018 } \\
\text { Tarde }\end{array}$ & 15 & 13 \\
\hline Grupo $3^{111}$ & $\begin{array}{l}\text { 02/08/2018 } \\
\text { Tarde }\end{array}$ & $\begin{array}{l}\text { 07/08/2018 } \\
\text { Tarde }\end{array}$ & 10 & 7 \\
\hline Grupo $4^{112}$ & $\begin{array}{c}\text { 04/08/2018 } \\
\text { Manhã }\end{array}$ & $\begin{array}{c}04 / 08 / 2018 \\
\text { Tarde } \\
\end{array}$ & 14 & 10 \\
\hline Total & & & 59 & 42 \\
\hline
\end{tabular}

Fonte: Do autor (2019).

\footnotetext{
${ }^{111}$ A dinâmica do grupo 3 foi realizada com o espaço de uma semana entre os encontros para verificar se o intervalo temporal influenciaria a assiduidade.

${ }^{112}$ A dinâmica do grupo 4 foi realizada em um único dia, selecionado intencionalmente em um sábado, para averiguar se a escolha no dia da semana influenciaria a participação e o engajamento.
} 
Se relativizarmos a população consultada pelo número de audiências realizadas, teremos para o Município de São Paulo a taxa de 0,0016\% da população por audiência, e, na aplicação da proposta metodológica, $0,0225 \%$ por encontro. Isso pode reforçar a hipótese deste trabalho de que é possível desenvolver e aplicar metodologias mais efetivas do que a prática corrente adotada em planejamento urbano, de modo que integrem a participação popular em processos decisórios.

Foram 15 cartazes fixados em pontos relevantes no bairro, em escolas, universidades e postos de saúde, entre 8 de junho e 31 de agosto de 2018. Foram distribuídos 2000 convites entregues, sendo 1200 em domicílios, e 800 distribuídos pessoalmente a pedestres nas estações Bresser e Belém do metrô, a um custo total aproximado de $\mathrm{R} \$ 500,00$, considerando somente as impressões.

Diante disso, questiona-se se seria viável para as prefeituras do Brasil programar atividades participativas ao longo do ano, com uma agenda clara, e enviar esta agenda anualmente, por exemplo, junto ao envio do IPTU para os cidadãos.

Foram elaboradas e inseridas 32 publicações na página virtual do projeto no Facebook, alcançando 22.000 pessoas, com 1.301 envolvimentos (curtidas, comentários e compartilhamentos), sem demandar recursos financeiros. $\mathrm{O}$ alcance das mídias é quase que ilimitado, e se com a manutenção de uma página (criada sem apoio profissional) durante pouco mais de dois meses, foi possível emanar tal alcance, para as prefeituras do país isso pode ser ainda mais potencializado.

Cabe salientar que todas as mensagens enviadas com a chancela de "Projeto Não Governamental" foram mantidas, de maneira que com o apoio da chancela governamental, o alcance, mais uma vez, pode ser expandido. Isso evidencia a inevitabilidade de os espaços participativos promovidos pelo Estado utilizarem os canais das mídias sociais.

Também ao analisar o perfil dos participantes nos encontros, ficou evidente a força das mídias sociais. Afinal, dos 42 presentes, 30 afirmaram que souberam do evento por meio do Facebook, 9 por meio dos convites recebidos na residência e apenas 3 ao verificar o cartaz em algum lugar público conforme figura 84 . 
Figura 84 - Distribuição dos participantes por canal de envolvimento

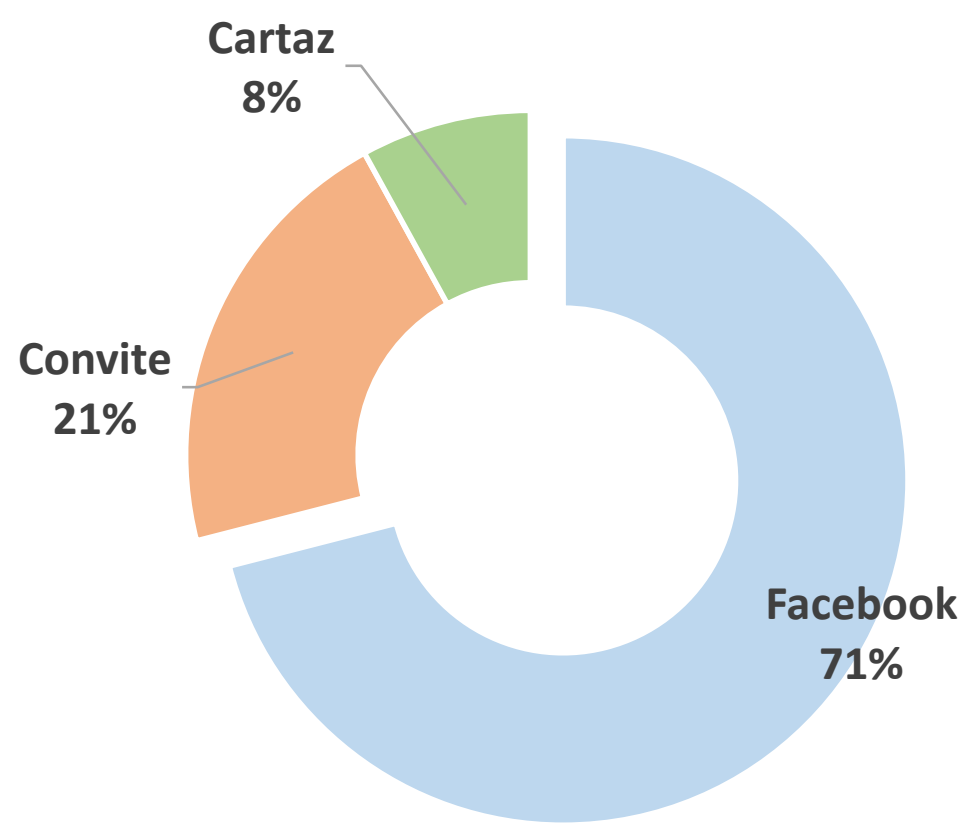

Fonte: Do autor (2019).

Este resultado, na figura 70, por sua vez, tem de ser melhor explorado, pois eventualmente as pessoas podem ter recebido o convite impresso e acessado a página, e se programaram para participar das atividades a partir do acompanhamento nas mídias sociais, o que pode distorcer o resultado, então este deve ser generalizado com cautela.

Quanto à distribuição etária, aproximadamente 23\% das pessoas têm entre 20 e 25 anos, $60 \%$ entre 25 e 30 anos, $7 \%$ entre 30 e 35 anos e $10 \%$ mais de 35 anos. Estes resultados segue a mesma tendência das entrevistas realizadas na pesquisa, no item 3.6, reiterando a dificuldade de envolver os mais velhos nos espaços participativos. Os resultados apontam que os mais jovens são mais engajados em participar de processos de planejamento urbano, porém esse resultado não pode ser generalizado, pois a delimitação da amostra não seguiu requisitos estatísticos necessários e não tinha esse objetivo. Também é possível que a amostra reflita a distribuição da pirâmide etária do país ${ }^{113}$, pois aproximadamente $46 \%$ da população brasileira tem menos de 30 anos, conforme tabela 44.

Ao analisar a escolaridade e a renda da população consultada, conforme quadro a seguir, os grupos apresentaram $7 \%$ dos participantes com ensino médio, $71 \%$ com ensino superior

\footnotetext{
${ }^{113}$ Amostra da PNAD-C (Pesquisa Nacional por Amostra de Domicílios Continua) publicada em 2017 pelo IBGE (Instituto Brasileiro de Geografia e Estatística). Disponível em: < https://educa.ibge.gov.br/jovens/conheca-o-brasil/populacao/18320quantidade-de-homens-e-mulheres.html> Acesso em: 24 mar. 2019.
} 
incompleto e $22 \%$ com ensino superior completo. O resultado contribui com as entrevistas realizadas, evidenciando que há uma tendência de que as pessoas com maior escolaridade participem mais dos processos consultivos em planejamento urbano. Isso também merece ser melhor explorado, pois a pesquisa desenvolvida não teve o objetivo de produzir dados paramétricos que possam ser generalizados.

Tabela 44 - Distribuição Etária e por Gênero das dinâmicas

\begin{tabular}{ccccccc|c}
\hline Grupo & Mulheres & Homens & $\begin{array}{c}\mathbf{2 0} \text { a 25 } \\
\text { anos }\end{array}$ & $\begin{array}{c}\text { 25 a 30 } \\
\text { anos }\end{array}$ & $\begin{array}{c}\text { 30 a 35 } \\
\text { anos }\end{array}$ & $\begin{array}{c}\text { Mais de } \\
\text { 35 anos }\end{array}$ & Total \\
\hline Grupo 1 & 8 & 4 & 2 & 8 & 1 & 1 & $\mathbf{1 2}$ \\
Grupo 2 & 8 & 5 & 3 & 7 & 0 & 3 & $\mathbf{1 3}$ \\
Grupo 3 & 5 & 2 & 5 & 1 & 1 & 0 & $\mathbf{7}$ \\
Grupo 4 & 7 & 3 & 0 & 9 & 1 & 0 & $\mathbf{1 0}$ \\
\hline Total & $\mathbf{2 8}$ & $\mathbf{1 4}$ & $\mathbf{1 0}$ & $\mathbf{2 5}$ & $\mathbf{3}$ & $\mathbf{4}$ & $\mathbf{4 2}$ \\
\hline
\end{tabular}

Fonte: Do autor (2019).

Conforme quadro a seguir, aproximadamente $74 \%$ da amostra tem renda superior a 4 salários mínimos, $16 \%$ tem renda entre 2 e 4 salários mínimos e 10\% informou que não possui renda, conforme tabela 45. Particularmente, os que não possuem renda, na realidade, não representam os mais pobres, pois são estudantes que não contextualizaram a renda familiar apenas o seu próprio rendimento. De todo modo, alinhada com as entrevistas realizadas no item 3.6, curiosamente, pode ser notada uma disposição maior da população com maior renda para atuar em espaços participativos de planejamento urbano. Esses resultados apontam uma tendência e não uma generalização da população.

Tabela 45 - Distribuição de renda e escolaridade dos participantes

\begin{tabular}{ccccccc}
\hline Grupo & $\begin{array}{c}\text { Ensino } \\
\text { Médio }\end{array}$ & $\begin{array}{c}\text { Ensino } \\
\text { Superior } \\
\text { Incompleto }\end{array}$ & $\begin{array}{c}\text { Ensino } \\
\text { Superior } \\
\text { Completo }\end{array}$ & $\begin{array}{c}\text { Entre 2 e 4 } \\
\text { Salários } \\
\text { Mínimos }\end{array}$ & $\begin{array}{c}\text { Mais do 4 } \\
\text { Salários } \\
\text { Mínimos }\end{array}$ & $\begin{array}{c}\text { Sem } \\
\text { Renda }\end{array}$ \\
\hline $\begin{array}{c}\text { Grupo } \\
\mathbf{1}\end{array}$ & 1 & 8 & 3 & 3 & 8 & 1 \\
$\begin{array}{c}\text { Grupo } \\
\mathbf{2}\end{array}$ & 0 & 10 & 3 & 2 & 11 & 0 \\
$\begin{array}{c}\text { Grupo } \\
\mathbf{3}\end{array}$ & 1 & 5 & 1 & 1 & 5 & 1 \\
$\begin{array}{c}\text { Grupo } \\
\mathbf{4}\end{array}$ & 1 & 7 & 2 & 1 & 7 & 2 \\
\hline Total & $\mathbf{3}$ & $\mathbf{3 0}$ & $\mathbf{9}$ & $\mathbf{7}$ & $\mathbf{3 1}$ & $\mathbf{4}$ \\
\hline
\end{tabular}

Fonte: Do autor (2019). 
Provavelmente, como a estratégia de comunicação com maior abrangência e atratividade foi a mídia digital, embora pareça mais abrangente e inclusiva, pode negligenciar as pessoas de menor escolaridade, as mais pobres e as mais velhas, visto que são exclusas desse meio de comunicação, seja pela restrição de acesso ou por dificuldades operacionais e funcionais de cada indivíduo. Diante disso, evidencia-se que ainda é um desafio proporcionar estratégias de engajamento e participação para as populações mais velhas, de menor renda e com menor escolaridade. Portanto, questiona-se as limitações da inclusão proporcionada pela informatização dos processos participativos.

Por fim, um fato positivo é que na pesquisa de satisfação, quando perguntado "você voltaria a participar de eventos como este?", dos 42 participantes, apenas 2 responderam negativamente, ou seja, mais de $95 \%$ dos participantes foram envolvidos efetivamente no processo. Para os dois que responderam negativamente, o formulário aplicado não previu um campo para que os participantes justificassem as respostas, então não é possível diagnosticar as razões das repostas negativas, já que as notas dadas às demais questões foram favoráveis.

\subsubsection{Avaliação da Estratégia Inclusiva - Propositiva}

Inerente às questões de pesquisa colocadas, a respeito, entre outros, da capacidade de ferramentas e modelos técnicos ou científicos para coletar dados e estabelecer estratégias que traduzam as percepções da participação popular, e da existência de critérios sinérgicos (que podem ser extraídos da participação popular) que contribuam para o avanço dos processos de decisão e hierarquização em projetos de intervenção ou transformação urbanística, a proposta metodológica em sua etapa inclusiva e propositiva lançou mão de uma série de instrumentos.

Alguns resultados podem ser analisados em função dos dados gerados nos quatro diferentes grupos, simultaneamente, pois, por exemplo, investigar as críticas registradas no painel de frases mórbidas é uma avaliação qualitativa de elementos que podem limitar o pensamento criativo dos cidadãos. A lista de frases mórbidas segue na figura 85 , e nas quatro dinâmicas apenas oito frases foram registradas.

Embora, numericamente, nas quatro dinâmicas tenha sido obtido um número reduzido de frases, o aspecto psicológico de restringir as críticas se mostrou interessante para que o ambiente favorecesse a expressão de ideias, propostas e sugestões sem receio dos participantes. Acerca das expectativas geradas, ilustradas na figura 86, notou-se que as principais foram 
aprender, adquirir conhecimento e informações correlatas. Ou seja, além de contribuir, as pessoas têm a necessidade de aprender, mesmo em processos participativos de consulta.

Figura 85 - Distribuição de frases mórbidas

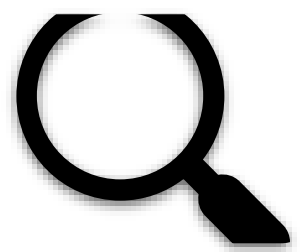

"Depende de como você olha"

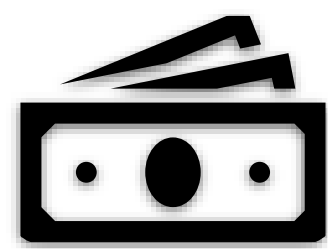

"Mas e se não tiver dinheiro?"

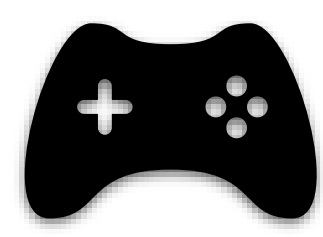

"É só passatempo"

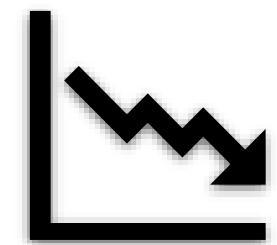

"Ja tentaram isso, e não deu derto"

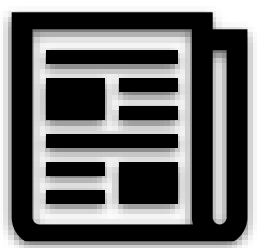

"Só para atender a cota"

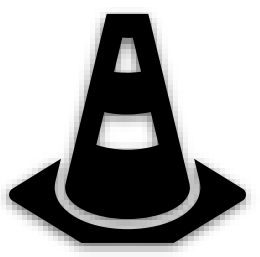

"Na prática é diferente"

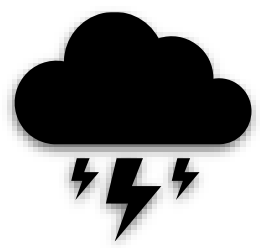

"Falar de problema é fácil"

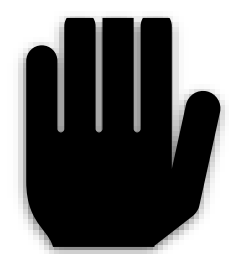

"Será que isso dá certo mesmo?"

Fonte: Do autor (2019).

Os resultados gerados nesta fase são indicativos dos fatores que motivam as pessoas a participar. Analisando as entrevistas já apresentadas anteriormente na pesquisa, o que se nota é que a população se motiva a participar quando nota que sua contribuição fornece elementos de melhoria para a cidade.

Figura 86 - Distribuição de expectativas

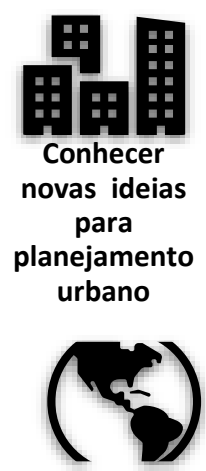

Refletir sobre a abrangência das soluções

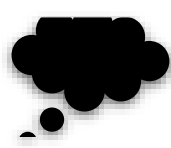

Conhecer

novas pesperctivas

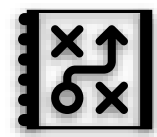

Entender como a cidade é conectada

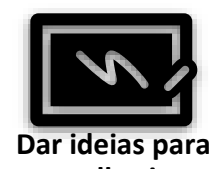

melhoria

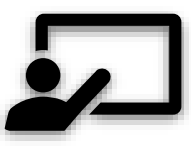

Aprender

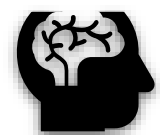

Vivenciar experiências

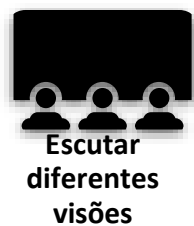

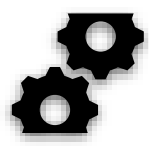

Conhecer 0 funcionamento da cidade

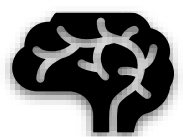

Adiquirir conhecimento

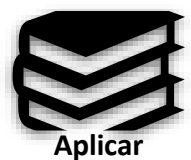

conhecimento

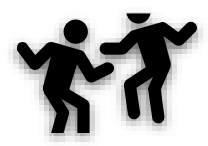

Entender como mobilizar a população

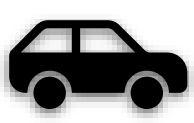

Promover acessibilidade

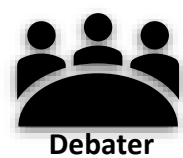

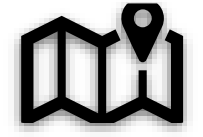

Aprender sobre o Belém

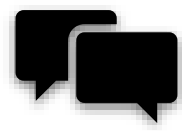

Contribuir

Fonte: Do autor (2019). 


\subsubsection{Avaliação da Seleção de Problemas}

O que se notou em lato sensu foi que, majoritariamente, em todos os grupos, as pessoas, de início, têm dificuldade de materializar e concretizar problemas, no âmbito urbano, de forma que é muito comum listarem substantivos como "saúde", "segurança" e "lazer". Nesse tocante, o moderador precisa habilmente provocar a reflexão dos sujeitos para que, ao escrever problemas no painel, tentem ilustrar aos demais com exemplos e, a partir dos exemplos, materializar o problema com um adjetivo ou um verbo.

Entretanto, quando circulam para os painéis dos outros grupos, ao ler o que lá já está registrado - e como já listaram problemas na rodada anterior -, a partir da segunda e da terceira rodada, as pessoas conseguem manifestar com mais facilidade situações de problemas tangíveis. O processo de revelação dos problemas teve apoio do Painel de Seleção de Problemas e do Painel da Visão, que juntos apontam os problemas. É importante que a equipe de pesquisa também mantenha as anotações das falas dos sujeitos na explicação dos materiais. Assim, a equipe sintematiza o material e elabora os painéis que serão aplicados na valoração, conforme esquema da figura 87.

Figura 87 - Interpretação dos painéis para seleção dos problemas

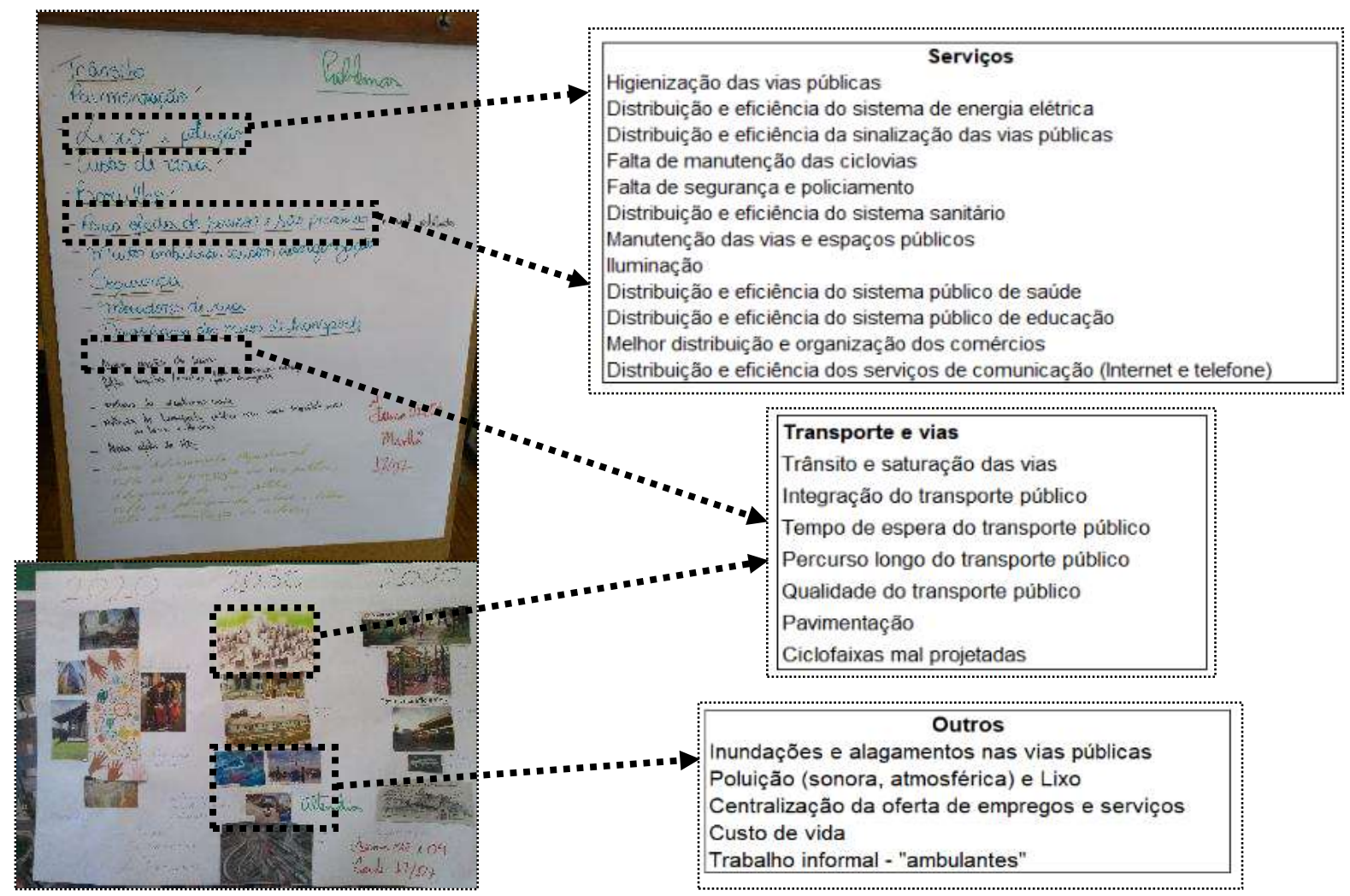

Fonte: Do autor (2019). 
Os resultados desta dinâmica foram analisados separadamente para cada um dos grupos, a fim de que se obtivesse mais amostras que consolidassem a aplicabilidade da proposta metodológica. Portanto, os resultados desta parte serão apresentados separadamente para os grupos 1, 2, 3 e 4 .

\subsection{Seleção de Problemas para o Grupo 1}

As informações geradas nesta etapa foram interpretadas e sistematizadas conforme descrito na aplicação da proposta metodológica. Elas resultaram em uma lista de 29 problemas que deveriam ser tratados no bairro ou na cidade, conforme a figura 88.

Figura 88 - Sistematização de problemas para o grupo 1

\begin{tabular}{|c|}
\hline $\begin{array}{c}\text { Defasagem do } \\
\text { planejamento viário }\end{array}$ \\
\hline $\begin{array}{c}\text { Pouca diversificação e } \\
\text { integração } \\
\text { dos modais de } \\
\text { transporte } \\
\end{array}$ \\
\hline $\begin{array}{c}\text { Malhas ferroviárias } \\
\text { pouco } \\
\text { desenvolvidas }\end{array}$ \\
\hline Congestionamento \\
\hline $\begin{array}{l}\text { Inadequação e } \\
\text { defasagem do } \\
\text { serviço público de } \\
\text { transporte }\end{array}$ \\
\hline $\begin{array}{l}\text { Pouca quantidade e } \\
\text { distribuição de } \\
\text { faixas exclusivas de } \\
\text { ônibus }\end{array}$ \\
\hline Déficit habitacional \\
\hline $\begin{array}{c}\text { Pouco adensamento } \\
\text { populacional }\end{array}$ \\
\hline
\end{tabular}

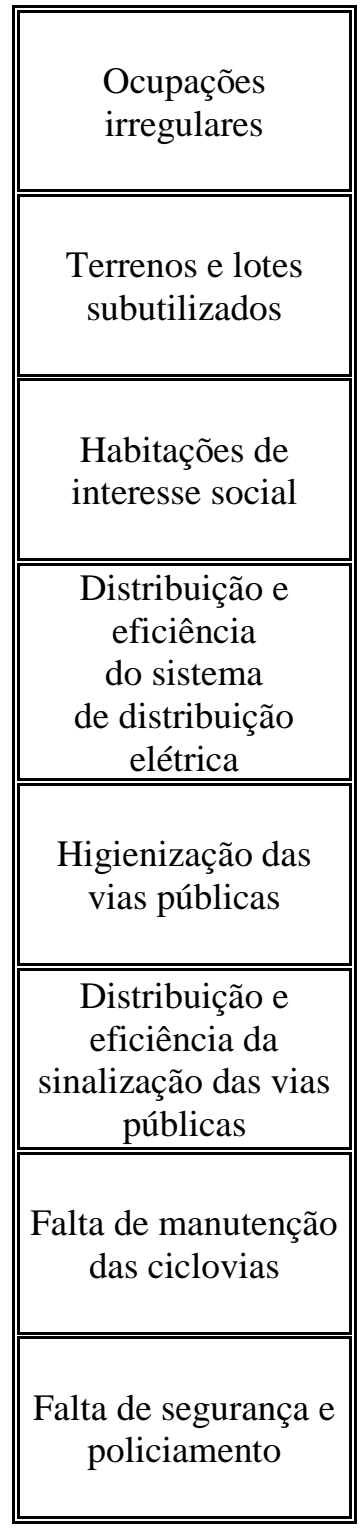

\begin{tabular}{||c||}
\hline $\begin{array}{c}\text { Distribuição e } \\
\text { eficiência do } \\
\text { sistema sanitário }\end{array}$ \\
\hline \hline $\begin{array}{c}\text { Manutenção das vias } \\
\text { e dos } \\
\text { espaços públicos }\end{array}$ \\
\hline $\begin{array}{c}\text { Poluição sonora e } \\
\text { atmosférica }\end{array}$ \\
\hline \hline $\begin{array}{c}\text { Iluminação } \\
\text { Distribuição e } \\
\text { sanitário }\end{array}$ \\
\hline $\begin{array}{c}\text { Distribuição e } \\
\text { eficiência do sistema } \\
\text { eficiência do sistema } \\
\text { público de saúde } \\
\text { comisação dos } \\
\text { eficiência do sistema } \\
\text { público de educação }\end{array}$ \\
\hline \hline \hline \begin{tabular}{c} 
Delribuicão e \\
\hline \hline
\end{tabular} \\
\hline \hline
\end{tabular}

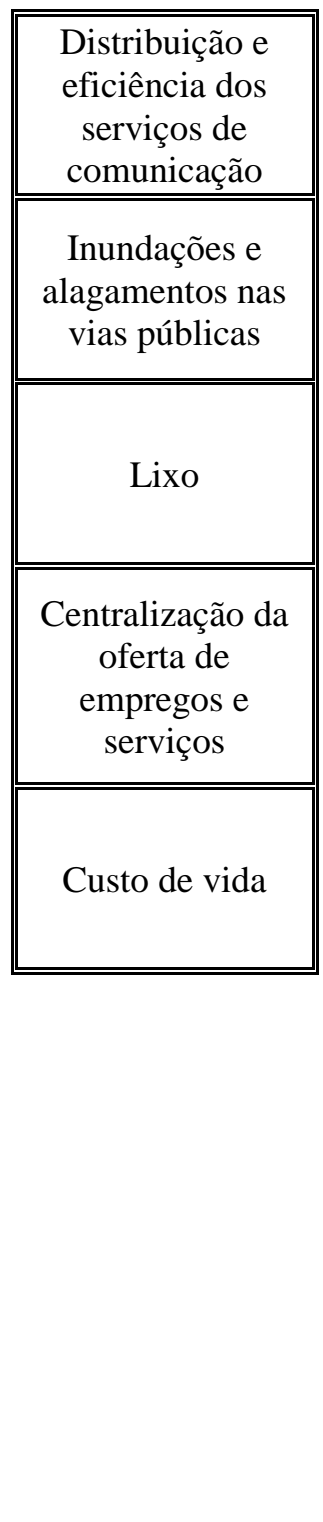

Fonte: Do autor (2019). 
No grupo, os doze participantes foram divididos em quatro equipes, com três pessoas cada (equipes A, B, C e D). Nos primeiros oito minutos, cada equipe escreveu os problemas em seu Painel de Problemas. Na segunda rodada, a Equipe A foi ao painel da Equipe B, a Equipe B foi ao painel da Equipe C, a Equipe $C$ foi ao Painel da Equipe D, e a Equipe D foi ao painel da Equipe $\mathrm{A}$ - e assim sucessivamente até que cada equipe retornasse ao seu painel. Para a elaboração do Painel da Visão, os participantes foram divididos em duas equipes, de seis pessoas cada, elaborando dois Mapas Falantes. Ao fim da elaboração dos mapas falantes, cada equipe apresentou o seu; a equipe de apoio gravou em vídeo os depoimentos e registrou as informações em papel.

\subsection{Seleção de problemas para o Grupo 2}

As informações geradas nesta etapa foram interpretadas e sistematizadas conforme descrito na aplicação da proposta metodológica. Elas resultaram em uma lista de 24 problemas que deveriam ser tratados no bairro ou na cidade, conforme a figura 89 .

Figura 89 - Sistematização de problemas para o grupo 2

\begin{tabular}{|c|c|c|c|}
\hline $\begin{array}{c}\text { Trânsito e saturação } \\
\text { das vias }\end{array}$ & $\begin{array}{c}\text { Ciclofaixas mal } \\
\text { projetadas }\end{array}$ & $\begin{array}{l}\text { Defíciência de } \\
\text { equipamentos } \\
\text { culturais }\end{array}$ & Áreas verdes \\
\hline $\begin{array}{l}\text { Integração do } \\
\text { transporte público }\end{array}$ & $\begin{array}{l}\text { Deficiência de } \\
\text { equipamentos de } \\
\text { saúde }\end{array}$ & $\begin{array}{l}\text { Violência e } \\
\text { segurança }\end{array}$ & $\begin{array}{c}\text { Planejamento } \\
\text { desorganizado das } \\
\text { calçadas }\end{array}$ \\
\hline $\begin{array}{l}\text { Tempo de espera do } \\
\text { transporte público }\end{array}$ & $\begin{array}{c}\text { Deficiência de } \\
\text { equipamentos de } \\
\text { lazer }\end{array}$ & $\begin{array}{l}\text { Crescimento } \\
\text { desordenado }\end{array}$ & Acessibilidade \\
\hline $\begin{array}{l}\text { Percurso longo do } \\
\text { transporte público }\end{array}$ & $\begin{array}{l}\text { Deficiência de } \\
\text { equipamentos } \\
\text { educacionais }\end{array}$ & $\begin{array}{c}\text { Divulgação de } \\
\text { oportunidades } \\
\text { de participação } \\
\text { pública }\end{array}$ & $\begin{array}{c}\text { Vandalismo e } \\
\text { insuficiência das } \\
\text { lixeiras }\end{array}$ \\
\hline $\begin{array}{l}\text { Qualidade do } \\
\text { transporte público }\end{array}$ & Iluminação & $\begin{array}{c}\text { Poluição sonora, } \\
\text { visual e atmosférica }\end{array}$ & $\begin{array}{l}\text { Imóveis e terrenos } \\
\text { abandonados }\end{array}$ \\
\hline Pavimentação & Centros comerciais & Geração de lixo & Projetos sociais \\
\hline
\end{tabular}

Fonte: Do autor (2019). 
No grupo, os treze participantes foram divididos em quatro equipes, três delas com três pessoas e uma com quatro pessoas (equipes A, B, C e D). Nos primeiros oito minutos, cada equipe escreveu os problemas em seu Painel de Problemas. Na segunda rodada, a Equipe A foi ao painel da Equipe B, a Equipe B foi ao painel da Equipe C, a Equipe C foi ao Painel da Equipe D, e a Equipe D foi ao painel da Equipe A - e assim sucessivamente até que cada equipe retornasse ao seu painel. Para a elaboração do Painel da Visão, os participantes foram divididos em duas equipes, uma com seis pessoas e outra com sete, elaborando dois Mapas Falantes. Ao fim da elaboração, cada equipe apresentou o seu; a equipe de apoio gravou em vídeo os depoimentos e registrou as informações em papel.

\subsection{Seleção de problemas para o Grupo 3}

As informações geradas nesta etapa foram interpretadas e sistematizadas conforme descrito na aplicação da proposta metodológica. Elas resultaram em uma lista de 18 problemas que deveriam ser tratados no bairro ou na cidade, conforme a figura 90.

Figura 90 - Sistematização de problemas para o grupo 3

\begin{tabular}{|c|}
\hline Segurança \\
\hline Moradores de rua \\
\hline Zeladoria urbana \\
\hline Atendimento à saúde \\
\hline Ocupações irregulares \\
\hline $\begin{array}{c}\text { Falta de espaços para } \\
\text { humanização, engajamento } \\
\text { e democracia }\end{array}$ \\
\hline
\end{tabular}

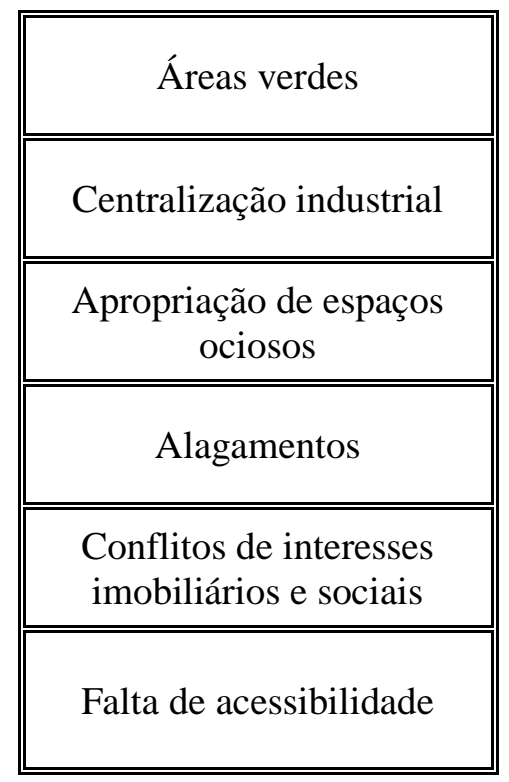

Fonte: Do autor (2019).

\begin{tabular}{||c||}
\hline Falta de mobilidade \\
\hline $\begin{array}{c}\text { Deficiências na promoção } \\
\text { da cultura na cidade }\end{array}$ \\
\hline $\begin{array}{c}\text { Ausência de programas de } \\
\text { integração social }\end{array}$ \\
\hline \hline $\begin{array}{c}\text { Falta de espaços de } \\
\text { cultura e lazer }\end{array}$ \\
\hline \hline $\begin{array}{c}\text { Estimulo a métodos de } \\
\text { ensino inovadores }\end{array}$ \\
\hline \hline $\begin{array}{c}\text { Falta de senso de } \\
\text { comunidade e união para } \\
\text { serviços no bairro }\end{array}$ \\
\hline \hline
\end{tabular}

serviços no bairro

No grupo, os sete participantes foram divididos em duas equipes, uma com três pessoas e uma com quatro pessoas (equipes A e B). Nos primeiros oito minutos, cada equipe escreveu os problemas em seu Painel de Problemas. Na segunda rodada, a Equipe A foi ao painel da Equipe B, a Equipe B foi para o painel da Equipe A. Para a elaboração do Painel da Visão, os 
participantes foram divididos em duas equipes, uma com três e outra com quatro pessoas, elaborando dois Mapas Falantes. Ao fim da elaboração, cada equipe apresentou o seu; a equipe de apoio gravou em vídeo os depoimentos e registrou as informações em papel.

\subsection{Seleção de problemas para o Grupo 4}

As informações geradas nesta etapa foram interpretadas e sistematizadas conforme descrito na aplicação da proposta metodológica. Elas resultaram em uma lista de 21 problemas que deveriam ser tratados no bairro ou na cidade, conforme a figura 91.

Figura 91 - Sistematização de problemas para o grupo 4

\begin{tabular}{||c||}
\hline Trânsito e saturação das vias \\
\hline $\begin{array}{c}\text { Integração do transporte } \\
\text { público }\end{array}$ \\
\hline $\begin{array}{c}\text { Faltam opções de transporte } \\
\text { público }\end{array}$ \\
\hline $\begin{array}{c}\text { público } \\
\text { Percurso longo do transporte } \\
\text { transporte público }\end{array}$ \\
\hline \hline Pavimentação precária \\
\hline \hline Ciclofaixas mal projetadas
\end{tabular}

\begin{tabular}{||c||}
\hline $\begin{array}{c}\text { Deficiência de equipamentos } \\
\text { de saúde }\end{array}$ \\
Faltam opções de lazer \\
\hline \hline $\begin{array}{c}\text { Faltam estabelecimentos de } \\
\text { ensino }\end{array}$ \\
Falta iluminação \\
\hline \hline $\begin{array}{c}\text { Não existem centros } \\
\text { comerciais }\end{array}$ \\
\hline \hline $\begin{array}{c}\text { Faltam equipamentos } \\
\text { culturais }\end{array}$ \\
\hline \hline Violência e segurança \\
\hline \hline
\end{tabular}

\begin{tabular}{||c||}
\hline Crescimento desordenado \\
\hline $\begin{array}{c}\text { Ausência de ofertas de } \\
\text { emprego }\end{array}$ \\
\hline $\begin{array}{c}\text { Poluição sonora, visual e } \\
\text { atmosférica }\end{array}$ \\
Geração de lixo \\
\hline \hline $\begin{array}{c}\text { Áreas verdes insuficientes } \\
\text { e mal distribuídas }\end{array}$ \\
\hline \hline Planejamento das Calçadas \\
\hline \hline Grandes áreas abandonadas
\end{tabular}

Fonte: Do autor (2019).

No grupo, os dez participantes foram divididos em três equipes, duas com três pessoas cada e uma equipe com quatro (equipes A, B e C.) Nos primeiros oito minutos, cada equipe escreveu os problemas em seu Painel de Problemas. Na segunda rodada, a Equipe A foi ao painel da Equipe B, a Equipe B foi ao painel da Equipe C, e a Equipe C foi ao Painel da Equipe $\mathrm{A}$ - e assim sucessivamente até que cada equipe retornasse ao seu painel. Para a elaboração do Painel da Visão, os participantes foram divididos em duas equipes de cinco pessoas, elaborando dois Mapas Falantes. Ao fim da elaboração, cada equipe apresentou o seu; a equipe de apoio gravou em vídeo os depoimentos e registrou as informações em papel. 


\subsubsection{Avaliação da Seleção de Alternativas}

A proposta de soluções foi delineada a partir da técnica de escrita rotativa, chamada, na proposta metodológica, de tempestade cerebral de soluções, a qual é uma adaptação do Brain Writing. A técnica se mostrou interessante, em contraponto a uma audiência pública convencional em que as pessoas assumem um poder de fala em um palanque, pois a escrita reflexiva faz com que, livres de críticas e receios, as pessoas manifestem suas ideias e, ao receber uma ficha escrita com outras soluções de uma pessoa desconhecida, apresentem novas soluções baseadas naquelas já escritas. É uma técnica de consenso e apresentação de ideias interessante, pois há um diálogo silencioso - o diálogo que o indivíduo faz consigo mesmo ao ler as manifestações de outras pessoas.

Por outro lado, é inegável que o processo colaborativo fortalece o indivíduo, de modo que a utilização do Painel Colaborativo da Visão é o momento para tal. Ao utilizar uma técnica lúdica de desenhos, recortes e apresentação oral, o Mapa Falante permite identificar exemplos de aplicação, assim como alternativas cuja verbalização é complexa para pessoas mais simples. Aqui, não se julga se uma técnica é melhor do que a outra, posto que são, em si, complementares. Sua justaposição permite à equipe de pesquisa consolidar de forma mais adequada as alternativas propostas.

A sistematização das fichas preenchidas, as gravações das explicações do mapa falante e as anotações registradas pela equipe permitem a consolidação das alternativas e, futuramente, a construção dos painéis que serão aplicados nas próximas etapas, conforme figura 92.

Figura 92 - Interpretação das alternativas

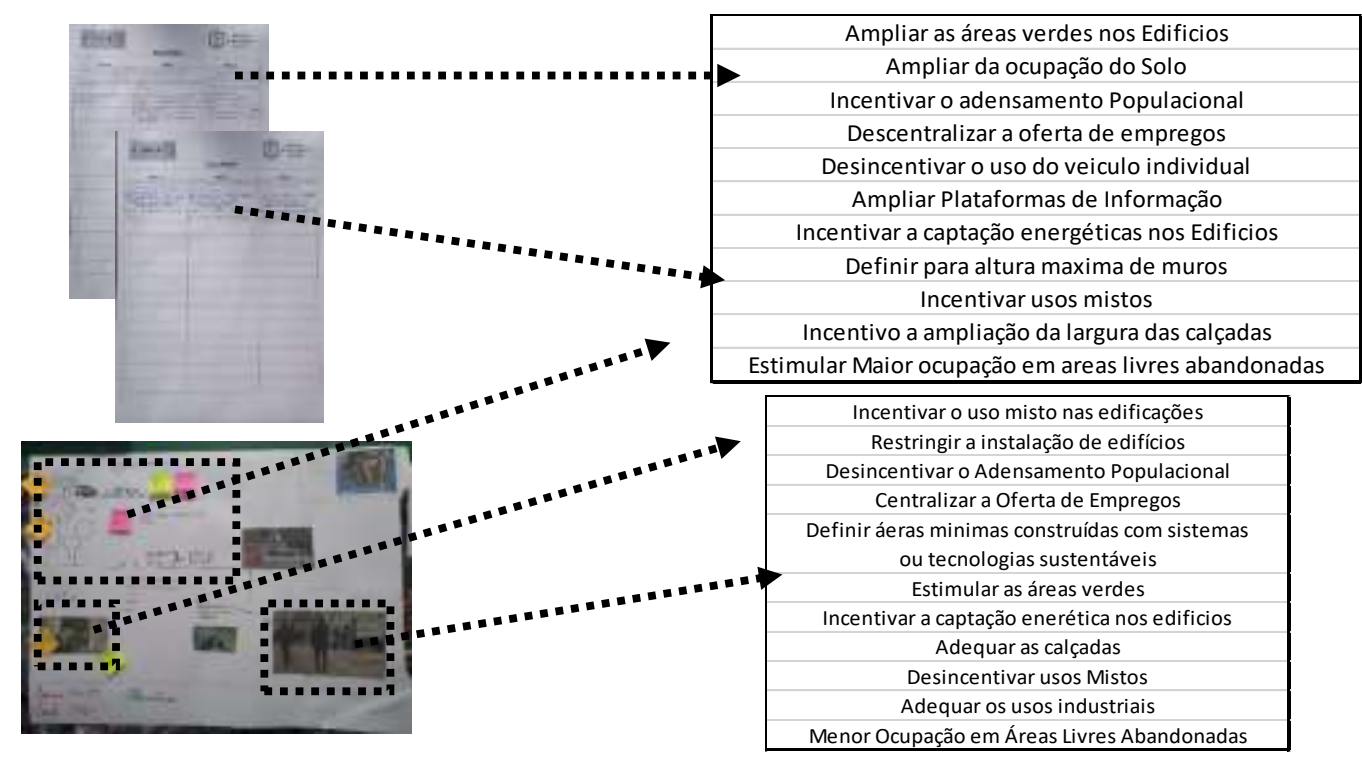

Fonte: Do autor (2019). 


\subsection{Seleção de Alternativas para o Grupo 1}

As informações geradas nesta etapa foram interpretadas e sistematizadas conforme descrito na aplicação da proposta metodológica. Elas resultaram em uma lista de 20 alternativas, que poderiam ser implantadas no bairro ou na cidade, conforme a lista de problemas na figura 93.

Figura 93 - Sistematização de alternativas para o grupo 1

\begin{tabular}{||c||}
\hline \hline $\begin{array}{c}\text { Ampliação de áreas } \\
\text { verdes nos edifícios }\end{array}$ \\
\hline \hline $\begin{array}{c}\text { Redução de áreas } \\
\text { verdes nos edifícios }\end{array}$ \\
\hline \hline $\begin{array}{c}\text { Ampliação da } \\
\text { ocupação do solo }\end{array}$ \\
\hline \hline $\begin{array}{c}\text { Redução da ocupação } \\
\text { do solo }\end{array}$ \\
\hline \hline $\begin{array}{c}\text { Incentivar o } \\
\text { adensamento } \\
\text { populacional }\end{array}$ \\
\hline \hline
\end{tabular}

\begin{tabular}{|c|c|}
\hline $\begin{array}{l}\text { Desincentivo ao } \\
\text { adensamento } \\
\text { populacional }\end{array}$ & $\begin{array}{l}\text { Ampliar plataformas } \\
\text { de informação }\end{array}$ \\
\hline $\begin{array}{c}\text { Descentralizar a } \\
\text { oferta de empregos }\end{array}$ & $\begin{array}{c}\text { Incentivar a captação } \\
\text { energéticas nos } \\
\text { edifícios }\end{array}$ \\
\hline $\begin{array}{c}\text { Centralizar a oferta } \\
\text { de empregos }\end{array}$ & $\begin{array}{l}\text { Definição para altura } \\
\text { máxima de muros }\end{array}$ \\
\hline $\begin{array}{l}\text { Desincentivo ao } \\
\text { uso do veículo } \\
\text { individual }\end{array}$ & Incentivar usos mistos \\
\hline $\begin{array}{l}\text { Incentivar o uso do } \\
\text { veículo individual }\end{array}$ & $\begin{array}{c}\text { Desincentivo aos usos } \\
\text { mistos }\end{array}$ \\
\hline
\end{tabular}

\begin{tabular}{||c||}
\hline $\begin{array}{c}\text { Incentivo à } \\
\text { ampliação da largura } \\
\text { das calçadas }\end{array}$ \\
\hline \hline $\begin{array}{c}\text { Desincentivo à } \\
\text { ampliação da largura } \\
\text { das calçadas }\end{array}$ \\
\hline $\begin{array}{c}\text { Incentivar usos } \\
\text { industriais na região }\end{array}$ \\
\hline $\begin{array}{c}\text { Maior ocupação em } \\
\text { áreas livres } \\
\text { abandonadas }\end{array}$ \\
\hline \hline $\begin{array}{c}\text { Menor ocupação em } \\
\text { áreas livres } \\
\text { abandonadas }\end{array}$ \\
\hline \hline
\end{tabular}

Fonte: Do autor (2019).

Cabe observar que os mapas da região que estavam fixados nas paredes do espaço de realização dos encontros, foram consultados pelos participantes. Ou seja, a utilização de material cartográfico de qualidade foi interessante, pois auxiliou os participantes a desenvolver o domínio territorial, o que é fundamental para atividades relacionadas a planejamento urbano.

\subsection{Seleção de Alternativas para o Grupo 2}

As informações geradas nesta etapa foram interpretadas e sistematizadas conforme descrito na aplicação da proposta metodológica. Elas resultaram em uma lista de 20 alternativas 
que poderiam ser implantadas no bairro ou na cidade, conforme a lista de problemas na figura 94.

Cabe observar que na etapa de propostas de soluções escritas, na tempestade cerebral de soluções, os indivíduos sentiram-se bastante à vontade. Se houvesse maior disponibilidade de tempo, poderiam elaborar mais rodadas de preenchimento, o que certamente ampliaria o número de propostas e soluções.

Figura 94 - Sistematização de alternativas para o grupo 2

\begin{tabular}{||c||}
\hline Ampliação de áreas \\
verdes nos edifícios \\
\hline \hline $\begin{array}{c}\text { Redução de áreas } \\
\text { verdes nos edifícios }\end{array}$ \\
\hline $\begin{array}{c}\text { Controle de emissão } \\
\text { de poluentes nas } \\
\text { edificações }\end{array}$ \\
\hline \hline $\begin{array}{c}\text { Definição de regras } \\
\text { para conservação de } \\
\text { áreas verdes }\end{array}$ \\
\hline \hline $\begin{array}{c}\text { Integração entre } \\
\text { espaços públicos e } \\
\text { privados }\end{array}$ \\
\hline \hline
\end{tabular}

\begin{tabular}{|c|}
\hline $\begin{array}{c}\text { Incentivar a } \\
\text { instalação de muros } \\
\text { e grades }\end{array}$ \\
\hline $\begin{array}{c}\text { Desincentivar a } \\
\text { instalação de muros } \\
\text { e grades }\end{array}$ \\
\hline $\begin{array}{c}\text { Definição de regras } \\
\text { para iluminação nos } \\
\text { edifícios }\end{array}$ \\
\hline $\begin{array}{l}\text { Definição de regras } \\
\text { para sistemas de } \\
\text { segurança nos } \\
\text { edifícios }\end{array}$ \\
\hline $\begin{array}{l}\text { Regras para } \\
\text { favorecer as vias } \\
\text { para fluidez do } \\
\text { transporte individual }\end{array}$ \\
\hline
\end{tabular}

\begin{tabular}{||c||}
\hline $\begin{array}{c}\text { Regras para } \\
\text { desincentivar as vias } \\
\text { para fluidez do } \\
\text { transporte individual }\end{array}$ \\
\hline \hline $\begin{array}{c}\text { Incentivar edifícios } \\
\text { ou imóveis com } \\
\text { usos mistos }\end{array}$ \\
\hline \hline $\begin{array}{c}\text { Desincentivar } \\
\text { edifícios e imóveis } \\
\text { com usos mistos }\end{array}$ \\
\hline \hline $\begin{array}{c}\text { Restringir a } \\
\text { instalação de } \\
\text { edifícios }\end{array}$ \\
\hline $\begin{array}{c}\text { Favorecer a } \\
\text { instalação de } \\
\text { edifícios }\end{array}$ \\
\hline
\end{tabular}

\begin{tabular}{|c||}
\hline $\begin{array}{c}\text { Incentivar usos } \\
\text { comerciais e de } \\
\text { serviços }\end{array}$ \\
\hline \hline $\begin{array}{c}\text { Desincentivar usos } \\
\text { comerciais e de } \\
\text { serviços }\end{array}$ \\
\hline $\begin{array}{c}\text { Incentivar usos } \\
\text { industriais }\end{array}$ \\
\hline \hline $\begin{array}{c}\text { Desincentivar usos } \\
\text { industriais }\end{array}$ \\
\hline \hline Áreas construídas \\
mínimas com \\
sistemas \\
sustentáveis \\
\hline \hline
\end{tabular}

Fonte: Do autor (2019).

\subsection{Seleção de Alternativas para o Grupo 3}

As informações geradas nesta etapa foram interpretadas e sistematizadas conforme descrito na aplicação da proposta metodológica. Elas resultaram em uma lista de 19 alternativas que poderiam ser implantadas no bairro ou na cidade, conforme a lista de problemas na figura 95.

As ferramentas aplicadas foram, aparentemente, bem recebidas pelos participantes e assimiladas de imediato, de maneira que os resultados foram visíveis desde o começo do 
processo metodológico. Durante o encontro, a equipe notou que a curiosidade pelo próximo passo motivava os indivíduos a realizar as tarefas, o que denota que tanto a lógica do processo quanto e o papel de cada um foram entendidos e assimilados.

Figura 95 - Sistematização de alternativas para o grupo 3

\begin{tabular}{||c||}
\hline Ampliação de áreas \\
verdes nos edifícios \\
\hline $\begin{array}{c}\text { Induzir ou incentivar } \\
\text { a construção de } \\
\text { equipamentos e } \\
\text { edifícios de uso } \\
\text { cultural }\end{array}$ \\
\hline \hline $\begin{array}{c}\text { Uso compulsório de } \\
\text { áreas ociosas para } \\
\text { atividades coletivas }\end{array}$ \\
\hline \hline $\begin{array}{c}\text { Induzir a construção } \\
\text { de edifícios } \\
\text { comerciais com } \\
\text { áreas de trabalho } \\
\text { colaborativos }\end{array}$ \\
\hline \hline
\end{tabular}

\begin{tabular}{|c||}
\hline $\begin{array}{c}\text { Definir regras mais } \\
\text { restritivas para } \\
\text { utilização dos } \\
\text { recursos naturais na } \\
\text { construção }\end{array}$ \\
\hline \hline Ampliar e definir \\
regras para estimular \\
construções \\
sustentáveis \\
\hline \hline Ampliar espaços \\
públicos para \\
população idosa \\
\hline \hline Proporcionar novos \\
canais para \\
participação e ação \\
das pessoas \\
\hline \hline Promover a \\
instalação de \\
espaços para \\
oferecimento de \\
alimentação de \\
baixo custo \\
\hline \hline
\end{tabular}

\begin{tabular}{||c||}
\hline Incentivar a \\
instalação de \\
equipamentos e \\
edificações para \\
serviços de saúde \\
\hline \hline \\
Incentivar a \\
instalação de muros \\
nas edificações \\
\hline \hline \\
Restringir a \\
instalação de muros \\
nas edificações \\
\hline \hline \\
Favorecer a \\
instalação de \\
edificações \\
populares \\
\hline \hline Definir regras mais \\
duras para \\
atendimento de \\
acessibilidade em \\
edificações e \\
espaços públicos \\
\hline \hline
\end{tabular}

\begin{tabular}{||c||}
\hline $\begin{array}{c}\text { Ampliar corredores } \\
\text { de ônibus }\end{array}$ \\
\hline \hline Incentivar e \\
favorecer o uso \\
comercial \\
\hline \hline Promover a \\
regularização de \\
imóveis já \\
construídos \\
\hline \hline Favorecer e \\
incentivar a \\
instalação de \\
equipamentos e \\
edificações para uso \\
religiosos \\
\hline \hline
\end{tabular}

Fonte: Do autor (2019).

\subsection{Seleção de Alternativas para o Grupo 4}

As informações geradas nesta etapa foram interpretadas e sistematizadas conforme descrito na aplicação da proposta metodológica. Elas resultaram em uma lista de 18 alternativas que poderiam ser implantadas no bairro ou na cidade, conforme a lista de problemas na figura 96.

Curiosamente, mesmo com quantidades de participantes diferentes, os grupos geraram um número total de soluções, ou alternativas, muito parecidos: entre 18 e 20 sugestões. Este 
resultado chama atenção e coloca a questão acerca da influência da quantidade de pessoas que participa de um processo participativo na quantidade de propostas geradas.

Figura 96 - Sistematização de alternativas para o grupo 4

\begin{tabular}{||c||}
\hline $\begin{array}{c}\text { Ampliar as áreas construídas } \\
\text { nas edificações }\end{array}$ \\
\hline \hline $\begin{array}{c}\text { Ampliação de áreas verdes } \\
\text { nos edifícios }\end{array}$ \\
\hline $\begin{array}{c}\text { Redução de áreas verdes nos } \\
\text { edifícios }\end{array}$ \\
\hline $\begin{array}{c}\text { Ampliação da ocupação do } \\
\text { solo }\end{array}$ \\
\hline \hline $\begin{array}{c}\text { Redução da ocupação do } \\
\text { solo }\end{array}$ \\
\hline \hline $\begin{array}{c}\text { Regras para desincentivar o } \\
\text { transporte individual }\end{array}$ \\
\hline \hline
\end{tabular}

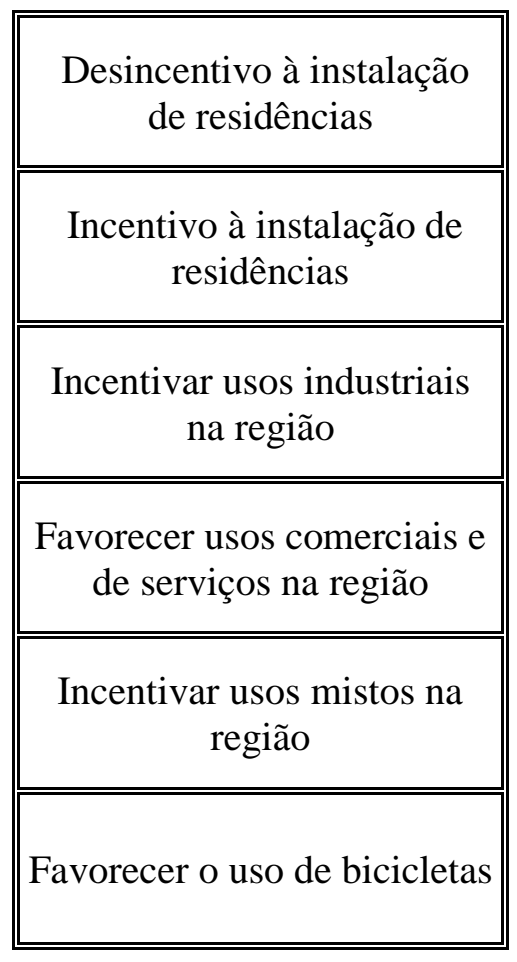

\begin{tabular}{||c||}
\hline $\begin{array}{c}\text { Restringir a instalação de } \\
\text { edifícios altos }\end{array}$ \\
\hline \hline $\begin{array}{c}\text { Incentivar a captação } \\
\text { energética nos edifícios }\end{array}$ \\
\hline \hline $\begin{array}{c}\text { Incentivo à ampliação da } \\
\text { largura das calçadas }\end{array}$ \\
\hline \hline $\begin{array}{c}\text { Favorecer o uso do } \\
\text { transporte público }\end{array}$ \\
\hline \hline $\begin{array}{c}\text { Estimular a ocupação de } \\
\text { áreas abandonadas }\end{array}$ \\
\hline \hline $\begin{array}{c}\text { Integrar área dos edifícios a } \\
\text { área pública }\end{array}$ \\
\hline \hline
\end{tabular}

Fonte: Do autor (2019).

\subsubsection{Avaliação da Estratégia de Valoração-Avaliação e Consolidação dos Índices}

Nesta etapa, os participantes realizaram reflexão e avaliação a respeito dos problemas propostos, das alternativas apontadas e das relações existentes entre os problemas e as alternativas. Resumidamente, esta etapa consistiu no preenchimento dos diversos painéis, produzindo dados que permitiriam a extração de índices e a hierarquização, sob diversas perspectivas, dos problemas e das alternativas.

Verificou-se que as dinâmicas preliminares - de reforço do compromisso, laboral de estreitamento e de fortalecimento de vínculos - apoiam o processo, no sentido de que reestabelecem a arena igualitária entre os sujeitos, removem a esfera inicial de apreensão, reforçam o compromisso de não criticar e reconhecem cada um dos sujeitos como protagonista do processo. 


\title{
7.1.3.1 Avaliação da Hierarquização Multicriterial de Problemas
}

Os problemas definidos a partir da aplicação das atividades participativas anteriores e geraram os painéis, foram avaliados a partir da valoração do Painel de Efeitos e Impactos dos Problemas. Em cada um dos encontros, as pessoas foram divididas em dois subgrupos e receberam adesivos coloridos de quatro cores diferentes (azul, verde, vermelho e magenta).

Para cada dimensão, em cada um dos problemas, os participantes atribuíram uma valoração de 1 a $3^{114}$. Foram 4 dimensões de valoração, considerando que a frequência (azul) representava a recorrência do problema, a relevância (verde) representava a consequência do problema e como ele atingia as pessoas, a dificuldade de correção (vermelho) representava o esforço necessário para se solucionar o problema, e a dificuldade de detecção (magenta) representava a facilidade de se observar o problema. A pontuação associada permitiria a obtenção dos índices que valoram e hierarquizam os problemas, conforme sinteticamente ilustrado na figura 97.

Figura 97 - Obtenção dos índices a partir dos painéis valorados

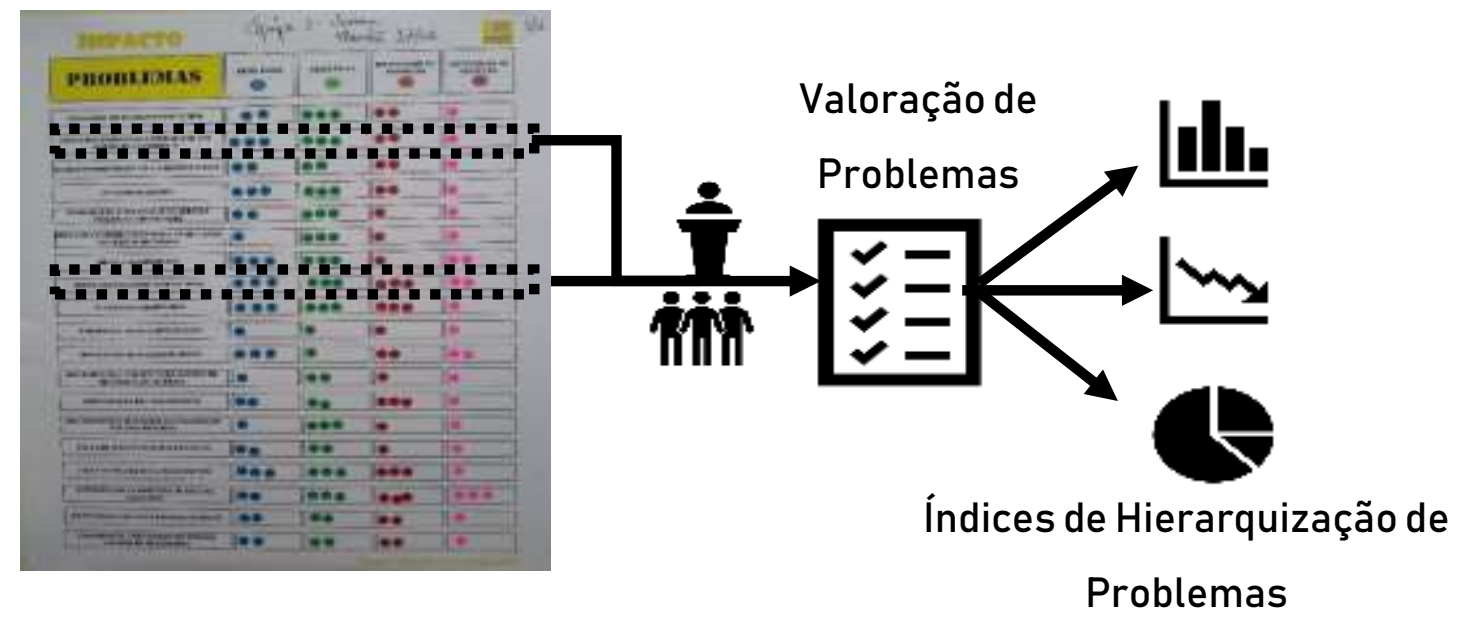

Fonte: Do autor (2019).

\begin{abstract}
${ }^{114}$ A história da construção de escalas de mensuração tem como trabalho seminal o estudo de Rensis Likert, publicado em 1932. No entanto, como Clason e Dormody (1994) ressaltam, muitos estudos têm usado diversas opções, paralelas à escala tradicional de cinco pontos, obtendo resultados satisfatórios. A variação no número de itens da escala tem fomentado inúmeras discussões sobre a escolha da escala a ser utilizada. O problema da escolha de escalas está relacionado à forma como o entrevistado as interpretará. Este trabalho não tem como objetivo discutir as escalas, em si, foram adotados os níveis entre 1 a 3 , onde 1 indica um baixo impacto, 2 um médio impacto, e 3 um alto impacto. A escala de 3 pontos oferece opções de respostas suficientes, se ajusta a pequenas amostras e demanda pouco tempo de resposta. A escala de 1 a 3 apresenta maior facilidade de assimilação pelas pessoas, e maior velocidade conforme Dalmoro e Vieira (2013).
\end{abstract}

CLASON, D.L.; DORMODY, T.J. Analyzing data measured by individual Likert-type items. Journal of Agricultural Education. v. 35, n. 4, p. 54-71, 1994.

DALMORO, M.; VIEIRA, K. M. Dilemas na construção de escalas tipo Likert: O número de itens e a disposição influenciam nos resultados? Revista gestão organizacional. v.6,n.3, p.161-174.2013.

LIKERT, R. A technique for the measurement of attitudes. Archives of Psychology. v. 22, n. 140, p. 44-53, 1932. 
Dessa maneira, cada um dos problemas receberá um valor numérico que o represente. A partir da pontuação atribuída pelos sujeitos, foi possível sistematizar os dados e calcular: o $\operatorname{ICP}_{(\mathrm{p})}$ (Índice de Caracterização de Problemas Preliminar), que avalia o impacto de um problema a partir de sua frequência e relevância; o IIP (Índice de Intervenção de Problemas), que avalia a dificuldade de detecção e correção de um problema; e o $\operatorname{ICP}_{(a)}$ (Índice de Caracterização de Problemas Ampliado), que avalia de forma mais abrangente um problema, considerando a frequência, a relevância, a dificuldade de detecção e a dificuldade de correção. Por fim, com esses dados, foi possível hierarquizar os problemas a partir do o IHP (Índice Hierárquico de Problemas).

\subsection{Avaliação Multicriterial de Problemas para o Grupo 1}

Os participantes negociaram entre si os pesos, associados a cada dimensão, problema a problema. Mesmo que a nota mínima seja 1 ponto, a cada dimensão, optou-se por não deixar 1 ponto previamente preenchido, a fim de que os participantes refletissem, inclusive, para atribuir a pontuação mais baixa. Após a aplicação, os resultados foram sumarizados na tabela 46.

Tabela 46 - Preenchimento dos Painel de Impacto dos Problemas para o grupo 1

\begin{tabular}{ccccc}
\hline Problemas & Frequência & Relevância & $\begin{array}{c}\text { Dificuldade } \\
\text { de Correção }\end{array}$ & $\begin{array}{c}\text { Dificuldade } \\
\text { de Detecção }\end{array}$ \\
\hline $\begin{array}{c}\text { Defasagem do planejamento } \\
\text { viário }\end{array}$ & $\mathbf{2}$ & $\mathbf{3}$ & $\mathbf{2}$ & $\mathbf{1}$ \\
$\begin{array}{c}\text { Pouca diversificação e } \\
\text { integração dos modos de } \\
\text { transporte }\end{array}$ & $\mathbf{3}$ & $\mathbf{3}$ & $\mathbf{2}$ & $\mathbf{1}$ \\
$\begin{array}{c}\text { Malhas ferroviárias pouco } \\
\text { desenvolvidas }\end{array}$ & $\mathbf{2}$ & $\mathbf{2}$ & $\mathbf{2}$ & $\mathbf{1}$ \\
$\begin{array}{c}\text { Congestionamento } \\
\text { Inadequação e defasagem do } \\
\text { serviço público de transporte }\end{array}$ & $\mathbf{2}$ & $\mathbf{3}$ & $\mathbf{2}$ & $\mathbf{1}$ \\
$\begin{array}{c}\text { Pouca quantidade e } \\
\text { distribuição de faixas }\end{array}$ & $\mathbf{1}$ & $\mathbf{3}$ & $\mathbf{1}$ & $\mathbf{1}$ \\
$\begin{array}{c}\text { exclusivas de ônibus } \\
\text { Déficit habitacional }\end{array}$ & $\mathbf{3}$ & $\mathbf{3}$ & $\mathbf{1}$ & $\mathbf{1}$ \\
Pouco adensamento & $\mathbf{3}$ & $\mathbf{3}$ & $\mathbf{1}$ & $\mathbf{2}$ \\
populacional & $\mathbf{3}$ & $\mathbf{3}$ & $\mathbf{3}$ & $\mathbf{2}$ \\
Ocupações irregulares & $\mathbf{1}$ & $\mathbf{1}$ & $\mathbf{3}$ & $\mathbf{1}$ \\
Terrenos e lotes subutilizados & $\mathbf{3}$ & $\mathbf{1}$ & $\mathbf{2}$ & $\mathbf{1}$ \\
Habitações de interesse social & & & & $\mathbf{2}$ \\
& & & Continua.
\end{tabular}




\section{Continuação.}

Distribuição e eficiência do sistema de distribuição elétrica

Higienização das vias públicas

Distribuição e eficiência da sinalização das vias públicas

Falta de manutenção das ciclovias

Falta de segurança e policiamento

Distribuição e eficiência do sistema sanitário

Manutenção de vias e espaços públicos

Iluminação

2

2

1

1

2

2

3

1

1

\section{3}

1

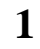

2

3

2

1

1

3

3

1

2

3

3

3

2

1

2

2

1

Distribuição e eficiência do sistema público de saúde

Distribuição e eficiência do sistema público de educação

Melhor distribuição e organização dos comércios

Distribuição e eficiência do sistema sanitário

Distribuição e eficiência dos serviços de comunicação Inundações e alagamentos nas vias públicas

Poluição sonora e atmosférica Lixo

Centralização das ofertas de empregos e serviços

Custo de vida

3

3

2

1

3

3

3

1

3

3

2

1

1

\section{1}

1

1

2

3

3

3

1

2

1

1

2

3

3

2

3

3

3

1

2

3

3

1

2

2

2

2

Trabalho informal ("ambulantes")

\section{3}

3

3

1

Fonte: Do autor (2019).

Com estes resultados, foram calculados o $\mathrm{ICP}_{(\mathrm{p})}$ (Índice de Caracterização de Problemas Preliminar), o IIP (Índice de Intervenção de Problemas) e o ICP (a) (Índice de Caracterização de Problema Ampliado). Os índices são apresentados na tabela 47, organizados em ordem decrescente em função do $\operatorname{ICP}_{(a)}$.

$\mathrm{Na}$ abordagem sistêmica, em que se associa o impacto dos problemas às dificuldades inerentes a eles, para este grupo, curiosamente, os três problemas prioritários - aqueles que têm 
alto impacto e baixa dificuldade de correção e detecção - são associados ao transporte, correlatos à inadequação do transporte público, à diversificação do transporte público e ao congestionamento.

Tabela 47 - Cálculo do ICP(p), IIP e ICP (a) para o grupo 1

\begin{tabular}{|c|c|c|c|}
\hline Problemas & $\mathbf{I C P}_{(\mathbf{p})}$ & IIP & $\operatorname{ICP}_{(\mathbf{a})}$ \\
\hline Inadequação e defasagem do serviço público de transporte & 6 & 1 & 6,00 \\
\hline Pouca diversificação e integração dos modos de transporte & 9 & 2 & 4,50 \\
\hline Congestionamento & 9 & 2 & 4,50 \\
\hline Déficit habitacional & 9 & 2 & 4,50 \\
\hline Distribuição e eficiência do sistema público de educação & 9 & 2 & 4,50 \\
\hline Distribuição e eficiência do sistema de distribuição elétrica & 4 & 1 & 4,00 \\
\hline Falta de manutenção das ciclovias & 4 & 1 & 4,00 \\
\hline Defasagem do planejamento viário & 6 & 2 & 3,00 \\
\hline Pouca quantidade e distribuição de faixas exclusivas de ônibus & 3 & 1 & 3,00 \\
\hline Ocupações irregulares & 9 & 3 & 3,00 \\
\hline Distribuição e eficiência da sinalização das vias públicas & 3 & 1 & 3,00 \\
\hline Falta de segurança e policiamento & 9 & 3 & 3,00 \\
\hline Distribuição e eficiência do sistema público de saúde & 9 & 3 & 3,00 \\
\hline Poluição sonora e atmosférica & 9 & 3 & 3,00 \\
\hline Custo de vida & 9 & 3 & 3,00 \\
\hline Trabalho informal (“ambulantes") & 3 & 1 & 3,00 \\
\hline Malhas ferroviárias pouco desenvolvidas & 4 & 2 & 2,00 \\
\hline Manutenção das vias e espaços públicos & 4 & 2 & 2,00 \\
\hline Distribuição e eficiência dos serviços de comunicação & 2 & 1 & 2,00 \\
\hline Lixo & 6 & 3 & 2,00 \\
\hline Pouco adensamento populacional & 9 & 6 & 1,50 \\
\hline Iluminação & 3 & 2 & 1,50 \\
\hline Higienização das vias públicas & 4 & 3 & 1,33 \\
\hline Terrenos e lotes subutilizados & 1 & 1 & 1,00 \\
\hline Melhor distribuição e organização dos comércios & 1 & 1 & 1,00 \\
\hline Inundações e alagamentos nas vias públicas & 6 & 6 & 1,00 \\
\hline Centralização da oferta de empregos e serviços & 4 & 4 & 1,00 \\
\hline Habitações de interesse social & 3 & 4 & 0,75 \\
\hline Distribuição e eficiência do sistema sanitário & 6 & 9 & 0,67 \\
\hline
\end{tabular}


Outro fato que chama a atenção é que, na quarta posição, está o déficit habitacional, porém a instalação das habitações de interesse social é a penúltima colocada. Possivelmente isso seja um indicativo que na região há uma carência de inserção de habitações voltadas ao mercado popular ${ }^{115}$.

O índice hierárquico de problemas (IHP), é um valor que cada problema recebe, a partir de sua representatividade na matriz de julgamentos relativos de problemas. O IHP, é um índice relativo, que apresenta uma relativização dos problemas quando comparados entre si, que para o grupo 1 foram calculados e apresentados na tabela 48.

Tabela 48 -Cálculo do IHP para o grupo 1

\begin{tabular}{|c|c|}
\hline Problemas & IHP \\
\hline Inadequação e defasagem do serviço público de transporte & 0,0782 \\
\hline Pouca diversificação e integração dos modais de transporte & 0,0586 \\
\hline Congestionamento & 0,0586 \\
\hline Déficit habitacional & 0,0586 \\
\hline Distribuição e eficiência do sistema público de educação & 0,0586 \\
\hline Distribuição e eficiência do sistema de distribuição elétrica & 0,0521 \\
\hline Falta de manutenção das ciclovias & 0,0521 \\
\hline Defasagem do planejamento viário & 0,0391 \\
\hline Pouca quantidade e distribuição de faixas exclusivas de ônibus & 0,0391 \\
\hline Ocupações irregulares & 0,0391 \\
\hline Distribuição e eficiência da sinalização das vias públicas & 0,0391 \\
\hline Falta de segurança e policiamento & 0,0391 \\
\hline Distribuição e eficiência do sistema público de saúde & 0,0391 \\
\hline Poluição sonora e atmosférica & 0,0391 \\
\hline Custo de vida & 0,0391 \\
\hline Trabalho informal - "ambulantes" & 0,0391 \\
\hline Malhas ferroviárias pouco desenvolvidas & 0,0261 \\
\hline Manutenção das vias e espaços públicos & 0,0261 \\
\hline Distribuição e eficiência dos serviços de comunicação & 0,0261 \\
\hline Lixo & 0,0261 \\
\hline Pouco adensamento populacional & 0,0195 \\
\hline Iluminação & 0,0195 \\
\hline Higienização das vias públicas & 0,0173 \\
\hline Terrenos e lotes subutilizados & 0,0130 \\
\hline Melhor distribuição e organização dos comércios & 0,0130 \\
\hline Inundações e alagamentos nas vias públicas & 0,0130 \\
\hline Centralização da oferta de empregos e serviços & 0,0130 \\
\hline Habitações de interesse social & 0,0098 \\
\hline Distribuição e eficiência do sistema sanitário & 0,0087 \\
\hline$\Sigma$ & 1 \\
\hline
\end{tabular}

Fonte: O Autor (2019)

${ }^{115}$ Habitação de Mercado Popular (HMP) corresponde àquela destinada à família com renda igual ou inferior a 16 (dezesseis) salários mínimos, de promoção privada. 


\subsection{Avaliação Multicriterial de Problemas para o Grupo 2}

Os participantes negociaram entre si os pesos, associados a cada dimensão, problema a problema. Mesmo que a nota mínima seja 1 ponto, a cada dimensão, optou-se por não deixar 1 ponto previamente preenchido, a fim de que os participantes refletissem, inclusive, para atribuir a pontuação mais baixa. Após a aplicação, os resultados foram sumarizados na tabela 49.

Tabela 49 - Preenchimento dos Painel de Impacto dos Problemas para o grupo 2

\begin{tabular}{|c|c|c|c|c|}
\hline Problemas & Frequência & Relevância & $\begin{array}{l}\text { Dificuldade } \\
\text { de Correção }\end{array}$ & $\begin{array}{l}\text { Dificuldade } \\
\text { de Detecção }\end{array}$ \\
\hline Trânsito e saturação das vias & 3 & 3 & 2 & 1 \\
\hline $\begin{array}{l}\text { Integração do transporte } \\
\text { público }\end{array}$ & 1 & 3 & 1 & 1 \\
\hline $\begin{array}{l}\text { Tempo de espera do } \\
\text { transporte público }\end{array}$ & 2 & 2 & 1 & 1 \\
\hline $\begin{array}{l}\text { Percurso longo do transporte } \\
\text { público }\end{array}$ & 1 & 1 & 1 & 2 \\
\hline $\begin{array}{l}\text { Qualidade do transporte } \\
\text { público }\end{array}$ & 2 & 3 & 2 & 1 \\
\hline Pavimentação & 3 & 3 & 3 & 1 \\
\hline Ciclofaixas mal projetadas & 2 & 2 & 2 & 2 \\
\hline $\begin{array}{l}\text { Deficiência de equipamentos } \\
\text { de saúde }\end{array}$ & 2 & 3 & 3 & 2 \\
\hline $\begin{array}{l}\text { Deficiência de equipamentos } \\
\text { de lazer }\end{array}$ & 1 & 2 & 2 & 3 \\
\hline $\begin{array}{l}\text { Deficiência de equipamentos } \\
\text { educacionais }\end{array}$ & 3 & 3 & 3 & 2 \\
\hline Iluminação & 2 & 3 & 1 & 1 \\
\hline Centros comerciais & 2 & 3 & 2 & 2 \\
\hline $\begin{array}{l}\text { Deficiência de equipamentos } \\
\text { culturais }\end{array}$ & 1 & 2 & 2 & 2 \\
\hline Violência e segurança & 3 & 3 & 3 & 1 \\
\hline Crescimento desordenado & 2 & 3 & 3 & 2 \\
\hline $\begin{array}{l}\text { Divulgação de oportunidades } \\
\text { de participação pública }\end{array}$ & 3 & 3 & 1 & 1 \\
\hline
\end{tabular}

Continua. 
Continuação.

Poluição sonora, visual e atmosférica

Geração de lixo

Áreas verdes

Planejamento desorganizado das calçadas

Acessibilidade

Vandalismo e insuficiência das lixeiras

Imóveis e terrenos abandonados

Projetos sociais
2

3

2

3

3

3

1

2

3

3

3

3

3

3

2

3

3

3

1

Fonte: Do autor (2019).
1
2

1

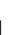

1

2

1

2

3

Com estes resultados, foram calculados o $\operatorname{ICP}_{(\mathrm{p})}$, o $\operatorname{IIP}$ e o $\operatorname{ICP}_{(\mathrm{a})}$. Os índices são apresentados na tabela 50, organizados em ordem decrescente em função do $\operatorname{ICP}_{(a)}$.

Tabela 50 - Cálculo do ICP $(\mathrm{p})$, IIP e ICP (a) para o grupo 2

\begin{tabular}{cccc}
\hline Problemas & ICP(p) & IIP & ICP(a) \\
\hline Divulgação de oportunidades de participação pública & 9 & 1 & 9,00 \\
Vandalismo e insuficiência das lixeiras & 9 & 1 & 9,00 \\
Iluminação & 6 & 1 & 6,00 \\
Áreas verdes & 6 & 1 & 6,00 \\
Trânsito e saturação das vias & 9 & 2 & 4,50 \\
Tempo de espera do transporte público & 4 & 1 & 4,00 \\
Integração do transporte público & 3 & 1 & 3,00 \\
Qualidade do transporte público & 6 & 2 & 3,00 \\
Pavimentação & 9 & 3 & 3,00 \\
Violência e segurança & 9 & 3 & 3,00 \\
Planejamento desorganizado das calçadas & 9 & 3 & 3,00 \\
Acessibilidade & 9 & 4 & 2,25 \\
Poluição sonora, visual e atmosférica & 6 & 3 & 2,00 \\
Deficiência de equipamentos educacionais & 9 & 6 & 1,50 \\
Centros comerciais & 6 & 4 & 1,50 \\
& & & Continua.
\end{tabular}




\begin{tabular}{ccccc} 
Geração de lixo & \multicolumn{3}{c}{ Continuação. } \\
Ciclofaixas mal projetadas & 9 & 6 & 1,50 \\
Deficiência de equipamentos de saúde & 4 & 4 & 1,00 \\
Crescimento desordenado & 6 & 6 & 1,00 \\
Projetos sociais & 6 & 6 & 1,00 \\
Percurso longo do transporte público & 6 & 6 & 1,00 \\
Deficiência de equipamentos culturais & 1 & 2 & 0,50 \\
Deficiência de equipamentos de lazer & 2 & 4 & 0,50 \\
Imóveis e terrenos abandonados & 2 & 6 & 0,33 \\
\hline
\end{tabular}

Fonte: Do autor (2019).

Neste grupo, os problemas prioritários são associados à divulgação de oportunidade de participação pública, vandalismo e insuficiência de lixeiras e iluminação. Logo após, são apontados problemas acerca ao transporte, tal como no grupo 1.

O IHP, é um índice relativo, que apresenta uma relativização dos problemas quando comparados entre si, que para o grupo 2 foram calculados e apresentados na tabela 51.

Tabela 51 -Cálculo do IHP para o grupo 2

\begin{tabular}{cc}
\hline Problemas & IHP \\
\hline Divulgação de oportunidades de participação pública & 0,1325 \\
Vandalismo e insuficiência das lixeiras & 0,1325 \\
Iluminação & 0,0884 \\
Areas verdes & 0,0884 \\
Tempansito e saturação das vias & 0,0663 \\
Integração do transporte público & 0,0589 \\
Qualidade do transporte público & 0,0442 \\
Pavimentação & 0,0442 \\
Violência e segurança & 0,0442 \\
Acessibilidade & 0,0442 \\
Planejamento desorganizado das Calçadas & 0,0442 \\
Poluição sonora, visual e atmosférica & 0,0331 \\
Deficiência de equipamentos educacionais & 0,0295 \\
Centros comerciais & 0,0221 \\
Geração de lixo & 0,0221 \\
Ciclo faixas mal projetadas & 0,0221 \\
Deficiência de equipamentos de saúde & 0,0147 \\
Crescimento desordenado & 0,0147 \\
Projetos sociais & 0,0147 \\
Percurso longo do transporte público & 0,0147 \\
Deficiência de equipamentos culturais & 0,0074 \\
& 0,0074 \\
& Continua.
\end{tabular}


Deficiência de equipamentos de lazer

Continuação.

Imóveis e terrenos abandonados

0,0049

0,0049

$\Sigma$

Fonte: O Autor (2019)

\subsection{Avaliação Multicriterial de Problema para o Grupo 3}

Os participantes negociaram entre si os pesos, associados a cada dimensão, problema a problema. Mesmo que a nota mínima seja 1 ponto, a cada dimensão, optou-se por não deixar 1 ponto previamente preenchido, a fim de que os participantes refletissem, inclusive, para atribuir a pontuação mais baixa. Após a aplicação, os resultados foram sumarizados na tabela 52 .

Tabela 52 - Preenchimento dos Painel de Impacto dos Problemas para o grupo 3

\begin{tabular}{|c|c|c|c|c|}
\hline Problemas & Frequência & Relevância & $\begin{array}{l}\text { Dificuldade de } \\
\text { Correção }\end{array}$ & $\begin{array}{c}\text { Dificuldade de } \\
\text { Detecção }\end{array}$ \\
\hline Segurança & 3 & 3 & 1 & 1 \\
\hline Moradores de rua & 3 & 3 & 2 & 1 \\
\hline Zeladoria urbana & 2 & 3 & 3 & 1 \\
\hline Atendimento à saúde & 3 & 3 & 1 & 2 \\
\hline Ocupações irregulares & 3 & 2 & 1 & 1 \\
\hline $\begin{array}{l}\text { Falta de espaços para } \\
\text { humanização, } \\
\text { engajamento e } \\
\text { democracia }\end{array}$ & 3 & 3 & 3 & $\mathbf{1}$ \\
\hline Áreas verdes & 2 & 2 & 2 & 1 \\
\hline Centralização industrial & 2 & 2 & 2 & 1 \\
\hline $\begin{array}{c}\text { Apropriação de espaços } \\
\text { ociosos }\end{array}$ & 2 & 2 & 3 & 3 \\
\hline Alagamentos & 3 & 3 & 3 & 1 \\
\hline $\begin{array}{l}\text { Conflito de interesses } \\
\text { imobiliários e sociais }\end{array}$ & 3 & 2 & 2 & 2 \\
\hline Falta de acessibilidade & 2 & 2 & 1 & 1 \\
\hline Falta de mobilidade & 2 & 2 & 1 & 3 \\
\hline $\begin{array}{c}\text { Deficiências na } \\
\text { promoção da cultura na } \\
\text { cidade }\end{array}$ & 1 & 1 & $\mathbf{1}$ & 2 \\
\hline $\begin{array}{l}\text { Ausência de programas } \\
\text { de integração social }\end{array}$ & 3 & 2 & 2 & 2 \\
\hline
\end{tabular}


Continuação.

Falta de espaços de cultura e lazer

Estímulo a métodos de ensino inovadores

Falta de senso de comunidade e união para serviços no bairro

1

3

2
1

3

1

2
2

2

1

Fonte: Do autor (2019).

Com estes resultados, foram calculados o $\mathrm{ICP}_{(\mathrm{p})}$, o $\mathrm{IIP}$ e o $\operatorname{ICP}_{(\mathrm{a})}$. Os índices são apresentados na tabela 53, organizados em ordem decrescente em função do $\operatorname{ICP}_{(a)}$.

Tabela 53 - Cálculo do ICP(p), IIP e ICP (a) para o grupo 3

\begin{tabular}{cccc}
\hline Problemas & ICP(p) $_{(\mathbf{P}}$ & IIP & ICP $_{(\mathbf{a})}$ \\
\hline Segurança & 9 & 1 & 9,00 \\
Ocupações irregulares & 6 & 1 & 6,00 \\
Moradores de rua & 9 & 2 & 4,50 \\
Atendimento à saúde & 9 & 2 & 4,50 \\
Falta de acessibilidade & 4 & 1 & 4,00 \\
Falta de espaços para humanização, engajamento e democracia & 9 & 3 & 3,00 \\
Alagamentos & 9 & 3 & 3,00 \\
Estímulo a métodos de ensino inovadores & 9 & 4 & 2,25 \\
Zeladoria urbana & 6 & 3 & 2,00 \\
Área verdes & 4 & 2 & 2,00 \\
Centralização industrial & 4 & 2 & 2,00 \\
Conflito de interesses imobiliários e sociais & 6 & 4 & 1,50 \\
Ausência de programa de integração social & 6 & 4 & 1,50 \\
Falta de mobilidade & 4 & 3 & 1,33 \\
Falta de senso de comunidade e união para serviços no bairro & 2 & 2 & 1,00 \\
Deficiências na promoção da cultura na cidade & 1 & 2 & 0,50 \\
Falta de espaços de cultura e lazer & 1 & 2 & 0,50 \\
Apropriação de espaços ociosos & 4 & 9 & 0,44 \\
\hline
\end{tabular}

Fonte: Do autor (2019).

Neste grupo, os problemas prioritários foram associados a segurança, ocupações irregulares e moradores de rua. Particularmente nesse caso, o que se notou foram problemas associados a questões sociais, o que é interessante, pois a proposta se mostrou aplicável mesmo em problemas dessa natureza, o IHP para este grupo é apresentado na tabela 54. 
Tabela 54 -Cálculo do IHP para o grupo 3

\begin{tabular}{cc} 
Problemas & IHP \\
Segurança & 0,1836 \\
Ocupações irregulares & 0,1224 \\
Moradores de rua & 0,0918 \\
Atendimento à saúde & 0,0918 \\
Falta de acessibilidade & 0,0816 \\
Falta de espaços para humanização, engajamento e democracia & 0,0612 \\
Alagamentos & 0,0612 \\
Estimulo a métodos de ensino inovadores & 0,0459 \\
Zeladoria urbana & 0,0408 \\
Área verdes & 0,0408 \\
Centralização industrial & 0,0408 \\
Conflito de interesses imobiliários e sociais & 0,0306 \\
Ausência de programa de integração social & 0,0306 \\
Falta de mobilidade & 0,0271 \\
Falta de senso de comunidade e união para serviços no bairro & 0,0204 \\
Deficiências na promoção da cultura na cidade & 0,0102 \\
Falta de espaços de cultura e lazer & 0,0102 \\
Apropriação de espaços ociosos & 0,0090 \\
\hline $\mathbf{\Sigma}$ & $\mathbf{1}$ \\
\hline
\end{tabular}

\subsection{Avaliação Multicriterial de Problemas para o Grupo 4}

Os participantes negociaram entre si os pesos, associados a cada dimensão, problema a problema. Mesmo que a nota mínima seja 1 ponto, a cada dimensão, optou-se por não deixar 1 ponto previamente preenchido, a fim de que os participantes refletissem, inclusive, para atribuir a pontuação mais baixa. Após a aplicação, os resultados foram sumarizados na tabela 55 .

Tabela 55 - Preenchimento dos Painel de Impacto dos Problemas para o grupo 4

\begin{tabular}{ccccc} 
Problemas & Frequência & Relevância & $\begin{array}{c}\text { Dificuldade } \\
\text { de Correção }\end{array}$ & $\begin{array}{c}\text { Dificuldade de } \\
\text { Detecção }\end{array}$ \\
\hline $\begin{array}{c}\text { Trânsito e saturação das } \\
\text { vias }\end{array}$ & $\mathbf{3}$ & $\mathbf{2}$ & $\mathbf{2}$ & $\mathbf{1}$ \\
$\begin{array}{c}\text { Integração do transporte } \\
\text { público }\end{array}$ & $\mathbf{3}$ & $\mathbf{2}$ & $\mathbf{1}$ & $\mathbf{1}$ \\
$\begin{array}{c}\text { Falta de opções de } \\
\text { transporte público }\end{array}$ & $\mathbf{3}$ & $\mathbf{3}$ & $\mathbf{1}$ & $\mathbf{1}$ \\
$\begin{array}{c}\text { Percurso longo do } \\
\text { transporte público }\end{array}$ & $\mathbf{2}$ & $\mathbf{2}$ & $\mathbf{2}$ & $\mathbf{1}$
\end{tabular}

Continua. 
Continuação.

Baixa qualidade do transporte público

Pavimentação precária 2 2

1

Ciclofaixas mal projetadas

Deficiência de equipamentos de saúde 2 3

2

Falta de opções de lazer 2

Falta de estabelecimentos de ensino

Falta de iluminação

2

2

1

Não existem centros comerciais

2

3

1

Falta de equipamentos culturais

Violência e segurança

2

2

2

2

3

3

3

1

Crescimento desordenado

1

2

2

2

Ausência de oferta de empregos

2

3

1

2

Poluição sonora, visual e atmosférica

Geração de lixo

2

2

2

2

2

2

2

1

Áreas verdes insuficientes e mal distribuídas

2

3

3

2

Planejamento das calçadas

1

2

1

2

Grandes áreas abandonadas

2

1

2

2

Fonte: Do autor (2019).

Com estes resultados, foram calculados o $\operatorname{ICP}_{(\mathrm{p})}$, o IIP e o $\operatorname{ICP}_{(\mathrm{a})}$. Os índices são apresentados na tabela 56, organizados em ordem decrescente em função do $\operatorname{ICP}_{(a)}$. 
Tabela 56 - Cálculo do ICP(p), IIP e ICP (a) para o grupo 4

\begin{tabular}{cccc}
\hline Problemas & ICP(p) & IIP & ICP(a) $_{(\mathbf{a}}$ \\
\hline Falta de opções de transporte público & 9 & 1 & 9,00 \\
Integração do transporte público & 6 & 1 & 6,00 \\
Baixa qualidade do transporte público & 4 & 1 & 4,00 \\
Trânsito e saturação das vias & 6 & 2 & 3,00 \\
Não existem centros comerciais & 6 & 2 & 3,00 \\
Violência e segurança & 9 & 3 & 3,00 \\
Ausência de oferta de empregos & 6 & 2 & 3,00 \\
Percurso longo do transporte público & 4 & 2 & 2,00 \\
Pavimentação precária & 4 & 2 & 2,00 \\
Falta de iluminação & 4 & 2 & 2,00 \\
Geração de lixo & 4 & 2 & 2,00 \\
Deficiência de equipamentos de saúde & 6 & 6 & 1,00 \\
Falta de equipamentos culturais & 4 & 4 & 1,00 \\
Poluição sonora, visual e atmosférica & 4 & 4 & 1,00 \\
Áreas verdes insuficientes e mal distribuídas & 6 & 6 & 1,00 \\
Planejamento das calçadas & 2 & 2 & 1,00 \\
Falta de opções de lazer & 4 & 6 & 0,67 \\
Ciclofaixas mal projetadas & 2 & 4 & 0,50 \\
Falta de estabelecimentos de ensino & 2 & 4 & 0,50 \\
Crescimento desordenado & 2 & 4 & 0,50 \\
Grandes áreas abandonadas & 4 & 0,50 \\
\hline & & & \\
\hline & & 6 & 6
\end{tabular}

Fonte: Do autor (2019).

No grupo 4, novamente, os principais problemas são intrínsecos às questões associadas ao transporte. Entretanto, para quase todos os grupos, grandes áreas abandonadas, apropriação de espaços ociosos, imóveis e terrenos abandonados figuraram entre as últimas colocações, não porque não sejam relevantes ou pouco frequentes, mas por sua dificuldade de intervenção, segundo a percepção das pessoas., conforme IHP demostrado na tabela 57.

Tabela 57 -Cálculo do IHP para o grupo 4

\begin{tabular}{cc}
\hline Problemas & IHP \\
\hline Faltam opções de transporte público & 0,1928 \\
Integração do transporte público & 0,1286 \\
Baixa Qualidade do transporte público & 0,0857 \\
Trânsito e saturação das vias & 0,0643 \\
& Continua.
\end{tabular}


Não existem centros comerciais

Continuação

Violência e segurança

0,0643

0,0643

Ausência de oferta de empregos

0,0643

$\begin{array}{cc}\text { Percurso longo do transporte público } & 0,0429 \\ \text { Pavimentação precária } & 0,0429\end{array}$

Falta iluminação $\quad 0,0429$

Geração de lixo $\quad 0,0429$

Deficiência de equipamentos de saúde $\quad 0,0214$

Falta equipamentos culturais $\quad 0,0214$

Poluição sonora, visual e atmosférica $\quad 0,0214$

Áreas verdes insuficientes e mal distribuídas $\quad 0,0214$

Planejamento das Calçadas $\quad 0,0214$

Faltam opções de lazer $\quad 0,0144$

Ciclo faixas mal projetadas $\quad 0,0107$

Falta de estabelecimentos de ensino $\quad 0,0107$

Crescimento desordenado $\quad 0,0107$

Grandes áreas abandonadas $\quad 0,0107$

\begin{tabular}{lc}
\hline $\boldsymbol{\Sigma}$ & $\mathbf{1}$ \\
\hline
\end{tabular}

Fonte: O Autor (2019)

\subsubsection{Hierarquização Multicriterial de Ligação entre Problemas e Alternativas}

A partir dos dados gerados no painel de análise e correlação de alternativas é possível calcular os índices: i.) IEA(c) - Índice de eficácia das alternativas; ii.) IEA(f) - Índice de efetividade das alternativas; iii.) IAA - Índice de abrangências das alternativas; iv.) IEA(e) Índice de eficiência das alternativas; v.) ISA - Índice de assertividade das alternativas; vi.) ICA - Índice de colateralidade das alternativas; vii.) IIA - Índice de incompletude das alternativas; viii.) IGA-A(p) - Índice de geral de abrangência das alternativas ponderado; ix.) IGA-A (h) Índice de Abrangência Geral das Alternativas hierárquico; x.) IEP(c) - Índice de eficácia dos problemas; xi.) IEP(f) - Índice de efetividade dos problemas; xii.) IAP - Índice de abrangências dos problemas; xiii.) IEP(e) - Índice de eficiência dos problemas; xiii.) ISP - Índice de assertividade nos problemas; xiv.) IOP - Índice de colateralidade nos problemas; xv.) IUP Índice de incompletude nos problemas; xvi.) IGA-P(p) - Índice de geral de abrangência dos problemas ponderado; xvii.) IGA-P (h) - Índice Geral de Assertividade dos Problemas hierárquico; xviii.) AQC - Avaliador de qualidade de completude do processo; xix.) AAP Avaliador de atendimento dos problemas; xx.) AEP - Avaliador de efetividade no processo; xxi.) AFP - Avaliador de eficiência do processo. 


\subsection{Resultados do painel de análise e correlação de alternativas para o Grupo 1}

Para aplicação do metodologia proposta, com o cálculo dos índices associados as alternativas, somou-se os atendimento completos e incompletos, diretos e indiretos para cada alternativas proposta no processo, gerando a tabela 58 .

Tabela 58 - Analisa do painel de correção de alternativas e problemas para o grupo 1

\begin{tabular}{|c|c|c|c|c|c|}
\hline Alternativas & DC & DI & IC & II & $\Sigma$ \\
\hline Ampliação da ocupação do solo & 5 & 5 & 1 & 5 & 16 \\
\hline Ampliação de áreas verdes nos edifícios & 1 & 0 & 0 & 1 & 2 \\
\hline Ampliar plataformas de informação & 2 & 11 & 1 & 6 & 20 \\
\hline Incentivar a oferta de empregos & 0 & 0 & 0 & 1 & 1 \\
\hline Definição para altura máxima de muros & 3 & 4 & 2 & 13 & 22 \\
\hline Descentralizar a oferta de empregos & 1 & 0 & 0 & 4 & 5 \\
\hline Desincentivo à ampliação da largura das calçadas & 1 & 0 & 2 & 4 & 7 \\
\hline Desincentivo ao adensamento populacional & 7 & 5 & 1 & 3 & 16 \\
\hline Desincentivo ao uso do veículo individual & 0 & 0 & 0 & 1 & 1 \\
\hline Desincentivo ao usos mistos & 1 & 0 & 1 & 0 & 2 \\
\hline Incentivar a captação energéticas nos edifícios & 1 & 2 & 0 & 0 & 3 \\
\hline Incentivar o adensamento populacional & 8 & 7 & 1 & 8 & 24 \\
\hline Incentivar o uso do veículo individual & 0 & 0 & 0 & 0 & 0 \\
\hline Incentivar usos industriais na região & 1 & 0 & 0 & 0 & 1 \\
\hline Incentivar usos mistos & 0 & 0 & 0 & 1 & 1 \\
\hline Incentivo a ampliação da largura das calçadas & 1 & 0 & 0 & 10 & 11 \\
\hline Maior ocupação em áreas livres abandonadas & 6 & 4 & 1 & 7 & 18 \\
\hline Disciplinar a ocupação em áreas livres abandonadas & 1 & 1 & 0 & 0 & 2 \\
\hline Redução da ocupação do solo & 1 & 0 & 0 & 0 & 1 \\
\hline Redução de áreas verdes nos edifícios & 0 & 1 & 0 & 0 & 1 \\
\hline$\Sigma$ & 40 & 40 & 10 & 64 & 154 \\
\hline
\end{tabular}

Fonte: O Autor (2019)

A partir destes resultados é possível calcular os índices de avaliação de efetividade, eficácia e abrangência para apoiar a avaliação de cada uma das alternativas propostas, conforme tabela 60 . 
Tabela 59 - Cálculo do $\operatorname{IEA}_{(c)}, \operatorname{IEA}_{(f)}$ e IAA para o Grupo 1

\begin{tabular}{|c|c|c|c|}
\hline Alternativas & IEA $_{(c)}$ & $\operatorname{IEA}_{(f)}$ & IAA \\
\hline Ampliação da ocupação do solo & 0,207 & 0,345 & 0,552 \\
\hline Ampliação de áreas verdes nos edifícios & 0,034 & 0,034 & 0,069 \\
\hline Ampliar plataformas de informação & 0,103 & 0,448 & 0,690 \\
\hline Incentivar a oferta de empregos & 0,000 & 0,000 & 0,034 \\
\hline Definição para altura máxima de muros & 0,172 & 0,241 & 0,759 \\
\hline Descentralizar a oferta de empregos & 0,034 & 0,034 & 0,172 \\
\hline Desincentivo à ampliação da largura das calçadas & 0,103 & 0,034 & 0,241 \\
\hline Desincentivo ao adensamento populacional & 0,276 & 0,414 & 0,552 \\
\hline Desincentivo ao uso do veículo individual & 0,000 & 0,000 & 0,034 \\
\hline Desincentivo ao usos mistos & 0,069 & 0,034 & 0,069 \\
\hline Incentivar a captação energéticas nos edifícios & 0,034 & 0,103 & 0,103 \\
\hline Incentivar o adensamento populacional & 0,310 & 0,517 & 0,828 \\
\hline Incentivar o uso do veículo individual & 0,000 & 0,000 & 0,000 \\
\hline Incentivar usos industriais na Região & 0,034 & 0,034 & 0,034 \\
\hline Incentivar usos mistos & 0,000 & 0,000 & 0,034 \\
\hline Incentivo a ampliação da largura das calçadas & 0,034 & 0,034 & 0,379 \\
\hline Maior ocupação em áreas livres abandonadas & 0,241 & 0,345 & 0,621 \\
\hline Disciplinar a ocupação em áreas livres abandonadas & 0,034 & 0,069 & 0,069 \\
\hline Redução da ocupação do solo & 0,034 & 0,034 & 0,034 \\
\hline Redução de áreas verdes nos edifícios & 0,000 & 0,034 & 0,034 \\
\hline
\end{tabular}

Fonte: O Autor (2019)

Para o caso do grupo 1 o que se nota é que a alternativa mais eficaz é o incentivo ao adensamento populacional na região com um índice de 0,310 e as menos eficazes, o incentivo ao uso misto, ações sobre o uso do veículo individual e a centralização de oferta de empregos. É interessante observar, neste grupo, que o consenso possibilitou que alternativas, evidentemente negativas, figurem entre as menos eficazes, como por exemplo a redução de áreas verdes nos edifícios.

Também será mais efetivo o incentivo ao adensamento populacional com um índice de 0,517, por outro lado menos efetivas novamente a centralização da oferta de empregos, ações sobre o uso do veículo individual e o incentivo aos usos mistos. 
Para o grupo 1 o incentivo ao adensamento populacional se apresenta como a mais abrangentes, por outro lado, chamam a atenção os índices elevados para a definição de maior ocupação de áreas livres abandonadas e a para a ampliação das plataformas de informação. Reforçando que quanto maior a abrangência mais problemas são atacados por esta alternativa.

Também, com o resultado desta dinâmica, é possível calcular a eficiência das alternativas, a assertividade das alternativas, a colateralidade das alternativas e sua incompletude, com os índices sumarizados na tabela 60.

Tabela 60 - Cálculo do IEA $_{(\mathrm{e})}$, ISA, ICA e IIA para o grupo 1

\begin{tabular}{|c|c|c|c|c|}
\hline Alternativas & IEA(e) & ISA & ICA & IIA \\
\hline Ampliação da ocupação do Solo & 0,313 & 0,625 & 0,375 & 0,625 \\
\hline Ampliação de áreas verdes nos edifícios & 0,500 & 0,500 & 0,500 & 0,500 \\
\hline Ampliar Plataformas de Informação & 0,100 & 0,650 & 0,350 & 0,850 \\
\hline Incentivar a Oferta de Empregos & 0,000 & 0,000 & 1,000 & 1,000 \\
\hline Definição para altura máxima de muros & 0,136 & 0,318 & 0,682 & 0,773 \\
\hline Descentralizar a oferta de empregos & 0,200 & 0,200 & 0,800 & 0,800 \\
\hline Desincentivo à ampliação da largura das calçadas & 0,143 & 0,143 & 0,857 & 0,571 \\
\hline Desincentivo ao Adensamento Populacional & 0,438 & 0,750 & 0,250 & 0,500 \\
\hline Desincentivo ao uso do veículo individual & 0,000 & 0,000 & 1,000 & 1,000 \\
\hline Desincentivo ao usos Mistos & 0,500 & 0,500 & 0,500 & 0,000 \\
\hline Incentivar a captação energéticas nos Edifícios & 0,333 & 1,000 & 0,000 & 0,667 \\
\hline Incentivar o adensamento Populacional & 0,333 & 0,625 & 0,375 & 0,625 \\
\hline Incentivar o Uso do veículo Individual & 0,000 & 0,000 & 0,000 & 0,000 \\
\hline Incentivar usos industriais na Região & 1,000 & 1,000 & 0,000 & 0,000 \\
\hline Incentivar usos mistos & 0,000 & 0,000 & 1,000 & 1,000 \\
\hline Incentivo a ampliação da largura das calçadas & 0,091 & 0,091 & 0,909 & 0,909 \\
\hline Maior ocupação em áreas livres abandonadas & 0,333 & 0,556 & 0,444 & 0,611 \\
\hline Disciplinar a Ocupação em Áreas Livres Abandonadas & 0,500 & 1,000 & 0,000 & 0,500 \\
\hline Redução da Ocupação do Solo & 1,000 & 1,000 & 0,000 & 0,000 \\
\hline Redução de áreas verdes nos edifícios & 0,000 & 1,000 & 0,000 & 1,000 \\
\hline
\end{tabular}

Fonte: O Autor (2019)

A partir destes índices calculados, para o grupo 1, é possível perceber uma dicotomia interessante de resultados, pois as alternativas que são mais eficientes, ou seja, que atuam 
diretamente e completamente sobre os problemas, seja positiva ou negativamente ${ }^{116}$, são a redução da ocupação do solo e o incentivo a usos industriais na região. Mas isso se deve ao fato de serem alternativas que atuam pontualmente em questões especificas.

Com os dados apresentados também é possível calcular o Índice de geral de abrangência das alternativas ponderado, ou gera que considera o quão abrangente são as alternativas ao mesmo tempo em que se valoriza o quanto elas são completas, conforme tabela 61 .

Tabela 61 - Cálculo do IGA-A(p) para o grupo 1.

\begin{tabular}{cc}
\hline Alternativas & IGA-A(p) \\
\hline Ampliação da ocupação do Solo & 0,759 \\
Ampliação de áreas verdes nos edifícios & 0,103 \\
Ampliar Plataformas de Informação & 0,793 \\
Incentivar a Oferta de Empregos & 0,034 \\
Definição para altura máxima de muros & 0,931 \\
Descentralizar a oferta de empregos & 0,207 \\
Desincentivo à ampliação da largura das calçadas & 0,345 \\
Desincentivo ao Adensamento Populacional & 0,828 \\
Desincentivo ao uso do veículo individual & 0,034 \\
Desincentivo ao usos Mistos & 0,138 \\
Incentivar a captação energéticas nos Edifícios & 0,138 \\
Incentivar o adensamento Populacional & 1,138 \\
Incentivar o Uso do veículo Individual & 0,000 \\
Incentivar usos industriais na Região & 0,069 \\
Incentivar usos mistos & 0,034 \\
Incentivo a ampliação da largura das calçadas & 0,414 \\
Maior ocupação em áreas livres abandonadas & 0,862 \\
Disciplinar a Ocupação em Áreas Livres Abandonadas & 0,103 \\
Redução da Ocupação do Solo & 0,069 \\
\hline Redo de áreas verdes nos edifícios & 0,034 \\
\hline
\end{tabular}

Fonte: O Autor (2019)

O que se nota, é que apenas pela abrangência e completude para o grupo, as alternativas que podem ser mais interessantes para a região são o adensamento populacional, um maior controle sobre a altura máxima dos muros e uma maior ocupação das áreas livres. Contudo esta

\footnotetext{
116 Alternativas que atuam negativamente são aquelas que asseveram um determinado problema.
} 
hierarquia não é absoluta, pois uma análise conjunta de todos os índices fornece um panorama mais completo de analise, e o que se pode afirmar é que sem dúvida o incentivo ao adensamento populacional para a região, segundo a população consultada é uma alternativa interessante, contudo também aparece o desincentivo ao adensamento populacional relativamente próximo ao incentivo, este resultado aponta que embora tenha ocorrido dificuldade no consenso para esta questão, o incentivo foi melhor pontuado ligeiramente melhor.

Por fim, é possível estabelecera hierarquização de comparação pareada para construção do índice geral de assertividade das alternativas hierarquizado (IGA-A $(h)$ ), conforme tabela 62, em uma escala de 0 a 1.

Tabela 62 - Cálculo do IGA-A $(h)$ para o grupo 1

\begin{tabular}{|c|c|}
\hline Alternativas & IGA-A(h) \\
\hline Incentivar o adensamento Populacional & 0,162 \\
\hline Definição para altura máxima de muros & 0,132 \\
\hline Maior ocupação em áreas livres abandonadas & 0,123 \\
\hline Desincentivo ao Adensamento Populacional & 0,118 \\
\hline Ampliar Plataformas de Informação & 0,113 \\
\hline Ampliação da ocupação do Solo & 0,107 \\
\hline Incentivo a ampliação da largura das calçadas & 0,059 \\
\hline Desincentivo à ampliação da largura das calçadas & 0,049 \\
\hline Descentralizar a oferta de empregos & 0,029 \\
\hline Desincentivo ao usos Mistos & 0,020 \\
\hline Incentivar a captação energéticas nos Edifícios & 0,020 \\
\hline Ampliação de áreas verdes nos edifícios & 0,015 \\
\hline Disciplinar a Ocupação em Áreas Livres Abandonadas & 0,015 \\
\hline Incentivar usos industriais na Região & 0,010 \\
\hline Redução da Ocupação do Solo & 0,010 \\
\hline Incentivar a Oferta de Empregos & 0,005 \\
\hline Desincentivo ao uso do veículo individual & 0,005 \\
\hline Incentivar usos mistos & 0,005 \\
\hline Redução de áreas verdes nos edifícios & 0,005 \\
\hline Incentivar o Uso do veículo Individual & 0,001 \\
\hline$\Sigma$ & 1 \\
\hline
\end{tabular}

Fonte: O Autor (2019) 
Também a partir do painel de análise e correlação das alternativa é possível avaliar qual o nível de atendimento dos problemas, em função das alternativas propostas. Este resultado é sumarizado sob a ótica dos problemas na tabela 63.

Tabela 63 - Marcações para atendimento dos problemas no grupo 1

\begin{tabular}{|c|c|c|c|c|}
\hline Problemas & DC & DI & IC & II \\
\hline Centralização da oferta de empregos e serviços & 1 & 2 & 1 & 4 \\
\hline Congestionamento & 1 & 1 & 1 & 1 \\
\hline Custo de vida & 1 & 2 & 0 & 1 \\
\hline Defasagem do planejamento viário & 2 & 1 & 0 & 2 \\
\hline Déficit habitacional & 1 & 1 & 1 & 2 \\
\hline Distribuição e eficiência da sinalização das vias públicas & 2 & 2 & 0 & 2 \\
\hline Distribuição e eficiência do sistema de distribuição elétrica & 2 & 1 & 0 & 3 \\
\hline Distribuição e eficiência do sistema público de educação & 1 & 1 & 0 & 3 \\
\hline Distribuição e eficiência do sistema público de saúde & 2 & 1 & 0 & 1 \\
\hline Distribuição e eficiência do sistema sanitário & 1 & 1 & 0 & 3 \\
\hline Distribuição e eficiência dos serviços de comunicação & 1 & 1 & 0 & 1 \\
\hline Falta de manutenção das ciclovias & 1 & 2 & 0 & 1 \\
\hline Falta de segurança e policiamento & 1 & 1 & 1 & 4 \\
\hline Habitações de interesse social & 2 & 1 & 1 & 1 \\
\hline Higienização das vias públicas & 1 & 1 & 0 & 1 \\
\hline Iluminação & 2 & 2 & 0 & 2 \\
\hline Inadequação e defasagem do serviço público de transporte & 1 & 1 & 0 & 2 \\
\hline Inundações e alagamentos nas vias públicas & 2 & 1 & 0 & 3 \\
\hline Lixo & 1 & 1 & 1 & 3 \\
\hline Malhas ferroviárias pouco desenvolvidas & 2 & 1 & 1 & 1 \\
\hline Manutenção das vias e espaços públicos & 1 & 2 & 1 & 3 \\
\hline Melhor distribuição e organização dos comércios & 2 & 2 & 0 & 2 \\
\hline Ocupações irregulares & 2 & 2 & 0 & 1 \\
\hline Poluição sonora e atmosférica & 1 & 2 & 0 & 3 \\
\hline Pouca diversificação e integração dos modais de transporte & 1 & 2 & 0 & 1 \\
\hline Pouca quantidade e distribuição de faixas exclusivas de ônibus & 1 & 1 & 0 & 4 \\
\hline Pouco adensamento populacional & 2 & 2 & 1 & 5 \\
\hline Terrenos e lotes subutilizados & 1 & 1 & 1 & 1 \\
\hline Trabalho informal - "ambulantes" & 1 & 1 & 0 & 3 \\
\hline
\end{tabular}

Fonte: O Autor (2019) 
A partir destes resultados é possível calcular a eficácia e a efetividade de atuação nos problemas propostos, conforme tabela 64

Tabela 64 -Cálculo do $\operatorname{IEP}_{(\mathrm{c})}$ e $\operatorname{IEP}_{(\mathrm{f})}$ para o grupo 1

\begin{tabular}{|c|c|c|}
\hline Problemas & IEP(c) & IEP(f) \\
\hline Centralização da oferta de empregos e serviços & 0,100 & 0,150 \\
\hline Congestionamento & 0,100 & 0,100 \\
\hline Custo de vida & 0,050 & 0,150 \\
\hline Defasagem do planejamento viário & 0,100 & 0,150 \\
\hline Déficit habitacional & 0,100 & 0,100 \\
\hline Distribuição e eficiência da sinalização das vias públicas & 0,100 & 0,200 \\
\hline Distribuição e eficiência do sistema de distribuição elétrica & 0,100 & 0,150 \\
\hline Distribuição e eficiência do sistema público de educação & 0,050 & 0,100 \\
\hline Distribuição e eficiência do sistema público de saúde & 0,100 & 0,150 \\
\hline Distribuição e eficiência do sistema sanitário & 0,050 & 0,100 \\
\hline Distribuição e eficiência dos serviços de comunicação & 0,050 & 0,100 \\
\hline Falta de manutenção das ciclovias & 0,050 & 0,150 \\
\hline Falta de segurança e policiamento & 0,100 & 0,100 \\
\hline Habitações de interesse social & 0,150 & 0,150 \\
\hline Higienização das vias públicas & 0,050 & 0,100 \\
\hline Iluminação & 0,100 & 0,200 \\
\hline Inadequação e defasagem do serviço público de transporte & 0,050 & 0,100 \\
\hline Inundações e alagamentos nas vias públicas & 0,100 & 0,150 \\
\hline Lixo & 0,100 & 0,100 \\
\hline Malhas ferroviárias pouco desenvolvidas & 0,150 & 0,150 \\
\hline Manutenção das vias e espaços públicos & 0,100 & 0,150 \\
\hline Melhor distribuição e organização dos comércios & 0,100 & 0,200 \\
\hline Ocupações irregulares & 0,100 & 0,200 \\
\hline Poluição sonora e atmosférica & 0,050 & 0,150 \\
\hline Pouca diversificação e integração dos modais de transporte & 0,050 & 0,150 \\
\hline Pouca quantidade e distribuição de faixas exclusivas de ônibus & 0,050 & 0,100 \\
\hline Pouco adensamento populacional & 0,150 & 0,200 \\
\hline Terrenos e lotes subutilizados & 0,100 & 0,100 \\
\hline Trabalho informal - "ambulantes" & 0,050 & 0,100 \\
\hline
\end{tabular}

Fonte: O Autor (2019) 
No caso proposto, e analisado pelo grupo 1, há uma distribuição quase que homogênea de eficácia e de efetividade de ação nos problemas, sendo difícil elencar quais os mais importantes, portanto, verificar a abrangência e a eficiência podem apontar uma hierarquia mais clara, conforme tabela 65

Tabela 65 - Cálculo do IAP e IEP(e) para o grupo 1

\begin{tabular}{|c|c|c|}
\hline Problemas & IAP & IEP(e) \\
\hline Centralização da oferta de empregos e serviços & 0,400 & 0,125 \\
\hline Congestionamento & 0,200 & 0,250 \\
\hline Custo de vida & 0,200 & 0,250 \\
\hline Defasagem do planejamento viário & 0,250 & 0,400 \\
\hline Déficit habitacional & 0,250 & 0,200 \\
\hline Distribuição e eficiência da sinalização das vias públicas & 0,300 & 0,333 \\
\hline Distribuição e eficiência do sistema de distribuição elétrica & 0,300 & 0,333 \\
\hline Distribuição e eficiência do sistema público de educação & 0,250 & 0,200 \\
\hline Distribuição e eficiência do sistema público de saúde & 0,200 & 0,500 \\
\hline Distribuição e eficiência do sistema sanitário & 0,250 & 0,200 \\
\hline Distribuição e eficiência dos serviços de comunicação & 0,150 & 0,333 \\
\hline Falta de manutenção das ciclovias & 0,200 & 0,250 \\
\hline Falta de segurança e policiamento & 0,350 & 0,143 \\
\hline Habitações de interesse social & 0,250 & 0,400 \\
\hline Higienização das vias públicas & 0,150 & 0,333 \\
\hline Iluminação & 0,300 & 0,333 \\
\hline Inadequação e defasagem do serviço público de transporte & 0,200 & 0,250 \\
\hline Inundações e alagamentos nas vias públicas & 0,300 & 0,333 \\
\hline Lixo & 0,300 & 0,167 \\
\hline Malhas ferroviárias pouco desenvolvidas & 0,250 & 0,400 \\
\hline Manutenção das vias e espaços públicos & 0,350 & 0,143 \\
\hline Melhor distribuição e organização dos comércios & 0,300 & 0,333 \\
\hline Ocupações irregulares & 0,250 & 0,400 \\
\hline Poluição sonora e atmosférica & 0,300 & 0,167 \\
\hline Pouca diversificação e integração dos modais de transporte & 0,200 & 0,250 \\
\hline Pouca quantidade e distribuição de faixas exclusivas de ônibus & 0,300 & 0,167 \\
\hline Pouco adensamento populacional & 0,500 & 0,200 \\
\hline Terrenos e lotes subutilizados & 0,200 & 0,250 \\
\hline Trabalho informal - "ambulantes" & 0,250 & 0,200 \\
\hline
\end{tabular}

Fonte: O Autor (2019)

Neste caso, notou-se que o pouco adensamento populacional é um problema que possui atuações (ou desdobramentos) mais abrangentes com um índice IAP de 0,500 explicando a hierarquia predominante da alternativa de incentivar o adensamento populacional. Por outro 
lado, surge como um problema também relevante a centralização de oferta de empregos e serviços. Contudo, as ações que atam na correção deste problema- o adensamento populacional, quando avaliadas sob a ótica de abrangência das alternativas, é a $8^{\text {a }}$ colocada em um total de 20 opções. Para complementar a avaliação, é possível analisar a assertividade nos problemas e a colateralidade de ação das alternativas nos problemas, conforme tabela 66.

Tabela 66 - Cálculo do ISP e do IOP para o grupo 1

\begin{tabular}{|c|c|c|}
\hline $\begin{array}{c}\text { Problemas } \\
\end{array}$ & ISP & IOP \\
\hline Centralização da oferta de empregos e serviços & 0,375 & 0,625 \\
\hline Congestionamento & 0,500 & 0,500 \\
\hline Custo de vida & 0,750 & 0,250 \\
\hline Defasagem do planejamento viário & 0,600 & 0,400 \\
\hline Déficit habitacional & 0,400 & 0,600 \\
\hline Distribuição e eficiência da sinalização das vias públicas & 0,667 & 0,333 \\
\hline Distribuição e eficiência do sistema de distribuição elétrica & 0,500 & 0,500 \\
\hline Distribuição e eficiência do sistema público de educação & 0,400 & 0,600 \\
\hline Distribuição e eficiência do sistema público de saúde & 0,750 & 0,250 \\
\hline Distribuição e eficiência do sistema sanitário & 0,400 & 0,600 \\
\hline Distribuição e eficiência dos serviços de comunicação & 0,667 & 0,333 \\
\hline Falta de manutenção das ciclovias & 0,750 & 0,250 \\
\hline Falta de segurança e policiamento & 0,286 & 0,714 \\
\hline Habitações de interesse social & 0,600 & 0,400 \\
\hline Higienização das vias públicas & 0,667 & 0,333 \\
\hline Iluminação & 0,667 & 0,333 \\
\hline Inadequação e defasagem do serviço público de transporte & 0,500 & 0,500 \\
\hline Inundações e alagamentos nas vias públicas & 0,500 & 0,500 \\
\hline Lixo & 0,333 & 0,667 \\
\hline Malhas ferroviárias pouco desenvolvidas & 0,600 & 0,400 \\
\hline Manutenção das vias e espaços públicos & 0,429 & 0,571 \\
\hline Melhor distribuição e organização dos comércios & 0,667 & 0,333 \\
\hline Ocupações irregulares & 0,800 & 0,200 \\
\hline Poluição sonora e atmosférica & 0,500 & 0,500 \\
\hline Pouca diversificação e integração dos modais de transporte & 0,750 & 0,250 \\
\hline Pouca quantidade e distribuição de faixas exclusivas de ônibus & 0,333 & 0,667 \\
\hline Pouco adensamento populacional & 0,400 & 0,600 \\
\hline Terrenos e lotes subutilizados & 0,500 & 0,500 \\
\hline Trabalho informal - "ambulantes" & 0,400 & 0,600 \\
\hline
\end{tabular}

Fonte: O Autor (2019)

Sob este novo prisma de problemas, que até então não figuravam entre os que mais tem atenção das alternativas, começam a ser melhor hierarquizados, tais como as ocupações 
irregulares, dessa forma explicando a hierarquia elevada da alternativa de que incentiva maior ocupação em área abandonadas.

Também é possível analisar os problemas a partir da incompletude das ações atuantes e da abrangência ponderada de ações completas e totais nos problemas, conforme tabela 67.

Tabela 67 - Cálculo do IUP e do IGA-P(p) do grupo 1

\begin{tabular}{|c|c|c|}
\hline 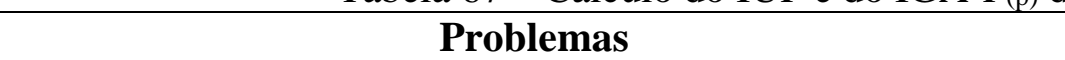 & IUP & IGA-P $_{(p)}$ \\
\hline Centralização da oferta de empregos e serviços & 0,750 & 0,500 \\
\hline Congestionamento & 0,500 & 0,300 \\
\hline Custo de vida & 0,750 & 0,250 \\
\hline Defasagem do planejamento viário & 0,600 & 0,350 \\
\hline Déficit habitacional & 0,600 & 0,350 \\
\hline $\begin{array}{c}\text { Distribuição e eficiência da sinalização } \\
\text { das vias públicas }\end{array}$ & 0,667 & 0,400 \\
\hline $\begin{array}{c}\text { Distribuiçãa e eficiência do sistema } \\
\text { de distribuição elétrica }\end{array}$ & 0,667 & 0,400 \\
\hline $\begin{array}{c}\text { Distribuição e eficiência do sistema público } \\
\text { de educação }\end{array}$ & 0,800 & 0,300 \\
\hline $\begin{array}{l}\text { Distribuiçãa e eficiência do sistema } \\
\text { público de saúde }\end{array}$ & 0,500 & 0,300 \\
\hline Distribuição e eficiência do sistema sanitário & 0,800 & 0,300 \\
\hline $\begin{array}{c}\text { Distribuição e eficiência dos serviços } \\
\text { de comunicação }\end{array}$ & 0,667 & 0,200 \\
\hline Falta de manutenção das ciclovias & 0,750 & 0,250 \\
\hline Falta de segurança e policiamento & 0,714 & 0,450 \\
\hline Habitações de interesse social & 0,400 & 0,400 \\
\hline Higienização das vias públicas & 0,667 & 0,200 \\
\hline Iluminação & 0,667 & 0,400 \\
\hline $\begin{array}{l}\text { Inadequação e defasagem do serviço } \\
\text { público de transporte }\end{array}$ & 0,750 & 0,250 \\
\hline $\begin{array}{c}\text { Inundações e alagamentos nas } \\
\text { vias públicas }\end{array}$ & 0,667 & 0,400 \\
\hline Lixo & 0,667 & 0,400 \\
\hline Malhas ferroviárias pouco desenvolvidas & 0,400 & 0,400 \\
\hline Manutenção das vias e espaços públicos & 0,714 & 0,450 \\
\hline Melhor distribuição e organização dos comércios & 0,667 & 0,400 \\
\hline Ocupações irregulares & 0,600 & 0,350 \\
\hline Poluição sonora e atmosférica & 0,833 & 0,350 \\
\hline Pouca diversificação e integração dos modais de transporte & 0,750 & 0,250 \\
\hline Pouca quantidade e distribuição de faixas exclusivas de ônibus & 0,833 & 0,350 \\
\hline Pouco adensamento populacional & 0,700 & 0,650 \\
\hline Terrenos e lotes subutilizados & 0,500 & 0,300 \\
\hline Trabalho informal - "ambulantes" & 0,800 & 0,300 \\
\hline
\end{tabular}

Fonte: O Autor (2019)

Por fim, os problemas podem ser hierarquizados a partir do Índice Geral de Abrangência dos Problemas Hierárquico, e assim quanto maior o índice maior será a abrangência, e a 
completude do atendimento de um problema, e, portanto, as ações que atuam sobre ele podem ser priorizadas gerando resultados mais efetivos, eficazes e eficientes, simultaneamente, sob a ótica da população, conforme tabela 68

Tabela 68 - Cálculo do IGA-P $($ h) para o grupo 1

\begin{tabular}{|c|c|}
\hline Problemas & IGA-P(h) \\
\hline Pouco adensamento populacional & 0,064 \\
\hline Centralização da oferta de empregos e serviços & 0,049 \\
\hline Falta de segurança e policiamento & 0,044 \\
\hline Manutenção das vias e espaços públicos & 0,044 \\
\hline Distribuição e eficiência da sinalização das vias públicas & 0,039 \\
\hline Distribuição e eficiência do sistema de distribuição elétrica & 0,039 \\
\hline Habitações de interesse social & 0,039 \\
\hline Iluminação & 0,039 \\
\hline Inundações e alagamentos nas vias públicas & 0,039 \\
\hline Lixo & 0,039 \\
\hline Malhas ferroviárias pouco desenvolvidas & 0,039 \\
\hline Melhor distribuição e organização dos comércios & 0,039 \\
\hline Defasagem do planejamento viário & 0,034 \\
\hline Déficit habitacional & 0,034 \\
\hline Ocupações irregulares & 0,034 \\
\hline Poluição sonora e atmosférica & 0,034 \\
\hline Pouca quantidade e distribuição de faixas exclusivas de ônibus & 0,034 \\
\hline Congestionamento & 0,029 \\
\hline Distribuição e eficiência do sistema público de educação & 0,029 \\
\hline Distribuição e eficiência do sistema público de saúde & 0,029 \\
\hline Distribuição e eficiência do sistema sanitário & 0,029 \\
\hline Terrenos e lotes subutilizados & 0,029 \\
\hline Trabalho informal - "ambulantes" & 0,029 \\
\hline Custo de vida & 0,025 \\
\hline Falta de manutenção das ciclovias & 0,025 \\
\hline Inadequação e defasagem do serviço público de transporte & 0,025 \\
\hline Pouca diversificação e integração dos modais de transporte & 0,025 \\
\hline Distribuição e eficiência dos serviços de comunicação & 0,020 \\
\hline Higienização das vias públicas & 0,020 \\
\hline$\Sigma$ & 1 \\
\hline
\end{tabular}

Fonte: O Autor (2019)

Essa avaliação multifacetada aponta que os problemas que tem maior chance de serem atendidos pelas alternativas propostas são o pouco adensamento populacional, centralização da oferta de empregos e a falta de segurança e policiamento.

Também a partir deste painel é possível avaliar com indicadores a riqueza e qualidade do procedimento participativo aplicado a partir de índices, ou aqui denominados "Avaliadores" que qualificam o procedimento, e para o grupo 1 são apresentados na tabela 69 . 
Tabela 69 - Cálculo dos avaliadores do processo para o grupo 1

\begin{tabular}{cccc}
\hline AQC & AAP & AEP & AFP \\
\hline 1,724 & 5,310 & 2,758 & 1,379 \\
\hline
\end{tabular}

Fonte: O Autor (2019)

Estes avaliadores não são comparáveis entre si, mas comparáveis com diferentes dinâmicas participativas aplicadas.

\subsection{Resultados do painel de análise e correlação de alternativas para o Grupo 2}

Aplicação do método e o cálculo dos índices associados as alternativas, somou os atendimento completos e incompletos, diretos e indiretos para cada alternativas proposta no processo, gerando a tabela 70 .

Tabela 70 - Marcações no painel de correlação para o grupo 1

\begin{tabular}{cccccc}
\hline Alternativas & DC & DI & IC & II & $\boldsymbol{\Sigma}$ \\
\hline Incentivar edifícios ou imóveis com usos mistos & 8 & 4 & 6 & 2 & $\mathbf{2 0}$ \\
Ampliação de áreas verdes nos edifícios & 6 & 3 & 8 & 2 & $\mathbf{1 9}$ \\
Integração entre espaços públicos e privados & 4 & 9 & 2 & 11 & $\mathbf{2 6}$ \\
individual & 1 & 5 & 3 & 11 & $\mathbf{2 0}$ \\
Regras para desincentivar as vias para fluidez do transporte & 5 & 5 & 2 & 1 & $\mathbf{1 3}$ \\
Definição de regras para conservação de áreas verdes & 5 & 4 & 2 & 1 & $\mathbf{1 2}$ \\
Favorecer a instalação de edifícios & 2 & 0 & 5 & 3 & $\mathbf{1 0}$ \\
Incentivar usos comerciais e de serviços & 5 & 1 & 1 & 1 & $\mathbf{8}$ \\
Áreas construídas mínimas com sistemas sustentáveis & 0 & 2 & 2 & 1 & $\mathbf{5}$ \\
Definição de regras para iluminação nos edifícios & 1 & 2 & 1 & 1 & $\mathbf{5}$ \\
Definição de regras para sistemas de segurança nos edifícios & 0 & 0 & 2 & 2 & $\mathbf{4}$ \\
Desincentivar a instalação de muros e grades & 0 & 1 & 0 & 3 & $\mathbf{4}$ \\
Controle de emissão de poluentes nas edificações & 1 & 0 & 1 & 0 & $\mathbf{2}$ \\
Incentivar a instalação de muros e grades & 1 & 0 & 0 & 1 & $\mathbf{2}$ \\
Incentivar usos industriais & 0 & 0 & 0 & 3 & $\mathbf{3}$ \\
Regras para favorecer as vias para fluidez do transporte individual & 0 & 0 & 0 & 1 & $\mathbf{1}$ \\
Desincentivar edifícios e imóveis com usos mistos & 0 & 0 & 0 & 1 & $\mathbf{1}$ \\
Desincentivar usos comerciais e de serviços & 0 & 0 & 0 & 1 & $\mathbf{1}$ \\
Desincentivar usos industriais & 0 & 0 & 0 & 1 & $\mathbf{1}$ \\
Redução de áreas verdes nos edifícios & 0 & 0 & 0 & 1 & $\mathbf{1}$ \\
Restringir a instalação de edifícios & $\mathbf{3 9}$ & $\mathbf{3 6}$ & $\mathbf{3 5}$ & $\mathbf{4 8}$ & $\mathbf{1 5 8}$ \\
\hline $\mathbf{\Sigma}$ & & & &
\end{tabular}

Fonte: O Autor (2019) 
A partir destes resultados é possível calcular os índices de avaliação de efetividade, eficácia e abrangência que podem avaliar cada uma das alternativas nas diferentes possibilidades propostas, conforme tabela 71 .

\begin{tabular}{cccc} 
Tabela 71 - IEA $(c)$, IEA $_{(f)}$ e IAA para o grupo 2 & & \\
Alternativas & IEA $_{(c)}$ & IEA $_{(f)}$ & IAA \\
\hline Ampliação de áreas verdes nos edifícios & 0,583 & 0,375 & 0,792 \\
Áreas construídas mínimas com sistemas sustentáveis & 0,250 & 0,250 & 0,333 \\
Controle de emissão de poluentes nas edificações & 0,000 & 0,042 & 0,167 \\
Definição de regras para conservação de áreas verdes & 0,292 & 0,417 & 0,542 \\
Definição de regras para iluminação nos edifícios & 0,083 & 0,083 & 0,208 \\
Definição de regras para sistemas de segurança nos edifícios & 0,083 & 0,125 & 0,208 \\
Desincentivar a instalação de muros e grades & 0,083 & 0,000 & 0,167 \\
Desincentivar edifícios e imóveis com usos mistos & 0,000 & 0,000 & 0,042 \\
Desincentivar usos comerciais e de serviços & 0,000 & 0,000 & 0,042 \\
Desincentivar usos industriais & 0,000 & 0,000 & 0,042 \\
Favorecer a instalação de edifícios & 0,292 & 0,375 & 0,500 \\
Incentivar a instalação de muros e grades & 0,083 & 0,042 & 0,083 \\
Incentivar edifícios ou imóveis com usos mistos & 0,583 & 0,500 & 0,833 \\
Incentivar usos comerciais e de serviços & 0,292 & 0,083 & 0,417 \\
Incentivar usos industriais & 0,042 & 0,042 & 0,083 \\
Integração entre espaços públicos e privados & 0,250 & 0,542 & 1,083 \\
Redução de áreas verdes nos edifícios & 0,000 & 0,000 & 0,042
\end{tabular}
Fonte: O Autor (2019)

Para o caso do grupo 2 o que se nota é que as alternativas mais eficazes são a ampliação de áreas verdes nos edifícios e o incentivo aos usos mistos ambas com um índice de 0,583 e as menos eficazes são o controle de emissão de poluentes nos edifícios e a restrição de instalação de edifícios na região, por exemplo.

Por outro lado, as alternativas mais efetivas são a integração de espaços públicos e privados e o incentivo a usos mistos com um índice de 0,542 e 0,500 respectivamente, contudo as menos efetivas serão novamente a restrição de instalação de edifícios e o favorecimento das vias para o transporte individual.

Também é possível listar a alternativas mais abrangentes, para o grupo 2, que são por exemplo a integração entre espaços públicos e privados, o incentivo a usos mistos, as regras 
para desincentivar as vias para o transporte individual, a ampliação das áreas verdes e o favorecimento de instalação de edifícios, quanto maior a abrangência mais problemas são atacados por esta alternativa.

Também com o resultado desta dinâmica é possível calcular a eficiência das alternativas, a assertividade das alternativas, a colateralidade das alternativas e sua incompletude, com os índices sumarizados na tabela 72 .

Tabela 72 - Cálculo do IEA(e), ISA, ICA e IIA para o grupo 2

\begin{tabular}{|c|c|c|c|c|}
\hline Alternativas & $\operatorname{IEA}(\mathrm{e})$ & ISA & ICA & IIA \\
\hline Ampliação de áreas verdes nos edifícios & 0,316 & 0,474 & 0,526 & 0,263 \\
\hline Áreas construídas mínimas com sistemas sustentáveis & 0,625 & 0,750 & 0,250 & 0,250 \\
\hline Controle de emissão de poluentes nas edificações & 0,000 & 0,250 & 0,750 & 1,000 \\
\hline Definição de regras para conservação de áreas verdes & 0,385 & 0,769 & 0,231 & 0,462 \\
\hline Definição de regras para iluminação nos edifícios & 0,000 & 0,400 & 0,600 & 0,600 \\
\hline $\begin{array}{c}\text { Definição de regras para sistemas de segurança nos } \\
\text { edifícios }\end{array}$ & 0,200 & 0,600 & 0,400 & 0,600 \\
\hline Desincentivar a instalação de muros e grades & 0,000 & 0,000 & 1,000 & 0,500 \\
\hline Desincentivar edifícios e imóveis com usos mistos & 0,000 & 0,000 & 1,000 & 1,000 \\
\hline Desincentivar usos comerciais e de serviços & 0,000 & 0,000 & 1,000 & 1,000 \\
\hline Desincentivar usos industriais & 0,000 & 0,000 & 1,000 & 1,000 \\
\hline Favorecer a instalação de edifícios & 0,417 & 0,750 & 0,250 & 0,417 \\
\hline Incentivar a instalação de muros e grades & 0,500 & 0,500 & 0,500 & 0,000 \\
\hline Incentivar edifícios ou imóveis com usos mistos & 0,400 & 0,600 & 0,400 & 0,300 \\
\hline Incentivar usos comerciais e de serviços & 0,200 & 0,200 & 0,800 & 0,300 \\
\hline Incentivar usos industriais & 0,500 & 0,500 & 0,500 & 0,500 \\
\hline Integração entre espaços públicos e privados & 0,154 & 0,500 & 0,500 & 0,769 \\
\hline Redução de áreas verdes nos edifícios & 0,000 & 0,000 & 1,000 & 1,000 \\
\hline $\begin{array}{c}\text { Regras para desincentivar as vias para fluidez do } \\
\text { transporte individual }\end{array}$ & 0,050 & 0,300 & 0,700 & 0,800 \\
\hline $\begin{array}{c}\text { Regras para favorecer as vias para fluidez do transporte } \\
\text { individual }\end{array}$ & 0,000 & 0,000 & 1,000 & 1,000 \\
\hline Restringir a instalação de edifícios & 0,000 & 0,000 & 1,000 & 1,000 \\
\hline
\end{tabular}

Fonte: O Autor (2019) 
A partir destes índices calculados, para o grupo 2, é possível perceber que as alternativas que são mais eficientes, ou seja, que atuam diretamente e completamente sobre os problemas, seja positiva ou negativamente, são a inserção de áreas construídas mínimas com sistemas sustentáveis, o incentivo a muros e grades, o incentivo aos usos industriais e a o favorecimento de instalação de edifícios, particularmente o incentivo de usos industriais também figurava nesta lista para o grupo 1 .

Com os dados apresentados também é possível calcular o Índice de geral de abrangência das alternativas ponderado, que considera o quão abrangente são as alternativas ao mesmo tempo em que se valoriza o quanto elas são completas, conforme tabela 73.

Tabela 73 - Cálculo IGA-A $(p)$ para o grupo 2

\begin{tabular}{cc}
\hline Alternativas & IGA-A(p) \\
\hline Ampliação de áreas verdes nos edifícios & 1,375 \\
Áreas construídas mínimas com sistemas sustentáveis & 0,583 \\
Controle de emissão de poluentes nas edificações & 0,167 \\
Definição de regras para conservação de áreas verdes & 0,833 \\
Definição de regras para iluminação nos edifícios & 0,292 \\
Definição de regras para sistemas de segurança nos edifícios & 0,292 \\
Desincentivar a instalação de muros e grades & 0,250 \\
Desincentivar edifícios e imóveis com usos mistos & 0,042 \\
Desincentivar usos comerciais e de serviços & 0,042 \\
Desincentivar usos industriais & 0,042 \\
Favorecer a instalação de edifícios & 0,792 \\
Incentivar a instalação de muros e grades & 0,167 \\
Incentivar edifícios ou imóveis com usos mistos & 1,417 \\
Incentivar usos comerciais e de serviços & 0,708 \\
Incentivar usos industriais & 0,125 \\
Integração entre espaços públicos e privados & 1,333 \\
Redução de áreas verdes nos edifícios & 0,042 \\
Regras para desincentivar as vias para fluidez do transporte individual & 1,000 \\
Regras para favorecer as vias para fluidez do transporte individual & 0,125 \\
Restringir a instalação de edifícios & 0,042 \\
\hline
\end{tabular}

Fonte: O Autor (2019)

O que se nota, é que apenas pela abrangência e completude para o grupo 2, as alternativas que podem ser mais interessantes para a região são o incentivo a usos mistos, ampliação das áreas verdes, integração entre espaços públicos e privados, desincentivo ao transporte individual, o favorecimento da instalação de edifícios e o incentivo a usos comerciais e de serviços. Contudo esta hierarquia não é absoluta, uma análise conjunta de todos os índices fornece um panorama mais completo de análise. 
Por fim, é possível estabelece a hierarquização de comparação pareada para construção índice geral de assertividade das alternativas hierarquizado $\left(\operatorname{IGA}^{\left.-\mathrm{A}_{(h)}\right)}\right.$, conforme tabela 74 , em uma escala de 0 a 1.

Tabela 74 - Cálculo do IGA (h) para o grupo 2

\begin{tabular}{cc}
\hline Alternativas & IGA-A(h) \\
\hline Incentivar edifícios ou imóveis com usos mistos & 0,147 \\
Ampliação de áreas verdes nos edifícios & 0,143 \\
Integração entre espaços públicos e privados & 0,139 \\
Regras para desincentivar as vias para fluidez do transporte individual & 0,104 \\
Definição de regras para conservação de áreas verdes & 0,087 \\
Favorecer a instalação de edifícios & 0,082 \\
Incentivar usos comerciais e de serviços & 0,074 \\
Áreas construídas mínimas com sistemas sustentáveis & 0,061 \\
Definição de regras para iluminação nos edifícios & 0,030 \\
Definição de regras para sistemas de segurança nos edifícios & 0,030 \\
Desincentivar a instalação de muros e grades & 0,026 \\
Controle de emissão de poluentes nas edificações & 0,017 \\
Incentivar a instalação de muros e grades & 0,017 \\
Incentivar usos industriais & 0,013 \\
Regras para favorecer as vias para fluidez do transporte individual & 0,013 \\
Desincentivar edifícios e imóveis com usos mistos & 0,004 \\
Desincentivar usos comerciais e de serviços & 0,004 \\
Desincentivar usos industriais & 0,004 \\
Redução de áreas verdes nos edifícios & 0,004 \\
Restringir a instalação de edifícios & 0,004 \\
\hline \multirow{\Sigma}{*}{ F } & $\mathbf{1}$ \\
\hline
\end{tabular}

Fonte: O Autor (2019)

Também a partir do painel de análise e correlação das alternativa é possível avaliar qual o nível de atendimento dos problemas, em função das alternativas propostas. Este resultado é sumarizado sob a ótica dos problemas na tabela 75 .

A partir destes resultados é possível calcular a eficácia e a efetividade de atuação nos problemas propostos, conforme tabela 76.

No caso proposto, e analisado pelo grupo 2, há uma distribuição quase que homogênea de eficácia e de efetividade de ação nos problemas, contudo sob esta avaliação os problemas associados ao transporte público são aqueles que se destacam como os que tem um maior número de ações sobre eles, portanto, verificar a abrangência e a eficiência podem apontar uma hierarquia mais clara, conforme tabela 77. 
Tabela 75 - Marcações no painel de correlações para os problemas no grupo 2

\begin{tabular}{|c|c|c|c|c|}
\hline Problemas & DC & DI & IC & II \\
\hline Divulgação de oportunidades de participação pública & 2 & 1 & 1 & 2 \\
\hline Vandalismo e insuficiência das lixeiras & 1 & 1 & 1 & 2 \\
\hline Iluminação & 1 & 1 & 1 & 1 \\
\hline Áreas verdes & 1 & 1 & 2 & 2 \\
\hline Trânsito e saturação das vias & 3 & 2 & 3 & 1 \\
\hline Tempo de espera do transporte público & 4 & 1 & 2 & 1 \\
\hline Integração do transporte público & 2 & 4 & 3 & 3 \\
\hline Qualidade do transporte público & 2 & 1 & 1 & 3 \\
\hline Pavimentação & 2 & 1 & 1 & 2 \\
\hline Violência e segurança & 1 & 2 & 1 & 5 \\
\hline Planejamento desorganizado das Calçadas & 1 & 3 & 1 & 1 \\
\hline Acessibilidade & 1 & 1 & 2 & 2 \\
\hline Poluição sonora, visual e atmosférica & 2 & 1 & 3 & 1 \\
\hline Deficiência de equipamentos educacionais & 1 & 2 & 1 & 1 \\
\hline Centros comerciais & 3 & 1 & 1 & 4 \\
\hline Geração de lixo & 2 & 1 & 1 & 1 \\
\hline Ciclo faixas mal projetadas & 1 & 2 & 2 & 1 \\
\hline Deficiência de equipamentos de saúde & 1 & 1 & 1 & 1 \\
\hline Crescimento desordenado & 2 & 3 & 1 & 4 \\
\hline Projetos sociais & 2 & 1 & 2 & 1 \\
\hline Percurso longo do transporte público & 1 & 1 & 1 & 2 \\
\hline Deficiência de equipamentos culturais & 1 & 1 & 1 & 2 \\
\hline Deficiência de equipamentos de lazer & 1 & 1 & 1 & 1 \\
\hline Imóveis e terrenos abandonados & 1 & 2 & 1 & 4 \\
\hline
\end{tabular}

Fonte: O Autor (2019).

Neste caso, é reforçada a hierarquia elevada das questões quanto ao transporte público, porém o crescimento desordenado surge como um problema que as alternativas atuam de forma abrangente também. Para complementar a avaliação é possível analisar a assertividade nos problemas e a colateralidade de ação das alternativas nos problemas, conforme tabela 78 
Tabela 76 - Cálculo do $\operatorname{IEP}_{(\mathrm{c})}$ e $\operatorname{IEP}_{(\mathrm{f})}$ para o grupo 1

\begin{tabular}{|c|c|c|}
\hline Problemas & $\mathbf{I E P}_{(\mathbf{c})}$ & $\operatorname{IEP}_{(\mathbf{f})}$ \\
\hline Divulgação de oportunidades de participação pública & 0,150 & 0,150 \\
\hline Vandalismo e insuficiência das lixeiras & 0,100 & 0,100 \\
\hline Iluminação & 0,100 & 0,100 \\
\hline Áreas verdes & 0,150 & 0,100 \\
\hline Trânsito e saturação das vias & 0,300 & 0,250 \\
\hline Tempo de espera do transporte público & 0,300 & 0,250 \\
\hline Integração do transporte público & 0,250 & 0,300 \\
\hline Qualidade do transporte público & 0,150 & 0,150 \\
\hline Pavimentação & 0,150 & 0,150 \\
\hline Violência e segurança & 0,100 & 0,150 \\
\hline Planejamento desorganizado das Calçadas & 0,100 & 0,200 \\
\hline Acessibilidade & 0,150 & 0,100 \\
\hline Poluição sonora, visual e atmosférica & 0,250 & 0,150 \\
\hline Deficiência de equipamentos educacionais & 0,100 & 0,150 \\
\hline Centros comerciais & 0,200 & 0,200 \\
\hline Geração de lixo & 0,150 & 0,150 \\
\hline Ciclo faixas mal projetadas & 0,150 & 0,150 \\
\hline Deficiência de equipamentos de saúde & 0,100 & 0,100 \\
\hline Crescimento desordenado & 0,150 & 0,250 \\
\hline Projetos sociais & 0,200 & 0,150 \\
\hline Percurso longo do transporte público & 0,100 & 0,100 \\
\hline Deficiência de equipamentos culturais & 0,100 & 0,100 \\
\hline Deficiência de equipamentos de lazer & 0,100 & 0,100 \\
\hline Imóveis e terrenos abandonados & 0,100 & 0,150 \\
\hline
\end{tabular}

Fonte: O Autor (2019) 
Tabela 77 - Cálculo do IAP e do $\operatorname{IEP}_{(\mathrm{e})}$ para o grupo 2

\begin{tabular}{|c|c|c|}
\hline Problemas & IAP & $\operatorname{IEP}(\mathbf{e})$ \\
\hline Divulgação de oportunidades de participação pública & 0,300 & 0,333 \\
\hline Vandalismo e insuficiência das lixeiras & 0,250 & 0,200 \\
\hline Iluminação & 0,200 & 0,250 \\
\hline Áreas verdes & 0,300 & 0,167 \\
\hline Trânsito e saturação das vias & 0,450 & 0,333 \\
\hline Tempo de espera do transporte público & 0,400 & 0,500 \\
\hline Integração do transporte público & 0,600 & 0,167 \\
\hline Qualidade do transporte público & 0,350 & 0,286 \\
\hline Pavimentação & 0,300 & 0,333 \\
\hline Violência e segurança & 0,450 & 0,111 \\
\hline Planejamento desorganizado das Calçadas & 0,300 & 0,167 \\
\hline Acessibilidade & 0,300 & 0,167 \\
\hline Poluição sonora, visual e atmosférica & 0,350 & 0,286 \\
\hline Deficiência de equipamentos educacionais & 0,250 & 0,200 \\
\hline Centros comerciais & 0,450 & 0,333 \\
\hline Geração de lixo & 0,250 & 0,400 \\
\hline Ciclo faixas mal projetadas & 0,300 & 0,167 \\
\hline Deficiência de equipamentos de saúde & 0,200 & 0,250 \\
\hline Crescimento desordenado & 0,500 & 0,200 \\
\hline Projetos sociais & 0,300 & 0,333 \\
\hline Percurso longo do transporte público & 0,250 & 0,200 \\
\hline Deficiência de equipamentos culturais & 0,250 & 0,200 \\
\hline Deficiência de equipamentos de lazer & 0,200 & 0,250 \\
\hline Imóveis e terrenos abandonados & 0,400 & 0,125 \\
\hline
\end{tabular}

Fonte: O Autor (2019)

Sob este novo prisma a hierarquização aponta problemas, que até então não figuravam entre os que mais tem atenção das alternativas, começam a ser melhor hierarquizados, tais como a divulgação de oportunidade de participação, a geração de lixo, a deficiência de equipamentos de saúde a acessibilidade, as áreas verdes, entre outros. 
Tabela 78 - Cálculo do ISP e do IOP para o grupo 2

\begin{tabular}{|c|c|c|}
\hline Problemas & ISP & IOP \\
\hline Divulgação de oportunidades de participação pública & 0,500 & 0,500 \\
\hline Vandalismo e insuficiência das lixeiras & 0,400 & 0,600 \\
\hline Iluminação & 0,500 & 0,500 \\
\hline Áreas verdes & 0,333 & 0,667 \\
\hline Trânsito e saturação das vias & 0,556 & 0,444 \\
\hline Tempo de espera do transporte público & 0,625 & 0,375 \\
\hline Integração do transporte público & 0,500 & 0,500 \\
\hline Qualidade do transporte público & 0,429 & 0,571 \\
\hline Pavimentação & 0,500 & 0,500 \\
\hline Violência e segurança & 0,333 & 0,667 \\
\hline Planejamento desorganizado das Calçadas & 0,667 & 0,333 \\
\hline Acessibilidade & 0,333 & 0,667 \\
\hline Poluição sonora, visual e atmosférica & 0,429 & 0,571 \\
\hline Deficiência de equipamentos educacionais & 0,600 & 0,400 \\
\hline Centros comerciais & 0,444 & 0,556 \\
\hline Geração de lixo & 0,600 & 0,400 \\
\hline Ciclo faixas mal projetadas & 0,500 & 0,500 \\
\hline Deficiência de equipamentos de saúde & 0,500 & 0,500 \\
\hline Crescimento desordenado & 0,500 & 0,500 \\
\hline Projetos sociais & 0,500 & 0,500 \\
\hline Percurso longo do transporte público & 0,400 & 0,600 \\
\hline Deficiência de equipamentos culturais & 0,400 & 0,600 \\
\hline Deficiência de equipamentos de lazer & 0,500 & 0,500 \\
\hline Imóveis e terrenos abandonados & 0,375 & 0,625 \\
\hline
\end{tabular}

Fonte: O Autor (2019) 
Também é possível analisar os problemas a partir de incompletude das ações atuantes e da abrangência ponderada de ações completas e totais nos problemas, conforme tabela 79 .

Tabela 79 - Cálculo do IUP e do IGA-P(p) para o grupo 2

\begin{tabular}{|c|c|c|}
\hline Problemas & IUP & IGA-P(p) \\
\hline Divulgação de oportunidades de participação pública & 0,500 & 0,450 \\
\hline Vandalismo e insuficiência das lixeiras & 0,600 & 0,350 \\
\hline Iluminação & 0,500 & 0,300 \\
\hline Áreas verdes & 0,500 & 0,450 \\
\hline Trânsito e saturação das vias & 0,333 & 0,750 \\
\hline Tempo de espera do transporte público & 0,250 & 0,700 \\
\hline Integração do transporte público & 0,583 & 0,850 \\
\hline Qualidade do transporte público & 0,571 & 0,500 \\
\hline Pavimentação & 0,500 & 0,450 \\
\hline Violência e segurança & 0,778 & 0,550 \\
\hline Planejamento desorganizado das Calçadas & 0,667 & 0,400 \\
\hline Acessibilidade & 0,500 & 0,450 \\
\hline Poluição sonora, visual e atmosférica & 0,286 & 0,600 \\
\hline Deficiência de equipamentos educacionais & 0,600 & 0,350 \\
\hline Centros comerciais & 0,556 & 0,650 \\
\hline Geração de lixo & 0,400 & 0,400 \\
\hline Ciclo faixas mal projetadas & 0,500 & 0,450 \\
\hline Deficiência de equipamentos de saúde & 0,500 & 0,300 \\
\hline Crescimento desordenado & 0,700 & 0,650 \\
\hline Projetos sociais & 0,333 & 0,500 \\
\hline Percurso longo do transporte público & 0,600 & 0,350 \\
\hline Deficiência de equipamentos culturais & 0,600 & 0,350 \\
\hline Deficiência de equipamentos de lazer & 0,500 & 0,300 \\
\hline Imóveis e terrenos abandonados & 0,750 & 0,500 \\
\hline
\end{tabular}

Fonte: O Autor (2019)

Por fim, os problemas podem ser hierarquizados a partir do Índice Geral de Assertividade dos Problemas hierárquico, e assim quanto maior o índice maior será a abrangência e a completude do atendimento de um problema, e, portanto, as ações que atuam sobre ele podem ser priorizadas gerando resultados mais efetivos, eficazes e eficientes simultaneamente sob a ótica da população, conforme tabela 80 . 
Tabela 80 - Cálculo do IGA-P $($ h) para o grupo 2

\begin{tabular}{cc}
\hline Problemas & IGA-P(h) \\
\hline Integração do transporte público & 0,073 \\
Trânsito e saturação das vias & 0,065 \\
Tempo de espera do transporte público & 0,060 \\
Centros comerciais & 0,056 \\
Crescimento desordenado & 0,056 \\
Poluição sonora, visual e atmosférica & 0,052 \\
Violência e segurança & 0,047 \\
Qualidade do transporte público & 0,043 \\
Projetos sociais & 0,043 \\
Imóveis e terrenos abandonados & 0,043 \\
Divulgação de oportunidades de participação pública & 0,039 \\
Áreas verdes & 0,039 \\
Pavimentação & 0,039 \\
Acessibilidade & 0,039 \\
Ciclo faixas mal projetadas & 0,039 \\
Geração de lixo & 0,034 \\
Planejamento desorganizado das Calçadas & 0,034 \\
Vandalismo e insuficiência das lixeiras & 0,030 \\
Deficiência de equipamentos educacionais & 0,030 \\
Percurso longo do transporte público & 0,030 \\
Deficiência de equipamentos culturais & 0,030 \\
Iluminação & 0,026 \\
Deficiência de equipamentos de saúde & 0,026 \\
Deficiência de equipamentos de lazer & 0,026 \\
\hline $\mathbf{\Sigma}$ & $\mathbf{1}$ \\
\hline
\end{tabular}

Fonte: O Autor (2019)

Essa avaliação multifacetada aponta que os problemas que tem maior chance de serem atendidos pelas alternativas propostas são a integração do transporte público e a saturação das vias, o tempo de espera do transporte público, a necessidade de centros comerciais e o crescimento desordenado na região.

Também a partir deste painel é possível avaliar com indicadores a riqueza e qualidade do procedimento participativo aplicado a partir de índices, ou aqui denominados "Avaliadores" que qualificam o procedimento, e para o grupo 2 são apresentados na tabela 81 .

Tabela 81 - Avaliadores do processo para o grupo 2

\begin{tabular}{cccc}
\hline AQC & AAP & AEP & AFP \\
\hline 3,083 & 6,583 & 3,125 & 1,625 \\
\hline
\end{tabular}

Fonte: O Autor (2019)

Estes avaliadores não são comparáveis entre si, mas comparáveis com diferentes dinâmicas participativas aplicadas. 


\subsection{Resultados do painel de análise e correlação de alternativas para o Grupo 3}

Aplicação do método e o cálculo dos índices associados as alternativas, somou os atendimento completos e incompletos, diretos e indiretos para cada alternativas proposta no processo, gerando a tabela 82 .

Tabela 82 - Marcações das alternativas no painel de correlação para o grupo 3

\begin{tabular}{|c|c|c|c|c|c|}
\hline Alternativas & DC & DI & IC & II & $\Sigma$ \\
\hline Ampliação de áreas verdes nos edifícios & 2 & 1 & 3 & 3 & 9 \\
\hline Ampliar corredores de Ônibus & 5 & 4 & 4 & 3 & 16 \\
\hline Ampliar e definir regras para estimular construções sustentáveis & 2 & 0 & 2 & 1 & 5 \\
\hline Ampliar e incentivar o transporte publico & 5 & 4 & 2 & 2 & 13 \\
\hline Ampliar espaços públicos para população idosa & 0 & 2 & 0 & 2 & 4 \\
\hline $\begin{array}{l}\text { Definir regras mais duras para atendimento de acessibilidade nas } \\
\text { edificações e espaços públicos }\end{array}$ & 2 & 0 & 2 & 0 & 4 \\
\hline $\begin{array}{l}\text { Definir regras mais restritivas para utilização dos recursos naturais } \\
\text { na construção }\end{array}$ & 1 & 0 & 0 & 4 & 5 \\
\hline Favorecer a instalação de edificações populares & 6 & 4 & 5 & 7 & 22 \\
\hline $\begin{array}{l}\text { Favorecer e incentivar a instalação de equipamentos e edificações } \\
\text { para uso religiosos }\end{array}$ & 1 & 0 & 0 & 1 & 2 \\
\hline $\begin{array}{c}\text { Incentivar a instalação de equipamentos e edificações para serviços } \\
\text { de saúde }\end{array}$ & 2 & 0 & 2 & 1 & 5 \\
\hline Incentivar e favorecer o uso comercial & 9 & 0 & 7 & 5 & 21 \\
\hline $\begin{array}{c}\text { Induzir a construção de edifícios comerciais com áreas de trabalho } \\
\text { colaborativos }\end{array}$ & 8 & 2 & 5 & 3 & 18 \\
\hline $\begin{array}{c}\text { Induzir ou incentivar a construção de equipamentos e edifícios de } \\
\text { uso cultural }\end{array}$ & 2 & 0 & 2 & 0 & 4 \\
\hline $\begin{array}{l}\text { Promover a instalação de espaços para oferecimento de alimentação } \\
\text { de baixo custo }\end{array}$ & 0 & 0 & 1 & 2 & 3 \\
\hline Promover a regularização de imóveis já construídos & 0 & 3 & 0 & 2 & 5 \\
\hline Proporcionar novos canais para participação e ação das pessoas & 5 & 2 & 2 & 5 & 14 \\
\hline Restringir a instalação de muros nas edificações & 0 & 1 & 0 & 3 & 4 \\
\hline Uso compulsório de áreas ociosas para atividades coletivas & 5 & 2 & 3 & 2 & 12 \\
\hline$\Sigma$ & 55 & 25 & 40 & 46 & 166 \\
\hline
\end{tabular}

Fonte: O Autor (2019) 
A partir destes resultados é possível calcular os índices de avaliação de efetividade, eficácia e abrangência que podem avaliar cada uma das alternativas nas diferentes possibilidades propostas, conforme tabela 83.

Tabela 83 - Cálculo do $\operatorname{IEA}_{(c)}, \operatorname{IEA}_{(f)}$ e IAA para o grupo 3

\begin{tabular}{|c|c|c|c|}
\hline Alternativas & $\operatorname{IEA}_{(c)}$ & $\operatorname{IEA}_{(f)}$ & IAA \\
\hline Ampliação de áreas verdes nos edifícios & 0,263 & 0,158 & 0,474 \\
\hline Ampliar corredores de Ônibus & 0,474 & 0,474 & 0,842 \\
\hline Ampliar e definir regras para estimular construções sustentáveis & 0,211 & 0,105 & 0,263 \\
\hline Ampliar e incentivar o transporte publico & 0,368 & 0,474 & 0,684 \\
\hline Ampliar espaços públicos para população idosa & 0,000 & 0,105 & 0,211 \\
\hline $\begin{array}{c}\text { Definir regras mais duras para atendimento de acessibilidade nas } \\
\text { edificações e espaços públicos }\end{array}$ & 0,211 & 0,105 & 0,211 \\
\hline $\begin{array}{l}\text { Definir regras mais restritivas para utilização dos recursos naturais } \\
\text { na construção }\end{array}$ & 0,053 & 0,053 & 0,263 \\
\hline Favorecer a instalação de edificações populares & 0,579 & 0,526 & 1,158 \\
\hline $\begin{array}{l}\text { Favorecer e incentivar a instalação de equipamentos e edificações } \\
\text { para uso religiosos }\end{array}$ & 0,053 & 0,053 & 0,105 \\
\hline $\begin{array}{c}\text { Incentivar a instalação de equipamentos e edificações para serviços } \\
\text { de saúde }\end{array}$ & 0,211 & 0,105 & 0,263 \\
\hline Incentivar e favorecer o uso comercial & 0,842 & 0,474 & 1,105 \\
\hline $\begin{array}{c}\text { Induzir a construção de edifícios comerciais com áreas de trabalho } \\
\text { colaborativos }\end{array}$ & 0,684 & 0,526 & 0,947 \\
\hline $\begin{array}{c}\text { Induzir ou incentivar a construção de equipamentos e edifícios de } \\
\text { uso cultural }\end{array}$ & 0,211 & 0,105 & 0,211 \\
\hline $\begin{array}{l}\text { Promover a instalação de espaços para oferecimento de alimentação } \\
\text { de baixo custo }\end{array}$ & 0,053 & 0,000 & 0,158 \\
\hline Promover a regularização de imóveis já construídos & 0,000 & 0,158 & 0,263 \\
\hline Proporcionar novos canais para participação e ação das pessoas & 0,368 & 0,368 & 0,737 \\
\hline Restringir a instalação de muros nas edificações & 0,000 & 0,053 & 0,211 \\
\hline Uso compulsório de áreas ociosas para atividades coletivas & 0,421 & 0,368 & 0,632 \\
\hline
\end{tabular}

Fonte: O Autor (2019)

Para o caso do grupo 3 as alternativas mais eficazes são o favorecimento de usos comerciais na região, a indução de áreas colaborativas de trabalho nos edifícios comerciais, e o favorecimento as habitações populares, que também estão entre as mais efetivas

Também é possível listar a alternativas mais abrangentes, para o grupo 3, que são por exemplo o favorecimento de usos comerciais, a ampliação dos corredores de ônibus e proporcionar canais de participação e ação das pessoas. 
Também com o resultado desta dinâmica é possível calculas a eficiência das alternativas, a assertividade das alternativas, a colateralidade das alternativas e sua incompletude, com os índices sumarizados na tabela 84

Tabela 84 - Cálculo do IEA $_{(e)}$, ISA, ICA e IIA para o grupo 3

\begin{tabular}{|c|c|c|c|c|}
\hline Alternativas & $\operatorname{IEA}_{(e)}$ & ISA & ICA & IIA \\
\hline Ampliação de áreas verdes nos edifícios & 0,222 & 0,333 & 0,667 & 0,444 \\
\hline Ampliar corredores de Ônibus & 0,313 & 0,563 & 0,438 & 0,438 \\
\hline $\begin{array}{l}\text { Ampliar e definir regras para estimular construções } \\
\text { sustentáveis }\end{array}$ & 0,400 & 0,400 & 0,600 & 0,200 \\
\hline Ampliar e incentivar o transporte publico & 0,385 & 0,692 & 0,308 & 0,462 \\
\hline Ampliar espaços públicos para população idosa & 0,000 & 0,500 & 0,500 & 1,000 \\
\hline $\begin{array}{l}\text { Definir regras mais duras para atendimento de } \\
\text { acessibilidade nas edificações e espaços públicos }\end{array}$ & 0,500 & 0,500 & 0,500 & 0,000 \\
\hline $\begin{array}{c}\text { Definir regras mais restritivas para utilização dos recursos } \\
\text { naturais na construção }\end{array}$ & 0,200 & 0,200 & 0,800 & 0,800 \\
\hline Favorecer a instalação de edificações populares & 0,273 & 0,455 & 0,545 & 0,500 \\
\hline $\begin{array}{c}\text { Favorecer e incentivar a instalação de equipamentos e } \\
\text { edificações para uso religiosos }\end{array}$ & 0,500 & 0,500 & 0,500 & 0,500 \\
\hline $\begin{array}{l}\text { Incentivar a instalação de equipamentos e edificações para } \\
\text { serviços de saúde }\end{array}$ & 0,400 & 0,400 & 0,600 & 0,200 \\
\hline Incentivar e favorecer o uso comercial & 0,429 & 0,429 & 0,571 & 0,238 \\
\hline $\begin{array}{l}\text { Induzir a construção de edifícios comerciais com áreas de } \\
\text { trabalho colaborativos }\end{array}$ & 0,444 & 0,556 & 0,444 & 0,278 \\
\hline $\begin{array}{c}\text { Induzir ou incentivar a construção de equipamentos e } \\
\text { edifícios de uso cultural }\end{array}$ & 0,500 & 0,500 & 0,500 & 0,000 \\
\hline $\begin{array}{c}\text { Promover a instalação de espaços para oferecimento de } \\
\text { alimentação de baixo custo }\end{array}$ & 0,000 & 0,000 & 1,000 & 0,667 \\
\hline Promover a regularização de imóveis já construídos & 0,000 & 0,600 & 0,400 & 1,000 \\
\hline $\begin{array}{l}\text { Proporcionar novos canais para participação e ação das } \\
\text { pessoas }\end{array}$ & 0,357 & 0,500 & 0,500 & 0,500 \\
\hline Restringir a instalação de muros nas edificações & 0,000 & 0,250 & 0,750 & 1,000 \\
\hline $\begin{array}{l}\text { Uso compulsório de áreas ociosas para atividades } \\
\text { coletivas }\end{array}$ & 0,417 & 0,583 & 0,417 & 0,333 \\
\hline
\end{tabular}

Fonte: O Autor (2019)

No grupo 3, as alternativas que são mais eficientes, ou seja, que atuam diretamente e completamente sobre os problemas, seja positiva ou negativamente, são por exemplo o atendimento a acessibilidade na edificações nos espaços públicos. Com os dados apresentados também é possível calcular o Índice de geral de abrangência das alternativas ponderado, que considera o quão abrangente são as alternativas ao mesmo tempo em que se valoriza o quanto elas são completas, conforme tabela 85 . 
Tabela 85 - Cálculo do IGA-A $(p)$ para o grupo 3

\begin{tabular}{|c|c|}
\hline Alternativas & IGA-A $(p)$ \\
\hline Ampliação de áreas verdes nos edifícios & 0,737 \\
\hline Ampliar corredores de Ônibus & 1,316 \\
\hline Ampliar e definir regras para estimular construções sustentáveis & 0,474 \\
\hline Ampliar e incentivar o transporte publico & 1,053 \\
\hline Ampliar espaços públicos para população idosa & 0,211 \\
\hline $\begin{array}{l}\text { Definir regras mais duras para atendimento de acessibilidade nas edificações e } \\
\text { espaços públicos }\end{array}$ & 0,421 \\
\hline $\begin{array}{c}\text { Definir regras mais restritivas para utilização dos recursos naturais na } \\
\text { construção }\end{array}$ & 0,316 \\
\hline Favorecer a instalação de edificações populares & 1,737 \\
\hline $\begin{array}{c}\text { Favorecer e incentivar a instalação de equipamentos e edificações para uso } \\
\text { religiosos }\end{array}$ & 0,158 \\
\hline Incentivar a instalação de equipamentos e edificações para serviços de saúde & 0,474 \\
\hline Incentivar e favorecer o uso comercial & 1,947 \\
\hline $\begin{array}{c}\text { Induzir a construção de edifícios comerciais com áreas de trabalho } \\
\text { colaborativos }\end{array}$ & 1,632 \\
\hline Induzir ou incentivar a construção de equipamentos e edifícios de uso cultural & 0,421 \\
\hline $\begin{array}{c}\text { Promover a instalação de espaços para oferecimento de alimentação de baixo } \\
\text { custo }\end{array}$ & 0,211 \\
\hline Promover a regularização de imóveis já construídos & 0,263 \\
\hline Proporcionar novos canais para participação e ação das pessoas & 1,105 \\
\hline Restringir a instalação de muros nas edificações & 0,211 \\
\hline Uso compulsório de áreas ociosas para atividades coletivas & 1,053 \\
\hline
\end{tabular}

Fonte: O Autor (2019)

Sob a perspectiva da abrangência e da completude para o grupo 3 , as alternativas que podem ser mais interessantes para a região são o incentivo ao uso comercial ( que também já foi apontado no grupo 1 e no grupo 2), a instalação de edificações populares (para o grupo foi apontando o adensamento populacional para a região, portanto, complementarmente ao grupo 1 o grupo 3 aponta que esse adensamento deve ser com habitações populares), induzir a construção de edifícios com áreas de trabalho colaborativas (que complementa a solicitação do grupo quanto ao favorecimento de usos comerciais e de serviço), a ampliação de corredores de ônibus, proporcionar novos canais de participação e ação das pessoas (alternativa que também foi hierarquizada com prioritária para o grupo 1), e a ampliação das áreas verdes. 
Por fim, é possível estabelecer a hierarquização de comparação pareada para construção índice geral de abrangência das alternativas hierarquizado $\left(\operatorname{IGA}-\mathrm{A}_{(h)}\right)$, conforme tabela 86 , em uma escala de 0 a 1.

Tabela 86 - IGA-A $(h)$ para o grupo 3

\begin{tabular}{|c|c|}
\hline Alternativas & IGA-A $(h)$ \\
\hline Incentivar e favorecer o uso comercial & 0,1418 \\
\hline Favorecer a instalação de edificações populares & 0,1264 \\
\hline $\begin{array}{c}\text { Induzir a construção de edifícios comerciais com áreas de trabalho } \\
\text { colaborativos }\end{array}$ & 0,1188 \\
\hline Ampliar corredores de Ônibus & 0,0958 \\
\hline Proporcionar novos canais para participação e ação das pessoas & 0,0805 \\
\hline Ampliar e incentivar o transporte publico & 0,0766 \\
\hline Uso compulsório de áreas ociosas para atividades coletivas & 0,0766 \\
\hline Ampliação de áreas verdes nos edifícios & 0,0536 \\
\hline Ampliar e definir regras para estimular construções sustentáveis & 0,0345 \\
\hline Incentivar a instalação de equipamentos e edificações para serviços de saúde & 0,0345 \\
\hline $\begin{array}{l}\text { Definir regras mais duras para atendimento de acessibilidade nas edificações e } \\
\text { espaços públicos }\end{array}$ & 0,0307 \\
\hline Induzir ou incentivar a construção de equipamentos e edifícios de uso cultural & 0,0307 \\
\hline $\begin{array}{l}\text { Definir regras mais restritivas para utilização dos recursos naturais na } \\
\text { construção }\end{array}$ & 0,0230 \\
\hline Promover a regularização de imóveis já construídos & 0,0192 \\
\hline Ampliar espaços públicos para população idosa & 0,0153 \\
\hline $\begin{array}{c}\text { Promover a instalação de espaços para oferecimento de alimentação de baixo } \\
\text { custo }\end{array}$ & 0,0153 \\
\hline Restringir a instalação de muros nas edificações & 0,0153 \\
\hline $\begin{array}{c}\text { Favorecer e incentivar a instalação de equipamentos e edificações para uso } \\
\text { religiosos }\end{array}$ & 0,0115 \\
\hline$\Sigma$ & 1 \\
\hline
\end{tabular}

Fonte: O Autor (2019) 
Também a partir do painel de análise e correlação das alternativa é possível avaliar qual o nível de atendimento dos problemas, em função das alternativas propostas. Este resultado é sumarizado sob a ótica dos problemas na tabela 87.

Tabela 87 - Marcações nos problemas no painel de correlação para o grupo 3

Problemas

Alagamentos

Apropriação de espaços ociosos

Área verdes

Atendimento à saúde

Ausência de programa de integração social

Centralização industrial

Conflito de interesses imobiliários e sociais

Deficiências na promoção da cultura na cidade

Estimulo a métodos de ensino inovadores

Falta de acessibilidade

Falta de espaços de cultura e lazer

Falta de espaços para humanização, engajamento e democracia

Falta de mobilidade

Falta de senso de comunidade e união para serviços no bairro

Moradores de rua

Ocupações irregulares

Segurança

Zeladoria urbana
DC DI IC II

$\begin{array}{llll}0 & 2 & 4 & 3\end{array}$

$\begin{array}{llll}4 & 1 & 4 & 3\end{array}$

$\begin{array}{llll}5 & 2 & 1 & 5\end{array}$

$\begin{array}{llll}2 & 1 & 3 & 1\end{array}$

$\begin{array}{llll}2 & 1 & 3 & 3\end{array}$

$\begin{array}{llll}2 & 2 & 1 & 2\end{array}$

$\begin{array}{llll}4 & 1 & 1 & 4\end{array}$

$\begin{array}{llll}1 & 1 & 1 & 2\end{array}$

$\begin{array}{llll}1 & 1 & 2 & 5\end{array}$

$\begin{array}{llll}3 & 1 & 5 & 1\end{array}$

$\begin{array}{llll}4 & 1 & 3 & 1\end{array}$

$\begin{array}{llll}3 & 1 & 1 & 2\end{array}$

$\begin{array}{llll}5 & 2 & 1 & 4\end{array}$

$\begin{array}{llll}2 & 1 & 2 & 1\end{array}$

$\begin{array}{llll}5 & 1 & 1 & 2\end{array}$

$\begin{array}{llll}5 & 2 & 2 & 2\end{array}$

$\begin{array}{llll}4 & 2 & 3 & 2\end{array}$

$\begin{array}{llll}4 & 2 & 2 & 4\end{array}$

Fonte: O Autor (2019)

A partir destes resultados é possível calcular a eficácia e a efetividade de atuação nos problemas propostos, conforme tabela 88 . 
Tabela 88 - Cálculo do $\operatorname{IEP}_{(c)}$ e IEP $(f)$ para o grupo 3

\begin{tabular}{|c|c|c|}
\hline Problemas & $\mathbf{I E P}_{(c)}$ & $\mathbf{I E P}_{(f)}$ \\
\hline Alagamentos & 0,222 & 0,111 \\
\hline Apropriação de espaços ociosos & 0,444 & 0,278 \\
\hline Área verdes & 0,333 & 0,389 \\
\hline Atendimento à saúde & 0,278 & 0,167 \\
\hline Ausência de programa de integração social & 0,278 & 0,167 \\
\hline Centralização industrial & 0,167 & 0,222 \\
\hline Conflito de interesses imobiliários e sociais & 0,278 & 0,278 \\
\hline Deficiências na promoção da cultura na cidade & 0,111 & 0,111 \\
\hline Estimulo a métodos de ensino inovadores & 0,167 & 0,111 \\
\hline Falta de acessibilidade & 0,444 & 0,222 \\
\hline Falta de espaços de cultura e lazer & 0,389 & 0,278 \\
\hline Falta de espaços para humanização, engajamento e democracia & 0,222 & 0,222 \\
\hline Falta de mobilidade & 0,333 & 0,389 \\
\hline Falta de senso de comunidade e união para serviços no bairro & 0,222 & 0,167 \\
\hline Moradores de rua & 0,333 & 0,333 \\
\hline Ocupações irregulares & 0,389 & 0,389 \\
\hline Segurança & 0,389 & 0,333 \\
\hline Zeladoria urbana & 0,333 & 0,333 \\
\hline
\end{tabular}

\section{Fonte: O Autor (2019)}

No caso proposto, e analisado pelo grupo 3, não há uma distribuição homogênea de eficácia e de efetividade de ação nos problemas, sob esta avaliação os problemas associados a apropriação de espaços ócios, acessibilidade, segurança, ocupações irregulares e falta de espaços de cultura e lazer são aqueles que se destacam como os que tem um maior número de ações sobre eles. Também é possível avaliar a abrangência e a eficiência das ações sobre os problema e apontar uma hierarquia mais clara, conforme tabela 89. 
Tabela 89 - Cálculo do IAP e $\operatorname{IEP}_{(e)}$ para o grupo 3

\begin{tabular}{ccc}
\hline Problemas & IAP & IEP(e) \\
\hline Alagamentos & 0,500 & 0,000 \\
Apropriação de espaços ociosos & 0,667 & 0,333 \\
Área verdes & 0,722 & 0,385 \\
Atendimento à saúde & 0,389 & 0,286 \\
Ausência de programa de integração social & 0,500 & 0,222 \\
Centralização industrial & 0,389 & 0,286 \\
Conflito de interesses imobiliários e sociais & 0,556 & 0,400 \\
Deficiências na promoção da cultura na cidade & 0,278 & 0,200 \\
Estimulo a métodos de ensino inovadores & 0,500 & 0,111 \\
Falta de acessibilidade & 0,556 & 0,300 \\
Falta de espaços de cultura e lazer & 0,500 & 0,444 \\
Falta de espaços para humanização, engajamento e democracia & 0,389 & 0,429 \\
Falta de mobilidade & 0,667 & 0,417 \\
Falta de senso de comunidade e união para serviços no bairro & 0,333 & 0,333 \\
Moradores de rua & 0,500 & 0,556 \\
Ocupações irregulares & 0,611 & 0,455 \\
Segurança & 0,611 & 0,364 \\
Zeladoria urbana & 0,667 & 0,333 \\
\hline
\end{tabular}

Fonte: O Autor (2019)

Neste caso, novos problemas possuem uma hierarquia elevada, tais como a zeladoria urbana, as áreas verdes, a falta de mobilidade e os alagamentos, são problemas que as alternativas atuam de forma mais abrangente. Para complementar a avaliação é possível analisar a assertividade nos problemas e a colateralidade de ação das alternativas nos problemas, conforme tabela 90 .

Sob esta perspectiva de hierarquização para o grupo 3 a centralização industrial ganha destaque e, também, a falta de espaço de cultura e lazer, a ausência de programas de integração social e os moradores de rua que até então não figuravam entre os que mais tem atenção das alternativas. Isto reforça que a hierarquização é algo relativo, que diferentes formas de abordagem de um problema, ou de uma alternativa, podem hierarquiza-los de forma distinta. $\mathrm{O}$ que se deve ter em mente, é que a forma de hierarquizar deve ser adequada aos resultados esperados das ações nos problemas. 
Tabela 90 - Cálculo do ISP e do IOP para o grupo 3

\begin{tabular}{ccc}
\hline Problemas & ISP & IOP \\
\hline Alagamentos & 0,222 & 0,778 \\
Apropriação de espaços ociosos & 0,417 & 0,583 \\
Área verdes & 0,538 & 0,462 \\
Atendimento à saúde & 0,429 & 0,571 \\
Ausência de programa de integração social & 0,333 & 0,667 \\
Centralização industrial & 0,571 & 0,429 \\
Conflito de interesses imobiliários e sociais & 0,500 & 0,500 \\
Deficiências na promoção da cultura na cidade & 0,400 & 0,600 \\
Estimulo a métodos de ensino inovadores & 0,222 & 0,778 \\
Falta de acessibilidade & 0,400 & 0,600 \\
Falta de espaços de cultura e lazer & 0,556 & 0,444 \\
Falta de espaços para humanização, engajamento e democracia & 0,571 & 0,429 \\
Falta de mobilidade & 0,583 & 0,417 \\
Falta de senso de comunidade e união para serviços no bairro & 0,500 & 0,500 \\
Moradores de rua & 0,667 & 0,333 \\
Ocupações irregulares & 0,636 & 0,364 \\
Segurança & 0,545 & 0,455 \\
Zeladoria urbana & 0,500 & 0,500 \\
\hline
\end{tabular}

Fonte: O Autor (2019)

Também é possível analisar os problemas a partir de incompletude das ações atuantes e da abrangência ponderada de ações completas e totais nos problemas, conforme tabela 91.

Tabela 91 - Cálculo do IUP e do IGA-P $(p)$ para o grupo 3

\begin{tabular}{ccc}
\hline Problemas & IUP & IGA-P $(p)$ \\
\hline Alagamentos & 0,556 & 0,722 \\
Apropriação de espaços ociosos & 0,333 & 1,111 \\
Área verdes & 0,538 & 1,056 \\
Atendimento à saúde & 0,286 & 0,667 \\
Ausência de programa de integração social & 0,444 & 0,778 \\
Centralização industrial & 0,571 & 0,556 \\
Conflito de interesses imobiliários e sociais & 0,500 & 0,833 \\
Deficiências na promoção da cultura na cidade & 0,600 & 0,389 \\
Estimulo a métodos de ensino inovadores & 0,667 & 0,667 \\
Falta de acessibilidade & 0,200 & 1,000 \\
Falta de espaços de cultura e lazer & 0,222 & 0,889 \\
Falta de espaços para humanização, engajamento e democracia & 0,429 & 0,611 \\
Falta de mobilidade & 0,500 & 1,000 \\
Falta de senso de comunidade e união para serviços no bairro & 0,333 & 0,556 \\
Moradores de rua & 0,333 & 0,833 \\
Ocupações irregulares & 0,364 & 1,000 \\
Segurança & 0,364 & 1,000 \\
Zeladoria urbana & 0,500 & 1,000 \\
\hline
\end{tabular}

Fonte: O Autor (2019)

Por fim, os problemas podem ser hierarquizados a partir do Índice Geral de Assertividade dos Problemas hierárquico, e assim quanto maior o índice maior será a abrangência e a 
completude do atendimento de um problema, e, portanto, as ações que atuam sobre ele podem ser priorizadas gerando resultados mais efetivos, eficazes e eficientes simultaneamente sob a ótica da população, conforme tabela 92.

Tabela 92 - Cálculo do IGA-P $(h)$ para o grupo 3

\begin{tabular}{cc}
\hline Problemas & IGA-P $(\boldsymbol{h})$ \\
\hline Apropriação de espaços ociosos & 0,0758 \\
Área verdes & 0,0720 \\
Falta de acessibilidade & 0,0682 \\
Falta de mobilidade & 0,0682 \\
Ocupações irregulares & 0,0682 \\
Segurança & 0,0682 \\
Zeladoria urbana & 0,0682 \\
Falta de espaços de cultura e lazer & 0,0606 \\
Conflito de interesses imobiliários e sociais & 0,0568 \\
Moradores de rua & 0,0568 \\
Ausência de programa de integração social & 0,0530 \\
Alagamentos & 0,0492 \\
Atendimento à saúde & 0,0455 \\
Estimulo a métodos de ensino inovadores & 0,0455 \\
Centralização industrial & 0,0417 \\
Falta de espaços para humanizão, engajamento e democracia & 0,0379 \\
Deficiências na promoção da cultura na cidade & 0,0379 \\
$\boldsymbol{\Sigma}$ & 0,0265 \\
\hline
\end{tabular}

Fonte: O Autor (2019)

Essa avaliação multifacetada aponta que os problemas que tem maior chance de serem atendidos pelas alternativas propostas são a apropriação de espaços ociosos, as áreas verdes e a falta de acessibilidade

Também a partir deste painel é possível avaliar com indicadores a riqueza e qualidade do procedimento participativo aplicado a partir de índices, ou aqui denominados "Avaliadores" que qualificam o procedimento, e para o grupo 3 são apresentados na tabela 93.

Tabela 93 - Avaliadores do processo para o grupo 3

\begin{tabular}{cccc}
\hline AQC & AAP & AEP & AFP \\
\hline 5,000 & 8,737 & 2,895 & 2,895 \\
\hline
\end{tabular}

Fonte: O Autor (2019)

Estes avaliadores não são comparáveis entre si, mas comparáveis com diferentes dinâmicas participativas aplicadas. 


\subsection{Resultados do painel de análise e correlação de alternativas para o Grupo 4}

Aplicação do método e o cálculo dos índices associados as alternativas, somou os atendimento completos e incompletos, diretos e indiretos para cada alternativas proposta no processo, gerando a tabela 94.

Tabela 94 - Marcações nas alternativas no painel de correlação para o grupo 4

\begin{tabular}{cccccc}
\hline Alternativas & DC & DI & IC & II & $\boldsymbol{\Sigma}$ \\
\hline Ampliação da ocupação do Solo & 5 & 2 & 8 & 6 & $\mathbf{2 1}$ \\
Ampliação de áreas verdes nos edifícios & 2 & 0 & 2 & 3 & $\mathbf{7}$ \\
Ampliar as áreas construídas nas edificaçães & 5 & 6 & 4 & 10 & $\mathbf{2 5}$ \\
Desincentivo à instalação de residências & 1 & 2 & 3 & 4 & $\mathbf{1 0}$ \\
Estimular a ocupação de áreas abandonadas & 6 & 0 & 9 & 0 & $\mathbf{1 5}$ \\
Favorecer o uso de Bicicletas & 1 & 0 & 0 & 7 & $\mathbf{8}$ \\
Favorecer o uso do transporte publico & 5 & 2 & 7 & 9 & $\mathbf{2 3}$ \\
Favorecer usos comerciais e de serviços na Região & 6 & 9 & 6 & 9 & $\mathbf{3 0}$ \\
Incentivar a captação energéticas nos Edifícios & 2 & 0 & 5 & 1 & $\mathbf{8}$ \\
Incentivar usos industriais na Região & 1 & 0 & 0 & 4 & $\mathbf{5}$ \\
Incentivar usos Mistos na região & 5 & 2 & 4 & 5 & $\mathbf{1 6}$ \\
Incentivo a ampliação da largura das calçadas & 1 & 3 & 0 & 2 & $\mathbf{6}$ \\
Incentivo à instalação de residências & 2 & 0 & 0 & 4 & $\mathbf{6}$ \\
Integrar área dos edifícios a área publica & 3 & 5 & 6 & 4 & $\mathbf{1 8}$ \\
Redução da Ocupação do Solo & 0 & 0 & 0 & 2 & $\mathbf{2}$ \\
Redução de áreas verdes nos edifícios & 0 & 0 & 0 & 1 & $\mathbf{1}$ \\
Regras para desincentivar o transporte individual & 3 & 2 & 2 & 2 & $\mathbf{9}$ \\
Restringir a instalação de edifícios altos & 1 & 0 & 0 & 1 & $\mathbf{2}$ \\
\hline $\boldsymbol{\Sigma}$ & $\mathbf{4 9}$ & $\mathbf{3 3}$ & $\mathbf{5 6}$ & $\mathbf{7 4}$ & $\mathbf{2 1 2}$ \\
\hline
\end{tabular}

Fonte: O Autor (2019)

A partir destes resultados é possível calcular os índices de avaliação de efetividade, eficácia e abrangência que podem avaliar cada uma das alternativas nas diferentes possibilidades propostas, conforme tabela 95.

No grupo 4 as alternativas mais eficazes são o estimulo à ocupação de áreas abandonadas e a ampliação da ocupação do solo, que também estão entre as mais efetivas juntamente com a ampliação das áreas construídas nas edificações e o favorecimento, mais uma vez como nos grupos anteriores, aos usos comerciais. Também é possível listar a alternativas mais abrangentes, tal como no grupo 3 o favorecimento ao transporte público. 
Tabela 95 - Cálculo do $\operatorname{IEA}_{(c)}, \operatorname{IEA}_{(f)}$ e IAA para o grupo 4

\begin{tabular}{cccc}
\hline Alternativas & IEA $_{(c)}$ & IEA $_{(f)}$ & IAA \\
\hline Ampliação da ocupação do Solo & 0,619 & 0,333 & 1,000 \\
Ampliação de áreas verdes nos edifícios & 0,190 & 0,095 & 0,333 \\
Ampliar as áreas construídas nas edificações & 0,429 & 0,524 & 1,190 \\
Desincentivo à instalação de residências & 0,190 & 0,143 & 0,476 \\
Estimular a ocupação de áreas abandonadas & 0,714 & 0,286 & 0,714 \\
Favorecer o uso de Bicicletas & 0,048 & 0,048 & 0,381 \\
Favorecer o uso do transporte publico & 0,571 & 0,333 & 1,095 \\
Favorecer usos comerciais e de serviços na Região & 0,571 & 0,714 & 1,429 \\
Incentivar a captação energéticas nos Edifícios & 0,333 & 0,095 & 0,381 \\
Incentivar usos industriais na Região & 0,048 & 0,048 & 0,238 \\
Incentivar usos Mistos na região & 0,429 & 0,333 & 0,762 \\
Incentivo a ampliação da largura das calçadas & 0,048 & 0,190 & 0,286 \\
Incentivo à instalação de residências & 0,095 & 0,095 & 0,286 \\
Integrar área dos edifícios a área publica & 0,429 & 0,381 & 0,857 \\
Redução da Ocupação do Solo & 0,000 & 0,000 & 0,095 \\
Redução de áreas verdes nos edifícios & 0,000 & 0,000 & 0,048 \\
Regras para desincentivar o transporte individual & 0,238 & 0,238 & 0,429 \\
Restringir a instalação de edifícios altos & 0,048 & 0,048 & 0,095 \\
\hline
\end{tabular}

Fonte: O Autor (2019)

Também com o resultado desta dinâmica é possível calculas a eficiência das alternativas, a assertividade das alternativas, a colateralidade das alternativas e sua incompletude, com os índices sumarizados na tabela 96.

Tabela 96 - Cálculo do IEA $_{(e)}$, ISA, ICA e IIA para o grupo 4

\begin{tabular}{ccccc}
\hline Alternativas & IEA(e) & ISA & ICA & IIA \\
\hline Ampliação da ocupação do Solo & 0,238 & 0,333 & 0,667 & 0,381 \\
Ampliação de áreas verdes nos edifícios & 0,286 & 0,286 & 0,714 & 0,429 \\
Ampliar as áreas construídas nas edificações & 0,200 & 0,440 & 0,560 & 0,640 \\
Desincentivo à instalação de residências & 0,100 & 0,300 & 0,700 & 0,600 \\
Estimular a ocupação de áreas abandonadas & 0,400 & 0,400 & 0,600 & 0,000 \\
Favorecer o uso de Bicicletas & 0,125 & 0,125 & 0,875 & 0,875 \\
Favorecer o uso do transporte publico & 0,217 & 0,304 & 0,696 & 0,478 \\
Favorecer usos comerciais e de serviços na Região & 0,200 & 0,500 & 0,500 & 0,600 \\
Incentivar a captação energéticas nos Edifícios & 0,250 & 0,250 & 0,750 & 0,125 \\
Incentivar usos industriais na Região & 0,200 & 0,200 & 0,800 & 0,800 \\
Incentivar usos Mistos na região & 0,313 & 0,438 & 0,563 & 0,438 \\
Incentivo a ampliação da largura das calçadas & 0,167 & 0,667 & 0,333 & 0,833 \\
Incentivo à instalação de residências & 0,333 & 0,333 & 0,667 & 0,667 \\
Integrar área dos edifícios a área publica & 0,167 & 0,444 & 0,556 & 0,500 \\
Redução da Ocupação do Solo & 0,000 & 0,000 & 1,000 & 1,000 \\
Redução de áreas verdes nos edifícios & 0,000 & 0,000 & 1,000 & 1,000 \\
Regras para desincentivar o transporte individual & 0,333 & 0,556 & 0,444 & 0,444 \\
Restringir a instalação de edifícios altos & 0,500 & 0,500 & 0,500 & 0,500 \\
\hline
\end{tabular}


No grupo 4, as alternativas que são mais eficientes, ou seja, que atuam diretamente e completamente sobre os problemas, seja positiva ou negativamente, são o incentivo aos usos mistos na região e, mais uma vez como no outros grupos, o incentivo a instalação de residências e um forte estimulo a ocupação de áreas abandonadas. Esse padrão de alternativas vem se repetindo nos grupos realizados em datas distintas, mas com a população local. Dessa forma esta repetição de alternativas privilegiadas demonstra a capacidade de replicabilidade da metodologia para hierarquizar ações e alternativas no âmbito do planejamento urbano.

Também é interessante que alternativas disruptivas tais como o incentivo a captação enérgica nos edifícios por exemplo são hierarquizadas positivamente pela população.

Com os dados apresentados também é possível calcular o Índice de geral de abrangência das alternativas ponderado, que considera o quão abrangente são as alternativas ao mesmo tempo em que se valoriza o quanto elas são completas, conforme tabela 97.

Tabela 97 - Cálculo do IGA-A $(p)$ para o grupo 4

\begin{tabular}{cc}
\hline Alternativas & IGA-A $(\boldsymbol{p})$ \\
\hline Ampliação da ocupação do Solo & 1,619 \\
Ampliação de áreas verdes nos edifícios & 0,579 \\
Ampliar as áreas construídas nas edificações & 1,789 \\
Desincentivo à instalação de residências & 0,737 \\
Estimular a ocupação de áreas abandonadas & 1,579 \\
Favorecer o uso de Bicicletas & 0,474 \\
Favorecer o uso do transporte publico & 1,842 \\
Favorecer usos comerciais e de serviços na Região & 2,211 \\
Incentivar a captação energéticas nos Edifícios & 0,789 \\
Incentivar usos industriais na Região & 0,316 \\
Incentivar usos Mistos na região & 1,316 \\
Incentivo a ampliação da largura das calçadas & 0,368 \\
Incentivo à instalação de residências & 0,421 \\
Integrar área dos edifícios a área publica & 1,421 \\
Redução da Ocupação do Solo & 0,105 \\
Redução de áreas verdes nos edifícios & 0,053 \\
Regras para desincentivar o transporte individual & 0,737 \\
Restringir a instalação de edifícios altos & 0,158 \\
\hline
\end{tabular}

Fonte: O Autor (2019) 
Também chama atenção o posicionamento como umas das 8 principais alternativas o incentivo a captação energética nos edifícios, o que para uma população, formalmente leiga no assunto, é um percepção relevante. Por fim, é possível estabelecer a hierarquização de comparação pareada para construção índice geral de abrangência das alternativas hierarquizado $\left(\operatorname{IGA}_{-} \mathrm{A}_{(h)}\right)$, conforme tabela 98 , em uma escala de 0 a 1.

Tabela 98 - Cálculo do IGA-A $(h)$

\begin{tabular}{cc}
\hline Alternativas & IGA-A $(\boldsymbol{h})^{\text {Favorecer usos comerciais e de serviços na Região }}$ \\
Favorecer o uso do transporte publico & 0,1339 \\
Ampliar as áreas construídas nas edificações & 0,1115 \\
Ampliação da ocupação do Solo & 0,1084 \\
Estimular a ocupação de áreas abandonadas & 0,0980 \\
Integrar área dos edifícios a área publica & 0,0956 \\
Incentivar usos Mistos na região & 0,0861 \\
Incentivar a captação energéticas nos Edifícios & 0,0797 \\
Desincentivo à instalação de residências & 0,0478 \\
Regras para desincentivar o transporte individual & 0,0446 \\
Ampliação de áreas verdes nos edifícios & 0,0446 \\
Favorecer o uso de Bicicletas & 0,0351 \\
Incentivo à instalação de residências & 0,0287 \\
Incentivo a ampliação da largura das calçadas & 0,0255 \\
Incentivar usos industriais na Região & 0,0223 \\
Restringir a instalação de edifícios altos & 0,0191 \\
Redução da Ocupação do Solo & 0,0096 \\
Redução de áreas verdes nos edifícios & 0,0064 \\
\hline & 0,0032 \\
\hline
\end{tabular}

Fonte: O Autor (2019)

Portanto, ao avaliar a abrangência e a completude da ações para o grupo 4, as alternativas que podem ser mais interessantes para a região são novamente o favorecimento de usos comerciais e de serviço para a região, o favorecimento do transporte público, a ampliação nas áreas construídas nas edificações (cuja leitura leva a crer um incentivo ao coeficiente de aproveitamento maior), a ampliação na ocupação do solo (cuja leitura leva a crer um incentivo na ampliação das taxas de ocupação), um estimulo a ocupação das áreas abandonadas ( o que se novamente se repete como nos grupos anteriores), a integração das áreas públicas nos 
edifícios, e novamente como apontado em todos os grupos anteriores o favorecimento dos usos mistos nas edificações.

Também a partir do painel de análise e correlação das alternativa é possível avaliar qual o nível de atendimento dos problemas, em função das alternativas propostas. Este resultado é sumarizado sob a ótica dos problemas na tabela 99.

Tabela 99 - Marcações para os problemas no painel de correlação para o grupo 4

\begin{tabular}{|c|c|c|c|c|}
\hline Problemas & DC & DI & IC & II \\
\hline Áreas verdes insuficientes e mal distribuídas & 4 & 1 & 3 & 3 \\
\hline Ausência de oferta de empregos & 3 & 5 & 1 & 4 \\
\hline Baixa Qualidade do transporte público & 5 & 2 & 3 & 5 \\
\hline Ciclo faixas mal projetadas & 2 & 2 & 1 & 2 \\
\hline Crescimento desordenado & 2 & 3 & 1 & 6 \\
\hline Deficiência de equipamentos de saúde & 1 & 2 & 3 & 5 \\
\hline Falta de estabelecimentos de ensino & 1 & 1 & 2 & 2 \\
\hline Falta equipamentos culturais & 1 & 1 & 1 & 4 \\
\hline Falta iluminação & 2 & 1 & 6 & 2 \\
\hline Faltam opções de lazer & 1 & 1 & 4 & 2 \\
\hline Faltam opções de transporte público & 2 & 1 & 4 & 2 \\
\hline Geração de lixo & 3 & 1 & 5 & 3 \\
\hline Grandes áreas abandonadas & 3 & 2 & 1 & 5 \\
\hline Integração do transporte público & 3 & 1 & 2 & 4 \\
\hline Não existem centros comerciais & 5 & 1 & 4 & 5 \\
\hline Pavimentação precária & 1 & 1 & 2 & 2 \\
\hline Percurso longo do transporte público & 2 & 1 & 3 & 2 \\
\hline Planejamento das Calçadas & 2 & 1 & 5 & 5 \\
\hline Poluição sonora, visual e atmosférica & 2 & 1 & 2 & 2 \\
\hline Trânsito e saturação das vias & 2 & 2 & 1 & 3 \\
\hline Violência e segurança & 2 & 2 & 2 & 6 \\
\hline
\end{tabular}
Fonte: O Autor (2019)

A partir destes resultados é possível calcular a eficácia e a efetividade de atuação nos problemas propostos, conforme tabela 100. 
Tabela 100 - Cálculo do $\operatorname{IEP}_{(c)}$ e $\operatorname{IEP}_{(f)}$ para o grupo 4

\begin{tabular}{|c|c|c|}
\hline Problemas & $\operatorname{IEP}_{(c)}$ & $\operatorname{IEP}_{(f)}$ \\
\hline Áreas verdes insuficientes e mal distribuídas & 0,389 & 0,278 \\
\hline Ausência de oferta de empregos & 0,222 & 0,444 \\
\hline Baixa Qualidade do transporte público & 0,444 & 0,389 \\
\hline Ciclo faixas mal projetadas & 0,167 & 0,222 \\
\hline Crescimento desordenado & 0,167 & 0,278 \\
\hline Deficiência de equipamentos de saúde & 0,222 & 0,167 \\
\hline Falta de estabelecimentos de ensino & 0,167 & 0,111 \\
\hline Falta equipamentos culturais & 0,111 & 0,111 \\
\hline Falta iluminação & 0,444 & 0,167 \\
\hline Faltam opções de lazer & 0,278 & 0,111 \\
\hline Faltam opções de transporte público & 0,333 & 0,167 \\
\hline Geração de lixo & 0,444 & 0,222 \\
\hline Grandes áreas abandonadas & 0,222 & 0,278 \\
\hline Integração do transporte público & 0,278 & 0,222 \\
\hline Não existem centros comerciais & 0,500 & 0,333 \\
\hline Pavimentação precária & 0,167 & 0,111 \\
\hline Percurso longo do transporte público & 0,278 & 0,167 \\
\hline Planejamento das Calçadas & 0,389 & 0,167 \\
\hline Poluição sonora, visual e atmosférica & 0,222 & 0,167 \\
\hline Trânsito e saturação das vias & 0,167 & 0,222 \\
\hline Violência e segurança & 0,222 & 0,222 \\
\hline
\end{tabular}

Fonte: O Autor (2019)

A análise do grupo 4 quando avaliadas a eficácia e a efetividade de ação nos problemas a distribuição das áreas verdes, o planejamento das calçadas, a geração de lixo, a falta de iluminação e a inexistência de centros comerciais são aqueles que se destacam como os que tem um maior número de ações sobre eles. Também é possível avaliar a abrangência e a eficiência das ações sobre os problema e apontar uma hierarquia mais clara, conforme tabela 101. 
Tabela 101 - Cálculo do IAP e do $\operatorname{IEP}_{(e)}$ para o grupo 4

\begin{tabular}{|c|c|c|}
\hline Problemas & IAP & $\operatorname{IEP}_{(e)}$ \\
\hline Áreas verdes insuficientes e mal distribuídas & 0,611 & 0,364 \\
\hline Ausência de oferta de empregos & 0,722 & 0,231 \\
\hline Baixa Qualidade do transporte público & 0,833 & 0,333 \\
\hline Ciclo faixas mal projetadas & 0,389 & 0,286 \\
\hline Crescimento desordenado & 0,667 & 0,167 \\
\hline Deficiência de equipamentos de saúde & 0,611 & 0,091 \\
\hline Falta de estabelecimentos de ensino & 0,333 & 0,167 \\
\hline Falta equipamentos culturais & 0,389 & 0,143 \\
\hline Falta iluminação & 0,611 & 0,182 \\
\hline Faltam opções de lazer & 0,444 & 0,125 \\
\hline Faltam opções de transporte público & 0,500 & 0,222 \\
\hline Geração de lixo & 0,667 & 0,250 \\
\hline Grandes áreas abandonadas & 0,611 & 0,273 \\
\hline Integração do transporte público & 0,556 & 0,300 \\
\hline Não existem centros comerciais & 0,833 & 0,333 \\
\hline Pavimentação precária & 0,333 & 0,167 \\
\hline Percurso longo do transporte público & 0,444 & 0,250 \\
\hline Planejamento das Calçadas & 0,722 & 0,154 \\
\hline Poluição sonora, visual e atmosférica & 0,389 & 0,286 \\
\hline Trânsito e saturação das vias & 0,444 & 0,250 \\
\hline Violência e segurança & 0,667 & 0,167 \\
\hline
\end{tabular}

Fonte: O Autor (2019)

Neste caso, novos problemas possuem uma hierarquia elevada, tais como a baixa qualidade do transporte público, a ausência de oferta de empregos e o crescimento desordenado, que representam problemas que as alternativas atuam de forma mais abrangente. Para complementar a avaliação é possível analisar a assertividade nos problemas e a colateralidade de ação das alternativas nos problemas, conforme tabela 102. 
Tabela 102 - Cálculo do ISP e do IOP para o grupo 4

\begin{tabular}{|c|c|c|}
\hline Problemas & ISP & IOP \\
\hline Áreas verdes insuficientes e mal distribuídas & 0,455 & 0,545 \\
\hline Ausência de oferta de empregos & 0,615 & 0,385 \\
\hline Baixa Qualidade do transporte público & 0,467 & 0,533 \\
\hline Ciclo faixas mal projetadas & 0,571 & 0,429 \\
\hline Crescimento desordenado & 0,417 & 0,583 \\
\hline Deficiência de equipamentos de saúde & 0,273 & 0,727 \\
\hline Falta de estabelecimentos de ensino & 0,333 & 0,667 \\
\hline Falta equipamentos culturais & 0,286 & 0,714 \\
\hline Falta iluminação & 0,273 & 0,727 \\
\hline Faltam opções de lazer & 0,250 & 0,750 \\
\hline Faltam opções de transporte público & 0,333 & 0,667 \\
\hline Geração de lixo & 0,333 & 0,667 \\
\hline Grandes áreas abandonadas & 0,455 & 0,545 \\
\hline Integração do transporte público & 0,400 & 0,600 \\
\hline Não existem centros comerciais & 0,400 & 0,600 \\
\hline Pavimentação precária & 0,333 & 0,667 \\
\hline Percurso longo do transporte público & 0,375 & 0,625 \\
\hline Planejamento das Calçadas & 0,231 & 0,769 \\
\hline Poluição sonora, visual e atmosférica & 0,429 & 0,571 \\
\hline Trânsito e saturação das vias & 0,500 & 0,500 \\
\hline Violência e segurança & 0,333 & 0,667 \\
\hline
\end{tabular}

Fonte: O Autor (2019)

A hierarquização proposta pelo índices da tabela anterior, para o grupo 4 apontam a ausência de oferta de empregos, as ciclo faixas mal projetas, a falta de equipamento culturais e a falta de opções de lazer entre os que mais tem atenção das alternativas. Também é possível analisar os problemas a partir de incompletude das ações atuantes e da abrangência ponderada de ações completas e totais nos problemas, conforme tabela 103. 
Tabela 103 - Cálculo do IUP e do IGA-P $(p)$ para o grupo 4

\begin{tabular}{|c|c|c|}
\hline Problemas & IUP & IGA-P $(p)$ \\
\hline Áreas verdes insuficientes e mal distribuídas & 0,364 & 1,000 \\
\hline Ausência de oferta de empregos & 0,692 & 0,944 \\
\hline Baixa Qualidade do transporte público & 0,467 & 1,278 \\
\hline Ciclo faixas mal projetadas & 0,571 & 0,556 \\
\hline Crescimento desordenado & 0,750 & 0,833 \\
\hline Deficiência de equipamentos de saúde & 0,636 & 0,833 \\
\hline Falta de estabelecimentos de ensino & 0,500 & 0,500 \\
\hline Falta equipamentos culturais & 0,714 & 0,500 \\
\hline Falta iluminação & 0,273 & 1,056 \\
\hline Faltam opções de lazer & 0,375 & 0,722 \\
\hline Faltam opções de transporte público & 0,333 & 0,833 \\
\hline Geração de lixo & 0,333 & 1,111 \\
\hline Grandes áreas abandonadas & 0,636 & 0,833 \\
\hline Integração do transporte público & 0,500 & 0,833 \\
\hline Não existem centros comerciais & 0,400 & 1,333 \\
\hline Pavimentação precária & 0,500 & 0,500 \\
\hline Percurso longo do transporte público & 0,375 & 0,722 \\
\hline Planejamento das Calçadas & 0,462 & 1,111 \\
\hline Poluição sonora, visual e atmosférica & 0,429 & 0,611 \\
\hline Trânsito e saturação das vias & 0,625 & 0,611 \\
\hline Violência e segurança & 0,667 & 0,889 \\
\hline
\end{tabular}

Fonte: O Autor (2019)

Por fim, os problemas podem ser hierarquizados a partir do Índice Geral de Abrangência dos Problemas hierárquico, e assim quanto maior o índice maior será a abrangência e a completude do atendimento de um problema, e, portanto, as ações que atuam sobre ele podem ser priorizadas gerando resultados mais efetivos, eficazes e eficientes simultaneamente sob a ótica da população, conforme tabela 104. 
Tabela 104 - Cálculo do IGA-P $(h)$ para o grupo 4

\begin{tabular}{cc}
\hline Problemas & IGA-P $(\boldsymbol{h})$ \\
\hline Não existem centros comerciais & 0,0757 \\
Baixa Qualidade do transporte público & 0,0726 \\
Geração de lixo & 0,0631 \\
Planejamento das Calçadas & 0,0631 \\
Falta iluminação & 0,0599 \\
Áreas verdes insuficientes e mal distribuídas & 0,0568 \\
Ausência de oferta de empregos & 0,0536 \\
Violência e segurança & 0,0505 \\
Crescimento desordenado & 0,0473 \\
Deficiência de equipamentos de saúde & 0,0473 \\
Faltam opções de transporte público & 0,0473 \\
Grandes áreas abandonadas & 0,0473 \\
Integração do transporte público & 0,0473 \\
Faltam opções de lazer & 0,0410 \\
Percurso longo do transporte público & 0,0410 \\
Poluição sonora, visual e atmosférica & 0,0347 \\
Trânsito e saturação das vias & 0,0347 \\
Ciclo faixas mal projetadas & 0,0315 \\
Falta de estabelecimentos de ensino & 0,0284 \\
Falta equipamentos culturais & 0,0284 \\
Pavimentação precária & 0,0284 \\
\hline $\mathbf{\Sigma}$ & $\mathbf{1}$ \\
\hline
\end{tabular}

Fonte: O Autor (2019)

Essa avaliação multifacetada aponta que os problemas que tem maior chance de serem atendidos pelas alternativas propostas são inexistência de centros comerciais, a baixa qualidade do transporte públicos (ações que já haviam sido hierarquizadas nos grupos anteriores) e agora surgem também como relevantes a geração de lixo planejamento das calçadas e falta de iluminação. Tal como pontuado no grupo 3, também aparece como relevante a distribuição das áreas verdes e a ausência de oferta de empregos.

Também a partir deste painel é possível avaliar com indicadores a riqueza e qualidade do procedimento participativo aplicado a partir de índices, ou aqui denominados "Avaliadores" que qualificam o procedimento, e para o grupo 4 são apresentados na tabela 105.

Tabela 105 - Avaliador do processo para o grupo 4

\begin{tabular}{cccc}
\hline AQC & AAP & AEP & AFP \\
\hline 5,000 & 10,095 & 2,333 & 2,333 \\
\hline
\end{tabular}

Fonte: O Autor (2019) 


\subsubsection{Avaliação comparativa do processo para os 4 grupos}

Portanto é possível comparar o processo aplicado nos quatro diferentes grupos. Com isso, os resultados dos grupos 3 e 4, são aqueles que apontam alternativas que atuam de forma mais completa nos problemas, e, portanto, são mais eficazes pois possuem os maiores avaliadores de qualidade de completude do processo (AQC). Também são aqueles que mais atendem os problemas propostos pois possuem os maiores avaliadores de atendimento dos problemas (AAP).

Por outro lado, os resultados do grupo 2 foram os mais efetivos, pois indicam mais ações atuam diretamente em problemas, diagnosticado a partir do avaliador de efetividade do processo (AEP).

Também os resultados dos grupos 3 e 4 são os mais eficientes, pois apontam um maior número soluções que resolvam completamente problemas, são as alternativas apresentadas no processo e consequentemente o maior Avaliador de eficiência do processo (AFP), conforme tabela 106.

Tabela 106 - Comparativo entre os avaliadores do processo para os diferentes grupos

\begin{tabular}{lcccc}
\hline & AQC & AAP & AEP & AFP \\
\hline Grupo 1 & 1,724 & 5,310 & 2,758 & 1,379 \\
\hline Grupo 2 & 3,083 & 6,583 & 3,125 & 1,625 \\
\hline Grupo 3 & 5,000 & 8,737 & 2,895 & 2,895 \\
\hline Grupo 4 & 5,000 & 10,095 & 2,333 & 2,333 \\
\hline
\end{tabular}

Fonte: O Autor (2019)

\subsubsection{Avaliação Hierárquica de Alternativas}

As alternativas propostas no processo foram avaliadas a partir da análise e da valoração de oportunidades e ameaças referentes a elas. Neste painel, os participantes podem inserir de um a três marcadores em cada dimensão associada à dificuldade de implantação das alternativas, com os títulos "Técnica" (legenda azul), "Econômica" (legenda verde), "Politica" (legenda vermelha) e "Aceitação Popular" (legenda magenta), para cada uma, conforme ilustrado na figura 97. 
Figura 98 - Processo de hierarquização das alternativas a partir da valoração dos painéis

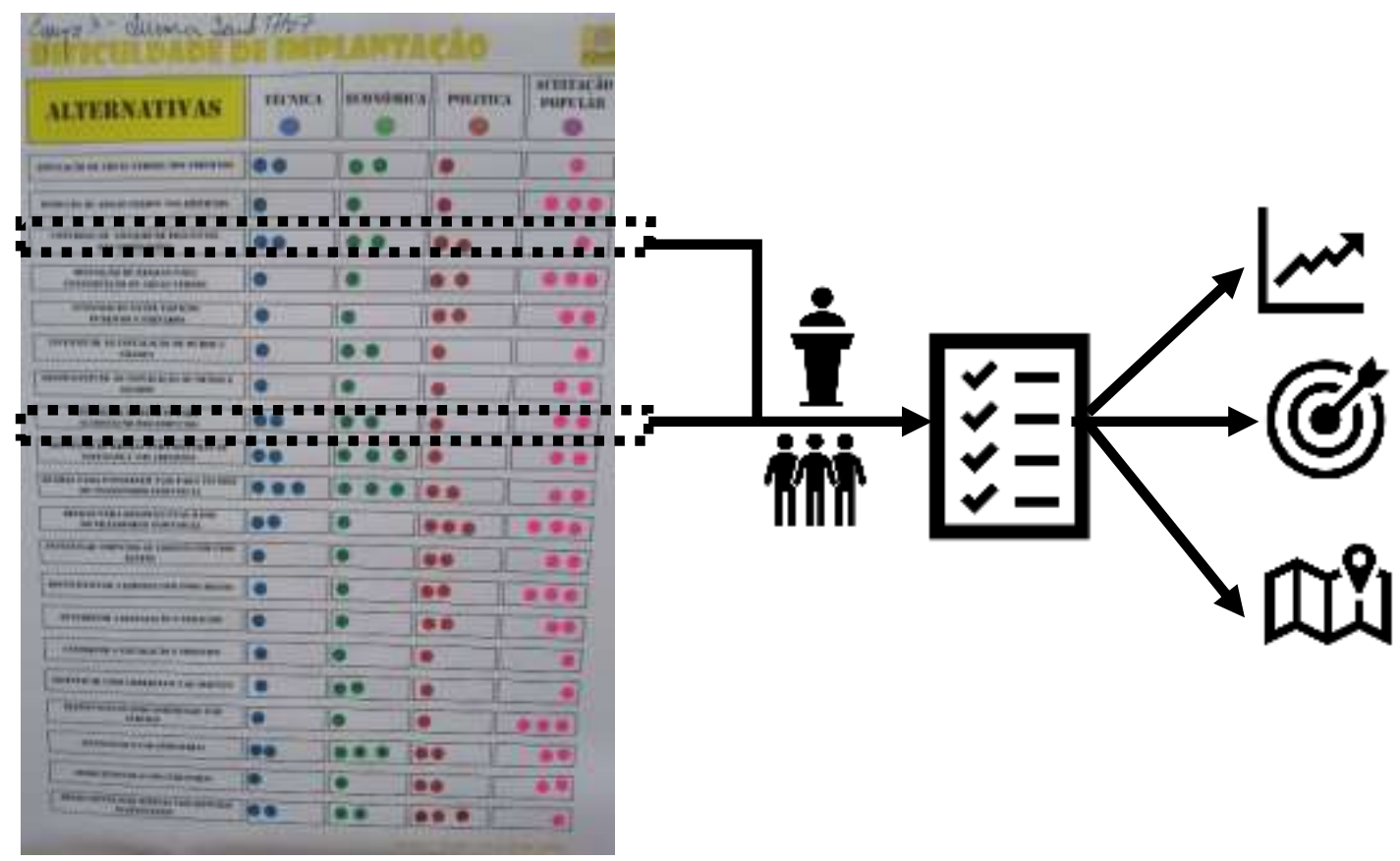

Fonte: Do autor (2019).

Nesta atividade, foram usados adesivos coloridos. Os resultados produzidos permitiram o cálculo dos índices: IDI-A (Índice de Dificuldade de Implantação de Alternativas); IDA-A (Índice de Dificuldade de Ação nas Alternativas); IGD-A (Índice Geral de Dificuldade da Alternativa); e IHA (Índice Hierárquico de Alternativas).

\subsection{Avaliação Multicriterial de Alternativas para o Grupo 1}

Os participantes negociaram entre si os pesos, associados a cada dimensão, alternativa a alternativa. Mesmo que a nota mínima seja 1 ponto, a cada dimensão, optou-se por não deixar 1 ponto previamente preenchido, a fim de que os participantes refletissem, inclusive para atribuir a pontuação mais baixa. Após a aplicação, os resultados foram sumarizados na tabela 107.

Tabela 107 - Preenchimento do painel de dificuldades para o grupo 1

\begin{tabular}{ccccc}
\hline Alternativas & Técnica & Econômica & Política & Aceitação Popular \\
\hline $\begin{array}{c}\text { Ampliação de áreas verdes nos } \\
\text { edifícios }\end{array}$ & $\mathbf{3}$ & $\mathbf{2}$ & $\mathbf{1}$ & $\mathbf{2}$ \\
$\begin{array}{c}\text { Redução de áreas verdes nos } \\
\text { edifícios }\end{array}$ & $\mathbf{2}$ & $\mathbf{1}$ & $\mathbf{1}$ & $\mathbf{2}$ \\
Ampliação da ocupação do solo & $\mathbf{3}$ & $\mathbf{1}$ & $\mathbf{2}$ & $\mathbf{2}$ \\
Redução da ocupação do solo & $\mathbf{1}$ & $\mathbf{2}$ & $\mathbf{3}$ & $\mathbf{2}$
\end{tabular}

Continua. 
Incentivo ao adensamento populacional

Desincentivo ao adensamento populacional

Descentralização das ofertas de empregos

Centralização das ofertas de empregos

Desincentivo ao uso do veículo individual

Incentivo ao uso do veículo individual

Ampliação das plataformas de informação

Incentivo à captação energética nos edifícios

Definição para altura máxima de muros

Incentivo aos usos mistos

Desincentivo aos usos mistos

Incentivo à ampliação da largura das calçadas

Desincentivo à ampliação da largura das calçadas

Incentivo a usos industriais na região

Maior ocupação em áreas livres abandonadas

Menor ocupação em áreas livres abandonadas
3

3

2

1

3

1

3

3

1

1

2

1

3

1

1

1
3

3

3

1

3

1

2

2

1

1

2

1

3

1

2

1
Continuação.

\section{2}

3

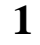

3

3

1

1

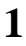

3

2

2

2

2

2

1

2

Fonte: Do autor (2019).

Com estes resultados, foram calculados os índices IDI-A, IDA-A e IGD-A. Estes são apresentados na tabela 108, organizados em ordem decrescente em função do IGD-A.

Tabela 108 - Cálculo no IDI-A, IDA-A e IGD-A para o grupo 1

\begin{tabular}{cccc}
\hline Alternativas & IDI-A & IDA-A & IGD-A \\
\hline Incentivo ao uso do veículo Individual & 1,000 & 1,000 & 1,000 \\
Incentivo a usos industriais na região & 1,000 & 0,500 & 0,500 \\
Maior ocupação em áreas livres abandonadas & 0,500 & 1,000 & 0,500 \\
Menor ocupação em áreas livres abandonadas & 1,000 & 0,500 & 0,500 \\
Centralização das ofertas de empregos & 1,000 & 0,333 & 0,333 \\
Definição para altura máxima de muros & 1,000 & 0,333 & 0,333 \\
Redução de áreas verdes nos edifícios & 0,500 & 0,500 & 0,250 \\
Incentivo a usos mistos & 1,000 & 0,250 & 0,250 \\
Incentivo à ampliação da largura das calçadas & 1,000 & 0,250 & 0,250 \\
Descentralização das ofertas de empregos & 0,167 & 1,000 & 0,167 \\
& & & Continua.
\end{tabular}




\begin{tabular}{cccc} 
& & & Continuação. \\
Ampliação das plataformas de Informação & 0,167 & 1,000 & 0,167 \\
Ampliação de áreas verdes nos edifícios & 0,167 & 0,500 & 0,083 \\
Ampliação da ocupação do solo & 0,333 & 0,250 & 0,083 \\
Redução da ocupação do solo & 0,500 & 0,167 & 0,083 \\
Desincentivo ao usos mistos & 0,250 & 0,250 & 0,063 \\
Incentivo à captação energéticas nos edifícios & 0,167 & 0,333 & 0,056 \\
Incentivo ao adensamento populacional & 0,111 & 0,250 & 0,028 \\
Desincentivo à ampliação da largura das calçadas & 0,111 & 0,250 & 0,028 \\
Desincentivo ao adensamento populacional & 0,111 & 0,111 & 0,012 \\
Desincentivo ao uso do veículo individual & 0,111 & 0,111 & 0,012 \\
\hline
\end{tabular}

Fonte: Do autor (2019).

Os resultados de hierarquia de alternativas devem ser analisados cuidadosamente, pois uma alternativa listada como, por exemplo, "áreas verdes", para se evitar o viés, é destrinchada em duas opções, por exemplo, "incentivar áreas verdes” e “desincentivar áreas verdes”.

A última alternativa, por ora, pode parecer danosa às pessoas, mesmo que tenham avaliado negativamente a dificuldade ou a facilidade de sua implantação, sem julgar, neste momento, se ela soluciona os problemas. Um desdobramento possível é remover as alternativas que podem representar algo negativo e analisar a hierarquia somente para as alternativas que representem algo favorável. Para o caso em tela, as pessoas consideram que seja fácil incentivar o uso do automóvel, por exemplo, mas não avaliaram se isso é positivo ou negativo, ou se isso soluciona os problemas apontados - é apenas uma hierarquia das facilidades.

O que se pode afirmar é que as pessoas consideram essa alternativa mais fácil de ser implantada do que, por exemplo, desincentivar o uso do veículo individual. Nesse caso, chama à atenção também que tanto a maior quanto a menor ocupação de áreas livres, segundo a percepção das pessoas, têm a mesma dificuldade de implantação. Isso também foi observado para ampliação e redução da ocupação do solo. Com apoio do Painel Colaborativo da Visão, é possível, a partir da observação dos participantes, hierarquizar as alternativas, que na percepção popular representam elementos favoráveis ao desenvolvimento do bairro, hierarquizados a partir da tabela 109.

Tabela 109 - Cálculo do IDI-A, IDA-A e IGD-A para o grupo 1 apenas para alternativas favoráveis

\begin{tabular}{cccc}
\hline Alternativas & IDI-A & IDA-A & IGD-A \\
\hline Maior ocupação em áreas livres abandonadas & 0,500 & 1,000 & 0,500 \\
Definição para altura máxima de muros & 1,000 & 0,333 & 0,333 \\
Incentivo a usos mistos & 1,000 & 0,250 & 0,250
\end{tabular}

Continua. 
Continuação.

Incentivo à ampliação da largura das calçadas

$1,000 \quad 0,250$

0,250

Descentralização das ofertas de empregos

$0,167 \quad 1,000 \quad 0,167$

Ampliação das plataformas de informação

$0,167 \quad 1,000 \quad 0,167$

Ampliação de áreas verdes nos edifícios

$0,167 \quad 0,500 \quad 0,083$

Ampliação da ocupação do solo

$0,333 \quad 0,250$

0,083

Incentivo à captação energéticas nos edifícios

$0,167 \quad 0,333 \quad 0,056$

Incentivo ao adensamento populacional

$0,111 \quad 0,250 \quad 0,028$

Desincentivo ao uso do veículo individual

$0,111 \quad 0,111$

0,012

Fonte: Do autor (2019).

Analisando as críticas pontuadas no Painel de Crítica Postergada, é possível notar uma forte crítica ao incentivo de muros em edificações, conforme destacado na figura 98. Outro ponto que ainda não foi consenso e foi criticado é a instalação de edifícios altos sem uma análise do sombreamento gerado por eles.

Figura 99 - Painel de nós críticos para o grupo 1

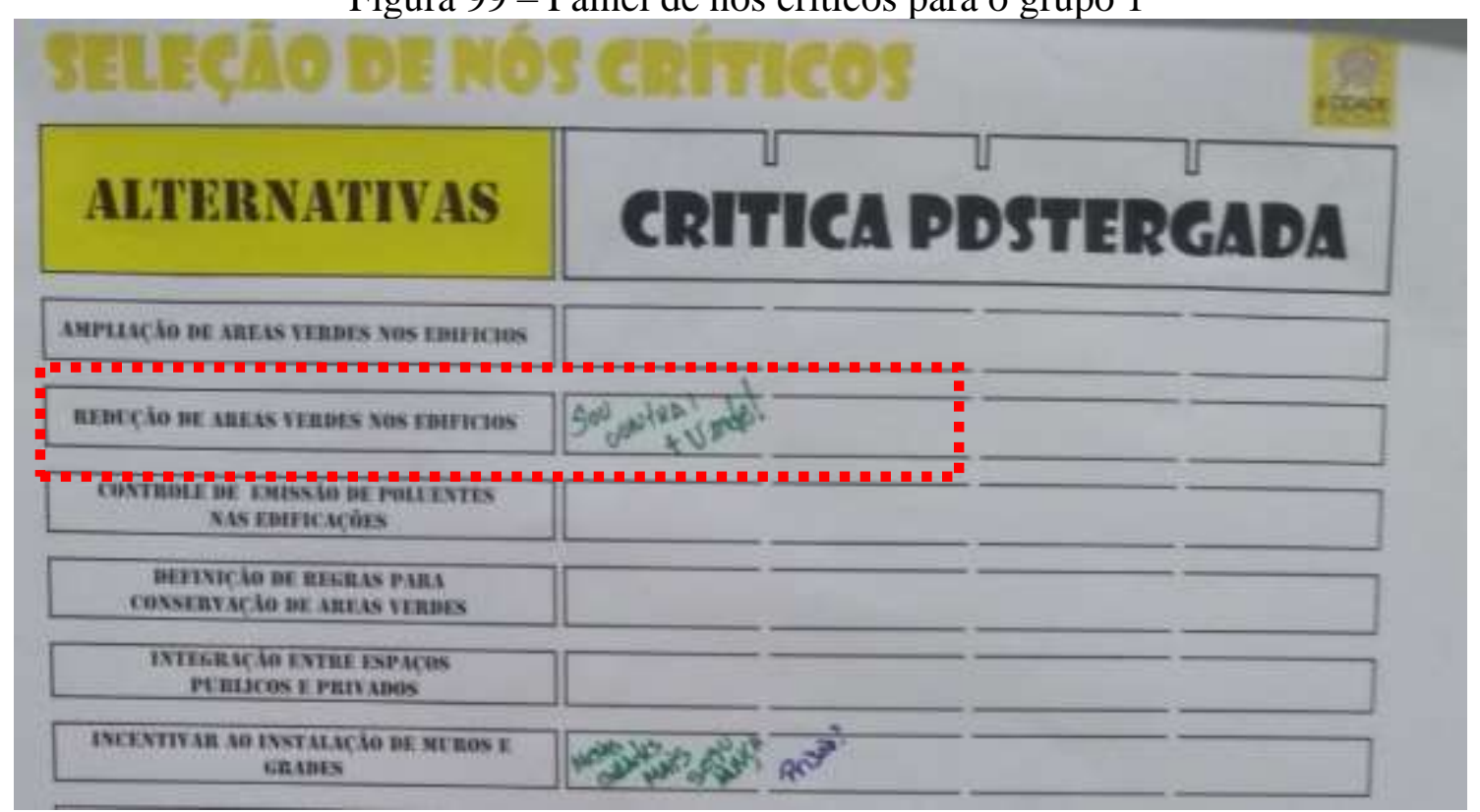

Fonte: Do autor (2019).

Por outro lado, ao se analisar a inserção territorial e as escalas, é interessante notar que as alternativas que têm menor dificuldade de implantação são aquelas que atuam em uma abrangência de quadra e de bairro, e as ações que devem ser implantadas no âmbito da cidade, possivelmente, terão maiores dificuldades de aceitação popular. Afinal, as diferentes regiões têm interesses heterogêneos. 
A determinação do Índice Hierárquico de Alternativas (IHA) para o grupo 1 permite, além de hierarquizar as alternativas, apresentar sua representatividade numérica quando comparada par-a-par com as demais, sendo apresentado na tabela 110.

Tabela 110 - Cálculo do IHA para o grupo 1

\begin{tabular}{cc}
\hline Hierarquização de Alternativas & IHA \\
\hline Incentivar o uso do racional de veículo individual & 0,2128 \\
Disciplinar a ocupação em áreas livres abandonadas & 0,1064 \\
Incentivar usos industriais na região & 0,1064 \\
Maior ocupação em áreas livres abandonadas & 0,1064 \\
Definição para altura máxima de muros & 0,0709 \\
Incentivar a oferta de empregos & 0,0709 \\
Incentivar usos mistos & 0,0532 \\
Incentivo a ampliação da largura das calçadas & 0,0532 \\
Redução de áreas verdes nos edifícios & 0,0532 \\
Ampliar plataformas de informação & 0,0355 \\
Descentralizar a oferta de empregos & 0,0355 \\
Ampliação da ocupação do solo & 0,0177 \\
Ampliação de áreas verdes nos edifícios & 0,0177 \\
Redução da ocupação do solo & 0,0177 \\
Desincentivo ao usos mistos & 0,0133 \\
Incentivar a captação energéticas nos edifícios & 0,0118 \\
Desincentivo à ampliação da largura das calçadas & 0,0059 \\
Incentivar o adensamento populacional & 0,0059 \\
Desincentivo ao adensamento populacional & 0,0026 \\
Desincentivo ao uso do veículo individual & 0,0026 \\
\hline $\mathbf{\Sigma}$ & $\mathbf{1}$ \\
\hline
\end{tabular}

Fonte: O Autor (2019)

Para o grupo 1 as alternativas hierarquicamente mais relevantes são o incentivo aos usos racional do veículo individual, o disciplinamento da ocupação em áreas livres abandonadas e o incentivo aos usos industriais.

\subsection{Avaliação Multicriterial de Alternativas para o Grupo 2}

Os participantes negociaram entre si os pesos, associados a cada dimensão, alternativa a alternativa. Mesmo que a nota mínima seja de 1 ponto, a cada dimensão, optou-se por não deixar 1 ponto previamente preenchido, a fim de que os participantes refletissem, inclusive para atribuir a pontuação mais baixa. Após a aplicação, os resultados foram sumarizados na tabela 111. 
Tabela 111 - Valoração para dificuldade nas alternativas para o grupo 2

\section{Alternativas}

Técnica Econômica Política Aceitação Popular

\begin{tabular}{|c|c|c|c|c|}
\hline $\begin{array}{c}\text { Ampliação de áreas verdes nos } \\
\text { edifícios }\end{array}$ & 1 & 1 & 2 & 1 \\
\hline $\begin{array}{l}\text { Áreas construídas mínimas com } \\
\text { sistemas sustentáveis }\end{array}$ & 3 & 3 & 3 & 2 \\
\hline $\begin{array}{l}\text { Controle de emissão de poluentes } \\
\text { nas edificações }\end{array}$ & 2 & 2 & 2 & 3 \\
\hline $\begin{array}{l}\text { Definição de regras para } \\
\text { conservação de áreas verdes }\end{array}$ & 3 & 1 & 1 & 2 \\
\hline $\begin{array}{l}\text { Definiçãa de regras para } \\
\text { iluminação nos edifícios }\end{array}$ & 1 & 2 & 1 & $\mathbf{1}$ \\
\hline $\begin{array}{c}\text { Definição de regras para sistemas } \\
\text { de segurança nos edifícios }\end{array}$ & 3 & 3 & 3 & 1 \\
\hline $\begin{array}{c}\text { Desincentivo à instalação de } \\
\text { muros e grades }\end{array}$ & 1 & 1 & 1 & 1 \\
\hline $\begin{array}{l}\text { Desincentivo a edifícios e } \\
\text { imóveis com usos mistos }\end{array}$ & 1 & 1 & 1 & 1 \\
\hline $\begin{array}{c}\text { Desincentivo a usos comerciais e } \\
\text { de serviços }\end{array}$ & 3 & 3 & 3 & 3 \\
\hline Desincentivo a usos industriais & 3 & 3 & 3 & 3 \\
\hline $\begin{array}{c}\text { Favorecimento à instalação de } \\
\text { edifícios }\end{array}$ & 1 & 1 & 1 & $\mathbf{1}$ \\
\hline $\begin{array}{c}\text { Incentivo à instalação de muros e } \\
\text { grades }\end{array}$ & 1 & 1 & 1 & 2 \\
\hline $\begin{array}{l}\text { Incentivo a edifícios ou imóveis } \\
\text { com usos mistos }\end{array}$ & 3 & $\mathbf{1}$ & 1 & 2 \\
\hline $\begin{array}{c}\text { Incentivo a usos comerciais e de } \\
\text { serviços }\end{array}$ & 2 & 1 & 1 & $\mathbf{1}$ \\
\hline Incentivo a usos industriais & 1 & 1 & 1 & 1 \\
\hline $\begin{array}{c}\text { Integração entre espaços públicos } \\
\text { e privados }\end{array}$ & 1 & 2 & 3 & 1 \\
\hline $\begin{array}{c}\text { Redução de áreas verdes nos } \\
\text { edifícios }\end{array}$ & 1 & 1 & 1 & 1 \\
\hline $\begin{array}{c}\text { Regras para desincentivar as vias } \\
\text { para fluidez do transporte } \\
\text { individual }\end{array}$ & 2 & 3 & 3 & 3 \\
\hline $\begin{array}{c}\text { Regras para favorecer as vias } \\
\text { para fluidez do transporte } \\
\text { individual }\end{array}$ & 3 & 3 & 3 & 3 \\
\hline $\begin{array}{c}\text { Restrição à instalação de } \\
\text { edifícios }\end{array}$ & 3 & 2 & 3 & 1 \\
\hline
\end{tabular}

Fonte: Do autor (2019).

Com estes resultados, foram calculados os índices IDI-A, IDA-A e IGD-A. Estes são apresentados na tabela 112, organizados em ordem decrescente em função do IGD-A. 
Tabela 112 - Cálculo do IDI-A, IDA-A e IGA-A para o grupo 2

\begin{tabular}{|c|c|c|c|}
\hline Alternativas & IDI-A & IDA-A & IGD-A \\
\hline Desincentivo à instalação de muros e grades & 1,000 & 1,000 & 1,000 \\
\hline Desincentivo a edifícios e imóveis com usos mistos & 1,000 & 1,000 & 1,000 \\
\hline Favorecimento à instalação de edifícios & 1,000 & 1,000 & 1,000 \\
\hline Incentivo a usos industriais & 1,000 & 1,000 & 1,000 \\
\hline Redução de áreas verdes nos edifícios & 1,000 & 1,000 & 1,000 \\
\hline Ampliação de áreas verdes nos edifícios & 1,000 & 0,500 & 0,500 \\
\hline Definição de regras para iluminação nos edifícios & 0,500 & 1,000 & 0,500 \\
\hline Incentivo à instalação de muros e grades & 1,000 & 0,500 & 0,500 \\
\hline Incentivo a usos comerciais e de serviços & 0,500 & 1,000 & 0,500 \\
\hline Definição de regras para conservação de áreas verdes & 0,333 & 0,500 & 0,167 \\
\hline Incentivo a edifícios ou imóveis com usos mistos & 0,333 & 0,500 & 0,167 \\
\hline Integração entre espaços públicos e privados & 0,500 & 0,333 & 0,167 \\
\hline Restrição à instalação de edifícios & 0,167 & 0,333 & 0,056 \\
\hline Controle de emissão de poluentes nas edificações & 0,250 & 0,167 & 0,042 \\
\hline Definição de regras para sistemas de segurança nos edifícios & 0,111 & 0,333 & 0,037 \\
\hline Áreas construídas mínimas com sistemas sustentáveis & 0,111 & 0,167 & 0,019 \\
\hline $\begin{array}{l}\text { Regras para desincentivar as vias para fluidez do transporte } \\
\text { individual }\end{array}$ & 0,167 & 0,111 & 0,019 \\
\hline Desincentivo a usos comerciais e de serviços & 0,111 & 0,111 & 0,012 \\
\hline Desincentivo a usos industriais & 0,111 & 0,111 & 0,012 \\
\hline $\begin{array}{l}\text { Regras para favorecer as vias para fluidez do transporte } \\
\text { individual }\end{array}$ & 0,111 & 0,111 & 0,012 \\
\hline
\end{tabular}

Fonte: Do autor (2019).

Com apoio do Painel Colaborativo da Visão, é possível, a partir da observação dos participantes, hierarquizar as alternativas, que na percepção popular, representam elementos favoráveis ao desenvolvimento do bairro, hierarquizados a partir da tabela 113.

Tabela 113 - IDI, IDA-A e IGD-A para o grupo 2 apenas para alternativas favoráveis

\begin{tabular}{cccc}
\hline Alternativas & IDI-A & IDA-A & IGD-A \\
\hline Desincentivo à instalação de muros e grades & 1,000 & 1,000 & 1,000 \\
Favorecimento à instalação de edifícios & 1,000 & 1,000 & 1,000 \\
Ampliação de áreas verdes nos edifícios & 1,000 & 0,500 & 0,500 \\
Definição de regras para iluminação nos edifícios & 0,500 & 1,000 & 0,500 \\
& & & Continua.
\end{tabular}




\begin{tabular}{ccccc} 
& & \multicolumn{3}{c}{ Continuação. } \\
Incentivo a usos comerciais e de serviços & 0,500 & 1,000 & 0,500 \\
Definição de regras para conservação de áreas verdes & 0,333 & 0,500 & 0,167 \\
Incentivo a edifícios ou imóveis com usos mistos & 0,333 & 0,500 & 0,167 \\
Integração entre espaços públicos e privados & 0,500 & 0,333 & 0,167 \\
Controle de emissão de poluentes nas edificações & 0,250 & 0,167 & 0,042 \\
Definição de regras para sistemas de segurança nos edifícios & 0,111 & 0,333 & 0,037 \\
Áreas construídas mínimas com sistemas sustentáveis & 0,111 & 0,167 & 0,019 \\
Regras para desincentivar as vias para fluidez do transporte & 0,167 & 0,111 & 0,019 \\
\hline individual & & & \\
\hline
\end{tabular}

Fonte: Do autor (2019).

Este grupo não manifestou pontuações no Painel de Crítica Postergada, pois entenderam que a valoração realizada já exauria a possibilidade de crítica e discussão acerca das alternativas propostas.

Para o grupo 2 seguindo a mesma metodologia de cálculo já discutida para o IHA, é possível notar que hierarquicamente as mais relevantes são o desincentivo a instalação de grades e muros, mesma percepção que também foi hierarquizada como uma das mais importantes para o grupo 1, contudo ficou posicionada em um patamar elevado o desincentivo aos edifícios mistos, provavelmente em função da dificuldade de se implantar esta modalidade nos edifícios já construídos na área objeto o Índice Hierárquico de Alternativas é apresentado para o grupo 2 na tabela 114, para este grupo é prioritário a redução das áreas verdes, comparativamente a ampliação das áreas verdes, ficaram seguidas uma da outras, o que denota a dificuldade de obtenção de consenso nesta questão.

Tabela 114 - IHA para o grupo 2

\begin{tabular}{cc}
\hline Alternativas & IHA \\
\hline Desincentivar a instalação de muros e grades & 0,12973 \\
Desincentivar edifícios e imóveis com usos mistos & 0,12973 \\
Favorecer a instalação de edifícios & 0,12973 \\
Incentivar usos industriais & 0,12973 \\
Redução de áreas verdes nos edifícios & 0,12973 \\
Ampliação de áreas verdes nos edifícios & 0,06486 \\
Definição de regras para iluminação nos edifícios & 0,06486 \\
Incentivar a instalação de muros e grades & 0,06486 \\
Incentivar usos comerciais e de serviços & 0,06486 \\
Definição de regras para conservação de áreas verdes & 0,02162 \\
Incentivar edifícios ou imóveis com usos mistos & 0,02162 \\
& Continua.
\end{tabular}


Integração entre espaços públicos e privados

Restringir a instalação de edifícios

Controle de emissão de poluentes nas edificações

Definição de regras para sistemas de segurança nos edifícios

Áreas construídas mínimas com sistemas sustentáveis

Regras para desincentivar as vias para fluidez do transporte individual

Desincentivar usos comerciais e de serviços

Desincentivar usos industriais

Regras para favorecer as vias para fluidez do transporte individual
Continuação

0,02162

0,00721

0,00541

0,00480

0,00240

0,00240

0,00160

0,00160

0,00160

\section{$\Sigma$}

Fonte: O Autor (2019)

\subsection{Avaliação Multicriterial de Alternativas para o Grupo 3}

Os participantes negociaram entre si os pesos, associados a cada dimensão, alternativa a alternativa. Mesmo que a nota mínima seja 1 ponto, a cada dimensão, optou-se por não deixar 1 ponto previamente preenchido, a fim de que os participantes refletissem, inclusive para atribuir a pontuação mais baixa. Após a aplicação, os resultados foram sumarizados na tabela 115.

Tabela 115 - Valoração das dificuldades das alternativas para o grupo 3

\begin{tabular}{|c|c|c|c|c|}
\hline Alternativas & Técnica & Econômica & Política & Aceitação Popular \\
\hline $\begin{array}{c}\text { Ampliação de áreas verdes nos } \\
\text { edifícios }\end{array}$ & 2 & 2 & 1 & 1 \\
\hline $\begin{array}{c}\text { Induzir ou incentivar a } \\
\text { construção de equipamentos e } \\
\text { edifícios de uso cultural }\end{array}$ & 3 & 2 & 1 & 1 \\
\hline $\begin{array}{c}\text { Uso compulsório de áreas } \\
\text { ociosas para atividades } \\
\text { coletivas }\end{array}$ & 1 & 1 & 3 & 2 \\
\hline $\begin{array}{l}\text { Induzir a construção de } \\
\text { edifícios comerciais com áreas } \\
\text { de trabalho colaborativos }\end{array}$ & 2 & 1 & 1 & 1 \\
\hline $\begin{array}{l}\text { Ampliar e incentivar o } \\
\text { transporte público }\end{array}$ & 2 & 3 & 1 & 1 \\
\hline $\begin{array}{l}\text { Definir regras mais restritivas } \\
\text { para utilização dos recursos } \\
\text { naturais na construção }\end{array}$ & 1 & 2 & 3 & 3 \\
\hline $\begin{array}{c}\text { Ampliar e definir regras para } \\
\text { estimular construções } \\
\text { sustentáveis }\end{array}$ & 2 & 3 & 3 & 2 \\
\hline
\end{tabular}

Continua. 


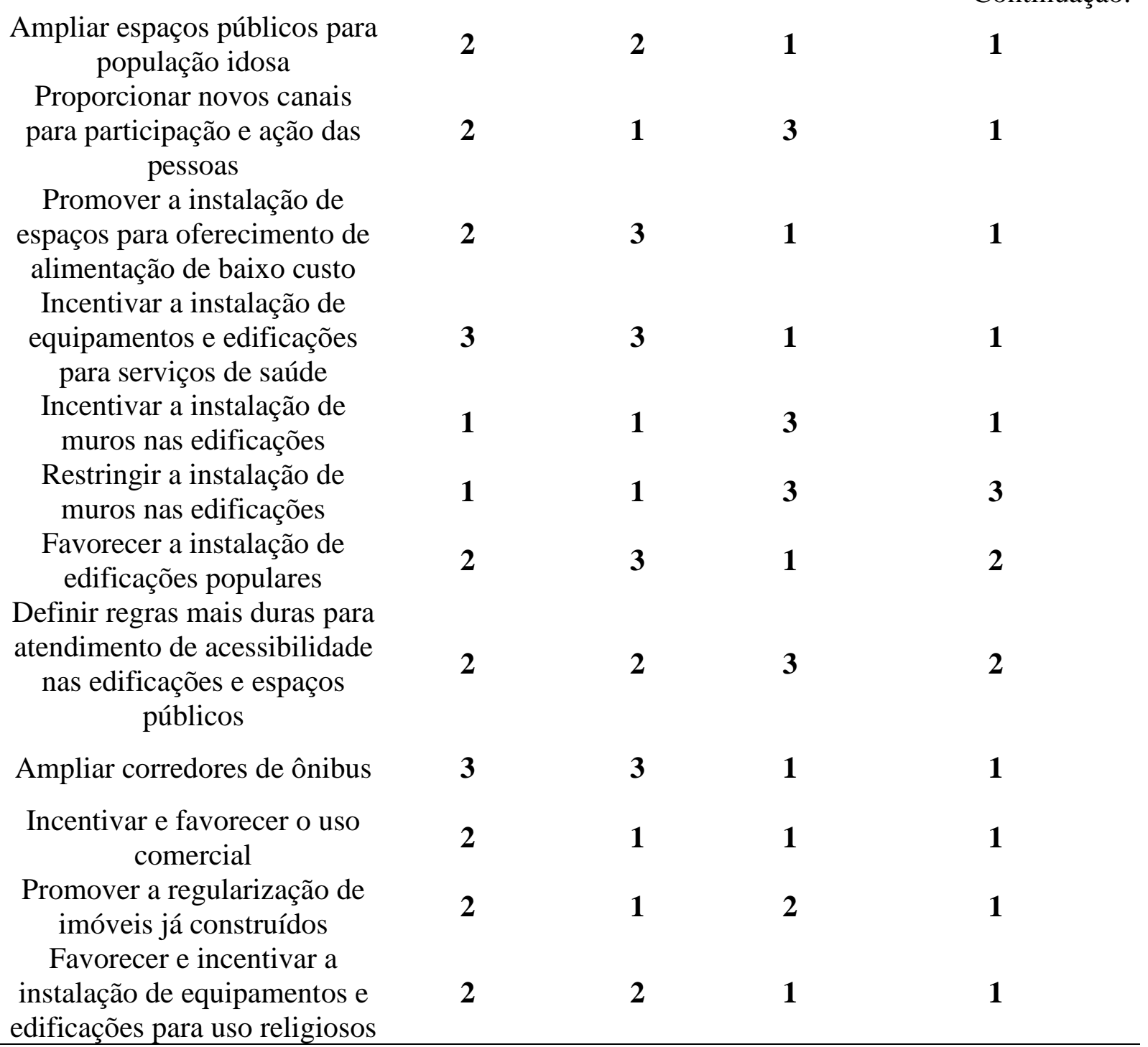

Continuação.

Fonte: Do autor (2019).

Com estes resultados, foram calculados os índices IDI-A, IDA-A e IGD-A. Estes são apresentados na tabela 116, organizados em ordem decrescente em função do IGD-A.

Tabela 116 - IDI-A, IDA-A e IGD-A para o grupo 3

\begin{tabular}{cccc}
\hline Alternativas & IDI-A & IDA-A & IGD-A \\
\hline $\begin{array}{c}\text { Induzir a construção de edifícios comerciais com áreas de } \\
\text { trabalho colaborativos }\end{array}$ & 0,500 & 1,000 & 0,500 \\
$\begin{array}{c}\text { Incentivar e favorecer o uso comercial } \\
\text { Incentivar a instalação de muros nas edificações }\end{array}$ & 0,500 & 1,000 & 0,500 \\
Ampliação de áreas verdes nos edifícios & 0,250 & 1,000 & 0,333 \\
Ampliar espaços públicos para população idosa & 0,250 & 1,000 & 0,333 \\
Promover a regularização de imóveis já construídos & 0,500 & 0,500 & 0,250 \\
& & & Continua.
\end{tabular}


Continuação.

Favorecer e incentivar a instalação de equipamentos e edificações para uso religiosos

$0,250 \quad 1,000 \quad 0,250$

Induzir ou incentivar a construção de equipamentos e edifícios de uso cultural

$0,167 \quad 1,000 \quad 0,167$

Uso compulsório de áreas ociosas para atividades coletivas $\begin{array}{rll}1,000 & 0,167 & 0,167\end{array}$

Ampliar e incentivar o transporte público $\quad 0,167 \quad 1,000 \quad 0,167$

Proporcionar novos canais para participação e ação das pessoas

$0,500 \quad 0,333 \quad 0,167$

Promover a instalação de espaços para oferecimento de alimentação de baixo custo

$0,167 \quad 1,000 \quad 0,167$

Incentivar a instalação de equipamentos e edificações para serviços de saúde

$0,111 \quad 1,000 \quad 0,111$

Restringir a instalação de muros nas edificações

$1,000 \quad 0,111 \quad 0,111$

Ampliar corredores de ônibus

$0,111 \quad 1,000 \quad 0,111$

Favorecer a instalação de edificações populares

$0,167 \quad 0,500 \quad 0,083$

Definir regras mais restritivas para utilização dos recursos naturais na construção

$0,500 \quad 0,111 \quad 0,056$

Definir regras mais duras para atendimento de acessibilidade nas edificações e espaços públicos

$0,250 \quad 0,167 \quad 0,042$

Ampliar e definir regras para estimular construções sustentáveis

$0,167 \quad 0,167 \quad 0,028$

Fonte: Do autor (2019).

Com apoio do Painel Colaborativo da Visão, é possível, a partir da observação dos participantes, hierarquizar as alternativas, que na percepção popular, representam elementos favoráveis ao desenvolvimento do bairro, hierarquizados a partir da tabela 117.

Tabela 117 - IDI-A, IDA-A e IGD-A somente para as alternativas favoráveis do grupo 3

\section{Alternativas}

Induzir a construção de edifícios comerciais com áreas de trabalho colaborativos

Incentivar e favorecer o uso comercial

Ampliação de áreas verdes nos edifícios

Ampliar espaços públicos para população idosa

Promover a regularização de imóveis já construídos
IDI-A IDA-A IGD-A

$\begin{array}{lll}0,500 & 1,000 & 0,500 \\ 0,500 & 1,000 & 0,500 \\ 0,250 & 1,000 & 0,250 \\ 0,250 & 1,000 & 0,250 \\ 0,500 & 0,500 & 0,250\end{array}$

Continua. 
Continuação.

Favorecer e incentivar a instalação de equipamentos e edificações para uso religiosos

$0,250 \quad 1,000 \quad 0,250$

Induzir ou incentivar a construção de equipamentos e edifícios de uso cultural

$0,167 \quad 1,000 \quad 0,167$

Uso compulsório de áreas ociosas para atividades coletivas

$1,000 \quad 0,167 \quad 0,167$

Ampliar e incentivar o transporte público

$0,167 \quad 1,000 \quad 0,167$

Proporcionar novos canais para participação e ação das pessoas

$0,500 \quad 0,333 \quad 0,167$

Promover a instalação de espaços para oferecimento de alimentação de baixo custo

$0,167 \quad 1,000 \quad 0,167$

Incentivar a instalação de equipamentos e edificações para serviços de saúde

$0,111 \quad 1,000 \quad 0,111$

Restringir a instalação de muros nas edificações

$1,000 \quad 0,111 \quad 0,111$

Ampliar corredores de ônibus

$0,111 \quad 1,000 \quad 0,111$

Favorecer a instalação de edificações populares

$0,167 \quad 0,500 \quad 0,083$

Definir regras mais restritivas para utilização dos recursos naturais na construção

$0,500 \quad 0,111 \quad 0,056$

Definir regras mais duras para atendimento de acessibilidade nas edificações e espaços públicos

$0,250 \quad 0,167 \quad 0,042$

Ampliar e definir regras para estimular construções sustentáveis

$0,167 \quad 0,167 \quad 0,028$

Fonte: Do autor (2019).

Neste grupo, o Painel de Crítica Postergada também não foi preenchido pelos participantes. Quando questionados, eles pontuaram que o processo de discussão, nas inúmeras atividades, gerou reflexão, inclusive dos mais críticos, surgindo uma consciência mais elaborada no diagnóstico dos problemas e na proposta de alternativas de ação no âmbito urbano.

Para o grupo 3 seguindo a mesma metodologia de cálculo já discutida para o IHA, há o incentivo e o favorecimento ao uso comercial como hierarquicamente mais relevante, contudo alternativas mais disruptivas se protagonizam tais como a indução à construção de edifícios comercias com áreas colaborativas de trabalho, conforme tabela 118. 
Tabela 118 - Cálculo do IHA para o grupo 3

\begin{tabular}{|c|c|}
\hline Alternativas & IHA \\
\hline Incentivar e favorecer o uso comercial & 0,14815 \\
\hline Induzir a construção de edifícios comerciais com áreas de trabalho colaborativos & 0,14815 \\
\hline Ampliação de áreas verdes nos edifícios & 0,07407 \\
\hline Ampliar espaços públicos para população idosa & 0,07407 \\
\hline $\begin{array}{l}\text { Favorecer e incentivas a instalação de equipamentos e edificações para uso } \\
\text { religiosos }\end{array}$ & 0,07407 \\
\hline Promover a regularização de imóveis já construídos & 0,07407 \\
\hline Ampliar e incentivar o transporte publico & 0,04938 \\
\hline Induzir ou incentivar a construção de equipamentos e edifícios de uso cultural & 0,04938 \\
\hline $\begin{array}{l}\text { Promover a instalação de espaços para oferecimento de alimentação de baixo } \\
\text { custo }\end{array}$ & 0,04938 \\
\hline Proporcionar novos canais para participação e ação das pessoas & 0,04938 \\
\hline Uso compulsório de áreas ociosas para atividades coletivas & 0,04938 \\
\hline Ampliar corredores de Ônibus & 0,03292 \\
\hline Incentivar a instalação de equipamentos e edificações para serviços de saúde & 0,03292 \\
\hline Restringir a instalação de muros nas edificações & 0,03292 \\
\hline Favorecer a instalação de edificações populares & 0,02469 \\
\hline Definir regras mais restritivas para utilização dos recursos naturais na construção & 0,01646 \\
\hline $\begin{array}{l}\text { Definir regras mais duras para atendimento de acessibilidade nas edificações e } \\
\text { espaços públicos }\end{array}$ & 0,01235 \\
\hline Ampliar e definir regras para estimular construções sustentáveis & 0,00823 \\
\hline$\Sigma$ & 1 \\
\hline
\end{tabular}

Fonte: O Autor (2019)

\subsection{Avaliação Multicriterial de Alternativas para o Grupo 4}

Os participantes negociaram entre si os pesos, associados a cada dimensão, alternativa a alternativa. Mesmo que a nota mínima seja 1 ponto, a cada dimensão, optou-se por não deixar 1 ponto previamente preenchido, a fim de que os participantes refletissem, inclusive para atribuir a pontuação mais baixa. Após a aplicação, os resultados foram sumarizados na tabela 119. 
Tabela 119 - Valoração das dificuldades das alternativas para o grupo 4

\begin{tabular}{|c|c|c|c|c|}
\hline Alternativas & Técnica & Econômica & Política & Aceitação Popular \\
\hline $\begin{array}{c}\text { Ampliação das áreas construídas } \\
\text { nas edificações }\end{array}$ & 3 & 3 & 1 & 1 \\
\hline $\begin{array}{c}\text { Ampliação de áreas verdes nos } \\
\text { edifícios }\end{array}$ & 2 & 3 & 1 & 1 \\
\hline $\begin{array}{c}\text { Redução de áreas verdes nos } \\
\text { edifícios }\end{array}$ & 2 & 2 & 3 & 3 \\
\hline Ampliação da ocupação do solo & 2 & 1 & 1 & 1 \\
\hline Redução da ocupação do solo & 2 & 1 & 3 & 3 \\
\hline $\begin{array}{l}\text { Desincentivo à instalação de } \\
\text { residências }\end{array}$ & 1 & 2 & 3 & 3 \\
\hline $\begin{array}{l}\text { Incentivo à instalação de } \\
\text { residências }\end{array}$ & 1 & 2 & 1 & 1 \\
\hline $\begin{array}{c}\text { Incentivo a usos industriais na } \\
\text { região }\end{array}$ & 1 & 3 & 2 & 3 \\
\hline $\begin{array}{l}\text { Favorecimento a usos comerciais } \\
\text { e de serviços na região }\end{array}$ & 1 & 3 & 2 & 1 \\
\hline Incentivo a usos mistos na região & 1 & 3 & 2 & 1 \\
\hline $\begin{array}{l}\text { Restrição à instalação de edifícios } \\
\text { altos }\end{array}$ & 1 & 2 & 3 & 2 \\
\hline $\begin{array}{c}\text { Incentivo à captação energética } \\
\text { nos edifícios }\end{array}$ & 3 & 3 & 1 & 1 \\
\hline $\begin{array}{c}\text { Incentivo à ampliação da largura } \\
\text { das calçadas }\end{array}$ & 2 & 2 & 2 & 2 \\
\hline $\begin{array}{l}\text { Favorecimento ao uso do } \\
\text { transporte público }\end{array}$ & 2 & 3 & 1 & 1 \\
\hline $\begin{array}{c}\text { Estímulo à ocupação de áreas } \\
\text { abandonadas }\end{array}$ & 1 & 2 & 3 & 1 \\
\hline $\begin{array}{l}\text { Regras para desincentivar o } \\
\text { transporte individual }\end{array}$ & 1 & 1 & 3 & 1 \\
\hline $\begin{array}{l}\text { Favorecimento ao uso de } \\
\text { bicicletas }\end{array}$ & 1 & 1 & 3 & 1 \\
\hline $\begin{array}{c}\text { Integração de área dos edifícios à } \\
\text { área pública }\end{array}$ & 2 & 2 & 3 & 2 \\
\hline
\end{tabular}

Fonte: Do autor (2019).

Com estes resultados, foram calculados os índices IDI-A, IDA-A e IGD-A. Estes são apresentados na tabela 120, organizados em ordem decrescente em função do IGD-A. 
Tabela 120 - IDI-A, IDA-A e IGD-A para o grupo 4

\begin{tabular}{cccc}
\hline Alternativas & IDI-A & IDA-A & IGD-A \\
\hline Ampliação da ocupação do solo & 0,50 & 1,00 & 0,50 \\
Incentivo à instalação de residências & 0,50 & 1,00 & 0,50 \\
Regras para desincentivar o transporte individual & 1,00 & 0,33 & 0,33 \\
Favorecimento ao uso de bicicletas & 1,00 & 0,33 & 0,33 \\
Ampliação de áreas verdes nos edifícios & 0,17 & 1,00 & 0,17 \\
Favorecimento a usos comerciais e de serviços na região & 0,33 & 0,50 & 0,17 \\
Incentivo a usos mistos na região & 0,33 & 0,50 & 0,17 \\
Favorecimento ao uso do transporte público & 0,17 & 1,00 & 0,17 \\
Estímulo à ocupação de áreas abandonadas & 0,50 & 0,33 & 0,17 \\
Ampliação das áreas construídas nas edificações & 0,11 & 1,00 & 0,11 \\
Incentivo à captação energética nos edifícios & 0,11 & 1,00 & 0,11 \\
Restrição à instalação de edifícios altos & 0,50 & 0,17 & 0,08 \\
Incentivo à ampliação da largura das calçadas & 0,25 & 0,25 & 0,06 \\
Redução da ocupação do solo & 0,50 & 0,11 & 0,06 \\
Desincentivo à instalação de residências & 0,50 & 0,11 & 0,06 \\
Incentivo a usos industriais na região & 0,33 & 0,17 & 0,06 \\
Integração de área dos edifícios à área pública & 0,25 & 0,17 & 0,04 \\
Redução de áreas verdes nos edifícios & 0,25 & 0,11 & 0,03 \\
\hline
\end{tabular}

Fonte: Do autor (2019).

Com apoio do Painel Colaborativo da Visão, é possível, a partir da observação dos participantes, hierarquizar as alternativas, que na percepção popular, representam elementos favoráveis ao desenvolvimento do bairro, hierarquizados a partir da tabela 121.

Tabela 121 - IDI-A, IDA-A e IGD-A para o grupo 4 considerando apenas as alternativas favoráveis

\begin{tabular}{cccc}
\hline Alternativas & IDI-A & IDA-A & IGD-A \\
\hline Ampliação da ocupação do solo & 0,50 & 1,00 & 0,50 \\
Incentivo à instalação de residências & 0,50 & 1,00 & 0,50 \\
Regras para desincentivar o transporte individual & 1,00 & 0,33 & 0,33 \\
Favorecimento ao uso de bicicletas & 1,00 & 0,33 & 0,33 \\
Ampliação de áreas verdes nos edifícios & 0,17 & 1,00 & 0,17 \\
Favorecimento a usos comerciais e de serviços na região & 0,33 & 0,50 & 0,17 \\
Incentivo a usos mistos na região & 0,33 & 0,50 & 0,17 \\
& & & Continua.
\end{tabular}


Continuação.

Favorecimento ao uso do transporte público $0,17 \quad 1,00 \quad 0,17$

Estímulo à ocupação de áreas abandonadas $0,50 \quad 0,33 \quad 0,17$ Ampliação das áreas construídas nas edificações $0,11 \quad 1,00 \quad 0,11$ Incentivo à captação energética nos edifícios $0,11 \quad 1,00 \quad 0,11$ Incentivo à ampliação da largura das calçadas $\quad 0,25 \quad 0,25 \quad 0,06$ $\begin{array}{llll}\text { Integração de área dos edifícios à área pública } & 0,25 & 0,17 & 0,04\end{array}$ Fonte: Do autor (2019).

Este grupo também não preencheu o Painel de Crítica Postergada. Quando questionados os motivos, os participantes apontaram que não existia naquele momento nenhuma crítica que necessitasse ser registrada no painel.

Para o grupo 4 as alternativas, hierarquicamente mais relevantes, são a ampliação da ocupação do solo, incentivo a instalação das residência e favorecer o uso de bicicletas, conforme IHA calculado na tabela 122 .

Tabela 122 - Cálculo do IHA para o grupo 4

\begin{tabular}{cc}
\hline Alternativas & IHA \\
\hline Ampliação da ocupação do Solo & 0,1610738 \\
Incentivo à instalação de residências & 0,1610738 \\
Favorecer o uso de Bicicletas & 0,1073826 \\
Regras para desincentivar o transporte individual & 0,1073826 \\
Ampliação de áreas verdes nos edifícios & 0,0536913 \\
Estimular a ocupação de áreas abandonadas & 0,0536913 \\
Favorecer o uso do transporte publico & 0,0536913 \\
Favorecer usos comerciais e de serviços na Região & 0,0536913 \\
Incentivar usos Mistos na região & 0,0536913 \\
Ampliar as áreas construídas nas edificações & 0,0357942 \\
Incentivar a captação energéticas nos Edifícios & 0,0357942 \\
Restringir a instalação de edifícios altos & 0,0268456 \\
Incentivo a ampliação da largura das calçadas & 0,0201342 \\
Desincentivo à instalação de residências & 0,0178971 \\
Incentivar usos industriais na Região & 0,0178971 \\
Redução da Ocupação do Solo & 0,0178971 \\
Integrar área dos edifícios a área publica & 0,0134228 \\
Redução de áreas verdes nos edifícios & 0,0089485 \\
\hline & $\mathbf{1}$ \\
\hline
\end{tabular}

Fonte: O Autor (2019)

A partir desta perspectiva hierarquizadora, quanto maior o índice hierárquico menores serão as dificuldades para implantação das alternativas, e, portanto, podem ser priorizadas sob a ótica da população, contudo podem ser fortalecidas com a associação a outros indicadores. 
Nos quatro grupos, notou-se que, em alguns momentos, que a população ficou insegura ao valorar alternativas sem saber ao certo se elas seriam positivas ou negativas. Nessa etapa, a equipe anotou as percepções da população, para que oportunamente fosse possível separá-las contribuindo para a análise alternativas que não atuem positivamente na solução de problemas.

Ainda assim, a metodologia se mostrou interessante, no sentido de que a população não precisava escolher o que é mais ou menos importante, nesse momento. A avaliação da alternativa, por si só, em aspectos que caracterizem sua dificuldade, é mais eficiente do que as comparar, entre si, ou fazer com que a população escolha entre alternativas ou aspectos mais ou menos importantes.

\subsubsection{Avaliação Integrada Multicriterial de Problemas e Alternativas}

Se por um lado o Índice Hierárquico de problema (IHP) permite a hierarquização dos problemas a partir de seu impacto, ou seja, a partir de sua frequência, relevância, dificuldade de correção e dificuldade de detecção, por outro lado o Índice Geral de Assertividade dos Problemas hierárquico (IGA-P $\left.{ }_{(h)}\right)$ permite a hierarquização dos problemas a partir das alternativas que atuam sobre ele, considerando a capacidade das alternativas solucionarem o problemas.

Nesta direção, é possível então incorporar as características das alternativas na hierarquização dos problemas, considerando o impacto dos problemas. Esta hierarquização se dá pela multiplicação do Índice Hierárquico de Problema (IHP) pelo Índice Geral de Assertividade dos Problemas hierárquico (IGA-P $\left.{ }_{(h)}\right)$ associado a cada problema. Este hierarquizador é um índice, sugerido nesta proposta metodológica, chamado de Índice Priorizador Geral de Problemas (IPG-P). Portanto, este índice associa as características do problema com as características das alternativas propostas.

Para o grupo 1 , o que se nota é que problemas que até então não eram hierarquizados como importantes passam a se destacar, como a distribuição e eficiência do sistema de distribuição elétrica, e outros problemas confirmam sua relevância tal como o déficit habitacional, os problemas com o transporte público e a falta de segurança, conforme tabela 123. 
Tabela 123 - Cálculo do IPG-P para o grupo 1

\begin{tabular}{|c|c|c|}
\hline Problemas & IPG-P & $\begin{array}{c}\text { IPG-P - } \\
\text { Normalizado }\end{array}$ \\
\hline Distribuição e eficiência do sistema de distribuição elétrica & 0,00203 & 0,06218 \\
\hline Déficit habitacional & 0,00199 & 0,06097 \\
\hline Inadequação e defasagem do serviço público de transporte & 0,00195 & 0,05983 \\
\hline Falta de segurança e policiamento & 0,00172 & 0,05265 \\
\hline Congestionamento & 0,00169 & 0,05201 \\
\hline Distribuição e eficiência do sistema público de educação & 0,00169 & 0,05201 \\
\hline Distribuição e eficiência da sinalização das vias públicas & 0,00152 & 0,04667 \\
\hline Pouca diversificação e integração dos modos de transporte & 0,00146 & 0,04483 \\
\hline Defasagem do planejamento viário & 0,00132 & 0,04068 \\
\hline Ocupações irregulares & 0,00132 & 0,04068 \\
\hline Poluição sonora e atmosférica & 0,00132 & 0,04068 \\
\hline $\begin{array}{c}\text { Pouca quantidade e distribuição de faixas exclusivas de } \\
\text { ônibus }\end{array}$ & 0,00132 & 0,04068 \\
\hline Falta de manutenção das ciclovias & 0,00130 & 0,03986 \\
\hline Pouco adensamento populacional & 0,00124 & 0,03819 \\
\hline Manutenção das vias e espaços públicos & 0,00114 & 0,03514 \\
\hline Distribuição e eficiência do sistema público de saúde & 0,00113 & 0,03470 \\
\hline Trabalho informal - "ambulantes" & 0,00113 & 0,03470 \\
\hline Lixo & 0,00101 & 0,03115 \\
\hline Malhas ferroviárias pouco desenvolvidas & 0,00101 & 0,03115 \\
\hline Custo de vida & 0,00097 & 0,02991 \\
\hline Iluminação & 0,00076 & 0,02327 \\
\hline Centralização da oferta de empregos e serviços & 0,00063 & 0,01949 \\
\hline Distribuição e eficiência dos serviços de comunicação & 0,00052 & 0,01597 \\
\hline Inundações e alagamentos nas vias públicas & 0,00050 & 0,01552 \\
\hline Melhor distribuição e organização dos comércios & 0,00050 & 0,01552 \\
\hline Habitações de interesse social & 0,00038 & 0,01170 \\
\hline Terrenos e lotes subutilizados & 0,00037 & 0,01154 \\
\hline Higienização das vias públicas & 0,00034 & 0,01059 \\
\hline Distribuição e eficiência do sistema sanitário & 0,00025 & 0,00772 \\
\hline
\end{tabular}

Fonte: O Autor (2019)

Para o grupo 2 são prioritários problemas quanto a divulgação de oportunidades de participação pública, trânsito e outras questões ligadas ao transporte, e novamente se 
apresentam outros problemas que até então não se revelavam como importantes, tais como o vandalismo e a insuficiência de lixeiras, conforme tabela 124. É importante ressaltar que as alternativas localizadas na base da hierarquia não significam que não são importantes, mas que a dificuldade de ação nela é complexa e as alternativas tem dificuldade de atuação na sua resolução.

Tabela 124 - Cálculo do IPG-P para o grupo 2

\begin{tabular}{|c|c|c|}
\hline Problemas & IPG-P & $\begin{array}{c}\text { IPG-P - } \\
\text { Normalizado }\end{array}$ \\
\hline Divulgação de oportunidades de participação pública & 0,00517 & 0,12353 \\
\hline Trânsito e saturação das vias & 0,00431 & 0,10302 \\
\hline Vandalismo e insuficiência das lixeiras & 0,00398 & 0,09502 \\
\hline Tempo de espera do transporte público & 0,00353 & 0,08448 \\
\hline Áreas verdes & 0,00345 & 0,08241 \\
\hline Integração do transporte público & 0,00323 & 0,07713 \\
\hline Iluminação & 0,00230 & 0,05494 \\
\hline Violência e segurança & 0,00208 & 0,04966 \\
\hline Qualidade do transporte público & 0,00190 & 0,04543 \\
\hline Pavimentação & 0,00172 & 0,04121 \\
\hline Poluição sonora, visual e atmosférica & 0,00153 & 0,03667 \\
\hline Planejamento desorganizado das Calçadas & 0,00150 & 0,03592 \\
\hline Acessibilidade & 0,00129 & 0,03086 \\
\hline Centros comerciais & 0,00124 & 0,02958 \\
\hline Crescimento desordenado & 0,00082 & 0,01968 \\
\hline Geração de lixo & 0,00075 & 0,01796 \\
\hline Deficiência de equipamentos educacionais & 0,00066 & 0,01585 \\
\hline Projetos sociais & 0,00063 & 0,01511 \\
\hline Ciclo faixas mal projetadas & 0,00057 & 0,01370 \\
\hline Deficiência de equipamentos de saúde & 0,00038 & 0,00914 \\
\hline Deficiência de equipamentos culturais & 0,00022 & 0,00531 \\
\hline Percurso longo do transporte público & 0,00022 & 0,00531 \\
\hline Imóveis e terrenos abandonados & 0,00021 & 0,00504 \\
\hline Deficiência de equipamentos de lazer & 0,00013 & 0,00305 \\
\hline
\end{tabular}

Fonte: O Autor (2019)

Para o grupo 3, são prioritários os problemas quanto à segurança, às ocupações irregulares e à falta de acessibilidade, por exemplo, conforme tabela 125. Neste grupo, diferente dos 
anteriores, os problemas ligados ao transporte não estão entre os mais importantes, por outro lado, surgem problemas interessantes, tais como o estimulo à métodos de ensino inovadores e a falta de espaços para humanização, engajamento e democracia. A proposta metodológica, com estes índices, não objetiva comparar os grupos entre si, mas ampliar o número de problemas e posicioná-los em uma ordem hierárquica para cada grupo.

Tabela 125 - Cálculo do IPG - P para o grupo 3

\begin{tabular}{|c|c|c|}
\hline Problemas & IPG-P & $\begin{array}{c}\text { IPG-P - } \\
\text { Normalizado }\end{array}$ \\
\hline Segurança & 0,01252 & 0,21479 \\
\hline Ocupações irregulares & 0,00835 & 0,14320 \\
\hline Falta de acessibilidade & 0,00557 & 0,09546 \\
\hline Moradores de rua & 0,00521 & 0,08945 \\
\hline Atendimento à saúde & 0,00418 & 0,07165 \\
\hline Alagamentos & 0,00301 & 0,05165 \\
\hline Área verdes & 0,00294 & 0,05039 \\
\hline Zeladoria urbana & 0,00278 & 0,04773 \\
\hline $\begin{array}{l}\text { Falta de espaços para humanização, engajamento e } \\
\text { democracia }\end{array}$ & 0,00255 & 0,04378 \\
\hline Estimulo a métodos de ensino inovadores & 0,00209 & 0,03583 \\
\hline Falta de mobilidade & 0,00185 & 0,03170 \\
\hline Conflito de interesses imobiliários e sociais & 0,00174 & 0,02982 \\
\hline Ausência de programa de integração social & 0,00162 & 0,02782 \\
\hline Centralização industrial & 0,00155 & 0,02653 \\
\hline $\begin{array}{l}\text { Falta de senso de comunidade e união para serviços no } \\
\text { bairro }\end{array}$ & 0,00077 & 0,01326 \\
\hline Apropriação de espaços ociosos & 0,00068 & 0,01170 \\
\hline Falta de espaços de cultura e lazer & 0,00062 & 0,01060 \\
\hline Deficiências na promoção da cultura na cidade & 0,00027 & 0,00464 \\
\hline
\end{tabular}
Fonte: Do Autor (2019).

Para o grupo 4, o que se nota, é prioridade a ação para enfrentamento de problemas associados ao transporte, tais como, a falta de opção de transporte público, a baixa qualidade do transporte público e a falta de integração entre os modais de transporte, conforme tabela 126. Interessante notar, que questões quanto a poluição sonora, visual e atmosférica também são 
discutidas e, conforme os participantes, podem ser hierarquizadas superiormente à falta de estabelecimentos de ensino.

Tabela 126 - Cálculo do IPG-P para o grupo 4

\begin{tabular}{|c|c|c|}
\hline Problemas & IPG-P & IPG-P - Normalizado \\
\hline Faltam opções de transporte público & 0,00912 & 0,18008 \\
\hline Baixa Qualidade do transporte público & 0,00622 & 0,12286 \\
\hline Integração do transporte público & 0,00608 & 0,12011 \\
\hline Não existem centros comerciais & 0,00487 & 0,09612 \\
\hline Ausência de oferta de empregos & 0,00345 & 0,06806 \\
\hline Violência e segurança & 0,00325 & 0,06412 \\
\hline Geração de lixo & 0,00271 & 0,05345 \\
\hline Falta iluminação & 0,00257 & 0,05074 \\
\hline Trânsito e saturação das vias & 0,00223 & 0,04406 \\
\hline Percurso longo do transporte público & 0,00176 & 0,03473 \\
\hline Planejamento das calçadas & 0,00135 & 0,02666 \\
\hline Pavimentação precária & 0,00122 & 0,02406 \\
\hline Áreas verdes insuficientes e mal distribuídas & 0,00122 & 0,02400 \\
\hline Deficiência de equipamentos de saúde & 0,00101 & 0,01999 \\
\hline Poluição sonora, visual e atmosférica & 0,00074 & 0,01466 \\
\hline Falta equipamentos culturais & 0,00061 & 0,01200 \\
\hline Faltam opções de lazer & 0,00059 & 0,01166 \\
\hline Crescimento desordenado & 0,00051 & 0,00999 \\
\hline Grandes áreas abandonadas & 0,00051 & 0,00999 \\
\hline Ciclo faixas mal projetadas & 0,00034 & 0,00666 \\
\hline Falta de estabelecimentos de ensino & 0,00030 & 0,00600 \\
\hline
\end{tabular}

Fonte: Do Autor (2019).

Se por um lado o Índice Hierárquico de Alternativas (IHA) permite a hierarquização das alternativas a partir da dificuldade de sua implantação, seja técnica, econômica, política ou de aceitação popular, por outro lado o IGA-A $(h)$ permite a hierarquização das alternativas a partir do atendimento aos problemas, ou seja, a abrangência da alternativa. Nesta direção é possível 
incorporar a hierarquização da dificuldade de implantação de uma alternativa à sua abrangência com o Índice Priorizador Geral de Alternativas (IPG-A).

Para o grupo 1, conforme tabela 127, nota-se que a população hierarquiza como prioritárias a as alternativas ligadas a maior ocupação em áreas livres abandonadas, a definição de altura máxima para muros, a ampliação das plataformas de informação, o incentivo a ampliação das calçadas, a ampliação da ocupação do solo e uma maior disciplina para a ocupação de áreas livres abandonadas.

A interpretação dessa hierarquia deve ser feita cuidadosamente, pois quando da sistematização das soluções, elas forem desdobradas em duas possibilidades, por exemplo, a alternativa foi escrita pelos participantes apenas como " áreas verdes", quando inserida nos painéis, ela é associada de duas formas, uma como "incentivar as áreas verdes" e a outra como "desincentivar as áreas verdes"- para evitar vieses no modelo, a hierarquia pode trazer estas duas alternativas, contudo a interpretação dos mapas falantes -como ferramenta de apoio, complementarmente, pode ajudar a descartar as alternativas, que podem não ser favoráveis, como por exemplo o desincentivo aos usos mistos, o desincentivo ao adensamento populacional e a redução das áreas verde.

O que se nota é que duas alternativas - maior ocupação em áreas livres abandonadas e a definição para altura máxima de muros, juntas, representam, mais do que todas as demais somadas, hierarquicamente, neste grupo particularmente, as áreas verdes , tanto o incentivo quanto o desincentivo, estão muito próximas, contudo para este grupo, neste momento, a redução das áreas verdes é encarada como prioritária comparativamente a ampliação das áreas verdes, isto pode confirmar a prioridade que se dá para a ampliação do uso do solo, sugerida neste grupo.

Tabela 127 - IPG-A para o grupo 1

\begin{tabular}{ccc}
\hline Alternativas & IPG-A & IPG-A - Normalizado \\
\hline Maior ocupação em áreas livres abandonadas & 0,013087 & 0,337402 \\
Definição para altura máxima de muros & 0,009359 & 0,241280 \\
Ampliar Plataformas de Informação & 0,004012 & 0,103421 \\
Incentivo a ampliação da largura das calçadas & 0,003139 & 0,080922 \\
Ampliação da ocupação do solo & 0,001894 & 0,048827 \\
Disciplinar a ocupação em áreas livres abandonadas & 0,001596 & 0,041147
\end{tabular}

Continua. 
Continuação.

$\begin{array}{ccc}\text { Incentivar usos industriais na região } & 0,001064 & 0,027431 \\ \text { Descentralizar a oferta de empregos } & 0,001030 & 0,026542 \\ \text { Incentivar o adensamento populacional } & 0,000956 & 0,024642 \\ \text { Incentivar a oferta de empregos } & 0,000355 & 0,009139 \\ \text { Desincentivo ao adensamento populacional } & 0,000307 & 0,007910 \\ \text { Desincentivo à ampliação da largura das calçadas } & 0,000289 & 0,007453 \\ \text { Incentivar usos mistos } & 0,000266 & 0,006858 \\ \text { Desincentivo ao usos mistos } & 0,000266 & 0,006858 \\ \text { Redução de áreas verdes nos edifícios } & 0,000266 & 0,006858 \\ \text { Ampliação de áreas verdes nos edifícios } & 0,000266 & 0,006845 \\ \text { Incentivar a captação energéticas nos edifícios } & 0,000236 & 0,006084 \\ \text { Incentivar o uso do racional de veículo individual } & 0,000213 & 0,005486 \\ \text { Redução da ocupação do solo } & 0,000177 & 0,004563 \\ \text { Desincentivo ao uso do veículo individual } & 0,000013 & 0,000335\end{array}$

Fonte: Do Autor (2019).

Para o grupo 2, o favorecimento à instalação de edifícios, à ampliação de áreas verdes, ao incentivo a usos comerciais e de serviços, ao desincentivo a instalação de muros e ao incentivo aos usos mistos, são as alternativas que se destacam, conforme tabela 128. As alternativas interpretadas a partir dos mapas falantes como negativas estão na parte inferior como por exemplo regras que favoreçam o transporte individual e o desincentivo aos usos mistos, conforme tabela 128 . Nota-se que três alternativas - o favorecimento à instalação de edifícios, à ampliação de áreas verde e ao incentivo a usos comerciais representam, juntas, mais do que todas as demais somadas.

Tabela 128 - Cálculo do IPG-A para o grupo 2

\begin{tabular}{ccc}
\hline Alternativas & IPG-A & $\begin{array}{c}\text { IPG-A - } \\
\text { Normalizado }\end{array}$ \\
\hline Favorecer a instalação de edifícios & 0,01064 & 0,24962 \\
Ampliação de áreas verdes nos edifícios & 0,00927 & 0,21764 \\
Incentivar usos comerciais e de serviços & 0,00480 & 0,11262 \\
Desincentivar a instalação de muros e grades & 0,00337 & 0,07915 \\
& & Continua.
\end{tabular}


Continuação.

\begin{tabular}{cll} 
Incentivar edifícios ou imóveis com usos mistos & 0,00318 & 0,07457 \\
Integração entre espaços públicos e privados & 0,00301 & 0,07052 \\
Definição de regras para iluminação nos edifícios & 0,00195 & 0,04566 \\
Definição de regras para conservação de áreas verdes & 0,00188 & 0,04414 \\
Incentivar usos industriais & 0,00169 & 0,03957 \\
Incentivar a instalação de muros e grades & 0,00110 & 0,02587 \\
Desincentivar edifícios e imóveis com usos mistos & 0,00052 & 0,01218 \\
Redução de áreas verdes nos edifícios & 0,00052 & 0,01218 \\
Regras para desincentivar as vias para fluidez do transporte & 0,00025 & 0,00586 \\
individual & 0,00015 & 0,00344 \\
Áreas construídas mínimas com sistemas sustentáveis & 0,00014 & 0,00338 \\
Definição de regras para sistemas de segurança nos edifícios & 0,000216 \\
Controle de emissão de poluentes nas edificações & 0,00009 & 0,00216 \\
Restringir a instalação de edifícios & 0,00003 & 0,00068 \\
Regras para favorecer as vias para fluidez do transporte & 0,00002 & 0,00049 \\
individual & 0,00001 & 0,00015 \\
Desincentivar usos comerciais e de serviços & 0,00001 & 0,00015 \\
\hline
\end{tabular}

Fonte: Do Autor (2019).

Para o grupo 3 , as alternativas que se destacam são o favorecimento ao uso comercial, a indução para a construção de edifícios comerciais com áreas de trabalho colaborativos e proporcionar novos canais para participação e ação das pessoas, por outro lado, para este grupo não há uma prioridade para ações sustentáveis, uma vez que a ampliação, com estimulo e regras, para as construções sustentáveis, e maior restrição ao uso dos recursos naturais figuram na parte inferior da hierarquia, conforme tabela 129.

Possivelmente, para esta população, existem questões que as atinge na atualidade como transporte, emprego e moradia, que são emergentes e imediatas. 
Tabela 129 - Cálculo do IPG-A para o grupo 3

\begin{tabular}{|c|c|c|}
\hline Alternativas & IPG-A & IPG-A - Normalizado \\
\hline Incentivar e favorecer o uso comercial & 0,02101 & 0,30556 \\
\hline $\begin{array}{l}\text { Induzir a construção de edifícios comerciais com áreas } \\
\text { de trabalho colaborativos }\end{array}$ & 0,01760 & 0,25599 \\
\hline $\begin{array}{l}\text { Proporcionar novos canais para participação e ação das } \\
\text { pessoas }\end{array}$ & 0,00398 & 0,05782 \\
\hline Ampliação de áreas verdes nos edifícios & 0,00397 & 0,05775 \\
\hline Ampliar e incentivar o transporte publico & 0,00378 & 0,05502 \\
\hline $\begin{array}{c}\text { Uso compulsório de áreas ociosas para atividades } \\
\text { coletivas }\end{array}$ & 0,00378 & 0,05502 \\
\hline Ampliar corredores de ônibus & 0,00315 & 0,04587 \\
\hline Favorecer a instalação de edificações populares & 0,00312 & 0,04539 \\
\hline $\begin{array}{l}\text { Induzir ou incentivar a construção de equipamentos e } \\
\text { edifícios de uso cultural }\end{array}$ & 0,00152 & 0,02205 \\
\hline Promover a regularização de imóveis já construídos & 0,00142 & 0,02068 \\
\hline $\begin{array}{c}\text { Incentivar a instalação de equipamentos e edificações } \\
\text { para serviços de saúde }\end{array}$ & 0,00114 & 0,01652 \\
\hline Ampliar espaços públicos para população idosa & 0,00113 & 0,01648 \\
\hline $\begin{array}{c}\text { Favorecer e incentivas a instalação de equipamentos e } \\
\text { edificações para uso religiosos }\end{array}$ & 0,00085 & 0,01239 \\
\hline $\begin{array}{l}\text { Promover a instalação de espaços para oferecimento de } \\
\text { alimentação de baixo custo }\end{array}$ & 0,00076 & 0,01099 \\
\hline Restringir a instalação de muros nas edificações & 0,00050 & 0,00733 \\
\hline $\begin{array}{l}\text { Definir regras mais duras para atendimento de } \\
\text { acessibilidade nas edificações e espaços públicos }\end{array}$ & 0,00038 & 0,00551 \\
\hline $\begin{array}{l}\text { Definir regras mais restritivas para utilização dos } \\
\text { recursos naturais na construção }\end{array}$ & 0,00038 & 0,00551 \\
\hline $\begin{array}{c}\text { Ampliar e definir regras para estimular construções } \\
\text { sustentáveis }\end{array}$ & 0,00028 & 0,00413 \\
\hline
\end{tabular}

Fonte: Do Autor (2019).

Para o grupo 4, ao se hierarquizar de forma ampliada as alternativa, conforme a valoração dos participantes serão prioritárias, a ampliação da ocupação do solo, o favorecimento ao uso de bicicletas e o favorecimento de usos comerciais na região, quando somadas, estas alternativas, correspondem a mais do que a somatória da hierarquia associada a todas as outras alternativas, conforme tabela 130.

Tabela 130 - Cálculo do IPG-A para o grupo 4

\begin{tabular}{ccc}
\hline Alternativas & IPG-A & IPG-A - Normalizado \\
\hline Ampliação da ocupação do solo & 0,01579 & 0,23444 \\
Favorecer o uso de bicicletas & 0,01164 & 0,17288 \\
Favorecer usos comerciais e de serviços na região & 0,00719 & 0,10678 \\
Favorecer o uso do transporte publico & 0,00599 & 0,08891 \\
Incentivo à instalação de residências & 0,00565 & 0,08397 \\
Ampliação de áreas verdes nos edifícios & 0,00513 & 0,07623 \\
Regras para desincentivar o transporte individual & 0,00479 & 0,07113
\end{tabular}

Continua. 
Incentivar a captação energéticas nos edifícios Incentivar usos mistos na região

Estimular a ocupação de áreas abandonadas

Desincentivo à instalação de residências

Ampliar as áreas construídas nas edificações

Restringir a instalação de edifícios altos

Integrar área dos edifícios a área publica

Incentivo a ampliação da largura das calçadas

Incentivar usos industriais na região

Redução de áreas verdes nos edifícios

Redução da ocupação do solo

$\begin{array}{rr}0,00285 & \text { Contin } \\ 0,00257 & 0,03812 \\ 0,00154 & 0,02289 \\ 0,00154 & 0,02289 \\ 0,00068 & 0,01015 \\ 0,00060 & 0,00889 \\ 0,00060 & 0,00889 \\ 0,00051 & 0,00763 \\ 0,00011 & 0,00170 \\ 0,00009 & 0,00128 \\ 0,00006 & 0,00085\end{array}$

Continuação.

Fonte: Do Autor (2019).

\subsubsection{Avaliação total estratégica de todos os grupos de consulta}

Para se avaliar conjuntamente o processo de consulta realizado nos 4 diferentes grupos, foram calculados o Índice Estratégico Geral de Problemas (IEG-P) - que agrega a somatória hierárquica dos problemas que se observaram nos grupos, dado pela equação 58 , e o Índice Estratégico Geral de Alternativas (IEG-A) que agrega a somatória hierárquica das alternativas que foram observadas nos grupos, dado pela equação 59.

Conforme tabela 131, considerando todos os grupos, os problemas prioritários são ligados à mobilidade, tais como, à deficiência na qualidade, na quantidade e na integração da oferta de transporte público, à violência e segurança, às ocupações irregulares, à participação pública e ao engajamento e, por fim, às deficiências nos serviços públicos urbanos.

Tabela 131 - Cálculo do IEG-P para definição de estratégias

\begin{tabular}{|c|c|c|c|c|c|}
\hline \multirow[b]{2}{*}{ PROBLEMA } & \multicolumn{4}{|c|}{ IGP-P $_{(h)}$} & \multirow[b]{2}{*}{ IEG-P } \\
\hline & $\underset{1}{\text { Grupo }}$ & $\begin{array}{l}\text { Grupo } \\
2\end{array}$ & $\begin{array}{c}\text { Grupo } \\
\mathbf{3}\end{array}$ & $\underset{4}{\text { Grupo }}$ & \\
\hline $\begin{array}{l}\text { Qualidade e quantidade de oferta do } \\
\text { transporte público e mobilidade }\end{array}$ & 0,05983 & 0,12991 & 0,03170 & 0,18008 & 0,40152 \\
\hline Violência e segurança & 0,05265 & 0,04966 & 0,21479 & 0,06412 & 0,38122 \\
\hline Integração do transporte público & 0,04483 & 0,07713 & - & 0,12011 & 0,24208 \\
\hline Ocupações irregulares & 0,04068 & - & 0,14320 & - & 0,18388 \\
\hline $\begin{array}{l}\text { Participação popular, engajamento e } \\
\text { mobilização social }\end{array}$ & - & 0,12353 & 0,05704 & - & 0,18057 \\
\hline Deficiência nos serviços urbanos & 0,16769 & - & - & - & 0,16769 \\
\hline
\end{tabular}


Continuação.

Área verdes

$\begin{array}{ccccc}- & 0,08241 & 0,05039 & 0,02400 & 0,15681 \\ 0,01059 & 0,09502 & 0,04773 & - & 0,15334 \\ - & 0,10302 & - & 0,04406 & 0,14707 \\ 0,01552 & 0,02958 & - & 0,09612 & 0,14122 \\ 0,02327 & 0,05494 & - & 0,05074 & 0,12896 \\ - & 0,03086 & 0,09546 & - & 0,12632 \\ - & - & - & 0,12286 & 0,12286 \\ 0,03115 & 0,01796 & - & 0,05345 & 0,10257 \\ 0,04068 & 0,03667 & - & 0,01466 & 0,09202\end{array}$

Moradores de rua

Falta, distribuição e eficiência do

sistema público de educação

Deficiência de ofertas de habitações de interesse social

Atendimento à saúde

Ausência de oferta de empregos

Inundações e Alagamentos

Pavimentação

$0,05201 \quad 0,01585$

0,08945

0,08945

$0,06097 \quad 0,01170$

$0,00600 \quad 0,07386$

(1)

Zeladoria urbana, higienização de

Trânsito e saturação das vias
- $\quad$ - $0,07165 \quad$ - 0,07165
- $\quad$ - $\quad$ - $\quad 0,068060,06806$

$0,01552 \quad-0,05165 \quad-\quad 0,06717$

Distribuição e Deficiência de

equipamentos de saúde

Deficiências no planejamento das

$$
\text { calçadas }
$$$$
\begin{array}{lllll}
- & 0,04121 \quad 0,02406 & 0,06526
\end{array}
$$

$\begin{array}{lllll}0,03470 & 0,00914 & - & 0,01999 & 0,06382\end{array}$

$\begin{array}{lllll}- & 0,03592 \quad 0,02666 & 0,06259\end{array}$

Ciclo faixas mal projetadas e

manutenção inadequada

$\begin{array}{lllll}0,03986 & 0,01370 \quad-\quad 0,00666 & 0,06022\end{array}$

Congestionamento e Saturação das Vias

0,05201

- $\quad 0,05201$

Planejamento do viário

0,04068

- 0,04068

Faixas exclusivas para ônibus

0,04068

- 0,04068

Percurso longo do transporte público

Pouco adensamento populacional

0,03819

0,00531

$0,03473 \quad 0,04004$

Estimulo a métodos de ensino inovadores

Trabalho informal - "ambulantes"

0,03470

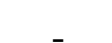

0,03819

- $0,03583 \quad$ - 0,03583

$\begin{array}{llll}- & - & - & -\end{array}$

Continua. 
Continuação.

Malhas ferroviárias pouco desenvolvidas

$\begin{array}{lllll}0,03115 & - & - & - & 0,03115 \\ 0,02991 & - & - & - & 0,02991\end{array}$

Custo de vida

Conflito de interesses imobiliários e sociais

Crescimento desordenado

Ausência de programa de integração social

Áreas abandonadas e/ou subutilizadas

$\begin{array}{lllll}0,01154 & 0,00504 & - & 0,00999 & 0,02657\end{array}$

Centralização Industrial

Deficiência na oferta de opções de lazer

Deficiência na oferta de cultura

Oferta de empregos e serviços

0,01949

0,02982

0,02982

$-\quad 0,01968$

0,00999

0,02967

Projetos sociais

$-\quad 0,01511$

0,02653

0,02653

$\begin{array}{lllll}- & 0,00305 & 0,01060 & 0,01166 & 0,02531\end{array}$

$\begin{array}{lllll}- & 0,00531 & 0,00464 & 0,01200 & 0,02194\end{array}$

Apropriação de espaços ociosos

Fonte: Do Autor (2019).

A hierarquização das alternativas, considerando todos os grupos, aponta que o incentivo aos usos comerciais e de serviço, a maior ocupação e aproveitamento de áreas ociosas, à ampliação de áreas verdes nos edifícios e à restrição para construção de muros e grades são alternativas que devem ser priorizadas, conforme tabela 132.

Tabela 132 - Cálculo do IEG -A para definição de estratégias

\section{ALTERNATIVAS}

IGP-A $(h)$

Grupo 1 Grupo 2 Grupo 3 Grupo 4

IEG -A

\begin{tabular}{ccccccc}
\hline $\begin{array}{c}\text { Incentivo a usos comerciais e de } \\
\text { serviço }\end{array}$ & - & 0,11262 & 0,56155 & 0,10678 & 0,78095 \\
$\begin{array}{c}\text { Ocupação e maior aproveitamento de } \\
\text { áreas ociosas }\end{array}$ & 0,37855 & - & 0,05502 & 0,02289 & 0,45645 \\
$\begin{array}{c}\text { Ampliação de áreas verdes nos } \\
\text { edifícios }\end{array}$ & 0,00684 & 0,26177 & 0,05775 & 0,07623 & 0,40260 \\
$\begin{array}{c}\text { Restrições para construção de muros } \\
\text { Ampliação da ocupação do solo }\end{array}$ & 0,24128 & 0,07915 & 0,00733 & - & 0,32775 \\
$\begin{array}{c}\text { Favorecer a construção de edifícios e } \\
\text { ampliação de áreas construídas }\end{array}$ & - & 0,24962 & - & 0,01015 & 0,25977 \\
& & & & & 0,23444 & 0,28327 \\
& & & & - & Continua.
\end{tabular}


Continuação.

Ampliação do transporte publico

Favorecer o uso de Bicicletas

Ampliar canais de participação popular e engajamento

Incentivar a construção de moradias e ao adensamento populacional Incentivo a ampliação da largura das calçadas

Desincentivo ao uso do transporte individual

Integração de espaços públicos e privados

Incentivar usos mistos

Incentivar usos industriais

Incentivar a captação energéticas nos Edifícios

Definição de regras para iluminação nos edifícios

Incentivar usos mistos

Incentivar e Descentralizar a oferta de empregos

Incentivar a instalação de grades e muros

Desincentivo à instalação de residências

Induzir ou incentivar a construção de equipamentos e edifícios de uso cultural

Promover a regularização de imóveis já construídos

Redução de áreas verdes nos edifícios

Desincentivar usos mistos

Incentivar a instalação de equipamentos e edificações para serviços de saúde

Ampliar espaços públicos para população idosa

Estimular de definir regras para construções sustentáveis

Favorecer e incentivas a instalação de equipamentos e edificações para uso religiosos

\begin{tabular}{|c|c|c|c|c|}
\hline- & - & 0,10089 & 0,08891 & 0,18980 \\
\hline- & - & - & 0,17288 & 0,17288 \\
\hline 0,10342 & - & 0,05782 & - & 0,16124 \\
\hline 0,02464 & - & 0,04539 & 0,08397 & 0,15400 \\
\hline 0,08092 & - & - & 0,00763 & 0,08855 \\
\hline 0,00582 & 0,00586 & - & 0,07113 & 0,08281 \\
\hline- & 0,07052 & - & 0,00889 & 0,07941 \\
\hline- & 0,07457 & - & - & 0,07457 \\
\hline 0,02743 & 0,03957 & - & 0,00170 & 0,06871 \\
\hline 0,00608 & - & - & 0,04237 & 0,04845 \\
\hline- & 0,04566 & - & - & 0,04566 \\
\hline 0,00686 & - & - & 0,03812 & 0,04497 \\
\hline 0,02654 & - & 0,00914 & - & 0,03568 \\
\hline- & 0,02587 & - & - & 0,02587 \\
\hline- & - & - & 0,02289 & 0,02289 \\
\hline- & - & 0,02205 & - & 0,02205 \\
\hline- & - & 0,02068 & - & 0,02068 \\
\hline 0,00686 & 0,01218 & - & 0,00128 & 0,02031 \\
\hline 0,00686 & 0,01218 & - & - & 0,01903 \\
\hline- & - & 0,01652 & - & 0,01652 \\
\hline- & - & 0,01648 & - & 0,01648 \\
\hline- & 0,00559 & 0,00964 & - & 0,01523 \\
\hline- & - & 0,01239 & - & 0,01239 \\
\hline
\end{tabular}

Continua. 
Continuação.

Promover a instalação de espaços para oferecimento de alimentação de baixo custo

\begin{tabular}{|c|c|c|c|c|c|}
\hline Restringir a instalação de edifícios & . & 0,00068 & - & 0,00889 & 0,00957 \\
\hline $\begin{array}{c}\text { Desincentivo ao Adensamento } \\
\text { Populacional }\end{array}$ & 0,00791 & - & - & - & 0,00791 \\
\hline $\begin{array}{c}\text { Desincentivo à ampliação da largura } \\
\text { das calçadas }\end{array}$ & 0,00745 & - & - & - & 0,00745 \\
\hline $\begin{array}{l}\text { Definir regras mais duras para } \\
\text { atendimento de acessibilidade nas } \\
\text { edificações e espaços públicos }\end{array}$ & - & - & 0,00551 & - & 0,00551 \\
\hline Redução da Ocupação do Solo & 0,00456 & - & - & 0,00085 & 0,00541 \\
\hline $\begin{array}{c}\text { Definição de regras para sistemas de } \\
\text { segurança nos edifícios }\end{array}$ & - & 0,00338 & - & - & 0,00338 \\
\hline $\begin{array}{c}\text { Promover o uso do transporte } \\
\text { individual }\end{array}$ & - & 0,00049 & - & - & 0,00049 \\
\hline Desincentivar usos comerciais & - & 0,00015 & - & - & 0,00015 \\
\hline Desincentivar usos industriais & - & 0,00015 & - & - & 0,00015 \\
\hline
\end{tabular}

Fonte: Do Autor (2019).

Portanto na elaboração das políticas públicas, e consequentemente o planejamento das ações urbanas, devem seguir estratégias que por um lado trabalhe na ampliação e integração do transporte público com favorecimento dos usos comercias e de serviço, com um maior aproveitamento de áreas ociosas, por exemplo.

\subsubsection{Resultados do Formulário de Percepção}

O formulário de percepção foi dividido em três blocos. Ele foi aplicado no início do primeiro dia de atividades e no final do segundo dia, para avaliar se houve mudança da percepção das pessoas. O primeiro bloco incluiu seis perguntas referentes à caracterização do perfil dos participantes, com perguntas sobre idade, gênero, escolaridade, atividades que realiza na cidade e renda, de modo que suas respostas evidentemente não sofreram alterações.

O segundo bloco incluiu perguntas para avaliação da cidade e do bairro, com notas (0 para “péssimo", 1 para "ruim", 2 para "regular", 3 para "bom” e 4 para “excelente") a serem atribuídas para aspectos como segurança, qualidade dos serviços públicos, mobilidade, custo de vida, tempo de deslocamento na cidade, frequência de utilização do transporte público, utilização de espaços públicos e desejos sobre a cidade. 
Na primeira rodada, ou seja, antes das dinâmicas, $45 \%$ dos participantes classificaram o quesito segurança como ruim, $25 \%$ como regular, $20 \%$ como bom, e $10 \%$ como péssimo. Na segunda rodada, houve uma pequena migração de respostas: $45 \%$ classificaram como ruim, $25 \%$ como regular, $15 \%$ como boa, e $15 \%$ com péssimo.

Ou seja, houve uma migração das pessoas que haviam avaliado como regular para péssimo, conforme ilustrado nos gráficos da figura 100.

Figura 100 - Avaliação da Segurança na Área de Estudo

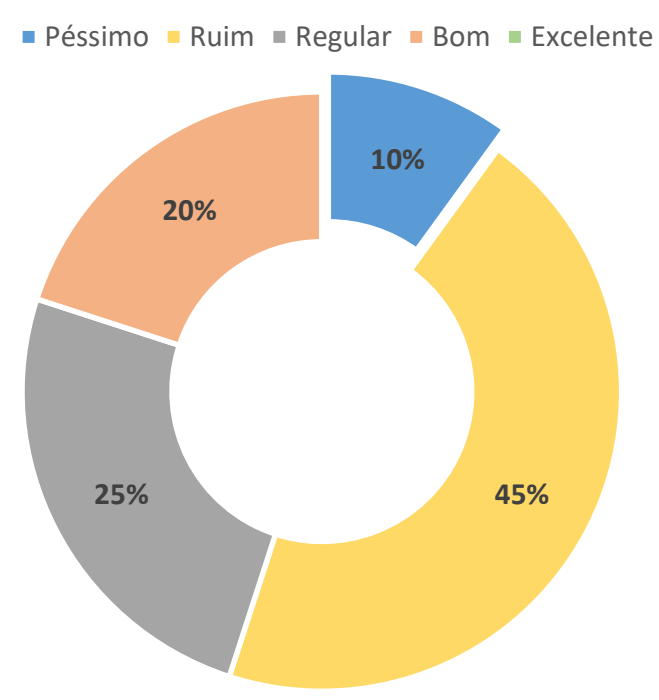

Antes da Dinâmica

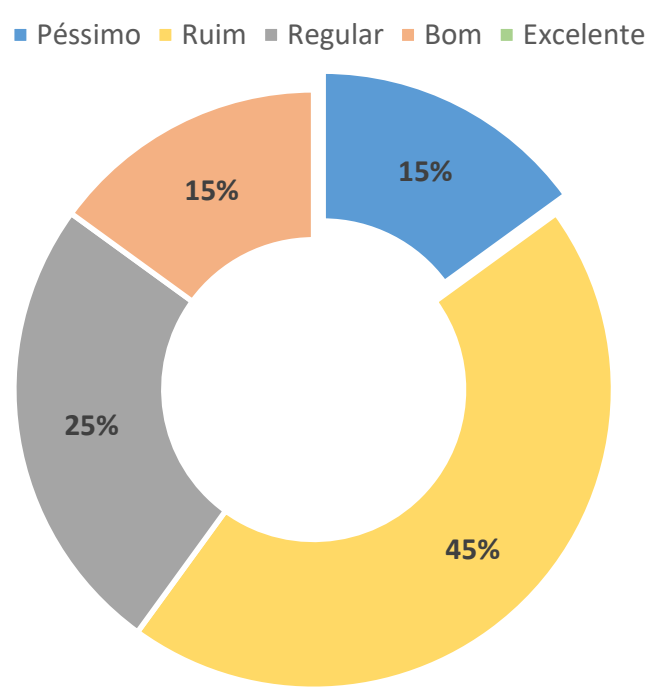

Depois da Dinâmica

Fonte: Do autor (2019).

Avaliando a qualidade dos serviços, ou seja, a qualidade dos hospitais, postos de saúde, escolas, creches, iluminação, limpeza das ruas e coleta de lixo, antes da aplicação das dinâmicas, o que se percebeu foi que $45 \%$ dos participantes avaliaram esse quesito com regular, $25 \%$ como ruim, $20 \%$ como bom e $10 \%$ como excelente. Após a realização das dinâmicas, por sua vez, $40 \%$ avaliaram como regular, $30 \%$ como bom e $30 \%$ como ruim.

O que se notou foi uma migração dos que o haviam avaliado como regular e excelente para ruim e bom, conforme ilustrado pela figura 101. No que tange à qualidade do transporte público, antes da aplicação das dinâmica, 55\% das pessoas julgaram-na regular, 25\% boa, 10\% excelente e $10 \%$ ruim. Após a aplicação das dinâmicas, o perfil de respostas aponta que 50\% avaliou o quesito como regular, $25 \%$ como boa, $15 \%$ como ruim e $10 \%$ como excelente. Houve uma migração dos que o haviam avaliado como regular para ruim, conforme ilustrado pela figura 102. 
Figura 101 - Avaliação dos Serviços na Área de Estudo

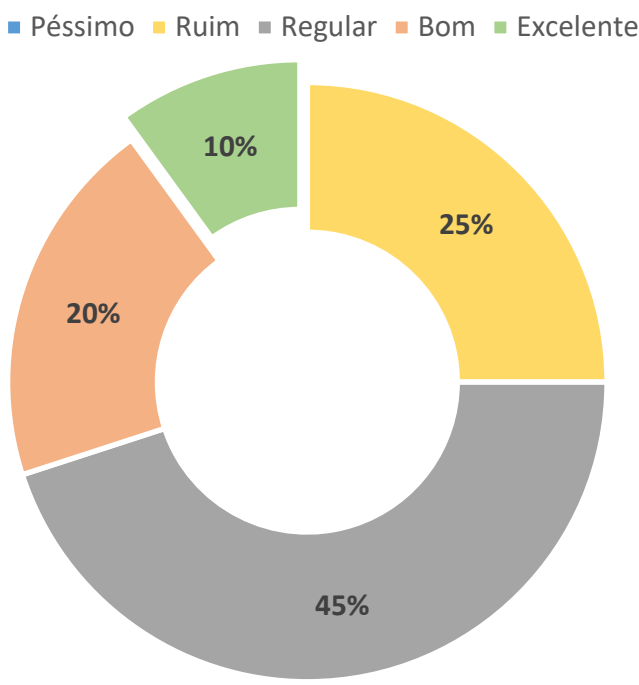

Antes da Dinâmica

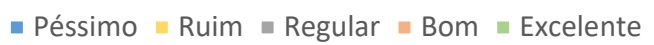

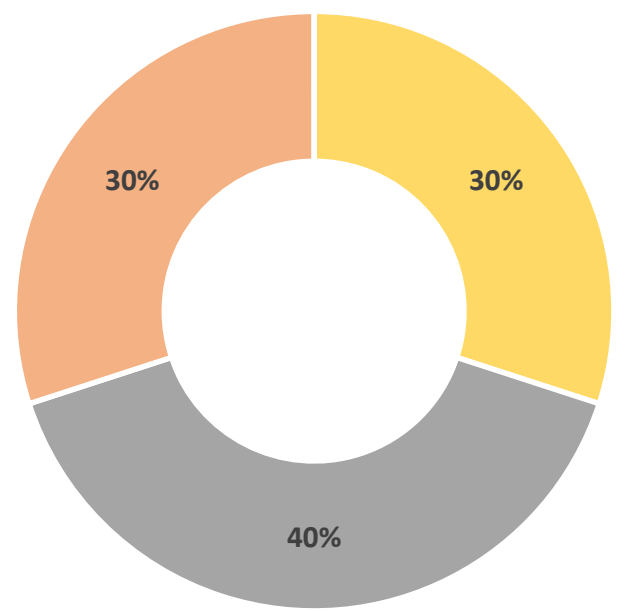

Depois da Dinâmica

Fonte: Do autor (2019).

No tocante à avaliação das opções de lazer, acerca tanto da quantidade quanto da qualidade (de praças, parques, clubes esportivos, museus, galerias e cinemas), antes da aplicação das dinâmicas, $40 \%$ da amostra avaliou o quesito com nota boa, 25\% regular, 15\% excelente, $15 \%$ ruim e 5\% péssimo. Após aplicação da dinâmica, 50\% da amostra avaliou com nota regular, $25 \%$ com nota boa, $15 \%$ ruim e $10 \%$ excelente.

Figura 102 - Avaliação do Transporte na Área de Estudo

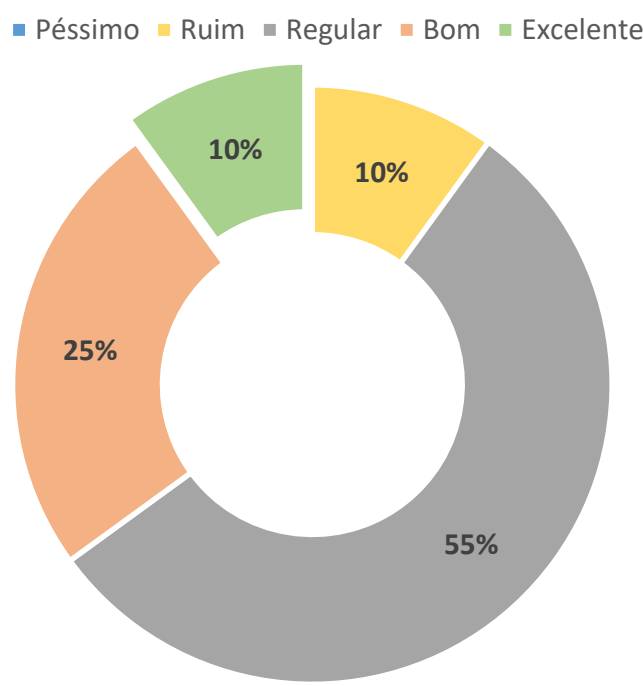

Antes da Dinâmica

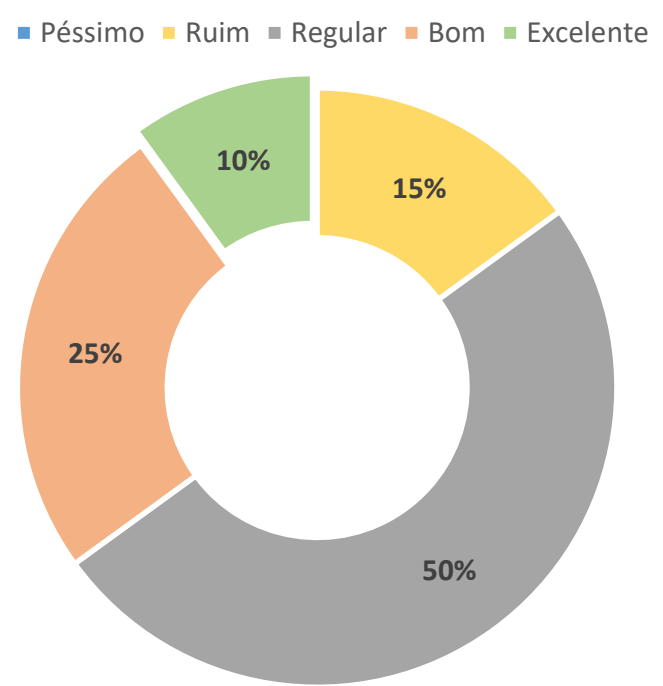

Depois da Dinâmica

Fonte: Do autor (2019).

O que se notou foi uma grande migração dos que haviam avaliado o quesito com nota boa para as notas regulares, conforme ilustra o gráfico da figura 103. 
Figura 103 - Avaliação do Lazer na Área de Estudo

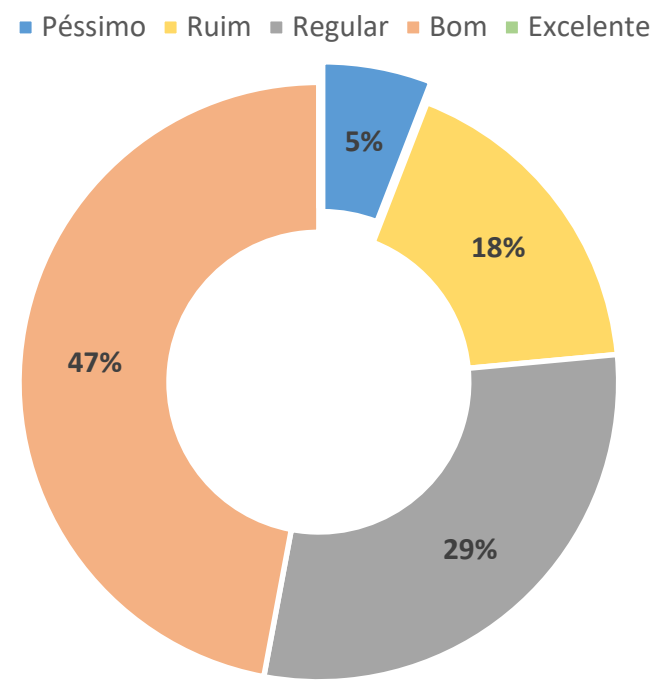

Antes da Dinâmica

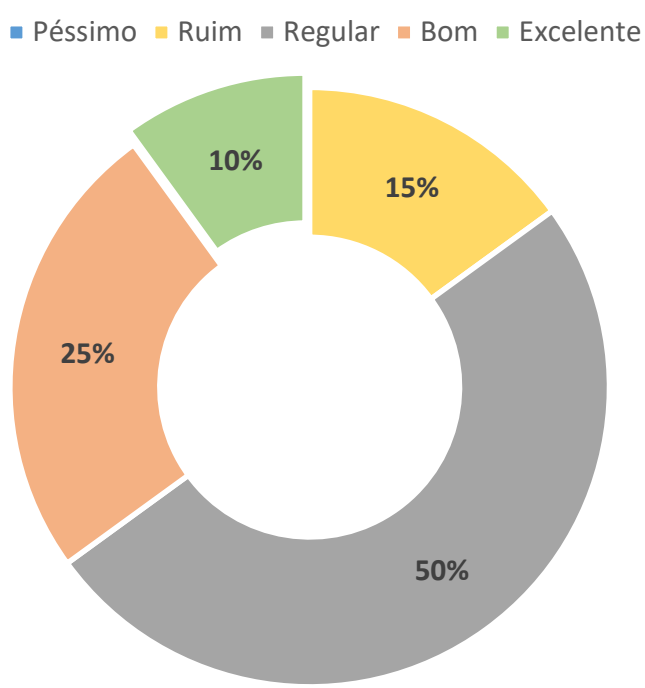

Depois da Dinâmica

Fonte: Do autor (2019).

Ao avaliar o custo de vida, considerando gastos com moradia, alimentação, transporte, saúde e educação, antes da aplicação das dinâmicas, as respostas apontaram uma avaliação de $40 \%$ com notas regulares, $35 \%$ com notas ruins, $20 \%$ com notas péssimas e $5 \%$ com notas boas. Após a aplicação das dinâmicas, a distribuição foi de $45 \%$ com notas ruins, $35 \%$ com notas regulares e 20\% com notas péssimas, conforme figura 104.

Figura 104 - Avaliação do custo de vida

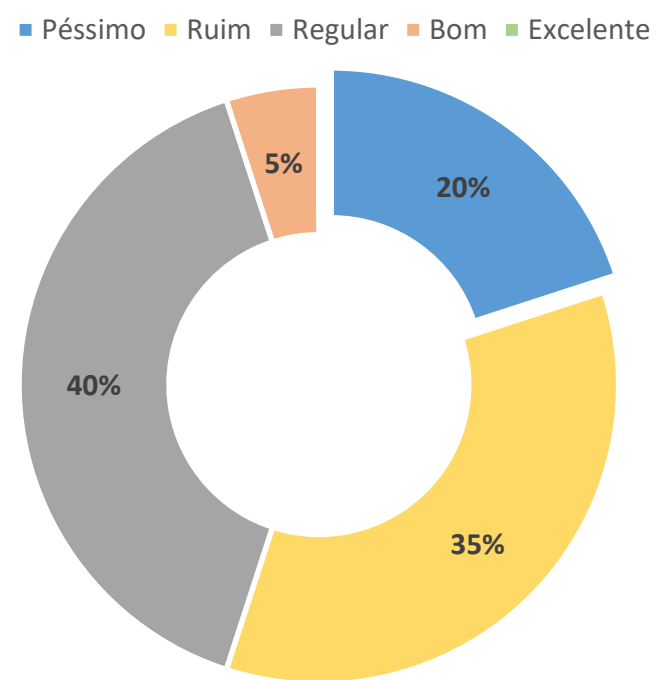

Antes da Dinâmica

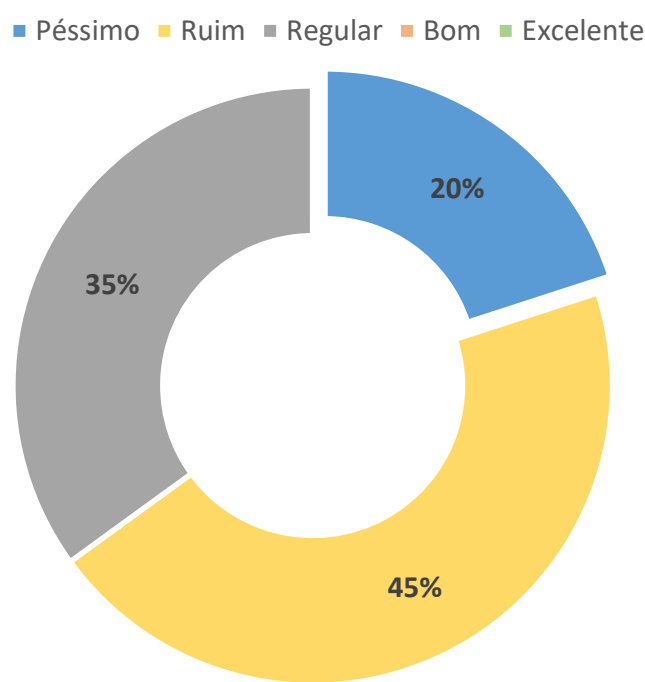

Depois da Dinâmica

Fonte: Do autor (2019).

Antes e depois da dinâmica, foi perguntado a respeito da descrição dos elementos que os sujeitos desejariam em uma bairro ou uma cidade ideal. Cabe notar que, entre as condições para a cidade ideal, existem soluções tanto na esfera pública, a exemplo de ampliação da rede de 
transportes, maior qualidade dos serviços públicos e transparência política, quanto na esfera pessoal, como consumo consciente e maior interação entre as pessoas, conforme figura 105.

Figura 105 - Considerações sobre o Bairro ou a Cidade Ideal - Antes da Aplicação das

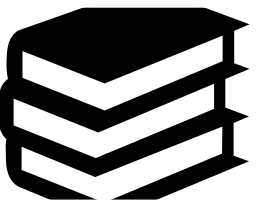

Educação de qualidade

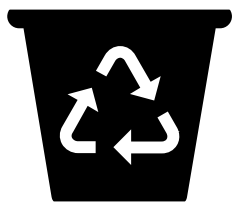

Redução da poluição

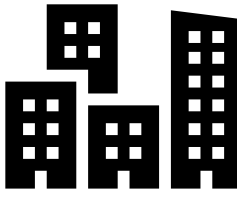

Aproximação entre moradia e trabalho

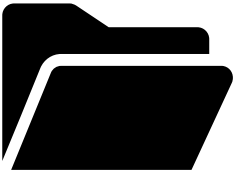

Transparência política

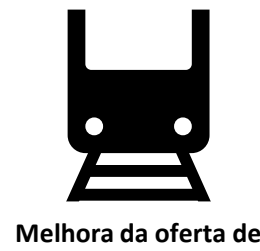
transporte

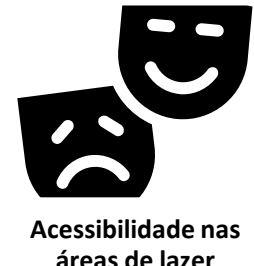

Dinâmicas

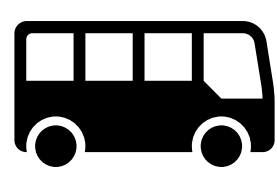

$$
\text { Intergração do }
$$
transporte público

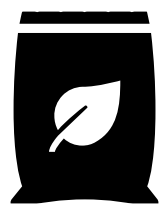

Consumo consciente

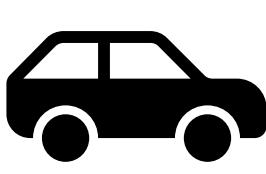

Melhor planejamento viário

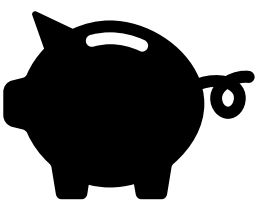

Custo de vida razoável

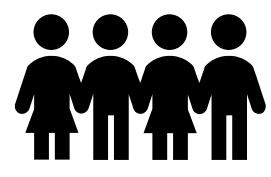

Maior interação entre as pessoas

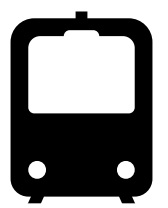

Ampliação na rede de transporte

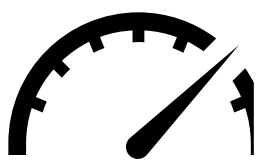

Qualidade dos serviçoes públicos

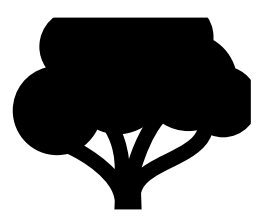

Ampliação das áreas verdes

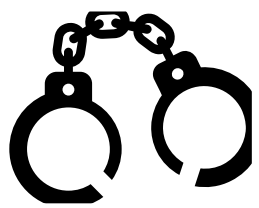

Segurança

Fonte: Do autor (2019).

O que se notou, antes de aplicar as dinâmicas, foi o número elevado de desejos associados a transporte e mobilidade, em suas diversas facetas, mas, curiosamente, uma demanda por maior interação entre as pessoas e a transparência política também foi manifestada pela população. Isso é positivo e vai na direção dos achados nas entrevistas realizadas anteriormente.

A mesma pergunta foi realizada após a aplicação das dinâmicas para avaliar se novas perspectivas de bairro ou cidade ideal foram listadas em função do suposto processo de aprendizado realizado no processo. Essa etapa apresentou as mudanças mais interessantes para a segunda entrega do questionário, de forma que surgiram várias novas resoluções para a obtenção da cidade ideal, bem como se mantiveram algumas das já citadas na primeira entrega. Persistiram as questões de responsabilidade da comunidade - como prática da coleta seletiva, participação social ativa e respeito pelo meio ambiente -, e surgiram questões mais específicas - como as tecnologias da construção civil e a conservação das calçadas -, além de questões globais - como a integração entre os setores político, econômico e social, a fim de atender 
diferentes interesses e chegar a um consenso para o desenvolvimento da cidade. Vê-se isso na ilustração da figura 106.

Figura 106 - Considerações sobre o Bairro ou a Cidade Ideal - Após a Aplicação das Dinâmicas

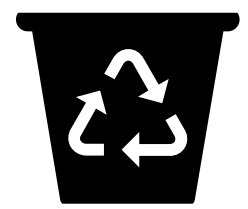

Coleta seletiva

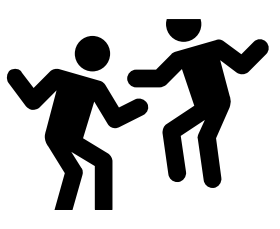

Conservação das calçadas

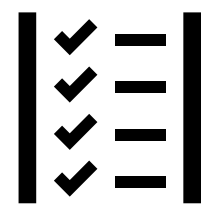

Qualidade nos serviços públicos

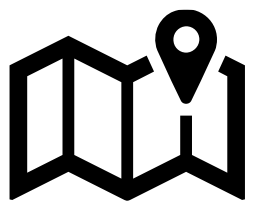

Maior detalhamento em projetos urbanos

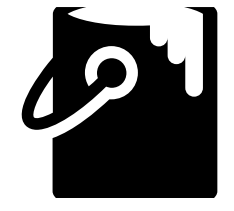

Novas tecnologias de construção

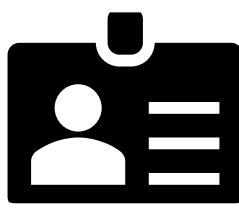

Ofertas descentralizadas de empregos

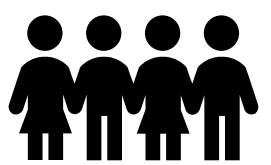

Particiapção social integrada ao governo

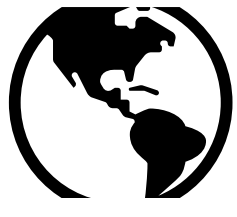

Incentivo à sustentabilidade

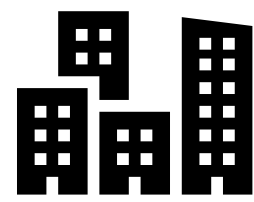

Resolver ocupações irregulares

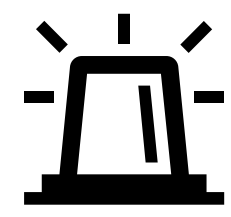

Melhor iluminação

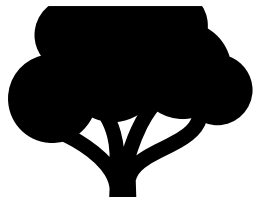

Respeito ao meio ambiente

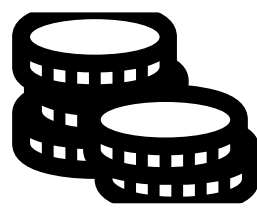

Custo de vida razoável

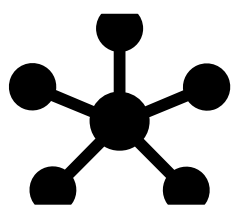

Concectivade social, econômica e política

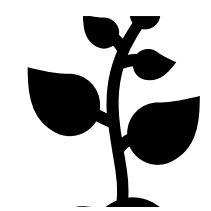

Ampliação de áreas verdes

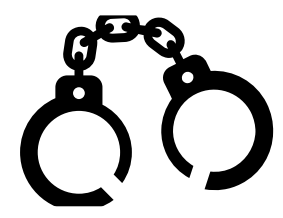

Segurança

Fonte: Do autor (2019).

$\mathrm{Na}$ segunda rodada, é interessante notar que surgiram outras questões, além das associadas ao transporte, demonstrando-se, dessa forma, a ampliação do repertório cidadão. Isso evidencia que a relação das pessoas com o transporte na realidade paulistana é uma questão latente, porém, após um processo de reflexão e de discussão, outras demandas também se apresentam e merecem ser discutidas no âmbito do planejamento urbano.

O terceiro e último bloco incluiu perguntas sobre política urbana, especificamente sobre o Plano Diretor do Município de São Paulo. O objetivo era apresentar, de forma rápida e simples, algumas das ideias propostas pelo Plano Diretor e obter uma primeira avaliação dos participantes. Uma das medidas dividiu opiniões: a redução do número de vagas em estacionamentos de edifícios residenciais, mostrando que a cultura de utilização de automóveis particulares é ainda resistente. Antes da realização das dinâmicas, 35\% dos participantes apontaram como "bom", 25\% como "excelente", 20\% como "ruim", 10\% como "regular", e 10\% como "péssimo". Após a aplicação das dinâmicas, a distribuição das respostas foi de 40\% 
como "bom", 25\% como "excelente", 20\% como "ruim", 10\% como "regular", e 5\% como “péssimo”, conforme ilustra o gráfico da figura 107.

Figura 107 - Avaliação quanto a redução do número de vagas de estacionamento

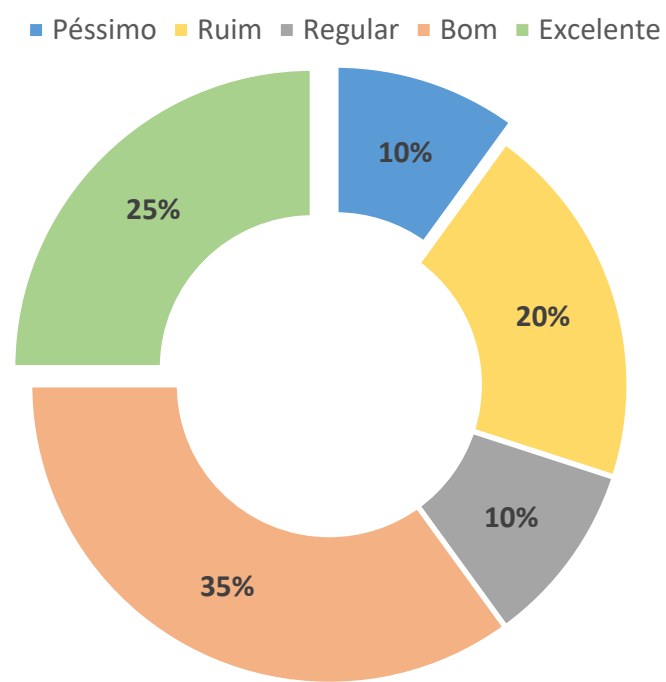

Antes da Dinâmica

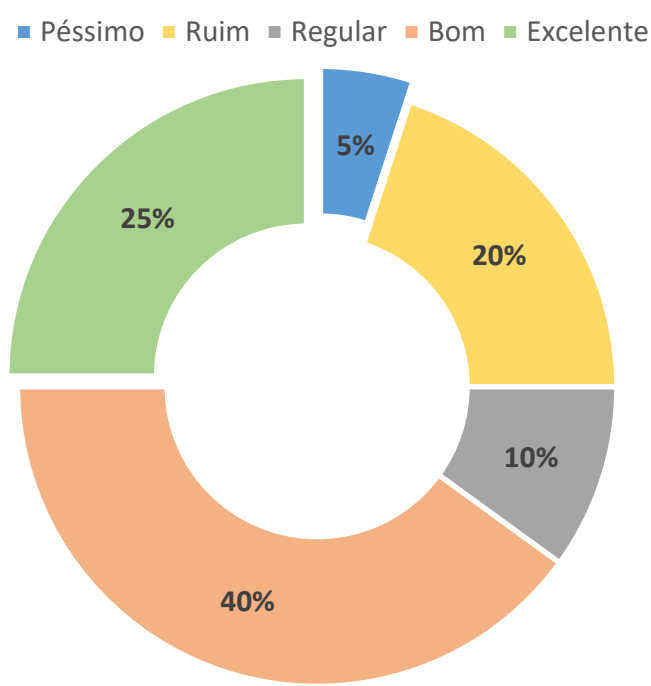

Depois da Dinâmica

Fonte: Do autor (2019).

Quando a pergunta envolve a ampliação da largura das calçadas e o favorecimento do pedestre, antes das dinâmicas, as resposta foram sempre positivas, com 55\% como "excelente", e 45\% como "bom". Isso se manteve igual depois das dinâmicas, conforme ilustra o gráfico da figura 108.

Figura 108 - Avaliação quanto à ampliação das calçadas

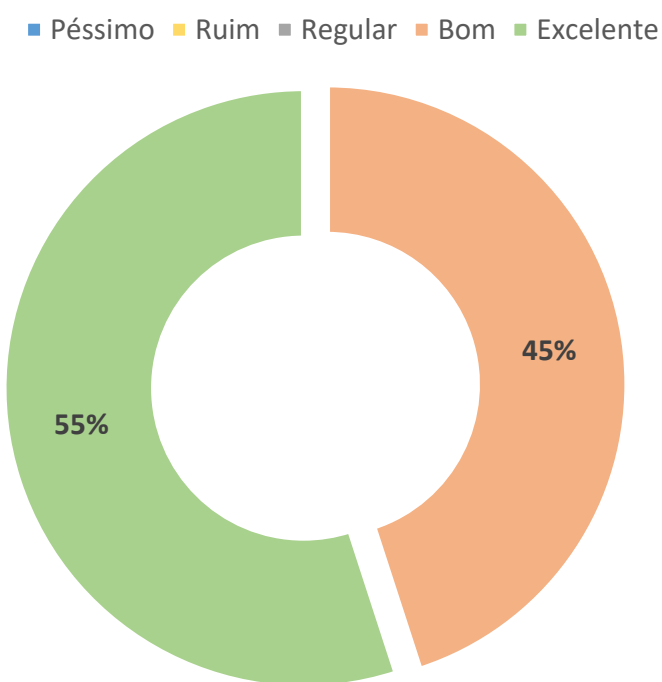

Antes da Dinâmica

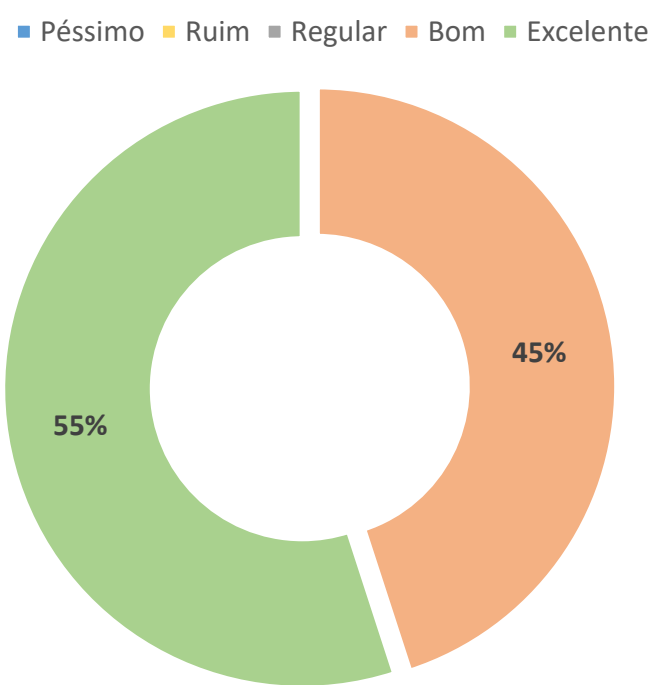

Depois da Dinâmica

Fonte: Do autor (2019).

Também foi avaliada a percepção dos participantes no que diz respeito à construção de edifícios mistos, ou seja, como os participantes avaliam a possibilidade da construção de 
edifícios que simultaneamente abriguem usos residenciais e comerciais. Antes da realização das dinâmicas, 65\% dos participantes pontuaram o quesito como "excelente", 30\% como “bom”, e 5\% como "regular". Após a realização das dinâmicas, 65\% dos participantes continuou avaliando como "excelente", e 35\% como "bom”, conforme o gráfico na figura 109.

Figura 109 - Avaliação sobre a construção de edifícios de uso misto

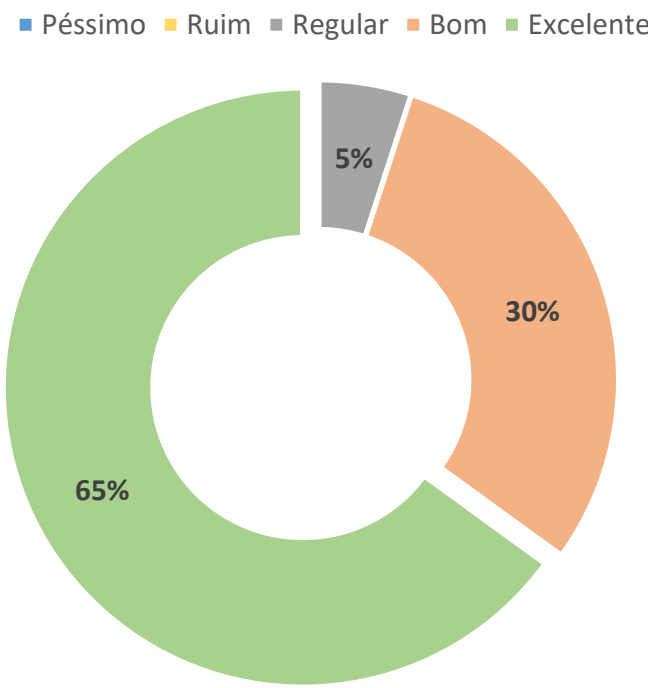

Antes da Dinâmica

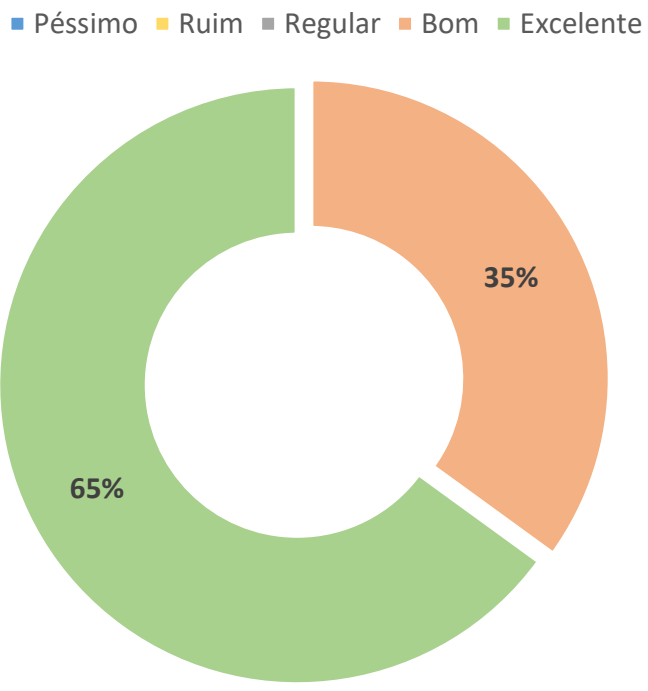

Depois da Dinâmica

Fonte: Do autor (2019).

Avaliando a fruição pública - a possibilidade de que o térreo das edificações absorva uma área comum de circulação -, 45\% das respostas julgaram o quesito como "bom", 40\% como “excelente", 10\% como "regular", e 5\% como "ruim", antes da aplicação das dinâmicas. As respostas se mantiveram após a aplicação, conforme o gráfico da figura 110.

Por fim, foi perguntada a opinião dos participantes no que tange a fachada ativa, ou seja, um térreo com área que conta com a presença de lojas, lanchonetes, restaurantes etc. Antes da aplicação das dinâmicas, 55\% deles pontuaram com "bom", 35\% como "excelente", 5\% como “ruim", e 5\% como "péssimo". Após a aplicação das dinâmicas, a distribuição das resposta ficou com $45 \%$ de avaliações "excelente", $45 \%$ de "bom", e 10\% de "regular", conforme ilustra o gráfico da figura 111. 
Figura 110 - Avaliação sobre a fruição pública

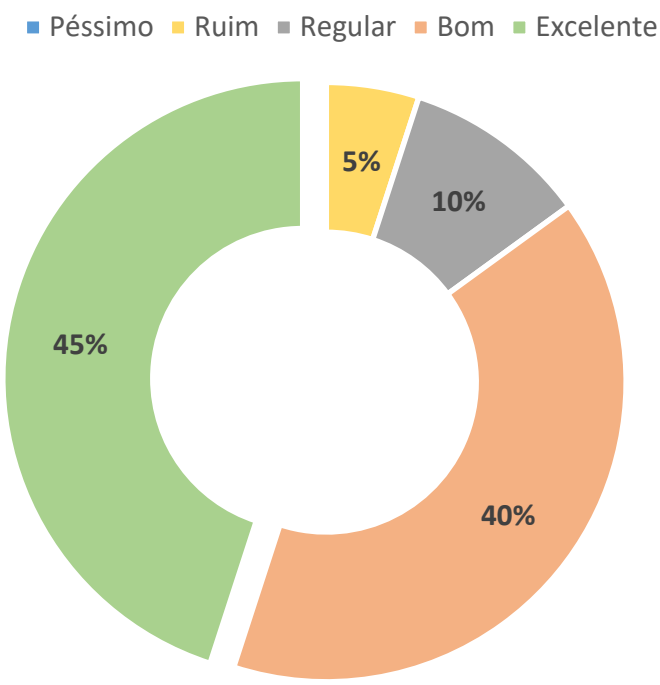

Antes da Dinâmica

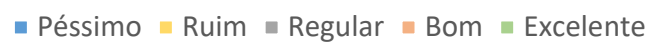

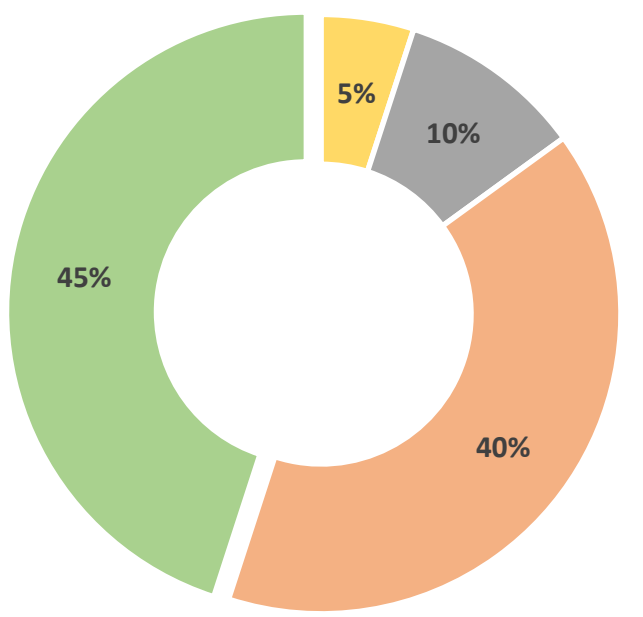

Depois da Dinâmica

Fonte: Do autor (2019).

Figura 111 - Avaliação sobre a fachada ativa

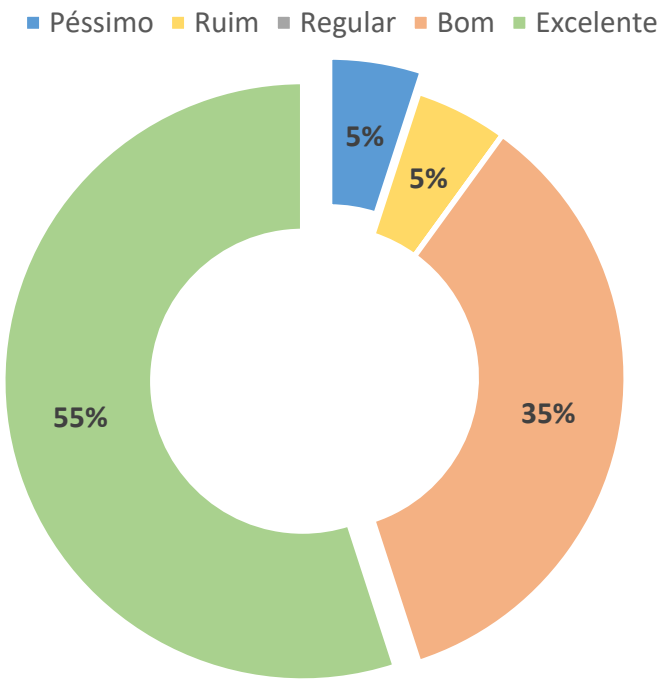

Antes da Dinâmica

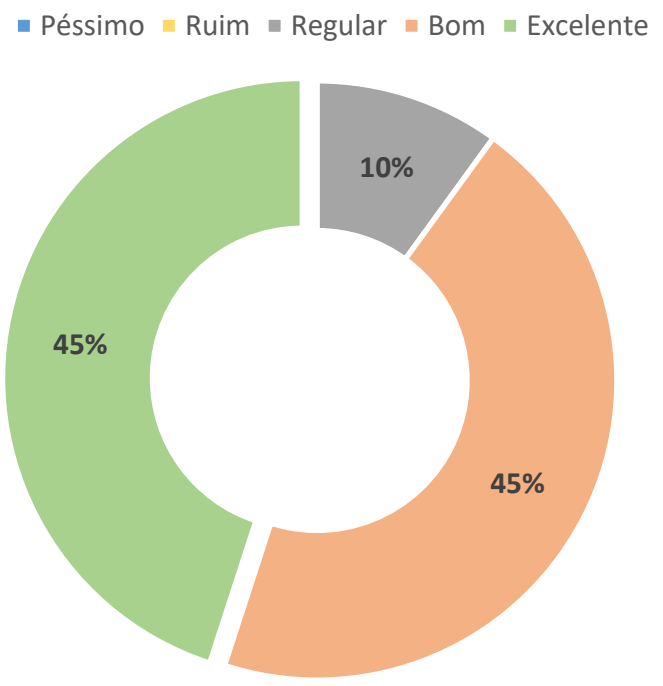

Depois da Dinâmica

Fonte: Do autor (2019).

Para mapear o perfil dos participantes, também se perguntou a respeito de elementos ligados à relação deles com a cidade, como o tempo médio de deslocamento, a frequência de utilização do transporte público, a frequência de deslocamento a pé, a frequência de utilização dos espaços públicos e a opinião sobre o tráfego. Quando perguntados sobre o tempo médio de deslocamento entre a moradia e o trabalho ou estudo, a maior parcela população está concentrada em um deslocamento inferior a 30 minutos ou entre 30 minutos e 1 hora, conforme figura 112 . 
Figura 112 - Tempo médio de deslocamento na cidade para os participantes

\section{Tempo Médio de Deslocamento na Cidade}

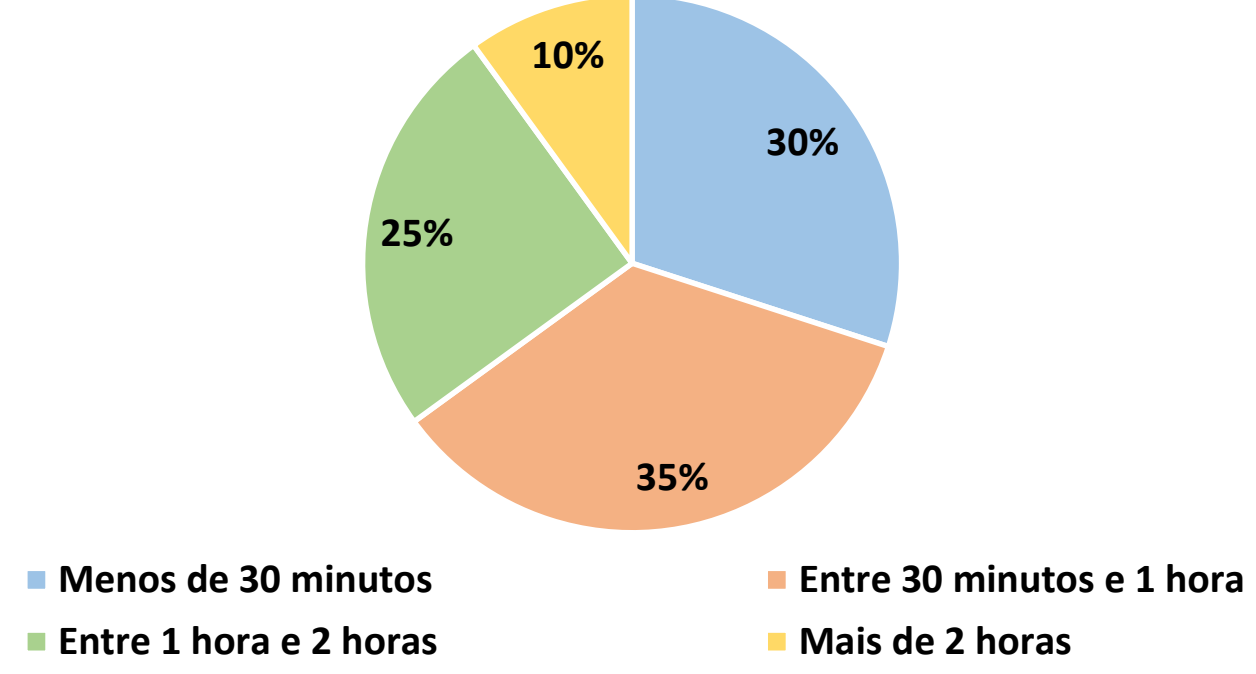

Fonte: Do autor (2019).

Mesmo com uma parcela significativa dos participantes com um tempo de deslocamento inferior a 1 hora, boa parte dos problemas manifestados no processo foi inerente ao transporte. Isso é curioso, mas não representa necessariamente o que acontece com a maior parte da população que estuda e trabalha em São Paulo - representa o perfil dos participantes da atividade.

Avaliando a frequência com que os participantes utilizam o transporte público, há uma dispersão na amostra. O que se pode afirmar é que $40 \%$ o utilizam todos os dias, $30 \%$ algumas vezes por semana, $25 \%$ algumas vezes por mês, e $5 \%$ não utilizam, conforme ilustrado no gráfico da figura 113.

Ademais, como a questão associada ao transporte é latente e o Plano Diretor Estratégico do Município de São Paulo, para diagnosticar preliminarmente os parâmetros quanto a caminhada o questionário avaliou a frequência com que os participantes realizam viagens a pé pela cidade. O que se notou é que $40 \%$ deles consideram que realizam poucas viagens a pé ou raramente, $35 \%$ todos dias, e $25 \%$ algumas vezes na semana, conforme o gráfico da figura 114 . 
Figura 113 - Frequência de utilização do transporte públicos pelos participantes

\section{Frequência de utilização do transporte público}

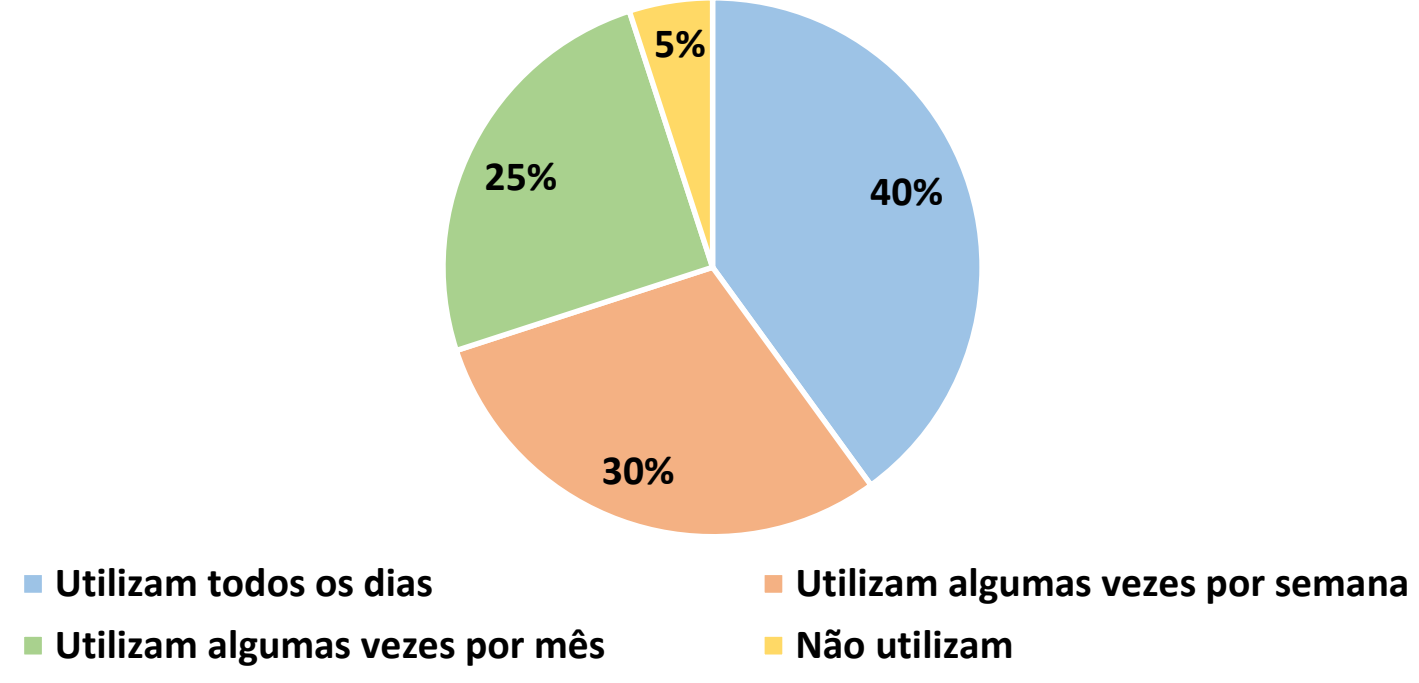

Fonte: Do autor (2019).

Figura 114 - Frequência de locomoção a pé pelos participantes

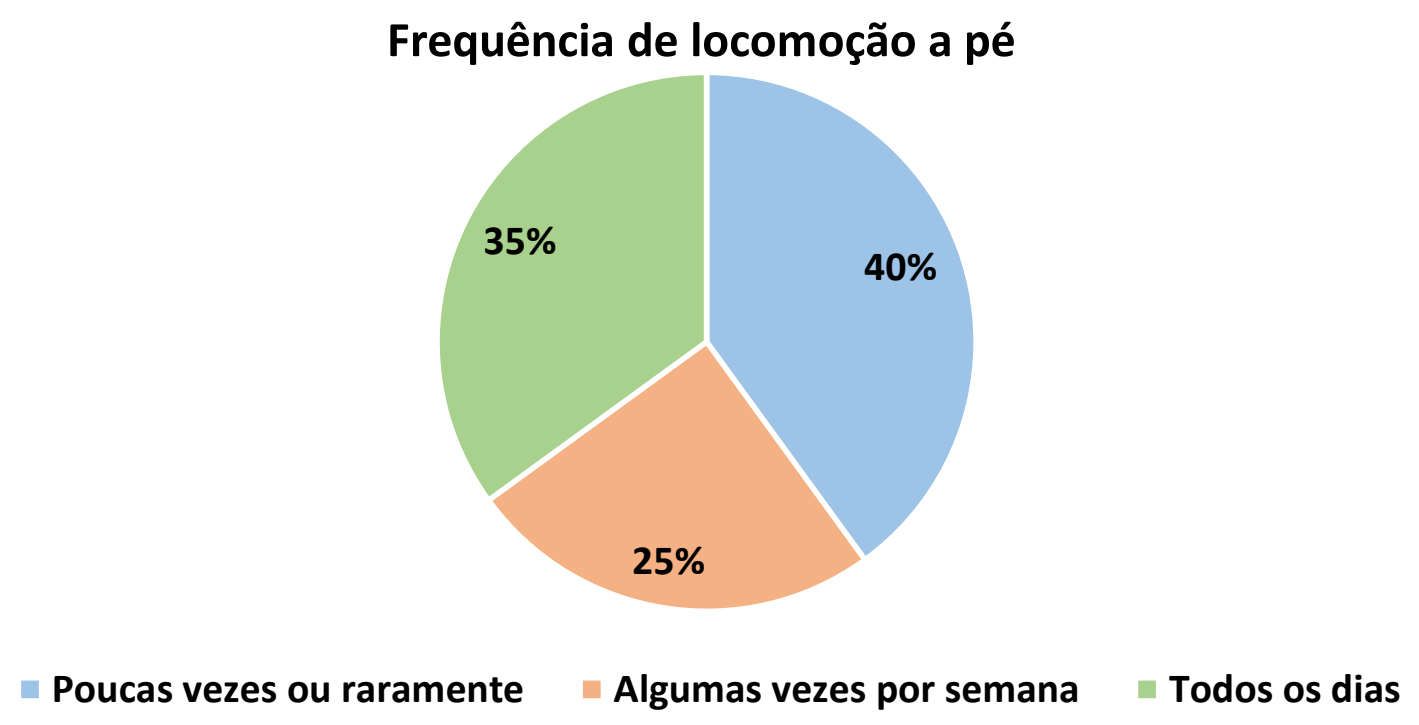

Fonte: Do autor (2019).

Quanto às opções de lazer, quando perguntados com que frequência utilizam os espaços públicos - tais como praças, parques e clubes -, 30\% dos participantes alegaram utilizar algumas vezes por mês, $30 \%$ algumas vezes por semana, $25 \%$ menos de uma vez por mês, e $15 \%$ não utilizam, conforme o gráfico da figura 115. 
Figura 115 - Frequência de utilização dos espaços públicos pelos participantes

\section{Frequência de utilização dos espaços públicos}

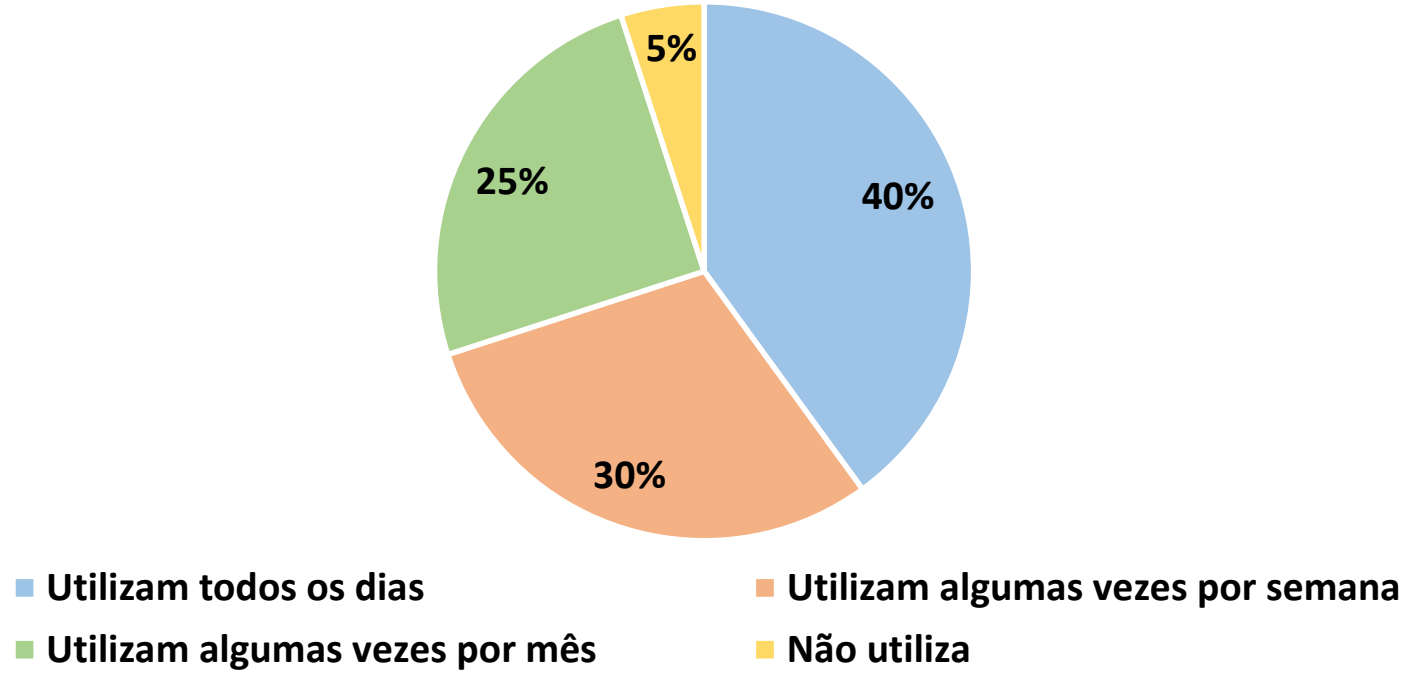

Fonte: Do autor (2019).

Ademais, majoritariamente, as respostas indicam que as pessoas se incomodam com o tráfego e suas consequências, $90 \%$ dos participantes manifestaram este incomodo e apenas $10 \%$ apontaram que é indiferente esta questão.

Resumidamente, os formulários aplicados. antes e depois da realização da proposta metodológica, os participantes ficaram mais críticos quanto da avaliação da segurança, dos serviços disponíveis, da qualidade do transporte e do custo de vida. Possivelmente a discussão em grupo ampliou a capacidade de avaliação dos participantes a partir da troca de experiências e da do processo reflexivo proposto.

Por outro lado, alterações vistas geralmente como controversas, por exemplo a redução da oferta do número de vagas nos edifícios, após a aplicação das dinâmicas tiveram as avaliações positivas -Excelente e Bom, aumentas, isto se repetiu no favorecimento dos edifícios mistos e no incentivo a fachada ativa.

Por fim, a aplicação da proposta metodológica reforça que alguns métodos podem ser utilizados pelo poder público, para ampliar o alcance das audiências públicas, ou demais canais de participação promovidos a fim de contribuir com o engajamento da sociedade, o incentivo a formação de uma identidade comunitária, a construção de uma relação de confiança e parceria com o poder público. 
A efetiva participação da sociedade nos processos de tomada de decisões ocorre com a descentralização das ações e, principalmente, com a assimilação de uma nova cultura quanto à gestão da coisa pública, por parte de dirigentes e servidores públicos, na direção da ampliação dos canais de comunicação entre os diversos atores, vinculado à aprendizagem, escuta, troca de informações e experiências, e estímulo às inovações coletivas.

\subsubsection{Resultados da Pesquisa de Satisfação}

Ao final da aplicação da proposta metodológica, a equipe de pesquisa, para avaliar os instrumentos de pesquisa aplicados aplicou-se uma pesquisa de satisfação aos participantes. A aplicação deste questionário, preenchido anonimamente, objetivou aprimorar, se necessário, a proposta metodológica e captar suas possíveis deficiências. Foram 10 perguntas das quais: (i) as três primeiras os participantes poderiam das uma nota de 0 a 10 à etapa inclusiva-propositiva, à etapa de valoração e avaliação, e ao processo metodológico como um todo; (ii) uma pergunta em que os participantes deveriam das uma nota de 0 a 10 para as dinâmicas de apresentação e estreitamento, para o painel de seleção de problemas, para tempestade cerebral de soluções, e para o painel gráfico colaborativo da visão; (iii) uma pergunta em que os participantes deveriam atribuir uma nota de 0 a 10 sobre o a dificuldade de preenchimento dos painéis com as etiquetas coloridas; (iv) uma pergunta com a escala ruim, regular, bom e excelente em que o participantes poderiam avaliar a duração dos encontros; (v) uma pergunta com as opções sim, não e parcialmente, para os participantes responderem se suas expectativas individuais foram atendidas; (vi) uma pergunta com as opções sim ou não, para que os participantes respondessem se voltariam a participar de uma proposta igual; (vii) uma pergunta com as opções sim ou não, para que os participantes respondessem se sentem capacitados a reproduzir as atividades que foram propostas; e por fim (viii) uma pergunta aberta para que que os participantes fizessem críticas ou sugestões.

No que tange a avaliação geral do processo, houve no geral uma avaliação positiva, com a predominância de nota 10 , conforme figura 116 . O que se nota é uma pequena redução nas notas 10 para a etapa de valoração e avaliação, possivelmente decorrente do maior labor aplicado nesta etapa, que por vezes pode cansar os participantes, e é ai que a informatização do processo pode contribuir por um lado para maior velocidade e redução do trabalho, contudo por outro, pode reduzir a interação entre os sujeitos. 
Figura 116 - Satisfação dos participantes quanto as etapas da proposta metodológica

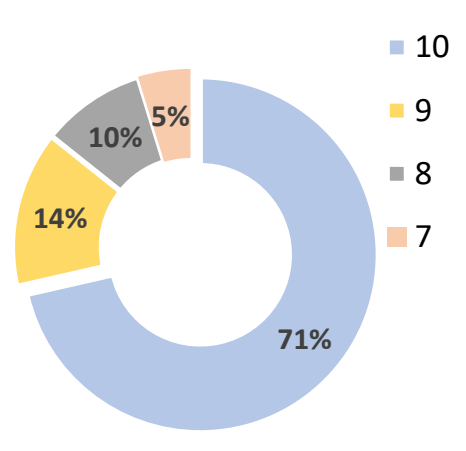

Avaliação da Etapa Inclusiva - Propositiva

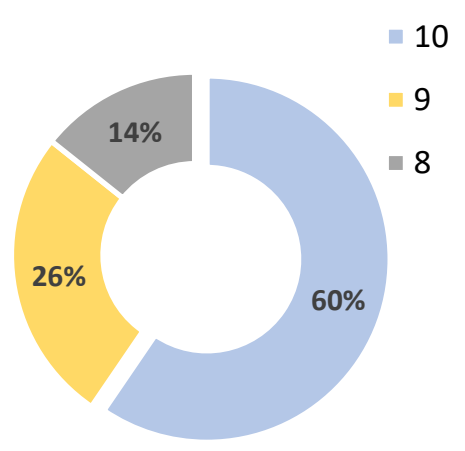

Avaliação da Etapa de Valoração e Avaliação Fonte: Do autor (2019).

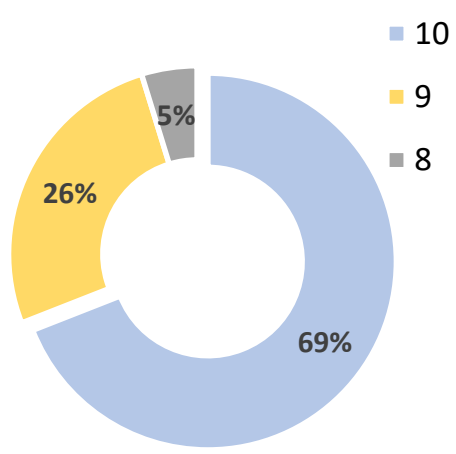

Avaliação geral do processo metodológico

Já quando avaliados a dinâmica de apresentação e o painel de seleção de problemas, para a dinâmica de apresentação $90 \%$ dos participantes avaliaram com nota 10, e para o painel de seleção de problemas $88 \%$ dos participantes avaliaram com nota 10, o que aponta a satisfação com os instrumentos aplicados, conforme figura 117. Importante observar que o painel de seleção de problemas segue um delineamento parecido com a técnica do painel integrado, já explicado na pesquisa.

Figura 117 - Avaliação dos participantes quanto ao instrumentos

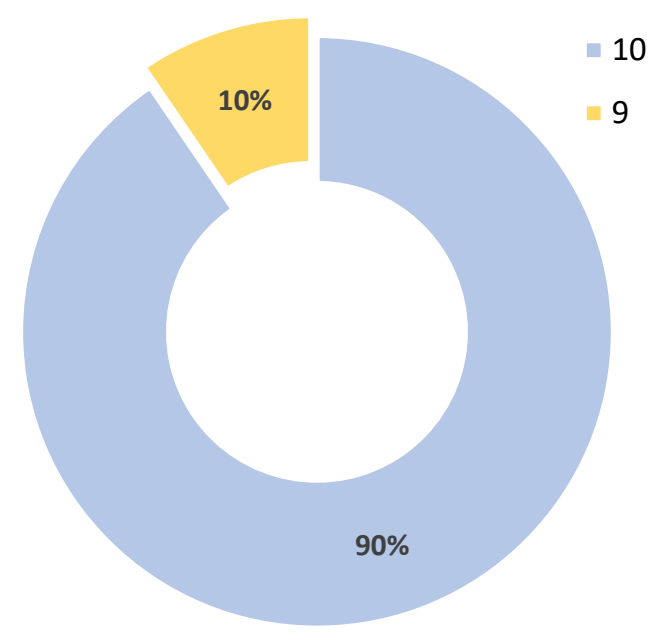

Dinâmica de Apresentação e estreitamento

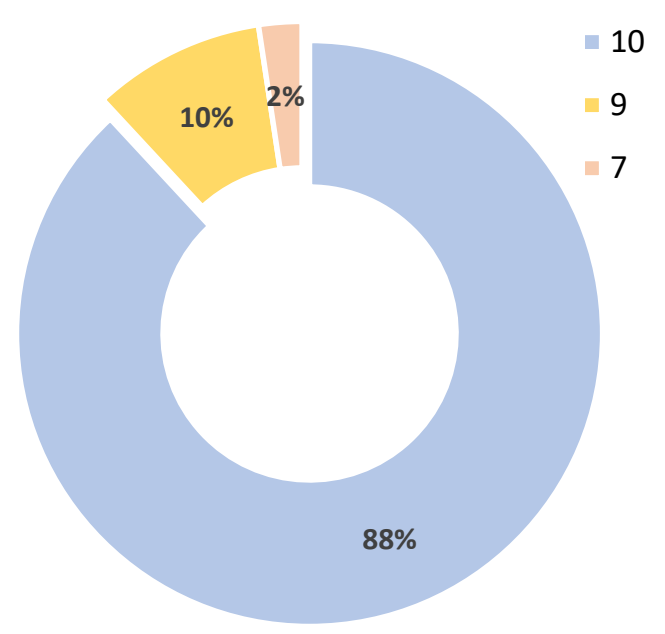

Painel de Seleção de Problemas Fonte: Do autor (2019).

$\mathrm{Na}$ avaliação da atividade de tempestade cerebral de soluções, que segue um modelo parecido ao brain writing $86 \%$ dos participantes apontaram uma avaliação positiva com nota 10, para o caso do painel gráfico colaborativo da visão, $98 \%$ dos participantes avaliaram positivamente, conforme figura 118. O painel gráfico colaborativo da visão segue contornos de 
mapas falantes tal atividade, com envolvimento lúdico, apresentou um envolvimento bastante interessante da população.

Figura 118 - Avaliação dos participantes quanto ao instrumentos e sua dificuldade

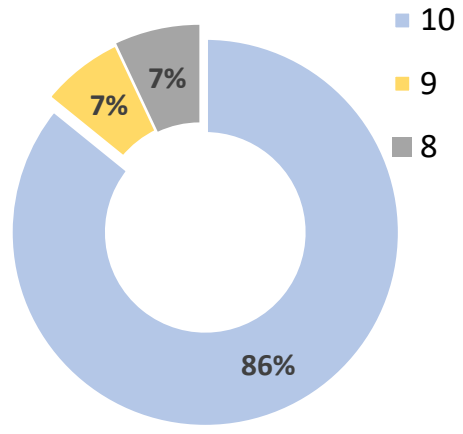

Tempestade Cerebral de Soluções

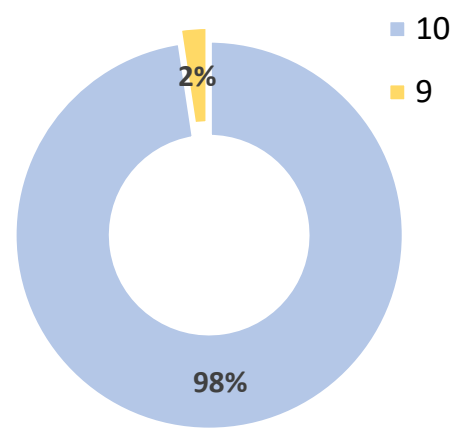

Painel Gráfico Colaborativo da Visão

Fonte: Do autor (2019).

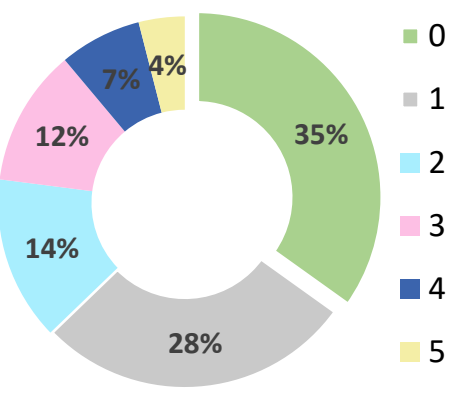

Grau de dificuldade de preenchimento dos painéis

Quanto a dificuldade para preenchimento dos painéis, todos os participantes atribuíram no máximo um grau de dificuldade 5, sendo o máximo 10 , entretanto $63 \%$ dos participantes apontaram como dificuldade nula - nota 0 , ou muito baixa -nota 1 .

Ao avaliar se os participantes participariam novamente, todos os participantes responderam positivamente, quanto as expectativas aproximadamente $98 \%$ dos participantes consideraram que foram atendidas, e quanto a capacitação para reproduzir as atividades $85 \%$ dos participantes apontaram positivamente, conforme figura 119.

Figura 119 - Avaliação dos participantes quanto as expectativas

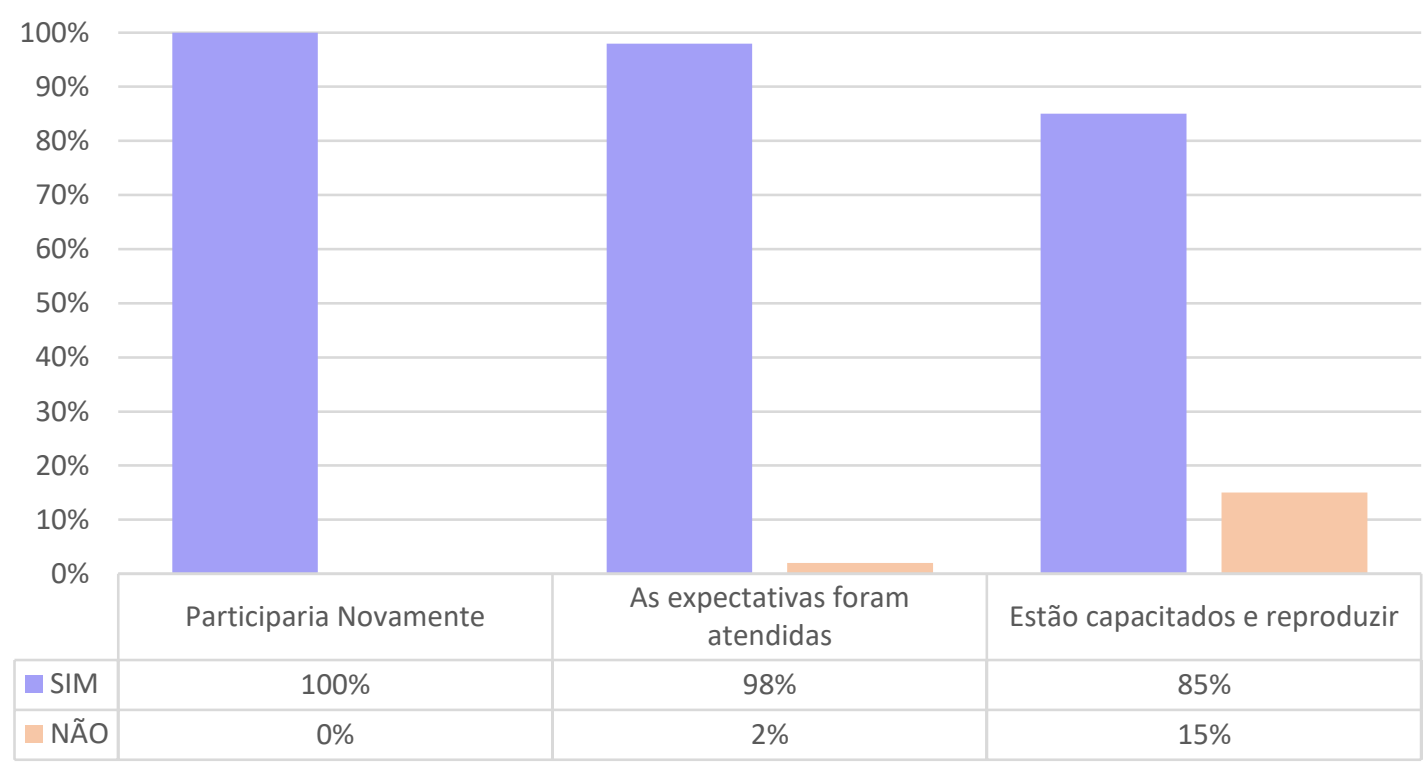

Fonte: Do autor (2019). 
E por fim, quanto a duração das atividades, 15 pessoas apontaram como boa, 14 como regular, 7 como excelente e 6 como ruim. Ao analisar as críticas, e sugestões, foi pontuado pelos participantes que as dinâmicas poderiam ser desenvolvidas com mais tempo disponível para o preenchimento dos painéis.

A questão do tempo ainda é uma questão importante, pois por um lado quando participam das dinâmicas as pessoas requerem um maior tempo para aprofundamento dos temas, por outro lado geralmente as pessoas de tempo para participar de processos participativos, portanto este ainda é um desafio que requisita maior investigação. 


\section{CONCLUSÕES E CONSIDERACÕES FINAIS}

\subsection{COMPROVAÇÃO DA HIPÓTESE}

A partir dos resultados obtidos na revisão bibliográfica, nas entrevistas e na aplicação da proposta metodológica em um estudo de caso selecionado, a hipótese de que a participação popular pode fornecer contribuições mais efetivas para o diagnóstico de demandas e a proposição de estratégias em desenvolvimento urbano, foi comprovada. Esta confirmou-se ao se aplicar a metodologia desenvolvida tanto nas etapas de catalisação da participação popular quanto de avaliação dos pontos elencados para apoio à decisão. O que se notou, na prática, é que os insumos obtidos com a proposta metodológica podem indicar ações reais e hierarquizadas do Estado, atendendo às necessidades da população.

Ademais, em resposta às questões de pesquisa, sob o olhar operacional, verificou-se que quando os processos participativos são instrumentalizados, de forma adequada, podem favorecer a interação de perfis diversificados em torno de questões que são comuns a todos e, dentro da aplicação da proposta metodológica, Cruz \& Marins apontam soluções que propiciam benefícios sociais coletivos com melhor qualidade para as demandas urbanas.

Por outro lado, a integração multidisciplinar de ferramentas participativas aplicadas à abordagem do ambiente urbano, abrangeu desde métodos de coleta de dados intrínsecos a ciências humanas e sociais, à construção coletiva de saberes e aos modelos matemáticos multicriteriais. Apesar de complexa, demonstrou complementariedade, podendo-se afirmar que, no escopo desta pesquisa, eficiência, efetividade e eficácia foram usados para coletar dados e elencar estratégias que traduzem os anseios populares.

A sistematização dos painéis aplicados na proposta metodológica, inspirados em painéis integrados, mapas falantes e brain writing, quando delineados a partir de contornos estruturados analogamente a grupos focais, permitem aos condutores de processos participativos elaborar painéis que conseguem extrair e representar critérios sinérgicos para o avanço do processo de tomada de decisão, a partir da hierarquização dos elementos que devem ser percebidos em projetos de intervenção urbana, por exemplo, e consequentemente, as alternativas hierarquizadas que devem compor estes projetos urbanos, em uma escala local.

As percepções, transformadas em problemas urbanos, e as ideias, transformadas em alternativas, compõem um quadro de soluções não só urbanísticas, mas também sociais. Assim, a avaliação tanto dos problemas, quanto das alternativas, é transparente e construída 
coletivamente, contribuindo para a criação de uma relação de confiança com a população e, assim, também pavimentando o caminho para a partilha de poder e controle social das ações do Estado.

A pesquisa apresentou, sob a ótica da participação popular em planejamento urbano, que a efetividade dos processos participativos é diretamente proporcional à capacidade de deliberação do arranjo participativo consolidado. No contexto ampliado do planejamento participativo, há condições para que, nas principais arenas participativas atuais, ou seja, as audiências públicas e os conselhos participativos, seja possível agregar métodos para operacionalizar esses arranjos, com a integração das percepções da sociedade frente aos problemas urbanos, além da definição de ações e soluções urbanísticas, aplicando um aporte metodológico mais efetivo.

Embora a diversidade das pessoas que compõem um processo participativo seja inerente ao processo, na prática, com o adequado aporte metodológico, é possível perceber que esse complexo cenário pode trazer novos elementos para a compreensão do desenvolvimento urbano em âmbito local, com a absorção de diferentes perspectivas de diversos agentes que interagem com as transformações urbanas.

A extensa revisão bibliográfica nacional e internacional desenvolvida neste trabalho deu suporte ao caráter inédito da pesquisa, utilizando a integração de ferramentas diversificadas, aplicadas em ciências sociais, às ferramentas de tomada de decisão, baseadas em análises multicriteriais, para compor uma metodologia nova de apoio à decisão em planejamento urbano. A tese visou operacionalizar, de forma mais efetiva, o planejamento estratégico participativo quando da elaboração de estratégias e da hierarquização de alternativas, partindo do delineamento e da compreensão dos problemas que permeiam o planejamento e o desenvolvimento de áreas urbanas.

\subsection{CONCLUSÕES}

Embora, no contex to de planejamento urbano, existam exemplos e esforços na direção da ampliação dos processos participativos, a realidade aponta que a participação popular ainda é pouco eficaz, eficiente e efetiva, tanto no diagnóstico de problemas quanto no levantamento de soluções. No contexto atual, é importante que as prioridades sejam verificadas a partir de processos participativos. Diante disso, o ineditismo deste trabalho não está tão somente na proposta metodológica em si, mas na consolidação de um pool de índices que os gestores, 
decisores e planejadores podem utilizar para fundamentar suas decisões, em uma efetiva consulta popular. Também o objeto de estudo apontou que a participação popular é melhor instrumentalizada com a ampliação integrada e sistêmica de uma série de instrumentos de coleta de dados, de ferramentas de escuta à população, da real inclusão das demandas populares nas políticas e com o estabelecimento de um sistema claro e transparente de tomada de decisão.

Outro ponto relevante é a contribuição da pesquisa na forma de aplicar modelos multicriteriais adaptados a partir do AHP. A comparação par-a-par de problemas e alternativas a partir de uma função especifica reduz as inconsistências do processo e atenua a subjetividade dos pesos atribuídos.

O desenvolvimento e a aplicação de uma proposta metodológica para participação popular na definição de estratégias de planejamento urbano auxiliam nos processos de tomada de decisão para priorização de projetos de intervenção e transformação urbana, no contexto do Município de São Paulo. Isso pôde ser observado uma vez que a proposta foi, de fato, desenvolvida e aplicada no recorte selecionado. Por sua vez, a questão de como integrar os insumos decorrentes do processo participativo no planejamento e na tomada de decisão em projetos urbanos, agregando efetividade às soluções, do ponto de vista popular, também foi respondida, posto que as atividades inerentes à proposta geraram soluções advindas diretamente da população. Os resultados apontaram que, quando há integração de abordagens à luz da ciência pós-normal, de instrumentos e técnicas de consulta popular e da ciência de decisões, em processos de planejamento urbano, é possível um delineamento de diretrizes e procedimentos para tornar a participação popular mais efetiva do que a prática corrente.

O modelo multicriterial de apoio à decisão consolidado nesta pesquisa, ao incorporar julgamentos semânticos de preferência associados à distância relativa entre os objetos valorados, apresenta uma valiosa contribuição para a ciência das decisões - cuja aplicação no contexto de planejamento urbano foi um "balão de ensaio" - e pode ser explorado em outros contextos. Para o caso de definição de estratégias em planejamento urbano, o modelo multicriterial contribuiu para estruturar, complementar e ratificar as preferências da população, não apontando uma "solução-ótima", mas o delineamento de uma ordem hierarquizada de alternativas e de problemas. Nesse caso, a simples estruturação do modelo permite um maior aprofundamento nos problemas, considerando as variáveis que o envolvem, nas alternativas, considerando a dificuldade de sua implantação, e na relação entre os problemas e as alternativas.

As etapas de aplicação da proposta metodológica, com hierarquização a partir de um modelo MCDA, mostraram-se interessantes também para aprofundar o conhecimento e o 
aprendizado da população na temática proposta. De maneira geral, as ciências sociais e as ciências exatas caminharam juntas para solução dos problemas urbanos, construindo conhecimentos e servindo de suporte ao planejamento. Nesse sentido, os resultados das dinâmicas propuseram um conjunto relevante e coerente de estratégias, e permitiram um avanço do entendimento acerca dos requisitos necessários para o enfretamento dos problemas urbanos.

As atividades propostas nas etapas denominadas "inclusiva-propositiva" e "valoraçãoavaliação" contribuíram tanto com objeto de pesquisa quanto com os participantes, além de permitirem a construção cooperativa do saber. A reflexão entre os sujeitos e a equipe de pesquisa fomentou uma espiral ascendente de saberes. Por outro lado, para os pesquisadores, essa troca fornece um diagnóstico participativo e descortina a possibilidade de estudos específicos, ou seja, contribui metodologicamente para novos instrumentos e parâmetros de decisão em pesquisa participativa. No âmbito do planejamento urbano, a aplicação das atividades poderá fornecer respostas a indagações necessárias para consolidar uma decisão política - por exemplo, como os insumos e as demandas surgem a partir dos sujeitos e por eles são valorados, o processo aumenta a credibilidade em relação às tomadas de decisão. No entanto, se há preocupação com a elevação dos níveis de participação, o cenário proposto, inclusive com a certificação, eleva a autoestima e o empoderamento dos sujeitos, além de multiplicar os sujeitos sociais e sua participação na busca de soluções que atendam a sua envoltória de ação. Quando os sujeitos notam sua contribuição, detêm maior conhecimento de sua capacidade de transformação.

Para se colocar em prática a elaboração de políticas públicas urbanas verdadeiramente participativas, é necessária uma aproximação multidisciplinar ao tema. Os responsáveis pela condução dos processos precisam desenvolver uma visão ampliada dos instrumentos e construir um diagnóstico multifacetado do objeto de estudo. O planejamento urbano envolve mais do que uma decisão, pois requer uma ampla quantidade de ações, estrategicamente hierarquizadas, selecionadas a partir da decisão política e participativa. Esta decisão corresponde à escolha de um conjunto de possíveis alternativas que atendam a um conjunto de problemas, conforme a hierarquização consolidada pela preferência de múltiplos atores, a qual expressará maior ou menor grau de adequação dos objetivos propositados e as dificuldades intrínsecas a cada solução. Ainda que o planejamento urbano possa ser considerado um processo complexo de tomada de decisões, a clareza quanto à definição dos problemas, as estratégias participativas de construção do consenso para a quantificação dos objetivos e as interações entre os atores - à 
medida que eles negociam durante o processo -, são elementos que permitem um maior envolvimento da população e uma redução da complexidade na tomada de decisão.

Complementarmente, notou-se que, apesar de as visões teóricas contribuírem para a prática do planejamento participativo, ainda são escassas as sugestões reais para operacionalização de procedimentos que possam ser aplicados na condução de processos de planejamento urbano participativo. Portanto, ao incorporar, inclusive, aspectos comunicativos, e permitir uma real interação dos atores, a proposta metodológica pode contribuir para que os gestores públicos delineiem políticas públicas "de baixo para cima", com governança participativa em planejamento urbano. Além disso, promove um ambiente em que as decisões incorporam os anseios de especialistas e também de agentes sociais, contribuindo para o desenvolvimento planejado das cidades.

As atividades propostas tiveram resultados positivos quando aplicadas a um recorte urbano, simulando-se uma situação real. As dinâmicas e seus procedimentos foram bem avaliados pelos participantes e entendidos rapidamente; os resultados, por sua vez, ficaram claros para a equipe de pesquisa, para formação das alternativas e tomada de decisão. Quando, após a inclusão da problemática nas dinâmicas, os atores começam a apresentar alternativas para sua resolução, essas propostas expressam interesses diversos, os quais devem ser combinados de tal maneira que se chegue a uma solução aceitável para o maior número de partes envolvidas. A etapa de avaliação representa um conjunto de procedimentos de julgamento dos resultados inerentes às alternativas, segundo critérios que expressam valores, e destina-se a subsidiar as decisões dos gestores para que os resultados esperados sejam obtidos. Ocorre, então, a tomada de decisão participativa.

Nesse novo arranjo, há uma corresponsabilização na decisão e em seus resultados, ainda que cada ator possa vir a ter papéis diferenciados na implementação das ações. O modelo sistêmico, consoante à proposta metodológica de Cruz \& Marins, pode ser considerado satisfatório e pretende representar uma contribuição útil para estruturação de processos participativos, especialmente como suporte ao planejamento urbano, incentivando novas aplicações e futuros desdobramentos dos resultados. A proposta metodológica consolida a idéia de que os processos participativos podem ser mais atrativos, dinâmicos e fluídos, preenchendo lacunas importantes na consulta popular.

Finalmente, a proposta metodológica apresentada nesta pesquisa pretende sensibilizar os órgãos governamentais para se criar e implementar instrumentos adequados para elaboração e detalhamento de ações em planejamento urbano que incorporem, verdadeiramente, os anseios 
da população. Entretanto há de se investigar o comportamento da proposta quando aplicada a grupos identitários e vulneráveis, que por sua caracteristica têm muita dificuldade em participar , de fato, dos processos participativos.

Também, ao aplicar a metodologia proposta, verificou-se a relevância de aplicação da aplicação de metodologias participativa no território em que as mudanças podem ser aplicadas. Essa decisão poderá compor uma diversidade de participantes interessante que, por sua vez, poderá gerar uma amplitude maior de alternativas à região.

A participação em si pode gerar ganhos, e no caso da proposta metodológica, pode atenuar a arbitrariedade do Estado, quando do compartilhamento na hierarquização de alternativas que emanam da população. Por outro lado o benefício cognitivo é importante, pois fortalece a atuação comunitária e fortalece a habilidade do cidadão em diagnosticar problemas e refletir o comportamento de ações que podem ser implantadas que, no caso do âmbito da pesquisa, reduz o analfabetismos urbanístico.

Também, quanto ao recrutamento da pessoas envolvidas na proposta metodológica é uma variável que deve ser investigada, pois definir a quantidade de pessoas que de fato são suficientes para produzir um processo com a riqueza necessária gerará ganhos de escala na aplicação do processo, uma vez que não há uma decisão única e verdadeira para um determinado problema, ou uma alternativa que sempre atenderá com dominância todas as situações pois, são questões que envolvem múltiplos critérios e atores sociais.

Neste contexto a proposta metodológica, com sua natureza plural e interdisciplinar é um instrumento que promove um bom processo de tomada de decisão em situações complexas, pois absorve uma tratativa aos múltiplos critérios compondo um quadro de avaliação considerando instrumentos técnicos, sociais, legais e de políticas públicas incorporando a percepção participativa de diversos atores.

\subsection{RECOMENDAÇÕES PARA CONTINUIDADE DA PESQUISA E OPORTUNIDADE DE TRABALHOS FUTUROS}

O desenvolvimento da proposta metodológica sugerida nesta tese de doutorado objetivou estabelecer um procedimento fundamental para a inclusão da participação popular nas tomadas de decisão referentes ao planejamento urbano. Enfocaram-se algumas condicionantes do processo participativo, para viabilizar a integração das ciências sociais às ciências exatas no delineamento de estratégias mais eficazes e efetivas para atendimento das 
demandas populares, bem como a instrumentalização, de forma mais robusta, dos técnicos responsáveis pela gestão das cidades. No entanto, a proposta metodológica não tem a pretensão de reunir todos os elementos, tampouco todas as condicionantes inerentes ao planejamento urbano e à participação popular. Trata-se, sinteticamente, de um esforço na proposição de metodologia e de ferramentas que apoiem a tomada de decisão em planejamento urbano, com aporte multicriterial. Recomenda-se que, em continuidade à pesquisa, além da aplicação da proposta metodológica em outros estudos de caso, possam ser explorados alguns aprimoramentos, tais como:

a.) O estudo e a aplicação da proposta considerando sua total informatização e apoio de outras ferramentas de tecnologia de informação e comunicação, e verificação do engajamento, da mobilização e da produção de insumos nesse contexto;

b.) A verificação da possibilidade de a ampliação do número de grupos em que a proposta metodológica é aplicada gerar um número maior de problemas e alternativas, inclusive observando se há uma convergência, ou não, na hierarquização das estratégias;

c.) A utilização de outras estratégias de convite, diferentes daquelas aplicadas ao estudo de caso proposto nesta pesquisa, diagnosticando as melhores estratégias para mobilização dos diferentes grupos etários e de renda;

d.) A comparação de resultados usando as atuais metodologias de participação e a proposta metodológica consolidada nesta pesquisa, por exemplo, no estabelecimento de planos de bairro;

e.) A normatização da proposta metodológica, bem como de suas diretrizes, seus requisitos e procedimentos;

f.) A adoção da proposta metodológica e de seus respectivos índices de avaliação como instrumento legal para operacionalizar os espaços participativos, principalmente em audiências públicas e conselhos participativos de planejamento urbano. 


\section{REFERÊNCIAS}

ACSELRAD, H. Introdução: o debate sobre cartografia e processos de territorialização anotações de leitura. In: ACSELRAD, H. et al. (Orgs.). Cartografias sociais, lutas por terra e lutas por território. Rio de Janeiro: Universidade Federal do Rio de Janeiro, Instituto de Pesquisa e Planejamento Urbano e Regional, 2015, p. 8-29.

ACSELRAD, H.; COLI, L.R. Disputas cartográficas e disputas territoriais. In: et al. (Org.). Cartografias sociais e território. Rio de Janeiro: Universidade Federal do Rio de Janeiro, Instituto de Pesquisa e Planejamento Urbano e Regional, 2008, p. 13-43.

ADEODATO, M.T.P.C. A razão e os limites das Políticas Nacionais de desenvolvimento urbano: uma análise comparativa das proposições de 1975 e 2004. 2010. 301 f. Tese (Doutorado) - Faculdade de Arquitetura e Urbanismo da Universidade de São Paulo, 2010.

AIRES, M. C. A. A dimensão representativa da participação na teoria democrática contemporânea. Dossiê Partidos, Eleições e Participação, Revista Debates, Porto Alegre: v. 3, n. 2, p. 12-38, jul.-dez. 2009.

ACKERMAN, B.; FISHKIN, J. Deliberation Day. Journal of Political Philosophy, v. 10, n. 2, p. 129-152, 2002.

ALMEIDA, C.R. O papel do plano diretor na organização espacial das cidades: o caso do município de Três Rios - Juiz de Fora. 2012. Dissertação (Mestrado) - Universidade Federal de Juiz de Fora. Juiz de Fora, MG, 2012.

ALVES, A., ROCHA NETO, J. M. A Nova Política Nacional de Desenvolvimento Regional - PNDR II: entre a perspectiva de inovação e a persistência de desafios. Revista Política e Planejamento Regional, Rio de Janeiro: v. 1, n. 2, p. 311-338, jul./dez. 2014.

ASSOCIAÇÃO NACIONAL DE PESQUISA, DESENVOLVIMENTO E ENGENHARIA DAS EMPRESAS INOVADORAS (ANPEI). Como alavancar a inovação tecnológica nas empresas. São Paulo, 2004, p.146.

ARAUJO, A.A. Participação da sociedade na decisão urbana. 2014. 166 f. Dissertação (Mestrado) - Universidade Federal do Rio de Janeiro, Escola Politécnica, Rio de Janeiro, 2014.

ARAÚJO, L. M. Desenvolvimento Sustentável, Estudo de Impacto Ambiental e Estudo de Impacto de Vizinhança. 1. ed. Curitiba: Letra da Lei, v. 1, p. 174, 2008.

ARAÚJO, T.B. A experiência de planejamento regional no Brasil. In: LENA, L.; CARLEIAL, L. M.F.; NABUCO, M. R. (Orgs.). Reestruturação do espaço urbano e regional no Brasil. São Paulo: AMPUR, 1993.

ARGAN, G. C. Arte Moderna: do Iluminismo aos movimentos Contemporâneos. Tradução de Denise Bottmann e Frederico Carotti. 9. ed. São Paulo: Companhia das Letras, 1992.

ARNSTEIN, S. A ladder of citizen participation in the USA. Journal of the American Institute of Planners, v. 35, n. 4, p. 216-224, 1969. 
ARNSTEIN, S. R. Uma escada da participação cidadã. Revista da Associação Brasileira para o Fortalecimento da Participação. PARTICIPE, Porto Alegre/Santa Cruz do Sul, v. 2, n. 2, p. 4-13, jan. 2002.

ASSOCIAÇÃO BRASILEIRAS DE NORMAS TÉCNICAS. ABNT NBR ISO 9000:2015. Sistemas de gestão de qualidade - fundamentos e vocabulário. Rio de Janeiro. 2015

AVENIER, M. J.; NOURRY, L. Sciences of the Artificial and Knowledge Production: The Crucial Role of Intervention Research in Management Sciences. Design Research, v. 15, p. 55-70, 1999.

AVRITZER, L. Sociedade Civil, Instituições Participativas e Representação: Da Autorização à Legitimidade da Ação. DADOS - Revista de Ciências Sociais, Rio de Janeiro: v. 50, n. 3 , p. 443-464, 2007.

Instituições participativas e desenho institucional: algumas considerações sobre a variação da participação no Brasil democrático. Opinião Pública, v. 14, n. 1, p. 43-64, 2008.

AZEVEDO, S.; ANASTÁSIA, F. Governança, accountability e responsividade: reflexões sobre a institucionalização da participação popular em experiências desenvolvidas em Minas Gerais. Revista de Economia Política, São Paulo: v. 22, n. 1, p. 79-97, 2002.

BALDUSCO, L. F. Gestão metropolitana e o papel do município periférico: Itapecerica da Serra. 2006. Dissertação (Mestrado em Arquitetura e Urbanismo) - Universidade Presbiteriana Mackenzie, São Paulo, 2006. Disponível em: <http://www.dominiopublico.gov.br/download/texto/cp031213.pdf>. Acesso em: $17 \mathrm{dez}$. 2014.

BANA E COSTA, C. A.; DE CORTE, J. M.; VANSNICK, J. C. On the mathematical foundations of MACBETH. In: FIGUEIRA, J.; GRECCO, S.; EHRGOTT, M. (Eds.). Multiple criteria decision analysis: state of art surveys. Boston: Springer Science, Business Media, cap. 10, p. 409-442, 2005.

; SANCHEZ-LOPEZ, R. El enfoque MacBeth para la incorporación de temas transversales en la evaluación de proyectos de desarrollo. Lisboa, Portugal: Instituto Superior Técnico, Centro de Estudos de Gestão Working Paper, n. 2, 2009.

; VANSNICK, J. C. A critical analysis of the eigenvalue method used to derive priorities in AHP. European Journal of Operational Research, n. 187, p. 1422-1428, 2008 .

BARAT, J. Estrutura Metropolitana e sistema de transportes: estudo de caso do Rio de Janeiro. 1975. Tese (Livre Docência) - Monografia n. 20, IPE/INEPES. Universidade Federal do Rio de Janeiro, Rio de Janeiro, RJ, 1975.

BARBOSA, C.; CARVALHO, P. F. Zoneamento urbano-ambiental: possibilidades de compatibilização entre análise geomorfológica e padrões de ocupação urbanos para a construção de cidades sustentáveis. In: VI Seminário Latino Americano de Geografia Física e II Seminário Ibero Americano de Geografia Física Universidade de Coimbra, 2010. 
BARDACH, E. Los Ocho Pasos para el Análisis de Políticas Públicas. México: Centro de Documentación y Docencia Económicas, 1998.

BARDIN, L. Análise de conteúdo. Lisboa: Edições 70, 1977.

BARROS, L. C. Sobre sistemas dinâmicos Fuzzy: teoria e aplicações. 1997. 113 f. Tese (Doutorado) - Instituto de Matemática, Estatística e Computação Científica, Universidade Estadual de Campinas, Campinas, SP, 1997.

BASCH, C. E. Focus group interview: an underutilized research techinique for improving theory and practice in health education. Health Educ Q, v. 14, n. 4, p. 411-448, 1987.

BAXAMUSA, M. The Third E: Equity as a Condition of Sustainability. Projections, Justice, Equity + Sustainability. MIT- Department of Urban Studies + Planning. Cambridge, MA, v. 8, p. 17-31, 2008.

BELTON, V. A comparison of the analytic hierarchy process and a simple multiattribute value function. European Journal of Operational Research, v. 26, p. 7-21, 1986.

; STEWART, T. J. Multicriteria decision analysis an integrated approach.

Boston: Kluwer Academic Publishers, 2001.

BERNAR, E.; GULLO, M. C. R.; MAYORGA, C.; NUNES, F. O.; PEDONE, C. E. M.

Sustentabilidade urbana em Caxias do Sul: aplicação de indicadores. In: RECH, A. U. (Org.). Instrumentos de desenvolvimento e sustentabilidade urbana [Recurso eletrônico]. Caxias do Sul: Educs, 2014, p. 84-109.

BICKERSTAFF, K.; LORENZONI, I.; JONES, M.; PIDGEON, N. Locating Scientific Citizenship, The Institutional Contexts and Cultures of Public Engagement Science.

Technology and Human Values, v. 35, p. 474-550, 2010.

BILLIG, M. Arguing and thinking: a rhetorical approach to social psychology. 2. ed. Londres: Sage, 1996.

BLUM, G.G. Os conceitos de Espaço, Território e Estado numa perspectiva políticogeográfica dos Investimentos Estrangeiros Diretos no Estado do Paraná. Conjuntura Global, v. 3, n. 1, jan./ mar., p. 28-42, 2014.

BOBBIO, N. A era dos direitos. Rio de Janeiro: Elsevier, 2004.

BODMER, M. E.; MARTINS, J. A .Transport Service Quality and Social Responsibility through the Relationship Marketing. 8th Thredbook, Rio de Janeiro, 2003.

BOGARDI, I.; SZIDAROVSZKY, F.; DUCKSTEIN, L. Multiobjective Analysis of Mine Water Protection and Environmental Effects (in Russian). Publication of the Hungarian Central Institute for the Development of Mining, n. 21, p. 69-76, 1978.

Books, 2001.

BOOTH, W. C.; COLOMB, G. G.; WILliAMS, J. M. A arte da pesquisa. São Paulo: Martins Fontes, 2000. 
BOURDIC; SALAT, S.; NOWACKI, C. Assessing cities: a new system of cross-scale spatial indicators. Building Research \& Information, v. 40, n. 5, p. 592-605, 2012.

BOURDIN, A. A questão local. Rio de Janeiro: DP\&A. In: FREY, K. Governança Urbana e Participação Pública, RAC-Eletrônica, v. 1, n. 1, art. 9, p. 136-150, jan./abr. 2007.

Disponível em: 〈http://www.anpad.org.br/rac-e>.

BRAGA, M. L. A. Infra-Estrutura e Projeto Urbano. 2006. Tese (Doutorado) - Faculdade de Arquitetura e Urbanismo da Universidade de São Paulo. São Paulo, SP, 2006.

BRAGA, T. M.; BRITO, F.; FREITAS, A. P.; MARQUES, D. H. F. Sustentabilidade e condições de vida em áreas urbanas: medidas e determinantes nas Regiões Metropolitanas de São Paulo e Belo Horizonte. In: XIV Encontro Nacional de Estudos Populacionais, ABEP. Caxambu, MG, set. 2004, 20 p.

BRANS, J. P.; MARESCHAL, B. PROMETHEE methods. In: FIGUEIRA, J.; GRECCO, S.; EHRGOTT, M. (Ed.). Multiple criteria decision analysis: state of art surveys. Boston: Springer Science, Business Media, 2005. cap. 5, p. 163-196.

BRASIL. Câmara dos Deputados. Guia para Implementação pelos Municípios e Cidadãos: Lei n. 10.257, de 10 de julho de 2001, que estabelece diretrizes gerais da política urbana. 2. ed. Brasília: Coordenação de Publicações, 2001. 273 p.

Câmara dos Deputados. Estatuto da Cidade. Guia para implementação pelos municípios e cidadãos. 3. ed. Brasília, 2005.

Ministério das Cidades. Cadernos MCidades n. 1: Política Nacional de Desenvolvimento Urbano. Brasília, 2004.

Constituição da República Federativa do Brasil de 1988. Disponível em: <http://www.planalto.gov.br/ccivil_03/Constituicao/Constituiçao.htm>.

BRAUN, K.; KROPP, C. Beyond speaking the truth? Institutional responses to uncertainty in scientific governance. Science, Technology \& Human Values, v. 35, n. 6, p. 771-782, 2010.

BREDARIOL, C. S. Conflito Ambiental e Negociação, Para Uma Política Local de Meio Ambiente. 2001. 224 f. Tese - COPPE/UFRJ, PHD, Programa de Planejamento Energético, Universidade Federal do Rio de Janeiro, Rio de Janeiro, RJ, 2001.

BUARQUE, S. C. Construindo o desenvolvimento local sustentável: metodologia de planejamento. 4. ed. Rio de Janeiro: Garamond, 2006.

BUCCHI, M.; NERESINI, F. Science and public participation. In: HACKETT, E.; AMSTERDAMSKA, O.; LYNCH, M.; WAJCMAN, J. (Eds.). The Handbook of Science and Technology Studies. Massachusetts: MIT, 2008, p. 449-473.

BUCCI, M.P.D. Notas para uma metodologia de análise de políticas públicas. Politicas Publicas: Possibilidade e limites. Org. FORTINI, C. ESTEVES, J.C. DIAS, M.T.F. Belo Horizonte. 2008

BUCHANAN, L.; O’CONNELL, A. Uma breve história da tomada de decisão. Harvard Business Review, p. 20-29, jan. 2006. 
BURTON, P.; MUSTELIN, J. Planning for Climate Change: Is Greater Public Participation the Key to Success? Urban Policy and Research, 2013.

CALDAS, M. F. Política urbana, ação governamental e a utopia da reforma urbana no Brasil. 2015. 271 f. Tese (Doutorado) - Universidade Federal de Minas Gerais, Escola de Arquitetura, MG, 2015.

CANTALICE, A. S. C. Uma breve reflexão sobre forma urbana. ARCHITECTON Revista de arquitetura e Urbanismo, v. 2, n. 2, 2012.

CARBALLEDA, A. J. M. Cartografías e Intervención en lo social. In: TETAMANTI, M. D. (Org.). Cartografía social: investigaciones e intervención desde las ciencias sociales métodos y experiencias de aplicación. 1. ed. Comodoro Rivadavia: Universitaria de la Patagonia, 2012. 162 p.

CARDOSO, A. L.; RIBEIRO, L. C. Q. A cidade e seu estatuto: uma avaliação urbanística do Estatuto da Cidade. In: RIBEIRO, L.; CARDOSO, A. L. (Orgs.). Reforma Urbana e Gestão Democrática: promessas e desafios do Estatuto da Cidade. Rio de Janeiro: Revan, FASE, 2003.

CARDOSO, F. H. Aspectos políticos do planejamento. In: LAFER, B. M. (Ed.)

Planejamento no Brasil. São Paulo: Perspectiva, 1975.

CARLINI-COTRIM, B. Potencialidades da técnica qualitativa grupo focal em investigação sobre o abuso de substâncias. Rev Saúde Pública, v. 30, n. 3, p. 285-293, 1996.

CARLSSON, C.; FULLÉR, R. Fuzzy multiple criteria decision making: recent developmens. Fuzzy Sets and Systems, n. 78, p. 139-153, 1996.

CARNEIRO, C. B. L. Conselhos de políticas públicas: desafios para sua institucionalização. In: FERRAREZI, E.; SARAIVA, E. POLÍTICAS PÚBLICAS, COLETÂNEA. Brasília: ENAP, 2006.

CASTELLS, M. A sociedade em rede. A era da informação: economia, sociedade e cultura. v. 1. São Paulo: Paz e Terra,1999.

Terra, 2009.

A Questão Urbana. Tradução de Arlene Caetano. Rio de Janeiro: Paz e

Cidade, democracia e socialismo. São Paulo: Paz e Terra, 1980.

CENTRO DE ESTUDOS DA METRÓPOLE (CEM). Serviços de consultoria para subsidiar a Comissão de política urbana - Relatoria do Plano Diretor, 2014a. Produto 3.1. Sistematização final das contribuições escritas ou apresentadas verbalmente pelo público nas reuniões técnicas, nas audiências públicas, pelo endereço eletrônico da Câmara Municipal ou enviadas via correio à Comissão de Política Urbana, Metropolitana e Meio Ambiente. São Paulo: CEM/CEBRAP, 2014a.

Relatório para subsidiar a Comissão de

política urbana - Relatoria do Plano Diretor, 2014b. Produto 4. Compilação dos estudos elaborados sobre temas do Plano. São Paulo: CEM/CEBRAP, 2014b. 
CERVERO, R. The Transit Metropolis: a global inquiry. Washington, D.C.: Island Press, 1998.

CHAMBERS, R. Participatory mapping and geographic information systems: Whose map? Who is empowered and who disempowered? Who gains who loses? Eletronic Journal on information Systems in Developing Countries, v. 25, n. 2, p. 1-11, 2006.

CHARMAZ, K. Grounded theory: Objectivist and constructivist methods. In: DENZIN, N. K.; LINCOLN, Y. (Orgs.). Handbook of qualitative research, EUA: Sage Publications Inc., 2000, p. 509-536.

CHOGUILL, M. B. G. A ladder of community participation for underdeveloped countries. Habitat International, v. 20, n. 3, p. 431-444,1996.

COCHRANE, J. L.; ZELENY, M. (Eds.). Multiple criteria decision making. Columbia, USA: University of South Carolina Press, 1973.

COLLINS, H.; EVANS, R. Rethinking Expertise. Chicago: The University of Chicago Press, 2007.

COLLIS, J.; HUSSEY, R. Pesquisa em administração. 2. ed. Porto Alegre: Bookman, 2005.

COOKE, B.; KOTHARI, U. Participation: The new tyranny? London: Zed Books, 2001.

CORDEIRO NETTO, O. M.; SOUZA, M. A. A.; CARNEIRO, G. A.; NERI, L.; LOPES JUNIOR, R. P. Uma metodologia para análise tecnológica de sistemas com reatores biológicos anaeróbios para tratamento de águas residuárias municipais. Anais do XXVII Congresso Interamericano de Engenharia Sanitária e Ambiental, v. 1, p. 1-14, Porto Alegre, RS, 2000.

CORK, S. L.; DELANEY, K.; SALT, D. Futures Thinking ... about landscapes, lifestyles and livelihood in Australia. Land \& Water Australia, 2005.

COSTA, A. G.; PERES, U.D. Modelos Teóricos Explicativos Para Instituições Participativas: Construção de um Quadro Conceitual. Revista Gestão e Politicas Publicas, v. 4, n. 1, p. 121, 2014.

COSTA, D. B. Diretrizes para concepção, implementação e uso de sistemas de indicadores de desempenho para empresas da construção civil. 2003. 176 f. Dissertação (Mestrado) - Escola de Engenharia, Universidade Federal do Rio Grande do Sul, Porto Alegre, RS, 2003.

COSTA, G. M. Prática e ensino em planejamento (urbano) no Brasil: da "velha" compreensividade multidisciplinar à abordagem transdisciplinar. In:

MENDONÇA, J. G. (Orgs.). Planejamento urbano no Brasil: Trajetória, avanços e perspectivas. Belo Horizonte: C/Artes, 2008.

COSTA, M. S. Mobilidade Urbana Sustentável: Um estudo Comparativo e as Bases de um Sistema de Gestão para Brasil e Portugal. 2003. 196 f. Dissertação (Mestrado) - Escola de Engenharia de São Carlos da Universidade de São Paulo, São Carlos, SP, 2003. 
. Um índice de Mobilidade Urbana Sustentável. 2008. 274 f. Tese (Doutorado) Escola de Engenharia de São Carlos da Universidade de São Paulo, São Carlos, SP, 2008.

CRUZ, R. B. C. Aplicação de Modelo de Decisão Multicritério para apoio às tomadas de decisão na incorporação de edifícios comerciais de pequeno porte. 2013. $126 \mathrm{f}$.

Dissertação (Mestrado em Engenharia Civil) - Instituto de Pesquisas Tecnológicas do Estado de São Paulo (IPT), São Paulo, SP, 2013.

; MARINS, K.R.C . Avaliação do índice de compacidade nas subprefeituras do município de São Paulo. Revista Eletrônica De Engenharia Civil, v. 13, n. 2, p. 287-298, 2017.

CUBIDES, A. H. Y. P. La Cartografia Social como instrumento metodológico em los procesos de construción de territorio a partir de la participación ciudadana em la planeación territorial y la construción del espacio público. 2009. 163 f. Tesis (Maestría) Universidad Pontificia Javeriana, 2009.

CUNHA, L. H.; COELHO, M. C. N. Políticas e Gestão Ambiental. In: CUNHA, S. B.; GUERRA, A. J. T. (Orgs.). A Questão Ambiental: diferentes abordagens. Rio de Janeiro: Bertrand Brasil, 2003, p. 43-79.

DAGNINO, R. Mais além da participação pública na ciência: buscando uma reorientação dos Estudos sobre Ciência, Tecnologia e Sociedade em Ibero-América. Revista IberoAmericana de Ciencia, Tecnologia, Sociedade y Innovacion, n. 7, 2006.

DALLARI, D. A. Direito de participação. In: SOORENTINO, M. (Coord.). Ambientalismo e participação na contemporaneidade. São Paulo: EDUC/ FAPESP, 2001, p. 85-114.

O que é participação política. 3. ed. São Paulo: Brasiliense, 1984.

DASSO JÚNIOR, A. E. A participação cidadã além do poder local: em busca de diretrizes e princípios universais para uma gestão pública emancipadora. In: XVII Congreso

Internacional del CLAD sobre la Reforma del Estado y de la Administración Pública, Cartagena, Colômbia, 30 out.-2 nov. 2012. Disponível em:

<http://201.200.251.131/dgsc/documentos/cladxvii/dassojun.pdf>. Acesso em: 28 jan. 2015.

DAZA, L.A. M. Projetos de Waterfront e integração de políticas de transporte e uso do solo. 2002. Dissertação (Mestrado) - PET / COPPE, Universidade Federal do Rio de Janeiro, Rio de Janeiro, RJ, 2002.

DE TONI, J.; SALERNO, G.; BERTINI, L. Uma abordagem estratégica no planejamento de grupos: o Método Altadir de Planejamento Popular - MAPP. In: JACQUES, M. G. C. et al. (Orgs.). Relações sociais e ética. Rio de Janeiro: Centro Edelstein de Pesquisas Sociais, 2008, p. 140-150.

DEMO, P. Participação é conquista: noções da política social participativa. São Paulo: Cortez, 1996.

DI GIULIO, G. M. Risco, ambiente e saúde: um debate sobre comunicação e governança do risco em áreas contaminadas. São Paulo: Annablume, 2012. 
DI GIULIO, G. M.; FIGUEIREDO, B. R.; FERREIRA, L. C.; ANJOS, J. A. S. Experiências brasileiras e o debate sobre comunicação e governança do risco em áreas contaminadas por chumbo. Ciência e Saúde coletiva, v. 17, p. 337-349. 2012.

DICK, B. You want to do action research thesis: how to conduct and report action research, 1993. Disponível em: 〈http://www.scu.edu.au/schools/gcm/ar/art/arthome.html>. Acesso em: 15 dez. 2016.

DINIZ, E. Governabilidade, Democracia e Reforma do Estado: Os Desafios da Construção de uma Nova Ordem no Brasil dos Anos 90. DADOS - Revista de Ciências Sociais, Rio de Janeiro, v. 38, n. 3, 1995.

DOWBOR, L. Descentralização e Meio Ambiente. In: BURSZTYN, M. et al. Para pensar o desenvolvimento sustentável. São Paulo: Brasiliense, 1993, p. 103-142.

DROR, Y. Public policymaking re-examined. Oxford: Transaction Publishers, 1983.

DUARTE, A. B. S. Grupo Focal Online e Offline como Técnica de Coleta de Dados. Inf. \& Soc.: Est., v. 17, n. 1, p. 75-85, João Pessoa, jan./abr. 2007.

DUARTE, F.; SÁNCHEZ, K.; LIBARDI, R. Introdução à Mobilidade Urbana. 1. ed. Curitiba: Juruá, 2008.

ELKINGTON, J. Triple bottom line revolution: reporting for the third millennium. Australian CPA, 1999.

ENSSLIN, L.; MONTIBELLER NETO, G.; NORONHA, S. M. Apoio à decisão: metodologia para estruturação de problemas e avaliação multicritério de alternativas. Florianópolis: Insular, 2001. 296 p.

FABRETTI, T. R.; FANTINATTI, P. A. P.; JACOMAZZI, M. A.; ZUFFO, A. C. Cobrança pelo uso da água para fins de abastecimento: proposta de cálculo por meio de análise multicritério. In: SIMPÓSIO BRASILEIRO DE RECURSOS HÍDRICOS, 19., 2011, Maceió. Anais...: Maceió, 2011.

FANTINATTI, P. A. P. Abordagem MCDA como ferramenta de mudança de paradigma no planejamento dos recursos hídricos. 2011. $400 \mathrm{f}$. Tese (Doutorado) - Faculdade de Engenharia Civil, Arquitetura e Urbanismo da Universidade Estadual de Campinas, Campinas, SP, 2011.

Ações de gestão do conhecimento na construção civil: evidências a partir da assistência técnica de uma construtora. 2008. 148 f. Dissertação (Mestrado em Engenharia Civil) - Faculdade de Engenharia Civil, Arquitetura e Urbanismo da Universidade Estadual de Campinas, Campinas, 2008.

; ZUFFO, A. C.; FERRÃO, A. M. A. Indicadores de sustentabilidade em engenharia. 1. ed. Rio de Janeiro: Elsevier, 2015.

FEENBERG, A. A filosofia da tecnologia numa encruzilhada. Tradução de Newton Ramos de Oliveira. 1999. Disponível em: <http://www-rohan.sdsu.edu/ faculty!feenberg>. Acesso em: nov. 2015. 
FEENBERG, A. Critical Theory of Technology. New York: Oxford University Press, 1991.

Racionalización Democrática: tecnologia, poder y líbertad.1992. Disponível em: <http://www-rohan.sdsu.edu /facul eenberg>. Acesso em: nov. 2015.

Transforming Technology. New York: Oxford University Press, 2002.

FELLOWS, R.; LIU, A. Research methods for construction. 2. ed. Hong-Kong: Blackwell Science, 2005. 262 p.

FELT, U.; WYNNE, B. Taking European Knowledge Seriously. Report of the Expert Group on Science and Governance to the Science, Economy and Society Directorate, Brussels, Directorate-General for Research, European Commission, 2007.

FERREIRA, C. M. S.; FONSECA, A. Análise da participação popular nos Conselhos Municipais de Meio Ambiente do Médio Piracicaba (MG). Ambiente e Sociedade, São Paulo, v. 17, n. 3, p. 239-258, set. 2014.

FERN, E. F. Advanced focus group research. California: Thousand Oaks, 2001.

FERNANDES, E. Reforma Urbana e Reforma Jurídica no Brasil: duas questões para reflexão. In: COSTA, G. M.; MENDONÇA, J. (Orgs.). Planejamento Urbano no Brasil: trajetória, avanços e perspectivas. Belo Horizonte: C/Arte, 2008, p. 128.

FERNANDES, K. D. L. M. A influência da forma urbana e da legislação urbanística na mobilidade urbana: O caso do Plano Diretor de Olinda. 2008. Dissertação (Mestrado) Faculdade de Engenharia Civil da Universidade Federal de Pernambuco, Recife, PE, 2008.

; MAIA, M. L. A.; FERRAZ, C. Forma Urbana e deslocamentos

pendulares: uma análise dos bairros de casa caiada e jardim Brasil em Olinda- PE. 2008.

FERREIRA, L. C. A questão ambiental: sustentabilidade e políticas públicas no Brasil. São Paulo: Bomtempo Editorial, 1998.

FERREIRA, S. L. Democracia direta vs. representativa: uma dicotomia inconciliável com algumas reinvenções. Direto Público (estudos, conferências e nota). v. 1, n. 18, out./ nov./ dez. 2007. Disponível em:

<http://www.direitopublico.idp.edu.br/index.php/direitopublico/article/viewArticle/396>. Acesso em: 18 mar. 2015.

FEYERABAND, P. Contra o método: esboço de uma teoria anárquica da teoria do conhecimento. Rio de Janeiro: Francisco Alves, 1977.

FIGUEIRA, J.; GRECO, S.; EHRGOTT, M. (Eds.). Multiple criteria decision analysis: state of art surveys. Boston: Springer Science, Business Media, 2005.

; MOUSSEAU, V.; ROY, B. ELECTRE methods. In: ; GRECCO,

S.; EHRGOTT, M. (Eds.). Multiple criteria decision analysis: state of art surveys. Boston: Springer Science, Business Media, 2005. cap. 4, p. 133-162. 
FINCHER, R. Urban redevelopment in Boston: Rhetoric and reality. In: COX, K. R.; JOHNSTON, R. J. (Eds.). Conflict, Politics and the Urban Scene. New York: St. Martin's Press, 1982.

FRANCO, E. Gestão do conhecimento na construção civil: uma aplicação dos mapas cognitivos na concepção ergonômica da tarefa de gerenciamento dos canteiros de obras. 2001. 253 f. Tese (Doutorado) - Universidade Federal de Santa Catarina, Florianópolis, 2001.

FRANCO, M. I. Agenda 21 na educação: construindo ferramentas pedagógicas para trilhar o caminho da sustentabilidade. Agenda 21 - Educação Ambiental em Áreas de Proteção aos Mananciais, Embu. Sociedade Ecológica Amigos de Embu (SEAE), Fundo Estadual de Recursos Hídricos (FEHIDRO), 2006.

FRANEK, J., KRESTA, A. Judgment scales and consistency measure in AHP. Procedia Economics and Finance, 12, pp. 164-173. 2014

FREIDE, R. Democracia e Estado de Direito. Novos estudos jurídicos, ano IV, n. 7, p. 6168, 1998. Disponível em: <http://www.buscalegis.ufsc.br/revistas/files/anexos/25887-258891-PB.htm>. Acesso em: 15 mai. 2015.

FREITAS, C. M. A contribuição dos estudos de percepção de riscos na avaliação e no gerenciamento de riscos relacionados aos resíduos perigosos. In: SISINNO, C. L. S.; OLIVEIRA, R. M. (Orgs.). Resíduos sólidos, ambiente e saúde: uma visão multidisciplinar. Rio de Janeiro: Fiocruz, 2000, p.111-128.

FUNTOWICZ, S.; RAVETZ, J. Ciência pós-normal e comunidades ampliadas de pares face aos desafios ambientais. História, Ciências, Saúde. Manguinhos, ano IV, n. 2, p. 219-230, jul.-out. 1997.

FUNG, A. Varieties of Participation in Complex Governance. Public Administration Review, Special Issue, 2006.

; COHEN, J. Democracia radical. Política e Sociedade, v.11, p. 221-237, 2007.

GALLAFHER, L. The End of the Suburbs: Where the American Dream Is Moving. New York: The Penguin Group Inc., 2013.

GALVÃO, O. Externalidades e Desenvolvimento urbano: reflexões a partir do Estatuto da Cidade. Revista Brasileira de Estudos Urbanos, v. 7, n. 2, 2005.

GASPAR, W. J. Proposta metodológica de avaliação do grau de satisfação de população de área urbana. Estudo de caso: bairro Antenor Garcia, município de São Carlos, SP. 2007. 163 f. Tese (Doutorado) - Universidade Federal de São Carlos, São Carlos, SP, 2007.

GENTIL, C. D. A Contribuição dos elementos da forma urbana na construção da mobilidade sustentável. 2015. 172 f. Tese (Doutorado) Universidade de Brasília, Brasília, DF, 2015.

; BEZERRA, M. C. L.; MEDEIROS, V. A. S. de. As faces da mobilidade urbana: configuração, uso do solo e políticas públicas em Goiânia (Brasil). In: 6 Congresso Luso-brasileiro para o planejamento urbano, integrado e sustentável - PLURIS. Lisboa, 2014. 
GERSHON, M.; DUCKSTEIN, L. Multiobjective approaches to river basin planning. Journal of Water Planning and Management, v. 109, n. 1, p.13-28, jan. 1983.

GIARETTA, J. B. Z. Participação social e gestão ambiental municipal no Brasil: desafios e condicionantes. 2011. 146 f. Dissertação (Mestrado) - Faculdade de Saúde Pública da Universidade de São Paulo, 2011.

GIATTI, L. L.; LANDIN, R.; TOLEDO, R. F. Aplicabilidade da ecologia de saberes em saúde e ambiente e sua permeabilidade na produção acadêmica. Ciência e Saúde coletiva (impresso), v. 19, p. 4091-4102, 2014.

GIDDENS, A. Beyond Left and Right. Cambridge: Polity, 1994.

Conseqüências da modernidade. São Paulo: Unesp,1992.

1999.

Run-Away World: How globalization is reshaping our world. London: Profile,

The Consequences of Modernity. Cambridge: Polity, 1990.

The Third Way. Cambridge: Polity, 1998.

GIL, A. C. Como elaborar projetos de pesquisa. 4. ed. São Paulo: Atlas, 2002.

GILBERT, M. J. The antropologist as alcohologist: qualitatitive perspectives and methods in alcohol research. Int J Addict, v. 25, n. 2A, p. 127-48, 1990-91.

GLIK, D., GORDON, A. A focus group methods forformativa research in child survival. An ivorianexample. Int Q Comm Health Educ, v. 8, n. 4, p. 297-315, 1988.

GOHN, M. G. Movimentos Sociais no Início do Século XXI: antigos e novos atores sociais. Petrópolis: Vozes, 2003.

GONDIM, S. M. G. Grupos focais como técnica de investigação qualitativa: desafios metodológicos. Paidéia, v. 12, n. 24, p. 149-161, 2003.

GORAYEB, A.; MEIRELES, A. J. A.; SILVA, E. V. Princípios básicos de Cartografia e Construção de Mapas Sociais. In: GORAYEB, A.; MEIRELES, A. J. A.; SILVA, E. V. (Orgs.). Cartografia Social e Cidadania: experiências de mapeamento participativo dos territórios de comunidades urbanas e tradicionais. Fortaleza: Expressão Gráfica Editora, 2015, p. 9-24.

Mobilização Social, 2014

Cartografia Social e Populações Vulneráveis. Rede Nacional de

GRABISCH, M.; LABREUCHE, C. Fuzzy measures and integrals in MCDA. In: FIGUEIRA, J.; GRECCO, S.; EHRGOTT, M. (Eds.). Multiple criteria decision analysis: state of art surveys. Boston: Springer Science, Business Media, 2005, cap. 14, p. 563-608.

GRANJA, A. D. Pesquisa-ação: uma análise crítica. Campinas: [s.n.], 2009. Disponível em: <http://www.fec.unicamp.br/ adgranja/index_arquivos/pesquisa\%20acao\%20>. 
GUDMUNSSON, H. Sustainable Transport and Performance Indicator. In: HESTER, R. E.; HARRISON, R. M. (Eds.). Issues in Environmental Science and Technology, n. 20, p. 3563, 2004.

GUIVANT, J.; MACNAGHTEN, P. O mito do consenso: Uma Perpectiva comparativa sobre governança tecnológica. Ambiente \& Sociedade, Campinas, v. XIV, n. 2, p. 89-104, jul.-dez. 2011.

HABERMAS, J. Direito e Democracia: entre a facticidade e validade, v. 1 e 2, 2003a. Tradução de Flávio Beno Siebeneichler. Rio de Janeiro: Tempo Brasileiro. [Faktizität und Geltung. Beiträge zur Diskurstheorie des Rechts und des demokratische Rechtstaadts. Frankfurt am Main: Suhrkamp Verlag, 1992] 2003a.

Brasileiro, 1997.

Direito e democracia: entre facticidade e validade. Rio de Janeiro: Tempo

.Mudança Estrutural da Esfera Pública: Investigações quanto a uma categoria da sociedade burguesa, 2003b. Tradução de Flávio Kothe. 2. ed. Rio de Janeiro: Tempo Brasileiro, p. 42. (Strukturwandel der Öffentlichkeit. Darmistadt: Herman Luchterhand Verlag, 1961) 2003b.

HALLER, W., TIEDEMAN, E., WHITAKER, R. Expert choice - User Manual. Pittsburgh, PA: Expert Choice. 1996

HARMONICOP. Public participation and the European water framework directive: role of information and communication tools. Work Package Report of the Harmonicop, 2003a. deliverable, 2003 b.

Social Learning Pool of questions. Harmonicop combined WP2/WP3

HARVEY, D. Condição Pós-Moderna. São Paulo: Loyola, 1993.

HERCE VALLEJO, M.; FARRERONS, J. M. El soporte infraestructural de la ciudad. Barcelona: Edcions UPC.2002

Proyectos de infraestructuras urbana. O.P. Obra Publica 43. Revista

del colégio de ingenieros de caminhos, canales y puertos, Barcelona, p. 33-41, 1998.

HERNANDEZ, F. M.; BERMANN, C. Participação da Sociedade Civil no Planejamento como elemento de uma nova ética ambiental. Considerações sobre o Gerenciamento Participativo de áreas de Mananciais em Santo André. III Encontro da ANPPAS. Brasília, DF, 23-26 mai. 2006.

HOGHOOD, B.; GUNN, L. Policy analysis for the real world. Oxford: Oxford University Press, 1984.

HOLANDA, F.; PASSOS, A. M.; CAVALCANTE, A.; SIMÕES DE BELLO, L. R.; MEÇASSO, P. Eccentric Brasilia. Proceedings of the Space Syntax. In: III International Symposium, A. Alfred Taubman College of Architecture and Urban Planning, University of Michigan, Ann Arbor, p. 531-538, 2001.

HOLANDA, F. O espaço de exceção. Brasília: Editora Universidade de Brasília, 2002. 
Uma ponte para a urbanidade. In: HOLANDA, F. (Org.). Arquitetura \&

Urbanidade. São Paulo: Pro Editores Associados Ltda., 2003. cap. 2. Disponível em:

<http://www.buscalegis.ufsc.br/revistas/files/anexos/25887-25889-1-PB.html>. Acesso em: 15 mai. 2015.

IERVOLINO, S. A.; PELICIONI, M. C. F. A utilização do grupo focal como metodologia qualitativa na promoção da saúde. Revista da Escola de Enfermagem da USP, v. 35, n. 2, p. 115-121, jun. 2001.

INTERNATIONAL FUND FOR AGRICULTURAL DEVELOPMENT (IFAD). Good practices in participatory mapping: a review prepared for the International Fund for Agricultural Development (IFAD). Italy: IFAD, 2009.

IRWIN, A. Citizen Science: a study of people, expertise, and sustainable development. London: Routledge, 1995.

. The politics of talk, coming to terms with the 'new' scientific governance. Social Studies of Science, v. 36, n. 2., p. 299-330, 2006.

ISHIZAKA, A., LABIB, A. Review of the main developments in the analytic hierarchy process. Expert Systems with Applications, 38(11), pp. 14336-14345. 2011.

JACOBI, P. R. Educação ambiental: o desafio da construção de um pensamento crítico, complexo e reflexivo. Educação e Pesquisa, São Paulo, Faculdade de Educação da USP, v. 31, n. 2, p. 233-250, mai./ ago. 2005.

. Políticas sociais locais e os desafios da participação cidadania. Ciência \&

Saúde Coletiva, v. 7, n. 3, p. 443-54, 2002.

; GRANJA, S. I. B.; FRANCO, M. I. Aprendizagem social: práticas educativas

e participação da sociedade civil como estratégias de aprimoramento para a gestão compartilhada em bacias hidrográficas. São Paulo em Perspectiva, São Paulo: Fundação Seade, v. 20, n. 2, p. 5-18, abr./ jun. 2006.

JAHANGEER, A. P., SHOWKAT, A. G., SULTAN BHAT, M. GIS based land suitability analysis using AHP model for urban services planning in Srinagar and Jammu urban centers of J\&K, India. Journal of Urban Management, v.7, n.2, pp. 46-56. 2018.

JOLY, P. B.; KAUFMANN, A. Lost in translation? The need for 'upstream engagement' with nanotechnology on trial. Science as Culture, v. 17, n. 3, p. 225-247, 2008.

JUNQUEIRA, M. R. Aplicação da teoria dos jogos cooperativos para a alocação de custos de transmissão em mercados elétricos. 2005. Dissertação (Mestrado) - Universidade Federal do Rio de Janeiro, Rio de Janeiro, RJ, 2005. 107 p.

KAUFFMAN S. A. The Origins of Order: Self-Organization and Selection in Evolution. Oxford University Press, 1992.

. At home in the universe: The search for the laws of selforganization and complexity. Oxford University Press, 1995. 
KAY, J. J.; REGIER, H. A.; BOYLE, M.; FRANCIS, G. An ecosystem approach for sustainability: addressing the challenge of complexity. Futures, 1999, p. 721-742.

KEENEY, R. L. Value-focused thinking: a path to creative decision-making. Cambridge: Harvard University Press, 1992.

KLAUSER, F.; KEARNES, M. (Eds.). Risk Research: Practices, Politics and

KLIKSBERG, B. Seis teses não-convencionais sobre participação. Revista de Administração Pública, v. 33, n. 3, p. 7-37, 1999.

KRUEGER, R.A. Focus Group: a practical guide for applied research. Newbury Park: Sage Publications, 1988.

Focus Groups: A practical guide for applied research. University of Michigan: Sage Publications, 1994.

KUHN, T. S. The structure of scientific revolutions. Chicago: Universidade de Chicago, 1962.

LAMAS, J. 1. R. G. Morfologia Urbana e Desenho da Cidade. 4. ed. Lisboa: Fundação Calouste Gulbenkian - Fundação para a Ciência e Tecnologia, 2007.

LAVAlLE, A. G.; HOUTZAGER, P. P.; CASTELLO, G. Democracia, pluralização da representação e sociedade civil. O futuro da representação, v. 67, p. 49-103, 2006.

Disponível em: <http://www.cedec.org.br/files_pdf/luanova/ln-67.pdf\#page=49>. Acesso em: 22 nov. 2015.

; VERA, E. I. A trama da crítica democrática: da participação à representação e à Accountability. Revista Lua Nova, São Paulo, v. 84, p. 353-64, 2011.

LAVILLE, C.; DIONNE, J. A construção do saber: manual de metodologia da pesquisa em ciências humanas. Porto Alegre: Editora Artes Médicas Sul, 1999.

LE GALES, P. Du gouvernement des villes à la gouvernance urbaine. Revue française des sciences politiques, Paris: Presses Universitaires de France, v. 45, n. 1, p. 57- 95, 1995.

. Du gouvernment des villes à la gouvernance urbaine. Revue Française de Science Politique, v. 45, n. 1, p. 57-95, 1995.

Le retour des villes européennes: sociétés urbaines, mondialisation, gouvernement et gouvernance. Paris: Presses de Sciences Politique, 2003. Française, 2006.

Gouvernement et gouvernance des territoires. Paris: La Documentation

LEACH, M.; SCOONES, I.; WYNNE, B. Science and Citizens: Globalization and the challenge of engagement. London: Zed Books, 2005.

SCOONES, I.; WYNNE, B. (Eds.). Science and Citizens: Globalization and the challenge of engagement. London: Zed Books, 2005. 
LEITE, C.; AWAD J. C. M. Cidades Sustentáveis Cidades Inteligentes: desenvolvimento sustentável num planeta urbano. Porto Alegre: Bookman, 2012.

LENTINO, I. K. Análise Multicriterial de Proposta de Gestão da Mobilidade para Grandes Empreendimentos Urbanos. 2005. Tese (Doutorado) - Centro de Tecnologia da Universidade Federal do Rio de Janeiro, Rio de Janeiro, RJ, 2005.

LI, X.; YEH, A. G. O. Analyzing spatial restructuring of land use patterns in a fast growing region using remote sensing and GIS. Landscape and Urban Planning, v. 69, n. 4, p. 335354, 2004.

LINDBLOM, C. O Processo de Decisão Política. Brasília: Universidade de Brasília, 1981.

LITMAN, T. Land Use Impacts on Transport: How Land Use Factors Affect Travel Behavior. 2012.

LOEWENSTEIN, K. Teoría de la Constitución. Traducción de A. Gallego Anabitarte. Barcelona: Edit. Ariel St., 1983.

LONG, N. From paradigm lost to paradigm regained? The case for an actor-oriented sociology of development. In: LONG, N.; LONG, A. (Eds.). Battlefields of Knowledge: The interlocking of theory and practice in social research and development. London: Routledge, 1992.

; VILLAREAL, M. The interweaving of knowledge and power in development interfaces. In: SCOONES, I.; THOMPSON, J. (Eds.). Beyond Farmer First: Rural people's knowledge, agricultural research and extension practice. London: IT Publications, 1994.

LU, C.; LIU, Y. Effects of China's urban form on urban air quality. Urban Studies, v. 53, n. 12, p. 2607-2623, 2016.

LÜCHMANN, L. H. H. A representação no interior das experiências de participação. Revista Lua Nova, São Paulo, n. 70, 2007.

MACHADO, E. G. Planejamento e agentes urbanos no Brasil. Pensar, Fortaleza, v. 13, n. 1, p. 95-106, jan./ jun. 2008.

MACHADO, E.G. Planejamento urbano, democracia e participação popular: o caso da revisão do Plano Diretor de Fortaleza (2003-2008). 2010. 451 f. Tese (Doutorado em Sociologia) - Departamento de Ciências Sociais, Programa de Pós-Graduação em Sociologia, Universidade Federal do Ceará, Fortaleza, CE, 2010.

MACNAGHTEN, P.; CHILVERS, J. Governing risky technology. In: LANE, S.; KLAUSER, F.; KEARNES, M. (Eds.). Risk Research: Practices, Politics and Ethics. London: WileyBlackwell, 2012, p. 99-124.

; GUIVANT, J. Converging citizens? nanotechnology and the political imaginary of public engagement in Brazil and the United Kingdom. Public Understanding of Science, v. 20, n. 2, p. 207-220, 2010.

MALINOWSKI, A. Aplicação de metodologia para a estruturação de diretrizes para o planejamento do reúso de água no meio urbano. 2006. $221 \mathrm{f}$. Dissertação (Mestrado) - 
Programa de Pós-graduação em Recursos Hídricos e Ambiental, Universidade Federal do Paraná, Curitiba, 2006.

MANCINI, L. M. A participação na governança de projetos urbanos metropolitanos no Rio de Janeiro: a experiência do projeto Reconstrução Rio. 2014. 274 f. Tese (Doutorado) Departamento de Ciências Sociais da Pontifícia Universidade Católica do Rio de Janeiro, Rio de Janeiro, RJ, 2014.

MARCHAND B. Simulating Negotiations on the Computer. Comput, Environment and Urban Systems, Elsevier Science, U.K., v. 20, n. 1, 1997.

MARICATO, E. O Estatuto da cidade periférica. In: SANTOS CARVALHO, C.; ROSSBACH, A. (Orgs.). O Estatuto da Cidade comentado. São Paulo: Ministério das Cidades, Aliança das Cidades, 2010.

. O lugar fora das idéias e as idéias fora do lugar: Planejamento Urbano no Brasil. In: ARANTES, O.; VAINER, C.; MARICATO, E. A cidade do pensamento único: Desmanchando consensos. 5. ed. Petrópolis: Vozes, 2009.

. O Ministério das Cidades e a política nacional de desenvolvimento urbano.

Políticas Sociais: Acompanhamento e análise, Brasília, DF, n. 12, p. 211-220, fev. 2006.

; FERREIRA, J. S. W. Operação Urbana Consorciada: Diversificação Urbanística Participativa ou Aprofundamento da Desigualdade? Estatuto da Cidade e Reforma Urbana: Novas Perspectivas para as Cidades Brasileiras. Porto Alegre: Sergio Antônio Fabris Editor, 2002, p. 215-250.

MARINS, K. R. C. C. Proposta Metodológica para Planejamento Energético no Desenvolvimento de Áreas Urbanas. O potencial da integração de estratégias e soluções em morfologia e mobilidade urbana, edifícios, energia e meio ambiente: caso da operação urbana Agua Branca, São Paulo. 2010. 798 f. Tese (Doutorado) - Faculdade de Arquitetura e Urbanismo, Universidade de São Paulo, São Paulo, SP, 2010.

Comparação de estratégias e soluções de sustentabilidade aplicadas a

bairros urbanos. In: XV ENCONTRO NACIONAL DE TECNOLOGIA DO AMBIENTE CONSTRUÍDO. Maceió, 2014.

; CATTO, V. M.; PACIFICI, M.; CRUZ, R. B C.; LAMOUR, Q.;

TIERNO, R. Estudo Multicriterial da Forma Urbana em Area de adensamento Urbano em São Paulo. In: IX ENCONTRO NACIONAL, VII ENCONTRO LATINO-AMERICANO, II ENCONTRO LATINO-AMERICANO E EUROPEU SOBRE EDIFICAÇÕES E COMUNIDADES SUSTENTÁVEIS - UNISINOS. Anais...São Leopoldo, RS, 2017, p.1965 -1975 .

; GIROTTI, C.; PACIFICI, M.; CRUZ, R.B.C. Modelagem e Comparação de Efeitos Simultâneos da Forma Urbana sobre a Geração de Energia Fotovoltaica e o Conforto dos Espaços Externos. O caso do Belenzinho, em São Paulo. In: XVII ENCONTRO NACIONAL DE TECNOLOGIA DO AMBIENTE CONSTRUÍDO, 2018, Foz do Iguaçu. Anais...Foz do Iguaçu: Desafios da Inovação no Ambiente Construído, 2018, p. 321-331. 
MARSICK, V. J.; WATKINS, K. E. Demonstrating the value of an organization's learning culture: the dimensions of the learning organization questionnaire. Advances in Developing Human Resources, v. 5, n. 2, p. 132-151, 2003.

MARTINS J. D. S. As temporalidades da História na dialética de Lefebvre. In: MARTINS, J. D. S. (Ed.). Henri Lefebvre e o retorno à dialética. São Paulo: Hucitec, 1996, p. 13-24.

MARTINS, J.A. E BODMER, M. Decision theory and analytic hierarchy process for consumers transport service choice simulation, 8th Thredbook. Rio de Janeiro, 2003.

Relatório Técnico: Estudo de Viabilidade Técnico-

Econômica de sistemas Hidroviários de Passageiros. Rio de Janeiro: Móbile COPPE/ UFRJ BNDES, 2002.

MASCARO, J. L. Manual de Loteamentos e Urbanizações. Porto Alegre: SAGRA/DC, Luzzato, 1994.

Desenho Urbano e Custos de Urbanização. Brasília: MHU/SAM, 1987.

MATOS, F.G. Negociação gerencial: aprendendo a negociar. Rio de Janeiro: José Olympio, 1989.

MATUS, C. Curso de Planificação e Governo - Guia de Análise teórica — Projeto Gestão. Florianópolis, 1991.

Política, Planificación y Gobierno. Caracas: Fundação Altadir, 1987.

MCCARNEY, P. Cities and Governance. New Directions in Latin America, Asia and Africa. Toronto: Centre for Urban \& Community Studies - University of Toronto, 1997a. 203 p.

. Considerciones sobre la noción de 'gobernabilidad'. Nuevos rumbos para las ciudades del mundo en desarrollo. EI Salvador en construcción, El Salvador: s/e, n. 13, p. 11-26, 1997. ; BLANCO, H.; CARMIN, J.; COLLEY, M. Climate Change and Cities:

First Assessment Report of the Urban Climate Change Research Network. Cambridge: Cambridge University Press, 2011.

MCKINLAY, J.B. Health promot ion throug healthy publicpolicy: the contribution of complementary research methods. Can J Public Health, v. 83, supl. 1, p. 11-9, 1992.

MEDEIROS, V. A. S. de. Urbis Brasiliae ou sobre cidades do Brasil: inserindo assentamentos urbanos do país em investigações configuracionais comparativas. 2006. Tese (Doutorado) - Universidade de Brasília, Brasília, DF, 2006.

UnB, 2013.

. Urbis Brasiliae: o labirinto das cidades brasileiras. Brasília: Editora

MELLINGER, L.; FLORIANI, D. Participação democrática na gestão dos bens naturais comuns e populações nativas no Litoral Sul do Paraná. Ambiente e Sociedade, São Paulo, v. 18 , n. 2, p. 1-22, jun. 2015. 
MEXIMIANO, A. C. A.. Além da Hierarquia: como implantar estratégias participativas para administrar a empresa enxuta. São Paulo: Atlas, 1995.

MEYER, P.; ROUBENS, M. Choice, ranking and storing in Fuzzy Multiple Criteria Decision Aid. In: FIGUEIRA, J.; GRECCO, S.; EHRGOTT, M. (Eds.). Multiple criteria decision analysis: state of art surveys. Boston, USA: Springer Science, Business Media, 2005. cap. 12, p. 471-506.

MILANI, C. R. S. O princípio da participação social na gestão de políticas públicas locais: uma análise de experiências latino-americanas e europeias. Revista de Administração Pública, v. 42, n. 3, p. 551-557, 2008.

MISOCZKY, M. C. A.; GUEDES, P. Planejamento e programação na administração pública. 2. ed. reimp. Florianópolis: Departamento de Ciências da Administração da Universidade de Santa Catarina, 2012. 182 p.

Mudanças na administração municipal: possibilidades de uma formação político-organizacional. Revista de Administração Contemporânea, v. 6, n. 2, p. 99-122, 2002.

MITCHELL, M. Complexity: A Guided Tour. Oxford University Press, 2011.

MODESTO, P. Participação Popular na Administração Pública: Mecanismos de Operacionalização. Vitória: Jus Vigilantibus, 1999.

MONTE-MÓR, R. L. M. Do Urbanismo à Política Urbana: notas sobre a experiência brasileira. In: COSTA, G. M.; MENDONÇA, J. G. de. Planejamento Urbano no Brasil:

trajetórias, avanços e perspectivas. Belo Horizonte: C/Arte, 2008.

MONTIBELLER NETO, G. Mapas cognitivos difusos para apoio à decisão: uma metodologia integrada para construção de problemas e exploração do impacto de alternativas nos valores do tomador de decisão. 2000. Tese (Doutorado em Engenharia de Produção) Universidade Federal de Santa Catarina, Florianópolis, 2000.

MOREIRA NETO, D. de F. Mutações do Direito Público. Rio de Janeiro: Renovar, 2006. p. 85-86.

MORGAN, D. L. Focus group as qualitative research. Qualitative Research Methods Series, n. 16. Londres: Sage Publications,1997.

Focus group as qualitative research. Sage university paper series. In:

Qualitative research methods. Newbury Park: Sage Publications, 1988.

The focus group guidebook. Londres: Sage Publications, 1998.

MOTTA, F. C. P. Burocracia e Autogestão: A Proposta de Proudhon. São Paulo: Brasiliense, 1981.

MOTTA, S. Direito Constitucional. 21. ed. Rio de Janeiro: Campus, 2009. 896 p.

MOTTA. A proposta de participação na teoria gerencial: a participação indireta. R. Adm. públ .. Rio de Janeiro, v. 15, n. 3, p. 54-70, jul./ set. 1981. 
MOURA, A. C. M. Geoprocessamento na Gestão e no Planejamento Urbano. 2. ed. Belo Horizonte: Ed. da autora, 2005.

NAHAS, M. I. P.; CABANNER, Y. Indicadores de Sustentabilidade Urbana para regiões metropolitanas. In: XVI Encontro Nacional ENANPUR. Espaço, planejamento e insurgências: alternativas contemporâneas para o desenvolvimento urbano e regional, 2015. Belo Horizonte. Anais...ANPUR. 20 p.

NASH, J. F. Non cooperative games. Annals of Mathematics, n. 54, p. 286-295, 1951. Apud JUNQUEIRA, M. R. Aplicação da teoria dos jogos cooperativos para a alocação de custos de transmissão em mercados elétricos. 2005. 107 f. Dissertação (Mestrado) - Universidade Federal do Rio de Janeiro, Rio de Janeiro, 2005.

NETO, F. O. L.; SILVA, E. V.; COSTA, N. O. Cartografia Social instrumento de construção do conhecimento territorial: Reflexões e Proposições acerca dos procedimentos metodológicos do mapeamento participativo. Revista da Casa da Geografia de Sobral, Sobral/CE, Volume especial em parceria com o V Congresso Brasileiro de Educação Ambiental Aplicada à Gestão Territorial, v. 18, n. 2, p. 56-70, set. 2016.

NETTO, V. M.; SABOYA, R. A urgência do planejamento: a revisão dos instrumentos normativos de ocupação urbana. Arquitextos - Vitruvius, n. 125.02, 2010.

NEW URBANISM. Creating Livable Sustainable Communities. 2013. Disponível em: <http://www.newurbanism.org/>. Acesso em: 5 mai. 2015.

NIERENBERG, G.I. The art of negotiating. 2. ed. Nova Iorque: Simon \& Schuster, 1981.

O'BRIEN, P. Scenario Planning - A Strategic Tool. Bureau of Rural Science, Department of Agriculture, Fisheries \& Forestry Australia, Commonwealth of Australia. 2000, 36 p.

OBSERVATÓRIO DAS METRÓPOLES. Relatório Nacional: Rede de Avaliação e Capacitação para a implementação dos Planos Diretores Participativos. 2010. Disponível em: <http://web.observatoriodasmetropoles.net/images/abook_file/plano_diretor.pdf/>. Acesso em: 13 mar. 2016.

OLIVEIRA, F. L.; BIASOTTO, R. O Acesso à Terra Urbanizada nos Planos Diretores Brasileiros. In: SANTOS JR, O. A.; MONTANDON, D. T. (Orgs.). Os Planos Diretores Municipais Pós-Estatuto da Cidade: balanço crítico e perspectivas. Rio de Janeiro: Letra Capital, Observatório das Cidades, IPPUR/UFRJ, 2011.

ONU-HABITAT. O direito à cidade: unindo o urbano dividido. Documento de referência da quinta sessão do Fórum Urbano Mundial. Rio de Janeiro, 2010.

OROFINO, F. V. G. Aplicação de um sistema de suporte multicritério - Saaty for Windows - na gestão dos resíduos sólidos de serviços de saúde: caso do hospital Celso Ramos. 1996. Dissertação (Mestrado em Engenharia) - Programa de Pós-graduação em Engenharia de Produção, Universidade Federal de Santa Catarina, Florianópolis, 1996.

OTTINGER, G. Buckets of resistance, standards and the effectiveness of citizenscience.

Science, Technology and Human Values, v. 35, n, 2, p. 244-270, 2010. 
PAGANI, E. A. O Direito de Propriedade e o Direito à Moradia: um diálogo comparativo entre o direito de propriedade urbana imóvel e o direito à moradia. Porto Alegre: EdiPUCRS, 2009.

PATEMAN, C. Participação e teoria democrática. Rio de Janeiro: Paz e Terra, 1992.

PELICIONI, A. C. Educação Ambiental na Formação de Agentes Comunitários. In:

PHILIPPI JR, A.; PELICIONI, M. C. F. (Eds.). Educação Ambiental: Desenvolvimento de Cursos e Projetos. Universidade de São Paulo, Faculdade de Saúde Pública, Núcleo de Informações em Saúde Ambiental. São Paulo: Signus Editora, 2000.

PELIZZOLI, M. L. Correntes da ética ambiental. Petrópolis: Vozes, 2002.

PETERSON, G. D.; CUMMING, G. S.; CARPENTER, S. R. Scenario Planning: a tool for conservation in an uncertain world. Conservation Biology, v. 17, n. 2, p. 358-366, 2003.

PIZZIRANI, F. O papel dos processos de participação popular na gestão municipal: estudo do orçamento participativo no município de Rio Claro/SP. 2006. Dissertação (Mestrado) - Faculdade de Filosofia, Letras e Ciências Humanas, Geografia Humana, São Paulo, SP, 2006.

PLÁ, J. V. A. Industrialização e transição demográfica no Brasil. Revista Economia \& Tecnologia (RET), v. 9, n. 1, p. 61-78, jan./ mar. 2013.

PONTUAL, P. C. O processo educativo no orçamento participativo: Aprendizados dos atores da Sociedade Civil e do Estado. 2000. 54 f. Tese (Doutorado) - Pontifícia Universidade Católica de São Paulo, São Paulo, 2000.

PUSSININI, N.; PIDORODESKI, A.; TOLEDO, B. H. C. Cartografia Social dos Povos e Comunidades Tradicionais no Paraná: Novas perspectivas temáticas para a Cartografia. Entre-Lugar, Dourados, MS, ano III, n. 5, p. 19-36, 2012.

LAMOUR, L. Avaliação da Estratégia dos Eixos de Estruturação da Transformação Urbana, do Município de São Paulo, frente à teoria do Desenvolvimento Orientado pelo Transporte (DOT). Estudo de Caso: área de influencia d Estação Belém do Metro. 2018. 371 f. Dissertação (Mestrado) - Escola Politécnica da Universidade de São Paulo, São Paulo, SP, 2018.

RAMIREZ, A.G, SHEPPERD, J. The use of focus group in health research. Scand. J Primary Healthy Care, suppl. 1, p. 81-90, 1988.

RAMOS, A. W. A cidade como negócio: aspectos da atuação do setor imobiliário e da relação público-privado na Barra Funda e na Água Branca (Município de São Paulo) um exame crítico da Operação Urbana Água Branca e do projeto "Bairro Novo". 2006. 274 f. Tese (Doutorado) - Curso de Filosofia Letras e Ciências Humanas, Departamento de Geografia, Universidade de São Paulo, São Paulo, 2006.

RATTNER, H. (Org.). Brasil no limiar do século XXI: Alternativas para a construção de uma sociedade sustentável. São Paulo: Edusp. (Coleção Brasil 500 anos), 2000.

REASON, P., BRADBURY, H. (Eds.). Handbook of Action Research. London: Sage, 2006. 
RENN, O. Risk governance: coping with uncertainty in a complex world. London:

Earthscan, 2008.

RESOLVE. Consensus Building Approach. USA, 1999. Disponível em:

$<$ http://www.resolve.org/>.

RIBEIRO, H.; VARGAS, H. C. (Orgs.). Novos instrumentos de gestão ambiental urbana. São Paulo: EDUSP, 2001a. cap. 5, p. 71-90. . Sempre uma questão de ética. In:

(Orgs.). Novos instrumentos de gestão ambiental urbana. São Paulo: EDUSP, 2001b. cap. 9, p. 151-152.

RIBEIRO, R.; HOLANDA, F.; COELHO, J. Índices de qualidade configuracional urbana: O caso do Distrito Federal, Brasil. EURE artículos. v. 38, n. 114, p. 229-255, mai. 2012.

RIVERA, U. Planejamento e Programação em Saúde: um enfoque estratégico. São Paulo: Ed. Cortez/Abrasco, 1992.

ROBBINS, S. Administração Estratégica Mudanças e Perspectivas. Saraiva, 2001.

ROCHA NETO, J.M. Cooperação e Competição entre políticas públicas no Brasil: os custos da governabilidade no presidencialismo de coalizão. 2013. Tese de DoutoradoUniversidade Federal do Rio Grande do Norte, Natal/RN. 2013.

RODRIGUES, E.; BARBOSA, B. R. Movimentos populares e o Estatuto da Cidade. 2010.

ROGERS, R.; GUMUCHDJIAN, P. Cidades para um pequeno planeta. Barcelona: Editorial Gustavo Gili, 2001.196 p.

ROLNIK, R. A construção de uma política fundiária e de planejamento urbano para o país: Avanços e Desafios - Ipea políticas sociais - acompanhamento e análise. 12 fev. 2006, p.199 -210.

(Org). Estatuto da Cidade: Guia para implementação pelos municípios e cidadãos. Brasília: Câmara dos Deputados, 2001.

ROMERO, M. A. B. A. Estratégias Bioclimáticas de Reabilitação Ambiental Adaptadas ao Projeto. In: ROMERO, M. A. B. A. (Org.). Reabilitação Ambiental Sustentável Arquitetônica e Urbanística. Brasília: FAU/UnB, 2009.

. Frentes do Urbano para a Construção de Indicadores de

Sustentabilidade Intra Urbana. Paranoá: cadernos de arquitetura e urbanismo da FAU-UnB, Brasília, ano VI, n. 4, nov. 2007.

. Sustentabilidade do Ambiente Urbano da Capital. In: GOUVÊA, L. A. C.; PAVIANI, A. (Orgs.). Brasília: Controvérsias Ambientais. Brasília: Editora UnB, Coleção Brasília, 2003.

ROTHMAN, J.; THOMAS, E. J. (Eds). Intervention research-design and development for human service. New York: The Haworth Press, 1994. 
RUDD, T.; COLLIGANE, F.; NAIK, R. Futurelab: Learner voice handbook. Research report. Harbourside: Bristol, 2006.

RUEDA, S. P. Modelo Urbano Para el Desarrollo de Ecobarrios. Barcelona: BCN Ecologia, 2005.

. Modelos de Ordenación del Territorio Más Sostenibles. In: CONGRESO NACIONAL DE MEDIO AMBIENTE, Barcelona, 2002.

. Modelos e Indicadores Para Ciudades Más Sostenibles: taller sobre indicadores de huella e calidad ambiental. Barcelona: Fundación Forum Ambiental, Departament de Medi Ambient de la Generalitat de Catalunya, 1999.

RUSSO, R.F.S.M., CAMACHO, R. Criteria in AHP: a Systematic Review of Literature. Procedia Computer Science,55, pp. 1123 - 1132. 2015.

SAATY, T. L. A scaling method for priorities in hierarchical structures. Journal of Mathematical Psychology, v. 15, n. 3, p. 234-281, 1977.

The Analytic Hierarchy Process. New York: McGraw-Hill, 1980.

, SHIH, H.S. (2009) Structures in decision making: On the subjective geometry of hierarchies and networks. European Journal of Operation Research, 199, pp. 867872.2009.

., SHANG, J.S. An innovative orders-of-magnitude approach to AHP-based mutli-criteria decision making: Prioritizing divergent intangible humane acts. European Journal of Operational Research, v.214, pp.703-715. 2011.

SABOYA, R.T. Segregação espacial urbana. 2009.

Concepção de um sistema de suporte à elaboração de planos diretores participativos. 2007. $231 \mathrm{f}$. Tese (Doutorado) - Universidade Federal de Santa Catarina, Florianópolis, SC, 2007.

SALES FILHO, L. H. O Uso de Indicadores de Acessibilidade na Avaliação de Redes Estruturais de Transporte Urbano. (Prêmio João Lyra Filho). Rio de Janeiro: Instituto Serzebello Corrêa, 1998.

SALLES, C. P. A situação da gestão ambiental municipal no Brasil. 2000. Dissertação (Mestrado em Saúde Pública) - Faculdade de Saúde Pública, Universidade de São Paulo, São Paulo, 2000.

SAMANIEGO G., C. A. Princípios e ferramentas do lean thinking na estabilização básica: diretrizes para implantação no processo de fabricação de telhas de concreto préfabricadas. 2007. 128 f. Dissertação (Mestrado em Arquitetura e Construção) - Faculdade de Engenharia Civil, Arquitetura e Urbanismo, Universidade Estadual de Campinas, Campinas, SP, 2007.

SANTORO, P. F. Planejar a expansão urbana: dilemas e perspectivas. 2012. $360 \mathrm{f}$. Tese (Doutorado) - Faculdade de Arquitetura e Urbanismo da Universidade de São Paulo, São Paulo, 2012, 
SANTOS JÚNIOR, O. A.; RIBEIRO, L. C. Q.; AZEVEDO, S. (Orgs.). Governança democrática e poder local: a experiência dos Conselhos municipais no Brasil. Rio de Janeiro: Revan, FASE, 2004.

; MONTANDON, D. T. (Orgs.). Os Planos Diretores Municipais

Pós-Estatuto da Cidade: balanço crítico e perspectivas. Rio de Janeiro: Letra Capital, 2011.

SANTOS, B. S. (Org.). Produzir para viver: os caminhos da produção não capitalista. Rio de Janeiro: Civilização Brasileira, 2002.

SANTOS, C. N. F. A cidade como um jogo de cartas. Niterói: Universidade Federal Fluminense, EDUFF; São Paulo: Projetos Editores, 1989.

A cidade como um jogo de cartas. Niterói: Universidade Federal

Fluminense, EDUFF; São Paulo: Projeto Editores, 1988.

SANTOS, R. F.; THOMAZIELLO, S.; WEILL, M. A. Planejamento da paisagem. In: SANTOS, R. F. (Org.). Vulnerabilidade ambiental. Brasília: MMA, 2007. cap. 11, p. 165175.

SÃO PAULO. Secretaria Municipal de Desenvolvimento Urbano. Gestão Urbana Relatório do Plano Diretor Estratégico. São Paulo, 2014. Disponível em: <http://gestaourbana.prefeitura.sp.gov.br/arquivos/PDE_lei_final_aprovada/APRESENTACA O/SMDU_PDE_140731_sancao_FINAL.pdf >. Acesso em: 09 jan. 2015.

SÃO PAULO. Secretaria Municipal de Desenvolvimento Urbano. Infocidade. São Paulo, 2015. Disponível em:

<http://infocidade.prefeitura.sp.gov.br/htmls/7_populacao_recenseada_e_taxas_de_crescime_ 1980_702.html>. Acesso em: 13 jan. 2015.

SARTORI, G. A teoria da democracia revisitada. Rio de Janeiro: Ática, 1994.

SCARE, R. F.; MARTINELLI, D. P. Negotiation strategies applied on agribusiness certification. In: III International Conference on Agri-Food Chain/Networks Economics and Management. Anais do Congresso. Ribeirão Preto, SP, 24-26 out. 2001.

SCHERMERHORN JOHN, R.; HUNT, G.; JAMES; OSBORN; RICHARD, N.

Fundamentos de comportamento organizacional. Porto Alegre: Bookman, 1999.

SCHIER, A. C. R. A participação popular na administração pública: o direito de reclamação. Rio de Janeiro: Renovar, 2002.

SCHMIDT, A. M. A. Processo de apoio a tomada de decisão - abordagens AHP e MACBETH. 1995. Dissertação (Mestrado em Engenharia) - Programa de Pós-graduação em Engenharia de Produção, Universidade Federal de Santa Catarina, Florianópolis, 1995.

SCHOCK, S. Projecting Land Use Change: A Summary of Models for Assessing the Effects of Growth and Change on Land Use Patterns, EPA/600/R-00/098. Washington, D. C.: National Exposure Research Laboratory, Office of Research and Development, US Environmental Protection Agency, 2000.

SCHÖN, D. The reflective practitioner. New York: Basic Books, 1982. 
SCOONES, I., THOMPSON, J.(Eds.). Beyond farmer first. Rural people's

SERRA, G. Urbanização e centralismo autoritário. São Paulo: Nobel/Editora da Universidade de São Paulo, 1991.

SHEN, L. Y.; OCHOA, J. J.; SHAH, M. N.; ZHANG, X. The application of urban sustainability indicators - A comparison between various practices. Habitat International Journal, v. 35, n. 1, p. 17-29, 2011.

SILVA, C. N.; VERBICARO, C. C. O mapeamento participativo como metodologia de análise do território. Scientia Plena, v. 12, n. 6, 2016.

SILVA, E. T.; RIBEIRO, L. C. Q. Movimento Pendular e Tendências da Reconfiguração Socioespacial. In: Anais da Semana de Planejamento Urbano e Regional, XIV. IPPUR/ UFRJ, 2008.

Migração e Pendularidade na Região Metropolitana do Rio de Janeiro: Uma Análise Socioespacial da Mobilidade. In: Encontro Nacional da ANPUR, XIII. 2009.

. Organização Sócio-Territorial e Movimentos Populacionais na Região Metropolitana do Rio de Janeiro. In: Encontro Nacional da ABEP, XVII. Caxambu, MG, set. 2010.

; RODRIGUES, J. M.; RIBEIRO, L. C. Q. Mobilidade Residencial e

Reconfiguração Territorial nas Áreas Metropolitanas Brasileiras. In: Encontro Nacional da ABEP, XVII. Caxambu, MG, set. 2010.

Territorios, Bogotá, Colômbia, n. 22, 2010.

Mobilidade Espacial nas Metrópoles Brasileiras. Revista

SILVA, G. P. Forma Urbana e Sustentabilidade: Algumas notas sobre o modelo de cidade compacta. Prospectiva e Planejamento, v. 15, 2008.

Forma urbana e sustentabilidade: algumas notas sobre o modelo de cidade compacta. Cadernos de Arquitetura e Urbanismo, v. 20, n. 26, 1ºm. 2013.

SILVA, G. J. A.; ROMERO, M. A. B. Urbanismo sustentável no Brasil - a revisão de conceitos urbanos para o século XXI. Arquitextos 129.08, ano XI, fev. 2011a.

Cidades sustentáveis: uma nova condição urbana: estudo de caso: CuiabáMT. 2011. 376 f. Tese (Doutorado) - Universidade de Brasília, Faculdade de Arquitetura e Urbanismo, Programa de Pesquisa e Pós-Graduação em Arquitetura e Urbanismo, Brasília, DF, 2011b.

A Construção de Indicadores Para Avaliação da Qualidade do Espaço Urbano no Distrito Federal do Brasil. Revista do Programa de Pesquisa e Pós-Graduação da FAUUnB, Brasília, DF, v. 9, n. 5, abr. 2010a.

SILVA, J. S. V.; FEITOSA, R. G. F. Fatores que influenciam na velocidade de venda dos imóveis: um estudo de caso usando a metodologia AHP. Revista Tecnológica de Fortaleza, Fortaleza, CE, v. 28, n. 2, p. 229-237, 2007. 
SILVA, M. D.; AVILA, G. M. Bairro Sustentável: Uma alternativa sustentável ou estratégia de marketing? Cidades Verdes, v. 2, n. 2, p. 43-59, 2014.

SILVA, M. K. Construção da participação popular: análise comparativa de processos de participação social na discussão pública do orçamento em municípios da Região Metropolitana de Porto Alegre (RS). 2001. 295 f. Tese (Doutorado em Sociologia) Universidade Federal do Rio Grande do Sul, 2001.

SIMIONE, A. A.; CKAGNAZAROFF, I. B. Governança Participativa em Moçambique. Administração Pública e Gestão Social, v. 9, n. 1, p. 64-74, jan.-mar. 2017.

SIMON, H. A. Comportamento administrativo: estudo dos processos decisórios nas organizações administrativas. 2. ed. Rio de Janeiro: FGV, 1970.

SIQUEIRA, H.C.H.; PORTELA, M.R.; AREJANO, C.B.; A produção do conhecimento: o construtivismo como estratégia metodológica. Revista Texto \& Contexto, 2000, 9(1), p. 93111.

SMITH, C. Content analysis and narrative analysis. In: REIS, H. T.; JUDD, C. M. (Orgs.). Handbook of research methods in social and personality psychology. UK: Cambridge University Press, 2000, p. 313-338.

SOBRAL, A., FREITA, C.M.,PEDROSO, M.M, GURGEL, H. Definições básicas: dado, indicador e índice. In: Brasil. Ministério da Saúde. Secretaria de Vigilância em Saúde. Departamento de Vigilância em Saúde Ambiental e Saúde do Trabalhador. Saúde ambiental: guia básico para construção de indicadores. Brasília: Ministério da Saúde, 2011. p. 25-52. (Série B. Textos Básicos de Saúde). Disponível em:

<http://bvsms.saude.gov.br/bvs/publicacoes/saude_ambiental_guia_basico.pdf >. Acesso em: 14 jul. 2019.

SMITH, G. Democratic innovations: designing institutions for citizen participation. Cambridge University Press, 2009.

SOUZA, C. Construção e consolidação de instituições democráticas: papel do orçamento participativo. São Paulo em perspectiva, ano XV, n. 4, p. 84-97, 2001.

SOUZA, M. A. A.; CORDEIRO NETTO, O. M.; CARNEIRO, G. A.; LOPES JÚNIOR, R. P. Análise tecnológica de alternativas para pós-tratamento de efluentes de reatores anaeróbios: resultados da avaliação multiobjetivo. In: $2^{\circ}$ CONGRESSO BRASILEIRO DE ENGENHARIA SÁNITÁRIA E AMBIENTAL. João Pessoa, 2001.

SOUZA, M. J. L. O Desafio metropolitano. Um estudo sobre a problemática socioespacial nas metrópoles brasileiras. 2. ed. Rio de Janeiro: Bertrand, 2000.

SOUSA, M. L. Mudar a cidade. Rio de Janeiro: Bertrand Brasil, 2002.

SOUZA, M. L.; RODRIGUES, G. B. Planejamento Urbano e Ativismos Sociais.

STEPHAN, I. I. C. A Aplicação dos Planos Diretores e Leis de Controle do Uso e Ocupação do Solo em cidades de médio porte demográfico, em Minas Gerais, no período 1988-1998. 2005. 381 f. Tese (Doutorado em Arquitetura e Urbanismo) - Faculdade de Arquitetura e Urbanismo, Universidade de São Paulo, São Paulo, SP, 2006. 
STRAUSS, A.; CORBIN, J. Grounded theory methodology: an overview. In: Denzin, N. K.; LINCOLN, Y. (Orgs.). Handbook of qualitative research. EUA: Sage Publications, 1994, p. 273-85.

SWAPAN. Who participates and who doesn't? Adapting Community participation model for developing countries. Cities, n. 43, p. 70-77, 2016.

TALEN, E. Urbanism in America: Ideals, Connections and Conflicts. Chicago: University of Illinois, Urbana-Champaign, 2003.

; ELLIS, C. Beyond relativism: Reclaiming the search for good city form. Journal of Planning Education and Research, v. 22, n. 1, p. 36-49, 2002.

TATAGIBA, L. Os conselhos gestores e a democratização das políticas públicas no Brasil. In: DAGNINO, E. (Org.). Sociedade civil e espaços públicos no Brasil. São Paulo: Paz e Terra, 2002, p. 47-103.

Os desafios da articulação entre Sociedade Civil e Sociedade Política sob o marco da democracia gerencial. O caso do Projeto Rede Criança em Vitória/ES. In: DAGNINO, E.; OLVERA, A. J.; PANFICHI, A. (Orgs.). A disputa pela construção democrática na América Latina. São Paulo: Paz e Terra; Campinas: Editora Unicamp, 2006.

TEIXEIRA, A. O perfil psicológico e o estilo de negociação dos negociadores de energia elétrica no Brasil. 2011. 195 f. Dissertação (Mestrado) - Universidade Federal de Santa Catarina, Centro Tecnológico, Programa de Pós-Graduação em Engenharia e Gestão do Conhecimento, Florianópolis, SC, 2011.

TEIXEIRA, E. C. As dimensões da participação cidadã. Cadernos CRH, Salvador, UFBA, v. 10, n. 26, 2001.

TETAMANTI, R. M. D. Cartografía Social. Herramienta de intervención e investigación social compleja. El vertebramiento inercial como processo mapeado. In: TETAMANTI, M. D. (Org.). Cartografía social: investigaciones e intervención desde las ciencias sociales: métodos y experiencias de aplicación. 1. ed. Comodoro Rivadavia: Universitaria de la Patagonia, 2012. 162 p.

THIOLLENT, M. Pesquisa-ação nas organizações. São Paulo: Atlas, 1997

THOMAS, K. W. Conflict and Negotiation Processes in Organizations. 2 ed., vol. 3. Palo Alto, CA: Consulting Psychologists Press, 1992, p. 652-717.

THOMAZ, S. R. T. Using Multi-Criteria Decision Analysis to develop a prototype model to assess integrated proposals for the Rodrigo de Freitas lagoon. 2002. $58 \mathrm{f}$. Dissertação (MSc in Decision Sciences) - London School of Economics \& Political Science, London, UK, 2002.

THOMAZIELLO, S. Usos da terra e sua influência sobre a qualidade ambiental. In:

SANTOS, R. F. (Org.). Vulnerabilidade ambiental. Brasília: MMA, 2007. cap. 3, p. 23-38.

TOLEDO, R. F. Comunidade indígena na Amazônia: metodologia da pesquisa - ação em educação ambiental. O mundo da saúde São Paulo, v. 30, n. 4, p. 559-659, out./ dez. 2005. 
; GIATTI, L. L. Challenges to participation in action research. Health Promotion International, v. 00, p. 1-12, 2014.

; CUTOLO, S. A.; BARREIRA, L. P.; PELICIONI, M. C. F. Um

sistema metodológico aberto, dinâmico e legítimo na participação: Uma experiência multidisciplinar com pesquisa-ação em Iauretê/AM. In: TOLEDO, R. F. de; JACOBI, P. R. (Orgs.). A pesquisa-ação na interface da saúde, educação e ambiente: princípios, desafios e experiências interdisciplinares. São Paulo: Annablume, 2012, p. 115-131.

; PELICIONI, M. C. F. Mobilização Social em Saúde e

Saneamento em Processo de Pesquisa-ação em uma Comunidade Indígena no Noroeste Amazônico. Saúde e Sociedade, v. 21, n. 1, p. 206-218, 2012.

TONELLA, C. Políticas Urbanas no Brasil: marcos legais, sujeitos e instituições. Revista Sociedade e Estado, v. 28, n. 1, p. 29-52, jan./ abr. 2013.

UGARTE, P. S. Que participação para qual democracia? In: COELHO, V.; SCHATTAN, P.; NOBRE, M. (Orgs.). Participação e deliberação: teoria democrática e experiências institucionais no Brasil contemporâneo. Editora 34, 2004, p. 93-106.

UGEDA JUNIOR, J. C.; AMORIM, M. C. C. T. Indicadores ambientais e planejamento urbano. Caderno Prudentino de Geografia, n. 31, v. 2, p. 5-35, jul./ dez. 2009.

UNITED NATIONS. Department of Economic and Social Affairs/Population Division. World Urbanization Prospects: The 2007 Revision. New York, 2006.

UNITED NATIONS. Urbanization and Development: Emerging Futures. World Cities Report 2016. Nairobi: UN-Habitat, 2016.

VARGAS, H. A arte da negociação. In: RIBEIRO, H.; VARGAS, H. C. (Orgs.). Novos instrumentos de gestão ambiental urbana. São Paulo: EDUSP, 2001. cap. 7, p. 107-124.

VEIGA, L.; GONDIM, S. M. G. A utilização de métodos qualitativos na ciência política e no marketing político. Opinião Pública, v. 2, n. 1, p. 1-15, 2001

VIEIRA, R.; PEREIRA, L. N.; ANJOS, F. A.; SCHROEDER, T. Participação popular no processo de planejamento urbano: a universidade como "decodificadora" de um sistema de muitos códigos - urbe. Revista Brasileira de Gestão Urbana (Brazilian Journal of Urban Management), v. 5, n. 2, p. 115-130, jul./ dez. 2013.

VILLAÇA, F. Dilemas do Plano Diretor: Desenvolvimento Físico-Territorial. O

MUNICÍPIO NO SÉCULO XXI: Cenários e Perspectivas, p.237-247, 1999.

. As ilusões do Plano Diretor. São Paulo: Edição do autor, 2005. Disponível em: <www.usp.br/fau/fau/galeria/paginas/index.html>. Acesso em: 10 out. 2016.

Institute, 2001.

Espaço intra-urbano no Brasil. São Paulo: Studio Nobel, FAPESP, Lincoln

. Uma contribuição para a história do Planejamento Urbano no Brasil. In: CSABA,

D.; SCHIFFER, S. R. (Orgs.). O Processo de Urbanização no Brasil. 2. ed. (atualizada). São Paulo: Editora da Universidade de São Paulo, 2010. 
WALTNER-TOEWS, D. An ecossystem approach to health and its applications to tropical and emerging diseases. Cadernos de Saúde Pública, Rio de Janeiro, v. 17, p. 7-36, 2001.

WCED- COMISSÃO MUNDIAL SOBRE O MEIO AMBIENTE E DESENVOL. VIMENTO (WCED). Nosso Futuro Comum. Rio de Janeiro: FGV, 1987.

WEBER, M. Economia y sociedade. México: Fondo de Cultura Econômica, 1964.

WEBER, M. Os fundamentos da organização burocrática: uma construção do tipo ideal. In: CAMPOS, E. (Org.). Sociologia da burocracia. Rio de Janeiro: J. Zahar, 1966, p.16-27.

WEIL, P. Holística: uma nova visão e abordagem do real. São Paulo: Palas Athena, 1990.

WEILAND, U. Sustainability Indicators and Sustainable Development. In: WUYI, W.; KRAFFT, T.; KRAAS, F. Global Change, Urbanization and Health. Beijing: China Meteorological Press, 2006, p. 241-250.

WEILL, M. A. M.; PIRES NETO, A. G. Erosão e assoreamento. In: SANTOS, R. F. (Org.). Vulnerabilidade ambiental. Brasília: MMA, 2007. cap. 4, p. 39-58.

WESTPHAL, M.F.; BOGUS, C. M.; FARIA, M. M. Grupos focais: experiências precursoras em programas educativos em saúde no Brasil. Bol Oficina Sanit Panama, v. 120, n. 6, 1996.

WHEELER, S. M. Planning for metropolitan sustainability. Journal of Planning Education and Research, Association of Collegiate Schools of Planning, v. 20, p. 133-145, 2000.

WILLIANS, K.; BURTON, E.; JENKS, M. Achieving Sustainable Urban Form. London: E \& FN, 2000. 408 p.

WILSDON, J.; WILLIS, R. See-through Science: Why public engagement needs to move upstream. London: Demos, 2004.

WORLD BANK. World Bank participatory sourcebook. 1996.

WORLD URBAN FORUM 6 (WUF). The urban future: concept paper and outline of dialogues - the 21 st century: century of the city. HSP/WUF/6/2, p. 10. Disponível em: <http://www.urbangateway.org/document/wuf6-concept-paper-and-outline-dialogues>. Acesso em: 11 jan. 2016.

WYNNE, B. May the sheep safely graze? A reflexive view of the expert-lay knowledge divide. In: LASH, S.; SZERSZYNSKI, B.; WYNNE, B. (Eds.). Risk, Environment and Modernity. London: Sage Publications, 1996.

YACH, D. The use and value of qualitative methods in health research in developing countries. Social Sci Med, v. 35, n. 4, p. 603-612, 1992.

YIN, R. K. Estudo de caso planejamento e métodos. 4. ed. Porto Alegre: Bookman, 2010.

YOUNG, I. M. Representação política, identidade e minorias. Revista Lua Nova, v. 67, p. 139-190, São Paulo, 2006. 
ZABOTTO, M. C. Caminhos e descaminhos da participação popular: os centros comunitários em Rio Claro - SP. Rio Claro: [s.n.], 2006.

ZHEN, F.; QIN, X.; YE, X. ; SUN, H.; LUOSANG, Z. Analyzing urban development patterns based on the flow analysis method. Cities, Article in press, out. 2018.

ZMITROWICZ, W.; DE ANGELIS NETO, G. Infra-Estrutura Urbana. São Paulo: POLIUSP, Textos Técnicos, 1997.

ZUFFO, A. C. Seleção e aplicação de métodos multicriteriais ao planejamento ambiental de recursos hídricos. 1998. 302 f. Tese (Doutorado em Engenharia Civil) - Escola de Engenharia de São Carlos, Universidade Estadual de São Paulo, São Carlos, 1998.

; GENOVEZ, A. M. Método multicriterial utilizado como indicador da qualidade de água. In: CONGRESSO LATINOAMERICANO DE HIDRÁULICA, 22, 2006, Ciudad de Guavana, Venezuela. Anais... Ciudad de Guavana, Venezuela: IAHR, 2006.

; REIS, L. F. R.; SANTOS, R. F.; CHAUDHRY, F. H. Aplicação de métodos multicriteriais ao planejamento de recursos hídricos. Revista Brasileira de Recursos Hídricos, São Paulo, v. 7, n. 1, p. 81-102, 2002. 
ANEXOS 


\section{ANEXO A - Aprovação do Comitê de Ética em Pesquisa}

\section{USP - FACULDADE DE SAÚDE PÜBLICA DA UNIVERSIDADE DE SÃO PAULO - FSP/USP}

\section{PARECER CONSUBSTANCIADO DO CEP}

\section{DADOS DO PROJETO DE PESQUISA}

Titulo da Pesquisa: Proposta metodologica para inclusăo da participaçăo popular nos processos de tomada de decisâo para hierarquizaçâo de projetos de intervençăo e transformaçao urbana

Pesquisador: RAFAEL BARRETO CASTELO DA CRUZ

Área Temática:

Versao: 1

CAAE: 65227017.4 .0000 .5421

Instituiçăo Proponente:UNIVERSIDADE DE SAO PAULO

Patrocinador Principal: Financiamento Próprio

\section{DADOS DO PARECER}

Número do Parecer: 2.015.106

\section{Apresentaçäo do Projeto:}

Projeto da área de planejamento urbano, que parte da hipotese de que a participaçaso popular pode fornecer contribuiçøes mais efetivas para os projetos de intervençaio urbana,especialmente se desenvolvidos e aplicados procedimentos metodológicos nos processos de tomada de decisalo que suportem e orientem a participaçao da populaçăo

Objetivo da Pesquisa:

desenvolvimento e a aplicaçăo de uma proposta metodológica para inclusåo da participaçáo popular nos processos de tomada de decisaio para priorizaçao de projetos de intervençăo e transformaçao urbana.

\section{Avaltaçăo dos Riscos e Beneficios:}

A contribuiçăo para a planejamento urbano e um importante beneficlo.

Os riscos sao mínimos, decorrente apenas de possivel incomodo na realizaçao das entrevistas elou grupos focais.

Comentários e Consideraçoes sobre a Pesquisa:

Projeto muito bem estruturado, excelente revisalo do tema, objetivos e metodologia claros.

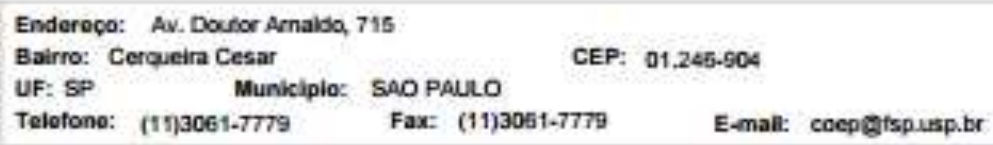




\section{USP - FACULDADE DE SAÚDE PÚBLICA DA UNIVERSIDADE DE SÃO PAULO - FSP/USP

Cortinuachts de Patecer. 2.687 .560

Consideraçöes sobre os Termos de apresentação obrigatória:

TCLE adequado

Recomendações:

Sem recomendações

Conclusōes ou Pendências e Lista de Inadequações:

Sem pendências

Consideraçöes Finais a critério do CEP:

Este parecer foi elaborado baseado nos documentos abaixo relacionados:

\begin{tabular}{|c|c|c|c|c|}
\hline Tipo Documento & \begin{tabular}{|c|} 
Arquivo \\
\end{tabular} & Postagem & Autor & Situação \\
\hline $\begin{array}{l}\text { Informaçóes Básicas } \\
\text { do Proieto }\end{array}$ & $\begin{array}{l}\text { PB_INFORMAÇOES_BASICAS_DO_P } \\
\text { ROJETO } 854384 \text { odf }\end{array}$ & $\begin{array}{c}27 / 03 / 2018 \\
13: 38: 29\end{array}$ & & Aceito \\
\hline $\begin{array}{l}\text { TCLE / Termos de } \\
\text { Assentimento / } \\
\text { Justificativa de } \\
\text { Auséncia }\end{array}$ & TCLE_M_07.pdf & $\begin{array}{c}27 / 03 / 2018 \\
13: 38: 10\end{array}$ & $\begin{array}{l}\text { RAFAEL BARRETO } \\
\text { CASTELO DA CRUZ }\end{array}$ & Aceito \\
\hline $\begin{array}{l}\text { Projeto Detalhado / } \\
\text { Brochura } \\
\text { Investigadior }\end{array}$ & $\begin{array}{l}\text { Plano_de_Pesquisa_Rafael_Castelo_re } \\
\text { v_Final.poff }\end{array}$ & $\begin{array}{c}24 / 02 / 2017 \\
08: 17: 02\end{array}$ & $\begin{array}{l}\text { RAFAEL BARRETO } \\
\text { CASTELL DA CRUZ }\end{array}$ & Aceito \\
\hline Folha de Rosto & digitalizar0007.pdf & $\begin{array}{c}24 / 02 / 2017 \\
08: 12: 39 \\
\end{array}$ & $\begin{array}{l}\text { RAFAEL BARRETO } \\
\text { CASTELO DA CRUZ }\end{array}$ & Aceito \\
\hline
\end{tabular}

Situação do Parecer:

Aprovado

Necessita Apreciaçäo da CONEP:

Não

SAO PAULO, 22 de Maio de 2018

Assinado por:

Kelly Polido Kaneshiro Olympio

(Coordenador)

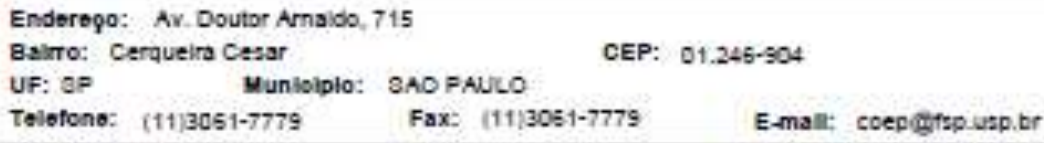


ANEXO B - Fluxo geral do Planejamento Estratégico Situacional - Método Altadir de Planejamento Popular MAPP
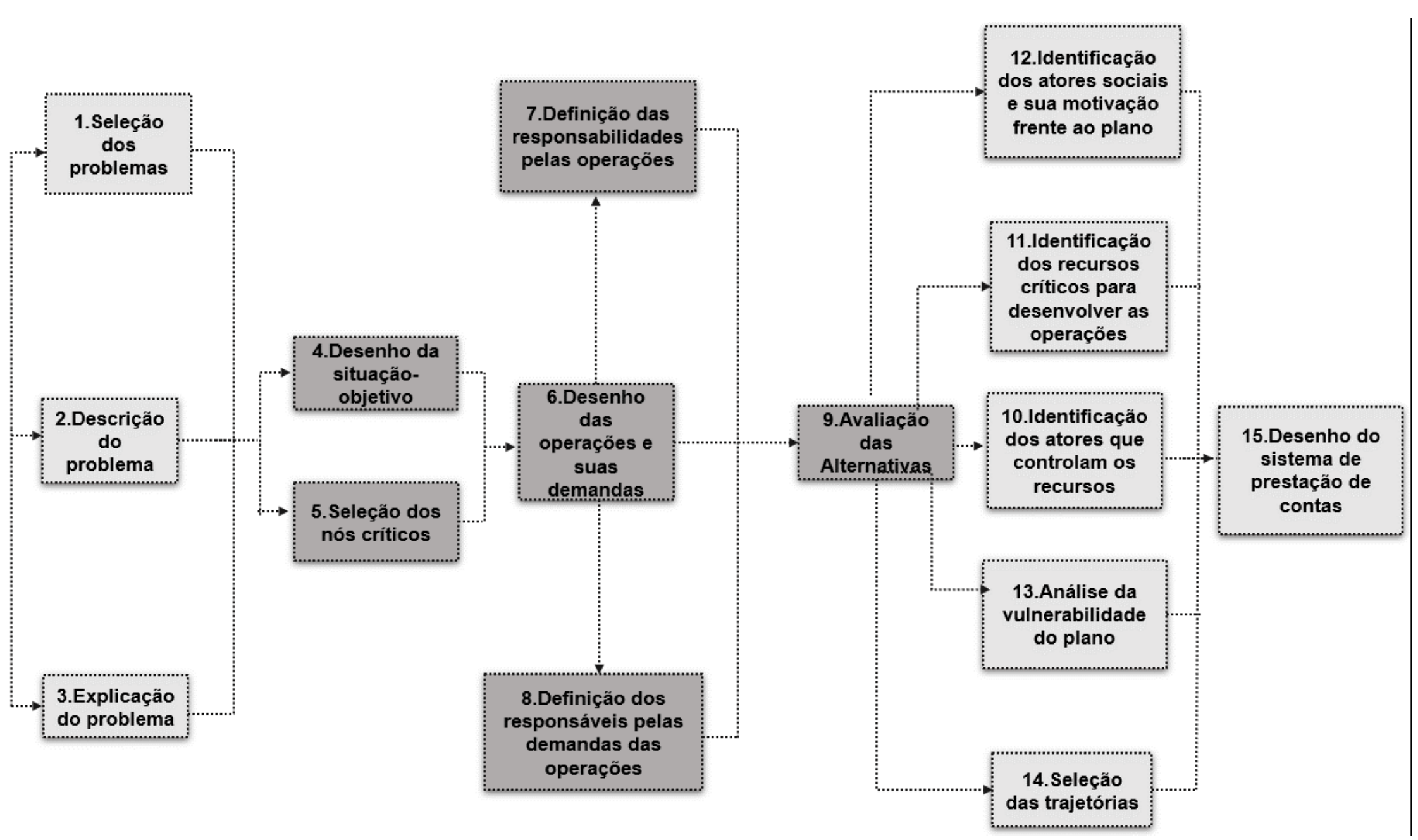


\section{APÊNDICES}




\title{
APÊNDICE A - Termo de Consentimento e Livre Esclarecimento
}

\author{
TERMO DECONSENTIMENTO LIVRE E ESCLARECIDO
}

\begin{abstract}
Título do Projeto: Proposta metodológica para inclusão da participação popular nos processos de tomada de decisão para hierarquização de projetos de intervenção e transformação urbana
\end{abstract}

\section{Pesquisador Responsável: Rafael Barreto Castelo da Cruz Contato: rafaelcastelo@usp.br}

Este projeto tem o objetivo de desenvolver e a aplicar de uma proposta metodológica para inclusão da participação popular nos processos de tomada de decisão para priorização de projetos de intervenção e transformação urbana.

Serão aplicados o mapas falantes e grupos focais, ambos são métodos estruturados em dinâmicas de grupos captando a percepção dos participantes, conduzidos pelo pesquisador responsável, cujas opiniões, percepções e dados coletados colaborarão para um processo de hierarquização de projetos voltados ao planejamento urbano. Estas dinâmicas são realizadas em datas agendas com as associações participantes. Dentro de nossas pesquisas, trabalharemos no diagnóstico de áreas urbanas, engenharia urbana, planejamento e projetos de intervenção urbana na escala do bairro.

São pesquisadores, engenheiros, arquitetos, alunos de graduação, mestrado e doutorado, que neste momento procedem investigações na área de abrangência do município de São Paulo. A aplicação da pesquisa, não possui riscos. E os benefícios trazidos pelos resultados é a construção coletiva de uma priorização de estratégias voltadas ao planejamento urbano.

O questionário, e as dinâmicas de grupo serão realizadas com o enfoque de compreender a percepção dos moradores, sua realidade local e como determinam as prioridades nas ações de planejamento urbano.

Após ler e receber explicações sobre a pesquisa, e ter meus direitos de:

1. Receber resposta a qualquer pergunta e esclarecimento sobre os procedimentos, riscos, benefícios e outros relacionados à pesquisa;

2. Retirar o consentimento a qualquer momento e deixar de participar do estudo;

3. Não ser identificado e ser mantido o caráter confidencial das informações relacionadas à privacidade.

4. Procurar esclarecimentos com o Comitê de Ética em Pesquisa da Faculdade de Saúde Pública da Universidade de São Paulo, no telefone 11 3061-7779 ou Av. Dr. Arnaldo, 715 - Cerqueira César, São Paulo - SP, em caso de dúvidas ou notificação de acontecimentos não previstos.

A pesquisa tem características de consonância com o caráter processual e dialogal, e possui grau de risco mínimo. Serão considerados o respeito pela dignidade humana e pela especial proteção devida aos participantes. Também são respeitados os valores culturais, sociais, morais, religiosos e éticos, como também os hábitos e costumes, quando as pesquisas envolverem comunidades 
Declaro estar ciente do exposto e desejar participar do projeto de pesquisa

São Paulo, de de

Nome do responsável:

Assinatura:

$\mathrm{Eu}$, declaro que forneci todas as informações referentes ao projeto ao participante e/ou responsável.

Data:

Telefone: 


\section{APÊNDICE B - Lista das Associações e Organizações Atuantes na Subprefeitura da Mooca}

1. Organizações não governamentais (ONGs)

As ONGs (associações sem fins lucrativos) atuantes na região possuem diferentes campos de atuação. Dentre elas, algumas voltadas ao ensino, profissionalização, saúde e sustentabilidade. As ONGs presentes na Subprefeitura são:

ASSOCIACC̃̃O DOS NORDESTINOS DE SÃO PAULO E LEGIÃO INTERNACIONAL DE FRATERNIDADE E ECOLOGIA - ANESP/LIFE

Rua Gomes Cardim, 420

ASSOCIACÃO DE APOIO AO ENSINO E DESENVOLVIMENTO SOCIAL DO BAIRRO BRÁS

Avenida Alcântara Machado, 28

\section{ASSOCIAC̄̃̃O RÁDIO COMUNITÁRIA INFINTA}

Rua Rubino de Oliveira, 224

ASSOCIACÃO DOS NORDESTINOS DO ESTADO DE SÃO PAULO - ANESP

Avenida do Estado, 2023

ASSOCIAČ̃̃ COMUNITÁRIA DE DESENVOLVIMENTO CULTURAL E ARTÍSTICO DO PARI

Rua Gustavo Bresser, 46

ASSOCIAČ̃̃ COMUNITÁRIA DE DESENVOLVIMENTO CULTURAL E ARTÍSTICO DA MOOCA

Rua Terezina, 7

ASSOC. COMUNIT. CULT. EDUCAC. DIF. SOCIAL MOOCA LESTE

Rua Visconde de Laguna, 14 
ASSOCIACÃO DE ALUNOS DE CURSO LIVRE DO BAIRRO DA MOOCA

Avenida Paes de Barros, 118

\section{ASSOCIACÃO CULTURAL COMUNITÁRIA LUZ DO AMANHÃ}

Rua dos Trilhos, 257

\section{CONSELHO COMUNITÁRIO DE SÃO PAULO}

Praça Santa Terezinha, 49

ASSOC. E MOV. CULT. BENEFICENTE RÁDIO COMUNITÁRIA ZONA LESTE FM

Rua Emílio Mallet, 95 - Bloco 1 - Térreo, 2A - Vila Gomes Cardim - Tatuapé

ASSOCIAÇÃO ASSINDES SERMIG

Rua Doutor Almeida Lima, 900 - Mooca - São Paulo - SP

Tel.: 11-22920977

\section{ASSOCIACÃO NACIONAL DOS MORADORES DE CONDOMÍNIO}

Rua Paschoal Moreira, 376 - Mooca - São Paulo - SP

Tel.: 11-66063531

ASSOCIAÇÃO NOVOS PASSOS

Rua Prof. Oliveira Fausto, 236 - Mooca - São Paulo - SP

Tel.: 26099575

\section{ASSOCIACÃO PORTA DA VIDA DE ACÃO SOCIAL}

Rua Jaboticabal, 166 - Sala 01 - Mooca - São Paulo - SP

Tel.: 11-64860006

CASA DA DIVINA PROVIDÊNCIA MADRE TERESA MICHEL

Rua Da Mooca, 113 - Mooca - São Paulo - SP

Tel.: 11-32091132 


\section{CENTRO ASSISTENCIAL SOCIAL ESTRELA GUIA}

Rua Tobias Barreto, 966 - Mooca - São Paulo - SP

Tel.: 11-26972186

CENTRO DE APOIO PROFISSIONALIZANTE EDUCACIONAL E SOCIAL

Rua Maria Luisa De Pinho, 30 - Mooca - São Paulo - SP

Tel.: 11-22720067

\section{CENTRO DE ASSISTÊNCIA SOCIAL BRÁS MOOCA}

Rua João Caetano, 113 - Mooca - São Paulo - SP

Tel.: 11-26955365

CENTRO DE TREINAMENTO DA VIDA

Rua Visconde De Parnaiba, 1461 - Apto. 64 - Mooca - São Paulo - SP

Tel.: 11-6698-6450

\section{COMITÊ SETH DE DESENVOLVIMENTO SOCIAL}

Rua Dos Campineiros, 814 - Mooca - São Paulo - SP

Tel.: 11-21544449

ESCOLAS PROFISSIONAIS SALESIANAS

Rua Dom Bosco, 441 - Mooca - São Paulo - SP

Tel.: 11-32744900

\section{EXECUTIVA NACIONAL DO MICROEMPREENDEDOR INDIVIDUAL}

Rua Alto Bonito, 40 - 10 C - Mooca - São Paulo - SP

Tel.: 11-37134848

FUNDAÇÃO NELSON LIBERO

Avenida Alcântara Machado, 80 - 50 Andar - Conj. 53 - Mooca - São Paulo - SP

Tel.: 11-32090963 


\section{FUNDACÃO NINHO JARDIM CONDESSA MARINA R. CRESPI}

Rua João Antonio De Oliveira, 59 - Mooca - São Paulo - SP

Tel.: 11-38878161

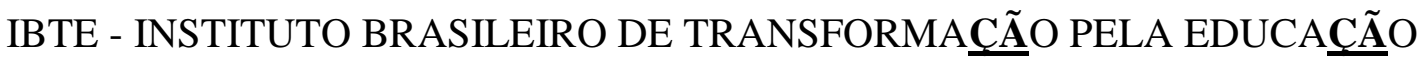

Rua Da Mooca, 336 - Apto. 163 - Bloco B - Mooca - São Paulo - SP

Tel.: 11-32777517

\section{INSTITUTO BRASILEIRO DE CONTROLE DO CÂNCER}

Avenida Alcântara Machado, 2576 - Mooca - São Paulo - SP

Tel.: 11-34744245

INSTITUTO INTEGRUS

Rua Do Oratório, 1606 - Cj. 406 - Mooca - São Paulo - SP

Tel.: 11-77506683

INSTITUTO S.O.S. SISTEMAS ORGANIZADOS PARA SUSTENTABILIDADE

Rua Carmelo Adam, 80 - Fundos - Mooca - São Paulo - SP

Tel.: 11-28934448

ISES - INSTITUTO DE SOCIOECONOMIA SOLIDÁRIA

Rua Hipias, 30 - Mooca - São Paulo - SP

Tel.: 11-37993367

\section{LAR DA REDENĊ̃̃O}

Rua Cassandoca, 535 - Mooca - São Paulo - SP

Tel.: 11-26958874

LAR DONA COTINHA

Rua Messias De Pina, 77 - Mooca - São Paulo - SP

Tel.: 11-26920565 


\section{MAPAS - METODOS DE APOIO A PRATICAS AMBIENTAIS E SOCIAIS}

Avenida Henry Ford, 511 - Sala 5 - Mooca - São Paulo - SP

Tel.: 11-61638222

NOVA 4E - ENTIDADE ESPECIALIZADA EM PESSOAS ESPECIAIS

Rua Bresser, 2701 - Mooca - São Paulo - SP

Tel.: 11-26934777

\section{ONG TREVO}

Avenida Henry Ford, 686 - Mooca - São Paulo - SP

Tel.: 11-61613867

PROJETECH - PROJETOS TÉCNICOS E SOCIAIS

Rua Marina Crespi, 62 - A - Mooca - São Paulo - SP

Tel.: 11-26986848

\section{SOS POVOS DA MATA ATLÂNTICA}

Praça Presidente Kennedy, 134 - Mooca - São Paulo - SP

Tel.: 11-60991030

2. Associação de classe

A principal associação de classe presente na Subprefeitura da Mooca é a Associação Comercial de São Paulo (ACSP). É uma associação que trabalha pelo interesse dos comerciantes dos bairros da Mooca, Alto da Mooca, Água Rasa, Vila Oratório, Belém, Brás, Vila Prudente, São Lucas e Sapopemba. E tem sua sede na Rua Madre de Deus, 222 - Mooca.

A associação atende desde comércios familiares a grandes indústrias. Possui como causas promover ambiente favorável para os negócios e facilitar o empreendedorismo. 
APÊNDICE C - Questionário aplicado às entrevistas
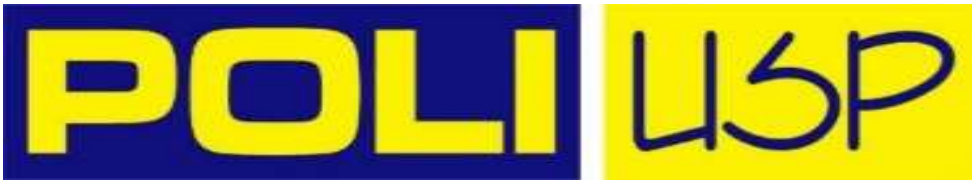

Questionário de pesquisa universitária - Escola Politécnica da Universidade de São Paulo

- Pesquisa de doutorado: Proposta metodológica para inclusão da participação popular nos processos de tomada de decisão para hierarquização de projetos de intervenção urbana - Aluno: Rafael Castelo

- Pesquisa de iniciação científica: Diagnostico da participação popular em projetos urbanos, no município de São Paulo - Aluna: Sílvia Mauad

- Orientadora: Professora Dra. Karin Marins

\section{Informações gerais:}

1. Sexo:

Feminino

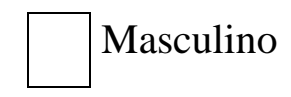

2. Faixa de idade:

Até 25 anos

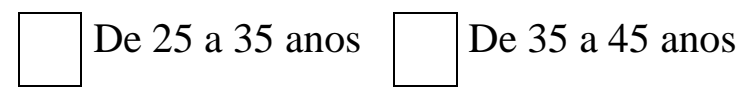

$\square$ De

De 45 a 60 anos

Acima de 60 anos

3. Escolaridade:

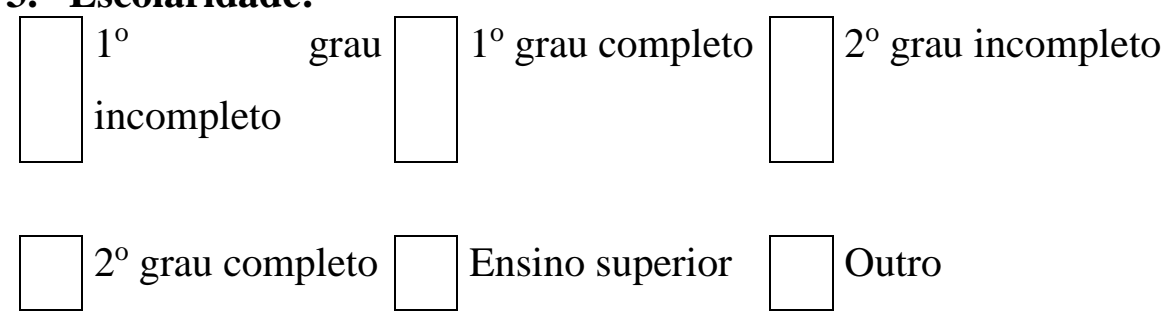

4. Qual/ quais atividades exerce na região?

Moro aqui 
Participação no planejamento urbano:

5. Você sabe o que é Plano Diretor e Zoneamento?

$\square \operatorname{Sim} \square$ Não

6. Sabe o que é Plano Regional da Subprefeitura?

$\square$ Sim $\square$ Não

7. Sabe o que é Projeto de Intervenção Urbanística (PIU)?

$\longrightarrow \operatorname{Sim}$ Não

8. Sabe como funciona o processo de elaboração dos planos citados?<smiles>O=[N+]([O-])C1C2CC1C1CCC1[SiH2]2</smiles>

9. Ficou sabendo do processo participativo do novo Plano Diretor vigente?

$\square$ Sim $\square$ Não

10. Participou do processo, comparecendo às audiências promovidas?

11. Já

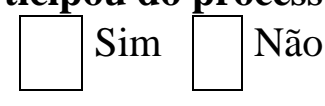

participou de algum outro processo de consulta que o Governo promoveu?

12. Se

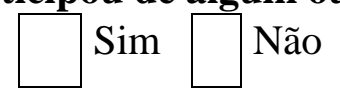

sim, quais?

13. Já participou de alguma associação de bairro, ONG, conselho municipal?

14. Se

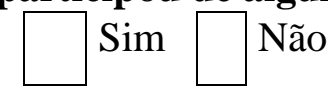

sim, quais?

15. Caso a sua resposta tenha sido afirmativa nas perguntas 10,11 ou 13 , poderia dizer por que decidiu participar? 
16. Caso a sua resposta tenha sido afirmativa nas perguntas 10,11 ou 13 , poderia dizer o que achou de positivo e negativo sobre o evento em que participou?

17. Caso a sua resposta tenha sido afirmativa nas perguntas 10,11 ou 13 , você acha que a sua participação tenha sido realmente ouvida e/ou atendida de alguma forma pelo Poder Público?

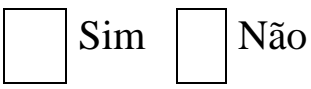

18. Caso a sua resposta tenha sido afirrmativa nas perguntas 10,11 ou 13 , você sabe ou foi informado posteriormente se sua sugestão gerou uma contribuição concreta para alguma proposta ou decisão?

$\square$ Sim Não

19. Caso a sua resposta tenha sido negativa nas perguntas 10,11 ou 13 , você consideraria participar novamente de outro processo caso tenha oportunidade?<smiles>O=[N+]([O-])C1C2C[SiH2]C1C1CCC12</smiles>

20. Você considera que é importante que a população participe desses processos de planejamento de cidade?

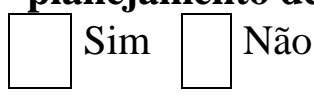

21. Por que razões? 
APÊNDICE D- Fluxo Geral da Proposta Metodológica Cruz \& Marins

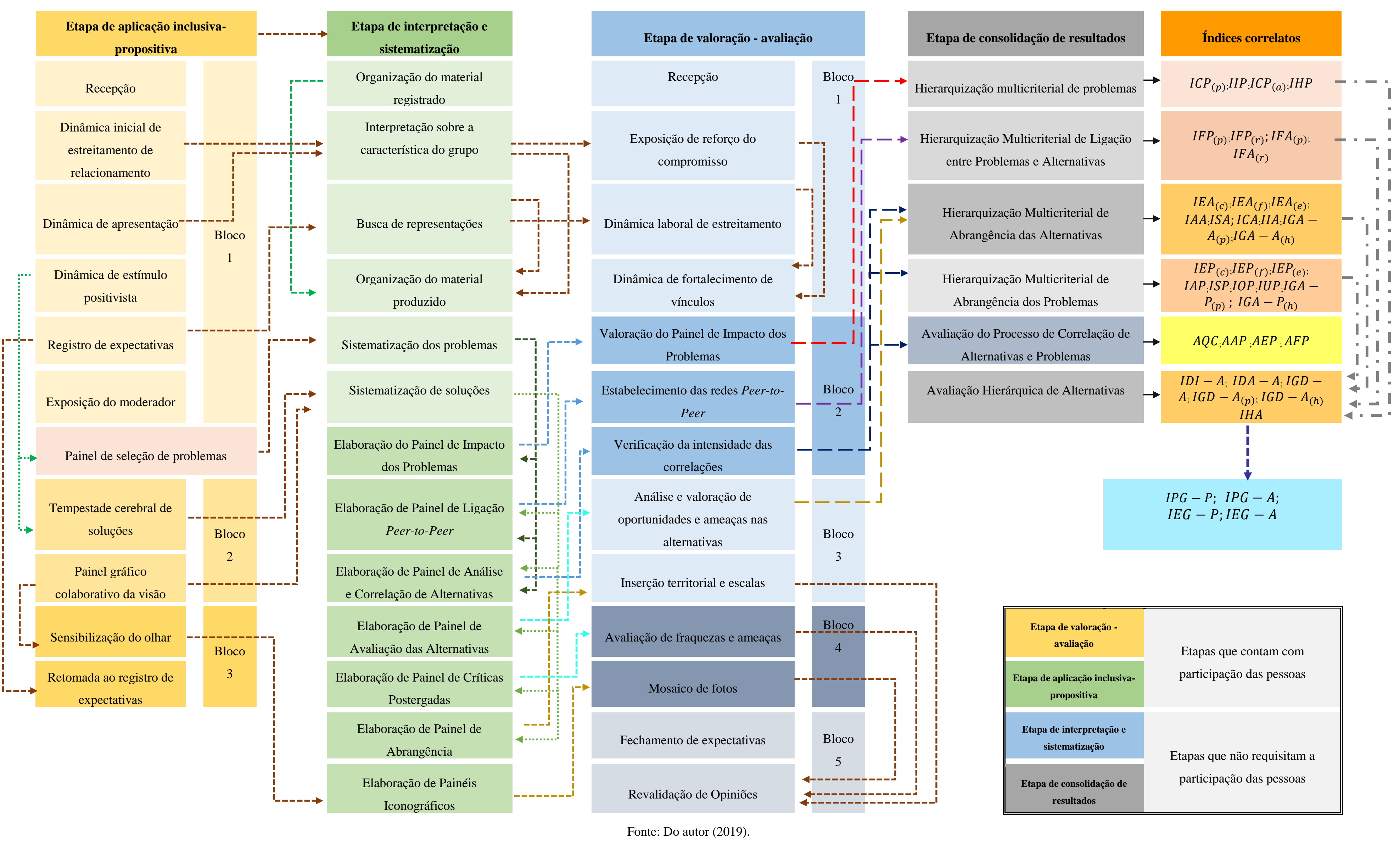

